UNITED STATES DEPARTMENT OF THE INTERIOR

J. A. Krug, Secretary

GEOLOGICAL SURVEY

W. E. Wrather, Director

Water-Supply Paper 966

\title{
MINOR FLOODS OF 1938 \\ IN THE \\ NORTH ATLANTIC STATES
}

\author{
Prepared by \\ WATER RESOURCES BRANCH
}

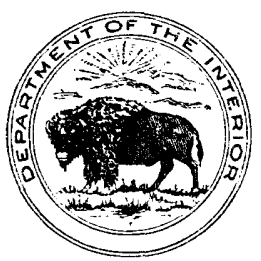

UNITED STATES

GOVERNMENT PRINTING OFFICE

WASHINGTON : 1947 
NotE.-This report was prepared in 1939 and 1940. Conditions arising out of the war have delayed its publication. 


\section{CONTENTS}

Abstract ......... Page

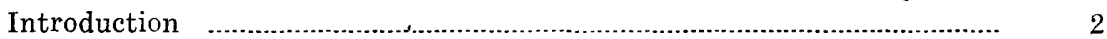

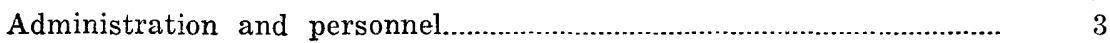

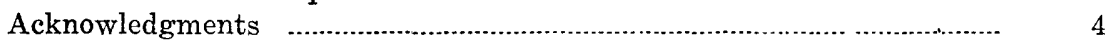

General description of information

Antecedent conditions ................................................................... 5

Precipitation ...................................................................................

Stages and discharges at stream-gaging stations............................ 8

Explanation of data..................................................................

Summary of flood stages and discharges...................................... 11

Rainfall and runoff studies........................................................... 12

Flood of January 1938 in Connecticut, by L. W. Furness....................... 12

Introduction ..................................................................... 12

General features of the flood.......................................................... 15

Weather associated with floods in Connecticut on January 25-26, 1938, by G. N. Brancato............................................................... 17

Antecedent conditions ................................................................... 24

Precipitation …............................................................................... 29

Areal distribution ............................................................... 38

Area-depth relations .............................................................. 38

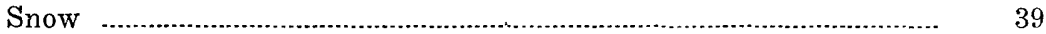

Frost in the ground...................................................................

Stages and discharges at stream-gaging stations........................ 46

Explanation of data.................................................................. 46

Thames River Basin................................................................. 51

Willimantic River near South Coventry, Conn.................. 51

Shetucket River near Willimantic, Conn.......................... $\quad 52$

Hop River near Columbia, Conn........................................ 54

Natchaug River at Willimantic, Conn............................... $\quad 55$

Quinebaug River at Quinebaug, Conn.............................. $\quad 56$

Quinebaug River at Putnam, Conn....................................... 58

Quinebaug River at Jewett City, Conn............................. $\quad 59$

Five Mile River at Killingly, Conn..................................... $\quad 60$

Moosup River at Moosup, Conn......................................... $\quad 62$

Yantic River at Yantic, Conn............................................... 63

Connecticut River Basin............................................................. 64

Connecticut River at Hartford, Conn..................................... 64

Scantic River at Broad Brook, Conn....................................... $\quad 65$

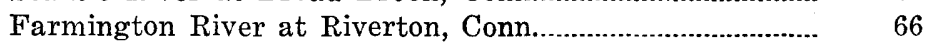

Farmington River at Tariffville, Conn................................. 67

Otis Reservoir at Cold Spring, Mass.................................. $\quad 69$

Barkhamsted Reservoir near Barkhamsted, Conn............. $\quad 70$

East Branch Reservoir at New Hartford, Conn................... $\quad 71$

Nepaug Reservoir near Collinsville, Conn.......................... $\quad 72$

Burlington Brook near Burlington, Conn............................ 73

South Branch of Park River at Hartford, Conn................. $\quad 74$

Park River at Hartford, Conn....................................... $\quad 76$

North Branch of Park River at Hartford, Conn................. $\quad 77$

Hockanum Piver at outlet of Shenipsit Lake, at Rockville, Conn. 
Hंockanum River near East Hartford, Conn.

Salmon River near East Hampton, Conn.

East Branch of Eightmile River near North Lyme, Conn.

West Branch of Eightmile River near North Lyme, Conn.

Quinnipiac River at Wallingford, Conn............................... $\quad 85$

Housatonic River Basin......................................................... 86

Housatonic River at Falls Village, Conn........................... 86

Zoar Lake at Stevenson, Conn........................................ $\quad 87$

Housatonic River at Stevenson, Conn............................... 88

'Tenmile River near Gaylordsville, Conn............................ $\quad 89$

Rocky River at outlet of Candlewood Lake, near New Milford, Conn.

Still River near Lanesville, Conn.

Shepaug River at outlet of Shepaug Reservoir, at Woodville, Conn.

Shepaug River near Roxbury, Conn..

Pomperaug River at Southbury, Conn.

Naugatuck River near Thomaston, Conn.

Naugatuck River near Naugatuck, Conn.

Leadmine Brook near Thomaston, Conn.

Branch of Naugatuck River at outlet of Wigwam Reservoir, near Thomaston, Conn.

Saugatuck River Basin.

Saugatuck River near Westport, Conn........................... 101

Summary of flood discharges........................................................ 103

Storage reservoirs ...................................................................... 106

Rainfall and runoff studies................................................... 109

Comparison with other floods............................................... 119

Thames River Basin .................................................... 122

Connecticut River Basin...................................................... 123

Housatonic River Basin..................................................... 123

Flood of June 1938 in New Jersey, by Otto Lauterhahn and W. B.

Introduction and general features.......................................... 124

Monthly distribution of floods........................................... 127

Meteorologic features of the flood.............................................. 128

Antecedent conditions ........................................................ 128

Weather conditions associated with the storm ....................... 129

Precipitation ................................................................... 131

Stages and discharges......................................................... 143

Summary of flood stages and discharges....................................... 144

Rainfall and runoff studies................................................... 147

Floods of July 1938 in the northeastern States, by L. W. Furness,

C. E. Knox, Otto Lauterhahn, C. C. McDonald, and W. B. Langbein

Introduction and general features.

Meteorologic and hydrologic conditions.................................... 159

Weather associated with floods of July 17-25, 1938, by A. K. 
Floods of July 1938 in the Northeastern States-Continued

Meteorologic and hydrologic conditions-Continued

Antecedent conditions

Precipitation

Areal distribution

Area-depth relations

Stages and discharges at stream-gaging stations.

Merrimack River Basin.

Concord River below River Meadow Brook, at Lowell, Mass.

Wastage from Sudbury River Basin at outlets of Framingham Reservoir No. 1, near Framingham Center, Mass., and Lake Cochituate at Cochituate, Mass.

Ipswich River at South Middleton, Mass............................. 203

Ipswich River near Ipswich, Mass...................................... 204

Charles River Basin............................................................... 205

Charles River at Charles River Village, Mass................... 205

Charles River at Waltham, Mass..................................... 206

Mother Brook at Dedham, Mass........................................ 208

Taunton River Basin ............................................................. 209

Taunton River at State Farm, Mass.................................. 209

Wading River near Norton, Mass....................................... $\quad 210$

Providence River Basin..................................................... 211

Blackstone River at Worcester, Mass............................... 211

Blackstone River at Woonsocket, R. I.............................. 212

Thames River Basin................................................................. 214

Willimantic River near South Coventry, Conn................... 214

Shetucket River near Willimantic, Conn........................... 215

Hop River near Columbia, Conn....................................... 216

Natchaug River at Willimantic, Conn.............................. 218

Quinebaug River at Quinebaug, Conn.............................. 219

Quinebaug River at Putnam, Conn...................................... 221

Quinebaug River at Jewett City, Conn.............................. 222

Five Mile River at Killingly, Conn..................................... 224

Moosup River at Moosup, Conn.......................................... $\quad 225$

Yantic River at Yantic, Conn............................................. $\quad 226$

Connecticut River Basin........................................................ 228

Connecticut River at Hartford, Conn................................. 228

Scantic River at Broad Brook, Conn................................ 229

Farmington River near New Boston, Mass......................... 230

Farmington River at Riverton, Conn................................. 231

Farmington River at Tariffville, Conn................................. 233

Otis Reservoir at Cold Spring, Mass..................................... 234

Barkhamsted Reservoir near Barkhamsted, Conn................ 235

East Branch Reservoir at New Hartford, Conn.................. $\quad 236$

Nepaug Reservoir near Collinsville, Conn........................... $\quad 237$

Burlington Brook near Burlington, Conn.............................. 238

South Branch of Park River at Hartford, Conn.................. $\quad 240$

Park River at Hartford, Conn........................................ 241

North Branch of Park River at Hartford, Conn................. 243 
Floods of July 1938 in the Northeastern States-Continued

Stages and discharges at stream-gaging stations-Continued

Connecticut River Basin-Continued

Hockanum River at outlet of Shenipsit Lake, at Rockville, Conn.

Hockanum River near East Hartford, Conn.

Salmon River near East Hampton, Conn..

East Branch of Eightmile River near North Lyme, Conn.

West Branch of Eightmile River near North Lyme, Conn.

Quinnipiac River at Wallingford, Conn.

Housatonic River Basin

Housatonic River at Coltsville, Mass.

Housatonic River near Great Barrington, Mass.

Housatonic River at Falls Village, Conn

Zoar Lake at Stevenson, Conn.

Housatonic River at Stevenson, Conn.

Tenmile River near Gaylordsville, Conn..

Rocky River at outlet of Candlewood Lake, near New Milford, Conn.

Still River near Lanesville, Conn.

Shepaug River at outlet of Shepaug Reservoir, at Woodville, Conn.

Shepaug River near Roxbury, Conn..

Pomperaug River at Southbury, Conn.

Naugatuck River near Thomaston, Conn.

Naugatuck River near Naugatuck, Conn.

Leadmine Brook near Thomaston, Conn.

Branch of Naugatuck River at outlet of Wigwam Reservoir, near Thomaston, Conn.

Saugatuck River near Westport, Conn................................ 270

Hudson River Basin....................... 272

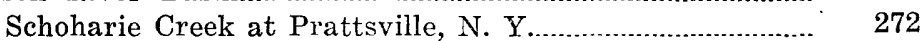

Schoharie Creek at Gilboa Dam, at Gilboa, N. Y............... 272

Catskill Creek at Oak Hill, N. Y.......................................... 273

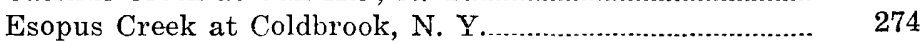

Rondout Creek near Lowes Corners, N. Y........................... 274

Rondout Creek near Lackawack, N. Y................................. 276

Rondout Creek at Rosendale, N. Y....................................... 277

Chestnut Creek above Red Brook, at Grahamsville, N. Y. $\quad 279$

Wallkill River near Unionville, N. Y............................... 280

Wallkill River at Pellets Island Mountain, N. Y................ 281

Wallkill River at Gardiner, N. Y...................................... 281

Hackensack River Basin................................................. 282

Oradell Reservoir at Oradell, N. J...................................... 282

Hackensack River at New Milford, N. J.............................. 283

Woodcliff Lake at Hillsdale, N. J........................................ 284

Pascack Brook at Westwood, N. J....................................... 285

Passaic River Basin.............................................................. 287

Rockaway River above reservoir at Boonton, N. J........... 287 
Floods of July 1938 in the Northeastern States-Continued

Stages and discharges at stream-gaging stations-Continued

Passaic River Basin-Continued

Boonton Reservoir at Boonton, N. J.

288

Rockaway River below reservoir at Boonton, N. J............ 289

Saddle River at Lodi, N. J............................................ 291

Elizabeth River Basin............................................................. 292

Elizabeth River at Irvington, N. J................................. $\quad 292$

Elizabeth River at Elizabeth, N. J................................... 293

Rahway River Basin................................................................ 295

Rahway River near Springfield, N. J................................. 295

Rahway River at Rahway, N. J....................................... 296

Raritan River Basin............................................................. 298

South Branch of Raritan River at Stanton, N. J.............. 298

Raritan River at Manville, N. J.......................................... 299

Neshanic River at Reaville, N. J......................................... $\quad 300$

North Branch of Raritan River at Milltown, N. J............ 302

Lake Carnegie at Princeton, N. J................................... 303

Millstone River near Kingston, N. J.................................. 304

Millstone River at Blackwells Mills, N. J........................... 305

Green Brook at Plainfield, N. J........................................ 307

Reservoir on Lawrence Brook at Farrington Dam, N. J. 308

Lawrence Brook at Farrington Dam, N. J....................... 309

Deep Run near Brownton, N. J........................................ $\quad 310$

Coastal basins in New Jersey................................................. 312

Tinton Falls Reservoir near Red Bank, N. J................... 312

Swimming River near Red Bank, N. J............................. $\quad 313$

Manasquan River at Squankum, N. J.............................. $\quad 315$

Toms River near Toms River, N. J.................................... $\quad \mathbf{3 1 6}$

Cedar Creek at Lanoka Harbor, N. J.................................. $\quad 318$

Batsto River at Batsto, N. J.......................................... $\quad 320$

East Branch of Wading River at Harrisville, N. J............ 321

Great Egg River at Folsom, N. J..................................... 322

Manantico Creek near Millville, N. J................................ 324

Delaware River Basin......................................................... $\quad 327$

East Branch of Delaware River at Margaretville, N. Y. $\quad \mathbf{3 2 7}$

East Branch of Delaware River at Harvard, N. Y............ $\quad 327$

East Branch of Delaware River at Fishs Eddy, N. Y........ $\quad 328$

Delaware River at Port Jervis, N. Y............................... $\quad 329$

Mill Brook at Arena, N. Y................................................... $\quad 329$

Tremper Kill near Shavertown, N. Y.............................. $\quad 330$

Terry Clove Kill near Pepacton, N. Y............................... 330

Beaver Kill at Craigie Clair, N. Y.................................. 331

Beaver Kill at Cooks Falls, N. Y........................................ 332

Willowemac Creek near Livingston Manor, N. Y................ $\quad 333$

Little Beaver Kill neär Livingston Manor, N. Y................. 335

West Branch of Delaware River at Delhi, N. Y................ $\quad 336$

West Branch of Delaware River at Hale Eddy, N. Y........ $\quad 336$

Little Delaware River near Delhi, N. Y............................. 337

Neversink River at Halls Mills, near Curry, N. Y.......... 337

Neversink River at Woodbourne, N. Y............................ 339 
Floods of July 1938 in the Northeastern States-Continued

Stages and discharges at stream-gaging stations-Continued

Delaware River Basin-Continued

Neversink River at Oakland Valley, N. Y.

Neversink River at Godeffroy, N. Y.

Flat Brook near Flatbrookville, N. J.

Paulins Kill at Blairstown, N. J.

Lake Hopatcong at Landing, N. J.

Musconetcong River near Bloomsbury, N. J.

Assunpink Creek at Trenton, N. J.

North Branch of Rancocas Creek at Pemberton, N. J.

Oldmans Creek near Woodstown, N. J.

Summary of flood discharges

Storage reservoirs

Flood-crest stages

Rainfall and runoff studies.

Flood of August 1938 in the Catskill Mountain region, New York, by

C. C. McDonald and W. B. Langbein

Introduction and general features.

Antecedent conditions

Precipitation

Stages and discharges at river-measurement stations

Storage

Summary of flood stages and discharges

413

Rainfall and runoff studies.

\section{ILLUSTRATIONS}

Plate 1. A, January 1938 flood passing over dam on Housatonic River at Stevenson, Conn.; $B$, January 1938 floodwaters encroaching on cottages along Housatonic River.

2. Marooned residents rescued by police in boats. Photo by Hartford (Conn.) Courant

3.. Isohyetal map of Connecticut and parts of adjoining States, showing total precipitation, in inches, January 20-26, 1938

4. Isohyetal map of Connecticut and parts of adjoining States, showing total precipitation, in inches, January 24-26, 1938

5. Map of Connecticut and parts of adjoining States, showing depth, in inches, of water equivalent of snow on ground January 20, 1938

6. Isohyetal map of New Jersey and parts of adjoining States, showing total precipitation, June 25-29, 1938

7. $A$, Concrete box culvert destroyed by July 1938 flood at Killingworth, Conn.; $B$, Aerial photograph of reach of Charles River near Medfield Junction, Mass. Photo by Corps of Engineers, U. S. Army.

8. A, Quinebaug River at Danielson, Conn., near peak, July 24, 1938; $B$, Five Mile River at Danielson, Conn., near peak, July 24, 1938. Photos by Guerino Del Pesco. 
9. Flood scenes on Rondout Creek, July 1938: A, Barn washed from foundation near Lowes Corners, N. Y.; $B$, Culvert near Grahamsville, N. Y. Photos by Middletown (N. Y.) Times-Herald

10. Flood scenes near Florida, N. Y., July 1938: $A$, Onion fields overflowed by Quaker Creek; $B$, Onion farmer's home surrounded by floodwaters of Quaker Creek. Photos by Middletown (N. Y.) Times-Herald.

11. Map of North Atlantic States, showing locations of principal drainage basins, precipitation stations, and total precipitation, July 17-25, 1938. In pocket

12. Map showing locations of flood-flow determinations in the areas covered by this report In pocket

13. Flood scenes, August 1938: A, Pearl Street, Livingston Manor, N. Y.; $B$, Summer residence near Godeffrey, N. Y. Photos by Middletown (N. Y.) Times-Herald.

14. Highway scenes, flood of August 1938: $A$, State Highway 52 near Liberty, N. Y., after being overflowed by Mongaup River; $B$, State Highway 211 near Cuddebackville, N. Y., overflowed by Neversink River. Photos by Middletown (N. Y.) Times-Herald.

Figure 1. Map showing location of areas in which record-breaking or noteworthy floods occurred in January 1938.

2. Isentropic chart of the United States, January $24,1938 \ldots \ldots . . \quad 19$

3. Isentropic chart of the United States, January 25, 1938........

4. Surface weather chart of eastern United States and Canada, 7:30 p.m., January 24, 1938

5. Vertical cross section of atmosphere, January $24,1938$.

6. Surface weather chart of eastern United States and Canada, 7:30 a.m., January 25, 1938

7. Monthly precipitation, snowfall, temperature, and accumulated departures from normal for Connecticut, October 1, 1937, to February 28, 1938

8. Comparison of typical records of ground-water level with precipitation and stream flow

9. Daily precipitation and temperature at representative stations in Connecticut for the period December 1, 1937, to February 28, 1938 .

10. Hourly precipitation at representative stations in and near Connecticut, January 20-26, 1938.

11. Graphs of daily discharges at various stream-gaging stations for the period January 1 to February 28, 1938.

12. Hydrographs of discharge at various stream-gaging stations in the Thames River Basin, January 1938.

13. Hydrographs of discharge at various stream-gaging stations in the Connecticut River Basin, January 1938.

14. Hydrographs of discharge at various stream-gaging stations in the Housatonic River Basin, January 1938. 
15. Chart showing maximum discharges, in second-feet per square mile, for drainage basins given in tables 8 and 24 for floods of January and July 1938 in comparison with maximum discharges of record for Connecticut prior to 1939

16. Hydrograph of discharge of Naugatuck River near Thomaston, Conn., showing method of analysis used in determining the direct runoff associated with the flood of January 1938

17. Relation of water equivalent of snow plus storm rainfall to direct runoff for river-measurement stations in Connecticut during flood of January 1938.

18. Relation of water equivalent of snow plus storm rainfall to basin retention for river-measurement stations in Connecticut during flood of January 1938.

19. Map of New Jersey showing drainage areas in which noteworthy floods occurred during June 1938.

20. Surface weather chart of the United States, 7:30 a.m., June 27, 1938.

21. Hourly precipitation at selected recording rain gages in New Jersey during storm of June 1938.

22. Hydrographs of discharge at selected gaging stations in New Jersey during flood of June 1938.

23. Hydrograph of discharge for gaging station on Deep Run near Brownton, N. J., and graph of precipitation at Marlboro, N. J., during flood of June 1938.

24. Relation between precipitation and associated direct runoff during flood of June 1938 in New Jersey.

25. Hydrographs of discharge at selected stream-gaging stations in New Jersey during flood of July 1938.

26. Hydrographs of discharge at selected stream-gaging stations in New York during flood of July 1938.

27. Hydrographs of discharge at selected stream-gaging stations in Connecticut River Basin, Conn., during flood of July 1938

28. Hydrographs of discharge at selected stream-gaging stations in Thames River Basin, Conn., during flood of July 1938

29. Map showing drainage basins in which record-breaking or extraordinary floods occurred in July 1938

30. Diagrams showing temperature distribution in the atmosphere above Washington, D. C., July 19-23, 1938

31. Comparison of typical record of ground-water levels with precipitation and stream flow in Connecticut, June to August 1938

32. Cumulative relative soil moisture in Park River Basin above Hartford, Conn., April to September 1938.

33. Hourly precipitation at selected recording rain gages during storm of July 1938 .

34. Hydrographs of daily discharges at selected stream-gaging stations for the period June 1 to August 31, 1938 . 
35. Chart showing maximum discharges during flood of July 1938 , in second-feet per square mile, in relation to drainage area

36. Hydrograph of discharge of Naugatuck River near Thomaston, Conn., showing method of analysis used in determining the direct runoff associated with the flood of July 1938

37. Relation between precipitation and associated direct runoff during flood of July 17-25, 1938, for basins in Massachusetts and Connecticut.

38. Relation between precipitation and associated direct runoff during flood of July 17-25, 1938, for basins in New York...

39. Relation between precipitation and associated direct runoff during flood of July 17-25, 1938, for basins in New Jersey

40. Graph of mean areal precipitation and hydrograph of discharge of Rondout Creek near Lackawack, N. Y., for the storm period July 17-25, 1938 ..

41. Hydrographs of discharge at stream-gaging stations on Rondout Creek during the flood of August 1938.

42. Hydrographs of discharge at stream-gaging stations in the Beaver Kill Basin during the flood of August 1938............

43. Hydrographs of discharge at stream-gaging stations on Neversink River during the flood of August 1938.

44. Drainage map of Catskill Mountain region, New York..

45. Map of Catskill Mountain region showing lines of equal precipitation, August 6-11, 1938.

46. Hourly precipitation, in inches, August 1-15, 1938, at recording rain gages in or near the Catskill Mountain region

47. Map of Catskill Mountain region showing lines of equal precipitation, night of August 10, 1938.

48. Graph of annual floods at five selected stream-gaging stations in the Catskill Mountain region

49. Hydrograph of discharge of Rondout Creek near Lackawack, N. Y., showing method of analysis used in determining direct runoff associated with flood of August 1938

50. Relation between precipitation and associated direct runoff during flood of August 1938.

\section{TABLES}

TABLE 1. Daily precipitation, in inches, January 20-26, 1938...........

2. Precipitation, in inches, for period ending at indicated time, January 24-26, 1938

3. Rate and duration of precipitation, January $24-26,1938 \ldots \ldots . .$.

4. Depth of average rainfall in relation to areal extent for notable storms in the North Atlantic Coast region

5. Snow depth, in inches, on ground at indicated days, December 1937 and January 1938. 
6. Snow depth, in inches, and water equivalent of snow, in inches, at snow course in Connecticut, Massachusetts, and New York during January and February 1938

7. Frost conditions in cemeteries at indicated towns in Massachusetts and Connecticut during winter of 1937-38.

8. Maximum discharges for flood of January 1938 in Connecticut

9. Precipitation, water equivalent of snow, and associated direct runoff of flood of January 1938 in Connecticut.

10. Comparison of recent floods in Connecticut

11. Annual floods of two selected streams in New Jersey.

12. Monthly precipitation and temperature at Indian Mills, N. J., during spring and summer of 1938

13. Daily precipitation, in inches, June 20-30, 1938

14. Precipitation, in inches, for period ending at indicated time, June 1938

15. Intense rainstorms in New Jersey and nearby parts of adjoining States

16. Topographic characteristics of the Manasquan River Basin and the Great Egg River Basin

17. Maximum discharges for flood of June 1938 in New Jersey

18. Flood-crest stages, June 1938 .

19. Precipitation and associated direct runoff of flood of June 1938 in New Jersey

20. Monthly precipitation and temperature in New Jersey and Connecticut, March to July 1938.

21. Daily precipitation, in inches, July 15-26, 1938

22. Precipitation, in inches, for period ending at indicated time, July 1938

23. Maximum storm precipitation during indicated intervals, storm of July 17-25, 1938.

24. Maximum discharges during flood of July 1938

25. Flood-crest stages, July 1938.

26. Altitude, in feet, at indicated places in the Elizabeth River Basin for floods in which the peak discharge was 1,200 second-feet or more at Westfield Avenue, Elizabeth, N. J.

27. Altitude, in feet, at indicated places in the Rahway River Basin for floods in which the altitude was 10.0 feet or higher at Church Street, Rahway, N. J..

28. Altitude, in feet, at indicated places for several previous floods on Green Brook in the Raritan River Basin, N. J....

29. Precipitation and associated direct runoff for flood of July 1938

30. Approximate volumes of rainfall and runoff, in inches, over the Rondout Creek Basin during the storm of July 17-25, 1938 
31. Monthly distribution of annual floods at two river-measurement stations in the Catskill Mountain region

32. Monthly precipitation and temperature at Jeffersonville, $\mathrm{N}$. Y., during the spring and summer of 1938

33. Daily precipitation, in inches, August 5-12, 1938, at stations in and near the Catskill Mountain region, New York

34. Areas enclosed within indicated isohyets for storm of August 6-11, 1938

35. Precipitation, in inches, for period ending at indicated time, August 1938

36. Maximum discharges during flood of August 1938 in the Catskill Mountain region

37. Annual floods at five selected stream-gaging stations in the Catskill Mountain region.

38. Precipitation and associated direct runoff of flood of August 1938

39. Precipitation and direct runoff associated with the several peaks during the flood of August 1938. 



\section{MINOR FLOODS OF 1938 IN THE NORTH A'TLANTIC STATES}

\section{ABSTRACT}

Five noteworthy floods occurred during 1938 in the North Atlantic States. The first flood was in January, the others were in June, July, August, and September. The floods of January, June, and August were relatively local events in Connecticut, New Jersey, and New York, respectively. The floods of July and September were widespread, reaching from New Jersey and New York to New Hampshire in generally coincident locations. The flood of September, the most severe, is described in appropriate detail in Water-Supply Paper 867; the others in this volume are in separate sections arranged chronologically.

Extraordinary floods in Connecticut during January 1938 resulted from a critical combination of warm rainfall and virtual overnight melting of the accumulated snowfall of winter. Seven small streams in central and western Connecticut rose to levels on January 25 higher than those reached during the great floods of March 1936. Crest discharge of these streams approximated 100 second-feet per square mile. Ice cover was loosened and sent downstream in recurrent jams. In general, the larger rivers did not attain extraordinary stages. The Connecticut River at Hartford peaked at a stage 3.6 feet above ordinary flood level. Direct damage by the flood was relatively small. Snow cover on January 20, at the beginning of the rains, varied from 0.25 inch along the coast to 2.75 inches water equivalent in the northern part of the State. Precipitation between January 24 and 26 exceeded 2.75 inches in only three small areas. Total supply as water in snow and precipitation did not exceed 4.8 inches over any tributary area. Maximum measured flood run-off was 2.7 inches.

The flood of June 1938 in New Jersey was the immediate result of a 30-hour rainstorm on June 26-27 that centered along a line extending from Odessa, Del., to Milton, N. J. Storm rainfall exceeded 5 inches over a total area of 2,900 square miles. River stages in the central parts of the storm area rose to levels that approached and on a few rivers exceeded previous maxima of record. Damage was extensive throughout the storm area, especially in Burlington, N. J., where Sylvan Lake Dam failed. The highest rate of flow per unit of area measured was 88 second-feet per square mile. However, all peak discharges were exceeded during the later floods of 1938 or by the flood of September 1, 1940, which produced discharges over 1,000 second-feet per square mile in southern New Jersey. The maximum volume of direct runoff during the flood, expressed in mean depth in inches on the drainage area, was 2.1 inches.

From July 17 to 25,1938 , there was an irregular series of rainstorms over the eastern seaboard that brought more than 10 inches of rain over an area of 2,000 square miles and more than 6 inches over 23,000 square miles. Nearly 14 inches of rain fell at Long Branch, N. J. Extraordinary floods occurred mainly in the smaller tributary streams. Damage to highways, homes, factories, and crops, particularly the tobacco crop in Connecticut, was extensive. Crest discharges at 12 gaging stations exceeded those previously observed. Maximum rates of discharge varied from 601 second-feet per 
square mile for an area of 2.91 square miles in New Jersey to 35 second-feet per square mile for an area of 711 square miles in Connecticut. Antecedent soil moisture prior to the storm was probably normal or a little above. The maximum volume of direct runoff was 4.75 inches in Massachusetts, 5.6 inches in eastern Connecticut, 6.75 inches in the Catskill Mountain region of New York, and 4.95 inches in the Raritan River Basin of New Jersey. Infiltration indices from 0.09 to 0.21 inch per hour were computed, such rates being within the range defined for basins in the same areas during the floods of September 1938.

The flood of August 6-11, 1938, in the Catskill Mountain region of New York resulted from heavy rains with a maximum of 8 inches at two centers. Rainfall exceeded 3 inches over more than 3,000 square miles. The storm was located over almost the same area as the greater storm of July, which occurred 3 weeks previously. The July storm so diminished the absorptive capacity of the ground that the volumes of runoff and the peak discharges were greater than average, though not of record-breaking magnitude. River stages. particularly in the Delaware River Basin, exceeded those reached in July, but damage in general was not so extensive. Discharges at five gaging stations exceeded 100 second-feet per square mile, and the greatest rate per square mile was 154 second-feet for an area of 12.2 square miles. More than 3 inches of direct runoff was measured at six gaging stations.

The report presents records of stage and discharge at 123 stream-gaging stations, records of storage in many reservoirs, summaries of flood discharges with comparative data, records of daily measurement of precipitation at about 575 places, and records of more frequent observations at about 76 places of measurement. The report also includes basic information in regard to the general weather conditions associated with the floods, analyses of rainfall and runoff, and many other data pertinent to the floods.

\section{INTRODUCTION}

Along the North Atlantic seaboard the year 1938 was notable for its sequence of floods. During the first month of the year, widespread floods occurred in Connecticut as a result of a critical combination of rainfall and virtual overnight melting of the accumulated snow of winter. Seven small streams in central and western Connecticut reached higher levels on January 25 than ever previously recorded.

There were three floods during the summer. In the period June 26-27 an area of 2,900 square miles in New Jersey and the adjoining part of Delaware received 5 inches or more of rainfall. River levels in the central part of the storm area rose to heights that approached and on a few rivers exceeded previous maxima of record.

During the period July 17-25 an irregular series of showers and thunderstorms deposited widely varying concentrations of rain over the eastern seaboard from Florida to New Hampshire. Within the storm area north of the Potomac River, where the floods were most severe, total precipitation exceeded 6 inches over 23,000 square miles. As a result, crest discharges at twelve long-estab- 
lished gaging stations exceeded those previously observed, and in general the floods were widespread and severe.

About 2 weeks later, from August 6 to 11, heavy rain again fell over the Catskill Mountain region in an area almost coincident with that of the July storm in the region. Rainfall exceeded 5 inches over an area of 950 square miles. Although the rainfall during the July storm was greater, the retentive capacity of the ground after that storm was so diminished that the runoff from the two storms was comparable in volume. Flood discharges closely approached but did not exceed previously recorded maxima. The floods were highest in the western part of the Catskill Mountains that is tributary to the Delaware River.

The floods and hurricane of September 1938 climaxed this sequence. The damaging effects of a combination of river floods, hurricane winds, and ocean storms produced unsurpassed havoc in the North Atlantic States from New Jersey to New Hampshire. Storm precipitation between September 17 and 21, 1938, averaged 11.5 inches over 10,000 square miles that generally coincided with the area of heavy rain during July. Peak stages in many places exceeded those previously recorded during the outstanding storms of November 1927 and March 1936. The floods of September 1938 are described in detail in Water-Supply Paper 867.

The floods of 1938 , occurring in close sequence comparatively soon after the floods of November 1927 in New England, and the widespread inundations of March 1936 impressed upon the inhabitants of the flooded regions, as never before, the seriousness of the problem of controlling and confining flood waters. Each local, State, or Federal organization engaged in formulating plans for protective measures requires sound and adequate basic information relating to the stages, discharges, and other characteristics of these outstanding floods that have affected their particular areas. Such information has been published by the Geological Survey, United States Department of the Interior, for the floods of November 1927, March 1936, and September 1938 in Water-Supply Papers $636-\mathrm{C}, 798$, and 867 , respectively.

This report aims to complete the history of the floods of 1938 for the North Atlantic States. It is divided into four parts, each part treating one of the floods from January to August 1938.

\section{ADMINISTRATION AND PERSONNEL}

The field and office work incident to the preparation of this report was performed by personnel of the Water Resources Branch of the Geological Survey under the general administrative direction of N. C. Grover, chief hydraulic engineer, up to the time of 
his retirement from Government service on January 31, 1939, then under C. G. Paulsen, acting chief hydraulic engineer, until October 17, 1939, and thereafter under G. L. Parker, chief hydraulic engineer. In the Surface Water Division of the branch, administrative direction was under C. G. Paulsen, chief, until April 1940, and thereafter under R. G. Kasel, acting chief.

Engineers in the district offices of the Geological Survey in the States of New Jersey, New York, Connecticut, and Massachusetts prepared the report, as credited in appropriate places in the report, computed the discharge data, and compiled records of stage, precipitation, and other related information concerning the floods in their respective districts. These engineers also prepared descriptions of the floods and general textual discussion. The general review, analysis, and integration of the data, as well as the assembling of the report, were carried on in the Division of Water Utilization, R. W. Davenport, chief, by W. B. Langbein, associate engineer, and M. D. Brands, assistant engineer.

\section{ACKNOWLEDGMENTS}

The Geological Survey, acting through its district field offices, cooperates with State and municipal agencies. Acknowledgment is made to these cooperating agencies for participation in the systematic collection of the records of river discharge that form the broad base for the specific flood information and in the maintenance of field organizations in which engineers trained for investigation of this kind were available for the special studies related to the collection of the field data and to the preparation of the report.

Information appearing in this report has been obtained from many sources, including individuals, corporations, and local, State, and Federal governmental organizations. Financial cooperation in connection with the regular river-measurement program of the Geological Survey in the areas covered by this report has been received from the following agencies: In Connecticut, the State Water Commission, the city of New Britain Board of Water Commissioners, and the city of Hartford Flood Investigation and Improvement Commission; in Massachusetts, the Department of Public Works, the Department of Public Health, the Metropolitan District Water Supply Commission, and the Metropolitan District Commission; in New Jersey, the State Water Policy Commission. the North Jersey District Water Supply Commission, and the Delaware River Joint Toll Bridge Commission; in New York, the State Water Power and Control Commission, the State Department of Public Works, the State Department of Conservation, and 
the New York City Board of Water Supply.

Federal agencies to whom acknowledgments are made for services rendered or data furnished include the Weather Bureau, the Corps of Engineers of the United States Army, the Soil Conservation Service, and the Works Progress Administration. Some financial assistance was rendered by the Federal Emergency Administration of Public Works in accordance with the National Industrial Recovery Act of 1933, through an allotment of funds to the Geological Survey in July 1938 for survey of floods and droughts.

Special assistance in collecting data and furnishing records was also rendered by the Connecticut State Water Commission, the Massachusetts Department of Public Health, the Water Bureau of the Hartford Metropolitan District, the Connecticut Light \& Power Co., the Connecticut Power Co., the Hartford Electric Light Co., the Bureau of Engineering of the city of Waterbury, Conn., the Collins Co. of Connecticut, the Water \& Aqueduct Co. of Rockville, Conn., the New York City Department of Water Supply, Gas \& Electricity, and the Hackensack Water Co. So far as practicable, acknowledgments for individual contributions of information are given at appropriate places in the report.

\section{GENERAL DESCRIPTION OF INFORMATION}

\section{ANTECEDENT CONDITIONS}

To a considerable extent the foundation of a flood may be laid on the meteorologic events that precede the directly causative storm. In winter the most significant antecedent factors are the amount of snow on the ground and the extent and depth of frost in the ground. Information regarding these important factors is given in the section on the winter flood of January 1938 to which they apply. Of some importance in winter but of transcendary significance in the nonwinter seasons are the factors of soil moisture and ground-water levels, which influence the rate of infiltration into the soil and the volume available for storage in the soil and as ground water. As satisfactory direct measures of these quantities are not generally available, recourse is made to relative or indirect inference from pertinent climatologic data. Monthly variations from normal rainfall and temperatures based on Weather Bureau records are presented as a convenient means for studying seasonal conditions preceding the flood.

Tables of monthly precipitation, departure of monthly precipitation from normal, cumulative departure from normal for 3 or 4 months preceding and including the month in which the flood occurred, and monthly mean temperature and departure from 
normal are given for each flood. From the data in these tables the trend in soil moisture and ground-water levels can be inferred.

A persistence of above-normal precipitation in combination with below-normal temperature would strongly suggest above-normal soil moisture and hence a condition conducive to a lesser infiltration and retention of water in the soil. Ground-water levels under such a combination would likewise tend to be higher, and therefore available ground-water storage would be correspondingly low. A combination of below-normal precipitation and abovenormal temperature would deplete soil moisture, and ground-water levels would recede. This combination of conditions preceded the outstanding storm of September 16-17, 1932, in New England, which, although it averaged more than 9 inches over 2,000 square miles, did not produce any flood. During 1938, however, rainfall was generally above normal, as is evident by the succession of flood-producing rainstorms. Monthly temperatures were both above and below normal, averaging above normal for the whole season. Specific data and conclusions with respect to the effect of antecedent precipitation and temperature are given under the heading "Antecedent conditions" for the respective floods.

Relative monthly soil-moisture changes during the summer of 1938 are presented for the Park River Basin in Connecticut in the section on the flood of July 1938. Similar studies have been given for the Westfield River Basin in Massachusetts. ${ }^{1}$ These relative changes were computed from monthly precipitation, temperature, and stream flow by the methods explained in Water-Supply Paper $772^{2}$ and represent evaluations of the fluctuations in climatologic elements on soil moisture.

Ground-water levels were inferred generally from the record of a selected typical observation well. Fluctuations of water level in different wells varied widely, owing to the depth of the well and to the vagaries of geologic, topographic, and water-bearing characteristics. In general, however, the fluctuations were in accordance with the trend in precipitation and temperature, which affect ground-water levels in the same degree as soil moisture.

Areal ground-water levels can be inferred also from rates of base flow as derived from inspection of hydrographs of discharge. This procedure, explained in detail by Youngquist and Langbein, ${ }^{3}$

\footnotetext{
1 Paulsen, C. G., and others, Hurricane floods of September 1938: U. S. Geol. Survey Water-Supply Paper 867, p. 44, fig. 23, 1940.

${ }^{2}$ Hoyt, W. G., and others, Studies of relations of rainfall and runoff in the United States: U. S. Geol. Survey Water-Supply Paper 772, pp. 248-255, 1936.

3 Youngquist, C. V., and Langbein, Flood of August 1935 in the Muskingum River Basin, Ohio: U. S. Geol. Water-Supply Paper 869, pp. 73-88, 1941.
} 
was utilized in a study of the conditions preceding the flood of July 1938.

\section{PRECIPITATION}

Considerable effort was made to collect all available precipitation records within the area covered by this report and also in bounding areas, so that the basic information might be as complete and accurate as possible. These records were furnished by several governmental agencies, public utility companies, and many individuals whose cooperation in this connection is hereby acknowledged. The daily precipitation during the respective storm periods are tabulated herein (tables $1,13,21,33$ ) with appropriate footnotes indicating the time of measurement and the source of the record. The.numbers assigned to the rain gages conform to those used in Water-Supply Paper 867. ${ }^{4}$ A majority of the records of precipitation were collected by the Weather Bureau and unless otherwise noted were obtained from that source. The other records, received from the sources as credited in the tables, have been of great value in supplementing the data of the Weather Bureau. The rainfall stations are grouped by major drainage basins and subdivided by States. Records in adjoining minor coastal basins are listed under the general heading "Minor basins."

The figures in the tables are the reported amounts of daily precipitation. They are not strictly comparable for the individual days because the observers read their nonrecording gages at different times of day. Much difficulty in interpretation was caused by the non-uniform practice of listing morning readings either for the day on which the observation was made or for the previous day, sometimes without indicating the method used. Comparison of the readings with hourly records from the nearest automatic gages occasionally showed that the readings were not listed in conformity with the tabulating method reportedly in use. Accordingly, the morning readings are listed as furnished, but the footnotes explaining whether the precipitation was measured in the morning of the day indicated or the following day have been adjusted, if necessary, to make the readings conform to recordingstation data. Additional notations in the respective tables concerning days for which the precipitation was included in the following measurement, or for which the record was missing, were inserted after careful consideration definitely indicated that they were applicable.

Records of hourly precipitation based on autographic rain gages have also been compiled and presented in tahles included in the

4 Paulsen, C. G., and others, op. cit., pp. 46-61, table 4. 
reports on the respective floods. The time of day, so far as ascertainable, is given in these tables as eastern standard, the original records based on daylight saving time having been corrected. Otherwise the records are published as furnished without modification.

All complete precipitation records were used in the preparation of isohyetal maps (pls. 3, 6, 11, fig. 45) of total storm rainfall to show areal distribution. The maps have been reduced to an appropriate scale for publication from the original drawn on Geological Survey base maps (scale 1:500,000). In drawing the isohyets, groups of stations in close proximity were generally averaged, but extra weight was given to some of the more consistent records of the group. The isohyets were interpolated between the points of known precipitation. No weight was given to the influence of topography other than as defined by available records, as time did not permit a thorough analysis of the recorded data with respect to altitude and aspect. The basic data included in this report will enable a reader to make other more detailed analyses if desired.

\section{STAGES AND DISCHARGES AT STREAM-GAGING STATIONS}

One of the foremost purposes of this report is to publish useful, detailed information regarding the stages and discharges of streams during the floods described that will not be available in the summarized records of river discharge published annually in the surface water-supply papers of the Geological Survey. The justification for publication of such detailed information rests upon the recognized need for records of flood behavior that will show not only the mean daily discharge and the maximum rates of discharge during a flood, as usually published for a gaging station, but also the stages and rates of discharge at frequent times throughout the flood period which will make possible the definition of conditions of stage and discharge at all stations in a basin at a given time during the progress of a flood. This detail is essential for intensive and comprehensive studies of the characteristics of floods and promotes the formulation of appropriate plans for flood protection and control. It furnishes basic information for studying the behavior of flood crests, including the incidence of crests from the tributaries of a stream, the progress of flood crests throughout a river system, and other features useful in deriving the elements necessary for forecasting flood heights and for appraising the characteristics of different basins in the shedding of flood waters. Basic information is also provided for the consideration of the feasibility of detention reservoirs, channel 
improvement, forest management, soil treatment, flood forecasting, and other measures, with respect to their merits for reducing damage and losses caused by floods.

In general, records of gaging stations published in this report relate to those streams on which floods occurred or which are situated adjacent to the margins of the flooded regions and so serve to define the areal extent of the floods.

\section{EXPLANATION OF DATA}

The basic data systematically collected at stream-gaging stations consist of records of stage, measurements of discharge, and general information useful in determining the daily flow from the records of gage heights and discharge measurements.

The data presented in this report for each regular stream-gaging station comprise, in general, a description of the station, an upper table showing the daily discharges throughout a 2-month or longer period embracing a sufficient length of time before and after the flood to give a general perspective of the stream-flow conditions, and monthly volume of runoff. A lower table shows the stage and discharge at indicated times during the period of major flood flow in sufficient detail to permit the delineation of reasonably accurate graphs of the instantaneous stage and discharge throughout the flood period. The data are intended to be reasonably complete and explicit with respect to essential information, although they are presented in concise form.

The description of the station gives information concerning the type, location, and datum of the gage, the area of the drainage basin, and the record of gage heights. Information regarding gage heights describes the method of determining the stage during the flood and is of special technical significance because the flood conditions at some localities prevented the use of the usual method of obtaining records of stage and discharge. A statement regarding the stage-discharge relation explains briefly the methods used in the delineation of the rating curve over the ranges of stage in the respective flood and gives information on ice conditions or other factors that affected the stage-discharge relation. The description also includes information about auxiliary methods used in obtaining the discharge, such as by flow through turbines or gates or by venturi meters. The maximum stages and discharges at the gaging station are given for the respective flood and for the indicated period of record prior thereto, and also at some stations for floods antedating such period of continuous record. Miscellaneous notes and comments essential or helpful to an understanding of the record are included as remarks. When pertinent 
and when records are available, reference is made to daily or monthly records of change of contents of reservoirs and diversion that may be used to adjust the records of observed flow past the river-measurement station.

The lower tables showing stage and discharge at indicated times are designed to present the rise and recession of the flood in detail. In general, each table begins well before the beginning of the major flood rise and continues through the peak, until the flood has largely passed out of the river systems. Eastern standard time is used throughout. This table is accompanied by footnotes of supplemental records of stage and discharge necessary to afford an adequate record for the given river-measurement station.

The stages at the indicated times were obtained from records of continuous water-stage recorders, so far as such records were available. For stations for which the records of stage were intermittent and consisted of a few gage readings a day or for which the records were broken because of some failure in the recording system, stage graphs have been developed on the basis of all available information and the stages at indicated times have been obtained from these graphs.

In addition to records of the regular stream-flow stations, records are also included for the larger regulated reservoirs that affect the flow at regular stations. The data generally were furnished or computed from basic information furnished by the agencies that control the reservoirs. Acknowledgment is made herein for their cooperation in making available this valuable information, which shows the influence of storage reservoirs on flood flows and adds useful data on the characteristics of drainage basins in the shedding of flood waters. The descriptions of the reservoir stations and records are presented as similarly as possible to station descriptions of the regular gaging stations. For some of the reservoir stations, daily records of stage are shown, as well as diversion, if any, and change of contents as computed from a capacity curve. At the remaining reservoir stations, where observed discharge past the dam was measured by venturi meters or by calibrated spillways and gates or where it could be computed from spillwaydischarge formulas, the daily observed discharges, changes in contents of reservoirs, and discharges adjusted for changes in contents and diversions, if any, are shown. The adjusted mean monthly flows at these reservoirs compare favorably with those of adjacent regular stream-gaging stations, but the inaccuracies of the computations should be kept in mind in using the daily figures. The records are presented primarily to define clearly the modifications and adjustments introduced by storage. Storage 
reservoirs as a factor influencing the flood discharge are considered further as a part of the discussion of the respective floods.

The records are presented in the order regularly used by the Geological Survey in its water-supply papers, that is, by major drainage basins, from north to south, in order of their discharge into the Atlantic Ocean.

Reference may be made to water-supply papers of the Geological Survey for other available published records of flow of the streams discussed in this report. The records of flow published here are based on all the information available at this time. Channel erosion and deposition in the river channels owing to the flood have changed the stage-discharge relation at some streamgaging stations, and the changes may not have become fully defined within the period available for observations since the flood.

\section{SUMMARY OF FLOOD STAGES AND DISCHARGES}

The results of the determinations of maximum flood flows at existing stream-gaging stations and other places on streams in the flood areas where peak discharge has been determined have been tabulated for the respective floods (tables 8, 17, 24, 36) and compared with maximum flows previously recorded. The time of day in these tables is eastern standard time. The reference numbers conform to those given in Water-Supply Paper $847^{5}$ have been platted on plate 12 to aid in identifying the places where discharges were determined. Some miscellaneous determinations of discharge have been given reference numbers that are not in Water-Supply Paper 847 because they were not available when that paper was published.

The discharges for existing stream-gaging stations were determined by methods described in greater detail in the section "Stages and discharges at stream-gaging stations." For existing stream-gaging stations the method of determination is designated "stage-discharge relation." Where the recorded discharge was not measured at a regular station a brief reference is made to the method of determination. For general information, some discharges are presented for streams in basins adjoining or near those most affected by the floods.

The basic data and computations for the determinations of discharge may be examined in the respective field offices of the Geological Survey.

5 Williams, G. R., and Crawford, L. C., Maximum discharges at stream-measurement stations through December 31, 1937 ; U. S. Geol. Survey Water-Supply Paper 847, 272 pp., 1940. 


\section{RAINFALL AND RUNOFF STUDIES}

The studies of rainfall and runoff are presented with the object of advancing an understanding of the significant features of precipitation and runoff during each of the several floods. Moreover, comparisons between rainfall and associated runoff serve as tests of the accuracy and adequacy of the base data. The first step in the analysis was the determination of the mean areal precipitation and mean water equivalent of the snow cover over the drainage area above each river-measurement station in the flood areas; the second, the determinations of flood runoff directly attributable thereto; and finally, the comparisons of the precipitation with its associated direct runoff. These essential results are summarized in tables of rainfall and runoff that accompany the section on each flood.

The preparation of the isohyetal maps for the respective storms has already been explained in detail, and the preparation of a map of water equivalent of snow on the ground before the storm of January 1938 is explained in the section on that report. On each of these maps the areas between isohyets were measured by planimeter within the drainage basin above each stream-gaging station and weighted to give the mean areal precipitation or mean water equivalent of snow, in inches, over the respective drainage areas.

Volumes of direct runofi at each gaging station were computed by plotting hydrographs of discharge by using the tables of discharge at indicated times previously explained. On these plotted hydrographs estimates were made of the discharge generated by meteorologic events preceding the storm under consideration and of the discharge resulting from base flow. The enclosed area above the antecedent discharge and the estimated base flow was assumed to represent the increment in stream flow resulting from the direct runoff associated with the given storm. No general rules can be stated for this procedure as these estimates were based in large part on storm and hydrograph characteristics peculiar to each flood. Therefore, the procedure followed for performing this operation is explained in connection with each flood with due regard to its special features.

\section{FLOOD OF JANUARY 1938 IN CONNECTICUT}

By L. W. FurNesS

INTRODUCTION

During 1938 the State of Connecticut was subjected to three extraordinary floods in addition to several of smaller magnitude. For the climatic year ending September 30, 1938, the runoff from 


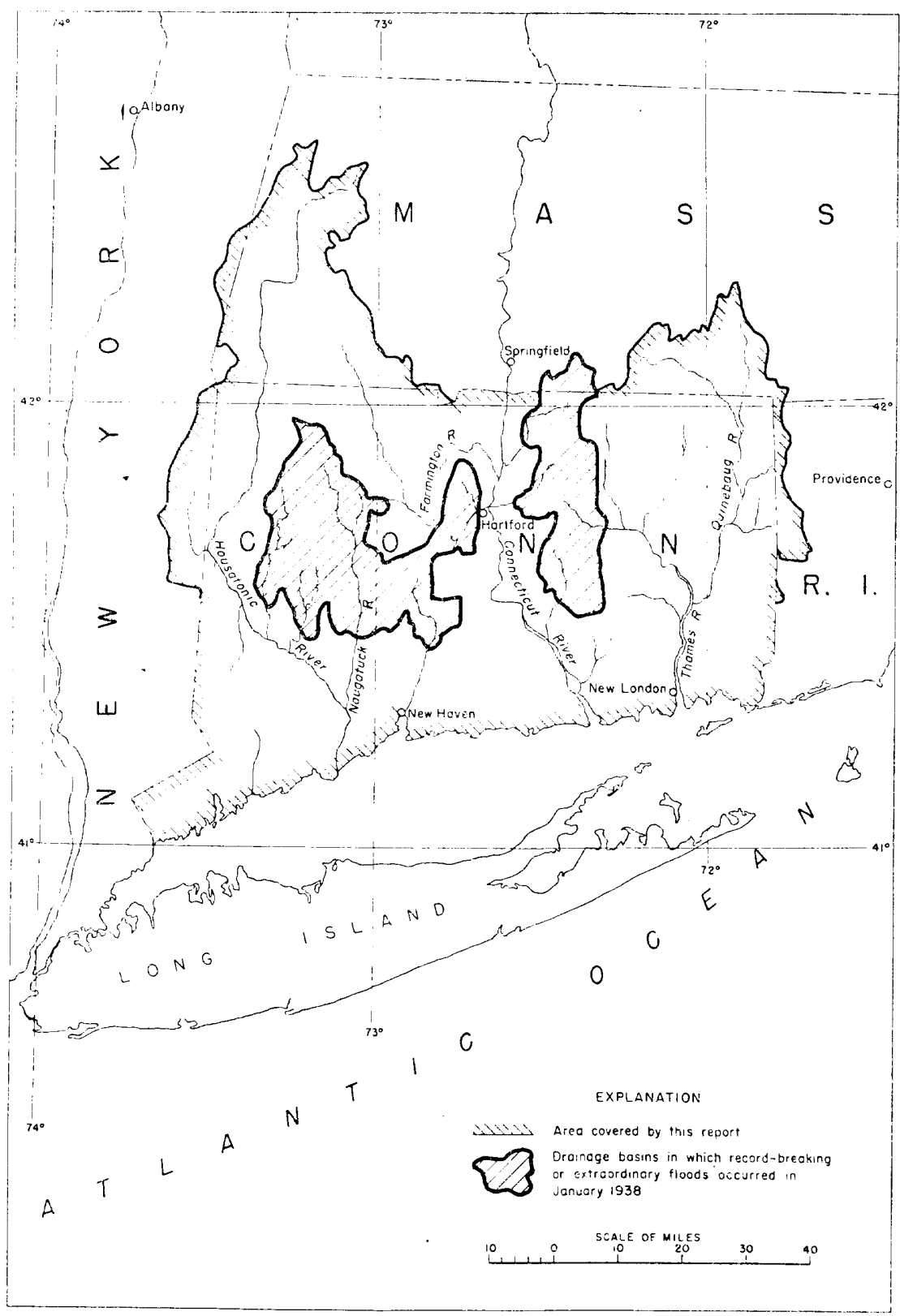

Figcre 1.--Map showing location of areas in which record-breaking or noteworthy flocds oceurred in January 1938. 
streams in Connecticut averaged more than 38 inches and from two streams was even greater than the normal yearly rainfall.

The first of these floods, the one on January 25, 1938, was the result of several days of warm weather followed by a short, intense rainfall that overnight removed virtually all of the accumulated snow fall of winter. A heavy ice cover on the streams was loosened and broken by the upward surge of the floodwaters and sent downstream in recurrent jams. Seven small streams in central and western Connecticut rose to levels higher than those reached during the great floods of March 1936, and peak rates of flow exceeded any previously recorded on these streams. Figure 1 shows the drainage basins where record-breaking or extraordinary floods occurred within the area covered by this report. In general, the larger rivers did not attain extraordinary discharges. The Connecticut River at Hartford, for instance, peaked at a stage only 3.6 feet above ordinary flood level. Accordingly, direct damage was relatively small. The State Highway Department of Connecticut estimated about $\$ 10,000$ damage to the main highways. Ice hastened destruction of the flashboards on many dams, operation of several mills was interrupted by floodwater, sewers were overloaded, streets and highways were flooded, and numerous cellars and lower floors of low-lying houses were inundated.

As part of its Nation-wide stream-gaging program, the Geological Survey maintains in Connecticut, through its Hartford office, 32 regular river-measurement stations within the area affected by the floods of January 1938 shown on figure 1. These stations have been operated by the Geological Survey largely in cooperation with the State and municipalities and generally for periods beginning several years prior to 1938. By this program the Survey, assisted by the cooperating agencies, has collected systematic records of stages, rates, and volumes of flow of the streams covering the range from extreme drought to extraordinary flood.

At the beginning of the fiscal year 1938, funds were allotted to the Geological Survey by the Federal Emergency Administration of Public Works, in accordance with the provisions of the National Industrial Recovery Act of 1933, for "surveys of floods and droughts." From these funds a total of $\$ 4,000$ was allocated to the Hartford district to supplement regular and cooperative appropriations in obtaining basic data on the recent floods. The devastating and widespread flood and hurricane of September 1938 generally wiped out evidences of flood stages and profiles established by the floods of January and July 1938 and temporarily 
interrupted studies in connection therewith until the report of the more important flood of September was completed.

This report contains all the basic information relating to stages and discharges collected at the regular river-measurement stations maintained by the Hartford district office, also computations from the operation records of nine reservoirs, the results of several flood-flow determinations made at points where regular gaging stations were not being maintained, all basic meteorologic and hydrologic information, and the results of analyses of rainfall and runoff. Figure 1 shows that the area covered by this report includes all of Connecticut and the out-of-State parts of the drainage areas of those streams on which gaging stations are maintained by the Hartford district office. Unless otherwise noted, all references herein involve only the area shown in figure 1.

\section{GENERAL FEATURES OF THE FLOOD}

During the early part of January 1938, weather and stream conditions in the flood area followed the normal trend. Rain and warm temperatures caused a so-called January thaw, which removed most of the snow along the coast of Connecticut and saturated and compressed the snow over the remainder of the area. As a result, stream flow increased on January 7 or 8 , receded quickly again when the temperature fell below freezing on January 9, and continued to recede while the temperature remained below freezing, with the exception of but a few hours, until January 21. Frost penetrated deeper into the ground. Snowfall on January 13 varied in depth from 4 to 13 inches. Subsequent smaller snowstorms added their quota until, on January 20, the total depth of compacted snow reported by Weather Bureau stations varied from 2 to 10 inches. As shown on plate 5, the computed water content of snow on the ground on January 20 varied from 0.25 or 0.50 inch along the coast to as high as 2.75 inches in the northern parts of the drainage basins. After January 21, temperatures were above freezing during the warmer parts of the days, and consequently the 0.1 inch to 1.6 inches of precipitation between January 21 and 23 fell variously as snow, sleet, or rain. Streams that had been falling gradually as the groundwater was depleted now steadied or rose slightly.

The stage was set for the flood. The ground was frozen, water content of the snow cover was comparatively high, and the snow had been "ripened" by warm temperatures. The main flood-motivating factors made their entrance during the evening of January 24 and the morning of January 25 . Temperatures rose rapidly into the fifties, and a warm, intense rainfall, accompanied by 
strong winds, removed practically all of the snow during the night. Plate 4 shows the areal distribution of precipitation for the period from January 24 to 26 during which most of the rain fell in 12 to 17 hours. Rainfall exceeded 2.75 inches in only three small areas. As shown in column 9 of table 9 the combined average precipitation and water content of snow did not exceed 4.8 inches on any tributary drainage area studied in this report.

Connecticut basins often have had more water available for runoff, but only occasionally in recent years have peak discharges on the smaller streams exceeded those attained during this flood. The snow melted rapidly, and most of its initial melt, finding passage into the frozen ground materially impaired, joined the fallen rain in a surface course to the swelling streams. Cover-ice on these channels cracked, was crowded downstream in recurrent jams, and took the flashboards from many dams. However, before the ice jams had done serious damage they were usually broken up by the press of the rapidly rising floodwater. Record-breaking discharges occurred only on the smaller tributary streams, which have more narrowly defined channels and steeper gradients than the larger streams of the State. Accordingly, damage was small in comparison with that caused by the greater and more widespread floods of March 1936 and September 1938. Direct damage resulted mainly from the flooding of several mills and numerous cellars and lower floors of low-lying buildings, and from the overloading of sewers and inundation or washing out of streets and highways. Plates 1 and 2 show typical examples of conditions existing during the flood. On figure 15 a comparison can be marle between peak discharges, in second-feet per square mile, for the flood of January and the maxima of record in Connecticut, including those for September 1938. On the basis of drainage area alone, the envelope of peak discharges for the flood of January gives results varying from about one-half of the discharge rate shown by the maximum envelope for 10 square miles to about one-third for 1,000 square miles. Such a comparison, however, disregards the individual runoff characteristics of the various basins and the areal distribution of the several storms.

Considering each river-measurement station individually, the momentary peak discharge in January 1938 was the maximum for the prior period of record at the following seven stations in Connecticut:

Connecticut River Basin.- South Branch of Park River at Hartford, Park River at Hartford, North Branch of Park River at Hartford, Hockanum River near East Hartford. 
Housatonic River Basin.--Shepaug River at Woodville, Naugatuck River near Thomaston.

Quinnipiac River Basin.-Quinnipiac River at Southington.

Peak discharges of the flood of January were greater than the hurricane flood of September 1938 at the following three gaging stations in Connecticut: Moosup River at Moosup, Park River at Hartford, North Branch of Park River at Hartford.

Few studies have been made of winter floods in Connecticut. Geological Survey Water-Supply Paper 798 contains analyses of the floods of March 1936 for which considerable snow cover was available for runoff. However, in Connecticut, information was limited concerning the water content of this snow and the part of it that ran off in the first of the two storms. Fortunately, Statewide snow surveys were completed just prior to the flood of January 1938, and almost all of this snow was removed during the short flood period. Therefore, these more complete data become especially valuable in analysis of the influence of snow on flood runoff. This report endeavors to present all the basic factors relating to this winter flood as a contribution toward devising sound measures of forewarning, control, and protection from like or greater floods in the future.

\section{WEATHER ASSOCIATED WITH FLOODS IN CONNECTICUT} ON JANUARY 25-26, 1938

By G. N. Brancato ${ }^{6}$

The storm that produced the heavy rain on the night of January 24-25, 1938, and associated high temperatures and wind velocities, which were very effective in rapidly melting the snow cover, had its origin over Texas on the morning of January 23. The synoptic and upper air charts for that morning showed a trough of low pressure from Texas northward through the Dakotas, with air of polar Pacific origin to the west of the trough and a northward flow of warm moist air with increasing tropical maritime characteristics to the east. The synoptic chart showed a separate weak low pressure center over Texas. Soundings in the tropical air showed it to be very moist and convectively unstable, as evidenced by the widespread thunderstorm activity over Texas, Oklahoma, and western Louisiana.

A chart showing the altitude of a selected value of the potential temperature, in millibars of pressure, is called an isentropic chart. The potential temperature is defined as the absolute temperature a parcel of air would possess if raised or lowered dry-adiabatically to 1,000 millibar pressure. The significance of the isentropic chart

${ }^{B}$ Meteorologist, U. S. Weather Bureau. 
is that masses of air maintain the same potential temperature regardless of lifting or lowering, as long as radiation or condensation processes are not active. The order of magnitude of radiation processes are so small that they can be neglected for 24-hour changes. The isentropic charts are drawn on the assumption that if the flow pattern in the moist currents can be identified before condensation takes place, a reasonable extrapolation of the flow patterns after condensation takes place can be obtained from the shape of the area of condensation. The solid lines of pressure are almost a direct measure of the elevation of the potential temperature surface. The distribution of moisture on the potential temperature surface is best identified by the specific humidity. The specific humidity is a weight ratio between the mass of water vapor and the mass of air and is usually expressed in terms of grams of moisture per kilogram of moist air. Since for any given potential temperature surface a given value of specific humidity can have only one pressure at which saturation will result, the lines of specific humidity are also labeled in terms of the pressure at which saturation will be reached. ${ }^{\top}$

The isentropic chart for January 23 indicates a deep mass of polar air over the Northwestern States that was advancing rapidly southeastward. The leading edge of this air mass at this time extended as far south as northwestern Texas. Moist tropical air was spreading northward from the Gulf over the southern Great Plains region with precipitation as far north as Oklahoma and Arkansas.

It has been shown by C. G. Rossby in an unpublished report that a strong southward thrust of cold air with little change in its lapse rate acquires an increasing cyclonic circulation as it moves southward. The mass of cold air over the Northwest on January 23 moved progressively southeastward on January 24-25, as shown by the isentropic charts on figures 2 and 3. Soundings taken in this air mass produced near record minimum temperatures at 5,000 meters at all stations. At Oklahoma City it produced a record minimum of $-35.2^{\circ} \mathrm{C}$. at 4,460 meters the morning of January 25, and if the lapse rate below this point were extrapolated up to 5,000 meters it would give a temperature of about $-42^{\circ} \mathrm{C}$. This would exceed the record minimum for that level by about $10^{\circ} \mathrm{C}$. Atmospheric cross sections through the cold air on January 24 and 25 also show that there was little change in the lapse rate. The increasing cyclonic circulation induced by this strong southward thrust of cold air was attended by the

'Byers, H. R., On the thermodynamic interpretation of isentropic charts: Monthly Weather Rev., vol. 66, pp. 63-68, March 1938. 


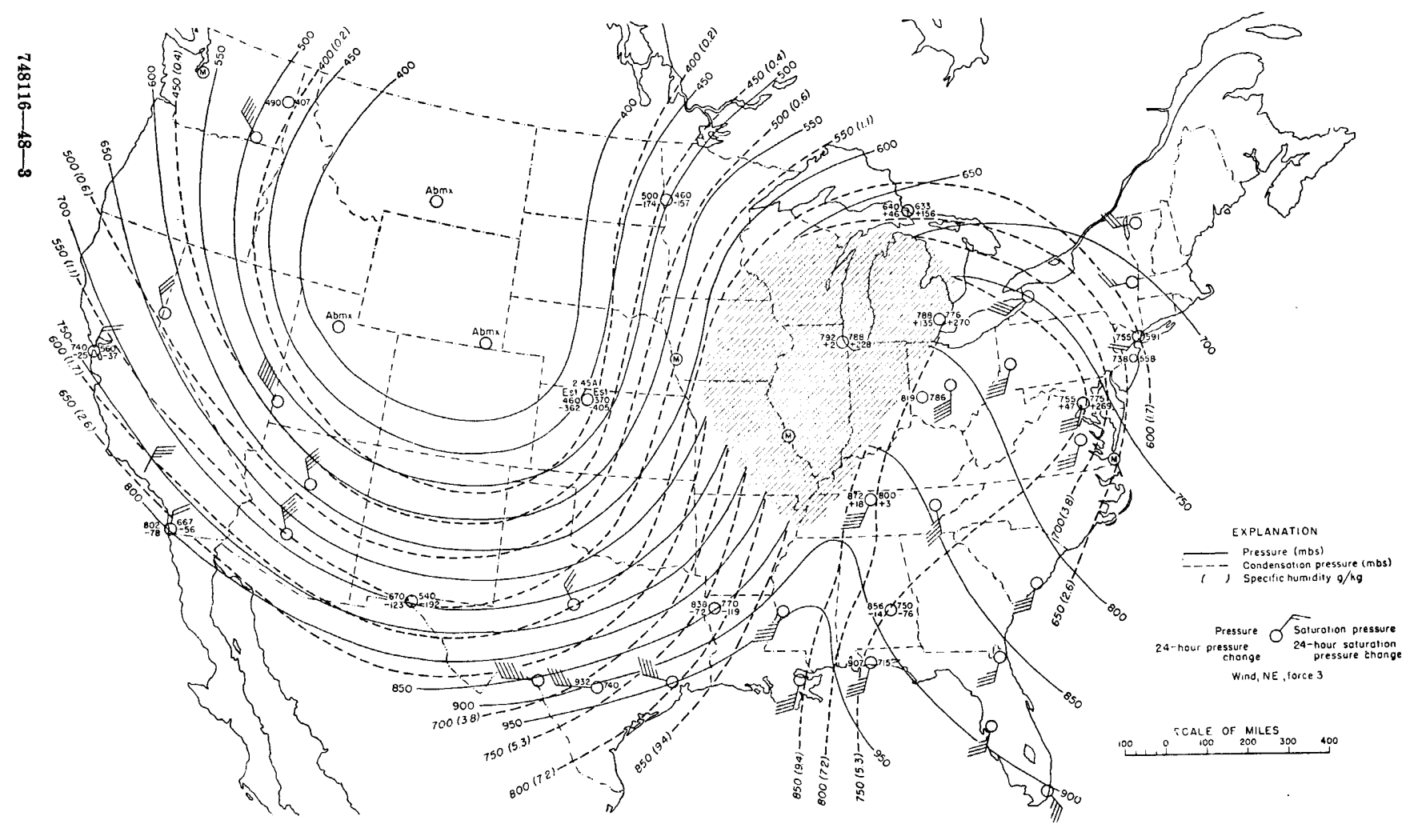

Figure 2.--Isentropic chart of the United States, January 24, 1938. 
development of a center of low pressure in upper elevations over the cold air. The pressure in a vertical column of air decreases with height at a rate directly proportional to the density, and pressure decreases most rapidly with height in cold air as the colder the air the greater the density. Soundings made on the morning of January 23 indicate that this center of low pressure aloft was coincident with the lowest temperature over Spokane, Wash. As the cold air moved southward it tended to circulate cyclonically about the center of low pressure, while the increasing cyclonic circulation produced a pressure distribution that brought about balanced flow and caused a compensating northward flow of warm, moist air in advance of the cold air. This northward upglide flow of warm, moist air over the colder more stable air in the lower layers led to active condensation and precipitation over most of the Mississippi and Missouri Valleys.

The result of the increasing cyclonic circulation due to the southward thrust of cold air was a rapid decrease in pressure in the warm moist current to the east. The weak low that centered over Texas on the morning of January 23 developed a deep center and intense circulation that moved rapidly northeastward. At $7: 30$ p.m. on January 24 this intense cyclone centered over northern Michigan, as shown on figure 4 . The leading edge of the cold air or surface cold front had advanced eastward to eastern Ohio and southward through eastern Tennessee and central Alabama. As shown by the cross section from Pensacola through Shreveport to Oklahoma City for the morning of January 24 (figure 5), polar Pacific air aloft had pushed ahead of the surface front and was identified on the 7:30 p.m. general chart of January 24 as a cold front aloft (figure 4) extending from western Pennsylvania southward through South Carolina and Florida. Ahead and in connection with this front there was active upglide motion and convergence of the unstable warm, moist tropical air over colder more stable air in the surface layers. The lifting produced convection in the warm, moist air, which together with convergence resulted in general heavy precipitation. Following the upper front, owing to active subsidence, there was little or no precipitation except with the passage of the surface cold front. This produced showers or thunderstorms of light to moderate intensity, followed by instability showers in the cold air, which produced no appreciable amounts of precipitation.

At $7: 30$ a.m. January 25, as shown by the surface weather map on figure 6, the upper cold front extended from Canton, N. Y., southward through Albany, and, as shown by precipitation records, 


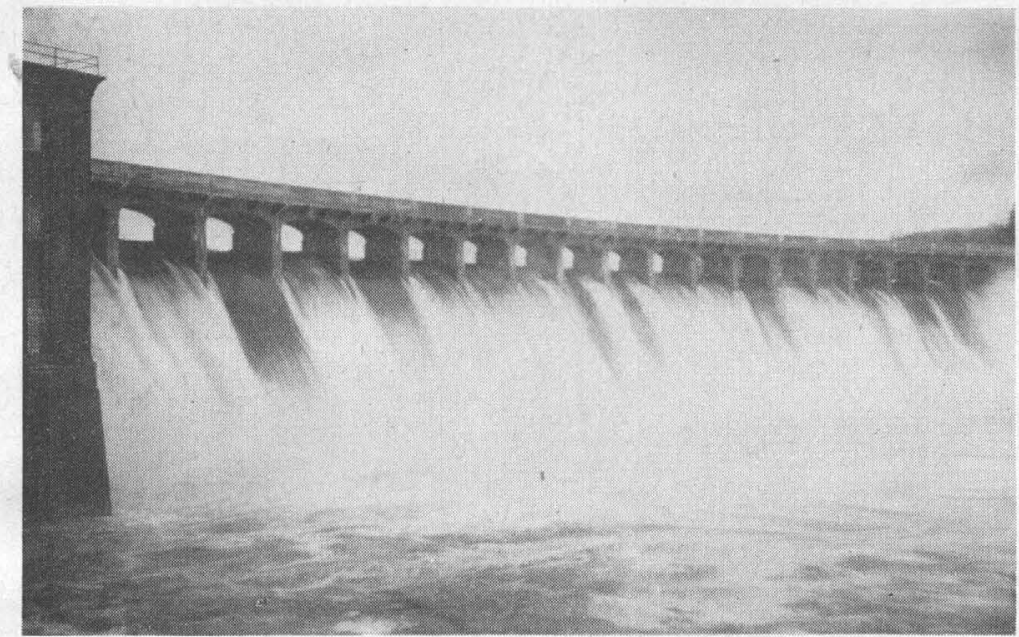

A. JANUARY 1938 FLOOD PASSING OVER DAM ON HOUSATONIC RIVER AT STEVENSON, CONN.

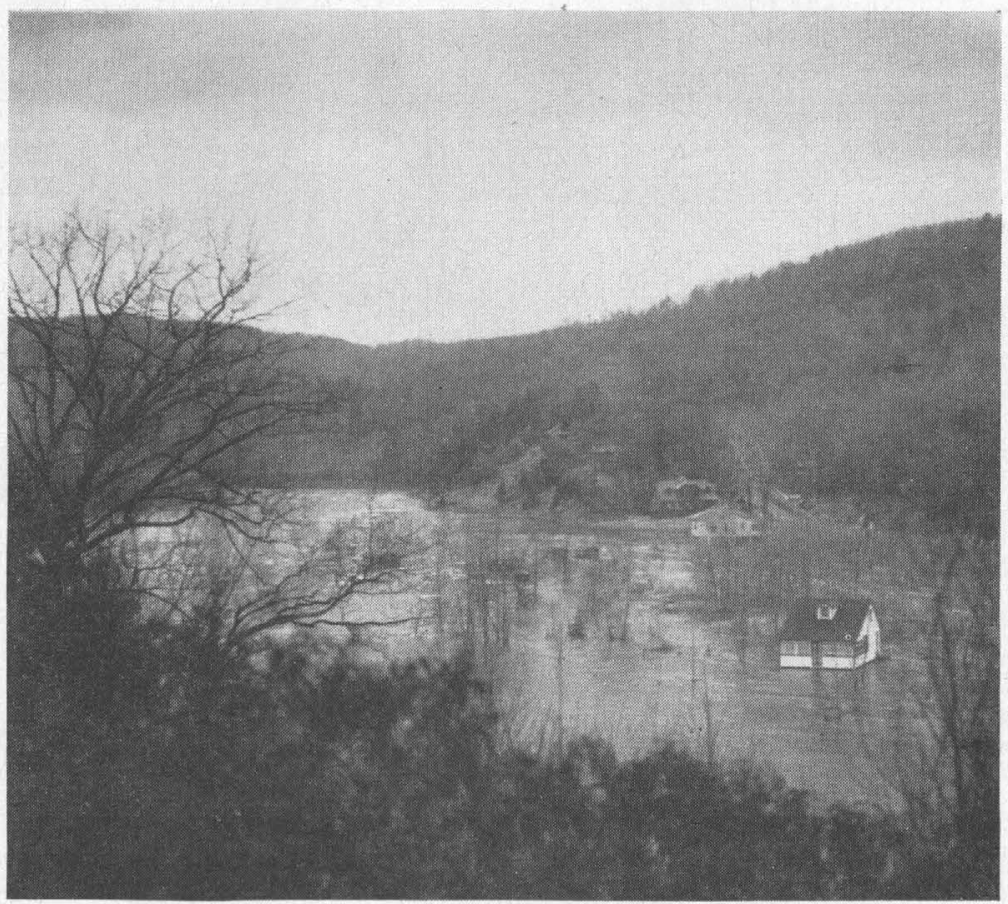

B. JANUARY 1938 FLOODWATERS ENCROACHING ON COTTAGES ALONG HOUSATONIC RIVER. 


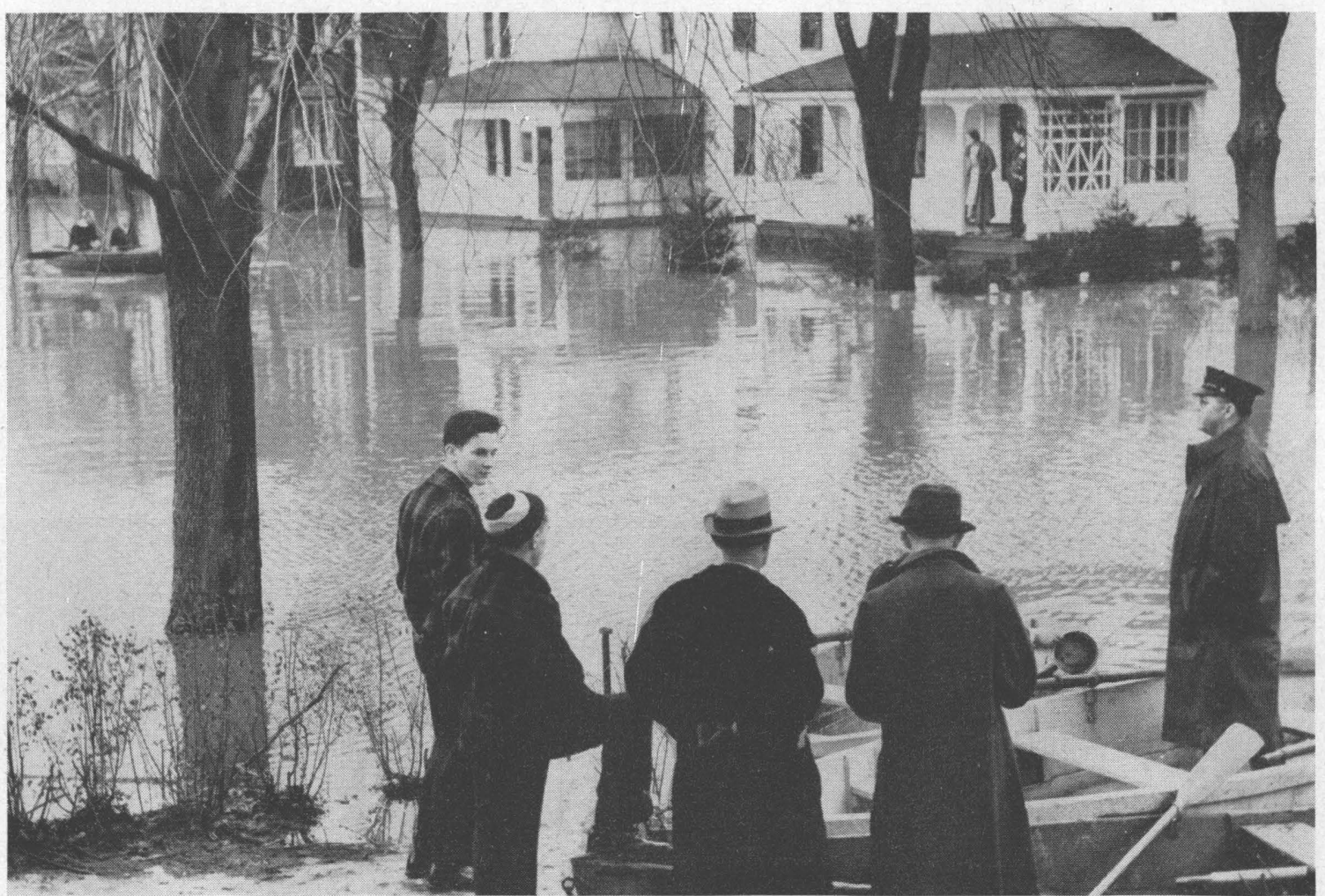

MAROONED RESIDENTS RESCUED BY POLICE IN BOATS.

Photo by Hartford (Conn.) Courant. 


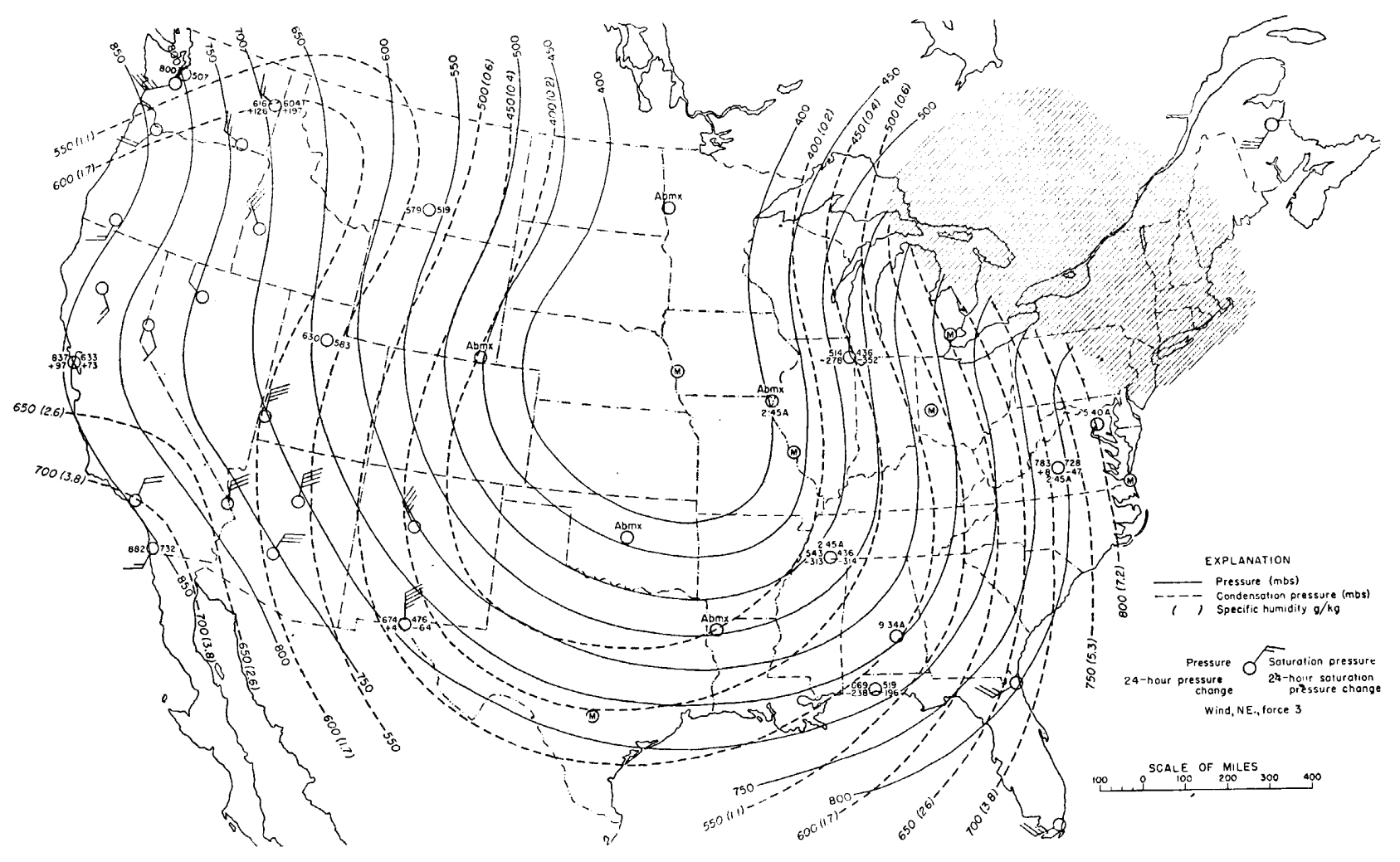

FicURE 3.-Isentropic chart of the United States, January 25, 1938. 


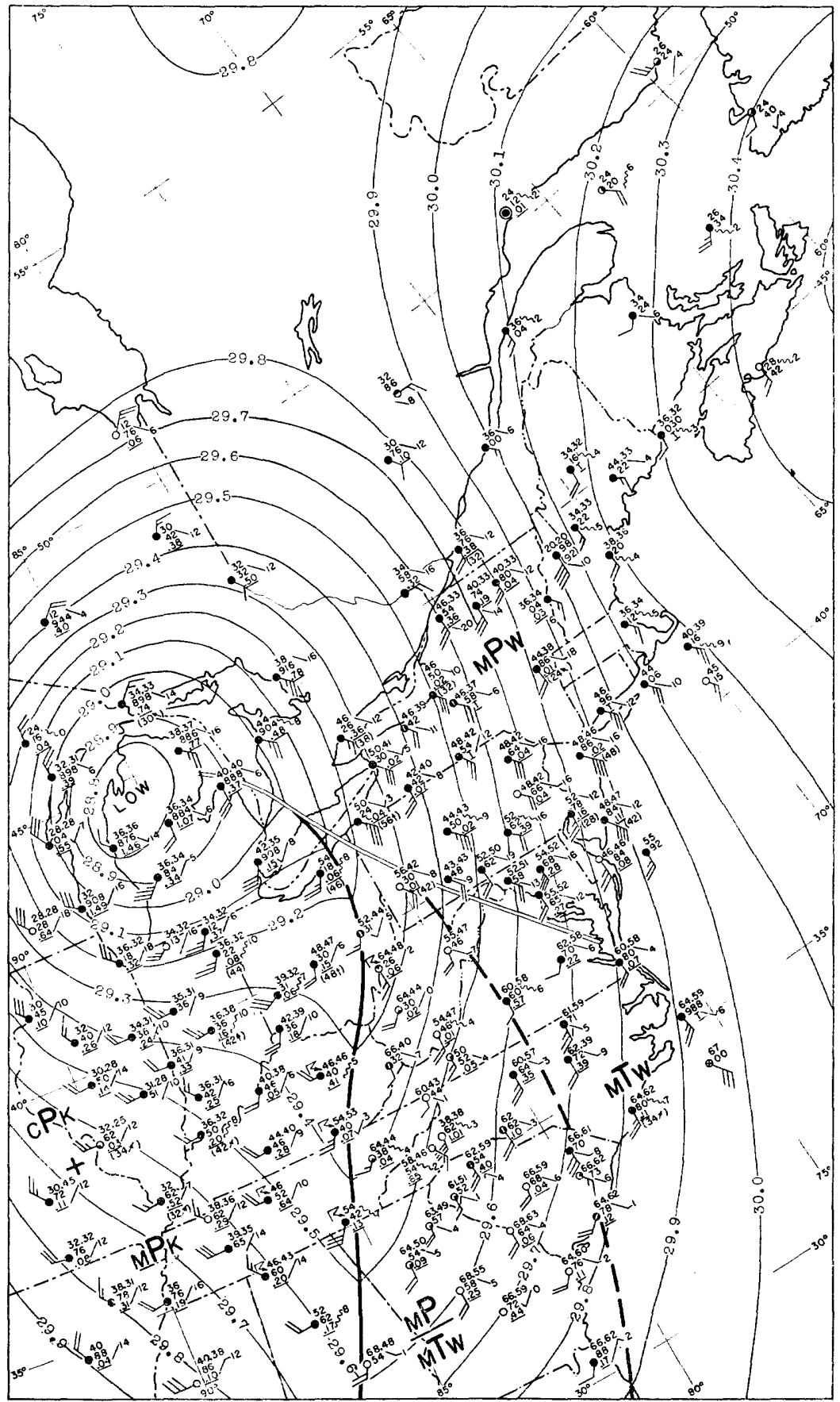

Fig. 4.--Surface weather chart of eastern United States and Canada, $7: 30$ p.m. Jan. 24, 1938 
the heavy precipitation in Connecticut ended with its eastward passage during the morning.

During winter, when there is an appreciable snow cover, this type of storm is always a potential flood producer over the Northeastern States. The warm, moist southerly winds ahead of frontal developments of this type increase slowly and not only transport increasing amounts of precipitable water over the region but are very effective in rapidly melting the snow. Active convergence within the moist tropical air produced by the deepening depression and upglide motion over colder surface air is the direct cause of condensation and the resulting heavy precipitation. For a total period of 24 to 48 hours preceding and accompanying the period of heavy rain, temperatures in Connecticut rose about $20^{\circ} \mathrm{F}$. above the mean freezing temperature of January 24 and were attended

Explanution of symbols used on surfece weather charts (figs. 4 and 6 )

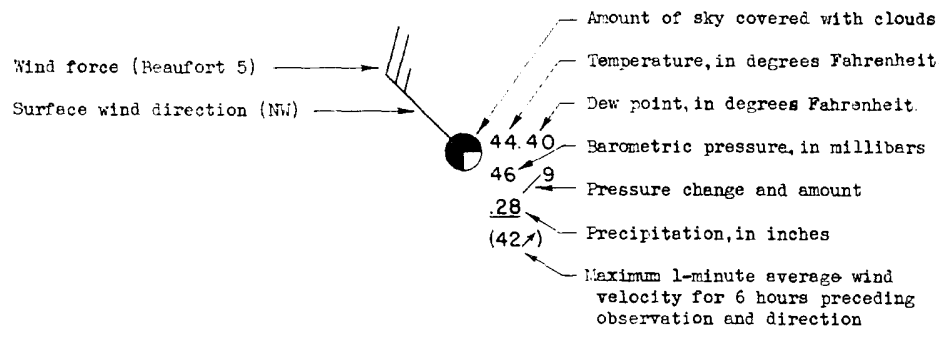

Light linos are isobers dzawn for each tenth of an lach

Fropts

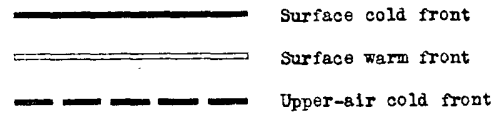

A1r-mass symbola

MPW Naritime polar air, warmer than the surfice over which it is passing (stable in lower layers)

MTW Maritime tropical e1r, warmer than the surface over which it is passing istable at lower lagers)

MP Martime polor als

MPK Maritimo polar air, oolder than surface over which it lies or is passine (steep lapse rate)

CPK Coxtinuntel polar air, colder then surfaoe over which it is passing (steep lapse rate)

MP Nartitme polar air aloft and

Maritima tropical air below 
by strong wind velocities. Maximum wind velocities of 34 and 35 miles per hour, respectively, were registered at Hartford and New Haven, Conn., on January 25. These strong winds probably hastened the removal of snow cover by rapidly dispersing the colder atmosphere at the exposed surface. It is this sequence of events that makes this type of storm one of the most critical in producing floods where there is a deep snow cover.

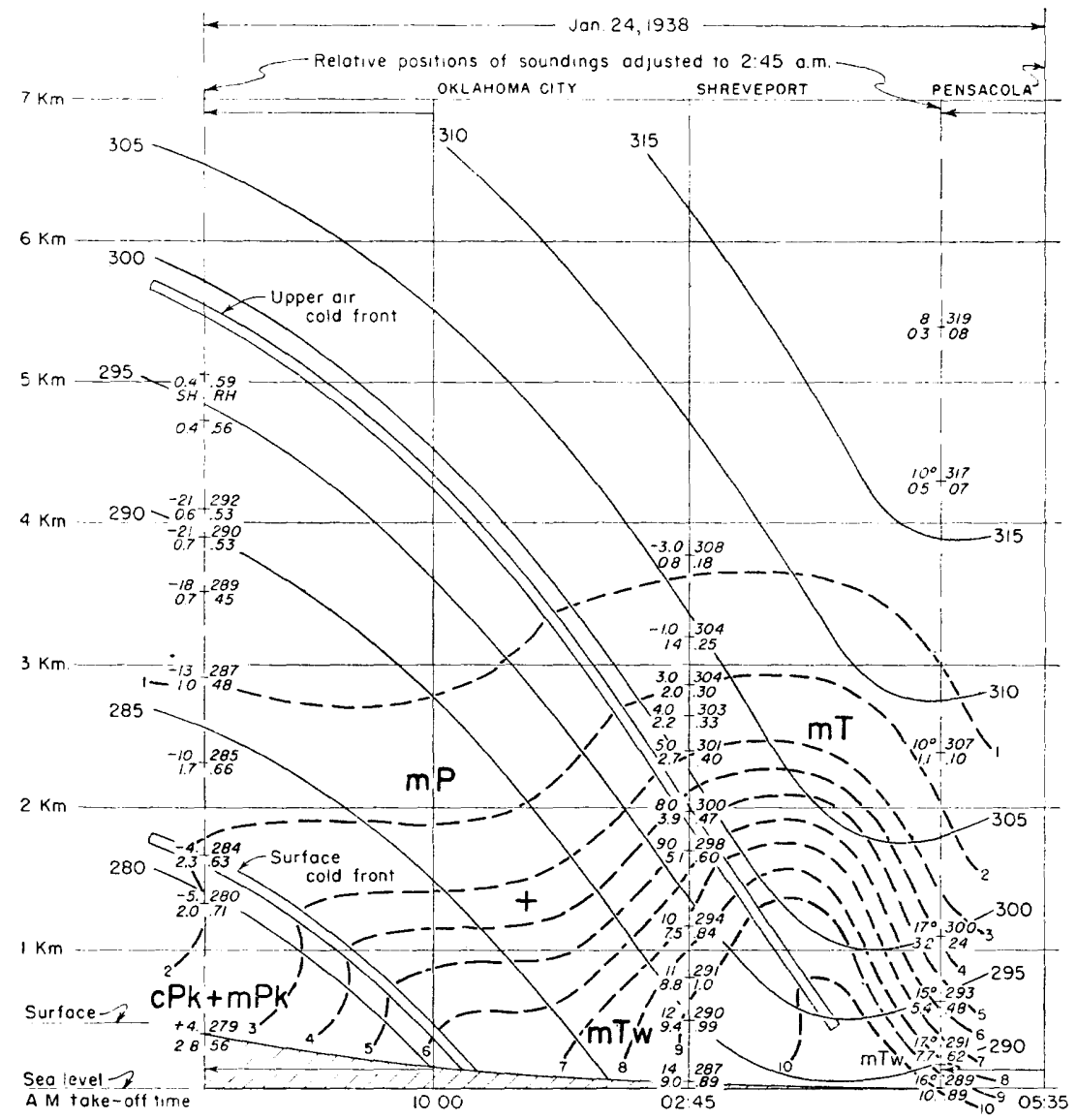

Ficure 5.- Vertical cross section of atmosphere, January 24, 1938.

\section{ANTECEDENT CONDITIONS}

Monthly figures of precipitation, snowfall, and temperature with respective departures from normal taken from Weather Bureau records are shown graphically for Connecticut in figure 7 for the months of October 1937 to February 1938, inclusive. Weekly observations of water level in several hundred wells and daily 


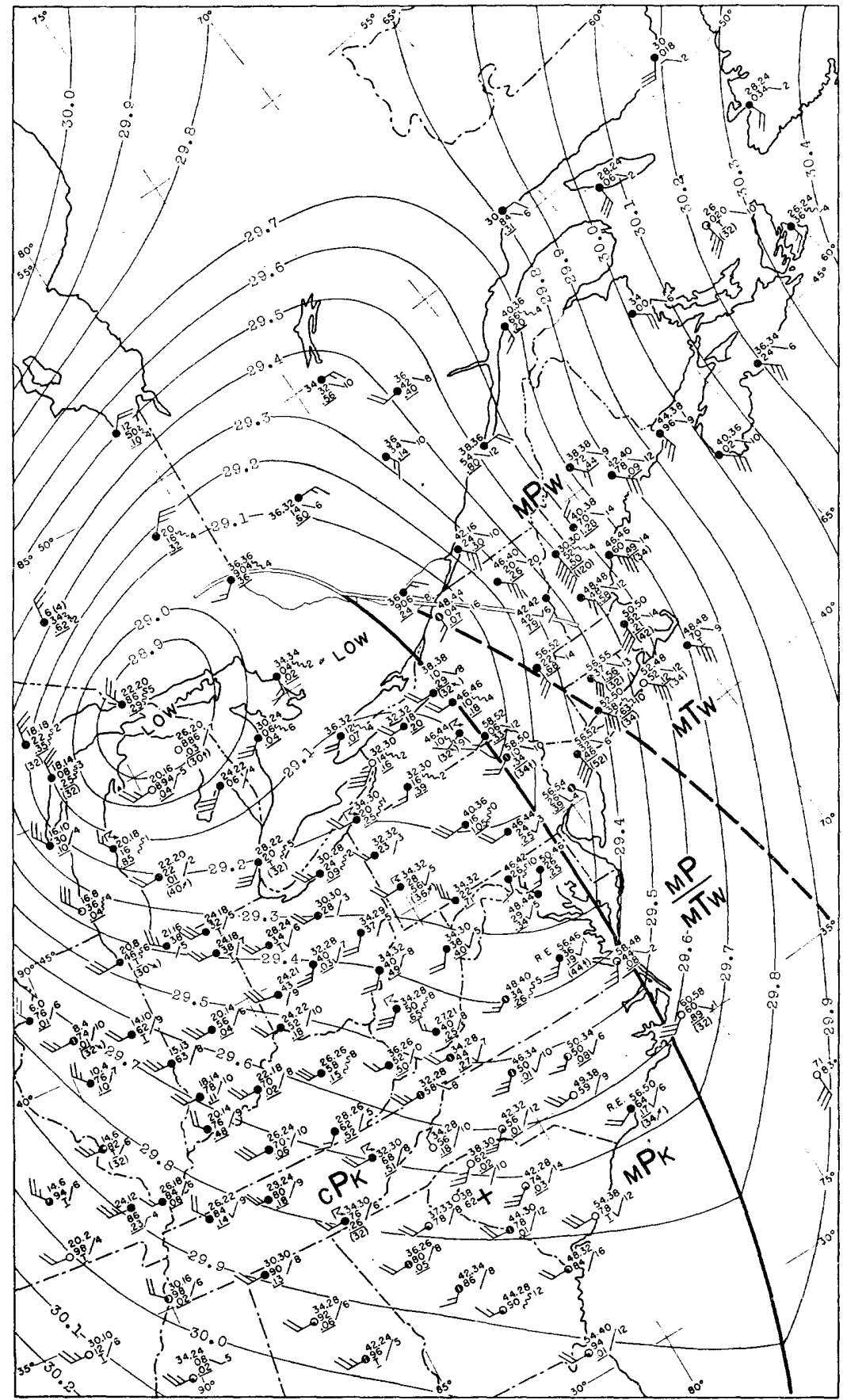

Figurg 6.-Surface weather chart of eastern United States and Canada, 7:30 a.m., January 25, 1938. (For explanation of symbols see p. 23.) 


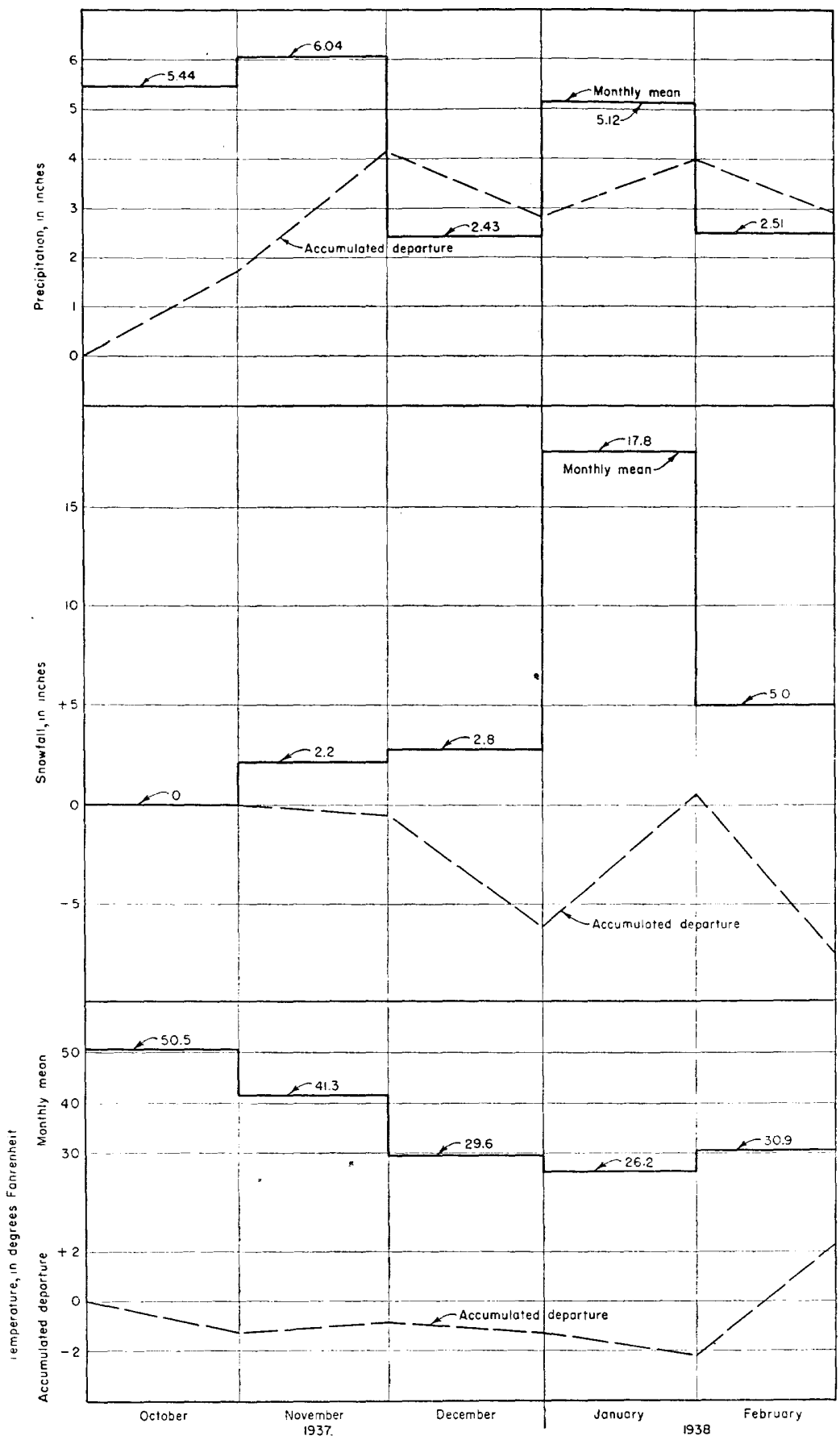

FICURE 7.-Monthly precipitation, snowfall, temperature, and accumulated departures from normal for Connecticut, October 1, 1937, to February 28, 1938. 


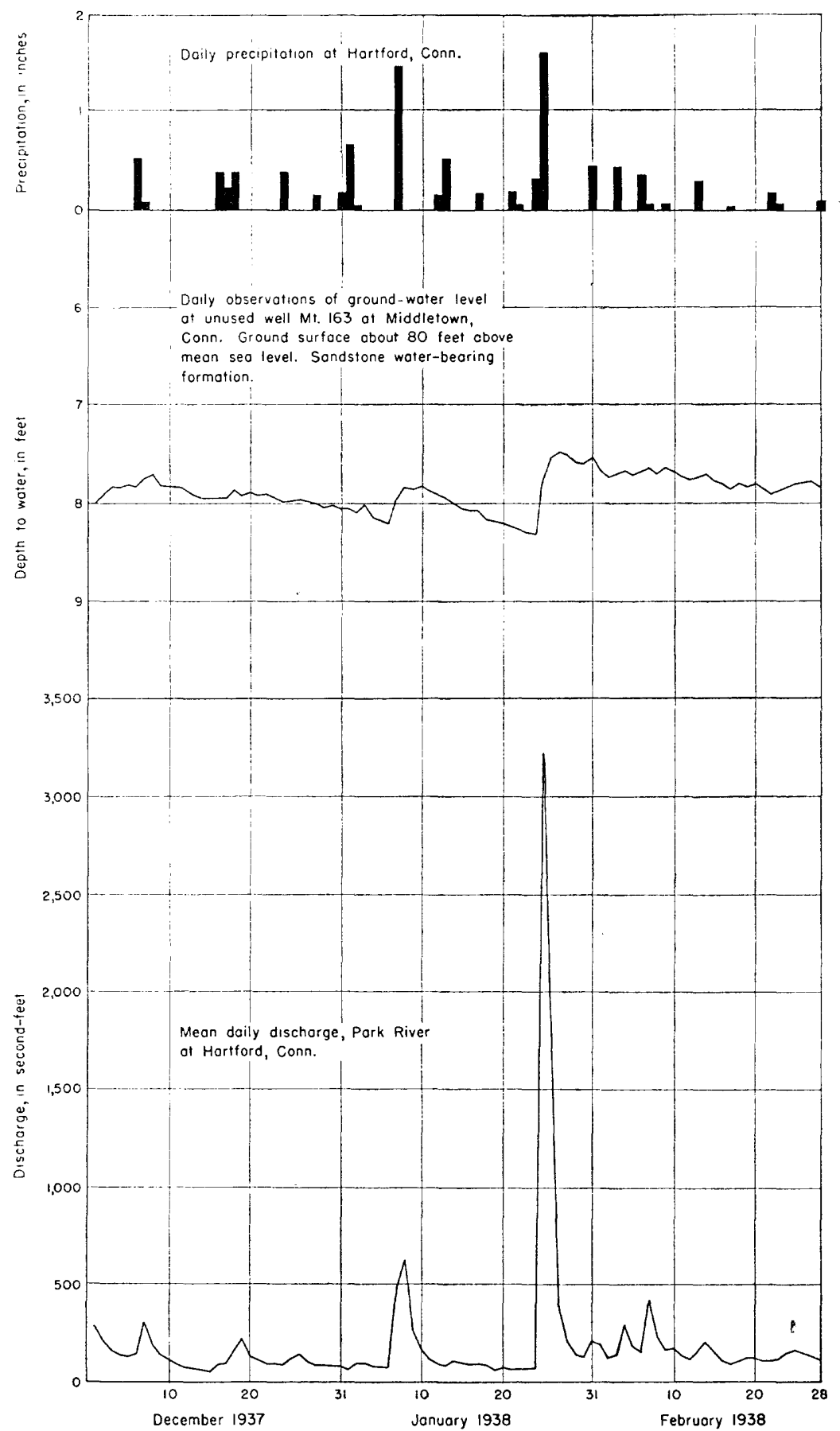

FIGURE 8.-Comparison of typical records of ground-water level with precipitation and stream flow. 


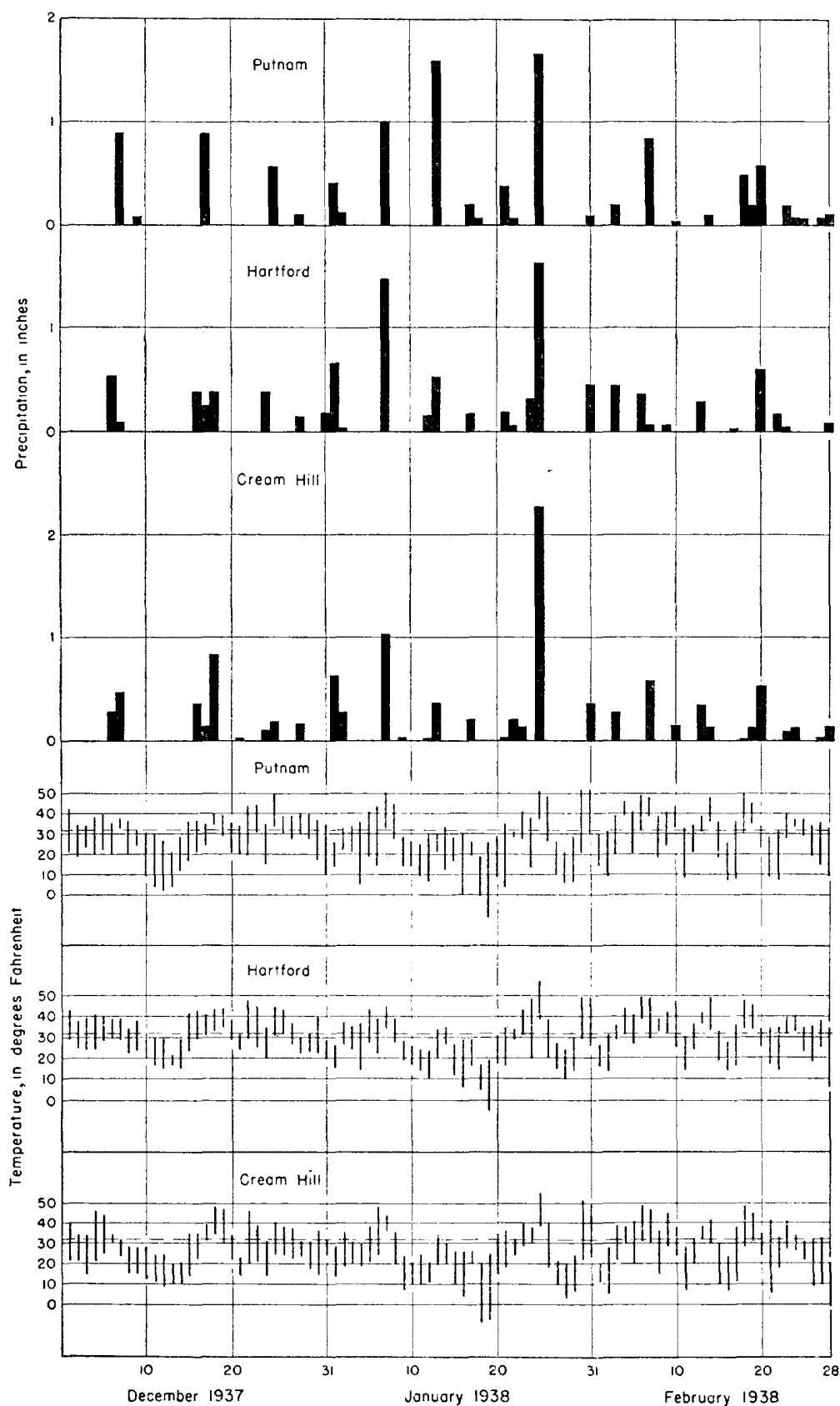

Figure 9.-Daily precipitation and temperature at representative stations in Connecticut for the period December 1, 1937, to February 28, 1938. 
observations in a few other wells are available. These observations were made by the Federal Works Progress Administration under the sponsorship of the Connecticut State Water Commission and the supervision of the Geological Survey, As might be expected, the fluctuations of water level in the different wells covered a wide range, owing partly to the vagaries of topographic, geologic, and water-bearing characteristics. Figure 8 compares the daily changes at one of these wells with records of daily precipitation and stream flow. Figure 9 shows graphs of daily precipitation and range in temperature at three Weather Bureau stations in Connecticut.

From figures 7, 8, and 9 several facts may be noted. Monthly temperatures for Connecticut were close to normal from October 1937 to January 1938. Average temperatures for December and January were below freezing, and thus the penetration of frost into the ground was possible. Precipitation was greater in October and November than during January. A heavy warm rain during the latter part of November undoubtedly removed all the snow that had fallen prior thereto and raised the ground-water level. During December, precipitation averaged only 2.43 inches and included 3 inches of unmelted snow. The ground-water table lowered during the month either because of insufficient rain or because of obstruction of penetration by the frost barrier. A warm rain on January 7 raised the ground-water level at the Middletown well but not as much as the drop during the following cold period. Snowfall during January was 6.8 inches above normal in Connecticut. Considered by major drainage basins, snowfall in January at three Weather Bureau stations in the Thames River Basin averaged 5.9 inches above normal, at five stations in the lower Connecticut River Basin 5.4 inches above normal, and at seven stations in the Housatonic River Basin 5.3 inches above normal. Most of the snow during the month came prior to January 25. Seemingly inconsistent with the magnitude of the January flood, the precipitation for the month was only 1.20 inches above normal, thereby illustrating that large excesses of concurrent precipitation are not necessarily a prerequisite to a winter flood.

\section{PRECIPITATION}

Precipitation records collected at about 175 stations were compiled and used for the construction of the isohyetal maps presented herein and for the study of the relation between rainfall and runoff. Daily precipitation and computed total storm precipitation at these stations are presented in table 1.

The precipitation for the calendar days January 24-26, the period directly associated with the flood, is given in the next to the last 
column of table 1 . The last column of table 1 shows the total precipitation measured from January 20 to 26. Plus signs after figures indicate that the records are probably incomplete. The numbers assigned to each precipitation station indicate its location on plate 11 and conform with those assigned to the same stations in the reports on the floods of July 1938 and September 1938. ${ }^{8}$

\footnotetext{
${ }^{8}$ Paulsen, C. G., and others, Hurricane floods of September 1938: U. S. Geol. Survey WaterSupply Paper 867, pp. 46-61, table 4, 1940.
}

TABLE 1.-Daily precipitation, in inches, January 20-26, 1938

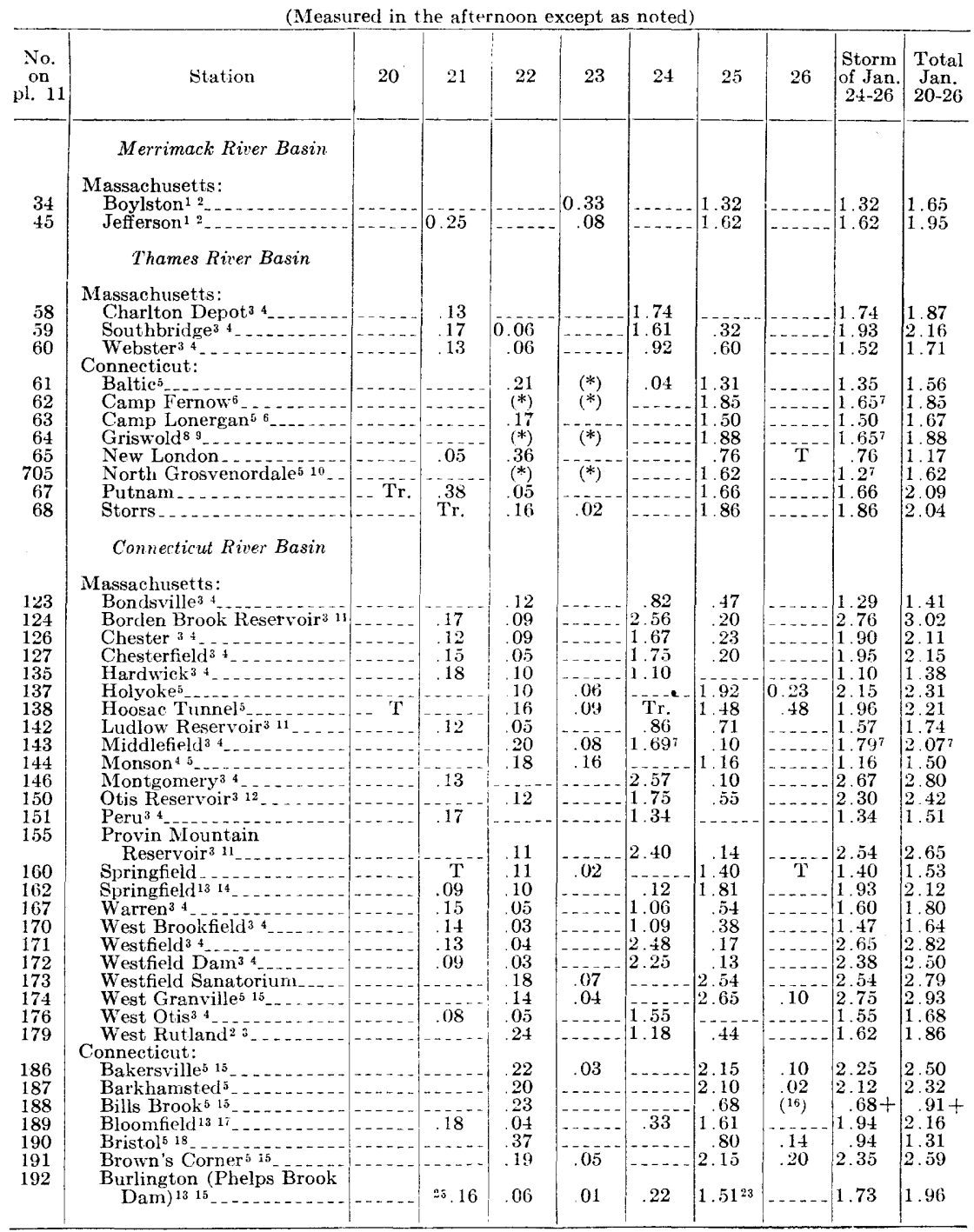

See footnotes at end of table. 
$\mathrm{T}_{\mathrm{ABLF}}$ 1.-Daily precipitation, in inches, January 20-26, 1938-Continued

[Measured in the afternoon except as noted]

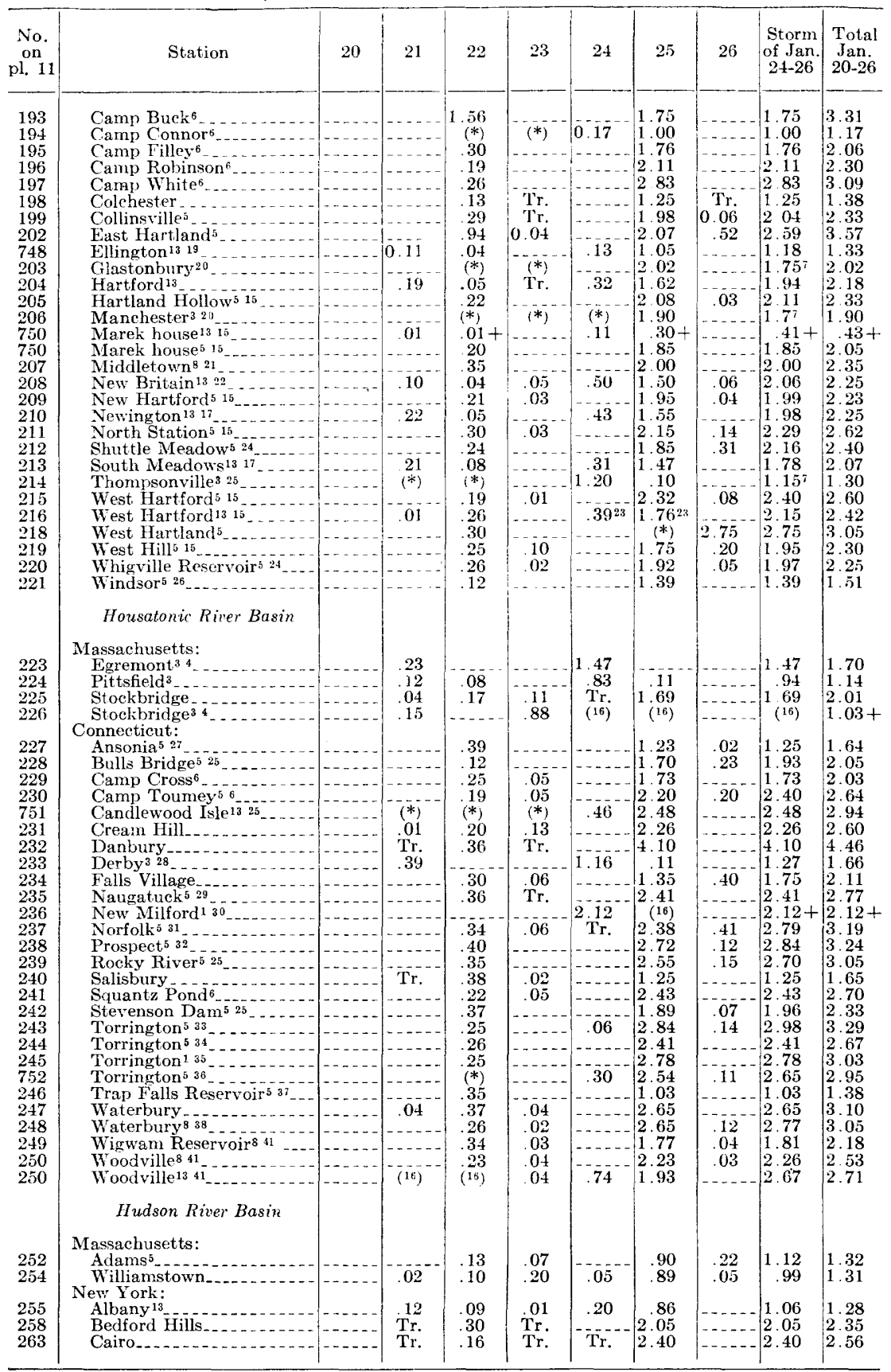

See footnotes at end of table. 
TABLE 1.-Daily precipitation, in inches, January 20-26, 1938-Continued

[Measured in the afternoon except as noted]

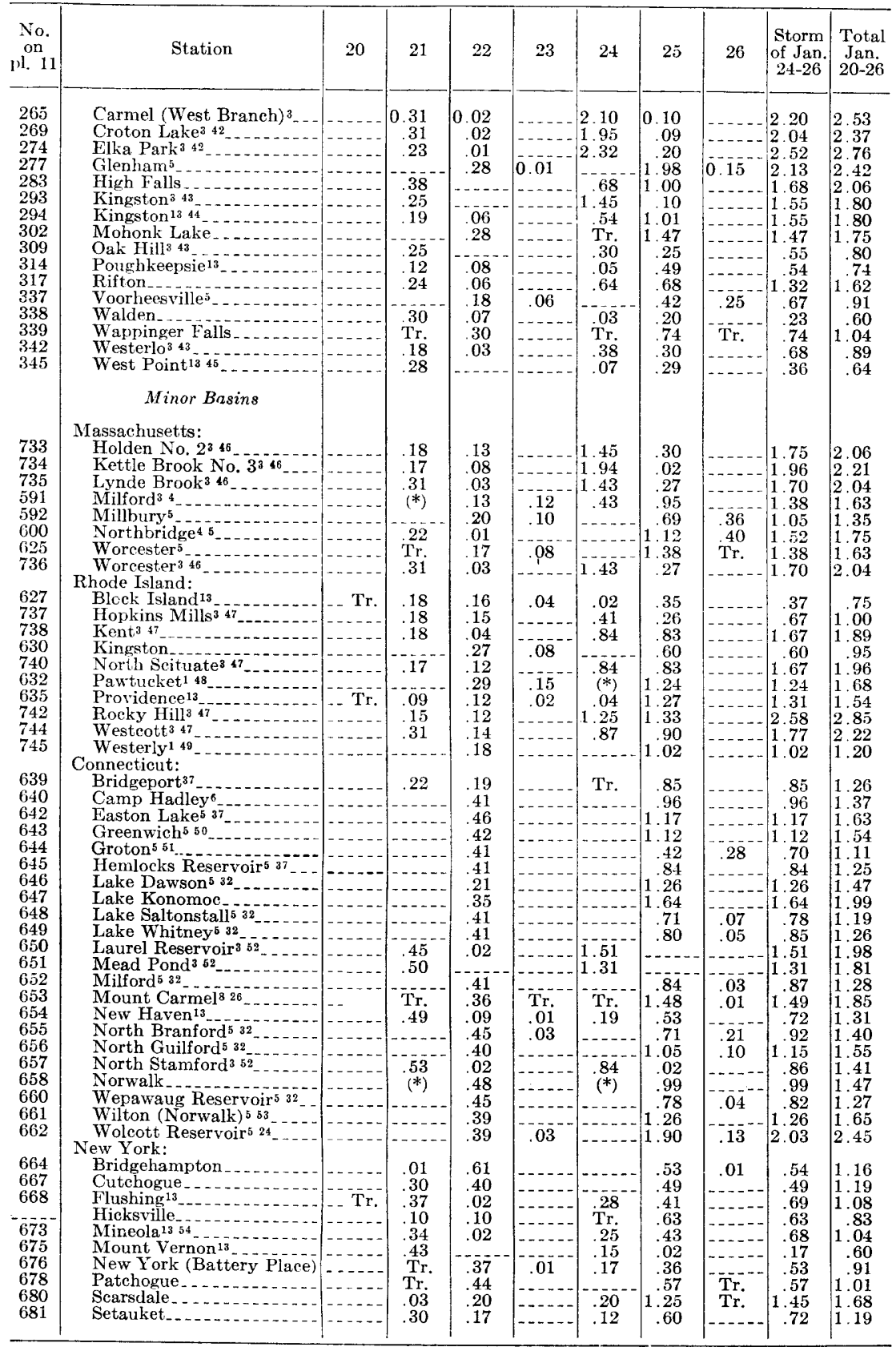

See footnotes on opposite page. 
* Included in following measurement.

1 Measured at irregular times.

2 Metropolitan District Commission.

3 Measured in morning after day indicated.

4 Massachusetts Department of Public Health.

${ }^{5}$ Measured in morning of day indicated.

6 Connecticut State Forestry Department.

7 Estimated.

8 Measured at noon.

- Jewett City Water Co., Jewett City, Conn

10 Grosvenordale Co., North Grosvenordale, Conn.

11 Springfield Water Works, Springfield, Mass.

12 Collins Co. Collinsville, Conn.

13 Measured at midnight.

14 City of Springfield, Department of Streets and Engineering.

15 Hartford Metropolitan Water Bureau.

16 Record missing or station not in operation.

17 City Engineer, Hartford, Conn.

${ }^{18}$ Bristol Water Co., Bristol, Conn.

19 Soil Conservation Service.

20 Manchester Water Co., Manchester, Conn.

21 City of Middletown, Middletown, Conn.

22 City Engineer, New Britain, Conn.

${ }_{23}$ Adjusted to auxiliary non-recording gage record.

24 Board of Water Commissioners, New Britain, Conn.

25 Connecticut Light \& Power Co.

26 Connecticut Agricultural Experiment Station.

27 Ansonia Water Co., Ansonia, Conn.

28 Birmingham Water Co., Shelton, Conn.

29 Naugatuck Water Co., Naugatuck, Conn.

30 J. H. Nettleton, New Milford, Conn.

31 Edward C. Childs, Norfolk, Conn.

32 New Haven Water Co., New Haven, Conn.

33 Torrington Register.

${ }^{34}$ General S. H. Wadhams.

35 Torrington Water Co., Torrington, Conn.

36 The American Brass Co.

37 Bridgeport Hydraulic Co.

38 City of Waterbury, Waterbury, Conn.

41 City of Waterbury, Bureau of Engineering.

42 New York City, Department of Water Supply, Gas, and Electricity

43 New York City, Board of Water Supply.

${ }_{44}$ City Engineer, Kingston, N. Y.

45 Signal Officer, U. S. Military Academy.

46 Water Department, Worcester, Mass.

47 Department of Public Works, Providence, R. I.

48 City Engineer, Pawtucket, R.I.

49 Board of Water Commissioners, Westerly, R. I.

so Water Co., Greenwich, Conn.

51 Water and Electric Department, Groton, Conn.

52 Water Co., Stamford, Conn.

s3 Water Department, South Norwalk, Conn.

54 Nassau County, Department of Public Works, Hydrological Bureau. 
TABLE 2.-Precipitation, in inches, for period

\begin{tabular}{|c|c|c|c|c|c|c|c|c|c|c|c|}
\hline \multirow{2}{*}{$\begin{array}{c}\text { No. } \\
\text { on } \\
\text { pl. } 11\end{array}$} & \multirow[b]{2}{*}{ tation } & \multirow[b]{2}{*}{ Day } & \multicolumn{9}{|c|}{ a.m. } \\
\hline & & & 1 & 2 & 3. & 4 & 5 & 6 & 7 & 8 & 9 \\
\hline & Connecticut River Basin & & & & & & & & & & \\
\hline 162 & Springfield, Mass. ${ }^{1}-\ldots$ & $\left\{\begin{array}{l}24 \\
25\end{array}\right.$ & 0.11 & 0.17 & 0.17 & 0.15 & 0.22 & 0.24 & 0.12 & 0.37 & 0.22 \\
\hline 189 & Bloomfield, Conn. ${ }^{2}$ - & $\{24$ & 01 & & & 10 & & & & & \\
\hline 192 & & & & & & & & & & & \\
\hline 102 & Conn. 3 & $\left\{25^{4}\right.$ & .08 & .14 & .18 & .17 & .19 & 26 & 19 & 25 & 02 \\
\hline 148 & Ellington, Conn. ${ }^{5}-\ldots$ & $\{24$ & & & & & & & & & \\
\hline & & 25 & .05 & 11 & .06 & .04 & .12 & .15 & .05 & .25 & .22 \\
\hline 204 & Hartford, Conn. ${ }^{6}-{ }_{-1}$ & $\left\{\begin{array}{l}24 \\
25\end{array}\right.$ & .16 & 24 & .12 & $.1 \overline{3}$ & .17 &.$\overline{1}$ & .13 &.$\overline{1} \overline{1}$ & 13 \\
\hline 208 & New Britain, Conn. ${ }^{7} \ldots$ & $\left\{\begin{array}{l}24 \\
25\end{array}\right.$ & .20 & 19 & .19 & .18 & .18 & 18 & .17 & .17 & ........ \\
\hline 210 & & & & & & & & & & & \\
\hline & & $\{25$ & .22 & .19 & .14 & .11 & .16 & .14 & .16 & .25 & .15 \\
\hline 213 & South Meadows, Conn. ${ }^{2}-$ & $\left\{\begin{array}{l}24 \\
25\end{array}\right.$ & 13 & .19 & .10 & .12 & .12 & .22 & 15 & 27 & .14 \\
\hline 216 & West Hartford, Conn. ${ }^{3}-$ & $24^{4}$ & & & & & & & & & \\
\hline & Housatonic River Basin & & .10 & .20 & .18 & .20 & .19 & .20 & .15 & .16 & .15 \\
\hline 751 & Candlewood Isle, Conn. ${ }^{8}$ & $\left\{\begin{array}{l}24 \\
25\end{array}\right.$ & $\left({ }^{9}\right)$ & $\begin{array}{l}(9) \\
.01\end{array}$ & $\begin{array}{l}(9) \\
.02\end{array}$ & $\begin{array}{l}(9) \\
.33\end{array}$ & $\begin{array}{l}(9) \\
.11\end{array}$ & $\begin{array}{l}(9) \\
.15\end{array}$ & $\begin{array}{l}(9) \\
.11\end{array}$ & $\begin{array}{l}(9) \\
.21\end{array}$ & $\begin{array}{l}(9) \\
24\end{array}$ \\
\hline 250 & Woodville, Conn. ${ }^{10}{ }^{-}$ & $\{24$ & 17 & & 80 & 8 & $\bar{a}$ & $-i$ & 16 & i & \\
\hline & Hudson River Basin & & & & & & & & & & \\
\hline 255 & Albany, N.Y.6 & 24 & & & & & & & & & \\
\hline & & 25 & 05 & .06 & .08 & .07 & .07 & .08 & .08 & .02 & .02 \\
\hline 294 & Kingston, N.Y, $11 \ldots$ & $\left\{\begin{array}{l}24 \\
25\end{array}\right.$ & 22 & 19 & 15 & 19 & 03 & 01 & $\cdots$ & 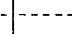 & $\cdots$ \\
\hline & Minor basins & & & & & & & & & & \\
\hline 627 & Block Island, R.I. ${ }^{6}$. & $\left\{\begin{array}{l}24 \\
25\end{array}\right.$ & .07 & .02 & 01 & Tr. & Tr. & & & $\mathrm{Tr}$. & .06 \\
\hline 635 & Providence, R.I. ${ }^{6}-\ldots$ & $\left\{\begin{array}{l}24 \\
25\end{array}\right.$ & .09 & .13 & $.0 \overline{6}$ & .06 & .04 & .01 & .03 & .15 & 14 \\
\hline 654 & New Haven, Conn $6 \ldots$ & $\{24$ & & & & & & & & & \\
\hline & & & .06 & .03 & .08 & .03 & .08 & Tr. & .11 & .11 & Tr. \\
\hline 673 & Mineola, N.Y.12 & $\left\{\begin{array}{l}24 \\
25\end{array}\right.$ & .03 & .06 & .07 & .05 & .04 & .05 & .13 & & $\ldots$ \\
\hline 676 & New York, N.Y.(Battery Place $)^{6}$ & $\{24$ & & & & & & & & & \\
\hline & & $\{25$ & .02 & .06 & .03 & .05 & .12 & .01 & .03 & & \\
\hline
\end{tabular}

NoTE.-No precipitation recorded on Jan. 26 if no data are shown for that day.

${ }^{1}$ City of Springfield, Department of Streets and Engineering.

${ }^{2}$ City Engineer, Hartford, Conn.

3Hartford Metropolitan Water Bureau.

"Hourly figures adjusted on basis of daily readings of auxiliary non-recording gage.

5 Soil Conservation Service.

${ }^{6} \mathrm{U}$. S. Weather Bureau.

TCity Engineer, New Britain, Conn. 
ending at indicated time, January 24-26, 1938

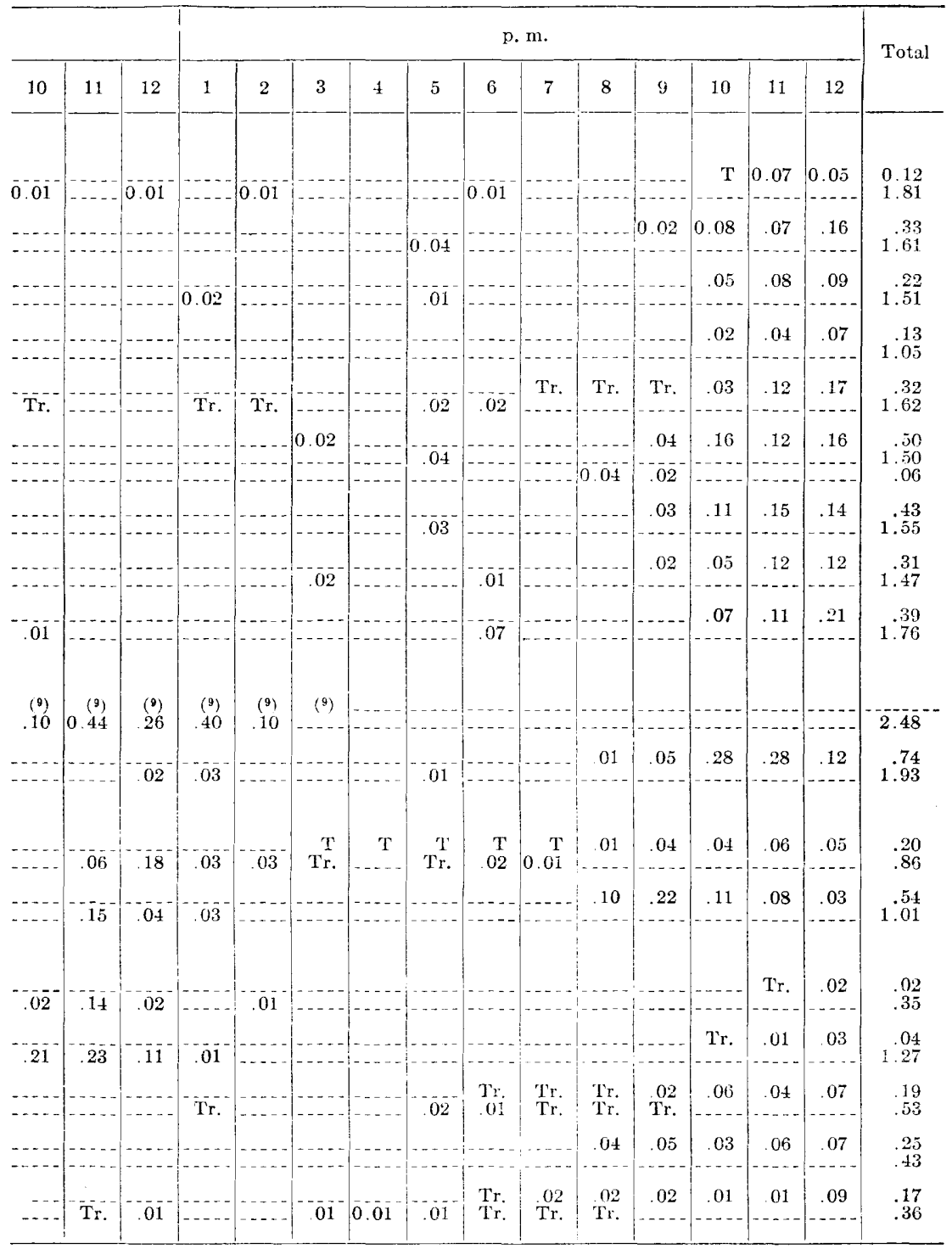

${ }^{8}$ Connecticut Light \& Power Co.

${ }^{9}$ Record missing.

${ }^{\circ}$ City of Waterbury, Bureau of Engineering. See No. 250, table 1, for daily precipitation measured in nonrecording gage.

1 1 City Engineer, Kingston, N.Y.

${ }_{12}$ Nassau County, Department of Public Works, Hydrological Bureau. 
TABLE 3.-Rate and duration of precipitation, January 24-26, 1938

\begin{tabular}{|c|c|c|c|c|c|c|c|c|c|c|}
\hline \multirow[t]{2}{*}{ Station } & \multirow{2}{*}{$\begin{array}{c}\text { Total } \\
\text { precip- } \\
\text { itation } \\
\text { (inches) }\end{array}$} & \multicolumn{7}{|c|}{$\begin{array}{l}\text { Total time, in hours, in which pre- } \\
\text { cipitation exceeded indicated rate, } \\
\text { in inches per hour }\end{array}$} & \multicolumn{2}{|c|}{$\begin{array}{l}\text { Maximum 1-hour } \\
\text { precipitation } \\
\text { in inches }\end{array}$} \\
\hline & & Trace & 0.02 & 0.04 & 0.06 & 0.10 & 0.15 & 0.25 & Date & $\begin{array}{l}\text { Precip- } \\
\text { itation }\end{array}$ \\
\hline $\begin{array}{c}\text { Massachusetts } \\
\text { Springfield } 1 \text { - }\end{array}$ & 1.93 & 15 & 11 & 11 & 10 & 9 & 6 & 1 & Jan. 25 & 0.37 \\
\hline $\begin{array}{l}\text { Rhode Island } \\
\text { Block Island }{ }^{2}-2 \\
\text { Providence }^{2}-\end{array}$ & $\begin{array}{r}.37 \\
1.31\end{array}$ & $\begin{array}{r}9 \\
15\end{array}$ & $\begin{array}{r}3 \\
12\end{array}$ & $\begin{array}{l}3 \\
9\end{array}$ & $\begin{array}{l}2 \\
7\end{array}$ & $\begin{array}{l}1 \\
6\end{array}$ & $\begin{array}{l}0 \\
2\end{array}$ & $\begin{array}{l}0 \\
0\end{array}$ & $\begin{array}{l}\text { do. } \\
\text { do. }\end{array}$ & .14 \\
\hline 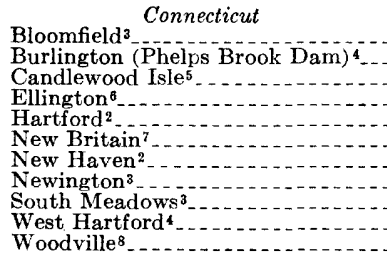 & $\begin{array}{l}1.94 \\
1.73 \\
2.48 \\
1.18 \\
1.94 \\
2.06 \\
.72 \\
1.98 \\
1.78 \\
2.15 \\
2.67\end{array}$ & $\begin{array}{l}14 \\
14 \\
13 \\
12 \\
14 \\
16 \\
13 \\
14 \\
15 \\
14 \\
17\end{array}$ & $\begin{array}{l}13 \\
11 \\
11 \\
11 \\
12 \\
14 \\
10 \\
14 \\
12 \\
13 \\
14\end{array}$ & $\begin{array}{r}12 \\
11 \\
11 \\
9 \\
11 \\
11 \\
7 \\
12 \\
12 \\
13 \\
13\end{array}$ & $\begin{array}{r}12 \\
10 \\
11 \\
6 \\
11 \\
11 \\
5 \\
12 \\
11 \\
13 \\
11\end{array}$ & $\begin{array}{r}8 \\
7 \\
9 \\
5 \\
11 \\
11 \\
2 \\
12 \\
10 \\
11 \\
11\end{array}$ & $\begin{array}{r}7 \\
6 \\
6 \\
2 \\
6 \\
10 \\
0 \\
5 \\
3 \\
8 \\
9\end{array}$ & $\begin{array}{l}1 \\
1 \\
4 \\
0 \\
1 \\
0 \\
0 \\
0 \\
1 \\
1 \\
4\end{array}$ & $\begin{array}{l}\text { do. } \\
\text { do. } \\
\text { do. } \\
\text { do. } \\
\text { do. } \\
\text { do. } \\
\text { do. } \\
\text { do. } \\
\text { do. } \\
\text { do. } \\
\text { do. }\end{array}$ & $\begin{array}{l}.26 \\
.26 \\
.44 \\
.25 \\
.31 \\
.20 \\
.11 \\
.25 \\
.27 \\
.26 \\
.36\end{array}$ \\
\hline $\begin{array}{l}\text { New York } \\
\text { Albany }{ }^{2} \quad \text { Kingston }{ }^{9}\end{array}$ & $\begin{array}{l}1.06 \\
1.55\end{array}$ & $\begin{array}{l}20 \\
14\end{array}$ & $\begin{array}{l}15 \\
13\end{array}$ & $\begin{array}{r}11 \\
9\end{array}$ & $\begin{array}{l}6 \\
9\end{array}$ & $\begin{array}{l}1 \\
7\end{array}$ & $\begin{array}{l}1 \\
4\end{array}$ & $\begin{array}{l}0 \\
0\end{array}$ & $\begin{array}{c}\text { do. } \\
\text { Jan. } 24,\end{array}$ & $\begin{array}{l}.18 \\
.22\end{array}$ \\
\hline $\begin{array}{l}\text { Mineola }{ }^{10} \\
\text { New York (Battery Place) }{ }^{2}\end{array}$ & $\begin{array}{l}.68 \\
.53\end{array}$ & $\begin{array}{l}12 \\
17\end{array}$ & $\begin{array}{r}12 \\
6\end{array}$ & $\begin{array}{l}8 \\
4\end{array}$ & $\begin{array}{l}3 \\
2\end{array}$ & $\begin{array}{l}1 \\
1\end{array}$ & $\begin{array}{l}0 \\
0\end{array}$ & $\begin{array}{l}0 \\
0\end{array}$ & $\begin{array}{l}\text { Jan. } 25 \\
\text { do. }\end{array}$ & $\begin{array}{l}.13 \\
.12\end{array}$ \\
\hline
\end{tabular}

${ }^{1}$ City of Springfield, Department of Streets and Engineering.

${ }^{2}$ U. S. Weather Bureau.

aCity Engineer, Hartford, Conn.

Hartford Metropolitan Water Bureau. Hourly amounts adjusted on basis of daily determinations at auxiliary nonrecording gage.

sConnecticut Light \& Power Co.

osoil Conservation Service.

${ }^{7}$ City Engineer, New Britain, Conn.

${ }^{8}$ City of Waterbury, Bureau of Engineering.

${ }^{\circ}$ City Engineer, Kingston, N. Y.

10 Nassau County, Department of Public Works, Hydrological Bureau.

All available records of hourly rainfall on January 24-26 are listed in table 2. Figure 10 shows the hourly distribution of precipitation at 14 selected recording stations for January 20-26, 1938. These data show that the main storm precipitation began between 7 and 8 p.m. on January 24 and stopped between 8 a.m. and noon on January 25. The rainfall within this period accounted for nearly all of the precipitation on January 24-25. Except for 0.06 inch recorded at New Britain, no precipitation fell on January 26. If these records may be used as criteria for the distribution of precipitation measured at non-recording stations, then the amounts reported from January 24 to 26 at nonrecording stations fell largely within a 24-hour period and the storm may be classified as of 1-day duration. Table 3 shows the rate and duration of precipitation of this storm period at the 18 recording stations given in table 2. For stations in Connecticut, disregarding consecutiveness, the total time in which precipitation was greater than a trace varied from 12 to 17 hours and the maximum precipitation in any 1 hour varied from 0.11 to 0.44 inch. 


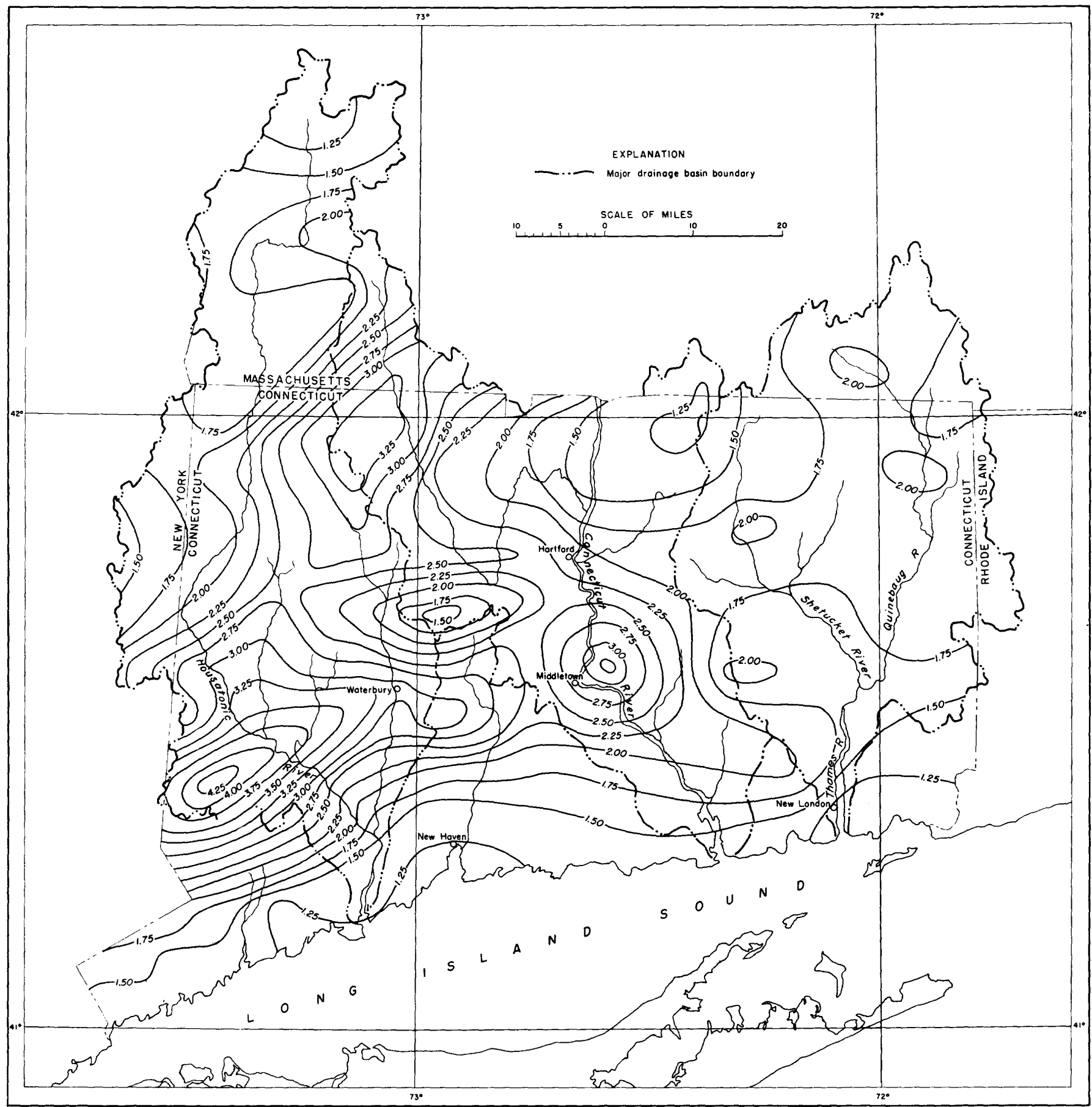

ISOHYETAL MAP OF CONNECTICUT AND PARTS OF ADJOINING STATES, SHOWING 


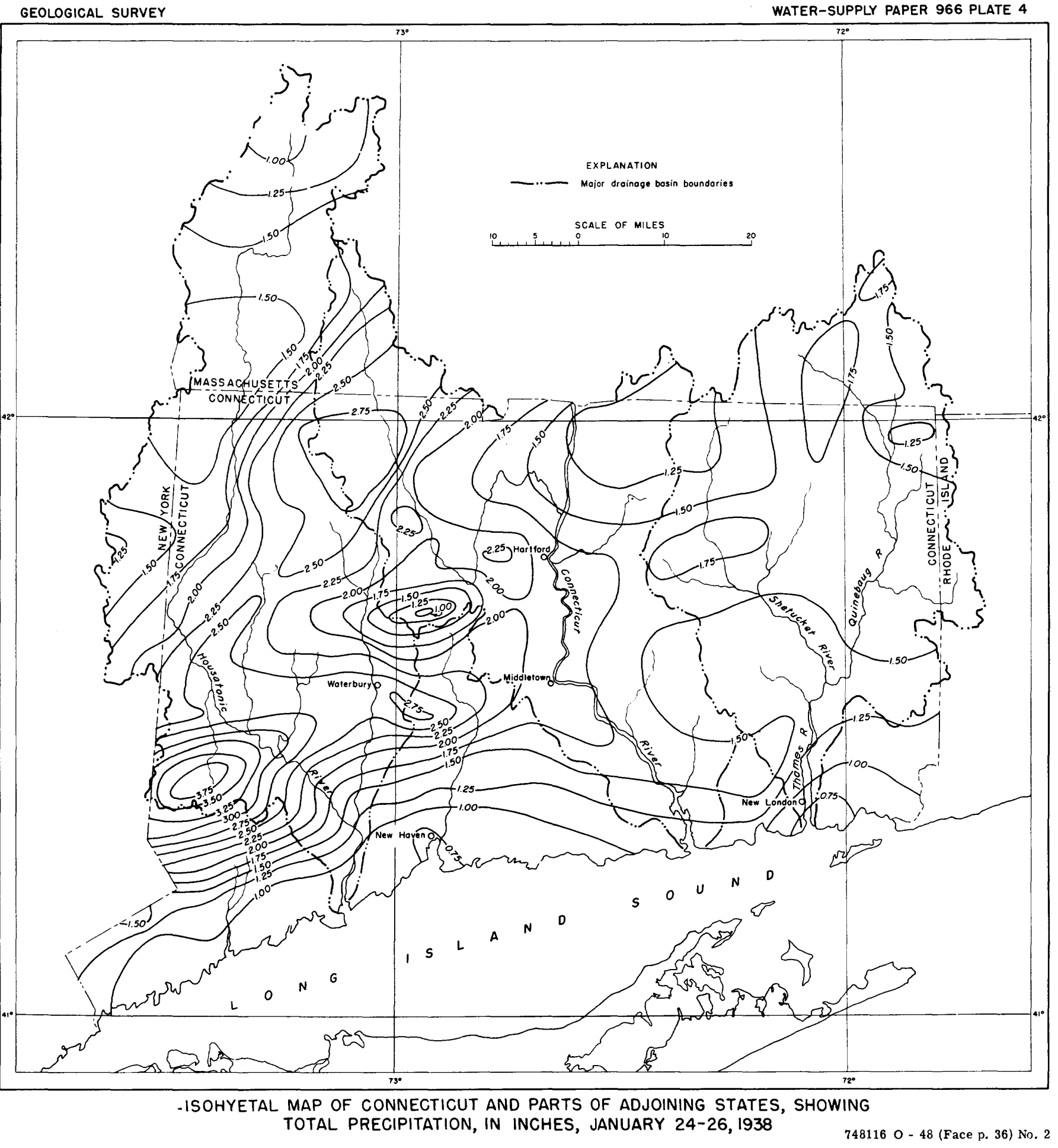




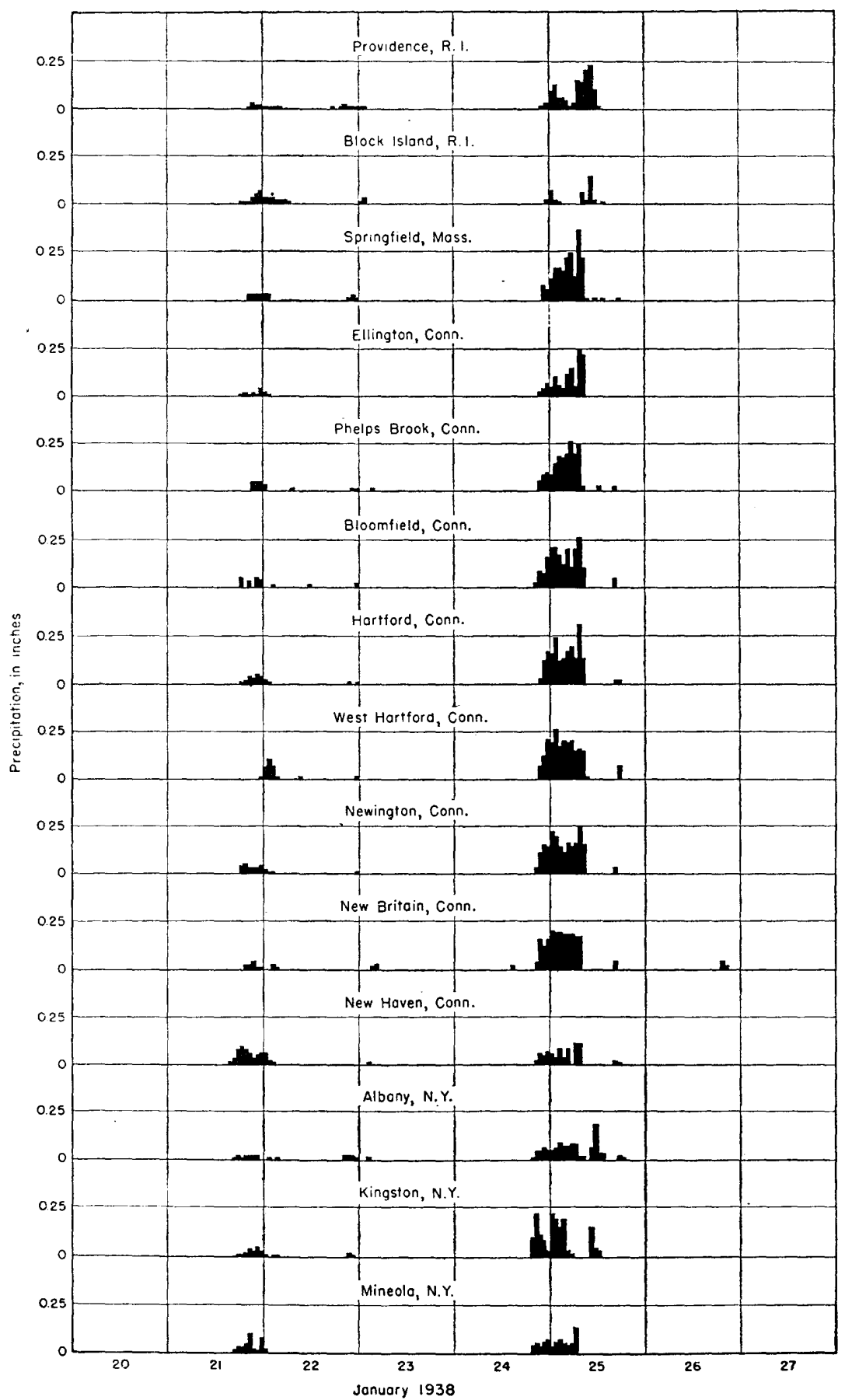

Figure 10.-Hourly precipitation at representative stations in and near Connecticut, January 20-26, 1938. 
AREAL DISTRIBUTION

Lack of precipitation immediately before or after the period January 20-26 permitted convenient segregation of the period as a unit for study. Recording rainfall stations showed no precipitation on January 20, and, as that was the end of the cold period, records of water content of snow could be adjusted to this date. Precipitation from January 21 to 23 was reported mostly as snow except along the coast, where some sleet and rain were reported. However, temperatures rose and records at most river-measurement stations showed slight runoff therefrom. Accordingly, the total precipitation from January 20 to 26 could best be added to the water content of snow as of January 20 to determine the total water available for runoff in the flood.

Plate 3 presents an isohyetal map for the total period January $20-26,1938$, for the area covered by this report, and plate 4 presents a similar map for precipitation from January 24 to 26 , which was largely received within a 24 -hour period.

Plate 4 shows two major storm centers, the greater center in southwestern Connecticut and the lesser near the ConnecticutMassachusetts State line. Climatological data published by the Weather Bureau indicate that there was another center in Massachusetts just south of the intersection of the Massachusetts, New Hampshire, and Vermont State lines. Thus, the path of maximum precipitation ran about N. $30^{\circ}$ E., with places of especially heavy precipitation about 50 miles apart. Flanking each side of this path were other scattered concentrations of less magnitude.

The areas between isohyetal lines were measured by planimeter on the original maps of plates 3 and 4 for the drainage basins upstream from each of the 32 river-measurement stations, and a value was obtained for the average total precipitation in each basin. The results of these determinations are given in table 9 .

\section{AREA-DEPTH RELATIONS}

The areas within various isohyetal lines shown on plate 4 for this 1-day storm were planimetered for the area covered by this report. The results were as follows: More than 4 inches of precipitation on about 2 square miles, more than 3 inches on 130 square miles, more than 2 inches on 1,490 square miles, and more than 1 inch on 5,740 square miles. It should be emphasized that these areas are only those within the area of this report, which covers about 6,200 square miles. Time did not permit a determination for the entire area of the storm.

The Miami Conservancy District analyzed many of the notable storms in this region by comparing the area enclosed by each iso- 
hyetal of a storm with the average rainfall within it. The envelop of determinations for the various isohyets showed the variation of average precipitation with respect to areal extent. Table 4 compares the storms of January and July 1938 with those in this region computed by the Miami Conservancy District and also with other recent storms. (See page 84 of Geological Survey WaterSupply Paper 867.) Isohyets greater than 2 inches for the storm of January 1938 were defined beyond the area of this report using only the records published by the Weather Bureau in Climatological Data. The closure lines would undoubtedly have been more accurate if all possible rainfall records had been obtained. The rainfall of January 24-26, 1938, compared with that of other storms, was small in amount, and a combination with other factors was required to produce the flood. For a composite comparison of the rainfall, runoff, and peak-flow relations of recent great storms in Connecticut, reference should be made to table 10 .

TABLE 4.--Depth of average rainfall in relation to areal extent for notable storms in the North Atlantic coast region

\begin{tabular}{|c|c|c|c|c|c|c|c|c|}
\hline \multirow{2}{*}{ Date } & \multirow{2}{*}{$\begin{array}{l}\text { Center of } \\
\text { storm }\end{array}$} & \multicolumn{6}{|c|}{$\begin{array}{c}\text { Average rainfall, in inches, over indicated } \\
\text { area, in square miles }\end{array}$} & \multirow{2}{*}{$\begin{array}{c}\text { Dura } \\
\text { tion } \\
\text { (days) }\end{array}$} \\
\hline & & 1 & 500 & 1,000 & 2,000 & 4,000 & 6,000 & \\
\hline 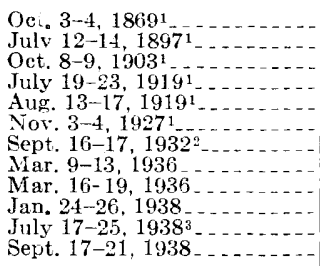 & 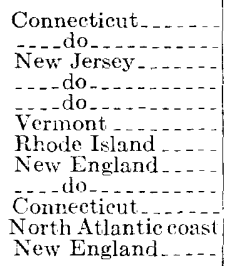 & $\begin{aligned} 12.4 \\
10.3 \\
15.0 \\
12.8 \\
10.2 \\
9.4 \\
12.2 \\
9.2 \\
9.0 \\
4.1 \\
14.0 \\
18.0\end{aligned}$ & $\begin{array}{r}10.1 \\
9.5 \\
11.9 \\
10.4 \\
9.9 \\
9.1 \\
11.2 \\
7.9 \\
8.0 \\
30 \\
11.8 \\
15\end{array}$ & $\begin{array}{r}9.7 \\
9.1 \\
10.9 \\
47 \\
6.6 \\
8.9 \\
10.4 \\
7.3 \\
7.7 \\
2.8 \\
11.1 \\
14.8\end{array}$ & $\begin{array}{l}8.9 \\
8.5 \\
9.9 \\
8.5 \\
9.2 \\
8.6 \\
9.4 \\
6.0 \\
7.4 \\
2.5 \\
10.2 \\
14.0\end{array}$ & $\begin{array}{l}8.1 \\
7.5 \\
9.0 \\
7.5 \\
8.4 \\
8.1 \\
8.3 \\
5.9 \\
7.0 \\
9.2 \\
9.0\end{array}$ & $\begin{aligned} 7.8 \\
6.9 \\
8.4 \\
7.0 \\
7.7 \\
7.7 \\
7.8 \\
5.45 \\
6.8 \\
8.9 \\
12.3\end{aligned}$ & $\begin{array}{l}2 \\
2 \\
2 \\
5 \\
5 \\
5 \\
2 \\
1 \\
4 \\
3 \\
1 \\
7 \\
4\end{array}$ \\
\hline
\end{tabular}

IStorm rainfall of eastern United States, Miami Conservancy District Tech. Repts, pt. 5 (revised), 1. 278, Dayton, Ohio, 1936.

${ }^{2}$ White, G. W., Great storm of September 16 and 17, 1932, New England Water Works Assoc. Jour., vol. 47 , No. 2 , pp. 164-183, 1933 .

${ }^{3}$ Area north of Potomac River only.

\section{SNOW}

In combination with rainfall and frozen ground, snow was one of the major factors contributing to the January flood. In a preceding section of this report, entitled "Antecedent conditions," data show by months the amounts and variations of antecedent snowfall. Presented herewith are basic data used and analyses made to determine finally the amount of potential water stored in the snow cover for runoff during the flood.

The best means for determining snow-water available for runoff during a flood is a survey made just prior thereto of the water 
equivalent of snow. As the time for such a survey can seldom be accurately anticipated, it is generally necessary to adjust some periodic survey to the date of the flood by adding intervening rainfall and snowfall adjusted for evaporation and runoff. Also records of depth of snow on the ground at Weather Bureau cooperative stations when converted to equivalent inches of water provide supplemental values for localities where no surveys are made.

Table 5 shows records of snow depth on various days of December 1937 and January 1938 for all available stations, principally of the United States Weather Bureau, within the area covered by this report and for some stations just outside the area. Footnotes indicate the source of the information. Most of these stations are situated in urban or rural communities and may not be accurately representative of the surrounding countryside. There are, moreover, significant differences between snow depths in areas of hardwood and coniferous trees.

It may be noted from table 5 that snow cover on December 25 was very light, but by January 5 snow storms had increased the depth. Records for January 10 indicate that the warm rain on January 7 had removed most of this snow in Rhode Island and from a band averaging somewhat more than 10 miles wide along the entire coast of Connecticut. Elsewhere the records show that this rain caused a definite decrease in snow depth. The remaining snow was probably well saturated, inasmuch as all the Connecticut stream-flow records showed a decided rise after January 7. From January 10 to 22 the snow depth increased at all stations. Records for January 25 show that the storm of that date had removed most of the snow in Connecticut, and by January 27 only two stations in the immediate vicinity, in northwestern Massachusetts, reported more than 0.4 inch still on the ground. 
TABLE 5.-Snow depth, in inches, on ground on indicated days, December 1937 and January 1938

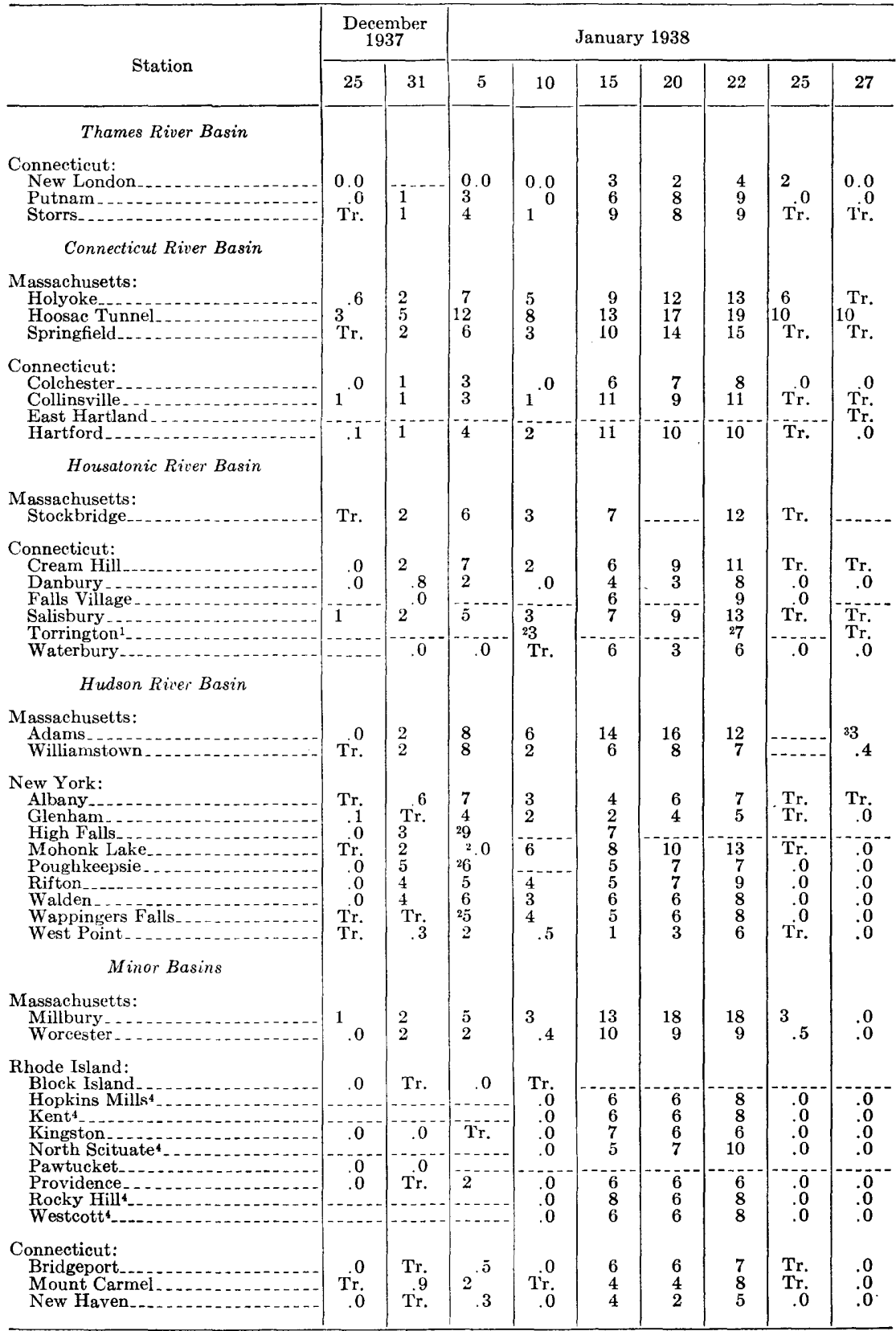

NoтE.-Data furnished by U. S. Weather Bureau unless otherwise indicated.

1Data furnished by Torrington Register, Torrington, Conn.

2Estimated from observations on adjacent days.

${ }^{3}$ No snow on Jan. 31 .
${ }^{2}$ Data furnished by State Department of Public Works, Providence, R. I. 
TaBle. 6.-Snow depth, in inches, and water equivalent of snow, in inches, at snow courses in Connecticut, Massachusetts, and New York during January and February 1938

\begin{tabular}{|c|c|c|c|c|c|}
\hline \multirow{2}{*}{$\begin{array}{l}\text { No. } \\
\text { on } \\
\text { pl. } \\
5\end{array}$} & \multirow[b]{2}{*}{ Place of measurement } & \multirow{2}{*}{$\begin{array}{c}\text { Day of } \\
\text { mieasurement }\end{array}$} & \multirow[b]{2}{*}{$\begin{array}{l}\text { Snow } \\
\text { depth }\end{array}$} & \multicolumn{2}{|c|}{ Water equivalent } \\
\hline & & & & Observed & $\begin{array}{l}\text { Adjusted to } \\
\text { January } 20\end{array}$ \\
\hline & Thames River Basin & & & & \\
\hline 1 & $\begin{array}{l}\text { Stafford, Conn. (aiong Furnace Brook } 3 \text { miles } \\
\text { ujstream froni mouth) }\end{array}$ & $\begin{array}{l}\text { Jan. } 18 \\
\text { Feb. } 4\end{array}$ & $\begin{array}{r}11.5 \\
.0\end{array}$ & $\begin{array}{l}1.46 \\
.0\end{array}$ & 1.46 \\
\hline 2 & $\begin{array}{l}\text { South Coventry, Conn. (along Willimantic } \\
\text { River } 2 \text { miles upstream from Hop River) }\end{array}$ & $\begin{array}{l}\text { Jan. } 18 \\
\text { Feb. } 9\end{array}$ & $7^{7}$ & 1.19 & 1.19 \\
\hline 3 & $\begin{array}{l}\text { Hampton, Conn. (1 mile north of center of } \\
\text { town) }\end{array}$ & $\begin{array}{l}\text { Jan. } 18 \\
\text { Feb. } 4\end{array}$ & 8.0 & $\begin{array}{l}1.16 \\
.0\end{array}$ & 1.16 \\
\hline 4 & $\begin{array}{l}\text { Putriam, Conn. (along Quinebaug River near } \\
\text { Muddy Brook) }\end{array}$ & $\begin{array}{l}\text { Jan. } 18 \\
\text { Feb. } 4\end{array}$ & $\begin{array}{r}7.5 \\
.0\end{array}$ & $\begin{array}{l}1.05 \\
.0\end{array}$ & 1.05 \\
\hline 5 & $\begin{array}{l}\text { Jewett City, Conn. (along Quinebaug River } \\
\text { near Pachaug River) }\end{array}$ & $\begin{array}{l}\text { Jan. } 13 \\
\text { Jan. } 27\end{array}$ & ${ }^{6} .0$ & $\begin{array}{l}.44 \\
.0\end{array}$ & .58 \\
\hline & Connecticut River Basin & & & & \\
\hline 6 & $\begin{array}{l}\text { Hartford, Conn, (in Goodwin Park, near } \\
\text { Wethersfield township line, } 2 \text { miles west of } \\
\text { Connecticut River) }\end{array}$ & Jan. 16 & 8.5 & 1.58 & 1.70 \\
\hline 7 & Branford, Mass. (Borden Brook Reservoir)_ & $\begin{array}{l}\text { Jan. } 20 \\
\text { Jan. } 21 \\
\text { Jan. } 22\end{array}$ & $\begin{array}{l}13 \\
15 \\
16\end{array}$ & $\begin{array}{l}1.09 \\
1.26 \\
1.35\end{array}$ & 1.09 \\
\hline 8 & $\begin{array}{l}\text { Riverton, Conn. (along Farmington River be- } \\
\text { Jow Still River) }\end{array}$ & $\begin{array}{l}\text { Jan. } 15 \\
\text { Feb. } 3\end{array}$ & 8 & $\begin{array}{c}2.68 \\
.0\end{array}$ & 2.85 \\
\hline 9 & $\begin{array}{l}\text { Tariffville, Conn. (along Farmington River } 1 \\
\text { mile southwest of Tarifiville) }\end{array}$ & $\begin{array}{l}\text { Jan, } 15 \\
\text { Feb. } 2\end{array}$ & $\frac{11.5}{\operatorname{Tr} .}$ & $\begin{array}{l}2.02 \\
3.1\end{array}$ & 2.16 \\
\hline 10 & $\begin{array}{l}\text { Burlington. Conn. (along Burlington Brook } 1 \\
\text { mile north of Burlington) }\end{array}$ & $\begin{array}{l}\text { Jan. } 19 \\
\text { Feb. } 1\end{array}$ & 10 & 34.1 .92 & 1.92 \\
\hline 11 & $\begin{array}{l}\text { Farmington. Conn. (2 miles east of town beside } \\
\text { abandoned Hartford Reservoir) } \text { ) }^{5}\end{array}$ & Jan. 3 & $\begin{array}{r}4.5 \\
11.5\end{array}$ & $\begin{array}{l}1.08 \\
1.42\end{array}$ & 1.52 \\
\hline 12 & $\begin{array}{l}\text { Newirgton, Conn. (1 mile southwest of con- } \\
\text { fluence of 'ront Brook and South Branch of } \\
\text { Park River) }\end{array}$ & Jan. 14 & 11 & 1.71 & 1.81 \\
\hline 13 & $\begin{array}{l}\text { West Hartford, Conn. (1 } 1 \text { miles west of con- } \\
\text { fluence of South and North Branches of } \\
\text { Park Riter)1 }\end{array}$ & $\begin{array}{l}\text { Jan. } 15 \\
\text { Jan. } 22\end{array}$ & $\begin{array}{l}11 \\
10.5\end{array}$ & $\begin{array}{l}1.74 \\
2.00\end{array}$ & 1.92 \\
\hline 14 & $\begin{array}{l}\text { Bloomfield, Conn. (in rillage, west of Wash } \\
\text { Brook) }\end{array}$ & $\begin{array}{l}\text { Jan. } 3 \\
\text { Jan. } 14\end{array}$ & 11.5 & $\begin{array}{l}1.14 \\
1.62\end{array}$ & 1.78 \\
\hline 15 & $\begin{array}{l}\text { Tolland, Conn } 1 \text { mile east of Shenipsit Lake } \\
\text { and on divicle between Conrecticut and } \\
\text { Thanes River Basins) }\end{array}$ & $\begin{array}{l}\text { Jan, } 18 \\
\text { Feb. } 4\end{array}$ & 10.0 & $\begin{array}{l}1.49 \\
.0\end{array}$ & 1.49 \\
\hline 16 & $\begin{array}{l}\text { East Hambion, Conn. (along Salmon River } 3 \\
\text { miles southeast of East Hampton) }\end{array}$ & $\begin{array}{l}\text { Jan. } 13 \\
\text { Feb. } 10\end{array}$ & 8.0 & $\begin{array}{l}.69 \\
.0\end{array}$ & .89 \\
\hline 17 & $\begin{array}{l}\text { Sorth Lyme, Conn. (near confiuence of Fast } \\
\text { and West Branches of tightmile River) }\end{array}$ & $\begin{array}{l}\text { Jan. } 13 \\
\text { Jan. } 31\end{array}$ & 7 & $3+.1$ & .59 \\
\hline & Quinnipiac River Basin & & & & \\
\hline 18 & $\begin{array}{l}\text { Plantsville, Conn. (near confluence of Quinn- } \\
\text { ipiac and Eightmile Rivers) }\end{array}$ & $\begin{array}{l}\text { Jan. } 19 \\
\text { Feb. } 15\end{array}$ & 7.5 & $\begin{array}{l}1.65 \\
.0\end{array}$ & 1.65 \\
\hline 19 & $\begin{array}{l}\text { Wailingford, Conn. (along Quinnipiac River } \\
\text { west of borough) }\end{array}$ & $\begin{array}{l}\text { Jan. } 19 \\
\text { Feb. } 2\end{array}$ & Tr. & $\begin{array}{l}1.09 \\
3.1\end{array}$ & ].09 \\
\hline & Housatonic River Basin & & & & \\
\hline 20 & $\begin{array}{l}\text { Falls Village, Conn. (along Housatonic River } 1 \\
\text { mile below Hollenbeck River) }\end{array}$ & $\begin{array}{l}\text { Jan. } 17 \\
\text { Feb. } 7\end{array}$ & $\begin{array}{r}5 . \tilde{j} \\
.0\end{array}$ & .86 & .97 \\
\hline 21 & $\begin{array}{l}\text { Stevenson, Conn. (along Housatonic River } \\
\text { near Eighimile Biook) }\end{array}$ & $\begin{array}{l}\text { Jan. } 14 \\
\text { Jan. } 31\end{array}$ & $\begin{array}{r}6.5 \\
.0\end{array}$ & .0 & .85 \\
\hline 22 & $\begin{array}{l}\text { Norfolk, Conn. ( } 2 \text { miles east of town on divide } \\
\text { betwcen Housatonic and Connecticut River } \\
\text { Basins) }\end{array}$ & $\begin{array}{l}\text { Jan. } 17 \\
\text { Feb. } 7\end{array}$ & 7.0 & $\begin{array}{l}.0 \\
.0\end{array}$ & 1.66 \\
\hline 23 & $\begin{array}{l}\text { Gaylordsville, Conn. (along Tenmile River } 1 \\
\text { mille upstream from mouth) }\end{array}$ & $\begin{array}{l}\text { Jan. } 17 \\
\text { Feb. } 7\end{array}$ & $\begin{array}{r}6.5 \\
.0\end{array}$ & $\begin{array}{l}1.55 \\
.0\end{array}$ & 1.60 \\
\hline 24 & New Fairfield, Corn. (north side of village) & $\begin{array}{l}\text { Jan. } 17 \\
\text { Feb. } 2\end{array}$ & 5 & .71 & .73 \\
\hline 25 & $\begin{array}{l}\text { Woodville, Conn. (along sliepaug River } 3 \\
\text { miles above Bantam River) }\end{array}$ & $\begin{array}{l}\text { Jan. } 14 \\
\text { Feb. } 2\end{array}$ & $7 \mathrm{Tr}$ & $\begin{array}{l}1.29 \\
3.1\end{array}$ & 1.40 \\
\hline
\end{tabular}

See footnotes at end of table. 
TABLE 6.-Snow depth, in inches, and water equivalent of snow, in inches, at snow courses in Connecticut, Massachusetts, and New York during January and February 1938 -Continued

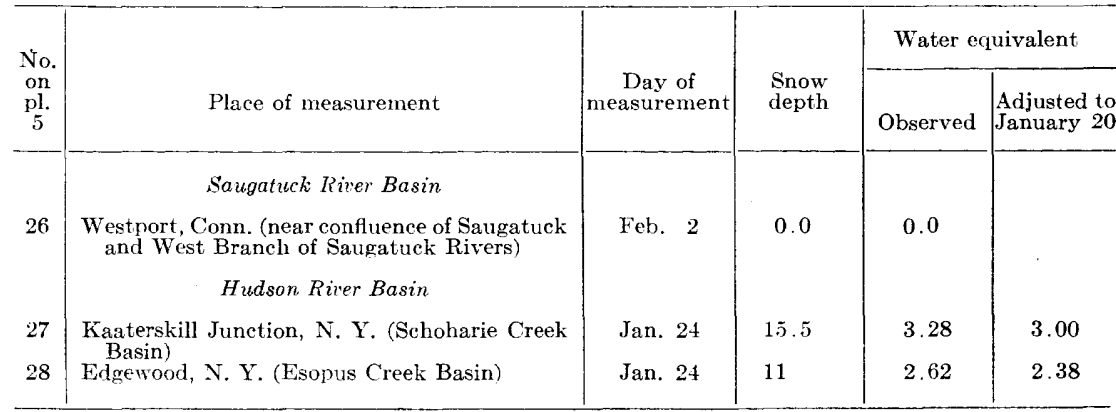

Note.--Observations by Geological Survey unless otherwise indicated.

IObservation by U. S. Weather Bureau.

2Observation by Springfield Water Works, Springfield, Mass.

Estimated.

sObserver reported snow on ground to be of recent origin

sObservation by city engineer, Hartford, Conn.

Table 6 shows the depth and water content of snow at various snow courses. No data could be obtained for Rhode Island and for but one place in Massachusetts. Many determinations were made in New York, and the two listed are closest to the area covered by this report. Observations in Connecticut by the Geological Survey were obtained by averaging the depth and weight of eight samples taken 50 to 100 feet apart at courses laid out in a pattern to compensate best for snow drifting.

Most of the snow surveys prior to the flood were made during the period of January 13-20. From January 10 to 20 all precipitation was in the form of snow and temperatures were below freezing for all but a few hours. Average daily temperatures at Hartford for this period, computed from hourly readings, ranged from $8.4^{\circ}$ to $30.2^{\circ} \mathrm{F}$. and averaged $20.4^{\circ}$ during the 11 -day period. Considering the inaccuracy involved in applying a local determination over a large area, it was deemed permissible to neglect corrections for any slight evaporation, condensation, or melting that might have occurred during this period. Therefore, any observations between January 10 and 20 were readily converted to any other date in the period by adding or subtracting the intervening precipitation at the place. Where there were no precipitation stations in the vicinity of the snow-survey courses, a fair approximation for the intermediate course and a better mean for the surrounding area was made by computing a weighted average of the precipitation at several of the closest stations. Temperatures were above freezing for longer periods after January 20, and stream-flow records indicate a slight direct runoff. Accordingly, the snow surveys could 
be best adjusted to January 20 and the last column of table 6 shows these figures.

The map on plate 5 has been prepared to show an estimate of the water equivalent of snow on January 20. It was reduced to an appropriate scale for publication from the original traced over a Geological Survey base map, scale 1:500,000. Index numbers on the map correspond to those in table 6 .

In drawing this map, considerable use was made of precipitation and snow-depth records to supplement the snow surveys. For the greater part of Rhode Island and areas along the coast of Connecticut, where it was reported that the ground was bare of snow on January 10, the water equivalent of snow on January 20 was about equal to the total precipitation during the intervening period. For the remaining area, various methods were used to estimate the water equivalent of snow from the supplemental information. The elevation of the snow courses in Connecticut varies from about 30 to 1,380 feet, which range includes the elevation of most of the stations where records of snow depth on the ground were taken. In this limited range of elevation no definite trend was discernible between altitude and snow density. Accordingly, snow cover at Weather Bureau stations that were within a few miles of snow courses was assumed to have a density equal to the snow of the same date at the snow courses. Adjusted as previously explained by using intervening precipitation to January 20 and weighted according to distances from the various snow courses, approximate values of water equivalent of snow were thus available for many of the Weather Bureau stations.

The water equivalent of snow could not be so accurately or readily determined for areas, particularly in Massachusetts and New York, that were distant from snow courses. The density of snow cover on January 10 was probably more uniform throughout the area because of the heavy rainfall on January 7 than it was after subsequent snowfall. The density on January 10 was computed to average about 0.6 at the snow courses in Connecticut where the depth of this old snow was determined separately from that of subsequent snowfalls. Assuming a density of 0.5 for the higher or more northern areas in Massachusetts and New York, a map was drawn showing roughly the water content of snow on January 10. It was fairly well defined in Connecticut by adjustment of the water-content-of-snow surveys to January 10 and seemed reasonable in Massachusetts and New York when compared with approximate computations of precipitation from December 25 to January 10 minus estimated loss of water content of the snow during that period. Estimated water equivalent of 
snow for January 10, plus precipitation from January 10 to 20 , was then used as a basis for drawing the lines of equal water equivalent of snow as of January 20 (pl. 5) for the areas in Massachusetts and New York, some weight being given to topography.

The areas between the lines indicating water content were measured by planimeter, and the average water content of the snow, in depth in inches, for the drainage basins above the principal gaging stations was determined. These data are shown in table 9 .

\section{FROST IN THE GROUND}

Frost in the ground prior to the January flood played an important part in causing river stages to rise to higher levels than they otherwise would have risen, in that the snow-melt and rain could not readily infiltrate into the ground.

Accurate frost observations are almost wholly lacking in New England and this constitutes a serious deficiency in climatologic information useful for the detailed study of the causes of winter floods. The observations and estimates of frost conditions are submitted in table 7. The estimates were obtained from superintendents of cemeteries, and as it is general practice to locate cemeteries in gravelly and sandy soils and in open areas these data may not be representative for other types of soil nor for wooded or more sheltered areas. In addition to these records the bulletin issued by the New York Cooperative Snow Survey on January 31,1938 , indicates that frost was 3 to 8 inches deep in certain areas of central New York prior to the flood.

TABLE 7.-Frost conditions in cemeteries at indicated towns in Massachusetts and Connecticut during winter of 1937-1938

\begin{tabular}{|c|c|c|}
\hline Location & Date & Depth of frost penetration \\
\hline \multicolumn{3}{|l|}{ Thames River Basin } \\
\hline $\begin{array}{l}\text { Willimantic, Conn } \\
\text { Norwich, Conn } \\
\text { New London, Conn }\end{array}$ & $\left\{\begin{array}{l}\text { Dec. 16, } 1937 \\
\text { Dec. 20,1937 } \\
\text { Jan. 20,1938 } \\
\text { Jan. 24, } 1938 \\
\text { Feb. 4, 1938 } \\
\text { Feb. 8, 1938 }\end{array}\right.$ & $\begin{array}{l}6 \text { inches. } \\
\text { About } 3 \text { inches. } \\
\text { About } 12 \text { inches. } \\
3 \text { inches. } \\
\text { No frost. } \\
\text { No frost. }\end{array}$ \\
\hline \multicolumn{3}{|l|}{ Connecticut River Basin } \\
\hline $\begin{array}{l}\text { Huntington, Mass } \\
\text { Brookfield, Mass. } \\
\text { Palmer, Mass } . . .\end{array}$ & $\begin{array}{l}\text { During winter } \\
\text { December } 1937 \\
\text { Jan. } 6,1938 \\
\text { Jan. 16, 1938 } \\
\text { Jan. 20, 1938 } \\
\text { Feb. 19, 1938 } \\
\text { During winter } \\
\text { January } 1938\end{array}$ & $\begin{array}{l}8 \text { to } 14 \text { inches; less than normal. } \\
\text { Only frozen turf. } \\
8 \text { inches. } \\
14 \text { inches. } \\
14 \text { inches. } \\
12 \text { inches. } \\
\text { Not over } 2-3 \text { inches. } \\
4 \text { to } 6 \text { inches; less than normal. }\end{array}$ \\
\hline \multicolumn{3}{|l|}{ Minor basin } \\
\hline Worcester, Mass & Prior to Jan. 25, 1938 & 12 to 14 inches; normal depth. \\
\hline
\end{tabular}


From table 7 it may be noted that before the flood on January 25 frost was in the ground at all the reporting places and ranged in depth from 2 to 14 inches. These records do not show conclusively that the frost came out of the ground during or immediately after January 25, but records of water level in wells throughout Connecticut show a general rise, and stream-flow records indicate an increased ground-water flow after the flood, all of which could be possible only if the ground were largely free from frost while water was available for infiltration.

\section{STAGES AND DISCHARGES AT STREAM-GAGING STATIONS} EXPLANATION OF DATA

Records of discharge at 32 stream-gaging stations in Connecticut are presented in this section. These records are the essence of this report and are of wide utility in many kinds of flood problems. The make-up of the tables, significance of the descriptive notes, methods of collecting and computing records of stream flow,

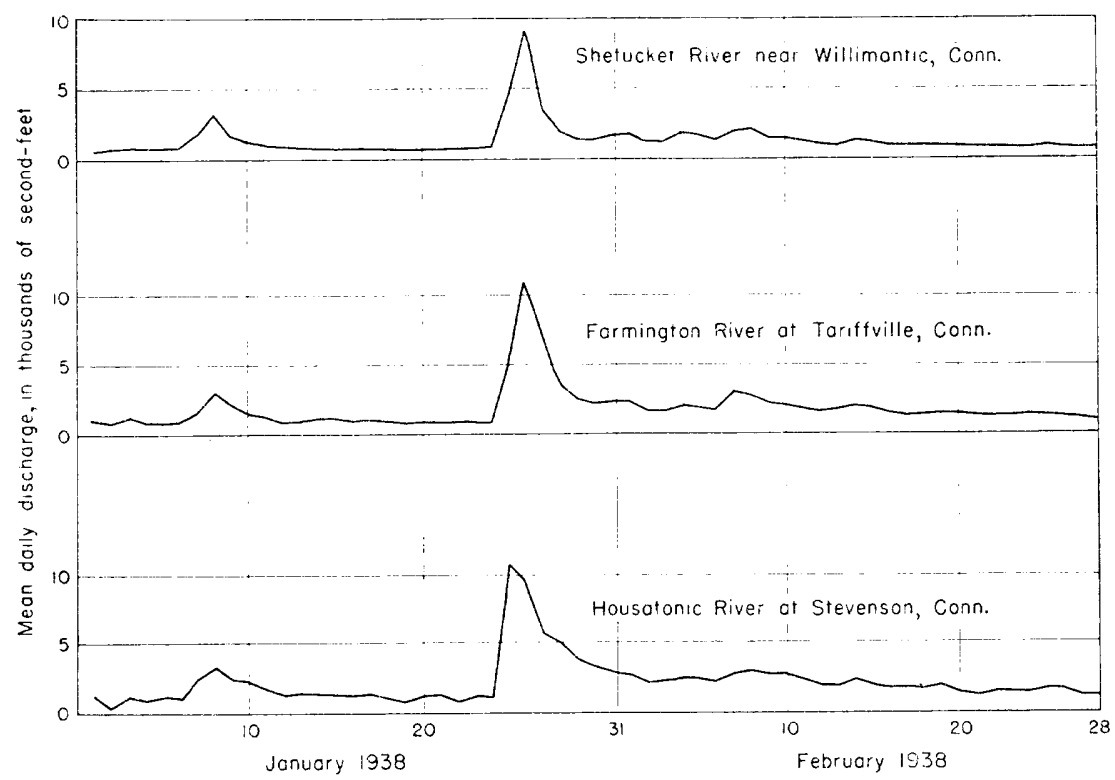

Figure 11.-Graphs of daily discharges at various stream-gaging stations for the period January 1 to February 28, 1938.

and extent of their limitations have been explained in appropriate detail in pages 8 to 11 . Figure 11 gives a general perspective of stream-flow conditions during January and February based on records of daily discharge selected from among those included in 
this section. The rivers were in flood 4 days from about January 25 to about January 29. Flow preceding and following these dates was relatively low, though higher after the flood than before it. More detailed characteristics of the flood peaks and conditions of stream flow during the flood period are shown by hydrographs of discharge based on tables of "discharge at indicated time" for selected stream-gaging stations in the Thames, Connecticut, and Housatonic River Basins in figures 12 to 14 , inclusive. 


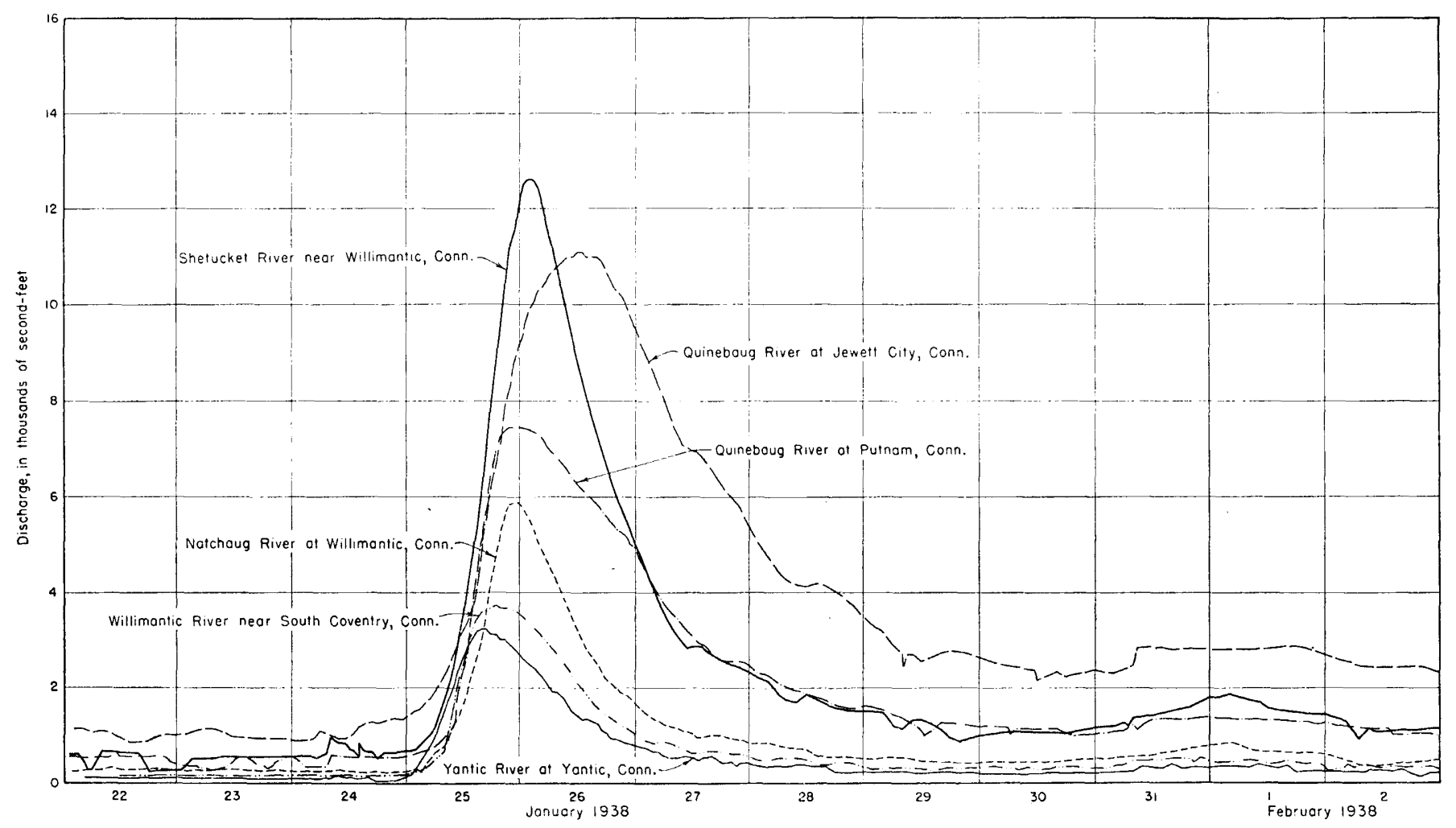

Figure 12,-Hydrographs of discharge at various stream-gaging stations in the Thames River Basin, January 1938. 


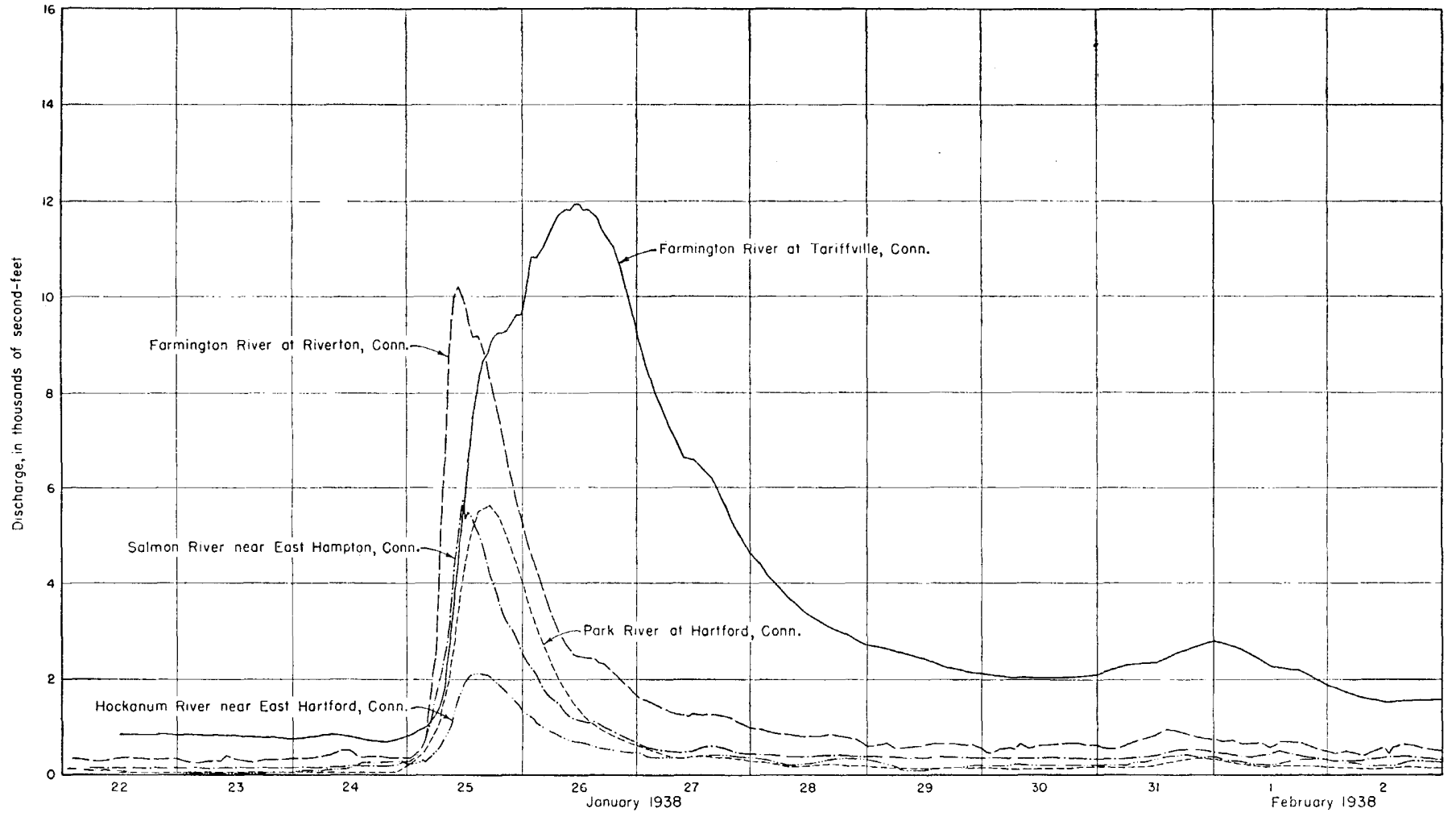

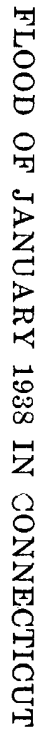

Figure 13.-Hydrographs of discharge at various stream-gaging stations in the Connecticut River Basin, January 1938. 


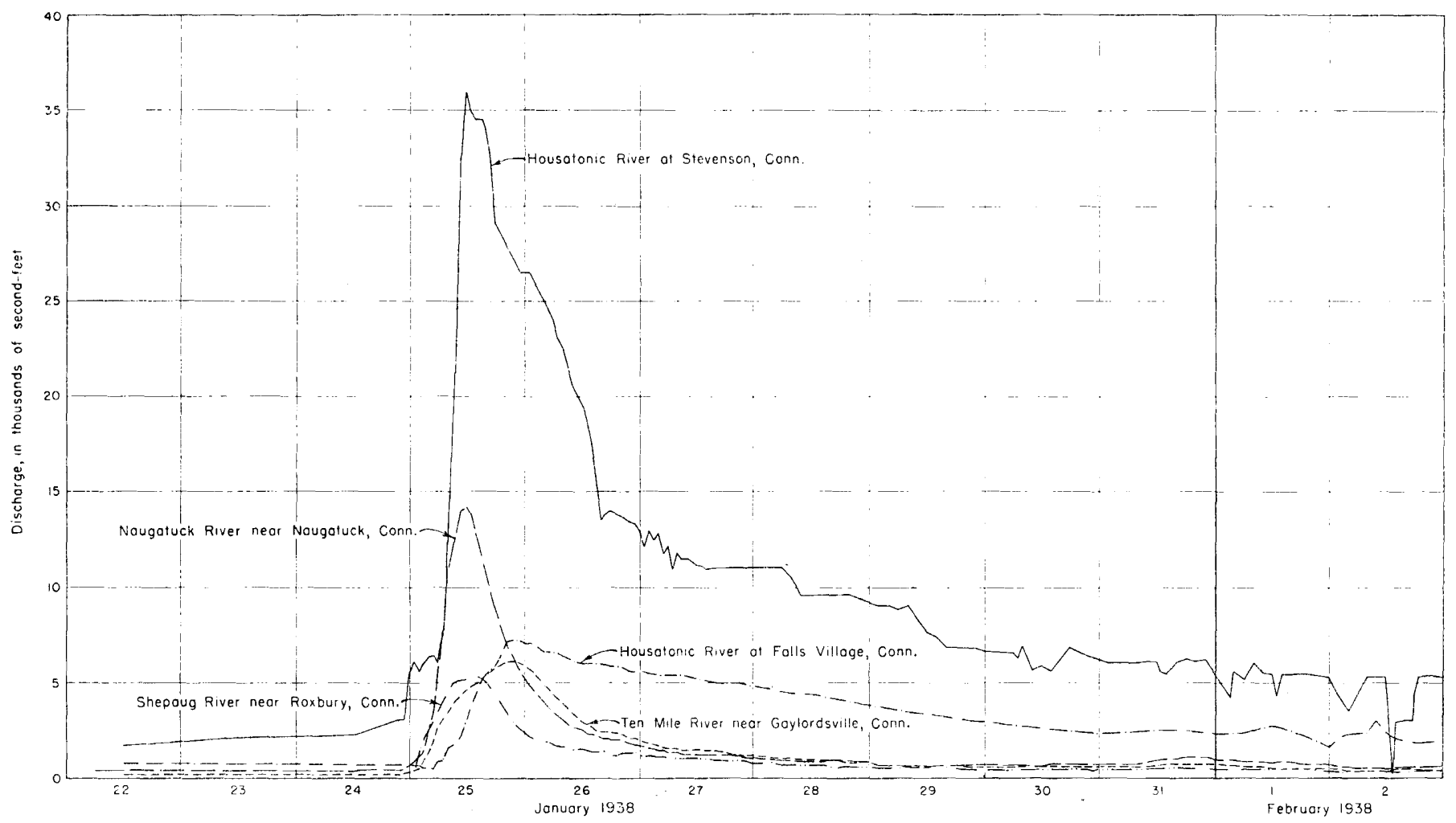

Figvre 14--Hydrographs of discharge at various stream-gaging stations in the Housatonic River Basin, January 1938. 
THAMES RIVER BASIN

WIIIIMANTIC RIVER NEAR SOUTH COVENTRY, CONN.

Location.-Lat. $41^{\circ} 45^{\prime} 00^{\prime \prime}$, long. $72^{\circ} 16^{\prime} 00^{\prime \prime}$, 700 feet upstream from highway bridge, 2 miles southeast of South Coventry, Tolland County, and 21/2 miles upstream from Hop River. Datum of gage is 239.05 feet above mean sea level, datum of 1929 (levels by Corps of Engineers, U. S. Army).

Drainage area.-121 square miles.

GAGE-HEIGHT RECORD.-Water-stage recorder graph except for periods 4 p.m. Jan. 15 to 4 p.m. Jan. 18, 6 p.m. Jan. 18 to 2 p.m. Jan. 25, 6 p.m. Jan. 25 to 9 a.m. Jan. 27, when record was computed on basis of recorded range of stage, existing record, and hydrologic comparison with nearby stations.

Stage-discharge relation.-Defined by current-meter measurements. Affected by ice Jan. 10-14, Feb. 27, 28.

Maxima.-January 1938: Discharge, 3,770 second-feet 7 p. m. Jan. 25 (gage height, 9.81 feet).

1931 to December 1937: Discharge, 7,880 second-feet Mar. 12, 1936 (gage height, 12.19 feet).

REMARKs.-Flood discharge affected by storage in several ponds and reservoirs.

Mean discharge, in second-feet, 1938

\begin{tabular}{|c|c|c|c|c|c|c|c|c|c|c|c|}
\hline Day & Jan. & Feb. & Dav & Jan. & Feb. & Day & Jan. & Feb. & Day & Jan. & Feb. \\
\hline $\begin{array}{l}1 \ldots \ldots \\
2 \ldots \ldots \\
3 \ldots \ldots- \\
4 \ldots-\ldots \\
5 \ldots \ldots- \\
6 \ldots \ldots \\
7 \ldots \ldots \\
8 \ldots \ldots--\end{array}$ & $\begin{array}{l}144 \\
199 \\
222 \\
168 \\
188 \\
209 \\
800 \\
530\end{array}$ & $\begin{array}{l}460 \\
365 \\
346 \\
545 \\
408 \\
358 \\
648 \\
575\end{array}$ & $\begin{array}{r}9 \\
10 \\
11 \\
12_{\ldots} \\
13_{\ldots} \\
14_{\ldots} \\
15_{\ldots} \\
16_{\ldots}\end{array}$ & $\begin{array}{l}362 \\
280 \\
220 \\
200 \\
190 \\
180 \\
180 \\
180\end{array}$ & $\begin{array}{l}432 \\
407 \\
341 \\
256 \\
282 \\
391 \\
335 \\
272\end{array}$ & $\begin{array}{l}17 \ldots \\
18 \ldots \\
19 \ldots \\
20 \ldots \\
21 \ldots \\
22 \ldots \\
23 \ldots \\
24 \ldots\end{array}$ & $\begin{array}{l}170 \\
170 \\
170 \\
170 \\
170 \\
165 \\
165 \\
165\end{array}$ & $\begin{array}{l}231 \\
214 \\
251 \\
252 \\
268 \\
240 \\
240 \\
251\end{array}$ & $\begin{array}{l}25 \ldots \\
26 \ldots \\
27 \ldots \\
28 \ldots \\
29 \ldots \\
30 \ldots \\
31 \ldots \\
\end{array}$ & $\begin{array}{r}2,150 \\
2,210 \\
762 \\
497 \\
343 \\
346 \\
482\end{array}$ & $\begin{array}{c}249 \\
226 \\
150 \\
150 \\
- \\
-\end{array}$ \\
\hline \multicolumn{10}{|c|}{$\begin{array}{l}\text { Mean monthly discharge, in second-feet } \\
\text { Runoff, in inches }\end{array}$} & $\begin{array}{r}400 \\
3.82\end{array}$ & $\begin{array}{r}327 \\
2.81\end{array}$ \\
\hline
\end{tabular}


Gage-height, in feet, and discharge, in second-feet, at indicated time, 1938

\begin{tabular}{|c|c|c|c|c|c|c|c|c|c|c|c|c|}
\hline \multirow{2}{*}{ Hour } & Feet & Sec.-ft. & Feet & Sec.-ft. & Feet & Sec.-ft. & Feet & Sec.ft. & Feet & Sec.-ft. & Feet & Sec.-ft. \\
\hline & \multicolumn{2}{|c|}{ January 22} & \multicolumn{2}{|c|}{ Jamiary 23} & \multicolumn{2}{|c|}{ January 24} & \multicolumn{2}{|c|}{ January 2.5} & \multicolumn{2}{|c|}{ January 26} & \multicolumn{2}{|c|}{ January 27} \\
\hline $\begin{array}{c}1 \mathrm{a} . \mathrm{m} . \\
2 \\
3 \\
4 \\
5 \\
5 \\
6 \\
7 \\
8 \\
9 \\
10 \\
11 \\
12 \mathrm{n} . \\
1 \mathrm{p} . \mathrm{m} . \\
2 \\
3 \\
4 \\
5 \\
6 \\
7 \\
8 \\
9 \\
10 \\
11 \\
12 \mathrm{~m} .\end{array}$ & & $\begin{array}{l}- \\
- \\
--\end{array}$ & & & 3.35 & 195 & $\begin{array}{l}8.75 \\
9.37 \\
9.69 \\
9.79 \\
9.81 \\
9.79 \\
9.75 \\
9.65\end{array}$ & $\begin{array}{r}2,600 \\
3,300 \\
3,630 \\
3,700 \\
3,770 \\
3,700 \\
3,700 \\
3,600\end{array}$ & $\begin{array}{r}8.80 \\
8.19 \\
7.48 \\
6.90 \\
6.35\end{array}$ & $\begin{array}{c}2,700 \\
2,130 \\
1,600 \\
1,300 \\
1,050\end{array}$ & $\begin{array}{l}6.00 \\
5.87 \\
5.90 \\
5.72 \\
5.54 \\
5.12 \\
5.10 \\
5.17 \\
5.23 \\
5.28 \\
5.28 \\
5.23 \\
5.17 \\
5.10 \\
5.06 \\
5.02 \\
5.00 \\
4.89\end{array}$ & $\begin{array}{c}920 \\
880 \\
900 \\
840 \\
782 \\
656 \\
650 \\
671 \\
689 \\
704 \\
701 \\
689 \\
671 \\
650 \\
638 \\
626 \\
620 \\
587\end{array}$ \\
\hline & Janu & $\operatorname{ary} 28$ & Janu & $\operatorname{ary} 29$ & $\operatorname{Jan} u$ & $\operatorname{ary} 30$ & $J_{\text {anu }}$ & $\operatorname{ary} 31$ & Febr & uary 1 & Febr & ary 2 \\
\hline $\begin{array}{c}2 \mathrm{a} . \mathrm{m} . \\
4 \\
6 \\
8 \\
10 \\
12 \mathrm{n} . \\
2 \mathrm{p} . \mathrm{m} . \\
4 \\
6 \\
8 \\
10 \\
12 \mathrm{~m} .\end{array}$ & $\begin{array}{l}4.64 \\
4.65 \\
4.72 \\
4.82 \\
4.82 \\
4.66 \\
4.36 \\
4.39 \\
4.50 \\
4.50 \\
4.42 \\
4.10\end{array}$ & $\begin{array}{l}512 \\
515 \\
536 \\
566 \\
566 \\
518 \\
435 \\
442 \\
470 \\
470 \\
450 \\
370\end{array}$ & $\begin{array}{l}3.93 \\
4.00 \\
4.00 \\
4.11 \\
4.01 \\
3.97 \\
3.86 \\
3.90 \\
4.00 \\
4.03 \\
4.04 \\
4.01\end{array}$ & $\begin{array}{l}328 \\
345 \\
345 \\
372 \\
348 \\
338 \\
310 \\
320 \\
345 \\
352 \\
355 \\
348\end{array}$ & $\begin{array}{l}4.00 \\
3.97 \\
3.93 \\
3.90 \\
3.99 \\
3.87 \\
3.90 \\
4.09 \\
4.11 \\
4.10 \\
4.10 \\
4.01\end{array}$ & $\begin{array}{l}345 \\
338 \\
328 \\
320 \\
342 \\
312 \\
320 \\
368 \\
372 \\
370 \\
370 \\
348\end{array}$ & $\begin{array}{l}4.00 \\
4.13 \\
4.20 \\
4.60 \\
4.60 \\
4.61 \\
4.71 \\
4.80 \\
4.82 \\
4.82 \\
4.88 \\
4.45\end{array}$ & $\begin{array}{l}345 \\
378 \\
395 \\
500 \\
500 \\
503 \\
533 \\
560 \\
566 \\
566 \\
584 \\
458\end{array}$ & $\begin{array}{l}4.50 \\
4.54 \\
4.48 \\
4.71 \\
4.56 \\
4.44 \\
4.44 \\
4.49 \\
4.42 \\
4.43 \\
4.43 \\
3.99\end{array}$ & $\begin{array}{l}470 \\
482 \\
465 \\
533 \\
488 \\
455 \\
455 \\
468 \\
450 \\
452 \\
452 \\
342\end{array}$ & $\begin{array}{l}3.92 \\
4.19 \\
4.03 \\
4.37 \\
4.08 \\
4.06 \\
4.01 \\
4.07 \\
4.13 \\
4.11 \\
4.13 \\
3.78\end{array}$ & $\begin{array}{l}325 \\
392 \\
352 \\
438 \\
365 \\
360 \\
348 \\
362 \\
378 \\
372 \\
378 \\
290\end{array}$ \\
\hline
\end{tabular}

Supplemental records.--Jan. 30, 11 a.m., $4.06 \mathrm{ft}, 360$ see-ft.: Jan. $31,9 \mathrm{p} . \mathrm{m} ., 4.53 \mathrm{ft} .479$ sec-ft.; Feb. 1, 11 p.m., $4.39 \mathrm{ft}$., 442 sec.ft.; Feb. $2,12: 30$ a.m.., $3.83 \mathrm{ft}$., 302 sec.-ft.; $3: 30$ a.m., 4.02 ft., 350 sec.-ft.; $4: 30$ a.m., $4.30 \mathrm{ft}$., 420 sec.-ft.; 7 a.m., 4.06 ft., 360 sec.-ft., 11 k.m., $4.11 \mathrm{ft} ., 372$ sec.-ft.

\section{SHETUCKET RIVER NEAR WITIMMANTIC, CONN.}

Location.-Lat. $41^{\circ} 41^{\prime} 58^{\prime \prime}$, long. $72^{\circ} 10^{\prime} 53^{\prime \prime}$, at Bingham Bridge, 1 mile downstream from confluence of Willimantic and Natchaug Rivers and 11/2 miles southeast of Willimantic, Windham County. Datum of gage is 131.40 feet above mean sea level, datum of 1929 (levels by Corps of Engineers, U. S. Army).

Drainage AREA.-401 square miles.

GAGE-HEIGHT RECORD.-Water-stage recorder graph.

Stage-discharge relation.-Defined by current meter measurements. Affected by ice Jan. 16-21.

Maxima.-January 1938: Discharge, 12,600 second-feet 2 a.m. Jan. 26 (gage height, 13.31 feet).

1904-5; 1933 to December 1937: Discharge, 23,900 second-feet Mar. 12, 1936 (gage height, 18.35 feet, from floodmarks).

REMARKs.-Flood discharge affected by storage in numerous ponds and reservoirs. 


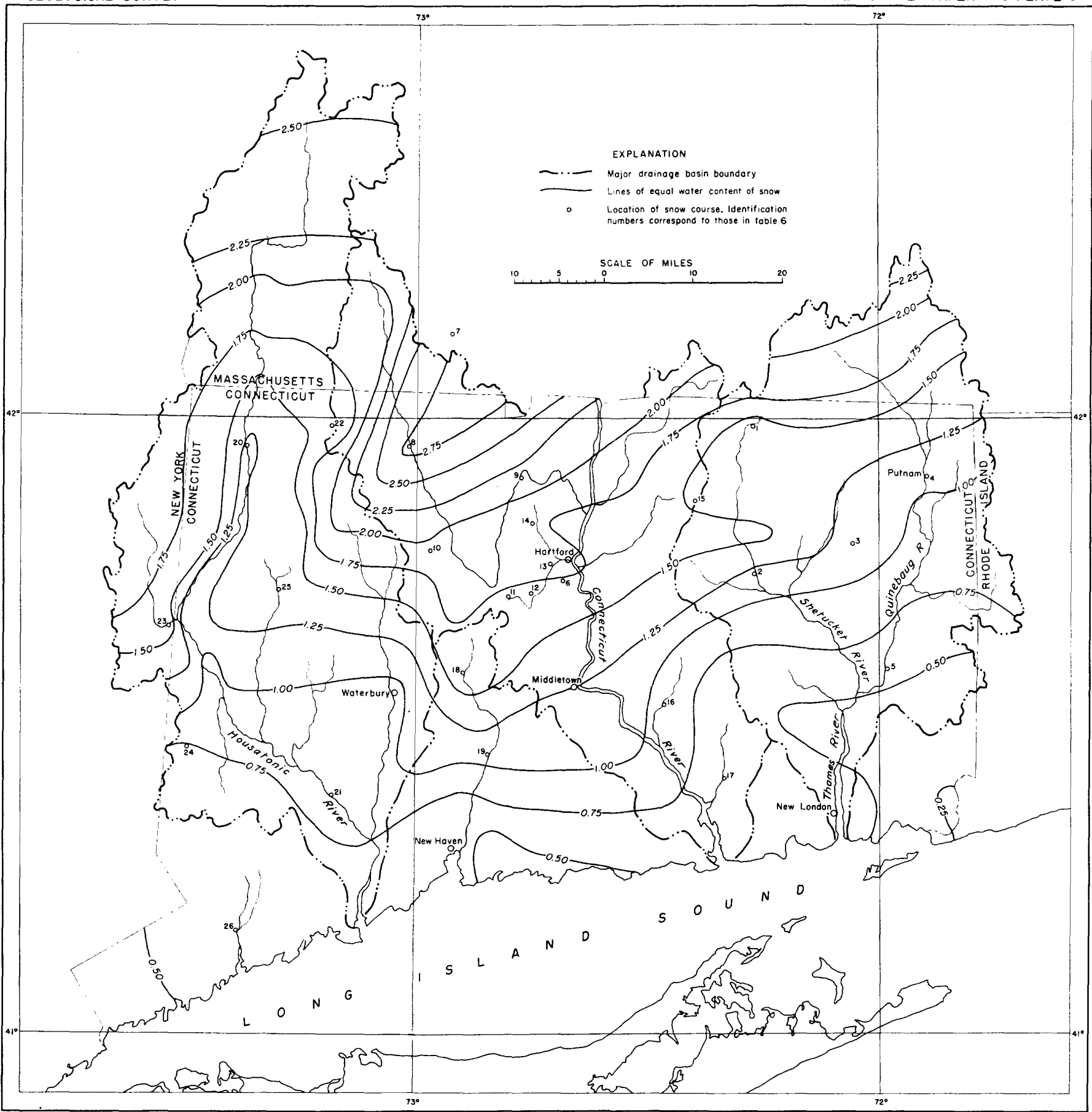

MAP OF CONNECTICUT AND PARTS OF ADJOINING STATES, SHOWING DEPTH, IN INCHES, OF WATER EQUIVALENT OF SNOW ON GROUND, JANUARY 20, 1938 


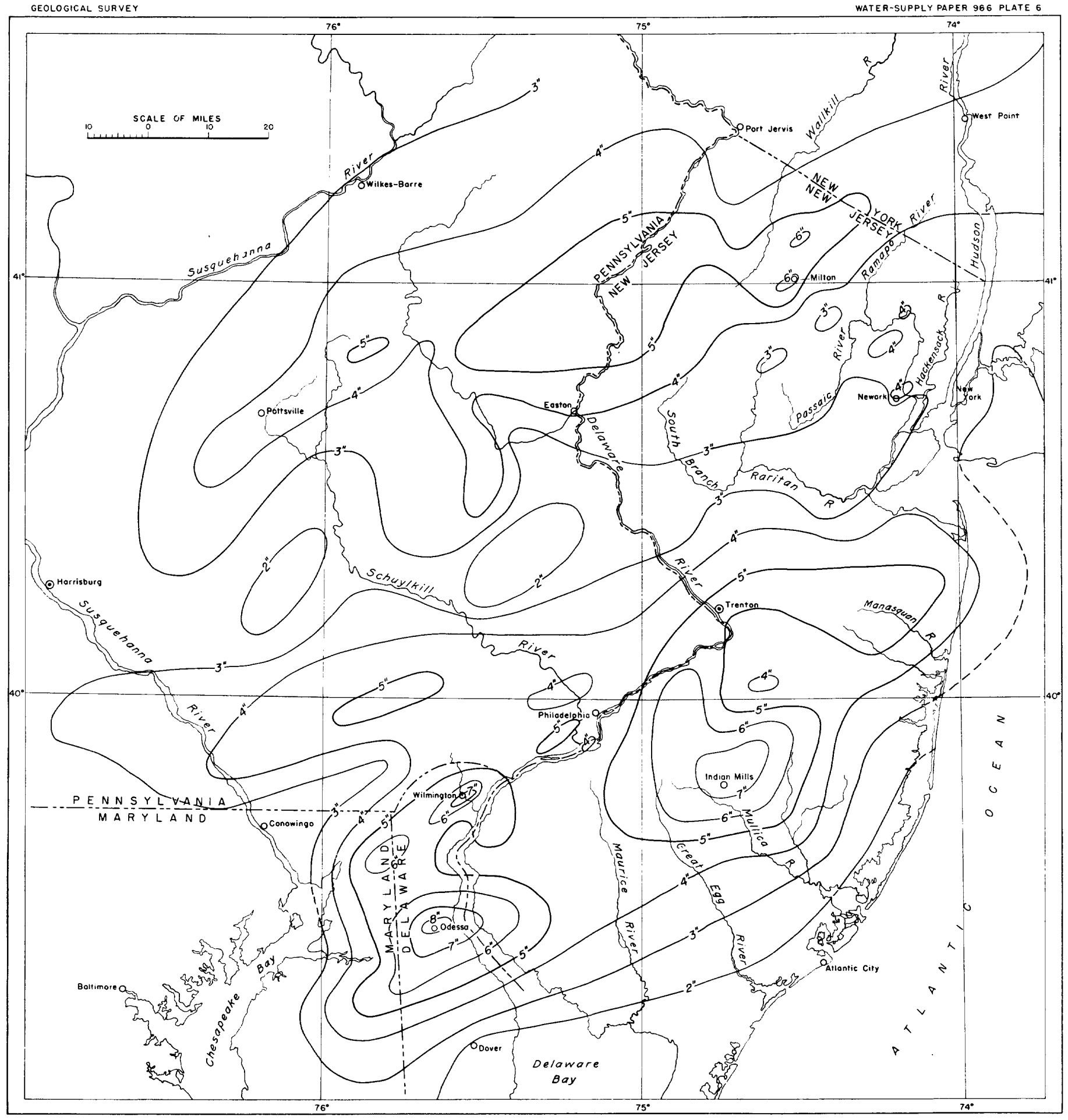

ISOHYETAL MAP OF NEW JERSEY AND PARTS OF ADJOINING STATES, SHOWING TOTAL PRECIPITATION, JUNE 25-29,1938 
Mean discharge, in second-feet, 1938

\begin{tabular}{|c|c|c|c|c|c|c|c|c|c|c|c|}
\hline Day & Jan. & Feb. & Day & Jan. & Feb. & Day & Jan. & Feb. & Day & Jan. & Feb. \\
\hline 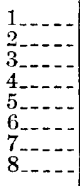 & $\begin{array}{r}516 \\
551 \\
719 \\
588 \\
572 \\
553 \\
1,470 \\
3,150\end{array}$ & $\begin{array}{l}1,670 \\
1,170 \\
1,100 \\
1,880 \\
1,530 \\
1,240 \\
1,920 \\
2,040\end{array}$ & 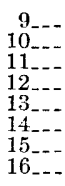 & $\begin{array}{r}1,640 \\
1,200 \\
926 \\
748 \\
703 \\
692 \\
624 \\
550\end{array}$ & $\begin{array}{r}1,440 \\
1,340 \\
1,130 \\
940 \\
910 \\
1,270 \\
1,160 \\
880\end{array}$ & $\begin{array}{l}17 \ldots \\
18 \ldots \\
19 \ldots \\
20 \ldots \\
21 \ldots \\
22 \ldots \\
23 \ldots \\
24 \ldots\end{array}$ & $\begin{array}{l}650 \\
550 \\
500 \\
500 \\
550 \\
510 \\
526 \\
679\end{array}$ & $\begin{array}{l}772 \\
790 \\
779 \\
820 \\
798 \\
757 \\
790 \\
820\end{array}$ & $\begin{array}{l}25 \ldots \\
26 \ldots \\
27_{-}- \\
28_{-} \\
29_{-} \\
30_{\ldots} \\
31_{\ldots}\end{array}$ & $\begin{array}{l}4,640 \\
9,040 \\
3,170 \\
1,810 \\
1,230 \\
1,080 \\
1,450\end{array}$ & $\begin{array}{r}850 \\
746 \\
660 \\
730 \\
-\end{array}$ \\
\hline \multicolumn{11}{|c|}{$\begin{array}{l}\text { Mean montly discharge, in second-feet } \ldots \ldots \ldots \\
\text { Runoff, in inches }\end{array}$} & $\begin{array}{r}1,105 \\
2.87\end{array}$ \\
\hline
\end{tabular}

Gage-height, in feet, and discharge, in second-feet, at indicated time, 1938

\begin{tabular}{|c|c|c|c|c|c|c|c|c|c|c|c|c|}
\hline \multirow{2}{*}{ Hour } & Feet & Ser.ft. & Feet & Sec.-ft. & Feet & Sec.-ft. & Feet & Sec.-ft. & Feet & Sec.-ft. & Feet & Sec.-ft. \\
\hline & \multicolumn{2}{|c|}{ Jarulary 22} & \multicolumn{2}{|c|}{ January 23} & \multicolumn{2}{|c|}{ January 24} & \multicolumn{2}{|c|}{ January 25} & \multicolumn{2}{|c|}{ January 26} & \multicolumn{2}{|c|}{ January 27} \\
\hline $1 \mathrm{a} . \mathrm{m}$ & 3.51 & 615 & 2.75 & 285 & 3.40 & 565 & 3.71 & 715 & 13.26 & 12,500 & & \\
\hline & 3.50 & 610 & 2.98 & 377 & 3.43 & 578 & 3.73 & 725 & 13.31 & 12,600 & 8.03 & 4,570 \\
\hline 3 & 3.51 & 615 & 3.25 & 498 & 3.41 & 570 & 3.87 & 802 & 13.30 & 12,600 & & \\
\hline 4 & 3.31 & 538 & 3.30 & 520 & 3.38 & 556 & 4.05 & 910 & 13.20 & 12,400 & 7.61 & 4,060 \\
\hline 5 & 2.80 & 305 & 3.29 & 516 & 3.32 & 529 & 4.20 & 1,000 & 13.01 & 12,000 & & \\
\hline 6 & 2.76 & 289 & 3.30 & 520 & 3.43 & 578 & 4.49 & 1.190 & 12.80 & 11,600 & 7.14 & 3,540 \\
\hline 7 & 3.30 & 520 & 3.32 & 529 & 3.47 & 596 & 4.79 & 1,400 & 12.57 & 11,200 & & \\
\hline 8 & 3.60 & 660 & 3.34 & 538 & 1.32 & 1,070 & 5.16 & 1,690 & 12.30 & 10,700 & 6.82 & 3,210 \\
\hline 9 & 3.64 & 680 & 3.33 & 534 & +00 & 880 & 5.46 & 1,930 & 12.03 & 10,300 & & \\
\hline 10 & 3.66 & 690 & 3.36 & 547 & 3.95 & 850 & 6.03 & 2,440 & 11.77 & 9,820 & 6.55 & 2,940 \\
\hline 11 & 364 & 680 & 3.41 & 570 & 3.90 & 820 & 6.50 & 2,890 & 11.50 & 9,400 & & \\
\hline $12 \mathrm{n}$. & 3.60 & 660 & 3.41 & 570 & 3.75 & 735 & 7.06 & 3.460 & 11.21 & 8,940 & 6.53 & 2,920 \\
\hline 1 p.m. & 3.60 & 660 & 3.40 & 565 & 3.70 & 710 & 7.52 & 3,960 & 10.90 & $8,4,70$ & & \\
\hline & 3.59 & 655 & 3.40 & 565 & 3.98 & 868 & 8.16 & 4.720 & 10.67 & 8,100 & 6.48 & 2,870 \\
\hline 3 & 3.59 & $65 \tilde{5}$ & 3.40 & $\tilde{5} 65$ & 3.08 & 700 & 8.67 & 5,370 & 10.43 & $7,7 \uparrow 0$ & & \\
\hline 4 & 3.60 & 660 & 3.40 & 565 & 3.6 .3 & 675 & 9.26 & 6,140 & 10.19 & 7.410 & 6.32 & 2,710 \\
\hline 5 & 3.30 & 520 & 3.39 & 560 & 3.55 & 635 & 9.76 & 6,800 & 9.90 & 7.000 & & \\
\hline 6 & 2.80 & 305 & 3.40 & 565 & 3.45 & 588 & 10.43 & 7.740 & 9.64 & 6,649 & 6.21 & 2,600 \\
\hline 7 & 2.78 & 297 & 3.40 & 565 & 3.57 & 64.5 & 11.00 & 8,600 & 9. 44 & 6,370 & & \\
\hline 8 & 2.78 & 297 & 3.40 & 565 & 3.59 & 655 & 11.56 & 9.500 & 9.21 & 6,070 & 613 & 2,530 \\
\hline 9 & 2.78 & 297 & 3.40 & 565 & 3.60 & 660 & 12.08 & 10,300 & 9.00 & 5,800 & & \\
\hline 10 & 2.78 & 297 & 3.39 & 560 & 3.60 & 600 & 12.50 & 11,100 & 8.79 & 5,500 & 6194 & 2,450 \\
\hline 11 & 2.78 & 297 & 3.39 & 560 & 3.58 & $6: 50$ & 12.71 & 11,500 & 8.60 & 5,280 & & \\
\hline $12 \mathrm{~m}$ & 2.77 & 293 & 3.40 & 565 & 3.6 .5 & $68 j$ & $13.0 \mathrm{ti}$ & 12,100 & 8.40 & 5,020 & 5.93 & 2,350 \\
\hline
\end{tabular}

\begin{tabular}{|c|c|c|c|c|c|c|c|c|c|c|c|c|}
\hline & \multicolumn{2}{|c|}{ Junuary 28} & \multicolumn{2}{|c|}{ Janutry 29} & \multicolumn{2}{|c|}{ January 30} & \multicolumn{2}{|c|}{ January 31} & \multicolumn{2}{|c|}{ February 1} & \multicolumn{2}{|c|}{ Fobruary 2} \\
\hline & 5.80 & 2,230 & 4.97 & 1,540 & & & & & & & & \\
\hline & 5.70 & 2,14 & 4.88 & 1.47 & & & 4.50 & 1,200 & 5.40 & 1,880 & 4.70 & 1,340 \\
\hline & $\begin{array}{l}0.31 \\
5.24\end{array}$ & $\begin{array}{l}1,810 \\
1,750\end{array}$ & $\begin{array}{l}4.58 \\
4.49\end{array}$ & $\begin{array}{l}1,260 \\
1,190\end{array}$ & $\begin{array}{c}4.34 \\
-\ldots . . .\end{array}$ & $\begin{array}{r}1,000 \\
\ldots . . .\end{array}$ & 4.78 & 1,400 & 5.30 & 1,800 & 4.31 & 1,070 \\
\hline $10 \mathrm{n}$ & 5.20 & 1,720 & 4.73 & 1,360 & $---\overline{-1}$ & $-0=-1$ & & & & & & \\
\hline $\begin{array}{r}12 \mathrm{n} . \\
2 \mathrm{p} . \mathrm{m}\end{array}$ & $\begin{array}{l}5.37 \\
5.30\end{array}$ & $\begin{array}{l}1,860 \\
1,800\end{array}$ & $\begin{array}{l}4.69 \\
4.61\end{array}$ & $\begin{array}{l}1,330 \\
1,280\end{array}$ & 4.32 & 1,070 & 4.86 & 1,450 & 5.06 & 1,610 & 4.33 & 1,080 \\
\hline & 5.15 & 1,680 & $\begin{array}{l} \pm .01 \\
4.44\end{array}$ & 1,160 & 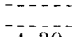 & 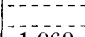 & 4.96 & 1,530 & 5.00 & 1,560 & 4.40 & 1,130 \\
\hline & $\begin{array}{l}5.06 \\
5.02\end{array}$ & $\begin{array}{l}1,610 \\
1,580\end{array}$ & $\begin{array}{l}4.11 \\
4.05\end{array}$ & $\begin{array}{l}946 \\
910\end{array}$ & 4.30 & 1,060 & 5.11 & 650 & 4.92 & 1,500 & 439 & \\
\hline 10 & 5.00 & 1,5 & 4.1 & 970 & & -1 & & & & & & 1,120 \\
\hline $12 \mathrm{~m}$. & 5.00 & 1,560 & 4.23 & 1,020 & 4.47 & 1,180 & 5.35 & 1,840 & 4.89 & 1,470 & 4.45 & 1,160 \\
\hline
\end{tabular}

Supplemental records.-Jan. $22,6: 30$ a.m., $2.77 \mathrm{ft}$., $293 \mathrm{sec} . \mathrm{ft}$; $7: 30$ a.m., $3.59 \mathrm{ft} ., 655$ sec.-ft.; Jan. $24,1: 15$ p.m., $3.36 \mathrm{ft}$., 547 sec.ft.: Jan. 27,11 a.m., $6.46 \mathrm{ft}, 2.850$ sec.ft.; Jan. 31,7 a.m., $4.54 \mathrm{ft} ., 1,230$ sec.-ft.; Feb. 2,7 a.m., $4.17 \mathrm{ft} ., 982$ sec.-ft.; 9 a.m., $4.48 \mathrm{ft} ., 1,190$ sec.-ft. 
HOP RIVER NEAR COIUMBIA, CONN.

Location.-Lat. $41^{\circ} 43^{\prime} 25^{\prime \prime}$, long. $72^{\circ} 18^{\prime} 05^{\prime \prime}$, 1,000 feet downstream from abandoned mill and dam, a quarter of a mile downstream from Hop River station on New York, New Haven \& Hartford Railroad, 2 miles north of Columbia, Tolland County, and $3 \frac{1}{2}$ miles upstream from mouth. Datum of gage is 249.25 feet above mean sea level, datum of 1929 (levels by Corps of Engineers, U. S. Army).

Drainage AREA.-76.2 square miles.

GAGE-HEIGHT RECORD.-Water-stage recorder graph.

Stage-discharge relation.-Defined by current-meter measurements. Affected by ice Jan. 1-6, 10-12, Jan. 16 to 6 a.m. Jan. 24, 9 to 11 a.m. Jan. 27, 6 p.m. Jan. 27 to 11 a.m. Jan. 28, 10 p.m. Jan. 28 to 11 a.m. Jan. 29, 9 p.m. Jan. 29 to 7 a.m. Jan. 30, 4 p.m. Feb. 1 to 7 a.m. Feb. 2, 5 p.m. Feb. 2 to Feb. 3, Feb. 11-14, 16, 17, 20-23, 27, 28. Affected by change in recording conditions 2 to 9 p.m. Jan. 25, when water was above floor of gage shelter.

Maxima.-January 1938: Discharge, 2,970 second-feet 4:30 p. m. Jan. 25 (gage height, 12.99 feet).

1932 to December 1937: Discharge, 3,300 second-feet Mar. 12, 1936 (gage-height, 13.85 feet, from floodmarks).

Remarks.-Flood runoff affected by storage in two reservoirs.

Mean discharge, in second-feet, 1938

\begin{tabular}{|c|c|c|c|c|c|c|c|c|c|c|c|}
\hline Day & Jan. & Fet. & Day & Jan. & F'eb. & Day & Jan. & Feb. & Day & Jan. & Feb. \\
\hline 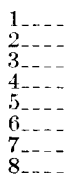 & $\begin{array}{r}80 \\
90 \\
90 \\
85 \\
90 \\
30 \\
462 \\
616\end{array}$ & $\begin{array}{l}299 \\
215 \\
236 \\
441 \\
305 \\
275 \\
434 \\
355\end{array}$ & $\begin{array}{l}9 \ldots \\
10 \ldots \\
11 \\
12 \\
13 \\
14 \ldots \\
15 \\
16\end{array}$ & $\begin{array}{l}283 \\
210 \\
160 \\
150 \\
136 \\
129 \\
124 \\
120\end{array}$ & $\begin{array}{l}295 \\
285 \\
220 \\
160 \\
170 \\
240 \\
221 \\
170\end{array}$ & $\begin{array}{l}17 \\
18 \ldots \\
19 \ldots \\
20 \\
21 \ldots \\
22 \\
2 . \\
24 \ldots \\
24 \ldots\end{array}$ & $\begin{array}{r}110 \\
110 \\
100 \\
95 \\
95 \\
100 \\
110 \\
119\end{array}$ & $\begin{array}{l}140 \\
162 \\
162 \\
140 \\
120 \\
120 \\
130 \\
158\end{array}$ & $\begin{array}{l}25 \\
26- \\
27- \\
28 \\
29 \\
30 \\
31\end{array}$ & $\begin{array}{r}1,630 \\
1,200 \\
524 \\
352 \\
255 \\
232 \\
323\end{array}$ & $\begin{array}{c}155 \\
142 \\
120 \\
100 \\
\end{array}$ \\
\hline \multicolumn{10}{|c|}{$\begin{array}{l}\text { Mean monthly discharge, in second-feet } \\
\text { Runoff, in inches }\end{array}$} & $\begin{array}{r}267 \\
4.04\end{array}$ & $\begin{array}{r}213 \\
2.92\end{array}$ \\
\hline
\end{tabular}

Gage-height, in feet, and discharge, in second-feet, at indicated time, 1938

\begin{tabular}{|c|c|c|c|c|c|c|c|c|c|c|c|c|}
\hline \multirow{2}{*}{ Hour } & Feet & Sec.-ft. & Feet & Sectoft. & Feet & Sec.-ft. & Feet & Sec.-ft. & Feet & Sec.-ft. & Feet & Sec.-ft. \\
\hline & \multicolumn{2}{|c|}{ Tanuary 22} & \multicolumn{2}{|c|}{ January 23} & \multicolumn{2}{|c|}{ January 24} & \multicolumn{2}{|c|}{ January 25} & \multicolumn{2}{|c|}{ January 26} & \multicolumn{2}{|c|}{ January 27} \\
\hline $\begin{array}{l}1 \mathrm{a} . \mathrm{m} . \\
2 \\
3 \\
4 \\
5 \\
6 \\
7 \\
8 \\
9 \\
10 \\
11 \\
12 \mathrm{n} . \\
1 \mathrm{p} . \mathrm{m} . \\
2 \\
3 \\
4 \\
5 \\
6 \\
7\end{array}$ & 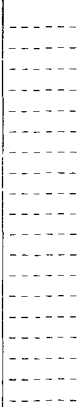 & $\mid$\begin{tabular}{l}
- \\
- \\
$-\cdots$ \\
- \\
- \\
\hdashline- \\
-- \\
-- \\
-- \\
--
\end{tabular} & $\mid \begin{array}{l}-\cdots \\
-\ldots- \\
-\cdots- \\
--\cdots \\
-\cdots- \\
-\cdots \\
-\cdots \\
-\cdots\end{array}$ & 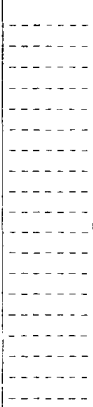 & \begin{tabular}{c}
$3.90^{-}$ \\
3.89 \\
3.89 \\
03.96 \\
33.90 \\
3.91 \\
\hdashline
\end{tabular} & 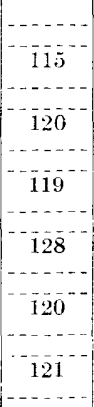 & $\begin{array}{r}4.00 \\
4.15 \\
4.41 \\
4.70 \\
5.10 \\
5.60 \\
6.23 \\
6.97 \\
7.90 \\
8.60 \\
9.17 \\
10.00 \\
11.05 \\
12.25 \\
12.78 \\
12.98 \\
12.97 \\
12.82 \\
12.61\end{array}$ & $\begin{array}{r}133 \\
154 \\
195 \\
245 \\
322 \\
428 \\
578 \\
762 \\
1,040 \\
1,250 \\
1,420 \\
1,720 \\
2,130 \\
2,580 \\
2,850 \\
2,970 \\
2,960 \\
2,930 \\
2,880\end{array}$ & $\begin{array}{r}10.76 \\
10.44 \\
10.14 \\
9.89 \\
9.59 \\
9.29 \\
9.00 \\
8.72 \\
8.47 \\
8.25 \\
8.05 \\
7.83 \\
7.65 \\
7.49 \\
7.34 \\
7.22 \\
7.14 \\
7.06 \\
7.01\end{array}$ & $\begin{array}{r}2,080 \\
1,960 \\
1,840 \\
1,740 \\
1,620 \\
1,510 \\
1,410 \\
1,310 \\
1,230 \\
1,160 \\
1,100 \\
1,030 \\
980 \\
932 \\
895 \\
865 \\
845 \\
825 \\
812\end{array}$ & $\begin{array}{c}6 . \overline{39} \\
-6.14 \\
5.94 \\
\overline{5} . \overline{82} \\
-5 . \overline{83} \\
5.80 \\
5.75 \\
5.75 \\
5.75 \\
-5 \overline{5}\end{array}$ & $\begin{array}{c}658 \\
-595 \\
545 \\
-515 \\
-500 \\
510 \\
498 \\
498 \\
490\end{array}$ \\
\hline
\end{tabular}


Gage-height, in feet, and discharge, in second-feet, at indicated time, 1938-Continued

\begin{tabular}{|c|c|c|c|c|c|c|c|c|c|c|c|c|}
\hline \multirow{2}{*}{ Hour } & Feet & Sec.-ft. & Feet & Sec.-ft. & Feet & Sec.-ft. & Feet & Sec.-ft. & Feet & Sec.-it. & Feet & Sec.-ft. \\
\hline & \multicolumn{2}{|c|}{$J_{\text {anuary }} 22$} & \multicolumn{2}{|c|}{ January 23} & \multicolumn{2}{|c|}{ January 24} & \multicolumn{2}{|c|}{ January 25} & \multicolumn{2}{|c|}{ January 26} & \multicolumn{2}{|c|}{ January 27} \\
\hline \multirow[t]{2}{*}{$\begin{array}{r}8 \\
9 \\
10 \\
11 \\
12 \mathrm{~m} .\end{array}$} & & & 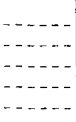 & 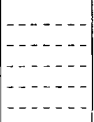 & $\begin{array}{c}-\overline{3} . \overline{8} \\
-\overline{3} . \overline{9}\end{array}$ & $\mid \begin{array}{c}--1 \overline{3} \\
---3^{--}\end{array}$ & $\begin{array}{l}12.35 \\
12.08 \\
11.65 \\
11.34 \\
11.04\end{array}$ & $\begin{array}{l}2,760 \\
2,620 \\
2,500 \\
2,350 \\
2,200\end{array}$ & $\begin{array}{l}6.96 \\
6.92 \\
6.88 \\
6.81 \\
6.70\end{array}$ & $\begin{array}{l}800 \\
790 \\
780 \\
762 \\
735\end{array}$ & $\begin{array}{c}5.77 \\
-5-7 \overline{4} \\
-5.71\end{array}$ & $\begin{array}{c}470 \\
--740 \\
--\end{array}$ \\
\hline & \multicolumn{2}{|c|}{ January 28} & \multicolumn{2}{|c|}{ January 29} & \multicolumn{2}{|c|}{ January 30} & \multicolumn{2}{|c|}{ January 31} & \multicolumn{2}{|c|}{ February 1} & \multicolumn{2}{|c|}{ February 2} \\
\hline $\begin{array}{r}2 \text { a.m. } \\
4 \\
6 \\
8 \\
10 \\
12 \text { n. } \\
2 \text { p.m. } \\
4 \\
6 \\
8 \\
10 \\
12 \mathrm{~m} .\end{array}$ & $\begin{array}{l}5.64 \\
5.51 \\
5.39 \\
5.30 \\
5.18 \\
5.04 \\
5.22 \\
5.14 \\
5.10 \\
5.04 \\
5.00 \\
5.00\end{array}$ & $\begin{array}{l}380 \\
360 \\
350 \\
340 \\
340 \\
343 \\
379 \\
363 \\
355 \\
343 \\
320 \\
300\end{array}$ & $\begin{array}{l}4.96 \\
4.90 \\
4.86 \\
4.82 \\
4.67 \\
4.57 \\
4.68 \\
4.60 \\
4.59 \\
4.56 \\
4.57 \\
4.59\end{array}$ & $\begin{array}{l}280 \\
260 \\
250 \\
245 \\
240 \\
249 \\
271 \\
255 \\
253 \\
247 \\
245 \\
235\end{array}$ & $\begin{array}{l}4.56 \\
4.51 \\
4.47 \\
4.43 \\
4.41 \\
4.40 \\
4.41 \\
4.47 \\
4.54 \\
4.61 \\
4.61 \\
4.58\end{array}$ & $\begin{array}{l}235 \\
230 \\
225 \\
221 \\
217 \\
215 \\
217 \\
229 \\
243 \\
257 \\
257 \\
251\end{array}$ & $\begin{array}{l}4.57 \\
4.58 \\
4.60 \\
4.63 \\
4.71 \\
4.86 \\
5.05 \\
5.19 \\
5.33 \\
5.39 \\
5.37 \\
5.29\end{array}$ & $\begin{array}{l}249 \\
251 \\
255 \\
261 \\
277 \\
307 \\
345 \\
373 \\
404 \\
417 \\
412 \\
395\end{array}$ & $\begin{array}{l}5.20 \\
5.08 \\
4.93 \\
4.79 \\
4.79 \\
4.74 \\
4.78 \\
4.80 \\
4.86 \\
4.87 \\
4.75 \\
4.61\end{array}$ & $\begin{array}{l}375 \\
351 \\
321 \\
293 \\
293 \\
283 \\
291 \\
290 \\
280 \\
260 \\
245 \\
225\end{array}$ & $\begin{array}{l}4.48 \\
4.39 \\
4.32 \\
4.27 \\
4.33 \\
4.50 \\
4.45 \\
4.48 \\
4.54 \\
4.58 \\
4.59 \\
4.56\end{array}$ & $\begin{array}{l}210 \\
195 \\
195 \\
190 \\
201 \\
235 \\
225 \\
231 \\
235 \\
225 \\
220 \\
215\end{array}$ \\
\hline
\end{tabular}

Supplemental records.-Jan. $25,4: 30$ p.m., $12.99 \mathrm{ft} ., 2,970$ sec.-ft.

\section{NATCHAUG RIVER AT WILIIMANTIC, CONN.}

Location.-Lat. $41^{\circ} 43^{\prime} 14^{\prime \prime}$, long. $72^{\circ} 11^{\prime} 53^{\prime \prime}, 200$ feet downstream from New York, New Haven \& Hartford Railroad bridge and 1 mile northeast of Willimantic, Windham County. Datum of gage is 150.31 feet above mean sea level, datum of 1929 (levels by Corps of Engineers, U. S. Army).

Drainace area.-169 square miles.

GAGE-HEIGHT RECORD.-Water-stage recorder graph.

Stage-discharge relation.-Defined by current-meter measurements. Affected by ice Jan. 2-7, 10-16, 18-22, 5 a.m. to 1 p.m. Jan. 24, Feb. 21, $22,28$.

Maxima.-January 1938: Discharge, 5,880 second-feet 11 p.m. Jan. 25 (gage height, 11.02 feet).

1930 to December 1937: Discharge, resulting from breaking of dam above station, 14,200 second-feet Mar. 18, 1936 (gage height, 13.57 feet). Remarks.-Flood discharge affected by storage in several small ponds. About one million gallons per day pumped from reservoir 2 miles above station for municipal supply of Willimantic.

Mean discharge, in second-feet, 1938

\begin{tabular}{|c|c|c|c|c|c|c|c|c|c|c|c|}
\hline Day & Jan. & Feb. & Day & Jan. & Feb. & Day & Jan. & Feb. & Day & Jan. & Feb. \\
\hline $\begin{array}{l}1 \\
2 \\
3 \\
4 \\
4 \\
5 \\
6 \ldots \\
7 \\
8 \ldots \ldots-\end{array}$ & $\begin{array}{r}254 \\
260 \\
260 \\
260 \\
240 \\
240 \\
650 \\
1,340\end{array}$ & $\begin{array}{l}698 \\
453 \\
46 \tilde{3} \\
833 \\
640 \\
518 \\
840 \\
810\end{array}$ & 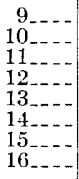 & $\begin{array}{l}660 \\
440 \\
360 \\
300 \\
260 \\
260 \\
280 \\
280\end{array}$ & $\begin{array}{l}570 \\
518 \\
423 \\
395 \\
395 \\
500 \\
482 \\
350\end{array}$ & $\begin{array}{l}17 \\
18 \ldots \\
19 \\
20 \ldots \\
21 \ldots \\
22 \ldots \\
23 \ldots \\
24 \ldots\end{array}$ & $\begin{array}{l}278 \\
280 \\
280 \\
280 \\
280 \\
285 \\
274 \\
244\end{array}$ & $\begin{array}{l}315 \\
344 \\
362 \\
350 \\
280 \\
300 \\
341 \\
365\end{array}$ & $\begin{array}{l}25 \ldots- \\
26 \ldots \\
27 \ldots \\
28 \ldots \\
29 \ldots- \\
30 \ldots \\
31 \ldots\end{array}$ & $\begin{array}{r}2,370 \\
3,440 \\
1,120 \\
688 \\
472 \\
461 \\
616\end{array}$ & $\begin{array}{c}356 \\
335 \\
303 \\
280 \\
\\
\end{array}$ \\
\hline \multicolumn{10}{|c|}{$\begin{array}{l}\text { Mean monthly discharge, in second-feet. } \\
\text { Runoff, in inches }\end{array}$} & $\begin{array}{r}571 \\
3.90\end{array}$ & $\begin{array}{r}458 \\
2.82\end{array}$ \\
\hline
\end{tabular}


Gage-height, in feet, and discharge, in second-feet, at indicated time, 1938

\begin{tabular}{|c|c|c|c|c|c|c|c|c|c|c|c|c|}
\hline \multirow{2}{*}{ Hour } & Feet & Sec.-ft. & Feet & Sec.-ft. & Fect & Sec.-ft. & Feet & Sec.ft. & Feet & Sec.-ft. & Feet & Sec.-ft. \\
\hline & \multicolumn{2}{|c|}{ January 22} & \multicolumn{2}{|c|}{ January 23} & \multicolumn{2}{|c|}{ January 24} & \multicolumn{2}{|c|}{ January 25} & \multicolumn{2}{|c|}{ January 26} & \multicolumn{2}{|c|}{ January 27} \\
\hline \multirow{18}{*}{$\begin{array}{c}12 \mathrm{a} . \mathrm{m} . \\
2 \\
3 \\
4 \\
5 \\
6 \\
7 \\
8 \\
9 \\
10 \\
11 \\
12 \mathrm{n} . \\
1 \mathrm{p} . \mathrm{m} . \\
2 \\
3 \\
4 \\
5 \\
6 \\
7 \\
8 \\
9 \\
10 \\
11 \\
12 \mathrm{~m} .\end{array}$} & & & & & & & & 230 & 10.92 & 5,730 & 5.52 & 1,570 \\
\hline & 2.55 & 260 & 2.44 & 262 & 2.29 & 222 & & & & & & \\
\hline & 2.64 & 290 & 2.51 & & 2.34 & & & & & & & \\
\hline & & & & & & & 3.28 & & 10. & & & \\
\hline & 2.66 & 290 & 2.52 & 284 & 2.41 & 245 & & 642 & 9. & & & \\
\hline & 2.66 & 290 & 2.51 & 281 & $-\overline{4} . \overline{5}$ & 25 & & & & & & \\
\hline & & & & & & & 4.32 & 97 & 9. & & & \\
\hline & 2.77 & 330 & 2.61 & 309 & 2.61 & 280 & 4.73 & & & & & \\
\hline & $\overline{2} . \overline{6}$ & 300 & 2.57 & 298 & 2.45 & 250 & $\begin{array}{l}5.15 \\
5.66\end{array}$ & & & & & \\
\hline & $\overline{2}-\overline{3}$ & 290 & 24 & 273 & & & & & & & & \\
\hline & & 290 & 2.4 & 273 & 2.36 & 241 & $\begin{array}{l}5.83 \\
7.39\end{array}$ & & $\frac{7}{7}$ & & & \\
\hline & 2.60 & 280 & 2.45 & 264 & 2.35 & 238 & 8.02 & & 7. & & & \\
\hline & $2 . \overline{9}$ & 280 & 2.43 & 259 & 234 & 235 & & & & & & \\
\hline & & & & & & & & & 6. & & 4 & \\
\hline & 2.58 & 270 & 2.43 & 259 & 2.35 & 238 & 10.57 & & 6.36 & & 4.30 & 960 \\
\hline & $2-57$ & 270 & 2 & 256 & 336 & 241 & & & & & & \\
\hline & 2.08 & & .72 & 2.70 & & & 11. & & & & & 1 \\
\hline & 2.54 & 260 & 2.41 & 254 & 2.37 & 243 & 10.99 & 5,840 & 5.71 & 1,660 & 4.06 & 847 \\
\hline & \multicolumn{2}{|c|}{ January 28} & \multicolumn{2}{|c|}{ January 29} & \multicolumn{2}{|c|}{ January 80} & \multicolumn{2}{|c|}{ January 31} & \multicolumn{2}{|c|}{ February 1} & \multicolumn{2}{|c|}{ F'ebruary 2} \\
\hline $2 a$ & & & & & & & & & & & & \\
\hline & & & 97 & & 3.10 & 465 & & & 4.02 & 829 & 3.17 & $490^{-}$ \\
\hline & & & $3 \cdot 2$ & & & & & & & & & \\
\hline 10 & 3 & 730 & 3.24 & & & & & & & & & \\
\hline & & & & & 3.04 & 444 & 3.43 & 582 & 3.58 & 642 & 2.90 & 395 \\
\hline & & & & & 3.04 & 444 & 3.57 & 638 & 3.64 & 666 & 3.04 & 44 \\
\hline & & & & & & & & & & & & \\
\hline & & & & & 3.15 & 482 & 3.82 & 739 & 3.55 & 630 & 3.09 & 462 \\
\hline $\begin{array}{l}10 \\
12 \mathrm{r}\end{array}$ & & & & & $3 . \overline{7}$ & 524 & 3.97 & 806 & $3 . \overline{49}$ & 606 & $3.2 \overline{2}$ & 507 \\
\hline
\end{tabular}

\section{QUINEBAUG RIVER AT QUINFBAUG, CONN.}

Location.-Lat. $42^{\circ} 01^{\prime} 20^{\prime \prime}$, long. $71^{\circ} 57^{\prime} 15^{\prime \prime}$, at Quinebaug, Windham County, 500 feet upstream from highway bridge, a quarter of a mile downstream from Massachusetts-Connecticut State line, and 7 miles upstream from French River.

Drainage AREA.-157 square miles.

GAGE-HEIGHT RECORD.-Water-stage recorder graph.

Stage-discharge RElation.-Defined by current-meter measurements to 2,000 second-feet; extended to peak stage on basis of computations of March 1936 and September 1938 peak flows at bridge 500 feet below station and determination of peak flow of March 1936 flood at dam a quarter of a mile above station.

Maxima.-January 1938: Discharge, 3,470 second-feet 9:30 p.m. Jan. 25 (gage height, 7.21 feet).

1931 to December 1937: Discharge, 10,500 second-feet Mar. 18, 1936 (gage height, 13.44 feet).

REMarKs.-Flood discharge doubtless affected by storage in several lakes and ponds. 
Mean discharge, in second-feet, 1938

\begin{tabular}{|c|c|c|c|c|c|c|c|c|c|c|c|}
\hline Day & Jan. & Feb. & Day & Jan. & Feb. & Day & Jan. & Feb. & Day & Jan. & Feb. \\
\hline $\begin{array}{l}1 \ldots \ldots \\
2 \ldots \\
3 \\
4 \\
5 \ldots \\
6 \ldots \\
7 \ldots \\
8 \ldots\end{array}$ & $\begin{array}{l}244 \\
215 \\
316 \\
291 \\
276 \\
252 \\
417 \\
570\end{array}$ & $\begin{array}{l}568 \\
441 \\
455 \\
580 \\
500 \\
480 \\
694 \\
633\end{array}$ & $\begin{array}{r}9 \\
10 \\
11 \ldots \\
12 \\
13 \\
14 \ldots \\
15 \ldots \\
16 \ldots\end{array}$ & $\begin{array}{l}510 \\
465 \\
392 \\
349 \\
337 \\
324 \\
295 \\
233\end{array}$ & $\begin{array}{l}535 \\
495 \\
410 \\
371 \\
345 \\
379 \\
366 \\
312\end{array}$ & $\begin{array}{l}17 \\
18 \\
19 \\
20 \\
21 \\
22 \\
23 \\
24\end{array}$ & $\begin{array}{l}288 \\
342 \\
310 \\
257 \\
263 \\
248 \\
213 \\
235\end{array}$ & $\begin{array}{l}287 \\
271 \\
283 \\
287 \\
295 \\
271 \\
275 \\
263\end{array}$ & $\begin{array}{l}25 \ldots \\
26 . . \\
27 \\
28 . \\
29 \\
30 \ldots \\
31 \ldots \\
1 \ldots\end{array}$ & $\begin{array}{r}1,770 \\
2,160 \\
1,140 \\
753 \\
577 \\
452 \\
572\end{array}$ & $\begin{array}{c}263 \\
263 \\
267 \\
267 \\
\end{array}$ \\
\hline \multicolumn{11}{|c|}{$\begin{array}{l}\text { Mean monthly discharge, in second-feet } \\
\text { Runoff, in inches }\end{array}$} & $\begin{array}{r}388 \\
2.57\end{array}$ \\
\hline
\end{tabular}

Gage height, in feet, and discharge, in second-feet, at indicated time, 1938

\begin{tabular}{|c|c|c|c|c|c|c|c|c|c|c|c|c|}
\hline \multirow{2}{*}{ Hour } & Feet & Sec.-ft. & Feet & Sec.-ft. & Feet & Sec.-ft. & Feet & Sec-ft. & Feet & Sec.-ft. & Feet & Sec.-ft. \\
\hline & \multicolumn{2}{|c|}{ January 22} & \multicolumn{2}{|c|}{ January 23} & \multicolumn{2}{|c|}{ January 24} & \multicolumn{2}{|c|}{ January 25} & \multicolumn{2}{|c|}{ January 26} & \multicolumn{2}{|c|}{ January 27} \\
\hline $\begin{array}{l}1 \text { a.m. } \\
2 \\
3 \\
4 \\
4 \\
5 \\
6 \\
7 \\
8 \\
9 \\
10 \\
11 \\
12 \mathrm{n} . \\
1 \mathrm{p} . \mathrm{m} . \\
2 \\
3 \\
4 \\
5 \\
6 \\
7 \\
8 \\
9 \\
10 \\
11 \\
12 \mathrm{~m} .\end{array}$ & $\begin{array}{l}2.77 \\
2.69 \\
2.77 \\
2.81 \\
2.85 \\
2.86 \\
2.88 \\
3.07 \\
3.15 \\
3.16 \\
3.08 \\
2.91 \\
2.80 \\
2.78 \\
2.74 \\
2.72 \\
2.51 \\
2.54 \\
2.65 \\
2.72 \\
2.75 \\
2.76 \\
2.76 \\
2.76\end{array}$ & $\begin{array}{l}229 \\
201 \\
229 \\
244 \\
260 \\
263 \\
271 \\
349 \\
384 \\
388 \\
354 \\
283 \\
240 \\
233 \\
218 \\
211 \\
141 \\
1.51 \\
187 \\
211 \\
222 \\
226 \\
226 \\
226\end{array}$ & $\begin{array}{l}2.78 \\
2.80 \\
2.81 \\
2.81 \\
2.80 \\
2.79 \\
2.79 \\
2.77 \\
2.76 \\
2.75 \\
2.72 \\
2.72 \\
2.70 \\
2.70 \\
2.70 \\
2.70 \\
2.69 \\
2.67 \\
2.66 \\
2.65 \\
2.65 \\
2.6-1 \\
2.64 \\
2.64\end{array}$ & $\begin{array}{l}233 \\
240 \\
244 \\
244 \\
240 \\
236 \\
236 \\
229 \\
226 \\
222 \\
211 \\
211 \\
204 \\
204 \\
204 \\
204 \\
201 \\
194 \\
190 \\
187 \\
187 \\
184 \\
184 \\
184\end{array}$ & $\begin{array}{l}2.65 \\
2.66 \\
2.66 \\
2.67 \\
2.67 \\
2.67 \\
2.67 \\
2.91 \\
2.90 \\
2.86 \\
2.8 .5 \\
2.85 \\
2.86 \\
2.91 \\
2.98 \\
2.98 \\
2.85 \\
2.80 \\
2.77 \\
2.67 \\
2.70 \\
2.72 \\
2.76 \\
2.81\end{array}$ & $\begin{array}{l}187 \\
190 \\
190 \\
194 \\
194 \\
194 \\
194 \\
283 \\
279 \\
263 \\
260 \\
260 \\
263 \\
283 \\
312 \\
312 \\
260 \\
240 \\
229 \\
194 \\
204 \\
211 \\
226 \\
244\end{array}$ & $\begin{array}{l}2.85 \\
2.87 \\
2.88 \\
2.90 \\
2.97 \\
3.11 \\
3.32 \\
3.71 \\
4.18 \\
4.76 \\
5.40 \\
6.43 \\
6.34 \\
6.24 \\
6.25 \\
6.29 \\
6.61 \\
6.59 \\
6.60 \\
6.96 \\
6.77 \\
7.06 \\
6.90 \\
6.78\end{array}$ & $\begin{array}{r}260 \\
267 \\
271 \\
279 \\
308 \\
366 \\
460 \\
660 \\
928 \\
1,310 \\
1,780 \\
2,670 \\
2,590 \\
2,500 \\
2,500 \\
2,540 \\
2,850 \\
2.830 \\
2,840 \\
3,200 \\
3,010 \\
3,310 \\
3,140 \\
3,020\end{array}$ & $\begin{array}{l}6.69 \\
6.69 \\
6.56 \\
6.47 \\
6.34 \\
6.29 \\
6.27 \\
6.22 \\
6.01 \\
5.82 \\
5.70 \\
5.64 \\
5.62 \\
5.62 \\
5.58 \\
5.58 \\
5.55 \\
5.46 \\
5.29 \\
5.23 \\
5.20 \\
5.15 \\
5.11 \\
5.04\end{array}$ & $\begin{array}{l}2,930 \\
2,930 \\
2,800 \\
2,710 \\
2,590 \\
2,540 \\
2,520 \\
2,480 \\
2,290 \\
2,120 \\
2,020 \\
1,970 \\
1,960 \\
1,960 \\
1,920 \\
1,920 \\
1,900 \\
1,830 \\
1,690 \\
1,610 \\
1,620 \\
1,580 \\
1,560 \\
1,510\end{array}$ & $\begin{array}{l}4.90 \\
4.87 \\
4.79 \\
4.69 \\
4.66 \\
4.63 \\
4.60 \\
4.65 \\
4.55 \\
4.50 \\
4.50 \\
4.52 \\
4.41 \\
4.36 \\
4.34 \\
4.40 \\
4.45 \\
4.44 \\
4.39 \\
4.35 \\
4.30 \\
4.24 \\
4.20 \\
4.09\end{array}$ & $\begin{array}{r}1,410 \\
1,390 \\
1,330 \\
1,260 \\
1,240 \\
1,220 \\
1,200 \\
1,240 \\
1,160 \\
1,130 \\
1,130 \\
1,140 \\
1,070 \\
1,040 \\
1,020 \\
1,060 \\
1,100 \\
1,090 \\
1,050 \\
1,030 \\
1,000 \\
964 \\
940 \\
874\end{array}$ \\
\hline $12 \mathrm{~m}$ & \multicolumn{2}{|c|}{ January 28} & \multicolumn{2}{|c|}{ January 29} & \multicolumn{2}{|c|}{ January 30} & \multicolumn{2}{|c|}{ January 31} & \multicolumn{2}{|c|}{ February 1} & \multicolumn{2}{|c|}{ February 2} \\
\hline $\begin{array}{l}2 \mathrm{a} . \mathrm{m} . \\
4 \\
6 \\
8 \\
10 \\
12 \mathrm{n} . \\
2 \mathrm{p} . \mathrm{m} . \\
4 \\
6 \\
8 \\
10 \\
12 \mathrm{~m} .\end{array}$ & $\begin{array}{l}4.00 \\
4.00 \\
1.02 \\
1.10 \\
4.00 \\
3.92 \\
3.16 \\
3.70 \\
3.89 \\
3.85 \\
3.74 \\
3.67\end{array}$ & $\begin{array}{l}820 \\
820 \\
832 \\
880 \\
820 \\
776 \\
388 \\
655 \\
760 \\
738 \\
677 \\
638\end{array}$ & $\begin{array}{l}3.60 \\
3.64 \\
3.66 \\
3.67 \\
3.55 \\
3.49 \\
3.52 \\
3.46 \\
3.47 \\
3.50 \\
3.50 \\
3.47\end{array}$ & $\begin{array}{l}600 \\
622 \\
633 \\
638 \\
575 \\
545 \\
560 \\
530 \\
535 \\
550 \\
550 \\
535\end{array}$ & $\begin{array}{l}3.43 \\
3.40 \\
3.39 \\
3.43 \\
3.39 \\
3.12 \\
2.84 \\
3.10 \\
3.30 \\
3.36 \\
3.36 \\
3.33\end{array}$ & $\begin{array}{l}515 \\
500 \\
495 \\
515 \\
495 \\
371 \\
256 \\
362 \\
450 \\
480 \\
480 \\
465\end{array}$ & $\begin{array}{l}3.35 \\
3.36 \\
3.40 \\
3.52 \\
3.55 \\
3.59 \\
3.55 \\
3.74 \\
3.74 \\
3.66 \\
3.59 \\
3.54\end{array}$ & $\begin{array}{l}475 \\
480 \\
500 \\
560 \\
575 \\
505 \\
575 \\
677 \\
677 \\
633 \\
595 \\
570\end{array}$ & $\begin{array}{l}3.57 \\
3.56 \\
3.56 \\
3.65 \\
3.54 \\
3.48 \\
3.49 \\
3.52 \\
3.51 \\
3.57 \\
3.53 \\
3.35\end{array}$ & $\begin{array}{l}585 \\
580 \\
580 \\
628 \\
570 \\
540 \\
545 \\
560 \\
555 \\
585 \\
565 \\
475\end{array}$ & $\begin{array}{l}3.36 \\
3.36 \\
3.37 \\
3.41 \\
3.34 \\
3.29 \\
3.27 \\
3.22 \\
3.11 \\
3.15 \\
3.12 \\
3.14\end{array}$ & $\begin{array}{l}480 \\
480 \\
485 \\
505 \\
470 \\
446 \\
436 \\
414 \\
366 \\
384 \\
371 \\
379\end{array}$ \\
\hline
\end{tabular}

Supplemental records.-Jan. 25, 4:50 p.m., 6.33 ft., 2,580 sec.-ft.; 9:30 p.m., 7.21 ft., 3,470 sec.-ft. Jan. 28, 1:30 p.m., 3.81 ft., 716 sec.-ft.; Jan. 30, 11 a.m., $3.36 \mathrm{ft} ., 480$ sec.ft.; 1 p.m., $2.91 \mathrm{ft} ., 283$ sec.-ft.; Feb. 2, 7 a.m. 3.52 ft., 560 sec.-ft. 
QUINEBAUG RIVER AT PUTNAM, CONN.

Location.-Lat. $41^{\circ} 54^{\prime} 30^{\prime \prime}$, long. $71^{\circ} 54^{\prime} 30^{\prime \prime}$, at Putnam, Windham County, 600 feet downstream from Muddy Brook and 3 miles downstream from French River. Datum of gage is 216.76 feet above mean sea level, datum of 1929 .

Drainage AREA.--331 square miles.

GAGE-HEIGHT RECORD.-Water-stage recorder graph.

STAGE-Discharge RELATION.-Defined by current-meter measurements below 2,900 second-feet; extended to peak stage on basis of determination of flood flow at dam 1 mile above station plus inflow from Muddy Brook determined by flow over spillway at dam 2 miles above its mouth.

Maxima.-January 1938: Discharge, 7,450 second-feet midnight Jan. 25 (gage height, 11.68 feet).

1929 to December 1937: Discharge, 17,200 second-feet Mar. 19, 1936 (gage height, 17.28 feet, from floodmarks).

REMARKs.-Flood discharge affected by storage in several ponds and reservoirs. City of Putnam diverts about 1,000,000 gallons per day from Muddy Brook for municipal supply.

Mean discharge, in second-feet, 1938

\begin{tabular}{|c|c|c|c|c|c|c|c|c|c|c|c|}
\hline Day & Jan. & Feb. & Day & Jan. & Feb. & Day & Jan. & Feb. & Day & Jan. & Feb. \\
\hline $\begin{array}{l}1 \\
2 \\
3 \\
4 \\
5 \\
6 \\
7 \\
8\end{array}$ & $\begin{array}{r}494 \\
450 \\
569 \\
584 \\
566 \\
478 \\
864 \\
1,380\end{array}$ & $\begin{array}{l}1,330 \\
1,130 \\
1,080 \\
1,320 \\
1,180 \\
1,110 \\
1,510 \\
1,530\end{array}$ & $\begin{array}{c}9 \\
10 \\
11 \ldots \\
12 \\
13 \ldots- \\
14 \ldots- \\
15 \ldots- \\
16 \ldots-\end{array}$ & $\begin{array}{r}1,110 \\
1,040 \\
742 \\
685 \\
620 \\
620 \\
592 \\
464\end{array}$ & $\begin{array}{r}1,320 \\
1,180 \\
1,040 \\
836 \\
820 \\
982 \\
824 \\
747\end{array}$ & $\begin{array}{l}17 \\
18 \ldots \\
19 \ldots \\
20 \ldots \\
21 \ldots \\
22 \ldots \\
23 \ldots \\
24 \ldots\end{array}$ & $\begin{array}{l}564 \\
597 \\
502 \\
550 \\
541 \\
543 \\
403 \\
514\end{array}$ & $\begin{array}{l}662 \\
640 \\
640 \\
620 \\
701 \\
640 \\
620 \\
620\end{array}$ & $\begin{array}{l}25 \ldots \\
26 \ldots \\
27 \ldots \\
28 \ldots \\
29_{-} \\
30_{\ldots} \\
31 \ldots\end{array}$ & $\begin{array}{l}3,380 \\
6,290 \\
3,270 \\
1,910 \\
1,310 \\
1,120 \\
1,260\end{array}$ & $\begin{array}{c}620 \\
600 \\
600 \\
600 \\
0\end{array}$ \\
\hline \multicolumn{11}{|c|}{$\begin{array}{l}\text { Monthly mean discharge, in second-feet } \\
\text { Runoff, in inches }\end{array}$} & $\begin{array}{r}911 \\
2.86\end{array}$ \\
\hline
\end{tabular}

Gage height, in feet, and discharge, in second-feet, at indicated time, 1938

\begin{tabular}{|c|c|c|c|c|c|c|c|c|c|c|c|c|}
\hline \multirow{2}{*}{ Hour } & Feet & Sec.-ft. & Feet & Sec.-ft. & Feet & Sec.-ft. & Feet & Sec.-ft. & Feet & Sec.-ft. & Feet & Sec.-ft. \\
\hline & \multicolumn{2}{|c|}{ January 22} & \multicolumn{2}{|c|}{ January 23} & \multicolumn{2}{|c|}{ January 24} & \multicolumn{2}{|c|}{ January 25} & \multicolumn{2}{|c|}{ January 26} & \multicolumn{2}{|c|}{ January 27} \\
\hline $\begin{array}{c}1 \mathrm{a} . \mathrm{m} . \\
2 \\
3 \\
4 \\
5 \\
6 \\
7 \\
8 \\
9 \\
10 \\
11 \\
12 \mathrm{n} . \\
1 \mathrm{p} . \mathrm{m} . \\
2 \\
3 \\
4 \\
5 \\
6 \\
7 \\
8 \\
9 \\
10 \\
11 \\
12 \mathrm{~m} .\end{array}$ & $\begin{array}{l}3.69 \\
3.68 \\
3.66 \\
3.66 \\
3.66 \\
3.65 \\
3.49 \\
3.65 \\
3.66 \\
3.67 \\
3.85 \\
3.71 \\
3.71 \\
3.71 \\
3.71 \\
3.71 \\
3.70 \\
3.70 \\
3.70 \\
3.70 \\
3.70 \\
3.58 \\
3.31 \\
3.25\end{array}$ & $\begin{array}{l}556 \\
552 \\
544 \\
544 \\
544 \\
540 \\
482 \\
540 \\
544 \\
548 \\
620 \\
564 \\
564 \\
564 \\
564 \\
564 \\
560 \\
560 \\
560 \\
560 \\
560 \\
513 \\
418 \\
400\end{array}$ & $\begin{array}{l}3.20 \\
3.16 \\
3.11 \\
3.10 \\
2.95 \\
2.98 \\
2.82 \\
2.82 \\
2.91 \\
3.02 \\
3.15 \\
3.54 \\
3.66 \\
3.67 \\
3.67 \\
3.36 \\
3.20 \\
3.12 \\
3.01 \\
3.08 \\
3.45 \\
3.62 \\
3.67 \\
3.68\end{array}$ & $\begin{array}{l}385 \\
373 \\
358 \\
355 \\
310 \\
319 \\
272 \\
272 \\
298 \\
331 \\
370 \\
499 \\
544 \\
548 \\
548 \\
436 \\
385 \\
361 \\
328 \\
349 \\
468 \\
528 \\
548 \\
552\end{array}$ & $\begin{array}{l}3.55 \\
3.25 \\
3.07 \\
3.16 \\
3.11 \\
3.09 \\
3.09 \\
3.79 \\
3.77 \\
3.75 \\
3.73 \\
3.72 \\
3.71 \\
3.70 \\
3.70 \\
3.70 \\
3.70 \\
3.70 \\
3.70 \\
3.70 \\
3.71 \\
3.71 \\
3.72 \\
3.71\end{array}$ & $\begin{array}{l}502 \\
400 \\
346 \\
373 \\
358 \\
352 \\
352 \\
596 \\
588 \\
580 \\
572 \\
568 \\
564 \\
560 \\
560 \\
560 \\
560 \\
560 \\
560 \\
560 \\
564 \\
564 \\
568 \\
576\end{array}$ & $\begin{array}{r}3.75 \\
3.82 \\
3.90 \\
3.99 \\
4.10 \\
4.25 \\
4.39 \\
4.60 \\
4.73 \\
5.02 \\
6.48 \\
7.06 \\
7.64 \\
8.40 \\
9.13 \\
9.83 \\
10.38 \\
10.88 \\
11.25 \\
11.50 \\
11.63 \\
11.67 \\
11.67 \\
11.68\end{array}$ & $\begin{array}{r}580 \\
608 \\
640 \\
680 \\
730 \\
798 \\
860 \\
960 \\
1,020 \\
1,170 \\
2,060 \\
2,460 \\
2,900 \\
3,600 \\
4,350 \\
5,150 \\
5,810 \\
6,410 \\
6,900 \\
7,220 \\
7,390 \\
7,440 \\
7,440 \\
7,450\end{array}$ & $\begin{array}{r}11.65 \\
11.64 \\
11.61 \\
11.56 \\
11.47 \\
11.35 \\
11.25 \\
11.18 \\
11.08 \\
10.96 \\
10.88 \\
10.76 \\
10.67 \\
10.59 \\
10.50 \\
10.40 \\
10.30 \\
10.19 \\
10.09 \\
9.99 \\
9.90 \\
9.85 \\
9.74 \\
9.60\end{array}$ & $\begin{array}{l}7,420 \\
7,400 \\
7,360 \\
7,300 \\
7,180 \\
7,020 \\
6,900 \\
6,800 \\
6,670 \\
6,520 \\
6,410 \\
6,260 \\
6,150 \\
6,060 \\
5,950 \\
5,830 \\
5,710 \\
5,580 \\
5,460 \\
5,340 \\
5,230 \\
5,170 \\
5,040 \\
4,870\end{array}$ & $\begin{array}{l}9.46 \\
9.29 \\
9.10 \\
8.91 \\
8.71 \\
8.59 \\
8.45 \\
8.33 \\
8.22 \\
8.05 \\
7.94 \\
7.88 \\
7.71 \\
7.63 \\
7.53 \\
7.38 \\
7.26 \\
7.20 \\
7.19 \\
7.18 \\
7.18 \\
7.17 \\
7.14 \\
7.07\end{array}$ & $\begin{array}{l}4,720 \\
4,530 \\
4,320 \\
4,110 \\
3,910 \\
3,790 \\
3,650 \\
3,530 \\
3,420 \\
3,260 \\
3,170 \\
3,110 \\
2,960 \\
2,890 \\
2,810 \\
2,690 \\
2,600 \\
2,560 \\
2,550 \\
2,550 \\
2,550 \\
2,540 \\
2,520 \\
2,470\end{array}$ \\
\hline
\end{tabular}


Gage-height, in feet, and discharge, in second-feet, at indicated time, 1938-Continued

\begin{tabular}{|c|c|c|c|c|c|c|c|c|c|c|c|c|}
\hline \multirow{2}{*}{ Hour } & Feet & Sec.-ft. & Feet & Sec. $f \mathrm{ft}$. & Feet & Sec.-ft, & Feet & Sec.-ft. & Feet & Sec.-ft. & Feet & Sec.-ft. \\
\hline & \multicolumn{2}{|c|}{ January 28} & \multicolumn{2}{|c|}{ January 29} & \multicolumn{2}{|c|}{ January 30} & \multicolumn{2}{|c|}{ January 31} & \multicolumn{2}{|c|}{ February 1} & \multicolumn{2}{|c|}{ February 2} \\
\hline 2 a.m. & 6.85 & 2,320 & 5.73 & 1,580 & 5.08 & 1,200 & 4.80 & 1,060 & 5.40 & 1,380 & 5.17 & 1.240 \\
\hline & 6.76 & 2,250 & 5.63 & 1,520 & 5.06 & $\begin{array}{l}1,200 \\
1,190\end{array}$ & $\begin{array}{l}4.80 \\
4.84\end{array}$ & $\begin{array}{l}1,000 \\
1,080\end{array}$ & $\begin{array}{l}0.40 \\
5.35\end{array}$ & $\begin{array}{l}1,300 \\
1,350\end{array}$ & 5.10 & $\begin{array}{l}1,240 \\
1,210\end{array}$ \\
\hline 6 & 6.59 & 2,130 & 5.50 & 1,440 & 5.03 & 1,180 & 4.92 & 1,120 & 5.33 & 1,340 & 5.06 & 1,190 \\
\hline 8 & 6.43 & 2,020 & 5.40 & 1,380 & $\begin{array}{l}4.96 \\
4.96\end{array}$ & $\begin{array}{l}1,140 \\
1,140\end{array}$ & 5.16 & 1,240 & 5.35 & 1,350 & 5.01 & 1,160 \\
\hline 10 & 6.39 & 1,990 & 5.16 & 1,240 & 4.96 & $\begin{array}{l}1,140 \\
1,140\end{array}$ & 5.13 & 1,220 & 535 & $\begin{array}{l}1,350 \\
1,350\end{array}$ & 5.00 & 1,160 \\
\hline $12 \mathrm{n}$. & 6.22 & 1,870 & $\begin{array}{l}4.86 \\
4\end{array}$ & 1,090 & 4.96 & 1,140 & 5.34 & 1,340 & 5.35 & 1,350 & & 1,160 \\
\hline 2 p.m. & 5.91 & 1,690 & $\begin{array}{l}4.97 \\
4.97\end{array}$ & 1,140 & 4.97 & 1,140 & 5.35 & 1,350 & 5.32 & 1,330 & 4.78 & 1,050 \\
\hline & 5.95 & 1,710 & 5.20 & $\begin{array}{l}1,140 \\
1,260\end{array}$ & $\begin{array}{l}4.94 \\
4\end{array}$ & 1,130 & 5.36 & 1,360 & 5.30 & $\begin{array}{l}1,000 \\
1,320\end{array}$ & $\begin{array}{r}4.74 \\
\end{array}$ & 1,030 \\
\hline 6 & 5.87 & 1,660 & 5.18 & 1,25 & 4.81 & 1.060 & 5.36 & 1,360 & 5.27 & 1,300 & & 1,050 \\
\hline 8 & 5.76 & 1,600 & 5.15 & 1,240 & $\begin{array}{l}4.71 \\
4.72\end{array}$ & 1,020 & 5.37 & 1,360 & 5.26 & 1,300 & & 1,050 \\
\hline 10 & 5.75 & 1,590 & 5.10 & 1,210 & 4.7 & 1,020 & 5.43 & $\begin{array}{l}1,400 \\
1,400\end{array}$ & 5.22 & $\begin{array}{l}1,270 \\
1,270\end{array}$ & 4.76 & 1,040 \\
\hline $12 \mathrm{~m}$. & & 1,620 & 5.09 & 1,200 & 4.74 & 1,030 & 5.45 & 1,410 & 5.20 & 1,260 & 4.71 & 1,020 \\
\hline
\end{tabular}

Supplemental records.-Jan. $29,12: 30$ p.m., $4.76 \mathrm{ft} ., 1,040 \mathrm{sec}$ ft.; Jan. $30,6: 30$ a.m., 4.87 feet, 1,100 sec.-ft.; Jan. 31, 9 a.m., 5.02 feet, 1,170 sec.-ft.; Feb. 2, 1 p.m., 5.00 feet, 1,160 sec.-ft.'

\section{QUINEBAUG RIVER AT JEWITT CITY, CONN.}

Location.-Lat. $41^{\circ} 35^{\prime} 55^{\prime \prime}$, long. $71^{\circ} 59^{\prime} 05^{\prime \prime}$, at Jewett City, New London County, 1,000 feet downstream from railroad bridge and 570 feet downstream from canal from Slater Mills (mouth of Pachaug River). Datum of gage is 63.07 feet above mean sea level, datum of 1929 .

Drainage AREA.-711 square miles.

GAGE-HEIGHT RECORD.-Water-stage recorder graph.

Stage-discharge Relation.-Defined by current-meter measurements.

Maxima.-January 1938: Discharge, 11,100 second-feet 12:20 p.m. Jan. 26 (gage height, 15.51 feet).

1918 to December 1937: Discharge, 29,200 second-feet Mar. 19, 1936 (gage height, 24.0 feet, from floodmarks).

REMARKs.-Flood discharge affected by unregulated storage in numerous ponds and reservoirs.

Mean discharge, in second-feet, 1938

\begin{tabular}{|c|c|c|c|c|c|c|c|c|c|c|c|}
\hline Day & Jan. & Feb. & Day & Jan. & Feb. & Day & Jan. & Feb. & Day & Jan. & Feb. \\
\hline $\begin{array}{l}1 \\
2 \\
3 \\
4 \\
5 \\
6 \\
7 \\
8\end{array}$ & $\begin{array}{l}1,010 \\
1,110 \\
1,260 \\
1,230 \\
1,250 \\
1,180 \\
1,830 \\
3,380\end{array}$ & $\begin{array}{l}2,810 \\
2,470 \\
2,190 \\
2,930 \\
2,930 \\
2,430 \\
3,020 \\
3,200\end{array}$ & $\begin{array}{r}9 \\
10 \\
10 \\
12 \\
13 \\
14 \ldots \\
15 \\
16 \ldots\end{array}$ & $\begin{array}{l}2,750 \\
2,320 \\
1,910 \\
1,450 \\
1,380 \\
1,370 \\
1,260 \\
1,020\end{array}$ & $\begin{array}{l}2,840 \\
2,510 \\
2,190 \\
1,840 \\
1,700 \\
2,030 \\
1,990 \\
1,700\end{array}$ & $\begin{array}{l}17 \\
18 \\
19 \\
20 \\
21 \\
22 \\
23 \\
24\end{array}$ & $\begin{array}{l}1,220 \\
1,260 \\
1,140 \\
1,050 \\
1,140 \\
1,020 \\
1,000 \\
1,110\end{array}$ & $\begin{array}{l}1,480 \\
1,450 \\
1,340 \\
1,380 \\
1,470 \\
1,460 \\
1,420 \\
1,480\end{array}$ & $\begin{array}{l}25 \ldots \\
26 \ldots \\
27 \ldots \\
28 \ldots \\
29 \ldots \\
30_{\ldots} \\
31 \ldots\end{array}$ & $\begin{array}{r}4,050 \\
10,500 \\
7,170 \\
4,260 \\
2,830 \\
2,380 \\
2,660\end{array}$ & $\begin{array}{r}1,500 \\
1,350 \\
1,290 \\
1,470 \\
\\
\end{array}$ \\
\hline \multicolumn{11}{|c|}{$\begin{array}{l}\text { Monthly mean discharge, in second-feet } \\
\text { Runoff, in inches }\end{array}$} & $\begin{array}{r}1,995 \\
2.93\end{array}$ \\
\hline
\end{tabular}

Gage height, in feet, and discharge, in second-feet, at indicated time, 1938

\begin{tabular}{|c|c|c|c|c|c|c|c|c|c|c|c|c|}
\hline \multirow{2}{*}{ Hour } & Feet & Sec, $-\mathrm{ft}$. & Feet & Sec.-ft. & Feet & Sec.-ft. & Feet & Sec.-ft. & Feet & Sec.-ft. & Feet & Sec.-ft. \\
\hline & \multicolumn{2}{|c|}{ January 22} & \multicolumn{2}{|c|}{ January 23} & \multicolumn{2}{|c|}{ January 24} & \multicolumn{2}{|c|}{ January 25} & \multicolumn{2}{|c|}{ January 26} & \multicolumn{2}{|c|}{ January 27} \\
\hline \multirow{6}{*}{$\begin{array}{l}1 \text { a.m. } \\
2 \\
3 \\
4 \\
5 \\
6 \\
7\end{array}$} & & & & & 6.08 & 899 & 7.00 & 1,450 & 1444 & 9,460 & 14.31 & 9,260 \\
\hline & 6.51 & 1,150 & 6.31 & 1,030 & 6.0 & 894 & 7.0 & 1,510 & 14.71 & 9,860 & 14.15 & 9,020 \\
\hline & & & & & 6.06 & & 7.19 & & 14.83 & 10,000 & 14.00 & \\
\hline & 6.48 & 1,130 & 6.44 & 1,100 & 6.10 & 910 & 7.35 & 1,700 & 14.97 & 10,300 & 13.81 & 8,530 \\
\hline & 6.40 & 1,080 & 6.50 & 1,140 & 6.44 & $\begin{array}{r}8 \\
1,100\end{array}$ & 7.6 & $\begin{array}{l}1,700 \\
1,890\end{array}$ & 15.2 & $\begin{array}{l}10,4 \\
10,4\end{array}$ & $\begin{array}{ll}10.02 \\
13 & 4\end{array}$ & 8,060 \\
\hline & & & & & 6.38 & 1,070 & 7.83 & 2,050 & 15.28 & 10,700 & 13.30 & 7,820 \\
\hline
\end{tabular}


Gage-height, in feet, and discharge, in second-feet, at indicated time, 1938-Continued

\begin{tabular}{|c|c|c|c|c|c|c|c|c|c|c|c|c|}
\hline \multirow{2}{*}{ Irour } & Feet & Sec-ft. & Feet & Sec.-ft. & Feet & Sec.-ft. & Feet & Sec.-ft. & Feet & Sec.-ft. & Feet & Sec.-ft. \\
\hline & \multicolumn{2}{|c|}{ January 22} & \multicolumn{2}{|c|}{ January 23} & \multicolumn{2}{|c|}{ January 24} & \multicolumn{2}{|c|}{ January 25} & \multicolumn{2}{|c|}{ January 26} & \multicolumn{2}{|c|}{ January 27} \\
\hline \multirow{13}{*}{$\begin{array}{c}8 \\
9 \\
10 \\
11 \\
12 \mathrm{n} . \\
1 \mathrm{p} . \mathrm{m} . \\
2 \\
3 \\
4 \\
5 \\
6 \\
7 \\
8 \\
9 \\
10 \\
11 \\
12 \mathrm{~m} .\end{array}$} & 6.43 & 1,100 & 6.46 & 1,120 & & & 8. & & 5.29 & 10,8 & 13.07 & \\
\hline & & & & & & & & & & & & \\
\hline & 6.36 & 1,060 & 6.36 & 1,060 & & & & & & & & \\
\hline & 6.20 & 965 & 6.23 & 982 & 6.2 & & 9. & & & & & \\
\hline & & & & & & & & & & & & \\
\hline & & 888 & $6:$ & 94 & & & 9. & & & & & \\
\hline & 6.03 & 872 & 6.16 & $9 \pm 3$ & & & 10. & & & & & \\
\hline & & & & & & & 11. & & & & 12. & \\
\hline & 6.09 & 904 & 6.13 & 926 & & & & & & & 12. & \\
\hline & 6.25 & 992 & 6.10 & 910 & & & & & & & & \\
\hline & & & & & & & 13. & & & & 11 . & \\
\hline & 6.30 & 1,020 & 6.10 & 910 & & & 13. & & & 10 , & 11 . & \\
\hline & 6.27 & 1,000 & 6.09 & 904 & & $\begin{array}{l}1,340 \\
1,380\end{array}$ & $\begin{array}{l}13.94 \\
14.22\end{array}$ & $\begin{array}{l}8,720 \\
9,130\end{array}$ & & & & \\
\hline & \multicolumn{2}{|c|}{ January 28} & \multicolumn{2}{|c|}{ January 29} & \multicolumn{2}{|c|}{ January 30} & \multicolumn{2}{|c|}{ January 31} & \multicolumn{2}{|c|}{ February 1} & \multicolumn{2}{|c|}{ February 2} \\
\hline \multirow{10}{*}{$\begin{array}{c}2 \mathrm{a} . \mathrm{m} . \\
4 \\
6 \\
8 \\
10 \\
12 \mathrm{n} . \\
2 \mathrm{p.m} . \\
4 \\
6 \\
8 \\
10 \\
12 \mathrm{~m} .\end{array}$} & \multirow{10}{*}{$\begin{array}{r}11.05 \\
10.77 \\
10.52 \\
10.34 \\
10.23 \\
10.20 \\
10.28 \\
10.19 \\
10.09 \\
9.96 \\
9.76 \\
9.51\end{array}$} & \multirow{10}{*}{$\begin{array}{l}5,040 \\
4,730 \\
4,450 \\
4,270 \\
4,160 \\
4,130 \\
4,210 \\
4,120 \\
4,020 \\
3,890 \\
3,700 \\
3,480\end{array}$} & \multirow{10}{*}{$\begin{array}{l}9.34 \\
9.15 \\
8.89 \\
8.69 \\
8.62 \\
8.50 \\
8.53 \\
8.68 \\
8.71 \\
8.69 \\
8.63 \\
8.55\end{array}$} & \multirow{10}{*}{$\begin{array}{l}3,330 \\
3,160 \\
2,920 \\
2,740 \\
2,690 \\
2,590 \\
2,610 \\
2,730 \\
2,760 \\
2,740 \\
2,690 \\
2,630\end{array}$} & \multirow{10}{*}{$\begin{array}{l}8.47 \\
8.40 \\
8.35 \\
8.30 \\
8.28 \\
7.95 \\
8.07 \\
8.17 \\
8.07 \\
8.11 \\
8.19 \\
8.20\end{array}$} & \multirow{10}{*}{$\begin{array}{l}2,570 \\
2,510 \\
2,470 \\
2,430 \\
2,410 \\
2,150 \\
2,250 \\
2,330 \\
2,250 \\
2,280 \\
2,340 \\
2,350\end{array}$} & & & \multirow[b]{2}{*}{8.77} & \multirow[b]{2}{*}{2,810} & \multirow[b]{2}{*}{8.47} & \\
\hline & & & & & & & 8.18 & 2,330 & & & & 2,570 \\
\hline & & & & & & & 8.38 & 2,490 & 8.74 & 2,790 & 8 & 2,440 \\
\hline & & & & & & & & & & & & \\
\hline & & & & & & & 8.79 & 2,830 & 8.78 & 2,820 & 8.29 & 2,420 \\
\hline & & & & & & & & & & & & \\
\hline & & & & & & & & & & & & \\
\hline & & & & & & & 8.78 & 2,820 & 8.79 & 2,830 & 8.31 & 2,440 \\
\hline & & & & & & & & & & & & \\
\hline & & & & & & & 8.77 & 2,810 & 8.62 & 2,690 & 8.16 & 2,320 \\
\hline
\end{tabular}

Supplemental records.-Jan, 26, 12:20 p.m., $15.51 \mathrm{ft}$, 11,100 sec.-ft.; Jan. 29, 8:30 a.m., $8.35 \mathrm{ft}$, 2,470 sec.-ft.; 9 a.m., 8.61 ft., 2,680 sec.ft.; Jan. $30,11: 30$ a.m., 8.26 ft., 2,400 sec.-ft.; Jan. 31,9 a.m., 8.78 ft., 2,820 sec.-ft.

FIVI MILE RIVER AT KILTINGIY, CONN.

Location.-Lat. $41^{\circ} 50^{\prime} 10^{\prime \prime}$, long. $71^{\circ} 53^{\prime} 09^{\prime \prime}$, at northwest abutment of New York, New Haven \& Hartford Railroad bridge, five-eights of a mile south of Killingly, Windham County, and 2.7 miles upstream from mouth. Datum of gage is 222.22 feet above mean sea level, datum of 1929 .

Drainage AREa.--58.2 square miles.

GAGE-HEICHT RECORD.-Water-stage recorder graph.

Stage-dischafige relation.-Defined by current-meter measurements. Affected by ice Jan. 15-19, noon Jan. 25.

Maxima.-January 1938: Discharge, 630 second-feet 5 to 6 a.m. Jan. 26 (gage height, 3.94 feet).

November-December 1937: Discharge, 730 second-feet Nov. 29, 1937 (gage height, 4.3 feet).

REMARKs.-Flood discharge affected by storage in ponds and reservoirs. 
Mean discharge, in second-feet, 1938

\begin{tabular}{|c|c|c|c|c|c|c|c|c|c|c|c|}
\hline Day & Jan. & Feb. & Day & Jan. & Feb. & Day & Jan. & Feb. & Day & Jan. & Feb. \\
\hline & 110 & 219 & 9 & 208 & 210 & 17. & 104 & 125 & & 399 & 127 \\
\hline & 114 & 187 & $10 \ldots$ & 176 & 195 & $18_{-}$ & 97 & 123 & & 567 & 114 \\
\hline & 123 & 182 & $11 \ldots$ & 153 & 175 & 19 & 96 & 121 & 27 & 418 & 114 \\
\hline & 111 . & 232 & $12 \ldots$ & 133 & 152 & 20 & 98 & 127 & 28 & 353 & 117 \\
\hline & 102 & 215 & 13 & 128 & 1.52 & 21 & 94 & 127 & 29 . & 276 & \\
\hline & 102 & 198 & $14 \ldots$ & 120 & 165 & $22 \ldots$ & 79 & 114 & & 208 & 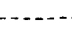 \\
\hline & $\begin{array}{l}177 \\
250\end{array}$ & $\begin{array}{l}248 \\
238\end{array}$ & $15--$ & $\begin{array}{r}108 \\
02\end{array}$ & $\begin{array}{l}158 \\
1+1\end{array}$ & $23+-$ & 193 & $\begin{array}{l}116 \\
124\end{array}$ & $31 \ldots$ & & \\
\hline \multirow{2}{*}{\multicolumn{10}{|c|}{$\begin{array}{l}\text { Monthly mean discharge, in second-feet } \\
\text { Runoff, in inches }\end{array}$}} & 175 & 161 \\
\hline & & & & & & & & & & & \\
\hline
\end{tabular}

Gage height, in feet, and discharge, in second-feet, at indicated time, 1938

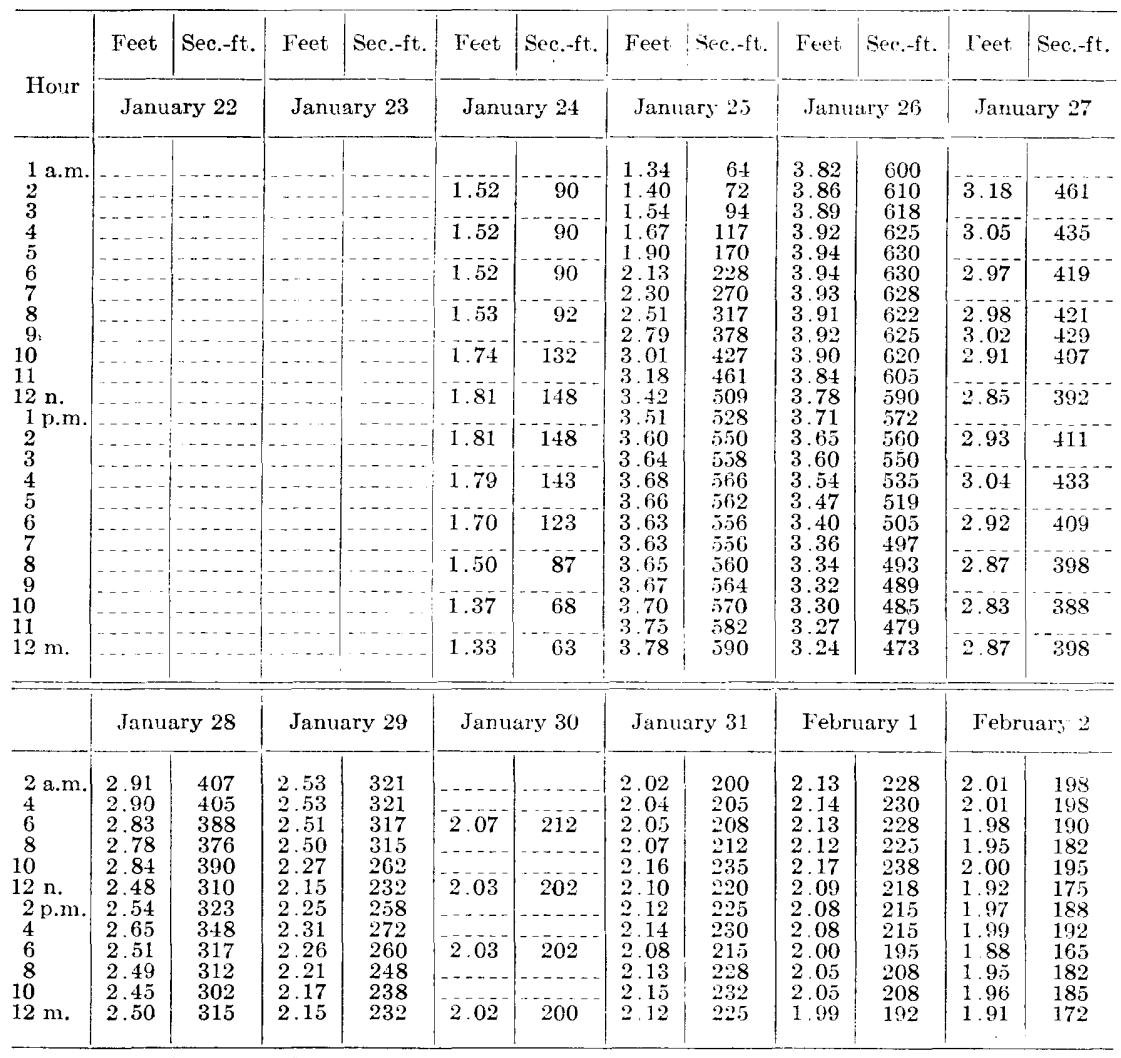

Supplemental records.-Jan. 28,9 a.m., 2.85 ft., 392 sec.-ft.; Jan. 31,9 a.m. 2.25 ft., 258 sec.ft.; Feb. 1 , 9 a.m., $2.24 \mathrm{ft}$., 255 sec.-ft.; Feb. 2, 9 a.m., $2.10 \mathrm{ft}$., $220 \mathrm{sic.-ft}$. 
MOOSUP RIVER AT MOOSUP, CONN.

Location.-Lat. $41^{\circ} 42^{\prime} 40^{\prime \prime}$, long. $71^{\circ} 53^{\prime} 15^{\prime \prime}$, at outlet of tailrace from Aldrich Bros. mill, 100 feet upstream from New York, New Haven \& Hartford Railroad bridge at Moosup, Windham County, and $3 \frac{1}{2}$ miles upstream from mouth. Datum of gage is $\mathbf{1 9 6 . 6 4}$ feet above mean sea level, datum of 1929.

Drainage AREA.--83.5 square miles.

GAGE-HEIGHT RECORD.-Water-stage recorder graph.

Stage-discharge relation.-Defined by current-meter measurements below 1,000 second-feet; extended logarithmically to peak stage on basis of two determinations of flood discharge at dam a quarter of a mile above station. Affected by ice Jan. 16-19, 21.

Maxima.-January 1938: Discharge, 1,380 second-feet 4 to 5 p.m. Jan. 25 (gage height, 5.04 feet).

1932 to December 1937: Discharge, 4,260 second-feet Mar. 12, 1936 gage height, 8.35 feet) from a sharp, short rise of unknown origin; discharge (natural), 4,080 second-feet Mar. 12, 1936 (gage height, 8.18 feet). Remarks.-Flood discharge affected by storage in several ponds.

Mean discharge, in second-feet, 1938

\begin{tabular}{|c|c|c|c|c|c|c|c|c|c|c|c|}
\hline Day & Jan. & Feb. & Day & Jan, & Feb. & Day & Jan. & Feb. & Day & Jan. & Feb. \\
\hline $\begin{array}{l}1 \ldots \ldots \\
2 \ldots \\
3 \\
4 \ldots \\
5 \\
6 \ldots \\
7 \ldots \\
8 \ldots\end{array}$ & $\begin{array}{l}112 \\
139 \\
159 \\
125 \\
124 \\
122 \\
389 \\
557\end{array}$ & $\begin{array}{l}334 \\
265 \\
253 \\
412 \\
390 \\
306 \\
373 \\
339\end{array}$ & $\begin{array}{c}9 \\
10 \ldots \\
11 \ldots \\
12 \ldots \\
13 \ldots \\
14 \ldots \\
15 \ldots \\
16 \ldots\end{array}$ & $\begin{array}{l}383 \\
283 \\
200 \\
170 \\
157 \\
151 \\
138 \\
130\end{array}$ & $\begin{array}{l}286 \\
255 \\
217 \\
193 \\
184 \\
252 \\
225 \\
184\end{array}$ & $\begin{array}{l}17 \\
18 \\
19 \\
20 \\
21 \\
22 \\
23 \\
24\end{array}$ & $\begin{array}{r}140 \\
130 \\
130 \\
123 \\
120 \\
123 \\
84 \\
145\end{array}$ & $\begin{array}{l}160 \\
162 \\
173 \\
164 \\
171 \\
150 \\
161 \\
191\end{array}$ & $\begin{array}{l}25 \ldots \\
26 \ldots \\
27 \\
28 \\
29 \\
30 \\
31\end{array}$ & $\begin{array}{r}892 \\
1,140 \\
612 \\
400 \\
265 \\
216 \\
321\end{array}$ & \begin{tabular}{c}
203 \\
193 \\
169 \\
189 \\
- \\
\hdashline
\end{tabular} \\
\hline \multicolumn{10}{|c|}{$\begin{array}{l}\text { Monthly mean discharge, in second-feet } \\
\text { Runoff, in inches }\end{array}$} & $\begin{array}{r}264 \\
3.64\end{array}$ & $\begin{array}{r}234 \\
2.92\end{array}$ \\
\hline
\end{tabular}

Gage height, in feet, and discharge, in second-feet, at indicated time, 1938

\begin{tabular}{|c|c|c|c|c|c|c|c|c|c|c|c|c|}
\hline \multirow{2}{*}{ Hour } & Feet & Sec.-ft. & Feet & Sec.-ft. & Feet & Sec.-ft. & Feet & Sec.-ft. & Feet & Sec.-ft. & Feet & Sec. ft. \\
\hline & \multicolumn{2}{|c|}{ January 22} & \multicolumn{2}{|c|}{ January 23} & \multicolumn{2}{|c|}{ January 24} & \multicolumn{2}{|c|}{ January 25} & \multicolumn{2}{|c|}{ January 26} & \multicolumn{2}{|c|}{ January 27} \\
\hline $\begin{array}{c}1 \text { a.m. } \\
2 \\
3 \\
4 \\
5 \\
6 \\
7 \\
8 \\
9 \\
10 \\
11 \\
12 \mathrm{n} . \\
1 \mathrm{p} . \mathrm{m} . \\
2 \\
3 \\
4 \\
5 \\
6 \\
7 \\
8 \\
9 \\
10 \\
11 \\
12 \mathrm{~m} .\end{array}$ & $\begin{array}{l}2.00 \\
1.68 \\
1.57 \\
1.56 \\
1.23 \\
1.07 \\
1.03 \\
1.03 \\
2.12 \\
2.08 \\
2.08 \\
2.07 \\
2.07 \\
2.07 \\
2.06 \\
2.07 \\
2.08 \\
2.08 \\
2.08 \\
2.07 \\
2.06 \\
2.06 \\
2.06 \\
2.06\end{array}$ & $\begin{array}{r}140 \\
80 \\
65 \\
64 \\
32 \\
22 \\
20 \\
20 \\
168 \\
158 \\
158 \\
156 \\
156 \\
156 \\
1.54 \\
156 \\
158 \\
158 \\
158 \\
156 \\
154 \\
154 \\
154 \\
154\end{array}$ & $\begin{array}{l}1.72 \\
1.57 \\
1.56 \\
1.28 \\
1.08 \\
1.03 \\
1.01 \\
1.01 \\
1.02 \\
1.66 \\
1.76 \\
1.79 \\
1.85 \\
1.85 \\
1.87 \\
1.87 \\
1.87 \\
1.89 \\
1.88 \\
1.88 \\
1.88 \\
1.88 \\
1.88 \\
1.88\end{array}$ & $\begin{array}{l}86 \\
65 \\
64 \\
36 \\
23 \\
20 \\
19 \\
19 \\
19 \\
77 \\
93 \\
98 \\
110 \\
110 \\
113 \\
113 \\
113 \\
117 \\
115 \\
115 \\
115 \\
115 \\
115 \\
115\end{array}$ & $\begin{array}{l}1.85 \\
1.88 \\
1.88 \\
1.88 \\
1.88 \\
1.89 \\
1.88 \\
2.17 \\
2.35 \\
2.18 \\
2.13 \\
2.11 \\
1.62 \\
2.20 \\
2.17 \\
2.10 \\
2.09 \\
1.78 \\
2.03 \\
2.03 \\
2.03 \\
2.05 \\
2.07 \\
2.12\end{array}$ & $\begin{array}{r}110 \\
115 \\
115 \\
115 \\
115 \\
117 \\
115 \\
180 \\
228 \\
183 \\
170 \\
166 \\
72 \\
188 \\
180 \\
163 \\
161 \\
97 \\
147 \\
147 \\
147 \\
152 \\
156 \\
168\end{array}$ & $\begin{array}{l}2.22 \\
2.37 \\
2.07 \\
2.10 \\
2.41 \\
2.80 \\
3.13 \\
3.67 \\
3.98 \\
4.28 \\
4.49 \\
4.66 \\
4.81 \\
4.93 \\
4.98 \\
5.04 \\
5.04 \\
5.01 \\
4.98 \\
4.92 \\
4.85 \\
4.80 \\
4.76 \\
4.73\end{array}$ & $\begin{array}{r}193 \\
233 \\
156 \\
163 \\
244 \\
360 \\
460 \\
658 \\
786 \\
930 \\
1,040 \\
1,150 \\
1,240 \\
1,310 \\
1,340 \\
1,380 \\
1,380 \\
1,360 \\
1,340 \\
1,300 \\
1,260 \\
1,230 \\
1,210 \\
1,190\end{array}$ & $\begin{array}{l}4.73 \\
4.73 \\
4.67 \\
4.72 \\
4.76 \\
4.78 \\
4.79 \\
4.86 \\
4.85 \\
4.82 \\
4.80 \\
4.78 \\
4.74 \\
4.74 \\
4.67 \\
4.63 \\
4.58 \\
4.51 \\
4.47 \\
4.42 \\
4.36 \\
4.29 \\
4.23 \\
4.17\end{array}$ & $\begin{array}{r}1,190 \\
1,190 \\
1,150 \\
1,180 \\
1,210 \\
1,220 \\
1,220 \\
1,270 \\
1,260 \\
1,240 \\
1,230 \\
1,220 \\
1,190 \\
1,190 \\
1,150 \\
1,130 \\
1,100 \\
1,060 \\
1,030 \\
1,000 \\
970 \\
935 \\
905 \\
875\end{array}$ & $\begin{array}{l}4.10 \\
4.03 \\
3.93 \\
3.82 \\
3.77 \\
3.70 \\
3.61 \\
3.67 \\
3.62 \\
3.52 \\
3.47 \\
3.43 \\
3.40 \\
3.40 \\
3.38 \\
3.39 \\
3.38 \\
3.35 \\
3.32 \\
3.29 \\
3.27 \\
3.24 \\
3.22 \\
3.19\end{array}$ & $\begin{array}{l}810 \\
808 \\
764 \\
718 \\
698 \\
670 \\
634 \\
658 \\
638 \\
598 \\
580 \\
566 \\
555 \\
555 \\
548 \\
552 \\
548 \\
538 \\
527 \\
516 \\
510 \\
499 \\
492 \\
482\end{array}$ \\
\hline
\end{tabular}


Gage-height, in feet, and discharge, in second-feet, at indicated time, 1938-Continued

\begin{tabular}{|c|c|c|c|c|c|c|c|c|c|c|c|c|}
\hline \multirow{2}{*}{ Hour } & Feet & Sec.-ft. & Feet & Sec.-ft. & Feet & Sec. $-\mathrm{ft}$. & Feet & Sec.-ft. & Feet & Sec.-ft. & Feet & Sec.-ft. \\
\hline & \multicolumn{2}{|c|}{ January 28} & \multicolumn{2}{|c|}{ January 29} & \multicolumn{2}{|c|}{ January 30} & \multicolumn{2}{|c|}{ January 31} & \multicolumn{2}{|c|}{ February 1} & \multicolumn{2}{|c|}{ February 2} \\
\hline 2 a.m. & 3.13 & 460 & 2.60 & 300 & 2.08 & 158 & 2.40 & 241 & 2.77 & 351 & 2.54 & 282 \\
\hline & 2.92 & 396 & 2.31 & 217 & 2.23 & 196 & 2.42 & 247 & 2.52 & 276 & 2.24 & 198 \\
\hline 6 & 2.94 & 402 & 2.41 & 244 & 2.28 & 209 & 246 & 25 & 2.62 & 30 & 2.35 & 228 \\
\hline 8 & 3.13 & 460 & 2.73 & 339 & 2.29 & 211 & 2.70 & 330 & 2.84 & 372 & 2.60 & 300 \\
\hline 10 & 3.03 & 429 & 2.67 & 321 & 2.29 & 211 & 2.68 & 32 & 2.77 & 351 & 2.53 & 279 \\
\hline $12 \mathrm{n}$. & 2.92 & 396 & 2.46 & 258 & 2.33 & 222 & 2.72 & 33 & 2.78 & 354 & 2.49 & 267 \\
\hline 2 p.m. & 2.92 & 396 & 2.43 & 250 & 2.36 & 230 & 2.79 & 357 & 2.80 & 360 & 2.58 & 294 \\
\hline & 2.91 & 393 & 2.43 & 250 & 2.37 & 23 & 2.7 & $3 \tilde{J}$ & 2.75 & 34 & 2.5 & 270 \\
\hline 6 & 2.88 & 384 & 2.43 & 250 & 2.38 & 236 & 2.7 & $3 \bar{J}$ & 2.71 & 333 & 2.4 & 264 \\
\hline 8 & 2.79 & 357 & 2.41 & 244 & 2.37 & 233 & 2.82 & 36 & 2.68 & 324 & 2.48 & 264 \\
\hline & 2.70 & 330 & 2.37 & 233 & 2.37 & 233 & 2.80 & 360 & 2.62 & 306 & 2.44 & 253 \\
\hline $12 \mathrm{~m}$. & 2.64 & 312 & 2.36 & 230 & 2.39 & 238 & 2.79 & 357 & 2.57 & 291 & 2.43 & 250 \\
\hline
\end{tabular}

Supplemental records.--Jan. 23, 3:30 a.m., 1.56 ft., 64 sec.-ft.; Jan. 30, 1:30 a.m., $2.03 \mathrm{ft}$., 147 sec.-ft.; Jan. 31 , 8:30 a.m., 2.91 ft., 393 sec.-ft.; Feb. 2, 3 a.m., 2.53 ft., 279 sec.-ft.; 1 p.m., 2.43 ft., 250 sec.-ft.

YANTIC RIVER AT YANTIC, CONN.

Location.-Lat. $41^{\circ} 33^{\prime} 35^{\prime \prime}$, long. $72^{\circ} 07^{\prime} 20^{\prime \prime}, 700$ feet downstream from stonearch highway bridge at Yantic, New London County, and 1 mile downstream from Susquetonscut Brook. Datum of gage is 94.46 feet above mean sea level (general adjustment of 1929).

Drainage area.--88.6 square miles.

GAGE-HEIGHT RECORD.-Water-stage recorder graph except for period 10 a.m. Jan. 25 to 3 a.m. Jan. 26, when graph was based on floodmark, existing record, and normal shape of flood hydrographs.

Stage-discharge relation.-Defined by current-meter measurements. Shiftingcontrol method used 9 a.m. to 3 p.m. Jan. 25. Affected by ice Jan. 16, 19 . Maxima.-January 1938: Discharge, 3,230 second-feet 4 p.m. Jan. 25 (gage height, 8.07 feet, from floodmark).

1930 to December 1937: Discharge, 6,300 second-feet Mar. 12, 1936 (gage height, 11.32 feet).

REMARKs.-Flood discharge affected by storage in a few lakes and ponds.

Mean discharge, in second-feet, 1938

\begin{tabular}{|c|c|c|c|c|c|c|c|c|c|c|c|}
\hline Pay & Jan. & Feb. & Day & Jan. & Feb. & Day & Jan. & Feb. & Day & Jan. & Feb. \\
\hline $\begin{array}{l}1 \\
2 \\
3 \\
4 \\
5 \\
5 \\
6 \\
7 \\
8 \\
8\end{array}$ & $\begin{array}{l}114 \\
132 \\
135 \\
122 \\
111 \\
109 \\
814 \\
892\end{array}$ & $\begin{array}{l}334 \\
252 \\
263 \\
487 \\
369 \\
306 \\
396 \\
374\end{array}$ & $\begin{array}{r}9 \\
9 \\
10 \\
11 \\
12^{-} \\
13 \\
14 \\
15_{-} \\
16_{\ldots}\end{array}$ & $\begin{array}{l}425 \\
263 \\
206 \\
154 \\
139 \\
139 \\
130 \\
130\end{array}$ & $\begin{array}{l}293 \\
276 \\
232 \\
200 \\
215 \\
273 \\
261 \\
193\end{array}$ & $\begin{array}{l}17 \\
18 \\
19 \\
20 \\
21 \\
22_{-} \\
23 \\
24\end{array}$ & $\begin{array}{l}135 \\
135 \\
130 \\
130 \\
134 \\
117 \\
114 \\
117\end{array}$ & $\begin{array}{l}155 \\
161 \\
187 \\
203 \\
182 \\
153 \\
175 \\
211\end{array}$ & $\begin{array}{l}25 \\
26 \\
27 \\
28 \\
29 \\
30 \ldots \\
31 \ldots \\
\end{array}$ & $\begin{array}{r}2,060 \\
1,580 \\
556 \\
340 \\
231 \\
207 \\
317\end{array}$ & $\begin{array}{l}229 \\
212 \\
197 \\
201\end{array}$ \\
\hline \multicolumn{11}{|c|}{\begin{tabular}{l|r|r} 
Monthly mean discharge, in second-feet & 333 \\
Runoff, in inches
\end{tabular}} & $\begin{array}{r}250 \\
2.94\end{array}$ \\
\hline
\end{tabular}


Gage height, in feet, and discharge, in second-feet, at indicated time, 1938

\begin{tabular}{|c|c|c|c|c|c|c|c|c|c|c|c|c|}
\hline \multirow{2}{*}{ Hour } & Feet & Sec.ft. & Feet & Sec.-ft. & Feet & Sec.-ft. & Feet & Sec.ft. & Feet & Sec.-ft. & Feet & Sec.-ft. \\
\hline & \multicolumn{2}{|c|}{ January 22} & \multicolumn{2}{|c|}{$\mathbf{J}_{\text {anuary }} \mathbf{2 3}$} & \multicolumn{2}{|c|}{ January 24} & \multicolumn{2}{|c|}{ January 25} & \multicolumn{2}{|c|}{ January 26} & \multicolumn{2}{|c|}{ January 27} \\
\hline \multirow[t]{2}{*}{$\begin{array}{c}1 \mathrm{a} . \mathrm{m} . \\
2 \\
3 \\
4 \\
5 \\
6 \\
7 \\
8 \\
9 \\
10 \\
11 \\
12 \mathrm{n} . \\
1 \mathrm{p} . \mathrm{m} . \\
2 \\
3 \\
4 \\
5 \\
6 \\
7 \\
8 \\
9 \\
10 \\
11 \\
12 \mathrm{~m} .\end{array}$} & -- & & & & $\begin{array}{l}1.97 \\
1.97 \\
1.97 \\
1.99 \\
2.00 \\
2.01 \\
2.29 \\
2.12 \\
2.54 \\
2.53 \\
2.38 \\
2.31 \\
2.13 \\
1.98 \\
2.16 \\
2.17 \\
1.79 \\
1.46 \\
1.43 \\
1.50 \\
1.63 \\
1.77 \\
1.92 \\
2.14\end{array}$ & $\begin{array}{r}109 \\
109 \\
109 \\
112 \\
113 \\
114 \\
154 \\
129 \\
194 \\
192 \\
168 \\
157 \\
130 \\
111 \\
134 \\
136 \\
88 \\
55 \\
53 \\
59 \\
71 \\
86 \\
103 \\
132\end{array}$ & $\begin{array}{l}2.53 \\
3.14 \\
3.71 \\
4.27 \\
4.79 \\
5.37 \\
5.94 \\
6.55 \\
7.02 \\
7.36 \\
7.61 \\
7.83 \\
7.96 \\
8.03 \\
8.07 \\
8.07 \\
8.04 \\
7.98 \\
7.92 \\
7.85 \\
7.77 \\
7.68 \\
7.59 \\
7.49\end{array}$ & $\begin{array}{r}192 \\
310 \\
444 \\
596 \\
762 \\
978 \\
1,210 \\
1,500 \\
1,760 \\
2,050 \\
2,300 \\
2,600 \\
2,800 \\
3,000 \\
3,200 \\
3,230 \\
3,200 \\
3,100 \\
3,100 \\
3,000 \\
3,000 \\
2,900 \\
2,800 \\
2,700\end{array}$ & $\begin{array}{l}7.39 \\
7.27 \\
7.14 \\
7.02 \\
6.88 \\
6.70 \\
6.50 \\
6.45 \\
6.31 \\
6.13 \\
5.92 \\
5.73 \\
5.60 \\
5.61 \\
5.52 \\
5.41 \\
5.14 \\
5.06 \\
4.80 \\
4.80 \\
4.75 \\
4.66 \\
4.55 \\
4.51\end{array}$ & $\begin{array}{r}2,600 \\
2,500 \\
2,400 \\
2,320 \\
2,200 \\
2,070 \\
1,930 \\
1,900 \\
1,800 \\
1,670 \\
1,530 \\
1,420 \\
1,340 \\
1,350 \\
1,290 \\
1,240 \\
1,100 \\
1,060 \\
940 \\
940 \\
918 \\
877 \\
828 \\
810\end{array}$ & $\begin{array}{l}4.46 \\
4.36 \\
4.25 \\
4.13 \\
4.02 \\
3.93 \\
3.87 \\
3.85 \\
3.86 \\
3.91 \\
3.82 \\
3.80 \\
3.69 \\
3.79 \\
3.93 \\
3.91 \\
3.78 \\
3.48 \\
3.47 \\
3.52 \\
3.33 \\
3.39 \\
3.40 \\
3.36\end{array}$ & $\begin{array}{l}789 \\
749 \\
705 \\
657 \\
617 \\
586 \\
564 \\
558 \\
561 \\
578 \\
547 \\
540 \\
502 \\
536 \\
586 \\
578 \\
533 \\
439 \\
436 \\
451 \\
398 \\
412 \\
415 \\
405\end{array}$ \\
\hline & \multicolumn{2}{|c|}{ January 28} & \multicolumn{2}{|c|}{ January 29} & \multicolumn{2}{|c|}{ January 30} & \multicolumn{2}{|c|}{ January 31} & \multicolumn{2}{|c|}{ February 1} & \multicolumn{2}{|c|}{ February 2} \\
\hline $\begin{array}{l}24 \mathrm{a} . \mathrm{m} . \\
4 \\
6 \\
8 \\
10 \\
12 \mathrm{n} . \\
2 \text { p.m. } \\
4 \\
6 \\
8 \\
10 \\
12 \mathrm{~m} .\end{array}$ & $\begin{array}{l}3.29 \\
3.26 \\
3.30 \\
3.28 \\
3.33 \\
3.13 \\
3.13 \\
3.17 \\
2.74 \\
2.72 \\
2.76 \\
2.73\end{array}$ & $\begin{array}{l}388 \\
380 \\
390 \\
385 \\
398 \\
348 \\
348 \\
358 \\
254 \\
249 \\
258 \\
252\end{array}$ & $\begin{array}{l}2.67 \\
2.68 \\
2.72 \\
2.71 \\
2.60 \\
2.56 \\
2.62 \\
2.64 \\
2.62 \\
2.59 \\
2.56 \\
2.52\end{array}$ & $\begin{array}{l}239 \\
241 \\
249 \\
247 \\
224 \\
216 \\
228 \\
232 \\
228 \\
222 \\
216 \\
208\end{array}$ & $\begin{array}{l}2.50 \\
2.50 \\
2.50 \\
2.48 \\
2.47 \\
2.49 \\
2.53 \\
2.53 \\
2.54 \\
2.55 \\
2.55 \\
2.57\end{array}$ & $\begin{array}{l}204 \\
204 \\
204 \\
200 \\
198 \\
202 \\
210 \\
210 \\
212 \\
214 \\
216 \\
218\end{array}$ & $\begin{array}{l}2.59 \\
2.63 \\
2.81 \\
2.90 \\
3.22 \\
3.10 \\
3.12 \\
3.44 \\
2.95 \\
3.10 \\
3.22 \\
3.22\end{array}$ & $\begin{array}{l}222 \\
230 \\
269 \\
290 \\
370 \\
340 \\
345 \\
427 \\
302 \\
340 \\
370 \\
370\end{array}$ & $\begin{array}{l}3.21 \\
3.18 \\
3.14 \\
3.09 \\
3.41 \\
3.24 \\
3.02 \\
3.26 \\
2.74 \\
2.76 \\
2.81 \\
2.83\end{array}$ & $\begin{array}{l}368 \\
360 \\
350 \\
338 \\
418 \\
375 \\
320 \\
380 \\
254 \\
258 \\
269 \\
274\end{array}$ & $\begin{array}{l}2.80 \\
2.76 \\
2.70 \\
2.73 \\
2.90 \\
2.90 \\
2.78 \\
3.00 \\
2.47 \\
2.27 \\
2.56 \\
2.58\end{array}$ & $\begin{array}{l}267 \\
258 \\
245 \\
252 \\
290 \\
290 \\
263 \\
315 \\
198 \\
162 \\
216 \\
220\end{array}$ \\
\hline
\end{tabular}

Supplemental records.-Fek. 2,9 a.m., $2.97 \mathrm{ft} ., 308$ sec.-ft.

\section{CONNECTICUT RIVER BASIN}

CONNECTICUT RIVER AT HARTFORD, CONN.

Location.-Lat. $41^{\circ} 46^{\prime} 10^{\prime \prime}$, long. $72^{\circ} 40^{\prime} 00^{\prime \prime}$, at Memorial Bridge in Hartford, Hartford County, three-quarters of a mile upstream from Park River and $1 \frac{1}{2}$ miles upstream from Hockanum River. Datum of gage is 0.55 foot below mean sea level.

Drainage AREa.-10,480 square miles.

GAGE-HEIGHT RECORD.-Water-stage recorder graph. Gage heights given to tenths.

Maxima.-January 1938: Gage height, 19.6 feet 11 p.m. Jan. 26 (discharge, about 90,000 second-feet).

1896 to December 1937: Discharge, 313,000 second-feet Mar. 20, 1936, (augmented by breaching of Hartford dikes); gage height, 37.6 feet Mar. 21, 1936.

1639 to December 1937: stage known, that of Mar. 211936.

Remarks.-Low stages affected by tide. Flow affected by a total storage capacity of 27,000,000,000 cubic feet (revised) above station. Record furnished by United States Weather Bureau. 
Gage height, in feet, at 8 a.m., 1938

\begin{tabular}{|c|c|c|c|c|c|c|c|c|c|c|c|}
\hline Day & Jan. & Feb. & Day & Jan. & Feb. & Day & Jan. & Feb. & Day & Jan. & Feb. \\
\hline 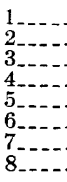 & $\begin{array}{l}3.7 \\
4.4 \\
5.4 \\
5.5 \\
5.3 \\
5.6 \\
6.0\end{array}$ & $\begin{array}{l}8.5 \\
7.8 \\
7.5 \\
7.6 \\
7.0 \\
6.4 \\
7.2 \\
9.2\end{array}$ & $\begin{array}{r}9 \\
10- \\
11 \\
12 \\
13 \\
14 . \\
15 \\
16-\end{array}$ & $\begin{array}{l}7.4 \\
5.8 \\
5.1 \\
5.7 \\
6.5 \\
7.4 \\
8.0 \\
7.4\end{array}$ & $\begin{array}{r}10.5 \\
10.1 \\
9.0 \\
7.8 \\
6.9 \\
6.5 \\
7.3 \\
7.7\end{array}$ & $\begin{array}{l}17 \\
18 \\
19 \\
20 \\
21 \\
22 \\
23 \\
24 \\
24\end{array}$ & $\begin{array}{l}6.7 \\
6.3 \\
6.9 \\
6.9 \\
6.6 \\
6.6 \\
5.9 \\
5.0\end{array}$ & $\begin{array}{r}7.2 \\
7.0 \\
6.6 \\
6.5 \\
\\
\end{array}$ & $\begin{array}{l}25 \ldots \\
26 \\
27 \\
28 \\
29 \\
30 \\
31 \ldots \\
\end{array}$ & $\begin{array}{r}7.4 \\
18.5 \\
19.3 \\
17.4 \\
14.0 \\
10.1 \\
8.9\end{array}$ & \\
\hline
\end{tabular}

SCANTIC RIVER AT BROAD BROOK, CONN.

LoCATION.-Lat. $41^{\circ} 54^{\prime} 45^{\prime \prime}$, long. $72^{\circ} 34^{\prime} 05^{\prime \prime}, 300$ feet upstream from highway bridge, half a mile downstream from Broad Brook, 1 mile southwest of town of Broad Brook, Hartford County, and 51/2 miles upstream from mouth.

DrainaGe AREA.-98.4 square miles.

GAGE-HEIGHT RECORD.-Water-stage recorder graph except for period 5 p.m. Jan. 24 to 5 p.m. Jan. 26 when graph was computed on basis of range line, floodmarks, one inspection, shape of normal recession graph, and, relation to time of peak at station on Hockanum River at East Hartford.

Stage-DISCHARGE RELATION.-Defined by current-meter measurements below 550 second-feet; extended to peak stage on basis of determinations of flood flows of September 1938 at dams 7 and 9 miles above station.

Maxima.-January 1938: Discharge, 1,810 second-feet 6 a.m. Jan. 26 (gage height, 10.15 feet, from floodmark).

1928 to December 1937: Discharge, 1,820 second-feet Mar. 13, 1936 (gage height, 10.17 feet); gage height, 12.31 feet Mar. 21 (backwater from Connecticut River).

REMARKs.-Flood discharge affected by storage in one reservoir and several small ponds.

Mean discharge, in second-feet, 1938

\begin{tabular}{|c|c|c|c|c|c|c|c|c|c|c|c|}
\hline Day & Jan. & Feb. & Day & Jan. & Feb. & Day & Jan. & Feb. & Day & Jan. & Fol, \\
\hline $\begin{array}{l}1 \\
2 \\
3 \\
4 \\
6 \\
6 \\
7 \\
8\end{array}$ & $\begin{array}{r}97 \\
111 \\
125 \\
114 \\
109 \\
112 \\
273 \\
415\end{array}$ & $\begin{array}{l}261 \\
227 \\
219 \\
317 \\
290 \\
260 \\
421 \\
436\end{array}$ & $\begin{array}{r}9 \\
10 \\
11 \\
12 \\
13 \\
14 \\
15_{-} \\
16\end{array}$ & $\begin{array}{l}374 \\
249 \\
171 \\
140 \\
136 \\
137 \\
129 \\
141\end{array}$ & $\begin{array}{l}338 \\
265 \\
231 \\
202 \\
212 \\
236 \\
226 \\
196\end{array}$ & $\begin{array}{l}17 \\
18 \\
19 \\
20 \\
21 \\
22 \\
23 \ldots \\
24 \ldots\end{array}$ & $\begin{array}{l}129 \\
124 \\
126 \\
125 \\
119 \\
112 \\
116 \\
128\end{array}$ & $\begin{array}{l}165 \\
162 \\
168 \\
185 \\
173 \\
156 \\
161 \\
180\end{array}$ & $\begin{array}{l}25 \\
26 \ldots \\
27 \\
28 \\
29 \\
30 \\
31 \\
\end{array}$ & $\begin{array}{r}495 \\
1,490 \\
727 \\
392 \\
244 \\
221 \\
255\end{array}$ & $\begin{array}{l}181 \\
181 \\
172 \\
175\end{array}$ \\
\hline \multicolumn{10}{|c|}{$\begin{array}{l}\text { Monthly mean discharge, in second-feet } \\
\text { Runoff, in inches. }\end{array}$} & $\begin{array}{r}216 \\
2.88\end{array}$ & $\begin{array}{r}228 \\
2.42\end{array}$ \\
\hline
\end{tabular}

Gage height, in feet, and discharge, in second-feet, at indicated time, 1938

\begin{tabular}{|c|c|c|c|c|c|c|c|c|c|c|c|c|}
\hline \multirow{2}{*}{ Hour } & Feet & Sec.-ft. & Feet & Sec.-ft. & Feet & Sec.-ft. & Feet & Ser.-ft. & Feet & Sec.-ft. & Feet & Sec.-ft. \\
\hline & \multicolumn{2}{|c|}{ January 22} & \multicolumn{2}{|c|}{ January 23} & \multicolumn{2}{|c|}{ January 24} & \multicolumn{2}{|c|}{ January 25 } & \multicolumn{2}{|c|}{ January 26} & \multicolumn{2}{|c|}{ January 27} \\
\hline $\begin{array}{l}1 \text { a.m. } \\
2 \\
3 \\
4 \\
5\end{array}$ & & & & & $\begin{array}{l}1.24 \\
1.24 \\
1.24 \\
1.23 \\
1.22\end{array}$ & $\begin{array}{l}117 \\
117 \\
117 \\
116 \\
114\end{array}$ & $\begin{array}{l}1.56 \\
1.60 \\
1.68 \\
1.80 \\
1.90\end{array}$ & $\begin{array}{l}165 \\
170 \\
180 \\
200 \\
210\end{array}$ & $\begin{array}{r}9.15 \\
9.55 \\
9.90 \\
10.08 \\
10.13\end{array}$ & $\begin{array}{l}1,500 \\
1,600 \\
1,700 \\
1,800 \\
1,800\end{array}$ & $\begin{array}{l}6.73 \\
6.54 \\
6.38 \\
6.26 \\
6.13\end{array}$ & $\begin{array}{l}939 \\
903 \\
873 \\
852 \\
828\end{array}$ \\
\hline
\end{tabular}


Gage-height, in feet, and discharge, in second-feet, at indicated time, 1938-Continued

\begin{tabular}{|c|c|c|c|c|c|c|c|c|c|c|c|c|}
\hline \multirow[b]{2}{*}{ Hour } & Feet & Sec.-ft. & Feet & Sec.-ft, & Feet & Sec.-ft. & Feet & Sec.-ft. & Feet & Sec.-ft. & Feet & Sec.-ft. \\
\hline & \multicolumn{2}{|c|}{ January 22} & \multicolumn{2}{|c|}{ January 23} & \multicolumn{2}{|c|}{ January 24} & \multicolumn{2}{|c|}{ January 25} & \multicolumn{2}{|c|}{ January 26} & \multicolumn{2}{|c|}{ January 27} \\
\hline $\begin{array}{r}6 \\
7 \\
8 \\
9 \\
10 \\
11 \\
12 \mathrm{n} . \\
1 \mathrm{p} . \mathrm{m} . \\
2 \\
3 \\
4 \\
5 \\
6 \\
7 \\
8 \\
9 \\
10 \\
11 \\
12 \mathrm{~m} .\end{array}$ & & & & & $\begin{array}{l}1.21 \\
1.21 \\
1.20 \\
1.20 \\
1.20 \\
1.22 \\
1.25 \\
1.27 \\
1.28 \\
1.29 \\
1.31 \\
1.35 \\
1.40 \\
1.44 \\
1.47 \\
1.49 \\
1.50 \\
1.51 \\
1.53\end{array}$ & $\begin{array}{l}113 \\
113 \\
111 \\
111 \\
111 \\
114 \\
119 \\
122 \\
124 \\
125 \\
129 \\
135 \\
145 \\
150 \\
155 \\
155 \\
160 \\
160 \\
160\end{array}$ & $\begin{array}{l}2.00 \\
2.11 \\
2.23 \\
2.38 \\
2.57 \\
2.77 \\
3.00 \\
3.32 \\
3.63 \\
4.10 \\
4.60 \\
5.10 \\
5.60 \\
6.20 \\
6.65 \\
7.20 \\
7.65 \\
8.20 \\
8.70\end{array}$ & $\begin{array}{r}220 \\
230 \\
245 \\
260 \\
280 \\
300 \\
320 \\
360 \\
410 \\
480 \\
560 \\
640 \\
740 \\
840 \\
920 \\
1,050 \\
1,100 \\
1,250 \\
1,350\end{array}$ & $\begin{array}{r}10.15 \\
10.13 \\
10.11 \\
10.00 \\
9.88 \\
9.75 \\
9.58 \\
9.40 \\
9.20 \\
9.00 \\
8.78 \\
8.55 \\
8.31 \\
8.08 \\
7.87 \\
7.66 \\
7.43 \\
7.19 \\
6.93\end{array}$ & $\begin{array}{l}1,810 \\
1,800 \\
1,800 \\
1,750 \\
1,700 \\
1,650 \\
1,600 \\
1,550 \\
1,500 \\
1,450 \\
1,400 \\
1,300 \\
1,260 \\
1,210 \\
1,170 \\
1,120 \\
1,080 \\
1,030 \\
977\end{array}$ & $\begin{array}{l}6.03 \\
5.92 \\
5.82 \\
5.74 \\
5.68 \\
5.62 \\
5.51 \\
5.47 \\
5.45 \\
5.43 \\
5.36 \\
5.26 \\
5.12 \\
4.96 \\
4.78 \\
4.61 \\
4.46 \\
4.34 \\
4.23\end{array}$ & $\begin{array}{l}810 \\
791 \\
773 \\
758 \\
747 \\
737 \\
717 \\
710 \\
706 \\
703 \\
691 \\
674 \\
650 \\
623 \\
593 \\
565 \\
541 \\
521 \\
504\end{array}$ \\
\hline & \multicolumn{2}{|c|}{ January 28} & \multicolumn{2}{|c|}{ January 29} & \multicolumn{2}{|c|}{ January 30} & \multicolumn{2}{|c|}{ January 31} & \multicolumn{2}{|c|}{ February 1} & \multicolumn{2}{|c|}{ February 2} \\
\hline $\begin{array}{c}2 \text { a.m. } \\
4 \\
6 \\
8 \\
10 \\
12 \mathrm{n} . \\
2 \mathrm{p.m} . \\
4 \\
6 \\
8 \\
10 \\
12 \mathrm{~m} .\end{array}$ & $\begin{array}{l}4.03 \\
3.83 \\
3.73 \\
3.68 \\
3.60 \\
3.50 \\
3.51 \\
3.46 \\
3.26 \\
3.02 \\
2.82 \\
2.63\end{array}$ & $\begin{array}{l}472 \\
440 \\
426 \\
418 \\
406 \\
391 \\
392 \\
385 \\
356 \\
325 \\
302 \\
283\end{array}$ & $\begin{array}{l}2.47 \\
2.30 \\
2.17 \\
2.10 \\
2.07 \\
2.11 \\
2.23 \\
2.28 \\
2.28 \\
2.24 \\
2.18 \\
2.13\end{array}$ & $\begin{array}{l}267 \\
250 \\
237 \\
231 \\
228 \\
232 \\
243 \\
248 \\
248 \\
244 \\
238 \\
234\end{array}$ & $\begin{array}{l}2.10 \\
2.06 \\
2.04 \\
1.99 \\
1.97 \\
2.12 \\
2.07 \\
1.96 \\
1.92 \\
1.91 \\
1.91 \\
1.92\end{array}$ & $\begin{array}{l}231 \\
227 \\
225 \\
220 \\
218 \\
233 \\
228 \\
217 \\
212 \\
211 \\
211 \\
212\end{array}$ & $\begin{array}{l}1.93 \\
1.96 \\
2.00 \\
2.04 \\
2.20 \\
2.35 \\
2.51 \\
2.64 \\
2.75 \\
2.67 \\
2.78 \\
2.72\end{array}$ & $\begin{array}{l}213 \\
217 \\
221 \\
225 \\
240 \\
255 \\
271 \\
284 \\
295 \\
287 \\
298 \\
292\end{array}$ & $\begin{array}{l}2.58 \\
2.48 \\
2.44 \\
2.42 \\
2.40 \\
2.37 \\
2.39 \\
2.42 \\
2.40 \\
2.34 \\
2.26 \\
2.17\end{array}$ & $\begin{array}{l}278 \\
268 \\
264 \\
262 \\
260 \\
257 \\
259 \\
262 \\
260 \\
254 \\
246 \\
237\end{array}$ & $\begin{array}{l}2.12 \\
2.12 \\
2.14 \\
1.88 \\
1.86 \\
2.11 \\
2.13 \\
2.15 \\
2.14 \\
2.08 \\
2.02 \\
1.91\end{array}$ & $\begin{array}{l}233 \\
233 \\
235 \\
208 \\
205 \\
232 \\
234 \\
236 \\
235 \\
229 \\
223 \\
211\end{array}$ \\
\hline
\end{tabular}

FARMINGTON RIVER AT RIVERTON, CONN.

LoCATION.-Lat. $41^{\circ} 57^{\prime} 15^{\prime \prime}$, long. $73^{\circ} 00^{\prime} 45^{\prime \prime}$, a quarter of a mile downstream from Still River, 1 mile downstream from Riverton, Litchfield County, and 4 miles northeast of Winsted.

Drainage AREA.-216 square miles.

GAGE-HEIGHT RECORD.-Water-stage recorder graph.

Stage-Discharge Relation.-Defined by current-meter measurements below 5,700 second-feet; extended. Affected by ice Jan. 3-7, 18-21, 3 to 4 a.m. and 8:10 a.m. Jan. 25, Feb. 21, 22, 26-28.

Maxima.-January 1938: Discharge, 10,200 second-feet 11 a.m. Jan. 25 (gage height, 9.52 feet); gage height, 9.96 feet 8:10 a.m. Jan. 25 (result of ice jam).

1929 to December 1937: Discharge, 19,900 second-feet Mar. 18, 1936 (gage height, 13.42 feet).

Remarks.-Flow regulated by storage in Otis Reservoir (p. 69). 
Mean discharge, in second-feet, 1938

\begin{tabular}{|c|c|c|c|c|c|c|c|c|c|c|c|}
\hline Day & Jan. & Feb. & Day & Jan. & Feb. & Day & Jan. & Feb. & Day & Jan. & Feb. \\
\hline $\begin{array}{l}1 \\
2 \\
3 \\
4 \\
6 \\
7 \\
8\end{array}$ & $\begin{array}{l}284 \\
324 \\
300 \\
300 \\
280 \\
260 \\
900 \\
955\end{array}$ & $\begin{array}{r}628 \\
493 \\
486 \\
615 \\
530 \\
551 \\
1,730 \\
922\end{array}$ & $\begin{array}{r}9 \\
10 \ldots \\
11 \\
12 \ldots \\
13 \ldots \\
14 \\
15 \\
16\end{array}$ & $\begin{array}{l}692 \\
555 \\
462 \\
422 \\
433 \\
397 \\
377 \\
329\end{array}$ & $\begin{array}{l}716 \\
674 \\
520 \\
462 \\
516 \\
621 \\
520 \\
394\end{array}$ & $\begin{array}{l}17 \\
18 \\
19 \\
20 \\
21 \\
22 \\
23 \\
24\end{array}$ & $\begin{array}{l}354 \\
320 \\
300 \\
320 \\
320 \\
332 \\
313 \\
392\end{array}$ & $\begin{array}{l}396 \\
434 \\
467 \\
426 \\
380 \\
360 \\
414 \\
413\end{array}$ & $\begin{array}{l}25_{-} \\
26 \\
27_{-} \\
28 \\
29 \\
30 \\
31 \ldots \\
\end{array}$ & $\begin{array}{r}6,060 \\
2,870 \\
1,280 \\
809 \\
596 \\
577 \\
734\end{array}$ & $\begin{array}{l}395 \\
340 \\
300 \\
240\end{array}$ \\
\hline \multicolumn{11}{|c|}{$\begin{array}{l}\text { Monthly mean discharge, in second-feet } \\
\text { Runoff, in inches. }\end{array}$} & $\begin{array}{l}534 \\
2.57\end{array}$ \\
\hline
\end{tabular}

Gage height, in feet, and discharge, in second-feet, at indicated time, 1938

\begin{tabular}{|c|c|c|c|c|c|c|c|c|c|c|c|c|}
\hline \multirow{2}{*}{ Hour } & Feet & Sec.-ft. & Feet & Sec.-ft. & Feet & Sec.ft. & Feet & Sec.-ft. & Feet & Sec.-ft. & Feet & Sec.-ft. \\
\hline & \multicolumn{2}{|c|}{ January 22} & \multicolumn{2}{|c|}{ January 23} & \multicolumn{2}{|c|}{ January 24} & \multicolumn{2}{|c|}{ January 25} & \multicolumn{2}{|c|}{ January 26} & \multicolumn{2}{|c|}{ January 27} \\
\hline \multirow{17}{*}{$\begin{array}{c}1 \\
2 \mathrm{a} . \mathrm{m} . \\
3 \\
4 \\
5 \\
6 \\
7 \\
8 \\
9 \\
10 \\
11 \\
12 \mathrm{n} . \\
1 \mathrm{p} . \mathrm{m} . \\
2 \\
3 \\
4 \\
5 \\
6 \\
7 \\
8 \\
9 \\
10 \\
11 \\
12 \mathrm{~m} .\end{array}$} & & & & & & & 2.22 & 373 & 6.73 & 4,960 & 4.08 & 1,610 \\
\hline & 2.12 & 335 & 2.02 & 298 & $2.1 \overline{7}$ & 354 & & & & & 4.02 & \\
\hline & 2.08 & $320^{-}$ & 1.91 & 260 & 2.21 & 369 & $\begin{array}{l}2.75 \\
3.40\end{array}$ & $\begin{array}{l}5+0 \\
780\end{array}$ & & & & $\begin{array}{l}1,500 \\
1,450\end{array}$ \\
\hline & & & & & & & 3.94 & 1,490 & 5. & & 385 & 1.400 \\
\hline & 2.03 & 302 & 2.00 & 291 & 2.27 & 393 & 5.00 & & & & 3.81 & $\begin{array}{l}1,370 \\
1,320\end{array}$ \\
\hline & 2.03 & 302 & 2.06 & 313 & 2.35 & 426 & $\begin{array}{l}0.40 \\
7.72\end{array}$ & $\begin{array}{l}4,4 \\
6,6\end{array}$ & $\begin{array}{l}.030 \\
5.34\end{array}$ & 2,9 & $\begin{array}{l}3.75 \\
3.72\end{array}$ & $\begin{array}{l}1,020 \\
1,290\end{array}$ \\
\hline & & & 2.06 & 313 & & & 8.85 & 8,790 & 5.20 & & 3.70 & 1,270 \\
\hline & 2.08 & 320 & 2.34 & 422 & 2.50 & 495 & 9.41 & 9,970 & 5.08 & 2,630 & 3.68 & 1,250 \\
\hline & 2.21 & 369 & 2.07 & 316 & 2.53 & 510 & $\begin{array}{l}9.52 \\
9.39\end{array}$ & $\begin{array}{r}10,2 \\
9,9\end{array}$ & $\begin{array}{l}4.99 \\
4.95\end{array}$ & 30 & $\begin{array}{l}3.6 \\
3.6\end{array}$ & $\begin{array}{l}1,220 \\
1,240\end{array}$ \\
\hline & 224 & 381 & 2.02 & 298 & 215 & 346 & 9.18 & & & & & $\begin{array}{l}1,250 \\
1,240\end{array}$ \\
\hline & & & & & & & 9.05 & & 4. & 2,4 & 3.6 & 1,250 \\
\hline & 2.15 & 346 & 1.95 & 274 & 224 & 381 & 8.94 & & & & 3.6 & 1,250 \\
\hline & 2.09 & 323 & 2.11 & 331 & 2.27 & 393 & $\begin{array}{l}8.68 \\
8.43\end{array}$ & & $\begin{array}{l}4.79 \\
4.72\end{array}$ & & $\begin{array}{l}3.64 \\
3.64\end{array}$ & $\begin{array}{l}1,220 \\
1,220\end{array}$ \\
\hline & & & 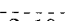 & & & & 8.23 & & 4.6 & & & 1,180 \\
\hline & 2.11 & 331 & 2.10 & 327 & 2.20 & 365 & 8.00 & 7,1 & 4.53 & 2,0 & 3.5 & $\begin{array}{l}1,150 \\
1,100\end{array}$ \\
\hline & 2.10 & 327 & 2.10 & 327 & 2.12 & 335 & 7.44 & & $\begin{array}{l}4 . \pm \\
4.3\end{array}$ & 1,8 & 3.4 & 1,060 \\
\hline & 207 & 316 & 212 & 335 & 214 & 342 & 696 & & & 1,760 & $\begin{array}{l}3.37 \\
3.22\end{array}$ & 1,020 \\
\hline & & & & & & & & & & & & \\
\hline & \multicolumn{2}{|c|}{ January 28} & \multicolumn{2}{|c|}{ January 29} & \multicolumn{2}{|c|}{ January 30} & \multicolumn{2}{|c|}{ January 31} & \multicolumn{2}{|c|}{ February 1} & \multicolumn{2}{|c|}{ February 2} \\
\hline $2 \mathrm{a}$ & & & & 600 & & & & & & & & 422 \\
\hline & & & & & & & & & & & & 476 \\
\hline & & & & & & & & & & & & 418 \\
\hline 8 & 3.07 & & 2.6 & & 2 & & 2.8 & & 2 . & & 2 & 405 \\
\hline & 3.04 & & & & & & & & & & & 467 \\
\hline & 3.04 & & & & & & 3. & & & & & 53 \\
\hline & 3.06 & & 2.7 & & 2.7 & & 3.2 & & 2. & 66 & 2.6 & 570 \\
\hline & 3.09 & & 2.7 & & & & 3.2 & & & & & 612 \\
\hline & & & & & & & 3.0 & & & & & 600 \\
\hline & 2.98 & & 2.7 & & 2 & & 3.0 & & 27 & & 2 & 520 \\
\hline & & & & & & & & & & & & 486 \\
\hline $12 \mathrm{~m}$. & & 585 & & 520 & 2.67 & 580 & 2.90 & 710 & 2.44 & 467 & 2.45 & 472 \\
\hline
\end{tabular}

Supplemental records.-Jan. 25, 8:10 a.m., 9.96 ft. (ice jam); Jan. 30, 1 a.m., 2.38 ft., 439 sec.-ft.; 7 a.m., 2.61 ft., 550 sec.-ft.; Feb. 2, 1 p.m., $2.34 \mathrm{ft}$., 422 sec.-ft.

FARMINGTON RIVER AT TARIFFVIIIF, CONN.

Location.-Lat. $41^{\circ} 54^{\prime} 35^{\prime \prime}$, long. $72^{\circ} 45^{\prime} 40^{\prime \prime}$, at Tariffville, Hartford County, half a mile upstream from Hartford Electric Light Co.'s plant, threequarters of a mile downstream from Salmon Brook, and 12 miles upstream from mouth.

Drainage AREa.-578 square miles.

$748116-48-6$ 
GACE-HEIGHT RECoRD.-Water-stage recorder graph, except for period Jan. 16-20 when float was frozen in well.

StAGE-Discharge RELATION.-Varies with number of generators operating at power plant. Base rating curves have been developed for flow through one and two generators operating at full capacity and for flow over spillway of dam with no generators operating. These ratings are correlated by stage-relation curves and are defined by discharge measurements and computations of flow over dam. When generators ran at less than full capacity discharge was determined from adjusted gage-height graph. Spillway rating used 6 p.m. Jan. 25 to 9 am. Jan. 29; one-generator rating used Jan. 8, 9, 10 a.m. Jan. 29 to 8 a.m. Jan. 30; two-generator rating used Jan. 1-7, Jan. 10 to 5 p.m. Jan. 25, 9 a.m Jan. 30 to Feb. 28, except for periods of ice effect, Jan. 1-4, Jan. 10 to 5 p.m. Jan. 25.

Maxima.-January 1938: Discharge, 11,900 second-feet 11 a.m. to noon January 26 (gage height, 9.62 feet).

1928 to December 1937: Discharge, 26,900 second-feet Mar. 19, 1936 (gage height, 13.4 feet).

Remarks.-Discharge during period of no gage-height record or periods of ice effect based on operation records of Hartford Electric Co.'s plant, half a mile below station. Flood discharge affected by storage and diversion. For information on storage and diversion see records for Otis Reservoir at Cold Spring, Mass., Barkhamsted Reservoir at Barkhamsted, Conn., East Branch Reservoir at New Hartford, Conn., Nepaug Reservoir near Collinsville, Conn.

Mean discharge, in second-feet, 1938

\begin{tabular}{|c|c|c|c|c|c|c|c|c|c|c|c|}
\hline Day & Jan. & Feb. & Day & Jan. & Feb. & Day & Jan. & Feb. & Day & Jan. & Feb. \\
\hline & $\begin{array}{r}950 \\
800 \\
1,100 \\
900 \\
832 \\
832 \\
1,500 \\
2,960\end{array}$ & $\begin{array}{l}2,330 \\
1,600 \\
1,620 \\
1,980 \\
1,930 \\
1,840 \\
3,030 \\
2,770\end{array}$ & $\begin{array}{r}9 \\
10 \\
11 \\
12 \\
13 \\
14 \\
15 \\
16\end{array}$ & $\begin{array}{r}2,080 \\
1,500 \\
1,300 \\
900 \\
850 \\
1,000 \\
1,100 \\
900\end{array}$ & $\begin{array}{l}2,130 \\
1,980 \\
1,800 \\
1,660 \\
1,750 \\
1,980 \\
1,930 \\
1,540\end{array}$ & $\begin{array}{l}17 \\
18 \\
19 \\
20 \\
21 \\
22 \\
23 \\
24\end{array}$ & $\begin{array}{l}950 \\
900 \\
750 \\
850 \\
850 \\
860 \\
840 \\
777\end{array}$ & $\begin{array}{l}1,300 \\
1,380 \\
1,460 \\
1,460 \\
1,340 \\
1,340 \\
1,340 \\
1,460\end{array}$ & $\begin{array}{l}25 \ldots \\
26 \ldots \\
27 \ldots \\
28 \ldots \\
29 \\
30 \ldots \\
31 \ldots \\
\end{array}$ & $\begin{array}{r}5,320 \\
11,100 \\
6,660 \\
3,460 \\
2,390 \\
2,060 \\
2,420\end{array}$ & $\begin{array}{r}1,340 \\
1,240 \\
1,100 \\
935\end{array}$ \\
\hline \multicolumn{11}{|c|}{$\begin{array}{l}\text { Monthly mean discharge, in second-feet. } \\
\text { Runoff, in inches. }\end{array}$} & $\begin{array}{r}1,699 \\
3.06\end{array}$ \\
\hline
\end{tabular}

Gage height, in feet, and discharge, in second-feet, at indicated time, 1938

\begin{tabular}{|c|c|c|c|c|c|c|c|c|c|c|c|c|}
\hline \multirow{2}{*}{ Hour } & Feet & Sec.-ft. & Feet & Sec.-ft. & Feet & Sec.-ft. & Feet & Sec.-ft. & Feet & Sec.-ft. & Feet & Sec.-ft. \\
\hline & \multicolumn{2}{|c|}{ January 22} & \multicolumn{2}{|c|}{ January 23} & \multicolumn{2}{|c|}{ January 24} & \multicolumn{2}{|c|}{ January 25} & \multicolumn{2}{|c|}{ January 26} & \multicolumn{2}{|c|}{ January 27} \\
\hline 1 a.n & & & & & & & 2.78 & 860 & 9.00 & 10,300 & & \\
\hline & & & & & & & $\begin{array}{l}2.81 \\
2.90\end{array}$ & $\begin{array}{l}90 \\
96\end{array}$ & $\begin{array}{l}9.20 \\
9.18\end{array}$ & $\begin{array}{l}10, \\
10\end{array}$ & 8.22 & 8,530 \\
\hline & & & & & 2.70 & 780 & 3.05 & 1,0 & 9.27 & 10,9 & 7.97 & 7,980 \\
\hline & & & & & & & & & 9. & 11 , & 775 & 7520 \\
\hline & & & & & & & 4 . & 1,4 & & 11,6 & 6.10 & $8,0<0$ \\
\hline & 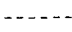 & $\ldots$ & 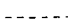 & $\ldots$ & 2.74 & 860 & 5.2 & & & 11 , & 7.53 & 7,050 \\
\hline 10 & & & & & -... & - & & & & & 733 & 6.650 \\
\hline & 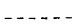 & - & & & & & 7.1 & 4,8 & 9. & 11 , & 7.29 & \\
\hline & & & & & 2.62 & 820 & 8. & & 9. & 11, & 7.20 & 6,600 \\
\hline & & & & & & & 8. & & & 11 & 7.10 & 6,400 \\
\hline $\begin{array}{l}3 \\
4\end{array}$ & & & & & 2.40 & 720 & $\begin{array}{l}8.64 \\
8.69\end{array}$ & $\begin{array}{l}8,200 \\
8,600\end{array}$ & $\begin{array}{l}9.54 \\
9.50\end{array}$ & $\begin{array}{l}11,700 \\
11,600\end{array}$ & 6.98 & 6,200 \\
\hline & & & & & & & & & & & & \\
\hline
\end{tabular}


Gage-height, in feet, and discharge, in second-feet, at indicated time, 1938-Continued

\begin{tabular}{|c|c|c|c|c|c|c|c|c|c|c|c|c|}
\hline \multirow{2}{*}{ Hour } & Feet & Sec.-ft. & Feet & Sec.-ft. & Feet & Sec. $-\mathrm{ft}$. & Feet & Sec.-ft. & Feet & Sec.-ft. & Feet & Sec.-ft. \\
\hline & \multicolumn{2}{|c|}{ January 22} & \multicolumn{2}{|c|}{ January 23} & \multicolumn{2}{|c|}{ January 24} & \multicolumn{2}{|c|}{ January 25} & \multicolumn{2}{|c|}{ January 26} & \multicolumn{2}{|c|}{ January 27} \\
\hline \multirow[t]{2}{*}{$\begin{array}{r}5 \\
6 \\
7 \\
8 \\
9 \\
10 \\
11 \\
12 \mathrm{~m} .\end{array}$} & & & & & $\begin{array}{l}2.60 \\
2.70 \\
2.7 \overline{7}\end{array}$ & $\begin{array}{r}700 \\
800\end{array}$ & $\begin{array}{l}8.78 \\
8.48 \\
8.53 \\
8.53 \\
8.56 \\
8.63 \\
8.69 \\
8.70\end{array}$ & $\begin{array}{l}8,800 \\
9,110 \\
9,220 \\
9,220 \\
9,290 \\
9,450 \\
9,590 \\
9,610\end{array}$ & $\begin{array}{l}9.46 \\
9.38 \\
9.30 \\
9.20 \\
9.07 \\
8.91 \\
8.73 \\
8.55\end{array}$ & $\begin{array}{r}11,400 \\
11,200 \\
11,000 \\
10,800 \\
10,500 \\
10,100 \\
9,680 \\
9,260\end{array}$ & $\begin{array}{l}6.79 \\
6.66 \\
6.42 \\
6.23\end{array}$ & $\begin{array}{l}5,800 \\
5,370 \\
4,940 \\
4,620\end{array}$ \\
\hline & \multicolumn{2}{|c|}{ January 28} & \multicolumn{2}{|c|}{ January 29} & \multicolumn{2}{|c|}{ January 30} & \multicolumn{2}{|c|}{ January 31} & \multicolumn{2}{|c|}{ February 1} & \multicolumn{2}{|c|}{ February 2} \\
\hline \multirow{6}{*}{$\begin{array}{l}2 \mathrm{a} . \mathrm{m} . \\
4 \\
6 \\
8 \\
10 \\
12 \mathrm{n} . \\
2 \mathrm{p.m} . \\
4 \\
6 \\
8 \\
10 \\
12 \mathrm{~m} .\end{array}$} & 5.91 & 4,110 & $\begin{array}{l}4.75 \\
4.84\end{array}$ & 2,610 & & & & & & & & \\
\hline & $\begin{array}{l}5.61 \\
5.42\end{array}$ & 3,660 & $\begin{array}{r}4.77 \\
4.69\end{array}$ & 2,520 & $\begin{array}{l}4.13 \\
4.11 \\
3.95\end{array}$ & $\begin{array}{l}2,050 \\
0\end{array}$ & $\begin{array}{l}4.04 \\
-\end{array}$ & & 4.44 & 2,600 & 3.44 & 1,650 \\
\hline & 5.29 & 3,300 & 4.48 & 2,400 & 3.92 & 2,050 & 4.17 & 2,350 & 4.09 & $2,250^{-}$ & 3.40 & 1,500 \\
\hline & 5.10 & 3,100 & $\begin{array}{l}7.40 \\
+.33\end{array}$ & 2,250 & & & & & & & & \\
\hline & 4.96 & 2,900 & 4.22 & 2,150 & 0.94 & $\begin{array}{l}2,050 \\
\ldots \ldots\end{array}$ & $\begin{array}{r}4.38 \\
\cdots . . . .\end{array}$ & $\begin{array}{l}2,600 \\
\ldots\end{array}$ & 3.99 & $\begin{array}{l}2,150 \\
\ldots \ldots\end{array}$ & 3.32 & $\begin{array}{r}1,550 \\
\ldots . . . . . .\end{array}$ \\
\hline & 4.82 & 2,700 & 4.17 & 2,100 & 3.93 & 2,100 & 4.50 & $2,800^{-}$ & 3.71 & $1,850^{-}$ & 3.25 & 1,550 \\
\hline
\end{tabular}

Supplemental records: Jan. 24, 4:30 p.m., 2.80 feet (ice effect).

\section{OTIS RESTRVOIR AT COID SPRING, MASS.}

Location.-Staff gage at dam, lat. $42^{\circ} 09^{\prime} 35^{\prime \prime}$, long. $73^{\circ} 03^{\prime} 33^{\prime \prime}$, on unnamed stream three-quarters of a mile upstream from its debouchment into Farmington River and 1 mile northeast of Cold Spring, Hampden County.

Drainage AREA.-17.2 square miles.

GAGE-HEIGHT RECORD.-One gage reading daily, usually at 7 a.m. Gage height at midnight computed from graph of gage readings and study of gate operation and weather records.

STAGE-DISCHARGE RELATION.-Outflow computed from record of gate openings. No flow over spillway during period Jan. 1 to Feb. 28.

REMARKs.- Inflow computed from outflow adjusted for change in contents of reservoir. No adjustments for evaporation from reservoir surface. Records based on data furnished by the Collins Co., Collinsville, Conn.

Discharge, in second-feet, and change in contents in equivalent second-feet, 1938

\begin{tabular}{|c|c|c|c|c|c|c|}
\hline \multirow{2}{*}{ Day } & \multicolumn{3}{|c|}{ January } & \multicolumn{3}{|c|}{ February } \\
\hline & $\begin{array}{c}\text { Observed } \\
\text { outflow }\end{array}$ & $\begin{array}{l}\text { Change in } \\
\text { Contents }\end{array}$ & Inflow & $\begin{array}{c}\text { Observed } \\
\text { outflow }\end{array}$ & $\begin{array}{l}\text { Change in } \\
\text { Contents }\end{array}$ & Inflow \\
\hline $\begin{array}{r}1 \\
2 \\
3 \\
4 \\
5 \\
6 \\
7 \\
8 \\
9 \\
10 \\
11 \\
12\end{array}$ & $\begin{array}{l}59 \\
59 \\
70 \\
88 \\
87 \\
75 \\
19 \\
29 \\
58 \\
58 \\
58 \\
58\end{array}$ & $\begin{array}{l}-40 \\
-39 \\
-58 \\
-78 \\
-78 \\
-53 \\
+58 \\
+24 \\
-19 \\
-24 \\
-24 \\
-24\end{array}$ & $\begin{array}{r}19 \\
20 \\
12 \\
10 \\
9 \\
22 \\
77 \\
53 \\
39 \\
34 \\
34 \\
34\end{array}$ & $\begin{array}{r}0.0 \\
.0 \\
.0 \\
.0 \\
.0 \\
.0 \\
.0 \\
.0 \\
.0 \\
.0 \\
.0 \\
.0\end{array}$ & $\begin{array}{r}+80 \\
+51 \\
+46 \\
+46 \\
+46 \\
+71 \\
+107 \\
+107 \\
+57 \\
+42 \\
+42 \\
+42\end{array}$ & $\begin{array}{r}80 \\
51 \\
46 \\
46 \\
46 \\
71 \\
107 \\
107 \\
57 \\
42 \\
42 \\
42\end{array}$ \\
\hline
\end{tabular}


Discharge, in second-feet, and change in contents in equivalent second-feet, 1938 -Continued

\begin{tabular}{|c|c|c|c|c|c|c|}
\hline \multirow{2}{*}{ Day } & \multicolumn{3}{|c|}{ January } & \multicolumn{3}{|c|}{ February } \\
\hline & $\begin{array}{c}\text { Observed } \\
\text { outflow }\end{array}$ & $\begin{array}{l}\text { Change in } \\
\text { Contents }\end{array}$ & Inflow & $\begin{array}{l}\text { Observed } \\
\text { outflow }\end{array}$ & $\begin{array}{l}\text { Change in } \\
\text { Contents }\end{array}$ & Infiow \\
\hline \multirow[t]{3}{*}{$\begin{array}{l}13 \\
14 \\
15 \\
16 \\
17 \\
18 \\
19 \\
20 \\
21 \\
22 \\
23 \\
24 \\
25 \\
26 \\
27 \\
28 \\
29 \\
30 \\
31\end{array}$} & $\begin{array}{l}58 \\
58 \\
58 \\
58 \\
58 \\
58 \\
58 \\
58 \\
58 \\
57 \\
57 \\
65 \\
27 \\
0.0 \\
0.0 \\
0.0 \\
0.0 \\
0.0 \\
0.0\end{array}$ & $\begin{array}{l}-24 \\
-24 \\
-24 \\
-24 \\
-24 \\
-24 \\
-19 \\
-19 \\
-19 \\
-19 \\
-19 \\
+415 \\
+131 \\
+100 \\
+85 \\
+80 \\
+80 \\
+85\end{array}$ & $\begin{array}{r}34 \\
34 \\
34 \\
34 \\
34 \\
34 \\
39 \\
39 \\
39 \\
38 \\
38 \\
65 \\
442 \\
131 \\
100 \\
85 \\
80 \\
80 \\
85\end{array}$ & \begin{tabular}{l}
0.0 \\
.0 \\
.0 \\
\multicolumn{1}{c}{.0} \\
34 \\
63 \\
63 \\
63 \\
63 \\
63 \\
63 \\
63 \\
78 \\
93 \\
93 \\
92 \\
-- \\
-- \\
--
\end{tabular} & $\begin{array}{l}+47 \\
+42 \\
+42 \\
+42 \\
+21 \\
-10 \\
-10 \\
-10 \\
-10 \\
-10 \\
-10 \\
-10 \\
-37 \\
-57 \\
-62 \\
-78 \\
-- \\
-- \\
--\end{array}$ & $\begin{array}{l}47 \\
42 \\
42 \\
42 \\
55 \\
53 \\
53 \\
53 \\
53 \\
53 \\
53 \\
53 \\
41 \\
36 \\
31 \\
14 \\
-- \\
-- \\
--\end{array}$ \\
\hline & & & & & January & February \\
\hline & \multicolumn{4}{|c|}{$\begin{array}{l}\text { Monthly mean outflow, in second-feet. } \\
\text { Outflow, in inches } \\
\text { Monthly mean inflow, in second-feet } \\
\text { Inflow, in inches. }\end{array}$} & $\begin{array}{l}46.6 \\
3.12 \\
59.0 \\
3.95\end{array}$ & $\begin{array}{l}29.7 \\
1.80 \\
52.1 \\
3.16\end{array}$ \\
\hline
\end{tabular}

BARKKAMSTED RESERVOIR NEAR BARKHAMSTED, CONN.

I.ocation.-Lat. $41^{\circ} 54^{\prime} 55^{\prime \prime}$, long. $72^{\circ} 57^{\prime} 05^{\prime \prime}$, on East Branch of Farmington River 11/4 miles south of Barkhamsted, Litchfield County, and $3 \frac{1 / 2}{2}$ miles upstream from mouth.

Drainage aREa.- -50.5 square miles.

REMARKs.-Elevations of reservoir surface are for 8 a.m. Change in contents is for 24-hour period prior to 8 a.m. except after Sundays and holidays when figure shown is change in contents for total period between readings. Record furnished by Water Bureau of the Metropolitan District Commission, Hartford, Conn.

Elevation, in feet, and change in contents, in millions of gallons, 1938

\begin{tabular}{|c|c|c|c|c|}
\hline \multirow{2}{*}{ Day } & \multicolumn{2}{|c|}{ January } & \multicolumn{2}{|c|}{ February } \\
\hline & Elevation & Change in contents & Elevation & Change in contents \\
\hline $\begin{array}{r}1 \\
2 \\
3 \\
4 \\
5 \\
6 \\
7 \\
8 \\
9 \\
10 \\
11 \\
12 \\
13 \\
14 \\
15 \\
16\end{array}$ & $\begin{array}{l}425.67 \\
425.50 \\
425.49 \\
425.41 \\
425.84 \\
430.40 \\
430.91 \\
430.03 \\
428.79 \\
427.91 \\
427.50 \\
427.08 \\
-\end{array}$ & $\begin{array}{r}-30 \\
-3 \\
-1 \\
-2 \\
+10 \\
+111 \\
-14 \\
+24 \\
-31 \\
-21 \\
-10 \\
-11 \\
-\end{array}$ & $\begin{array}{l}431.65 \\
430.60 \\
429.75 \\
429.21 \\
429.00 \\
430.19 \\
432.71 \\
432.35 \\
431.59 \\
430.79 \\
429.90 \\
428.79 \\
428.90 \\
427.45\end{array}$ & $\begin{array}{c}-19 \\
-30 \\
-22 \\
-14 \\
-6 \\
-- \\
+31 \\
+76 \\
-12 \\
-25 \\
-23 \\
-24 \\
-27 \\
-27 \\
+2 \\
-35\end{array}$ \\
\hline
\end{tabular}


Elevation, in feet, and change in contents, in millions of gallons, 1938-Continued

\begin{tabular}{|c|c|c|c|c|}
\hline \multirow{2}{*}{ Day } & \multicolumn{2}{|c|}{ January } & \multicolumn{2}{|c|}{ February } \\
\hline & Elevation & Change in contents & Elevation & Change in contents \\
\hline $\begin{array}{l}17 \\
18 \\
19 \\
20 \\
21 \\
22 \\
23 \\
24 \\
25 \\
26 \\
27 \\
28 \\
29 \\
30 \\
31\end{array}$ & $\begin{array}{l}426.20 \\
425.85 \\
425.41 \\
425.50 \\
425.38 \\
425.50 \\
425.32 \\
430.80 \\
447.62 \\
444.05 \\
439.35 \\
435.25 \\
432.25\end{array}$ & $\begin{array}{r}-19 \\
-8 \\
-9 \\
+1 \\
-4 \\
+4 \\
-4 \\
-\overline{5} \\
+134 \\
+829 \\
-202 \\
-257 \\
-206 \\
-121\end{array}$ & $\begin{array}{l}+27.29 \\
427.00 \\
426.97 \\
426.33 \\
426.00 \\
426.90 \\
427.35 \\
426.75 \\
427.00 \\
425.80 \\
-\ldots . .\end{array}$ & $\begin{array}{r}-4 \\
-6 \\
-1 \\
-15 \\
-15 \\
-7 \\
+21 \\
+10 \\
-14 \\
+6 \\
-28 \\
-28 \\
---\end{array}$ \\
\hline & & & January & February \\
\hline \multicolumn{3}{|c|}{ Change in contents, in millions of gallons } & +139 & -166 \\
\hline
\end{tabular}

\section{TAST BRANCH RESERVOIR AT NEW HARTFORD, CONN.}

Location.-Lat. $41^{\circ} 52^{\prime} 55^{\prime \prime}$, long. $72^{\circ} 57^{\prime} 25^{\prime \prime}$, on East Branch of Farmington River 1 mile east of New Hartford, Hartford County, and 11/4 miles upstream from mouth.

Drainage AREA.-61.2 square miles.

REMARKS.-Elevations of reservoir surface are for 8 a.m. crest of spillway at elevation 422.5 feet. Change in contents is for 24 -hour period previous to 8 a.m. except after Sundays and holidays when figure shown is change in contents for total period between readings. Record furnished by Water Bureau of the Metropolitan District Commission, Hartford, Conn.

Elevation, in feet, and change in contents, in millions of gallons, 1938

\begin{tabular}{|c|c|c|c|c|}
\hline \multirow{2}{*}{ Day } & \multicolumn{2}{|c|}{ January } & \multicolumn{2}{|c|}{ February } \\
\hline & Eleration & Change in contents & Elevation & Change in contents \\
\hline $\begin{array}{r}1 \\
2 \\
3 \\
4 \\
5 \\
6 \\
7 \\
8 \\
9 \\
10 \\
11 \\
12 \\
13 \\
14 \\
15 \\
16 \\
17 \\
18 \\
19 \\
20 \\
21 \\
22 \\
23 \\
24\end{array}$ & $\begin{array}{l}-. .- \\
412.95 \\
412.70 \\
412.30 \\
412.00 \\
411.55 \\
413.05 \\
415.55 \\
415.95 \\
416.10 \\
416.15 \\
416.05 \\
415.90 \\
415.35 \\
414.55 \\
413.80 \\
412.90 \\
412.40 \\
412.10 \\
411.35\end{array}$ & $\begin{array}{r}-\cdots \\
-347 \\
-23 \\
-39 \\
-28 \\
-36 \\
+137 \\
+277 \\
+40 \\
+19 \\
+6 \\
-12 \\
-16 \\
-58 \\
-58 \\
-84 \\
-82 \\
-105 \\
-48 \\
-28 \\
-25\end{array}$ & $\begin{array}{l}422.90 \\
422.90 \\
422.85 \\
422.55 \\
422.45 \\
421.50 \\
422.60 \\
422.65 \\
422.60 \\
422.45 \\
423.00 \\
420.00 \\
419.05 \\
417.95 \\
416.70 \\
415.25 \\
414.00 \\
411.85 \\
408.00 \\
406.20\end{array}$ & $\begin{array}{l}-8 \\
-8 \\
-4 \\
-45 \\
-15 \\
-138 \\
+160 \\
+8 \\
-8 \\
-22 \\
+83 \\
-426 \\
-117 \\
-133 \\
-136 \\
-163 \\
-131 \\
-\overline{2} \overline{27} \\
-\overline{-}-\overline{3} \\
-343\end{array}$ \\
\hline
\end{tabular}


Elevation, in feet, and change in contents, in millions of gallons, 1938-Continued

\begin{tabular}{|c|c|c|c|c|}
\hline \multirow{2}{*}{ Day } & \multicolumn{2}{|c|}{ January } & \multicolumn{2}{|c|}{ February } \\
\hline & Elevation & Change in contents & Elevation & Change in contents \\
\hline \multirow[t]{3}{*}{$\begin{array}{l}25 \\
26 \\
27 \\
28 \\
29 \\
30 \\
31\end{array}$} & $\begin{array}{l}411.30 \\
418.20 \\
422.70 \\
423.40 \\
423.00 \\
422.95\end{array}$ & $\begin{array}{r}-4 \\
+730 \\
+601 \\
+110 \\
-63 \\
-\quad-8\end{array}$ & $\begin{array}{l}405.95 \\
405.40 \\
404.70 \\
\ldots \ldots .\end{array}$ & $\begin{array}{l}-22 \\
-49 \\
--57 \\
-57 \\
--- \\
--- \\
---\end{array}$ \\
\hline & & & January & February \\
\hline & \multicolumn{2}{|c|}{ Change in contents, in millions of gallons } & +877 & -1940 \\
\hline
\end{tabular}

\section{NEPAUG RESERVOIR NEAR COLIINSVILIE, CONN.}

Location.-Lat. $41^{\circ} 49^{\prime} 40^{\prime \prime}$, long. $72^{\circ} 56^{\prime} 05^{\prime \prime}$, on Nepaug River a quarter of a mile upstream from mouth and 1/1/2 miles northwest of Collinsville, Hartford County.

Drainage area.- 32.0 square miles.

REMARKS.-Elevations of reservoir surface are for 8 a.m. crest of spillway at elevation of 485.0 feet. Change in contents is for 24 -hour period prior to $8 \mathrm{a} . \mathrm{m}$. Diversions for Hartford municipal supply are for calendar day. Record furnished by Water Bureau of the Metropolitan District Commission, Hartford, Conn.

Elevation, in feet, and change in contents and diversion, in millions of gallons, 1938

\begin{tabular}{|c|c|c|c|c|c|c|}
\hline \multirow{2}{*}{ Day } & \multicolumn{3}{|c|}{ January } & \multicolumn{3}{|c|}{ February } \\
\hline & Elevation & $\begin{array}{l}\text { Change in } \\
\text { contents }\end{array}$ & Diversion & Elevation & $\begin{array}{c}\text { Change in } \\
\text { contents }\end{array}$ & Diversion \\
\hline $\begin{array}{r}1 \\
2 \\
3 \\
4 \\
5 \\
6 \\
7 \\
8 \\
9 \\
10 \\
11 \\
12 \\
13 \\
14 \\
15 \\
16 \\
17 \\
18 \\
19 \\
20 \\
21 \\
22 \\
23 \\
24 \\
25 \\
26 \\
27 \\
28\end{array}$ & $\begin{array}{l}482.44 \\
482.54 \\
482.54 \\
482.58 \\
482.60 \\
482.62 \\
482.78 \\
483.07 \\
483.08 \\
482.91 \\
482.69 \\
482.45 \\
482.27 \\
482.02 \\
481.74 \\
481.70 \\
481.75 \\
481.77 \\
481.83 \\
481.85 \\
481.87 \\
481.92 \\
481.95 \\
481.97 \\
482.32 \\
485.23 \\
485.21 \\
485.05\end{array}$ & $\begin{array}{r}-5.4 \\
+26.9 \\
0.0 \\
+10.8 \\
+5.4 \\
+5.4 \\
+43.1 \\
+78.4 \\
+2.7 \\
-46.0 \\
-59.4 \\
-64.6 \\
-60.3 \\
-55.0 \\
-74.8 \\
-10.7 \\
+13.4 \\
+5.3 \\
+16.0 \\
+5.3 \\
+5.3 \\
+13.4 \\
+8.0 \\
+5.4 \\
+93.8 \\
+793.5 \\
-5.5 \\
-44.3\end{array}$ & $\begin{array}{l}23.5 \\
23.5 \\
23.5 \\
23.5 \\
23.5 \\
23.5 \\
23.5 \\
23.5 \\
23.5 \\
23.5 \\
23.5 \\
23.5 \\
23.0 \\
23.0 \\
23.0 \\
23.0 \\
23.0 \\
23.0 \\
23.0 \\
23.0 \\
23.0 \\
23.0 \\
23.0 \\
23.0 \\
22.0 \\
19.5 \\
19.5 \\
19.5\end{array}$ & $\begin{array}{l}484.48 \\
484.30 \\
484.09 \\
483.99 \\
483.85 \\
483.70 \\
483.76 \\
483.88 \\
483.80 \\
483.66 \\
483.48 \\
483.29 \\
483.10 \\
482.96 \\
482.83 \\
482.92 \\
483.01 \\
483.07 \\
483.17 \\
483.25 \\
483.35 \\
483.39 \\
483.47 \\
483.36 \\
483.12 \\
482.87 \\
482.90 \\
483.00\end{array}$ & $\begin{array}{l}-13.7 \\
-49.4 \\
-57.5 \\
-27.4 \\
-38.2 \\
-40.9 \\
+16.4 \\
+32.7 \\
-21.8 \\
-38.1 \\
-49.0 \\
-51.6 \\
-51.5 \\
-37.9 \\
-35.1 \\
+24.3 \\
+24.3 \\
+16.2 \\
+27.1 \\
+21.7 \\
+27.1 \\
+10.9 \\
+21.7 \\
-29.9 \\
-65.1 \\
-67.6 \\
+8.1 \\
+27.0\end{array}$ & $\begin{array}{l}19.5 \\
19.5 \\
19.5 \\
19.5 \\
19.5 \\
19.5 \\
19.5 \\
19.5 \\
19.5 \\
19.5 \\
19.8 \\
20.0 \\
20.0 \\
19.8 \\
19.0 \\
18.9 \\
18.9 \\
20.8 \\
22.2 \\
22.0 \\
22.0 \\
22.0 \\
22.0 \\
22.0 \\
22.0 \\
22.0 \\
22.0 \\
22.0\end{array}$ \\
\hline
\end{tabular}


Elevation, in feet, and change in contents and diversion, in millions of gallons, 1938 -Continued

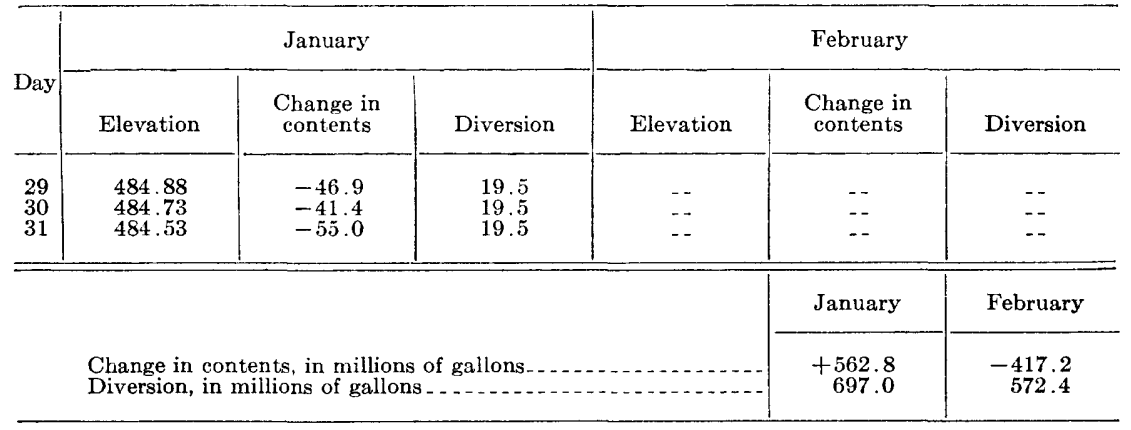

BURIINGTON BROOK NEAR BURIINGTON, CONN.

Location.-Lat. $41^{\circ} 47^{\prime} 10^{\prime \prime}$, long. $72^{\circ} 57^{\prime} 55^{\prime \prime}, 1^{1 / 4}$ miles north of Burlington, Hartford County, 21/2 miles upstream from mouth, and 3 miles southwest of Collinsville.

Drainage area.- 4.1 square miles.

GAGE-HEIGHT RECORD.-Water-stage recorder graph.

Stage-discharge relation.-Artificial control consists of a sharp-edged orifice 1 foot square and a sharp-crested rectangular weir 12 feet long with end contractions 5 feet high. Crest of weir is at gage height 1.02 feet and 1.02 feet above bottom edge of orifice. Rating curve which was developed from formula and coefficients checked by current-meter measurements below 49 second-feet. Affected by ice Jan. 1-4, 6, 9-21, 3 a.m. Jan. 27 to 11 a.m. Jan. 29, 5 a.m. to 12 m., 5 p.m., 6 p.m. Feb. 1, 12 p.m. Feb. 1 to 2 p.m. Feb. 2, Feb. 11, 16, 17, 20-22, 26, 28.

Maxima.-January 1938: Discharge, 474 second-feet 9:30 a.m. Jan. 25 (gage height, 6.42 feet).

1931 to December 1937: Discharge, 503 second-feet Mar. 12, 1936 (gage height, 6.58 feet).

Remarks.-Flood discharge not affected by artificial storage.

Mean discharge, in second-feet, 1938

\begin{tabular}{|c|c|c|c|c|c|c|c|c|c|c|c|}
\hline Day & Jan. & Feb. & Day & Jan. & Feb. & Day & Jan. & Feb. & Day & Jan. & Feb. \\
\hline $\begin{array}{l}1 \\
2 \\
3 \\
4 \\
5 \\
6 \\
7 \\
8\end{array}$ & $\begin{array}{c}6.3 \\
6.0 \\
7.2 \\
6.0 \\
5.77 \\
4.8 \\
32.3 \\
27.2\end{array}$ & $\begin{array}{c}13.5 \\
9.54 \\
10.1 \\
17.6 \\
11.4 \\
12.7 \\
32.2 \\
13.6\end{array}$ & $\begin{array}{r}9 \\
10 \\
11 \\
12 \\
13 \ldots \\
13 \\
15 \\
16 \ldots \\
16 \ldots\end{array}$ & $\begin{array}{r}11.5 \\
8.6 \\
7.7 \\
7.1 \\
5.5 \\
5.5 \\
6.0 \\
5.0\end{array}$ & $\begin{array}{c}12.1 \\
12.1 \\
9.3 \\
8.95 \\
10.3 \\
13.9 \\
10.6 \\
8.0\end{array}$ & $\begin{array}{l}17 \\
18 \\
19 \\
20 \\
21 \\
22 \\
23 \\
24\end{array}$ & $\begin{array}{l}5.8 \\
5.0 \\
4.8 \\
5.5 \\
5.8 \\
6.29 \\
5.05 \\
4.75\end{array}$ & $\begin{array}{l}8.0 \\
6.85 \\
8.63 \\
8.3 \\
8.6 \\
8.0 \\
8.00 \\
7.41\end{array}$ & $\begin{array}{l}25 \ldots \\
26 \ldots \\
27 \\
28 \\
29 \\
30 \ldots \\
31 \ldots \\
\end{array}$ & $\begin{array}{c}173 \\
35.7 \\
16.2 \\
10.9 \\
12.0 \\
9.47 \\
18.5\end{array}$ & $\begin{array}{l}7.71 \\
7.8 \\
5.52 \\
5.3\end{array}$ \\
\hline \multicolumn{10}{|c|}{$\begin{array}{l}\text { Monthly mean discharge, in second-feet } \\
\text { Runoff, in inches }\end{array}$} & $\begin{array}{c}15.2 \\
4.28\end{array}$ & $\begin{array}{c}10.6 \\
2.70\end{array}$ \\
\hline
\end{tabular}


Gage height, in feet, and discharge, in second-feet, at indicated time, 1938

\begin{tabular}{|c|c|c|c|c|c|c|c|c|c|c|c|c|}
\hline \multirow{2}{*}{ Hour } & Feet & Sec.-ft. & Feet & Sec.-ft. & Feet & Sec.-ft. & Feet & Sec.-ft. & Feet & Sec.-ft. & Feet & Sec.-ft. \\
\hline & \multicolumn{2}{|c|}{ January 22} & \multicolumn{2}{|c|}{ January 23} & \multicolumn{2}{|c|}{ January 24} & \multicolumn{2}{|c|}{ January 25} & \multicolumn{2}{|c|}{ January 26} & \multicolumn{2}{|c|}{ January 27} \\
\hline \multirow{16}{*}{$\begin{array}{l}1 \mathrm{la} \cdot \mathrm{m} . \\
2 \\
3 \\
4 \\
5 \\
6 \\
7 \\
8 \\
9 \\
10 \\
11 \\
12 \mathrm{n} . \\
1 \mathrm{p} . \mathrm{m} . \\
2 \\
3 \\
4 \\
5 \\
6 \\
7 \\
8 \\
9 \\
10 \\
11 \\
12 \mathrm{~m} .\end{array}$} & & & & & & & 1.23 & 8.00 & 2.35 & 66 & & \\
\hline & 1.13 & 5.26 & & & & & 1. 33 & 11 & 2.26 & 60 & & \\
\hline & 1.12 & 5.02 & & & -- & $\ldots$ & $\begin{array}{l}1.40 \\
163\end{array}$ & $\begin{array}{l}16.4 \\
24.0\end{array}$ & $\begin{array}{l}2.20 \\
2.13\end{array}$ & $\begin{array}{l}56 \\
52\end{array}$ & 1.50 & 17.5 \\
\hline & 1.12 & 5.02 & 1.12 & 5.02 & 1.11 & 4.78 & $\begin{array}{l}1.80 \\
1.98\end{array}$ & $\begin{array}{l}32.6 \\
42.8\end{array}$ & $\begin{array}{l}2.06 \\
1.96\end{array}$ & $\begin{array}{l}47.6 \\
41.6\end{array}$ & & \\
\hline & & & & & & - & 3.75 & $179^{\circ}$ & 1.90 & & & \\
\hline & 1.12 & 5.02 & & & $\ldots$ & $\ldots . .$. & 5.85 & $\begin{array}{l}394 \\
451\end{array}$ & 1.85 & 35.4 & 1.52 & 17.5 \\
\hline & 1.11 & 4.78 & & & - & - - - & 6.39 & $\begin{array}{l}401 \\
469\end{array}$ & $\begin{array}{l}1.80 \\
1.77\end{array}$ & $\begin{array}{l}32 \\
31\end{array}$ & $\cdots$ & $\ldots$ \\
\hline & 1.11 & 4.78 & 112 & 5.02 & 110 & 455 & $\begin{array}{l}6.05 \\
5.40\end{array}$ & $\begin{array}{l}418 \\
345\end{array}$ & $\begin{array}{l}1.78 \\
1.94\end{array}$ & $\begin{array}{l}31.6 \\
40.5\end{array}$ & 1.58 & \\
\hline & & & & $\ldots .$. & & & 4.85 & 286 & 1.81 & 33.2 & 1.50 & \\
\hline & 1.11 & 4.78 & & & & & 4.45 & 246 & 1.76 & & 1.60 & \\
\hline & 1.22 & 7.71 & & & $\cdots$ & $\ldots$ & $\begin{array}{l}4.16 \\
3.88\end{array}$ & $\begin{array}{l}217 \\
191\end{array}$ & $\begin{array}{l}1.74 \\
1.72\end{array}$ & & 1.49 & $1 \overrightarrow{6}$ \\
\hline & & & & & & & 360 & 165 & 1.71 & & 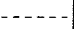 & $\ldots . . .$. \\
\hline & 1.28 & 9.60 & 1.12 & 5.02 & 1.10 & 4.55 & $\begin{array}{l}3.36 \\
3.18\end{array}$ & 144 & 1.69 & & $-\cdots$ & $-\ldots$ \\
\hline & 1.30 & 10.3 & & (n) & 1.10 & 4.55 & 2.99 & 114 & 1.63 & 24 & 1.41 & 14.5 \\
\hline & 1.22 & 7.71 & & $\ldots$ & 1.12 & 5.02 & $\frac{2}{2}$. & $\begin{array}{r}102 \\
91\end{array}$ & $\begin{array}{l}1.54 \\
1.48\end{array}$ & & 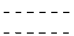 & $\cdots$ \\
\hline & 1.14 & 5.52 & 1.11 & 4.78 & 1.17 & 6.30 & & $\begin{array}{l}80 \\
74\end{array}$ & 1.47 & & 1.36 & 12.5 \\
\hline & \multirow{2}{*}{\multicolumn{2}{|c|}{ January 28}} & & & & & & & & & & \\
\hline & & & \multicolumn{2}{|c|}{ January 29} & \multicolumn{2}{|c|}{ January 30} & \multicolumn{2}{|c|}{ January 31} & \multicolumn{2}{|c|}{ February 1} & \multicolumn{2}{|c|}{ February 2} \\
\hline 2 a.r. & & & 30 & 1 & & & & & & & & \\
\hline & & & 1.30 & 10. & 1.26 & 8.95 & & 11 & & & & 9 . \\
\hline 6 & 1.32 & 11 & 1 & 10 & & & & 12 & & & & \\
\hline 8 & & & & & 1.25 & 8.63 & & & & & & \\
\hline 10 & 1 & 105 & 1.30 & 10.5 & 24 & 83 & & & & & & 8. \\
\hline $\begin{array}{l}12 \mathrm{n} . \\
2 \mathrm{p} . \mathrm{m} .\end{array}$ & 1.31 & 10.5 & $\begin{array}{l}1.30 \\
1.31\end{array}$ & $\begin{array}{l}10.5 \\
10.6\end{array}$ & 1.24 & & $\begin{array}{l}1.56 \\
1.65\end{array}$ & $\begin{array}{l}20 \\
25\end{array}$ & $\begin{array}{l}1.46 \\
1.46\end{array}$ & & & $\begin{array}{r}9 \\
12\end{array}$ \\
\hline & & & 1.42 & 14.7 & 1.27 & 9.27 & 1.7 & 27 & 1. & & 1. & 12. \\
\hline 6 & 1.30 & 10.5 & & 16. & & & & & 1. & & & \\
\hline & & & 1.45 & 16.0 & 1.32 & 11.0 & 1.63 & 24 & 1. & 13 & 1. & 8.63 \\
\hline $\begin{array}{l}10 \\
12 \mathrm{~m} .\end{array}$ & 1.30 & 105 & $\begin{array}{l}1.36 \\
1.29\end{array}$ & $\begin{array}{r}12.4 \\
9.93\end{array}$ & 1.33 & 11.4 & 1.5 & $\begin{array}{l}18.5 \\
15.1\end{array}$ & $\begin{array}{l}1.29 \\
.29\end{array}$ & & $\begin{array}{l}1.24 \\
1.24\end{array}$ & $\begin{array}{r}8.32 \\
8.32\end{array}$ \\
\hline & & & & & & & 2. & 10.1 & 1.20 & & 1.24 & 0.02 \\
\hline
\end{tabular}

Supplemental records.-Jan. $25,6: 45$ a.m., $2.20 \mathrm{ft}$., 56 second-feet; $9: 30$ a.m., $6.42 \mathrm{ft.}, 474$ second-feet; Feb. 1, 3 p.m., 1.49 ft., 17.6 second-feet.

SOUTH BRANCE OF PARK RIVTR AT HARTFORD, CONN.

Location.-Lat. $41^{\circ} 44^{\prime} 02^{\prime \prime}$, long. $72^{\circ} 42^{\prime} 51^{\prime \prime}$, at Newfield Avenue bridge, Hartford, Hartford County, 0.7 mile downstream from Trout Brook, and 3.3 miles upstream from confluence with North Branch of Park River. Datum of gage is 31.07 feet above mean sea level, (general adjustment of 1929).

Drainage AREA.-40.6 square miles.

GAGE-HEIGHT RECORD.-Water-stage recorder graph.

STAGE-Discharge RELATION.-Affected by rate of change of stage above gage height about 5 feet. Base rating cure defined by current-meter measurements (adjusted for changing stage when required) below 1,300 secondfeet and extended to peak stage on basis of comparison with stations on North Branch of Park River and Park River. Above gage heights about 5 feet, rather poorly defined rating curve developed for different rates of changing stage on basis of several measurements. Affected by change in recording conditions 1 to 8 p.m. Jan 25 when water entered gage house around door and through ventilators. Affected by ice Jan. 1-4, 7, Jan. 12 to 11 a.m. Jan. 23,5 a.m. to 1 p.m. Jan. 27,7 a.m. to 1 p.m. Jan. 28,4 a.m. to 7 a.m. and 9 a.m. to 2 p.m. Jan. 29, 1 a.m. to 12 m. Feb. 2, Feb. $16,17,21,22,28$. 
Maxima.-January 1938: Discharge, 2,860 second-feet 4 p.m. Jan. 25; gage height, 12.65 feet 5 p.m. Jan. 25.

1936 to December 1937: Discharge, 1,660 second-feet Nov. 29, 1937 gage height, 9.66 feet, Nov. 29, 1937 occurred 1 hour later than maximum discharge. Flood of Mar. 12, 1936, reached a stage of 12.1 feet as determined from floodmarks by city engineers of Hartford (discharge not determined).

Remarks.-Flood discharge not appreciably affected by artificial storage.

Mean discharge, in second-feet, 1938

\begin{tabular}{|c|c|c|c|c|c|c|c|c|c|c|c|}
\hline Day & Jan. & Feb. & Day & Jan. & Feb. & Day & Jan. & Feb. & Day & Jan. & Feb. \\
\hline $\begin{array}{l}1 \\
2 \\
3 \\
4 \\
5 \\
6 \\
7 \\
8\end{array}$ & $\begin{array}{r}44 \\
55 \\
55 \\
48 \\
47 \\
44 \\
240 \\
276\end{array}$ & $\begin{array}{r}114 \\
78 \\
99 \\
172 \\
102 \\
97 \\
224 \\
126\end{array}$ & $\begin{array}{r}9 \ldots \\
10 \\
11 \\
12 \\
13 \\
14 \\
15 \\
16 \ldots\end{array}$ & $\begin{array}{r}143 \\
100 \\
71 \\
60 \\
55 \\
70 \\
60 \\
55\end{array}$ & $\begin{array}{r}104 \\
107 \\
86 \\
79 \\
106 \\
118 \\
93 \\
75\end{array}$ & $\begin{array}{l}17 \ldots \\
18 \ldots \\
19 \ldots \\
20 \ldots \\
21 \ldots \\
22 \ldots \\
23 \ldots \\
24 \ldots\end{array}$ & $\begin{array}{l}60 \\
50 \\
44 \\
46 \\
44 \\
42 \\
44 \\
45\end{array}$ & $\begin{array}{r}70 \\
78 \\
86 \\
79 \\
75 \\
75 \\
82 \\
100\end{array}$ & $\begin{array}{l}25 \ldots \\
26 \\
27 \\
28 \\
29 \\
30 \ldots \\
31_{\ldots} \\
\end{array}$ & $\begin{array}{r}1,800 \\
681 \\
237 \\
132 \\
88 \\
83 \\
138\end{array}$ & $\begin{array}{r}100 \\
90 \\
82 \\
70\end{array}$ \\
\hline \multicolumn{11}{|c|}{$\begin{array}{l}\text { Monthly mean discharge, in second-feet } \\
\text { Runoff, in inches }\end{array}$} & $\begin{array}{l}98.8 \\
2.53\end{array}$ \\
\hline
\end{tabular}

Gage height, in feet, and discharge, in second-feet, at indicated time, 1938

\begin{tabular}{|c|c|c|c|c|c|c|c|c|c|c|c|c|}
\hline \multirow{2}{*}{ Hour } & Feet & Sec.-ft. & Feet & Sec.-ft. & Feet & Sec.-ft. & Feet & Sec.-ft. & Feet & Sec.-ft. & Feet & Sec-ft. \\
\hline & \multicolumn{2}{|c|}{ January 22} & \multicolumn{2}{|c|}{ January 23} & \multicolumn{2}{|c|}{ January 24} & \multicolumn{2}{|c|}{ January $2 \delta$} & \multicolumn{2}{|c|}{ January 26} & \multicolumn{2}{|c|}{ January 27} \\
\hline $\begin{array}{cc}1 & \mathrm{a} . \mathrm{m} . \\
2 \\
3 \\
4 \\
5 \\
5 \\
7 \\
8 \\
9 \\
10 \\
11 \\
12 \mathrm{n} . \\
1 \mathrm{p} . \mathrm{m} . \\
2 \\
3 \\
4 \\
5 \\
6 \\
7 \\
8 \\
9 \\
10 \\
11 \\
12 \mathrm{~m} .\end{array}$ & & & & & $\begin{array}{l}1.91 \\
1.90 \\
1.88 \\
1.87 \\
1 . \overline{8} \\
1.86 \\
1.85 \\
1.90 \\
1.92 \\
1.92 \\
1.98 \\
2.28\end{array}$ & $\begin{array}{c}44 \\
44 \\
43 \\
42 \\
42 \\
42 \\
42 \\
42 \\
44 \\
45 \\
45 \\
48 \\
66\end{array}$ & $\begin{array}{r}2.67 \\
3.32 \\
4.19 \\
5.10 \\
5.87 \\
6.48 \\
7.20 \\
8.01 \\
8.94 \\
9.77 \\
10.52 \\
11.10 \\
12.15 \\
12.40 \\
12.58 \\
12.64 \\
12.65 \\
12.60 \\
12.49 \\
12.28 \\
11.77 \\
11.50 \\
11.22 \\
10.91\end{array}$ & $\begin{array}{r}91 \\
138 \\
207 \\
305 \\
465 \\
650 \\
970 \\
1,290 \\
1,670 \\
1,980 \\
2,260 \\
2,470 \\
2,640 \\
2,760 \\
2,840 \\
2,860 \\
2,850 \\
2,820 \\
2,780 \\
2,720 \\
2,600 \\
2,440 \\
2,270 \\
2,100\end{array}$ & $\begin{array}{r}10.60 \\
10.26 \\
9.86 \\
9.52 \\
9.17 \\
8.81 \\
8.49 \\
8.17 \\
7.84 \\
7.57 \\
7.31 \\
7.09 \\
6.92 \\
6.78 \\
6.66 \\
6.57 \\
6.49 \\
6.41 \\
6.34 \\
6.28 \\
6.21 \\
6.13 \\
6.04 \\
5.96\end{array}$ & $\begin{array}{r}1,920 \\
1,700 \\
1,470 \\
1,270 \\
1,070 \\
865 \\
695 \\
590 \\
485 \\
440 \\
400 \\
380 \\
370 \\
365 \\
360 \\
360 \\
365 \\
365 \\
360 \\
350 \\
330 \\
320 \\
305 \\
290\end{array}$ & $\begin{array}{c}5.72 \\
55.29 \\
5.11 \\
5.26 \\
5.25 \\
5.03 \\
4.80 \\
4.59 \\
4 . \overline{34} \\
4.14 \\
3.96 \\
3.80\end{array}$ & $\begin{array}{c}275 \\
250^{2} \\
245 \\
245 \\
250 \\
270 \\
245 \\
230 \\
215 \\
200 \\
189 \\
176\end{array}$ \\
\hline & Janu & $\operatorname{ary} 28$ & Janu & $\operatorname{ary} 29$ & Janu & ary 30 & Janu & $\operatorname{ary} 31$ & $\mathrm{Fel}$ & uary 1 & Feb & $\operatorname{ary} 2$ \\
\hline $\begin{array}{c}2 \text { a.m. } \\
4 \\
6 \\
8 \\
10 \\
2 \\
2 \\
2 \\
2 \\
4 \\
6 \\
6 \\
8 \\
0 \\
2 \\
2 \mathrm{~m} . \mathrm{m} .\end{array}$ & $\begin{array}{l}3.65 \\
3.43 \\
3.24 \\
3.14 \\
3.20 \\
3.37 \\
3.39 \\
3.33 \\
3.18 \\
3.05 \\
2.96 \\
2.88\end{array}$ & $\begin{array}{l}164 \\
146 \\
131 \\
120 \\
120 \\
125 \\
143 \\
138 \\
127 \\
118 \\
111 \\
106\end{array}$ & $\begin{array}{l}2.78 \\
2.68 \\
2.61 \\
2.44 \\
2.61 \\
2.84 \\
2.82 \\
2.86 \\
2.70 \\
2.61 \\
2.58 \\
2.56\end{array}$ & $\begin{array}{r}99 \\
90 \\
82 \\
75 \\
74 \\
80 \\
96 \\
104 \\
93 \\
87 \\
85 \\
83\end{array}$ & $\begin{array}{c}2.53 \\
2.51 \\
2.49 \\
2.56 \\
2.67 \\
2.68\end{array}$ & $\begin{array}{c}81 \\
80^{8} \\
783^{-} \\
91^{-1} \\
92\end{array}$ & $\begin{array}{l}2.69 \\
2.72 \\
2.76 \\
2.81 \\
2.90 \\
3.19 \\
3.54 \\
3.88 \\
4.05 \\
4.00 \\
3.85 \\
3.65\end{array}$ & $\begin{array}{r}92 \\
94 \\
97 \\
101 \\
107 \\
127 \\
155 \\
182 \\
196 \\
192 \\
180 \\
164\end{array}$ & $\begin{array}{l}3.46 \\
3.28 \\
3.09 \\
2.90 \\
2.68 \\
3.01 \\
2.93 \\
2.91 \\
2.90 \\
2.85 \\
2.76 \\
2.63\end{array}$ & $\begin{array}{r}149 \\
134 \\
120 \\
107 \\
92 \\
115 \\
109 \\
108 \\
107 \\
104 \\
97 \\
88\end{array}$ & $\begin{array}{l}2.54 \\
2.44 \\
2.28 \\
2.27 \\
2.56 \\
2.60 \\
2.76 \\
2.66 \\
2.62 \\
2.59 \\
2.55 \\
2.49\end{array}$ & $\begin{array}{l}78 \\
68 \\
62 \\
60 \\
62 \\
82 \\
97 \\
90 \\
87 \\
85 \\
82 \\
78\end{array}$ \\
\hline
\end{tabular}

Sunnlemental records.-Feb. 1, 10:30 a.m., 2.64 feet, 89 sec.-ft. 
PARK RIVER AT MARTFORD, CONA.

Location.-Lat. $41^{\circ} 45^{\prime} 36^{\prime \prime}$, long. $72^{\circ} 41^{\prime} 42^{\prime \prime}$, at plate-girder footbridge on

Riverside Street, Hartford, Hartford County, 1300 feet downstream from confluence of North and South Branches of Park River, and 2.3 miles upstream from mouth. Datum of gage is 27.13 feet above mean sea level,

(general adjustment of 1929).

Drainage area.-74.0 square miles.

GAGE-HEIGHT RECORD.-Water-stage recorder graph.

Stage-discharge RELATION.-Defined by current-meter measurements.

Maxima.-January 1938: Discharge, 5,650 second-feet 5:30 p.m. Jan. 25 (gage height, 9.16 feet).

1936 to December 1937: Discharge, 2,880 second-feet Nov. 29, 1937 (gage height, 6.81 feet).

Flood of Mar. 12, 1936, reached a stage of 9.0 feet as determined from floodmarks by city engineers of Hartford (discharge, 5,400 second-feet). Backwater from Connecticut River on Mar. 21, 1936, caused a stage of 10.7 feet as determined from floodmarks.

Remarks.-Flood discharge probably not appreciably affected by artificial storage.

Mean discharge, in second-feet, 1938

\begin{tabular}{|c|c|c|c|c|c|c|c|c|c|c|c|}
\hline Day & Jan. & Feb. & Day & Jan. & Feb. & Day & Jan. & Feb. & Day & Jan. & Feb. \\
\hline $\begin{array}{l}1 \\
2 \\
4 \\
5 \\
6 \\
8\end{array}$ & $\begin{array}{r}59 \\
87 \\
87 \\
76 \\
73 \\
70 \\
481 \\
626\end{array}$ & $\begin{array}{l}194 \\
121 \\
140 \\
298 \\
184 \\
152 \\
421 \\
232\end{array}$ & $\begin{array}{r}9 \\
9 \\
10 \\
11 \\
12 \\
13 \\
14 \\
15_{-} \\
16_{-}\end{array}$ & $\begin{array}{r}256 \\
154 \\
112 \\
90 \\
82 \\
103 \\
96 \\
82\end{array}$ & $\begin{array}{l}168 \\
172 \\
136 \\
119 \\
161 \\
206 \\
157 \\
112\end{array}$ & $\begin{array}{l}17 .-- \\
19- \\
20- \\
21- \\
22- \\
23= \\
24_{--}\end{array}$ & $\begin{array}{l}87 \\
79 \\
59 \\
64 \\
59 \\
63 \\
64 \\
66\end{array}$ & $\begin{array}{r}96 \\
103 \\
122 \\
122 \\
106 \\
106 \\
119 \\
150\end{array}$ & $\begin{array}{l}25 \ldots \\
26 \ldots \\
27 \\
28 \ldots \\
29 \\
30 \ldots \\
31 \ldots \\
\end{array}$ & $\begin{array}{r}3,220 \\
1,690 \\
385 \\
201 \\
134 \\
124 \\
212\end{array}$ & $\begin{array}{l}160 \\
146 \\
129 \\
115\end{array}$ \\
\hline \multicolumn{11}{|c|}{$\begin{array}{l}\text { Monthly mean discharge, in second-feet } \\
\text { Runoff, in inches }\end{array}$} & $\begin{array}{r}159 \\
2.24\end{array}$ \\
\hline
\end{tabular}

Gage height, in feet, and discharge, in second-feet, at indicated time, 1938

\begin{tabular}{|c|c|c|c|c|c|c|c|c|c|c|c|c|}
\hline \multirow{2}{*}{ Hour } & Feet & Sec.-ft. & Feet & Sec.-ft. & Feet & Sec.-ft. & Feet & Sec.-ft. & Feet & Sec.-ft. & Feet & Sec.-ft. \\
\hline & \multicolumn{2}{|c|}{ January 22} & \multicolumn{2}{|c|}{ January 23} & \multicolumn{2}{|c|}{ January 24} & \multicolumn{2}{|c|}{ January 25} & \multicolumn{2}{|c|}{ January 26} & \multicolumn{2}{|c|}{ January 27} \\
\hline $\begin{array}{l}1 \\
2\end{array}$ & & & & & 2.59 & 64 & $\begin{array}{l}3.05 \\
3.31\end{array}$ & $\begin{array}{l}222 \\
334\end{array}$ & $\begin{array}{l}7.57 \\
7.30\end{array}$ & & $3 . \overline{3}$ & 535 \\
\hline 3 & & & & & 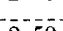 & -9 & 3. & 402 & 7.0 & 3,100 & & \\
\hline 4 & & & & & 2.59 & 64 & 3.7 & 540 & 6.7 & 2,850 & 3.58 & 460 \\
\hline 6 & & & & & 2.58 & 61 & 4.3 & 907 & 6.28 & 2,360 & 3.43 & 388 \\
\hline 7 & & & & & 258 & 61 & 4.2 & 1,180 & & 2,170 & 235 & $3 \overline{8}$ \\
\hline 9 & & & & & & & 6. & 2,110 & 5.6 & 1,80 & & \\
\hline 10 & - & & & $\cdots$ & 2.58 & 61 & 6.6 & & 5. & 1,6 & 3.32 & 339 \\
\hline $11 \mathrm{n}$. & & & & & 2.58 & $61^{-\cdots}$ & $\begin{array}{l}7.37 \\
7.98\end{array}$ & $\begin{array}{l}3,48 \\
4,20\end{array}$ & $\begin{array}{l}5.21 \\
5.03\end{array}$ & $\begin{array}{l}1,480 \\
1,350\end{array}$ & $3 . \overline{3} 8$ & $\overline{3} 6 \overline{6}$ \\
\hline $1 \mathrm{p.m}$ & 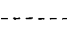 & - & & & $0=-$ & 01 & 8.44 & 4,750 & 4.8 & 1,240 & - & 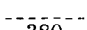 \\
\hline $\begin{array}{l}2 \\
3\end{array}$ & & & & & 2.58 & 61 & $\begin{array}{l}8.79 \\
9.02\end{array}$ & 5,1 & 4.73 & 1,140 & 3.41 & 380 \\
\hline 4 & & & & & 2.58 & 61 & 9.10 & 5,570 & 4.51 & 992 & 3.38 & 366 \\
\hline $\begin{array}{l}5 \\
6\end{array}$ & & & & & 258 & 61 & 9.1 & 5,620 & 4.41 & $\begin{array}{l}926 \\
868\end{array}$ & 335 & $352-$ \\
\hline 7 & & & & & & & 8. & 5,4 & 4.2 & 813 & - & \\
\hline $\begin{array}{l}8 \\
0\end{array}$ & & & & & 2.59 & 64 & 8.8 & 5,210 & 4.14 & 75 & 3.32 & 339 \\
\hline 10 & & & & & 2.61 & 70 & 8. & 4,6 & 4. & 68 & 3.26 & 312 \\
\hline & & & & & & & $\begin{array}{l}8.12 \\
7.84\end{array}$ & $\begin{array}{l}4,360 \\
4,030\end{array}$ & $\begin{array}{l}3.93 \\
3.86\end{array}$ & $\begin{array}{l}642 \\
603\end{array}$ & 3.18 & 276 \\
\hline & & & & & & & & & & & & \\
\hline
\end{tabular}


Gage-height, in feet, and discharge, in second-feet, at indicated time, 1938-Continued

\begin{tabular}{|c|c|c|c|c|c|c|c|c|c|c|c|c|}
\hline \multirow{2}{*}{ Hour } & Feet & Sec.-ft. & Feet & Sec.-ft. & Feet & Sec.-ft. & Feet & Ser.-ft. & Feet & Sec.-ft. & Feet & Sec.-ft. \\
\hline & \multicolumn{2}{|c|}{ January 28} & \multicolumn{2}{|c|}{ January 29} & \multicolumn{2}{|c|}{ January 30} & \multicolumn{2}{|c|}{ January 31} & \multicolumn{2}{|c|}{ February 1} & \multicolumn{2}{|c|}{ February 2} \\
\hline 2 a.m. & 3.12 & 251 & 2.87 & 154 & & & 2.83 & 140 & 3.18 & 276 & 2.81 & 132 \\
\hline & 3.06 & 226 & 2.83 & 140 & & & 2.84 & 143 & 3.09 & 238 & 2.77 & 119 \\
\hline 6 & 3.00 & 202 & 2.80 & 129 & 2.77 & 119 & 2.84 & 143 & 3.01 & 206 & 2.72 & 103 \\
\hline 8 & 2.93 & 175 & 2.78 & 122 & & & 2.85 & 146 & 2.95 & 18 & 2.69 & 93 \\
\hline 10 & 2.90 & 164 & 2.73 & 106 & & & 2.89 & 160 & 2.90 & 164 & 2.68 & 90 \\
\hline $12 \mathrm{n}$. & 2.94 & 179 & 2.76 & 116 & 2.76 & 116 & 3.00 & 202 & 2.89 & 160 & 2.76 & 116 \\
\hline 2 p.m. & 2.99 & 198 & 2.81 & 132 & & 10. & 3.07 & 230 & 2.95 & 183 & 2.80 & 129 \\
\hline & 3.02 & 210 & 2.84 & 143 & & & 3.12 & 251 & 2.94 & 17 & 2.82 & 136 \\
\hline 6 & 3.01 & 206 & 2.84 & 143 & 2.79 & 126 & 3.20 & 285 & 2.94 & 17 & & 136 \\
\hline 8 & 2.99 & 198 & 2.83 & 140 & & & 3.25 & 308 & 2.94 & 179 & 2.82 & 136 \\
\hline & 2.95 & 183 & 2.81 & 132 & & & 3.27 & 316 & 2.90 & 164 & 2.80 & 129 \\
\hline $12 \mathrm{~m}$. & 2.91 & 168 & 2.80 & 129 & 2.83 & $1+10$ & 3.23 & 298 & 2.85 & 146 & 2.78 & 122 \\
\hline
\end{tabular}

Supplemental records.-.-Jan. 25, 5:30 p.m., 9.16 feet, 5,650 sec.-ft.

\section{NORTH BRANCH OF PARK RIVFR AT HARTFORD, CONN.}

Location.-Lat. $41^{\circ} 47^{\prime} 03^{\prime \prime}$, long. $72^{\circ} 42^{\prime} 31^{\prime \prime}, 60$ feet downstream from stone arch bridge on Albany Avenue, Hartford, Hartford County, and 3 miles upstream from confluence with South Branch of Park River. Datum of gage is 34.20 feet above mean sea level (general adjustment of 1929).

Drainage area.-25.3 square miles.

GAGE-HEIGHT RECORD.-Water-stage recorder graph except for period Jan. 16-22 when float was bound by frost. Affected by change in recording conditions 11 a.m. to 5:30 p.m. Jan. 25 when water was over gage-house floor. Stage-discharge Relation.-Defined by current-meter measurements below 800 second-feet; extended logarithmically to peak stage and verified by areavelocity computations and comparisons with flood records for stations on South Branch and Park River. Affected by ice Jan. 1-7, 12-15, 3 a.m. to 10 a.m. and $12 \mathrm{~m}$. to 12 p.m. Jan. 281 a.m. to 2 p.m. Jan 29 (6 to 10 a.m. and 9:30 p.m. to 12 p.m.). Jan. 30 10:30 a.m. to 11:30 a.m. Jan. 31 3 a.m. to 12 m. and 8 p.m. to 12 p.m. Feb. 1, 1 a.m. to 11 a.m. Feb. 212 , $13,16,17,21,22,28$. Affected by change in recording conditions 11 a.m. to 5:30 p.m. Jan. 25 when water was over gage-house floor.

Maxima.—January 1938: Discharge, 1,640 second-feet 2 p.m. Jan. 25 (gage height, 11.81 feet).

1936 to December 1937: Discharge, 960 second-feet Nov, 29, 1937 (gage height, 7.8 feet).

Flood of Mar. 12, 1936, reached a stage of 11.2 feet as determined from floodmarks by Hartford city engineers (discharge probably 1,520 secondfeet).

Remarks.-Flood discharge probably not appreciably affected by artificial storage. 
Mean discharge, in second-feet, 1938

\begin{tabular}{|c|c|c|c|c|c|c|c|c|c|c|c|}
\hline Day & Jan. & Feb. & Day & Jan. & Feb. & Day & Jan. & Feb. & Day & Jan. & Feb. \\
\hline $\begin{array}{l}1 \\
2 \\
3 \\
5 \\
6 \\
7 \\
8\end{array}$ & $\begin{array}{r}10 \\
16 \\
22 \\
18 \\
18 \\
16 \\
230 \\
253\end{array}$ & $\begin{array}{r}58 \\
39 \\
42 \\
110 \\
63 \\
56 \\
185 \\
72\end{array}$ & $\begin{array}{c}9 \\
10 \\
11 \\
12 \\
13 \\
14 \\
15_{-} \\
16 \\
\ldots\end{array}$ & $\begin{array}{l}95 \\
47 \\
29 \\
20 \\
18 \\
20 \\
19 \\
18\end{array}$ & $\begin{array}{l}48 \\
50 \\
36 \\
32 \\
50 \\
68 \\
42 \\
24\end{array}$ & $\begin{array}{l}17 \ldots \\
18 \ldots \\
19 \\
20 \ldots \\
21 \\
22 \\
23 \\
24 \ldots\end{array}$ & $\begin{array}{l}17 \\
16 \\
15 \\
14 \\
14 \\
18 \\
21 \\
22\end{array}$ & $\begin{array}{l}20 \\
24 \\
34 \\
32 \\
24 \\
26 \\
29 \\
39\end{array}$ & $\begin{array}{l}25 \\
26 \\
27 \\
28 \\
29 \\
30 \\
31 \ldots\end{array}$ & $\begin{array}{r}1,060 \\
414 \\
104 \\
55 \\
38 \\
33 \\
80\end{array}$ & $\begin{array}{l}47 \\
43 \\
37 \\
30\end{array}$ \\
\hline \multicolumn{10}{|c|}{$\begin{array}{l}\text { Monthly mean discharge, in serond-feet } \\
\text { Runff, in inches }\end{array}$} & $\begin{array}{l}89.4 \\
4.07\end{array}$ & $\begin{array}{l}48.6 \\
2.00\end{array}$ \\
\hline
\end{tabular}

Gage height, in feet, and discharge, in second-feet, at indicated time, 1938

\begin{tabular}{|c|c|c|c|c|c|c|c|c|c|c|c|c|}
\hline \multirow[b]{2}{*}{ Hour } & Feet & Sec.-ft. & Feet & Sec.-ft. & Feet & Sec.-ft. & Feet & Sec.-ft. & Feet & Sec.-ft. & Feet & Sec.-ft. \\
\hline & \multicolumn{2}{|c|}{ January 22} & \multicolumn{2}{|c|}{ January 23} & \multicolumn{2}{|c|}{ January 24} & \multicolumn{2}{|c|}{ January 25} & \multicolumn{2}{|c|}{ January 26} & \multicolumn{2}{|c|}{ January 27} \\
\hline \multirow[t]{2}{*}{$\begin{array}{c}1 \mathrm{a} . \mathrm{m} . \\
2 \\
3 \\
4 \\
5 \\
6 \\
7 \\
8 \\
9 \\
10 \\
11 \\
12 \mathrm{n} . \\
11 \mathrm{p.m} . \\
2 \\
3 \\
4 \\
5 \\
6 \\
7 \\
8 \\
9 \\
10 \\
11 \\
12 \mathrm{~m} .\end{array}$} & & & & & $\begin{array}{r}1.84 \\
1.84 \\
1.85 \\
1.95\end{array}$ & $\begin{array}{r}21 \\
222 \\
28\end{array}$ & $\begin{array}{r}2.16 \\
2.45 \\
2.75 \\
3.24 \\
4.45 \\
5.85 \\
6.95 \\
8.40 \\
9.45 \\
10.30 \\
10.90 \\
11.50 \\
11.75 \\
11.81 \\
11.77 \\
11.58 \\
11.31 \\
10.81 \\
10.40 \\
9.93 \\
9.42 \\
8.86 \\
8.34 \\
7.84\end{array}$ & $\begin{array}{r}45 \\
88 \\
152 \\
283 \\
495 \\
672 \\
828 \\
1,060 \\
1,240 \\
1,390 \\
1,500 \\
1,580 \\
1,630 \\
1,640 \\
1,630 \\
1,590 \\
1,540 \\
1,480 \\
1,410 \\
1,330 \\
1,240 \\
1,140 \\
1,050 \\
968\end{array}$ & $\begin{array}{l}7.37 \\
6.91 \\
6.47 \\
6.01 \\
5.56 \\
5.12 \\
4.77 \\
4.42 \\
4.08 \\
3.80 \\
3.61 \\
3.42 \\
3.34 \\
3.29 \\
3.20 \\
3.13 \\
3.05 \\
3.00 \\
2.96 \\
2.90 \\
2.82 \\
2.73 \\
2.68 \\
2.65\end{array}$ & $\begin{array}{l}890 \\
822 \\
757 \\
692 \\
629 \\
568 \\
530 \\
492 \\
453 \\
415 \\
382 \\
335 \\
312 \\
297 \\
271 \\
251 \\
230 \\
216 \\
206 \\
190 \\
169 \\
147 \\
136 \\
129\end{array}$ & $\begin{array}{c}259 \\
22.54 \\
2.50 \\
2.51 \\
2.54 \\
2.61 \\
2.46 \\
2.37\end{array}$ & $\begin{array}{c}116 \\
105 \\
97 \\
99 \\
105 \\
120 \\
89 \\
73\end{array}$ \\
\hline & \multicolumn{2}{|c|}{ January 28} & \multicolumn{2}{|c|}{ January 29} & \multicolumn{2}{|c|}{ January 30} & \multicolumn{2}{|c|}{ January 31} & \multicolumn{2}{|c|}{ February 1} & \multicolumn{2}{|c|}{ February 2} \\
\hline $\begin{array}{l}2 \mathrm{a} . \mathrm{m} . \\
4 \\
6 \\
8 \\
8 \\
10 \\
12 \mathrm{n} . \\
2 \mathrm{p} . \mathrm{m} . \\
4 \\
6 \\
8 \\
10 \\
12 \mathrm{~m} .\end{array}$ & $\begin{array}{l}2.30 \\
2.28 \\
2.27 \\
2.24 \\
2.16 \\
2.32 \\
2.51 \\
2.55 \\
2.55 \\
2.48 \\
2.44 \\
2.41\end{array}$ & $\begin{array}{l}62 \\
54 \\
49 \\
45 \\
43 \\
49 \\
60 \\
66 \\
62 \\
56 \\
52 \\
49\end{array}$ & $\begin{array}{r}2.34 \\
2.20 \\
2.10 \\
2.10 \\
2.11 \\
2.04\end{array}$ & $\begin{array}{c}41 \\
33 \\
34 \\
39 \\
40 \\
35\end{array}$ & $\begin{array}{l}2.01 \\
1.99 \\
1.98 \\
1.97 \\
1.96 \\
1.98 \\
2.02 \\
2.04 \\
2.06 \\
2.09 \\
2.30 \\
2.14\end{array}$ & $\begin{array}{l}33 \\
31 \\
30 \\
28 \\
28 \\
31 \\
33 \\
35 \\
36 \\
38 \\
40 \\
41\end{array}$ & $\begin{array}{l}2.12 \\
2.13 \\
2.16 \\
2.20 \\
2.27 \\
2.42 \\
2.53 \\
2.60 \\
2.62 \\
2.61 \\
2.58 \\
2.50\end{array}$ & $\begin{array}{r}41 \\
42 \\
45 \\
49 \\
58 \\
82 \\
103 \\
118 \\
122 \\
120 \\
114 \\
97\end{array}$ & $\begin{array}{l}2.36 \\
2.40 \\
2.40 \\
2.41 \\
2.33 \\
2.26 \\
2.34 \\
2.38 \\
2.34 \\
2.27 \\
2.31 \\
2.32\end{array}$ & $\begin{array}{l}72 \\
52 \\
45 \\
44 \\
47 \\
54 \\
68 \\
75 \\
68 \\
56 \\
49 \\
43\end{array}$ & $\begin{array}{l}2.30 \\
2.29 \\
2.28 \\
2.27 \\
2.12 \\
2.10 \\
2.11 \\
2.16 \\
2.13 \\
2.08 \\
2.04 \\
2.02\end{array}$ & $\begin{array}{l}39 \\
38 \\
38 \\
37 \\
36 \\
39 \\
40 \\
45 \\
42 \\
38 \\
35 \\
33\end{array}$ \\
\hline
\end{tabular}

Supplemental records.-Jan. 28, 11 a.m., 2.15 ft., 44 sec.ft.; Jan, 30, 9:30 p.m., $2.10 \mathrm{ft} . ;$.Jan. 31,11 a.m., $2.41 \mathrm{ft}$.

\section{HOCKANUM RIVER AT OUTIET OF SHENIPSIT IAKE, AT ROCKVILIE, CONN.}

Location.-Lat. $41^{\circ} 52^{\prime} 06^{\prime \prime}$, long. $72^{\circ} 25^{\prime} 56^{\prime \prime}$, three-quarters of a mile east of Rockville, Tolland County.

Drainage AREA.-16.5 square miles.

GAGE-HFIGHT RECORD.—One reservoir gage reading daily in morning except Sun- 
days. Gage height at midnight determined from graph of gage readings. Stage-discharge relation.-Observed discharge computed from flow over spillway and through pumps, venturi meter, wheel, and gate.

REMARKs.-Daily and monthly mean discharges adjusted for change in contents of Shenipsit Lake. No corrections made for evaporation from lake surface. Basic data furnished by Rockville Water \& Aqueduct Co.

Discharge, in second-feet, and change in contents, in equivalent second-feet, 1938

\begin{tabular}{|c|c|c|c|c|c|c|}
\hline \multirow{2}{*}{ Day } & \multicolumn{3}{|c|}{ January } & \multicolumn{3}{|c|}{ February } \\
\hline & Observed & $\begin{array}{c}\text { Change in } \\
\text { contents }\end{array}$ & Adjusted & Observed & $\begin{array}{l}\text { Change in } \\
\text { contents }\end{array}$ & Adjusted \\
\hline $\begin{array}{r}1 \\
2 \\
3 \\
4 \\
5 \\
6 \\
7 \\
8 \\
9 \\
10 \\
11 \\
12 \\
13 \\
14 \\
15 \\
16 \\
17 \\
18 \\
19 \\
20 \\
21 \\
22 \\
23 \\
24 \\
25 \\
26 \\
27 \\
28 \\
29 \\
30 \\
31\end{array}$ & $\begin{array}{c}4 \\
0.0 \\
29 \\
31 \\
31 \\
37 \\
34 \\
8 \\
0.0 \\
33 \\
45 \\
48 \\
45 \\
60 \\
24 \\
0.0 \\
46 \\
60 \\
58 \\
58 \\
58 \\
28 \\
0.0 \\
45 \\
90 \\
109 \\
100 \\
98 \\
83 \\
58 \\
60\end{array}$ & $\begin{array}{r}+15 \\
+18 \\
-6 \\
-12 \\
-6 \\
-6 \\
+124 \\
+41 \\
+47 \\
+9 \\
-3 \\
-9 \\
-15 \\
-36 \\
-3 \\
+21 \\
-27 \\
-41 \\
-41 \\
-41 \\
-38 \\
-6 \\
+21 \\
+15 \\
+405 \\
+66 \\
-32 \\
-35 \\
-32 \\
-19 \\
-13\end{array}$ & $\begin{array}{r}19 \\
18 \\
23 \\
19 \\
25 \\
31 \\
158 \\
49 \\
47 \\
42 \\
42 \\
39 \\
30 \\
24 \\
21 \\
21 \\
19 \\
19 \\
17 \\
17 \\
20 \\
22 \\
21 \\
30 \\
495 \\
175 \\
68 \\
63 \\
51 \\
39 \\
47\end{array}$ & $\begin{array}{c}60 \\
60 \\
60 \\
60 \\
23 \\
0.0 \\
45 \\
61 \\
60 \\
60 \\
60 \\
23 \\
0.0 \\
45 \\
60 \\
50 \\
48 \\
55 \\
27 \\
0.0 \\
36 \\
36 \\
33 \\
33 \\
32 \\
21 \\
6 \\
36 \\
- \\
\cdots \\
-\end{array}$ & $\begin{array}{r}-13 \\
-13 \\
-13 \\
-13 \\
+28 \\
+63 \\
+63 \\
-9 \\
-19 \\
-22 \\
-25 \\
+13 \\
+38 \\
+6 \\
-9 \\
-9 \\
-13 \\
-22 \\
+6 \\
+38 \\
-3 \\
-6 \\
-6 \\
-3 \\
-6 \\
+6 \\
+16 \\
-16 \\
-. \\
-\end{array}$ & $\begin{array}{r}47 \\
47 \\
47 \\
47 \\
51 \\
63 \\
108 \\
52 \\
41 \\
38 \\
35 \\
36 \\
38 \\
51 \\
51 \\
41 \\
35 \\
33 \\
33 \\
38 \\
33 \\
30 \\
27 \\
30 \\
26 \\
27 \\
22 \\
20 \\
- \\
-- \\
-.\end{array}$ \\
\hline \multirow{2}{*}{31} & & & & & January & February \\
\hline & $\begin{array}{l}\text { Monthly me } \\
\text { Ruzoff, in in } \\
\text { Monthly me } \\
\text { Runoff, in in }\end{array}$ & $\begin{array}{l}\text { lischarge, in } \\
\text { (observed) } \\
\text { ischarge, in } \\
\text { (adjusted) }\end{array}$ & $\begin{array}{l}\text { d-feet cobs } \\
\text { d-feet (adj }\end{array}$ & $\cdots$ & $\begin{array}{l}44.5 \\
3.11 \\
55.2 \\
3.86\end{array}$ & $\begin{array}{l}38.9 \\
2.46 \\
41.0 \\
2.58\end{array}$ \\
\hline
\end{tabular}

\section{HOCKANUM RIVFR NEAR EAST HARTFORD, CONN.}

Locatron.-Lat. $41^{\circ} 46^{\prime} 57^{\prime \prime}$, long. $72^{\circ} 35^{\prime} 20^{\prime \prime}$, at Case \& Marshall paper mill, 11/2 miles downstream from South Branch of Hockanum River and 23/4 miles east of East Hartford, Hartford County. Datum of gage is 54.5 feet above mean sea level (general adjustment of 1929 , levels by Department of Engineering, City of Hartford).

Drainage area.-74.5 square miles.

GAGE-HEIGHT RECORD.--Water-stage recorder graph.

Stage-discharce RElation.--Defined by current-meter measurements.

Maxima.-January 1938: Discharge, 2,140 second-feet 2:20 p.m. Jan. 25 (gage height, 8.79 feet).

1919-21, 1928 to December 1937: Discharge, 1,920 second-feet Mar. 5, 1934 (gage height, 8.3 feet). 
Remarks.-Flow affected by storage in Shenipsit Lake (see record for Hockanum River at outlet of Shenipsit Lake at Rockville, Conn.).

Mean discharge, in second-feet, 1938

\begin{tabular}{|c|c|c|c|c|c|c|c|c|c|c|c|}
\hline Day & Jan. & Feb. & Day & Jan. & Feb. & Day & Jan. & Feb. & Day & Jan. & Feb. \\
\hline $\begin{array}{l}1 \\
2 \\
3 \\
4 \\
5 \\
5 \\
6 \\
7 \\
8\end{array}$ & $\begin{array}{r}70 \\
42 \\
137 \\
104 \\
126 \\
123 \\
252 \\
381\end{array}$ & $\begin{array}{l}256 \\
238 \\
215 \\
255 \\
164 \\
176 \\
347 \\
255\end{array}$ & $\begin{array}{r}9 \ldots \\
10 \ldots \\
11 \ldots \\
12 \ldots \\
13 \\
14 \ldots \\
15 \ldots \\
16 \ldots\end{array}$ & $\begin{array}{r}205 \\
215 \\
136 \\
160 \\
137 \\
82 \\
83 \\
81\end{array}$ & $\begin{array}{l}236 \\
229 \\
177 \\
111 \\
108 \\
258 \\
188 \\
160\end{array}$ & $\begin{array}{l}17 \ldots \\
18 \ldots \\
19 \\
20 \\
21 \\
22 \\
23 \\
24\end{array}$ & $\begin{array}{r}165 \\
121 \\
84 \\
139 \\
178 \\
87 \\
51 \\
182\end{array}$ & $\begin{array}{r}164 \\
171 \\
108 \\
68 \\
193 \\
166 \\
140 \\
164\end{array}$ & $\begin{array}{l}25 \ldots \\
26 \\
27- \\
28 \\
29- \\
30- \\
31 \ldots\end{array}$ & $\begin{array}{r}1,270 \\
740 \\
375 \\
280 \\
164 \\
193 \\
290\end{array}$ & $\begin{array}{r}159 \\
110 \\
71 \\
168\end{array}$ \\
\hline \multicolumn{11}{|c|}{$\begin{array}{l}\text { Monthly mean discharge, in second-feet } \\
\text { Runoff, in inches. }\end{array}$} & $\begin{array}{r}181 \\
2.53\end{array}$ \\
\hline
\end{tabular}

Gage height, in feet, and discharge, in second-feet, at indicated time, 1938

\begin{tabular}{|c|c|c|c|c|c|c|c|c|c|c|c|c|}
\hline \multirow{2}{*}{ Hour } & Feet & Sec.-ft. & Feet & Sec.-ft. & Feet & Sec,-ft. & Feet & Sec.-ft. & Feet & Sec,-ft. & Fent & Sec.ft. \\
\hline & \multicolumn{2}{|c|}{ January 22} & \multicolumn{2}{|c|}{ January 23} & \multicolumn{2}{|c|}{ January 24} & \multicolumn{2}{|c|}{ January 25 } & \multicolumn{2}{|c|}{ January 26} & \multicolumn{2}{|c|}{ January 27} \\
\hline & 2.36 & 148 & 48 & 44 & 179 & 76 & 3.06 & 259 & 684 & 1.290 & 3.88 & +16 \\
\hline & $\begin{array}{l}2.30 \\
2.31\end{array}$ & $\begin{array}{l}1 \pm 8 \\
141\end{array}$ & $\begin{array}{l}1.48 \\
1.47\end{array}$ & $\begin{array}{l}\mathbf{4} \\
43\end{array}$ & $\begin{array}{l}1.79 \\
1.79\end{array}$ & 76 & 3.07 & 269 & 6.04 & $\begin{array}{l}1,290 \\
1,190\end{array}$ & $\begin{array}{l}3.05 \\
3.74\end{array}$ & $\begin{array}{l}+10 \\
388\end{array}$ \\
\hline & 2.26 & 134 & 1.47 & 43 & 1.80 & 77 & 3.17 & 279 & 6.38 & 1,100 & 3.67 & 374 \\
\hline 4 & 2.20 & 126 & 1.47 & 43 & 1.81 & 78 & 3.10 & 266 & 6.17 & 1,020 & 3.63 & 366 \\
\hline 5 & 2.14 & 118 & 1.46 & 42 & 1.82 & 79 & 3.49 & 33 & 5.97 & 954 & 3.60 & 360 \\
\hline 6 & 2.07 & 109 & 1.43 & 0 & 1.81 & 78 & +.04 & 44 & 5.78 & 894 & 3.58 & 356 \\
\hline 7 & 2.03 & 104 & 1.43 & 40 & 2.05 & 106 & 4.51 & 55 & 5.60 & 840 & 3.56 & 352 \\
\hline 8 & 1.97 & 96 & 1.41 & & 2.24 & 132 & 5.24 & 74 & & 797 & 3.54 & $3+8$ \\
\hline 9 & 2.16 & 121 & 1.41 & 3 & 2.25 & 133 & 5.8 & 92 & 5.30 & 758 & 3.53 & $\begin{array}{l}346 \\
346\end{array}$ \\
\hline 10 & 2.08 & 110 & 1.44 & 41 & 2.32 & 143 & 6.75 & 1,250 & 5.17 & 724 & 3.58 & 356 \\
\hline 11 & 2.03 & 10 & 1.45 & 42 & 2.40 & 154 & 7.62 & & 5.04 & 690 & 3.67 & 374 \\
\hline $12 \mathrm{n}$ & 1.75 & & 1.46 & 42 & 2.53 & 174 & 8.20 & 1,87 & 4.94 & 664 & 3.71 & 382 \\
\hline $1 \mathrm{p.m}$ & 1.86 & & 1.49 & $4 \tilde{5}$ & 2.68 & 197 & 8.56 & 2,03 & 4.84 & 638 & 3.74 & 388 \\
\hline & 1.64 & 6 & 1.52 & 48 & 2.83 & 221 & 8.7 & 2,11 & 4.75 & 616 & 3.75 & 390 \\
\hline & 1.61 & & 1.56 & 52 & 2.93 & 237 & 8.78 & 2,13 & 4.65 & 592 & 3.75 & 390 \\
\hline 4 & 1.60 & 56 & 1.58 & 54 & 3.03 & 254 & 8.71 & 2,10 & $\begin{array}{l}4.56 \\
\end{array}$ & 570 & 3.74 & 388 \\
\hline 5 & 1.60 & 56 & 1.63 & 59 & 3.12 & 270 & 8.62 & 2,06 & 4.4 & 551 & 3.73 & 386 \\
\hline & 1.60 & & 1.66 & +12 & 3.17 & 279 & 8.48 & 2,000 & 4.1 & 53 & 3.72 & 384 \\
\hline 7 & 1.57 & 53 & 1.6 & 64 & 3.20 & 284 & 8.2 & 1,90 & 4.3 & 518 & 3.70 & 380 \\
\hline & 1.56 & 52 & 1. 7 & 67 & 3.23 & 289 & 8.0 & 1,80 & 4.2 & 49 & 3.67 & 374 \\
\hline 9 & 1.54 & 50 & 1.74 & 70 & 3.25 & 293 & 7.81 & 1,69 & 4.19 & 482 & 3.6 .5 & 370 \\
\hline 10 & 1.52 & 48 & 1.77 & 74 & 3.22 & 288 & 7.5 & & 4.14 & 47 & 3.64 & 368 \\
\hline & 1.50 & 46 & 1.7 & 75 & 3.16 & 277 & 7.31 & 1,4 & 4.1 & 43 & 3.6 & 366 \\
\hline \multirow[t]{2}{*}{$12 \mathrm{~m}}$. & 1.50 & 46 & 1.78 & 75 & 3.10 & 266 & 7.07 & 1,380 & 4.03 & 447 & 3.63 & 366 \\
\hline & \multicolumn{2}{|c|}{ January 28} & \multicolumn{2}{|c|}{ January 29} & \multicolumn{2}{|c|}{ Jantary 30} & \multicolumn{2}{|c|}{ January 31} & \multicolumn{2}{|c|}{ February 1} & \multicolumn{2}{|c|}{ February 2} \\
\hline 2 a.m. & 3.40 & 320 & 3.1 & 271 & 2.58 & 185 & 2.63 & 192 & 3.26 & 295 & 3.30 & 302 \\
\hline & 3.11 & & & 228 & 2.6 & 191 & & 19 & & 252 & & 25 \\
\hline & 2.85 & 22 & 2.6 & 192 & 2.6 & 19 & & 19 & 2.7 & 216 & 2 . & 21 \\
\hline & 2.70 & & 1.9 & 101 & 2.6 & 19 & 3. & & & 19 & & \\
\hline 10 & 2.67 & 19 & 1.8 & 93 & 2.66 & 197 & 3. & 27 & 2. & 184 & 2.5 & 173 \\
\hline $12 \mathrm{n}$ & 2.90 & & 1.9 & 100 & 2.67 & 198 & 3. & 31 & 2.6 & 200 & 2. & 186 \\
\hline $2 \mathrm{p}$ & 3.14 & & 2.05 & 11. & 2.67 & 198 & 3.5 & 35 & 2 . & 224 & 2 . & 203 \\
\hline & 3.30 & & 2.1 & 12 & 2.6 & 19 & 3. & & 3. & 260 & & 22 \\
\hline & 3.40 & & 2.2 & 14 & 2.6 & 19 & 3.7 & 38 & 3. & 29 & 3. & 258 \\
\hline & 3.46 & 332 & 2.36 & 153 & 2.62 & 191 & 3.61 & 36 & 3.3 & 309 & 3.1 & 279 \\
\hline 10 & 3.46 & 332 & 2.43 & 163 & 2.61 & 190 & 3.52 & 34 & 3.4 & 320 & 3.15 & 28.5 \\
\hline $12 \mathrm{~m}$. & 3.46 & 332 & 2.53 & 178 & 2.61 & 190 & 3.44 & 328 & 3.43 & 326 & 3.03 & 255 \\
\hline
\end{tabular}

Supplemental records.-Jan. $25,3: 45$ a.m., $3.32 \mathrm{ft}$, 306 sec.-ft.; $2: 20$ p.m., 8.79 ft., 2,140 sec.-ft.; Jan. 29, 7:40 a.m., 2.48 it., 170 sec.-ft.; Jan. 31,7 a.m., $2.63 \mathrm{ft} ., 192$ see.ft. 


\section{SAIMON RTVER MEAR EAST HAMPTON, CONN.}

Location.-Lat. $41^{\circ} 33^{\prime} 14^{\prime \prime}$, long. $72^{\circ} 27^{\prime} 00^{\prime \prime}$, at Comstock Bridge, on HartfordMiddlesex County line, 0.7 mile downstream from Dickinson Creek and $31 / 2$ miles southeast of East Hampton, Middlesex County.

Drainage AREA. - 105 square miles.

GAGE-hEIGHT RECORD.-Water-stage recorder graph.

Stage-Discharge RELATion.-Defined by current-meter measurements below 500 second-feet; extended to peak stage on basis of shape of previous and subsequent rating curves. Affected by ice Jan. 4-7, Jan. 10 to 8 a.m. Jan. 25, 2 a.m. Jan. 28 to 2 p.m. Jan. 30, Feb. 16, 17, 21, 22.

Maxima.-January 1938: Discharge, 5,720 second-feet noon Jan. 25 (gage height, 6.21 feet).

1905-6, 1928 to December 1937: Discharge, 6,250 second-feet Mar. 12, 1936 (gage height, 6.98 feet, ice jam).

REMARKs.-Flood discharge not materially affected by storage.

Mean discharge, in second-feet, 1938

\begin{tabular}{|c|c|c|c|c|c|c|c|c|c|c|c|}
\hline Day & Jan. & Feb. & Day & Jan. & Feb. & Day & Jan. & Feb. & Day & Jan. & Feb. \\
\hline & $\begin{array}{r}156 \\
178 \\
181 \\
170 \\
170 \\
170 \\
1.050 \\
894\end{array}$ & $\begin{array}{l}394 \\
324 \\
339 \\
587 \\
400 \\
347 \\
506 \\
405\end{array}$ & 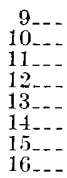 & $\begin{array}{l}424 \\
280 \\
260 \\
240 \\
240 \\
220 \\
220 \\
200\end{array}$ & $\begin{array}{l}333 \\
342 \\
282 \\
253 \\
286 \\
347 \\
290 \\
220\end{array}$ & $\begin{array}{l}17 \\
18 \\
19 \\
20 \\
21 \\
22 \\
23 \\
24 \ldots\end{array}$ & $\begin{array}{l}200 \\
190 \\
170 \\
160 \\
150 \\
140 \\
149 \\
183\end{array}$ & $\begin{array}{l}200 \\
212 \\
242 \\
230 \\
200 \\
200 \\
212 \\
253\end{array}$ & $\begin{array}{l}25 \\
26 \\
27 \\
28 \\
29 \\
30 \\
31\end{array}$ & $\begin{array}{r}3,070 \\
1,320 \\
518 \\
384 \\
345 \\
326 \\
414\end{array}$ & $\begin{array}{l}249 \\
230 \\
212 \\
194\end{array}$ \\
\hline \multicolumn{11}{|c|}{$\begin{array}{l}\text { Monthly mean discharge, in second-feet } \\
\text { Runoff, in inches }\end{array}$} & $\begin{array}{r}296 \\
2.94\end{array}$ \\
\hline
\end{tabular}

Gage height, in feet, and discharge, in second-feet, at indicated time, 1938

\begin{tabular}{|c|c|c|c|c|c|c|c|c|c|c|c|c|}
\hline \multirow{2}{*}{ Hour } & Feet & Sec. $-\mathrm{ft}$. & Feet & Sec.-ft. & Feet & Sec.ft. & Feet & Sec.-ft. & Feet & Sec.-ft. & Feet & Sec-ft. \\
\hline & \multicolumn{2}{|c|}{ January 22} & \multicolumn{2}{|c|}{ January 23} & \multicolumn{2}{|c|}{ January 24} & \multicolumn{2}{|c|}{ January 25} & \multicolumn{2}{|c|}{ January 26} & \multicolumn{2}{|c|}{ January 27} \\
\hline $\begin{array}{c}1 \mathrm{a} . \mathrm{m} . \\
2 \\
3 \\
4 \\
5 \\
6 \\
7 \\
8 \\
9 \\
10 \\
11 \\
12 \mathrm{n} . \\
1 \mathrm{p} . \mathrm{m} . \\
2 \\
3 \\
4 \\
5 \\
6 \\
7 \\
8 \\
9 \\
10 \\
11 \\
12 \mathrm{~m} .\end{array}$ & & & & & $\begin{array}{l}1.57 \\
1.57 \\
1.56 \\
1.56 \\
1.60 \\
1.56 \\
1.55 \\
1.55 \\
1.54 \\
1.62 \\
1.78 \\
1.81 \\
1.78 \\
1.78 \\
1.73 \\
1.69 \\
1.67 \\
1.67 \\
1.67 \\
1.66 \\
1.68 \\
1.72 \\
1.81 \\
1.87\end{array}$ & $\begin{array}{l}160 \\
160 \\
160 \\
160 \\
170 \\
155 \\
155 \\
155 \\
155 \\
165 \\
195 \\
205 \\
200 \\
200 \\
195 \\
190 \\
185 \\
185 \\
190 \\
190 \\
195 \\
210 \\
250 \\
280\end{array}$ & $\begin{array}{l}1.98 \\
2.08 \\
2.70 \\
3.00 \\
3.23 \\
3.48 \\
3.90 \\
4.45 \\
4.79 \\
5.40 \\
5.80 \\
6.21 \\
6.09 \\
6.04 \\
5.86 \\
5.71 \\
5.45 \\
5.25 \\
5.05 \\
4.84 \\
4.70 \\
4.58 \\
4.44 \\
4.27\end{array}$ & $\begin{array}{r}300 \\
380 \\
540 \\
800 \\
1,100 \\
1,500 \\
1,900 \\
2,500 \\
3,310 \\
4,260 \\
4,960 \\
5,720 \\
5,480 \\
5,390 \\
5,070 \\
4,800 \\
4,340 \\
4,020 \\
3,700 \\
3,380 \\
3,180 \\
3,010 \\
2,820 \\
2,580\end{array}$ & $\begin{array}{l}4.11 \\
3.97 \\
3.84 \\
3.71 \\
3.57 \\
3.45 \\
3.35 \\
3.24 \\
3.13 \\
3.03 \\
2.96 \\
2.91 \\
2.91 \\
2.89 \\
2.84 \\
2.77 \\
2.71 \\
2.68 \\
2.63 \\
2.56 \\
2.47 \\
2.41 \\
2.31 \\
2.25\end{array}$ & $\begin{array}{r}2,390 \\
2,220 \\
2,070 \\
1,910 \\
1,770 \\
1,650 \\
1,550 \\
1,440 \\
1,330 \\
1,240 \\
1,170 \\
1,130 \\
1,130 \\
1,110 \\
1,070 \\
1,020 \\
968 \\
944 \\
904 \\
850 \\
784 \\
742 \\
676 \\
638\end{array}$ & $\begin{array}{l}2.18 \\
2.15 \\
2.12 \\
2.08 \\
2.06 \\
2.02 \\
1.99 \\
1.96 \\
1.95 \\
1.97 \\
1.99 \\
2.00 \\
2.07 \\
2.14 \\
2.19 \\
2.19 \\
2.15 \\
2.09 \\
2.08 \\
1.98 \\
1.94 \\
1.90 \\
1.87 \\
1.86\end{array}$ & $\begin{array}{l}593 \\
575 \\
557 \\
534 \\
523 \\
501 \\
485 \\
470 \\
465 \\
475 \\
485 \\
490 \\
528 \\
569 \\
599 \\
599 \\
575 \\
540 \\
534 \\
480 \\
460 \\
440 \\
425 \\
420\end{array}$ \\
\hline
\end{tabular}


Gage height in feet, and discharge, in second-feet, at indicated time, 1938-Continued

\begin{tabular}{|c|c|c|c|c|c|c|c|c|c|c|c|c|}
\hline \multirow{2}{*}{ Hour } & Feet & Sec.-ft. & Feet & Sec.-ft. & Feet & Sec.-ft. & Feet & Sec.-ft. & Feet & Sec.-f t. & Feet & Sec.-ft. \\
\hline & \multicolumn{2}{|c|}{ January 28} & \multicolumn{2}{|c|}{ January 29} & \multicolumn{2}{|c|}{ January 30} & \multicolumn{2}{|c|}{ January 31} & \multicolumn{2}{|c|}{ February 1} & \multicolumn{2}{|c|}{ February 2} \\
\hline \multirow{6}{*}{$\begin{array}{c}2 \mathrm{a} . \mathrm{m} \\
4 \\
6 \\
8 \\
10 \\
12 \mathrm{n} . \\
2 \mathrm{p} . \mathrm{m} \\
4 \\
6 \\
8 \\
10 \\
12 \mathrm{~m} .\end{array}$} & 1.84 & 400 & 1.87 & 340 & 1.92 & 320 & 1.68 & 333 & 1.81 & 395 & 1.57 & 286 \\
\hline & 1.86 & 370 & 1. 96 & 320 & 1.92 & 320 & 1.72 & 352 & 1.73 & 356 & 1.62 & 377 \\
\hline & 1.92 & 380 & 2.02 & 350 & 1.90 & 340 & 1.82 & 400 & 1.87 & 425 & 1.71 & 347 \\
\hline & 1.99 & 400 & 2.04 & 370 & 1.69 & 338 & 2.03 & 506 & 1.89 & 435 & 1.79 & 385 \\
\hline & 1.88 & 370 & 1.97 & 350 & 1.64 & 310 & 2.03 & 506 & 1.71 & 347 & $1.6 \overline{5}$ & 320 \\
\hline & 1.85 & 350 & 1.94 & 330 & 1.64 & 316 & 1.95 & 465 & 1.61 & 302 & 1.59 & 294 \\
\hline
\end{tabular}

Supplemental records.--Jan. 25, $12: 45$ p.m., $6.01 \mathrm{ft}$., 5,340 sec.ft.

\section{EAST BRANCH OF FIGHTMILE RIVER NEAR NORTH LYME, CONN.}

Location.-Lat. $41^{\circ} 25^{\prime} 40^{\prime \prime}$, long. $72^{\circ} 20^{\prime} 05^{\prime \prime}$, at highway bridge 0.4 miles upstream from confluence with West Branch of Eightmile River, 1.1 miles north of North Lyme, New London County, and 5 $\frac{1}{2} 2$ miles upstream from mouth of Eightmile River.

DRAINAGE AREA.-22.0 square miles.

GAGE-HEIGHT RECORD.-Water-stage recorder graph.

Stage-discharge relation.-Defined by current-meter measurements below 300 second-feet; extended to peak stage on basis of flow characteristics at control section. Affected by ice Jan. 4, 10-16, 18-21, 1 p.m. Jan. 23 to 11 a.m. Jan. 24 , intermittently 1 a.m. to 5 p.m. Jan. 25, 12 p.m. Jan. 29 to $12 \mathrm{~m}$. Jan. 30.

Maxima.-January 1938: Discharge, 514 second-feet 9 p.m. Jan. 25 (gage height, 3.68 feet).

September to December 1937: Discharge, 1,010 second-feet Nov. 29, 1937 (gage height, 5.25 feet).

REMARKs.-Flood discharge affected by storage in several small ponds.

Mean discharge, in second-feet, 1938

\begin{tabular}{|c|c|c|c|c|c|c|c|c|c|c|c|}
\hline Day & Jan. & Feb. & Day & Jan. & Feb. & Day & Jan. & Feb. & Day & Jan. & Feb \\
\hline $\begin{array}{l}1 \\
2 \\
3 \\
4 \\
5 \\
6 \\
7 \\
8\end{array}$ & $\begin{array}{r}36 \\
44 \\
44 \\
44 \\
43 \\
42 \\
141 \\
234\end{array}$ & $\begin{array}{r}82 \\
66 \\
63 \\
110 \\
96 \\
74 \\
75 \\
75\end{array}$ & $\begin{array}{r}9 \\
10 \\
11 \\
12 \\
13 \\
14 \\
15_{\ldots} \\
16\end{array}$ & $\begin{array}{r}101 \\
70 \\
65 \\
65 \\
55 \\
55 \\
48 \\
46\end{array}$ & $\begin{array}{l}63 \\
62 \\
56 \\
51 \\
53 \\
66 \\
63 \\
48\end{array}$ & $\begin{array}{l}17 \ldots \\
18 \ldots \\
19 \\
20 \ldots \\
21 \ldots \\
22 \ldots \\
23 \ldots \\
24 \ldots\end{array}$ & $\begin{array}{l}45 \\
42 \\
36 \\
32 \\
28 \\
27 \\
30 \\
38\end{array}$ & $\begin{array}{l}44 \\
45 \\
51 \\
53 \\
48 \\
44 \\
45 \\
57\end{array}$ & $\begin{array}{l}25 \\
26 \\
27 \\
28 \\
29 \\
30 \\
31 \ldots \\
\end{array}$ & $\begin{array}{r}259 \\
273 \\
108 \\
81 \\
69 \\
63 \\
74\end{array}$ & $\begin{array}{l}58 \\
54 \\
48 \\
45\end{array}$ \\
\hline \multicolumn{11}{|c|}{$\begin{array}{l}\text { Monthly mean discharge, in second-feet } \\
\text { Runoff, in inches. }\end{array}$} & $\begin{array}{l}60.5 \\
2.86\end{array}$ \\
\hline
\end{tabular}


Gage height, in feet, and discharge, in second-feet, at indicated time, 1938

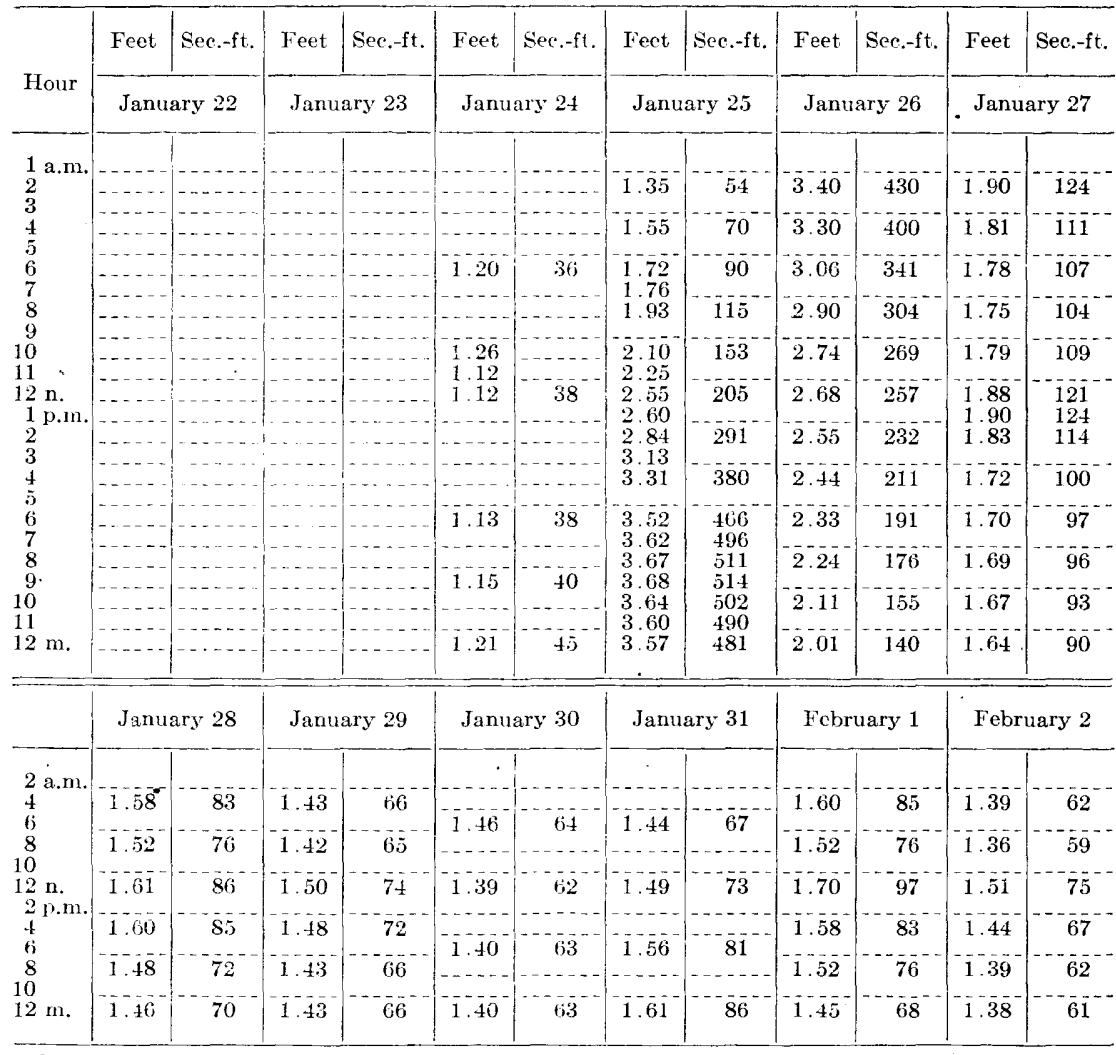

Supplemental records.- Jan. 25, 3:15 p.m., 3.30 ft.; Jan. 28,1 p.m., 1.71 ft., 98 sec.-ft.; Jan. 29,1 p.m., $1.56 \mathrm{ft}$., 81 sec.-ft.; Feb. 2.1 p.m., $1.59 \mathrm{ft} ., 84$ sec.-ft.

\section{WEST BRANCH OF FIGFTMILE RIVER NEAR NORTH IYME, CONN.}

Location.--Lat. $41^{\circ} 25^{\prime} 55^{\prime \prime}$, long. $72^{\circ} 20^{\prime} 10^{\prime \prime}$, on highway bridge 300 feet upstream from confluence with East Branch of Eightmile River, 11/2 miles north of North Lyme, New London County, and 51/2 miles upstream from mouth of Eightmile River.

Drainage area.-19.2 square miles.

GAGE-HEIGHT RECORD.-Staff gage read once daily at 4 p.m. except Jan. 7-9, 2527 , Feb. 4, 7, when it was read twice daily at 9 a.m. and 4 p.m. Gageheight graph based on gage readings and comparison with record for station on East Branch used Jan. 7, 8, 24-31, Feb. 1-5, 8, 13.

STAGe-discharge RELation.-Defined by current-meter measurements below 225 second-feet; extended above on basis of determination of September 1938 peak flow at bridge half a mile above station. Affected by ice Jan. 16-24, 29, Feb. 16-18, 21, 22.

Maxima.-January 1938: Discharge observed 426 second-feet 4 p.m. Jan. 25 (gage height, 4.88 feet).

September to December 1937: Discharge, 1,020 second-feet Nov. 29, 1937 (gage height, 6.8 feet, from floodmark).

$748116-48-7$ 
Remarks.-Flood discharge not affected by artificial storage. Shaw Lake (Lake Hayward) controls headwater discharge to some extent.

Mean discharge, in second-feet, 1938

\begin{tabular}{|c|c|c|c|c|c|c|c|c|c|c|c|}
\hline Day & Jan. & Feb. & Day & Jan. & Feb. & Day & Jan. & Feb. & Day & Jan. & Feb. \\
\hline $\begin{array}{l}1 \\
2 \\
3 \\
4 \\
5 \\
6 \\
7 \\
8\end{array}$ & $\begin{array}{r}38 \\
41 \\
41 \\
43 \\
41 \\
39 \\
162 \\
184\end{array}$ & $\begin{array}{r}80 \\
62 \\
54 \\
110 \\
88 \\
67 \\
79 \\
68 .\end{array}$ & $\begin{array}{c}9 \\
10 \\
11 \ldots \\
12 \ldots \\
13 \ldots \\
14 \ldots \\
15 \\
16 \ldots\end{array}$ & $\begin{array}{r}100 \\
73 \\
58 \\
52 \\
50 \\
47 \\
44 \\
40\end{array}$ & $\begin{array}{l}55 \\
64 \\
52 \\
47 \\
58 \\
64 \\
55 \\
46\end{array}$ & $\begin{array}{l}17 \ldots \\
18 \ldots \\
19 \ldots \\
20 \ldots \\
21 \ldots \\
22 \ldots \\
23 \ldots \\
24 \ldots\end{array}$ & $\begin{array}{l}40 \\
36 \\
34 \\
30 \\
28 \\
26 \\
28 \\
38\end{array}$ & $\begin{array}{l}42 \\
42 \\
49 \\
50 \\
46 \\
44 \\
44 \\
54\end{array}$ & $\begin{array}{l}25 \\
26 \\
27 \\
28 \\
29 \\
30 \ldots \\
31 \ldots \\
\end{array}$ & $\begin{array}{r}290 \\
223 \\
120 \\
80 \\
64 \\
59 \\
81\end{array}$ & $\begin{array}{l}50 \\
49 \\
46 \\
40\end{array}$ \\
\hline \multicolumn{11}{|c|}{$\begin{array}{l}\text { Monthly mean discharge, in second-feet } \\
\text { Runoff, in inches. }\end{array}$} & $\begin{array}{l}57.3 \\
3.10\end{array}$ \\
\hline
\end{tabular}

Gage height, in feet, and discharge, in second-feet, at indicated time, 1938

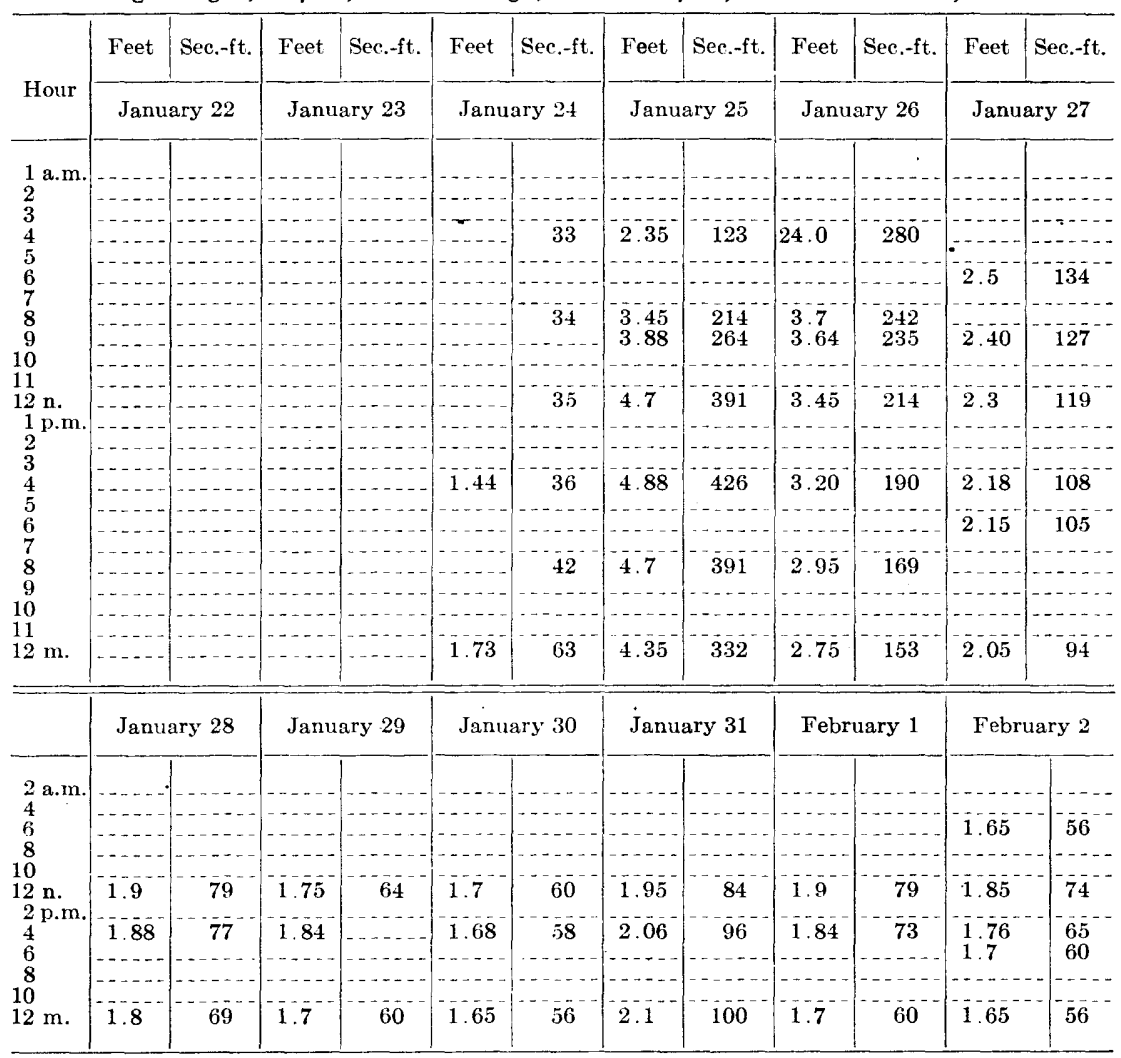

Note,-All gage readings are included in above table. 


\section{QUINNIPLAC RIVER BASIN}

\section{QUINAIPIAC RIVER AT WAITIMGFORD, CONN.}

Location.-Lat. $41^{\circ} 26^{\prime} 58^{\prime \prime}$, long. $72^{\circ} 50^{\prime} 29^{\prime \prime}, 0.4$ mile downstream from Quinnipiac Street bridge in Wallingford, New Haven County, and 2 miles upstream from Worton Brook.

Drainage AREA.- 109 square miles.

GAGE-HEIGHT RECORD.-Water-stage recorder graph.

Stage-discharge Relation.-Defined by current-meter measurements below 1,400 second-feet; extended to peak stage on basis of determination of flood flow at dam 1 mile above station.

Maxima.-January 1938: Discharge, 2,760 second-feet 4 to 5 a.m. Jan. 26 (gage .height, 7.78 feet).

1930 to December 1937: Discharge, 3,240 second-feet Mar. 12, 1936 (gage height, 8.2 feet).

REMARKs.-Flood discharge affected by storage and regulation in several small ponds.

Mean discharge, in second-feet, 1938

\begin{tabular}{|c|c|c|c|c|c|c|c|c|c|c|c|}
\hline Day & Jan. & Feb. & Day & Jan. & Feb. & Day & Jan. & Feb. & Day & Jan. & Feb. \\
\hline $\begin{array}{l}1 \\
2 \\
3 \\
4 \\
6 \\
7 \\
8\end{array}$ & $\begin{array}{l}212 \\
222 \\
225 \\
206 \\
201 \\
197 \\
498 \\
765\end{array}$ & $\begin{array}{l}409 \\
346 \\
351 \\
497 \\
420 \\
358 \\
428 \\
420\end{array}$ & $\begin{array}{r}9 \\
10 \\
11 \\
12 \\
13 \ldots \\
14 \\
15 \\
16_{-}\end{array}$ & $\begin{array}{l}514 \\
347 \\
285 \\
254 \\
244 \\
245 \\
234 \\
220\end{array}$ & $\begin{array}{l}354 \\
341 \\
316 \\
293 \\
305 \\
357 \\
339 \\
336\end{array}$ & $\begin{array}{l}17 \\
18 \\
19 \\
20 \\
21 \\
22 \\
23 \\
24 \ldots\end{array}$ & $\begin{array}{l}233 \\
216 \\
196 \\
201 \\
198 \\
204 \\
205 \\
212\end{array}$ & $\begin{array}{l}389 \\
279 \\
285 \\
295 \\
285 \\
271 \\
275 \\
305\end{array}$ & $\begin{array}{l}25 \\
26 \\
27 \\
28 \\
28 \\
29 \\
30- \\
31 \ldots \\
\end{array}$ & $\begin{array}{r}1,800 \\
2,340 \\
958 \\
537 \\
394 \\
352 \\
396\end{array}$ & $\begin{array}{l}316 \\
295 \\
279 \\
253\end{array}$ \\
\hline \multicolumn{11}{|c|}{$\begin{array}{l}\text { Monthly mean discharge, in second-feet } \\
\text { Runoff, in inches }\end{array}$} & $\begin{array}{r}336 \\
3.21\end{array}$ \\
\hline
\end{tabular}

Gage height, in feet, and discharge, in second-feet, at indicated time, 1938

\begin{tabular}{|c|c|c|c|c|c|c|c|c|c|c|c|c|}
\hline \multirow{2}{*}{ Hour } & Feet & Sec.-ft. & Feet & Sec.-ft. & Feet & Sec.-ft. & Feet & Sec.-ft. & Feet & Sec.-ft. & Feet & Sec.-ft. \\
\hline & \multicolumn{2}{|c|}{ January 22} & \multicolumn{2}{|c|}{ January 23} & \multicolumn{2}{|c|}{ January 24} & \multicolumn{2}{|c|}{ January 25} & \multicolumn{2}{|c|}{ January 26} & \multicolumn{2}{|c|}{ January 27} \\
\hline $\begin{array}{c}1 \mathrm{a} . \mathrm{m} . \\
2 \\
3 \\
4 \\
5 \\
6 \\
7 \\
8 \\
9 \\
10 \\
11 \\
12 \mathrm{n} . \\
\cdot 1 \mathrm{p} . \mathrm{m} . \\
2 \\
3 \\
4 \\
5 \\
6 \\
7 \\
8 \\
9 \\
10 \\
11 \\
12 \mathrm{~m} .\end{array}$ & & & & & $\begin{array}{l}1.65 \\
1.68 \\
1.64 \\
1.64 \\
1.67 \\
1.72 \\
1.80 \\
1.98\end{array}$ & $\begin{array}{c}208 \\
208 \\
215 \\
\end{array}$ & $\begin{array}{l}2.32 \\
2.75 \\
3.32 \\
4.02 \\
4.77 \\
5.44 \\
5.92 \\
6.22 \\
6.50 \\
6.83 \\
7.00 \\
7.12 \\
7.20 \\
7.32 \\
7.34 \\
7.35 \\
7.36 \\
7.34 \\
7.39 \\
7.45 \\
7.51 \\
7.56 \\
7.62 \\
7.67\end{array}$ & $\begin{array}{r}351 \\
440 \\
554 \\
705 \\
921 \\
1,180 \\
1,420 \\
1,580 \\
1,750 \\
1,980 \\
2,100 \\
2,180 \\
2,240 \\
2,340 \\
2,350 \\
2,360 \\
2,370 \\
2,350 \\
2,390 \\
2,440 \\
2,490 \\
2,540 \\
2,600 \\
2,650\end{array}$ & $\begin{array}{l}7.70 \\
7.75 \\
7.77 \\
7.78 \\
7.78 \\
7.77 \\
7.75 \\
7.73 \\
7.71 \\
7.65 \\
7.57 \\
7.43 \\
7.37 \\
7.31 \\
7.20 \\
7.09 \\
6.96 \\
6.81 \\
6.69 \\
6.61 \\
6.52 \\
6.44 \\
6.34 \\
6.23\end{array}$ & $\begin{array}{l}2,680 \\
2,730 \\
2,750 \\
2,760 \\
2,760 \\
2,750 \\
2,730 \\
2,710 \\
2,690 \\
2,630 \\
2,550 \\
2,420 \\
2,380 \\
2,330 \\
2,240 \\
2,160 \\
2,070 \\
1,970 \\
1,880 \\
1,830 \\
1,760 \\
1,710 \\
1,650 \\
1,590\end{array}$ & $\begin{array}{l}6.10 \\
5.99 \\
5.86 \\
5.70 \\
5.56 \\
5.41 \\
5.28 \\
5.25 \\
5.23 \\
5.09 \\
4.91 \\
4.48 \\
4.39 \\
4.38 \\
4.27 \\
4.17 \\
3.92 \\
3.75 \\
3.74 \\
3.75 \\
3.75 \\
3.74 \\
3.72 \\
3.70\end{array}$ & $\begin{array}{r}1,510 \\
1,460 \\
1,390 \\
1,310 \\
1,240 \\
1,160 \\
1,110 \\
1,100 \\
1,090 \\
1,040 \\
964 \\
834 \\
807 \\
804 \\
771 \\
742 \\
682 \\
645 \\
643 \\
645 \\
645 \\
643 \\
638 \\
634\end{array}$ \\
\hline
\end{tabular}


Gage-height, in feet, and discharge, in second-feet, at indicated time, 1938-Continued

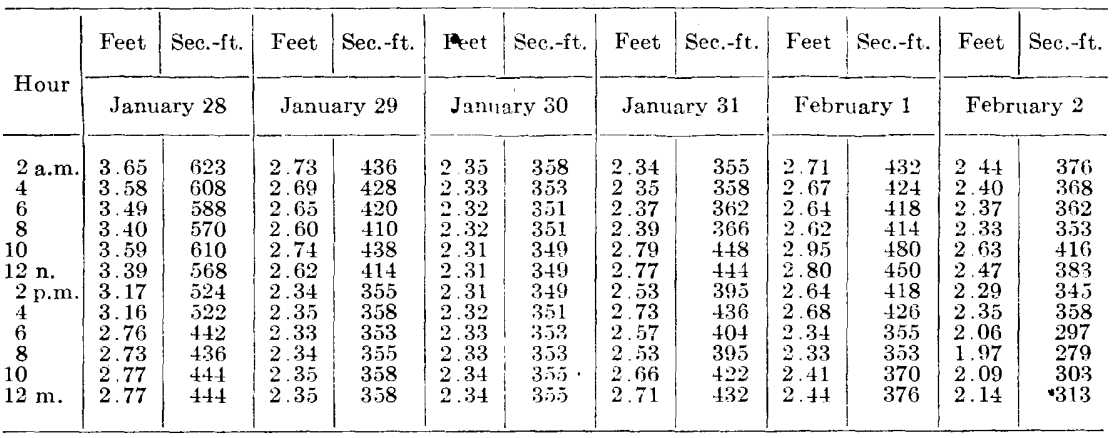

Supplemental records.-Jan. 28, 1 p.m., $2.99 \mathrm{ft} ., 488$ sec.-ft.; Jan. $31,1: 30$ p.'11., $2.36 \mathrm{ft} ., 360$ sec.-ft.; Feb. 1, 1:15 p.m., 2.39 ft., 366 see.ft.; Feb. 2, 1:20 p.m., 2.09 ft., 303 ses.ft.

\section{HOUSATONIC RIVER BASIN}

\section{HOUSATONIC RIVER AT FAIIS VILIAGI, CONN.}

Location.-Lat. $41^{\circ} 57^{\prime} 15^{\prime \prime}$, long. $73^{\circ} 22^{\prime} 05^{\prime \prime}$, at Falls Village, Litchfield County, half a mile downstream from power plant of Connecticut Power Co., and 11/1 miles downstream from Hollenbeck River. Datum of gage is 522.41 feet above mean sea level (general adjustment of 1929).

Drainage area.-632 square miles.

GAGE-HEIGHT RECORD.-Water-stage recorder graph except for periods 11 a.m. Jan. 25 to 11 a.m. Feb. 2 and Feb. 19 when record was based on observer's readings, power plant data, and computations of flow at dam at Bulls Bridge.

Stage-discharge relation.--Defined by current-meter measurements. Affected by ice Jan. 1-25, Feb. 25-28.

Maxima.-January 1938: Discharge, 7,200 second-feet 9 to 11 p.m. Jan. 25

(gage height, 11.6 feet, from power plant data).

1912 to December 1937: Discharge, 14,500 second-feet Mar. 20, 1936

(gage height, 17.41 feet).

Remarks.-Flood discharge affected by storage.

Mean discharge, in second-feet, 1938

\begin{tabular}{|c|c|c|c|c|c|c|c|c|c|c|c|}
\hline Day & Jan. & Feb. & Day & Jan. & Feb. & Day & Jạn. & Feb. & Day & Jan. & Feb. \\
\hline $\begin{array}{l}2 \\
3 \\
4 \\
6 \\
8 \\
8\end{array}$ & $\begin{array}{r}750 \\
600 \\
550 \\
750 \\
850 \\
800 \\
1,200 \\
1,800\end{array}$ & $\begin{array}{l}2,350 \\
2,180 \\
1,840 \\
1,830 \\
1,620 \\
1,830 \\
2,220 \\
2,660\end{array}$ & $\begin{array}{c}9 \\
10 \\
11 \\
12 \\
13 \\
14 \\
15 \\
16\end{array}$ & $\begin{array}{r}1,800 \\
1,500 \\
1,200 \\
1,100 \\
1,000 \\
1,000 \\
950 \\
800\end{array}$ & $\begin{array}{l}2,640 \\
2,470 \\
2,110 \\
1,870 \\
1,640 \\
1,720 \\
1,590 \\
1,510\end{array}$ & $\begin{array}{l}17 \\
18 \ldots \\
19 \ldots \\
20 \\
21 \\
22 \\
23 \ldots \\
24 \\
24\end{array}$ & $\begin{array}{l}650 \\
650 \\
650 \\
600 \\
700 \\
750 \\
750 \\
700\end{array}$ & $\begin{array}{l}1,260 \\
1,290 \\
1,200 \\
1,190 \\
1,090 \\
1,010 \\
1,030 \\
1,060\end{array}$ & $\begin{array}{l}25 \ldots \\
26 \ldots \\
27 \\
28 \\
29 \\
30 \ldots \\
31 \ldots \\
\end{array}$ & $\begin{array}{l}3,500 \\
6,190 \\
5,200 \\
4,350 \\
3,380 \\
2,650 \\
2,410\end{array}$ & $\begin{array}{r}1,100 \\
1,000 . \\
950 \\
750\end{array}$ \\
\hline \multicolumn{10}{|c|}{$\begin{array}{l}\text { Monthly mean discharge, in second-feet } \\
\text { Rumoff, in inches }\end{array}$} & $\begin{array}{r}1,606 \\
2.93\end{array}$ & $\begin{array}{r}1,618 \\
2.67\end{array}$ \\
\hline
\end{tabular}


Gage height, in feet, and discharge, in second-feet, at indicated time, 1938

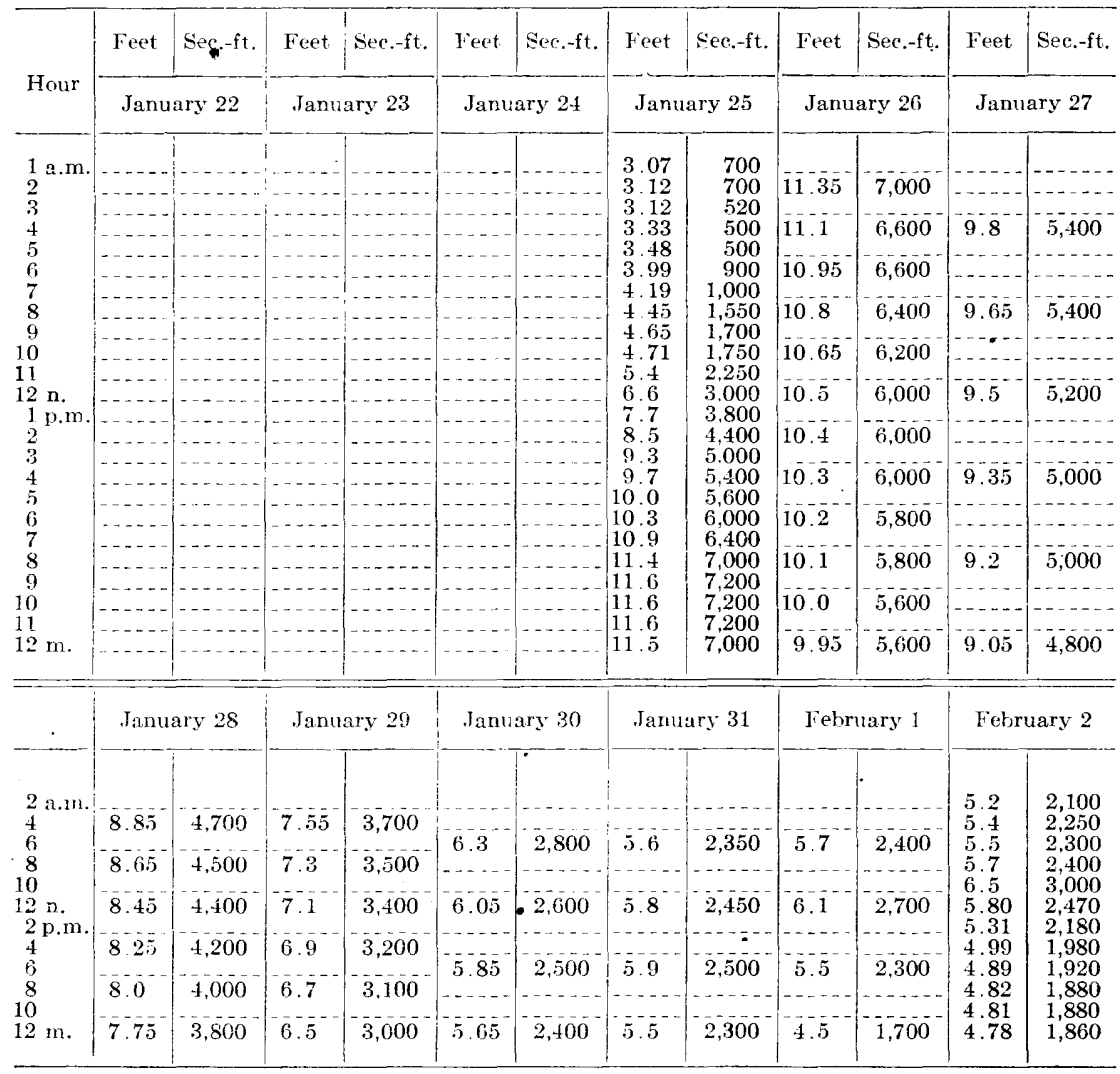

\section{ZOAR IAKE AT STEVENSON, CONN.}

Location.-Staff gage, lat. $41^{\circ} 22^{\prime} 55^{\prime \prime}$, long. $73^{\circ} 10^{\prime} 05^{\prime \prime}$, on Housatonic River at Stevenson Dam of Connecticut Light \& Power Co. at Stevenson, Fairfield County.

Drainage AREa.-1,544 square miles.

REMARKs.-Change in contents in equivalent second-feet computed from elevations of lake at midnight as furnished by Connecticut Light \& Power Co., Waterbury, Conn. 
Change in contents, in equivalent second-feet, 1938

\begin{tabular}{|c|c|c|c|c|c|c|}
\hline Day & & January & February & Day & January & February \\
\hline \multicolumn{2}{|l|}{$\begin{array}{r}1 \\
2 \\
3 \\
4 \\
5 \\
6 \\
7 \\
8 \\
9 \\
10 \\
11 \\
12 \\
13 \\
14 \\
15 \\
16\end{array}$} & $\begin{array}{c}-358 \\
+671 \\
-157 \\
+157 \\
-104 \\
+104 \\
+1120 \\
-216 \\
-533 \\
-884 \\
+102 \\
+571 \\
-104 \\
+52 \\
-157\end{array}$ & $\begin{array}{r}-200 \\
-100 \\
+50 \\
+150 \\
-150 \\
-250 \\
+807 \\
-307 \\
-50 \\
-400 \\
.0 \\
+50 \\
-197 \\
+49 \\
+399\end{array}$ & $\begin{array}{l}17 \\
18 \\
19 \\
20 \\
21 \\
22 \\
23 \\
24 \\
25 \\
26 \\
27 \\
28 \\
29 \\
30 \\
31\end{array}$ & $\begin{array}{r}-209 \\
-51 \\
+156 \\
+52 \\
-464 \\
+359 \\
-155 \\
-154 \\
+2400 \\
-765 \\
-430 \\
-425 \\
-418 \\
-258 \\
-358\end{array}$ & $\begin{array}{r}1-250 \\
-100 \\
-677 \\
+385 \\
+692 \\
-400 \\
+200 \\
+200 \\
-250 \\
-394 \\
+195 \\
+449\end{array}$ \\
\hline & & & & & & February \\
\hline \multicolumn{4}{|c|}{ Change in contents, in equivalent second-feet... } & \multicolumn{2}{|c|}{-14.7} & -3.54 \\
\hline
\end{tabular}

Estimated.

FOUSATONIC RIVER AT STgVENSON, CONT.

LocATION.-Lat. $41^{\circ} 23^{\prime} 05^{\prime \prime}$, long. $73^{\circ} 09^{\prime} 55^{\prime \prime}$, in New Haven County, a quarter of a mile upștream from Eightmile Brook and a quarter of a mile downstream from Stevenson Dam of Connecticut Light \& Power Co. at Stevenson, Fairfield County. Datum of gage is 24.98 feet above mean sea level (general adjustment of 1929), levels by Corps of Engineers, U. S. Army. DraINAGE AREA.- 1,545 square miles.

GAGE-HEIGHT RECORD.-Water-stage recorder graph except for periods $12 \mathrm{~m}$. Jan. 25 to 12 m. Jan. 26 and 4 p.m. Jan. 27 to 9 a.m. Jan. 31 when record was based on floodmark and relation with hourly readings of tailrace gage at Stevenson Dam.

Stage-discharge Relation.-Defined by current-meter measurements.

Maxima.-January 1938: Discharge, 36,000 second-feet noon Jan. 25 (gage height, 16.80 feet, from floodmark).

1928 to December 1937: Discharge, 69,500 second-feet Mar. 12, 1936 (gage height; 23.5 feet, from floodmarks).

REMARKs.-Flow affected by artificial storage. For information on storage see records for Zoar Lake at Stevenson, Conn;, Rocky River at outlet of Candlewood Lake, near New Milford, Conn., and Shepaug River at outlet of Shepaug Reservoir, at Woodville, Conn.

Mean discharge, in second-feet, 1938

\begin{tabular}{|c|c|c|c|c|c|c|c|c|c|c|c|}
\hline Day & Jan. & Feb. & Day & Jan. & Feb. & Day & Jan. & Feb. & Day & Jan. & Feb. \\
\hline $\begin{array}{l}1 \\
2 \\
3 \\
4 \\
5 \\
6 \\
7 \\
8 \ldots\end{array}$ & $\begin{array}{l}2,340 \\
b, 330 \\
2,370 \\
1,900 \\
2,370 \\
2,160 \\
5,060 \\
6,640\end{array}$ & $\begin{array}{l}5,260 \\
4,340 \\
4,460 \\
4,890 \\
4,670 \\
4,390 \\
5,660 \\
5,990\end{array}$ & $\begin{array}{r}9 \\
10 \\
11 \\
10 \\
13 \\
14 \\
15 \\
16\end{array}$ & $\begin{array}{l}4,900 \\
4,470 \\
3,390 \\
2,510 \\
3,060 \\
3,080 \\
2,750 \\
2,360\end{array}$ & $\begin{array}{l}5,450 \\
5,600 \\
4,640 \\
3,950 \\
4,060 \\
4,630 \\
3,900 \\
3,480\end{array}$ & $\begin{array}{l}17 \\
18 \\
19 \\
20 \\
21 \\
22 \\
23 \\
24\end{array}$ & $\begin{array}{l}2,920 \\
2,090 \\
1,630 \\
2,300 \\
2,280 \\
1,710 \\
2,100 \\
2,180\end{array}$ & $\begin{array}{l}3,550 \\
3,360 \\
3,870 \\
2,760 \\
2,350 \\
3,180 \\
2,870 \\
2,970\end{array}$ & $\begin{array}{l}25 \ldots \\
26 \\
27 \\
28 \\
29 \\
30 \\
31\end{array}$ & $\begin{array}{r}21,500 \\
19,100 \\
11,500 \\
10,000 \\
7,840^{\circ} \\
6,320 \\
5,980\end{array}$ & $\begin{array}{l}3,290 \\
3,180 \\
2,470 \\
2,190\end{array}$ \\
\hline \multicolumn{10}{|c|}{$\begin{array}{l}\text { Monthly mean discharge, in second-feet } \\
\text { Runoff, in inches }\end{array}$} & $\begin{array}{r}4,813 \\
3.61\end{array}$ & $\begin{array}{r}3,979 \\
2.69\end{array}$ \\
\hline
\end{tabular}


Gage height, in feet, and discharge, in second-feet, at indicated time, 1938

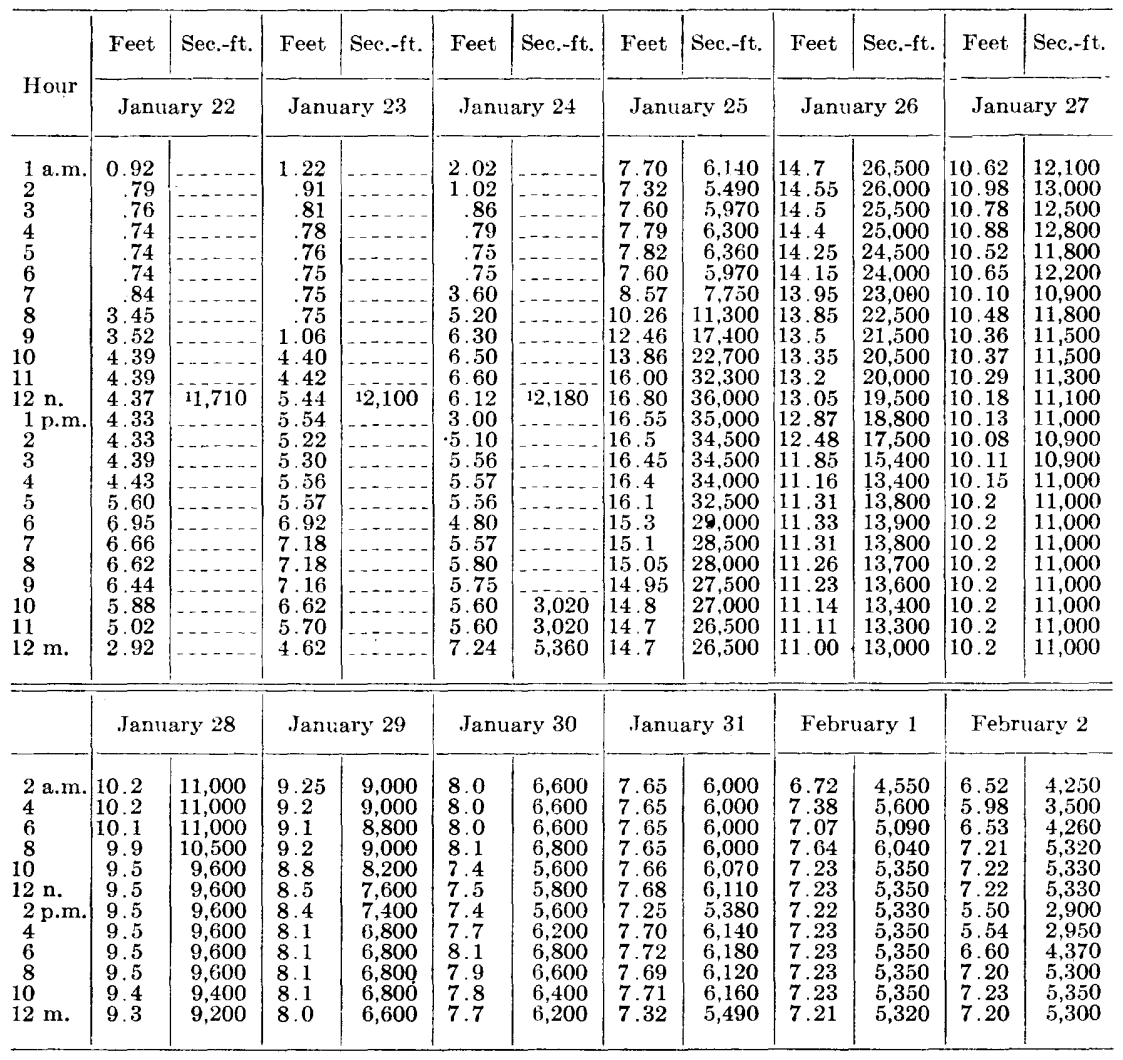

Supplemental Records.-Jan. 22, 4:45 p.m., 4.44 ft.; Jan. 24, 1:30 p.m., 1.60 ft.; Jan. 30, 7 a.m., 7.8 ft., 6,300 sec.-ft.; Jan. 31, 12:30 p.m., $7: 30$ ft., 5,460 sec.-ft.; Feb. 1,3 a.m., 6.50 ft., 4,220 sec.-ft.; 1 p.m., 6.52 ft., 4,250 sec.-ft.; Feb. 2, 1:20 p.m., $1.60 \mathrm{ft.,} 232$ sec.-ft., 5:30 p.m., 5.54 ft., 2,950 sec.-ft., 7 p.m., $7.20 \mathrm{ft}$., 5,300 sec.-ft.

iMean for the day.

TFNMILE RIVER NFAR GAYTORDSVIIIE, CONA.

Location.-Lat. $41^{\circ} 39^{\prime} 35^{\prime \prime}$, long. $73^{\circ} 31^{\prime} 45^{\prime \prime}$, 1 mile upstream from ConnecticutNew York State line, 11/2 mlies upstream from mouth, and $2 \frac{1}{2}$ miles northwest of Gaylordsville, Litchfield County.

Drainage AREA.-204 square miles.

GAGE-HEIGHT RECORD.-Water-stage recorder graph.

Stage-discharge relation.-Defined by current-meter measurements. Affected by ice Jan. 1-6, Jan. 8 to 1 p.m. Jan. 24, 2 p.m. Jan. 27 to 8 a.m. Jan. 28, 3 p.m. Jan. 28 to 2 a.m. Jan. 29, 12 n. to 2 p.m. Jan. 29, 7 p.m. Feb. 1, to 2 a.m. Feb. 2, 11 a.m. to 1 p.m. Feb. 2, 5 p.m. Feb. 2 to Feb. 3, Feb. $16,17,26-28$.

Maxima.-January 1938: Discharge, 6,120 second-feet 9 p.m. Jan. 25 (gage height, 9.13 feet).

1929 to December 1937: Discharge, 10,200 second-feet Mar. 12, 1936 (gage height, 11.61 feet).

REMARKs.-Flood discharge may be slightly affected by storage in several small ponds. 
Mean discharge, in second-feet, 1938

\begin{tabular}{|c|c|c|c|c|c|c|c|c|c|c|c|}
\hline Day & Jan. & Feb. & Day & Jan. & Feb. & Day & Jan. & Feb. & Day & Jan. & Feb \\
\hline $\begin{array}{l}1 \ldots \ldots \\
2 \\
3 \\
4 \\
4 \\
5 \\
6 \\
7 \\
7 \\
8 \ldots \ldots\end{array}$ & $\begin{array}{l}200 \\
220 \\
200 \\
180 \\
180 \\
190 \\
585 \\
950\end{array}$ & $\begin{array}{l}581 \\
435 \\
440 \\
620 \\
522 \\
494 \\
912 \\
688\end{array}$ & $\begin{array}{r}9 \\
10 \\
11 \\
12 \\
13 \\
14 \\
15 \\
16\end{array}$ & $\begin{array}{l}600 \\
460 \\
380 \\
320 \\
280 \\
260 \\
240 \\
220\end{array}$ & $\begin{array}{l}580 \\
568 \\
455 \\
423 \\
457 \\
549 \\
472 \\
340\end{array}$ & $\begin{array}{l}17 \ldots \\
18 \ldots \\
19 \ldots \\
20 \ldots \\
21 \ldots \\
22 \ldots \\
23 \ldots \\
24 \ldots\end{array}$ & $\begin{array}{l}200 \\
200 \\
200 \\
200 \\
190 \\
185 \\
195 \\
225\end{array}$ & $\begin{array}{l}300 \\
333 \\
356 \\
356 \\
292 \\
285 \\
304 \\
323\end{array}$ & $\begin{array}{l}25 \ldots \\
26 \ldots \\
27 \ldots \\
28 \ldots \\
29 \ldots \\
30 \ldots \\
31 \ldots\end{array}$ & $\begin{array}{r}4,030 \\
3,410 \\
1,440 \\
945 \\
672 \\
604 \\
676\end{array}$ & $\begin{array}{l}317 \\
260 \\
220 \\
200\end{array}$ \\
\hline \multicolumn{10}{|c|}{$\begin{array}{l}\text { Monthly mean discharge, in second-feet } \\
\text { Runoff, in inches. }\end{array}$} & $\begin{array}{r}608 \\
3.44\end{array}$ & $\begin{array}{r}432 \\
2.21\end{array}$ \\
\hline
\end{tabular}

Gage height, in feet, and discharge, in second-feet, at indicated time, 1938

\begin{tabular}{|c|c|c|c|c|c|c|c|c|c|c|c|c|}
\hline \multirow[b]{2}{*}{ Hour } & Feet & Sec.-ft. & Feet & Sec.-ft. & Feet & Sec. $-\mathrm{ft}$. & Feet & Sec.-ft. & Feet & Sec.-ft. & Feet & Sec. $-\mathrm{ft}$. \\
\hline & \multicolumn{2}{|c|}{ January 22} & \multicolumn{2}{|c|}{ January 23} & \multicolumn{2}{|c|}{ January 24} & \multicolumn{2}{|c|}{ January 25} & \multicolumn{2}{|c|}{ January 26} & \multicolumn{2}{|c|}{ January 27} \\
\hline $\begin{array}{c}1 \text { a.m. } \\
2 \\
.3 \\
4 \\
5 \\
6 \\
7 \\
8 \\
9 \\
10 \\
11 \\
12 \mathrm{n} . \\
1 \mathrm{p} . \mathrm{m} . \\
2 \\
3 \\
4 \\
5 \\
6 \\
7 \\
8 \\
9 \\
10 \\
11 \\
12 \mathrm{~m} .\end{array}$ & 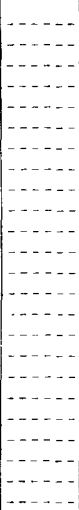 & 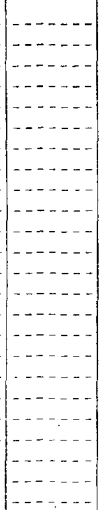 & 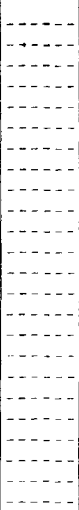 & 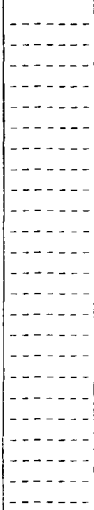 & $\begin{array}{l}1.98 \\
1.97 \\
1.98 \\
2.00 \\
2.05 \\
2.07 \\
1.96 \\
1.95 \\
11.95 \\
1.95 \\
1.95 \\
2.33\end{array}$ & 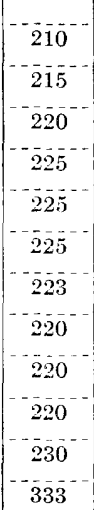 & $\begin{array}{l}2.64 \\
3.16 \\
3.94 \\
4.58 \\
5.24 \\
6.18 \\
6.56 \\
6.98 \\
7.36 \\
7.56 \\
7.78 \\
7.96 \\
8.09 \\
8.21 \\
8.38 \\
8.56 \\
8.75 \\
8.91 \\
9.03 \\
9.11 \\
9.13 \\
9.11 \\
9.02 \\
8.90\end{array}$ & $\begin{array}{r}442 \\
647 \\
1,040 \\
1,440 \\
1,910 \\
2,710 \\
3,070 \\
3,490 \\
3,910 \\
4,130 \\
4,390 \\
4,600 \\
4,760 \\
4,940 \\
5,120 \\
5,360 \\
5,600 \\
5,810 \\
5,980 \\
6,090 \\
6,120 \\
6,090 \\
5,970 \\
5,800\end{array}$ & $\begin{array}{l}8.74 \\
8.64 \\
8.43 \\
8.24 \\
8.03 \\
7.81 \\
7.59 \\
7.36 \\
7.14 \\
6.90 \\
6.70 \\
6.49 \\
6.28 \\
6.11 \\
5.96 \\
5.87 \\
5.82 \\
5.80 \\
5.78 \\
5.75 \\
5.65 \\
5.52 \\
5.42 \\
5.31\end{array}$ & $\begin{array}{l}5,590 \\
5,460 \\
5,190 \\
4,940 \\
4,690 \\
4,420 \\
4,160 \\
3,910 \\
3,660 \\
3,410 \\
3,210 \\
3,000 \\
2,800 \\
2,650 \\
2,510 \\
2,430 \\
2,390 \\
2,370 \\
2,350 \\
2,320 \\
2,240 \\
2,140 \\
2,060 \\
1,970\end{array}$ & $\begin{array}{l}5.20 \\
5.10 \\
4.99 \\
4.89 \\
4.81 \\
4.73 \\
4.67 \\
4.60 \\
4.56 \\
4.56 \\
4.58 \\
4.58 \\
4.54 \\
4.51 \\
4.54 \\
4.58 \\
4.64 \\
4.68 \\
4.67 \\
4.61 \\
4.53 \\
4.42 \\
4.36 \\
4.29\end{array}$ & $\begin{array}{l}1,880 \\
1,800 \\
1,720 \\
1,650 \\
1,600 \\
1,540 \\
1,500 \\
1,450 \\
1,420 \\
1,420 \\
1,440 \\
1,440 \\
1,410 \\
1,400 \\
1,350 \\
1,350 \\
1,300 \\
1,300 \\
1,250 \\
1,250 \\
1,200 \\
1,200 \\
1,150 \\
1,150\end{array}$ \\
\hline $12 \mathrm{~m}$. & \multicolumn{2}{|c|}{ January 28} & \multicolumn{2}{|c|}{ January 29} & \multicolumn{2}{|c|}{ January 30} & \multicolumn{2}{|c|}{ January 31} & \multicolumn{2}{|c|}{ February 1} & \multicolumn{2}{|c|}{ February 2} \\
\hline $\begin{array}{c}2 \text { a.m. } \\
4 \\
6 \\
8 \\
10 \\
12 \mathrm{n} . \\
2 \mathrm{p} . \mathrm{m} . \\
4 \\
6 \\
8 \\
10 \\
12 \mathrm{~m} .\end{array}$ & $\begin{array}{l}4.15 \\
4.04 \\
3.93 \\
3.83 \\
3.76 \\
3.88 \\
3.76 \\
3.76 \\
3.70 \\
3.58 \\
3.52 \\
3.44\end{array}$ & $\begin{array}{r}1,100 \\
1,050 \\
1,000 \\
960 \\
940 \\
1,010 \\
940 \\
900 \\
860 \\
820 \\
800 \\
760\end{array}$ & $\begin{array}{l}3.35 \\
3.29 \\
3.23 \\
3.19 \\
3.17 \\
3.40 \\
3.24 \\
3.24 \\
3.19 \\
3.16 \\
3.15 \\
3.14\end{array}$ & $\begin{array}{r}720 \\
706 \\
678 \\
660 \\
652 \\
660 \\
660 \\
683 \\
660 \\
647 \\
642 \\
638\end{array}$ & $\begin{array}{l}3.11 \\
3.09 \\
3.06 \\
3.05 \\
3.02 \\
3.01 \\
3.02 \\
3.02 \\
3.06 \\
3.08 \\
3.08 \\
3.07\end{array}$ & $\begin{array}{l}624 \\
616 \\
604 \\
600 \\
588 \\
584 \\
588 \\
588 \\
604 \\
612 \\
612 \\
608\end{array}$ & $\begin{array}{l}3.06 \\
3.07 \\
3.09 \\
3.12 \\
3.16 \\
3.24 \\
3.31 \\
3.37 \\
3.37 \\
3.35 \\
3.33 \\
3.32\end{array}$ & $\begin{array}{l}604 \\
608 \\
616 \\
629 \\
647 \\
683 \\
715 \\
745 \\
745 \\
735 \\
725 \\
720\end{array}$ & $\begin{array}{l}3.29 \\
3.24 \\
3.14 \\
3.05 \\
2.97 \\
2.86 \\
2.85 \\
2.90 \\
2.92 \\
2.95 \\
2.95 \\
2.86\end{array}$ & $\begin{array}{l}706 \\
683 \\
638 \\
600 \\
568 \\
525 \\
522 \\
541 \\
549 \\
540 \\
500 \\
480\end{array}$ & $\begin{array}{l}2.74 \\
2.61 \\
2.56 \\
2.54 \\
2.53 \\
2.72 \\
2.72 \\
2.72 \\
2.76 \\
2.76 \\
2.79 \\
2.79\end{array}$ & $\begin{array}{l}460 \\
431 \\
413 \\
405 \\
402 \\
420 \\
472 \\
472 \\
450 \\
430 \\
420 \\
410\end{array}$ \\
\hline
\end{tabular}

Supplemental records.-Jan. 29, 11 a.m., 3.18 feet; 1 p.m., 3.44 feet.

\section{ROCKY RIVIR AT OUTIET OF CANDIFWOOD IAKE, MEAR NEW MIIFORD, CONI.}

Location.-Non-recording gage and venturi meter, lat. $41^{\circ} 35^{\prime} 00^{\prime \prime}$, long. $73^{\circ} 26^{\prime} 00^{\prime \prime}$, at Rocky River plant of Connecticut Light \& Power Co., 11/2 miles northwest of New Milford, Litchfield County.

Drainage area.-40.4 square miles. 
GAGE-HEIGHT RECORD.-One lake-gage reading usually daily at about 8 a.m. Gage height at midnight computed from gage readings.

Stage-discharge RELation.-Observed discharge computed from flow through venturi meters.

Remarks.-Power plant is of pumped-storage type. Candlewood Lake stores flow of Rocky River and water pumped from Housatonic River, into which tailrace of plant discharges. Plus sign before observed discharge indicates water passed from lake through generators into Housatonic River; minus sign indicates water pumped from Housatonic River into lake. Daily and monthly mean discharges adjusted for change in contents of Candlewood Lake. No corrections for evaporation from reservoir surface, which is about 8 square miles. Record based on data furnished by the Connecticut Light \& Power Co.

Discharge, in second-feet, and change in contents, in equivalent second-feet, 1938

\begin{tabular}{|c|c|c|c|c|c|c|}
\hline \multirow[b]{2}{*}{ Day } & \multicolumn{3}{|c|}{ January } & \multicolumn{3}{|c|}{ February } \\
\hline & Observed & $\begin{array}{l}\text { Change in } \\
\text { contents }\end{array}$ & Adjusted & Observed & $\begin{array}{l}\text { Change in } \\
\text { contents }\end{array}$ & Adjusted \\
\hline \multirow[t]{3}{*}{$\begin{array}{r}1 \\
2 \\
3 \\
4 \\
5 \\
6 \\
7 \\
8 \\
9 \\
10 \\
11 \\
12 \\
13 \\
14 \\
15 \\
16 \\
17 \\
18 \\
19 \\
20 \\
21 \\
22 \\
23 \\
24 \\
25 \\
26 \\
27 \\
28 \\
29 \\
30 \\
31\end{array}$} & $\begin{array}{c}0.0 \\
+123 \\
+102 \\
+481 \\
+406 \\
+152 \\
0.0 \\
-44 \\
-173 \\
-2 \\
+301 \\
+290 \\
+258 \\
+183 \\
+132 \\
+19 \\
+345 \\
+226 \\
+472 \\
+197 \\
+140 \\
0.0 \\
0.0 \\
+131 \\
-14 \\
-61 \\
-29 \\
+22 \\
0.0 \\
-243 \\
-85\end{array}$ & $\begin{array}{c}0.0 \\
-110 \\
-55 \\
-406 \\
-298 \\
-81 \\
+54 \\
+271 \\
+271 \\
+135 \\
-162 \\
-162 \\
-135 \\
-162 \\
-108 \\
0.0 \\
-271 \\
-135 \\
-406 \\
-190 \\
-108 \\
+27 \\
+27 \\
0.0 \\
+1408 \\
+325 \\
+273 \\
+165 \\
+192 \\
+329 \\
+165\end{array}$ & $\begin{array}{r}0.0 \\
13 \\
47 \\
75 \\
108 \\
71 \\
54 \\
227 \\
98 \\
133 \\
139 \\
128 \\
123 \\
21 \\
24 \\
19 \\
74 \\
91 \\
66 \\
7 \\
32 \\
27 \\
27 \\
131 \\
1390 \\
264 \\
244 \\
187 \\
192 \\
86 \\
80\end{array}$ & $\begin{array}{c}-7 \\
+9 \\
+135 \\
0.0 \\
-59 \\
-91 \\
-87 \\
-41 \\
-29 \\
-19 \\
0.0 \\
0.0 \\
-84 \\
-62 \\
+12 \\
+223 \\
+325 \\
+116 \\
0.0 \\
0.0 \\
+244 \\
+130 \\
+370 \\
+319 \\
+113 \\
+252 \\
+294 \\
+353 \\
-- \\
-- \\
--\end{array}$ & $\begin{array}{r}+137 \\
+110 \\
+27 \\
+137 \\
+247 \\
+274 \\
+274 \\
+165 \\
+137 \\
+137 \\
+55 \\
+83 \\
+138 \\
+138 \\
+55 \\
-166 \\
-249 \\
-27 \\
+83 \\
+83 \\
-138 \\
0 \\
-110 \\
-219 \\
-55 \\
-165 \\
-219 \\
-329 \\
-2 \\
-- \\
--\end{array}$ & $\begin{array}{r}130 \\
119 \\
162 \\
137 \\
188 \\
183 \\
187 \\
124 \\
108 \\
118 \\
55 \\
83 \\
54 \\
76 \\
67 \\
57 \\
76 \\
89 \\
83 \\
83 \\
106 \\
130 \\
260 \\
100 \\
58 \\
87 \\
75 \\
24 \\
-- \\
-- \\
--\end{array}$ \\
\hline & \multirow{2}{*}{\multicolumn{4}{|c|}{$\begin{array}{l}\text { Monthly mean discharge, in second-feet (observed) } \\
\text { Runoff, in inches (observed) } \\
\text { Monthly mean discharge, in second-feet (adjusted) } \\
\text { Runoff, in inches (adjusted) }\end{array}$}} & January & February \\
\hline & & & & & $\begin{array}{r}107 \\
3.06 \\
135 \\
3.85\end{array}$ & $\begin{array}{r}86.3 \\
2.23 \\
108 \\
2.78\end{array}$ \\
\hline
\end{tabular}

STIII RIVER NEAR IANESVILIE, CONN.

Location.-Lat. $41^{\circ} 31^{\prime} 14^{\prime \prime}$, long. $73^{\circ} 25^{\prime} 09^{\prime \prime}$, at highway bridge $1 \frac{1}{1 / 2}$ miles south of Lanesville, Litchfield County, 2 miles upstream from mouth, and 4 miles south of New Milford. Datum of gage is 213.05 feet above mean sea level (general adjustment of 1929), levels by Corps of Engineers, U. S. Army. 
Drainage AREA.-68.5 square miles.

GAGE-HEIGHT RECORD.-Water-stage recorder graph except for periods Jan. 18 to 5 p.m. Jan. 25, 10 p.m. Jan. 26 to 6 p.m. Jan. 30, and Feb. 11-28 when record was based on range lines and records for Pomperaug River at Southbury, Shepaug River near Roxbury, and Tenmile River near Gaylordsville.

Stage-discharge ReLation.-Defined by current-meter measurements below 1,900 second-feet; extended logarithmically to peak stage. Affected by ice Jan. 1-6, 11-17, 3 a.m. to 1 p.m. Feb. 2.

Maxima.-January 1938: Discharge, 2,450 second-feet 9 p.m. Jan. 25 (gage height, 9.52 feet).

1931 to December 1937: Discharge, 3,930 second-feet Mar. 12, 1936 (gage height, 10.58 feet).

REMARKs.-Flood discharge not appreciably affected by storage or regulation.

Mean discharge, in second-feet, 1938

\begin{tabular}{|c|c|c|c|c|c|c|c|c|c|c|c|}
\hline Day & Jan. & Feb. & Day & Jan. & Feb. & Day & Jan. & Feb. & Day & Jan. & Feb. \\
\hline $\begin{array}{l}1 \\
2 \\
3 \\
5 \\
6 \\
7 \\
8 \ldots\end{array}$ & $\begin{array}{r}95 \\
95 \\
100 \\
90 \\
90 \\
90 \\
240 \\
553\end{array}$ & $\begin{array}{l}260 \\
208 \\
184 \\
255 \\
240 \\
192 \\
272 \\
311\end{array}$ & $\begin{array}{c}9 \\
10 \\
11 \\
12 \\
13 \\
14 \\
15 \\
16\end{array}$ & $\begin{array}{l}116 \\
240 \\
190 \\
140 \\
130 \\
120 \\
110 \\
110\end{array}$ & $\begin{array}{l}227 \\
209 \\
180 \\
170 \\
190 \\
220 \\
190 \\
140\end{array}$ & $\begin{array}{l}17 \ldots \\
18 \\
19 \\
20 \\
21 \\
22 \\
23 \\
24 \ldots\end{array}$ & $\begin{array}{r}110 \\
100 \\
100 \\
100 \\
100 \\
96 \\
96 \\
98\end{array}$ & $\begin{array}{l}120 \\
130 \\
140 \\
140 \\
120 \\
120 \\
120 \\
130\end{array}$ & $\begin{array}{l}25 \ldots \\
26 \\
27 \\
28 \\
29 \\
30 \\
31\end{array}$ & $\begin{array}{r}1,070 \\
1,210 \\
588 \\
313 \\
220 \\
225 \\
239\end{array}$ & $\begin{array}{r}120 \\
100 \\
85 \\
80\end{array}$ \\
\hline \multicolumn{10}{|c|}{$\begin{array}{l}\text { Monthly mean discharge, in second-feet } \\
\text { Runoff, in inches. }\end{array}$} & $\begin{array}{r}241 \\
4.06\end{array}$ & $\begin{array}{r}173 \\
2.64\end{array}$ \\
\hline
\end{tabular}

Gage height, in feet, and discharge, in second-feet, at indicated time, 1938

\begin{tabular}{|c|c|c|c|c|c|c|c|c|c|c|c|c|}
\hline \multirow{2}{*}{ Hour } & Feet & Sec.-ft. & Feet & Sec. $-\mathrm{ft}$. & Feet & Sec.-ft. & Feet & Sec.-ft. & Feet & Sec.-ft. & Feet & Sec.-ft. \\
\hline & \multicolumn{2}{|c|}{ January 22} & \multicolumn{2}{|c|}{ January 23} & \multicolumn{2}{|c|}{ January 24} & \multicolumn{2}{|c|}{ January 25} & \multicolumn{2}{|c|}{ January 26} & \multicolumn{2}{|c|}{ January 27} \\
\hline $\begin{array}{c}1 \mathrm{a} . \mathrm{m} . \\
2 \\
3 \\
4 \\
5 \\
6 \\
7 \\
8 \\
9 \\
10 \\
11 \\
12 \mathrm{n} . \\
1 \mathrm{p} . \mathrm{m} . \\
2 \\
3 \\
4 \\
5 \\
6 \\
7 \\
8 \\
9 \\
10 \\
11 \\
12 \mathrm{~m} .\end{array}$ & & & & & $\begin{array}{l}2.71 \\
2.71 \\
2.75 \\
2.84 \\
2.98\end{array}$ & $\begin{array}{r} \\
\end{array}$ & $\begin{array}{l}3.17 \\
3.39 \\
3.62 \\
3.95 \\
4.40 \\
4.93 \\
5.45 \\
5.84 \\
6.17 \\
6.47 \\
6.73 \\
7.00 \\
7.27 \\
7.63 \\
8.13 \\
8.58 \\
9.00 \\
9.28 \\
9.44 \\
9.50 \\
9.52 \\
9.50 \\
9.43 \\
9.33\end{array}$ & $\begin{array}{r}125 \\
140 \\
155 \\
180 \\
220 \\
270 \\
330 \\
390 \\
450 \\
520 \\
580 \\
660 \\
760 \\
920 \\
1,200 \\
1,550 \\
1,900 \\
2,190 \\
2,360 \\
2,430 \\
2,450 \\
2,430 \\
2,350 \\
2,240\end{array}$ & $\begin{array}{l}9.20 \\
9.06 \\
8.92 \\
8.77 \\
8.64 \\
8.50 \\
8.37 \\
8.25 \\
8.15 \\
8.04 \\
7.96 \\
7.87 \\
7.81 \\
7.75 \\
7.70 \\
7.65 \\
7.59 \\
7.54 \\
7.50 \\
7.46 \\
7.43 \\
7.40 \\
7.37 \\
7.34\end{array}$ & $\begin{array}{r}2,110 \\
1,970 \\
1,840 \\
1,700 \\
1,590 \\
1,480 \\
1,380 \\
1,280 \\
1,220 \\
1,140 \\
1,100 \\
1,040 \\
1,010 \\
975 \\
950 \\
925 \\
895 \\
870 \\
850 \\
834 \\
822 \\
820 \\
800 \\
780\end{array}$ & $\begin{array}{l}7.31 \\
7.27 \\
7.24 \\
7.20 \\
7.15 \\
7.10 \\
7.05 \\
7.00 \\
6.95 \\
6.89 \\
6.83 \\
6.76 \\
6.69 \\
6.62 \\
6.54 \\
6.45 \\
6.38 \\
6.31 \\
6.24 \\
6.17 \\
6.12 \\
6.06 \\
6.00 \\
5.95\end{array}$ & $\begin{array}{l}780 \\
760 \\
740 \\
740 \\
720 \\
700 \\
680 \\
660 \\
640 \\
620 \\
600 \\
580 \\
560 \\
540 \\
520 \\
500 \\
490 \\
480 \\
460 \\
450 \\
440 \\
430 \\
420 \\
410\end{array}$ \\
\hline
\end{tabular}


Gage-height, in feet, and discharge, in second-feet, at indicated time, 1938-Continued

\begin{tabular}{|c|c|c|c|c|c|c|c|c|c|c|c|c|}
\hline \multirow{2}{*}{ Hour } & Feet & Sec. $-\mathrm{ft}$. & Feet & Sec.-ft. & Feet & Sec.-ft. & Feet & Sec.-ft. & Feet & Sec.-ft. & Feet & Sec.-ft. \\
\hline & \multicolumn{2}{|c|}{ January 28} & \multicolumn{2}{|c|}{ January 29} & \multicolumn{2}{|c|}{ January 30} & \multicolumn{2}{|c|}{ January 31} & \multicolumn{2}{|c|}{$F \geqslant$ bruary 1} & \multicolumn{2}{|c|}{ February 2} \\
\hline 2 a.m. & 5.87 & 390 & 4.56 & 230 & 4.42 & 220 & & & & & & \\
\hline & 5.80 & 380 & 4.5 & 230 & 4.45 & 220 & 4.47 & 224 & 5.01 & 277 & 4.62 & 230 \\
\hline & $\begin{array}{l}5.70 \\
5.57\end{array}$ & $\begin{array}{l}360 \\
350\end{array}$ & $\begin{array}{l}4.48 \\
4.44\end{array}$ & $\begin{array}{l}225 \\
220\end{array}$ & $\begin{array}{l}4.48 \\
4.51\end{array}$ & $\begin{array}{l}225 \\
230\end{array}$ & 450 & 227 & 5.00 & 276 & 4.78 & 225 \\
\hline 10 & 5.44 & 330 & 4.40 & 220 & 4.52 & 230 & & & & & & \\
\hline $12 \mathrm{n}$. & 5.30 & 310 & 4.36 & 215 & 4.53 & 230 & 4.59 & 235 & 4.91 & 266 & 4.54 & 210 \\
\hline${ }_{4}^{2}$ p.m. & $\begin{array}{l}5.14 \\
4.98\end{array}$ & $\begin{array}{l}290 \\
270\end{array}$ & $\begin{array}{l}4.34 \\
4.33\end{array}$ & $\begin{array}{l}215 \\
210\end{array}$ & $\begin{array}{l}4.54 \\
4.53\end{array}$ & $\begin{array}{l}230 \\
230\end{array}$ & 4.70 & 245 & 4.76 & 251 & 4.13 & 194 \\
\hline 6 & 4.86 & 260 & 4.34 & 215 & 4.50 & 225 & & & & & & \\
\hline 8 & $\begin{array}{l}4.76 \\
4.68\end{array}$ & 250 & $\begin{array}{l}4.35 \\
4.37\end{array}$ & 215 & 4.47 & 224 & 4.82 & 257 & 4.61 & 237 & 3.99 & 183 \\
\hline $12 \mathrm{~m}$. & $\begin{array}{l}4.08 \\
4.61\end{array}$ & 235 & $\begin{array}{l}4.58 \\
4.39\end{array}$ & 215 & $\begin{array}{l}4.40 \\
4.45\end{array}$ & 222 & 4.93 & 268 & 4.55 & 232 & 3.98 & 182 \\
\hline
\end{tabular}

\section{SHEPAUG RIVER AT OUTIET OF SHEPAUG RESERVOIR, AT WOODVILIE, CONN.}

Location.-Nonrecording gages at dam at outlet of Shepaug Reservoir, lat. $41^{\circ} 43^{\prime} 16^{\prime \prime}$, long. $73^{\circ} 17^{\prime} 40^{\prime \prime}, 1$ mile north of Woodville, Litchfield County and 3 miles upstream from Bantam River.

Drainage area.- 38.0 square miles.

GAGE-HEIGHT RECORD.-One reservoir gage reading daily at noon; gage. height at midnight determined from graph constructed from gage readings.

Stage-discharce RELATION.-Observed discharge computed from flow through gates and fountain and over spillway for time when reservoir gage was read. During periods of rapid change in discharge, mean daily discharge computed from graphs drawn on basis of determinations of discharge at noon and records for station near Roxbury.

Maxima.-January 1938: Discharge, 4,100 second-feet about 11 a.m. Jan. 25, from graph developed from noon determinations of discharge and record for station near Roxbury.

1935 to December 1937: Discharge observed, 4,070 second-feet Mar. 12, 1936.

REMARKs.-Daily and monthly mean discharges adjusted for change in contents of Shepaug Reservoir. No diversion from reservoir to Naugatuck River drainage Jan. 1 to Feb. 28. No corrections for evaporation from reservoir surface. Minimum flow of 2.35 second-feet maintained below reservoir at all times. Basic data furnished by Bureau of Engineering, City of Waterbury.

Discharge, in second-feet, and change in contents, in equivalent second-feet, 1938

\begin{tabular}{|c|c|c|c|c|c|c|}
\hline \multirow[b]{2}{*}{ Day } & \multicolumn{3}{|c|}{ January } & \multicolumn{3}{|c|}{ February } \\
\hline & Observed & $\begin{array}{l}\text { Change in } \\
\text { contents }\end{array}$ & Adjusted & Observed & $\begin{array}{l}\text { Change in } \\
\text { contents }\end{array}$ & Adjusted \\
\hline $\begin{array}{l}1 \\
2 \\
3 \\
4 \\
5 \\
6 \\
7 \\
8 \\
9\end{array}$ & $\begin{array}{r}45 \\
48 \\
51 \\
51 \\
55 \\
53 \\
389 \\
280 \\
148\end{array}$ & $\begin{array}{r}0.0 \\
+1 \\
0.0 \\
0.0 \\
0.0 \\
0.0 \\
+49 \\
-27 \\
-8\end{array}$ & $\begin{array}{r}45 \\
49 \\
51 \\
51 \\
55 \\
53 \\
438 \\
253 \\
140\end{array}$ & $\begin{array}{r}13 j \\
90 \\
92 \\
135 \\
125 \\
107 \\
386 \\
155 \\
141\end{array}$ & $\begin{array}{c}-6 \\
-4 \\
+4 \\
+3 \\
-3 \\
0.0 \\
+11 \\
-7 \\
0.0\end{array}$ & $\begin{array}{r}129 \\
86 \\
96 \\
138 \\
122 \\
107 \\
397 \\
148 \\
141\end{array}$ \\
\hline
\end{tabular}


Discharge, in second-feet, and change in contents in equivalent second-feet, 1938 -Continued

\begin{tabular}{|c|c|c|c|c|c|c|}
\hline \multirow[b]{2}{*}{ Day } & \multicolumn{3}{|c|}{ January } & \multicolumn{3}{|c|}{ February } \\
\hline & Observed & $\begin{array}{l}\text { Change in } \\
\text { contents }\end{array}$ & Adjusted & Observed & $\begin{array}{l}\text { Change in } \\
\text { contents }\end{array}$ & Adjusted \\
\hline \multirow[t]{3}{*}{$\begin{array}{l}10 \\
11 \\
12 \\
13 \\
14 \\
15 \\
16 \\
17 \\
18 \\
19 \\
20 \\
21 \\
22 \\
23 \\
24 \\
25 \\
26 \\
27 \\
28 \\
29 \\
30 \\
31\end{array}$} & $\begin{array}{r}98 \\
79 \\
74 \\
69 \\
71 \\
62 \\
84 \\
84 \\
71 \\
71 \\
71 \\
53 \\
53 \\
51 \\
48 \\
2,110 \\
678 \\
345 \\
144 \\
131 \\
122 \\
173\end{array}$ & $\begin{array}{c}-5 \\
-2 \\
-1 \\
0.0 \\
0.0 \\
+2 \\
+2 \\
-1 \\
-2 \\
0.0 \\
-2 \\
-2 \\
0.0 \\
0.0 \\
+9 \\
+47 \\
-27 \\
-41 \\
+23 \\
+2 \\
+3 \\
+1 \\
+1\end{array}$ & $\begin{array}{r}93 \\
77 \\
73 \\
69 \\
71 \\
64 \\
86 \\
83 \\
69 \\
71 \\
69 \\
51 \\
53 \\
51 \\
57 \\
2,160 \\
651 \\
304 \\
167 \\
133 \\
125 \\
174\end{array}$ & $\begin{array}{r}151 \\
8.1 \\
98 \\
104 \\
141 \\
101 \\
64 \\
71 \\
69 \\
79 \\
71 \\
57 \\
53 \\
64 \\
64 \\
62 \\
44 \\
53 \\
44 \\
-- \\
-- \\
--\end{array}$ & $\begin{array}{l}-5 \\
-5 \\
+2 \\
+3 \\
0.0 \\
-6 \\
-2 \\
0.0 \\
+1 \\
0.0 \\
-2 \\
-2 \\
+1 \\
+1 \\
0.0 \\
-2 \\
-1 \\
0.0 \\
-2 \\
-- \\
-- \\
--\end{array}$ & $\begin{array}{r}146 \\
79 \\
100 \\
107 \\
141 \\
95 \\
62 \\
71 \\
70 \\
79 \\
69 \\
55 \\
54 \\
65 \\
64 \\
60 \\
43 \\
53 \\
42 \\
-- \\
-- \\
--\end{array}$ \\
\hline & \multirow{2}{*}{\multicolumn{4}{|c|}{$\begin{array}{l}\text { Monthly mean discharge, in seeond-feet (observed) } \\
\text { Runoff, in inches (observed) } \\
\text { Monthly mean discharge, in second-feet (adjusted) } \\
\text { Runoff, in inches (adjusted) }\end{array}$}} & January & February \\
\hline & & & & & $\begin{array}{r}189 \\
5.73 \\
190 \\
5.76\end{array}$ & $\begin{array}{r}101 \\
2.77 \\
101 \\
2.77\end{array}$ \\
\hline
\end{tabular}

SHFPAUG RIVER NFAR ROXBURY, CONN.

Location.-Lat. $41^{\circ} 32^{\prime} 53^{\prime \prime}$, long. $73^{\circ} 19^{\prime} 51^{\prime \prime}$, at highway bridge 0.7 mile south of Roxbury Station. 11/4 miles southwest of village of Roxbury, Litchfield County, and 2 miles upstream from Jacks Brook. Datum of gage is 282.07 feet above mean sea level (general adjustment of 1929).

Drainage AREA.-133 square miles.

- GAGE-HEIGHT RECORD.-Water-stage recorder' graph.

STAGE-DISCHARGE RELATION.--Defined by current-meter measurements below 3,500 second-feet; extended logarithmically to peak stage, partly on basis of determinations of flow at dam at Roxbury Station. Affected by ice Jan. 4, 5, Jan. 8 to 1 a.m. Jan. 25, 3 a.m. Jan. 25, 2 p.m. Jan. 27 to 2 p.m. Jan. 28, 7 p.m. Jan. 28 to 10 a.m. Jan. 30, Feb. 14-17, 26-28.

Maxima.-January 1938: Discharge, 5,340 second-feet 1:15 p.m. Jan 25 (gage height, 9.22 feet).

1930 to December 1937: Discharge, 7,000 second-feet Mar. 12, 1936 (gage height, $10: 77$ feet).

Remarks.-Flood discharge affected by storage in Shepaug Reservoir at Woodville (see page 93) and in Bantam Lake (drainage area at outlet, 33.2 square miles). 
Mean discharge, in second-feet, 1938

\begin{tabular}{|c|c|c|c|c|c|c|c|c|c|c|c|}
\hline Day & Jan. & Feb. & Day & Ian. & Feb. & Day & Jan. & Feb. & Day & Jan. & Feb. \\
\hline $\begin{array}{l}1 \ldots \ldots \\
2 \ldots \\
3 \\
4 \ldots \\
5 \\
6 \\
7 \\
8\end{array}$ & $\begin{array}{l}187 \\
208 \\
211 \\
190 \\
220 \\
211 \\
841 \\
650\end{array}$ & $\begin{array}{l}477 \\
413 \\
403 \\
467 \\
412 \\
404 \\
835 \\
525\end{array}$ & $\begin{array}{r}9 \ldots \\
10 \\
11 \ldots \\
12 \ldots \\
13 \ldots \\
14 \ldots \\
15 \ldots \\
16 \ldots\end{array}$ & $\begin{array}{l}400 \\
320 \\
280 \\
240 \\
240 \\
220 \\
220 \\
200\end{array}$ & $\begin{array}{l}467 \\
467 \\
383 \\
359 \\
408 \\
440 \\
360 \\
300\end{array}$ & $\begin{array}{l}17 \ldots \\
18 \ldots \\
19 \ldots \\
20 \ldots \\
21 \ldots \\
22 \ldots \\
23 \ldots \\
24 \ldots\end{array}$ & $\begin{array}{l}200 \\
200 \\
200 \\
220 \\
200 \\
200 \\
200 \\
200\end{array}$ & $\begin{array}{l}280 \\
279 \\
283 \\
279 \\
241 \\
234 \\
244 \\
258\end{array}$ & $\begin{array}{l}25 \\
26 \ldots \\
27 \ldots \\
28 \ldots \\
29 \ldots \\
30 \ldots \\
31 \ldots\end{array}$ & $\begin{array}{r}3,670 \\
1,560 \\
1,000 \\
674 \\
564 \\
517 \\
540\end{array}$ & $\begin{array}{l}231 \\
160 \\
180 \\
160\end{array}$ \\
\hline \multicolumn{10}{|c|}{$\begin{array}{l}\text { Monthly mean discharge, in second-feet } \\
\text { Runoff, in inches }\end{array}$} & $\begin{array}{r}483 \\
4.18\end{array}$ & $\begin{array}{r}355 \\
2.78\end{array}$ \\
\hline
\end{tabular}

Gage height, in feet, and discharge, in second-feet, at indicated time, 1938

\begin{tabular}{|c|c|c|c|c|c|c|c|c|c|c|c|c|}
\hline \multirow{2}{*}{ Hour } & Feet & Sec.-ft. & Feet & Sec.-ft. & Feet & Sec.-ft. & Feet & Ser.-ft. & Feet & Sec, ft. & Feet & Sec,-ft. \\
\hline & \multicolumn{2}{|c|}{ January 22} & \multicolumn{2}{|c|}{ January 23} & \multicolumn{2}{|c|}{ Jaruary 24} & \multicolumn{2}{|c|}{ January 25} & \multicolumn{2}{|c|}{ January 26} & \multicolumn{2}{|c|}{ January 27} \\
\hline $\begin{array}{c}1 \mathrm{a} . \mathrm{m} . \\
2 \\
3 \\
4 \\
5 \\
6 \\
7 \\
8 \\
9 \\
10 \\
11 \\
12 \mathrm{n} . \\
1 \mathrm{p} . \mathrm{m} . \\
2 \\
3 \\
4 \\
5 \\
6 \\
7 \\
8 \\
9 \\
10 \\
11 \\
12 \mathrm{~m} .\end{array}$ & 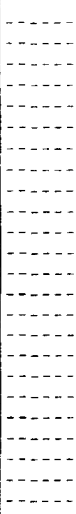 & 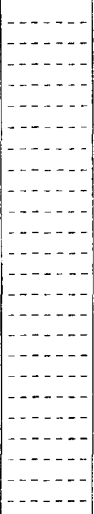 & 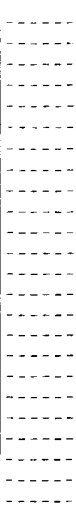 & 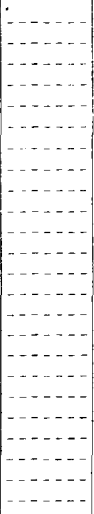 & $\left.\begin{array}{|c}\ldots \\
\cdots \\
\cdots\end{array}\right]$ & \begin{tabular}{|c|c|}
$\ldots$ \\
$\cdots$ \\
$\cdots$ \\
$\cdots$ \\
$\cdots$
\end{tabular} & $\begin{array}{l}3.82 \\
4.72 \\
7.34 \\
6.50 \\
6.99 \\
7.48 \\
8.07 \\
8.57 \\
8.91 \\
8.94 \\
9.03 \\
9.13 \\
9.20 \\
9.19 \\
9.12 \\
8.97 \\
8.72 \\
8.43 \\
8.04 \\
7.62 \\
7.23 \\
6.90 \\
6.61 \\
6.40\end{array}$ & $\begin{array}{r}400 \\
1,160 \\
1,850 \\
2,460 \\
2,890 \\
3,350 \\
3,970 \\
4,530 \\
4,940 \\
4,980 \\
5,090 \\
5,220 \\
5,310 \\
5,300 \\
5,210 \\
5,010 \\
4,710 \\
4,370 \\
3,930 \\
3,490 \\
3,110 \\
2,810 \\
2,550 \\
2,380\end{array}$ & $\begin{array}{l}6.21 \\
6.04 \\
5.92 \\
5.81 \\
5.69 \\
5.59 \\
5.48 \\
5.39 \\
5.31 \\
5.23 \\
5.16 \\
5.16 \\
5.12 \\
5.10 \\
5.10 \\
5.10 \\
5.08 \\
4.83 \\
4.85 \\
4.92 \\
4.94 \\
4.92 \\
4.90 \\
4.85\end{array}$ & $\begin{array}{l}2,230 \\
2,090 \\
2,000 \\
1,910 \\
1,820 \\
1,750 \\
1,680 \\
1,610 \\
1,560 \\
1,500 \\
1,450 \\
1,450 \\
1,420 \\
1,410 \\
1,410 \\
1,410 \\
1,400 \\
1,230 \\
1,240 \\
1,280 \\
1,300 \\
1,280 \\
1,270 \\
1,240\end{array}$ & $\begin{array}{l}4.80 \\
4.75 \\
4.71 \\
4.65 \\
4.61 \\
4.58 \\
4.54 \\
4.51 \\
4.50 \\
4.49 \\
4.51 \\
4.51 \\
4.49 \\
4.47 \\
4.45 \\
4.43 \\
4.42 \\
4.41 \\
4.39 \\
4.38 \\
4.36 \\
4.34 \\
4.27 \\
4.24\end{array}$ & $\begin{array}{r}1,210 \\
1,180 \\
1,160 \\
1,120 \\
1,100 \\
1,080 \\
1,050 \\
1,040 \\
1,030 \\
1,020 \\
1,040 \\
1,040 \\
1,020 \\
980 \\
920 \\
900 \\
880 \\
880 \\
880 \\
880 \\
880 \\
860 \\
840 \\
820\end{array}$ \\
\hline & Janu & ary 28 & Janu & $\operatorname{ars} 29$ & Janu & $\operatorname{ary} 30$ & $\operatorname{Jan}$ & ary 31 & Febr & uary 1 & Feb & tary 2 \\
\hline $\begin{array}{l}2 \text { a.m. } \\
4 \\
6 \\
8 \\
10 \\
12 \mathrm{n} . \\
2 \mathrm{p} . \mathrm{m} . \\
4 \\
6 \\
8 \\
10 \\
12 \mathrm{~m} .\end{array}$ & $\begin{array}{l}4.19 \\
4.13 \\
4.05 \\
4.01 \\
4.01 \\
4.04 \\
3.82 \\
3.65 \\
3.72 \\
3.80 \\
3.82 \\
3.82\end{array}$ & $\begin{array}{l}780 \\
760 \\
720 \\
680 \\
660 \\
660 \\
660 \\
592 \\
624 \\
620 \\
620 \\
600\end{array}$ & $\begin{array}{l}3.81 \\
3.77 \\
3.72 \\
3.70 \\
3.69 \\
3.71 \\
3.69 \\
3.67 \\
3.58 \\
3.59 \\
3.58 \\
3.57\end{array}$ & $\begin{array}{l}600 \\
580 \\
580 \\
580 \\
560 \\
560 \\
560 \\
560 \\
540 \\
540 \\
540 \\
540\end{array}$ & $\begin{array}{l}3.55 \\
3.53 \\
3.52 \\
3.50 \\
3.49 \\
3.47 \\
3.46 \\
3.48 \\
3.48 \\
3.48 \\
3.46 \\
3.47\end{array}$ & $\begin{array}{l}520 \\
520 \\
520 \\
520 \\
520 \\
512 \\
507 \\
516 \\
516 \\
516 \\
507 \\
512\end{array}$ & $\begin{array}{r}3.43 \\
3.47 \\
3.58 \\
3.64 \\
3.58 \\
3.53\end{array}$ & $\begin{array}{r}494 \\
512 \\
-561 \\
588 \\
561 \\
538\end{array}$ & $\begin{array}{c}3.43 \\
-3.40 \\
3.41 \\
3.41 \\
3.34 \\
3.27\end{array}$ & $\begin{array}{r}494 \\
480 \\
484 \\
484\end{array}$ & $\begin{array}{r}3.22 \\
3.18 \\
3.25 \\
3.31\end{array}$ & $\begin{array}{r}403 \\
387 \\
416 \\
441 \\
403 \\
403\end{array}$ \\
\hline
\end{tabular}

Supplemental records.--Jan, 25, $1: 15$ a.m., 4.14 feet: $3: 30$ a.m., 6.22 ft.; $1: 15$ p.m., 9.22 ft., 5,340 sec.-ft.; Feb. 1, 11 a.m., 3.34 ft., 454 sec.-ft.; Feb. 2, 1 p.m. 3.33 ft., 450 sec.-ft. 
POMPERAUG RIVER AT SOUTHBURY, CONN.

Location.-Lat. $41^{\circ} 28^{\prime} 50^{\prime \prime}$, long. $73^{\circ} 13^{\prime} 30^{\prime \prime}$, 200 feet upstream from highway bridge, three-quarters of a mile west of Southbury, New Haven County, and $5 \frac{1}{2}$ miles upstream from mouth.

Drainage area.-75.3 square miles.

GAGE-HEIGHT RECORD.-Water-stage recorder graph except for period 10 a.m. to 11 a.m. Jan. 25 (float against recorder table) when record was computed on basis of floodmark. Adjustments made for intake lag for periods 11 p.m. Jan. 24 to 8 a.m. Jan. 25,3 to 12 p.m. Jan. 25.

Stage-discharge RELATION.-Defined by current-meter measurements below 1,200 second-feet; extended to peak stage on basis of September 1938 peak flow determination at dam 2 miles below station.

Maxima.-January 1938: Discharge, 5,980 second-feet 10:30 a.m. Jan. 25 (gage height, 14.12 feet, from floodmark).

1932 to December 1937: Discharge, 5,990 second-feet Mar. 12, 1936 (gage height, 14.13 feet, from floodmark).

REMARKs.-Flood discharge not affected by artificial storage.

Mean discharge, in second-feet, 1938

\begin{tabular}{|c|c|c|c|c|c|c|c|c|c|c|c|}
\hline Day & Jan. & Feb. & Day & Jan. & Feb. & Day & Jan. & Feb. & Day & Jan, & Feb. \\
\hline $\begin{array}{l}1 \ldots \\
2 \ldots \\
3 \\
4 \ldots \\
5 \\
5 \ldots \ldots \\
6 \ldots \ldots \\
7 \ldots \ldots \\
8 \ldots \ldots\end{array}$ & $\begin{array}{l}108 \\
119 \\
116 \\
104 \\
106 \\
100 \\
643 \\
448\end{array}$ & $\begin{array}{l}199 \\
167 \\
188 \\
279 \\
188 \\
176 \\
430 \\
232\end{array}$ & $\begin{array}{r}9 \\
10_{\ldots} \\
11 \ldots \\
12_{\ldots} \\
13 \ldots \\
14 \ldots \\
15 \ldots \\
16 \ldots-\end{array}$ & $\begin{array}{l}251 \\
190 \\
163 \\
154 \\
147 \\
142 \\
132 \\
129\end{array}$ & $\begin{array}{l}199 \\
203 \\
159 \\
151 \\
216 \\
227 \\
175 \\
133\end{array}$ & $\begin{array}{l}17 \ldots-- \\
18 \ldots \\
19 \\
20 \ldots \\
21 \ldots- \\
22 \ldots- \\
23 \ldots \\
24 \ldots\end{array}$ & $\begin{array}{l}126 \\
110 \\
102 \\
112 \\
121 \\
103 \\
102 \\
103\end{array}$ & $\begin{array}{l}129 \\
137 \\
146 \\
144 \\
127 \\
121 \\
135 \\
171\end{array}$ & $\begin{array}{l}25 \\
26 \ldots \\
27 \\
28 \ldots \\
29 \\
30 \ldots \\
31 \ldots\end{array}$ & $\begin{array}{r}2,260 \\
672 \\
337 \\
253 \\
209 \\
204 \\
235\end{array}$ & $\begin{array}{l}154 \\
130 \\
124 \\
105\end{array}$ \\
\hline \multicolumn{10}{|c|}{$\begin{array}{l}\text { Monthly mean discharge, in second-feet } \\
\text { Runoff, in inches }\end{array}$} & $\begin{array}{r}261 \\
4.00\end{array}$ & $\begin{array}{r}177 \\
2.45\end{array}$ \\
\hline
\end{tabular}

Gage-height, in feet, and discharge, in second-feet, at indicated time, 1938

\begin{tabular}{|c|c|c|c|c|c|c|c|c|c|c|c|c|}
\hline \multirow{2}{*}{ Hour } & Feet & Sec.-ft. & Feet & Sec.-ft. & Feet & Sec.-ft. & Feet & Sec.-ft. & Feet & Sec.-ft. & Feet & Sec.-ft. \\
\hline & \multicolumn{2}{|c|}{ January 22} & \multicolumn{2}{|c|}{ January 23} & \multicolumn{2}{|c|}{ January 24} & \multicolumn{2}{|c|}{ January 25} & \multicolumn{2}{|c|}{ January 26} & \multicolumn{2}{|c|}{ January 27} \\
\hline $1 \mathrm{a} . \mathrm{m}$. & & & & & 3.51 & 102 & 4.55 & 310 & 6.63 & 1,160 & 4.83 & 394 \\
\hline & & $\ldots \ldots$ & - & $\ldots \ldots$ & 3.51 & 102 & 4.91 & 420 & 6.44 & 1,070 & 4.75 & 370 \\
\hline 3 & & $-\ldots . .-$ & - &.- & 3.50 & 101 & 5.16 & 500 & 6.27 & 986 & 4.71 & 358 \\
\hline 4 & & & & $\ldots$ & 3.49 & 100 & 5.42 & 600 & 6.14 & 928 & 4.68 & 349 \\
\hline 5 & & & & & 3.49 & 100 & 5.68 & 720 & 6.00 & 865 & 4.65 & 341 \\
\hline 6 & & & & --- & 3.46 & 95 & 5.94 & 840 & 5.88 & 811 & 4.62 & 333 \\
\hline 7 & & $-\ldots$ & & $\ldots$ & 3.43 & 90 & 6.25 & 980 & 5.76 & 757 & 4.60 & 327 \\
\hline 8 & & & & -- & 3.43 & 90 & 6.80 & 1,250 & 5.65 & 708 & 4.58 & 322 \\
\hline 9 & & & & $-\ldots$ & 3.43 & 90 & 8.60 & 2,260 & 5.58 & 676 & 4.55 & 314 \\
\hline 10 & & & $-\cdots$ & $\ldots . .--$ & 3.46 & 95 & 14.02 & 5,900 & 5.50 & 640 & 4.54 & 311 \\
\hline 11 & & & & 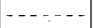 & 3.50 & 101 & 14.05 & 5,900 & 5.42 & 608 & 4.53 & 309 \\
\hline $12 \mathrm{n}$. & & $\ldots$ & & $\ldots$ & 3.46 & 95 & 13.55 & 5,550 & 5. 36 & 584 & 4.53 & 309 \\
\hline 1 p.m. & & & & $---\ldots$ & 3.46 & 95 & 12.64 & 4,910 & 5.31 & 564 & 4.55 & 314 \\
\hline 2 & & & $-\cdots$ & & 3.50 & 101 & 11.58 & 4,170 & 5.25 & 540 & 4.60 & 327 \\
\hline $\begin{array}{l}3 \\
4\end{array}$ & & $\ldots$ & -- & ------ & 3.52 & 104 & 10.50 & 3,400 & 5.22 & 528 & 4.64 & 338 \\
\hline $\begin{array}{l}4 \\
5\end{array}$ & & & & & $\begin{array}{l}3.52 \\
3.51\end{array}$ & $\begin{array}{l}104 \\
102\end{array}$ & $\begin{array}{l}9.60 \\
8.92\end{array}$ & $\begin{array}{l}2,900 \\
2,450\end{array}$ & $\begin{array}{l}5.21 \\
5.18\end{array}$ & $\begin{array}{l}524 \\
513\end{array}$ & $\begin{array}{l}4.66 \\
4.68\end{array}$ & $\begin{array}{l}344 \\
349\end{array}$ \\
\hline 6 & & & & -- & 3.51 & 102 & 8.50 & 2,200 & 5.15 & 502 & 4.68 & 349 \\
\hline 7 & & & & $\ldots \ldots$ & 3.51 & $10 \overline{2}$ & 8.13 & 2,000 & 5.14 & 498 & 4.68 & 349 \\
\hline 8 & & & & $-\ldots$ & 3.52 & 104 & 7.83 & 1,800 & 5.10 & 483 & 4.65 & 341 \\
\hline 9 & & & & & 3.52 & 104 & 7.55 & 1,650 & 5.05 & 466 & 4.62 & 333 \\
\hline 10 & & & & $\ldots-\ldots$ & 3.56 & 110 & 7.26 & 1,500 & 5.01 & 452 & 4.59 & 324 \\
\hline 11 & -- & --- & - & $-\ldots-.--$ & 3.70 & 130 & 7.02 & 1,350 & 4.96 & 436 & 4.55 & 314 \\
\hline & & & & $\ldots$ & 4.02 & 190 & 6.83 & 1,250 & 4.91 & 419 & 4.51 & 304 \\
\hline
\end{tabular}


Gage-height, in feet, and discharge, in second-feet, at indicated time, 1938-Continued

\begin{tabular}{|c|c|c|c|c|c|c|c|c|c|c|c|c|}
\hline \multirow{2}{*}{ Hour } & Feet & Sec.-ft. & Feet & Sec.-ft. & Feet & Sec.-ft. & Feet & Sec.-ft. & Feet & Sec.-ft. & Feet & Sec.-ft. \\
\hline & \multicolumn{2}{|c|}{ January 28} & \multicolumn{2}{|c|}{ January 29} & \multicolumn{2}{|c|}{ January 30} & \multicolumn{2}{|c|}{ January 31} & \multicolumn{2}{|c|}{ February 1} & \multicolumn{2}{|c|}{ - February 2} \\
\hline 2 a.m. & 4.41 & 278 & 4.13 & 214 & 4.11 & 209 & 4.12 & 211 & 4.25 & 240 & 3.78 & 146 \\
\hline 4 & 4.35 & 264 & 4.10 & 207 & $\begin{array}{l}4.10 \\
4\end{array}$ & 207 & 4.12 & 211 & 4.16 & 220 & 3.78 & 146 \\
\hline 6 & 4.29 & 250 & 4.09 & 205 & 4.10 & 207 & 4.12 & 211 & 4.07 & 201 & 3.78 & 146 \\
\hline 8 & 4.25 & 240 & 4.08 & 203 & 4.09 & 205 & 4.12 & 211 & 3.96 & 17 & 3.82 & 153 \\
\hline 10 & 4.23 & 236 & 4.11 & 209 & 4.07 & 201 & 4.12 & 211 & 3.91 & 169 & 3.85 & 158 \\
\hline $12 \mathrm{n}$. & 4.18 & 225 & 4.02 & 190 & 4.05 & 196 & 4.14 & 216 & 3.90 & 16 & 3.79 & 147 \\
\hline 2 p.m. & 4.25 & 240 & 4.06 & 199 & 4.05 & 196 & 4.18 & 225 & 3.98 & 18 & 3.86 & 160 \\
\hline & 4.33 & 259 & 4.11 & 209 & 4.07 & 201 & 4.26 & 243 & 4.0 & 20 & 4.00 & 186 \\
\hline 6 & 4.40 & 276 & 4.14 & 216 & 4.08 & 203 & 4.39 & 27 & 4.18 & 225 & 4.12 & 211 \\
\hline 8 & 4.35 & 264 & 4.16 & 220 & 4.10 & 207 & 4.45 & 28 & 4.12 & 211 & 4.06 & 199 \\
\hline 10 & 4.25 & 240 & 4.15 & 218 & 4.11 & 209 & 4.42 & 281 & 4.0 & 186 & 3.98 & 182 \\
\hline $12 \mathrm{~m}$. & 4.17 & 222 & 4.12 & 211 & 4.12 & 211 & 4.32 & 257 & 3.88 & 163 & 3.92 & 171 \\
\hline
\end{tabular}

Supplemental records.-Jan. 25, 10:30 a.m., 14.12 ft., 5,980 sec.-ft.

\section{NAUGATUCK RIVER NEAR THOMASTON, CONN.}

Location.-Lat. $41^{\circ} 42^{\prime} 11^{\prime \prime}$, long. $73^{\circ} 03^{\prime} 56^{\prime \prime}$, at highway bridge half a mile upstream from Leadmine Brook and 2 miles north of Thomaston, Litchfield County. Datum of gage is 389.44 feet above mean sea level (general adjustment of 1929).

Drainage ArEa.-71.9 square miles.

GAGE-HEIGHT RECORD.-Water-stage recorder graph.

Stage-discharge relation.-Defined by current-meter measurements below 6,000 second-feet; extended logarithmically to peak stage. Affected by ice Jan. $10,11,18-21$.

Maxima.-January 1938: Discharge, 6,830 second-feet noon Jan. 25 (gage height, 9.57 feet).

1930 to December 1937: Discharge, 6,590 second-feet Mar. 12, 1936 (gage height, 9.37 feet).

REMARKs.-Flood discharge slightly affected by storage in small ponds and reservoirs.

Mean discharge, in second-feet, 1938

\begin{tabular}{|c|c|c|c|c|c|c|c|c|c|c|c|}
\hline Day & Jan. & Feb. & Day & Jan. & Feb. & Day & Jan. & Feb. & Day & Jan. & Feb. \\
\hline $\begin{array}{l}1 \\
2 \\
3 \\
4 \\
6 \\
7 \\
8\end{array}$ & $\begin{array}{r}89 \\
108 \\
100 \\
93 \\
88 \\
82 \\
669 \\
502\end{array}$ & $\begin{array}{l}223 \\
167 \\
189 \\
272 \\
198 \\
205 \\
702 \\
288\end{array}$ & $\begin{array}{r}9 \\
10 \ldots \\
11 \ldots \\
12 \ldots \\
13 \\
14 \\
15 \\
16 \ldots\end{array}$ & $\begin{array}{r}242 \\
170 \\
140 \\
130 \\
125 \\
117 \\
108 \\
99\end{array}$ & $\begin{array}{l}218 \\
228 \\
164 \\
154 \\
201 \\
238 \\
180 \\
128\end{array}$ & $\begin{array}{l}17 \\
18 \\
19 \\
20 \\
21 \\
22 \\
23 \\
24\end{array}$ & $\begin{array}{r}106 \\
90 \\
80 \\
90 \\
90 \\
94 \\
91 . \\
85\end{array}$ & $\begin{array}{l}117 \\
123 \\
137 \\
137 \\
119 \\
110 \\
121 \\
130\end{array}$ & $\begin{array}{l}25 \\
26 \\
27 \\
28 \\
29 \\
30 \\
31\end{array}$ & $\begin{array}{r}3,800 \\
1,060 \\
393 \\
261 \\
194 \\
185 \\
270\end{array}$ & $\begin{array}{r}119 \\
102 \\
104 \\
78\end{array}$ \\
\hline \multicolumn{11}{|c|}{$\begin{array}{l}\text { Monthly mean discharge, in second-feet } \\
\text { Runoff, in inches. }\end{array}$} & $\begin{array}{r}184 \\
2.67\end{array}$ \\
\hline
\end{tabular}


Gage height, in feet, and discharge, in second-feet, at indicated time, 1938

\begin{tabular}{|c|c|c|c|c|c|c|c|c|c|c|c|c|}
\hline \multirow{2}{*}{ Hour } & Feet & Sec.-ft. & Feet & Sec.-ft. & Feet & Sec.-ft. & Feet & Sec.-ft. & Feet & Sec.-ft. & Feet & Sec.-ft. \\
\hline & \multicolumn{2}{|c|}{ January 22} & \multicolumn{2}{|c|}{ January 23} & \multicolumn{2}{|c|}{ January 24} & \multicolumn{2}{|c|}{ January 25} & \multicolumn{2}{|c|}{ January 26} & \multicolumn{2}{|c|}{ January 27} \\
\hline $\begin{array}{c}12 \mathrm{a} . \mathrm{m} . \\
2 \\
3 \\
4 \\
5 \\
6 \\
7 \\
8 \\
9 \\
10 \\
11 \\
12 \mathrm{n} . \\
1 \mathrm{p} . \mathrm{m} . \\
2 \\
3 \\
4 \\
5 \\
6 \\
7 \\
8 \\
9 \\
10 \\
11 \\
12 \mathrm{~m} .\end{array}$ & & & & & $\begin{array}{l}1.68 \\
1.67 \\
1.67 \\
1.66 \\
1.64 \\
11.64 \\
1.66 \\
1.67 \\
1.67 \\
1.66 \\
1.66 \\
1.76\end{array}$ & $\begin{array}{c}81 \\
81 \\
84 \\
86 \\
86 \\
84 \\
84 \\
102\end{array}$ & $\begin{array}{l}1.86 \\
2.08 \\
2.94 \\
3.80 \\
4.86 \\
6.17 \\
7.76 \\
8.55 \\
9.21 \\
9.45 \\
9.53 \\
9.57 \\
9.42 \\
8.90 \\
8.42 \\
7.85 \\
7.44 \\
7.05 \\
6.69 \\
6.37 \\
6.01 \\
5.71 \\
5.42 \\
5.15\end{array}$ & $\begin{array}{r}123 \\
178 \\
554 \\
1,120 \\
1,930 \\
3,070 \\
4,740 \\
5,610 \\
6,400 \\
6,690 \\
6,790 \\
6,830 \\
6,650 \\
6,030 \\
5,460 \\
4,840 \\
4,380 \\
3,960 \\
3,590 \\
3,270 \\
2,910 \\
2,640 \\
2,380 \\
2,160\end{array}$ & $\begin{array}{l}4.92 \\
4.70 \\
4.51 \\
4.35 \\
4.19 \\
4.04 \\
3.92 \\
3.81 \\
3.70 \\
3.60 \\
3.51 \\
3.44 \\
3.38 \\
3.33 \\
3.32 \\
3.36 \\
3.36 \\
3.33 \\
3.28 \\
3.22 \\
3.17 \\
3.14 \\
3.06 \\
2.97\end{array}$ & $\begin{array}{r}1,980 \\
1,800 \\
1,650 \\
1,520 \\
1,390 \\
1,290 \\
1,200 \\
1,130 \\
1,050 \\
980 \\
917 \\
868 \\
826 \\
791 \\
784 \\
812 \\
812 \\
791 \\
758 \\
722 \\
692 \\
674 \\
626 \\
572\end{array}$ & $\begin{array}{l}2.90 \\
2.83 \\
2.79 \\
2.73 \\
2.68 \\
2.66 \\
2.63 \\
2.60 \\
2.59 \\
2.59 \\
2.60 \\
2.62 \\
2.60 \\
2.57 \\
2.57 \\
2.58 \\
2.59 \\
2.58 \\
2.57 \\
2.57 \\
2.56 \\
2.54 \\
2.52 \\
2.50\end{array}$ & $\begin{array}{l}530 \\
492 \\
470 \\
440 \\
415 \\
405 \\
390 \\
375 \\
370 \\
370 \\
375 \\
385 \\
375 \\
362 \\
362 \\
366 \\
370 \\
366 \\
362 \\
362 \\
357 \\
348 \\
339 \\
330\end{array}$ \\
\hline & \multicolumn{2}{|c|}{ January 28} & \multicolumn{2}{|c|}{ January 29} & \multicolumn{2}{|c|}{ Ianuary 30} & \multicolumn{2}{|c|}{ January 31} & \multicolumn{2}{|c|}{ February 1} & \multicolumn{2}{|c|}{ February 2} \\
\hline \multirow{6}{*}{$\begin{array}{c}2 \mathrm{a} . \mathrm{m} . \\
4 \\
6 \\
8 \\
10 \\
12 \mathrm{n} . \\
2 \mathrm{p.m} . \\
4 \\
6 \\
8 \\
10 \\
12 \mathrm{~m} .\end{array}$} & 2.41 & 292 & 2.16 & 202 & 2.10 & 183 & \multirow{6}{*}{$\begin{array}{l}2.12 \\
2.12 \\
2.13 \\
2.16 \\
2.23 \\
2.37 \\
2.56 \\
2.60 \\
2.56 \\
2.50 \\
2.45 \\
2.41\end{array}$} & \multirow{6}{*}{$\begin{array}{l}189 \\
189 \\
192 \\
202 \\
224 \\
276 \\
357 \\
375 \\
357 \\
330 \\
309 \\
292\end{array}$} & 2.31 & 253 & 2.03 & 164 \\
\hline & 2.28 & 242 & 2.10 & 183 & 2.09 & 180 & & & 2.21 & 218 & 1.98 & 151 \\
\hline & 2.31 & 253 & 2.15 & 198 & 2.08 & 178 & & & 2.17 & 205 & 2.03 & 164 \\
\hline & 2.30 & 249 & 2.12 & 189 & 2.11 & 186 & & & 2.18 & 208 & 2.03 & 164 \\
\hline & 2.31 & 253 & 2.12 & 189 & 2.14 & 195 & & & 2.21 & 218 & 2.10 & 183 \\
\hline & 2.23 & 224 & 2.11 & 186 & 2.13 & 192 & & & 2.09 & 180 & 2.06 & $172^{-}$ \\
\hline
\end{tabular}

NAUGATUCK RIVER NEAR NAUGATUCK, CONN.

Location.-Lat. $41^{\circ} 28^{\prime} 15^{\prime \prime}$, long. $73^{\circ} 03^{\prime} 10^{\prime \prime}$, 0.2 mile upstream from Beacon Hill Brook, 1.3 miles downstream from Naugatuck, New Haven County, and 12 miles upstream from mouth. Datum of gage is 155.17 feet above mean sea level (general adjustment of 1929).

DrainaGe AREA.-246.square miles.

GAGE-HEIGHT RECORD.-Water-stage recorder graph. Adjustments made for intake lag for periods Jan. 7, Jan. 20 to 3 p.m. Jan. 22, 1 to 3 a.m. Jan. 25.

STAGE-DISCHARGE RELATION.-Defined by current-meter measurements below 4,700 second-feet; extended logarithmically to peak stage on basis of comparison with records for flood of September 1938 at stations on Leadmine Brook near Thomaston and Naugatuck River near Thomaston.

Maxima.-January 1938: Discharge, 14,200 second-feet noon Jan. 25 (gage height, 11.24 feet).

1918-24; 1928 to December 1937: Gage-height, 12.08 feet Apr. 7, 1924 (discharge uncertain; previously published figure probably too low).

Flood of November 1927 reached a stage of about 14 feet (discharge, about 18,300 second-feet).

Remarks.-Discharge affected by storage in Wigwam and Morris Reservoirs (see record for Branch of Naugatuck River at outlet of Wigwam Reservoir, near Thomaston, Conn.). 
Mean discharge, in second-feet, 1938

\begin{tabular}{|c|c|c|c|c|c|c|c|c|c|c|c|}
\hline Day & Jan. & Feb. & Day & Jan. & Teb. & Day & Tan. & Feh. & Daty & Jan. & Feb. \\
\hline $\begin{array}{l}1 \ldots \ldots \\
2 \ldots \\
3 \\
4 \\
4 \\
5 \\
6 \ldots \ldots \\
7 \\
7 \\
8\end{array} \ldots$ & $\begin{array}{r}338 \\
405 \\
392 \\
338 \\
334 \\
313 \\
1,600 \\
1,820\end{array}$ & $\begin{array}{r}787 \\
581 \\
670 \\
975 \\
727 \\
637 \\
1,600 \\
924\end{array}$ & $\begin{array}{c}9 \\
10 \\
11 \ldots \\
12 \\
13 \ldots \\
14 \ldots \\
15 \ldots \\
16 \ldots\end{array}$ & $\begin{array}{l}917 \\
642 \\
528 \\
472 \\
462 \\
462 \\
418 \\
367\end{array}$ & $\begin{array}{l}727 \\
721 \\
563 \\
528 \\
6135 \\
700 \\
621 \\
462\end{array}$ & $\begin{array}{l}17 \ldots- \\
18 \ldots \\
19 \ldots \\
20 \ldots \\
21 \ldots \\
22 \ldots- \\
23 \ldots \\
24 \ldots\end{array}$ & $\begin{array}{l}414 \\
367 \\
2 \times 7 \\
300 \\
320 \\
350 \\
344 \\
362\end{array}$ & $\begin{array}{l}427 \\
431 \\
462 \\
485 \\
427 \\
397 \\
431 \\
495\end{array}$ & $\begin{array}{l}25 \\
26 \ldots \\
27 \ldots \\
28 \ldots \\
29 \ldots \\
30 \ldots \\
31 \ldots\end{array}$ & $\begin{array}{r}7.920 \\
2.830 \\
1.280 \\
832 \\
676 \\
6614 \\
864\end{array}$ & $\begin{array}{l}467 \\
397 \\
384 \\
311\end{array}$ \\
\hline \multicolumn{10}{|c|}{$\begin{array}{l}\text { Monthly mean discharge, in second-feet } \\
\text { Runoff, in inches. }\end{array}$} & $\begin{array}{r}893 \\
4.18\end{array}$ & $\begin{array}{r}610 \\
2.58\end{array}$ \\
\hline
\end{tabular}

Gage height, in feet, and discharge, in second-feet, at indicated time, 1938 .

\begin{tabular}{|c|c|c|c|c|c|c|c|c|c|c|c|c|}
\hline \multirow[b]{2}{*}{ Hour } & Feet & Sec, $-\mathrm{ft}$. & Feet & sec. $-\mathrm{ft}$ & Ieet & Sec.tit. & Ftct & Eect-it. & Fect & ser.ft. & Feet & Sec.-ft. \\
\hline & \multicolumn{2}{|c|}{ January 22} & \multicolumn{2}{|c|}{ January 23} & \multicolumn{2}{|c|}{ January 24} & \multicolumn{2}{|c|}{ January 25} & \multicolumn{2}{|c|}{ Jannary 26} & \multicolumn{2}{|c|}{ Jamuary 27} \\
\hline $\begin{array}{c}1 \mathrm{a} . \mathrm{m} . \\
2 \\
3 \\
4 \\
5 \\
6 \\
7 \\
8 \\
9 \\
10 \\
11 \\
12 \mathrm{n} . \\
1 \mathrm{p.m} . \\
2 \\
3 \\
4 \\
5 \\
6 \\
7 \\
8 \\
9 \\
10 \\
11 \\
12 \mathrm{~m} .\end{array}$ & 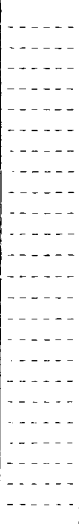 & 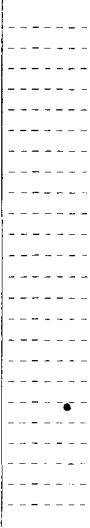 & 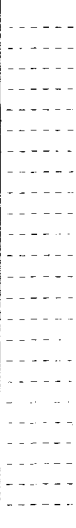 & 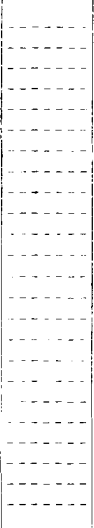 & $\begin{array}{l}1.39 \\
1.38 \\
1.37 \\
1.36 \\
1.34 \\
1.34 \\
1.33 \\
1.33 \\
1.34 \\
1.33 \\
1.34 \\
1.36 \\
1.43 \\
1.45 \\
1.45 \\
1.45 \\
1.45 \\
1.47 \\
1.48 \\
1.48 \\
1.49 \\
1.61 \\
1.77 \\
2.01\end{array}$ & $\begin{array}{l}342 \\
338 \\
334 \\
330 \\
321 \\
321 \\
317 \\
317 \\
321 \\
317 \\
321 \\
330 \\
359 \\
367 \\
367 \\
347 \\
367 \\
375 \\
380 \\
380 \\
384 \\
436 \\
509 \\
632\end{array}$ & $\begin{array}{rr}3 & 32 \\
2 & 70 \\
3 & 10 \\
4 & 40 \\
5 & 30 \\
6 & 38 \\
8 & 20 \\
9 & 46 \\
10 & 14 \\
10 & 72 \\
11 & 14 \\
11 & 24 \\
10 & 98 \\
10 & 52 \\
9 & 98 \\
9 & 44 \\
5 & 95 \\
8 & 38 \\
7 & 97 \\
7 & 58 \\
7 & 24 \\
6 & 92 \\
6 & 192 \\
6 & 36 \\
1\end{array}$ & 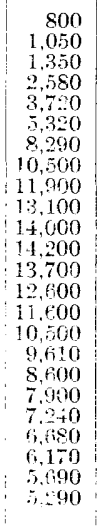 & $\begin{array}{l}6.10 \\
5.88 \\
5.67 \\
5.48 \\
5.30 \\
5.12 \\
4.96 \\
4.89 \\
4.66 \\
4.53 \\
4.40 \\
4.29 \\
4.18 \\
4.10 \\
4.04 \\
3.97 \\
3.93 \\
3.87 \\
3.83 \\
3.80 \\
3.74 \\
3.67 \\
3.60 \\
3.53\end{array}$ & $\begin{array}{l}4,900 \\
4,570 \\
4,260 \\
3,970 \\
3,720 \\
3,470 \\
3,260 \\
3,050 \\
2,880 \\
2,730 \\
2,580 \\
2,160 \\
2,240 \\
2,260 \\
2,200 \\
2,130 \\
2,090 \\
2,030 \\
1,990 \\
1,960 \\
1,900 \\
1,830 \\
1,770 \\
1,710\end{array}$ & $\begin{array}{l}3.46 \\
3.38 \\
3.29 \\
3.20 \\
3.14 \\
3.08 \\
3.02 \\
3.00 \\
2.96 \\
2.95 \\
2.94 \\
2.93 \\
2.94 \\
2.96 \\
2.97 \\
2.96 \\
2.96 \\
2.94 \\
2.90 \\
2.88 \\
2.86 \\
2.84 \\
2.80 \\
2.75\end{array}$ & $\begin{array}{l}1,640 \\
1,570 \\
1,490 \\
1,420 \\
1,370 \\
1,320 \\
1,280 \\
1,260 \\
1,230 \\
1,220 \\
1,210 \\
1,200 \\
1,210 \\
1,230 \\
1,240 \\
1,230 \\
1,230 \\
1,210 \\
1,180 \\
1,170 \\
1,150 \\
1,140 \\
1,110 \\
1,950\end{array}$ \\
\hline $12 \mathrm{~m}$ & \multicolumn{2}{|c|}{ January 28} & \multicolumn{2}{|c|}{ January 29} & \multicolumn{2}{|c|}{ Jannary 30} & \multicolumn{2}{|c|}{ innuary 31} & \multicolumn{2}{|c|}{ I'ctiruary 1} & \multicolumn{2}{|c|}{ 1 utruary 2} \\
\hline $\begin{array}{c}2 \text { a.m. } \\
4 \\
6 \\
8 \\
10 \\
12 \mathrm{n} . \\
2 \mathrm{p} . \mathrm{m} . \\
4 \\
6 \\
8 \\
10 \\
12 \mathrm{~m} .\end{array}$ & $\begin{array}{l}2.66 \\
2.56 \\
2.48 \\
2.42 \\
2.39 \\
2.33 \\
2.37 \\
2.45 \\
2.44 \\
2.39 \\
2.32 \\
2.26\end{array}$ & $\begin{array}{r}1,010 \\
951 \\
409 \\
867 \\
849 \\
814 \\
837 \\
885 \\
879 \\
849 \\
808 \\
773\end{array}$ & $\begin{array}{l}2.19 \\
2.12 \\
2.05 \\
2.00 \\
1.96 \\
2.00 \\
2.05 \\
2.10 \\
2.14 \\
2.15 \\
2.14 \\
2.10\end{array}$ & $\begin{array}{l}732 \\
692 \\
654 \\
626 \\
605 \\
620 \\
67.1 \\
681 \\
704 \\
710 \\
704 \\
681\end{array}$ & $\begin{array}{l}2.08 \\
2.09 \\
2.05 \\
2.04 \\
2.04 \\
2.04 \\
2.05 \\
2.00 \\
2.07 \\
2.10 \\
2.12 \\
2.12\end{array}$ & $\begin{array}{l}670 \\
659 \\
654 \\
625 \\
6-13 \\
648 \\
6.74 \\
630 \\
664 \\
681 \\
66+2 \\
692\end{array}$ & $\begin{array}{l}2.11 \\
2.10 \\
2.11 \\
2.15 \\
2.23 \\
2.45 \\
2.56 \\
2.58 \\
2.73 \\
2.77 \\
2.71 \\
2.63 \\
\end{array}$ & $\begin{array}{r}687 \\
681 \\
687 \\
710 \\
755 \\
885 \\
951 \\
963 \\
1,060 \\
1.090 \\
1.050 \\
994\end{array}$ & $\begin{array}{ll}2 & 64 \\
2 & 44 \\
2 & 37 \\
2 & 30 \\
2 & .23 \\
2 & 23 \\
2 & .24 \\
2 & 22 \\
2 & 17 \\
2 & 17 \\
2 & 13 \\
2 & .06\end{array}$ & $\begin{array}{l}939 \\
879 \\
837 \\
796 \\
755 \\
755 \\
761 \\
750 \\
721 \\
721 \\
698 \\
659\end{array}$ & $\begin{array}{l}1.90 \\
1.90 \\
1.84 \\
1.80 \\
1.80 \\
1.82 \\
1.88 \\
2.00 \\
1.98 \\
1.90 \\
1.97 \\
1.94\end{array}$ & $\begin{array}{l}621 \\
573 \\
543 \\
523 \\
523 \\
523 \\
5133 \\
626 \\
615 \\
621 \\
610 \\
594\end{array}$ \\
\hline
\end{tabular}

IFADMINE BROOK NEAR THOMASTON, CONN.

Location.-Lat. $41^{\circ} 42^{\prime} 10^{\prime \prime}$, long. $73^{\circ} 03^{\prime} 36^{\prime \prime}$, at highway bridge half a mile upstream from mouth and $2 \frac{1 / 4}{4}$ miles northeast of Thomaston, Litchfield County. Datum of gage is 401.23 feet above mean sea level (general adjustment of 1929).

Drainage area.-24.0 square miles.

GAGE-HEIGHT RECORD.-Water-stage recorder graph except for periods Jan. 28 $748116-48-8$ 
to Feb. 3 when float was frozen in well and Feb. 5-8 when clock was stopped.

Stage-discharge relation.-Defined by current-meter measurements below 500 second-feet; extended to peak stage on basis of logarithmic plotting and comparison with records for stations on Naugatuck River. Affected by ice Jan. 4, 5, Jan. 10 to 3 p.m. Jan. 23, Feb. 16, 17, 21, 22, 26-28.

Maxima.-January 1938: Discharge, 2,640 second-feet 9 a.m. Jan. 25 (gage height, 10.35 feet).

1930 to December 1937: Discharge, about 2,800 second-feet Sept. 17, 1934 (gage height 11.2 feet; from floodmarks).

REMARKs.-Flood discharge not affected by artificial storage.

Mean discharge, in second-feet, 1938

\begin{tabular}{|c|c|c|c|c|c|c|c|c|c|c|c|}
\hline Day & Jan. & Feb. & Day & Jan. & Feb. & Day & Jan. & Feb. & Day & Jan. & Feb. \\
\hline $\begin{array}{l}1 \\
2 \\
3 \\
4 \\
4 \\
5 \\
6 \\
7 \\
8\end{array}$ & $\begin{array}{r}27 \\
33 \\
27 \\
26 \\
26 \\
24 \\
276 \\
157\end{array}$ & $\begin{array}{r}80 \\
55 \\
60 \\
85 \\
70 \\
60 \\
240 \\
95\end{array}$ & $\begin{array}{r}9 \\
10_{\ldots} \\
11 \\
12 \ldots \\
13_{\ldots} \\
14 \ldots \\
15_{\ldots} \\
16 \ldots\end{array}$ & $\begin{array}{l}78 \\
60 \\
50 \\
44 \\
42 \\
38 \\
34 \\
32\end{array}$ & $\begin{array}{l}73 \\
73 \\
54 \\
51 \\
68 \\
78 \\
57 \\
44\end{array}$ & $\begin{array}{l}17 \ldots \\
18 \ldots \\
19 \ldots \\
20 \ldots \\
21 \ldots \\
22 \ldots \\
23 \ldots \\
24 \ldots\end{array}$ & $\begin{array}{l}30 \\
28 \\
26 \\
28 \\
32 \\
34 \\
32 \\
29\end{array}$ & $\begin{array}{l}38 \\
39 \\
46 \\
41 \\
38 \\
36 \\
41 \\
43\end{array}$ & $\begin{array}{l}25 \ldots \\
26 \ldots \\
27 \ldots \\
28 \ldots \\
29 \\
30 \ldots \\
31\end{array}$ & $\begin{array}{r}1,210 \\
264 \\
134 \\
85 \\
70 \\
65 \\
95\end{array}$ & $\begin{array}{l}39 \\
32 \\
32 \\
22\end{array}$ \\
\hline \multicolumn{10}{|c|}{$\begin{array}{l}\text { Monthly mean discharge, in second-feet. } \\
\text { Runoff, in inches. }\end{array}$} & $\begin{array}{r}101 \\
4.85\end{array}$ & $\begin{array}{l}60.4 \\
2.62\end{array}$ \\
\hline
\end{tabular}

Gage height, in feet, and discharge, in second-feet, at indicated time, 1938

\begin{tabular}{|c|c|c|c|c|c|c|c|c|c|c|c|c|}
\hline \multirow[b]{2}{*}{ Hour } & Feet & Sec.-ft. & Feet & Sec. $-\mathrm{ft}$. & Feet & Sec.-ft. & Feet & Sec.-ft. & Feet & Sec.-ft. & Feet & Sec.-ft. \\
\hline & \multicolumn{2}{|c|}{ January 22} & \multicolumn{2}{|c|}{ January 23} & \multicolumn{2}{|c|}{ January 24} & \multicolumn{2}{|c|}{ January 25} & \multicolumn{2}{|c|}{ January 26} & \multicolumn{2}{|c|}{ January 27} \\
\hline $\begin{array}{c}1 \text { a.m. } \\
2 \\
3 \\
4 \\
5 \\
6 \\
7 \\
8 \\
9 \\
10 \\
11 \\
12 \mathrm{n} . \\
1 \mathrm{p} . \mathrm{m} . \\
2 \\
3 \\
4 \\
5 \\
6 \\
7 \\
8 \\
9 \\
10 \\
11 \\
12 \mathrm{~m} .\end{array}$ & 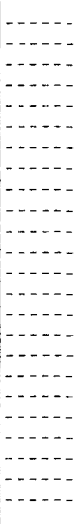 & 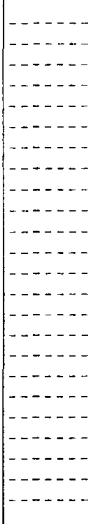 & 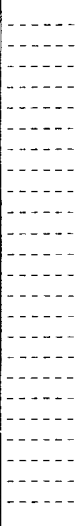 & 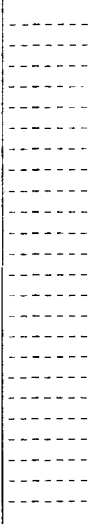 & $\begin{array}{c}2.86 \\
2.84 \\
2.82 \\
2.81 \\
2.82 \\
2.88 \\
2.87 \\
2.85 \\
2.84 \\
2.84 \\
2.87 \\
3.08\end{array}$ & 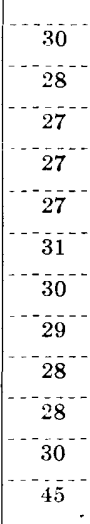 & $\begin{array}{r}3.46 \\
4.05 \\
4.43 \\
5.45 \\
6.90 \\
8.70 \\
9.50 \\
10.15 \\
10.35 \\
9.95 \\
9.60 \\
8.95 \\
8.25 \\
7.75 \\
7.35 \\
7.02 \\
6.76 \\
6.51 \\
6.28 \\
6.07 \\
5.88 \\
5.71 \\
5.56 \\
5.43\end{array}$ & $\begin{array}{r}83 \\
166 \\
237 \\
518 \\
1,060 \\
1,840 \\
2,220 \\
2,540 \\
2,640 \\
2,440 \\
2,270 \\
1,950 \\
1,630 \\
1,410 \\
1,240 \\
1,110 \\
1,000 \\
904 \\
812 \\
734 \\
668 \\
608 \\
556 \\
510\end{array}$ & 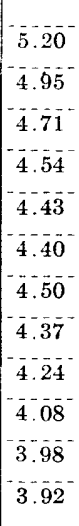 & 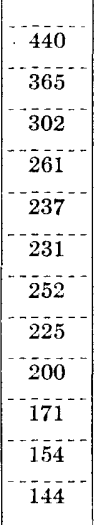 & 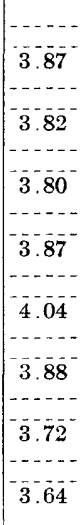 & \begin{tabular}{|c}
136 \\
$-129^{-1}$ \\
126 \\
136 \\
164 \\
138 \\
115 \\
104
\end{tabular} \\
\hline
\end{tabular}

Supplemental records.-Jan. 25, 3:45 a.m., 6.22 feet, $7: 15$ a.m., 10.05 ft., 2,500 sec.-ft.

\section{BRANCH OF NAUGATUCK RIVER AT OUTLET OF WIGWAM RESERVOIR, NEAR THOMASTON, CONN.}

Location.-Nonrecording gage and venturi meter at dam, lat. $41^{\circ} 39^{\prime} 45^{\prime \prime}$, long. $73^{\circ} 07^{\prime} 35^{\prime \prime}, 2 \frac{1 / 2}{2}$ miles west of Thomaston, Litchfield County, and 3 miles upstream from mouth. 
Drainage area.-18.0 square miles.

GAGE-HEIGHT RECORD.-Three reservoir gage readings daily; gage height at midnight determined from graph constructed from gage readings.

Stage-discharge Relation.-Observed discharge computed from flow over spillways and through venturi meter.

Maxima.-January 1938: Discharge, 3,100 second-feet about 8 a.m. (from graph based on gage readings).

Remarks.-Daily and monthly mean discharges adjusted for change in contents of Wigwam and Morris Reservoirs. No corrections for evaporation from reservoir surfaces. Basic data furnished by Bureau of Engineering, city of Waterbury.

Discharge, in second-feet, and change in contents, in equivalent second-feet, 1938

\begin{tabular}{|c|c|c|c|c|c|c|}
\hline \multirow[b]{2}{*}{ Day } & \multicolumn{3}{|c|}{ January } & \multicolumn{3}{|c|}{ February } \\
\hline & Observed & $\begin{array}{l}\text { Change in } \\
\text { contents }\end{array}$ & Adjusted & Observed & $\begin{array}{l}\text { Change in } \\
\text { contents }\end{array}$ & Adjusted \\
\hline $\begin{array}{r}1 \\
2 \\
3 \\
4 \\
5 \\
6 \\
7 \\
8 \\
9 \\
10 \\
11 \\
12 \\
13 \\
14 \\
15 \\
16 \\
17 \\
18 \\
19 \\
20 \\
21 \\
22 \\
23 \\
24 \\
25 \\
26 \\
27 \\
28 \\
29 \\
30 \\
31\end{array}$ & $\begin{array}{r}25 \\
17 \\
20 \\
19 \\
19 \\
17 \\
198 \\
100 \\
71 \\
52 \\
26 \\
24 \\
26 \\
24 \\
23 \\
21 \\
21 \\
21 \\
19 \\
19 \\
18 \\
21 \\
23 \\
23 \\
1,240 \\
142 \\
60 \\
36 \\
29 \\
30 \\
38\end{array}$ & $\begin{array}{c}+2 \\
-1 \\
-2 \\
-2 \\
-2 \\
-2 \\
+50 \\
+20 \\
-2 \\
-8 \\
-6 \\
-2 \\
+1 \\
+1 \\
-2 \\
-3 \\
-0 \\
-1 \\
-3 \\
-1 \\
-1 \\
+0 \\
+1 \\
+1 \\
-1 \\
+10 \\
+64 \\
+53 \\
-11 \\
-5 \\
-5 \\
-2 \\
+2 \\
+3\end{array}$ & $\begin{array}{r}27 \\
16 \\
18 \\
17 \\
17 \\
15 \\
248 \\
74 \\
63 \\
46 \\
24 \\
25 \\
27 \\
22 \\
20 \\
21 \\
20 \\
18 \\
18 \\
19 \\
19 \\
22 \\
22 \\
33 \\
1,300 \\
89 \\
49 \\
31 \\
27 \\
32 \\
41\end{array}$ & $\begin{array}{r}29 \\
24 \\
29 \\
72 \\
36 \\
45 \\
122 \\
47 \\
42 \\
42 \\
29 \\
23 \\
35 \\
48 \\
29 \\
24 \\
21 \\
21 \\
26 \\
27 \\
23 \\
21 \\
22 \\
26 \\
26 \\
22 \\
20 \\
17 \\
-- \\
-- \\
--\end{array}$ & $\begin{array}{c}-1 \\
-4 \\
+37 \\
-27 \\
-6 \\
+21 \\
-12 \\
-6 \\
0.0 \\
0.0 \\
-4 \\
+1 \\
+8 \\
-5 \\
-5 \\
-3 \\
-1 \\
+1 \\
+3 \\
+3 \\
0.0 \\
-2 \\
0.0 \\
+1 \\
+3 \\
-1 \\
-3 \\
0.0 \\
-5\end{array}$ & $\begin{array}{r}28 \\
20 \\
66 \\
45 \\
30 \\
66 \\
110 \\
41 \\
42 \\
42 \\
25 \\
24 \\
43 \\
43 \\
24 \\
21 \\
20 \\
22 \\
29 \\
27 \\
21 \\
21 \\
23 \\
29 \\
25 \\
19 \\
20 \\
12 \\
- \\
- \\
--\end{array}$ \\
\hline \multicolumn{5}{|c|}{ - } & January & February \\
\hline \multicolumn{5}{|c|}{$\begin{array}{l}\text { Monthly mean discharge, in second-feet (observed) } \\
\text { Runoff, in inches (observed) } \\
\text { Monthly mean discharge, in second-feet (adjusted) } \\
\text { Runoff, in inches (adjusted) }\end{array}$} & $\begin{array}{l}78.1 \\
5.00 \\
78.1 \\
5.00\end{array}$ & $\begin{array}{l}33.9 \\
1.96 \\
33.5 \\
1.94\end{array}$ \\
\hline
\end{tabular}

SAUGATUCK RIVER BASIN

\section{SAUGATUCK RTVER NEAR WESTPORT, CONN.}

Location.-Lat. $41^{\circ} 10^{\prime} 15^{\prime \prime}$, long. $72^{\circ} 22^{\prime} 00^{\prime \prime}$, on old Ford Road (Clinton), 400 feet downstream from West Branch of Saugatuck River, 600 feet downstream from dam of Dorr Co., and 2 miles north of Westport, Fairfield County.

Drainage AREA.-77.5 square miles.

GAGE-HEIGHT RECORD.-Water-stage recorder graph. 
Stage-discharge Relation.--Defined by current-meter measurements below 1,700 second-feet; extended to peak stage on basis of September $1938 \mathrm{flood}$ flow determination at Dorr Co.'s dam. Affected by ice Jan. 1-6, 16-22, 6 p.m. Jan. 27 to 2 p.m. Jan. 28, 7 p.m. to m. Jan. 28, 7 p.m. Feb. 2 to Feb.3. Maxima.-January 1938: Discharge, 2,230 second-feet 5 p.m. Jan. 25 (gage height, 7.63 feet).

1932 to December 1937: Discharge, 5,310 second-feet Mar. 12, 1936 (gage height, 11.30 feet).

Remarks.-Bridgeport Hydraulic Co. occasionally diverts the flow from 17 square miles of the Aspetuck River Basin. Water for diversion is stored in Aspetuck Reservoir and diverted by canal into Hemlocks Reservoir in Mill River Basin from which it is released for water supply. Daily and monthly mean discharges not adjusted for diversion. Runoff computations are based on total drainage area above station.

Mean discharge, in second-feet, 1938

\begin{tabular}{|c|c|c|c|c|c|c|c|c|c|c|c|}
\hline Day & Jan. & Teh. & Day & Itan. & Feb. & Day & Ian. & Feb. & Day & Jan. & Feb. \\
\hline $\begin{array}{l}1 \ldots \ldots \\
2 \ldots \ldots \\
3 \ldots \ldots \\
4 \ldots \ldots \\
5 \ldots \ldots \\
6 \ldots \ldots \\
7 \ldots \ldots \\
8 \ldots \ldots\end{array}$ & $\begin{array}{r}110 \\
100 \\
95 \\
95 \\
85 \\
85 \\
631 \\
631\end{array}$ & $\begin{array}{l}316 \\
231 \\
250 \\
375 \\
282 \\
250 \\
351 \\
293\end{array}$ & 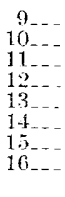 & $\begin{array}{l}345 \\
2100 \\
120 \\
192 \\
192 \\
180 \\
142 \\
140\end{array}$ & $\begin{array}{l}245 \\
247 \\
204 \\
188 \\
223 \\
288 \\
229 \\
177\end{array}$ & $\begin{array}{l}17 \ldots \\
18 \ldots \\
19 \ldots \\
20 \ldots \\
21 \ldots \\
22 \ldots \\
23 \ldots \\
24 \ldots\end{array}$ & $\begin{array}{l}130 \\
110 \\
100 \\
100 \\
100 \\
110 \\
119 \\
118\end{array}$ & $\begin{array}{l}151 \\
163 \\
161 \\
239 \\
188 \\
163 \\
181 \\
232\end{array}$ & $\mid \begin{array}{l}25 \ldots \\
26 \ldots \\
27 \\
28 \ldots \\
29 \ldots \\
30 \ldots \\
31 \ldots \\
\end{array}$ & $\begin{array}{r}1,420 \\
1,100 \\
541 \\
367 \\
302 \\
281 \\
327\end{array}$ & $\begin{array}{l}204 \\
163 \\
155 \\
135\end{array}$ \\
\hline \multicolumn{11}{|c|}{ 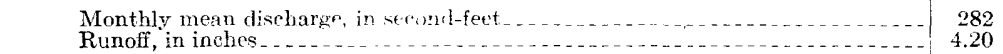 } & $\begin{array}{r}225 \\
3.02\end{array}$ \\
\hline
\end{tabular}

Gage-height, in feet, and distharge, in second-feet, at indicated time, 1938

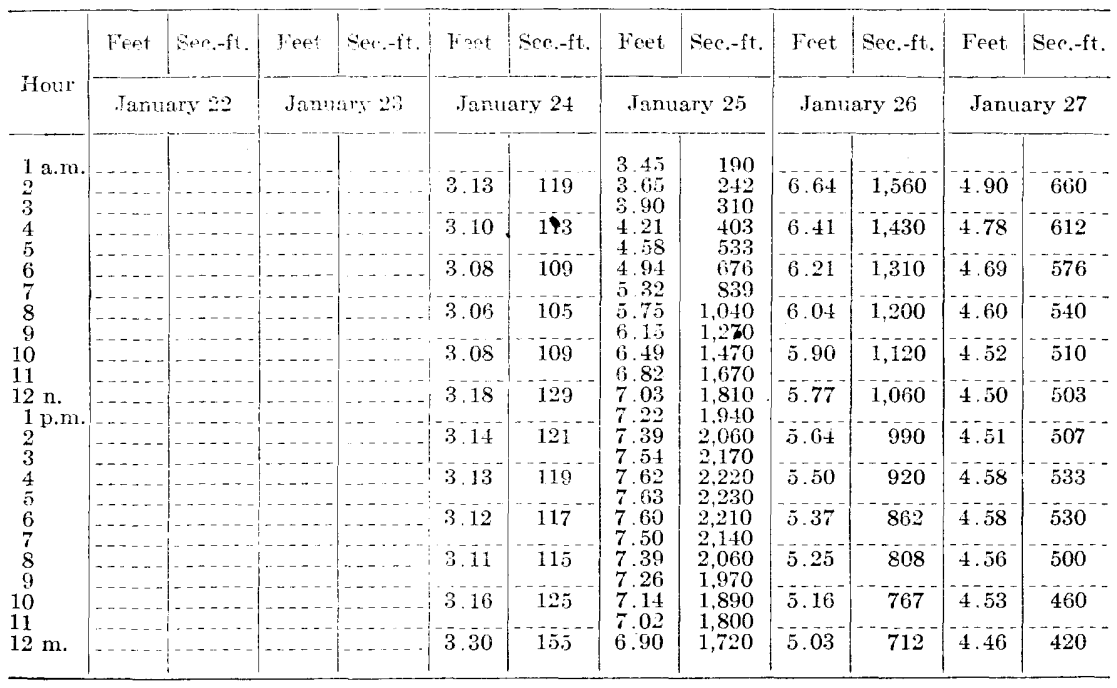


Gage-height, in feet, and discharge, in second-feet, at indicated time, 1938-Continued

\begin{tabular}{|c|c|c|c|c|c|c|c|c|c|c|c|c|}
\hline \multirow{2}{*}{ Hour } & Feet & Sec.-ft. & Feet & Sec.-ft. & Feet & Sec. $-\mathrm{ft}$. & Foet & Sec.-ft. & Feet & Sec.-ft. & Feet & Sec.-ft. \\
\hline & \multicolumn{2}{|c|}{ January 28} & \multicolumn{2}{|c|}{ January 29} & \multicolumn{2}{|c|}{ January 30} & \multicolumn{2}{|c|}{ Janiuary 31} & \multicolumn{2}{|c|}{ February 1} & \multicolumn{2}{|c|}{ February 2} \\
\hline 2 a.n & 4.34 & 390 & 3.89 & 307 & & & & & & & & \\
\hline & 4.24 & 370 & 3.84 & 293 & 3.82 & 288 & 3.79 & 279 & 4.05 & 354 & 3.54 & 214 \\
\hline $\begin{array}{l}6 \\
8\end{array}$ & $\begin{array}{l}4.18 \\
4.11\end{array}$ & $\begin{array}{l}350 \\
340\end{array}$ & $\begin{array}{l}3.82 \\
3.81\end{array}$ & $\begin{array}{l}288 \\
285\end{array}$ & 3.78 & 277 & 380 & 282 & 3.90 & 310 & 3.49 & 202 \\
\hline 10 & 4.08 & 340 & 3.81 & 285 & & & & & & & & \\
\hline $\begin{array}{r}12 \mathrm{n} . \\
2 \mathrm{p} . \mathrm{m} .\end{array}$ & 4.08 & 350 & 3.83 & 290 & 3.78 & 277 & 3.91 & 313 & 3.85 & 296 & 360 & 220 \\
\hline 4 & $\begin{array}{l}4.10 \\
4.22\end{array}$ & $\begin{array}{l}380 \\
407\end{array}$ & $\begin{array}{l}0.00 \\
3.94\end{array}$ & $\begin{array}{l}324 \\
322\end{array}$ & 3.78 & 277 & 4.09 & 366 & 3.95 & 324 & 3.76 & $27 \overline{1}$ \\
\hline $\begin{array}{l}6 \\
8\end{array}$ & 4.20 & 400 & 3.96 & $\begin{array}{l}327 \\
313\end{array}$ & 3.80 & 282 & 4.16 & 388 & 3.81 & 293 & 3.70 & 245 \\
\hline $\begin{array}{l}8 \\
10\end{array}$ & $\begin{array}{l}4.13 \\
4.06\end{array}$ & $\begin{array}{l}54 \\
34\end{array}$ & $\begin{array}{l}3.9 \\
3.8\end{array}$ & $\begin{array}{l}313 \\
304\end{array}$ & & & & & & & & $2+3$ \\
\hline $12 \mathrm{~m}$. & 3.96 & 320 & 3.84 & 293 & 3.50 & 282 & 4.14 & 381 & 3.70 & 255 & 3.68 & 230 \\
\hline
\end{tabular}

\section{SUMMARY OF FLOOD DISCHARGES}

Maximum discharges at all gaging stations and at other places on streams in Connecticut where the peak discharge was determined are presented in table 8 . Reference should be made to the introductory "General description of information," particularly pages 9 to 12, for an outline of the data given in this table. Records in table 8 compare only the flood of January 1938 with that of the previous maximum of record. For detailed information of other notable floods in this area the reader may refer to Water-Supply Paper 162, which includes a brief description of the flood of July 1905 on the Pepuonnock River, Conn.; WaterSupply Paper 636-C, The New England flood of November 1927; Water-Supply Paper 798, The floods of March 1936, part I, New England Rivers; Water-Supply Paper 836-A, Stages and flood discharges of the Connecticut River at Hartford, Conn.; and Water-Supply Paper 867, Hurricane floods of. September 1938. Water-Supply Papers 798 and 867 also contain detailed accounts and comparisons of many historic floods. This information is not repeated in this report. 


\begin{tabular}{|c|c|c|c|c|c|c|c|c|c|}
\hline \multirow{3}{*}{$\begin{array}{c}\text { No. } \\
\text { on } \\
\text { pl. } 12\end{array}$} & \multirow{3}{*}{ Stream and place of determination } & \multirow{3}{*}{$\begin{array}{c}\text { Drainage } \\
\text { area } \\
\text { square } \\
\text { miles }\end{array}$} & \multirow{3}{*}{$\begin{array}{c}\text { Period } \\
\text { of record }\end{array}$} & \multirow{2}{*}{\multicolumn{2}{|c|}{$\begin{array}{l}\text { Maximum discharge } \\
\text { prior to January } 1938\end{array}$}} & \multicolumn{4}{|c|}{ Maximum discharge during flood of January 1938} \\
\hline & & & & & & \multirow[b]{2}{*}{ Time } & \multirow[b]{2}{*}{$\begin{array}{c}\text { Second- } \\
\text { feet }\end{array}$} & \multirow{2}{*}{$\begin{array}{c}\text { Second- } \\
\text { feet } \\
\text { per } \\
\text { square } \\
\text { mile }\end{array}$} & \multirow{2}{*}{$\begin{array}{c}\text { Method } \\
\text { of } \\
\text { determination }\end{array}$} \\
\hline & & & & Date & $\begin{array}{c}\text { Second- } \\
\text { feet }\end{array}$ & & & & \\
\hline $\begin{array}{l}264 \\
267\end{array}$ & $\begin{array}{l}\text { Thames River Basin } \\
\text { Willimantic River near South Coventry } \\
\text { Shetucket River near Willimantic } . . .\end{array}$ & $\begin{array}{l}121 \\
401\end{array}$ & $\begin{array}{l}1931-38 \\
1904-05\end{array}$ & Mar. 12,1936 & $\begin{array}{r}7,880 \\
23,900\end{array}$ & $\begin{array}{l}\text { Jan. } 25,7 \text { p.m. } \\
\text { Jan. } 26,2 \text { a.m. }\end{array}$ & $\begin{array}{r}3,770 \\
12,600\end{array}$ & $\begin{array}{l}31.2 \\
31.4\end{array}$ & $\begin{array}{l}\text { Stage-discharge relation } \\
\text { Do. }\end{array}$ \\
\hline $\begin{array}{l}272 . \\
275 \\
282 \\
284 \\
286 \\
289 \\
290\end{array}$ & $\begin{array}{l}\text { Hop River near Columbia } \\
\text { Natchaug River at Willimantic } \\
\text { Quinebaug River at Quinebaug } \\
\text { Quinebaug River at Putham. } \\
\text { Quinebaug River at Dyer Dam, below Danielson } \\
\text { Quinebaug River at Dewett City } \\
\text { Quinebaug River at Taftrille }\end{array}$ & $\begin{array}{c}76.2 \\
169 \\
1.57 \\
331 \\
465 \\
711 \\
743\end{array}$ & $\begin{array}{l}195-38 \\
1932-38 \\
1930-38 \\
1931-38 \\
1929-38\end{array}$ & $\begin{array}{l}\text { Mar. } 18,1936 \\
\text { Mar. } 19,1936 \\
\text { Mar. } 19,1936\end{array}$ & $\begin{array}{r}3,300 \\
14,200 \\
10,500 \\
17,200 \\
29,200\end{array}$ & $\begin{array}{l}\text { Jan. } 25,4: 30 \text { p.m. } \\
\text { Jan. } 25,11 \text { p.m. } \\
\text { Jan. } 25,9: 30 \text { p.m. } \\
\text { Jan. } 25,12 \text { p.m. } \\
\text { Jan. } 26,6 \text { a.m. } \\
\text { Jan. } 26,12: 20 \text { p.m. } \\
\text { Jan. } 26,11 \text { a.m. to }\end{array}$ & $\begin{array}{r}2,970 \\
5,880 \\
3,470 \\
7,450 \\
7,260 \\
11,100 \\
12,100\end{array}$ & $\begin{array}{l}39.0 \\
34.8 \\
22.1 \\
22.5 \\
15.6 \\
15.6 \\
16.3\end{array}$ & $\begin{array}{l}\text { Do. } \\
\text { Do. } \\
\text { Do. } \\
\text { Do. } \\
\text { Flow over dam. } \\
\text { Stage-discharge relation } \\
\text { Flow over dam. }\end{array}$ \\
\hline \begin{tabular}{c|}
294 \\
295 \\
295.5 \\
298 \\
301
\end{tabular} & $\begin{array}{l}\text { French River at North Grosvenordale } \\
\text { Muddy Brook at Harrisville...... } \\
\text { Five Mile River at Killingly } \\
\text { Mosup River at Moosup } \\
\text { Yantic River at Yantic . }\end{array}$ & $\begin{array}{r}98.5 \\
36.4 \\
58.2 \\
83.5 \\
88.6\end{array}$ & $\begin{array}{l}1937-38 \\
192-38 \\
1930-38\end{array}$ & $\begin{array}{l}\text { Nov. } 29,1937 \\
\text { Mar. 12, } 1936 \\
\end{array}$ & $\begin{array}{l}730 \\
4,260 \\
6,300\end{array}$ & $\begin{array}{l}7 \text { p.m. } \\
\text { Jan. } 26,5 \text { a.m. } \\
\text { Jan. } 25,5 \text { to } 6 \text { a.m. } \\
\text { Jan. } 26,5,4 \text { to } 5 \text { p.m. } \\
\text { Jan. } 25,4 \text {. } \\
\text { Jan. } 25,4 \text { p.m. }\end{array}$ & $\begin{array}{r}1,840 \\
1825 \\
630 \\
1,380 \\
3,230\end{array}$ & $\begin{array}{l}18.7 \\
22.7 \\
10.8 \\
16.5 \\
36.5\end{array}$ & $\begin{array}{l}\text { Do. } \\
\text { Do. } \\
\text { Stage-discharge relation } \\
\text { Do. } \\
\text { Do. }\end{array}$ \\
\hline & Connecticut River Basin & & & & $\bullet$ & & & & \\
\hline $\begin{array}{l}318 \\
413 \\
416 \\
418\end{array}$ & $\begin{array}{l}\text { Conneticut River at Hartford } \\
\text { Scantic River at Broad Rrook } \\
\text { Farmington River at Riverton } \\
\text { Farmington River at Collinsville }\end{array}$ & $\left|\begin{array}{c}10,480 \\
98.4 \\
216 \\
354\end{array}\right|$ & $\begin{array}{l}1928-38 \\
1929-38\end{array}$ & $\begin{array}{l}\text { Mar. 21, } 1936 \\
\text { Mar. 13, } 1936 \\
\text { Mar. 18, } 1936\end{array}$ & $\begin{array}{r}237.6 \\
1,820 \\
19,900 \\
\end{array}$ & $\begin{array}{l}\text { Jan. } 26,11 \text { p.m. } \\
\text { Jan. } 26,6 \text { a.m. } \\
\text { Jan. } 25,11 \text { a.m. } \\
\text { Jan. } 25,1 \text { p.m. }\end{array}$ & $\begin{array}{r}319.6 \\
1,110 \\
10,200 \\
613,500\end{array}$ & $\begin{array}{c}18.4 \\
47.2 \\
38.1\end{array}$ & $\begin{array}{l}\text { Stage-discharge relation } \\
\text { Do. } \\
\text { Flow over dam. }\end{array}$ \\
\hline 419 & Farmington River at Tariffville ${ }^{5}$ & 578 & $1928-38$ & Mar. 19,1936 & 26,900 & Jan. 26,11 a.m. to & 11,900 & 20.6 & Stage-discharge relation \\
\hline $\begin{array}{l}420 \\
423 \\
427 \\
428 \\
429 \\
431\end{array}$ & $\begin{array}{l}\text { Farmington River at Rainbow } \\
\text { Burlington Brook near Burlington... } \\
\text { South Branch of Park River at Hartford } \\
\text { Park River at Hartford } \\
\text { North Branch of Park River at Hartford... } \\
\text { Hockanum River near East Hartford }\end{array}$ & \begin{tabular}{r|r|}
590 & \\
4.1 & \\
40.6 \\
74.0 \\
25.3 \\
74.5
\end{tabular} & $\begin{array}{l}1931-18 \\
1936-38 \\
-. d o-\ldots \\
1919-21 \\
190-21\end{array}$ & $\begin{array}{l}\text { Mar. } 12,1936 \\
\text { Nov. } 29,1937 \\
\text { Mar. 12, } 1936 \\
\text { Mar. } 5,1934\end{array}$ & $\begin{array}{r}503 \\
1,660 \\
5,400 \\
1,520 \\
1,920\end{array}$ & $\begin{array}{l}\text { Jan. } 26,3 \text { p.m. } \\
\text { Jan. } 25,9: 30 \text { a.m. } \\
\text { Jan. } 25,4 \text { p.m. } \\
\text { Jan. } 25,5: 30 \text { p.m. } \\
\text { Jan. } 25,2 \text { p.m. } \\
\text { Jan. } 25,2: 20 \text { p.m. }\end{array}$ & $\begin{array}{r}613,000 \\
474 \\
2,860 \\
5,650 \\
1,640 \\
2,140\end{array}$ & $\begin{array}{r}22.0 \\
116 \\
70.4 \\
76.4 \\
64.8 \\
28.7\end{array}$ & $\begin{array}{l}\text { Flow over dain. } \\
\text { Stage--discharge relation } \\
\text { Do. } \\
\text { Do. } \\
\text { Do. } \\
\text { Do. }\end{array}$ \\
\hline 432 & Salmon River near East Hampton & 105 & $\begin{array}{l}1928-38 \\
1905-06 \\
1908\end{array}$ & Mar. 12,1936 & 6,250 & Jan. $25,12 \mathrm{n}$. & 5,720 & 54.5 & Do. \\
\hline 433.7 & $\begin{array}{l}\text { East Branch of Eightmile River near North Lyme.- } \\
\text { West Branch of Eightmile River near North Lyme. }\end{array}$ & $\begin{array}{r}22.0 \\
19.2\end{array}$ & $\begin{aligned} 198-38 \\
1937-38 \\
\ldots . . . d o \ldots \ldots\end{aligned}$ & Nor. 29,1937 & $\begin{array}{l}1,010 \\
1,020\end{array}$ & $\begin{array}{l}\text { Jan. } 25,9 \text { p.m. } \\
\text { Jan. } 25,4 \text { p.m. }\end{array}$ & $\begin{array}{r}514 \\
1426\end{array}$ & $\begin{array}{l}23.4 \\
22.2\end{array}$ & $\begin{array}{l}\text { Do. } \\
\text { Do. }\end{array}$ \\
\hline
\end{tabular}




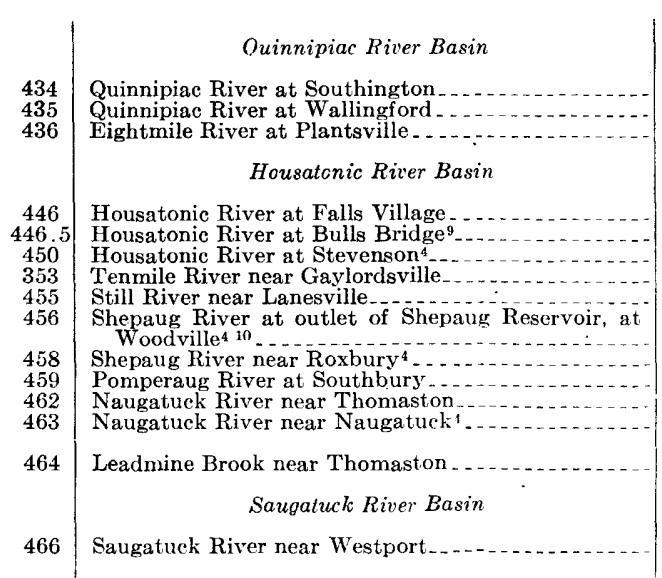

\begin{tabular}{r|r} 
& \\
17.6 & $1935-38$ \\
109 & $1930-38$ \\
14.9 & $1935-38$ \\
& \\
632 & $1912-38$ \\
782 & $191-38$ \\
1,545 & $1928-38$ \\
20.4 & $1929-38$ \\
68.5 & $1931-38$ \\
38.0 & $1935-38$ \\
133 & $1930-38$ \\
75.3 & $1932-38$ \\
71.9 & $1930-38$ \\
246 & $1918-24$ \\
24.0 & $1928-38$ \\
& $1930-38$ \\
77.5 & \\
77.5 & $1932-38$ \\
&
\end{tabular}

\begin{tabular}{|l}
\hline \\
\hdashline \\
\hline
\end{tabular}

${ }^{1}$ Maximum observed.

2Maximum stage known since 1639; maximum discharge, 313,000 second-feet Mar. $20,1936$.

Gage height from records of U.S. Weather Bureau; discharge, about 90,000 second${ }_{4 \text { Äffected by storage. }}$

\begin{tabular}{|c|c|c|c|c|c|}
\hline $\begin{array}{l}\text { Mar. } 12,1936 \\
0 \text { do_...... }\end{array}$ & $\begin{array}{r}8568 \\
3,240 \\
8755\end{array}$ & $\begin{array}{l}\text { Jan. } 26,4 \text { to } 5 \text { a.m. } \\
\text { Jan. } 25,1 \text { p.m. }\end{array}$ & $\begin{array}{r}8655 \\
2,760 \\
8755\end{array}$ & $\begin{array}{l}37.2 \\
25.3 \\
50.7\end{array}$ & $\begin{array}{l}\text { Do. } \\
\text { Do. } \\
\text { Do. }\end{array}$ \\
\hline Mar. 20, 1936 & 14,500 & Jan. 25,9 to 11 p.m. & 7,200 & 11.4 & Do. \\
\hline $\begin{array}{l}\text { Mar. } 12,1930 \\
\text { do }\end{array}$ & $\begin{array}{r}69,500 \\
10,200 \\
3,930\end{array}$ & $\begin{array}{l}\text { Jan. } 26,3 \text { a.m. } \\
\text { Jan. } 25,12 \text { n. } \\
\text { Jan. } 25,9 \text { p.m. }\end{array}$ & $\begin{array}{r}10,400 \\
36,000 \\
6,120 \\
2,450\end{array}$ & $\begin{array}{l}13.3 \\
23.3 \\
30.0 \\
35.8\end{array}$ & $\begin{array}{l}\text { Flow over dam. } \\
\text { Stage-discharge relation } \\
\text { Do. } \\
\text { Do. }\end{array}$ \\
\hline Nov., 1927 & $\begin{array}{r}14,070 \\
7,000 \\
5,990 \\
6,590 \\
18,300\end{array}$ & $\begin{array}{l}\text { Jan. 25, } 11 \text { a.m. } \\
\text { Jan. 25, } 1: 15 \text { p.m. } \\
\text { Jan. 25, 10:30 a.m. } \\
\text { Jan. 25, 12 n. }\end{array}$ & $\begin{array}{r}84,100 \\
5,340 \\
5,980 \\
6,830 \\
14,200\end{array}$ & $\begin{array}{r}108 \\
40.2 \\
79.4 \\
95.0 \\
57.7\end{array}$ & $\begin{array}{l}\text { Dam. } \\
\text { Stage-discharge relation } \\
\text { Do. } \\
\text { Do. } \\
\text { Do. }\end{array}$ \\
\hline Sept. 17, 1934 & 2,800 & Jan. 25,9 a.m. & 2,640 & 110 & Do. \\
\hline Mar. 12,1936 & 5,310 & Jan. 25,5 p.m. & 2,230 & 28.8 & Do. \\
\hline
\end{tabular}

SAffected by storage and diversion.

Condition of flashboards uncertain at time of peak.

8Tranley Works, New Britain, Conn.

8From graph based on gage readings

I"Basic data furnished by Bureau of Engineering, city of Waterbury, Conn. 
Figure 15 shows all the flood discharges in Connecticut, in second-feet per square mile, that are listed in tables 8 and 24 and plotted against the corresponding drainage areas. In this connection it should be understood that the discharges are given as observed, and many are affected by artificial storage, concerning which available information is presented in the preceding section, "Stages and discharges at stream-gaging stations." For comparative purposes, figure 15 also shows the maximum known discharges of record in Connecticut prior to 1939. Only those records are plotted that exceed the envelope of the floods of January and July 1938 and only the maximum of record for any one place. Appropriate symbols distinguish the various floods. When compared by drainage areas, it may be noted that maximum discharges of the flood of January 1938 were generally somewhat larger than for the flood of July 1938, but varied from about one-half of the envelope of maxima of record for areas of 10 square miles to about one-third for areas of 1,000 square miles.

\section{STORAGE RESERVOIRS}

Basic data for most of the important storage reservoirs have been given in the section "Stages and discharges at stream-gaging stations." The effect of these reservoirs on the flow at regular gaging stations is presented in the following section, "Rainfall and runoff studies." The section herewith is limited to a brief discussion of some of the examples of storage regulation.

Before the advent of steam and electricity for industrial use, the gradient of streams in Connecticut had been found well suited for water-power development, and consequently hundreds of small dams were constructed at existing natural ponds or at constrictions in the stream channels to divert water through the water wheels of mills. Later, detention reservoirs were constructed in the headwater streams to regulate the flow of water, and some of the natural ponds and lakes were enlarged or artificial reservoirs created for recreational or municipal water-supply purposes. Many of the old dams have been destroyed by floods and not rebuilt. Of the hundreds that remain, some have no control works and others have gates of various kinds, some used and some not used. The small ponds and reservoirs that remain practically full throughout the year have little effect individually in decreasing the peak flow of floods, but as a group, together with swamps and intervales, they provide excellent retarding basins, wider than the normal river channels, which are filled synchronously with the rising flood and do not release the temporarily stored water until the peak has passed. Hence, although this storage may be classi- 


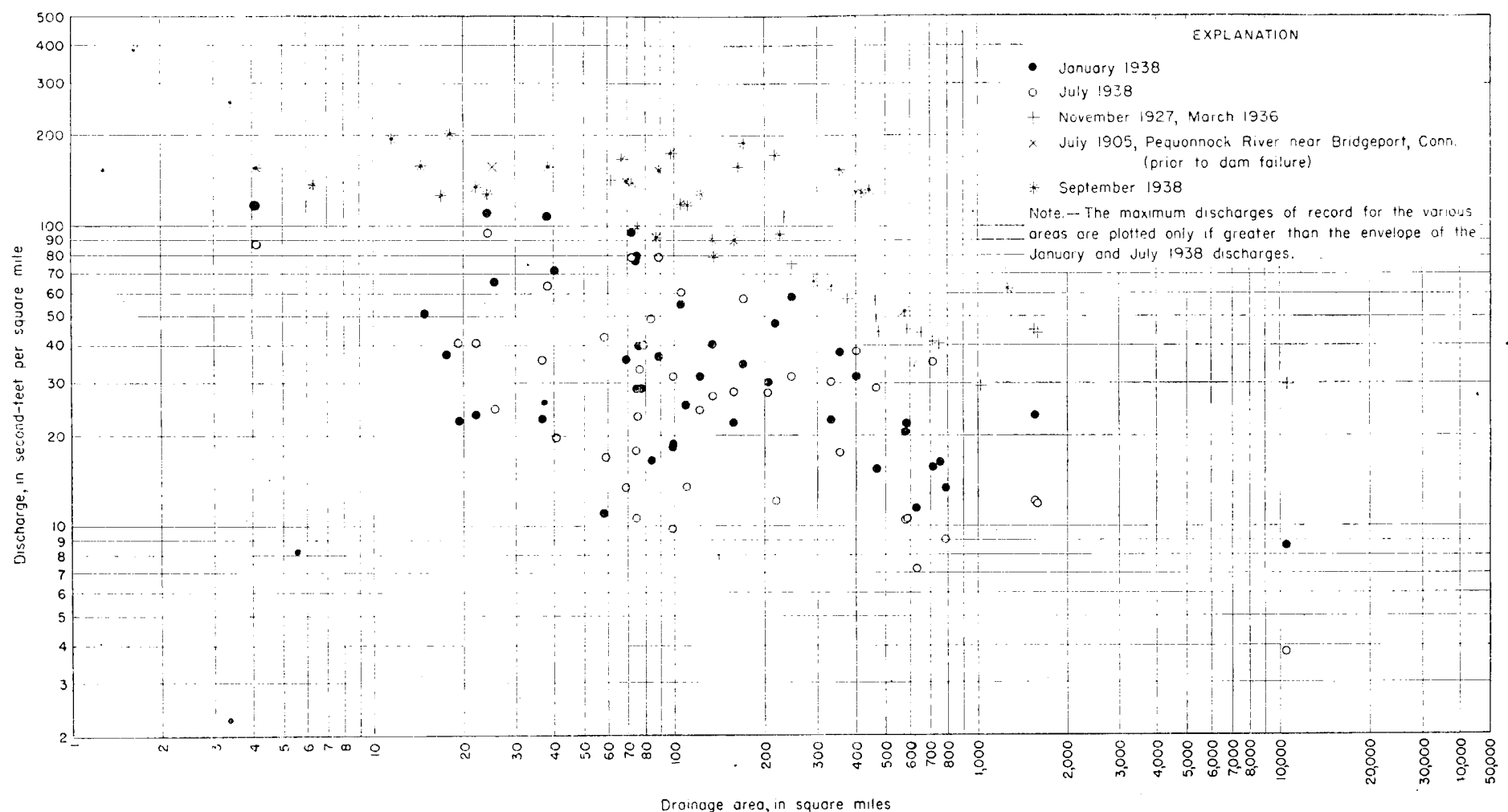

Drainage area, in square miles 
fied as more "natural" than "artificial," it does operate to reduce the magnitude of peak stages downstream. No records are available as to the areal extent or actual effect of these numerous small ponds, reservoirs, and flood basins in Connecticut.

The larger reservoirs, having appreciable storage capacity below the level of the spillway, have a more marked effect on flood flow. Records for nine reservoirs are presented in the section "Stages and discharges at stream-gaging stations," and they disclose some interesting facts. On January 25 the small discharge gates on Otis Reservoir at Cold Spring, Mass., were closed, and all the flood flow from 17.2 square miles of the Farmington River Basin was retained until February 17. Although the peak flow of the Hockanum River near East Hartford, Conn., on January 25 was greater than any previously recorded, outflow from Shenipsit Lake (drainage area, 16.5 square miles) in the headwaters of the river was held to less than 120 second-feet, while the retained storage averaged an equivalent of 405 second-feet. At Candlewood Lake on Rocky River near New Milford, Conn., all the runoff during the flood period from its 40.4 square miles of drainage area was stored, and, as it was a pumped-storage type of reservoir, water was pumped into storage from the Housatonic River. Zoar Lake at Stevenson, Conn., may be considered representative of the larger reservoirs at power developments, which are kept nearly full most of the time. The area of the lake surface is about $\mathbf{1 . 6}$ square miles, and for the calendar day of maximum flood flow its contents increased the equivalent of 2,400 second-feet, which was released again as the flood flow receded. Shepaug Reservoir on the Shepaug River at Woodville, Conn., is perhaps indicative of the effect of the smaller ponds and reservoirs mentioned in the preceding paragraph. This reservoir, which has a surface area of about 0.15 square mile, or 100 acres, affects the runoff from 38.0 square miles of drainage area. It was spilling water prior to the January flood. From a graph plotted from daily readings of reservoir elevation and discharge, the increase in contents of the reservoir for the 6 -hour period before the peak was about 150 acre-feet, equivalent to 0.07 inch over the drainage basin. For the 6 -hour period after the peak the reservoir lost about 80 acre-feet, equivalent to 0.04 inch over the basin. Of course this comparatively small temporary storage of water was undoubtedly greater than would have been retained as storage in the same stretch of the river if the dam had not been there.

The manner in which several reservoirs operated during the flood period of January 1938 can be illustrated by constructing hydrographs of observed and adjusted natural flow from the data 
given in the section "Stages and discharges at stream-gaging stations."

\section{RAINFALL AND RUNOFF STUDIES}

Climatologic, hydraulic, and hydrologic data previously presented provide information for a variety of detailed studies of runoff characteristics. This report includes only a limited appraisal of the data, as compiled in table 9 , for the 32 regular river-measurement stations in Connecticut. Index numbers to the left of the station names in table 9 indicate plotted locations on plate 12. The three major basins are discussed separately later in this section.

Various investigators have studied the amount of evaporation from snow ${ }^{9}$ and have found that it generally increases with factors such as wind velocity, temperature, exposure, porosity of snow, and decrease of humidity. Evaporation occurs at temperatures below $0^{\circ} \mathrm{F}$., but, as explained in the section on "Snow," no corrections for evaporation were used in determining the water content of snow as of January 20 because of the rough approximations in other assumptions that were made. However, during the warmer period from January 20 until the start of flood-producing precipitation on January 24, evaporation from snow may be computed by methods to be between 0.05 and 0.15 inch. Accordingly, the figures in column 8 of table 9 , showing the computed water equivalent of the snow on the ground on January 24, are equal to the figures in column 7 plus column 5 minus column 6 and minus a flat correction of 0.1 inch for evaporation losses after January 20. Probably neither the amount involved nor the accuracy of existing information on evaporation from snow warrants a closer refinement.

The values of direct runoff for the antecedent period January 20-24 and for the flood period, shown in columns 6 and 10, respectively, of table 9 were based on records of discharge at the gaging stations published in this report and were computed by the following procedure, conforming to methods described in previous flood reports of the Geological Survey.

A discharge hydrograph was constructed for each gaging-station record to be analyzed, covering the period from about January 10 to February 28. A part of the hydrograph for Naugatuck River

\footnotetext{
${ }^{9}$ Lee, C. H., An intensive study of the water resources of a part of Owens Valley, Calif.: U. S. Geol. Survey Water-Supply Paper 294, pp. 49, 50, 118, 1912. Horton, R. E., Evaporation from snow and errors of rain gage when used to catch snowfall: Monthly Weather Rev., pp. 99-100, February 1914; Water losses in high latitudes and at high elevations: Am. Geophys. U'nion Trans., pp. 351-379, 1934. Baker, F. S., Some field experiments on evaporation from snow surfaces: Monthly Weather Rev., pp. 363-366, July 1917. Church, J. E., Evaporation at high altitudes and latitudes: Am. Geophys. Union Trans., pp. 326-351, 1934.
} 
TABLE 9.-Precipitation, water equivalent of snow, and associated direct runoff of flood of January 1938 in Connecticut [Mean depth, in inches, over drainage basins]

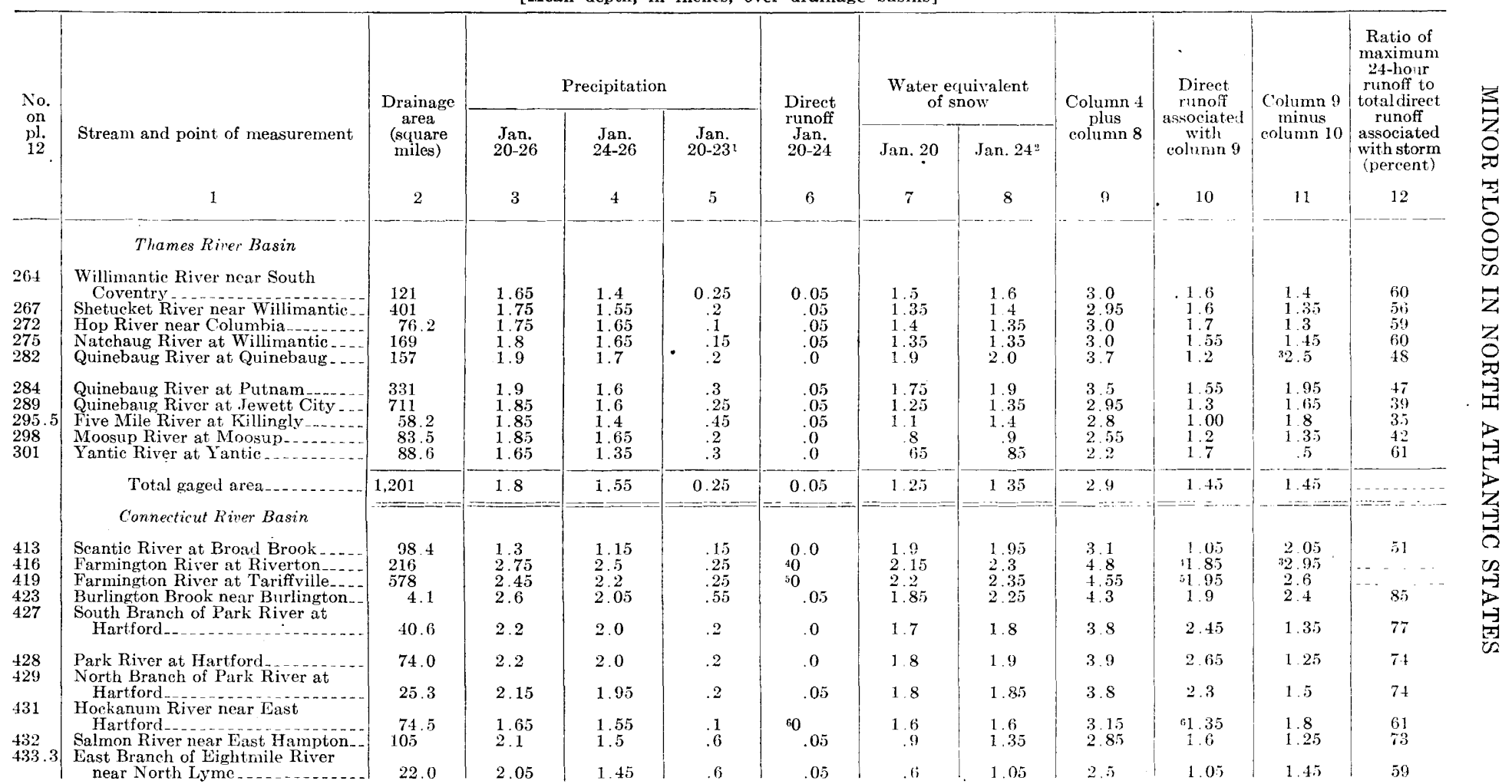




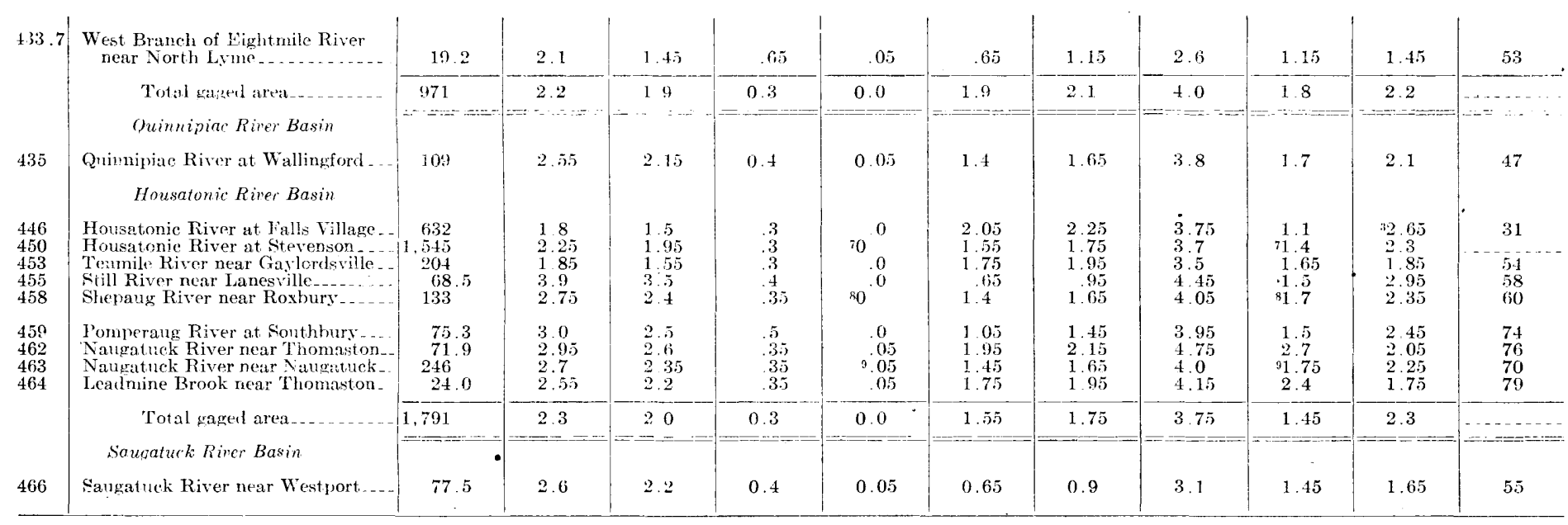

1Difference hetween columns 3 and 4 .

Barkhamsted Reservoirs.

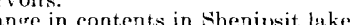

3Records of snow depth on ground January 27 indirate that this figure may include residual snow erfuivalent of 0,2 inch water.

${ }^{4}$ Adjusted for change in contents of Otis Reservoir

Adjusted for chinge in conterts in Zoar and Candlewood Lakes and Shepaug

sAdjuster for diversion and change in contents in Otis, Nepuug. East Branch, and 
near Thomaston, Conn., is presented in figure 16 and is in general typical of the behavior of the other streams that were studied. The graph in figure 16 outlined by letters A-B-C-D-E-F-G-H represents the observed discharge, in second-feet, past the gaging station. From $A$ to $B$ the stream flow consisted entirely of groundwater flow, which gradually diminished as the ground-water supply was depleted during this cold period. Slight diurnal fluctuations occurred because of the formation and release of temporary ice obstructions upstream, particularly on January 19, and because of minor regulation from mills on this river. If ground water had remained as the only contribution to flow, the graph of daily discharge would have continued approximately as drawn from $B$ to $C$. However, from $B$ to $D$ warmer temperatures released some of the water stored in the form of snow and the stream flow steadied or rose slightly. The rainfall, starting late on January 24 and continuing into the 25th, together with thawing temperatures caused most of the snow to melt, and the streams rose rapidly to flood peaks as at $E$. The peaks occurred on January 25 or 26 depending on the various runoff characteristics of the basins. Fortunately for the purpose of this study, there was negligible precipitation during the period January 26-30. Below-freezing temperatures generally prevailed from the morning of January 26 through the $29 \mathrm{th}$, and the recession side of the flood hydrographs departed from normal as the cold temperatures caused temporary ice obstructions upstream and froze the surface of the ground and possibly some subsurface water that had not yet reached the stream channels. Sunshine and warmer midday temperatures intermittently released part of this ice-bound storage so that the hydrographs of flow of the smaller streams showed the effects of the diurnal variations in temperature. During January 30 and 31, temperatures rose well above freezing, and on January 31 precipitation reported as rain and snow caused minor rises in stream flow ( $F$ to $G$ ).

The total area under the discharge hydrograph, A-B-D-E.F$L-M$, represents the runoff that reached the stream channels during the period both as surface and as ground-water runoff resulting from melted snow and from precipitation prior to January 27 , plus the runoff under $A-B-C$ that would have been maintained if there had been no increment of supply after January 19. The area under $A \cdot B \cdot J \cdot K-L$ represents the estimate of ground-water flow during the period, and the area between this line and $A-B-D-E$ $F-L$ is believed to include essentially all the direct surface runoff resulting from the melted snow and rain and may include some ground water that was discharged into stream channels with a 
promptness approaching that of surface runoff. Some difficulty was encountered in determining the magnitude and time of maximum ground-water flow $(K)$ after the flood peak, because subsequent rains prevented the accurate definition of the ground-water depletion curve. The time of $K$ was therefore determined from comparisons with other isolated uniform flood recessions on the same stream, and its magnitude was determined by estimating from the appearance of the graph the amount of delayed direct runoff that was being released by the warm weather at the time.

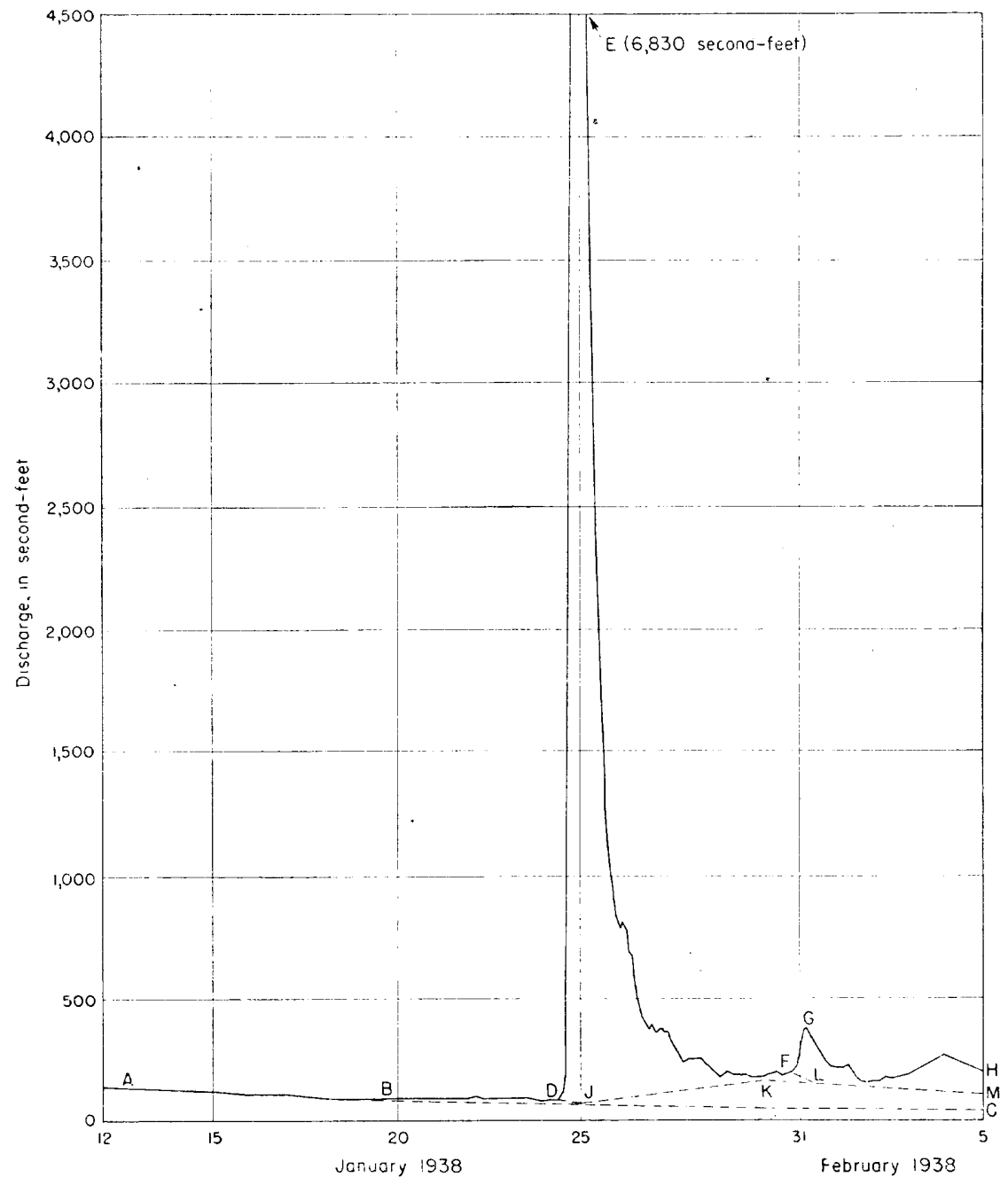

Ficure 16.-Hydrograph of discharge of Naugatuck River near Thomaston, Conn., showing method of analysis used in determining the direct runoff associated with the flood of January 1938. 
$K-M$ represents the subsequent estimated ground-water depletion curve, that is, the ground-water flow that would have occurred if there had been no subsequent direct surface runoff.

By estimating the positions of the short recession curves $D$-J and $F-L$, the hydrograph can be analyzed to show within reasonable limits the direct runoff, B.D.J, directly attributable to the antecedent period of warm weather January 20-24, and the direct runoff, $D-E-F-L-K-J$, directly attributable to melted snow and rainfall during the flood period. Point $F$ is not well defined. Warm weather on January 30-31 released some water that should have previously reached the stream channels had it not been delayed by freezing temperatures, but it could not be ascertained whether all this water was released before the small rise $F-G$ on January 31 . However, the runoff directly attributable to this rise was a small proportion of the rainfall on January 31 and could include only a slight amount, if any, of the direct runoff applicable to the previous flood. Accordingly, point $F$ was arbitrarily located on the hydrograph just prior to the time of significant direct runoff from the rain of January 31. As other investigators might make other estimates of direct runoff by drawing the separation curves differently, the basic data and methods of analysis are presented in sufficient detail so that they may do so if desired. But, in general, such differences in judgment would result in mathematical differences that would be relatively small in relation to the magnitude of direct runoff.

Values of direct runoff for the antecedent period and flood period are given to the nearest 0.05 inch in columns 6 and 10, respectively, of table 9 . Footnotes refer to the available records of diversion and change of contents in reservoirs that were used to adjust the observed stream flow to natural discharge during the periods. Other retarding basins probably affected the flow, but no records were available for determining their effect. Also during periods of low flow most streams were affected by diurnal fluctuations caused by the operation of relatively small millponds whose storage capacity is generally limited to less than 1 or 2 days' supply of normal low flow. The plotted discharge hydrographs were adjusted during the periods of low flow to balance these diurnal fluctuations and thus to improve the accuracy in determining the trend and amount of ground-water flow.

If the records of precipitation plus water content of snow shown in column 9 of table 9 and values of direct flood runoff shown in column 10 are substantially correct, then the difference between columns 9 and 10, or basin retention, represents the amount of water that was retained in the basin in the form of snow or as 
surface storage and absorption, or that was exaporated during the flood period. Most of these values seem reasonably consistent.

The direct flood runoff shown in column 10 of table 9 resulted from the rainfall of January 24-26 and the melting of the snow. The total water thus available for runoff is shown in column 9 . Direct runoff should be less than the supply by the amount of residual snow or ice on the ground plus evaporation, transpiration, change in soil moisture, and accretion to the ground-water table. Figure 17 presents a graphical comparison of the data in columns 9 and 10 and indicates that the direct runoff generally increased with the supply. Points plotted for the 32 regular rivermeasurement stations appear to have reasonably consistent results.

As the direct flood runoff generally is believed to be accurate within 10 percent, larger inconsistencies may indicate deficiencies in basic data or limitations in methods of analysis of the data. Figure 17 shows the place names of five gaging stations that appear to be the most inconsistent. Table 5 shows that at several rainfall stations in Connecticut, particularly at higher latitudes and altitudes, traces of snow were reported on the ground after the flood on January 27. These reported traces possibly consisted of patches of snow in more sheltered spots and probably were of negligible consequence over the basins as a whole. In Massachusetts a measureable amount of snow on January 27 was reported at three stations, at one of which the snow was reported to be gone by January 31 . Headwater streams of the three primary drainage basins, namely, Quinebaug River above Quinebaug, Conn., Farmington River above Riverton, Conn., and Housatonic River above Falls Village, Conn., extend into Massachusetts. As these basins lie at a higher elevation and latitude, it was presumed that a light snow cover amounting to possibly 0.2 inch of equivalent water content remained on them after the flood period. An examination of figure 17 shows that if the results for these three stations were adjusted by the estimated snow residual, they would plot more consistently with the results obtained for other stations. Also, as explained in the section on "Snow," the equivalent water content of snow in Massachusetts prior to the flood was determined from less comprehensive data than in Connecticut, and if the areal water content of snow was more accurately known for the above-mentioned stations a further revision of results might be indicated. The water content of snow on January 24 plus precipitation January 24-26 seems high and low, respectively, for the drainage basins above Still River near Lanesville, Conn., and 


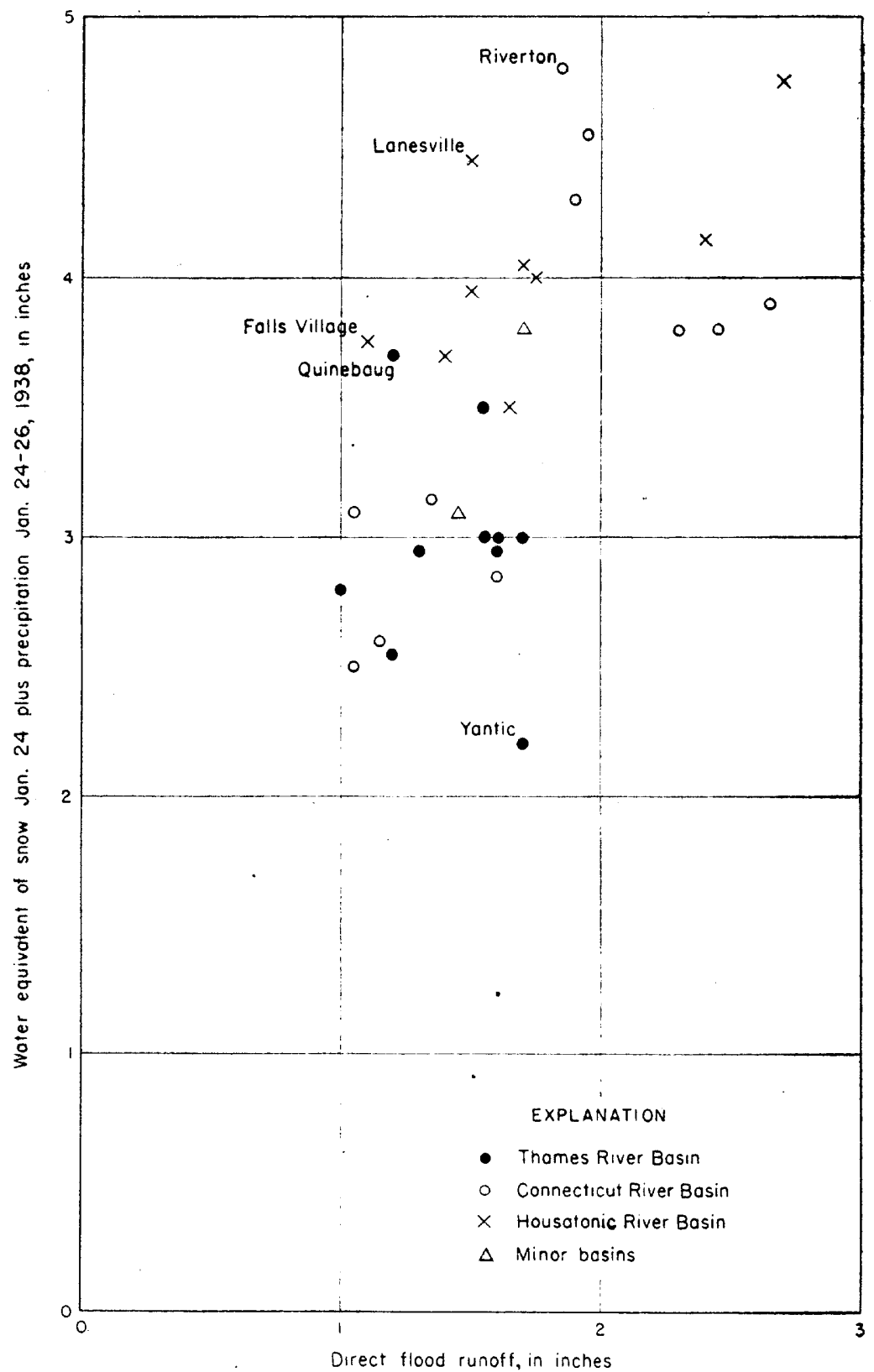

FicukE 17.--Relation of water equivalent of snow plus storm rainfall to direct runoff for rivermeasurement stations in Connecticut during flood of January 1988. 


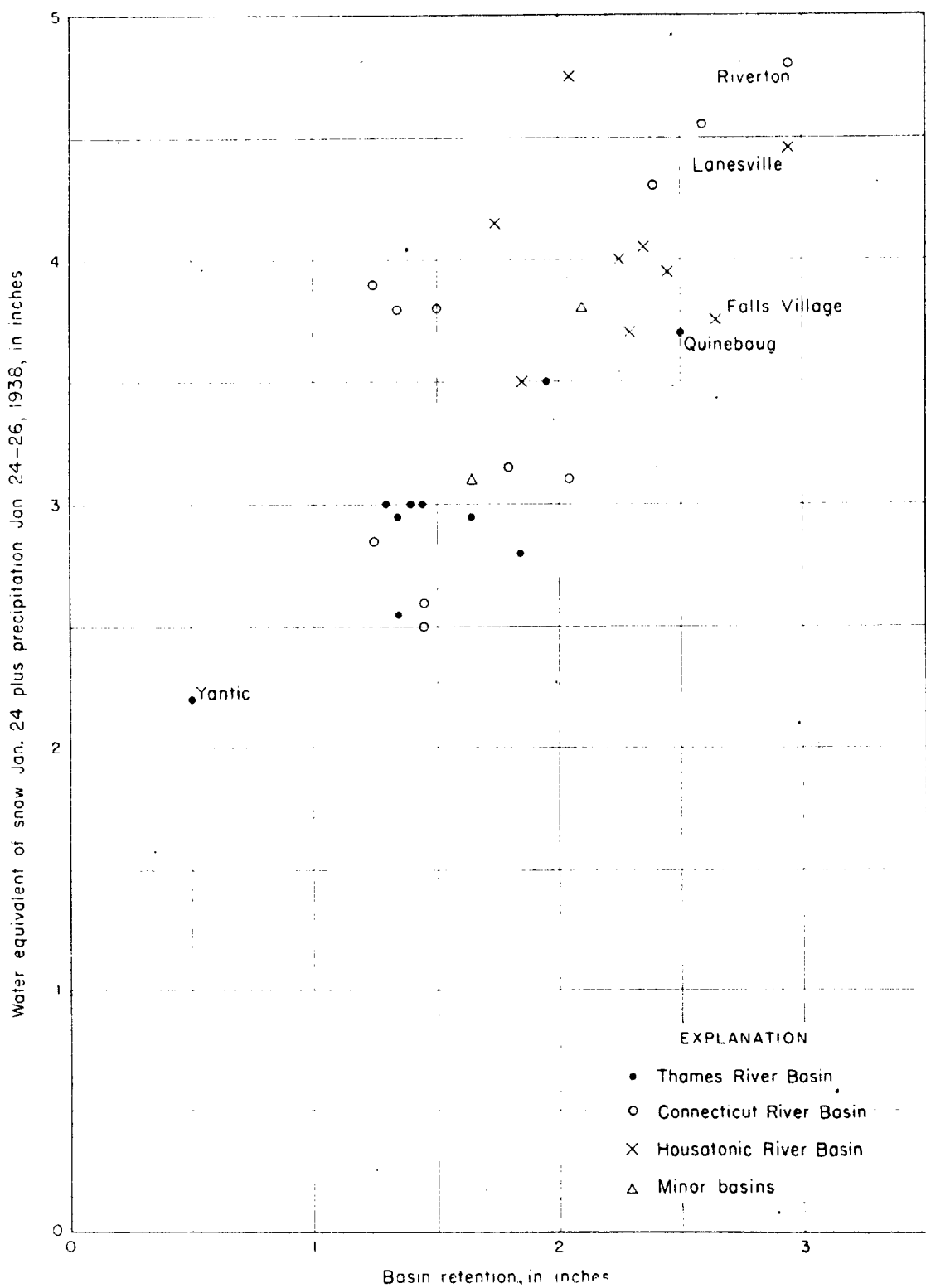

Fivike 18.--Relation of water equivalent of snow plus storm rainfall to basin retention for rivermeasurement stations in Connecticut during flood of January 1938. 
Yantic River at Yantic, Conn., possibly because of inadequacies in the delineation of storm precipitation.

The initial part of a winter rainfall is utilized in aiding the melting of any snow on the ground and combines with the melted snow to wet vegetation and ground surface, to fill surface depressions, and to aid the thawing of frost. Controlled by the extent that frost intereferes with absorption, the additional water after satisfying these initial requirements follows the surface courses to the stream channels. Release of frost from the surface downward permits increasing increments of water to be absorbed by the soil and provides subsurface passages to the streams. It is apparent that the frost was largely removed from the ground during the January flood.

The differences between the available water and the corresponding direct runoff, as shown in column 11 of table 9, include accretions to the ground both above the groundwater table as soil moisture and below it within the zone of saturation as ground water, the water equivalent of the slight residual snow cover previously discussed, the interception of vegetation and soil, and any slight direct evaporation and transpiration. They represent the basin retentions as closely as may be determined from the available data.

Figure 18 presents a graphical comparison between the available water and corresponding basin retentions for the 32 regular river-measurement stations in Connecticut. Most of the plotted points seem reasonably consistent. The 5 stations whose place names appear on the plot are the same stations discussed in connection with figure 17.

An important characteristic of flood runoff is its concentration with respect to time. The concentration may be conveniently evaluated in the form of a ratio between discharge during a selected short interval of time and the total direct discharge during the flood period. The last column of table 9 lists the ratio between the direct runoff during the maximum 24 hours and the total direct flood runoff. The factors believed to be of greatest influence upon these concentration ratios are as follows: Duration and intensity of storm, direction of storm movement, rapidity of snow melting, channel characteristics, and shape and slope of drainage basin. As the characteristics of the storm were fairly uniform over the area, variations in concentration ratio between different basins may be largely ascribed to rapidity of snow melting and inherent basin characteristics. Further reference to concentration ratios is made in the discussions of rainfall and runoff relations for the separate major basins.

The ground-water discharge was estimated to increase during 
the flood period, as from $J$ to $K$ in figure 16, and increased groundwater flow attributable to the flood continued until such a time as the extended ground-water depletion curve, $K-M$, approaches the extension of the initial ground-water depletion curve, $J C$. The area of the three-sided figure thus formed, expressed in inches of runoff, represents an increased volume of storage over the basin equivalent to the apparent ground-water recharge caused by the flood. Although generally less than total recharge by the amount of transpiration and evaporation from the ground-water supplies, it is probably closely equivalent to total recharge during the winter season. A direct computation of the area enclosed in the above-mentioned three-sided figure would be somewhat cumbersome, and the area is customarily solved by the algebraic summation of other areas under the flood hydrograph. As explained by Langbein and others, ${ }^{10}$ from a derived average ground-water depletion curve for the gaging station in question a relationship curve can be developed between the rate of ground-water discharge and the associated volume of storage. Then the apparent groundwater recharge may be computed by adding to the estimated base runoff during the flood period (represented by the area below the line $J-K-L$ the volume of ground-water storage equivalent to the discharge at $L$, less the volume of storage equivalent to the discharge at $J$. Apparent ground-water recharge was computed at only a few stations by this method as time did not permit such an analysis for all stations. An average coefficient was obtained to convert the difference between the ground-water flow, such as at $J$ and $K$, into the corresponding increment in ground-water storage for summation with the ground-water flow during the flood period to give the apparent ground-water recharge. Thus, values were approximately computed for each station, and an average figure was obtained for each of the three primary drainage basins, as presented in the discussion of the basins in a subsequent part of this section of the report.

\section{COMPARISON WITH OTHER FLOODS}

A general comparison of floods is of necessity indecisive because of the many variables involved. Minor storms of equal magnitude, duration, and intensity, but occurring during different seasons and under dissimilar soil-moisture conditions, cause widely variable amounts of surface runoff. Identical major storms may cause less divergent volumes of surface runoff because the variations in immediate losses, such as soil absorption and infiltration, represent a much less important proportion of the total precipitation. Also

\footnotetext{
${ }^{10}$ Langbein, W. B., and others, Major winter and nonwinter floods in selected basins in New York and Pennsylvania: U. S. Geol. Survey Water-Supply Paper 915.
} 
storms of equal magnitude but of varying duration or intensity produce widely variant flows. In Connecticut the runoff has been analyzed for major storms of March 1936 in Water-Supply Paper 798, of July 1938 in another part of this report, and of September 1938 in Water-Supply Paper 867. Water-Supply Paper 867 also includes a brief analysis of the storms of November 1927 and September 1932. Table 4 presents the area-depth relations for the precipitation during these storms.

Each storm was of a different type. In March 1936, major storms, spaced about a week apart, produced heavy precipitation when other prevailing conditions were favorable to the development of great volumes of flood runoff. In November 1927 both the duration and the intensity of precipitation were unusual and resulted in floods of extraordinary magnitude. In the storms of July and September 1938, seasonal flood-deterrent conditions were eliminated by extraordinary excesses of precipitation for several days immediately preceding the flood-producing rains. The storm of September 1932 is notable as an intense 1-day rainfall which, however, produced no important flood principally because of the absorptive capacity of the ground. Conversely, the 1-day storm of January 1938 was of minor magnitude, and only the combination of such factors as snow cover, frost, and warm temperatures produced a noteworthy flood.

Table 10 summarizes factors, as explained in the column headings, for the above-mentioned storms for river-measurement stations in Connecticut for which rainfall and runoff data are available. The data shown for each flood are influenced by the particular rainfall and snow-cover distribution, and by the runoff characteristics of the basins in that group. Such variations affect the interrelations among the data.

From table 10 it may be observed that the basin retention for the two winter floods was much less than for those of other seasons, partly because a frost barrier initially obstructed absorption of water into the ground. The storm of January 1938 supplied 30 percent less water but yielded three times greater direct runoff and seven times greater average peak rate of flow than the storm of September 1932. The average rainfall plus water equivalent of snow, the direct runoff, and the retention for the flood of January 1938 were about one-half of the like values for the flood of July 1938, whereas the average peak discharge was greater. The range of the extremes of ratios of direct runoff to the supply for the Quinebaug River at Jewett City is noteworthy, as it was only 11 percent of the rainfall in the storm of September 1932 but 88 percent of the available water in the storms of March 1936. 
TABLE 10.-Comparison of recent floods in Connecticut

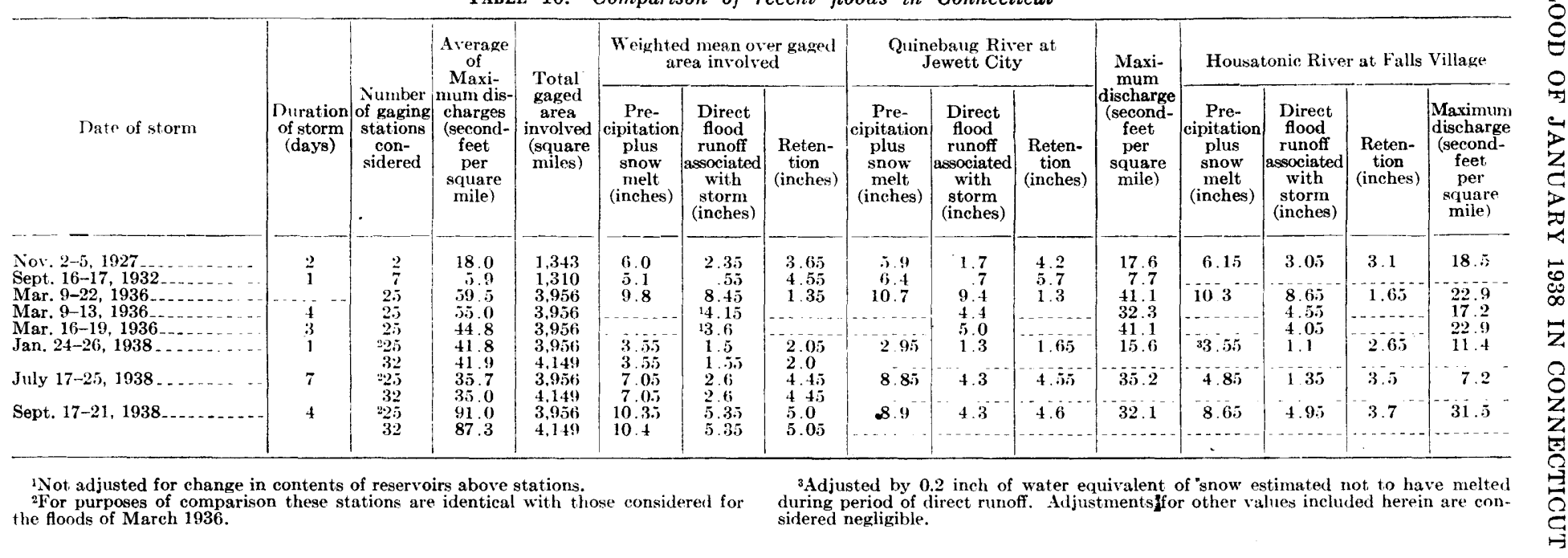


THAMES RIVER BASIN

Available records of precipitation in the Thames River Basin show comparatively uniform amounts over the area for the flood period. Plate 4 shows a minimum of less than 0.75 inch at the south end and an increase to somewhat more than 1.75 inches in other localities. Only 11 rainfall records were available for the whole area, and three of these were not fully usable. Additional records doubtless would have given a closer refinement of results. Plate 5 shows that the water content of snow on the ground January 20 increased from less than 0.5 inch near the south end of the basin to more than 2.25 inches at the northern extremity. The total available water on the tributary stream basins varied from 2.2 to 3.7 inches and averaged 2.9 inches over the 1,201 square miles of gaged drainage area.

Net artificial storage in the Thames River Basin was small for the total period considered in computing direct runoff, and accordingly the runoff values shown in column 10 of table 9 closely represent natural-flow conditions. The basin retention is shown in column 11 of table 9. The figures seem reasonably consistent except for the Quinebaug River at Quinebaug, records for which are probably affected by a residual of snow, and for the Yantic River at Yantic, results for which may reflect poorly defined precipitation within its basin.

An analysis of hydrographs showed an accretion to ground water of 0.8 inch to 1.3 inches, which averaged about 80 percent of the total retention. This accretion represents that part of the retention that appeared as ground-water effluent during and after the flood.

The concentration of direct flood runoff with respect to time, as measured by the ratio between the direct runoff during the maximum 24 hours and the total direct flood runoff, ranged from 35 to 61 percent. On the same river this concentration ratio usually decreases in a downstream direction, which indicates the increasing effect of channel storage and the leveling effect of tributary streams that discharge their peak rates of flow into the main stem at varying times. Under uniform storm conditions, with no snow on the ground, the concentration ratio may be presumed to be definitive of the topographic and channel characteristics of the basin. However, during the flood of January 1938 the rate and amount of snow melting probably obscured the normal display of those characteristics. 


\section{CONNECTICUT RIVER BASIN}

Thirty-nine records of precipitation within the area of the Connecticut River Basin studied in this report, together with records just outside the area, well define the variations in rainfall except possibly for three drainage areas in the southern part of the basin. Plate 4 shows that the rainfall reported for the period January 24-26, 1938, ranged from less than 1.0 inch to more than 2.75 inches. Plate 5 shows that the water equivalent of snow on the ground January 20 increased from less than 0.75 inch in the southern extremity of the basin to more than 2.75 inches in certain places elsewhere. Total available water during the flood period on the tributary stream basins varied from 2.5 to 4.8 inches and averaged 4.0 inches on the 971 square miles of gaged area.

The data on direct runoff shown in table 9 have been adjusted. for change in contents of all upstream reservoirs for which daily records are available. In addition, there are numerous small regulated ponds and reservoirs for which no records were available. The four large reservoirs above the Farmington River at Tariffville, Conn., reduced the direct flood runoff at that station by the equivalent of 0.3 inch of water over the entire basin. In table 9 the figures representative of basin retention seem reasonably consistent except for the Farmington River at Riverton, which possibly includes some residual snow.

On the basis of analyses of hydrographs, it is estimated that the part of the ground-water accretions that later appeared as stream flow ranged between 0.65 inch and 1.45 inches and averaged about 65 percent of the basin retention.

The concentration of direct flood runoff with respect to time, as measured by the ratio between the direct runoff during the maximum 24 hours and the total direct flood runoff, ranged between 51 and 85 percent. The ratio of 85 percent for Burlington Brook near Burlington indicates the tendency to greater concentration of flow on small streams.

\section{HOUSATONIC RIVER BASIN}

A maximum precipitation of 4.10 inches for the storm period January 24-26, 1938, was recorded at Danbury, Conn,,$\cdot$ in the Housatonic River Basin. The steep gradient of precipitation on all sides of this station, not defined by any nearby rainfall records, affected the accuracy of the computation of average precipitation principally for the basins above the Still River near Lanesville and the Saugatuck River near Westport. Figures 17 and 18 show the relations of total available water with direct runoff and basin retention. The plotted relations for the Saugatuck River near 
Westport seem consistent, but the relations for Still River near Lanesville indicate that the estimated available water was perhaps too high. This apparent discrepancy could have been adjusted by assuming a steeper gradient of precipitation north and east of Danbury, but this was not done as the isohyetal maps were prepared solely on the basis of precipitation data and independently of the evidence of the rainfall-runoff studies.

Plates 4 and 5 show, respectively, the variations in storm rainfall and the water equivalent of snow on the ground. As in other basins, the water equivalent of snow shows a tendency to increase with latitude and possibly with altitude, but this basin was probably more affected than other basins by the residual snow from old storms. Table 9 shows that total available water on the tributary stream basins within the Housatonic watershed varied from 3.5 to 4.75 inches and averaged 3.75 inches over the 1,791 square miles of the basin above the river-measurement stations.

The data on direct runoff in table 9 have been adjusted for change in contents of all upstream reservoirs for which daily records are available. No adjustments could be applied for the many small regulated ponds and reservoirs for which no records were available. During the flood period, storage in three reservoirs or lakes reduced the direct flood runoff above the gaging station at Stevenson, Conn., by the equivalent of 0.07 inch over the basin. In table 9 the figures representative of basin retention for the various streams seem reasonably consistent except for Housatonic River at Falls Village, which retention possibly includes some residual snow, and for Still River near Lanesville.

Estimates made by methods previously described indicate that the accretion to ground water during the flood period ranged from 1.1 to 1.8 inches and averaged about 60 percent of the basin retention.

\section{FLOOD OF JUNE 1938 IN NEW JERSEY}

By Otto LatterhahN and W. B. Langbein

INTRODUCTION AND GENERAL FEATURES

The flood of June 1938 in New Jersey was the immediate result of a 30-hour rainstorm on June 26-27 that centered around Odessa, Del., which received 8.55 inches rainfall, Indian Mills, N. J., which received 7.71 inches, and Milton, N. J., which received 6.29 inches. The rainfall about these three concentrations exceeded 5 inches over a total area of 2,900 square miles. River stages in the central parts of storm areas rose to levels that approached, and on a few rivers exceeded, previous maxima of record. The highest rates of flow per unit area were reached by Deep Run near Browntown and Oldmans Creek near Woodstown, which crested at 88 and 61.7 
second-feet per square mile, respectively. The areas in New Jersey in which noteworthy floods occurred are delineated on figure 19.

No records of discharge are available in Delaware, the area of most intense rainfall, and therefore rainfall-runoff relations in that part of the storm area cannot be studied.

Within New Jersey the storm was most intense in the southern part, a low region of small relief and not generally productive of intensive rates of discharge. However, during September 1, 1940, the area from Mount Holly to Salem was the center of a storm of West Indian origin that in 12 hours precipitated in excess of 10 inches of rainfall over an area of 1,000 square miles and produced rates of discharge on Oldmans Creek of more than 420 second-feet per square mile and on Salem Creek of 7,090 second-feet, or 1,650 second-feet per square mile from the tributary area of 4.3 square miles above Woods Mill. These rates of discharge vastly exceed any previously observed in this area. In contrast, the rates of the flood of June 1938 do not seem outstanding. Nevertheless, the latter flood caused much damage and merits study as a means to the amelioration of flood conditions in New Jersey.

A vivid impression of the storm and flood of June 1938 may be obtained from newspaper accounts, of which the following reflect the damage and effect on normal activities within the flooded region:

Flood waters from rain-swollen streams rolled with heavy toll today over farm fields and roads in Delaware, New Jersey, and Pennsylvania.

Damage was counted in millions of dollars in the tri-State area in the wake of a 24-hour northeast storm setting new records for June rainfall.

Delaware's downpour of 5.11 inches sent the Brandywine and Christina Rivers over their banks in places, and burst a dam at Silver Lake, Middletown.

Four square miles of land were under water today at Burlington, N. J., where 300 families were driven from their homes, mostly temporarily, in the collapse of a dam last night at Sylvan Lake.

Injury to crops, roads, and private and public property was placed at $\$ 2,000,000$ by unofficial estimate in Camden, Gloucester, Burlington, and Salem Counties, N. J. ${ }^{11}$

Three boys and two men were missing and feared drowned, and between 200 and 300 homes in the south and west portions of the city of Burlington were inundated shortly after 7 o'clock last night, when Sylvan Lake ripped through its banks under the pounding of torrential rain.

This was the worst of the consequences of a storm which was heralded Monday night by a series of savage electric storms, and which then settled down to almost continuous rain.12

\footnotetext{
11 Journal-_Every Evenin:r, Wilmington, Del., Tuesday, June 28, 1938.

1: Inquirer, Philadelphia, Pa., Tuesday morning, June 28, 1938.
} 


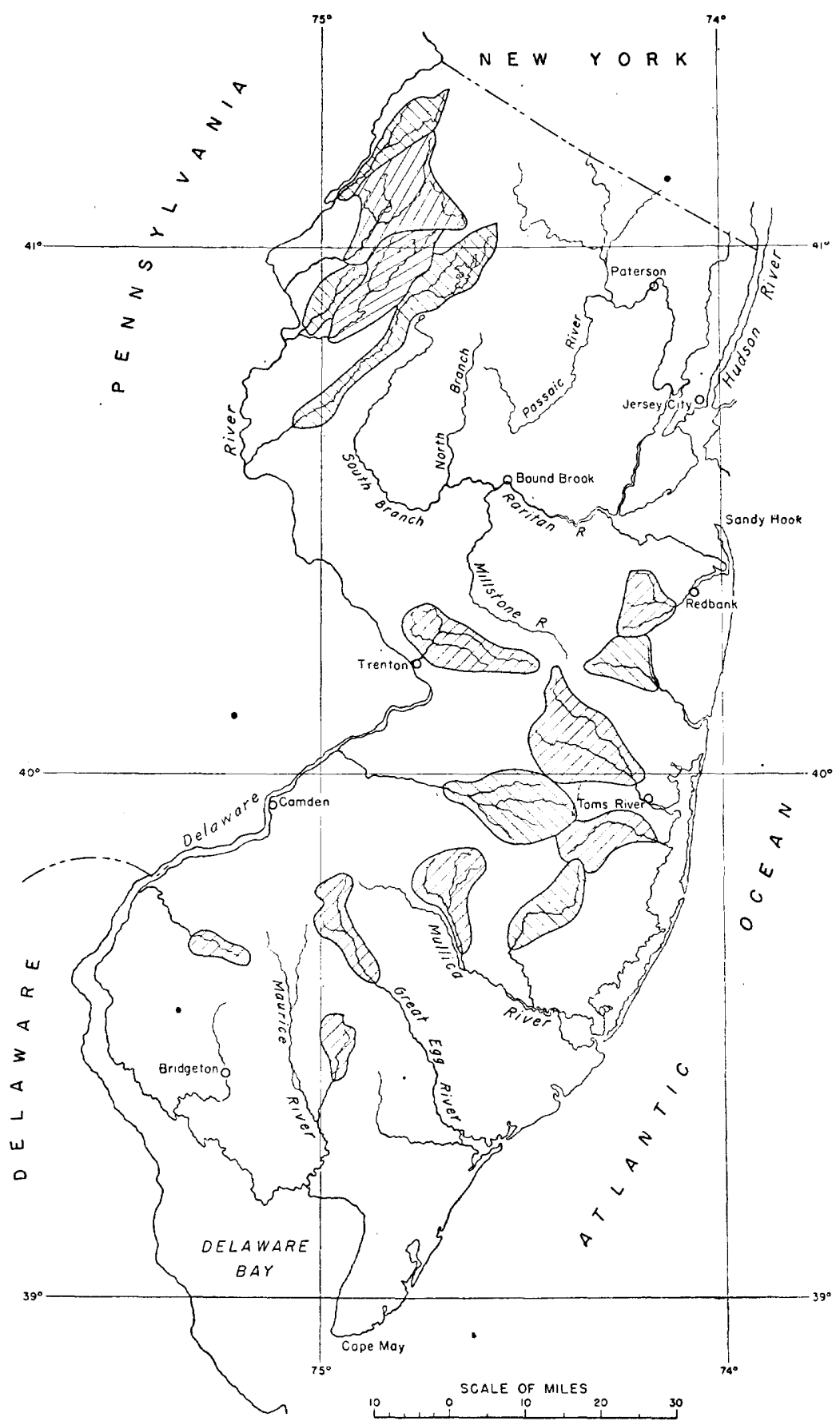

Figure 19.-Map of New Jersey showing drainage areas in which noteworthy floods occurred during June 1938. 
A downpour of $4 \frac{1}{2}$ inches of rain in 24 hours flooded the flat, sea-level , country of" southern New Jersey on June 26-27 causing considerable damage to county roads and highway bridges, and washing out an old earth dike that created a diversion lake at Burlington, releasing some 75 million gallons of water upon the city.

County roads and bridges were washed out in Burlington County. Road Supervisor L. A. MacFarland says the main damage to the county road system is loss of several miles of gravel shoulders, just completed and ready for oiling. The floods overtopped and washed out roads at many small culverts that were inadequate for the discharge, according to F. L. Branin, county engineer. A few old timber bridges were swept away, and fills behind abutments on newer structures were washed out. Damage on the State highway system was restricted to undermining of concrete slabs at a few points and erosion of wet slopes. ${ }^{13}$

New Jersey contains many large cities and has a high density of population. Fortunately, the storm was heaviest in the more sparsely populated regions, and damages were much smaller than they would have been otherwise.

\section{MONTHLY DISTRIBUTION OF FLOODS}

Floods in New Jersey predominate in two seasons, namely, late winter and late summer. Table 11 lists the dates and discharges of the annual floods on Paulins Kill at Blairstown in the northern part of the State and on Great Egg River at Folsom in the southern part. On Paulins Kill 11 floods occurred during the months from February to April and 5 floods from July to September. On Great Egg River, 7 annual floods occurred from February to April and 7 during August and September. No maximum annual flood occurred in either basin during May, June, October, or November. Floods during the late winter are generally produced by the melting of accumulated snowfall, rainfall, and high soil moisture, a combination of conditions especially favorable to production of major floods. This combination of conditions occurs more frequently in the northern basins than in the southern. Annual floods in summer occur as a result of heavy rainstorms, such as are produced by West Indian hurricanes or local thunderstorms. These storms are characterized by great intensity for short periods and over small areas and therefore tend to be productive of great floods on small drainage areas, such as are typical of streams in southern New Jersey. On large streams the late winter and early spring floods predominate. A count of annual floods on Passaic River at Paterson, a drainage area of 785 square miles, as obtained from

\footnotetext{
${ }^{13}$ Engineering News-Record, vol. 121, p. 5, July 7, 1938.
} 
data given in Water-Supply Paper $771^{14}$ for a period of 36 years, discloses that 26 occurred during the 3 months of February to April. Unusually widespread West Indian hurricanes, as those in October 1903 and August 1933, produce maxima during the late summer on drainage areas as large as the basin above Paterson, as well as on smaller basins such as those given in table 11.

TABLE 11.-Annual floods of two selected streams in New Jersey

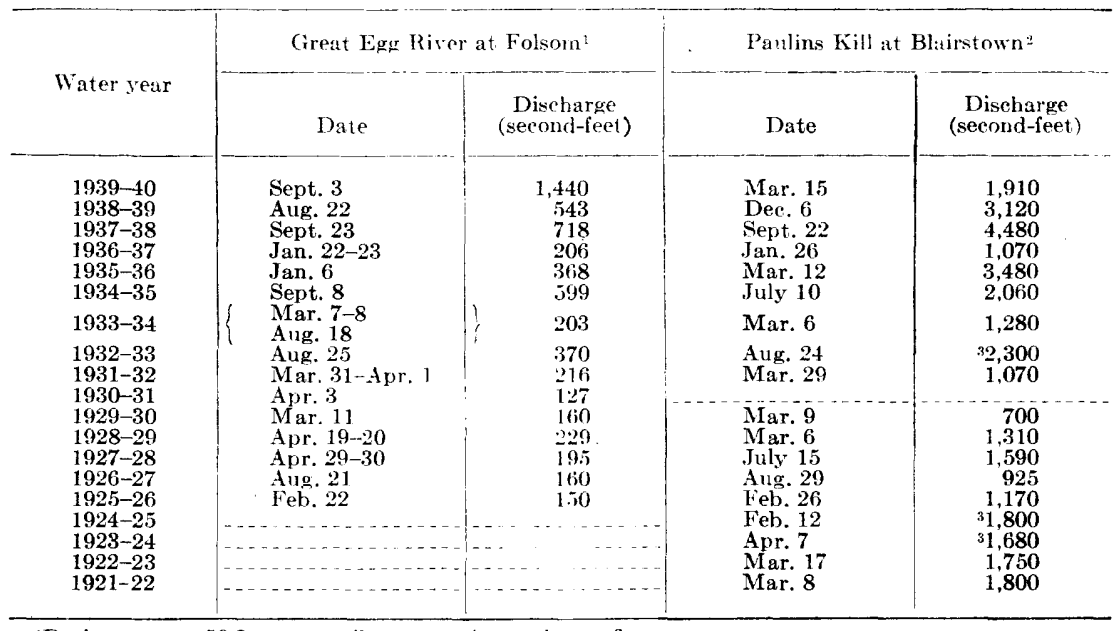

1Drainage area, 56.3 square miles.

"Drainage area, 126 sipuare miles.

There were three storms during the summer of 1938, each storm greater in intensity and in areal extent than the preceding. That of June 1938 was fairly local, centering in southern New Jersey and northern Delaware, but those of July and September covered wide areas including New Jersey. As a result of these three storms every stream in the State except one reached its annual flood during this summer, but only one stream, Oldmans Creek in the southern part of the State, reached its annual flood as a result of the storm of June 1938.

\section{METEOROLOGIC FEATURES OF THE FLOOD}

\section{ANTECEDENT CONDITIONS}

Precipitation during March and April 1938, as indicated by the rain gage at Indian Mills (table 12), was below normal, while the mean temperature was above normal. This combination of conditions would tend to produce a dry soil favorable for the retention of potential flood-producing rainfall. Precipitation during May, however, was slightly in excess of normal and temperature was

\footnotetext{
14 Jarvis, C. S., and others, Floods in the United States, magnitude and frequency: U. S. Geol. Survey Water-Supply Paper 771, p. 136, 1936.
} 
$1.3^{\circ}$ below normal, which would tend to build up soil moisture. The first 24 days of June, which preceded the flood, were about normal with respect to precipitation and to temperature. In general, therefore, it might be deduced that soil-moisture conditions were normal on June 25, except locally, to the extent that soil-moisture content may have been raised on June 23-24 by rainfall, which at four stations exceeded 2 inches but averaged less than 1 inch over the south half of the State.

TABLE 12.-Monthly precipitation and emperature at Indian Mills, N. J., during spring and summer of 1938

\begin{tabular}{|c|c|c|c|c|c|}
\hline \multirow[b]{2}{*}{ Perienl } & \multicolumn{3}{|c|}{ Precipitation } & \multicolumn{2}{|c|}{ Temperature } \\
\hline & $\begin{array}{l}\text { Total } \\
\text { inches }\end{array}$ & $\begin{array}{c}\text { Departure } \\
\text { from } \\
\text { normal } \\
\text { (inches) }\end{array}$ & $\begin{array}{c}\text { Cumulative } \\
\text { departure } \\
\text { from normal } \\
\text { (inches) }\end{array}$ & $\begin{array}{c}\text { Mean } \\
\left({ }^{\circ} \mathrm{F} .\right)\end{array}$ & $\begin{array}{c}\text { Departure } \\
\text { from } \\
\text { normal } \\
\left({ }^{\circ} \mathrm{F} .\right)\end{array}$ \\
\hline 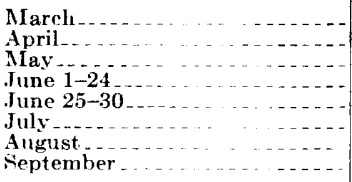 & $\begin{array}{r}1.98 \\
1.98 \\
3.83 \\
3.15 \\
7.71 \\
7.08 \\
1.93 \\
11.00\end{array}$ & $\begin{array}{r}-2.10 \\
-1.82 \\
+.49 \\
+.15 \\
+6.78 \\
+2.33 \\
-3.60 \\
+7.51\end{array}$ & $\begin{array}{l}-2.10 \\
-3.92 \\
-3.43 \\
-3.28 \\
+3.30 \\
+.383 \\
+2.23 \\
+9.74\end{array}$ & $\begin{array}{l}45.0 \\
54.6 \\
60.4 \\
70.0 \\
69.5 \\
76.0 \\
75.8 \\
64.4\end{array}$ & $\begin{array}{r}+3.9 \\
+4.1 \\
-1.3 \\
+.5 \\
+1.5 \\
+1.5 \\
+3.4 \\
-2.0\end{array}$ \\
\hline
\end{tabular}

Notw.-Figures determined from U.S. Weather Bureai recorts.

WEATHER CONDITIONS ASSOCIATED WITH THE STORM

The intense rainfall of June 26 and 27 in New Jersey was associated with a trough-shaped low-pressure area extending in a northeasterly direction and situated between a high-pressure area moving slowly southeastward over Lake Superior and a highpressure area east of Bermuda. The surface weather chart on the morning of June 27 illustrates these conditions. (See figure 20.)

On the afternoon of June 26, when the first heavy rainfall began abruptly, the low-pressure area was centered over the central Ohio River Basin and was advancing nearly due east. A well-defined cold front extended northeastward over New Jersey from this lowpressure center. On the morning of June 26 the front passed over Port Jervis, N. J., and on the morning of June 27, as shown on figure 20, it lay over southern New Jersey. By the morning of June 28 it had passed to a position about a hundred miles to the southeast. The passage of this front over the State may be noted from the time of beginning of rainfall as given in table 14. The passage of the front was marked by large lowering of temperature, as noted in figure 20. A few stations in New Jersey reported a drop of $20^{\circ}$ or more in temperature, as for example Flemington, which had a maximum temperature of $91^{\circ} \mathrm{F}$. on June 26 and of $65^{\circ} \mathrm{F}$. on June 27. On June 27, when most of New Jersey was 


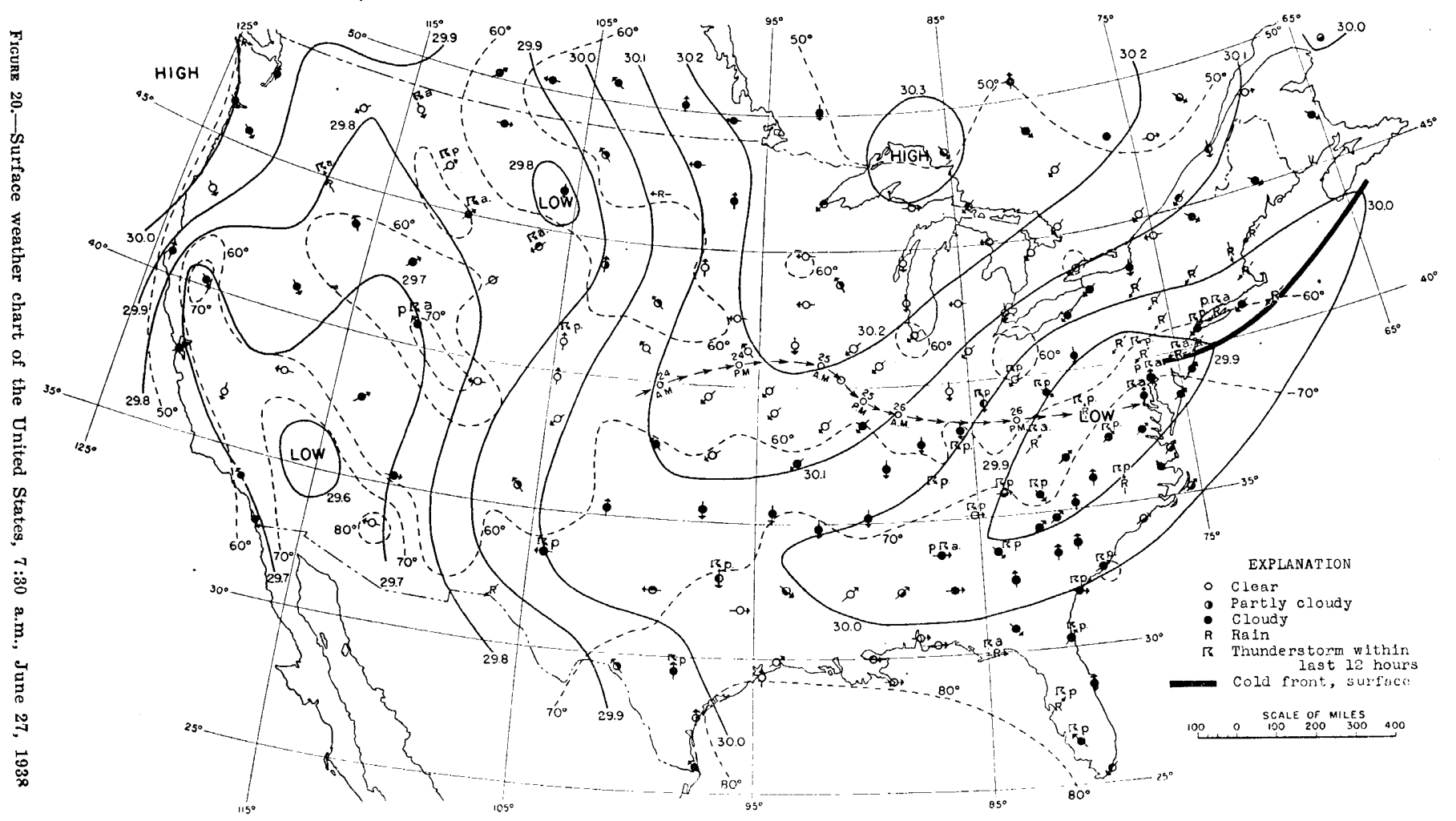


covered by cold air, fluctuations in temperature were small and most stations reported a difference of only $5^{\circ}$ or less between maximum and minimum. Along this cold front, violent thunderstorms occurred on the afternoon and evening of June 26. After the passage of the front steady rainfall continued throughout the morning of June 27 and culminated in most parts of the State in another period of heavy rainfall on the afternoon and evening of June 27. Heavy rain also occurred over the northeastern part of New Jersey on the early morning of June 28, but in the rest of the State precipitation was light. Very little rain fell on June 29 as the low-pressure area had moved out to sea and the highpressure area, which had centered over Lake Superior, now had extended over practically the entire eastern part of the United States.

\section{PRECIPITATION}

A total of 96 records of daily precipitation in New Jersey, including a few selected records in the central storm area in Delaware and adjoining parts of New York and Pennsylvania, are given in table 13. Most of the records were furnished by the United States Weather Bureau, but a thorough effort was made to compile records collected by other agencies and persons, with special emphasis on those in New Jersey. Among these records are 38 autographic records at which continuous records of precipitation are available. Precipitation at these gages during each hour of the storm is given in table 14. Most of these rain gages are in the northern part of the State, and none are at the places of heaviest rainfall. Days on which no precipitation fell during the period June 25-29 are omitted from table 14. 
TABLE 13.-Daily precipitation, in inches, June 20-30, 1938

[Measured in the afternoon except as noted]

\begin{tabular}{|c|c|c|c|c|c|c|c|c|c|c|c|c|c|}
\hline $\begin{array}{c}\text { No. } \\
\text { on } \\
\text { pl. } \\
11\end{array}$ & Station & 20 & 21 & 22 & 23 & 24 & 25 & 26 & 27 & 28 & 29 & 30 & $\begin{array}{l}\text { Total, } \\
25-29\end{array}$ \\
\hline & Hudson Biner Basin & & & & - & & & & & & & & \\
\hline & New York: & & & & & & & & & & & & \\
\hline 754 & $\begin{array}{l}\text { Sparkill } 2, \ldots \ldots \ldots \\
\text { New Jersoy: }\end{array}$ & (3) & (3) & (") & (3) & (3) & & 0.87 & 1.82 & 0.51 & & $\ldots$ & 3.20 \\
\hline $\begin{array}{l}755 \\
756 \\
757\end{array}$ & $\begin{array}{l}\text { Beemerville } e^{2} \text { a } \\
\text { Libertyville }{ }^{2} 4 \\
\text { Sussex }\end{array}$ & 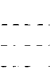 & & $\begin{array}{r}0.18 \\
.14\end{array}$ & 0.07 & 0.01 & $\begin{array}{r}0.02 \\
.04\end{array}$ & $\begin{array}{r}1.24 \\
.88 \\
.99\end{array}$ & $\begin{array}{l}2.57 \\
2.63 \\
1.62\end{array}$ & $\begin{array}{r}.07 \\
.17 \\
1.76\end{array}$ & (n) & (n) & $\begin{array}{l}3.90 \\
3.72 \\
4.37\end{array}$ \\
\hline & Hackensack River Basin & & & & & & & & & & & & \\
\hline & New York: & & & & & & & & & & & & \\
\hline 758 & $\begin{array}{l}\text { Spring Valley }{ }^{1}: \ldots \ldots \\
\text { New Jersey: }\end{array}$ & (3) & (3) & $\left(3^{3}\right)$ & (3) & (3) & & 1.46 & $2 . \dot{0} 2$ & .24 & $\ldots$ & - & 3.72 \\
\hline $\begin{array}{l}379 \\
385 \\
390\end{array}$ & $\begin{array}{l}\text { New Milford }{ }^{1}{ }^{2} \\
\text { Ridgefield1 }{ }_{2}^{2} \\
\text { Woodeliff Lake }{ }^{2}\end{array}$ & & & & Tr. & $\begin{array}{l}.08 \\
.13\end{array}$ & & $\begin{array}{r}1.00 \\
.80 \\
.98\end{array}$ & $\begin{array}{r}.85 \\
.52 \\
2.13\end{array}$ & $\begin{array}{r}1.21 \\
2.53 \\
.69\end{array}$ & & 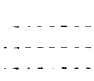 & $\begin{array}{l}3.06 \\
3.85 \\
3.80\end{array}$ \\
\hline & Passaic River Basin & & & & & & & & & & & & \\
\hline & New York: & & & & & & & & & & & & \\
\hline $\begin{array}{l}348 \\
349\end{array}$ & $\begin{array}{l}\text { Palisades Park } 25 \ldots \\
\text { Southfields }{ }^{2} 5 \ldots\end{array}$ & & & & .63 & 26 & & $\begin{array}{l}1.70 \\
1.80\end{array}$ & $\begin{array}{l}2.50 \\
2.65\end{array}$ & $\begin{array}{l}.34 \\
.22\end{array}$ & 0.0 .5 & 0.04 & $\begin{array}{l}+30 \\
+67\end{array}$ \\
\hline & New Jersey: & & & & & & & & & & & & \\
\hline $\begin{array}{l}350 \\
351 \\
352 \\
353 \\
354 \\
355 \\
356 \\
357 \\
358\end{array}$ & 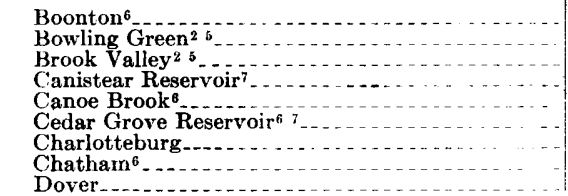 & & (3) & $\cdots \cdots$ & $\begin{array}{r}(3) \\
.83 \\
2.40 \\
.60 \\
1.75\end{array}$ & $\begin{array}{l}20 \\
(3) \\
.15 \\
.00 \\
.03 \\
03 \\
.12\end{array}$ & \begin{tabular}{c}
87 \\
$(3)$ \\
\hdashline-1 \\
\hdashline-1 \\
$\cdots$
\end{tabular} & $\begin{array}{r}.02 \\
(3) \\
1.91 \\
1.80 \\
.01 \\
40 \\
1.92 \\
1.92\end{array}$ & $\begin{array}{l}1.57 \\
1.62+ \\
1.46 \\
1.70 \\
1.14 \\
2.54 \\
2.00 \\
1.36 \\
1.24\end{array}$ & $\begin{array}{r}1.13 \\
.54 \\
.45 \\
2.60 \\
1.45 \\
1.94 \\
1.63 \\
1.81 \\
.33\end{array}$ & $\begin{array}{l}22 \\
0.3 \\
0.3 \\
15 \\
.34 \\
.07 \\
37\end{array}$ & 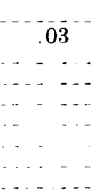 & $\begin{array}{l}2.94 \\
2.24+ \\
3.82 \\
6.15 \\
2.74 \\
4.83 \\
4.10 \\
3.54 \\
3.49\end{array}$ \\
\hline
\end{tabular}



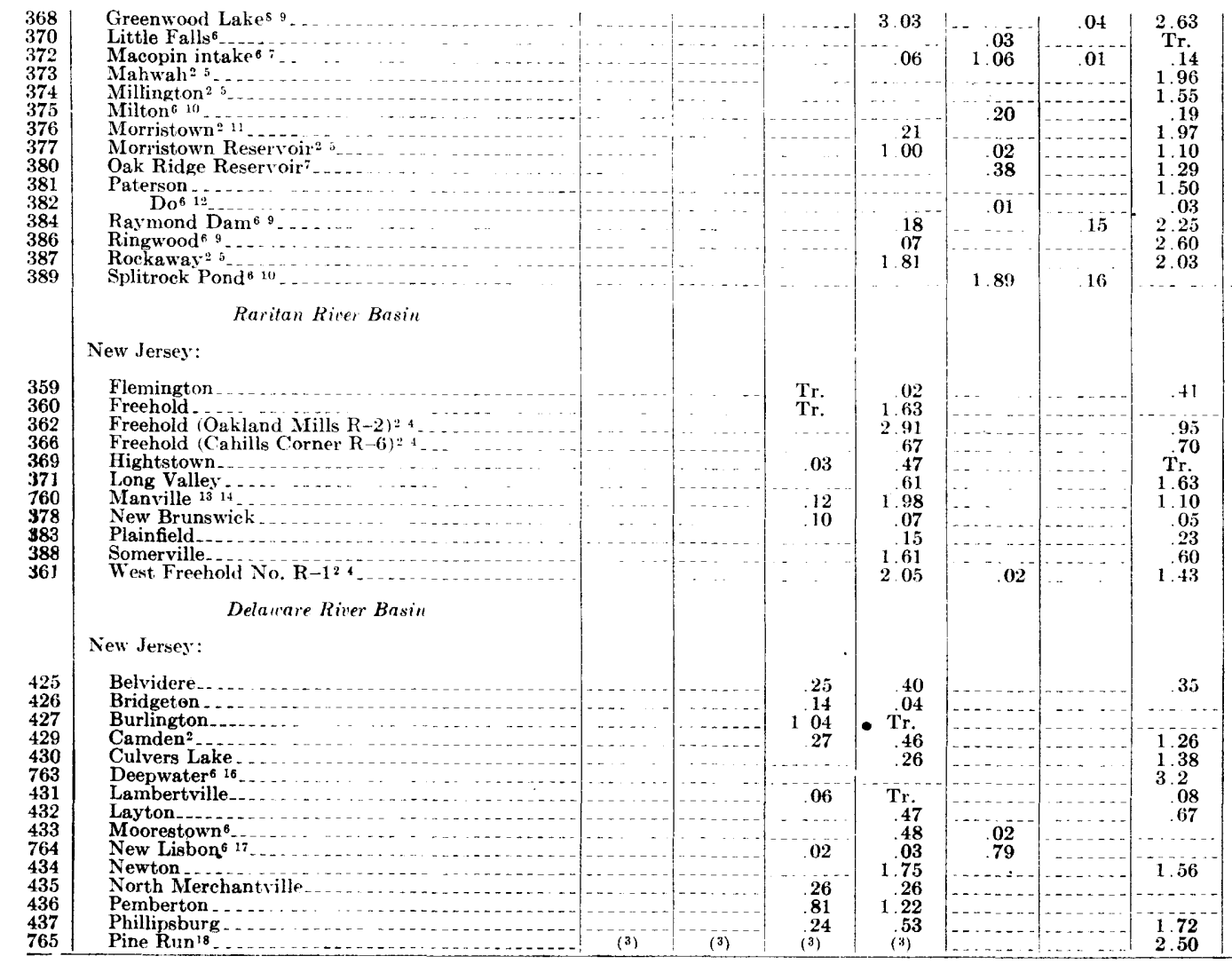

\begin{tabular}{|c|c|c|c|c|}
\hline & & & & \\
\hline 2.55 & 0.5 & & & 5.27 \\
\hline $\begin{array}{l}2.00 \\
2.81 \\
1.61\end{array}$ & $\begin{array}{r}1.50 \\
1.60 \\
08\end{array}$ & .14 & & $\begin{array}{l}3.64 \\
4.61 \\
2.61\end{array}$ \\
\hline $\begin{array}{l}63 \\
79\end{array}$ & $\begin{array}{l}.08 \\
.86\end{array}$ & & & $\begin{array}{l}3.67 \\
3.20\end{array}$ \\
\hline & 2.55 & 13 & & 6.29 \\
\hline & $\begin{array}{l}.00 \\
.56\end{array}$ & 03 & 02 & $\begin{array}{l}3.56 \\
2.62\end{array}$ \\
\hline $\begin{array}{l}48 \\
87\end{array}$ & 1.84 & .08 & & 5.69 \\
\hline 1.70 & $\begin{array}{l}1.65 \\
1.56\end{array}$ & .02 & & $\begin{array}{l}4.04 \\
3.43\end{array}$ \\
\hline 45 & $\begin{array}{l}12 \\
02\end{array}$ & & .. & $\begin{array}{r}3.82 \\
4.84\end{array}$ \\
\hline & $\begin{array}{r}.19 \\
3.46\end{array}$ & 18 & & $\begin{array}{r}3.09 \\
3.64\end{array}$ \\
\hline 1.57 & (i3 & .01 & & 2.62 \\
\hline & $\begin{array}{r}1+22 \\
.29\end{array}$ & .03 & & $\begin{array}{l}5.75 \\
5.50\end{array}$ \\
\hline 530 & .24 & 02 & & $\begin{array}{l}5.46 \\
5.57\end{array}$ \\
\hline .90 & 1.11 & & & 3.64 \\
\hline & .70 & & & 2.44 \\
\hline 30 & .51 & .02 & & 2.34 \\
\hline 11 & 79 & 02 & & 2.52 \\
\hline & & & & \\
\hline (15) & .5 .07 & & & \\
\hline $\begin{array}{l}2.63 \\
5.25\end{array}$ & 1.55 & .05 & & 4.23 \\
\hline 3.23 & .17 & & 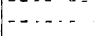 & 4.66 \\
\hline & & 25 & & $\begin{array}{l}5.00 \\
5.55\end{array}$ \\
\hline $\begin{array}{l}1.86 \\
.78\end{array}$ & $\begin{array}{l}.78 \\
.29\end{array}$ & $\mathrm{pr}_{\mathrm{r}}^{03}$ & & 2.75 \\
\hline & 3.16 & 11 & - & 6.39 \\
\hline 44 & $\begin{array}{l}1.05 \\
1.05\end{array}$ & 01 & & $\begin{array}{l}6.88 \\
5.06\end{array}$ \\
\hline 43 & .32 & Tr. & & $\begin{array}{r}4.75 \\
4.85\end{array}$ \\
\hline 2.02 & $\begin{array}{l}.26 \\
.50\end{array}$ & & & 4.00 \\
\hline
\end{tabular}


TABLE 13.-Daily precipitation, in inches, June 20-30, 1938-Continued

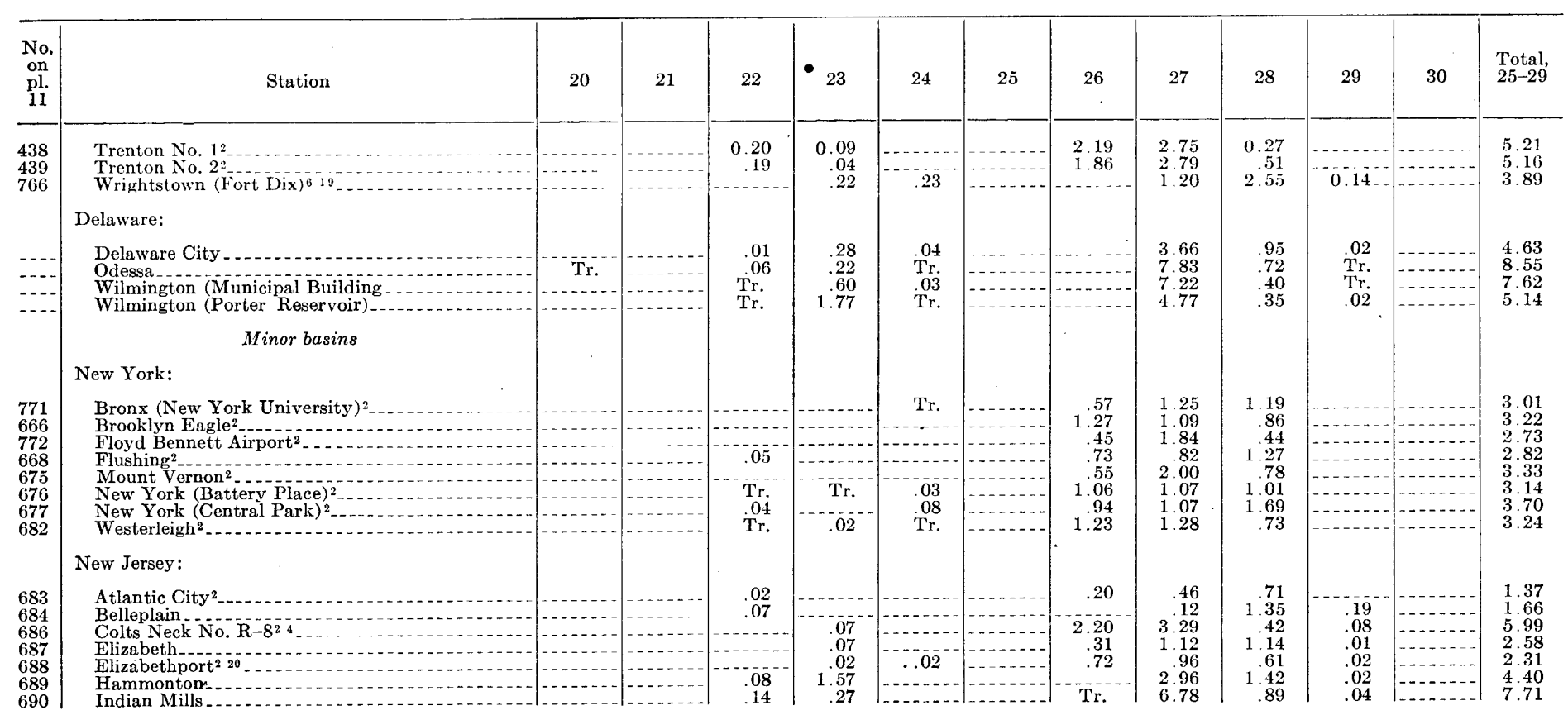




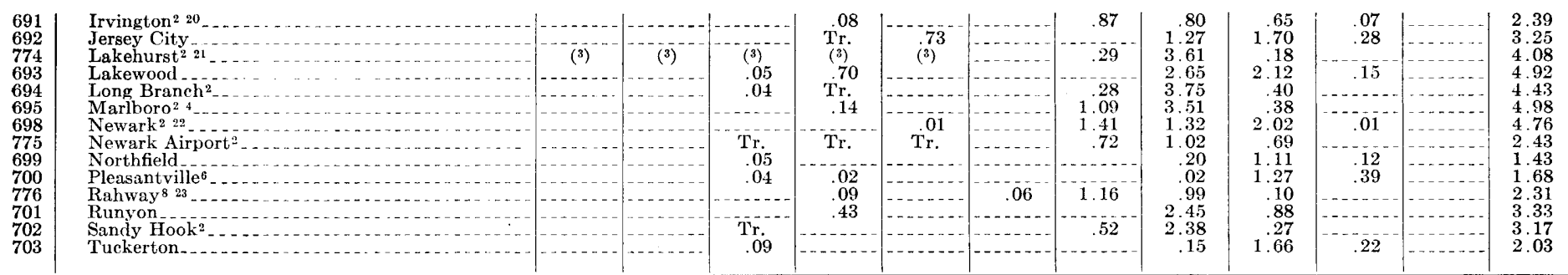

'Hackensack Water Co., Wechawken, N. J.

${ }_{13}^{13}$ Mlizabethtown Water Co., Elizabeth, N. J.
${ }_{13}$ Measured at 11 p.m.

Measured at midnight.

15Included in following measuremnet.

${ }^{16 E}$. I. duPont de Nemours \& Co., Inc., Dye Works.

${ }^{4}$ Soil Conservation Service.

${ }^{5}$ Corps of Engineers, U. S. Army.

6 Measured in morning of day indicated.

City of Newark, Department of Public Affairs.

8 Measured in morning after day indicated.

North Jersey District Water Supply Commission.

11Tepartment of Public Works, Jersey City, N. J.

12The Society for Kstablishing Useful Manufactures.

18W m. C. Armstrong, Blairstown, N. J., time of reading unknown.

${ }^{19}$ Commanding officer, Fort Dix, N. J.

20Joint meeting maintenance, Irvington, N. J.

Kresge Department

Store, William Wiener, meterologist. Recorder adjusted to nform with stick readings. 
TABLE 14.-Precipitation, in inches, for

\begin{tabular}{|c|c|c|c|c|c|c|c|c|}
\hline \multirow{2}{*}{$\begin{array}{c}\text { No. } \\
\text { on } \\
\text { [1]. } 11\end{array}$} & \multirow{2}{*}{ Station } & \multirow{2}{*}{ Day } & \multirow[b]{2}{*}{1} & \multirow[b]{2}{*}{2} & \multirow[b]{2}{*}{3} & \multirow[b]{2}{*}{4} & \multirow[b]{2}{*}{5} & \multirow[b]{2}{*}{6} \\
\hline & & & & & & & & \\
\hline \multirow[b]{2}{*}{754} & Hudson River Basin & \multirow[b]{2}{*}{$\begin{array}{l}26 \\
27 \\
28\end{array}$} & \multirow[b]{2}{*}{0.07} & \multirow[b]{2}{*}{0.01} & \multirow[b]{2}{*}{0.07} & \multirow[b]{2}{*}{02} & & \multirow{3}{*}{$\cdots$} \\
\hline & $\begin{array}{l}\text { Sparkill, N.Y. } \\
\text { Hackensack Water Co., Werhawken, X. .T. }\end{array}$ & & & & & & & \\
\hline 755 & Beemerville, N. J. & $\begin{array}{l}28 \\
25\end{array}$ & $-\cdots$ & .02 & .08 & .11 & 0.04 & \\
\hline \multirow{5}{*}{756} & U.S. Department of Agriculture, Soil Conservation Se & 26 & & 01 & 01 & & & \\
\hline & & $\begin{array}{l}27 \\
28\end{array}$ & $\begin{array}{l}.02 \\
.01\end{array}$ & .04 & $\begin{array}{l}.01 \\
.02\end{array}$ & 01 & -- & 0.24 \\
\hline & Libertyville. N. J., Gage $2-R$. & 25 & & & .02 & & & \\
\hline & U. S. Department of Agrienlture, Soil Conservation Scrvice & 26 & .01 & 04 & $-\ldots$ & $\cdots$ & - & \\
\hline & & 28 & .01 & $\mid \begin{array}{r}.04 \\
-.--\end{array}$ & .03 & .04 & .02 & .02 \\
\hline \multirow[b]{2}{*}{758} & Hackensack River Basin & & & & & & & \\
\hline & $\begin{array}{l}\text { Spring Valley, N. Y. } \\
\text { Hackensack Water Co., Weehawken, N. J. . }\end{array}$ & $\begin{array}{l}26 \\
27\end{array}$ & .06 & .01 & .04 & & & \\
\hline \multirow[t]{2}{*}{379} & New Milford, N. J. & 26 & 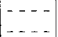 & & - & & & \\
\hline & Hackensack Water Co., Weehawken, X. J.. & 27 & .05 & .01 & .09 & .03 & $\cdots$ & 01 \\
\hline \multirow[t]{4}{*}{390} & Woodcliff Lake, N. J. & 28 & .01 & .04 & .25 & .31 & .01 & 08 \\
\hline & Hackensack Water Co., Weehawken, X. J. . . & 27 & 09 & 01 & 06 & & $-\cdots$ & \\
\hline & & & .... & .04 & .27 & .02 & .01 & .01 \\
\hline & Passaic River Basin & & & & & & & \\
\hline \multirow[t]{2}{*}{348} & Palisades Park, N. Y. & 26 & & & & & & \\
\hline & & 27 & .04 & .02 & $.0 \overline{3}$ & .01 & .01 & .02 \\
\hline 349 & Southfield, N. Y. & 26 & & & & & $\ldots$ & $\ldots$ \\
\hline & 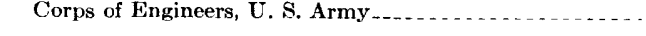 & 27 & .06 & .07 & & & 9 & 03 \\
\hline 351 & Bowling Green, N. J. & 27 & & & & & .02 & .03 \\
\hline & Corps of Engineers, U. S. Army & 28 & .01 & .03 & .08 & .03 & .02 & .02 \\
\hline 352 & Brook Valley, N. J. & 29 & & & & & & \\
\hline & Corps of Éngineers, U. S. Army & 27 & .01 & 04 & 04 & $\mathrm{Tr}$. & Tr. & $\mathrm{Tr}^{2}$ \\
\hline 373 & Mahwah, N. J. & 28 & 05 & .04 & .04 & .01 & .01 & .04 \\
\hline & Corps of Engineers, U. S. Army . ... & 27 & 01 & 07 & 09 & & -1 & $\ldots$ \\
\hline 374 & Millingtion, N.J. & 26 & & & & & & $\ldots$ \\
\hline & Corps of Engineers, C. S. Army & 27 & 0.5 & .01 & .01 & & & \\
\hline 376 & Morristown, N. J. & $\begin{array}{l}28 \\
26\end{array}$ & .20 & .20 & .20 & .02 & .15 & .03 \\
\hline & Town engineer, Morristown, N. J. & 27 & 07 & .07 & 06 & .10 & 07 & 05 \\
\hline 377 & Morristown, Reservoir, N. J. & $\begin{array}{l}28 \\
26\end{array}$ & 25 & . 13 & .05 & .02 & 01 & .03 \\
\hline & Corps of Engineers, U.S. Army ... & 27 & 18 & .01 & 07 & 03 & & \\
\hline & & $\begin{array}{l}28 \\
29\end{array}$ & .10 & .03 & .02 & .05 & .04 & .01 \\
\hline 387 & Roekaw & 26 & & & & -1 & $\cdots$ & $\ldots$ \\
\hline . & rps of Engineers. C. S. Army & 27 & .02 & 07 & 01 & $0 \overline{0}$ & & \\
\hline & Raritan River Basin & & & & & & & \\
\hline 362 & Freehold $(\mathrm{O}$ & 26 & & & & & & \\
\hline & & 27 & 09 & 02 & 1.5 & .12 & & 14 \\
\hline 366 & Freehold (Cahills Corner $\mathrm{R}-6 \mathrm{~b}), \mathrm{N} . J$ & 26 & & & & & & \\
\hline & U. S. Department of Agriculture, soil Conservation & 27 & .13 & 03 & .14 &.$\overline{7}$ & & .25 \\
\hline 361 & West Freehold No. R-1. N. J. & 26 & $0: 5 \mid$ & & .04 & & .01 & \\
\hline & U.S. Department of Agriculture, Soil Conservation Service & 27 & .06 & .03 & .11 & .13 & & 08 \\
\hline & . & 28 & .04 & & .04 & . & .01 & .01 \\
\hline
\end{tabular}




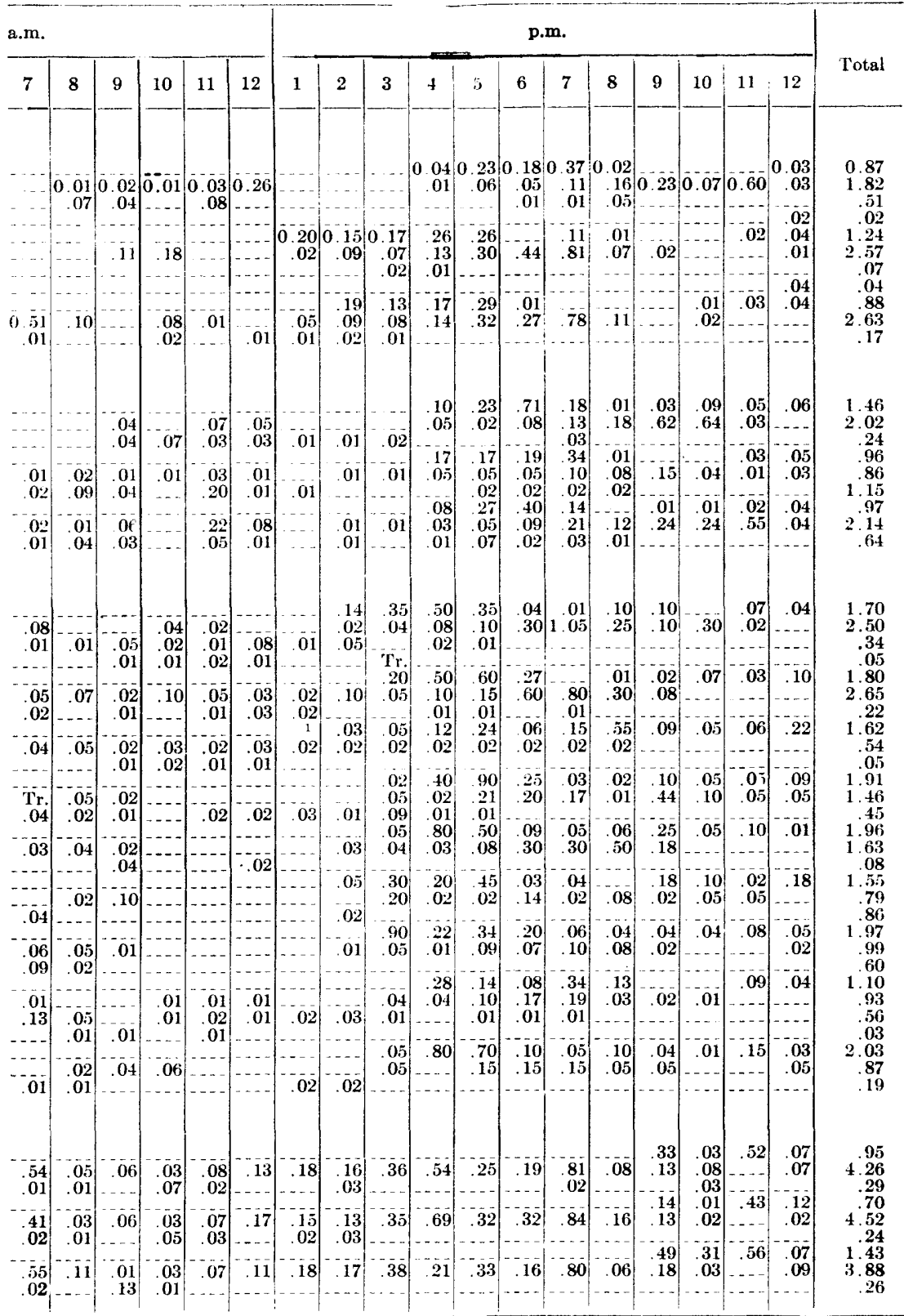


TABLE 14.-Precipitation, in inches, for period

\begin{tabular}{|c|c|c|c|c|c|c|c|c|}
\hline \multirow{2}{*}{$\begin{array}{l}\text { No. } \\
\text { on } \\
\text { pl. } 11\end{array}$} & \multirow[b]{2}{*}{ Station } & \multirow[b]{2}{*}{ Day } & & & & & & \\
\hline & & & 1 & 2 & 3 & 4 & 5 & 6 \\
\hline & Delaware River Basin & & & & & & & \\
\hline 429 & $\begin{array}{l}\text { Camden (airport), N. J. } \\
\text { U. S. Weather Bureau (Measured at 1:30 a.m., 7:30 a.m., } \\
\text { 1:30 p.m., 7:30 p.m.) }\end{array}$ & $\begin{array}{l}26 \\
27 \\
28 \\
29\end{array}$ & $\begin{array}{r}1.74 \\
.08 \\
T\end{array} \mid$ & $*$ & $*$ & $*$ & $*$ & * \\
\hline 433 & $\begin{array}{l}\text { Moorestown, N. J. } \\
\text { U. S. Department of Agriculture, Soil Conservation Service }\end{array}$ & $\begin{array}{l}29 \\
27 \\
28\end{array}$ & .14 & 0.02 & $\begin{array}{r}0.42 \\
.05\end{array}$ & 0.35 & {$\left[\begin{array}{r}0.10 \\
.04\end{array}\right.$} & 0.11 \\
\hline 438 & $\begin{array}{l}\text { Trenton No. 1, N. J. } \\
\text { U. S. Weather Bureau } \\
\text { Minor basins }\end{array}$ & $\begin{array}{l}26 \\
27 \\
28\end{array}$ & .02 & Tr. & Tr. & Tr. & .22 & .05 \\
\hline 771 & $\begin{array}{l}\text { Bronx (New York University), N. Y. } \\
\text { New York University Meteorological Dept. }\end{array}$ & $\begin{array}{l}25 \\
26 \\
27 \\
28\end{array}$ & $\begin{array}{c}* \\
* \\
* \\
*\end{array}$ & $\begin{array}{l}* \\
* \\
* \\
*\end{array}$ & $\begin{array}{l}* \\
* \\
* \\
*\end{array}$ & $\begin{array}{l}* \\
* \\
* \\
*\end{array}$ & $\begin{array}{l}* \\
* \\
* \\
*\end{array}$ & $\begin{array}{l}* \\
* \\
* \\
*\end{array}$ \\
\hline 666 & $\begin{array}{l}\text { Brooklyn, N. Y:, (Brooklyn Eagle) } \\
\text { U. S. Weather Bureau }\end{array}$ & $\begin{array}{l}26 \\
27 \\
28\end{array}$ & $\begin{array}{r}09 \\
06\end{array}$ & $\begin{array}{r}18 \\
24\end{array}$ & $\begin{array}{r}01 \\
09\end{array}$ & Tr. & $\mathrm{Tr}_{04}$ & .03 \\
\hline 772 & $\begin{array}{l}\text { Floyd Bennett Airport, N. Y. } \\
\text { U. S. Weather Bureau }\end{array}$ & $\begin{array}{l}26 \\
27 \\
28\end{array}$ & & .12 & {$\left[\begin{array}{r}* \\
* \\
*\end{array}\right.$} & r & & \\
\hline 668 & $\begin{array}{l}\text { Flushing, N. Y. } \\
\text { U. S. Weather Bureau }\end{array}$ & $\begin{array}{l}26 \\
27 \\
28\end{array}$ & $\begin{array}{r}-04 \\
.02\end{array}$ & $\begin{array}{l}.17 \\
55\end{array}$ & $\begin{array}{r}-.02 \\
.27\end{array}$ & $-0 \overline{0}$ & $|--\cdot|$ & .01 \\
\hline 676 & $\begin{array}{l}\text { New York, N. Y. (Battery Place) } \\
\text { U. S. Weather Bureau }\end{array}$ & $\begin{array}{l}26 \\
27 \\
27\end{array}$ & .08 & .16 & .01 & Tr. & $\mathrm{Tr}$ & .03 \\
\hline 677 & $\begin{array}{l}\text { New York, N. Y. (Central Park) } \\
\text { U. S. Weather Bureau } \ldots . . .\end{array}$ & $\begin{array}{l}28 \\
26 \\
27 \\
28\end{array}$ & \begin{tabular}{r|r}
.05 \\
$-.0 \overline{3}$ \\
.0
\end{tabular} & $\begin{array}{r}.27 \\
-23 \\
.23\end{array}$ & .15 & $\mathrm{Tr}_{3}$ & Tr. & $\begin{array}{l}.01 \\
.02 \\
\mathrm{Tr}\end{array}$ \\
\hline 682 & $\begin{array}{l}\text { Westerleigh, N. Y. } \\
\text { U. S. Weather Bureau ........ }\end{array}$ & $\begin{array}{l}20 \\
27 \\
27\end{array}$ & .10 & .16 & .03 & .01 & $.0 \overline{1}$ & .08 \\
\hline 683 & $\begin{array}{l}\text { Atlantic City, N. J. } \\
\text { U. S. Weather Bureau ..... }\end{array}$ & 26 & $\begin{array}{cc}.01 \\
\cdots-1 \\
--1\end{array}$ & \begin{tabular}{cc}
$\cdot 14$ \\
\hdashline$-\cdots$
\end{tabular} & $\left|\begin{array}{cc}.00 \\
-1 .- \\
-1-\end{array}\right|$ & Tr. & .01 & .01 \\
\hline 686 & $\begin{array}{l}\text { Colts Neck No. R-8, N. J. } \\
\text { U.S. Department of Agriculture, Soil Conservation Service }\end{array}$ & $\begin{array}{l}28 \\
26 \\
27 \\
28 \\
29\end{array}$ & $\begin{array}{r}.11 \\
.04 \\
.03\end{array}$ & .01 & $\begin{array}{r}.02 \\
.06 \\
.07\end{array}$ & $\begin{array}{r}.05 \\
--. \overline{12} \\
-.-\end{array}$ & $\left|\begin{array}{r}.08 \\
-0 . \\
-01 \\
01\end{array}\right|$ & .08 \\
\hline 688 & $\begin{array}{l}\text { Elizabethport, N. J. } \\
\text { Chief engineer, Joint Meeting Maintenance, } \\
\text { Irvington, N. J. }\end{array}$ & $\begin{array}{l}29 \\
26 \\
27 \\
28 \\
29\end{array}$ & $\begin{array}{r}-.-- \\
.25 \\
.09\end{array}$ & $\begin{array}{r}.02 \\
.09\end{array}$ & $\mid$\begin{tabular}{c|c}
---1 \\
-02 \\
.11
\end{tabular} & 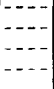 & $\mid \begin{array}{r}.01 \\
-02 \\
.07 \\
.02\end{array}$ & $\begin{array}{c}.01 \\
--.- \\
-\end{array}$ \\
\hline 691 & $\begin{array}{l}\text { Irvington, N. J. } \\
\text { Chief engineer, Joint Meeting Maintenance, } \\
\text { Irvington, N. J. }\end{array}$ & $\begin{array}{l}26 \\
27 \\
28\end{array}$ & $\begin{array}{r}-0 . \\
.09 \\
.04\end{array}$ & $\begin{array}{r}-0 . \\
.06 \\
.01\end{array}$ & $\begin{array}{r}-1.0 \\
.09 \\
.09\end{array}$ & $\begin{array}{r}.05 \\
.04 \\
.01\end{array}$ & $\begin{array}{r}.02 \\
.04 \\
.01\end{array}$ & .02 \\
\hline 774 & $\begin{array}{l}\text { Lakehurst, N.J. } \\
\text { Naval Air Station }\end{array}$ & $\begin{array}{l}29 \\
26 \\
27 \\
28\end{array}$ & \begin{tabular}{c|c|}
.01 \\
---- \\
----
\end{tabular} & .05 & .01 & $\begin{aligned} .01 \\
-\cdots \\
-\cdots\end{aligned}$ & .17 & .02 \\
\hline 694 & $\begin{array}{l}\text { Long Branch, N. J. } \\
\text { U. S. Weather Bureau }\end{array}$ & $\begin{array}{l}26 \\
27 \\
27\end{array}$ & .04 & Tr. & $\mid--1$ & 02 & 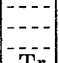 & .07 \\
\hline 695 & $\begin{array}{l}\text { Marlboro, N. J. } \\
\text { U.S. Department of Agriculture, Soil Conservation Service }\end{array}$ & $\begin{array}{l}28 \\
26 \\
27 \\
28\end{array}$ & .09 & .01 & $\mid .11$ & .08 & $-\cdots$ & -.03 \\
\hline 698 & $\begin{array}{l}\text { Newark, N. J. } \\
\text { Kresge department store, William Wiener, meteorologist. }\end{array}$ & $\begin{array}{l}26 \\
27 \\
28 \\
29\end{array}$ & $\begin{array}{l}.41 \\
.35 \\
.01\end{array}$ & .82 & $\left|\begin{array}{r}.10 \\
-06 \\
.08\end{array}\right|$ & .28 & 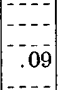 & $.0 \overline{0}$ \\
\hline 775 & $\begin{array}{l}\text { Newark Airport, N. J. } \\
\text { U. S. Weather Bureau (Measured at 1:30 a.m., 7:30 a.m., } \\
\text { 1:30 p.m., 7:30 p.m.) }\end{array}$ & $\begin{array}{l}26 \\
27 \\
28\end{array}$ & 0.42 & $*$ & $\begin{array}{r}* \\
* \\
*\end{array}$ & $\begin{array}{r}* \\
* \\
*\end{array}$ & $\begin{array}{l}* \\
* \\
*\end{array}$ & $\begin{array}{l}* \\
* \\
*\end{array}$ \\
\hline 702 & $\begin{array}{l}\text { Sandy Hook, N. J. } \\
\text { U.S. Weather Bureau }\end{array}$ & $\begin{array}{l}26 \\
27 \\
28\end{array}$ & .03 & .01 & $\mid \begin{array}{c}-\overline{0} \\
\dot{T} \mathrm{~T} \\
\end{array}$ & .01 & $\begin{array}{r}.04 \\
\text { Tr. }\end{array}$ & .16 \\
\hline
\end{tabular}

1Record began at 12:10 p.m.

2Total for 24-hour period ending at 7:30 a.m. of day indicated.

*Included in following measurement. 


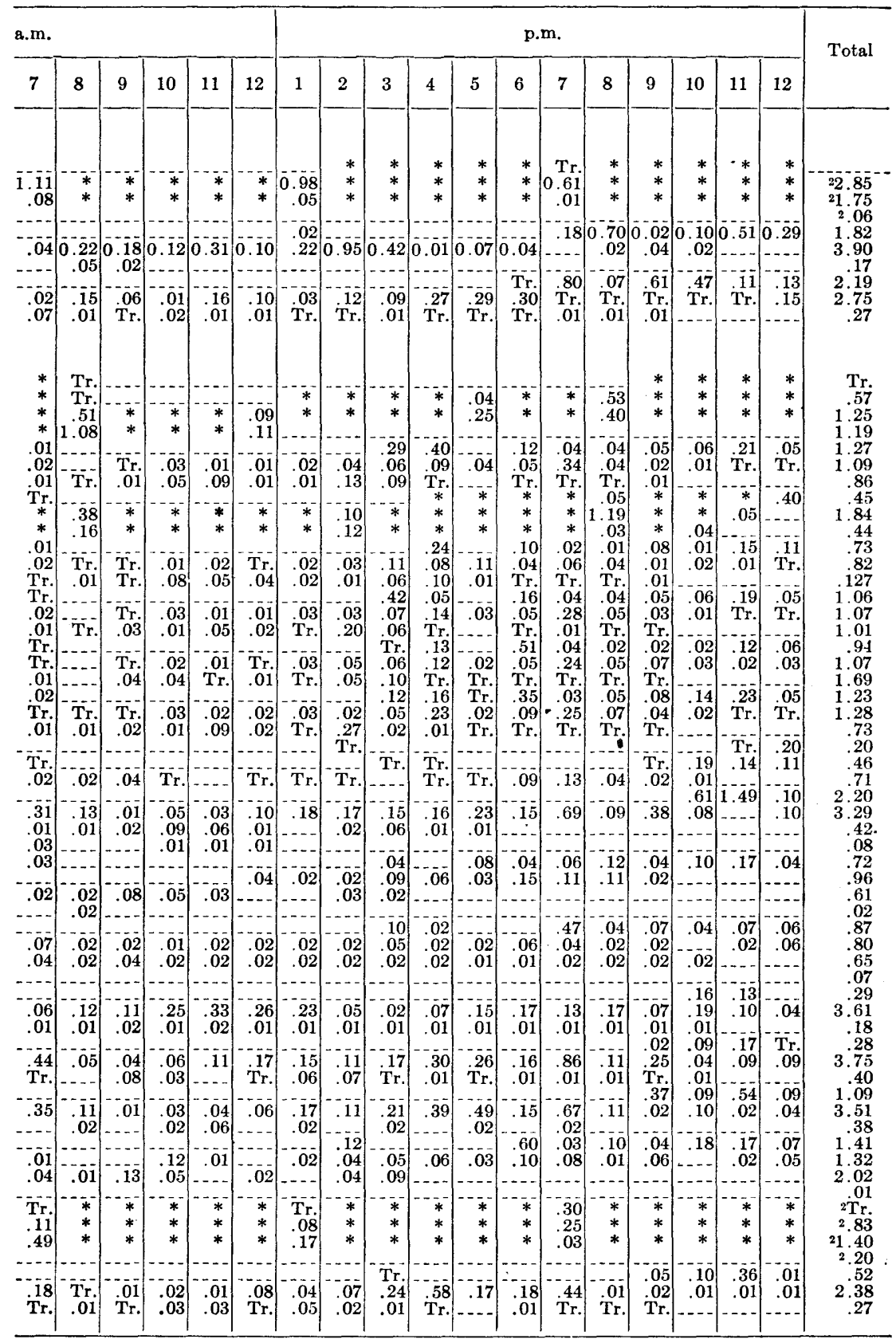


TABLE 15.--Intense rainstorms in New Jersey and nearby parts of adjoining States

\begin{tabular}{|c|c|c|}
\hline Place & Date & Precipitation (inches) \\
\hline t-hour periods & & \\
\hline 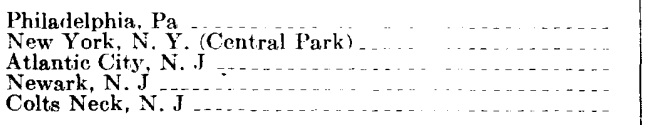 & $\begin{array}{l}\text { Aug. } 3,1898 \\
\text { Sept. } 4,1913 \\
\text { July } 22,1903 \\
\text { Aug. } 24,1897 \\
\text { June } 26,1938\end{array}$ & $\begin{array}{l}3.79 \\
3.31 \\
2.97 \\
2.95 \\
1.49\end{array}$ \\
\hline 2-hour periods & & \\
\hline $\begin{array}{l}\text { Long Level, York Co., Pa } \\
\text { New Lisbon, N. J } \\
\text { Philadelphia, Pa } \\
\text { Whitesbog, N, J } \\
\text { Colts Neck, N. J } \ldots\end{array}$ & $\begin{array}{l}\text { July } 1.5,1914 \\
\text { Aug. } 19,1939 \\
\text { Aug. } 3,1898 \\
\text { Ang. } 19,1939 \\
\text { June } 26,1998\end{array}$ & $\begin{array}{l}6.2 \\
15.5 \\
5.43 \\
5.1 \\
2.10\end{array}$ \\
\hline 6-hour periods & & \\
\hline $\begin{array}{l}\text { Manawaken, N. J } \\
\text { Cohansey, N. J } \\
\text { Paterson, N. J } \\
\text { Atlantic City, N. J } \\
\text { Freehold, N. J }\end{array}$ & $\begin{array}{l}\text { Aur. } 19,1939 \\
\text { Sept. } 1,1940 \\
\text { Sept. } 23,1882 \\
\text { July } 22,1903 \\
\text { June } 27,1938\end{array}$ & $\begin{array}{l}12.2 \\
10.93 \\
18.7 \\
3.40 \\
2.68\end{array}$ \\
\hline 24-hour periods & & \\
\hline 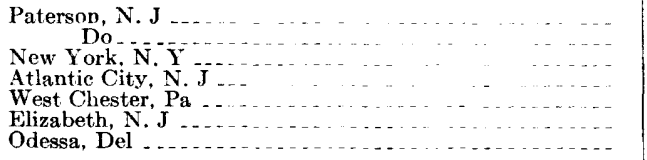 & $\begin{array}{l}\text { Oct. } 8-9,1903 \\
\text { Sept. } 22-23,1882 \\
\text { Oct. } 7-8,1903 \\
\text { Oct. } 8-9,1903 \\
\text { May } 20-21,1894 \\
\text { July } 28,1897 \\
\text { June } 26-27,1938\end{array}$ & $\begin{array}{r}14.30 \\
112.0 \\
9.40 \\
9.21 \\
99.03 \\
28.73 \\
27.83\end{array}$ \\
\hline
\end{tabular}

Note. - Based on compilation made by the New Jersey State Water Policy Commission, in cooperation with the Geological Survey.

${ }_{1}$ Based on once-daily readings of rain gage supplemented by study of observers notes of time of beginning and ending of rainfall and comparison with time-distribution of rainfall at nearby stations.

${ }^{2}$ Based on once-daily readings of rain gages. The duration of rainfall may be less than 24 hours.

Table 15 compares the rainfall for given periods during the storm of June 1938 with similar data for other storms. The maximum rainfall of record for each indicated time interval is given, and a few records near the maximum are given in order of magnitude, followed by the maximum rainfall observed at any station for the same time intervals during the storm of June 1938. For each interval from 1 hour to 24 hours, the storm of June 1938 was much less than the maximum of record in the New Jersey area.

Figure 21 shows the hourly distribution of rainfall during the storm at four rain gages in New Jersey. June 25 and the morning of June 26 were fair. Heavy rain began abruptly during the afternoon or evening of June 26, and some stations in the Passaic River Basin, of which the recording rain gage at Rockaway indicated on figure 21 is representative, registered the maximum intensity during this initial part of the storm period. This was also true of some stations in Monmouth County. In fact, the maximum 1- and 2-hour intensities at all the recording rain gages during the whole storm were measured at Colts Neck, Monmouth County, during the first 2 hours of the storm on June 26.

The rainfall continued with significant intensities until the 
afternoon of June 27, when at most stations, as illustrated by the records for Beemerville, Freehold, and Moorestown on figure 21, the maximum intensities during the storm were registered. This second period of high intensity began earlier at the southern stations than at the northern stations, whereas the cold front associated with the storm progressed from northwest toward southeast. The storm lasted longer in the northern than in the southern part of the State. After the heavy rain on June 27, light intermittent rains continued until about noon on June 28 , except in northeastern New Jersey, where the fall was quite heavy. The afternoon of June 28 and of June 29 was generally fair, although some scattered light showers were reported.

Although the time of beginning and ending of precipitation varied, at nearly all stations 90 percent of the total storm precipitation registered fell within a 30-hour period on June 26-27.

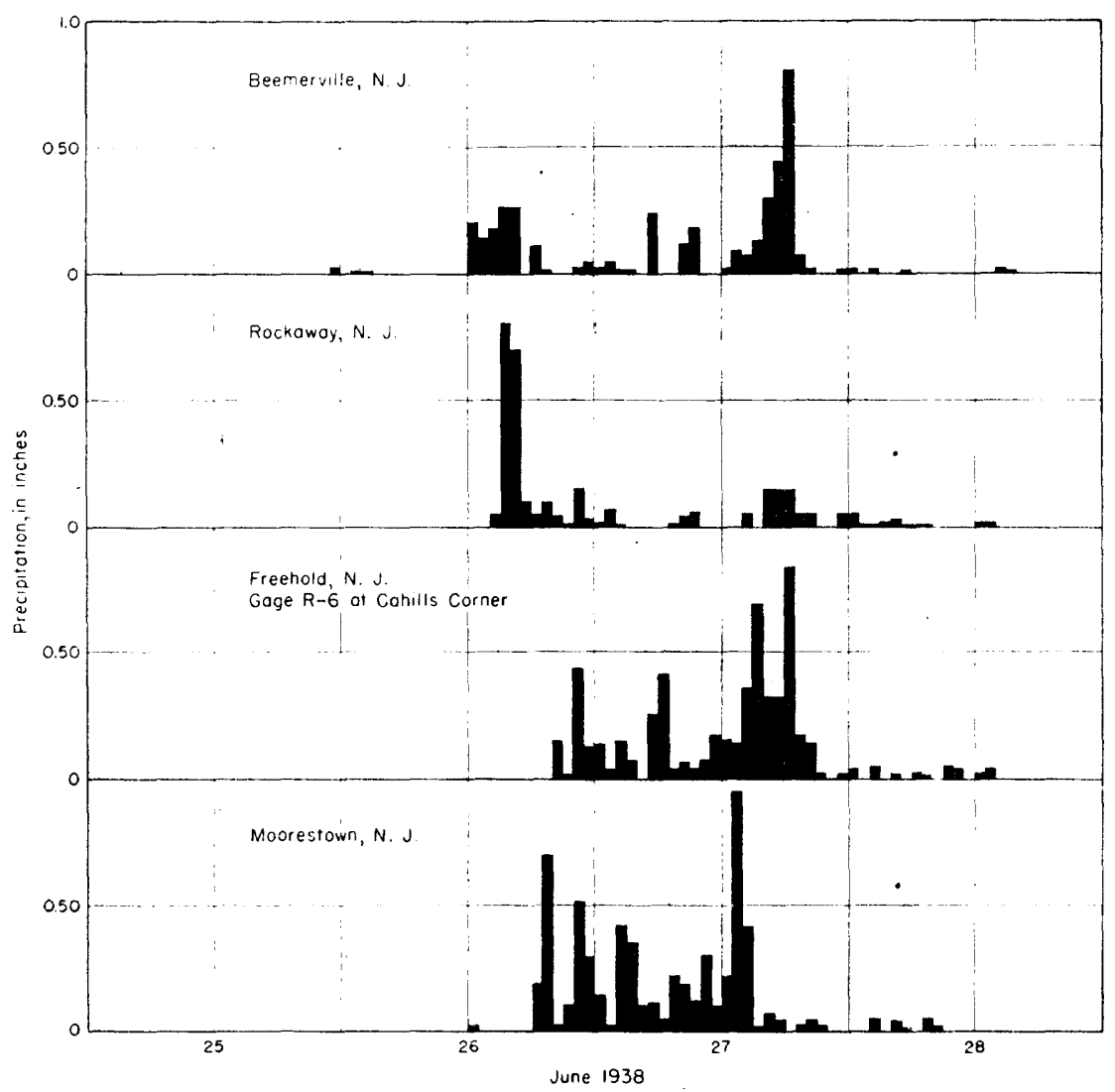

Firvre 21.-Hourly precipitation at selected recording rain gages in New Jersey during storm of June 1938. 
To determine the total amount of precipitation during the storm, readings given in table 13 for June 25-29, inclusive, were added together irrespective of the time of day at which the gages were read, with the exception that entries made on June 25 for those gages read in the morning and entered on the day of reading were omitted. Thus, the total in the final column of table 13 includes the light initial rains of June 25-26 and the light residual rains of June 28-29, as well as the 30-hour major storm of June 26-27. Separation, although possible, was not considered necessary.

Storm precipitation at the several stations given in table 13 has been plotted on a map, and lines of equal precipitation have been drawn to compare with the plotted points. The resultant isohyetal map is reproduced in this report as plate 6. The map shows three well-defined storm centers-one at Odessa, Del., with precipitation of 8.55 inches, a second at Indian Mills, N. J., with 7.71 inches, and a third less closely defined in the northern part of the State with a maximum at Milton, N. J., of 6.29 inches. The area within the several isohyetal lines was measured by planimeter, and the mean precipitation over these areas was computed about each of the three centers. From these data a graph was made showing area plotted against mean precipitation for each of the three storm centers during the storm of June 25-29, 1938, and a curve was drawn to envelop the plotted points. The following table gives the coordinates of the enveloping curve so defined:

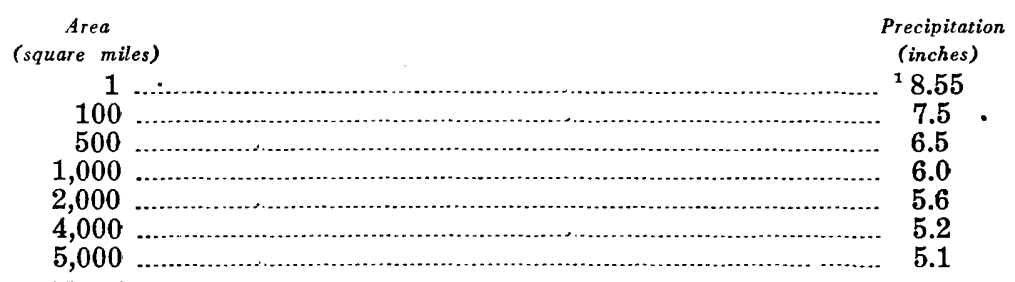

1 Recorded at Odessa, Del.

The results given in the foregoing table when compared with seven important storms of equivalent duration in New Jersey and adjoining areas, as reported by the Miami Conservancy District, ${ }^{15}$ indicate that the storm of June 1938 was exceeded by all but one. Although not of major proportion, the storm of June 1938 ranks among the important storms of record in New Jersey.

\footnotetext{
${ }^{15}$ Storm rainfall of eastern United States, Miami Conservancy District Tech. Repts. pt. 5 (revised), p. 278, 1936.
} 


\section{STAGES AND DISCHARGES}

Records of the stage and discharge at stream-gaging stations during the flood are included in the section "Floods of July 1938."

In general, the data presented for each stream-gaging station comprise a description of the station and a table giving the daily discharges during June, July, and August 1938. For the 14 streamgaging stations in New Jersey where the storm of June 1938 produced noteworthy stages tables are given showing stage and corresponding discharge at indicated times during the flood period in sufficient detail for reasonably reliable delineation of hydrographs. These tables are discussed on pages 9 to 11 .

Graphs of discharge during the flood in June at stream-gaging stations on two selected streams in the region are shown on figure 22. The rains of June 25-29 produced a single peak on all streams that occurred late on June 27 or thereafter depending on the characteristics of concentration of the particular basin. For example, the Manasquan River at Squankum, a stream of average

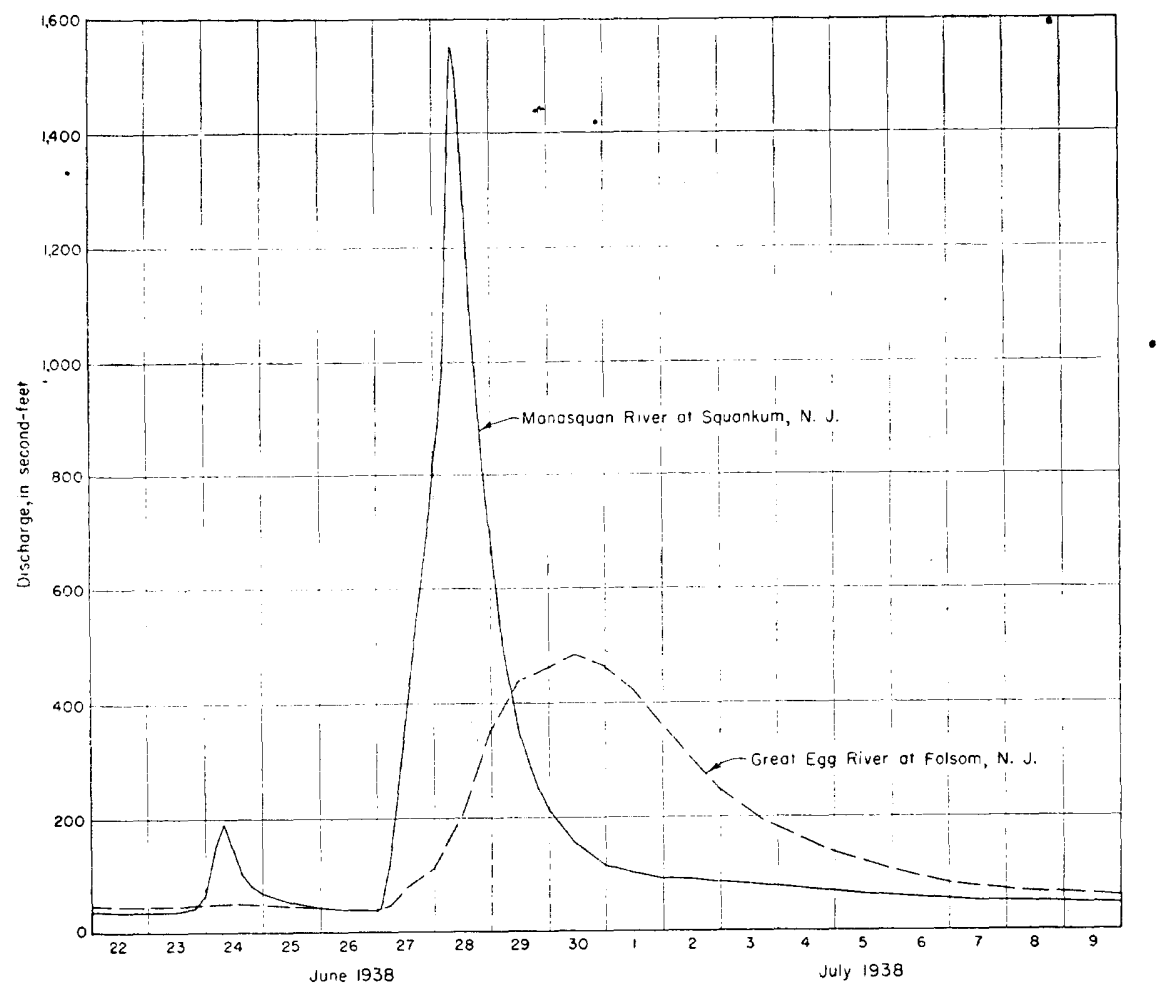

Ficure 22.--Hydrographs of discharge at selected gaging stations in New Jersey during flood of June 1938. 
responsiveness to rainfall, with a drainage area of 43.4 square miles, reached its crest early on June 28, whereas the Great Egg River at Folsom, with a drainage area of 56.3 square miles, crested more than 2 days later. This difference in behavior illustrated on figure 22 may be ascribed in large part to the topographic characteristics of these two drainage basins. (See table 16.)

The Great Egg River Basin above Folsom has a gradient about one-half that of the Manasquan River Basin. The differences in areas of swamp are also significant.

TABLE 16.-- Topographic characteristics of the Manusquan River Basin and the Great Egg River Basin

\begin{tabular}{|c|c|c|}
\hline & $\begin{array}{l}\text { Manasquan River } \\
\text { at Squankın, N.J. }\end{array}$ & $\begin{array}{l}\text { Great Egg River } \\
\text { at Folsom, N.J. }\end{array}$ \\
\hline $\begin{array}{l}\text { Drainage area. } \\
\text { Mean land slope } \\
\text { Mean slope of tributary streams } \\
\text { Mean slope of principal streams }\end{array}$ & $\begin{array}{c}43.4 \\
121 \\
27 \\
8 \\
1.8\end{array}$ & $\begin{array}{l}56.3 \\
52 \\
12 \\
6 \\
9.2\end{array}$ \\
\hline
\end{tabular}

\section{SUMMARY OF FLOOD STAGES AND DISCHARGES}

The maximum flood discharges at the stream-gaging stations in New Jersey that reached noteworthy stages are summarized in table 17. The numbers assigned to each station conform to those given in Water-Supply Paper $847^{16}$ and refer to its position on plate 12. The crest discharges during the flood of June 1938 exceeded the maximum discharges previously known on four

- streams. These discharges, however, were exceeded again during the floods of July and September 1938 on all but one stream, namely, Oldmans Creek near Woodstown. Nevertheless, the hurricane storm of September 1, 1940, which demolished the gaging station on Oldmans Creek, produced a discharge of more than 8,000 second-feet in comparison with only 1,190 second-feet during June 1938. Thus, none of the crest discharges attained during June 1938 stand as maxima at this date (1941).

Table 18 summarizes available altitudes and times of flood crests at several places along the affected rivers. Many of the data in this table were furnished by the New Jersey Riparian Stream and Waterways Survey of the Works Progress Administration.

\footnotetext{
18 Williams, G. R., and Crawford, L. C., Maximum discharges at-stream-measurement stations through December 31, 1937: U. S. Geol. Survey Water-Supply Paper 847, 272 pp., 1940.
} 


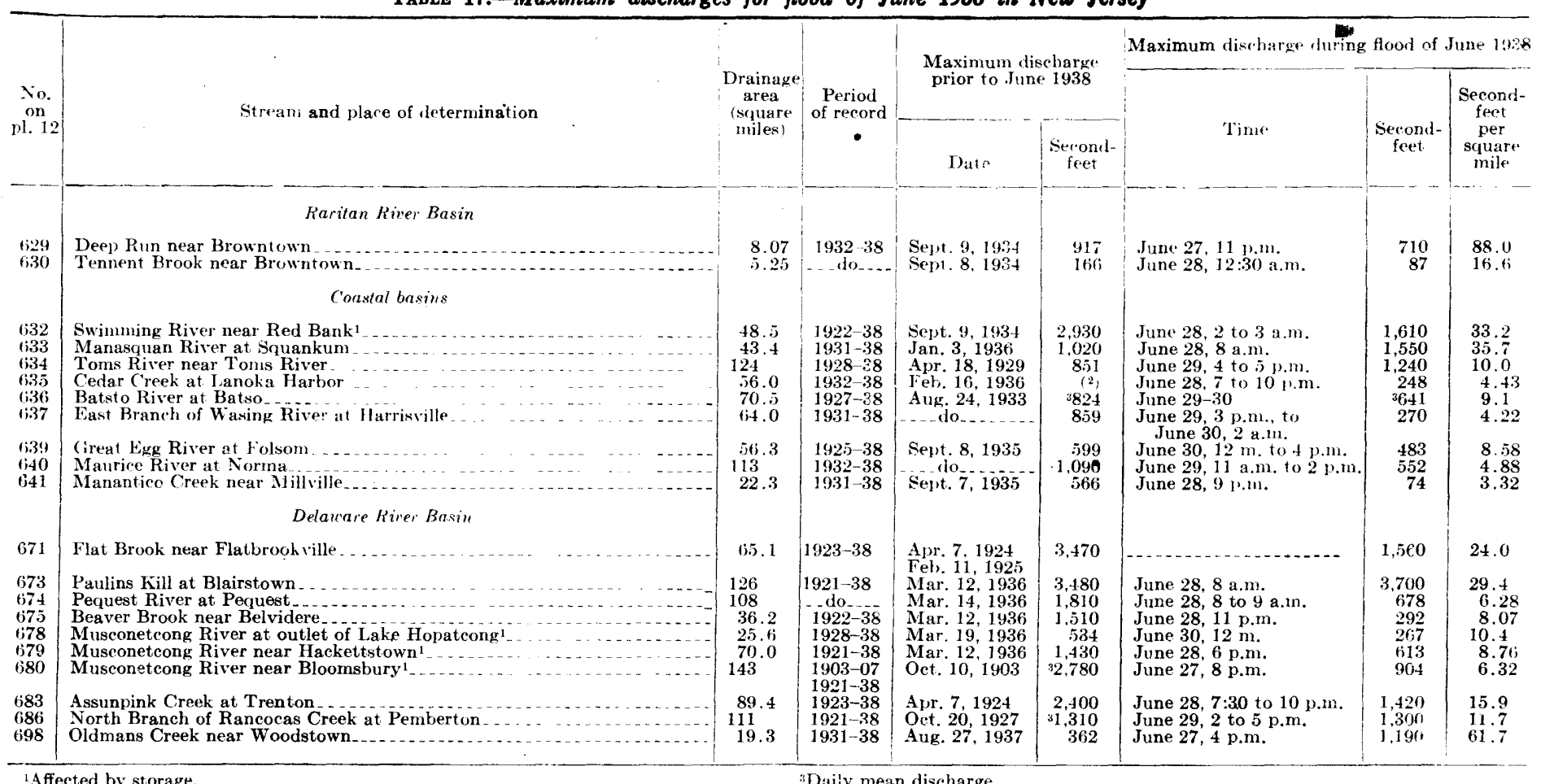


TABLe 18.-Flood crest stages, June 1938

[U. S. Coast and Geodetic Survey datum except as noted]

\begin{tabular}{|c|c|c|c|}
\hline Stream and location & $\begin{array}{l}\text { Miles } \\
\text { above } \\
\text { mouth }\end{array}$ & Date and time & $\underset{\text { (feet) }}{\text { Altitude }}$ \\
\hline $\begin{array}{l}\text { Deep Run: } \\
\text { Brownton, N. J., Geological Survey gage at Spring } \\
\text { Valley road bridge, } 18 / 4 \text { miles south of Browntown } \\
\text { Tennent Brook. }\end{array}$ & 5.0 & June 27, 11 p.m. & 17.47 \\
\hline $\begin{array}{l}\text { Browntown, N. J., Geological Survey gage } 11 / 4 \text { miles } \\
\text { northeast of Browntown } \\
\text { Swimming River: }\end{array}$ & 2.4 & June 28, 12:30 a.m. & 219.12 \\
\hline $\begin{array}{l}\text { Red Bank, N. J., Geological Survey gage on right bank, } \\
\text { above dam of Monmouth Consolidated Water Co. } \\
\text { and } 4 \text { miles upstream from Red Bank }\end{array}$ & 4.0 & June 28,2 to 3 a.m. & 14.60 \\
\hline $\begin{array}{l}\text { Manasquan River: } \\
\text { Squankum, N. J., Geological Survey gage on right } \\
\text { bank, just upstream from Farmingdale-Lakewood } \\
\text { road bridge }\end{array}$ & 10.5 & June 28,8 a.m. & 110.09 \\
\hline $\begin{array}{l}\text { Toms River: } \\
\text { Toms River, N. J., Geological Survey gage } 8 \text { left bank, } \\
1 \text { mile downstream from Union Branch and } 21 / 2 \text { miles } \\
\text { northwest of Toms River }\end{array}$ & 9.0 & June 29,4 to 5 p.m. & 19.2 \\
\hline $\begin{array}{l}\text { Cedar Creek: } \\
\text { Lanoka Harbor, N. J., Geological Survey gage on right } \\
\text { bank, upstream from highway bridge }\end{array}$ & 2.2 & June 29,1 to 2 a.m. & 233.52 \\
\hline $\begin{array}{l}\text { East Branch of Wading River: } \\
\text { Harrisville, N. J., Geological Survey gage on right } \\
\text { bank, just downstream from Jenkins-New Gretna } \\
\text { road bridge }\end{array}$ & .5 & $\begin{array}{l}\text { June } 29-30,3 \text { p.m. } \\
\text { to } 2 \text { a.m. }\end{array}$ & 13.98 \\
\hline $\begin{array}{l}\text { Great Egg River: } \\
\text { Folsom, N. J., Geological Survey gage on right bank, } \\
\text { just upstream from highway bridge and } 1 \text { mile south } \\
\text { of Folsom } \\
\text { Delaware River: }\end{array}$ & 29.0 & June $30,12 \mathrm{~m}$. to $4 \mathrm{p} . \mathrm{m}$. & 15.72 \\
\hline $\begin{array}{l}\text { Milford, Pa., Geological Survey gage on highway } \\
\text { bridge }\end{array}$ & 212.4 & June 29,8 a.m. & 4378.88 \\
\hline $\begin{array}{c}\text { Portland, Pa., Geological Survey gage on highway } \\
\text { bridge }\end{array}$ & & June 29,5 to 6 a.m. & 274.43 \\
\hline $\begin{array}{l}\text { Delaware, N. J., Geological Survey gage on highway } \\
\text { bridge }\end{array}$ & 170.9 & June 29,8 a.m. & 5263.48 \\
\hline $\begin{array}{l}\text { Belvidere, N. J., Geological Survey gage on left bank, } \\
\text { just downstream from Pequest River }\end{array}$ & 163.4 & June 29,4 to 8 a.m. & 235.38 \\
\hline Easton, Pa., Geological Survey gage on highway bridge & 149.5 & June 28,2 to 3 p.m. & 165.53 \\
\hline $\begin{array}{l}\text { Riegelsville, N. J., Geological Survey gage on left bank, } \\
\text { just upstream from suspension bridge }\end{array}$ & 140.6 & June 28,3 to 4 p.m. & 136.57 \\
\hline $\begin{array}{l}\text { Milford, N. J., Geological Survey gage on highway } \\
\text { bridge }\end{array}$ & 133.6 & June 28,4 to 5 p.m. & 116.91 \\
\hline $\begin{array}{l}\text { Frenchtown, N. J., Geological Survey gage on high- } \\
\text { way bridge }\end{array}$ & 130.1 & June 28,5 to 6 p.m. & 107.91 \\
\hline $\begin{array}{l}\text { Point Pleasant, Pa., Geological Survey gage on high- } \\
\text { way bridge }\end{array}$ & & June 28, 2 p.m. & 81.65 \\
\hline $\begin{array}{l}\text { Lumberville, Pa., Geological Survey gage on highway } \\
\text { bridge }\end{array}$ & 121.5 & June 28, 4 p.m. & 474.02 \\
\hline $\begin{array}{c}\text { Stockton, N. J., Geological Survey gage on highway } \\
\text { bridge }\end{array}$ & 118.0 & & 462.16 \\
\hline $\begin{array}{l}\text { Lambertville, N. J., Geological Survey gage on high- } \\
\text { way bridge }\end{array}$ & 114.9 & June 28,6 to 8 p.m. & 53.81 \\
\hline $\begin{array}{l}\text { Washington Crossing, N. J., Geological Survey gage on } \\
\text { highway bridge }\end{array}$ & 108.0 & June 28,4 p.m. & 432.04 \\
\hline $\begin{array}{l}\text { Yardley, Pa., Geological Survey gage on highway } \\
\text { bridge }\end{array}$ & 104.1 & June 28,6 p.m. & 422.26 \\
\hline $\begin{array}{l}\text { Trenton, N. J., Geological Survey gage on left bank, } \\
200 \text { feet upstream from Calhoun Street } \\
\text { lat Brook: }\end{array}$ & 100.6 & June 28,7 to 8 p.m. & 13.45 \\
\hline $\begin{array}{l}\text { Flatbrookville, N. J., Geological Survey gage } 1 \text { mile } \\
\text { upstream from Flatbrookville }\end{array}$ & 1.2 & June 28, 9 a.m. & 352.95 \\
\hline $\begin{array}{l}\text { Paulins Kill: } \\
\text { Blairstown, N. J., Geological Survey gage } 1,200 \text { feet } \\
\text { upstream from bridge on State Highway } 8\end{array}$ & 9.8 & June 28,8 a.m. & 342.94 \\
\hline $\begin{array}{l}\text { Pequest River: } \\
\text { Pequest, N. J., Geological Survey gage } 100 \text { feet up- } \\
\text { stream from Lehigh \& Hudson River Railway bridge }\end{array}$ & 6.6 & June 28,8 to 9 a.m. & 402.06 \\
\hline $\begin{array}{l}\text { Beaver Brook: } \\
\text { Belvidere, N. J., Geological Survey gage } 2,000 \text { feet up- } \\
\text { stream from mouth and } 2 \text { miles east of Belvidere }\end{array}$ & .4 & June 28,11 p.m. & 306.47 \\
\hline $\begin{array}{l}\text { Musconetcong River: } \\
\text { Landing, N. J., Geological Survey gage just above dam } \\
\text { on Lake Hopatcong }\end{array}$ & 42.4 & June 29,10 to 11 a.m. & 2924.31 \\
\hline $\begin{array}{l}\text { Landing, N. J., Geological Survey gage, just upstream } \\
\text { from highway bridge and } 300 \text { feet dowstream from } \\
\text { Lake Hopateong }\end{array}$ & 42.3 & June $30,12 \mathrm{~m}$. & 2907.23 \\
\hline
\end{tabular}


TABLE 18.-Flood crest stages, June 1938-Continued

\begin{tabular}{|c|c|c|c|}
\hline Stream and location & $\begin{array}{l}\text { Miles } \\
\text { above } \\
\text { mouth }\end{array}$ & Date and time & $\begin{array}{c}\text { Altitude } \\
\text { (feet) }\end{array}$ \\
\hline $\begin{array}{l}\text { Hackettstown, N. J., Geological Survey gage on left } \\
\text { bank, 500 feet upstream from Delaware, Lack- } \\
\text { awanna \& Western R.R. bridge and } 3 \text { miles northeast } \\
\text { of Hackettstown }\end{array}$ & 32.7 & June 28,6 p.m. & 2608.10 \\
\hline $\begin{array}{l}\text { Bloomsbury, N. J., Geological Survey gage, just down- } \\
\text { stream from highway bridge and 11/2 miles upstream } \\
\text { from Bloomsbury }\end{array}$ & 9.4 & June 27,8 p.m. & 278.19 \\
\hline $\begin{array}{l}\text { Assunpink Creek: } \\
\text { Trenton, N.J., Geological Survey gage at Chambers } \\
\text { Street Bridge }\end{array}$ & 1.5 & June $28,7: 30$ to 10 p.m. & ${ }^{231.62}$ \\
\hline $\begin{array}{l}\text { North Branch of Rancocas Creek: } \\
\text { Pemberton, N. J., Geological Survey gage, } 600 \text { feet } \\
\text { downstream from hightway bridge } \\
\text { North Branch of Cooper Creek: }\end{array}$ & 12.0 & June 29,2 to 5 p.m. & 33.43 \\
\hline $\begin{array}{l}\text { Ellisburg, N. J., at upstream side of ridge on State } \\
\text { Highway } 41\end{array}$ & 10.5 & June 27 & 16.0 \\
\hline $\begin{array}{l}\text { Ellisburg, N. J., at upstream side of Kings Highway } \\
\text { Bridge }\end{array}$ & 10.0 & do & 13.6 \\
\hline $\begin{array}{l}\text { Cooper Creek: } \\
\text { Camden, N. J., just unstream from Admiral Wilson } \\
\text { Boulevard }\end{array}$ & 1.3 & & 9.7 \\
\hline $\begin{array}{l}\text { South Branch of Big Timber Creek: } \\
\text { Turnersville, N. J., at county highway bridge } 90-7,35 \\
\text { feet upstream from Little Lebanon Creek and } 11 / 4 \\
\text { miles southeast of Turnersville }\end{array}$ & 7.7 & do & 80.56 \\
\hline $\begin{array}{l}\text { Turnersville, N. J., at spillway from Neely's Lake and } \\
\text { county highway bridge } 9 \mathrm{C}-4\end{array}$ & 6.4 & $\ldots$ do & 61.36 \\
\hline $\begin{array}{l}\text { Turnersville, N. J., at country highway bridge } 9 \mathrm{C}-1 \\
\text { (Sicklertown road) }\end{array}$ & 6.3 & do & 47.49 \\
\hline $\begin{array}{l}\text { Grenloch, N. J., at Black Horse Pike Bridge over Gren- } \\
\text { loch Lake }\end{array}$ & 5.5 & $\ldots \mathrm{do}$ & 42.49 \\
\hline $\begin{array}{l}\text { Grenloch. N. J., on dam of Grenloch Lake } \\
\text { Asyla, N. J.; at country highway bridge } 8 \mathrm{C}-11 \text { (Lake- } \\
\text { land road) }\end{array}$ & $\begin{array}{l}5.3 \\
4.5\end{array}$ & & $\begin{array}{l}43.63 \\
23.45\end{array}$ \\
\hline $\begin{array}{l}\text { Blackwood, N. J, upstream from Blackwood Lake Dam } \\
\text { Blackwood, N. J., downstream from Blackwood Lake } \\
\text { Dam }\end{array}$ & $\begin{array}{l}3.2 \\
3.2\end{array}$ & & $\begin{array}{l}21.18 \\
12.38\end{array}$ \\
\hline $\begin{array}{l}\text { Blackwood, N. J., at upstream side of Lower Landing } \\
\text { Road Bridge }\end{array}$ & 3.1 & do & 5.91 \\
\hline $\begin{array}{l}\text { Oldmans Creek: } \\
\text { Woodstown, N. J., Geological Survey gage, just up- } \\
\text { stream from Woodstown-Swedesboro highway bridge } \\
\text { and } 2 \text { miles north of Woodstown }\end{array}$ & 16.0 & June 27,4 p.m. & 19.08 \\
\hline
\end{tabular}

1 Assumed datum.

'New Jersey Geological Survey datum.

3High tide.

${ }^{4}$ Highest stage observed, peak stage may have been higher.

iBased on Pennsylyania Railroad bench mark.

\section{RAINFALL AND RUNOFF STUDIES}

Figure 23 shows the hydrograph of Deep Run near Browntown during the flood, together with a graph showing 4-hour amounts of rainfall at Marlboro, N. J., 4 miles from the Deep Run Basin. Deep Run, with a drainage area of 8.07 square miles, was chosen for study because it most nearly reflects runoff conditions unobscured by the channel and excess swamp storage, which is characteristic of the larger streams in this region.

On June 22, stream flow was low (A, fig. 23). In response to a local storm that centered near Freehold, stream flow rose to a crest (B) and then receded until June 26 (C), when its rate of flow was only slightly greater than on June 22 . The intense rains began late on June 26, as shown by the graph of rainfall on figure 
23 , and continued through June 28 . Stream flow rose slowly until about noon on June 27 (D), when the rate of rise slackened owing to a dropping off in rainfall intensity about that time. On the afternoon of June 27 rainfall increased and reached its maximum intensity between 3 and 7 p.m., producing a sharp crest in stream flow (E). Rainfall continued through most of June 28 but with intensities too light to sustain the high rate of stream flow. The discharge receded steadily to July 9.

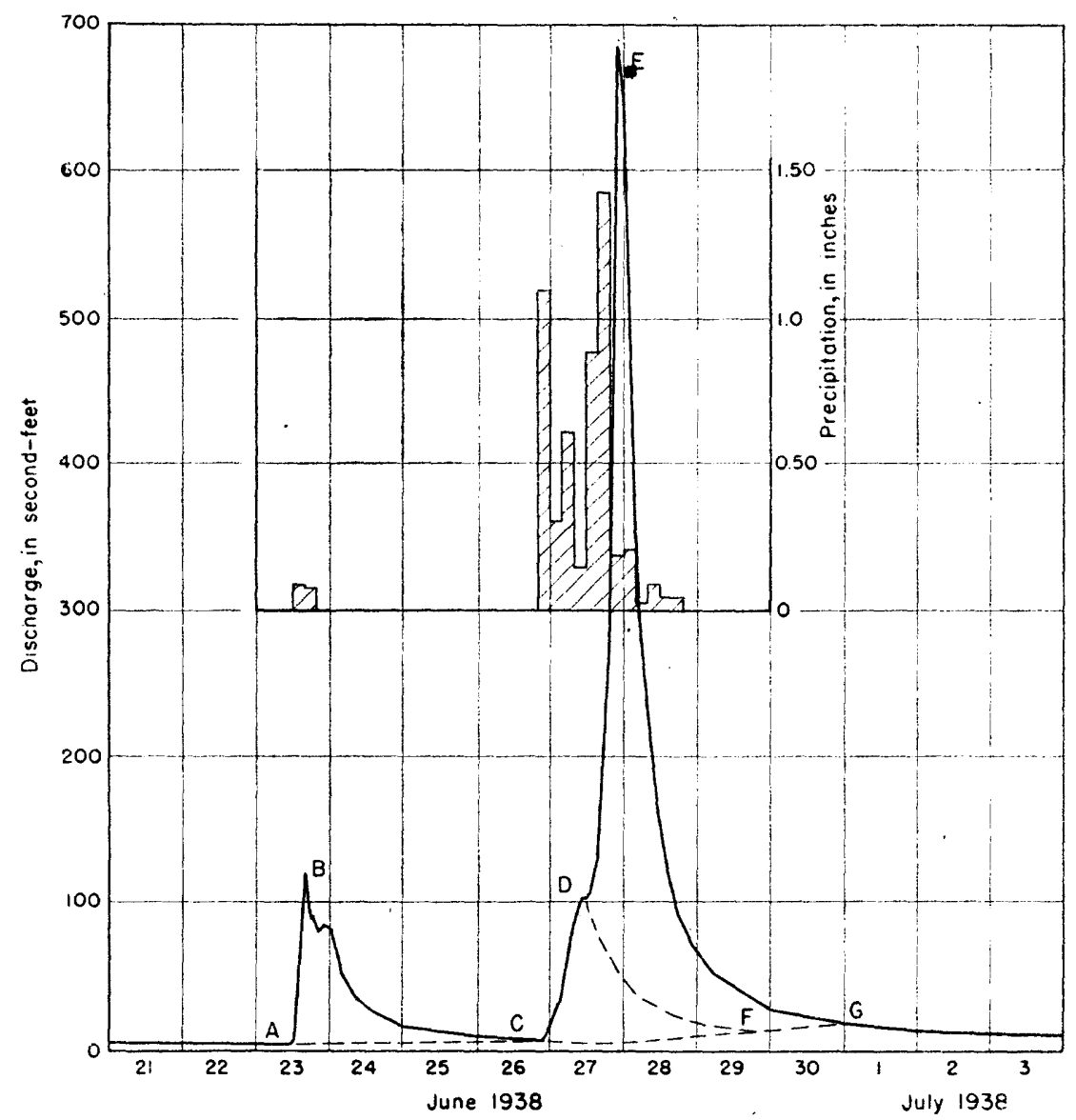

Ficuke 23.- Hydrograph of discharge for gaging station on Deep Run near Brownton, N. J.. and graph of precipitation at Marlboro, N. J., during flood of June 1938. 
TABLE 19.-...Precipitation and associated direct runoff of flood of Iune 1938 in New Jersey

[Mean depth, in inches, over drainage basins]

\begin{tabular}{|c|c|c|c|c|c|}
\hline $\begin{array}{l}\text { No. } \\
\text { on } \\
\text { fl. } 12\end{array}$ & Stream and locition & $\begin{array}{l}\text { Drainage } \\
\text { area } \\
\text { (square } \\
\text { miles) }\end{array}$ & $\begin{array}{c}\text { Precipi- } \\
\text { tation }\end{array}$ & R.unoif & $\begin{array}{l}\text { Differ- } \\
\text { ence }\end{array}$ \\
\hline 57.5 & Hackensack River at New Milford. & 113 & 3.5 & 11 & 21 \\
\hline 576 & Pascack Brook at Westwood $\ldots \ldots$ & 29.6 & 3.7 & 10 & $5 \cdot 7$ \\
\hline 583.5 & Rockaway River above reservoir, at Boontou. & $116^{\circ}$ & 4.2 & 1.4 & \\
\hline 606 & Saddle River at Lodi & 54.6 & 3.8 & 9 & 29 \\
\hline 608 & Elizabeth River at Elizabeth $\ldots$ & 180 & 2.7 & $\ddot{8}$ & 19 \\
\hline 609 & Rahway River at Rahway & 409 & 2.7 & 6 & 2.1 \\
\hline 614 & South Branch of Raritan River at Stanton & 147 & 3.5 & 7 & 2.8 \\
\hline 616 & Raritan River at Manville & 490 & 3.4 & 8 & 2.6 \\
\hline 619 & 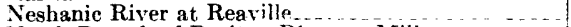 & 2.5 .7 & 2.7 & 6 & 21 \\
\hline 622 & North Branch of Raritan River at Milltown & 190 & 3.4 & .8 & 2.6 \\
\hline 624 & Millstone River near Kingston $\ldots \ldots \ldots \ldots$ & 171 & 4.7 & 1.1 & 3.6 \\
\hline 625 & Millstone River at Blackwells Mills . . . . . . . . & 258 & 4.4 & 1.2 & 3.2 \\
\hline 625.5 & Green Brook at Plainfield. & 9.75 & 2.9 & 7 & 2,2 \\
\hline 628 & Lawrence Brook at Farrington Dant . . . . & 34.4 & 3.4 & 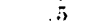 & 2.9 \\
\hline 629 & Deep Run near Browntown & 8.07 & 4.4 & 1.9 & 2.5 \\
\hline 632 & Swimming River near Red Bunk & 48.5 & 5.2 & 1.2 & 4.0 \\
\hline 633 & Manasquan River at Squankun . & 43.4 & $5 . \overline{2}$ & 1.5 & $\mathbf{3} .7$ \\
\hline 634 & Toms River near Toms River . . . . . . . . . . . & 124 & 4.4 & 1.0 & 3.4 \\
\hline 635 & Cedar Creek at Lanoka Harbor.... & .56 & 3.2 & 4 & 2.8 \\
\hline 636 & Batsto River at Batsto $\ldots \ldots \ldots$ & 70.5 & 6.5 & 1.2 & 5.3 \\
\hline 637 & East Branch of Wading River at Harrisville & 640 & 4.0 & 4 & 3.6 \\
\hline 639 & Great Egg River at Folsom & .56 .3 & 5.4 & 14 & 4.0 \\
\hline 641 & Manantico Creek near Millville & $2+2.3$ & 3.5 & .2 & 3.3 \\
\hline 671 & Flat Brook near lilatbrookville $\ldots$ & 6.5. 1 & 4.1 & 1.6 & 2.8 \\
\hline 673 & Paulins Kill at Blairstown $\ldots$ & 126 & 5,0 & 2.1 & 2.9 \\
\hline 680 & Musconetcong River near Blnomsbury & 143 & 4.5 & 1.2 & 3.3 \\
\hline 683 & Assunpink Creek at Trenton $\ldots . . . . .$. & 89.4 & 5.0 & 1.8 & 3.2 \\
\hline 686 & North Branch of Rancoeas Creek at Pemberton.... & 111 & 5.2 & 1.5 & 3.7 \\
\hline 698 & Oldmans Creek near Woodstown $\ldots \ldots$ & 19.3 & 4.5 & $\because 0$ & 2.5 \\
\hline
\end{tabular}

Volumes of direct runoff associated with the storm of June 1938 have been computed by the following method for each of the gaging stations for which stream-flow records are included in this report. A hydrograph comparable to that on figure 23 has been drawn for each of these stations and on this hydrograph has been drawn a line representing the flow from antecedent and groundwater sources by the method explained in Water-Supply Paper 867. ${ }^{17}$ This line is shown on figure 23 as A-C-G. The area between this line and the hydrograph of total flow, G-D-E-G-C, represents the direct runoff produced by the rains of June 26-28 and is tabulated in table 19 for each gaging station in terms of mean depth in inches over the respective drainage basins. Table 19 also lists the mean areal precipitation over the drainage area tributary to each gaging station listed. This information was obtained from the isohyetal map, plate 6 .

The relation between rainfall volumes and the associated direct runoff are shown on figure 24 . The results indicate that at least 2 inches of rain were required to produce an appreciable flood runoff. On figure 24 have been plotted lines of an equal infiltration index computed on the basis of records of hourly rainfall given in

\footnotetext{
if Paulsen, C. G. and others, Hurricane floods of September 1938: U. S. Geol. Survey WaterSupply Paver 867, pp. 121 42: 1940.
} 


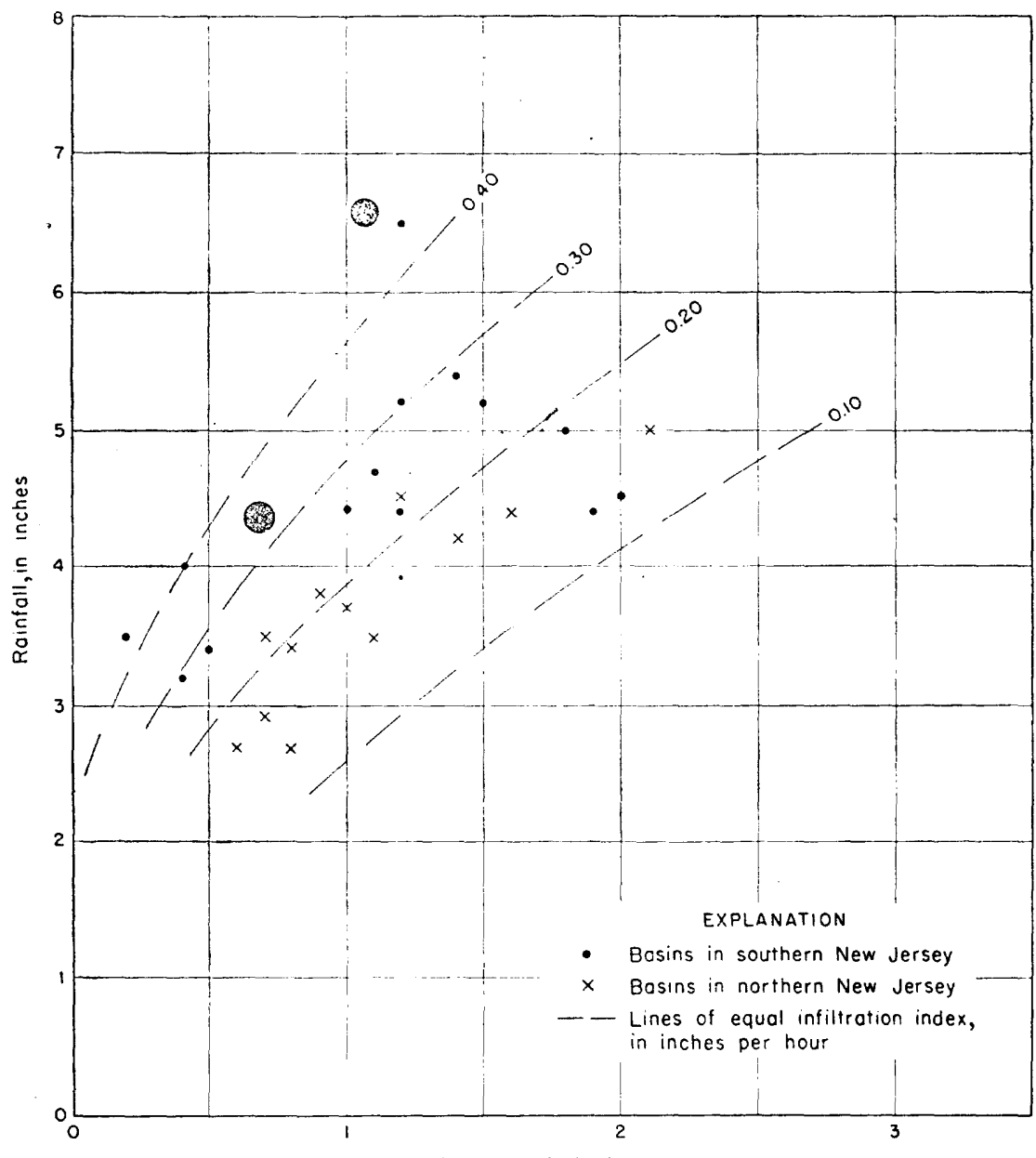

Direct runoff, in inches

Fluen: 24.--Relation between precipitation and associated direct runoff during flood of June 1938 in New Jersey.

table 14 by the method explained by Langbein..$^{18}$ Most of the points on figure 24 are located between infiltration indices of about 0.15 and 0.30 inch per hour.

Variations inherent in basin and soil characteristics are the principal factors to which the scattering of the plotted points on figure 24 may be attributed. There is a tendency, for example, for points representing basins in southern New Jersey to plot to the left of the points representing basins in the northern part of the State, which indicates that the former basins have a greater re-

\footnotetext{
${ }^{18}$ Langbein, W. B. and others, Maximum winter and non-winter floods in selected basins in New York and Pennsylvania: U. S. Geol. Survey Water-Supply Paper 915.
} 
tentive capacity. This characteristic conforms to the one indicated for this region during the hurricane flood of September 1938, as reported in Water-Supply Paper $867 .{ }^{19}$ Some variations in the rainfall-runoff relation shown on figure 24 may also be due to the fact that antecedent soil moisture was not the same over each basin. Moreover, errors in the determination of precipitation are probably substantial, particularly in basins distant from rain gages. For example, Oldmans Creek flows along the axis of heaviest storm precipitation, but it is in the center of an area of 1,500 square miles without a rain gage. Determinations of precipitation over specific small drainage areas during a summer storm may be of doubtful accuracy, although large areal averages may be reasonably correct. For the State as a whole there is an average of 95 square miles per rain gage, the coverage being most complete in the northern part of the State.

To show the variation in retention during the storm, the runoff represented by the hydrograph in figure 23 has been subdivided to show approximately the runoff before and after noon of June 26. The subdivision was indicated on figure 23 by drawing a recession line D-F to conform to B-C and E-G. Volume C-D-F is 0.5 inch, and volume D-E-G-F is 1.4 inches. The depths of rainfall over the Deep Run Basin during these two periods are 1.8 inches and 2.5 inches, respectively. The infiltration indices for these periods are 0.20 and 0.08 inch per hour, respectively, and indicate the decreasing capacity of the soil to absorb water.

\section{FLOODS OF JULY 1938 IN THE NORTHEASTERN STATES}

By L. W. Furness, C. E. Knox, Otto Lauterhahn, C. C. McDonald, and W. B. LANGBEIN

\section{INTRODUCTION AND GENERAL FEATURES}

During the period July 17-25, 1938, an irregular series of showers and thunderstorms deposited widely varying concentrations of water over the eastern seaboard from Florida to New Hampshire. As the resulting floods were more severe in the northern part of this area than in the southern, that part including New Jersey to Massachusetts is made the subject of this report. Within this area total precipitation from July 17 to 25 exceeded 10 inches at three centers in New Jersey, at one center in the Catskill Mountain region of New York, and at one elongated center extending through eastern Connecticut and Massachusetts. An area of almost 1,900 square miles received more than 10 inches of precipitation, and 23,000 square miles received 6 inches or more. The individual

\footnotetext{
${ }^{10}$ Paulsen, C. G. and others, op. cit., pp. 440-442.
} 
storms within this 8-day period were not unusual in themselves, but the rapid sequence in which they succeeded one another prevented the streams from recovering normality during the intervening intervals. A closer sequence of the storms would have produced greater peak flows, whereas, conversely, a wider sequence would have given the streams a chance to recede to lower stages between storms. As a result of the erratic distribution and intensity of precipitation within the respective drainage basins, most streams were pushed to successively higher stages in a series of peaks occurring irregularly from July 20 to 25 , as illustrated on the hydrographs of selected gaging stations in New Jersey, New York, and Connecticut. (See figs. 25-28.)

The drainage basins in which record-breaking or extraordinary floods occurred are shown on figure 29.

Crest discharges at 12 gaging stations (omitting those established in 1937) exceeded all discharges previously observed. The drainage areas of these stations ranged in size from 2.91 to 490 square miles. Rates of discharge reached 601 second-feet per square mile for Elizabeth River at Irvington, N. J., from an area of 2.91 square miles. Neversink River near Curry, N. Y., draining 68 square smiles, crested at 182 second-feet per square mile, and Raritan River at Manville, N. J., draining 490 square miles, reached 53.1 second-feet per square mile. Quinebaug River at Jewett City, Conn., draining 711 square miles, crested at $\mathbf{3 5 . 2}$ second-feet per square mile, but this was not the maximum of record, as it was exceeded once before during the flood of March 1936.

The flood of July 1938 was followed by the widespread floods of September 1938, which produced discharges that exceeded record-breaking discharges attained during July 1938 at the following five gaging stations, omitting those with 2 years of record or less.

Yantic River at Yantic, Conn.

Salmon River near East Hampton, Conn.

Raritan River at Manville, N. J.

Millstone River near Kingston, N. J.

Millstone River at Blackwells Mills, N. J.

With the exception of the lower Quinebaug River in Connecticut, the lower Raritan River in New Jersey, and the Charles River in Massachusetts, extraordinary flood stages occurred only in smaller tributary streams, which have narrowly confined channels and steep gradients. Accordingly, damage was slight in comparison with that caused by the greater and more widespread floods of March 1936 and September 1938. As the flood and excessive rain- 
fall occurred during the height of the growing season, they damaged crops by inundation or erosion. A number of small dams and ridges were destroyed, and many mills, homes, and highways vere flooded. Plate $7, A$, shows damage to a highway near Killing"rorth, Conn., caused by water released by failure of a small dam.

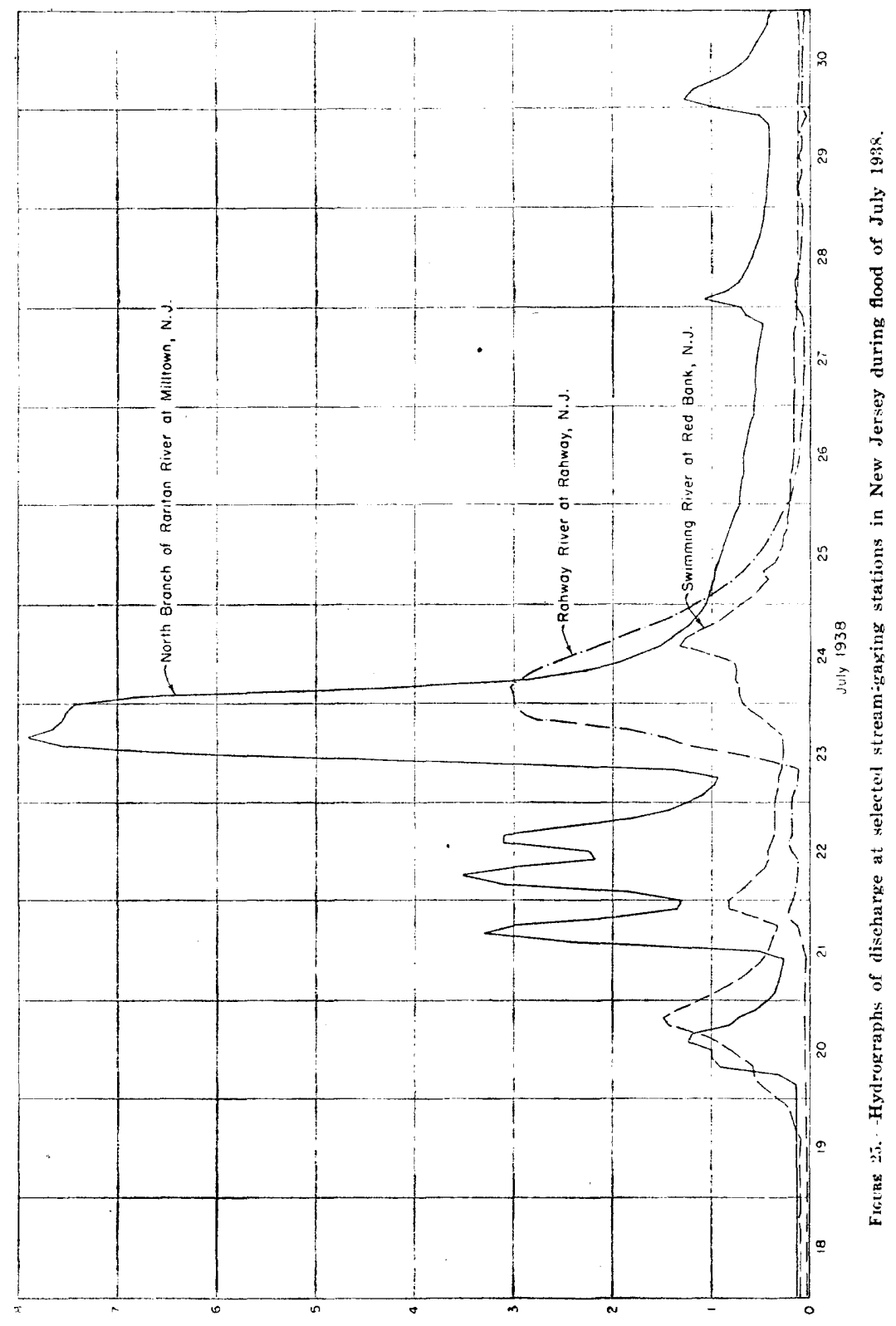

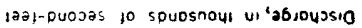




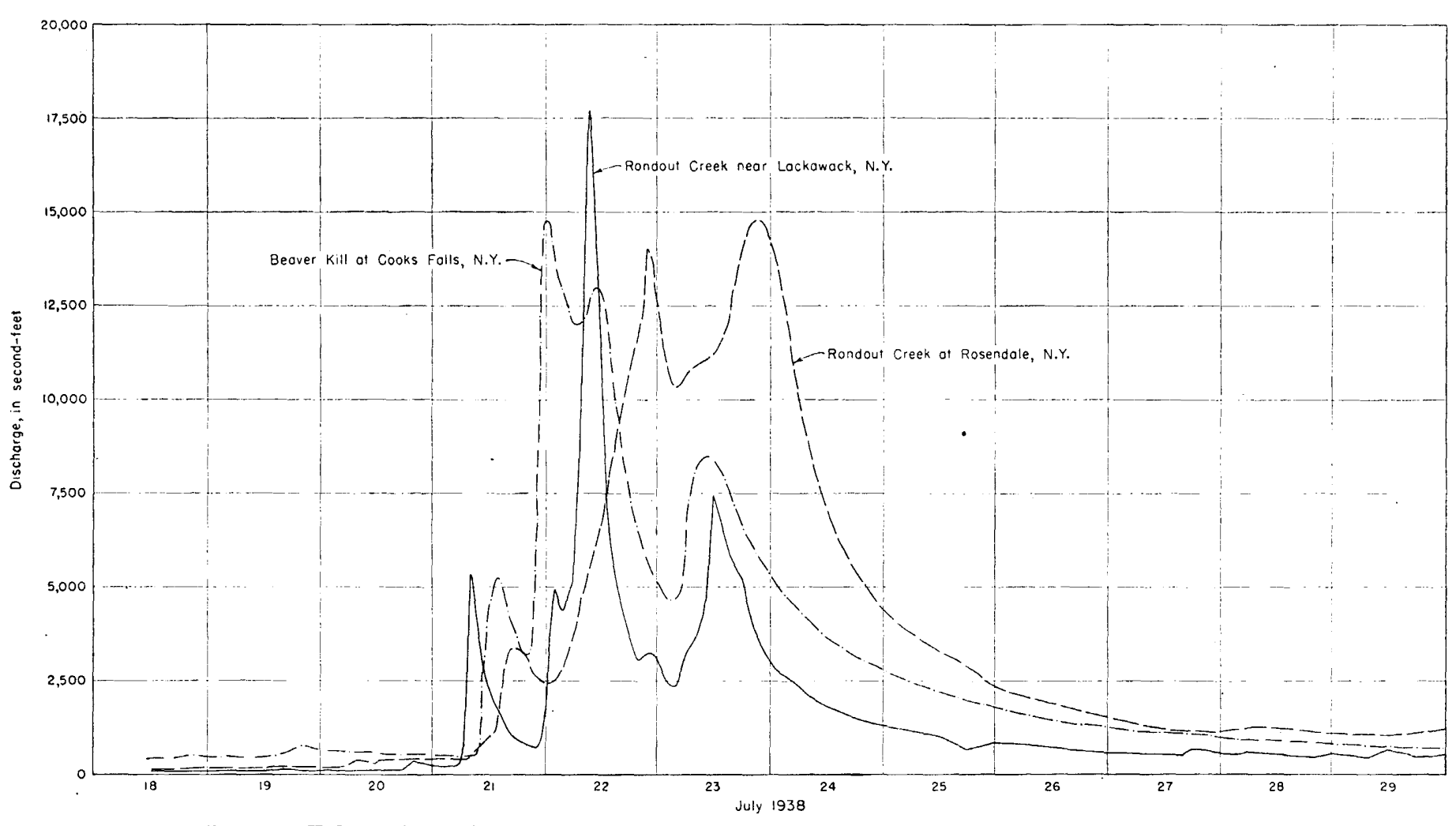

- Ficure 26.-Hydrographs of discharge at selected stream-gaging stations in New York during flood of July 1938 . 


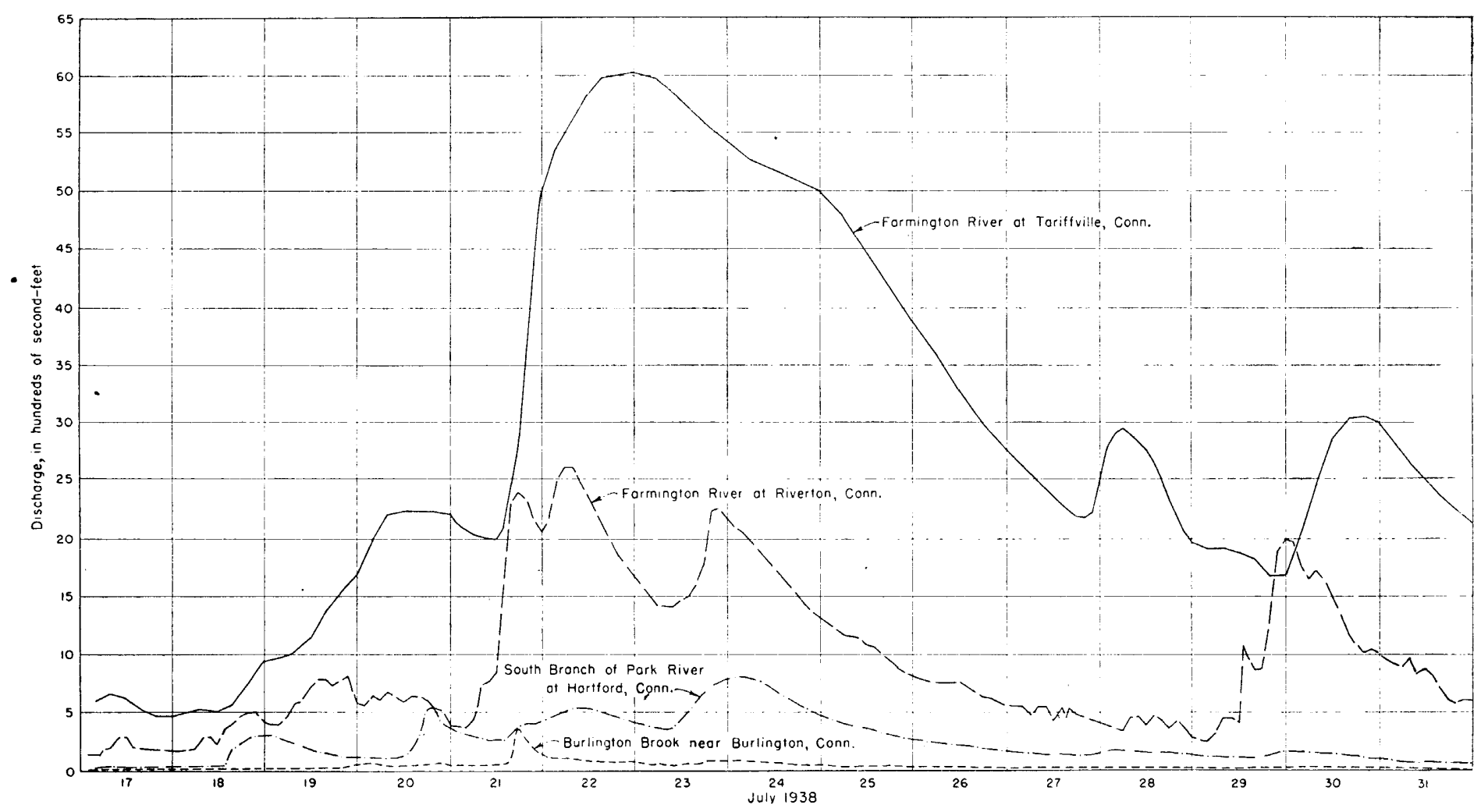

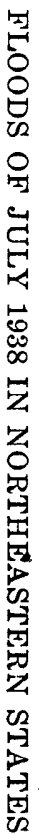

Figure 27. - Hydrographs of discharge at selected stream-gaging stations in Connecticut River Basin, Conn., during flood of July 1938, 


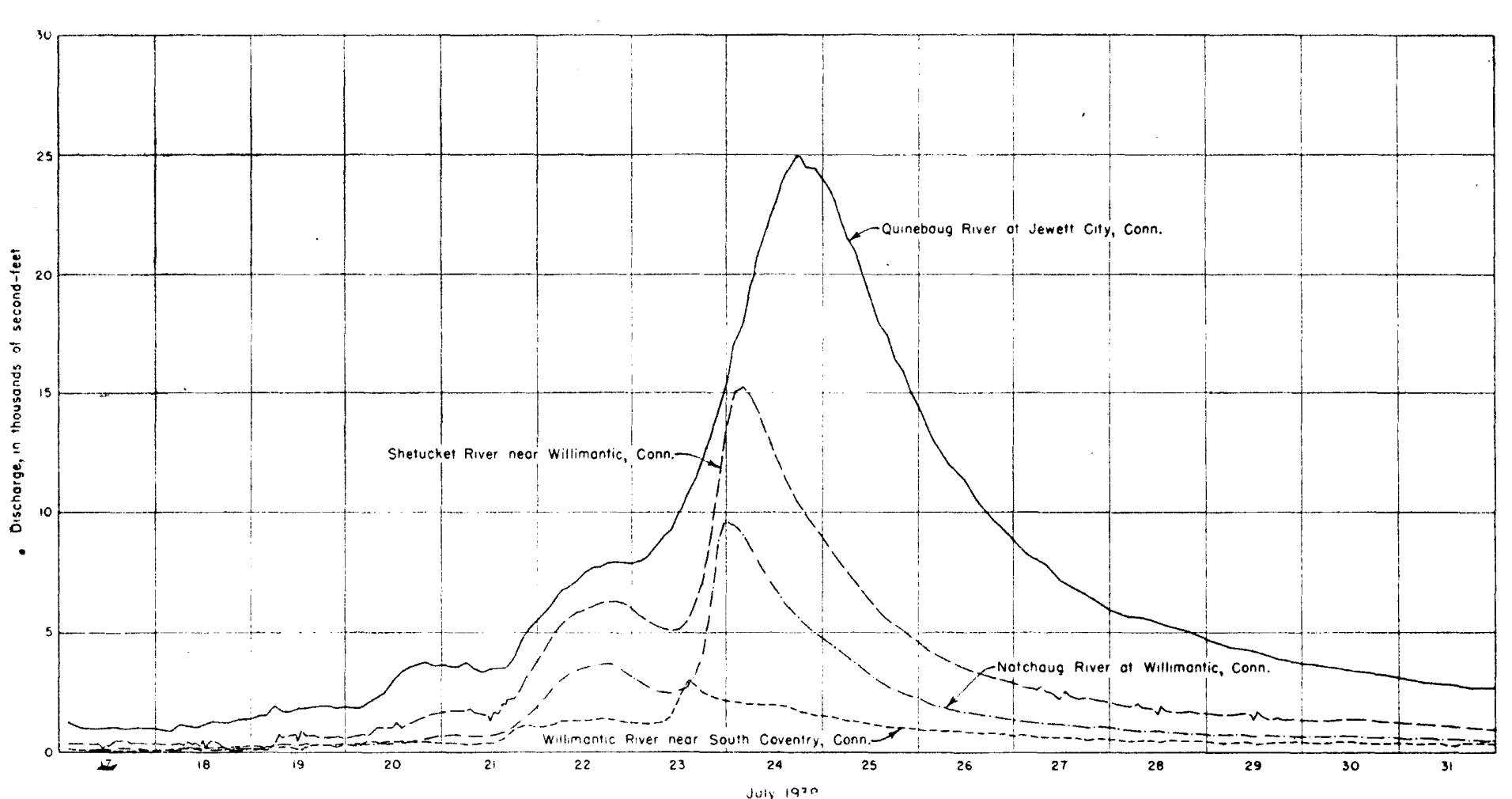

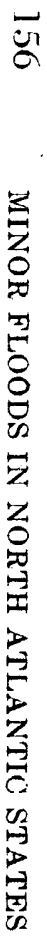

FIGUne 28.--Hydrographs of discharge at selected stream-gaging stations in Thames River Basin, Conn., during flood of July 1938 . 


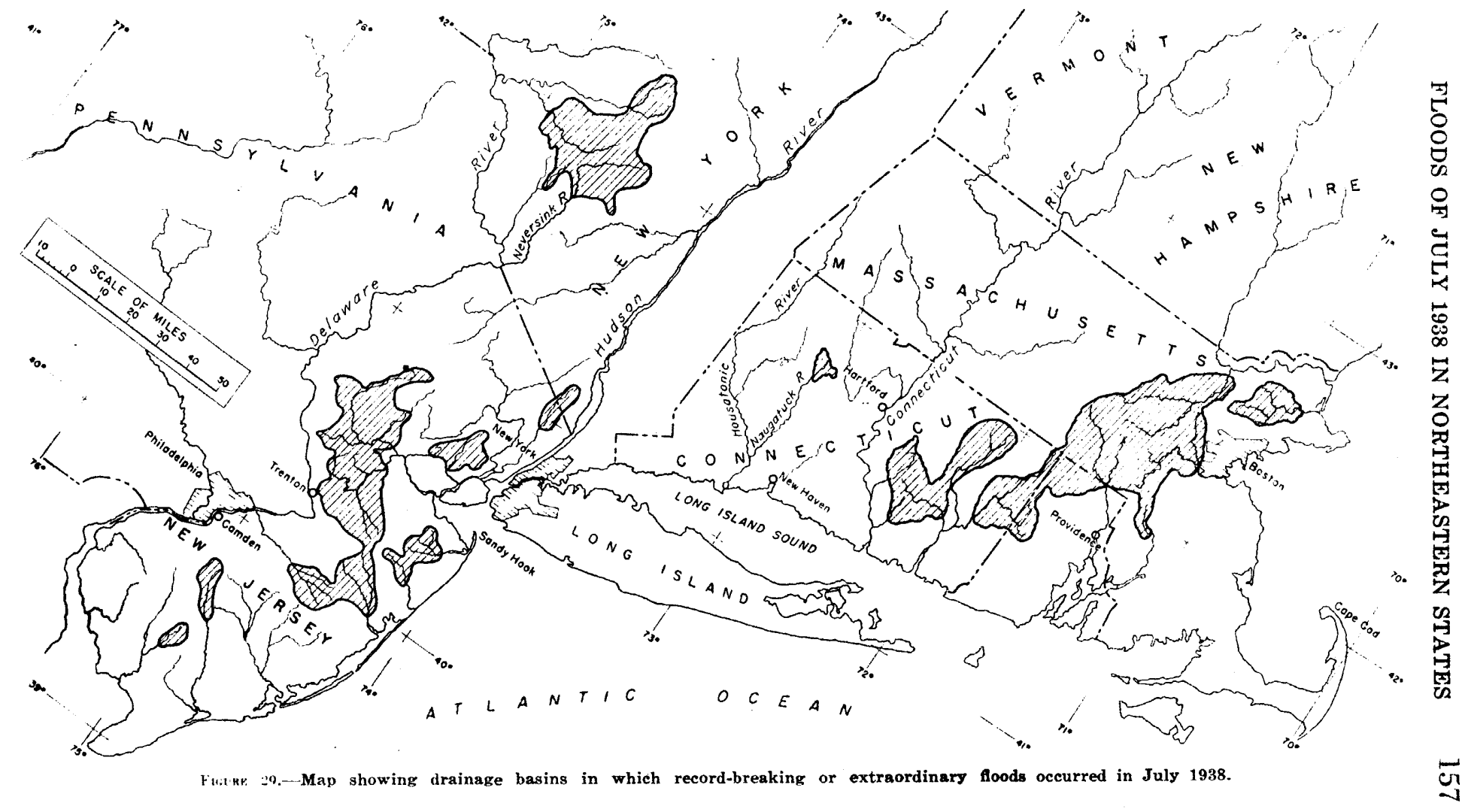


The area having the heaviest precipitation in Massachusetts embraces the headwaters of the Concord and Charles Rivers and the lower third of the Blackstone River drainage area above Woonsocket, R. I. Both the Concord and the Charles River Basin are for the most part very flat, contain much swamp and low meadow land, and produce long, flat hydrographs with slow rises, flat peaks, and gradual recessions.

The floods on the Concord River Basin and minor coastal basins in Massachusetts were light, and the damage was generally small.

In the upper reaches of the Charles River Basin in eastern Massachusetts the flood was the highest on record, but in the lower reaches it was lower than the floods of February 1886 and March 1936. Highways out of Millis, Mass., were flooded, and families were forced to abandon their homes. In the lower reaches of the Charles River, meadows, low highways, and some cellars were inundated with flood water. (See pl. 7, B.) As the velocities were low, the water was clear and very little silt deposited. Despite inconvenience, damage was comparatively small. Stages in the Charles River Basin above the pumping plant at Newton Upper Falls were reported to be $1 / 2$ foot to 4 feet higher than they were in the flood of March 1936. These excessive stages were due, in part, to backwater effect caused by the rank vegetation growing in the river channel, thus retarding the flow and decreasing the available cross section in the river. During the flood of March 1936 practically no vegetation was present in the river channel.

The Blackstone River Basin is steeper and has considerably less swamp area than the Charles River Basin. The river rises faster, the peaks are sharper, and the recessions are shorter. The peak discharge for July 1938 at Worcester was but 65 percent of the flood of March 1936, while at Woonsocket it was 100 second-feet greater. The flood of March 1936 was basinwide, whereas that of July 1938 was a downstream flood. Numerous textile mills, homes, and highways in the lower part of the Blackstone River Basin were inundated by the flood, which was there the highest on record. Mills were forced to shut down until the water receded. Sandbagging prevented serious damage to property. In Connecticut two small dams and bridges were reported destroyed. The Hartford County Farm Bureau estimated that crops in Connecticut were damaged by inundation or excessive rainfall to the extent of $\$ 2,302,000$, with the important tobacco crop accounting for $\$ 2,060,000$ of this figure. Several mills, numerous homes, and thoroughfares again were flooded. The Providence office of the Corps of Engineers, United States Army, determined the total direct flood losses in the Thames River Basin to be about $\$ 115,000$, 
which included $\$ 46,000$ for rural losses. Two views of the flood passing over dams in the Thames River Basin are given in plate 8.

Along Rondout Creek (pl. 9) in New York, swollen above flood stages, two bridges were destroyed, a house and barn near Lackawack were washed away, three cottages in Grahamsville were demolished, several bungalows near Eureka were partly submerged, and State Highway 55 was flooded in several places. The EllenvilleKingston highway was overflowed at Napanoch, where in 1928 the bridge was destroyed by a great flood. At Lackawack, where a large dam was under construction, a contractor's bridge and a small highway bridge were washed away.

In the Upper Wallkill River Basin the overflow from Wallkill River and Quaker Creek severely damaged about 1,200 acres of muck land planted with onions. (See pl. 10).

The magnitude of floods is dependent on many factors, such as amount and distribution of rainfall, antecedent precipitation, and the absorptive capacity of the ground. Variation of any one of these factors affects the peak flow and the amount of immediate runoff. Those who are working toward a better understanding of the causes of floods with intent to alleviate or utilize their effect, require detailed information on the types of floods that have occurred in the past as a basis of planning for similar or greater occurrences in the future. Accordingly, this report presents the basic factors relating to the flood of July 1938.

\section{METEOROLOGIC AND HYDROLOGIC CONDITIONS WEATHER ASSOCIATED WITH FLOODS OF JULY 17-25, 1938}

By A. K. Showalter ${ }^{20}$

The flood period July 17-25, 1938 was characterized by no outstanding meteorological phenomena, but from the standpoint of movement of pressure systems it was characterized by inactivity.

Recent investigations have shown that flood rains are most apt to occur when the general circulation of the atmosphere from west to east is decreasing in strength or is at a minimum. During such a period there are large fluctuations of cold, dry air far to the south and of warm, moist air far to the north. Abnormally low temperatures usually occur in the middle troposphere in the cold tongues, and moderate precipitation occurs below the central, forward, and west parts of the moist tongue.

During the period July 17-25 the general circulation from west to east was at a minimum, as indicated by the light westerly components reported in the winds aloft and also by the slow movement

\footnotetext{
${ }^{20}$ Meteorologist, U. S. Weather Bureau.
} 
and stagnation of surface fronts and pressure systems. The following temperatures at 5 kilometers above sea level set new low records during the latter part of July 1938:

July $15,-9.5^{\circ} \mathrm{C}$. at Billings, Mont.

July $20,-9.2^{\circ} \mathrm{C}$. at Oklahoma City, Okla.

July $20,-9.0^{\circ} \mathrm{C}$. at Omaha, Nebr.

July $21,-15.8^{\circ}$ C. at Fargo, N. Dak.

July $21,-6.2^{\circ} \mathrm{C}$. at St. Thomas, V. I.

It is significant that while record low temperatures were occurring at 5 kilometers in the Middle West, there was stagnation of warm, moist air over the eastern States. However, no record high temperatures occurred in the warm, moist air because the moist tongue was identified by unusually steep temperature lapse rates. An air mass is potentially or conditionally unstable if, when given an initial impulse, it is capable of sustaining internal convection. A rising mass of saturated air cools with lifting at what is known as the saturated adiabatic lapse rate. If the observed decrease in temperature with elevation is in excess of that indicated for a rising saturated parcel, the air mass is considered conditionally unstable. During the period July 17-25, 1938, the upper air soundings for eastern stations showed a preponderance of flights, with temperature lapse rates that indicated conditional instability.

The pseudoadiabatic diagrams for July 19 to 23 , shown on figure 30 , illustrate the potential instability of the persistent southwest current of tropical air.

These diagrams show the lapse in temperature with height. The ordinates are millibars of pressure, the measure of height, and the abscissae are temperatures in degrees centigrade. The sloping broken lines represent the lapse of temperature for a saturated particle of dry air under pseudoadiabatic conditions. Dry air is unstable if it has a lapse rate greater than $5.5^{\circ} \mathrm{F}$. per 1,000 feet; saturated air is unstable whenever it has a lapse rate greater than the saturated adiabats shown on figure 30 , which is less than the dry adiabat; and moist air may be unstable if it has a lapse rate intermediate between the two, depending on its moisture content. Increasing moisture content decreases its stability. Such air is said to be conditionally unstable because its instability is conditioned on some initial disturbing force or impulse raising the moist air to the level of free convection where it is saturated and completely unstable. The lapse rates at Washington were intermediate between the dry adiabats and the saturated adiabats and hence were conditionally unstable. The high moisture content of the tropical air between July 20-23 is indicated on figure 30 by the figures of relative humidity, generally above 80 percent. 


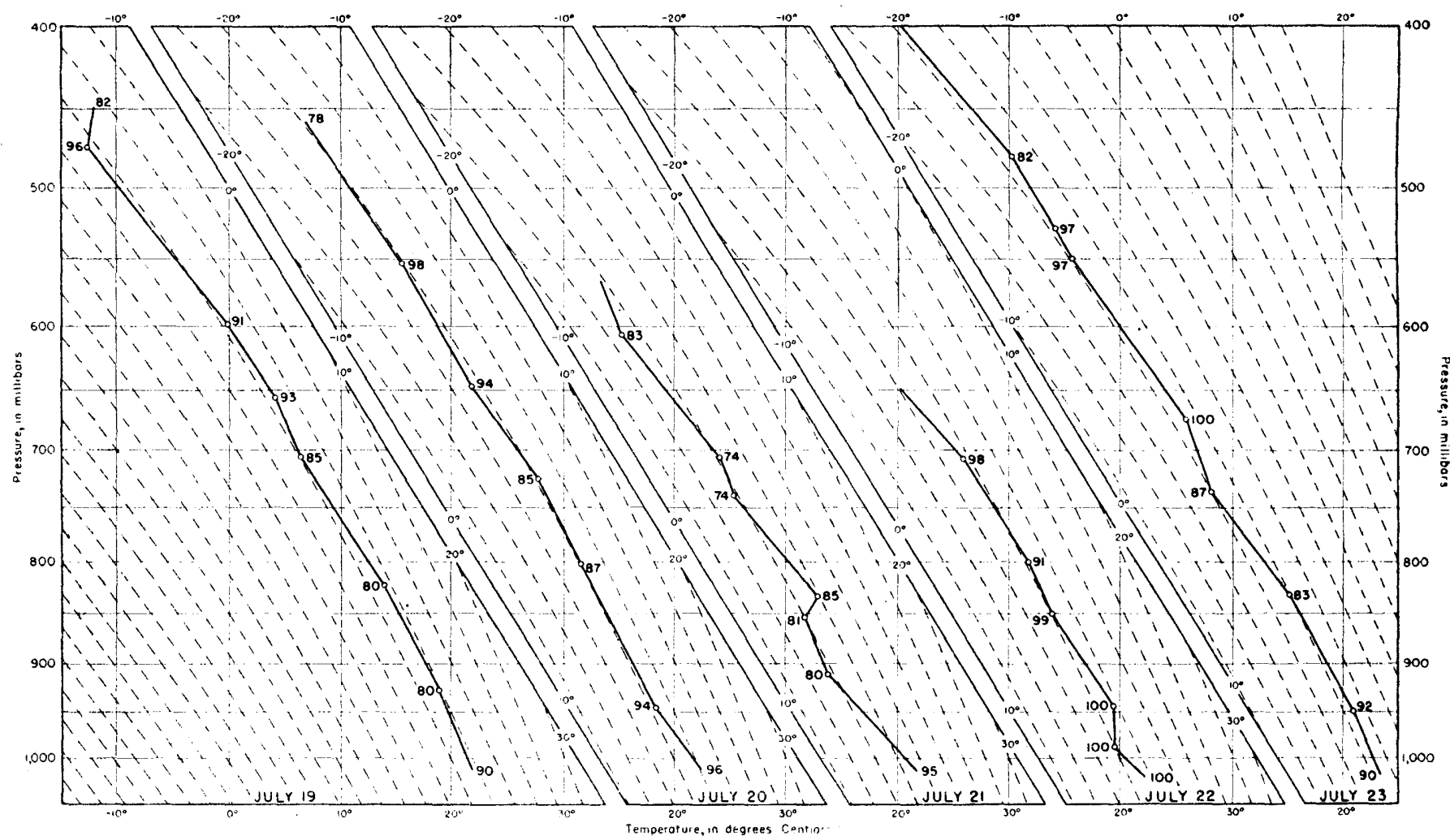

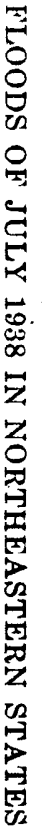

Figure 30.-Diagrams showing temperature distribution in the atmosphere above Washington, D. C., July 19-23. 1938. 
The stagnation of a mass of moist conditionally unstable air over the eastern United States resulted in widespread showers and thunderstorms. Local concentrations of thunderstorm activity produced critical discharges in smaller basins.

\section{ANTECEDENT CONDITIONS}

Monthly precipitation and temperature and accumulated departures from normal precipitation in New Jersey and Connecticut from March to July 1938, inclusive, as determined from Weather Bureau records, are listed in table 20. Figure 31 compares the daily changes of water level in a well at Middletown, Conn., with precipitation and stream flow at Hartford, Conn. The records of this well were reasonably typical of others throughout Connecticut, but actual fluctuations of water level in the different wells varied widely, depending partly on the depth of the well and partly on the vagaries of topographic, geologic, and water-bearing charactertistics. The observations at wells were made by the Federal Works Progress Administration under the sponsorship of the Connecticut State Water Commission and the supervision of the Geological Survey.

TABLE 20.-Monthly precipitation and temperature in New Jersey and Connecticut, March-July, 1938

\begin{tabular}{|c|c|c|c|c|c|}
\hline \multirow[b]{2}{*}{ Month } & \multicolumn{3}{|c|}{ Precipitation } & \multicolumn{2}{|c|}{ Temperature } \\
\hline & $\begin{array}{c}\text { Total } \\
\text { (inches) }\end{array}$ & $\begin{array}{c}\text { Departure } \\
\text { from normal } \\
\text { (inches) }\end{array}$ & $\begin{array}{l}\text { Cumulative } \\
\text { departure } \\
\text { from normal } \\
\text { (inches) }\end{array}$ & $\begin{array}{c}\text { Average } \\
\left({ }^{\circ} \mathrm{F} .\right)\end{array}$ & $\begin{array}{c}\text { Departure } \\
\text { from normal } \\
\left({ }^{\circ} \mathrm{F} .\right)\end{array}$ \\
\hline \multicolumn{6}{|c|}{ New Jersey } \\
\hline $\begin{array}{l}\text { March } \\
\text { April } \\
\text { May } \\
\text { June } \\
\text { July }\end{array}$ & $\begin{array}{l}2.15 \\
2.82 \\
3.52 \\
7.79 \\
8.84\end{array}$ & $\begin{array}{r}-1.63 \\
-.79 \\
-.22 \\
+4.08 \\
+4.05\end{array}$ & $\begin{array}{l}-1.63 \\
-2.42 \\
-2.64 \\
+1.44 \\
+5.49\end{array}$ & $\begin{array}{l}43.2 \\
53.0 \\
59.2 \\
67.2 \\
74.7\end{array}$ & $\begin{array}{l}+4.1 \\
+3.3 \\
-1.2 \\
+1.6 \\
+1.0\end{array}$ \\
\hline \multicolumn{6}{|c|}{ Connecticut } \\
\hline $\begin{array}{l}\text { March } \\
\text { April } \\
\text { May } \\
\text { June } \\
\text { July }\end{array}$ & $\begin{array}{l}2.14 \\
3.17 \\
4.05 \\
6.92 \\
9.57\end{array}$ & $\begin{array}{r}-1.91 \\
-.52 \\
+.41 \\
+3.44 \\
+5.61\end{array}$ & $\begin{array}{l}-1.91 \\
-2.43 \\
-2.02 \\
+1.42 \\
+7.03\end{array}$ & $\begin{array}{l}39.7 \\
49.9 \\
55.8 \\
66.6 \\
71.7\end{array}$ & $\begin{array}{r}+4.0 \\
+3.3 \\
-1.7 \\
+.5 \\
+1.0\end{array}$ \\
\hline
\end{tabular}

From table 20 and figure 31 several facts may be noted. Precipitation during March and April was below normal while temperatures averaged above normal, a climatic combination that tends to reduce soil moisture below average. Precipitation during May was nearly normal. June, however, was wet, and the deficiencies in March-May precipitation were eliminated. A large part of the pre- 


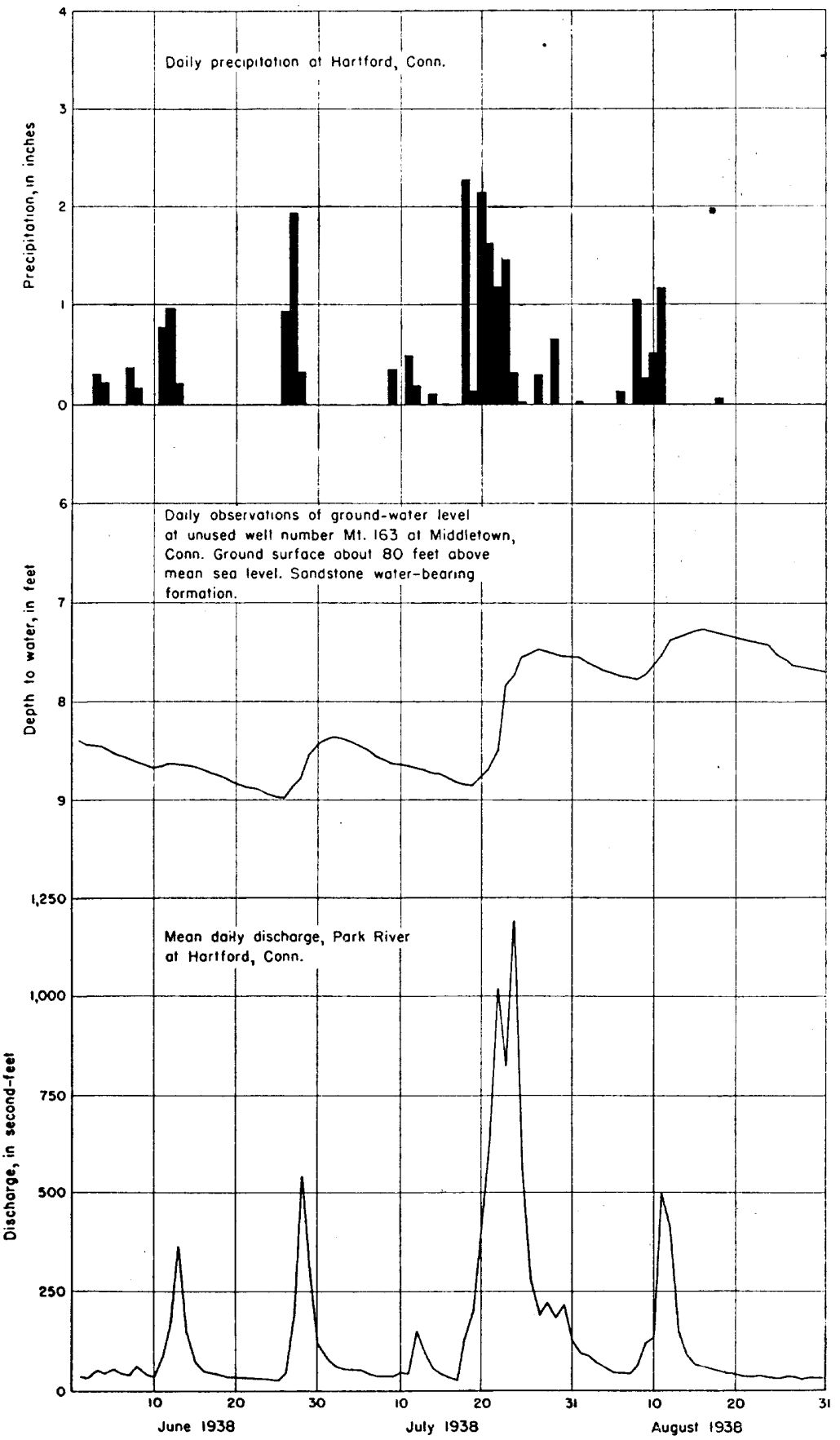

FIGURE 31.-Comparison of typical records of ground-water levels with precipitation and stream flow in Connecticut, June to August 1938. 
cipitation in June occurred within a few days during the latter part of the month, causing sizeable floods in New Jersey and minor floods on streams in New York and Connecticut and replenishing the ground-water supply. Although the total precipitation for July was 4 to 6 inches above normal, precipitation for the first 17 days of the month was slightly below normal, and this period of deficiency permitted a reduction in soil moisture and a lowering of the ground-water table and stream discharge.

The flood-producing storms began on July 18. The discharge of the streams just prior to the rain on July 18 consisted primarily of subsurface and ground-water flow. A computation of the average ground-water flow of the Salmon River near East Hampton, Conn., during July for 11 years of record, including 1938, indicated that the mean ground-water flow for the period July 1-18, 1938, was about 210 percent greater than average and on July 18, 1938, about 150 percent greater. Ground-water flow probably indicates the absorptive capacity of the ground on the basis that there is a general relation between the rate of such base flow, the level of the

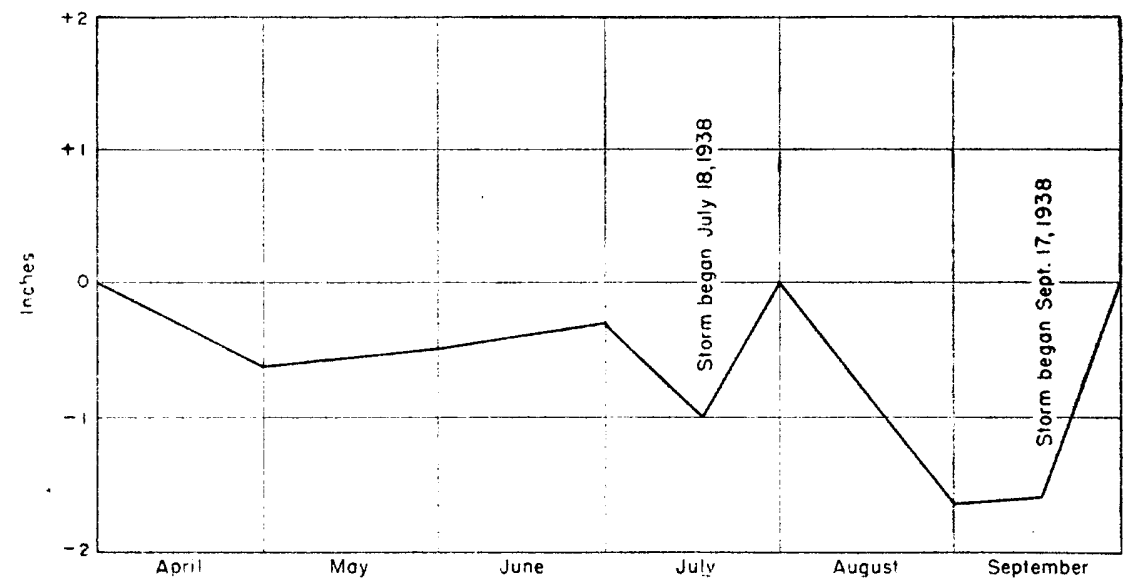

Figure 32.-Cumulative relative soil moisture in Park River Basin above Hartford, Con., April to September 1938 .

ground-water table, and soil-moisture conditions. Hence, it seems evident that on July 18 soil moisture was above normal in the Salmon River Basin. Time did not permit such analysis for other drainage basins, but probably similar conditions existed throughout the area.

Figure 32 shows a study of the cumulative relative soil moisture of the Park River Basin beginning April 1, 1938, and continuing through September 30 in order to compare the soil moisture prior to the July flood with that prior to the September flood. This graph 


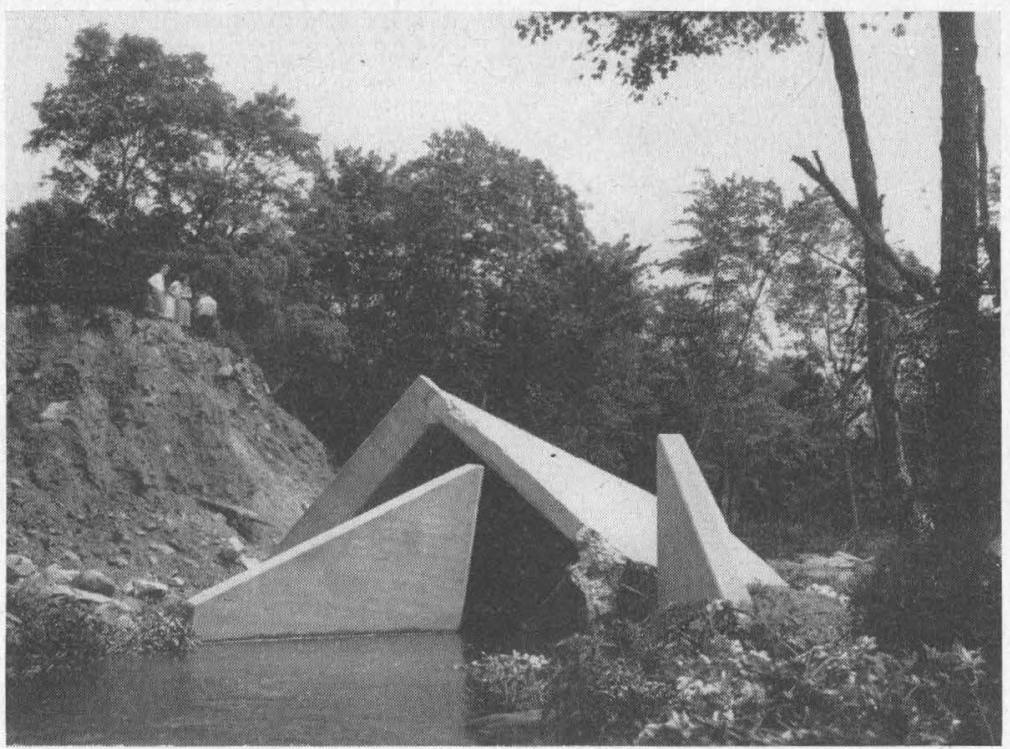

A. CONCRETE BOX CULVERT DESTROYED BY JULY 1938 FLOOD AT KILLINGWORTH, CONN.

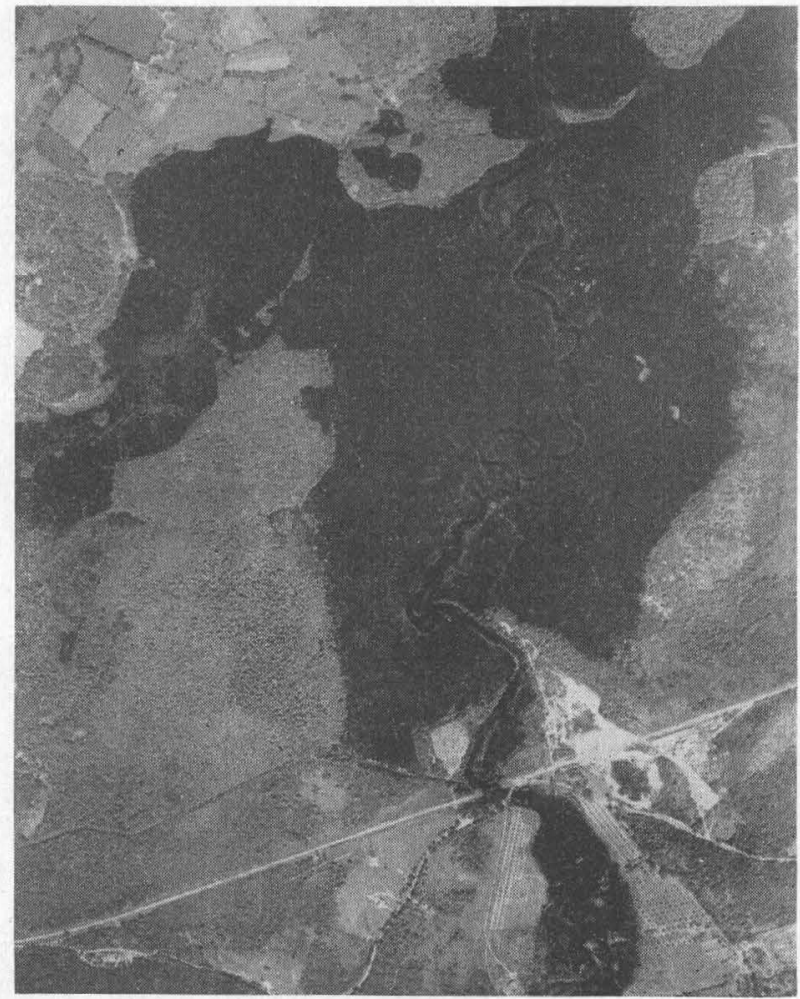

B. AERIAL PHOTOGRAPH OF REACH OF CHARLES RIVER NEAR MEDFIELD JUNCTION, MASS.

Photo by Corps of Engineers, U. S. Army. 


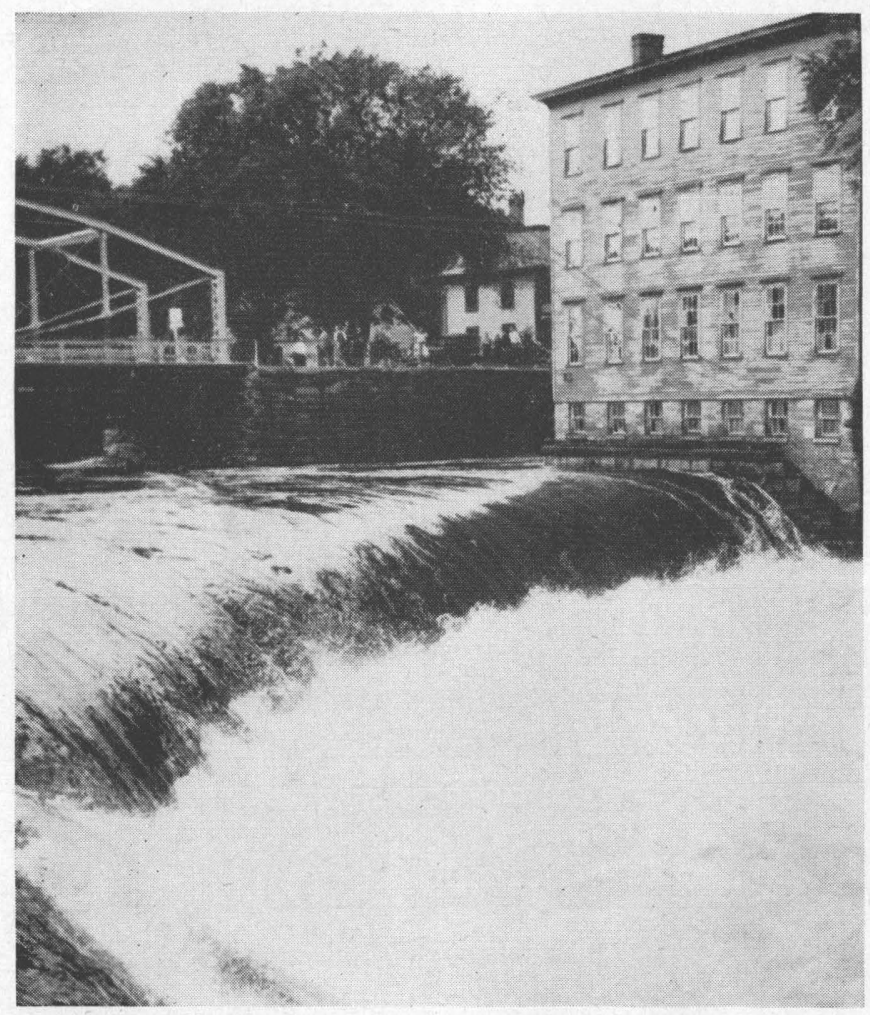

A. QUINEBAUG RIVER AT DANIELSON, CONN., NEAR PEAK, JULY 24, 1938.

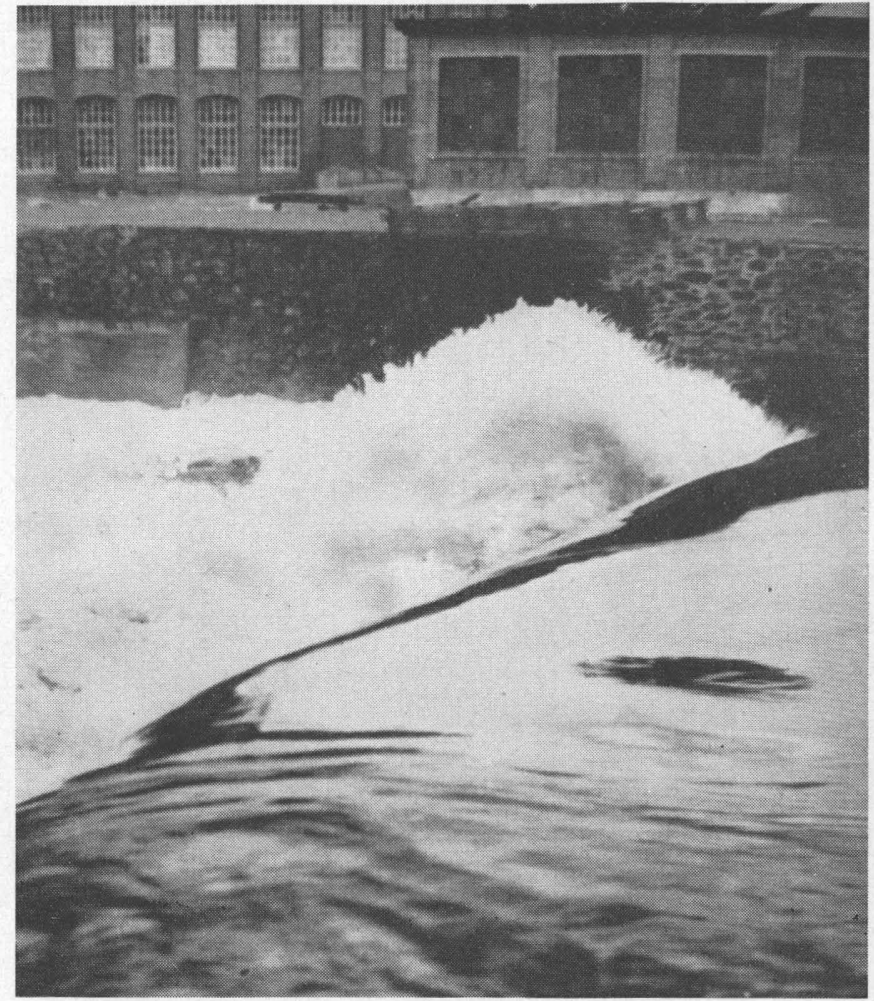

B. FIVE MILE RIVER AT DANIELSON, CONN., NEAR PEAK, JULY 24, 1938. 


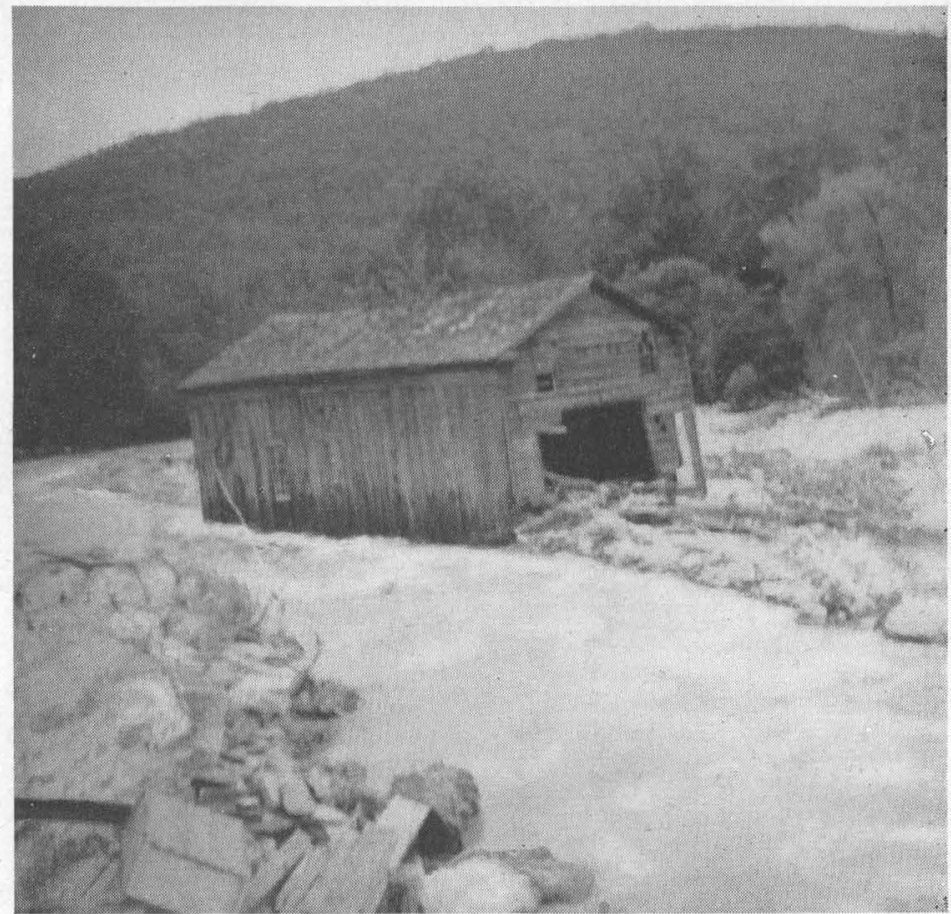

A. BARN WASHED FROM FOUNDATION NEAR LOWES CORNERS, N. Y.

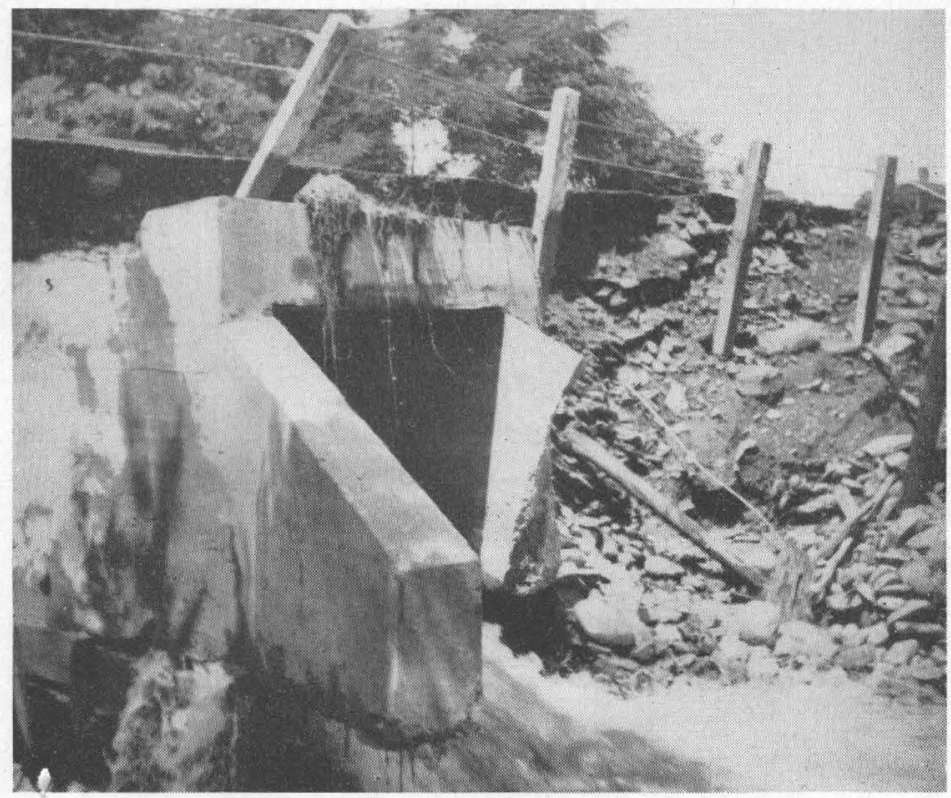

B. CULVERT NEAR GRAHAMSVILLE, N. Y.

FLOOD SCENES ON RONDOUT CREEK, JULY 1938.

Photos by Middletown (N. Y.) Times-Herald. 


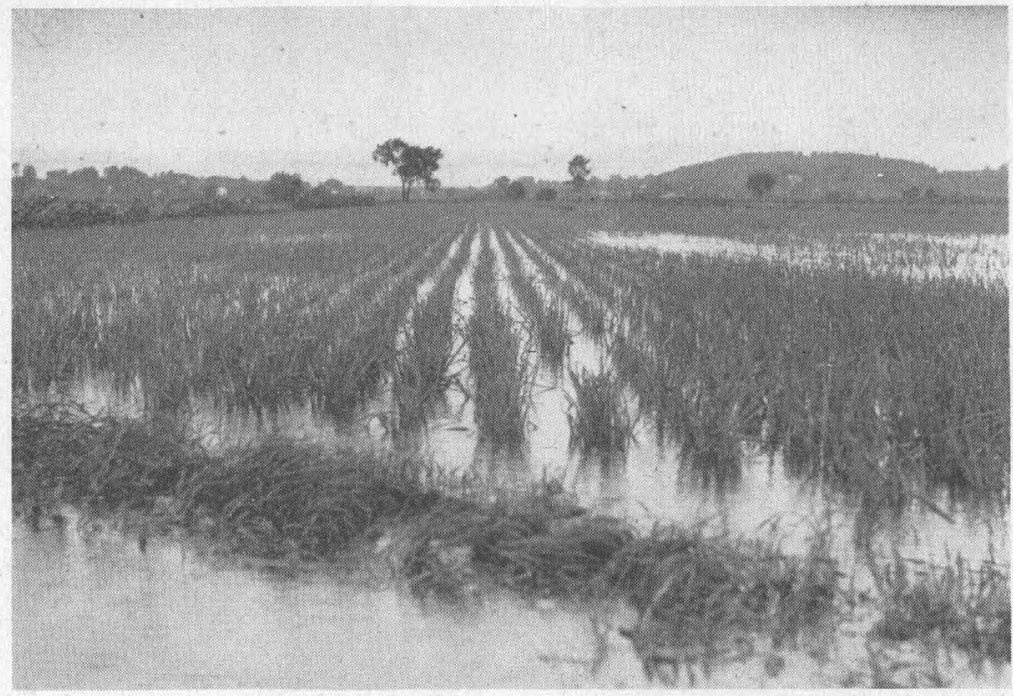

A. ONION FIELDS OVERFLOWED BY QUAKER CREEK.

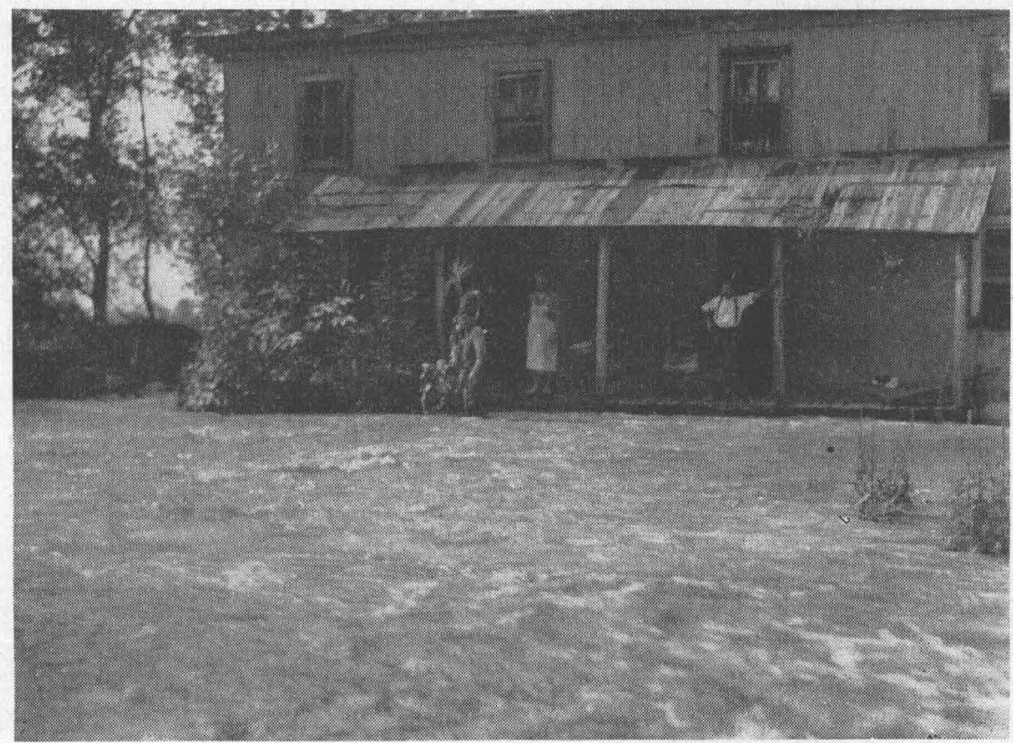

B. ONION FARMER'S HOME SURROUNDED BY FLOODWATERS OF QUAKER CREEK.

FLOOD SCENES NEAR FLORIDA, N. Y., JULY 1938.

Photos by Middletown (N. Y.) Times-Herald. 
was computed by methods outlined in Water-Supply Paper $772^{21}$ from records of precipitation, temperature, and stream-flow data in the Park River Basin. The normal tendency toward depletion of soil moisture during spring and summer was not evident in 1938, but the period of deficient precipitation during the first half of July was favorable to an increase in the rain-absorbing capacity of the ground. Further reference to this graph is made on page 389 . Similar graphs for other drainage basins might show differences owing to variations in the controlling factors. Water-Supply Paper $867^{22}$ shows a similar graph for the Westfield River Basin above Knightville, Mass., for 1938 and also for periods before the floods of 1927 and 1932.

\section{PRECIPITATION}

Precipitation records collected at about 575 stations were compiled and used for the construction of the isohyetal map presented herein and for the study of the relation between rainfall and runoff. Table 21 lists the daily precipitation for the period July 15-26, 1938 , with appropriate footnotes indicating the time of measurement and the source of record.

The last column of table 21 shows the total precipitation measured July 17-25. Plus signs after figures indicate that the records are probably incomplete. For convenience, the numbers assigned to each station in the first column show its location on plate 11 and are the same as those for the storm of September 1938 listed in Water-Supply Paper $867^{23}$.

${ }^{21}$ Hoyt, W. G., and others, Studies of rainfall and runoff in the United States: U. S. Geol. Survey Water-Supply Paper 772, pp. 248-255, 1936.

22 Paulsen, C. G., and others, Hurricane floods of September 1938 : U. S. Geol. Survey WaterSupply Paper 867, p. 44, fig. 23. 1940.

${ }^{23}$ Paulsen, C. G., and others, idem, pp. $46 \cdot 61$. 
TABLE 21.--Daily precipitation, in inches, July 15-26, 1938

[Measured in the afternoon except as noted. Asterisk indicates that data are included in following measurement]

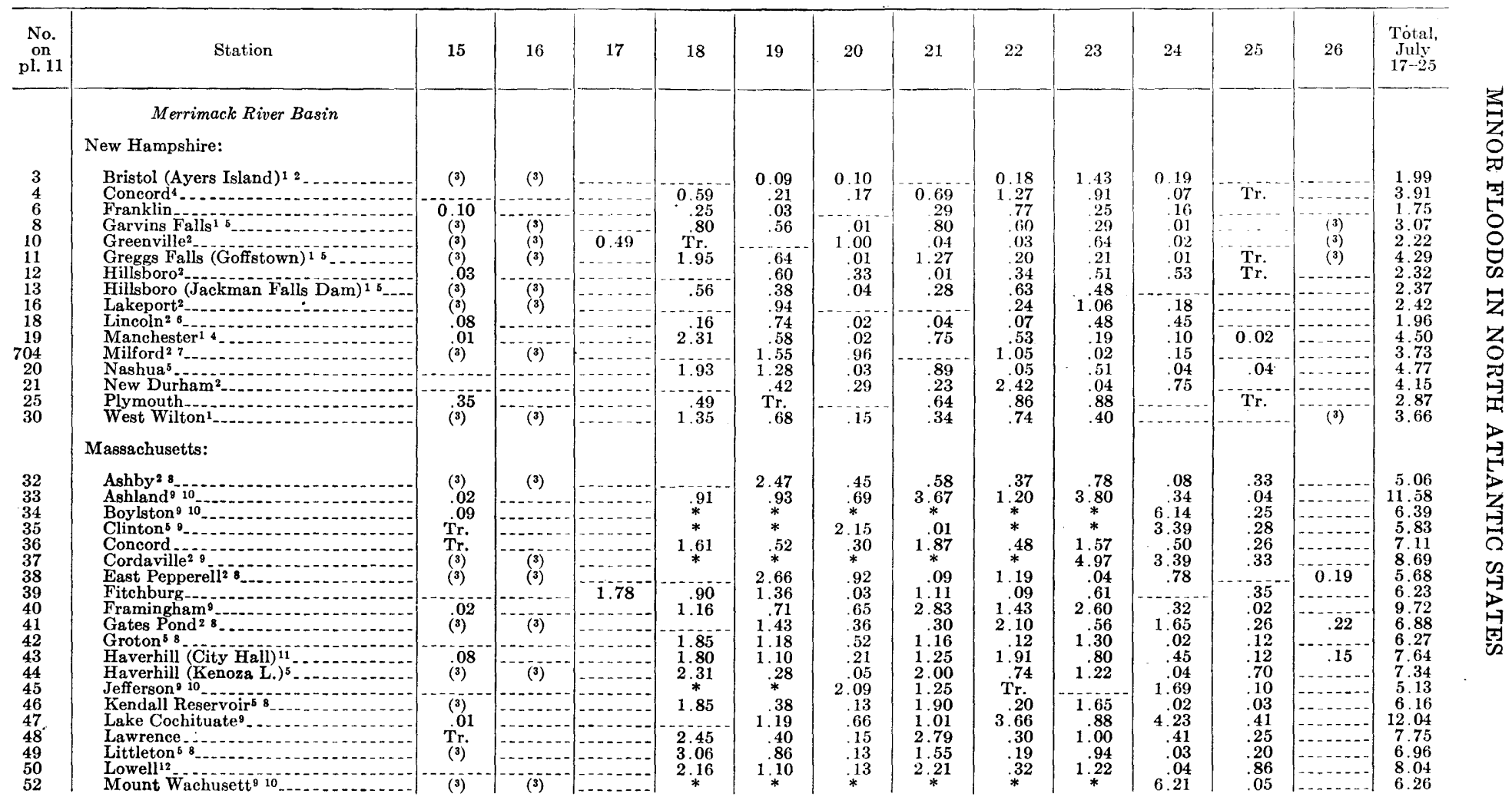




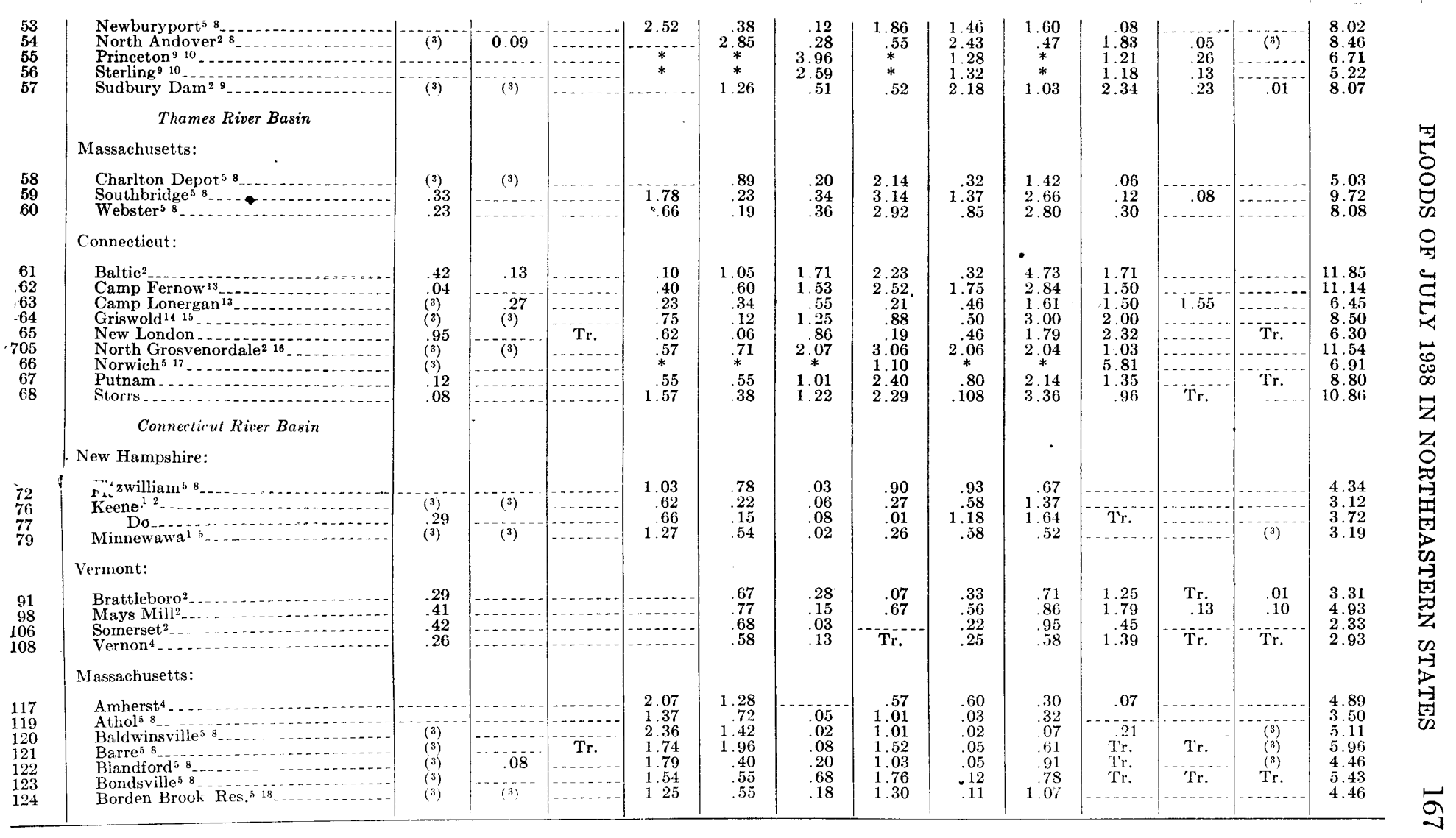


TABLE 21.-Daily precipitation, in inches, July 15-26, 1938-Continued

\begin{tabular}{|c|c|c|c|c|c|c|c|c|c|c|c|c|c|c|}
\hline $\begin{array}{c}\text { No. } \\
\text { on } \\
\text { pl. } 11\end{array}$ & Station & 15 & 16 & 17 & 18 & 19 & 20 & 21 & 22 & 23 & 24 & 25 & 26 & $\begin{array}{c}\text { Total, } \\
\text { July } \\
17-25\end{array}$ \\
\hline 126 & Chester ${ }^{5} 8 \ldots \ldots$ & 0.01 & & & 1.06 & 0.08 & 0.19 & 1.10 & 0.07 & 0.75 & & & & 3.25 \\
\hline 127 & Chesterfield ${ }^{5} 8$ & & & & 2.35 & .08 & .10 & .98 & .11 & .93 & & 0.06 & & 4.56 \\
\hline 746 & Chicopee Falls (Bircham Bend) ${ }^{5}$ & $(3)$ & & & 2.25 & 1.20 & .02 & 2.08 & .14 & .67 & & Tr. & (3) & 6.36 \\
\hline 128 & Colrain' ${ }^{5}$ & (3) & & & 1.94 & .05 & & .37 & .77 & 1.02 & & & (3) & 4.15 \\
\hline 129 & Cummington ${ }^{5} 8$ & $(3)$ & & & 1.61 & .10 & 72 & 82 & .33 & 1.19 & & & $(3)$ & 4.77 \\
\hline 130 & East Northfield & (3) & & & 1.54 & .26 & 08 & .66 & .08 & .64 & & & (3) & 3.26 \\
\hline 131 & Enfield ${ }^{5} 8 \ldots$ & (3) & (3) & 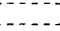 & 2.42 & 1.90 & .05 & 2.20 & .07 & .62 & & .02 & & 7.28 \\
\hline 132 & Fryville (Athol) & (3) & & & 2.40 & .56 & 07 & 1.01 & .06 & .41 & 0.04 & & (3) & -4.55 \\
\hline 133 & Gardner ${ }^{6} 8 \ldots$ & & & & 2.56 & 1.26 & & 1.00 & .10 & .30 & & & & 5.22 \\
\hline 134 & (ireenfield ${ }^{5} 8$ & $(3)$ & & & 1.82 & .36 & $12^{-}$ & 1.13 & .05 & .88 & & & (3) & 4.36 \\
\hline 135 & Hardwick ${ }^{5} 8_{-}$ & 17 & & & 1.76 & .78 & $*$ & 1. 58 & $*$ & .63 & & & 0.07 & +75 \\
\hline 136 & Heath ${ }^{5} 8$ & -1 & & $\mathrm{~T}$ & .80 & 19 & .20 & .50 & 1.01 & 1.51 & .04 & Tr. & & 4.25 \\
\hline 137 & Holyoke? & (3) & (3) & & .37 & 1.83 & .98 & .05 & 1.63 & .06 & .37 & & Tr. & 5.29 \\
\hline 138 & Hoosac Tunnel & .60 & & & & .99 & .24 & .47 & .38 & 1.23 & .62 & Tr. & & 3.93 \\
\hline 139 & Hubbardston ${ }^{5} y_{-}$ & & & Tr. & 1.81 & 1.72 & 01 & 1.17 & .06 & .44 & .01 & & & 5.22 \\
\hline 140 & Knightville ${ }^{5} 8$ & (3) & $\ldots . .$. & & $\begin{array}{l}2.01 \\
2.48\end{array}$ & .17 & 09 & 1.05 & .04 & .36 & & & & 4.19 \\
\hline 141 & Lake Pleasant ${ }^{58}$ & ${ }^{(3)}$ & & & 1.15 & .59 & .07 & 1.54 & .30 & .53 & .02 & & (3) & 4.20 \\
\hline 142 & Iudlow Reservoir & (3) & & & 1.78 & 1.05 & .04 & 1.86 & .16 & .57 & & .04 & & 5.46 \\
\hline 143 & Middlefield ${ }^{6}{ }^{8}$ & (3) & $\ldots . .$. & & 2.07 & & .40 & & 1.19 & 1.20 & 02 & & & 4.88 \\
\hline 1.44 & Monson 8 8 $\ldots$ & 33 & 烈 & & 1.15 & .51 & .33 & 1.84 & .10 & 1.46 & Tr. & 45 & & 5.39 \\
\hline 146 & Montgomery ${ }^{6} 8$ & (3) & & & 1.55 & 1.10 & .10 & 1. 24 & .12 & .69 & & & & 4.80 \\
\hline 147 & New Braintree ${ }^{58}$ & (3) & & & 1.56 & .56 & 12 & 1.39 & .10 & .69 & .02 & & (3) & 4.44 \\
\hline 148 & New Salem 5 & (3) & & & 3.00 & .55 & & & 1.40 & & & & $(3)$ & 5.46 \\
\hline 149 & North Rutland 8 & (3) & $\ldots$ & & 1.90 & 1.60 & $17^{-}$ & .98 & .82 & .64 & 63 & 02 & .04 & 6.78 \\
\hline 150 & Otis Reservoir ${ }^{5} 18^{-}$ & (3) & (3) & & .70 & .65 & 05 & 1.50 & .10 & .57 & & & & 3.57 \\
\hline 151 & Peru ${ }^{5} 8$ & .34 & & & 2.11 & .10 & .35 & .62 & 1.01 & .10 & & & & 4.29 \\
\hline 152 & Petersham ${ }^{2}$ & $(3)^{2}$ & $(3)$ & & $*$ & $*$ & 2.74 & $*$ & & & 2.28 & & & 5.02 \\
\hline 153 & Phillipston $^{5} 8_{-}^{-}$ & (3) & & & 2.35 & 1.18 & .25 & 1.00 & .02 & .25 & & & (3) & 5.05 \\
\hline 154 & Plainfield ${ }^{6} 8$ & 03 & & & 2.03 & .75 & .46 & $.5 \overline{5}$ & .85 & .90 & & $\ldots$ & & 5.54 \\
\hline 155 & Provin Mountain Residence ${ }^{5}$ & $(3)$ & $(3)$ & & 1.44 & 1.16 & .09 & 2.17 & .09 & .71 & 02 & & & 5.68 \\
\hline 156 & Rutland ${ }^{5} 8 \ldots$ & (3) & & & 1.24 & .98 & .11 & 1.26 & .27 & 1.08 & .02 & & & 4.96 \\
\hline 747 & Shelburne Falls ${ }^{20}$ & .28 & 0.04 & & & 1.46 & .09 & .60 & .47 & .40 & .88 & - & & 3.90 \\
\hline 158 & Shutesbury ${ }^{5} 8$ & $(3)$ & $\ldots . .$. & & 2.70 & .85 & .04 & 1.06 & .04 & .48 & & & & 5.17 \\
\hline 159 & South Deerfield ${ }^{8} 8$ & $(3)$ & & & 1.75 & 1.18 & .22 & .84 & .34 & .55 & & & (3) & 4.88 \\
\hline 160 & Springfield ...... & .38 & & & 1.51 & .84 & .56 & 1.56 & .96 & $*$ & .60 & 11 & & 6.14 \\
\hline 162 & Springfield 421 & (3) & $(3)$ & & 1.33 & 1.41 & .03 & 1.50 & .49 & .32 & .18 & .12 & & 5.38 \\
\hline 163 & Turners Falls.-.. & & & & 1.33 & .45 & .09 & 2.00 & .06 & .90 & & & & 4.83 \\
\hline 164 & Ware ${ }^{5} \ldots$ & $(3)$ & (3) & & 1.87 & .55 & .02 & 1.61 & .08 & .73 & & 06 & .... & 4.92 \\
\hline $16 ;$ & Ware Centre & & & & 2.30 & 75 & .05 & 1.58 & .08 & .80 & & .55 & & 5.56 \\
\hline 160 & Ware River intake & $(3)$ & $(3)$ & & 2.15 & .72 & .02 & 1.50 & & & .79 & .10 & & 5.28 \\
\hline 167 & Warren ${ }^{8} 8$ & (3) & & & 1.95 & .40 & .02 & 1.78 & .05 & 1.34 & & .03 & & 5.68 \\
\hline 168 & Warwick ${ }^{6} \mathrm{~B}_{2}$ & $(3)$ &.- & & .85 & .74 & 09 & .88 & .66 & .43 & . & $\ldots$ & (3) & 3.65 \\
\hline 169 & Wendell $6{ }^{8}$ & (3) & & & 1.42 & 1.10 & .08 & 1.04 & .35 & 70 & & & (3) & 4.69 \\
\hline 170 & West Brookfield o $8 . .$. & (3) & & & 2.19 & .45 & 12 & 1.82 & .04 & 1.12 & & .05 & & 5.79 \\
\hline 171 & Westfield 58 & (3) & & & 1.45 & 1.17 & 06 & 1.58 & .07 & 40 & & & .02 & 4.73 \\
\hline
\end{tabular}




\begin{tabular}{|c|c|c|c|c|c|c|c|c|c|c|c|c|c|c|}
\hline 172 & West field Dam /( iranville is 8 & (3) & & & .95 & 1.23 & 20 & 1.52 & $0 \bar{t}$ & 47 & & & & 4.44 \\
\hline 173 & Westfield Santorium & .23 & & & 1.21 & 1.04 & .58 & 1.46 & 74 & .52 & .54 & 01 & 0.7 & 6.13 \\
\hline 174 & West (iranville" & (3) & (:i) & & 1.25 & .65 & .18 & 1.30 & 11 & 1.07 & & & & 4.56 \\
\hline & $\begin{array}{l}\text { West Otis }{ }^{5} \\
\text { West Pelham }\end{array}$ & 21 & & - & 1.65 & .14 & .36 & .93 & .34 & 1.38 & . & & & $\begin{array}{r}4.80 \\
5.88\end{array}$ \\
\hline $\begin{array}{l}178 \\
179\end{array}$ & $\begin{array}{l}\text { West Pelham }{ }^{58} \\
\text { West Rutland }{ }^{5} 9\end{array}$ & $\begin{array}{l}(3) \\
(3)\end{array}$ & $\left(3_{\}}\right.$ & & 3.42 & $\begin{array}{l}.91 \\
69\end{array}$ & .03 & $\begin{array}{l}1.07 \\
1.28\end{array}$ & $(15)$ & .40 & 84 & (n!) & & $\begin{array}{l}9.88 \\
4.54\end{array}$ \\
\hline 180 & & (3) & (3) & & $*$ & 2.75 & . & 1.84 & * & .54 & & & & 5.13 \\
\hline 182 & Williamsburg 8 & (3) & & & 2.67 & .65 & 28 & .78 & 08 & 50 & - & & (3) & 496 \\
\hline 183 & Williamsville ${ }^{5} 8$ & (3) & - & & 2.32 & 2.10 & .05 & 1.50 & 06 & 40 & & & & 6. 43 \\
\hline 184 & $\begin{array}{l}\text { Winchendon } 8 \\
\text { Worthington } 8\end{array}$ & (3) & ... & $\ldots$ & $\begin{array}{l}2,02 \\
1,89\end{array}$ & .88 & .03 & 1.20 & 14 & 40 & $\cdots$ & (1) & . & 4.67 \\
\hline & $\begin{array}{l}\text { Worthington" } 8 \text {... } \\
\text { Connecticut: }\end{array}$ & (3) & & & 1.82 & .07 & $.16 i$ & $.9 n$ & .30 & 97 & & 0.3 & & \\
\hline 186 & Bakersville:22 & (3) & (:i) & & .01 & 53 & 1.80 & 84 & 4.28 & 20 & 122 & 01 & & 891 \\
\hline $\begin{array}{l}187 \\
188\end{array}$ & Barkhamsted ${ }^{2}-$ & 01 & & & .08 & 58 & 1.41 & 32 & 3.00 & 16 & 59 & & & 6. $1 \pm$ \\
\hline $\begin{array}{l}188 \\
189\end{array}$ & Bills Brook 222 & $\left({ }^{3}\right)$ & $\left({ }^{(3)}\right.$ & & .09 & 89 & 1.45 & .21 & 3.19 & 10 & $*$ & . 64.4 & $\cdots$ & 6.57 \\
\hline 189 & Bloomfield 423 . & $\cdots$ & & & 36 & .20 & 1.22 & 1.48 & .74 & 1.09 & .39 & & & 5.48 \\
\hline (90) & Bristol $^{2} 24 \ldots$ & (3) & (3) & & $\ldots \ldots$ & 2.82 & .88 & .11 & 1.98 & .21 & 1. $y:$ & 0.3 & & 7.98 \\
\hline $\begin{array}{lll} & \end{array}$ & Brown's Corner' 22 & (3) & (3) & & & .70 & 1.06 & 28 & 2.20 & 32 & 80 & & & 5.37 \\
\hline 192 & Burlington (Phelps Brook Dam) & .13 & 01 & & 17 & 43 & 1.33 & .2 & 3.38 & 24 & 1.08 & & (a) & 7.65 \\
\hline 193 & Camp Buck ${ }^{13}$ & 6 & $\ldots$. & & .40 & 1.60 & 1.25 & 1.25 & 1.20 & 2.10 & 90 & & . & 8.70 \\
\hline 194 & Camp Connor ${ }^{13}$ & .95 & $\ldots \ldots$ & & 60 & .51 & 32 & .72 & 48 & 70 & .63 & .01 & & 397 \\
\hline 196 & Camp Robinson ${ }^{13}$ & .57 & $\ldots$ & & 1.00 & .45 & .66 & 1.54 & fiti & 28 & .24 & 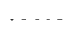 & $\ldots$ & 4.83 \\
\hline 197 & Canup White ${ }^{13} \ldots$ & $\ldots .$. & & & .10 & 65 & 1.10 & 2.60 & 87 & .65 & & .. & $-\cdots$ & 5.97 \\
\hline 198 & Colchester $\ldots . .$. & & .5 .5 & & $\ldots . .$. & .57 & .67 & 1.44 & .68 & 3.10 & 3.58 & & $\ldots \ldots$ & 10.04 \\
\hline 199 & Collinsville ${ }^{2} . .$. & .13 & $\ldots \ldots$ & & $\ldots$ & .48 & 1.13 & .89 & 3.06 & .21 & 1.01 & & & 6.78 \\
\hline 202 & East Hartland ${ }^{2}$. & .38 & $\ldots \ldots$ & & & 1.04 & 1.40 & .22 & 2.15 & 26 & .58 & 53 & & 6.20 \\
\hline 748 & Ellington 425 & .10 & & & .37 & .12 & .28 & 1.40 & 43 & 1.11 & 31 & 28 & - & 430 \\
\hline 749 & Enfield 425 & (3) & (3) & & .93 & .50 & .24 & 1.34 & .55 & .59 & .34 & - & & +50 \\
\hline 203 & Glastonbury ${ }^{26}$ & (3) & (3) & & .09 & * & $*$ & 3.76 & $*$ & * & 2.68 & & & 6.53 \\
\hline 204 & Hartford ${ }^{4}$ & Tr. & & $\ldots$ & 2.28 & .13 & 2.15 & 1.62 & 1.17 & 1.46 & 32 & .02 & & 9.15 \\
\hline 205 & Hartland Hollow 22 & $(3)$ & (3) & & .43 & 2.00 & .92 & .21 & 1.88 & .10 & $*$ & .48 & $\therefore$. & 6.02 \\
\hline 206 & Manchester $^{5}{ }^{26}$ & (3) & (3) & & 2.36 & .42 & .48 & 2.00 & .30 & 2.12 & .09 & & . & 7.77 \\
\hline 750 & Marek House ${ }^{2} 22^{2}$ & (3) & (3) & & .11 & 99 & 1.50 & .26 & 3.22 & & .70 & . . . & . & 6.91 \\
\hline 207 & Middletown ${ }^{27} \ldots$ & (3) & (3) & $\ldots$ & .14 & 84 & .86 & .22 & .95 & 1.75 & 1.18 & $\ldots$ & & 5.94 \\
\hline 208 & New Britain 48 & (8) & (3) & & 70 & .97 & .57 & 40 & .34 & 1.52 & .28 & $\ldots$ & & 4.78 \\
\hline 209 & New Hartford ${ }^{22} \ldots$ & .02 & & & $*$ & .55 & 1.54 & .59 & 2.64 & 19 & .72 & $\therefore$ & & 6.23 \\
\hline 210 & Newington 4 23 & & $\ldots$ & & 1.67 & 28 & .21 & 99 & .51 & 1.78 & .24 & $\ldots$ & $\ldots \ldots$ & 5.68 \\
\hline 211 & North Station ${ }^{22}$ & (3) & (3) & & 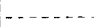 & .72 & 1.18 & $*$ & 4.30 & .24 & .84 & & - & 7.28 \\
\hline 212 & Shuttle Meadow 29 & (3) & (3) & & $-\ldots$ & 1.50 & .36 & .16 & 1.35 & .28 & 2.20 & .07 & & 5.92 \\
\hline 213 & South Meadows 23 & & & & 1.84 & 18 & .27 & .68 & .65 & 1.81 & .34 & .24 & $\ldots$ & 6.01 \\
\hline 214 & Thompsonville 230 & .06 & .60 & & - & .93 & .56 & .17 & 2.02 &, 16 & .86 & $\cdots$ & $\cdots$ & 4.70 \\
\hline $\begin{array}{l}215 \\
216\end{array}$ & West Hartford ${ }^{2} 22 \ldots$ & $\cdots \cdots$ & ............. & 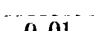 & .03 & 2.30 & .38 & .91 & 1.40 & .14 & $\begin{array}{r}2.03 \\
\mathbf{4 2}\end{array}$ & . 01 & & $\begin{array}{l}7.20 \\
6.92\end{array}$ \\
\hline $\begin{array}{l}216 \\
218\end{array}$ & $\begin{array}{l}\mathrm{Do}^{4} 22 \\
\text { West Hartiand }\end{array}$ & $\cdots$ & $75^{-}$ & $\begin{array}{l}0.01 \\
\ldots . . . .\end{array}$ & $\begin{array}{r}2.30 \\
\ldots\end{array}$ & .27 & $*^{75}$ & $\begin{array}{r}.98 \\
1.76\end{array}$ & $\begin{array}{l}.53 \\
1.45\end{array}$ & $\begin{array}{r}.01 \\
.76\end{array}$ & .56 & & & 5.33 \\
\hline 219 & $\begin{array}{l}\text { West Hartand }{ }^{2} \\
\text { West Hill }{ }_{22}-\ldots\end{array}$ & ()$^{-}$ & (3) & . & $\ldots$ & .68 & 2.25 & .65 & 3.50 & .30 & $\because \hat{a}$ & .65 & $\cdots$ & 8.03 \\
\hline 220 & $\begin{array}{l}\text { Whigville Reservoir }{ }^{29} \ldots \\
\text { Windsor }{ }^{2}{ }_{31}\end{array}$ & $\begin{array}{l}(3) \\
\text { (3) }\end{array}$ & $\begin{array}{l}(3) \\
(3)\end{array}$ & .... & $(-1)$ & $\begin{array}{l}.83 \\
.55\end{array}$ & $\begin{array}{r}1.31 \\
.25\end{array}$ & $\begin{array}{r}.14 \\
1.25\end{array}$ & 2.29 & $\begin{array}{l}.16 \\
.14\end{array}$ & $\begin{array}{l}1.24 \\
1.60\end{array}$ & & $\ldots \ldots$ & $\begin{array}{l}5.97 \\
5.81\end{array}$ \\
\hline & 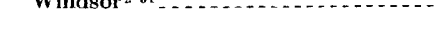 & & & & & & & & & & & & & \\
\hline
\end{tabular}


TABLE 21.-Daily precipitation, in inches, July 15-26, 1938-Continued

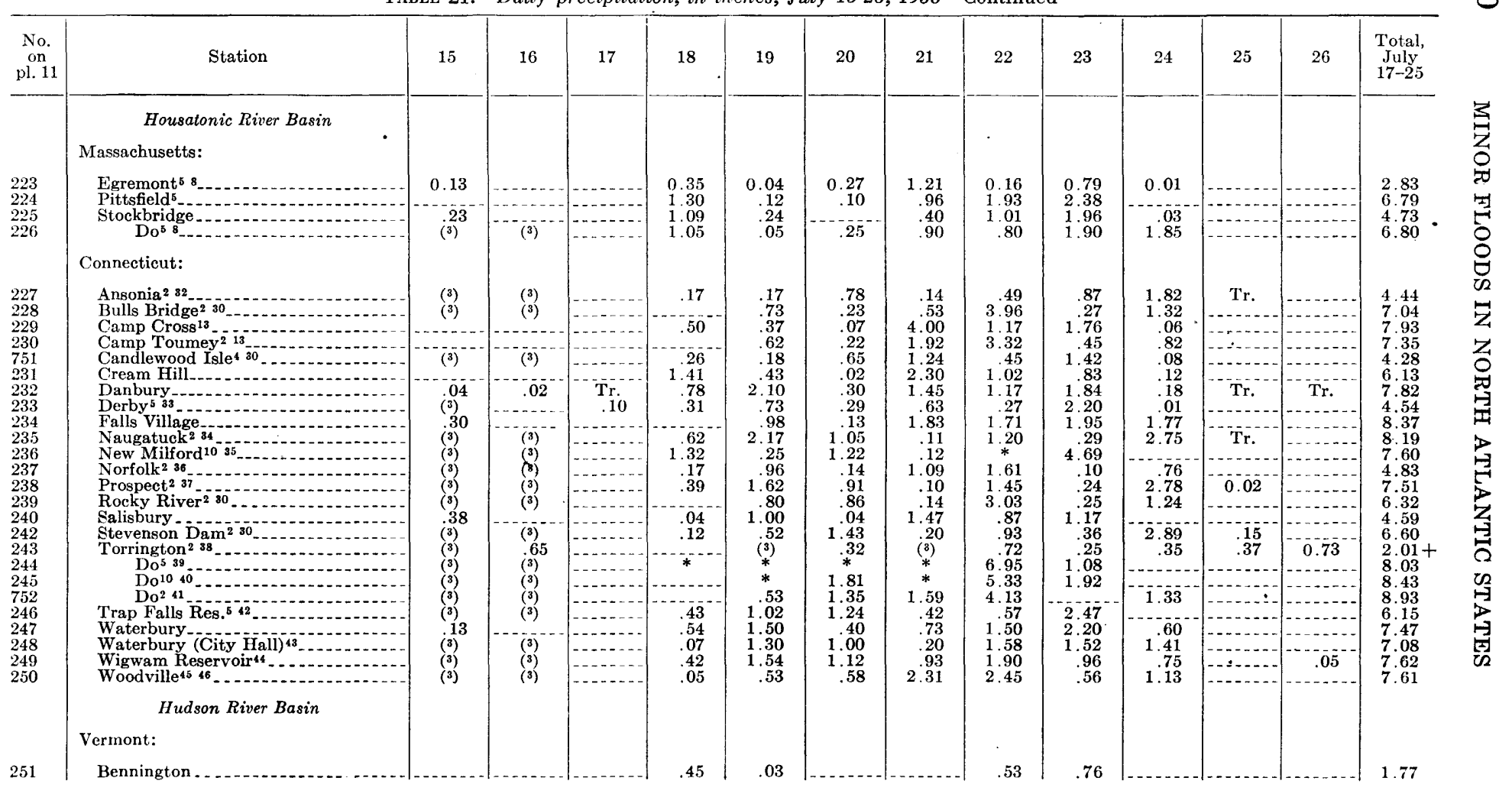




\begin{tabular}{|c|c|c|c|c|c|c|c|c|c|c|c|c|c|c|}
\hline 252 & $\begin{array}{l}\text { Massachusetts: } \\
\text { Adams2 } \\
\text { Williamstown }\end{array}$ & .99 & & & 1.24 & $\begin{array}{r}1.30 \\
.04\end{array}$ & .25 & .02 & .25 & $\begin{array}{r}1.17 \\
.47\end{array}$ & .94 & & & $\begin{array}{r}4.09 \\
2.79\end{array}$ \\
\hline & New York: & & & & & & & & & & & & & \\
\hline$\frac{255}{256}$ & $\begin{array}{l}\text { Albany }^{4} \\
\text { Albany (airport) }\end{array}$ & $\begin{array}{l}(3) \\
.01\end{array}$ & $\left({ }^{3}\right)$ & & .67 & .12 & $\begin{array}{l}\text { Tr. } \\
\text { Tr. }\end{array}$ & $\begin{array}{l}.05 \\
.05\end{array}$ & $\begin{array}{l}.39 \\
.28\end{array}$ & $\begin{array}{l}.64 \\
.42\end{array}$ & $\begin{array}{l}07 \\
\text { Tr. }\end{array}$ & & .28 & $\begin{array}{l}1.94 \\
1.0 .5\end{array}$ \\
\hline $\begin{array}{l}719 \\
258\end{array}$ & $\begin{array}{l}\text { Amawalk } 57 \text { 7 } \\
\text { Bedford Hills }\end{array}$ & $\begin{array}{l}.02 \\
.94\end{array}$ & $\cdots-$ & .10 & .06 & $\begin{array}{l}.60 \\
.58\end{array}$ & $\begin{array}{l}2.04 \\
.48\end{array}$ & 2.22 & $\begin{array}{r}.43 \\
1.10\end{array}$ & $\begin{array}{l}1.85 \\
2.60\end{array}$ & .82 & .05 & & $\begin{array}{l}.7 .31 \\
6.58\end{array}$ \\
\hline $\begin{array}{l}238 \\
259\end{array}$ & 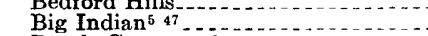 & & & & 1.04 & .72 & .15 & 2.00 & $\begin{array}{l}1.10 \\
.67\end{array}$ & $\begin{array}{l}2.00 \\
.25\end{array}$ & .02 & & & 4.83 \\
\hline 261 & $\begin{array}{l}\text { Boyds Corners } \\
\text { Brown Station } 47\end{array}$ & & & 03 & 38 & 1.01 & .76 & 4.03 & .44 & 1.50 & .03 & & $2^{(3)}$ & $\begin{array}{l}8.18 \\
59\end{array}$ \\
\hline 263 & $\begin{array}{l}\text { Brown Station }{ }^{5}{ }^{4}-\ldots \\
\text { Cairo }\end{array}$ & & . & & .87 & .13 & .05 & $\begin{array}{l}2.03 \\
.43\end{array}$ & $\begin{array}{l}2.02 \\
1.57\end{array}$ & .91 & & & & $\begin{array}{r}3.49 \\
3.96\end{array}$ \\
\hline 265 & $\begin{array}{l}\text { Carmel (West Branch) } \\
\text { Carme }\end{array}$ & & 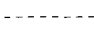 & .10 & .36 & .67 & .52 & 3.44 & .30 & 1.67 & .03 & & & 7.09 \\
\hline 720 & $\begin{array}{l}\text { Coldbrook }{ }^{5}{ }^{48} \\
\text { Cross River }{ }^{47}-\end{array}$ & .06 & & .04 & & .98 & .41 & $\begin{array}{l}3.31 \\
2.00\end{array}$ & $\begin{array}{l}1.82 \\
.34\end{array}$ & $\begin{array}{l}1.04 \\
2.41\end{array}$ & & & $(3)$ & 6.18 \\
\hline 721 & Croton Falls $47-$ & .01 & $\ldots$ & .34 & .11 & .39 & .87 & 2.21 & .34 & 1.94 & & . - & (3) & 6.20 \\
\hline 269 & Croton Lake ${ }^{47}$ & .03 & & .05 & .03 & .56 & .91 & 2.07 & .33 & 1.75 & $\ldots$ & .01 & (3) & 5.70 \\
\hline 722 & East Branch Reservoir (Sodom) ${ }^{5}{ }^{47} \ldots$ & & - & .14 & .18 & .48 & .51 & 2.15 & .27 & 2.03 & $\cdots$ & & $\left({ }^{(3)}\right.$ & 5.76 \\
\hline 272 & 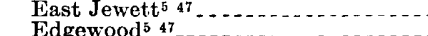 & & & .02 & 1.16 & .32 & .38 & 1.17 & 1.07 & .74 & $-\ldots$. & - & .01 & 4.86 \\
\hline 274 & $\begin{array}{l}\text { Edgewood } \\
\text { Elka Park }{ }^{5} 7_{7}-\ldots \\
\end{array}$ & & & .04 & .57 & .31 & .48 & 2.60 & $\begin{array}{l}1.96 \\
1.35\end{array}$ & 1.11 & .01 & & & 6.45 \\
\hline 277 & Glenham² & .01 & & & Tr. & 1.75 & .05 & .11 & 3.90 & .25 & 1.16 & & & 7.22 \\
\hline 280 & $\begin{array}{l}\text { Grahamsville } 548- \\
\text { Grand Gorge } 47^{-}\end{array}$ & & & & .72 & .19 & 1.91 & 5.13 & .77 & $\begin{array}{l}1.30 \\
12\end{array}$ & .02 & & 06 & 10.04 \\
\hline 283 & $\begin{array}{l}\text { Grand Gorge }{ }^{47} \\
\text { High Falls }\end{array}$ & & & .53 & 1.07 & Tr. & .51 & 1.74 & 2.94 & .1 .64 & .62 & & .06 & $\begin{array}{l}5.08 \\
5.86\end{array}$ \\
\hline 286 & Honk Falls & (3) & (3) & -. & 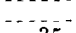 & .35 & .37 & 1.39 & 2.01 & 1.05 & & & $\cdots$ & 5.17 \\
\hline 293 & Kingston ${ }^{248}$ & & & & .35 & .10 & .30 & 1.88 & .15 & 1.10 & .55 & & & 4.43 \\
\hline 294 & $\begin{array}{c}D^{4} 49 \\
\text { Lackawack }\end{array}$ & (3) & ${ }^{(3)}$ & & $\begin{array}{r}.47 \\
.18\end{array}$ & 23 & 2.00 & $\begin{array}{l}1.27 \\
2.83\end{array}$ & $\begin{array}{l}1.20 \\
1.72\end{array}$ & $\begin{array}{r}1.49 \\
.42\end{array}$ & & & .06 & $\begin{array}{l}4.43 \\
7.38\end{array}$ \\
\hline 296 & Lake Hill ${ }^{5} 47$ & & & & .65 & .24 & .55 & 2.55 & 2.03 & 1.07 & & & .01 & 7.09 \\
\hline 297 & Lexington 647 & & & .07 & 1.20 & .23 & .53 & 1.17 & .68 & .21 & $\cdots$ & & .01 & 4.09 \\
\hline 300 & Manor Kill ${ }^{47} \ldots$ & & & .02 & 1.08 & .25 & .02 & .96 & $\begin{array}{l}1.00 \\
0.30\end{array}$ & .01 & & & .35 & 3.34 \\
\hline 302 & $\begin{array}{l}\text { Mohonk Lake } \\
\mathrm{Do}^{2}\end{array}$ & & & & .06 & .16 & $\begin{array}{l}.07 \\
09\end{array}$ & $\begin{array}{l}2.07 \\
1.35\end{array}$ & $\begin{array}{l}2.30 \\
2.47\end{array}$ & $\begin{array}{r}1.60 \\
.58\end{array}$ & .70 & & & $\begin{array}{l}6.26 \\
5.44\end{array}$ \\
\hline 307 & North Settlement ${ }^{5}{ }^{4}$ & & & 17 & 1.05 & .18 & .50 & 1.19 & 1.22 & .12 & .01 & .01 & .04 & 4.45 \\
\hline 309 & & & & .05 & .85 & .27 & .15 & .82 & 1.05 & .12 & .40 & & .05 & 3.71 \\
\hline 311 & Peekamoose 548 & Tr. & $\cdots$ & & .20 & .11 & .73 & 2.80 & 1.65 & 1.67 & & & 3.05 & 7.16 \\
\hline 312 & $\begin{array}{l}\text { Phoenicias } 47 \\
\text { Pin }\end{array}$ & & & .01 & .59 & .35 & .23 & 3.00 & 1.08 & .70 & . & & .02 & \\
\hline 313 & Pine Hill ${ }^{5} 47-\ldots$ & & & & .84 & .80 & $\begin{array}{r}.40 \\
02\end{array}$ & 1.6 & .85 & 1.37 & & & & 4.91 \\
\hline $\begin{array}{l}314 \\
315 \\
315\end{array}-20$ & 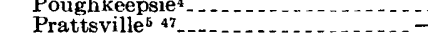 & & & .07 & .728 & .19 & 1.02 & 1.2 & $\begin{array}{l}1.25 \\
68\end{array}$ & $\begin{array}{l}1.06 \\
.07\end{array}$ & 01 & & .06 & $\begin{array}{l}6.01 \\
4.25\end{array}$ \\
\hline $\begin{array}{l}316 \\
316\end{array}$ & Preston Hollow 48 & & & & 1.00 & .28 & .45 & .72 & 1.11 & .10 & .11 & & .00 & 3. 77 \\
\hline $\begin{array}{l}317 \\
326\end{array}$ & 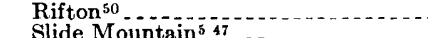 & & & 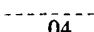 & Tr. & .28 & $\cdots 54$ & $\begin{array}{l}1.02 \\
3.49\end{array}$ & $\begin{array}{l}1.89 \\
1.43\end{array}$ & $\begin{array}{r}1.53 \\
.32\end{array}$ & & & & $\begin{array}{l}4.72 \\
7.59\end{array}$ \\
\hline 327 & ast Reservoir & & & & 1.10 & & & & & & & & & \\
\hline 75 & Sparkill 451 (19anch) & $(3)$ & & & .02 & .58 & .52 & 1.01 & 1.20 & 3.10 & .23 & (3) & (3) & 6.66 \\
\hline & Sundown ${ }^{5}{ }^{48}$ & & & & .53 & .40 & 2.78 & 4.78 & 1.19 & 1.60 & & & & 11.28 \\
\hline
\end{tabular}


TABLE 21.-Daily precipitation, in inches, July 15-26, 1938-Continued

\begin{tabular}{|c|c|c|c|c|c|c|c|c|c|c|c|c|c|c|}
\hline $\begin{array}{l}\text { No. } \\
\text { on } \\
\text { w. } 11\end{array}$ & Station & 15 & 16 & 17 & 18 & 19 & 20 & 21 & 22 & 23 & 24 & 25 & 26 & $\begin{array}{c}\text { Total, } \\
\text { July } \\
17-25\end{array}$ \\
\hline 333 & Tannersville ${ }^{5} 4 \ldots$ & & & 0.03 & 0.54 & 0.17 & 0.90 & 2.25 & 13 & 0.39 & & & & 5.41 \\
\hline 725 & Titicus Reservoir ${ }^{5} 47$ & 0.05 & $\ldots \ldots$ & $\begin{array}{r}0.08 \\
.46\end{array}$ & .05 & .65 & .95 & 2.07 & 27 & 2.32 & & & $(3)$ & 6.77 \\
\hline 337 & Voorheesville ${ }^{2} \ldots \ldots$ & .62 & $\cdots \cdots$ & & & .42 & .15 & & .26 & .45 & 0.40 & 1.09 & & 2.77 \\
\hline 338 & Walden & & & & 03 & .50 & & 2.06 & 2.61 & 1.89 & & & & 7.09 \\
\hline 339 & Wappinger Falls.- & .04 & & 02 & .42 & 2.10 & .04 & 2.31 & 2.75 & 1.02 & .04 & & $\cdots$ & 8.70 \\
\hline 341 & Warwick & .13 & ...... & Tr. & & .17 & .45 & 2.80 & .95 & 1.33 & .10 & & & 5.80 \\
\hline 342 & Westerlo 548 & & & & 1.26 & .28 & 20 & .30 & .45 & 1.15 & .02 & .... & 0.07 & 3.66 \\
\hline 343 & West Hurley 47 & 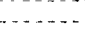 & & & .19 & .20 & .44 & 185 & 1.98 & .91 & & & .02 & 5.57 \\
\hline 344 & West Kills ${ }^{47}$ & & & .08 & 1.21 & .30 & .38 & 1.19 & .98 & .18 & & & .03 & 4.32 \\
\hline 345 & West Point & 烈....... & $\ldots$ & $\ldots . . .$. & .39 & .12 & .64 & 2.86 & .41 & 1.00 & .02 & -7 & & 5.44 \\
\hline 346 & West Shokan ${ }^{547}$ & & & & .15 & .53 & .30 & 4.22 & 1.32 & 1.78 & .04 & .01 & 04 & 8.35 \\
\hline \multirow{3}{*}{347} & White Pond 547 & & & .17 & 83 & .51 & .31 & 388 & .60 & 1.18 & & (3) & (3) & 7.48 \\
\hline & Windham ${ }^{4}{ }^{17}$ & .02 & ....... & 40 & 1.45 & 37 & .44 & 1.40 & .65 & .19 & - & $\ldots$ & .02 & 4.80 \\
\hline & New Jersey: & & & & & & & & & & & & & \\
\hline \multirow{5}{*}{$\begin{array}{l}755 \\
756 \\
757\end{array}$} & Beemerville4 $25 \ldots \ldots \ldots$ & ... & & ... . . & .58 & .08 & .25 & $1.8 t i$ & 1.88 & 1.77 & . & & (3) & 6.42 \\
\hline & libertyville4 25 & $\cdot \quad-\quad-$ & $\cdots$ & .... & .02 & .11 & .23 & 1.88 & 2.11 & 1.84 & $\ldots$ & & (3) & 660 \\
\hline & Anssex $\ldots \ldots \ldots$ & .20 & $\cdots \cdots$ & $\cdots \cdots$ & .58 & $\cdots$. & .36 & 2.40 & 1.24 & 1.34 & .... & & $\cdots \cdots$ & \\
\hline & $\begin{array}{c}\text { Hackensack, Passaic, and } \\
\text { Raritan River Basins }\end{array}$ & & & & & & & & & & & & & \\
\hline & New York: & & & & & & & & & & & & & \\
\hline 348 & Palisades Park ${ }^{53}$ & (3) & $(3)$ & .44 & & 15 & .89 & 2.17 & .61 & 1.43 & .05 & $\left({ }^{3}\right)$ & (3) & 5.74 \\
\hline 349 & Southfields ${ }^{4}{ }^{53}$ & (3) & & .65 & & .15 & 1.30 & 3.19 & .48 & 1.10 & & & & 6.87 \\
\hline \multirow[t]{2}{*}{758} & Spring Valley ${ }^{4}{ }_{1} \ldots \ldots$ & $(\because)$ & $\cdots$ & .23 & & .19 & 64 & 1.58 & .83 & 2.09 & .08 & $\cdots$ & (3) & $\overline{5} .64$ \\
\hline & Nin Jersey: & & & & $\cdot$ & & & & & & & & & \\
\hline 350 & Boonton $^{2}$ & .75 & 03 & & .15 & .08 & 60 & .31 & 2.60 & .52 & 1.69 & & & 5.95 \\
\hline 351 & Bowling Green 453 & .05 & & .33 & .05 & .19 & 1.08 & 3.19 & .46 & 1.50 & .06 & 03 & (3) & 6.89 \\
\hline 352 & Brook Valley ${ }^{63}$ & .08 & (n) & & & .28 & 1.35 & 2.44 & .51 & 2.28 & & & (3) & 6.88 \\
\hline 353 & Canistear Reservoir ${ }^{54}$ & .25 & - n... & $\ldots$ & $10^{-}$ & .20 & 1.25 & 2.90 & .70 & 1.65 & .30 & $\ldots . . .$. & (3) & 7.10 \\
\hline 354 & Canoe Brook ${ }^{2} \ldots$ & .36 & 26 & $\ldots .$. & .12 & .11 & .46 & .64 & 1.41 & 2.76 & 1.22 & & & 6.72 \\
\hline 355 & (edar Grove Reservoir $254 \ldots$. & .35 & .09 & & & .10 & .62 & .52 & 1.99 & .92 & 2.43 & $\ldots$ & (3) & 6.58 \\
\hline 356 & Charlottehurg 54 & .06 & & .25 & 02 & .23 & 2.10 & 1.85 & .82 & 1.65 & .16 & & $\ldots$ & $\pi .08$ \\
\hline 357 & Chatham $^{2} \ldots$ & .44 & 23 & $\ldots \ldots . .$. & .11 & 11 & .51 & .48 & 1.33 & 2.14 & 1.40 & -........ & $\ldots$ & 6.08 \\
\hline 759 & (linton Junction $2=\ldots$ & .16 & .30 & & .48 & .27 & .98 & .90 & .66 & 1.00 & .48 & 1.28 & $(3)$ & ti.0i \\
\hline 358 & Dover & .09 & $\ldots . . .$. & .18 & & .31 & 2.26 & 1.69 & .71 & 2.04 & .05 & 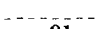 & $\ldots$ & $7 \cdot 24$ \\
\hline 359 & Flemington . . . . & 22 & …..... & .67 & .06 & .18 & 2.13 & .99 & 1.48 & 1.84 & .17 & .01 & & 7.53 \\
\hline 360 & Freehold ......... & .81 & (n) & .23 & & .35 & 2.80 & .52 & .45 & .53 & 1.71 & & .02 & 6.59 \\
\hline 362 & Freehold (Oaklanl Mills R-2) 4 & .78 & (n) & $\ldots$ & 15 & .17 & 2.54 & .65 & .28 & .64 & 1.21 & $\ldots$ & $(3)$ & 5.64 \\
\hline 366 & Freehold (Cahills (Corner $R-6 i) 4$ & 85 & & & .26 & .25 & 3.55 & 1.15 & .15 & .76 & 1.11 & & (3) & 7.23 \\
\hline
\end{tabular}




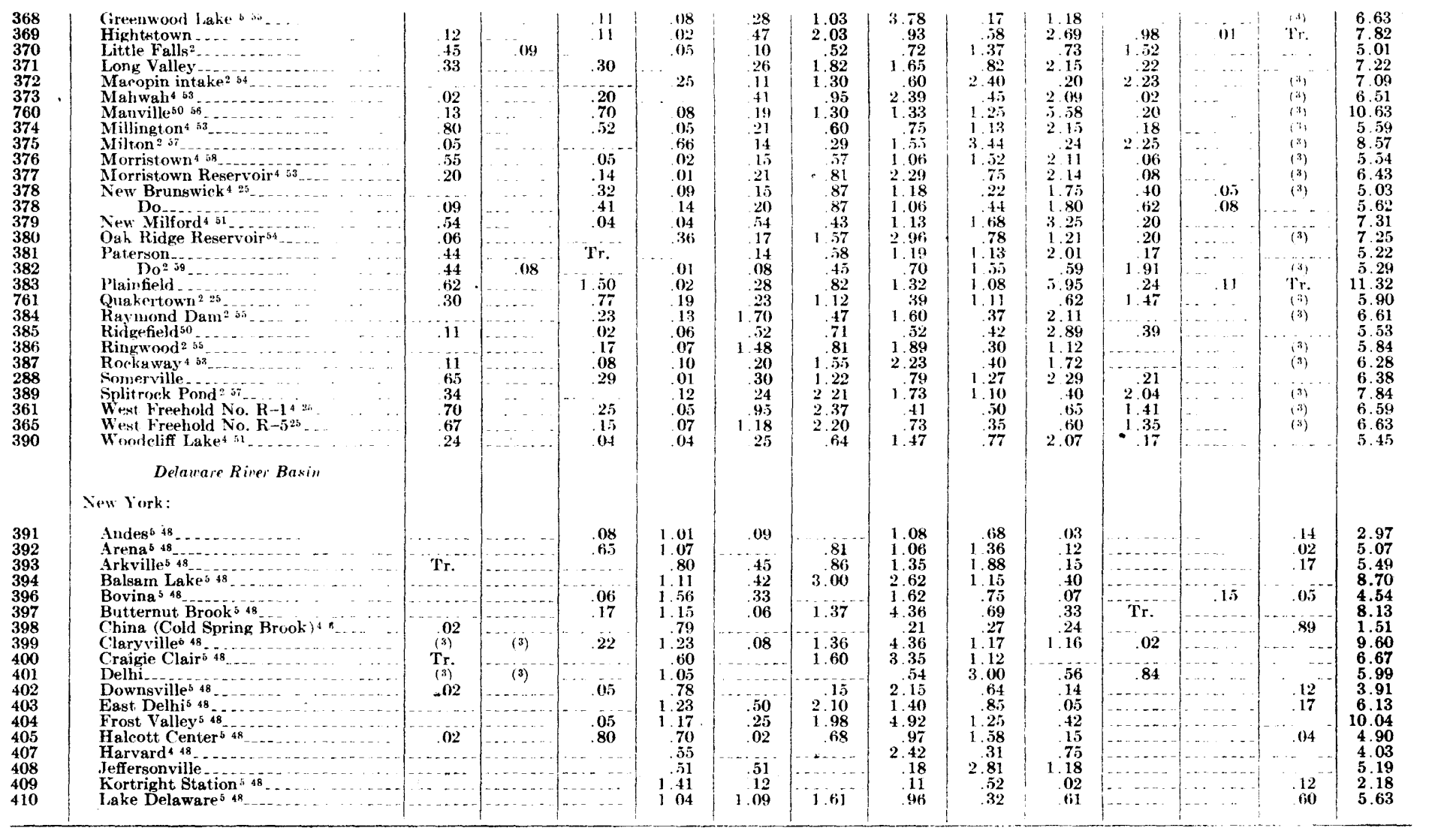


TABLE 21.-Daily precipitation, in inches, July 15-26, 1938-Continued

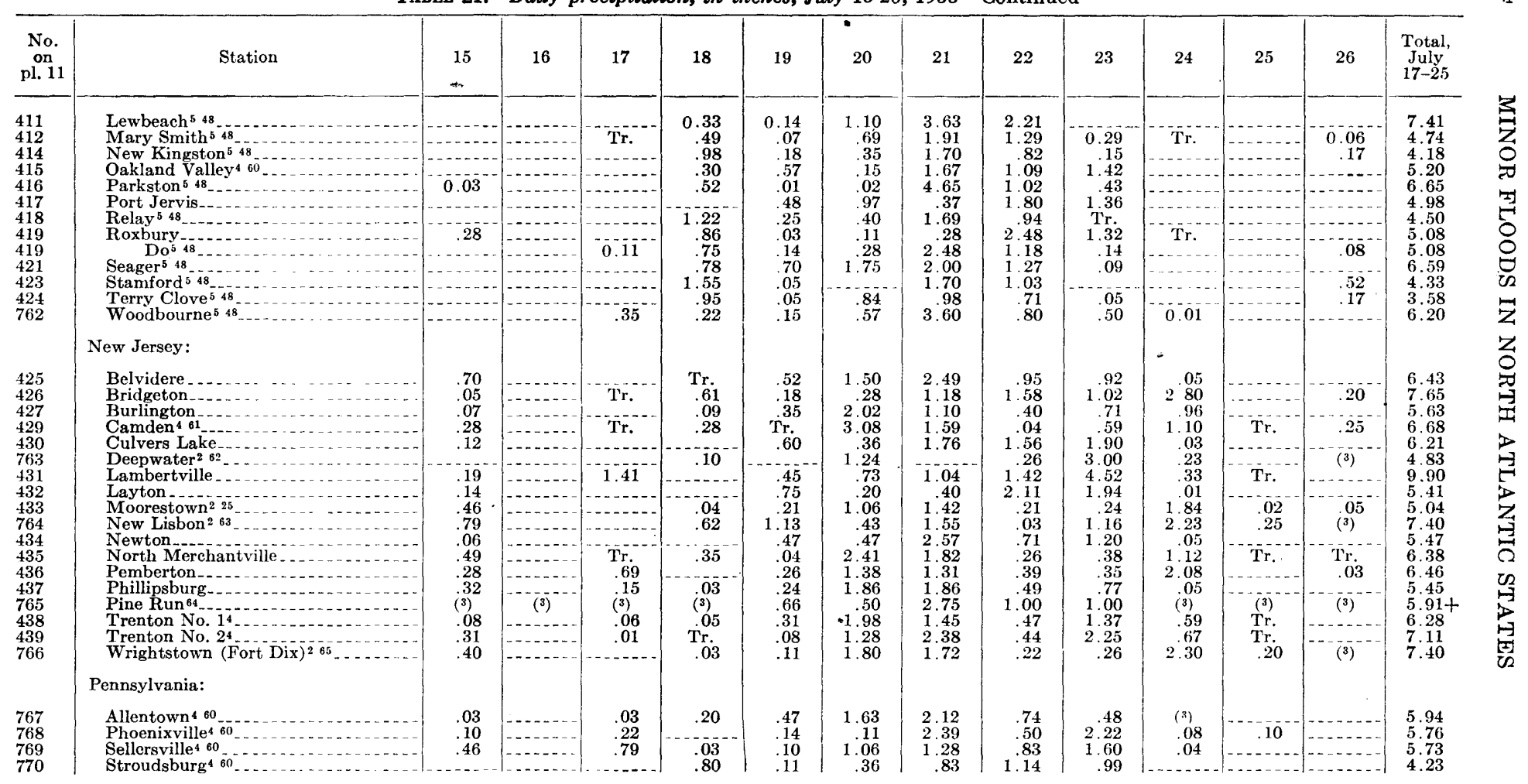




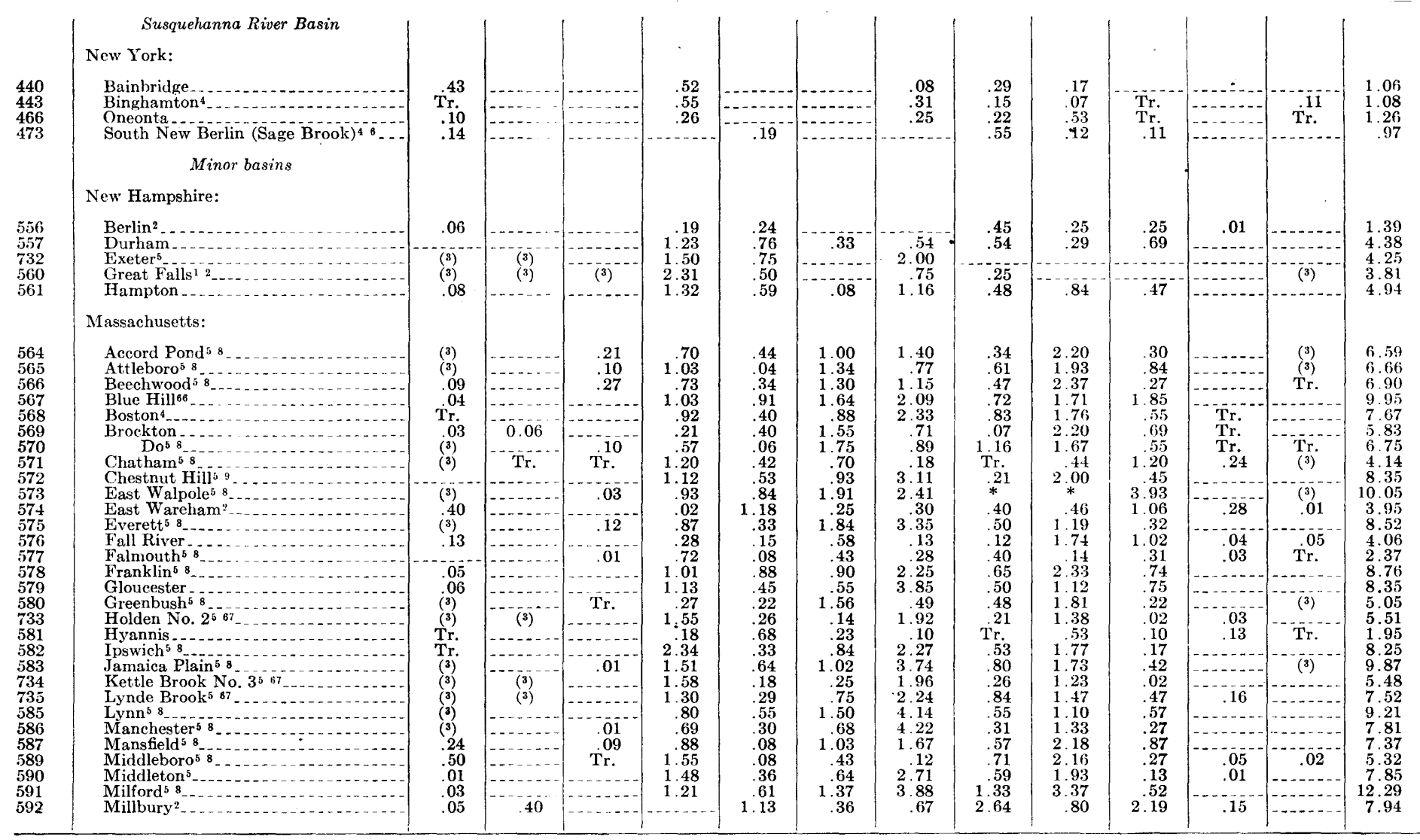


Table 21.- Daily precipitation, in inches, July $15-26,1938$-Continued

\begin{tabular}{|c|c|c|c|c|c|c|c|c|c|c|c|c|c|c|}
\hline $\begin{array}{l}\text { No. } \\
\text { on } \\
\text { pl. } 11\end{array}$ & Stration & 15 & 16 & 17 & 18 & 14 & 20 & 21 & 22 & 23 & 24 & 25 & $2 h$ & $\begin{array}{c}\text { Total, } \\
\text { July } \\
17-25\end{array}$ \\
\hline 593 & Milliso $8 \ldots$ & (3) & & & 0.98 & 0.75 & 1.19 & 3.20 & 0.43 & 2.63 & () 40 & & $(3)$ & 9.59 \\
\hline 594 & Nantucket ${ }^{4}$. & 002 & & & 0.88 & 0.73 & 34 & 0.13 & & .05 & .19 & 0.38 & 0.05 & 1.60 \\
\hline 595 & Needham ${ }^{5} 8$ & (3) & & & 1.19 & .72 & 1.00 & 3.09 & .30 & 2.13 & .37 & & (3) & 8.80 \\
\hline 596 & New Bedford 4 & .65 & & & 65 & .06 & .33 & .06 & .44 & .23 & .58 & & & 2.35 \\
\hline 597 & New Bedford (Clark's Point) & (3) & $\mathrm{Tr}$ & Tr. & 1.14 & .06 & .10 & 1.30 & .13 & .48 & .18 & 01 & (3) & 3.69 \\
\hline 598 & New Bedford (Clifford) s $^{5} \ldots$ & $i 3$ & & Tr. & .77 & .16 & .38 & .29 & .26 & .56 & 17 & .04 & (3) & 2.59 \\
\hline 599 & Newton 88 & $\left({ }^{3}\right)$ & & & 1.37 & .60 & 1.29 & 3.32 & .38 & 1.94 & 41 & Tr. & $\left({ }^{3}\right)$ & 9.31 \\
\hline 600 & Northbridge ${ }^{8} 8_{-}$ & .12 & & & .91 & 1.03 & 97 & 2.66 & 1.14 & 2.66 & 37 & 13 & & 9.87 \\
\hline 602 & Norwood ${ }^{8} 8 \ldots$ & $(3)$ & $\cdots$ & .01 & 1.10 & 1.82 & .32 & 2.31 & .56 & 2.33 & 61 & & (3) & 9.06 \\
\hline 603 & Onset, ${ }^{8} 8$ & (a) & & Tr. & 1.14 & .05 & 42 & .49 & .59 & .57 & .46 & Tr. & Tr. & 3.72 \\
\hline 604 & Peabody ${ }^{6} 8$ & (3) & .... & & .43 & 32 & .57 & 4.08 & 45 & 1.15 & .28 & & & 7.48 \\
\hline $\begin{array}{l}605 \\
606\end{array}$ & $\begin{array}{l}\text { P'embroke }{ }^{5} \mathbf{8} \\
\text { Plymouth }\end{array}$ & $\begin{array}{l}86 \\
37\end{array}$ & & & $\begin{array}{r}.47 \\
.38\end{array}$ & .21 & .97 & 12 & 1.54 & 2.13 & 17 & $\begin{array}{l}01 \\
\operatorname{Tr}\end{array}$ & $\begin{array}{l}.02 \\
03\end{array}$ & $\begin{array}{l}5.62 \\
+.24\end{array}$ \\
\hline 607 & $\mathrm{Do}^{5} \mathrm{~B}$ & $(3)$ & & & 1.05 & & .38 & .16 & $\begin{array}{l}.09 \\
.44\end{array}$ & $\begin{array}{r}1.34 \\
.59\end{array}$ & .35 & & (3) & 2.97 \\
\hline 608 & 'rovincetown... & .28 & .01 & & Tr. & 70 & .36 & 05 & .12 & .12 & 88 & .02 & Tr. & 2.25 \\
\hline 609 & Roekport & .05 & & & .18 & 1.00 & .55 & 1.40 & 2.00 & 1.04 & .70 & 02 & & 6. 89 \\
\hline 610 & Salem 58 & (3) & & & .56 & .52 & .55 & 3.95 & $\begin{array}{l}.38 \\
.38\end{array}$ & 1.32 & .35 & Tr. & & 7.63 \\
\hline 612 & Spot Pond 59 & .01 & & & .33 & .45 & 87 & 3.41 & .65 & 1.85 & 26 & 21. & & 8.02 \\
\hline 613 & State Farm $^{6} 8$ & $\left({ }^{3}\right)$ & (3) & & 46 & .10 & .58 & .20 & 1.48 & 1.78 & .20 & & .04 & 4.80 \\
\hline 614 & Swampscott... & & & & .95 & .29 & 83 & 2.94 & .67 & 1.32 & .70 & 01 & & 7.71 \\
\hline 615 & Taunton ${ }^{5} 8$ & .58 & & Tr. & .40 & .09 & 64 & .15 & .62 & 200 & .33 & & .05 & 4.23 \\
\hline 616 & Tisbury ${ }^{5} 8$ & (3) & & & & 4.10 & 15 & .60) & & .54 & .29 & & (3) & 5.68 \\
\hline 617 & U xbridge $^{5} 8$ & $(3)$ & ... & . & 66 & 1.09 & 69 & 3.16 & .95 & 4.68 & 32 & 02 & & 11.57 \\
\hline 618 & Waltham ${ }^{5} 8$ & (3) & & & 1.02 & .45 & 1.31 & 3.90 & 1.02 & 2.64 & 28 & & (3) & 10.62 \\
\hline 619 & Weaham Lake ${ }^{5} 8$ & (3) & & & .71 & .46 & .55 & 3.28 & 36 & 1.37 & .29 & & (3) & 7.02 \\
\hline 620 & Weston (Weston College) & .03 & & & .32 & 1.25 & .73 & 1.63 & 1.45 & 3.08 & 1.54 & Tr. & 1.1 & 1000 \\
\hline 621 & West Roxbury ${ }^{5} 8_{\ldots} \ldots \ldots$ & $(3)$ & & Tr. & 1.34 & .56 & 1.15 & 2.53 & 58 & 1.53 & .53 & 17. & (3) & 8.2 \\
\hline 622 & Wilmington ${ }^{5} 8^{8} \ldots$ & (s) & & & 2.40 & .27 & .96 & 2.54 & .49 & 1.83 & .12 & 02 & (3) & 8.til \\
\hline 623 & Winchester ${ }^{5} 8_{3}$ & (3) & & & .60 & 36 & .90 & 2.93 & .76 & 2.18 & 30 & & & 803 \\
\hline 624 & Wollaston 68 & & & 13 & 1.64 & .63 & .97 & 2.71 & .46 & 1.96 & 66 & & & 9.16 \\
\hline 625 & Worcester & Tr. & & & 1.64 & .32 & 30 & 1.71 & .36 & 1.72 & 18 & 12 & - & 6.65 \\
\hline 736 & $D^{567}$ & (3) & $\left({ }^{3}\right)$ & & 1.30 & .29 & 75 & 2.24 & .84 & 1.47 & .77 & .16 & & 7.3 \\
\hline 626 & Wrentham ${ }^{5} 8$ & $(3)$ & $\ldots$ & .24 & 1.72 & 1.01 & 1.05 & 2.92 & .47 & 2.97 & 9 & $\ldots \ldots$ & (3) & 1133 \\
\hline & Rhore Island: & & & & & & & & & & & & & \\
\hline 627 & Block Island ${ }^{4} \ldots$ & .37 & & & .18 & Tr. & .66 & .18 & .23 & .34 & .68 & & .02 & 2.27 \\
\hline 629 & Greenville & (3) & & & 1.31 & .23 & 1.15 & 2.20 & .13 & 2.16 & 2.36 & 23 & & 9.77 \\
\hline 737 & Hopkins Mills ${ }^{5}$ B8 & (3) & (a) & .02 & 1.74 & .60 & .97 & 2.13 & 1.49 & $3: 47$ & 1.32 & 07 & & 11.81 \\
\hline 738 & Kent ${ }^{568} \ldots$ & (3) & (3) & .01 & 83 & 86 & .26 & .51 & .56 & $\begin{array}{l}0.83 \\
2.53\end{array}$ & .96 & & & 6.52 \\
\hline 630 & Kingston $\ldots \ldots$ & 12 & & & .12 & .31 & .85 & .10 & .33 & 1.25 & 1.08 & & .03 & 4.04 \\
\hline 740 & North Scituate s8 $^{-1}$ & (3) & $(3)$ & 05 & 1.38 & 1.35 & .15 & .83 & .48 & 2.67 & 1.05 & .03 & & 7.99 \\
\hline 631 & North Smithfield 289 & (3) & (3) & & & .85 & 1.70 & .05 & 2.85 & 1.40 & 2.60 & 1.80 & & 11.25 \\
\hline 634 & l'ortsmouth & .11 & & & .18 & .58 & .56 & .08 & .18 & .44 & .58 & & .01 & 2.60 \\
\hline 635 & P'rovidenced $\ldots . . . . . . . . .$. & .62 & & & .50 & .07 & .87 & .60 & .17 & 2.51 & 1.10 & Tr. & Tr. & 5.82 \\
\hline
\end{tabular}



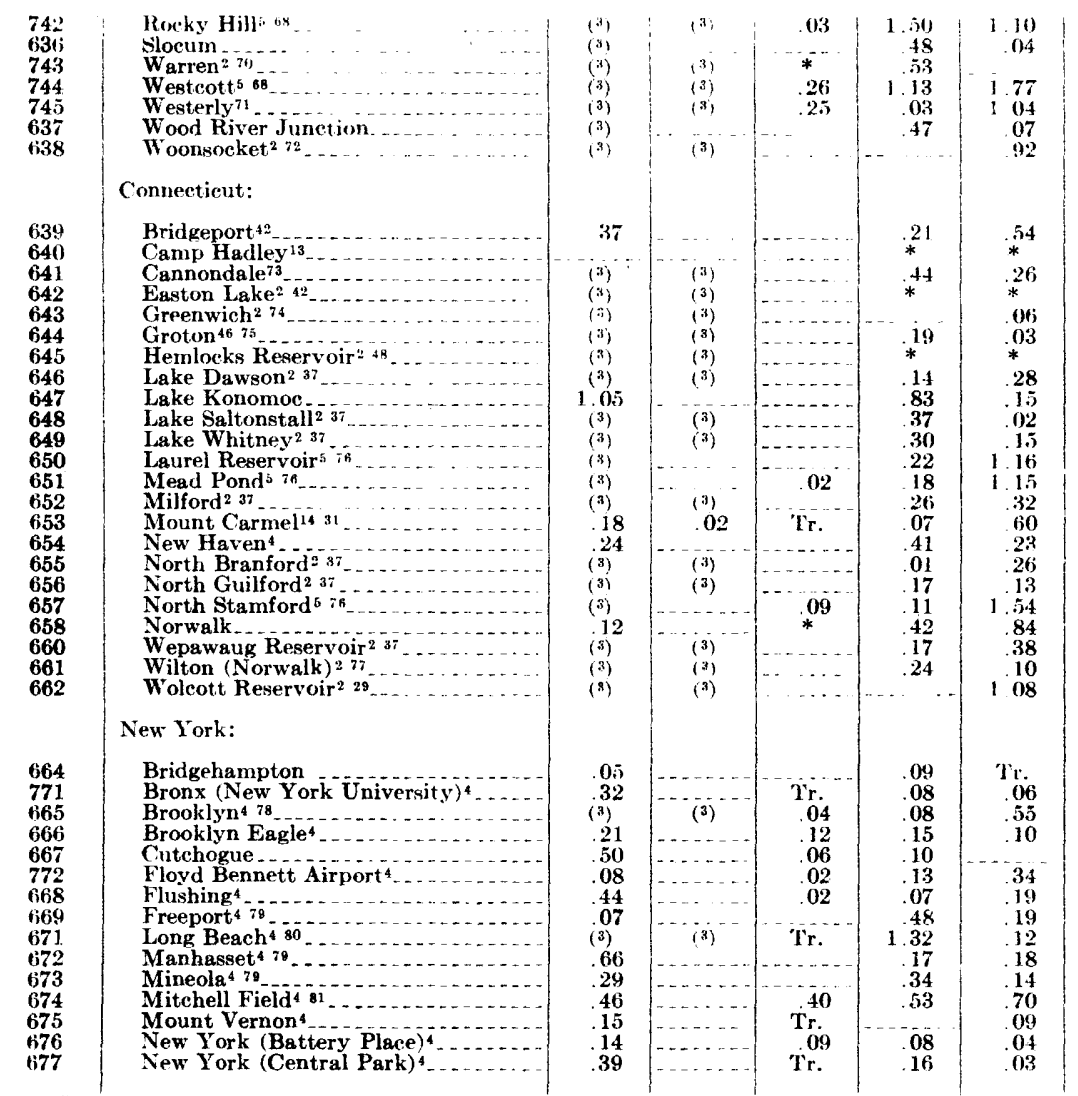

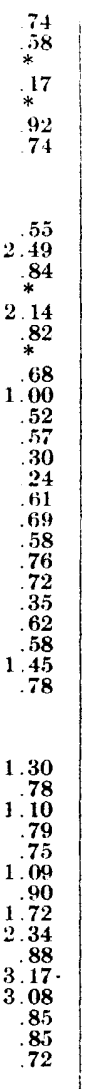

\begin{tabular}{|c|c|}
\hline \multirow{5}{*}{$\begin{array}{r}2.66 \\
.10 \\
.79 \\
60 \\
.59 \\
.18 \\
10\end{array}$} & \\
\hline & 19 \\
\hline & 57 \\
\hline & 48 \\
\hline & 260 \\
\hline & of \\
\hline 1.33 & 28 \\
\hline 1.62 & 56 \\
\hline $\begin{array}{l}.39 \\
16\end{array}$ & $\begin{array}{l}85 \\
.43\end{array}$ \\
\hline${ }^{*}$ & * \\
\hline 50 & 18 \\
\hline $\begin{array}{l}45 \\
.48\end{array}$ & $\begin{array}{r}80 \\
95\end{array}$ \\
\hline 1.07 & 40 \\
\hline $\begin{array}{l}1.16 \\
18\end{array}$ & $\begin{array}{r}.40 \\
1.14\end{array}$ \\
\hline 27 & $\begin{array}{r}14 \\
42\end{array}$ \\
\hline 42 & $\begin{array}{r}98 \\
1.10\end{array}$ \\
\hline 27 & 1.48 \\
\hline $\begin{array}{l}76 \\
79\end{array}$ & $\begin{array}{l}.36 \\
65\end{array}$ \\
\hline 26 & .58 \\
\hline 69 & 1.55 \\
\hline 18 & .31 \\
\hline 44 & .28 \\
\hline 68 & 31 \\
\hline 88 & .54 \\
\hline 70 & $\begin{array}{r}23 \\
69\end{array}$ \\
\hline 36 & .53 \\
\hline 40 & 33 \\
\hline $\begin{array}{l}81 \\
83\end{array}$ & .22 \\
\hline 63 & .28 \\
\hline & \\
\hline
\end{tabular}

\begin{tabular}{|c|c|c|c|c|}
\hline & & (t) & & \\
\hline 1.18 & $\begin{array}{r}1.03 \\
1.03\end{array}$ & 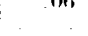 & .02 & 3.60 \\
\hline $\begin{array}{l}3.45 \\
2.45\end{array}$ & $\begin{array}{r}.72 \\
1.72\end{array}$ & & & $\begin{array}{r}5.49 \\
8.27\end{array}$ \\
\hline $\begin{array}{l}3.00 \\
3.65\end{array}$ & $*$ & .06 & & 3.62 \\
\hline $\begin{array}{l}1.14 \\
1.18\end{array}$ & $\begin{array}{l}1.61 \\
2.37\end{array}$ & . 82 & $(3)$ & $\begin{array}{l}4.89 \\
8.53\end{array}$ \\
\hline 1.48 & .43 & $\mathrm{Tr}$ & & 4.21 \\
\hline $\begin{array}{c}* \\
2.19\end{array}$ & 5.02 & on & & 9.12 \\
\hline & 2.12 & & $\ldots$ & 4.30 \\
\hline 68 & $\begin{array}{l}.04 \\
1.42\end{array}$ & 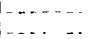 & & $\begin{array}{r}9.26 \mathrm{i} \\
4.73\end{array}$ \\
\hline$\pi$ & $\begin{array}{r}\text { t. } 99 \\
\text { - } 19\end{array}$ & 7 & $\ldots$ & $\begin{array}{r}4.99 \\
\quad-90\end{array}$ \\
\hline 25 & 3.21 & & & 8.12 \\
\hline $\begin{array}{l}4.5 \\
365\end{array}$ & $\begin{array}{l}2.16 \\
2.58\end{array}$ & 15 & - & 5.90 \\
\hline 93 & .05 & 1.10 & $\ldots$ & 8.13 \\
\hline 07 & $\begin{array}{r}.04 \\
1.60\end{array}$ & 01 & & 7.86 \\
\hline 75 & 1.11 & Tr. & Tr. & 4.91 \\
\hline $\begin{array}{l}2.10 \\
1.78\end{array}$ & $\begin{array}{r}.53 \\
1.90\end{array}$ & $\begin{array}{l}1 \mathrm{r} \\
.37\end{array}$ & & $\begin{array}{l}5.25 \\
6.63\end{array}$ \\
\hline $\begin{array}{l}1.85 \\
4.03\end{array}$ & 1.80 & $4 i$ & $\cdots$ & 6.87 \\
\hline & 1.72 & .67 & & 571 \\
\hline & 3.31 & .50 & & 7.01 \\
\hline 32 & 2.56 & .07 & & \\
\hline 39 & 1.49 & 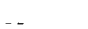 & .04 & \\
\hline $\begin{array}{l}3.58 \\
2.47\end{array}$ & $\begin{array}{r}.32 \\
1.13\end{array}$ & $-\cdots$ (3) & 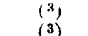 & $\begin{array}{r}5.54 \\
6.18\end{array}$ \\
\hline 1.99 & .53 & & (3) & $\begin{array}{l}4.67 \\
\end{array}$ \\
\hline $\begin{array}{r}08 \\
1.68\end{array}$ & $\begin{array}{r}.00 \\
.98\end{array}$ & & (3) & 5.66 \\
\hline $\begin{array}{l}40 \\
83\end{array}$ & $\begin{array}{r}.33 \\
92\end{array}$ & & & $\begin{array}{l}4.84 \\
5\end{array}$ \\
\hline 67 & .91 & $\ldots$ & $(3)$ & 6.25 \\
\hline $\begin{array}{l}1.69 \\
1\end{array}$ & $\begin{array}{r}.07 \\
.92\end{array}$ & $\cdots$ & $\ldots . . .$. & 7.43 \\
\hline $\begin{array}{l}1.44 \\
4.75\end{array}$ & $\begin{array}{l}1.15 \\
32\end{array}$ & … & $\cdots$ & $\begin{array}{l}8.33 \\
7.43\end{array}$ \\
\hline 2.07 & $\begin{array}{r}49 \\
.92\end{array}$ & & Tr. & 4.53 \\
\hline & & & & \\
\hline
\end{tabular}


TABLE 21.-Daily precipitation, in inches, July 15.26, 1938-Continued

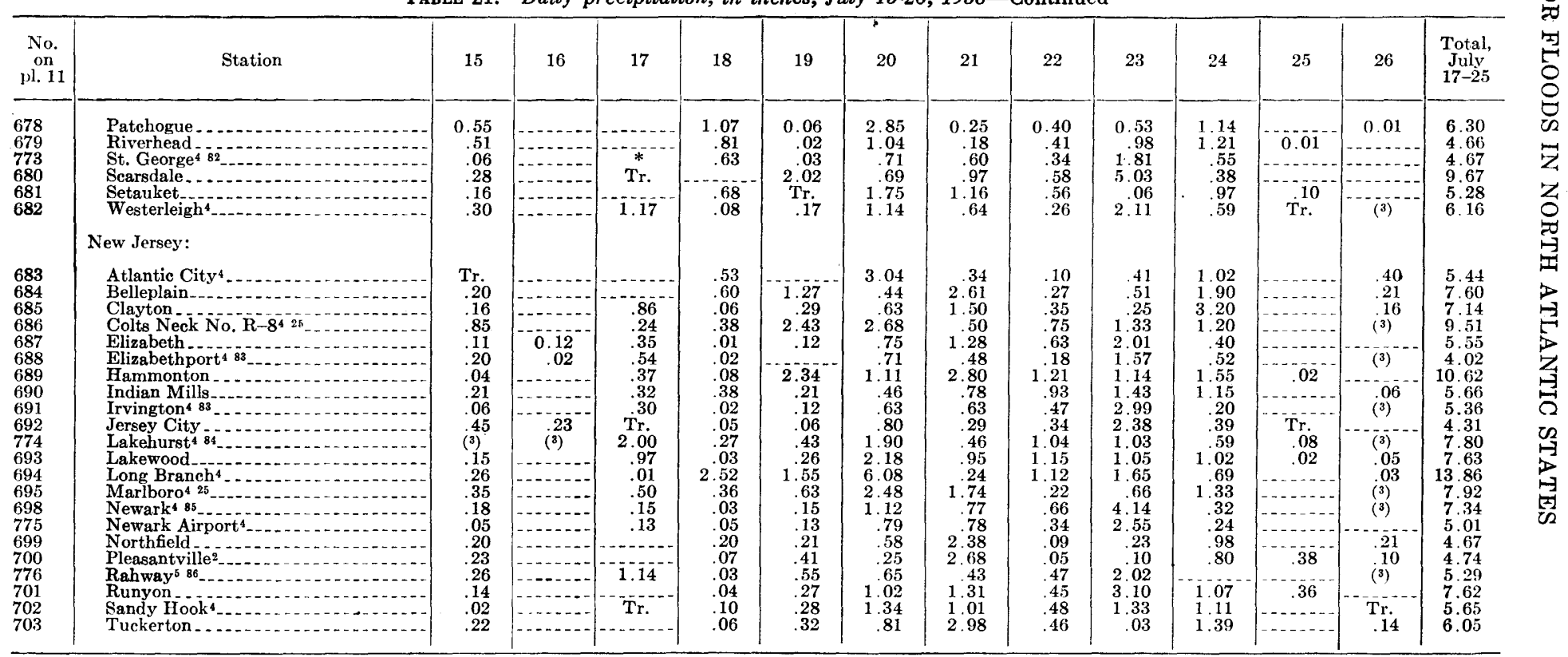


${ }_{1}$ Public Service Co. of New Hampshire.

${ }^{2}$ Measured in morning of day indieated.

Record missing.

Measured in morning after day indicated.

U. S. Geological Survey.

7Town of Milford.
8Massachusetts Department of Public Health

Metropolitan District Commission.

11City

City engineer, Haverhil, Mass.

2Proprietors of the locks and canals on Merrimack River.

${ }^{14}$ Measured at noon.

15 Jewett City Water Co.

${ }^{6}$ Grosvernordale Co.

${ }^{17}$ Norwich Water Department.

${ }^{18}$ Springfield Water Works.

19Collins Co., Collinsville, Conn.

21City of Springfield Department of Streets and Engineering.

${ }^{22}$ Hartford Metropolitan Water Bureau.

${ }^{23}$ City Engineer, Hartford, Conn.

${ }^{25 \mathrm{U}} \mathrm{B}$. S. Department of Agriculture, Soil Conservation Service.

${ }^{26}$ Manchester Water Co., Manchester, Conn.

${ }^{27}$ City of Middletown; measured at noon.

${ }^{28}$ City engineer, New Britain, Conn.

${ }^{29}$ New Britain Water Co., New Britain, Conn.

${ }^{30}$ Connecticut Light \& Power Co.

${ }^{31}$ Connecticut Agricultural Experiment Station.

32Ansonia Water Co., Ansonia, Conn.

33Birmingham Water Co., Shelton, Conn.

34Naugatuck Water Co., Naugatuck, Con

35J. H. Nettleton, New Milford, Conn

36Edward C. Childs, Norfolk, Conn.

${ }^{37}$ New Haven Water

8Torrington Register.

General S. H, Wadhams,

40Torrington Water $\mathrm{C}$

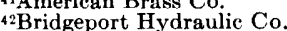

${ }^{43}$ City of Waterbury; measured at noon.
${ }^{44}$ Waterbury Water Co., Waterbury, Conn.; measured at noon.

${ }^{45}$ City of Waterbury, Bureau of Engineering.

${ }^{47 N e w ~ Y o r k ~ C i t y, ~ D e p a r t m e n t ~ o f ~ W a t e r ~ S u p p l y, ~ G a s, ~ a n d ~ E l e c t r i c i t y . ~}$

${ }^{48} \mathrm{New}$ York City Board of Water Supply.

${ }^{49}$ City engineer, Kingston, N. Y.

${ }^{50}$ Measured at 11 p.m.

${ }^{51}$ Hackensack Water Co., Weehawken, N. J.

52Signal Officer, U. S. Military Academy.

${ }^{33}$ Corps of Engineers, U. S. Army.

${ }^{54}$ City of Newark, N. J., Department of Public Affairs.

56:North Jersey District Water Supply Commission.

${ }^{57}$ Department of Public Works, Jersey City, N. J.

58Town engineer, Morristown, N. J

59Society for the Establishment of Useful Manufactures.

60Federal-State Flood Forecasting Service of Pennsylvania, Harrisburg. $\mathrm{Pa}$

${ }^{61}$ Central Airport.

${ }^{2}$ E. I. duPont de Nemours \& Co. Inc., dye works.

${ }^{63} \mathrm{U}$. S. Forest Service.

${ }^{64 W m}$. C. Armstrong, Blairstown, N. J.

${ }^{65}$ Commanding Officer, Fort Dix, N. J.

67Public Works Department, Bureau of Water, Worcester, Mass.

68Department of Public Works, Providence, R. I

70Bristol County Water Co.

"1Board of Water Commissioners, Westerly, R. I.

72Woonsocket, R. I., sewage works.

73D Henry Miller, Cannondale Conn.

${ }^{74}$ Greenwich, Conn., Water Co.

75Water and Electric Department, Groton, Conn.

${ }^{76}$ Stamford, Conn., Water Co.

77Water Department, South Norwalk, Conn.

${ }^{78}$ Gravesend-Ave. V; City of New York, Department of Sewer

${ }^{79} \mathrm{Nassau}$ County, Department of Public Works, Hydrological Bureau.

${ }^{80}$ City of Long Beach, N. Y.

81U. S. Army Air Corps.

82President of The Borough of Richmond.

soint Meeting Maintenance.

85Krese Departmen.

William Wiener, meteorologist.

86Rahway Valley Joint Meeting. 
TABLE 22.-Precipitation, in inches, for

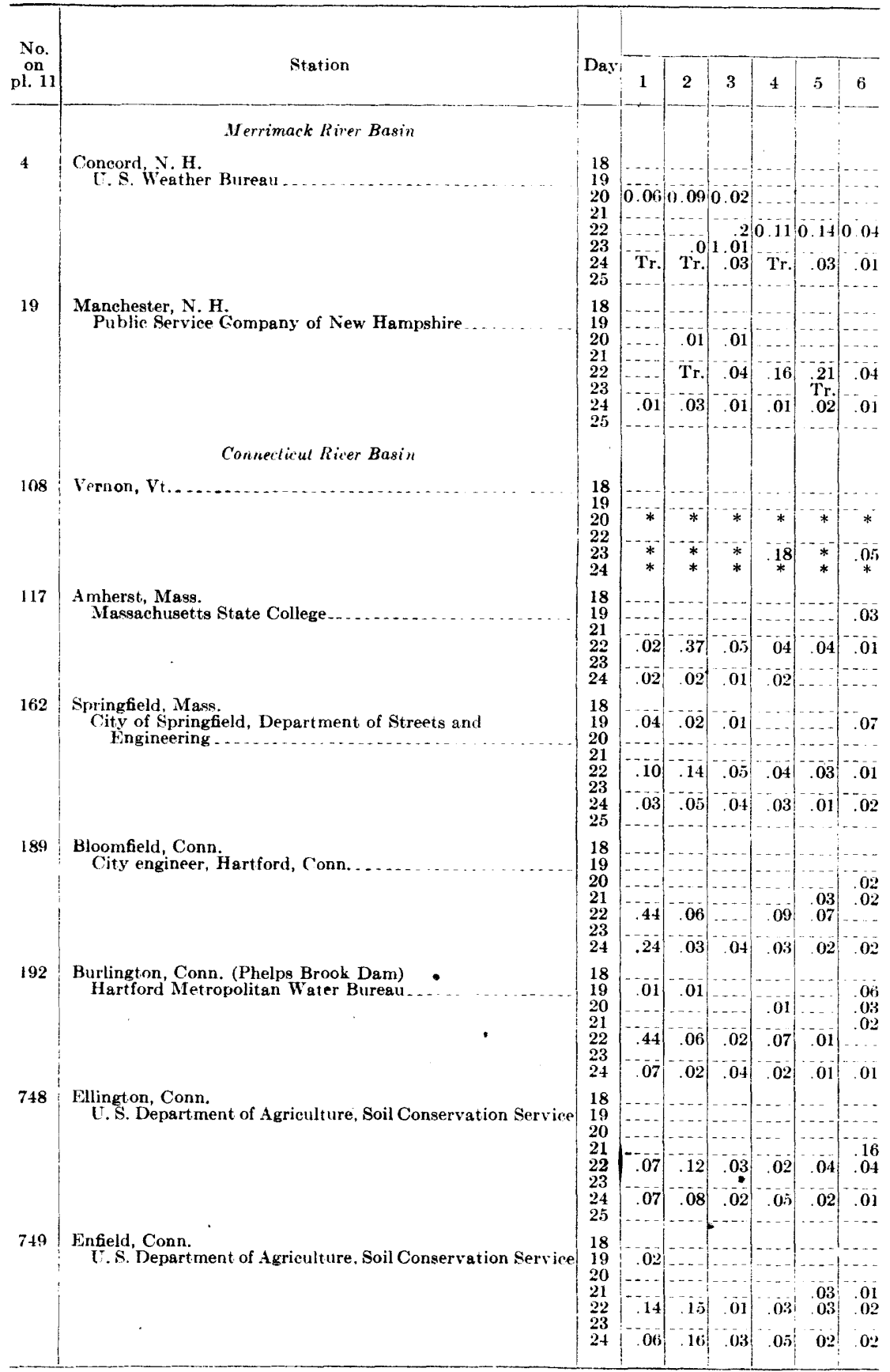


period ending at indicated time, July 1938

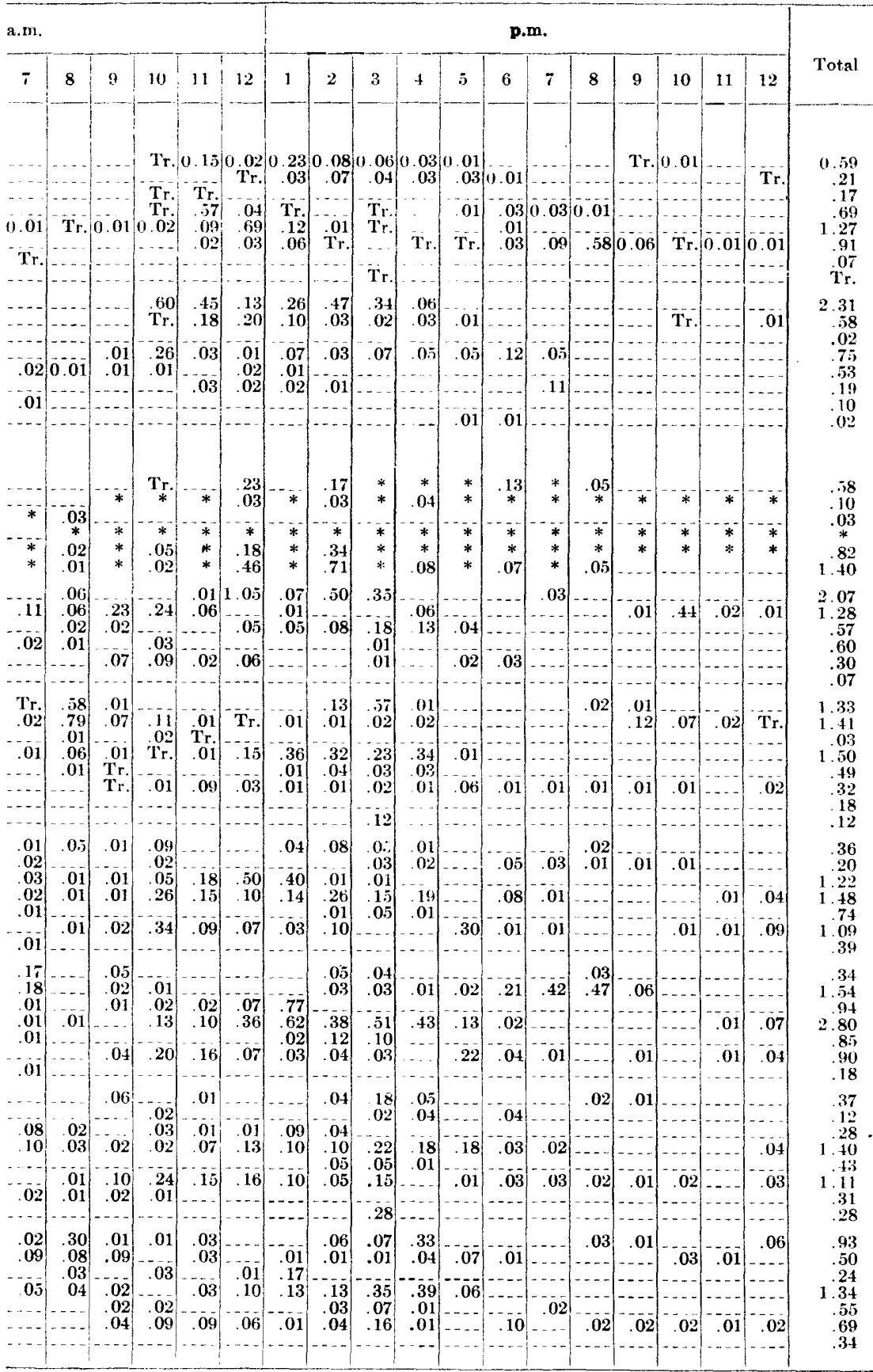


TABLE 22.-Precipitation, in inches, for period

\begin{tabular}{|c|c|c|c|c|c|c|c|c|}
\hline \multirow{2}{*}{$\begin{array}{l}\text { No. } \\
\text { on } \\
\text { pl. } 11\end{array}$} & \multirow[b]{2}{*}{ Station } & \multirow[b]{2}{*}{ Day } & \multirow[b]{2}{*}{1} & \multirow[b]{2}{*}{2} & \multirow[b]{2}{*}{3} & \multirow[b]{2}{*}{4} & \multirow[b]{2}{*}{5} & \multirow[b]{2}{*}{6} \\
\hline & & & & & & & & \\
\hline \multirow[t]{5}{*}{204} & Hartford, Conn. & 18 & 0.02 & Tr. & & & & \\
\hline & U. S. Weather Bureau .... & $\begin{array}{l}19 \\
20 \\
21\end{array}$ & $\begin{array}{l}\text { Tr. } \\
\text { Tr. }\end{array}$ & $\begin{array}{r}0.01 \\
\text { Tr. }\end{array}$ & $\begin{array}{l}\text { Tr. } \\
\mathbf{T r} .\end{array}$ & Tr. & $\begin{array}{l}\text { Tr. } \\
\text { Tr. } \\
\text { Tr }\end{array}$ & $\mid \begin{array}{c}\mathrm{Tr} . \\
0.02 \\
\mathrm{~T}\end{array}$ \\
\hline & & 22 & 49 & .14 & Tr. & 0.14 & 0.20 & .05 \\
\hline & & 24 & .08 & .08 & 0.03 & .02 & 02 & .02 \\
\hline & & & $-\cdots$ & & $-\cdots$ & $-\cdots$ & Tr. & Tr. \\
\hline \multirow[t]{5}{*}{750} & Marek House, Conn. & 18 & & & & & & \\
\hline & Hartford Metropolitan Water Bureau.......................... & 19 & .05 & .01 & $-\cdots$ & $-\cdots$ & $-\cdots$ & .01 \\
\hline & & 21 & & & -1 & $\left|\begin{array}{c}.01 \\
--.-1\end{array}\right|$ & .07 & .07 \\
\hline & & $\begin{array}{l}22 \\
23\end{array}$ & .21 & .15 & .03 & .08 & .01 & .01 \\
\hline & & $\overrightarrow{24}$ & .05 & 01 & .03 & .03 & $-\infty$ & .01 \\
\hline \multirow[t]{5}{*}{208} & New Britain, Conn. & 18 & & & & & & \\
\hline & 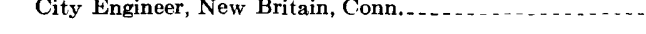 & 19 & $\begin{array}{r}.05 \\
02\end{array}$ & .03 & $\begin{array}{l}.05 \\
02\end{array}$ & .03 & 03 & .04 \\
\hline & & 21 & .02 & .02 & .02 & .02 & .02 & .02 \\
\hline & & 22 & .02 & .02 & .02 & .02 & .07 & .03 \\
\hline & . & $\begin{array}{l}20 \\
24\end{array}$ & .03 & .03 & .03 & .03 & .03 & .01 \\
\hline \multirow[t]{5}{*}{210} & Newington, Conn, & 18 & $-\ldots$ & & $\ldots$ & $-\ldots$ & 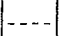 & $\ldots$ \\
\hline & City engineer, Hartford, Conn. . & $\begin{array}{l}19 \\
20\end{array}$ & $\cdots-$ & & $\mid--$ & $|-\cdots|$ & -01 & .08 \\
\hline & & $\begin{array}{l}21 \\
22\end{array}$ & & 10 & .04 & $-\cdots$ & .12 & $\begin{array}{l}.01 \\
.09\end{array}$ \\
\hline & & 23 & & & & & & .01 \\
\hline & & 24 & .05 & .01 & .04 & .04 & .01 & .03 \\
\hline \multirow[t]{5}{*}{213} & South Meadows, Conn. & 18 & --- & & $\ldots$ & $\ldots$ & $-\ldots$ & $-\ldots$ \\
\hline & City engineer, Hartford, Conn..... - & $\begin{array}{l}19 \\
20\end{array}$ & $\cdots$ & $0 \overline{2}$ & -- & 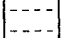 & $-\cdots$ & $-\cdots$ \\
\hline & & $\begin{array}{l}21 \\
22\end{array}$ & $\begin{array}{r}.01 \\
.16\end{array}$ & .01 & $-\cdots$ & $-\cdots-0$ & $--\overline{04}$ & $-\overline{0}$ \\
\hline & & 23 & 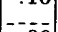 & & $-\cdots$ & $\mid \begin{array}{c}-\infty \\
-\cdots\end{array}$ & $\mid \begin{array}{cc}-07 \\
--.-2\end{array}$ & .01 \\
\hline & & 24 & .06 & .05 & .03 & .04 & .05 & .02 \\
\hline \multirow[t]{6}{*}{216} & West Hartford, Conn. & 17 & & & $\ldots$ & $\ldots$ & $\ldots$ & $-\ldots$ \\
\hline & Hartford Metropolitan Water Bureau_-- & $\begin{array}{l}18 \\
19\end{array}$ & .03 & 01 & $-\cdots$ & & $-\cdots$ & $-1-\overline{1}$ \\
\hline & & 20 & $\cdots$ & & $\ldots$ & $\cdots$ & 更 & $\cdots$ \\
\hline & & 22 & .19 & .05 & $\cdots$ & .08 & .08 & $.0 \overline{1}$ \\
\hline & & $\begin{array}{l}23 \\
24\end{array}$ & 08 & .22 & .03 & .02 & .02 & .01 \\
\hline & Housatonic River Basin & & & & & & & \\
\hline \multirow[t]{5}{*}{751} & Candlewood Isle, Conn. & 18 &.-- & & & & & $\ldots$ \\
\hline & Connecticut Light \& Power Co...-- & 19 & ... & & .01 & $-\ldots$ & .01 & $\cdots$ \\
\hline & & 21 & --- & & $\mid--$ & $\mid--1$ & .01 & 等- \\
\hline & & 22 & .07 &.- & .14 & $-\cdots$ & .02 & -1 \\
\hline & & 24 & 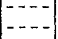 & .02 & .01 & 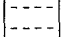 & .02 & .03 \\
\hline \multirow[t]{7}{*}{250} & Woodville, Conn. & 18 & & & & & & \\
\hline & City of Waterbury, Bureau of Engineering. - & 19 & .01 & & .01 & .09 & 07 & .02 \\
\hline & & 20 & $-\cdots$ & & .01 & $-\overline{0} \mid$ & .01 & .02 \\
\hline & & 22 & $--\overline{44}$ & 05 & .01 & $\begin{array}{l}.83 \\
.06\end{array}$ & .01 & .11 \\
\hline & & 23 & & & & & & \\
\hline & & 24 & .02 & -1 & .03 & .01 & .01 & -1 \\
\hline & Hudson River Basin & & & & & & & \\
\hline \multirow[t]{4}{*}{255} & Albany, N. Y. & 18 & $\ldots$ &.- & $\ldots$ & $-\ldots$ & $-\ldots$ & - - - \\
\hline & & 20 & & & $\cdots$ & $\mid \begin{array}{l}-\cdots \\
-\cdots\end{array}$ & $\mathbf{T r}$. & $\mathrm{Tr}$ \\
\hline & & 22 & .07 & .02 & .05 & .01 & .02 & .01 \\
\hline & & $\begin{array}{l}23 \\
24\end{array}$ & .01 & Tr. & .04 & .05 & .16 & .05 \\
\hline
\end{tabular}


ending at indicated time, July 1938-Continued

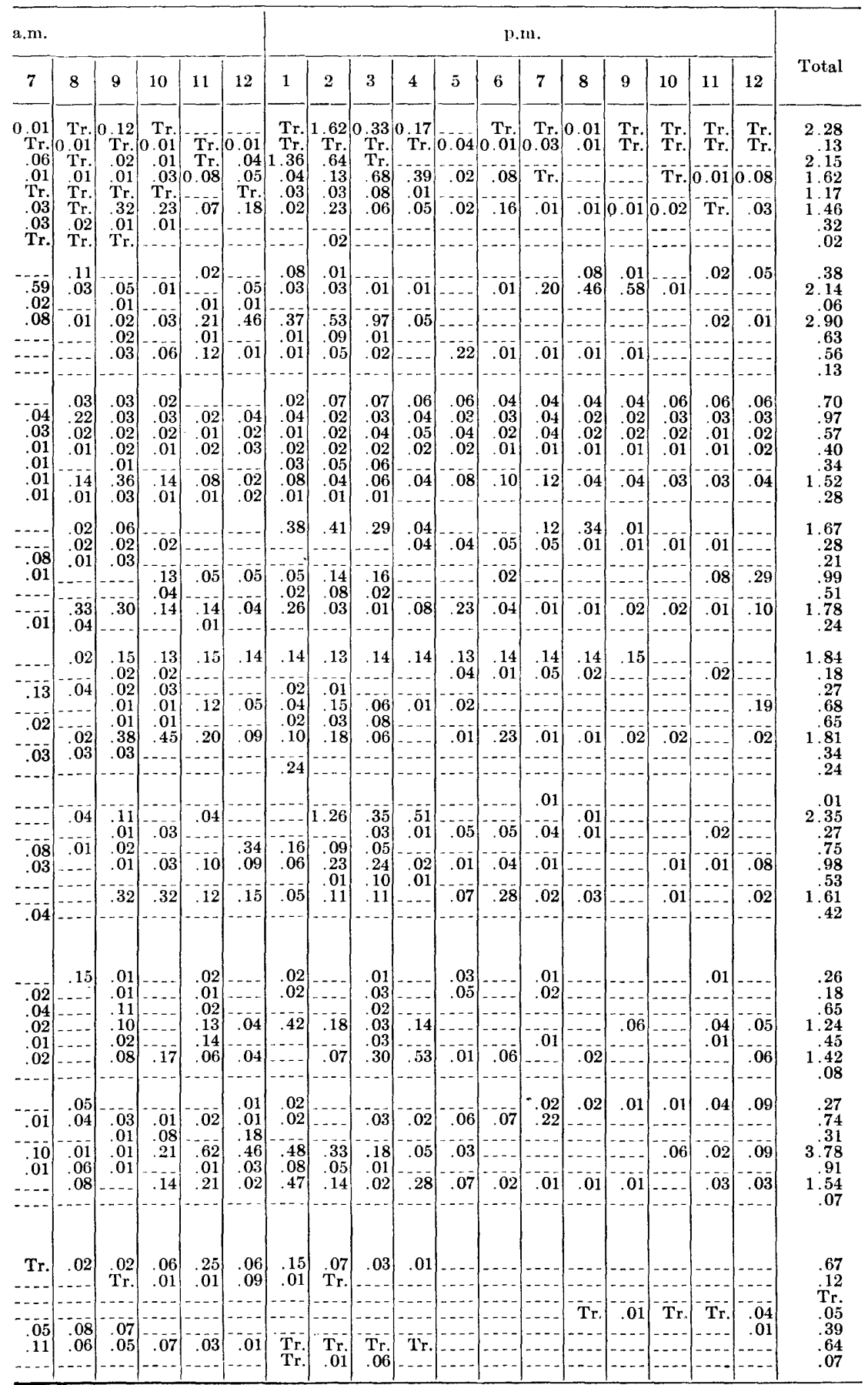


TABLE 22,-Precipitation, in inches, for period

\begin{tabular}{|c|c|c|c|c|c|c|c|c|}
\hline \multirow{2}{*}{$\begin{array}{c}\text { No. } \\
\text { on } \\
\text { pl. } 11\end{array}$} & \multirow[b]{2}{*}{ Station } & \multirow[b]{2}{*}{ Day } & & & & & & \\
\hline & & & 1 & 2 & 3 & 4 & 5 & 6 \\
\hline 256 & $\begin{array}{l}\text { Albany, N. Y. (airport) } \\
\text { Corps of Engineers, U. S. Army }\end{array}$ & $\begin{array}{l}18 \\
19 \\
20 \\
21 \\
22 \\
23 \\
24\end{array}$ & \begin{tabular}{c}
$\cdots$ \\
\hdashline Tr. \\
0.08 \\
0
\end{tabular} & $\left(\begin{array}{cc}0 & 02 \\
\mathrm{Tr}\end{array}\right.$ & \begin{tabular}{c}
0.02 \\
Tr \\
\hdashline
\end{tabular} & $\mid \begin{array}{c}\cdots \\
0.02 \\
08 \\
0\end{array}$ & $\begin{array}{r} \\
\text { Tr. } \\
0.01 \\
08 \\
0\end{array}$ & $\left\{\begin{array}{l}\mathrm{Tr} \\
0.01 \\
.04\end{array}\right.$ \\
\hline 294 & $\begin{array}{l}\text { Kingston, N. Y. } \\
\text { City engineer, Kingston, N. Y....... }\end{array}$ & $\begin{array}{l}18 \\
21 \\
22 \\
23\end{array}$ & $\begin{array}{c}.15 \\
\cdots\end{array}$ & $\begin{array}{l}.20 \\
.03\end{array}$ & $\begin{array}{l}.10 \\
.35 \\
\end{array}$ & $\begin{array}{l}07 \\
02\end{array}$ & $\begin{array}{l}25 \\
09 \\
16 \\
01\end{array}$ & $\begin{array}{l}.12 \\
.01 \\
.11 \\
\end{array}$ \\
\hline 754 & $\begin{array}{l}\text { Sparkill, N. Y. Water Co., Weehawken, N. J... } \\
\text { Hackensack Water }\end{array}$ & $\begin{array}{l}18 \\
19 \\
20 \\
21 \\
22 \\
23 \\
24\end{array}$ & $\begin{array}{r} \\
.13 \\
.10\end{array}$ & \begin{tabular}{c}
$\cdots$ \\
07 \\
0.07 \\
\hdashline
\end{tabular} & \begin{tabular}{c}
$\cdots$ \\
\hdashline- \\
\hdashline-1 \\
\hdashline$\cdots$ \\
$\cdots$
\end{tabular} & \begin{tabular}{r} 
\\
\hdashline .29 \\
.32 \\
.05 \\
0
\end{tabular} & $\begin{array}{r} \\
09 \\
.10 \\
.01\end{array}$ & $\begin{array}{r}. \\
.09 \\
02\end{array}$ \\
\hline 345 & $\begin{array}{l}\text { West Point, N. Y. } \\
\text { Signal Oflicer, U. S. Military Academy........ }\end{array}$ & $\begin{array}{l}18 \\
19 \\
20 \\
21 \\
22 \\
23 \\
24\end{array}$ & \begin{tabular}{c} 
\\
.01 \\
.04 \\
\hdashline \\
\end{tabular} & $\begin{array}{c}.01 \\
.22 \\
.04 \\
.07 \\
-. . \\
.\end{array}$ & $\begin{array}{l}.04 \\
10 \\
.01\end{array}$ & $\begin{array}{c}-\cdots \\
\cdots .04 \\
.02 \\
\cdots \\
-.\end{array}$ & {$\left[\begin{array}{l}.01 \\
.01 \\
.02 \\
.01 \\
-01\end{array}\right.$} & $\begin{array}{c}.01 \\
04 \\
\end{array}$ \\
\hline 755 & $\begin{array}{l}\text { Beemerville, N. J. } \\
\text { U.S. Department of Agriculture, Soil Conservation Service }\end{array}$ & $\begin{array}{l}18 \\
19 \\
20 \\
21 \\
22 \\
23\end{array}$ & $\begin{array}{r}.06 \\
.86 \\
\end{array}$ & \begin{tabular}{|c|}
.- \\
$\cdots$ \\
10 \\
.
\end{tabular} & \begin{tabular}{|c|}
$\cdots$ \\
$\cdots$ \\
$\cdots$
\end{tabular} & $\begin{array}{c}.01 \\
.06 \\
\end{array}$ & $\begin{array}{r}.01 \\
.01 \\
.02 \\
0\end{array}$ & $\begin{array}{r}01 \\
.01\end{array}$ \\
\hline 756 & Hackensack, Passaic and Raritan River Basins & $\begin{array}{l}18 \\
19 \\
20 \\
21 \\
22 \\
23\end{array}$ & $\begin{array}{c}.08 \\
1.08 \\
.08\end{array}$ & \begin{tabular}{|r} 
\\
.20 \\
.
\end{tabular} & 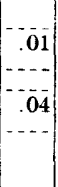 & \begin{tabular}{|c|}
- \\
-13 \\
-13 \\
.- \\
\end{tabular} & \begin{tabular}{|}
.01 \\
.03 \\
\end{tabular} & $\begin{array}{c}01 \\
0.01 \\
, 17\end{array}$ \\
\hline 348 & 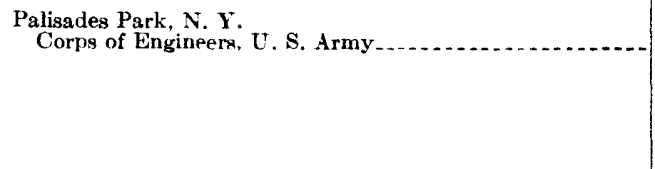 & $\begin{array}{l}17 \\
19 \\
20 \\
21 \\
22 \\
23 \\
24\end{array}$ & 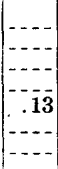 & \begin{tabular}{r}
-10 \\
\hdashline .01 \\
.01 \\
10
\end{tabular} & \begin{tabular}{|c|}
$-\ldots$ \\
\hdashline .12 \\
\hdashline .12 \\
\hdashline \\
-1
\end{tabular} & $\begin{array}{c}-1 . \\
.03 \\
.03 \\
\\
\end{array}$ & $\begin{array}{r}.08 \\
.05 \\
.03 \\
.01 \\
.01\end{array}$ & $\begin{array}{c}08 \\
0.01 \\
\\
\end{array}$ \\
\hline 349 & $\begin{array}{l}\text { Southfields, N. Y. } \\
\text { Corps of Engineers, U. S. Army } \ldots . . .\end{array}$ & $\begin{array}{l}17 \\
19 \\
20 \\
21 \\
22 \\
23\end{array}$ & $\begin{array}{r}.30 \\
.02 \\
.02 \\
\end{array}$ & $\begin{array}{r}.05 \\
10 \\
\end{array}$ & \begin{tabular}{|c|}
$\ldots$ \\
10 \\
\end{tabular} & $\begin{array}{c}0 . \\
.04 \\
\end{array}$ & \begin{tabular}{|c|} 
\\
.02 \\
.05 \\
04 \\
\end{tabular} & $\begin{array}{r}.03 \\
.03 \\
\hdashline \\
\hdashline\end{array}$ \\
\hline 758 & $\begin{array}{l}\text { Spring Valley, i. Y. } \\
\text { Hackensack Water Co., Wehawken, N. J..... }\end{array}$ & $\begin{array}{l}17 \\
19 \\
20 \\
21 \\
22 \\
23 \\
24\end{array}$ & \begin{tabular}{c}
$\ldots$ \\
\hdashline .23 \\
\hdashline \\
\hdashline
\end{tabular} & \begin{tabular}{c}
.- \\
\hdashline .05 \\
01 \\
.0 \\
\end{tabular} & \begin{tabular}{|}
- \\
\hdashline 12 \\
\hdashline 01
\end{tabular} & $\begin{array}{r}.01 \\
.18 \\
.01\end{array}$ & $\begin{array}{c} \\
.06 \\
.01 \\
.05 \\
.02 \\
* \\
*\end{array}$ & $\begin{array}{c}.04 \\
.03 \\
.05 \\
.03 \\
*\end{array}$ \\
\hline 351 & $\begin{array}{l}\text { Bowling Green, N.J. } \\
\text { Corps of Engineers, U. S. Army ... }\end{array}$ & $\begin{array}{l}17 \\
18 \\
19 \\
20 \\
21 \\
22 \\
23 \\
24 \\
25\end{array}$ & $\begin{array}{r}01 \\
0.01 \\
008 \\
.01\end{array}$ & \begin{tabular}{r}
.02 \\
14 \\
\hdashline \\
\hdashline \\
\end{tabular} & $\begin{array}{r}02 \\
02 \\
0\end{array}$ & $\begin{array}{l} \\
.01 \\
.05 \\
.02 \\
.02\end{array}$ & \begin{tabular}{|c|} 
\\
.09 \\
.03 \\
.01 \\
- \\
\end{tabular} & \begin{tabular}{c}
$\ldots$ \\
$\cdots 04$ \\
\hdashline \\
\\
\hdashline
\end{tabular} \\
\hline
\end{tabular}


ending at indicated time, July 1938-Continued

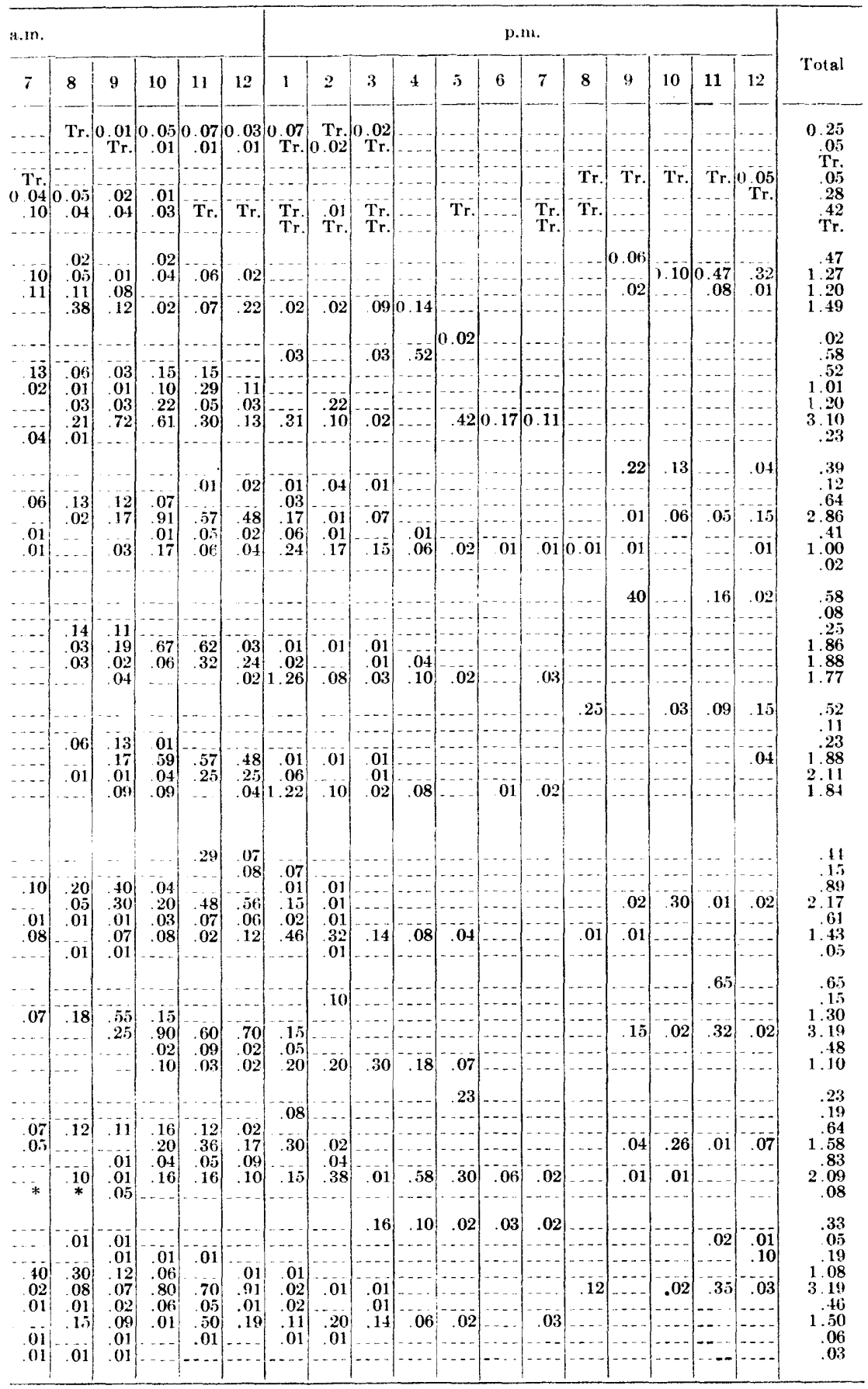


TABLE 22.--Precipitation, in inches, for period

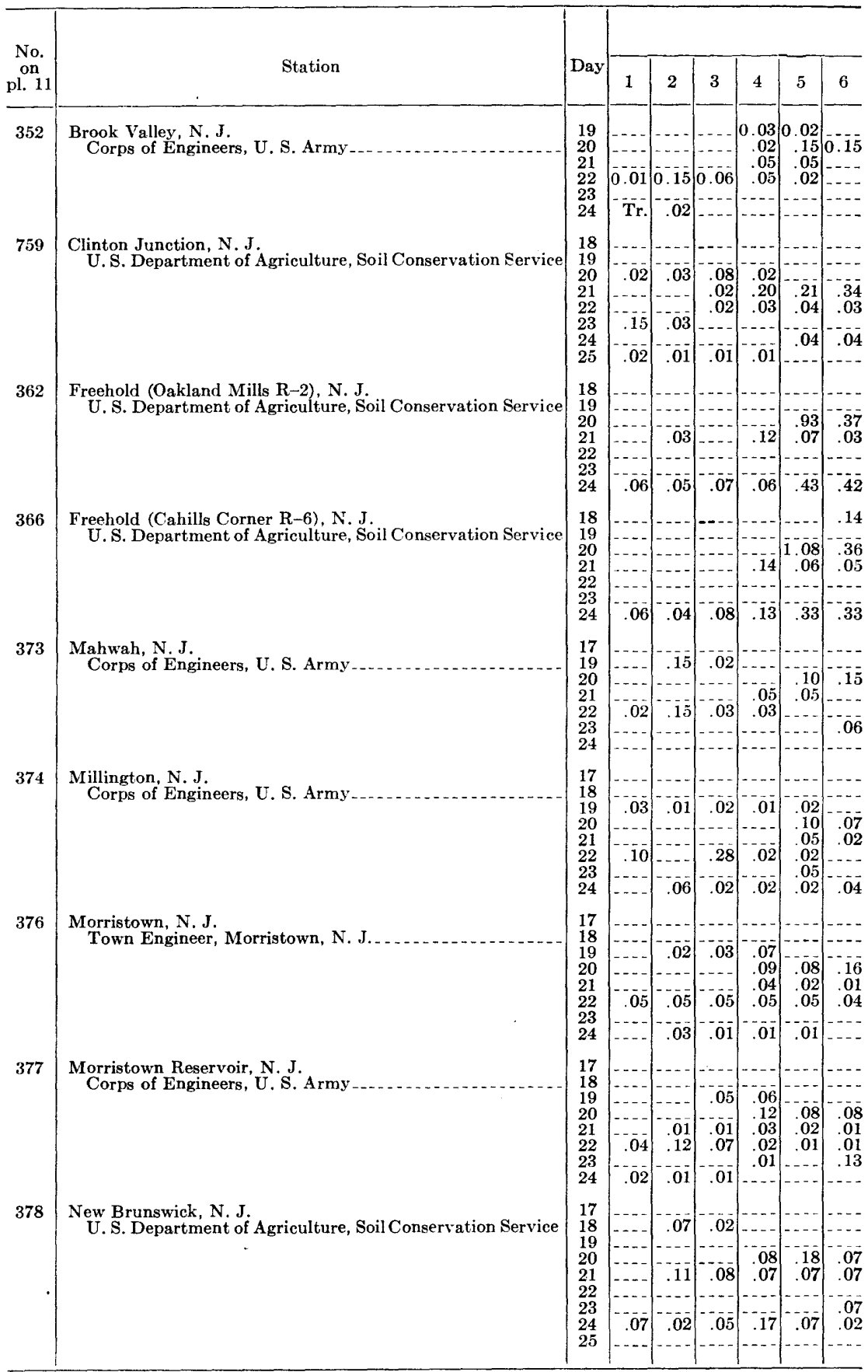


ending at indicated time, July 1938-_Continued

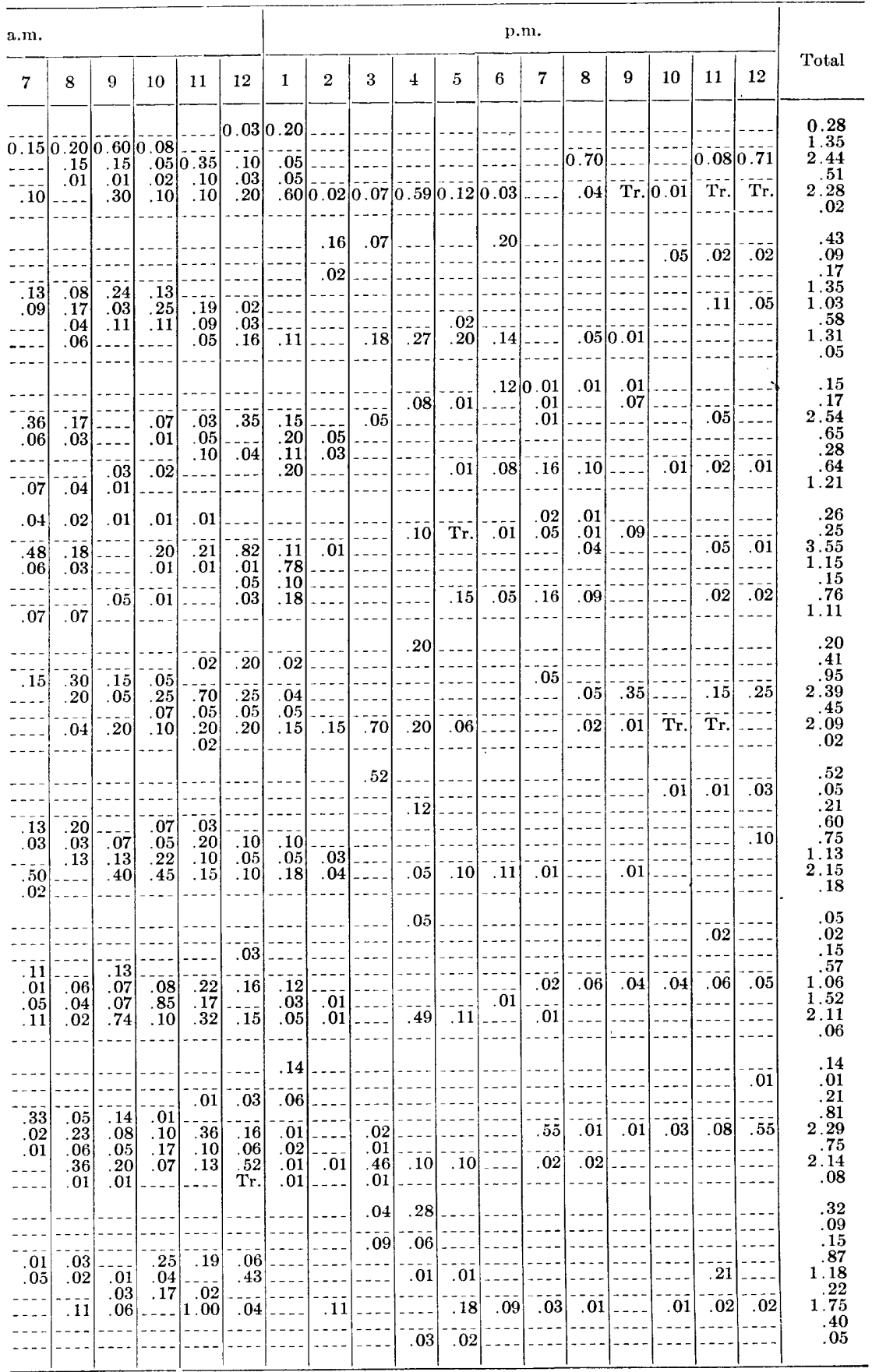


TABLE 22,--Precipitation, in inches, for period

\begin{tabular}{|c|c|c|c|c|c|c|c|c|}
\hline \multirow{2}{*}{$\begin{array}{l}\text { No. } \\
\text { on } \\
\text { pl. } 11\end{array}$} & \multirow[b]{2}{*}{ Station } & \multirow[b]{2}{*}{ Day } & & & & & & \\
\hline & & & 1 & 2 & 3 & 4 & $\therefore$ & 6 \\
\hline 379 & $\begin{array}{l}\text { New Milford, N.J. } \\
\text { Hackensack Water Co., Weehawken, N. J.......... }\end{array}$ & $\begin{array}{l}17 \\
18 \\
19 \\
20 \\
21 \\
22 \\
23 \\
24\end{array}$ & $\left|\begin{array}{c|} \\
\\
0.29 \\
04\end{array}\right|$ & $\left(\begin{array}{c} \\
0.04 \\
0.01\end{array}\right.$ & $\mid \begin{array}{r} \\
0.20 \\
04 \\
.03\end{array}$ & $\begin{array}{r}- \\
0.13 \\
19 \\
03\end{array}$ & $\begin{array}{r} \\
0.06 \\
.07 \\
\cdots\end{array}$ & 0.11 \\
\hline 761 & $\begin{array}{l}\text { Quakertown, N. J. } \\
\text { U.S. Department of Agriculture, Soil Conservation Service }\end{array}$ & $\begin{array}{l}17 \\
18 \\
19 \\
20 \\
21 \\
22 \\
23 \\
24\end{array}$ & $\begin{array}{l}01 \\
01 \\
02\end{array}$ & \begin{tabular}{r}
.01 \\
\hdashline .02 \\
02
\end{tabular} & $\mid$\begin{tabular}{c|} 
\\
$.0 t$ \\
.06 \\
.04 \\
\hdashline \\
\hdashline \\
\end{tabular} & $\begin{array}{r} \\
.03 \\
.81 \\
.03 \\
(*) \\
.02\end{array}$ & $\begin{array}{c} \\
.06 \\
.05 \\
(*) \\
.04 \\
-.\end{array}$ & \begin{tabular}{|c}
$\ldots$ \\
$\ldots$ \\
11 \\
0 \\
$(*)$ \\
04 \\
$\ldots$
\end{tabular} \\
\hline 387 & $\begin{array}{l}\text { Rockaway, N. J. } \\
\text { Corps of Engineers, U. S. Army }\end{array}$ & $\begin{array}{l}17 \\
18 \\
19 \\
20 \\
21 \\
22 \\
23\end{array}$ & $\begin{array}{c}\cdots \\
\cdots \cdots \\
\cdots \\
02\end{array}$ & $\begin{array}{c}0 \\
.18 \\
\end{array}$ & \begin{tabular}{|r|} 
\\
.01 \\
\end{tabular} & $\begin{array}{r}-10 \\
.02 \\
.0 \\
\end{array}$ & $\begin{array}{l}. \\
.10 \\
.10 \\
03\end{array}$ & $\begin{array}{r}-[ \\
08 \\
0\end{array}$ \\
\hline 361 & $\begin{array}{l}\text { West Freehold No. R-1, N. J. } \\
\text { U.S. Department of Agriculture, Soil Conservation Service }\end{array}$ & $\begin{array}{l}17 \\
18 \\
19 \\
20 \\
21 \\
22 \\
23 \\
24\end{array}$ & \begin{tabular}{|r|} 
\\
09 \\
05 \\
0 \\
\end{tabular} & $\begin{array}{r}.02 \\
.01 \\
.03\end{array}$ & \begin{tabular}{|c|} 
\\
\hdashline \\
\hdashline 10 \\
\\
\hdashline \\
\end{tabular} & $\begin{array}{r}\ldots \\
\cdots .11 \\
07\end{array}$ & $\begin{array}{r}.62 \\
.07 \\
.35\end{array}$ & $\begin{array}{r}\ldots \\
.17 \\
05 \\
0.70\end{array}$ \\
\hline 390 & $\begin{array}{l}\text { Woodcliff Lake, N. J. } \\
\text { Hackensack Water Co., Weehawken, N. J......... } \\
\text { Delaware River Basin }\end{array}$ & $\begin{array}{l}18 \\
19 \\
20 \\
21 \\
22 \\
23 \\
24\end{array}$ & $\begin{array}{c}0 \\
.06 \\
04\end{array}$ & \begin{tabular}{c}
$-\cdots$ \\
-06 \\
\hdashline-1 \\
\end{tabular} & $\begin{array}{r} \\
-0.5 \\
.20 \\
.05\end{array}$ & $\begin{array}{r} \\
-38 \\
.14 \\
-02\end{array}$ & $\begin{array}{r}. \\
.02 \\
.07 \\
.03 \\
\cdots\end{array}$ & $\begin{array}{l}.01 \\
.11 \\
.0 .5 \\
.01 \\
.02\end{array}$ \\
\hline 398 & $\begin{array}{l}\text { China (Cold Spring Brook), N. Y. } \\
\text { U. S. Geological Survey ......... }\end{array}$ & $\begin{array}{l}18 \\
21 \\
22 \\
23\end{array}$ & .01 & {$\left[\begin{array}{cc}-0 \\
-04\end{array}\right.$} & $\left|\begin{array}{c} \\
\hdashline .04 \\
\cdots\end{array}\right|$ & $\begin{array}{r}.08 \\
.04\end{array}$ & $\begin{array}{l} \\
.01 \\
.08 \\
.14\end{array}$ & $\begin{array}{l}.01 \\
.02 \\
.06\end{array}$ \\
\hline 407 & $\begin{array}{l}\text { Harvard, N. Y. } \\
\text { New York City Board of Water Supply } \ldots . .\end{array}$ & $\begin{array}{l}18 \\
21 \\
22 \\
23\end{array}$ & \begin{tabular}{|r|} 
\\
\hdashline 10 \\
\hdashline .10 \\
\end{tabular} & \begin{tabular}{c} 
\\
\hdashline. .04 \\
\hdashline .04 \\
\end{tabular} & \begin{tabular}{|c|} 
\\
\hdashline .04 \\
\hdashline .04 \\
\end{tabular} & \begin{tabular}{|c|} 
\\
$\cdots$ \\
.02 \\
.12
\end{tabular} & $\begin{array}{l} \\
.03 \\
.16\end{array}$ & $\begin{array}{l}.04 \\
.27\end{array}$ \\
\hline 415 & $\begin{array}{l}\text { Oakland Valley, N. Y. } \\
\text { Federal-State Flood Forecasting Service of Pennsylvania, } \\
\text { Harrisburg, Pa. }\end{array}$ & $\begin{array}{l}18 \\
19 \\
20 \\
21 \\
22 \\
23\end{array}$ & $\begin{array}{r}.01 \\
.15 \\
.29\end{array}$ & $\begin{array}{l}.09 \\
.96 \\
.05 \\
.33\end{array}$ & {$\left[\begin{array}{r}.04 \\
.15 \\
-04\end{array} \mid\right.$} & $\begin{array}{c}-01 \\
0.05 \\
.05 \\
\cdots\end{array}$ & $\begin{array}{c}05 \\
.02\end{array}$ & \begin{tabular}{|c}
0. \\
\hdashline \\
.04 \\
.34
\end{tabular} \\
\hline 429 & $\begin{array}{l}\text { Camden (airport), N. J. } \\
\text { U. S. Weather Bureau (Measured at } 1: 30 \text { a.m., } 7: 30 \text { a.m., } \\
1: 30 \text { p.m., } 7: 30 \text { p.m.) }\end{array}$ & $\begin{array}{l}17 \\
18 \\
19 \\
20 \\
21 \\
22 \\
23 \\
24 \\
25\end{array}$ & $\begin{array}{c}* \\
* \\
* \\
* \\
* \\
* \\
*\end{array}$ & $\begin{array}{c}\mathrm{Tr} \\
.01 \\
\mathrm{Tr} \\
.90 \\
.05 \\
-13\end{array}$ & $\begin{array}{l}* \\
* \\
* \\
* \\
* \\
* \\
* \\
*\end{array}$ & $\begin{array}{l}* \\
* \\
* \\
* \\
* \\
* \\
* \\
*\end{array}$ & $\begin{array}{l}- \\
* \\
* \\
* \\
* \\
* \\
* \\
* \\
*\end{array}$ & $\begin{array}{l}* \\
* \\
* \\
* \\
* \\
* \\
* \\
*\end{array}$ \\
\hline 433 & $\begin{array}{l}\text { Moorestown, N. J. } \\
\text { U.S. Depart ment of Agriculture, Soil Conservation Service }\end{array}$ & $\begin{array}{l}18 \\
19 \\
20 \\
21 \\
22 \\
23 \\
24\end{array}$ & \begin{tabular}{|r|}
.04 \\
\hdashline .24 \\
\hdashline .14 \\
\end{tabular} & $\begin{array}{r}0 . \\
.16 \\
.06 \\
.50\end{array}$ & \begin{tabular}{|r|}
.- \\
.04 \\
.10 \\
.28 \\
\end{tabular} & $\begin{array}{r}\ldots . \\
.36 \\
.10 \\
.10 \\
.08\end{array}$ & $\begin{array}{c}.07 \\
.08 \\
.04\end{array}$ & \begin{tabular}{c}
$\cdots$ \\
$\cdots$ \\
$\cdots$ \\
$\cdots$ \\
\hdashline \\
\end{tabular} \\
\hline
\end{tabular}




\section{ending at indicated time, July 1938 -Continued}

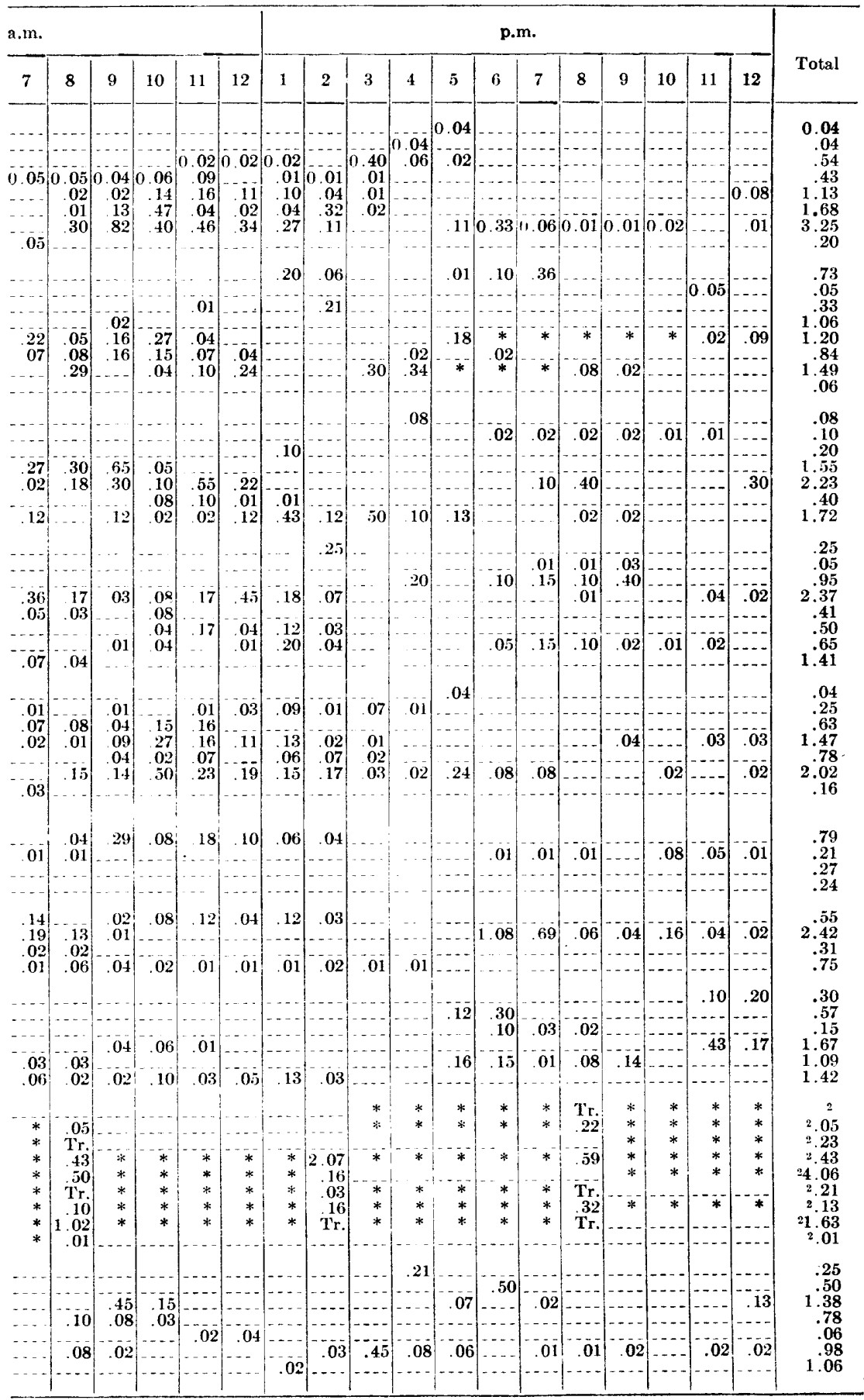


TABLE 22.-Precipitation, in inches, for period

\begin{tabular}{|c|c|c|c|c|c|c|c|c|}
\hline \multirow{2}{*}{$\begin{array}{l}\text { No. } \\
\text { on } \\
\text { pl. } 11\end{array}$} & \multirow[b]{2}{*}{ Station } & \multirow[b]{2}{*}{ Day } & \multirow[b]{2}{*}{1} & \multirow[b]{2}{*}{2} & \multirow[b]{2}{*}{3} & \multirow[b]{2}{*}{4} & \multirow[b]{2}{*}{ 5 } & \multirow[b]{2}{*}{6} \\
\hline & & & & & & & & \\
\hline \multirow[t]{3}{*}{438} & $\begin{array}{l}\text { Trenton No. 1, N. J. } \\
\text { U. S. Weather Bureau }\end{array}$ & $\begin{array}{l}17 \\
18 \\
19 \\
20 \\
21\end{array}$ & Tr. & $\begin{array}{r}\mathbf{T r} \\
0.01 \\
.04\end{array}$ & $\begin{array}{r}1.04 \\
.38\end{array}$ & $\begin{array}{r}\mathrm{Tr} \\
0.04 \\
.19\end{array}$ & $\begin{array}{r}- \\
\text { Tr. } \\
0.09 \\
.10\end{array}$ & $\begin{array}{l}0 \\
0.01 \\
.11\end{array}$ \\
\hline & & $\begin{array}{l}22 \\
23 \\
24 \\
25\end{array}$ & $\begin{array}{c}\mathrm{Tr} \\
0.05 \\
*\end{array}$ & $\begin{array}{c}\mathrm{Tr} \\
.01 \\
*\end{array}$ & $\begin{array}{r}.01 \\
.27 \\
*\end{array}$ & $\begin{array}{c}\mathrm{Tr} \\
.17 \\
*\end{array}$ & $\begin{array}{c}.04 \\
.04 \\
*\end{array}$ & $\begin{array}{l}.08 \\
.02 \\
*\end{array}$ \\
\hline & Coastal and Minor basins & & & & & & & \\
\hline \multirow[t]{5}{*}{568} & $\begin{array}{l}\text { Boston, Mass. } \\
\text { U. S. Weather Bureat } \ldots\end{array}$ & $\begin{array}{l}18 \\
19\end{array}$ & Tr. & & & & & .02 \\
\hline & & 20 & Tr. & $\mathrm{Tr}$ & $\mathrm{Tr}$ & $\mathrm{Tr}$. & $\mathbf{T r}$ & $\operatorname{Tr}_{\mathrm{r}}$ \\
\hline & & 22 & $\mathrm{Tr}$. & $\mathrm{Tr}$ & $.7 \overline{5}$ & .01 & & .05 \\
\hline & & 23 & $\operatorname{Tr}$. & Tre & Tr. & .02 & .05 & .30 \\
\hline & & 25 & 11 & & & 1.01 & $\begin{array}{r}.02 \\
-. .-\end{array}$ & $\begin{array}{ll}.02 \\
---.\end{array}$ \\
\hline \multirow[t]{5}{*}{625} & Worcester, Mass. & 18 & 03 & 01 & & & $-\cdots$ & $-\cdots$ \\
\hline & & 20 & $\begin{array}{l}.03 \\
.02\end{array}$ & .01 & 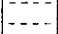 & $-\cdots$ & 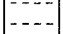 & $\cdots$ \\
\hline & & $\begin{array}{l}21 \\
22\end{array}$ & .01 & .04 & .19 & $.0 \overline{1}$ & $-\cdots$ & .01 \\
\hline & & $\begin{array}{l}23 \\
24\end{array}$ & .02 & $\begin{array}{l}.05 \\
.02\end{array}$ & .03 & .04 & .02 & $\begin{array}{l}.17 \\
.02\end{array}$ \\
\hline & & 25 & $\cdots$ & $-\cdots$ & $\cdots$ & $-\ldots$ & $-\cdots$ & $-\cdots$ \\
\hline \multirow[t]{5}{*}{736} & Worcester, Mass. sewage-treatment plant & 18 & 01 & & & $-\cdots$ & $\ldots$ & $-\cdots$ \\
\hline & & 20 & 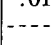 & $-\cdots$ & $-\cdots$ & $-\cdots$ & $-\cdots$ & --- \\
\hline & & 22 & (n- & .18 & .18 & .02 & .01 & .03 \\
\hline & & $2 \overline{3}$ & $\cdots 0$ & .01 & .01 & .03 & .03 & .14 \\
\hline & & $\begin{array}{l}24 \\
25\end{array}$ & .03 & $-\cdots$ & $\begin{array}{r}.02 \\
-\ldots-\end{array} \mid$ & $\begin{array}{c}.03 \\
---\end{array}$ & $\begin{array}{r}.07 \\
--.\end{array}$ & $\begin{array}{r}.02 \\
---\end{array}$ \\
\hline \multirow[t]{5}{*}{627} & Block Island, R. I. & 18 & -..- & & & & $-\ldots$ & $\ldots$ \\
\hline & U. S. Weather Bureau.... & 20 & $-\cdots$ & & & & .01 &.$\overline{05}$ \\
\hline & & 21 & -1 & .07 & .01 & .04 & .02 & .02 \\
\hline & & $\begin{array}{l}22 \\
23\end{array}$ & $-\cdots$ & & .... & .02 & .07 & Tr. \\
\hline & & 24 & $\mathbf{T r}$ & .08 & .02 & $.1 \overline{5}$ & .01 & $\operatorname{Tr}$. \\
\hline \multirow[t]{5}{*}{635} & Providence, R. I. & 18 & & $\mathrm{Tr}$. & & & & .01 \\
\hline & U. S. Weather Bureau & $\begin{array}{l}19 \\
20\end{array}$ & .01 & $\mathrm{Tr}$ & Tr. & .01 & Tr. & $\operatorname{Tr}$ Tr. \\
\hline & & $\begin{array}{l}21 \\
22\end{array}$ & $\begin{array}{ll}0 \\
-1\end{array}$ & --- & -1 & Tr. & .01 & .02 \\
\hline & & 23 & & & Tr. & .04 & .48 & .24 \\
\hline & & 24 & .01 & Tr. & .07 & .17 & .02 & .01 \\
\hline \multirow[t]{6}{*}{654} & New Haven, Conn. & 18 & .12 & & & & & .05 \\
\hline & U. S. Weather Bureau & $\begin{array}{l}19 \\
20\end{array}$ & $\mathrm{Tr}$. & Tr. & $\mathrm{Tr}$ & Tr. & $\begin{array}{c}T_{0} \\
01\end{array}$ & $\begin{array}{l}.02 \\
.22\end{array}$ \\
\hline & & 21 & -1 & -1 & $\mathrm{Tr}$ & .01 & Tr. & 02 \\
\hline & & 22 & .71 & Tr. & Tr. & 02 & .02 & Tr. \\
\hline & & $\begin{array}{l}23 \\
24\end{array}$ & $\begin{array}{l}.01 \\
.05\end{array}$ & $\mathrm{Tr}_{\mathbf{0}}$ & $\begin{array}{l}T r \\
.02\end{array}$ & 03 & $\begin{array}{l}\mathrm{Tr} \\
.04\end{array}$ & $\begin{array}{l}.04 \\
.10\end{array}$ \\
\hline & & 25 & $-\ldots$ & Tr. & Tr. & Tr. & Tr. & Tr. \\
\hline \multirow[t]{6}{*}{665} & Brooklyn, N. Y. (Gravesend, Avenue V) & 17 &.-- & & & & & $-\ldots$ \\
\hline & & 18 & $.0 \overline{1}$ & Tr. & 01 & Tr. & $\mathrm{Tr}$ & $-\ldots$ \\
\hline & & 20 & & & Tr. & .02 & 41 & .11 \\
\hline & & $\begin{array}{l}21 \\
22\end{array}$ & $\begin{array}{l}\text { Tr. } \\
\text { Tr. }\end{array}$ & $\stackrel{02}{\text { Tr. }}$ & Tr. & $\operatorname{Tr}$. & Tr. & .02 \\
\hline & & 23 & $\operatorname{Tr} \dot{0}$ & Tr. & Tr. & & .02 & Tr. \\
\hline & & & & & & & & \\
\hline \multirow[t]{2}{*}{666} & Brooklyn, N. Y. Brooklyn Eagle ${ }^{3}$ & 22 & .01 & Tr. & $\operatorname{Tr}$ & $-\ldots$ & $-\ldots$ & \\
\hline & & $\begin{array}{l}23 \\
24\end{array}$ & .03 & .05 & .08 & .10 & .12 & .02 \\
\hline
\end{tabular}


ending at indicated time, July 1938 -Continued

a.111.

p.n.

\begin{tabular}{l|l|l|l|l|l|l|l|l|l|l|l|l|l|l|l|l|l|l|l}
\hline 7 & 8 & 9 & 10 & 11 & 12 & 1 & 2 & 3 & 4 & 5 & 6 & 7 & 8 & 9 & 10 & 11 & 12 & Total \\
\hline
\end{tabular}

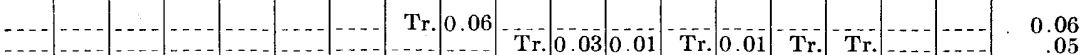

Tr.

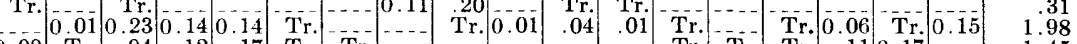

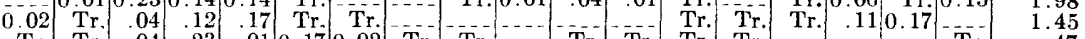

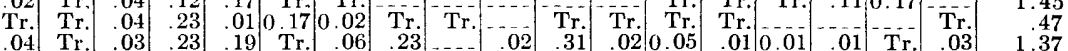

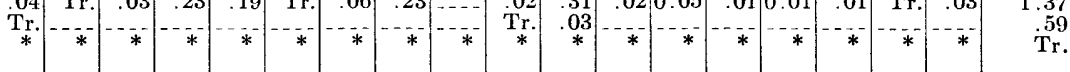

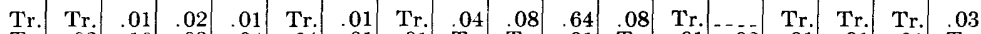

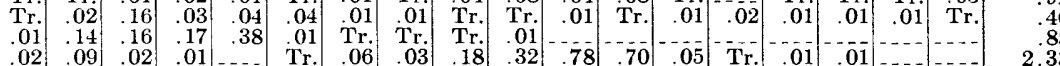

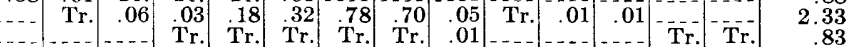

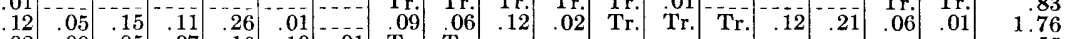

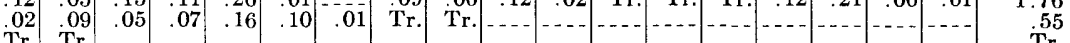

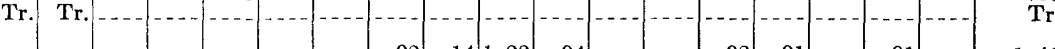

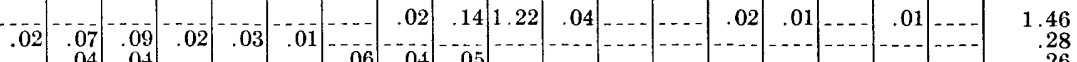

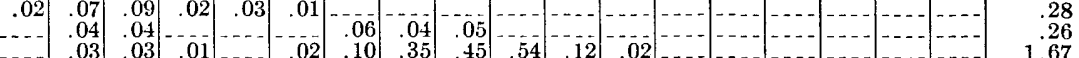

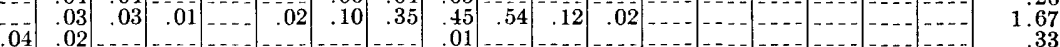

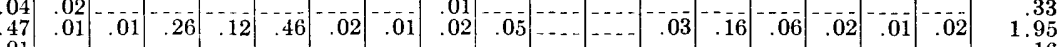

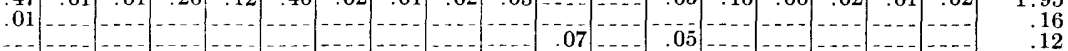

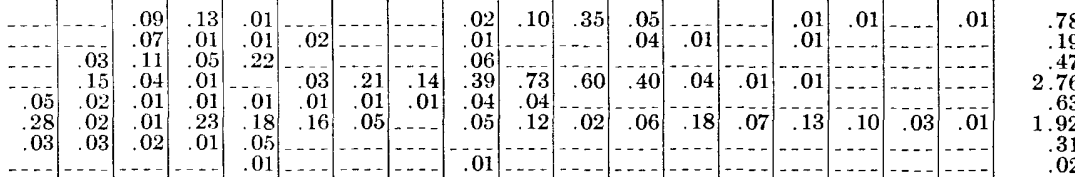

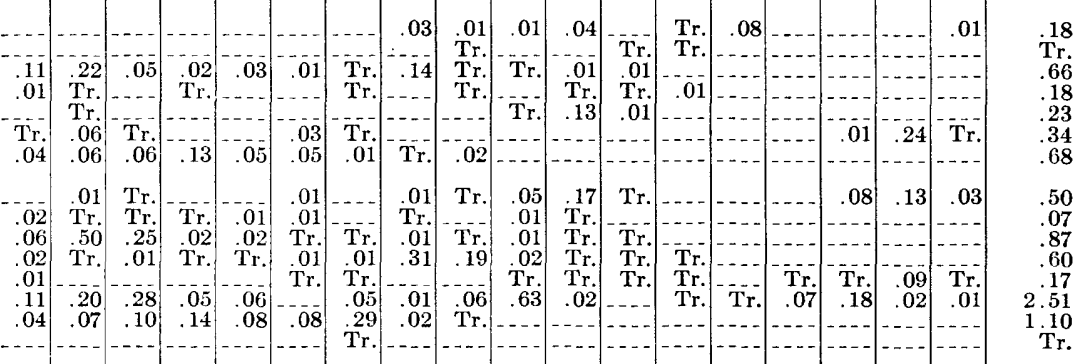

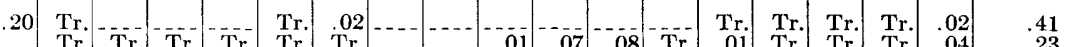

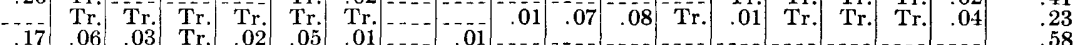

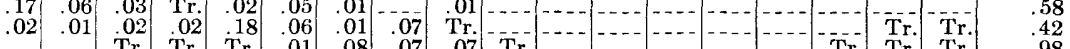

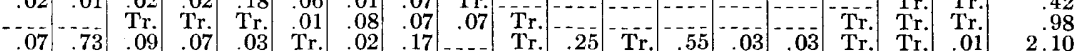

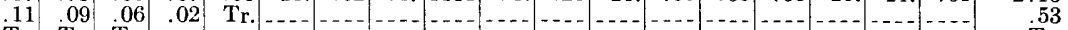

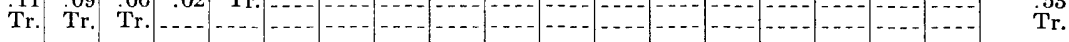

$\begin{array}{llllll}03 & 01 & 0 & 0 & 0 & 0\end{array}$

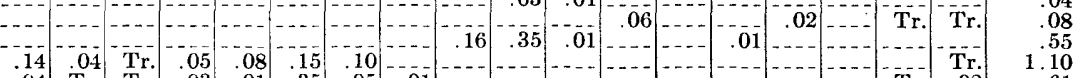

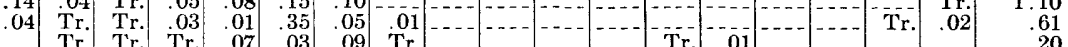

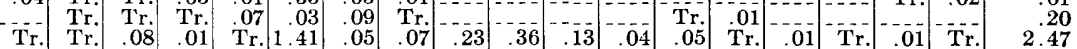

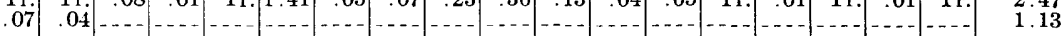

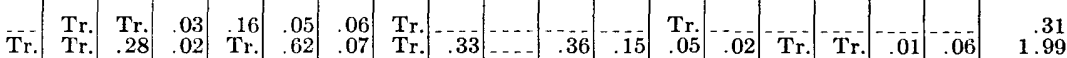

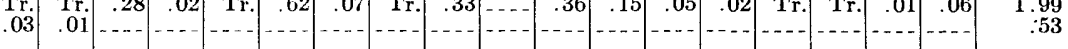


TABLE 22.-Precipitation, in inches, for period

\begin{tabular}{|c|c|c|c|c|c|c|c|c|}
\hline \multirow{2}{*}{$\begin{array}{l}\text { No. } \\
\text { fon } \\
\text { pl. } 11\end{array}$} & \multirow[b]{2}{*}{ Station } & \multirow[b]{2}{*}{ Day } & & & & & & \\
\hline & & & 1 & 2 & 3 & 4 & 5 & 6 \\
\hline 772 & $\begin{array}{l}\text { Floyd Bennett Airport, N. Y. }{ }^{3} \\
\text { U. S. Weather Burean. }\end{array}$ & $\begin{array}{l}22 \\
23 \\
24\end{array}$ & $\begin{array}{l}* \\
* \\
*\end{array}$ & $\begin{array}{l}\text { Tr. } \\
\text { Tr. } \\
0.07\end{array}$ & * & $*$ & Tr. & * \\
\hline 668 & $\begin{array}{l}\text { Flushing, N. Y. }{ }^{3} \\
\text { U. S. Weather Bureau . . . . . }\end{array}$ & $\begin{array}{l}22 \\
23 \\
24\end{array}$ & $\begin{array}{cc}\mathrm{Tr} \\
\mathrm{Tr} \\
0 & 06\end{array}$ & $\begin{array}{l}\mathrm{Tr} \\
0\end{array} \mid$ & $\begin{array}{cc}\mathrm{Tr} \\
0 & 03\end{array}$ & 0.04 & 0.08 & $0.0 \mathrm{Tr}$ \\
\hline 669 & $\begin{array}{l}\text { Freeport, } \mathrm{N} . \mathrm{Y} . \\
\text { Nassau County Department of Public Works, } \\
\text { Hydrological Bureau } . . . .\end{array}$ & $\begin{array}{l}19 \\
20 \\
21 \\
22 \\
23 \\
24\end{array}$ & $\begin{array}{l}\cdots \\
\cdots \\
12\end{array}$ & \begin{tabular}{|c|}
$\cdots$ \\
01 \\
0 \\
\end{tabular} & \begin{tabular}{|c|}
$\ldots$ \\
$\cdots$ \\
$\cdots$
\end{tabular} & $\begin{array}{r}02 \\
03\end{array}$ & $\begin{array}{r}52 \\
03 \\
.04\end{array}$ & $\begin{array}{r}07 \\
.02 \\
-12 \\
.55\end{array}$ \\
\hline 671 & $\begin{array}{l}\text { Long Beach, N. Y. } \\
\text { City of Jong Beach, N. Y...... }\end{array}$ & $\begin{array}{l}17 \\
18 \\
19 \\
20 \\
21 \\
22 \\
23 \\
24\end{array}$ & $\begin{array}{r} \\
\text { Tr. } \\
\text { Tr. } \\
.08\end{array}$ & $\begin{array}{r}.34 \\
\text { Tr. } \\
.01 \\
\hdashline .05\end{array}$ & \begin{tabular}{c}
$\mathrm{Tr}$ \\
$\mathrm{Tr}$ \\
$\mathrm{Tr}$ \\
.11 \\
\hdashline \\
\end{tabular} & $\begin{array}{r}\mathrm{Tr} \\
.32 \\
.01 \\
11\end{array}$ & $\begin{array}{l}.01 \\
71 \\
02 \\
\mathrm{Tr}_{\mathrm{r}} \\
.31\end{array}$ & $\begin{array}{l}.01 \\
.06 \\
.03\end{array}$ \\
\hline 672 & $\begin{array}{l}\text { Manhasset, } \mathrm{N} . \mathrm{Y} \\
\text { Nassan County Department of Public Works, } \\
\text { Hydrological Bureau........ }\end{array}$ & $\begin{array}{l}19 \\
20 \\
21 \\
22 \\
23 \\
24\end{array}$ & .01 & \begin{tabular}{|c|}
- \\
05 \\
0 \\
0 \\
0 \\
\end{tabular} & \begin{tabular}{|c|}
$-\cdots$ \\
$\cdots$ \\
\hdashline .05 \\
05
\end{tabular} & $\begin{array}{c}0.04 \\
.04\end{array}$ & $\begin{array}{r}.06 \\
02 \\
21\end{array}$ & $\begin{array}{r}.17 \\
02 \\
0.31\end{array}$ \\
\hline 673 & $\begin{array}{l}\text { Mineola, N. Y. } \\
\text { Nassau County Department of Public Works, } \\
\text { Hydrological Bureau }\end{array}$ & $\begin{array}{l}18 \\
19 \\
20 \\
21 \\
22 \\
23 \\
24\end{array}$ & 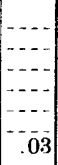 & $\mid$\begin{tabular}{c|}
04 \\
\hdashline 06 \\
\hdashline \\
\hdashline \\
\hdashline \\
\hdashline
\end{tabular} & $\mid$\begin{tabular}{c|}
01 \\
\hdashline \\
02
\end{tabular} & \begin{tabular}{r|}
.01 \\
03
\end{tabular} & \begin{tabular}{r|}
.27 \\
1.86 \\
.02 \\
.04 \\
17
\end{tabular} & $\begin{array}{r}.47 \\
.02 \\
.02 \\
44\end{array}$ \\
\hline 676 & $\begin{array}{l}\text { New York, N. Y. (Battery Place) } \\
\text { U. S. Weather Burean....... }\end{array}$ & $\begin{array}{l}17 \\
18 \\
19 \\
20 \\
21 \\
22 \\
23 \\
24\end{array}$ & $\begin{array}{c}\mathrm{T} \\
\mathrm{Tr} \\
\mathrm{Tr} \\
.03\end{array}$ & $\begin{array}{c}04 \\
\text { Tr. } \\
\mathrm{Tr} . \\
\mathrm{Tr} \\
\mathrm{Tr} \\
.05\end{array}$ & $\begin{array}{c}\mathrm{Tr} . \\
02 \\
\mathrm{Tr} . \\
\mathrm{Tr} . \\
.07\end{array}$ & $\begin{array}{r}\text { Tr. } \\
03 \\
.04 \\
.09\end{array}$ & $\begin{array}{r}\text { Tr. } \\
.17 \\
04 \\
011\end{array}$ & $\begin{array}{r}0 \\
.10 \\
01 \\
.03 \\
10\end{array}$ \\
\hline 677 & $\begin{array}{l}\text { New York, N. Y. (Central Park) } \\
\text { U. S. Weather Bureat ... }\end{array}$ & $\begin{array}{l}17 \\
18 \\
19 \\
20 \\
21 \\
22 \\
23 \\
24\end{array}$ & $\begin{array}{c} \\
\mathrm{Tr} \\
\mathrm{Tr} \\
\mathrm{Tr} \\
06\end{array}$ & 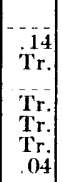 & $\begin{array}{c}01 \\
T \mathbf{T r} \\
\mathrm{Tr} . \\
\mathrm{Tr} . \\
\mathrm{Tr} . \\
\mathrm{Tr} . \\
03\end{array}$ & $\begin{array}{c}\mathrm{Tr} . \\
\mathrm{Tr} \\
.06 \\
.04 \\
01 \\
.04\end{array}$ & $\begin{array}{l}\mathrm{Tr} \\
.16 \\
02 \\
01 \\
.08\end{array}$ & 07 \\
\hline 773 & $\begin{array}{l}\text { St. George, N. Y. } \\
\text { President of the Borough of Richmond.... }\end{array}$ & $\begin{array}{l}17 \\
18 \\
19 \\
20 \\
21 \\
22 \\
23 \\
24\end{array}$ & $\begin{array}{r}(*) \\
(*) \\
\hdashline \\
0 \\
\hdashline 05\end{array}$ & {$\left[\begin{array}{c}(*, \\
(* 1 \\
\hdashline \\
\hdashline 04\end{array}\right.$} & \begin{tabular}{c}
$(*)$ \\
$(*)$ \\
0 \\
03 \\
\hdashline .03
\end{tabular} & $\begin{array}{r}(*) \\
(*) \\
.05 \\
03 \\
.18\end{array}$ & $\begin{array}{c}(*) \\
* \\
.21 \\
02 \\
0 \\
.13\end{array}$ & $\begin{array}{c}* 1 \\
* \\
00 \\
03 \\
01 \\
08\end{array}$ \\
\hline 682 & $\begin{array}{l}\text { Westerleigh, N. Y.3 } \\
\text { C.S. Weather Bureau ... }\end{array}$ & $\begin{array}{l}22 \\
23 \\
24\end{array}$ & $\begin{array}{l}\operatorname{Tr} . \\
\mathrm{Tr} \\
.08\end{array}$ & $\begin{array}{l}\mathrm{Tr} . \\
\mathrm{Tr} \\
.04\end{array}$ & .04 & 18 & $\mid \begin{array}{c}\mathrm{Tr} \\
.14\end{array}$ & .04 \\
\hline 683 & $\begin{array}{l}\text { Atlantic City, N. J. } \\
\text { U.S. Weather Bureau ... }\end{array}$ & $\begin{array}{l}18 \\
20 \\
21 \\
22 \\
23 \\
24\end{array}$ & $\begin{array}{r}.12 \\
.03\end{array}$ & $\begin{array}{r} \\
.19 \\
.01\end{array}$ & $\begin{array}{c}.15 \\
.01 \\
.0 \\
\end{array}$ & $\begin{array}{c}\text { Tr } \\
0 \quad \\
11\end{array}$ & $\begin{array}{c}.04 \\
.01 \\
.06 \\
\end{array}$ & $\begin{array}{r}.07 \\
02 \\
0\end{array}$ \\
\hline
\end{tabular}




\begin{tabular}{|c|c|c|c|c|c|c|c|c|c|c|c|c|c|c|c|c|c|c|}
\hline \multicolumn{6}{|l|}{ a.m. } & \multicolumn{12}{|c|}{$\mathrm{p} . \mathrm{m}$. } & \multirow{2}{*}{ Total } \\
\hline 7 & 8 & 9 & 10 & 11 & 12 & 1 & 2 & 3 & 4 & 5 & 6 & 7 & 8 & 9 & 10 & 11 & 12 & \\
\hline $\begin{array}{c}0.01 \\
*\end{array}$ & 0.91 & $\mathrm{Tr}$ & $\begin{array}{c}* \\
* \\
*\end{array}$ & $\begin{array}{r}* \\
* \\
*\end{array}$ & * & $\begin{array}{l}* \\
* \\
\end{array}$ & $\left|\begin{array}{r}* \\
0.63 \\
-\end{array}\right|$ & $\begin{array}{c}* \\
* \\
-\end{array}$ & {$\left[\begin{array}{ll}0 & 54 \\
* & *\end{array}\right.$} & $\cdots *$ & 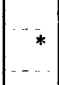 & $\begin{array}{r}* \\
* \\
*\end{array}$ & $\begin{array}{ll} & \mathbf{T r} . \\
0 & 98\end{array}$ & $*$ & * & $*$ & $\begin{array}{r}\mathrm{Tr} \\
0.06\end{array}$ & $\begin{array}{r}0.54 \\
1.68 \\
.98\end{array}$ \\
\hline $\begin{array}{l}.01 \\
.02\end{array}$ & $\begin{array}{l}\text { Tr. } \\
\text { Tr. }\end{array}$ & $\begin{array}{c}\text { Tr. } \\
0.06 \\
\text { Tr. }\end{array}$ & $\begin{array}{r}0.03 \\
.05\end{array}$ & $\mid \begin{array}{c}0.06 \\
\text { Tr. } \\
\ldots\end{array}$ & $\left|\begin{array}{r}0.04 \\
.10\end{array}\right|$ & \begin{tabular}{|r|}
0.08 \\
.74 \\
\end{tabular} & $\begin{array}{c}.02 \\
.12 \\
-.\end{array}$ & 0.33 & Tr. & 1070 & 0.18 & (1) $\begin{array}{c}\text { Tr. } \\
\text {. }\end{array}$ & 01 & $\mathbf{T r}$ & 0.01 & 0.01 & 07 & $\begin{array}{r}.23 \\
2.40 \\
.33\end{array}$ \\
\hline & & & & & & & & & .15 & .02 & & & .02 & & & & & \\
\hline $\begin{array}{l}.19 \\
.02\end{array}$ & .03 & $\begin{array}{r}03 \\
07\end{array}$ & $\begin{array}{r}18 \\
02\end{array}$ & .20 & .11 & $\begin{array}{r}29 \\
40\end{array}$ & .04 & & & .01 & - & & & $\cdots$ & $\cdots$ & .06 & & $\begin{array}{r}1.72 \\
69\end{array}$ \\
\hline .02 & .08 & .07 & $\begin{array}{l}02 \\
01\end{array}$ & .02 & $\begin{array}{l}01 \\
.44\end{array}$ & .11 & .09 & .01 & .01 & & & & & & & 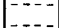 & & $\begin{array}{l}.09 \\
.69\end{array}$ \\
\hline .04 & & & .03 & $\ldots$ & & .12 & .01 & .01 & .05 & 01 & .07 & .26 & .05 & $\ldots$ & .... & & .06 & .83 \\
\hline .11 & .02 & .01 & .01 & & & $\ldots$ & & & & $\ldots$ & & & & $\ldots$ & & & & .92 \\
\hline & $\ldots$ & & & & & & Tr. & .08 & .32 & $\begin{array}{l}\text { Tr. } \\
\text { Tr. }\end{array}$ & .54 & .01 & .01 & 0.01 & .01 & Tr. & Tr. & $\begin{array}{r}\mathrm{Tr} . \\
1.32\end{array}$ \\
\hline & & & & & & & & .01 & .06 & .02 & & .01 & Tr. & & & & & .12 \\
\hline .12 & .04 & .01 & 21 & .30 & 11 & .33 & .06 & & & $\cdots$ & $\cdots$ & & & & $\mathbf{T r}$ & .06 & 01 & 2.34 \\
\hline .02 & .02 & .02 & .02 & .05 & $\mathrm{Tr}$ & .16 & $\mathrm{Tr}$ & & & & $\ldots$ & & Tr. & & & Tr. & Tr. & .36 \\
\hline$\overline{17}$ & $\mathrm{Tr}$ & $\mathbf{T r}$ & $\begin{array}{l}\mathrm{Tr} \\
.02\end{array}$ & $\begin{array}{l}\text { Tr. } \\
\text { Tr. }\end{array}$ & .37 & .08 & .08 & $\begin{array}{l}\text { Tr. } \\
\text { Tr. }\end{array}$ & Tr. & $\overline{T r}^{-}$ & 04 & $2 \overline{7}$ & .08 & $\overrightarrow{\mathrm{Tr}}$ & .01 & 01 & .01 & $\begin{array}{r}.53 \\
67\end{array}$ \\
\hline .05 & .01 & 11 & .02 & 1. & 1T. & 00 & 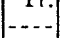 & $\begin{array}{l}11 \\
-2 .\end{array}$ & & 11. & .04 & .20 & .00 & Ir. & 80 & $\begin{array}{l}.01 \\
-0\end{array}$ & .01 & .01 \\
\hline .12 & & & & & & & & & .09 & .08 & .01 & & & & & & & .18 \\
\hline .02 & .08 & $\begin{array}{l}01 \\
01\end{array}$ & 01 & $\begin{array}{r}12 \\
03\end{array}$ & $\begin{array}{r}15 \\
01\end{array}$ & $\begin{array}{r}12 \\
25\end{array}$ & 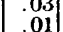 & & .01 & $\cdots$ & $\cdots$ & & & & $-\cdots-$ & & 05 & .88 \\
\hline & $\ldots$ & & & .07 & .10 & .08 & .09 & .01 & & & & & & & & & & 36 \\
\hline .04 & & & .08 & .01 & .01 & .30 & .01 & & .30 & .51 & .45 & .06 & .06 & $\cdots$ & 01 & & .02 & 1.86 \\
\hline .05 & .07 & .01 & -1 & - . - & $\ldots$ & $\ldots$ & .01 & & & $\cdots$ & $\ldots$ & $\ldots$ & & & $\ldots$ & $\ldots$ & & .84 \\
\hline .01 & & & & & & & & & & & & & & & - & & & .34 \\
\hline .11 & .13 & .04 & .03 & .04 & .08 & .15 & .23 & .02 & & $\begin{array}{l}.08 \\
.01\end{array}$ & $\cdots$ & & & & $-\cdots$ & & & 3.17 \\
\hline .02 & .01 & .05 & .02 & 02 & .01 & $\begin{array}{l}.59 \\
\end{array}$ & .06 & .01 & 01 & & & & & & $a$ & & & .84 \\
\hline .01 & & & .01 & .02 & .09 & .11 & .07 & .01 & .01 & & & & & & & & & .33 \\
\hline .17 & .02 & .01 & .04 & .01 & 1 & .43 & 01 & .01 & .30 & .38 & .17 & .04 & .01 & .01 & $-\ldots$ & .01 & .01 & 1.69 \\
\hline .08 & .06 & .01 & $\ldots$ & $\ldots$ & .01 & ? & .01 & & & & & & & & $\ldots$ & & & .92 \\
\hline & -1 & & & .01 & & & & & & & & & & $\overline{\mathrm{Tr}}$ & - & $\mathrm{Tr}$ & .03 & $\begin{array}{l}.09 \\
.08\end{array}$ \\
\hline .12 & Tr. & .06 & .11 & 08 & 10 & .08 & & & $\ldots$ & .01 & $-\cdots$ & & & & $\cdots$ & -1 & $\mathrm{Tr}$ & $\begin{array}{l}.04 \\
.85\end{array}$ \\
\hline .03 & .01 & 01 & .01 & .01 & .22 & Tr. & & & & & .01 & & & & & .01 & .21 & .63 \\
\hline & .01 & Tr. & .03 & .14 & .05 & .04 & .01 & & & & & Tr. & & & & & & .28 \\
\hline $\mathrm{Tr}$. & .01 & .56 & .03 & .01 & .47 & .04 & Tr. & .31 & & .34 & .14 & .04 & .02 & $\operatorname{Tr}$. & $\mathrm{Tr}$. & .01 & .06 & 2.07 \\
\hline .03 & .01 & $\cdots$ & $\ldots$ & $\cdots$ & $\ldots$ & $\ldots$ & $\cdots$ & $\cdots-$ & $\cdots$ & $\cdots$ & $\ldots$ & & & & & & & .49 \\
\hline & & & & Tr. & & & & & & & & & & Tr. & $\mathrm{Tr}$ & $\mathrm{Tr}$. & .01 & $\begin{array}{l}\mathrm{Tr} \text {. } \\
.16\end{array}$ \\
\hline .06 & & & Tr. & --7 & & & $T_{r}$ & Tr. & Tr. & $\mathrm{Tr}$ & Tr. & & Tr. & & $\cdots$ & $\ldots$ & & .03 \\
\hline $\begin{array}{l}.06 \\
.03\end{array}$ & Tr. & .03 & .09 & .12 & $\begin{array}{r}.09 \\
08\end{array}$ & .04 & $\mathrm{Tr}$. & & & -- & $\mathrm{Tr}$ & & - & -- & $\cdots$ & $\cdots$ & Tr. & $\begin{array}{r}.72 \\
35\end{array}$ \\
\hline & Tr. & .02 & .01 & .11 & .06 & .07 & .01 & & & & & $\mathrm{Tr}$. & & & & & & .30 \\
\hline .04 & .04 & $.5 \overline{3}$ & .09 & .01 & .46 & .08 & Tr. & 14 & Tr. & .63 & .17 & 01 & .01 & $\mathrm{Tr}$. & .01 & .01 & .06 & 2.40 \\
\hline .02 & Tr. & Tr. & $\rightarrow$ & $\cdots$ & $\cdots$ & $\cdots$ & $\cdots$ & & & $\cdots$ & $\cdots$ & $\cdots$ & & - & $-\cdots$ & --- & $\cdots$ & .33 \\
\hline$*$ & $*$ & $*$ & $*$ & $*$ & $*$ & $*$ & $*$ & $*$ & * & $*$ & * & * & * & * & $*$ & * & * & * \\
\hline * & * & * & * & * & * & * & $*$ & * & $*$ & $*$ & $*$ & * & * & * & $*$ & * & .63 & .63 \\
\hline 10 & 01 & 01 & 06 & .05 & .06 & .07 & $\mathrm{Tr}$. & & & & & & & & & & & .03 \\
\hline 02 & .01 & $\ldots$ & & .03 & .25 & .03 & Tr. & & $\ldots$ & -1 & & & $\cdots-$ & 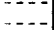 & & & 15 & .60 \\
\hline & & & .08 & .18 & .03 & .05 & Tr. & & & & & & & & & & & .34 \\
\hline $\mathrm{T}_{\mathrm{r}}$ & & .41 & .02 & & .39 & 0.5 & & .30 & $\mathrm{Tr}$ & .42 & .14 & .02 & .02 & $\mathrm{Tr}$ & $-\infty$ & - & .03 & 1.81 \\
\hline & Tr. & $\mathbf{T r}$ & $-\infty$ & $\ldots$ & $\ldots$ & $\ldots$ & $\cdots$ & $\ldots$ & - - & $-\cdots$ & $\ldots$ & $\ldots$ & $\ldots$ & $\cdots$ & & & & .55 \\
\hline & Tr. & .03 & .07 & .08 & .03 & .04 & .01 & & & Tr. & $\mathrm{Tr}$. & $\mathrm{Tr}$. & $\mathrm{Tr}$. & & & & & .26 \\
\hline Tr. & 01 & .52 & .01 & .23 & .25 & .02 & .14 & . 6 & & .34 & .28 & .04 & .02 & Tr. & .01 & .01 & .03 & 2.11 \\
\hline & Tr. & $\ldots$ & $\cdots$ & $\cdots$ & $\cdots$ & $\cdots$ & $\cdots$ & $\cdots$ & $\cdots$ & $\cdots$ & - - . & $\cdots$ & $\cdots$ & & $\cdots$ & & & .59 \\
\hline .02 & & & & & & & 0 & 1 & 60 & 05 & Tr. & .11 & .11 & .02 & .01 & 34 & & .53 \\
\hline $\mathrm{Tr}$. & .03 & & & $\ldots$ & & .09 & .02 & .18 & & 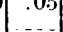 & & & & .90 & .31 & .34 & .48 & $\begin{array}{r}3.04 \\
34\end{array}$ \\
\hline & & & & & 04 & & $\mathrm{Tr}$ & .03 & .03 & Tr. & & & & & $\ldots$ & & $\cdots$ & .10 \\
\hline & & & & $\mathrm{Tr}$. & $\mathrm{Tr}$. & .01 & & & Tr. & & .02 & .04 & .07 & .02 & .01 & .14 & .10 & .41 \\
\hline & .05 & .17 & .06 & 02 & .02 & .01 & & Tr. & & & & & & & & $\ldots$ & $\ldots$ & 1.02 \\
\hline
\end{tabular}


TABLE 22.-Precipitation, in inches, for period

\begin{tabular}{|c|c|c|c|c|c|c|c|c|}
\hline \multirow{2}{*}{$\begin{array}{c}\text { No. } \\
\text { on } \\
\text { pl. } 11\end{array}$} & \multirow[b]{2}{*}{ Station } & \multirow[b]{2}{*}{ Day } & & & & & & \\
\hline & & & 1 & 2 & 3 & 4 & 5 & 6 \\
\hline 686 & $\begin{array}{l}\text { Colts Neck No. R-8, N. J. } \\
\text { U. S. Department of Agriculture, Soil Conservation Service }\end{array}$ & $\begin{array}{l}17 \\
18 \\
19 \\
20 \\
21 \\
22 \\
23 \\
24\end{array}$ & 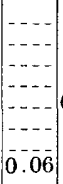 & \begin{tabular}{|c|} 
\\
\hdashline \\
\hdashline 0.02 \\
.04 \\
\end{tabular} & $\mid$\begin{tabular}{c}
$\cdots$ \\
\hdashline-1 \\
\hdashline 0.05 \\
\end{tabular} & \begin{tabular}{c}
$\cdots$ \\
\hdashline 0.08 \\
05
\end{tabular} & $\begin{array}{r}0.47 \\
.05 \\
-2 \\
-10\end{array} \mid$ & $\begin{array}{r}0 \\
0.07 \\
.03 \\
0 \\
.78\end{array}$ \\
\hline 688 & $\begin{array}{l}\text { Elizabethport, N. J. } \\
\text { Chief engineer, Joint Meeting Maintenance, } \\
\text { Irvington, N. J. }\end{array}$ & $\begin{array}{l}17 \\
18 \\
20 \\
21 \\
22 \\
23 \\
24\end{array}$ & $\begin{array}{c}-\cdots \\
01 \\
.0 \overline{1} \\
.03\end{array}$ & 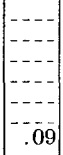 & 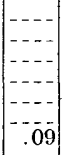 & $\begin{array}{c}. . . \\
-06 \\
.07 \\
-09 \\
.09 \\
\end{array}$ & $\begin{array}{c}.02 \\
.15 \\
.04 \\
-09 \\
.09\end{array}$ & $\begin{array}{c}-.05 \\
.05 \\
.08\end{array}$ \\
\hline 691 & $\begin{array}{l}\text { Irvington, N. J. } \\
\text { Chief engineer, Joint Meeting Maintenance, } \\
\text { Irvington, N.J. }\end{array}$ & $\begin{array}{l}17 \\
18 \\
19 \\
20 \\
21 \\
22 \\
23 \\
24\end{array}$ & \begin{tabular}{|c|}
-1 \\
0 \\
.05 \\
.02 \\
\end{tabular} & \begin{tabular}{|c|} 
\\
03 \\
03
\end{tabular} & \begin{tabular}{r} 
\\
\hdashline .01 \\
.01 \\
.03
\end{tabular} & $\begin{array}{c}-. . \\
.01 \\
.04 \\
.04 \\
.01 \\
.03\end{array}$ & $\begin{array}{c}0 . \\
.04 \\
.04 \\
0.01\end{array}$ & \begin{tabular}{c}
$\ldots$ \\
.06 \\
.02 \\
\hdashline \\
\hdashline \\
\hdashline
\end{tabular} \\
\hline 774 & $\begin{array}{l}\text { Lakehurst, N. J. } \\
\quad \text { Naval Air Station }\end{array}$ & $\begin{array}{l}17 \\
18 \\
19 \\
20 \\
21 \\
22 \\
23 \\
24 \\
25\end{array}$ & \begin{tabular}{|c|}
-- \\
\hdashline .06 \\
\hdashline .03 \\
\hdashline .0 \\
-0 \\
\end{tabular} & 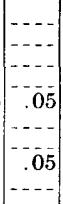 & \begin{tabular}{|r|}
- \\
\hdashline .02 \\
.09 \\
\hdashline .04 \\
-0
\end{tabular} & \begin{tabular}{|c|}
- \\
-06 \\
.03 \\
\hdashline .03 \\
-0
\end{tabular} & \begin{tabular}{c}
..- \\
\hdashline .02 \\
.03 \\
\hdashline .28 \\
.
\end{tabular} & $\begin{array}{c}. \\
.03 \\
.02 \\
.08 \\
.0\end{array}$ \\
\hline 694 & $\begin{array}{l}\text { Long Branch, N. J. } \\
\text { U. S. Weather Bureau }\end{array}$ & $\begin{array}{l}17 \\
18 \\
19 \\
20 \\
21 \\
22 \\
23 \\
24\end{array}$ & $\mid$\begin{tabular}{c}
0 \\
\hdashline .04 \\
.07 \\
.07 \\
-
\end{tabular} & \begin{tabular}{|c|}
$\ldots$ \\
\hdashline .01 \\
.01 \\
\hdashline .01 \\
.0 \\
\end{tabular} & $\mid$\begin{tabular}{c|}
$\cdots$ \\
\hdashline .02 \\
.02 \\
.04
\end{tabular} & \begin{tabular}{|r|}
. .94 \\
1.94 \\
.04 \\
.03 \\
.0 \\
\end{tabular} & $\begin{array}{c}-.- \\
.33 \\
.03 \\
.07\end{array}$ & $\begin{array}{r}- \\
.28 \\
.02 \\
.02 \\
.33\end{array}$ \\
\hline 695 & $\begin{array}{l}\text { Marlboro, N. J. } \\
\text { U. S. Department of Agriculture, Soil Conservation Service }\end{array}$ & $\begin{array}{l}17 \\
18 \\
19 \\
20 \\
21 \\
22 \\
23 \\
24\end{array}$ & 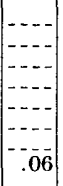 & \begin{tabular}{|c|}
0 \\
\hdashline .03 \\
\hdashline .07 \\
.0 \\
\end{tabular} & 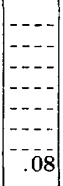 & 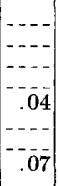 & $\begin{array}{r}-. \\
-2 . \\
\hdashline .47 \\
.06 \\
\hdashline .30\end{array}$ & $\begin{array}{c}- \\
.19 \\
.19 \\
.63\end{array}$ \\
\hline 698 & $\begin{array}{l}\text { Newark, N. J. } \\
\text { Kresge Department Store, William Wiener, meteorologist }\end{array}$ & $\begin{array}{l}17 \\
18 \\
19 \\
20 \\
21 \\
22 \\
23 \\
24\end{array}$ & \begin{tabular}{|c|}
- \\
.03 \\
\hdashline .02 \\
.06 \\
.06 \\
\end{tabular} & \begin{tabular}{|c|}
- \\
\hdashline .01 \\
.02 \\
\hdashline .06 \\
\end{tabular} & $\mid$\begin{tabular}{c}
- \\
\hdashline .06 \\
\hdashline .06 \\
\hdashline .06
\end{tabular} & $\begin{array}{c}-. . \\
-01 \\
.10 \\
.04 \\
-02\end{array}$ & \begin{tabular}{r}
$\cdots .$. \\
\hdashline .16 \\
.05 \\
06
\end{tabular} & $\begin{array}{l}. \\
.07 \\
.01 \\
(*) \\
.06 \\
.05\end{array}$ \\
\hline 775 & $\begin{array}{l}\text { Newark Airport, N. J. } \\
\text { U.S. Weather Bureau (Me asured at 1:30 a.m., 7:30 a.m., } \\
\text { 1:30 p.m., 7:30 p.m., } 12 \text { p.m.) }\end{array}$ & $\begin{array}{l}17 \\
18 \\
19 \\
20 \\
21 \\
22 \\
23 \\
24\end{array}$ & $\begin{array}{c}0 \\
- \\
\end{array}$ & 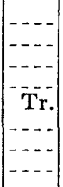 & $\begin{array}{r} \\
(*) \\
(*) \\
* \\
* \\
* \\
\hdashline *\end{array}$ & $\begin{array}{r}(*) \\
(*) \\
* \\
* \\
* \\
*\end{array}$ & $\begin{array}{c} \\
(*) \\
* \\
* \\
* \\
*\end{array}$ & $\begin{array}{l}* \\
* \\
* \\
* \\
*\end{array}$ \\
\hline 702 & $\begin{array}{l}\text { Sandy Hook, N. J. } \\
\text { U. S. Weather Bureau . - }\end{array}$ & $\begin{array}{l}17 \\
18 \\
19 \\
20 \\
21 \\
22 \\
23 \\
24\end{array}$ & \begin{tabular}{|c|} 
\\
.-- \\
.01 \\
.08 \\
.0
\end{tabular} & $\mid$\begin{tabular}{c}
$\mid-$. \\
\hdashline .01 \\
\hdashline .03 \\
\hdashline .0 \\
.03 \\
\end{tabular} & $\left|\begin{array}{c} \\
\hdashline \mathbf{T r} \\
.03 \\
\hdashline \\
.11\end{array}\right|$ & $\begin{array}{c} \\
.11 \\
.03 \\
\mathrm{Tr} \\
.11\end{array}$ & $\begin{array}{r}-. . \\
.23 \\
.04 \\
-01 \\
.58\end{array}$ & $\begin{array}{c}0 \\
.09 \\
03 \\
\mathrm{Tr} \\
.15\end{array}$ \\
\hline
\end{tabular}

*Included in following measurement.

'Hourly records adjusted on basis of daily readings of auxiliary nonrecording gage. 


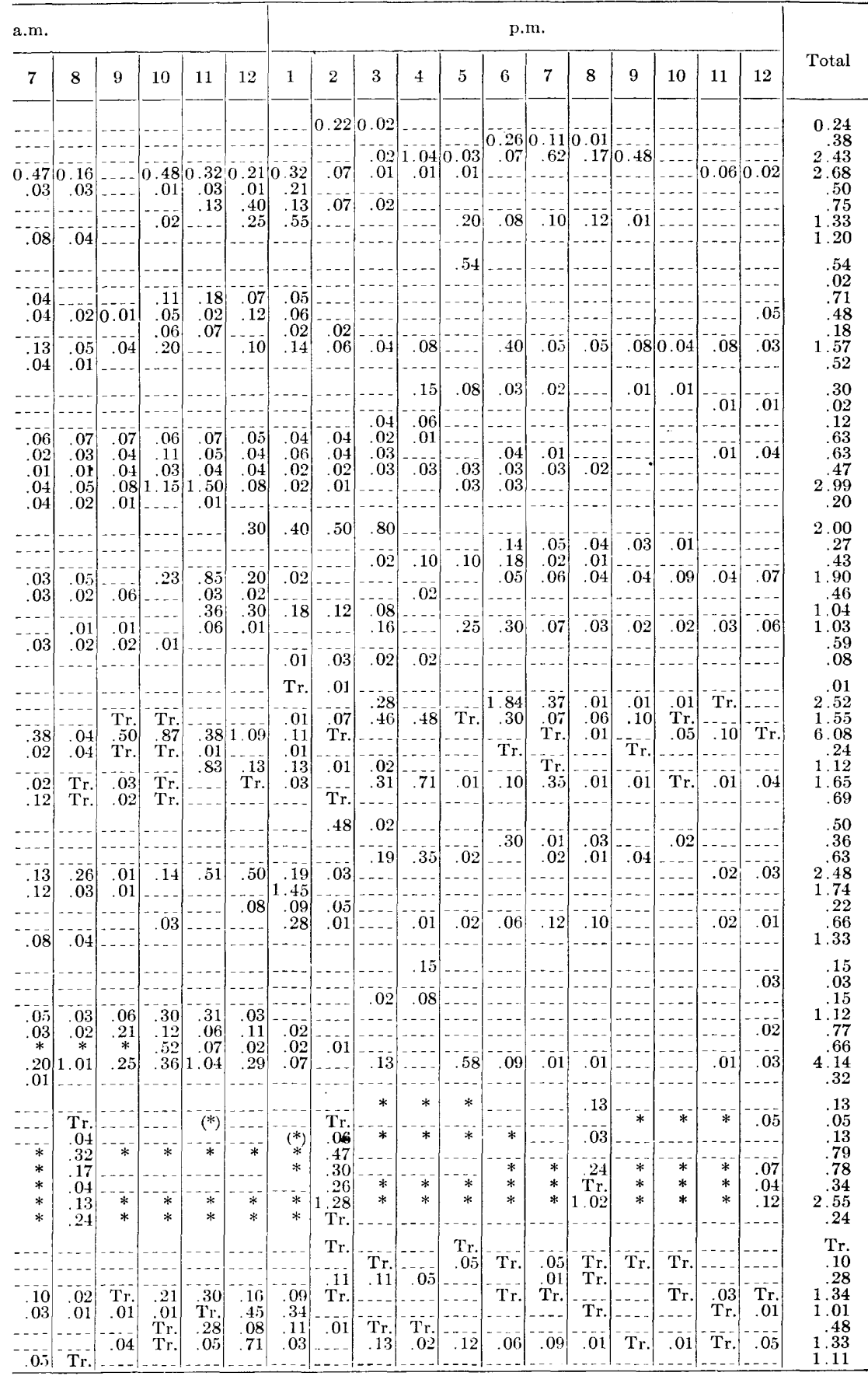

224-hour total at 7:30 a.m. of day indicated.

${ }^{3}$ Hourly records not a vailable for July $17-21$. See table 21 for daily records. $748116-48-14$ 
Records of hourly precipitation July $17-25$ at 76 recording rain gages are given in table 22 . Figure 33 shows the hourly precipitation at 5 selected rain gages. These graphs show that virtually no precipitation fell on July 17 and 25 . If these records may be accepted as criteria for the distribution of precipitation measured at nonrecording stations, then the storm period, for all practical purposes, lasted 7 days-July 18-24. The concentration of rainfall was erratic, as evidenced by comparison of the rainfall graph for New Milford, N. J., with that for Long Branch, N. J. An initial heavy downpour occurred during the early afternoon of July 18 at most stations. For example, 2.52 inches of rain fell at Long Branch, N. J., during 8 hours of the afternoon of July 18, whereas at Sandy Hook, N. J., nearby, only 0.10 inch was registered during the 12

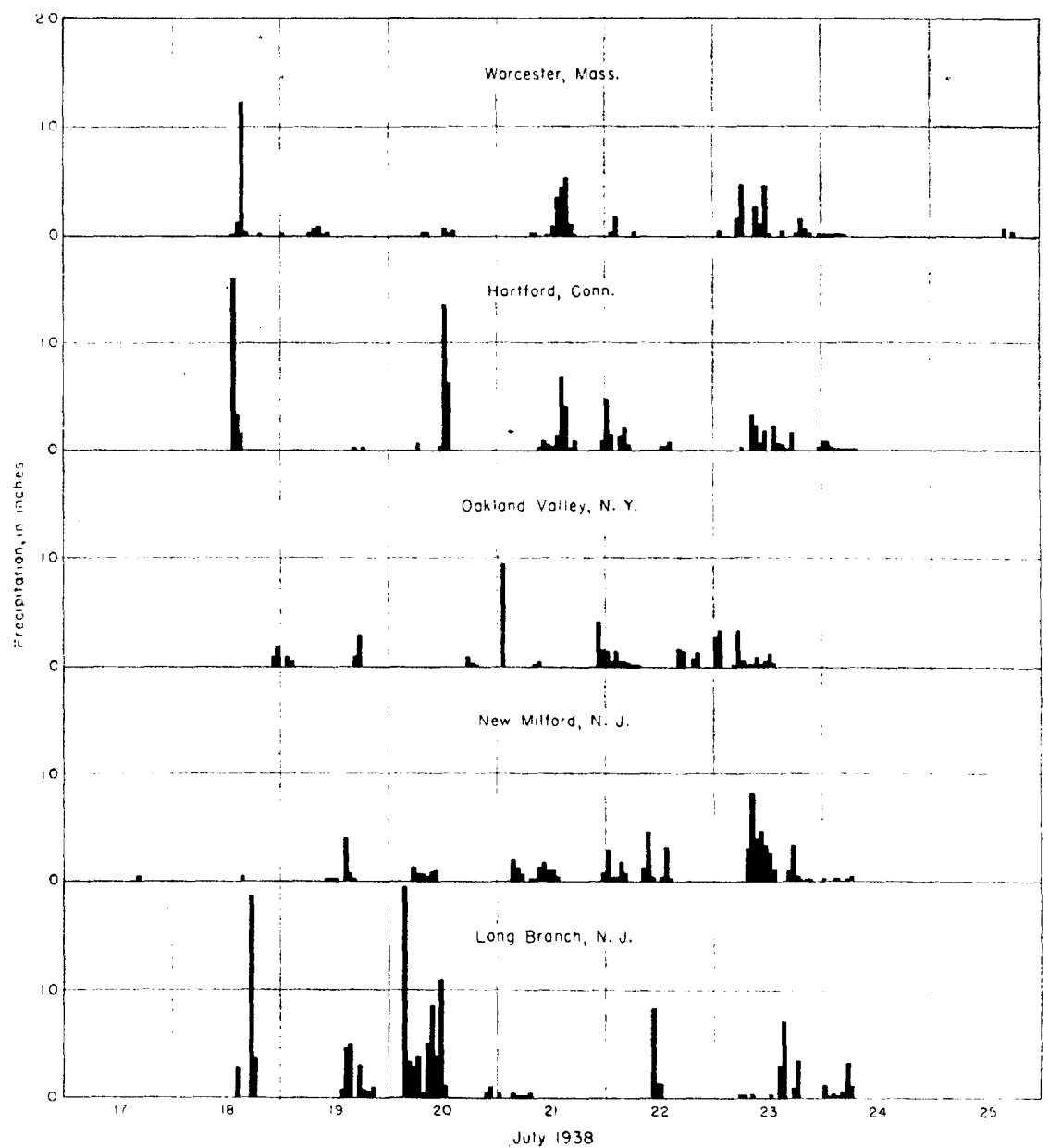

Figune 33.-Hourly precipitation at selected recording rain gages during storm of July 1938 . 
hours between noon and midnight of July 18. Many other examples of the erratic distribution may be found.

The maximum storm precipitation recorded along the northern Atlantic seaboard was 13.96 inches at Crisfield, Md., but within the area studied the maximum recorded was 13.85 inches at Long Branch, N. J., where an autographic rain gage is located. Table 23 lists maximum storm precipitation for intervals from 1 hour to 7 days at any station within the storm area. Maximum 7-day precipitation was registered at Long Branch, N. J., where also was registered the maximum 2-day, 1-day, 10-hour, 6-hour, and 1-hour rainfall. The amounts given in table 23 have, however, all been exceeded in other storms, as reported in table 15.

\section{AREAI DISTRIBUTIOX}

Plate 11 presents an isohyetal map of the area covered by this report for the storm period July 17-25, 1938, based on records published in table 21. With minor exceptions this storm lasted 7 days.

TABLE 23.-Maximum storm precipitation during indicated intervals, storm of July $17-25,1938$

\begin{tabular}{|c|c|c|c|}
\hline Period & Place & Date & Precipitation (inches \\
\hline $\begin{array}{l}\text { 7-day } \\
\text { 1-day } \\
\text { 10-hour } \\
\text { 6-hour } \\
\text { 2-hour } \\
\text { 1-hour } \ldots \ldots \ldots\end{array}$ & $\begin{array}{l}\text { Long Branch, N. J. } \\
\text { Crisfield, Md. } \\
\text { Long Braneh, N. J. } \\
\text { Crisfield, Md. } \\
\text { Long Branch, N. J. } \\
\text { Irvington, N. J. Jo } \\
\text { Long Branch, N. J. }\end{array}$ & $\begin{array}{l}\text { July } 18-24 \ldots \\
\text { July } 23-24 \ldots \\
\text { July } 20 \ldots \ldots \\
\text { July } 24 \ldots \ldots \\
\text { July } 20 \ldots \ldots \\
\text { July } 23 \ldots \ldots \ldots \\
\text { July } 20 \ldots \ldots\end{array}$ & $\begin{array}{l}13.85 \\
8.20 \\
7.63 \\
8.00 \\
6.08 \\
5.92 \\
3.47 \\
2.65 \\
1.94\end{array}$ \\
\hline
\end{tabular}

The isohyetals on plate 11 define a major axis of intense precipitation through Dover, Del. (11.02 inches); Hammondton, N. J. (10.62 inches) ; Long Branch, N. J. (13.86 inches); and an elongated center in Connecticut and Massachusetts with its maximum at Milford, Mass. (12.29 inches). The axis defined by these centers has an approximate bearing of $\mathrm{N} .45^{\circ} \mathrm{E}$. There are other centers, notably one to the east of the above-mentioned axis at Crisfield, Md. (13.96 inches). Another area of intense precipitation covered the Catskill Mountains, the areal distribution apparently being influenced by orographic effects of altitude.

The isohyetal lines on plate 11 may be compared advantageously with those for the hurricane storm of September 1938 given in Water-Supply Paper $867^{24}$. Although of different meteorologic or-

\footnotetext{
Paulsen, C. G., and others, Hurricane floods of September 1938: U. S. Geol. Survey WaterSupply Paper 867, Pl. 1 (in pocket), 1940.
} 
igin, the storm positions in general nearly coincided. Precipitation during the storm of July 1938 was heavier in parts of New Jersey and the Catskill Mountains than during the September storm; but the latter extended farther across central Massachusetts into New Hampshire and Vermont. In spite of these and other differences in areal distribution the storms were of sufficiently great geographic coincidence and shape that the unfavorable effect of the earlier storm in reducing soil retentive capacity before the later and heavier September storm cannot be questioned.

\section{AREA-DEPTH RELATIONS}

The areas within the various isohyetals shown on plate 11 for the 7-day storm have been planimetered, and the total areas over which the precipitation was greater than the indicated amounts were approximately as follows:

Over 12 inches, 175 square miles.

Over 11 inches, 890 square miles.

Over 10 inches, 1,930 square miles.

Over 9 inches, 3,740 square miles.

Over 8 inches, 7,580 square miles.

Over 6 inches, 23,600 square miles.

The areas tablulated above include those within all isohyetals north of the Potomac River shown on plate 11. The mean precipitation within the isohyetals about each storm center has been computed, and the results were used to prepare an enveloping curve showing the relation between maximum mean precipitation and the area enclosed within a continuous isohyetal. From this enveloping curve the following points were selected for comparing the storm of July 17-25, 1938, with other storms in the region:

\begin{tabular}{|c|c|c|}
\hline Area & Mean & precipitation \\
\hline (square miles) & & (inches) \\
\hline 1 & & ${ }^{1} 13.96$ \\
\hline 100 & & 12.9 \\
\hline 500 & & 11.6 \\
\hline $1,000 \ldots$ & (2) & 11.1 \\
\hline $2,000 \ldots$ & (1) & 10.2 \\
\hline 4,000 & 1 & 9.2 \\
\hline 6,000 & 수 & 8.9 \\
\hline 10,000 & 수 & 8.4 \\
\hline 223,600 & ................................ & 7.7 \\
\hline
\end{tabular}

1 Total storm precipitation recorded at Crisfield, Md.

2 Area within the 6-inch isohyet.

That the flood-producing storms of July 1938 continued for 7 consecutive days was a most unusual circumstance. The Miami Conservancy District Report ${ }^{25}$ analyzes on an area-depth basis 33

\footnotetext{
${ }^{25}$ Storm rainfall of eastern United States; Miami Conservancy District, Technical Reports, pt. 5 (revised), pp. 278, 279, 1936.
} 
important rainstorms that occurred from 1869 to 1933 in the northeastern United States. Only durations up to 5 days are shown in this report. If the 4-day storm of September 1938 is included, the 7-day storm of July 1938 was exceeded by six storms on the basis of 6,000 square miles, by four storms on the basis of 1,000 square miles, and only by the storm of September 1938 if point rainfalls are compared.

\section{STAGES AND DISCHARGES AT STREAM-GAGING STATIONS}

The data presented in the following pages for each regular stream-gaging station comprise in general a description of the station, an upper table showing the daily discharges throughout the 3-month period from June to August 1938 (except in New York, where discharges for July and August only are given), and a lower table showing the stage and discharge at the indicated times during the period of major flood flow. For those streams in New Jersey and in New York that were affected by the floods of June or August 1938 the table of discharge at indicated times has been expanded to include the respective flood periods. The latter table is sufficiently detailed to permit the delineation of reasonably accurate graphs of the instantaneous stage and discharge for the flood period. The data are intended to be reasonably complete and explicit with respect to essential information, although they are presented in concise form. Reference should be made to pages 8 to 11 for discussions of the tables of discharge presented herein.

Figure 34 shows hydrographs of daily mean discharge for this 3-month period for one stream-gaging station in New Jersey, New York, and Connecticut. This figure shows the relative size of the floods during June, July, and August 1938 in these three States. In all of them, the flood of July was either the largest or a close second. It was the only sizable flood in Connecticut during the 3 months shown. In New Jersey the flood of June 1938 was comparable to that of July and in New York (Catskill Mountains) that of August was comparable to that of July. These floods are described in separate parts of this volume, but the records of stream flow are presented in this part because the flood of July was common to all three States and for convenience, as the recession of one flood was nearly continuous with the beginning of the next.

The lower tables, showing stage and discharge at indicated times, are designed to present the rise and recession of the flood in detail. The table of discharge at indicated time begins well before the beginning of the major flood rise and continues until the 


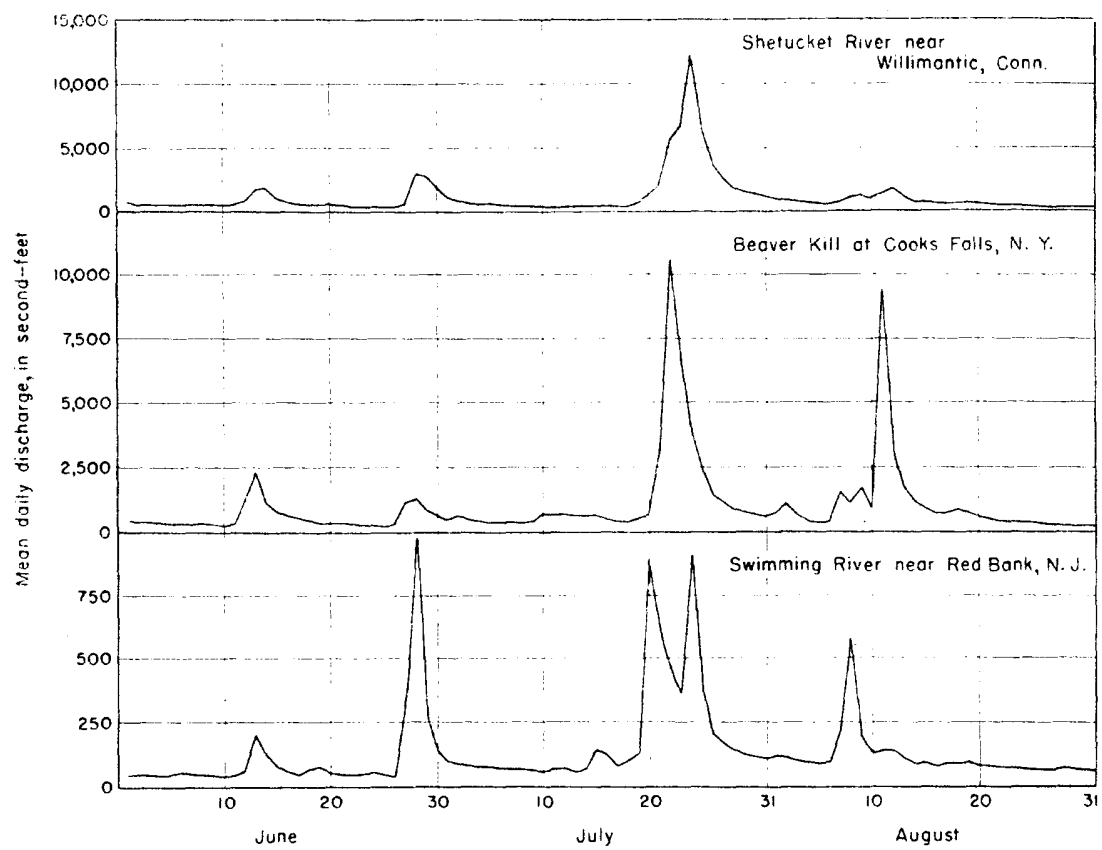

Figtre 34-- Hydrographs of daily discharges at selected stream-gaging stations for the period June 1 to August 31, 1938.

flood had largely passed out of the river systems. Hydrographs of discharge showing the characteristics of flood peaks and the conditions of stream flow during the flood period are shown for stream-gaging stations in New Jersey, New York, and Connecticut in figures 25 to 28 , inclusive. A striking example of the effect of the erratic distribution of rainfall on stream flow during this flood may be discerned in figure 25 by observing the very different fluctuations in discharge of the Rahway River at Rahway, N. J., and of the North Branch of the Raritan River at Milltown, N. J. These basins are about 20 miles apart.

Records for seven stations in New Jersey, presented in this part of the report, include discharges for the hurricane floods of September 1938. The records are presented in this report because they were not available when Water-Supply Paper $867^{26}$ was published and because they serve to complete the flood data presented in Water-Supply Paper 867.

${ }^{28}$ Paulsen, C. G., and others, Hurricane floods of September 1938 : U, S. Geol. Survey WaterSupply Paper 867, 562 pp., 1940. 


\section{MERRIMACK RIVER BASIN}

CONCORD RIVER BEIOW RIVIR MEADOW BROOK, AT IOWIII, MAgB.

Location.-Lat. $42^{\circ} 38^{\prime} 15^{\prime \prime}$, long. $71^{\circ} 18^{\prime} 10^{\prime \prime}$, at Lowell, Middlesex County, 300 feet downstream from Rogers Street Bridge, 0.3 mile downstream from River Meadow Brook, and 0.8 mile upstream from mouth. Datum of gage is 67.41 feet above mean sea level (general adjustment of 1929).

Drainage AREA.- Total area above gage, 405 square miles; net above gage, 312 square miles (Boston Metropolitan district).

CAGE-HEIGHT RECORD.-Water-stage recorder graph.

STAGE-Discharge RELATION.-Defined by current-meter measurements below 3,670 second-feet.

Maxima.-July 1938: Discharge, 3,790 second-feet 6 a. m. and 4:45 p. m. July 29 (gage height, 8.11 feet).

1936 to June 1938: Discharge, 1,900 second-feet Dec. 23, 1936 (gage height, 6.75 feet). discharge known, 6,490 second-feet Mar. 15, 1936 at North Billerica, Mass. (drainage area 374 square miles).

REMARкs.-Flood discharge affected by natural storage in swamps by water wasted by Boston Metropolitan district in diverting from 92.6 square miles in Sudbury River and Lake Cochituate Basins. Wasted water is included in discharge records. For information on wastage see record for wastage from Sudbury River Basin at outlets of Framingham Reservoir No. 1 near Framingham Center, Mass, and Lake Cochituate at Cochituate, Mass.

Mean discharge, in second-feet, 1938

\begin{tabular}{|c|c|c|c|c|c|c|c|c|c|c|c|}
\hline Day & June & July & Aug. & Day & June & July & Aug. & Day & June & July & Aug. \\
\hline $\begin{array}{r}1 \\
3 \\
3 \\
4 \\
5 \\
6 \\
7 \\
8 \\
9 \\
10\end{array}$ & $\begin{array}{l}555 \\
521 \\
487 \\
421 \\
426 \\
437 \\
410 \\
380 \\
360 \\
323\end{array}$ & $\begin{array}{r}1,110 \\
1,130 \\
1,130 \\
1,100 \\
1,060 \\
982 \\
902 \\
823 \\
725 \\
655\end{array}$ & $\begin{array}{l}3,1,30 \\
2,940 \\
2,690 \\
2,440 \\
2,180 \\
1,900 \\
1,720 \\
1,570 \\
1,440 \\
1,340\end{array}$ & $\begin{array}{l}11 \\
12 \\
13 \\
14 \\
15 \\
16 \\
17 \\
18 \\
19 \\
20\end{array}$ & $\begin{array}{l}274 \\
247 \\
448 \\
562 \\
641 \\
690 \\
711 \\
662 \\
641 \\
655\end{array}$ & $\begin{array}{l}620 \\
600 \\
588 \\
588 \\
614 \\
574 \\
549 \\
652 \\
744 \\
877\end{array}$ & $\begin{array}{r}1,300 \\
1,250 \\
1,160 \\
1,090 \\
1.040 \\
958 \\
926 \\
870 \\
823 \\
746\end{array}$ & $\begin{array}{l}21 \\
22 \\
23 \\
24 \\
25 \\
26 \\
27 \\
28 \\
29 \\
30 \\
31\end{array}$ & $\begin{array}{r}614 \\
568 \\
532 \\
487 \\
406 \\
395 \\
515 \\
662 \\
870 \\
1,010\end{array}$ & $\begin{array}{l}1,120 \\
1,480 \\
1,800 \\
2,350 \\
2,990 \\
3,370 \\
3,630 \\
3,660 \\
3,710 \\
3,450 \\
3,290\end{array}$ & $\begin{array}{l}718 \\
697 \\
65.5 \\
594 \\
555 \\
515 \\
448 \\
411 \\
448 \\
448 \\
426\end{array}$ \\
\hline \multicolumn{9}{|c|}{$\begin{array}{l}\text { Monthly mean discharge, in second-feet (adjusted for wastage }{ }^{1} \text { ) } \ldots \ldots \ldots \\
\text { Runoff, in inches (adjusted for wastage) } \ldots\end{array}$} & $\begin{array}{r}379 \\
1.35\end{array}$ & $\begin{array}{r}1,005 \\
3.71\end{array}$ & $\begin{array}{r}1,053 \\
3.90\end{array}$ \\
\hline
\end{tabular}

Gage height, in feet, and discharge, in second-jeet, at indicated time, 1938

\begin{tabular}{|c|c|c|c|c|c|c|c|c|c|c|c|c|}
\hline \multirow{2}{*}{ Hour } & Feet & Sec.-it. & Feet & šec, -ft. & Feet & Sec.-ft. & Feet & Siec.-ft. & Feet & Sec.-ft. & Feet & Sec.-f1. \\
\hline & \multicolumn{2}{|c|}{ July 17} & \multicolumn{2}{|c|}{ July 18} & \multicolumn{2}{|c|}{ July 19 } & \multicolumn{2}{|c|}{$J_{12} ! y 20$} & \multicolumn{2}{|c|}{ July 21} & \multicolumn{2}{|c|}{ July 22} \\
\hline $\begin{array}{rl}6 & \mathrm{a} .11 \mathrm{l} \\
12 \mathrm{n} . \\
6 \mathrm{p.111} \\
12 \mathrm{ml} .\end{array}$ & $\begin{array}{l}5.20 \\
5.19 \\
5.18 \\
5.16\end{array}$ & $\begin{array}{l}555 \\
549 \\
544 \\
.532\end{array}$ & $\begin{array}{l}5.25 \\
5.21 \\
5.56 \\
5.45\end{array}$ & $\begin{array}{l}788 \\
562 \\
802 \\
725\end{array}$ & $\begin{array}{l}5.48 \\
5.43 \\
5.49 \\
5.53\end{array}$ & $\begin{array}{l}746 \\
711 \\
753 \\
781\end{array}$ & $\begin{array}{l}5.59 \\
5.64 \\
5.73 \\
5.75\end{array}$ & $\begin{array}{l}823 \\
862 \\
934 \\
950\end{array}$ & $\begin{array}{l}5.81 \\
5.86 \\
6.14 \\
6.23\end{array}$ & $\begin{array}{r}998 \\
1,040 \\
1,290 \\
1,370\end{array}$ & $\begin{array}{l}6.29 \\
6.33 \\
6.40 \\
6.44\end{array}$ & $\begin{array}{l}1,430 \\
1,470 \\
1,540 \\
1,580\end{array}$ \\
\hline $12 \mathrm{mi}$ & \multicolumn{2}{|c|}{ July 23} & \multicolumn{2}{|c|}{ July 24} & \multicolumn{2}{|c|}{ July 25} & \multicolumn{2}{|c|}{$J_{11}+26$} & \multicolumn{2}{|c|}{ July 27} & \multicolumn{2}{|c|}{ July 28} \\
\hline $\begin{array}{rl}6 & \mathrm{a} . \mathrm{m} . \\
12 \mathrm{n} . \\
6 \mathrm{p.m} . \\
12 \mathrm{nt} .\end{array}$ & $\begin{array}{l}6.51 \\
6.60 \\
6.75 \\
6.88\end{array}$ & $\begin{array}{l}1,660 \\
1,760 \\
1,930 \\
2,090\end{array}$ & $\begin{array}{l}6.99 \\
7.10 \\
7.22 \\
7.34\end{array}$ & $\begin{array}{l}2,230 \\
2,370 \\
2,530 \\
2,680\end{array}$ & $\begin{array}{l}7.45 \\
7.60 \\
7.73 \\
7.74\end{array}$ & $\begin{array}{l}2,820 \\
3,020 \\
3,190 \\
3,210\end{array}$ & $\begin{array}{l}7.82 \\
7.92 \\
7.88 \\
7.94\end{array}$ & $\begin{array}{l}3,320 \\
3,470 \\
3,410 \\
3,500\end{array}$ & $\begin{array}{l}7.48 \\
8.03 \\
8.04 \\
8.05\end{array}$ & $\begin{array}{l}3,570 \\
3,650 \\
3,670 \\
3,680\end{array}$ & $\begin{array}{l}8.04 \\
8.03 \\
8.02 \\
8.07\end{array}$ & $\begin{array}{l}3,670 \\
3,650 \\
3,630 \\
3,720\end{array}$ \\
\hline
\end{tabular}


Gage-height, in feet, and discharge, in second-feet, at indicated time, 1938-Continued

\begin{tabular}{|c|c|c|c|c|c|c|c|c|c|c|c|c|}
\hline \multirow{2}{*}{ Hour } & Feet & Sec.-ft. & Feet & Sec.-ft. & Feet & Sec-ft. & Feet & Sec.-ft. & Feet & Sec.-ft. & Feet & Sec.-ft. \\
\hline & \multicolumn{2}{|c|}{ July 29} & \multicolumn{2}{|c|}{ July 30} & \multicolumn{2}{|c|}{ July 31} & \multicolumn{2}{|c|}{ August 1} & \multicolumn{2}{|c|}{ Angust 2} & \multicolumn{2}{|c|}{ August 3} \\
\hline $\begin{array}{r}6 \mathrm{a.m} . \\
12 \mathrm{n} . \\
6 \mathrm{p.m} . \\
12 \mathrm{~m} .\end{array}$ & $\begin{array}{l}8.11 \\
8.07 \\
8.06 \\
7.95\end{array}$ & $\begin{array}{l}3,790 \\
3,720 \\
3,700 \\
3,520\end{array}$ & $\begin{array}{l}7.93 \\
7.90 \\
7.88 \\
7.84\end{array}$ & $\begin{array}{l}3,490 \\
3,440 \\
3,410 \\
3,350\end{array}$ & $\begin{array}{l}7.83 \\
7.80 \\
7.77 \\
7.74\end{array}$ & $\begin{array}{l}3,340 \\
3,290 \\
3,250 \\
3,210\end{array}$ & $\begin{array}{l}7.70 \\
7.71 \\
7.67 \\
7.65\end{array}$ & $\begin{array}{l}3,150 \\
3,160 \\
3,110 \\
3,080\end{array}$ & $\begin{array}{l}7.58 \\
7.52 \\
7.50 \\
7.45\end{array}$ & $\begin{array}{l}2,990 \\
2,920 \\
2,890 \\
2,820\end{array}$ & $\begin{array}{l}7.38 \\
7.35 \\
7.30 \\
7.25\end{array}$ & $\begin{array}{l}2,730 \\
2,700 \\
2,630 \\
2,560\end{array}$ \\
\hline & \multicolumn{2}{|c|}{ August 4} & \multicolumn{2}{|c|}{ August 5} & \multicolumn{2}{|c|}{ August 6} & \multicolumn{2}{|c|}{ August 7} & \multicolumn{2}{|c|}{ August 8} & \multicolumn{2}{|c|}{ August 9} \\
\hline $\begin{array}{r}6 \mathrm{a} . \mathrm{m} . \\
12 \mathrm{n} . \\
6 \mathrm{p} . \mathrm{m} . \\
12 \mathrm{~m} .\end{array}$ & $\begin{array}{l}7.20 \\
7.17 \\
7.11 \\
7.05\end{array}$ & $\begin{array}{l}2,500 \\
2,460 \\
2,380 \\
2,300\end{array}$ & $\begin{array}{l}7.00 \\
6.97 \\
6.90 \\
6.84\end{array}$ & $\begin{array}{l}2,240 \\
2,200 \\
2,110 \\
2,040\end{array}$ & $\begin{array}{l}6.78 \\
6.72 \\
6.67 \\
6.64\end{array}$ & $\begin{array}{l}1,970 \\
1,890 \\
1,840 \\
1,800\end{array}$ & $\begin{array}{l}6.60 \\
6.56 \\
6.53 \\
6.49\end{array}$ & $\begin{array}{l}1,760 \\
1,720 \\
1,680 \\
1,640\end{array}$ & $\begin{array}{l}6.45 \\
6.44 \\
6.39 \\
6.36\end{array}$ & $\begin{array}{l}1,600 \\
1,580 \\
1,530 \\
1,500\end{array}$ & $\begin{array}{l}6.35 \\
6.32 \\
6.29 \\
6.24\end{array}$ & $\begin{array}{l}1,490 \\
1,460 \\
1,430 \\
1,380\end{array}$ \\
\hline
\end{tabular}

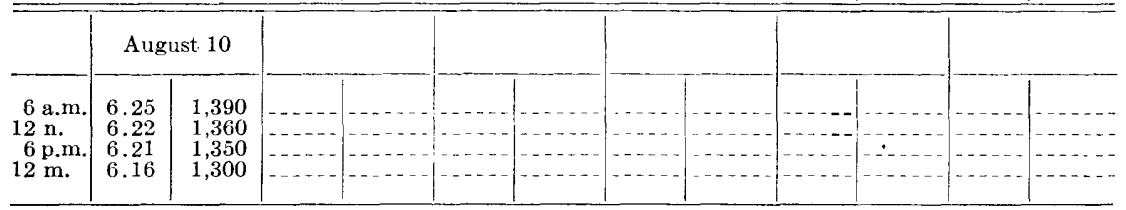

1Adjusted for wastage by Boston metropolitan district in diverting from 92.6 square miles in Sudbury River and Lake Cochituate Basirs.

\section{WASTAGE FROM SUDBURY RIVER BASIN AT OUTIETS OF FRAMINGHAM RESERVOIR NO. I, NEAR FRAMINGHAM CENTER, MASS., AND IATE COCHITUATE AT COCHITUATE, MASS.}

Location.-Outlet of Framingham Reservoir No. 1, lat. 42 17'30", long. $71^{\circ} 26^{\prime} 40^{\prime \prime}$, half a mile upstream from outlet of Farm Pond and threequarters of a mile southwest of Framingham Center, Middlesex County.

Outlet of Lake Cochituate, lat. $42^{\circ} 18^{\prime} 45^{\prime \prime}$, long. $71^{\circ} 23^{\prime} 15^{\prime \prime}$, threeeighths of a mile north of Cochituate railroad station, Middlesex County, and $1 \frac{1}{4}$ miles upstream from Sudbury River.

Drainage area.--92.6 square miles (tributary to Concord River).

Remarks.-Discharge is water wasted into Concord River and does not include diversions from Sudbury River Basin for water supply. Records furnished by water division of the Metropolitan District Commission.

Mean discharge, in second-feet, 1938

\begin{tabular}{r|r|r|r|r|r|r|r|r|r|r|r}
\hline Day & June & July & Aug. & Day & June & July & Aug. & Day & June & July & Aug. \\
\hline & & & & & & & & \\
1 & 95 & 435 & 500 & 11 & 42 & 48 & 138 & 21 & 110 & 599 & 104 \\
2 & 84 & 297 & 460 & 12 & 89 & 74 & 120 & 22 & 61 & 1,040 & 99 \\
3 & 51 & 197 & 287 & 13 & 220 & 88 & 100 & 23 & 57 & 1,720 & 105 \\
4 & 54 & 169 & 238 & 14 & 204 & 86 & 93 & 24 & 49 & 2,150 & 98 \\
5 & 59 & 142 & 224 & 15 & 281 & 92 & 129 & 25 & 42 & 1,720 & 88 \\
6 & 50 & 119 & 180 & 16 & 289 & 80 & 126 & 26 & 57 & 1,430 & 82 \\
7 & 42 & 106 & 179 & 17 & 272 & 72 & 130 & 27 & 162 & 1,040 & 73 \\
8 & 37 & 57 & 153 & 18 & 158 & 80 & 127 & 28 & 432 & 848 & 77 \\
9 & 32 & 50 & 172 & 19 & 126 & 146 & 120 & 29 & 583 & 763 & 31 \\
10 & 28 & 46 & 132 & 20 & 124 & 367 & 110 & 30 & 537 & 687 & 32 \\
& & & & & & & & 31 & & 642 & 45 \\
\hline
\end{tabular}




\section{IPSWICH RIVER BASIN}

\section{IPSWICH RIVER AT SOUTH MIDDIFTON, MASS.}

Location.-Lat. $42^{\circ} 34^{\prime} 10^{\prime \prime}$, long. $71^{\circ} 01^{\prime} 35^{\prime \prime}$, at South Middleton, Essex County, 700 feet downstream from Boston Street highway bridge, 1.3 miles downstream from Will's Brook, and 2 miles south of Middleton.

Drainage AREA.-43.4 square miles.

GAGE-HEIGHT RECORD.-Water-stage recorder graph.

StaGe-discharce RELATION.-Defined by current-meter measurements below 590 second-feet.

Maxima.-July 1938: Discharge, 608 second-feet 8 to 12 p. m. July 24 (gage height, 5.72 feet).

REMARKs.-Flood discharge considerably affected by natural storage and slightly affected by diversions.

Mean discharge, in second-feet, 1938

\begin{tabular}{|c|c|c|c|c|c|c|c|c|c|c|c|}
\hline Day & June & July & Aug. & Day & June & July & Aug. & Day & June & July & Aug. \\
\hline $\begin{array}{r}1 \\
2 \\
3 \\
4 \\
5 \\
6 \\
7 \\
8 \\
9 \\
10\end{array}$ & $\begin{array}{l}64 \\
61 \\
58 \\
54 \\
52 \\
49 \\
47 \\
47 \\
46 \\
41\end{array}$ & $\begin{array}{r}134 \\
138 \\
134 \\
119 \\
108 \\
79 \\
81 \\
66 \\
56 \\
49\end{array}$ & $\begin{array}{l}301 \\
274 \\
246 \\
221 \\
186 \\
158 \\
138 \\
126 \\
110 \\
100\end{array}$ & $\begin{array}{l}11 \\
12 \\
13 \\
14 \\
15 \\
16 \\
17 \\
18 \\
19 \\
20\end{array}$ & $\begin{array}{r}36 \\
42 \\
68 \\
71 \\
64 \\
67 \\
68 \\
67 \\
62 \\
57\end{array}$ & $\begin{array}{l}33 \\
55 \\
42 \\
37 \\
37 \\
37 \\
35 \\
37 \\
83 \\
96\end{array}$ & $\begin{array}{l}84 \\
72 \\
72 \\
67 \\
62 \\
59 \\
70 \\
68 \\
65 \\
62\end{array}$ & $\begin{array}{l}21 \\
22 \\
23 \\
24 \\
25 \\
26 \\
27 \\
28 \\
29 \\
30 \\
31\end{array}$ & $\begin{array}{r}54 \\
51 \\
47 \\
41 \\
38 \\
32 \\
54 \\
103 \\
116 \\
134\end{array}$ & $\begin{array}{l}161 \\
323 \\
397 \\
584 \\
584 \\
\tilde{5} 27 \\
474 \\
427 \\
383 \\
383 \\
334\end{array}$ & $\begin{array}{l}56 \\
56 \\
52 \\
47 \\
41 \\
29 \\
28 \\
30 \\
29 \\
27 \\
23\end{array}$ \\
\hline $\begin{array}{l}\text { Mor } \\
\text { Rur }\end{array}$ & $\mathrm{n} \mathrm{i}$ & $\begin{array}{l}\text { har } \\
\text { idju }\end{array}$ & & & & & & & $\begin{array}{c}60.7 \\
1.56\end{array}$ & $\begin{array}{r}196 \\
5.21\end{array}$ & $\begin{array}{c}96.4 \\
2.56\end{array}$ \\
\hline
\end{tabular}

Gage-height, in feet, and discharge, in second-feet, at indicated time, 1938

\begin{tabular}{|c|c|c|c|c|c|c|c|c|c|c|c|c|}
\hline \multirow{2}{*}{ Hour } & Feet & Sec.-ft. & Feet & Sec.-ft. & Feet & Sec.-ft. & Feet & Sec.-ft. & Feet & Sec.-ft. & Feet & Sec.-ft. \\
\hline & \multicolumn{2}{|c|}{ July 17} & \multicolumn{2}{|c|}{ July 18} & \multicolumn{2}{|c|}{ July 19} & \multicolumn{2}{|c|}{ July 20} & \multicolumn{2}{|c|}{ July 21} & \multicolumn{2}{|c|}{ July 22} \\
\hline \multirow[t]{2}{*}{$\begin{array}{c}6 \mathrm{a} . \mathrm{m} . \\
12 \mathrm{n} . \\
6 \mathrm{p.m} . \\
12 \mathrm{~m} .\end{array}$} & $\begin{array}{l}0.79 \\
.79 \\
.78 \\
.77\end{array}$ & $\begin{array}{l}35 \\
35 \\
34 \\
33\end{array}$ & $\begin{array}{l}0.77 \\
.77 \\
.82 \\
.98\end{array}$ & $\begin{array}{l}33 \\
33 \\
38 \\
58\end{array}$ & $\begin{array}{l}1.07 \\
1.29 \\
1.29 \\
1.31\end{array}$ & $\begin{array}{l}68 \\
88 \\
88 \\
90\end{array}$ & $\begin{array}{l}1.32 \\
1.41 \\
1.45 \\
1.51\end{array}$ & $\begin{array}{r}91 \\
98 \\
100 \\
104\end{array}$ & $\begin{array}{l}1.59 \\
2.21 \\
2.86 \\
3.38\end{array}$ & $\begin{array}{l}108 \\
151 \\
212 \\
266\end{array}$ & $\begin{array}{l}3.82 \\
3.95 \\
4.00 \\
4.02\end{array}$ & $\begin{array}{l}314 \\
328 \\
334 \\
336\end{array}$ \\
\hline & \multicolumn{2}{|c|}{ July 23} & \multicolumn{2}{|c|}{ July 24} & \multicolumn{2}{|c|}{ July 25} & \multicolumn{2}{|c|}{ July 26} & \multicolumn{2}{|c|}{ Juìy 27} & \multicolumn{2}{|c|}{ July 28} \\
\hline $\begin{array}{c}6 \mathrm{a} . \mathrm{m} . \\
12 \mathrm{n} . \\
6 \mathrm{p.m} . \\
12 \mathrm{~m} .\end{array}$ & $\begin{array}{l}4.08 \\
4.39 \\
4.82 \\
5.32\end{array}$ & $\begin{array}{l}344 \\
382 \\
445 \\
531\end{array}$ & $\begin{array}{l}5.52 \\
5.67 \\
5.71 \\
5.72\end{array}$ & $\begin{array}{l}568 \\
598 \\
606 \\
608\end{array}$ & $\begin{array}{l}5.69 \\
5.63 \\
5.55 \\
5.47\end{array}$ & $\begin{array}{l}602 \\
590 \\
574 \\
558\end{array}$ & $\begin{array}{l}5.38 \\
5.31 \\
5.23 \\
5.16\end{array}$ & $\begin{array}{l}541 \\
529 \\
514 \\
502\end{array}$ & $\begin{array}{l}5.09 \\
5.01 \\
4.92 \\
4.85\end{array}$ & $\begin{array}{l}489 \\
476 \\
461 \\
450\end{array}$ & $\begin{array}{l}4.76 \\
4.67 \\
4.57 \\
4.46\end{array}$ & $\begin{array}{l}436 \\
422 \\
408 \\
391\end{array}$ \\
\hline & \multicolumn{2}{|c|}{ July 29} & \multicolumn{2}{|c|}{ July 30} & \multicolumn{2}{|c|}{ July 31} & \multicolumn{2}{|c|}{ August 1} & \multicolumn{2}{|c|}{ August 2} & \multicolumn{2}{|c|}{ August 3} \\
\hline $\begin{array}{c}6 \mathrm{a} . \mathrm{m} \\
12 \mathrm{n} . \\
6 \mathrm{p.m} \\
12 \mathrm{~m} .\end{array}$ & $\begin{array}{l}4.34 \\
4.47 \\
4.48 \\
4.51\end{array}$ & $\begin{array}{l}375 \\
393 \\
394 \\
398\end{array}$ & $\begin{array}{l}4.48 \\
4.40 \\
4.30 \\
4.20\end{array}$ & $\begin{array}{l}394 \\
383 \\
370 \\
358\end{array}$ & $\begin{array}{l}4.12 \\
4.03 \\
3.93 \\
3.86\end{array}$ & $\begin{array}{l}348 \\
338 \\
326 \\
319\end{array}$ & $\begin{array}{l}3.79 \\
3.73 \\
3.64 \\
3.59\end{array}$ & $\begin{array}{l}311 \\
304 \\
294 \\
289\end{array}$ & $\begin{array}{l}3.53 \\
3.46 \\
3.36 \\
3.30\end{array}$ & $\begin{array}{l}282 \\
275 \\
264 \\
257\end{array}$ & $\begin{array}{l}3.24 \\
3.18 \\
3.12 \\
3.07\end{array}$ & $\begin{array}{l}250 \\
244 \\
238 \\
233\end{array}$ \\
\hline
\end{tabular}


Gage-height, in feet, and discharge, in second-feet, at indicated time, 1938-Continued

\begin{tabular}{|c|c|c|c|c|c|c|c|c|c|c|c|c|}
\hline \multirow{2}{*}{ Hour } & Feet & Sec.-ft. & Feet & Sec. $-\mathbf{f t}$. & Feet & Sec.-ft. & Feet & Sec. $-\mathrm{ft}$. & Feet & Sec.-ft. & Feet & sec. $-\mathrm{ft}$. \\
\hline & \multicolumn{2}{|c|}{ August 4} & \multicolumn{2}{|c|}{ August 5} & \multicolumn{2}{|c|}{ August 6} & \multicolumn{2}{|c|}{ August 7} & \multicolumn{2}{|c|}{ August 8} & \multicolumn{2}{|c|}{ Aurust 9} \\
\hline $\begin{array}{c}6 \mathrm{a.m} . \\
12 \mathrm{n.} \\
6 \mathrm{p.m} . \\
12 \mathrm{~m} .\end{array}$ & $\begin{array}{l}3.01 \\
2.98 \\
2.85 \\
2.77\end{array}$ & $\begin{array}{l}227 \\
224 \\
211 \\
203\end{array}$ & $\begin{array}{l}2.69 \\
2.61 \\
2.53 \\
2.45\end{array}$ & $\begin{array}{l}19.7 \\
187 \\
179 \\
172\end{array}$ & $\begin{array}{l}2.38 \\
2.30 \\
2.22 \\
2.14\end{array}$ & $\begin{array}{l}165 \\
158 \\
152 \\
145\end{array}$ & $\begin{array}{l}2.07 \\
2.01 \\
2.07 \\
2.02\end{array}$ & $\begin{array}{l}140 \\
135 \\
140 \\
136\end{array}$ & $\begin{array}{l}1.96 \\
1.90 \\
1.83 \\
1.79\end{array}$ & $\begin{array}{l}131 \\
126 \\
121 \\
118\end{array}$ & $\begin{array}{l}1.72 \\
1.66 \\
1.60 \\
1.55\end{array}$ & $\begin{array}{l}114 \\
111 \\
108 \\
106\end{array}$ \\
\hline & \multicolumn{2}{|c|}{ August 10} & & & & & & & & & & \\
\hline $\begin{array}{c}6 \mathrm{amm} . \\
12 \mathrm{n.} \\
6 \mathrm{v.m} . \\
12 \mathrm{m.}\end{array}$ & $\begin{array}{l}1.50 \\
1.43 \\
1.37 \\
1.31\end{array}$ & $\begin{array}{r}103 \\
99 \\
95 \\
90\end{array}$ & & & & $\mid \begin{array}{c}\cdots \\
\cdots \\
\cdots \\
\cdots \\
\cdots\end{array}$ & & & & $\mid \begin{array}{c}-\cdots \\
\cdots \\
\cdots \\
-\cdots\end{array}$ & & $\begin{array}{l}\cdots \\
\cdots \\
\cdots\end{array}$ \\
\hline
\end{tabular}

Adjusted for diversions for muniripal supply of Reading. Lynn, and Peabody.

IPSWICH RIVER NEAR IPSWICH, MAss.

Location.-Lat. $42^{\circ} 39^{\prime} 35^{\prime \prime}$, long. 70 $53^{\prime} 35^{\prime \prime}, 200$ feet downstream from Willowdale Dam, 11/2 miles downstream from Howlett Brook, and 4 miles upstream from Ipswich, Essex County. Datum of gage is 20.63 feet above mean sea level (general adjustment of 1929).

Dratiage area.-124 square miles (not including area drained by Suntaug Lake).

GAGE-HEIGHT RECORD.-Water-stage recorder graph.

Stage-discharge RELATION.-Rating curve defined by current-meter measurements below 2,530 second-feet.

Maxima.-July 1938: Discharge, 1,700 second-feet 6 to 8 a. m. July 26 (gage height, 6.29 feet).

1930 to June 1938: Discharge, 2,610 second-feet Mar. 15, 1936 (gage height, 7.70 feet).

REMARKs.-Flood discharge considerably affected by natural storage and slightly affected by diversions.

Mean discharge, in second-feet, 1938

\begin{tabular}{r|c|c|c|c|c|c|c|}
\hline Day & June & July & Aug. & Day & June & July & Aug. \\
\hline 1 & 171 & 247 & 932 & 11 & 110 & 157 & 368 \\
2 & 163 & 290 & 858 & 12 & 108 & 154 & 341 \\
3 & 154 & 302 & 768 & 13 & 118 & 144 & 302 \\
4 & 146 & 298 & 708 & 14 & 120 & 139 & 270 \\
5 & 146 & 282 & 640 & 15 & 127 & 132 & 240 \\
6 & 141 & 262 & 584 & 16 & 139 & 127 & 219 \\
7 & 134 & 240 & 522 & 17 & 152 & 118 & 222 \\
8 & 127 & 219 & 474 & 18 & 163 & 127 & 236 \\
9 & 123 & 193 & 430 & 19 & 154 & 139 & 262 \\
10 & 114 & 174 & 395 & 20 & 146 & 163 & 278 \\
& & & & & & & \\
\hline
\end{tabular}

Monthly mean discharge, in second-feet (adjusted for diversions ${ }^{1}$ )
Runoff, in inches (adjusted for diversions 1 )

\begin{tabular}{|c|c|c|c}
\hline Day & June & July & Aug. \\
\hline & & & \\
\hline 21 & 136 & 236 & 274 \\
22 & 130 & 410 & 251 \\
23 & 123 & 700 & 225 \\
24 & 116 & 1,220 & 206 \\
25 & 108 & 1,600 & 187 \\
26 & 102 & 1,680 & 171 \\
27 & 114 & 1,540 & 160 \\
28 & 136 & 1,400 & 146 \\
29 & 171 & 1,220 & 134 \\
30 & 212 & 1,120 & 123 \\
31 & & 1,010 & 114 \\
\hline & & & \\
\hline & 140 & 520 & 359 \\
\hline
\end{tabular}


Gage-height, in feet, and discharge, in second-feet, at indicated time, 1938

\begin{tabular}{|c|c|c|c|c|c|c|c|c|c|c|c|c|}
\hline \multirow{2}{*}{ Hour } & Feet & Sec.-ft. & Feet & Sec-ft. & Feft & Sec.-ft. & Feet & Sec. $\mathrm{ft}$. & Feet & Ser.ft. & Teet & Stert. $\mathrm{ft}$. \\
\hline & \multicolumn{2}{|c|}{ July 17} & \multicolumn{2}{|c|}{ July 18} & \multicolumn{2}{|c|}{ July 19} & \multicolumn{2}{|c|}{ July 20} & \multicolumn{2}{|c|}{ July 21} & \multicolumn{2}{|c|}{ July 22} \\
\hline fia.m. & 3.60 & 118 & 3.58 & 114 & 3.68 & 136 & $\bullet 3.72$ & 146 & 3.90 & 199 & 4.33 & 368 \\
\hline $12 \mathrm{n}$. & 3.60 & 118 & 3.58 & 114 & 3.69 & 139 & 3.75 & 154 & 3.9 & 216 & 4.42 & 410 \\
\hline (ip.ul) & 3.60 & 118 & 3.78 & 163 & 3.7 & 14 & 3.82 & 17 & 4. & 30 & 4.52 & 462 \\
\hline $12 \mathrm{n}$ & 3.59 & 11 & 3.69 & 139 & 3.71 & 144 & $3.8 \overline{7}$ & 184 & 4.23 & 323 & 4.61 & 516 \\
\hline
\end{tabular}

\begin{tabular}{|c|c|c|c|c|c|c|c|c|c|c|c|c|}
\hline \multirow{5}{*}{$\begin{array}{r}6 \mathrm{a} . \mathrm{m} . \\
12 \mathrm{n} . \\
6 \mathrm{p.m} . \\
12 \mathrm{~m} .\end{array}$} & \multicolumn{2}{|c|}{ July 23} & \multicolumn{2}{|c|}{ July 24} & \multicolumn{2}{|c|}{ July 25} & \multicolumn{2}{|c|}{ July $26 \mathrm{i}$} & \multicolumn{2}{|c|}{$J$ July 27} & \multicolumn{2}{|c|}{ July 28} \\
\hline & 4.7 & 577 & 5.40 & 1,080 & 6.08 & 1,560 & 6.29 & 1,700 & 6.13 & 1,590 & 5.92 & 1,440 \\
\hline & 4.87 & 692 & 5.61 & 1.230 & 6.20 & 1,640 & 6.26 & 1,680 & 6. 06 & 1,54 & 5.85 & 1,400 \\
\hline & 5.07 & 842 & 5.80 & 1,360 & 6.25 & 1,68 & 6.24 & 1,670 & 6.0 & 1,500 & 5.77 & 1,340 \\
\hline & 5.22 & 954 & 5.96 & 1,470 & 6.27 & 1,690 & 6.19 & 1,630 & 5.98 & 1,490 & 5.70 & 1,290 \\
\hline
\end{tabular}

\begin{tabular}{|c|c|c|c|c|c|c|c|c|c|c|c|c|}
\hline \multirow{5}{*}{$\begin{array}{c}6 \mathrm{a} . \mathrm{m} . \\
32 \mathrm{n} . \\
6 \mathrm{pm} . \\
12 \mathrm{~m} .\end{array}$} & \multicolumn{2}{|c|}{ duly 29} & \multicolumn{2}{|c|}{ July 30} & \multicolumn{2}{|c|}{ July 31} & \multicolumn{2}{|c|}{ August 1} & \multicolumn{2}{|c|}{ August 2} & \multicolumn{2}{|c|}{ August 3} \\
\hline & $=64$ & 1,250 & 51 & 1,160 & 5.35 & $1.0+0$ & 5.22 & 9.54 & 5.12 & 880 & j. 00 & 790 \\
\hline & 5.63 & 1,240 & $3 .+8$ & 1,140 & 5.32 & 1.020 & .19 & 432 & $\because 08$ & 850 & $\begin{array}{l}3.00 \\
4.96\end{array}$ & 760 \\
\hline & 5.60 & 1,220 & 5.42 & 1,090 & 5. 28 & $99 f i$ & 5.16 & 910 & $\therefore .05$ & 828 & $\begin{array}{r}4.94 \\
\end{array}$ & 745 \\
\hline & 5.56 & 1.190 & 5.39 & 1.070 & 5.25 & $97 \therefore$ & 5.15 & 902 & 5.02 & 805 & 4.93 & 738 \\
\hline
\end{tabular}

\begin{tabular}{|c|c|c|c|c|c|c|c|c|c|c|c|c|}
\hline \multirow[b]{2}{*}{$\begin{array}{r}6 \mathrm{a.m} . \\
12 \mathrm{n} . \\
6 \mathrm{p.m} . \\
12 \mathrm{ln} .\end{array}$} & \multicolumn{2}{|c|}{ August 4} & \multicolumn{2}{|c|}{ August j } & \multicolumn{2}{|c|}{ August 6} & \multicolumn{2}{|c|}{ August 7} & \multicolumn{2}{|c|}{ August 8} & \multicolumn{2}{|c|}{ August 9} \\
\hline & $\begin{array}{l}4.92 \\
+.90 \\
4.85 \\
4.83\end{array}$ & $\begin{array}{l}730 \\
715 \\
678 \\
662\end{array}$ & $\begin{array}{l}4.82 \\
4.80 \\
4.78 \\
4.75\end{array}$ & $\begin{array}{l}655 \\
640 \\
626 \\
605\end{array}$ & $\begin{array}{l}4.74 \\
1.72 \\
4.70 \\
4.67\end{array}$ & $\begin{array}{l}598 \\
584 \\
570 \\
552\end{array}$ & $\begin{array}{l}4.65 \\
4.62 \\
4.60 \\
4.58\end{array}$ & $\begin{array}{l}540 \\
52+2 \\
510 \\
498\end{array}$ & $\begin{array}{l}4.56 \\
4.54 \\
4.51 \\
4.50\end{array}$ & $\begin{array}{l}486 \\
474 \\
456 \\
450\end{array}$ & $\begin{array}{l}4.48 \\
4.46 \\
4.45 \\
4.43\end{array}$ & $\begin{array}{l}440 \\
430 \\
425 \\
415\end{array}$ \\
\hline
\end{tabular}

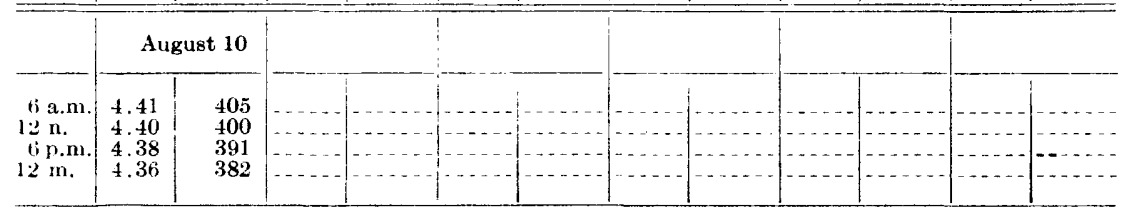

Adjusted for diversions for municipal supply of Reading, Lynn, Peabody, Danvers, Salem, and Beverly

\section{CHARLES RIVER BASIN}

CHARTES RIVRB AT CAARIFS RTVER VITLAGF, MASS.

Location.-Lat. $42^{\circ} 15^{\prime} 20^{\prime \prime}$, long. $71^{\circ} 15^{\prime} 40^{\prime \prime}$, in Charles River Village, Norfolk County, 0.25 mile downstream from highway bridge, and 0.8 mile downstream from unnamed tributary. Datum of gage is 89.76 feet above mean sea level (general adjustment of 1929).

INAINAGE AREA.-184 square miles.

CACE-HEIGHT RECORD.-Water-stage recorder graph.

STAGE-DISCHARGE RELATION.-Defined by current-meter measurements below 3,020 second-feet.

Maxina.-July 1938: Discharge, 3,110 second-feet 3 p. m. July 27 (gage height, 9.00 feet).

1937 to June 1938: Discharge 1,260 second-feet 8 a. m. Jan. 29, 1938 (gage height, 4.66).

Discharge known, 3,170 second-feet March 1936, by computation of flow over dam at site a quarter of a mile above station.

REMaRKs.-Flood discharge considerably affected by natural storage and slightly affected by diversions for municipal supply of Wellesley and Needham. 
Mean discharge, in second-feet, 1938

\begin{tabular}{|c|c|c|c|c|c|c|c|c|c|c|c|}
\hline Day & June & July & Aug. & Day & June & July & Aug. & Day & June & July & Aug. \\
\hline $\begin{array}{r}1 \\
2 \\
3 \\
4 \\
5 \\
6 \\
7 \\
8 \\
9 \\
10\end{array}$ & $\begin{array}{l}363 \\
342 \\
316 \\
270 \\
254 \\
246 \\
239 \\
216 \\
202 \\
188\end{array}$ & $\begin{array}{l}718 \\
814 \\
862 \\
862 \\
782 \\
702 \\
640 \\
568 \\
514 \\
464\end{array}$ & $\begin{array}{r}1,660 \\
1,460 \\
1,280 \\
1,110 \\
990 \\
902 \\
787 \\
705 \\
705 \\
640\end{array}$ & $\begin{array}{l}11 \\
12 \\
13 \\
14 \\
15 \\
16 \\
17 \\
18 \\
19 \\
20\end{array}$ & $\begin{array}{l}18 \% \\
206 \\
305 \\
374 \\
406 \\
440 \\
464 \\
464 \\
429 \\
406\end{array}$ & $\begin{array}{l}418 \\
406 \\
374 \\
363 \\
352 \\
335 \\
322 \\
326 \\
363 \\
429\end{array}$ & $\begin{array}{l}601 \\
550 \\
514 \\
478 \\
444 \\
402 \\
444 \\
444 \\
466 \\
502\end{array}$ & $\begin{array}{l}21 \\
22 \\
23 \\
24 \\
25 \\
26 \\
27 \\
28 \\
29 \\
30 \\
31\end{array}$ & $\begin{array}{l}363 \\
340 \\
310 \\
281 \\
267 \\
265 \\
303 \\
429 \\
540 \\
625\end{array}$ & $\begin{array}{r}561 \\
994 \\
1,240 \\
1,870 \\
2,300 \\
2,780 \\
3,020 \\
2,860 \\
2,500 \\
2,200 \\
1,920\end{array}$ & $\begin{array}{l}502 \\
478 \\
455 \\
412 \\
382 \\
353 \\
320 \\
294 \\
250 \\
214 \\
198\end{array}$ \\
\hline \multicolumn{9}{|c|}{$\begin{array}{l}\text { Monthly mean discharge, in second-feet (adjusted for diversions }{ }^{1} \text { ) } \\
\text { Runoff, in inches (adjusted for diversions }{ }^{1} \text { ) }\end{array}$} & $\begin{array}{r}338 \\
2.05\end{array}$ & $\begin{array}{r}1,063 \\
6.66\end{array}$ & $\begin{array}{r}614 \\
3.85\end{array}$ \\
\hline
\end{tabular}

Gage-height, in feet, and discharge, in second-feet, at indicated time, 1938

\begin{tabular}{|c|c|c|c|c|c|c|c|c|c|c|c|c|}
\hline \multirow{2}{*}{ Hour } & Feet & Sec.-ft. & Feet & Sec.-ft. & Feet & Sec.-ft. & Feet & Sec.-ft. & Feet & Sec.-ft. & Feet & Sec-ft. \\
\hline & \multicolumn{2}{|c|}{ July 17} & \multicolumn{2}{|c|}{ July 18} & \multicolumn{2}{|c|}{ July 19} & \multicolumn{2}{|c|}{ July 20} & \multicolumn{2}{|c|}{ July 21} & \multicolumn{2}{|c|}{ July 22} \\
\hline \multirow[t]{2}{*}{$\begin{array}{c}6 \mathrm{a.m} . \\
12 \mathrm{n} . \\
6 \mathrm{p.m} . \\
12 \mathrm{~m} .\end{array}$} & $\begin{array}{l}2.21 \\
2.20 \\
2.17 \\
2.15\end{array}$ & $\begin{array}{l}326 \\
324 \\
319 \\
316\end{array}$ & $\begin{array}{l}2.13 \\
2.14 \\
2.33 \\
2.41\end{array}$ & $\begin{array}{l}313 \\
314 \\
349 \\
365\end{array}$ & $\begin{array}{l}2.36 \\
2.44 \\
2.47 \\
2.47\end{array}$ & $\begin{array}{l}355 \\
371 \\
378 \\
378\end{array}$ & $\begin{array}{l}2.46 \\
2.68 \\
2.87 \\
2.88\end{array}$ & $\begin{array}{l}376 \\
424 \\
468 \\
470\end{array}$ & $\begin{array}{l}2.88 \\
2.92 \\
3.53 \\
4.22\end{array}$ & $\begin{array}{l}470 \\
480 \\
649 \\
868\end{array}$ & $\begin{array}{l}4.61 \\
4.70 \\
4.68 \\
4.71\end{array}$ & $\begin{array}{r}997 \\
1,030 \\
1,020 \\
1,030\end{array}$ \\
\hline & \multicolumn{2}{|c|}{ July 23} & \multicolumn{2}{|c|}{ July 24} & \multicolumn{2}{|c|}{ July 25} & \multicolumn{2}{|c|}{ July 26} & \multicolumn{2}{|c|}{ July 27} & \multicolumn{2}{|c|}{ July 28} \\
\hline \multirow[t]{2}{*}{$\begin{array}{c}6 \text { a.m. } \\
12 \mathrm{n} . \\
6 \mathrm{p.m} . \\
12 \mathrm{~m} .\end{array}$} & $\begin{array}{l}4.81 \\
5.18 \\
5.73 \\
6.27\end{array}$ & $\begin{array}{l}1,060 \\
1,200 \\
1,400 \\
1,610\end{array}$ & $\begin{array}{l}6.61 \\
6.88 \\
7.13 \\
7.34\end{array}$ & $\begin{array}{l}1,740 \\
1,860 \\
1,970 \\
2,070\end{array}$ & $\begin{array}{l}7.55 \\
7.78 \\
8.02 \\
8.25\end{array}$ & $\begin{array}{l}2,180 \\
2,290 \\
2,410 \\
2,530\end{array}$ & $\begin{array}{l}8.46 \\
8.64 \\
8.74 \\
8.81\end{array}$ & $\begin{array}{l}2,670 \\
2,810 \\
2,890 \\
2,950\end{array}$ & $\begin{array}{l}8.87 \\
8.90 \\
8.96 \\
8.91\end{array}$ & $\begin{array}{l}3,000 \\
3,020 \\
3,070 \\
3,030\end{array}$ & $\begin{array}{l}8.82 \\
8.73 \\
8.61 \\
8.48\end{array}$ & $\begin{array}{l}2,960 \\
2,880 \\
2,790 \\
2,690\end{array}$ \\
\hline & \multicolumn{2}{|c|}{ July 29} & \multicolumn{2}{|c|}{ July 30} & \multicolumn{2}{|c|}{ July 31} & \multicolumn{2}{|c|}{ August 1} & \multicolumn{2}{|c|}{ August 2} & \multicolumn{2}{|c|}{ August 3} \\
\hline \multirow[t]{2}{*}{$\begin{array}{c}6 \mathrm{a} . \mathrm{m} . \\
12 \mathrm{n} . \\
6 \mathrm{p.m} . \\
12 \mathrm{~m} .\end{array}$} & $\begin{array}{l}8.34 \\
8.20 \\
8.05 \\
7.91\end{array}$ & $\begin{array}{l}2,590 \\
2,500 \\
2,420 \\
2,360\end{array}$ & $\begin{array}{l}7.76 \\
7.61 \\
7.45 \\
7.30\end{array}$ & $\begin{array}{l}2,280 \\
2,200 \\
2,120 \\
2,050\end{array}$ & $\begin{array}{l}7.15 \\
7.01 \\
6.86 \\
6.72\end{array}$ & $\begin{array}{l}1,980 \\
1,920 \\
1,850 \\
1,790\end{array}$ & $\begin{array}{l}6.57 \\
6.44 \\
6.31 \\
6.17\end{array}$ & $\begin{array}{l}1,730 \\
1,680 \\
1,620 \\
1,570\end{array}$ & $\begin{array}{l}6.04 \\
5.92 \\
5.77 \\
5.64\end{array}$ & $\begin{array}{l}1,520 \\
1,470 \\
1,410 \\
1,360\end{array}$ & $\begin{array}{l}5.51 \\
5.40 \\
5.26 \\
5.15\end{array}$ & $\begin{array}{l}1,310 \\
1,280 \\
1,230 \\
1,200\end{array}$ \\
\hline & \multicolumn{2}{|c|}{ August 4} & \multicolumn{2}{|c|}{ August 5} & \multicolumn{2}{|c|}{ August 6} & \multicolumn{2}{|c|}{ August 7} & \multicolumn{2}{|c|}{ August 8} & \multicolumn{2}{|c|}{ August 9} \\
\hline $\begin{array}{c}6 \mathrm{a} . \mathrm{m} . \\
12 \mathrm{n} . \\
6 \mathrm{p.m} . \\
12 \mathrm{~m} .\end{array}$ & $\begin{array}{l}5.04 \\
4.93 \\
4.83 \\
4.72\end{array}$ & $\begin{array}{l}1,150 \\
1,120 \\
1,090 \\
1,060\end{array}$ & $\begin{array}{l}4.62 \\
4.52 \\
4.42 \\
4.32\end{array}$ & $\begin{array}{r}1,030 \\
996 \\
966 \\
937\end{array}$ & $\begin{array}{l}4.24 \\
4.16 \\
4.06 \\
3.97\end{array}$ & $\begin{array}{l}914 \\
890 \\
861 \\
835\end{array}$ & $\begin{array}{l}3.89 \\
3.81 \\
3.73 \\
3.66\end{array}$ & $\begin{array}{l}812 \\
790 \\
767 \\
748\end{array}$ & $\begin{array}{l}3.59 \\
3.50 \\
3.40 \\
3.59\end{array}$ & $\begin{array}{l}729 \\
705 \\
679 \\
729\end{array}$ & $\begin{array}{l}3.58 \\
3.51 \\
3.46 \\
3.40\end{array}$ & $\begin{array}{l}727 \\
708 \\
695 \\
679\end{array}$ \\
\hline $12 \mathrm{~m}$. & \multicolumn{2}{|c|}{ August 10} & \multicolumn{2}{|c|}{ August 11} & \multicolumn{2}{|c|}{ August 12} & \multicolumn{2}{|c|}{ August 13} & \multicolumn{2}{|c|}{ August 14} & \multicolumn{2}{|c|}{ August 15} \\
\hline $\begin{array}{c}6 \mathrm{a} . \mathrm{m} . \\
12 \mathrm{n} . \\
6 \mathrm{p.m} . \\
12 \mathrm{~m} .\end{array}$ & $\begin{array}{l}3.34 \\
3.27 \\
3.19 \\
3.13\end{array}$ & $\begin{array}{l}663 \\
645 \\
624 \\
609\end{array}$ & $\begin{array}{l}3.14 \\
3.14 \\
3.09 \\
3.03\end{array}$ & $\begin{array}{l}611 \\
611 \\
598 \\
583\end{array}$ & $\begin{array}{l}2.97 \\
2.92 \\
2.85 \\
2.81\end{array}$ & $\begin{array}{l}568 \\
555 \\
538 \\
528\end{array}$ & $\begin{array}{l}2.77 \\
2.74 \\
2.69 \\
2.65\end{array}$ & $\begin{array}{l}519 \\
512 \\
500 \\
490\end{array}$ & $\begin{array}{l}2.62 \\
2.59 \\
2.55 \\
2.51\end{array}$ & $\begin{array}{l}483 \\
476 \\
466 \\
457\end{array}$ & $\begin{array}{l}2.48 \\
2.45 \\
2.37 \\
2.33\end{array}$ & $\begin{array}{l}451 \\
444 \\
427 \\
418\end{array}$ \\
\hline
\end{tabular}

\footnotetext{
1Adjusted for diversions for municipal supply of Wellesley and Needham.
}

ChaRTES RIVBR AT WAITHAM, MASS.

Location.-Lat. $42^{\circ} 22^{\prime} 20^{\prime \prime}$, long. $71^{\circ} 14^{\prime} 05^{\prime \prime}, 600$ feet downstream from Moody Street Bridge in Waltham, Middlesex County, and a third of a mile upstream from Clematis Brook: Datum of gage is 20.02 feet above mean sea level (general adjustment of 1929). 
Drainace AREA.-227 square miles (not including 23.6 square miles drained by Stony Brook).

GAGE-HEIGHT RECORD.-Water-stage recorder graph.

Stage-discharge RELation.-Defined by current-meter measurements below 2,130 second-feet.

Maxima.-July 1938: Discharge, 2,180 second-feet 1 p. m. July 26, 9 a. m. and 2 p. m. July 29 (gage height) 4.56 feet.

1931 to June 1938: Discharge, 2,540 second-feet Mar. 19, 1936 (gage height, 4.79 feet).

REMARKs.-Flood discharge considerably affected by artificial and natural storage and diversions to Mother Brook and slightly affected by wastage from Stony Brook Reservoir and diversions for municipal supply of Wellesley, Needham, Dedham, Brookline, Newton, and Waltham.

Mean discharge, in second-feet, 1938

\begin{tabular}{|c|c|c|c|c|c|c|c|c|c|c|c|}
\hline Day & June & July & Aug. & Day & June & July & Aug. & Day & June & July & Aug. \\
\hline $\begin{array}{r}1 \\
2 \\
3 \\
4 \\
5 \\
6 \\
7 \\
8 \\
9 \\
10\end{array}$ & $\begin{array}{l}287 \\
324 \\
302 \\
280 \\
274 \\
254 \\
231 \\
224 \\
143 \\
197\end{array}$ & $\begin{array}{l}445 \\
492 \\
530 \\
560 \\
695 \\
595 \\
555 \\
540 \\
438 \\
439\end{array}$ & $\begin{array}{r}1,820 \\
1,530 \\
1,280 \\
1,170 \\
1,020 \\
925 \\
828 \\
765 \\
723 \\
658\end{array}$ & $\begin{array}{l}11 \\
12 \\
13 \\
14 \\
15 \\
16 \\
17 \\
18 \\
19 \\
20\end{array}$ & $\begin{array}{l}176 \\
198 \\
232 \\
210 \\
227 \\
255 \\
266 \\
302 \\
282 \\
339\end{array}$ & $\begin{array}{l}439 \\
434 \\
422 \\
394 \\
382 \\
335 \\
291 \\
332 \\
367 \\
391\end{array}$ & $\begin{array}{l}543 \\
500 \\
460 \\
420 \\
370 \\
340 \\
320 \\
340 \\
350 \\
366\end{array}$ & $\begin{array}{l}21 \\
22 \\
23 \\
24 \\
25 \\
26 \\
27 \\
28 \\
29 \\
30 \\
31\end{array}$ & $\begin{array}{l}298 \\
287 \\
283 \\
262 \\
234 \\
229 \\
296 \\
350 \\
378 \\
398\end{array}$ & $\begin{array}{r}525 \\
990 \\
1,460 \\
1,970 \\
1,970 \\
2,020 \\
2,070 \\
2,120 \\
2,170 \\
2,070 \\
1,920\end{array}$ & $\begin{array}{l}374 \\
390 \\
394 \\
411 \\
390 \\
382 \\
366 \\
362 \\
332 \\
291 \\
269\end{array}$ \\
\hline P.ur & & & & & & & & & $\begin{array}{r}401 \\
1.98\end{array}$ & $\begin{array}{r}1,226 \\
6.23\end{array}$ & $\begin{array}{r}849 \\
4.31\end{array}$ \\
\hline
\end{tabular}

Gage-height, in feet, and discharge, in second-feet, at indicated time, 1938

\begin{tabular}{|c|c|c|c|c|c|c|c|c|c|c|c|c|}
\hline \multirow{2}{*}{ Hour } & Feet & Sec.-ft. & Feet & Sec.-ft. & Feet & Sec.-ft. & Feet & Sec.-ft. & Feet & See, $-\mathrm{ft}$. & Feet & Sec. $-\mathrm{ft}$. \\
\hline & \multicolumn{2}{|c|}{ July 17} & \multicolumn{2}{|c|}{ July 18} & \multicolumn{2}{|c|}{ July 19} & \multicolumn{2}{|c|}{ July $\quad 20$} & \multicolumn{2}{|c|}{ July 21} & \multicolumn{2}{|c|}{ July 22} \\
\hline \multirow[t]{2}{*}{$\begin{array}{l}6 \mathrm{a.m} . \\
2 \mathrm{n} . \\
6 \mathrm{p.m} . \\
2 \mathrm{~m} .\end{array}$} & & & & & & & & & $\begin{array}{l}2.16 \\
2.19 \\
2.83 \\
2.90\end{array}$ & $\begin{array}{l}414 \\
426 \\
753 \\
795\end{array}$ & $\begin{array}{l}3.06 \\
3.42 \\
3.23 \\
3.17\end{array}$ & $\begin{array}{r}899 \\
1,140 \\
1,010 \\
970\end{array}$ \\
\hline & \multicolumn{2}{|c|}{ July 23} & \multicolumn{2}{|c|}{ July 24} & \multicolumn{2}{|c|}{ July 25 } & \multicolumn{2}{|c|}{ July 26} & \multicolumn{2}{|c|}{ July 27} & \multicolumn{2}{|c|}{ July 28} \\
\hline \multirow[t]{2}{*}{$\begin{array}{l}6 \mathrm{a} . \mathrm{m} . \\
\mathrm{J} . \\
6 \mathrm{n} . \\
\mathrm{j} . \mathrm{m} .\end{array}$} & $\begin{array}{l}3.23 \\
4.00 \\
4.21 \\
4.27\end{array}$ & $\begin{array}{l}1,010 \\
1,620 \\
1,830 \\
1,890\end{array}$ & $\begin{array}{l}4.30 \\
4.35 \\
4.42 \\
4.40\end{array}$ & $\begin{array}{l}1,920 \\
1,970 \\
2,040 \\
2,020\end{array}$ & $\begin{array}{l}4 . .^{25} \\
4.36 \\
4.35 \\
4.33\end{array}$ & $\begin{array}{l}1,970 \\
1,980 \\
1,970 \\
1,950\end{array}$ & $\begin{array}{l}4.33 \\
4.37 \\
4.47 \\
4.44\end{array}$ & $\begin{array}{l}1,950 \\
1,990 \\
2,090 \\
2,060\end{array}$ & $\begin{array}{l}4.45 \\
4.46 \\
4.48 \\
4.50\end{array}$ & $\begin{array}{l}2,070 \\
2,080 \\
2,100 \\
2,120\end{array}$ & $\begin{array}{l}4.48 \\
4.53 \\
4.54 \\
4.53\end{array}$ & $\begin{array}{l}2,100 \\
2,150 \\
2,160 \\
2,150\end{array}$ \\
\hline & \multicolumn{2}{|c|}{ July 29} & \multicolumn{2}{|c|}{ July 30} & \multicolumn{2}{|c|}{ July 31} & \multicolumn{2}{|c|}{ August 1} & \multicolumn{2}{|c|}{ August 2} & \multicolumn{2}{|c|}{ August 3} \\
\hline $\begin{array}{l}6 \mathrm{a} . \mathrm{m} . \\
2 \mathrm{n} . \\
6 \mathrm{p.m} . \\
2 \mathrm{~m} .\end{array}$ & $\begin{array}{l}4.53 \\
4.54 \\
4.54 \\
4.53\end{array}$ & $\begin{array}{l}2,150 \\
2,160 \\
2,160 \\
2,150\end{array}$ & $\begin{array}{l}4.52 \\
4.47 \\
4.44 \\
4.29\end{array}$ & $\begin{array}{l}2,140 \\
2,090 \\
2,060 \\
1,910\end{array}$ & $\begin{array}{l}4.31 \\
4.36 \\
4.24 \\
4.21\end{array}$ & $\begin{array}{l}1,930 \\
1,980 \\
1,860 \\
1,830\end{array}$ & $\begin{array}{l}4.16 \\
4.31 \\
4.17 \\
4.03\end{array}$ & $\begin{array}{l}1,780 \\
1,930 \\
1,790 \\
1,650\end{array}$ & $\begin{array}{l}3.95 \\
3.88 \\
3.83 \\
3.77\end{array}$ & $\begin{array}{l}1,580 \\
1,510 \\
1,470 \\
1,420\end{array}$ & $\begin{array}{l}3.73 \\
3.68 \\
3.42 \\
3.49\end{array}$ & $\begin{array}{l}1,380 \\
1,340 \\
1,140 \\
1,190\end{array}$ \\
\hline & \multicolumn{2}{|c|}{ August 4} & \multicolumn{2}{|c|}{ August 5} & \multicolumn{2}{|c|}{ August 6} & \multicolumn{2}{|c|}{ August 7} & \multicolumn{2}{|c|}{ August 8} & \multicolumn{2}{|c|}{ August 9} \\
\hline $\begin{array}{l}6 \mathrm{a} . \mathrm{m} . \\
12 \mathrm{n} . \\
6 \mathrm{p.m} . \\
\mathrm{T} 2 \mathrm{~m} .\end{array}$ & $\begin{array}{l}3.47 \\
3.46 \\
3.40 \\
3.35\end{array}$ & $\begin{array}{l}1,180 \\
1,180 \\
1,130 \\
1,100\end{array}$ & $\begin{array}{l}3.30 \\
3.27 \\
3.22 \\
3.17\end{array}$ & $\begin{array}{r}1,060 \\
1,040 \\
1,000 \\
970\end{array}$ & $\begin{array}{l}3.14 \\
3.14 \\
3.07 \\
3.04\end{array}$ & $\begin{array}{l}951 \\
951 \\
906 \\
886\end{array}$ & $\begin{array}{l}3.00 \\
2.98 \\
2.94 \\
2.90\end{array}$ & $\begin{array}{l}860 \\
8.17 \\
821 \\
795\end{array}$ & $\begin{array}{l}2.86 \\
2.85 \\
2.81 \\
2.83\end{array}$ & $\begin{array}{l}771 \\
765 \\
741 \\
753\end{array}$ & $\begin{array}{l}2.80 \\
2.79 \\
2.75 \\
2.72\end{array}$ & $\begin{array}{l}735 \\
729 \\
705 \\
687\end{array}$ \\
\hline
\end{tabular}


Gage-height, in feet, and discharge, in second-feet, at indicated time, 1938-Continued

\begin{tabular}{|c|c|c|c|c|c|c|c|c|c|c|c|c|}
\hline \multirow{2}{*}{ Hour } & Feet & Sec.-ft. & Feet & Sec- $-\mathrm{ft}$. & Feet & Sec. $-\mathrm{ft}$. & Feet & Sec.-ft. & Feet & Sec. $-\mathrm{ft}$. & Feet & Sec. $-\mathrm{ft}$. \\
\hline & \multicolumn{2}{|c|}{ August 10} & \multicolumn{2}{|c|}{ August 11} & \multicolumn{2}{|c|}{ August 12} & \multicolumn{2}{|c|}{ Angust 13} & \multicolumn{2}{|c|}{ August 14} & \multicolumn{2}{|c|}{ August 15} \\
\hline $\begin{array}{c}6 \mathrm{a} . \mathrm{m} . \\
12 \mathrm{n} . \\
6 \mathrm{p.m} . \\
12 \mathrm{~m} .\end{array}$ & $\begin{array}{l}2.69 \\
2.67 \\
2.65 \\
2.62\end{array}$ & $\begin{array}{l}670 \\
658 \\
648 \\
631\end{array}$ & & & & & & & & & & \\
\hline
\end{tabular}

1Adjusted for diversions to Mother Brook and for municif al supply of Wellesley, Needham, Dedham Brookline, Newton, and Waltham, and for wastage from Stony Brook Reservoir.

MOTHER BROOK AT DEDHAM, MASS.

Location.-Lat. $42^{\circ} 15^{\prime} 20^{\prime \prime}$, long. $71^{\circ} 09^{\prime} 55^{\prime \prime}$, in Dedham, Norfolk County, 0.3 mile downstream from point of diversion from Charles River. Datum of gage is 0.03 foot below mean sea level (general adjustment of 1929).

GAGE-HEIGH RECORD.-Two or more gage readings daily on float gage.

Stage-discharge relation.-Defined by current-meter measurements below 871 second-feet.

Maxıмa.-July 1938: Discharge, 909 second-feet July 28, 29 (gage height 91.84 feet from graph based on gage readings.

1931 to June 1938: Discharge, 900 second-feet Mar. 19, 1936 (gage height, 91.37 feet).

REMARks.-Entire flow of Mother Brook represents water diverted from Charles River.

Mean discharge, in second-teet, 1938

\begin{tabular}{|c|c|c|c|c|c|c|c|c|c|c|c|}
\hline Dav & June & July & Aug. & Day & June & July & Aug. & Day & June & July & Aug. \\
\hline $\begin{array}{r}1 \\
2 \\
3 \\
4 \\
5 \\
6 \\
7 \\
8 \\
9 \\
10\end{array}$ & $\begin{array}{r}128 \\
124 \\
120 \\
112 \\
108 \\
99 \\
90 \\
82 \\
76 \\
67\end{array}$ & $\begin{array}{l}199 \\
220 \\
245 \\
258 \\
258 \\
252 \\
245 \\
226 \\
209 \\
194\end{array}$ & $\begin{array}{l}693 \\
617 \\
543 \\
489 \\
426 \\
383 \\
341 \\
302 \\
280 \\
258\end{array}$ & $\begin{array}{l}11 \\
12 \\
13 \\
14 \\
15 \\
16 \\
17 \\
18 \\
19 \\
20\end{array}$ & $\begin{array}{r}62 \\
65 \\
83 \\
97 \\
104 \\
116 \\
124 \\
132 \\
136 \\
132\end{array}$ & $\begin{array}{l}180 \\
171 \\
158 \\
148 \\
140 \\
132 \\
124 \\
120 \\
128 \\
140\end{array}$ & $\begin{array}{l}238 \\
220 \\
199 \\
184 \\
171 \\
158 \\
171 \\
171 \\
166 \\
162\end{array}$ & $\begin{array}{l}21 \\
22 \\
23 \\
24 \\
25 \\
26 \\
27 \\
28 \\
29 \\
30 \\
31\end{array}$ & $\begin{array}{r}128 \\
120 \\
116 \\
108 \\
98 \\
94 \\
104 \\
132 \\
162 \\
180\end{array}$ & $\begin{array}{l}166 \\
245 \\
333 \\
471 \\
579 \\
713 \\
835 \\
900 \\
900 \\
835 \\
773\end{array}$ & $\begin{array}{r}162 \\
162 \\
1.8 \\
153 \\
140 \\
132 \\
120 \\
116 \\
101 \\
87 \\
76\end{array}$ \\
\hline \multicolumn{9}{|c|}{ Monthy mean diseharge, in second-feet $\ldots$} & 110 & 339 & 244 \\
\hline
\end{tabular}

Gage-height, in feet, and discharge, in second-feet, at indicated time, 1938

\begin{tabular}{|c|c|c|c|c|c|c|c|c|c|c|c|c|c|c|c|c|c|}
\hline Hour & Feet & $\begin{array}{l}\text { Sec-- } \\
\text { ft. }\end{array}$ & Hour & Feet & $\begin{array}{l}\text { Sec.- } \\
\text { ft. }\end{array}$ & Hour & Feet & $\begin{array}{c}\text { Sec.- } \\
\text { ft. }\end{array}$ & Hour & Feet & $\begin{array}{l}\text { Sec.- } \\
\text { ft. }\end{array}$ & Hour & Feet & $\begin{array}{c}\text { Sec. } \\
\mathrm{ft} .\end{array}$ & Hour & Feet & $\begin{array}{l}\text { Sec.- } \\
\mathrm{ft} .\end{array}$ \\
\hline \multicolumn{3}{|c|}{ July 18} & \multicolumn{3}{|c|}{ July 19} & \multicolumn{3}{|c|}{ July 20} & \multicolumn{3}{|c|}{ July 21} & \multicolumn{3}{|c|}{ July 22} & \multicolumn{3}{|c|}{ Juiy 23} \\
\hline $\begin{array}{l}8: 30 \\
\text { a.m. } \\
7: 30 \\
\text { p.m. }\end{array}$ & $\begin{array}{l}86.86 \\
86.97\end{array}$ & $\begin{array}{l}117 \\
126\end{array}$ & $\begin{array}{c}10: 00 \\
\text { a.m. } \\
8: 00 \\
\text { p.m. }\end{array}$ & $\begin{array}{l}87.03 \\
87.05\end{array}$ & 132 & $\begin{array}{c}10: 00 \\
\text { a.m. } \\
9: 15 \\
\text { p.n. }\end{array}$ & $\begin{array}{l}87.13 \\
87.23\end{array}$ & 147 & $\mid \begin{array}{c}11: 00 \\
\text { a:m. } \\
7: 15 \\
\text { p.m. }\end{array}$ & $\begin{array}{l}87.37 \\
87.67\end{array}$ & $\begin{array}{l}159 \\
186\end{array}$ & $\begin{array}{l}9: 45 \\
\text { a.n. } \\
\text { 9:00 } \\
\text { p.m. }\end{array}$ & $\begin{array}{c}88.17 \\
88.46\end{array}$ & $\begin{array}{l}241 \\
281\end{array}$ & $\begin{array}{l}8: 30 \\
\text { a.m. } \\
6: 30 \\
\text { p.m. }\end{array}$ & $\begin{array}{l}88.72 \\
88.99\end{array}$ & $\begin{array}{l}320 \\
364\end{array}$ \\
\hline \multicolumn{3}{|c|}{ July 24} & \multicolumn{3}{|c|}{ July 25} & \multicolumn{3}{|c|}{ July 26} & \multicolumn{3}{|c|}{ July 27} & \multicolumn{3}{|c|}{ July 28} & \multicolumn{3}{|c|}{ July 29} \\
\hline $\begin{array}{l}\text { 7:45 } \\
\text { a.m. } \\
\text { 5:30 } \\
\text { p.m. }\end{array}$ & $\begin{array}{l}89.43 \\
89.76\end{array}$ & 500 & $\begin{array}{c}\text { 7:30 } \\
\text { a.m. } \\
6: 15 \\
\text { p.m. }\end{array}$ & $\begin{array}{l}90.13 \\
90.38\end{array}$ & 566 & $\begin{array}{c}9: 00 \\
\text { a.m. } \\
6: 15 \\
\text { p.n1. }\end{array}$ & $\begin{array}{l}90.84 \\
91.10\end{array}$ & $\begin{array}{l}701 \\
753\end{array}$ & $\begin{array}{c}\text { 9:00 } \\
\text { a.m. } \\
\text { 5:00 } \\
\text { p.m. }\end{array}$ & $\begin{array}{l}91.46 \\
91.60\end{array}$ & $\begin{array}{l}827 \\
856\end{array}$ & $\begin{array}{l}7: 00 \\
\text { a.m. } \\
4: 30 \\
\text { p.m. }\end{array}$ & $\begin{array}{l}91.79 \\
91.84\end{array}$ & $\begin{array}{l}898 \\
909\end{array}$ & $\begin{array}{l}7: 15 \\
\text { a.m. } \\
5: 00 \\
\text { p.m. }\end{array}$ & $\begin{array}{l}91.82 \\
91.74\end{array}$ & $\begin{array}{l}904 \\
887\end{array}$ \\
\hline
\end{tabular}


Gage-height, in jeet, and discharge, in second-feet, at indicated time, 1938-Continued

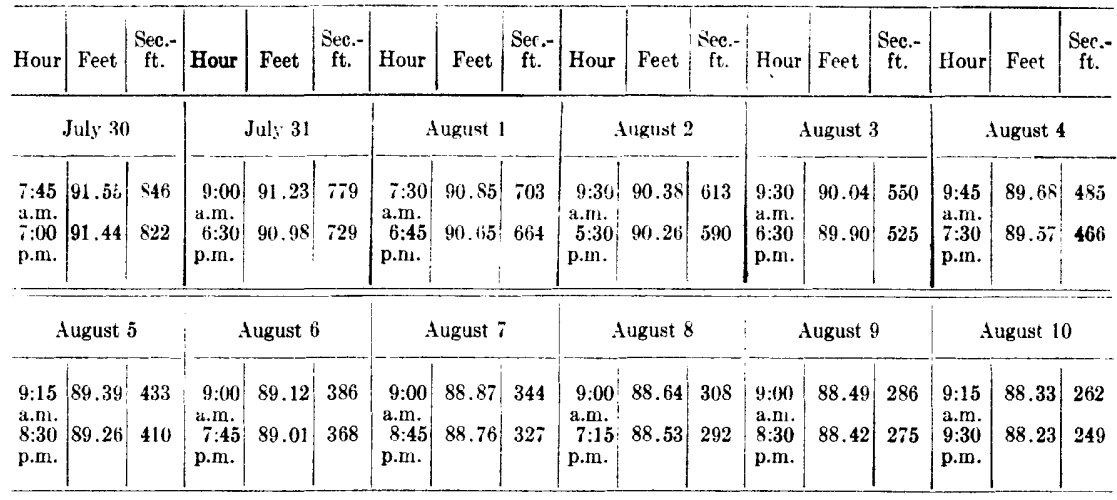

Supplemental records.--July $26,3: 35$ p.m., 91.04 ft., 741 sec.-ft.; July $2 \tau, 12: 10$ p.m., 91.50 ft., 835 sec.ft.; July 28 , 12:50 p.m., 91.84 ft., 909 sec.-ft.; $1: 30$ p.m., 91.83 ft., 907 sec.ft.; July $29,9: 10$ a.m., 91.84 ft., 909 sec.-ft.; $10: 10$ a.ml., $91.84 \mathrm{ft} ., 909$ sec.ft.; Aug. 1, 8:55 a.m., $90.85 \mathrm{ft}$., 703 sec.ft.; Aug. 4., 3:05 p.m., $89.60 \mathrm{ft} ., 471$ sec.-ft.

\section{TAUNTON RIVER BASIN}

TAUNTON RIVER AT STATE FARM, MASS.

Location.-Lat. $41^{\circ} 56^{\prime} 05^{\prime \prime}$, long. 70 57'20", at State Farm, Plymouth County, 1 mile upstream from Saw Mill Brook. Datum of gage is 9.61 feet above mean sea level (general adjustment of 1929).

Drainage area. - 260 square miles.

GAGE-HEIGHT RECORD.-Water-stage recorder graph.

STAGE-Discharge RELATION.-Defined by current-meter measurements below 2,990 second-feet.

Vaxina.-July 1938: Discharge, 2,480 second-feet 4 to 8 p. m. July 25 (gage height, 8.95 feet).

1929 to June 1938: Discharge, 3,050 second-feet Apr. 14, 1935; (gage height, 10.68 feet).

REMARKs.-Flood discharge affected by artificial storage and natural pondage and slightly affected by diversions.

Mean discharge, in second-feet, 1938

\begin{tabular}{|c|c|c|c|c|c|c|c|c|c|c|c|}
\hline Das & june & July & Aug. & Day & June & July & Aug. & Day & June & July & Aug. \\
\hline $\begin{array}{r}1 \\
2 \\
3 \\
4 \\
5 \\
6 \\
7 \\
8 \\
9 \\
10\end{array}$ & $\begin{array}{l}352 \\
374 \\
356 \\
324 \\
263 \\
352 \\
370 \\
324 \\
311 \\
271\end{array}$ & $\begin{array}{r}2,120 \\
1,720 \\
1,350 \\
1,120 \\
850 \\
725 \\
580 \\
545 \\
478 \\
424\end{array}$ & $\begin{array}{l}800 \\
675 \\
560 \\
464 \\
450 \\
414 \\
338 \\
370 \\
347 \\
311\end{array}$ & $\begin{array}{l}11 \\
12 \\
13 \\
14 \\
15 \\
16 \\
17 \\
18 \\
19 \\
20\end{array}$ & $\begin{array}{l}199 \\
211 \\
420 \\
650 \\
540 \\
500 \\
468 \\
383 \\
306 \\
360\end{array}$ & $\begin{array}{l}437 \\
432 \\
428 \\
410 \\
419 \\
486 \\
460 \\
460 \\
473 \\
525\end{array}$ & $\begin{array}{l}288 \\
288 \\
275 \\
231 \\
293 \\
293 \\
280 \\
324 \\
320 \\
298\end{array}$ & $\begin{array}{l}21 \\
22 \\
23 \\
24 \\
25 \\
26 \\
27 \\
28 \\
29 \\
30 \\
31\end{array}$ & $\begin{array}{r}365 \\
324 \\
316 \\
243 \\
223 \\
227 \\
387 \\
1,140 \\
2,220 \\
2,420\end{array}$ & $\begin{array}{r}\mathbf{8 7 5} \\
\mathbf{9 7 5} \\
\mathbf{1}, 300 \\
2,080 \\
2,420 \\
2,380 \\
2,080 \\
1,720 \\
1,300 \\
1,120 \\
950\end{array}$ & $\begin{array}{l}247 \\
284 \\
271 \\
247 \\
231 \\
227 \\
199 \\
120 \\
178 \\
207 \\
195\end{array}$ \\
\hline \multicolumn{9}{|c|}{$\begin{array}{l}\text { Monthly mean discharge, in second-feet (adjusied for diversions') } \\
\text { Runoff, in inches (adjusted for diversions') }\end{array}$} & $\begin{array}{r}518 \\
2.22\end{array}$ & $\begin{array}{r}1,030 \\
4.56\end{array}$ & $\begin{aligned} 333 \\
1.4 !\end{aligned}$ \\
\hline
\end{tabular}


Gage-height, in feet, and discharge, in second-feet, at indicated time, 1938

\begin{tabular}{|c|c|c|c|c|c|c|c|c|c|c|c|c|}
\hline \multirow{2}{*}{ Hour } & Feet & Sec. $-f t$. & Feet & Sec.-ft. & Freet & Sec.-ft. & Feet & Sec.-ft. & Feet & Sec.-ft. & Feet & Sec.-ft. \\
\hline & \multicolumn{2}{|c|}{ July 17} & \multicolumn{2}{|c|}{ July 18} & \multicolumn{2}{|c|}{ July 19} & \multicolumn{2}{|c|}{ July 20} & \multicolumn{2}{|c|}{ July 21} & \multicolumn{2}{|c|}{ July 22} \\
\hline $\begin{array}{c}6 \mathrm{a} . \mathrm{m} . \\
12 \mathrm{n} . \\
6 \mathrm{p.m} . \\
12 \mathrm{~m} .\end{array}$ & $\begin{array}{l}4.62 \\
4.59 \\
4.58 \\
4.59\end{array}$ & $\begin{array}{l}464 \\
450 \\
446 \\
450\end{array}$ & $\begin{array}{l}4.57 \\
4.62 \\
4.65 \\
4.65\end{array}$ & $\begin{array}{l}442 \\
464 \\
478 \\
478\end{array}$ & $\begin{array}{l}4.63 \\
4.62 \\
4.64 \\
4.66\end{array}$ & $\begin{array}{l}468 \\
464 \\
473 \\
482\end{array}$ & $\begin{array}{l}4.65 \\
4.65 \\
4.82 \\
5.13\end{array}$ & $\begin{array}{l}478 \\
478 \\
560 \\
715\end{array}$ & $\begin{array}{l}5.32 \\
5.49 \\
5.59 \\
5.60\end{array}$ & $\begin{array}{l}810 \\
895 \\
945 \\
950\end{array}$ & $\begin{array}{l}5.59 \\
5.64 \\
5.72 \\
5.79\end{array}$ & $\begin{array}{r}945 \\
970 \\
1,010 \\
1,040\end{array}$ \\
\hline & \multicolumn{2}{|c|}{ July 23} & \multicolumn{2}{|c|}{ July 24} & \multicolumn{2}{|c|}{ July 25} & \multicolumn{2}{|c|}{ July 26} & \multicolumn{2}{|c|}{ July 27} & \multicolumn{2}{|c|}{ July 28} \\
\hline \multirow[t]{2}{*}{$\begin{array}{c}6 \mathrm{a} . \mathrm{m} . \\
12 \mathrm{n} . \\
6 \mathrm{p.m} . \\
12 \mathrm{~m} .\end{array}$} & $\begin{array}{l}5.92 \\
6.27 \\
6.69 \\
7.25\end{array}$ & $\begin{array}{l}1,110 \\
1,280 \\
1,490 \\
1,7 \pm 0\end{array}$ & $\begin{array}{l}7.70 \\
8.05 \\
8.39 \\
8.64\end{array}$ & $\begin{array}{l}1,940 \\
2,000 \\
2,260 \\
2,360\end{array}$ & $\begin{array}{l}8.81 \\
8.90 \\
8.95 \\
8.92\end{array}$ & $\begin{array}{l}2,420 \\
2,460 \\
2,480 \\
2,470\end{array}$ & $\begin{array}{l}8.84 \\
8.72 \\
8.59 \\
8.42\end{array}$ & $\begin{array}{l}2,440 \\
2,390 \\
2,340 \\
2,270\end{array}$ & $\begin{array}{l}8.24 \\
8.03 \\
7.84 \\
7.64\end{array}$ & $\begin{array}{l}2,190 \\
2,090 \\
2,010 \\
1,920\end{array}$ & $\begin{array}{l}7.41 \\
7.20 \\
6.94 \\
6.65\end{array}$ & $\begin{array}{l}1,810 \\
1,720 \\
1,600 \\
1,470\end{array}$ \\
\hline & \multicolumn{2}{|c|}{ July 29} & \multicolumn{2}{|c|}{ July 30} & \multicolumn{2}{|c|}{ July 31} & \multicolumn{2}{|c|}{ August 1} & \multicolumn{2}{|c|}{ August 2} & \multicolumn{2}{|c|}{ August 3} \\
\hline $\begin{array}{l}6 \mathrm{a} . \mathrm{m} . \\
12 \mathrm{n} . \\
6 \mathrm{p} . \mathrm{m} . \\
12 \mathrm{~m} .\end{array}$ & $\begin{array}{l}6.47 \\
6.32 \\
6.21 \\
6.12\end{array}$ & $\begin{array}{l}1,380 \\
1,310 \\
1,260 \\
1,210\end{array}$ & $\begin{array}{l}6.02 \\
5.92 \\
5.87 \\
5.79\end{array}$ & $\begin{array}{l}1,160 \\
1,110 \\
1,080 \\
1,040\end{array}$ & $\begin{array}{l}5.69 \\
5.56 \\
5.52 \\
5.45\end{array}$ & $\begin{array}{l}995 \\
930 \\
910 \\
875\end{array}$ & $\begin{array}{l}5.41 \\
5.33 \\
5.18 \\
5.13\end{array}$ & $\begin{array}{l}855 \\
815 \\
740 \\
715\end{array}$ & $\begin{array}{l}5.09 \\
5.05 \\
5.01 \\
4.95\end{array}$ & $\begin{array}{l}695 \\
675 \\
655 \\
625\end{array}$ & $\begin{array}{l}4.92 \\
4.89 \\
4.70 \\
4.64\end{array}$ & $\begin{array}{l}610 \\
595 \\
500 \\
473\end{array}$ \\
\hline
\end{tabular}

\begin{tabular}{|c|c|c|c|c|c|c|c|c|c|c|c|c|}
\hline . & \multicolumn{2}{|c|}{ August 4} & \multicolumn{2}{|c|}{ August 5} & \multicolumn{2}{|c|}{ August 6} & \multicolumn{2}{|c|}{ August 7} & & & & \\
\hline $\begin{array}{l}6 \mathrm{a.m} . \\
12 \mathrm{n} . \\
6 \mathrm{p.m} . \\
12 \mathrm{~m} .\end{array}$ & $\begin{array}{l}4.62 \\
4.61 \\
4.62 \\
4.63\end{array}$ & $\begin{array}{l}464 \\
460 \\
464 \\
468\end{array}$ & $\begin{array}{l}4.62 \\
4.58 \\
4.57 \\
4.57\end{array}$ & $\begin{array}{l}464 \\
446 \\
442 \\
442\end{array}$ & $\begin{array}{l}4.55 \\
4.50 \\
4.47 \\
4.45\end{array}$ & $\begin{array}{l}432 \\
410 \\
396 \\
388\end{array}$ & $\begin{array}{l}4.35 \\
4.30 \\
4.32 \\
4.33\end{array}$ & $\begin{array}{l}342 \\
320 \\
329 \\
334\end{array}$ & $\mid$\begin{tabular}{c}
--- \\
$-\cdots$ \\
\hdashline-- \\
$-\cdots-$
\end{tabular} & 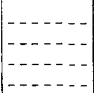 & 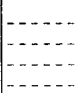 & $\mid \begin{array}{c}-\cdots \\
\cdots \\
\cdots\end{array}$ \\
\hline
\end{tabular}

Supplemental record.-July 25,4 to 8 p.m., $8.95 \mathrm{ft}, 2,480$ sec.-ft.

1Adjusted for diversions from Namasket River for municipal supply of Taunton and New Bedford and for pumpage from Silver Lake into Taunton River Basin for municipal supply of Brockton and other cities.

WADING RIVRR NFAR MORTON, MASS.

Location.-Lat. $41^{\circ} 56^{\prime} 50^{\prime \prime}$, long. $71^{\circ} 10^{\prime} 40^{\prime \prime}, 200$ feet downstream from highway bridge, three-quarters of a mile upstream from confluence with Rumford River, and $1 \frac{1 / 2}{2}$ miles southeast of Norton, Bristol County. Datum of gage is 49.63 feet above mean sea level (general adjustment of 1929).

Drainage area.-42.4 square miles.

GAGE-HEICHT RECORD.-Water-stage recorder graph.

Stage-discharge relation.-Defined by current-meter measurements below 691 second-feet.

Maxima.-July 1938: Discharge, 714 second-feet 2 to 3 a.m. July 25 (gage height, 9.52 feet).

1925 to June 1938: Discharge, 1,030 second-feet Mar. 12, 13, 1936 (gage height, 10.01 feet).

REMARKs.-Flood discharge affected by artificial and natural storage. 
Mean discharge, in second-feet, 1938

\begin{tabular}{|c|c|c|c|c|c|c|c|c|c|c|c|}
\hline Day & June & July & Aug. & Day & June & July & Aug. & Day & June & July & Aug. \\
\hline $\begin{array}{r}1 \\
2 \\
3 \\
4 \\
5 \\
6 \\
7 \\
8 \\
9 \\
10\end{array}$ & $\begin{array}{l}59 \\
55 \\
49 \\
38 \\
45 \\
42 \\
50 \\
24 \\
44 \\
19\end{array}$ & $\begin{array}{r}353 \\
271 \\
228 \\
203 \\
139 \\
129 \\
107 \\
94 \\
85 \\
72\end{array}$ & $\begin{array}{r}162 \\
149 \\
118 \\
124 \\
112 \\
83 \\
85 \\
72 \\
95 \\
47\end{array}$ & $\begin{array}{l}11 \\
12 \\
13 \\
14 \\
15 \\
16 \\
17 \\
18 \\
19 \\
20\end{array}$ & $\begin{array}{r}28 \\
56 \\
123 \\
181 \\
154 \\
113 \\
104 \\
70 \\
73 \\
72\end{array}$ & $\begin{array}{r}57 \\
70 \\
69 \\
62 \\
74 \\
103 \\
74 \\
67 \\
106 \\
145\end{array}$ & $\begin{array}{r}103 \\
78 \\
47 \\
65 \\
65 \\
61 \\
58 \\
102 \\
84 \\
44\end{array}$ & $\begin{array}{l}21 \\
22 \\
23 \\
24 \\
25 \\
26 \\
27 \\
28 \\
29 \\
30 \\
31\end{array}$ & $\begin{array}{r}65 \\
58 \\
53 \\
48 \\
34 \\
39 \\
102 \\
306 \\
491 \\
441\end{array}$ & $\begin{array}{l}214 \\
307 \\
415 \\
630 \\
690 \\
590 \\
484 \\
352 \\
307 \\
253 \\
214\end{array}$ & $\begin{array}{l}58 \\
61 \\
55 \\
48 \\
33 \\
30 \\
21 \\
27 \\
38 \\
30 \\
29\end{array}$ \\
\hline \multicolumn{9}{|c|}{$\begin{array}{l}\text { Monthly mean discharge, in second-feet } \\
\text { Runoff, in inches }\end{array}$} & $\begin{array}{r}101 \\
2.66\end{array}$ & $\begin{array}{r}225 \\
6.12\end{array}$ & $\begin{array}{l}70.5 \\
1.91\end{array}$ \\
\hline
\end{tabular}

Gage-height, in feet, and discharge, in second-feet, at indicated time, 1938

\begin{tabular}{|c|c|c|c|c|c|c|c|c|c|c|c|c|}
\hline \multirow{2}{*}{ Hour } & Feet & Sec.-ft. & Feet & Sec.-ft. & Feet & Sec. $-\mathrm{ft}$. & Feet & Sec.-ft. & Feet & Sec. $-\mathrm{ft}$. & Feet & Sec. $-\mathrm{ft}$. \\
\hline & \multicolumn{2}{|c|}{ July 17} & \multicolumn{2}{|c|}{ July 18} & \multicolumn{2}{|c|}{ July 19} & \multicolumn{2}{|c|}{ July 20} & \multicolumn{2}{|c|}{ July 21} & \multicolumn{2}{|c|}{ July 22} \\
\hline $\begin{array}{l}6 \mathrm{a.m} . \\
12 \mathrm{n} . \\
6 \mathrm{p.m} . \\
12 \mathrm{~m} .\end{array}$ & $\begin{array}{l}5.92 \\
5.85 \\
5.80 \\
5.80\end{array}$ & $\begin{array}{l}79 \\
72 \\
67 \\
67\end{array}$ & $\begin{array}{l}5.79 \\
5.82 \\
5.74 \\
5.88\end{array}$ & $\begin{array}{l}86 \\
69 \\
62 \\
75\end{array}$ & $\begin{array}{l}5.98 \\
6.43 \\
6.21 \\
6.10\end{array}$ & $\begin{array}{r}86 \\
143 \\
112 \\
99\end{array}$ & $\begin{array}{l}6.06 \\
6.63 \\
6.66 \\
6.64\end{array}$ & $\begin{array}{r}95 \\
173 \\
178 \\
174\end{array}$ & $\begin{array}{l}6.75 \\
6.82 \\
7.00 \\
7.26\end{array}$ & $\begin{array}{l}192 \\
203 \\
235 \\
282\end{array}$ & $\begin{array}{l}7.37 \\
7.60 \\
7.32 \\
7.31\end{array}$ & $\begin{array}{l}302 \\
343 \\
293 \\
291\end{array}$ \\
\hline
\end{tabular}

\begin{tabular}{|c|c|c|c|c|c|c|c|c|c|c|c|c|}
\hline \multirow[b]{2}{*}{$\begin{array}{l}6 \mathrm{a} . \mathrm{m} . \\
12 \mathrm{n} . \\
6 \mathrm{p.m} . \\
12 \mathrm{~m} .\end{array}$} & \multicolumn{2}{|c|}{ July 23} & \multicolumn{2}{|c|}{ July 24} & \multicolumn{2}{|c|}{ July 25} & \multicolumn{2}{|c|}{ July 26} & \multicolumn{2}{|c|}{ July 27} & \multicolumn{2}{|c|}{ July 28} \\
\hline & $\begin{array}{l}7.50 \\
8.14 \\
8.44 \\
8.72\end{array}$ & $\begin{array}{l}325 \\
442 \\
499 \\
554\end{array}$ & $\begin{array}{l}9.03 \\
9.02 \\
9.29 \\
9.50\end{array}$ & $\begin{array}{l}616 \\
614 \\
668 \\
710\end{array}$ & $\begin{array}{l}9.48 \\
9.44 \\
9.38 \\
9.28\end{array}$ & $\begin{array}{l}706 \\
698 \\
686 \\
666\end{array}$ & $\begin{array}{l}9.10 \\
8.94 \\
8.70 \\
8.63\end{array}$ & $\begin{array}{l}630 \\
598 \\
550 \\
536\end{array}$ & $\begin{array}{l}8.51 \\
8.39 \\
8.24 \\
7.93\end{array}$ & $\begin{array}{l}512 \\
489 \\
461 \\
402\end{array}$ & $\begin{array}{l}7.84 \\
7.43 \\
7.59 \\
7.53\end{array}$ & $\begin{array}{l}386 \\
312 \\
341 \\
330\end{array}$ \\
\hline
\end{tabular}

\begin{tabular}{|c|c|c|c|c|c|c|c|c|c|c|c|c|}
\hline \multirow[b]{2}{*}{$\begin{array}{l}6 \text { a.m. } \\
12 \mathrm{n} . \\
6 \mathrm{j.m} . \\
12 \mathrm{m.} .\end{array}$} & \multicolumn{2}{|c|}{ July 29} & \multicolumn{2}{|c|}{ July 30} & \multicolumn{2}{|c|}{ July 31} & \multicolumn{2}{|c|}{ August 1} & \multicolumn{2}{|c|}{ August 2} & & \\
\hline & $\begin{array}{l}7.46 \\
7.40 \\
7.35 \\
7.27\end{array}$ & $\begin{array}{l}318 \\
307 \\
298 \\
284\end{array}$ & $\begin{array}{l}7.19 \\
7.19 \\
6.90 \\
6.97\end{array}$ & $\begin{array}{l}269 \\
269 \\
217 \\
230\end{array}$ & $\begin{array}{l}6.95 \\
6.88 \\
6.82 \\
6.78\end{array}$ & $\begin{array}{l}226 \\
214 \\
203 \\
197\end{array}$ & $\begin{array}{l}6.72 \\
6.55 \\
6.33 \\
6.32\end{array}$ & $\begin{array}{l}189 \\
160 \\
129 \\
128\end{array}$ & $\begin{array}{l}6.39 \\
6.64 \\
6.48 \\
6.38\end{array}$ & $\begin{array}{l}138 \\
174 \\
150 \\
136\end{array}$ & 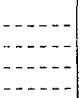 & 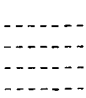 \\
\hline
\end{tabular}

\section{PROVIDENCE RIVER BASIN}

\section{BIACKSTONE RIVER AT WORCESTrR, MASS.}

Location.-Lat. $42^{\circ} 14^{\prime} 00^{\prime \prime}$, long. $71^{\circ} 50^{\prime} 10^{\prime \prime}$, at Webster Street Bridge in Worcester, Worcester County, three-quarters of a mile upstream from Tatnuck Brook. Datum of gage is $\mathbf{4 7 2 . 8 6}$ feet above mean sea level (general adjustment of 1929).

Drainage area. - 31.3 square miles.

GAGE-HEIGHT RECORD.-Water-stage recorder graph.

Stage-discharge Relation.-Defined by current-meter measurements below 550 second-feet.

Maxima.-July 1938: Discharge, 728 second-feet 8 to 10 a.m. July 24 (gage height, 5.12 feet).

1923 to June 1938: Discharge, 2,520 second-feet Mar. 18, 1936 (gage height, 8.58 feet, from floodmarks).

Remarks.-Flood discharge affected by artificial and natural storage and slightly affected by diversions.

$748116-48-15$ 
Mean discharge, in second-feet, 1938

\begin{tabular}{|c|c|c|c|c|c|c|c|c|c|c|c|}
\hline Day & June & July & Aug. & Day & June & July & Aug. & Day & June & July & Aug. \\
\hline $\begin{array}{r}1 \\
2 \\
3 \\
4 \\
5 \\
6 \\
7 \\
8 \\
9 \\
10\end{array}$ & $\begin{array}{l}28 \\
31 \\
35 \\
34 \\
33 \\
30 \\
26 \\
15 \\
14 \\
13\end{array}$ & $\begin{array}{l}67 \\
50 \\
37 \\
32 \\
28 \\
28 \\
26 \\
22 \\
22 \\
32\end{array}$ & $\begin{array}{c}101 \\
93 \\
77 \\
67 \\
62 \\
67 \\
70 \\
63 \\
62 \\
52\end{array}$ & $\begin{array}{l}11 \\
12 \\
13 \\
14 \\
15 \\
16 \\
17 \\
18 \\
19 \\
20\end{array}$ & $\begin{array}{l}17 \\
25 \\
52 \\
60 \\
46 \\
54 \\
45 \\
36 \\
30 \\
25\end{array}$ & $\begin{array}{r}46 \\
93 \\
178 \\
148 \\
97 \\
67 \\
52 \\
54 \\
80 \\
123\end{array}$ & $\begin{array}{l}64 \\
66 \\
48 \\
44 \\
40 \\
37 \\
42 \\
49 \\
46 \\
41\end{array}$ & $\begin{array}{l}21 \\
22 \\
23 \\
24 \\
25 \\
26 \\
27 \\
28 \\
29 \\
30 \\
31\end{array}$ & $\begin{array}{r}21 \\
18 \\
18 \\
16 \\
15 \\
15 \\
52 \\
118 \\
116 \\
89\end{array}$ & $\begin{array}{l}204 \\
504 \\
480 \\
700 \\
448 \\
294 \\
216 \\
201 \\
172 \\
142 \\
114\end{array}$ & $\begin{array}{l}34 \\
31 \\
32 \\
26 \\
20 \\
20 \\
23 \\
30 \\
26 \\
22 \\
20\end{array}$ \\
\hline \multicolumn{9}{|c|}{$\begin{array}{l}\left.\text { Monthly mean discharge, in second-feet (adjusted for diversion }{ }^{1}\right) \ldots \ldots \\
\text { Runoff, in inches (adjusted for diversion }{ }^{1} \text {. } \ldots \ldots \ldots\end{array}$} & $\begin{array}{l}47.2 \\
1.68\end{array}$ & $\begin{array}{r}163 \\
6.01\end{array}$ & $\begin{array}{l}57.5 \\
2.12\end{array}$ \\
\hline
\end{tabular}

Gage-height, in feet, and discharge, in second-feet, at indicated time, 1938

\begin{tabular}{|c|c|c|c|c|c|c|c|c|c|c|c|c|}
\hline \multirow{2}{*}{ Hour } & Feat & Sec, $-\mathrm{ft}$. & Feet & Sec $-f t$ & I cet & Seco.ft. & Fret & Ser.-ft. & lifet & Sect-ft. & Feet & Sec.-ft. \\
\hline & \multicolumn{2}{|c|}{ Iuly 17} & \multicolumn{2}{|c|}{$J_{\mathrm{tu}} l_{\mathrm{y}} 18$} & \multicolumn{2}{|c|}{ July 19} & \multicolumn{2}{|c|}{ Juty 20} & \multicolumn{2}{|c|}{ July 21} & \multicolumn{2}{|c|}{ July 22} \\
\hline 6 a.m. & 2.99 & 5 & 2.91 & 4.5 & 3.08 & $1 i 7$ & 3.33 & 114 & 3.53 & $1 t i 2$ & 4.62 & 528 \\
\hline $12 \mathrm{n}$. & 2.97 & 52 & 2.93 & +8 & 3.17 & 82 & 3.35 & 118 & 3.54 & 165 & 4.69 & $5 \pi 6$ \\
\hline i p.m. & 2.94 & 49 & 3.07 & 66 & 3.23 & 93 & 3.40 & 130 & 3.80 & 240 & 4.57 & 508 \\
\hline $12 \mathrm{~m}$. & 2.92 & th & 3.08 & 67 & 3.30 & 107 & 3.48 & 150 & 4.21 & 368 & 4.40 & 440 \\
\hline
\end{tabular}

\begin{tabular}{|c|c|c|c|c|c|c|c|c|c|c|c|c|}
\hline \multirow[b]{2}{*}{$\begin{array}{l}6 \mathrm{a} . \mathrm{m} . \\
12 \mathrm{n} . \\
6 \mathrm{j} . \mathrm{m} . \\
12 \mathrm{~m} .\end{array}$} & \multicolumn{2}{|c|}{ July 23} & \multicolumn{2}{|c|}{ Jully 24} & \multicolumn{2}{|c|}{ July 2.5} & \multicolumn{2}{|c|}{ July 26} & \multicolumn{2}{|c|}{ Nuly 27} & \multicolumn{2}{|c|}{ July 28} \\
\hline & $\begin{array}{l}4.28 \\
4.39 \\
4.67 \\
4.96\end{array}$ & $\begin{array}{l}393 \\
436 \\
548 \\
664\end{array}$ & $\begin{array}{l}5.09 \\
5.11 \\
5.05 \\
4.75\end{array}$ & $\begin{array}{l}716 \\
724 \\
700 \\
580\end{array}$ & $\begin{array}{l}4.54 \\
4.37 \\
4.31 \\
4.23\end{array}$ & $\begin{array}{l}496 \\
428 \\
404 \\
376\end{array}$ & $\begin{array}{l}4.10 \\
3.98 \\
3.84 \\
3.78\end{array}$ & $\begin{array}{l}330 \\
294 \\
252 \\
234\end{array}$ & $\begin{array}{l}3.74 \\
3.69 \\
3.65 \\
3.71\end{array}$ & $\begin{array}{l}222 \\
207 \\
195 \\
213\end{array}$ & $\begin{array}{l}3.68 \\
3.67 \\
3.65 \\
3.63\end{array}$ & $\begin{array}{l}204 \\
201 \\
195 \\
189\end{array}$ \\
\hline & \multicolumn{2}{|c|}{ July 29 } & \multicolumn{2}{|c|}{ July 30} & \multicolumn{2}{|c|}{ Suly 31} & \multicolumn{2}{|c|}{ Augurt 1} & \multicolumn{2}{|c|}{ August 2} & \multicolumn{2}{|c|}{ August 3} \\
\hline $\begin{array}{c}6 \mathrm{a} . \mathrm{m} . \\
12 \mathrm{n} . \\
6 \mathrm{p.m} . \\
12 \mathrm{~m} .\end{array}$ & $\begin{array}{l}3.60 \\
3.57 \\
3.55 \\
3.50\end{array}$ & $\begin{array}{l}180 \\
172 \\
168 \\
155\end{array}$ & $\begin{array}{l}3.47 \\
3.44 \\
3.45 \\
3.40\end{array}$ & $\begin{array}{l}148 \\
140 \\
142 \\
1.30\end{array}$ & $\begin{array}{l}3.36 \\
3.33 \\
3.31 \\
3.29\end{array}$ & $\begin{array}{l}121 \\
114 \\
109 \\
10.5\end{array}$ & $\begin{array}{l}3.28 \\
3.26 \\
3.24 \\
3.25\end{array}$ & $\begin{array}{r}103 \\
99 \\
95 \\
97\end{array}$ & $\begin{array}{l}3.24 \\
3.24 \\
3.22 \\
3.19\end{array}$ & $\begin{array}{l}95 \\
95 \\
91 \\
85\end{array}$ & $\begin{array}{l}3.16 \\
3.14 \\
3.15 \\
3.08\end{array}$ & $\begin{array}{l}80 \\
77 \\
78 \\
67\end{array}$ \\
\hline
\end{tabular}

1Adjusted for divorsion for muncilal supply of Worcester.

BIACKSTONE RIVER AT WOONSOCKET, R. I.

Location.-Lat. $42^{\circ} 00^{\prime} 20^{\prime \prime}$, long. 71 $30^{\prime} 05^{\prime \prime}$, in Woonsocket, Providence County, 50 feet downstream from Peters River. Datum of gage is 107.42 feet above mean sea level (general adjustment of 1929).

Drainage AREA.-416 square miles.

GACE-HEIGHT RECORD.-Water-stage recorder graph. Graph adjusted for intake lag for period 2 p.m. July 24 to Aug. 3.

Stage-uischarge ReLation.-Defined by current-meter measurements below 15,000 second-feet.

Maxima.-July 1938: Discharge, 15,100 second-feet 2 p.m. July 24 (gage height, 14.43 feet).

1929 to June 1938: Discharge, 15,000 second-feet Mar. 19, 1936 (gage height, 14.40 feet).

Remakks.-Flood discharge affected by artificial and natural storage and slightly affected by diversions. Figures of discharge include flow diverted from Nashua River Basin to Blackstone River Basin for municipal supply of Worcester and flow diverted around station in Hamlet trench. 
Mean discharge, in second-feet, 1938

\begin{tabular}{|c|c|c|c|c|c|c|c|c|c|c|c|}
\hline 1)a! & June & Juiv & Auy. & Day? & June & July & Aug. & Day & June & July & Alig. \\
\hline $\begin{array}{r}1 \\
2 \\
3 \\
4 \\
5 \\
6 \\
7 \\
8 \\
9 \\
10\end{array}$ & $\begin{array}{l}716 \\
646 \\
569 \\
445 \\
426 \\
465 \\
573 \\
573 \\
501 \\
449\end{array}$ & $\begin{array}{r}1,840 \\
1,360 \\
1,120 \\
968 \\
947 \\
754 \\
672 \\
618 \\
339 \\
331\end{array}$ & $\begin{array}{r}1,780 \\
1,700 \\
1,280 \\
1,180 \\
1,060 \\
919 \\
940 \\
1,130 \\
1,070 \\
1,020\end{array}$ & $\begin{array}{l}11 \\
12 \\
13 \\
14 \\
15 \\
16 \\
17 \\
18 \\
19 \\
20\end{array}$ & $\begin{array}{r}283 \\
50 . \\
2,760 \\
2,540 \\
1,660 \\
1,200 \\
1,000 \\
726 \\
686 \\
920\end{array}$ & $\begin{array}{r}5.30 \\
626 \\
1,020 \\
1,060 \\
1,000 \\
604 \\
449 \\
650 \\
755 \\
1,240\end{array}$ & $\begin{array}{r}968 \\
1,030 \\
898 \\
810 \\
877 \\
822 \\
1,340 \\
1,480 \\
1,220 \\
820\end{array}$ & $\begin{array}{l}21 \\
22 \\
23 \\
24 \\
25 \\
26 \\
27 \\
28 \\
29 \\
30 \\
31\end{array}$ & $\begin{array}{r}755 \\
593 \\
660 \\
517 \\
356 \\
313 \\
979 \\
3,040 \\
3,490 \\
2,560\end{array}$ & $\begin{array}{r}1,9,50 \\
5,490 \\
7,160 \\
13,700 \\
10,700 \\
6,260 \\
4,150 \\
3,120 \\
2,590 \\
2,180 \\
1,820\end{array}$ & $\begin{array}{l}766 \\
808 \\
678 \\
640 \\
615 \\
625 \\
145 \\
321 \\
577 \\
666 \\
625\end{array}$ \\
\hline \multicolumn{9}{|c|}{$\begin{array}{l}\left.\text { Monthly mean discharge, in second-feet (adjusted for diversion }{ }^{1}\right) \ldots \ldots \\
\text { Runoff, in inches (adjusted for diversion } 1 \text { ) } \ldots\end{array}$} & $\begin{array}{r}1,018 \\
2.73\end{array}$ & $\begin{array}{r}2,449 \\
6.79\end{array}$ & $\begin{array}{r}922 \\
2.56\end{array}$ \\
\hline
\end{tabular}

Gage-height, in feet, and discharge, in second-feet, at indicated time, 19,38

\begin{tabular}{|c|c|c|c|c|c|c|c|c|c|c|c|c|}
\hline \multirow{2}{*}{ Hour } & Feet & Sec.-ft. & Feet & secents. & Feet & $\Delta \mathrm{sec}-\mathrm{ft}$. & lieet & Sect-ft. & Feet & Sec. $-\mathrm{ft}$. & lifet & Sec.-ft. \\
\hline & \multicolumn{2}{|c|}{ Iuly 17} & \multicolumn{2}{|c|}{ July 18} & \multicolumn{2}{|c|}{ July 19} & \multicolumn{2}{|c|}{ July 20} & \multicolumn{2}{|c|}{ July 21} & \multicolumn{2}{|c|}{ July 22} \\
\hline 2 a.m. & 2.53 & 473 & 2.37 & .408 & 2.40 & 425 & 3.02 & 7.53 & 3.96 & 1,420 & 6.30 & 3.760 \\
\hline & 2.51 & 465 & 2.37 & 408 & 2.48 & 461 & 3.41 & 1.020 & 4.05 & 1,490 & 6.57 & 4,080 \\
\hline & 2.50 & 460 & 2.36 & 404 & 2.95 & 705 & 3.44 & $1,0-40$ & 4.10 & $1,5.40$ & 6.80 & 4,360 \\
\hline 8 & 2.66 & 535 & 2.99 & 724 & 3.28 & 921 & 4.06 & $1, \pi 00$ & 4.40 & 1,810 & 7.36 & 5,030 \\
\hline 10 & 2.65 & 530 & 2.90 & 670 & 3.11 & 807 & 3.81 & 1.300 & 4.24 & 1.670 & 7.68 & 5,430 \\
\hline $12 \mathrm{n}$. & 2.39 & $\$ 11$ & 2.99 & 724 & 3.05 & 767 & 3.83 & 1.310 & 4.17 & 1,600 & 8.09 & 5,970 \\
\hline z p.m. & 2.38 & .107 & 3.00 & 730 & 3.01 & 741 & 3.80 & 1,290 & 4.20 & 1,630 & 8.30 & 6,240 \\
\hline & 2.38 & 407 & 3.15 & 828 & 3.02 & 748 & 3.86 & 1,340 & 4.41 & 1,820 & 8.46 & 6.450 \\
\hline 6 & 2.37 & 403 & 3.04 & 756 & 3.20 & 865 & 3.93 & 1,390 & 5.15 & 2,520 & 8.48 & 6,470 \\
\hline & 2.37 & 403 & 3.00 & 730 & 3.27 & 914 & 3.97 & 1.430 & 5.26 & 2,630 & 8.51 & 6.510 \\
\hline 10 & 2.36 & 399 & 2.99 & 724 & 3.30 & 935 & 4.03 & 1.480 & 5.67 & 3.070 & 8.52 & 6,530 \\
\hline $12 \mathrm{~m}$. & 2.36 & 399 & 2.80 & 610 & 2.96 & 711 & 3.80 & 1.210 & 5.95 & 3,370 & 8.36 & 6,320 \\
\hline
\end{tabular}

\begin{tabular}{|c|c|c|c|c|c|c|c|c|c|c|c|c|}
\hline & \multicolumn{2}{|c|}{ July 23} & \multicolumn{2}{|c|}{ July 24} & \multicolumn{2}{|c|}{ July 25 } & \multicolumn{2}{|c|}{ July 20} & \multicolumn{2}{|c|}{ July 27} & \multicolumn{2}{|c|}{ July 28} \\
\hline & 8.34 & 6,300 & 12.04 & 11,600 & 13.03 & 13,000 & 9.30 & 7,600 & 7.10 & 4,750 & 5.91 & 3,360 \\
\hline & 8.29 & 6.240 & 12.62 & 12,400 & 12.55 & 12,300 & 9.02 & 7,220 & 7.00 & 4,630 & 5.90 & 3,340 \\
\hline 6 & 8.26 & 6,200 & 13.13 & 13,100 & 12,29 & 11,900 & 8.80 & 6,940 & 7.15 & 4,810 & 6.15 & 3,620 \\
\hline 8 & 8.22 & 6,150 & 13.63 & 13,900 & 12.03 & 11,500 & 8.60 & 6,680 & 6.90 & 4,510 & 5.85 & 3,300 \\
\hline 10 & 8.37 & 6,340 & 14.13 & 14,700 & 11.79 & 11,200 & 8.40 & 6,420 & 6.65 & 4,210 & 5.74 & 3,160 \\
\hline $12 \mathrm{n}$. & 8.51 & 6.520 & 14.33 & 14.900 & 11.49 & $10, \overline{700}$ & 8.25 & 6.220 & 6.53 & 4,070 & 5.70 & 3,120 \\
\hline $2 \mathrm{p.m}$. & 8.72 & 6,800 & 14.43 & 15,100 & 11.23 & 10,300 & 8.10 & 6,020 & 6.44 & 3,960 & 5.65 & 3,080 \\
\hline & 9.07 & 7,250 & 14.25 & 14,900 & 10.93 & 9,910 & 7.95 & 5,840 & 6.36 & 3,860 & 5.59 & 3,000 \\
\hline 6 & 9.43 & 7,740 & 13.99 & 14,500 & 10.58 & 9,420 & 7.75 & 5,580 & 6.25 & 3,740 & 5.52 & 2,920 \\
\hline 8 & 9.81 & 8,270 & 13.75 & 14.100 & 10.30 & 9,030 & 7.57 & 5,340 & 6.18 & 3,660 & 5.44 & 2,840 \\
\hline 10 & 10.93 & 9,840 & 13.52 & 13,700 & 10.00 & 8,610 & 7.38 & 5,100 & 6.08 & 3,550 & 5.37 & 2,760 \\
\hline $12 \mathrm{m.}$ & 11.41 & 10,500 & 13.25 & 13,400 & 9.6 .3 & 8,120 & 7.26 & 4.960 & 6.00 & 3,460 & 5.33 & 2,720 \\
\hline
\end{tabular}

\begin{tabular}{|c|c|c|c|c|c|c|c|c|c|c|c|c|}
\hline & \multicolumn{2}{|c|}{ July 29} & \multicolumn{2}{|c|}{ July 30} & \multicolumn{2}{|c|}{ July 31} & \multicolumn{2}{|c|}{ August 1} & \multicolumn{2}{|c|}{ August 2} & \multicolumn{2}{|c|}{ August 3} \\
\hline & 5.32 & 2,710 & 4.92 & 2,300 & +.59 & 1,990 & 4.23 & 1,670 & 4.10 & 1,550 & 3.73 & 1,220 \\
\hline & 5.37 & 2,760 & 4.90 & 2,280 & 4.52 & 1,930 & & & & 1,550 & 3.73 & 1,220 \\
\hline 6 & 5.66 & 3,080 & 4.89 & 2,2 & 4.4 & 1,9 & 4. & 1,8 & 4.5 & 1.9 & 3.95 & 1.420 \\
\hline 8 & 5.40 & 2,79 & 4.86 & 2,2 & 4.4 & 1.8 & 4.8 & 2,2 & & 1,6 & 4.20 & 1,640 \\
\hline 10 & 5.13 & 2,520 & 4.84 & 2,220 & 4.4 & 1,820 & 4.7 & 2,170 & 4.1 & 1,5 & 3.90 & 1,360 \\
\hline $12 \mathrm{n}$. & 5.09 & 2,480 & 4.80 & 2,180 & 4.3 & 1,7 & 4. & 1,840 & 4.0 & 1,4 & 3.80 & 1.280 \\
\hline 2 p.n. & 5.06 & 2,4 & 4.7 & 2,1 & 4.3 & & 4.3 & & 3. & & & 1,240 \\
\hline 4 & 5.03 & 2.420 & +.70 & 2,100 & 4.3 & 1,750 & 4.2 & 1,69 & 3.9 & 1,4 & 3.75 & 1,240 \\
\hline 6 & 5.00 & 2,39 & 4.6 & 2,0 & 4.3 & 1,7 & 4.2 & 1,6 & 3. & & 3 . & 1,180 \\
\hline 8 & 4.99 & 2,38 & 4.62 & 2,020 & 4.29 & 1,7 & 4.1 & 1,6 & 3. & $1,3 f$ & 3. & 1,140 \\
\hline & 4.97 & 2,360 & 4.61 & 2,020 & $\begin{array}{l}4.27 \\
\end{array}$ & 1,700 & 4.1 & 1,58 & 3.8 & 1,280 & 3. & 1,140 \\
\hline $12 \mathrm{in}$. & 4.94 & 2,330 & 4.60 & 2,000 & 4.24 & 1,680 & 4.11 & 1,560 & 3.76 & 1,240 & 3.65 & 1,140 \\
\hline
\end{tabular}

1Adjusted for diversion from Nashua River Basin to Blackstone River Basin for municipal supply of Worcester. 
THAMES RIVER BASIN

WIIIIMANTIC RIVIR NEAR SOUTH COVENTRY, CONN.

Location.-Lat. $41^{\circ} 45^{\prime} 00^{\prime \prime}$, long. $72^{\circ} 16^{\prime} 00^{\prime \prime}, 700$ feet upstream from highway bridge, 2 miles southeast of South Coventry, Tolland County, and $2 \frac{1}{2}$ miles upstream from Hop River. Datum of gage is 239.05 feet above mean sea level (general adjustment of 1929).

Drainage area. - 121 square miles.

Gage-height Recond.-Water-stage recorder graph.

Stage-discharge relation.-Defined by current-meter measurements.

Maxima.-July 1938: Discharge, 2,950 second-feet 2:30 p.m. July 23 (gage height, 9.09 feet).

1931 to June 1938: Discharge, 7,880 second-feet Mar. 12, 1936 (gage height, 12.19 feet).

Remarks.-Flood discharge affected by storage in several ponds and reservoirs.

Mean discharge, in second-feet, 1938

\begin{tabular}{r|r|r|r|r|r|r|r||r|r|r|r}
\hline Day & June & July & Aug. & Day & June & July & Aug. & Day & June & July & Aug. \\
\hline & 224 & 315 & 284 & 11 & 155 & 78 & 509 & 21 & 163 & 586 & 69 \\
1 & 187 & 242 & 228 & 12 & 413 & 125 & 481 & 22 & 128 & 1,290 & 174 \\
3 & 156 & 158 & 219 & 13 & 740 & 151 & 344 & 23 & 138 & 1,940 & 176 \\
4 & 161 & 171 & 195 & 14 & 725 & 152 & 197 & 24 & 48 & 1,880 & 155 \\
5 & 218 & 204 & 182 & 15 & 408 & 142 & 256 & 25 & 43 & 1,160 & 80 \\
6 & 229 & 160 & 165 & 16 & 277 & 146 & 199 & 26 & 63 & 810 & 88 \\
7 & 152 & 137 & 222 & 17 & 211 & 53 & 176 & 27 & 410 & 595 & 95 \\
8 & 163 & 132 & 389 & 18 & 183 & 171 & 182 & 28 & 875 & 447 & 30 \\
9 & 166 & 104 & 457 & 19 & 162 & 245 & 176 & 29 & 740 & 380 & 63 \\
10 & 135 & 15 & 390 & 20 & 186 & 409 & 171 & 30 & 469 & 367 & 106 \\
&
\end{tabular}

Gage-height, in feet, and discharge, in second-feet, at indicated time, 1938

\begin{tabular}{|c|c|c|c|c|c|c|c|c|c|c|c|c|}
\hline \multirow{2}{*}{ Hour } & Feet & Sec,-ft. & Feet & Sec.-ft. & Feet & Sec.-ft. & Feet & Sec.-ft. & Feet & Sec.-ft. & Feet & Sec.-ft. \\
\hline & \multicolumn{2}{|c|}{ July 17} & \multicolumn{2}{|c|}{ July 18} & \multicolumn{2}{|c|}{ July 19} & \multicolumn{2}{|c|}{ July 20} & \multicolumn{2}{|c|}{ July 21} & \multicolumn{2}{|c|}{ July 22} \\
\hline $\begin{array}{l}2 \text { a.m. } \\
4 \\
6 \\
8 \\
10 \\
12 \mathrm{n} . \\
2 \mathrm{p.m} . \\
4 \\
6 \\
8 \\
10 \\
12 \mathrm{~m} .\end{array}$ & $\begin{array}{l}3.17 \\
2.70 \\
2.19 \\
2.05 \\
2.03 \\
2.02 \\
2.20 \\
2.03 \\
2.55 \\
2.25 \\
2.51 \\
2.66\end{array}$ & $\begin{array}{r}158 \\
79 \\
25 \\
17 \\
16 \\
15 \\
26 \\
16 \\
59 \\
30 \\
54 \\
73\end{array}$ & $\begin{array}{l}2.63 \\
2.73 \\
2.74 \\
3.30 \\
3.40 \\
3.40 \\
3.40 \\
3.40 \\
3.41 \\
3.45 \\
3.51 \\
3.59\end{array}$ & $\begin{array}{r}69 \\
84 \\
85 \\
184 \\
205 \\
205 \\
205 \\
205 \\
207 \\
216 \\
228 \\
246\end{array}$ & $\begin{array}{l}3.60 \\
3.32 \\
3.37 \\
3.51 \\
3.60 \\
3.10 \\
3.59 \\
3.70 \\
3.78 \\
3.84 \\
3.88 \\
3.86\end{array}$ & $\begin{array}{l}248 \\
188 \\
199 \\
228 \\
248 \\
145 \\
246 \\
271 \\
290 \\
305 \\
315 \\
310\end{array}$ & $\begin{array}{l}3.70 \\
3.50 \\
4.61 \\
4.58 \\
4.48 \\
4.39 \\
4.36 \\
4.36 \\
4.35 \\
4.33 \\
4.31 \\
4.23\end{array}$ & $\begin{array}{l}271 \\
226 \\
503 \\
494 \\
465 \\
442 \\
435 \\
435 \\
432 \\
428 \\
422 \\
402\end{array}$ & $\begin{array}{l}4.12 \\
3.88 \\
3.89 \\
4.08 \\
4.01 \\
4.00 \\
4.45 \\
5.18 \\
6.10 \\
6.45 \\
6.46 \\
6.38\end{array}$ & $\begin{array}{r}375 \\
315 \\
318 \\
365 \\
348 \\
345 \\
458 \\
674 \\
950 \\
1,080 \\
1,080 \\
1,050\end{array}$ & $\begin{array}{l}6.35 \\
6.64 \\
6.91 \\
7.02 \\
7.04 \\
7.01 \\
7.05 \\
7.08 \\
7.02 \\
7.00 \\
6.94 \\
6.85\end{array}$ & $\begin{array}{l}1,040 \\
1,160 \\
1,300 \\
1,350 \\
1,360 \\
1,340 \\
1,360 \\
1,380 \\
1,350 \\
1,340 \\
1,310 \\
1,260\end{array}$ \\
\hline & \multicolumn{2}{|c|}{ July 23} & \multicolumn{2}{|c|}{ July 24} & \multicolumn{2}{|c|}{ July 25} & \multicolumn{2}{|c|}{ July 26} & \multicolumn{2}{|c|}{ July 27} & \multicolumn{2}{|c|}{ July 28} \\
\hline $\begin{array}{c}2 \text { a.m. } \\
4 \\
6 \\
8 \\
10 \\
12 \mathrm{n} . \\
2 \mathrm{p} . \mathrm{m} . \\
4 \\
6 \\
8 \\
10 \\
12 \mathrm{~m} .\end{array}$ & $\begin{array}{l}6.73 \\
6.61 \\
6.70 \\
6.86 \\
7.31 \\
8.48 \\
9.06 \\
8.93 \\
8.64 \\
8.46 \\
8.31 \\
8.22\end{array}$ & $\begin{array}{l}1,200 \\
1,140 \\
1,190 \\
1,270 \\
1,520 \\
2,370 \\
2,920 \\
2,790 \\
2,520 \\
2,350 \\
2,230 \\
2,160\end{array}$ & $\begin{array}{l}8.13 \\
8.08 \\
8.01 \\
8.00 \\
8.01 \\
7.98 \\
7.92 \\
7.84 \\
7.63 \\
7.52 \\
7.40 \\
7.30\end{array}$ & $\begin{array}{l}2,080 \\
2,040 \\
1,990 \\
1,980 \\
1,990 \\
1,970 \\
1,920 \\
1,870 \\
1,720 \\
1,640 \\
1,570 \\
1,510\end{array}$ & $\begin{array}{l}7.18 \\
7.01 \\
6.90 \\
6.89 \\
6.71 \\
6.56 \\
6.47 \\
6.34 \\
6.24 \\
6.18 \\
6.10 \\
6.00\end{array}$ & $\begin{array}{r}1,440 \\
1,340 \\
1,290 \\
1,280 \\
1,200 \\
1,120 \\
1,090 \\
1,0.10 \\
999 \\
978 \\
950 \\
920\end{array}$ & $\begin{array}{l}5.92 \\
5.88 \\
5.70 \\
5.76 \\
5.70 \\
5.62 \\
5.60 \\
5.58 \\
5.50 \\
5.42 \\
5.38 \\
5.09\end{array}$ & $\begin{array}{l}896 \\
884 \\
830 \\
848 \\
830 \\
806 \\
800 \\
794 \\
770 \\
746 \\
734 \\
647\end{array}$ & $\begin{array}{l}5.20 \\
5.05 \\
4.90 \\
5.07 \\
4.97 \\
+.90 \\
+.89 \\
4.88 \\
4.81 \\
4.77 \\
4.70 \\
4.60\end{array}$ & $\begin{array}{r}680 \\
635 \\
590 \\
641 \\
611 \\
590 \\
587 \\
584 \\
563 \\
551 \\
530 \\
500\end{array}$ & $\begin{array}{l}4.54 \\
4.37 \\
4.35 \\
4.54 \\
4.42 \\
4.35 \\
4.36 \\
4.40 \\
4.39 \\
4.36 \\
4.36 \\
4.30\end{array}$ & $\begin{array}{l}482 \\
438 \\
432 \\
482 \\
450 \\
432 \\
435 \\
415 \\
442 \\
435 \\
435 \\
420\end{array}$ \\
\hline
\end{tabular}


Gage-height, in feet, and discharge, in second-jeet, at indicated time, 1938 -Continued

\begin{tabular}{|c|c|c|c|c|c|c|c|c|c|c|c|c|}
\hline \multirow{2}{*}{ Hour } & Feet & See, -ft. & Feet & Sec. $-\mathrm{ft}$. & Feet & Sec. $-\mathrm{ft}$. & Feet & Sec.-ft. & Feet & Sec. $-\mathrm{ft}$. & Feet & Sec.-ft. \\
\hline & \multicolumn{2}{|c|}{ July 29} & \multicolumn{2}{|c|}{ July 30} & \multicolumn{2}{|c|}{ July 31} & \multicolumn{2}{|c|}{ August 1} & \multicolumn{2}{|c|}{ August 2} & \multicolumn{2}{|c|}{ August 3} \\
\hline 2 a.m. & 4.19 & 392 & 4.15 & 382 & 3.84 & 305 & 3.89 & 318 & 3.60 & 248 & 3.49 & 224 \\
\hline & 4.09 & 368 & 4.05 & 358 & 3.70 & 271 & 3.80 & 295 & 3.65 & 260 & 3.25 & 174 \\
\hline 6 & 4.09 & 368 & 3.97 & 338 & 3.77 & 288 & 3.72 & 276 & 3.53 & 233 & 3.26 & 176 \\
\hline 8 & 4.23 & 402 & 4.27 & 412 & 3.53 & 233 & 3.76 & 285 & 13.56 & 239 & 3.27 & 178 \\
\hline 10 & 4.13 & 378 & 4.16 & 385 & 3.91 & 322 & 3.90 & 320 & 3.66 & 262 & 3.59 & 246 \\
\hline $12 \mathrm{n}$. & 4.02 & 350 & 4.14 & 380 & 3.66 & 262 & 3.80 & 295 & 3.45 & 216 & 3.52 & 230 \\
\hline 2 p.m. & 4.08 & 365 & 4.10 & 370 & 3.70 & 271 & 3.76 & 285 & 3.47 & 220 & 3.50 & 226 \\
\hline & 4.04 & 355 & 4.09 & 368 & 3.78 & 290 & 3.75 & 283 & 3.39 & 203 & 3.51 & 228 \\
\hline 6 & 4.17 & 388 & 4.02 & 350 & 3.71 & 273 & 3.60 & 248 & 3.36 & 197 & 3.53 & 233 \\
\hline 8 & 4.20 & 395 & 4.01 & 348 & 3.70 & 271 & 3.61 & 250 & 3.40 & 205 & 3.54 & 235 \\
\hline 10 & 4.20 & 395 & 4.00 & 315 & 3.70 & 271 & 3.65 & 260 & 3.42 & 209 & 3.53 & 233 \\
\hline $12 \mathrm{~m}$ & 4.20 & 395 & 4.00 & 345 & 3.90 & 320 & 3.72 & 276 & 3.49 & 224 & 3.51 & 228 \\
\hline
\end{tabular}

Supplemental records.-July 17,9 p.m.,2.66 ft., 73 sec.-ft.; July 19, 9 a.m., 3.70 ft., 271 sec.-ft.; 11 a.m.' 3.53 ft., 233 sec.-ft.; 1 p.m., 2.79 ft., 92 sec.-ft.; July 23, 2:30 p.m., 9.09 ft., 2,950 sec.-ft.; Aug. 3,9 a.m., $3.59 \mathrm{ft} ., 246$ sec.-ft.

\section{SHETUCKFT RIVER NEAR WIITIMANTIC, CONN.}

Location.-Lat. $41^{\circ} 41^{\prime} 58^{\prime \prime}$, long. $72^{\circ} 10^{\prime} 53^{\prime \prime}$, at Bingham Bridge, 1 mile downstream from confluence of Willimantic and Natchaug Rivers, and 11/2 miles southeast of Willimantic, Windham County. Datum of gage is 131.40 feet above mean sea level, (general adjustment of 1929).

Drainage area.-401 square miles.

GAGE-HEIGHT RECORD.-Water-stage recorder graph.

Stage-discharge Relation.-Defined by current-meter measurements below 10,900 second-feet; extended logarithmically to peak stage on basis of computation of flood flow of March 1936 and of September 1938 over spillway of dams 5 and 8 miles below station correlated with combined flow at gaging stations on three main headwater streams.

Maxima.-July 1938: Discharge, 15,300 second-feet 4 a.m. July 24 (gage height, 14.65 feet).

1904-5; 1933 to June 1938: Discharge, 23,900 second-feet Mar. 12, 1936 (gage height, 18.35 feet, from floodmarks).

REMARKs.-Flood discharge affected by storage in numerous ponds and reservoirs.

Mean discharge, in second-feet, 1938

\begin{tabular}{r|c|c|c||c|c|c|c||c|c|c|c}
\hline Day & June & July & Aug. & Day & June & July & Aug. & Dav & June & July & Aug. \\
\hline & & & & & & \\
1 & 668 & 1,040 & 880 & 11 & 377 & 247 & 1,370 & 21 & 387 & 2,070 & 488 \\
2 & 564 & 790 & 760 & 12 & 888 & 241 & 1,780 & 22 & 338 & 5,680 & 428 \\
3 & 492 & 610 & 685 & 13 & 1,660 & 304 & 1,100 & 23 & 313 & 6,750 & 421 \\
4 & 502 & 524 & 633 & 14 & 1,840 & 337 & 735 & 24 & 286 & 12,600 & 406 \\
5 & 606 & 502 & 577 & 15 & 1,130 & 335 & 678 & 25 & 251 & 6,500 & 368 \\
6 & 603 & 433 & 542 & 16 & 779 & 349 & 586 & 26 & 258 & 3,560 & 307 \\
7 & 514 & 362 & 761 & 17 & 629 & 341 & 553 & 27 & 728 & 2,430 & 183 \\
8 & 442 & 312 & 1,020 & 18 & 547 & 289 & 594 & 28 & 3,000 & 1,790 & 167 \\
9 & 467 & 300 & 1,270 & 19 & 480 & 556 & 602 & 29 & 2,790 & 1,460 & 251 \\
10 & 394 & 249 & 1,080 & 20 & 444 & 1,090 & 565 & 30 & 1,680 & 1,310 & 252 \\
& & & & & & & 31 & & 1,050 & 254 \\
\hline
\end{tabular}


Gage-height, in feet, and discharge, in second-feet, at indicated time, 1938

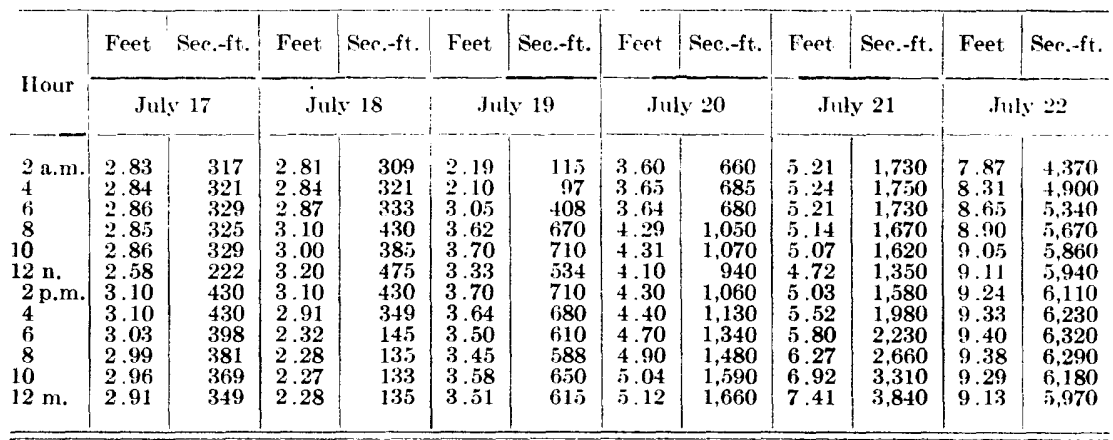

\begin{tabular}{|c|c|c|c|c|c|c|c|c|c|c|c|c|}
\hline & \multicolumn{2}{|c|}{ July 23} & \multicolumn{2}{|c|}{ July 24} & \multicolumn{2}{|c|}{ July 25 } & \multicolumn{2}{|c|}{$J u 1 y 26$} & \multicolumn{2}{|c|}{ July 27} & \multicolumn{2}{|c|}{ Ju ly 28} \\
\hline & 8.94 & $5,7 \cdot 20$ & 14.55 & 15,100 & & & & & 6.38 & 2,770 & 5.56 & 2,010 \\
\hline & 8.75 & 5,480 & 14.65 & 15,300 & 10.60 & 8,000 & 7.66 & 4.120 & 6.30 & 2,690 & $\tilde{3} .49$ & 1,950 \\
\hline 6 & 8.64 & 5,330 & 14.47 & 14,900 & & & & & 6.23 & 2,620 & 5.42 & 1,900 \\
\hline 8 & 8.51 & 5,160 & 14.08 & 14,100 & 10.04 & 7,200 & 7.35 & 3.780 & 6.15 & 2,540 & 5.32 & 1,820 \\
\hline 10 & 8.50 & 5,150 & 13.66 & 13,300 & & & & & 6.07 & 2,470 & 5.29 & 1,790 \\
\hline $12 \mathrm{n}$. & 8.52 & 5,180 & 13.24 & 12,400 & 9.41 & 6,330 & 7.05 & 3,440 & 5.84 & 2,270 & 5.02 & 1,580 \\
\hline 2 p.m. & 8.75 & 5,480 & 12.82 & 11.700 & & & & & 5.94 & 2,360 & 5.23 & 1,740 \\
\hline 4 & 9.36 & 6,270 & 12.45 & 11.000 & 8.86 & 5,620 & 6.85 & 3,240 & 5.77 & 2,200 & i. 10 & 1,640 \\
\hline i & 10.04 & 7,200 & 12.13 & 10,400 & & & & & 5.82 & 2,250 & 5). 14 & 1,670 \\
\hline 8 & 11.22 & 8,950 & 11.82 & 9,910 & 8.45 & $\overline{5}, 080$ & 6.65 & 3,040 & 5.75 & 2,180 & 5.11 & 1,600 \\
\hline 10 & 12.60 & 11,300 & 11.53 & $9,4,30$ & & $\ldots$ & & & 5.70 & 2,140 & $5.06 \mathrm{j}$ & 1,610 \\
\hline $12 \mathrm{~m}$. & 13.81 & 13,600 & 11.22 & 8,950 & 8.04 & 4.580 & 6.50 & 2,890 & 5.62 & 2,070 & $\overline{5} .03$ & 1,580 \\
\hline
\end{tabular}

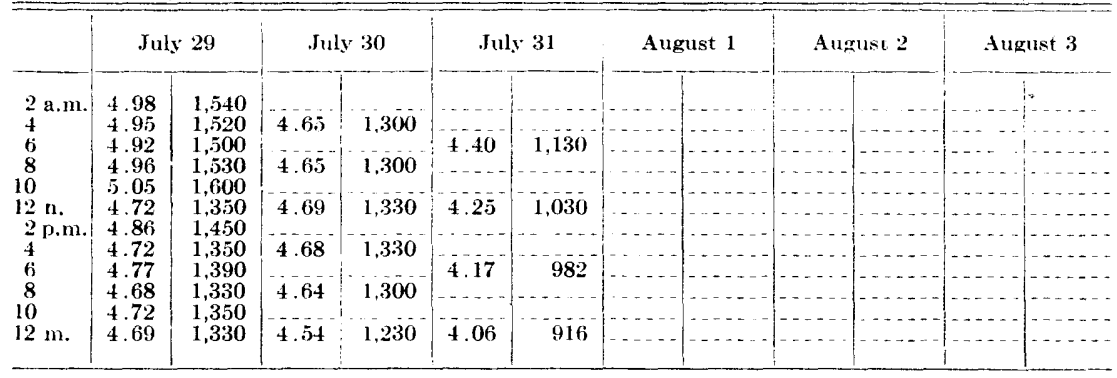

Supplemental records. - July 17,11 a.m., $2.30 \mathrm{ft} ., 140$ sec.-ft.; 1 p.m., $2.60 \mathrm{ft} ., 229 \mathrm{sec} . \mathrm{ft}$.; July 18 , 9 a.m., 2.94 ft., 361 sec.-ft.; 11 a.m., $2.65 \mathrm{ft.}, 247$ sec.-ft.; $12: 40$ p.m., 2.55 ft., 212 sec.-ft.; $1: 20$ p.m. $3.29 \mathrm{ft}$., 516 sec.-ft.; 5 p.m., 2.39 ft., 163 sec.-ft.; July 19, 7 a.m., $3.84 \mathrm{ft} ., 784$ sec.-ft.; $11: 30 \mathrm{a.m \%}, 3.72 \mathrm{ft}$. 720 sec.-ft.; 1 p.m., 4.04 ft., 904 sec.-ft.; July 20 , $11: 30$ a.m., 4.34 ft., 1,090 sec.-ft.; 1 p.m., $4.61 \mathrm{ft} ., 1,280$ sec.-ft.; July 21,7 a.m., $5.30 \mathrm{ft} ., 1,800$ sec.-ft.; $11: 40$ a.m., 4.99 ft., 1,550 sec.-ft.; 1 p.m., 5.20 ft., 1,720 sec.-ft.; 3 p.m., 5.63 ft., 2,080 sec.-ft.; $4: 30$ p.m., 5.72 ft., 2,160 sec.-ft.; July 24,3 a.m., 14.64 ft., 15,200 sec-ft.; July 27,7 a.m., $6.34 \mathrm{ft} ., 2,730$ sec.-ft.; $11: 30$ a.m., $5.84 \mathrm{ft} ., 2,270$ sec.-ft.; 1 p.m., $6.12 \mathrm{ft} ., 2,520$ sec.ft.; July 28, 7 a.m., 5.53 ft., 1,990 sec.-ft.; $11: 30$ a.m., 5.26 ft., 1,770 sec.-ft.; 1 p.m., 5.44 ft., 1,910 sec.-ft.; July 29, $11: 30$ a.m., 4.95 ft., 1,520 sec.-ft.; 1 p.m., 5.15 ft., 1,680 sec.-ft.

HOP RTVER NEAR COTUMBIA, CONN.

L.ocation.-Lat. $41^{\circ} 43^{\prime} 25^{\prime \prime}$, long. $72^{\circ} 18^{\prime} 05^{\prime \prime}, 1,000$ feet downstream from abandoned mill and dam, a quarter of a mile downstream from Hop River station on New York, New Haven \& Hartford Railroad, 2 miles north of Columbia, Tolland County, and $31 / 2$ miles upstream from mouth. Datum of gage is 249.25 feet above mean sea level, (general adjustment of 1929).

Drainace area. - 76.2 square miles.

GAGE-HEIGHT RECORD.-Water-stage recorder graph.

Stage-discharge relation.-Defined by current-meter measurements.

Maxima.-July 1938: Discharge, 2,530 second-feet 8 p.m. July 23 (gage height, 11.70 feet). 
1932 to June 1938: Discharge, 3,300 second-feet Mar. 12, 1936 (gage height, 13.85 feet, from floodmarks).

Remarкs.-Flood discharge affected by storage in two reservoirs.

Mean discharge, in second-feet, 1938

\begin{tabular}{|c|c|c|c|c|c|c|c|c|c|c|c|}
\hline Day & June & July & Aug. & Day & June & July & Aug. & Dav & June & July & Aug. \\
\hline $\begin{array}{r}1 \\
2 \\
3 \\
4 \\
5 \\
6 \\
7 \\
8 \\
9 \\
10\end{array}$ & $\begin{array}{r}129 \\
105 \\
96 \\
93 \\
122 \\
101 \\
83 \\
88 \\
82 \\
67\end{array}$ & $\begin{array}{r}229 \\
170 \\
115 \\
92 \\
79 \\
66 \\
57 \\
53 \\
46 \\
37\end{array}$ & $\begin{array}{r}142 \\
122 \\
104 \\
90 \\
84 \\
77 \\
71 \\
84 \\
208 \\
147\end{array}$ & $\begin{array}{l}11 \\
12 \\
13 \\
14 \\
1.5 \\
16 \\
17 \\
18 \\
19 \\
20\end{array}$ & $\begin{array}{r}68 \\
158 \\
245 \\
193 \\
140 \\
113 \\
93 \\
79 \\
68 \\
59\end{array}$ & $\begin{array}{r}51 \\
53 \\
58 \\
50 \\
50 \\
43 \\
41 \\
48 \\
153 \\
210\end{array}$ & $\begin{array}{r}360 \\
331 \\
190 \\
141 \\
105 \\
88 \\
92 \\
118 \\
107 \\
86\end{array}$ & $\begin{array}{l}21 \\
22 \\
23 \\
24 \\
25 \\
26 \\
27 \\
28 \\
29 \\
30 \\
31\end{array}$ & $\begin{array}{r}53 \\
47 \\
44 \\
42 \\
39 \\
40 \\
195 \\
680 \\
495 \\
315\end{array}$ & $\begin{array}{r}447 \\
1,000 \\
1,510 \\
1,600 \\
914 \\
604 \\
154 \\
362 \\
298 \\
250 \\
177\end{array}$ & $\begin{array}{l}73 \\
64 \\
60 \\
53 \\
46 \\
46 \\
34 \\
43 \\
47 \\
38 \\
33\end{array}$ \\
\hline \multicolumn{9}{|c|}{$\begin{array}{l}\text { Monthly mean discharge, in second-feet } \\
\text { Runoff, in inchess }\end{array}$} & $\begin{array}{r}138 \\
2.02\end{array}$ & $\begin{array}{r}301 \\
4.55\end{array}$ & $\begin{array}{l}106 \\
1.60\end{array}$ \\
\hline
\end{tabular}

Gage-height, in feet, and discharge, in second-feet, at indicated time, 1938

\begin{tabular}{|c|c|c|c|c|c|c|c|c|c|c|c|c|}
\hline \multirow{2}{*}{ Hour } & Feet & Sec.-ft. & Feet & Sec.-ft. & Feet & Sec.-ft. & Feet & Sec.-ft. & Feet & Sec.-ft. & Feet & Sec.-ft. \\
\hline & \multicolumn{2}{|c|}{ July 17} & \multicolumn{2}{|c|}{ July 18} & \multicolumn{2}{|c|}{ July 19} & \multicolumn{2}{|c|}{ July 20} & \multicolumn{2}{|c|}{ July 21} & \multicolumn{2}{|c|}{ July 22 } \\
\hline 2 a.m. & & & 2.99 & 37 & 4.17 & $17 \%$ & 3.87 & 125 & 4.98 & 331 & 7.55 & 950 \\
\hline & & & 2.97 & 36 & 4.24 & 184 & 3.88 & 126 & 4.87 & 309 & 7.67 & 986 \\
\hline 6 & 3.04 & 41 & 2.95 & 35 & 4.26 & 188 & 3.89 & 128 & 4.91 & 317 & 7.69 & 992 \\
\hline 8 & & & 2.95 & 35 & 4.21 & 179 & 4.12 & 163 & 4.79 & 293 & 7.70 & 995 \\
\hline 10 & & & 2.98 & 37 & 4.20 & 177 & 4.41 & 217 & 4.65 & 265 & 7.85 & 1,040 \\
\hline $12 \mathrm{n}$. & 3.06 & 42 & 3.20 & 53 & 4.13 & 165 & 4.45 & 225 & 4.57 & 249 & 8.05 & 1,100 \\
\hline $2 \mathrm{p.m}$ & & & 3.35 & 66 & 4.03 & 149 & 4.50 & 235 & 4.97 & 329 & 8.13 & 1,120 \\
\hline 4 & & & 3.32 & 63 & 3.97 & 140 & 4.57 & 249 & 5.99 & 558 & 8.01 & 1,090 \\
\hline 6 & 3.04 & 41 & 3.24 & 56 & 3.92 & 132 & 4.64 & 263 & 6.29 & 632 & 7.79 & 1,020 \\
\hline 8 & & & 3.20 & 53 & 3.82 & 118 & 4.87 & 30 & 6.54 & 695 & 7.55 & 950 \\
\hline 10 & & & 3.15 & 49 & 3.77 & 111 & 5.09 & 353 & 6.90 & 785 & 7.34 & 895 \\
\hline $12 \mathrm{nt}$ & 3.00 & 38 & 3.78 & 113 & 3.84 & 121 & 5.10 & 355 & 7.27 & 878 & 7.17 & 8.52 \\
\hline
\end{tabular}

\begin{tabular}{|c|c|c|c|c|c|c|c|c|c|c|c|c|}
\hline \multirow{3}{*}{$2 \mathrm{a}}$. & \multicolumn{2}{|c|}{ July 23} & \multicolumn{2}{|c|}{ July 24 } & \multicolumn{2}{|c|}{ July 25} & \multicolumn{2}{|c|}{ July 26} & \multicolumn{2}{|c|}{ July 27} & \multicolumn{2}{|c|}{ July 28} \\
\hline & 7.02 & $81 \%$ & 10.57 & 2,010 & & & & & & & & \\
\hline & 6.91 & & 10.21 & 1,8 & 8.01 & 1,090 & & & & & & \\
\hline & 7.00 & 810 & 9.96 & i. .760 & & & 6.34 & 645 & 5. 68 & 481 & 5.22 & 37, \\
\hline 8 & 7.15 & 848 & 9.70 & 1.660 & 7.63 & 97.4 & & & & $\ldots$ & & \\
\hline 10 & $\begin{array}{l}7.80 \\
8.91\end{array}$ & $\begin{array}{l}1,020 \\
1.380\end{array}$ & $\begin{array}{l}9.52 \\
9.38\end{array}$ & $\begin{array}{l}1,590 \\
1,540\end{array}$ & 7.29 & 889 & 617 & 602 & 57 & +56 & 514 & $36 \overline{3}$ \\
\hline 2 p.m. & 9.43 & $\begin{array}{l}1,380 \\
1,560\end{array}$ & 9.27 & $\begin{array}{l}1,040 \\
1,500\end{array}$ & & & & & & $+\infty 0$ & & 303 \\
\hline & 10.50 & 1,980 & 9.17 & 1,47 & 7.03 & 818 & & & & & & \\
\hline ; & 11.56 & 2,460 & 9.07 & 1,430 & & & 6.00 & 560 & 5.42 & 423 & 5.05 & 345 \\
\hline $\begin{array}{r}8 \\
10\end{array}$ & 11.70 & 2,530 & 8.93 & 1,390 & 6.78 & 755 & & & & & & \\
\hline $12 \mathrm{~m}$. & $\begin{array}{l}11.58 \\
10.98\end{array}$ & 2,170 & 8.47 & $\begin{array}{l}1.300 \\
1,230\end{array}$ & 6.56 & 700 & 582 & 315 & 5.30 & 307 & 4.96 & 327 \\
\hline
\end{tabular}

\begin{tabular}{|c|c|c|c|c|c|c|c|c|c|c|c|c|}
\hline \multirow{5}{*}{$\begin{array}{l}2 \text { a.m. } \\
4 \\
6 \\
8 \\
10\end{array}$} & \multicolumn{2}{|c|}{ July 29} & \multicolumn{2}{|c|}{ July 30} & \multicolumn{2}{|c|}{ July 31} & \multicolumn{2}{|c|}{ August 1} & \multicolumn{2}{|c|}{ August 2} & \multicolumn{2}{|c|}{ August 3} \\
\hline & & & 4.6 .5 & 265 & & & & & & & & \\
\hline & & & 4.69 & 273 & & & +.02 & $1+7$ & 3.89 & 128 & 3.74 & 105 \\
\hline & +.90 & 315 & $\begin{array}{r}+.70 \\
+70\end{array}$ & $27 \tilde{5}$ & +.25 & 186 & $+\left(0^{2}\right)$ & 147 & 38 & ivo & 37 & 108 \\
\hline & & & 4.69 & 273 & & & & 146 & 3.88 & 126 & 3.74 & 108 \\
\hline $12 \mathrm{n}$. & +.84 & 303 & 4.63 & 261 & 4.21 & 179 & +.02 & $1+7$ & 3.97 & $140^{\circ}$ & 3.87 & 125 \\
\hline & & & 4.49 & 233 & & & 3.99 & 142 & 3.86 & 123 & 3.73 & 107 \\
\hline$\stackrel{6}{8}$ & 4.73 & 281 & 4.53 & 241 & 4.13 & 165 & & & & & & \\
\hline & & & $\begin{array}{l}4.52 \\
4.37\end{array}$ & 239 & & & 3.92 & 132 & 3.74 & 108 & $\begin{array}{l}3.60 \\
3.47\end{array}$ & 91 \\
\hline $12 \mathrm{~m}$. & 4.62 & 259 & -4.33 & 201 & 4.06 & 154 & 3.80 & 115 & 3.67 & 99 & 3.56 & 87 \\
\hline
\end{tabular}

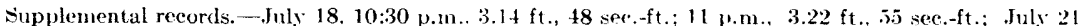
1 p.m., 4.in ft., 2.53 sec. $\mathrm{ft}$. 
NATCHAUG RIVER AT WITIMMANTIC, CONN.

Location.-Lat. $41^{\circ} 43^{\prime} 14^{\prime \prime}$, long. $72^{\circ} 11^{\prime} 53^{\prime \prime}, 200$ feet downstream from New York, New Haven \& Hartford Railroad bridge, and 1 mile northeast of Willimantic, Windham County. Datum of gage is 150.31 feet above mean sea level (general adjustment of 1929).

Drainage AREA.-169 square miles.

GAGE-HEIGHT RECORD.-Water-stage recorder graph.

StAGE-DIScharge RELATION.-Defined by current-meter measurements below 6,530 second-feet; extended to peak stage on basis of determinations of flood flows of March 1936 and September 1938 at dam 2 miles above station.

Maxima.-July 1938: Discharge, 9,740 second-feet 11:30 p.m. July 23 (gage height, 12.51 feet).

1930 to June 1938: Discharge, resulting from breaking of dam above station, 14,200 second-feet Mar. 18, 1936 (gage height, 13.57 feet).

Remarks.-Flood discharge affected by storage in several small ponds. Small diversions for municipal supply of Willimantic pumped from reservoir 2 miles above station. Monthly mean diversions: June, 1.45 second-feet; July, 1.33 second-feet; August, 1.39 second feet.

Mean discharge, in second-feet, 1938

\begin{tabular}{|c|c|c|c|c|c|c|c|c|c|c|c|}
\hline Day & June & July & Aug. & Day & June & July & Aug. & Day & June & July & Aug. \\
\hline $\begin{array}{r}1 \\
2 \\
3 \\
4 \\
5 \\
6 \\
7 \\
8 \\
9 \\
10\end{array}$ & $\begin{array}{l}233 \\
200 \\
184 \\
184 \\
241 \\
230 \\
179 \\
159 \\
166 \\
140\end{array}$ & $\begin{array}{r}382 \\
300 \\
259 \\
205 \\
175 \\
144 \\
119 \\
100 \\
103 \\
93\end{array}$ & $\begin{array}{l}412 \\
363 \\
322 \\
267 \\
235 \\
224 \\
474 \\
517 \\
503 \\
393\end{array}$ & $\begin{array}{l}11 \\
12 \\
13 \\
14 \\
15 \\
16 \\
17 \\
18 \\
19 \\
20\end{array}$ & $\begin{array}{l}132 \\
368 \\
816 \\
803 \\
452 \\
320 \\
267 \\
225 \\
193 \\
162\end{array}$ & $\begin{array}{c}100 \\
133 \\
153 \\
123 \\
120 \\
117 \\
108 \\
102 \\
263 \\
406\end{array}$ & $\begin{array}{l}589 \\
709 \\
426 \\
302 \\
250 \\
215 \\
225 \\
238 \\
267 \\
242\end{array}$ & $\begin{array}{l}21 \\
22 \\
23 \\
24 \\
25 \\
26 \\
27 \\
28 \\
29 \\
30 \\
31\end{array}$ & $\begin{array}{r}135 \\
120 \\
118 \\
99 \\
85 \\
96 \\
352 \\
1,330 \\
1,160 \\
648\end{array}$ & $\begin{array}{r}933 \\
3,230 \\
3,980 \\
7,030 \\
3,340 \\
1,710 \\
1,150 \\
834 \\
665 \\
616 \\
498\end{array}$ & $\begin{array}{r}187 \\
162 \\
141 \\
123 \\
114 \\
97 \\
91 \\
148 \\
112 \\
89 \\
95\end{array}$ \\
\hline \multicolumn{9}{|c|}{$\begin{array}{l}\text { Monthly mean discharge, in second-feet } \\
\text { Runoff, in inches. }\end{array}$} & $\begin{array}{r}327 \\
2.15\end{array}$ & $\begin{array}{r}887 \\
6.05\end{array}$ & $\begin{array}{r}275 \\
1.88\end{array}$ \\
\hline
\end{tabular}

Gage-height, in feet, and discharge, in second-feet, at indicated time, 1938

\begin{tabular}{|c|c|c|c|c|c|c|c|c|c|c|c|c|}
\hline \multirow{2}{*}{ Hour } & Feet & Sec.-ft. & Feet & Sec.-ft. & Feet & Sec. $-\mathrm{ft}$. & Feet & Sec.-ft. & Feet & Sec.-ft. & Feet & Sec.-ft. \\
\hline & \multicolumn{2}{|c|}{ July 17} & \multicolumn{2}{|c|}{ July 18} & \multicolumn{2}{|c|}{ July 19} & \multicolumn{2}{|c|}{ July 20} & \multicolumn{2}{|c|}{ July 21} & \multicolumn{2}{|c|}{ July 22} \\
\hline $\begin{array}{c}2 \text { a.m. } \\
4 \\
6 \\
8 \\
10 \\
12 \mathrm{n} . \\
2 \mathrm{p.m} . \\
4 \\
6 \\
8 \\
10 \\
12 \mathrm{~m} .\end{array}$ & $\begin{array}{l}1.67 \\
1.76 \\
1.78 \\
1.79 \\
1.78 \\
1.80 \\
1.98 \\
1.87 \\
1.80 \\
1.76 \\
1.48 \\
1.46\end{array}$ & $\begin{array}{r}93 \\
109 \\
112 \\
114 \\
112 \\
116 \\
151 \\
129 \\
116 \\
109 \\
62 \\
59\end{array}$ & $\begin{array}{l}1.61 \\
1.67 \\
1.71 \\
1.95 \\
1.85 \\
1.77 \\
1.74 \\
1.73 \\
1.71 \\
1.70 \\
1.70 \\
1.44\end{array}$ & $\begin{array}{r}83 \\
63 \\
100 \\
145 \\
126 \\
111 \\
105 \\
103 \\
100 \\
98 \\
98 \\
56\end{array}$ & $\begin{array}{l}1.80 \\
2.15 \\
2.42 \\
2.60 \\
2.61 \\
2.62 \\
2.63 \\
2.62 \\
2.59 \\
2.55 \\
2.45 \\
2.51\end{array}$ & $\begin{array}{l}116 \\
188 \\
256 \\
306 \\
309 \\
312 \\
315 \\
312 \\
303 \\
292 \\
264 \\
281\end{array}$ & $\begin{array}{l}2.50 \\
2.49 \\
2.53 \\
2.86 \\
2.82 \\
2.82 \\
2.92 \\
3.00 \\
3.15 \\
3.31 \\
3.46 \\
3.59\end{array}$ & $\begin{array}{l}278 \\
275 \\
286 \\
383 \\
371 \\
371 \\
402 \\
430 \\
482 \\
538 \\
594 \\
646\end{array}$ & $\begin{array}{l}3.73 \\
3.77 \\
3.77 \\
3.78 \\
3.67 \\
3.64 \\
3.97 \\
4.18 \\
4.44 \\
5.06 \\
5.62 \\
6.20\end{array}$ & $\begin{array}{r}702 \\
718 \\
718 \\
722 \\
678 \\
666 \\
806 \\
901 \\
1,030 \\
1,340 \\
1,620 \\
1,910\end{array}$ & $\begin{array}{l}6.88 \\
7.52 \\
8.02 \\
8.37 \\
8.50 \\
8.59 \\
8.72 \\
8.83 \\
8.84 \\
8.73 \\
8.50 \\
8.18\end{array}$ & $\begin{array}{l}2,320 \\
2,700 \\
3,050 \\
3,310 \\
3,410 \\
3,480 \\
3, \tilde{3} 90 \\
3,670 \\
3,680 \\
3,590 \\
3,410 \\
3,170\end{array}$ \\
\hline
\end{tabular}


Gage-height, in feet, and discharge, in second-feet, at indicated time, 1938 --Continued

\begin{tabular}{|c|c|c|c|c|c|c|c|c|c|c|c|c|}
\hline \multirow{2}{*}{ Hour } & Feeb & Sec.-ft. & Feet & Sec.-ft. & Feet & Sec.-ft. & Feet & Sec.-ft. & Feet & Sec.-ft. & Feet & Sec.-ft. \\
\hline & \multicolumn{2}{|c|}{ July 23} & \multicolumn{2}{|c|}{ July 24} & \multicolumn{2}{|c|}{ July 25} & \multicolumn{2}{|c|}{ July 26} & \multicolumn{2}{|c|}{ July 27} & \multicolumn{2}{|c|}{ July 28} \\
\hline $\begin{array}{l}2 \mathrm{a} . \mathrm{m} . \\
4 \\
6 \\
8 \\
8 \\
10 \\
12 \mathrm{n} . \\
2 \mathrm{p} . \mathrm{m} . \\
4 \\
6 \\
8 \\
10 \\
12 \mathrm{~m} .\end{array}$ & $\begin{array}{r}7.87 \\
7.60 \\
7.38 \\
7.23 \\
7.17 \\
7.23 \\
7.62 \\
8.30 \\
9.45 \\
11.22 \\
12.27 \\
12.49\end{array}$ & $\begin{array}{l}2,950 \\
2,760 \\
2,620 \\
2,530 \\
2,490 \\
2,530 \\
2,770 \\
3,250 \\
4,170 \\
6,240 \\
8,910 \\
9,660\end{array}$ & $\begin{array}{l}12.45 \\
12.33 \\
12.14 \\
11.93 \\
11.71 \\
11.50 \\
11.24 \\
11.03 \\
10.82 \\
10.60 \\
10.39 \\
10.15\end{array}$ & $\begin{array}{l}9,520 \\
9,100 \\
8,520 \\
7,890 \\
7,320 \\
6,800 \\
6,280 \\
5,900 \\
5,580 \\
5,250 \\
5,000 \\
4,780\end{array}$ & $\begin{array}{l}9.88 \\
9.58 \\
9.25 \\
8.93 \\
8.57 \\
8.25 \\
7.96 \\
7.69 \\
7.43 \\
7.20 \\
6.96 \\
6.73\end{array}$ & $\begin{array}{l}4,530 \\
4,270 \\
4,010 \\
3,750 \\
3,470 \\
3,220 \\
3,010 \\
2,820 \\
2,650 \\
2,510 \\
2,370 \\
2,230\end{array}$ & $\begin{array}{l}6.50 \\
6.33 \\
6.17 \\
6.03 \\
5.85 \\
5.71 \\
5.60 \\
5.49 \\
5.38 \\
5.28 \\
5.19 \\
5.05\end{array}$ & $\begin{array}{l}2,090 \\
1,990 \\
1,900 \\
1,820 \\
1,740 \\
1,660 \\
1,610 \\
1,560 \\
1,500 \\
1,450 \\
1,400 \\
1,340\end{array}$ & $\begin{array}{c}4.92 \\
4.82 \\
4.66 \\
4.54 \\
4.43 \\
4.31\end{array}$ & $\begin{array}{r}1,270 \\
1,220 \\
1,140 \\
1,080 \\
1,020 \\
965\end{array}$ & $\begin{array}{l}4.19 \\
4.08 \\
4.03 \\
3.95 \\
3.88 \\
3.78\end{array}$ & $\begin{array}{c}906 \\
856 \\
834 \\
798 \\
766\end{array}$ \\
\hline & \multicolumn{2}{|c|}{ July 29} & \multicolumn{2}{|c|}{ July 30} & \multicolumn{2}{|c|}{ July 31} & \multicolumn{2}{|c|}{ August 1} & \multicolumn{2}{|c|}{ August 2} & \multicolumn{2}{|c|}{ August 3} \\
\hline 2 a.m. & 3.73 & 702 & \\
\hline$\stackrel{0}{8}$ & 3.71 & 694 & 3.62 & 658 & 3.26 & 521 & 3.05 & 448 & 2.90 & 395 & 2.78 & 359 \\
\hline $\begin{array}{l}10 \\
12 \mathrm{n} .\end{array}$ & 3.63 & $6 \overline{6} 2$ & 3.55 & 630 & 3.19 & 496 & 2.94 & 409 & 2.78 & 359 & 2.66 & 323 \\
\hline & $3 . \overline{9}$ & 646 & 3.53 & 622 & 3.14 & $47 \overline{9}$ & 2.91 & 398 & $2.7 \overline{7}$ & 356 & $\begin{array}{l}2.63 \\
2.63\end{array}$ & $\begin{array}{l}315 \\
315\end{array}$ \\
\hline & $3 . \overline{5}$ & $630^{\circ}$ & & 606 & & 465 & & 389 & & 350 & 2.60 & 306 \\
\hline & 3.45 & 590 & & 546 & & & & & & $\begin{array}{l}344 \\
318\end{array}$ & 2.56 & 295 \\
\hline
\end{tabular}

Supplemental records.-July 17, 1 p.m., 1.97 ft., 149 sec.-ft.: July 18, 7 a.m., $1.92 \mathrm{ft} ., 139$ sec.-ft.; July 19,7 a.m., $2.60 \mathrm{ft}$., 306 sec.-ft.; July 21,7 a.m., 3.83 ft., 744 sec.-ft.; July $23,11: 30$ p.m., $12.51 \mathrm{ft}$., 9740 sec.-ft.; Aug. 3, 3 p.m., 2.50 ft., 278 sec.-ft.

\section{QUTNFBAUG RIVER AT QUINEBAUG, CONN.}

Location.-Lat. $42^{\circ} 01^{\prime} 20^{\prime \prime}$, long. $71^{\circ} 57^{\prime} 15^{\prime \prime}$, at Quinebaug, Windham County, 500 feet upstream from highway bridge, a quarter of a mile downstream from Massachusetts-Connecticut State line, and 7 miles upstream from French River.

Drainage AREA.-157 square miles.

GAGE-height RECORD.-Water-stage recorder graph.

STAGE-Discharge RELATION.-Defined by current-meter measurements to 2000 second-feet; extended to peak stage on basis of computations of March 1936 and September 1938 peak flows at bridge 500 feet below station and determination of peak flow of March 1936 flood at dam a quarter of a mile above station. Affected by backwater from aquatic growth June 7 to 3 p.m. July 23.

Maxima.-July 1938: Discharge, 4,390 second-feet 6:10 p.m. July 23 (gage height, 8.01 feet).

1931 to June 1938: Discharge, 10,500 second-feet Mar. 18, 1936 (gage height, 13.44 feet).

Remarks.-Flood discharge doubtless affected by storage in several lakes and ponds. 
Mean discharge, in second-feet, 1938

\begin{tabular}{|c|c|c|c|c|c|c|c|c|c|c|c|}
\hline Day & June & July & Aug. & Day & June & July & Aug. & Day & June & July & Aug. \\
\hline $\begin{array}{r}1 \\
2 \\
3 \\
4 \\
5 \\
6 \\
7 \\
8 \\
9 \\
10\end{array}$ & $\begin{array}{l}248 \\
211 \\
223 \\
195 \\
226 \\
271 \\
238 \\
231 \\
217 \\
197\end{array}$ & $\begin{array}{l}575 \\
458 \\
359 \\
305 \\
287 \\
240 \\
180 \\
177 \\
112 \\
111\end{array}$ & $\begin{array}{l}478 \\
454 \\
394 \\
358 \\
311 \\
328 \\
485 \\
470 \\
535 \\
505\end{array}$ & $\begin{array}{l}11 \\
12 \\
13 \\
14 \\
15 \\
16 \\
17 \\
18 \\
19 \\
20\end{array}$ & $\begin{array}{l}208 \\
257 \\
808 \\
705 \\
551 \\
433 \\
367 \\
245 \\
254 \\
290\end{array}$ & $\begin{array}{l}201 \\
453 \\
433 \\
332 \\
250 \\
241 \\
184 \\
277 \\
387 \\
420\end{array}$ & $\begin{array}{l}555 \\
530 \\
423 \\
341 \\
349 \\
316 \\
295 \\
275 \\
279 \\
230\end{array}$ & $\begin{array}{l}21 \\
22 \\
23 \\
24 \\
25 \\
26 \\
27 \\
28 \\
29 \\
30 \\
31\end{array}$ & $\begin{array}{l}236 \\
192 \\
153 \\
112 \\
203 \\
119 \\
391 \\
\mathbf{8 6 6} \\
\mathbf{8 8 6} \\
\mathbf{7 3 6}\end{array}$ & $\begin{array}{r}793 \\
1,680 \\
2,760 \\
3,090 \\
2,070 \\
1,500 \\
1,130 \\
851 \\
704 \\
628 \\
526\end{array}$ & $\begin{array}{l}184 \\
279 \\
229 \\
215 \\
213 \\
201 \\
178 \\
174 \\
233 \\
197 \\
190\end{array}$ \\
\hline \multicolumn{9}{|c|}{$\begin{array}{l}\text { Monthly mean discharge, in second-feet } \\
\text { Runoff, in inches }\end{array}$} & $\begin{array}{r}342 \\
2.43\end{array}$ & $\begin{array}{r}700 \\
5.14\end{array}$ & $\begin{array}{r}329 \\
2.42\end{array}$ \\
\hline
\end{tabular}

Gage-height, in feet, and discharge, in second-feet, at indicated time, 1938

\begin{tabular}{|c|c|c|c|c|c|c|c|c|c|c|c|c|}
\hline \multirow{2}{*}{ Hour } & Feet & Sec.-ft. & Feet & Sec.ft. & Feet & Sec.-ft & Feet & Sec.-ft. & Feet & Sec.ft. & Feet & Sec.-ft. \\
\hline & \multicolumn{2}{|c|}{ July 17} & \multicolumn{2}{|c|}{ July 18} & \multicolumn{2}{|c|}{ July 19} & \multicolumn{2}{|c|}{ July 20} & \multicolumn{2}{|c|}{ July 21} & \multicolumn{2}{|c|}{ July 22} \\
\hline \multirow{7}{*}{$\begin{array}{l}2 \mathrm{a} . \mathrm{m} . \\
4 \\
6 \\
8 \\
10 \\
12 \mathrm{n} . \\
2 \mathrm{p} . \mathrm{m} . \\
4 \\
6 \\
8 \\
10 \\
12 \mathrm{~m} .\end{array}$} & & & & & & & & & & & \multirow{7}{*}{$\begin{array}{l}5.24 \\
5.31 \\
5.40 \\
5.42 \\
5.48 \\
5.41 \\
5.35 \\
5.35 \\
5.30 \\
5.21 \\
5.18 \\
5.08\end{array}$} & \multirow{7}{*}{$\begin{array}{l}1,610 \\
1,670 \\
1,740 \\
1,760 \\
1,800 \\
1,750 \\
1,700 \\
1,700 \\
1,660 \\
1,590 \\
1,570 \\
1,500\end{array}$} \\
\hline & 3.04 & 200 & 3.00 & 177 & 3.41 & 381 & 3.38 & 361 & 3.55 & 455 & & \\
\hline & 2.95 & 160 & 3.02 & 185 & 3.42 & 385 & 3.44 & 395 & 3.56 & 461 & & \\
\hline & 3.01 & 184 & 3.39 & 372 & 3.43 & 391 & 3.53 & 445 & 3.59 & 478 & & \\
\hline & 3.01 & 184 & 3.13 & 237 & 3.39 & 369 & 3.51 & 434 & $\begin{array}{l}3.58 \\
3.90\end{array}$ & $\begin{array}{r}471 \\
656\end{array}$ & & \\
\hline & 3.02 & 187 & 3.44 & 398 & 3.43 & 391 & 3.57 & 467 & & & & \\
\hline & 2.94 & 151 & 3.50 & 432 & 3.40 & 374 & 3.56 & 461 & & & & \\
\hline & \multicolumn{2}{|c|}{ July 23} & \multicolumn{2}{|c|}{ July 24} & \multicolumn{2}{|c|}{ July 25} & \multicolumn{2}{|c|}{ July 26} & \multicolumn{2}{|c|}{ July 27} & \multicolumn{2}{|c|}{ July 28} \\
\hline \multirow{10}{*}{$\begin{array}{l}2 \mathrm{a} . \mathrm{m} . \\
4 \\
6 \\
8 \\
10 \\
12 \mathrm{n} . \\
2 \mathrm{p} . \mathrm{m} . \\
4 \\
6 \\
8 \\
10 \\
12 \mathrm{~m} .\end{array}$} & 5.03 & & 7.34 & & & & & & & & \multirow{10}{*}{$\begin{array}{l}4.20 \\
4.20 \\
4.17 \\
4.11 \\
4.04 \\
4.06 \\
4.01 \\
4.04 \\
3.90 \\
3.94 \\
3.92 \\
3.94\end{array}$} & \multirow{9}{*}{$\begin{array}{r}940 \\
940 \\
922 \\
886 \\
844 \\
\mathbf{8 5 6} \\
\mathbf{8 2 6} \\
\mathbf{8 4 4} \\
\mathbf{7 6 5} \\
787 \\
776 \\
\mathbf{7 8 7}\end{array}$} \\
\hline & 5.06 & & 7.16 & & 6.09 & 2,360 & 5.20 & 1,620 & 4.62 & 1,210 & & \\
\hline & $\begin{array}{l}5.20 \\
5.45\end{array}$ & $\begin{array}{l}1,5 \\
1,7\end{array}$ & $\begin{array}{l}7.03 \\
6.96\end{array}$ & $\begin{array}{l}3,270 \\
3,200\end{array}$ & 5.92 & 2,210 & 5.20 & 1,620 & 4.59 & 1,190 & & \\
\hline & 5.9 & 2,2 & 6.90 & 3.140 & & & & & & & & \\
\hline & 6.40 & & & & 5.70 & 2,020 & 4.96 & 1,450 & 4.50 & 1,130 & & \\
\hline & & & & & 5.61 & 1,950 & 4.95 & 1,440 & 4.47 & 1,110 & & \\
\hline & & & & & & & & & & & & \\
\hline & & & & 2,7 & 5.40 & 1,780 & 4.81 & 1,350 & 4.30 & 1,000 & & \\
\hline & $\begin{array}{l}7 \\
7\end{array}$ & $\begin{array}{l}3,900 \\
3,790\end{array}$ & & $\begin{array}{l}2,570 \\
2,470\end{array}$ & 5.30 & 1,700 & 4.72 & 1,280 & 4.26 & 976 & & \\
\hline & & & & & & & & & & & & \\
\hline
\end{tabular}

\begin{tabular}{|c|c|c|c|c|c|c|c|c|c|c|c|c|}
\hline \multirow[b]{2}{*}{$\mathrm{m}$. } & \multicolumn{2}{|c|}{ July 29} & \multicolumn{2}{|c|}{ July 30} & \multicolumn{2}{|c|}{ July 31} & \multicolumn{2}{|c|}{ August 1} & \multicolumn{2}{|c|}{ August 2} & \multicolumn{2}{|c|}{ August 3} \\
\hline & & & & & & & 3.37 & 485 & 3.30 & 450 & 3.20 & 405 \\
\hline & 3.87 & 748 & 3.70 & 655 & 3.50 & 550 & 3.3 & 490 & 3.30 & 450 & 3.20 & 405 \\
\hline $\begin{array}{l}6 \\
8\end{array}$ & ה-10 & 700 & $50-1$ & 701 & 340 & 515 & 3.4 & 500 & 3.30 & 450 & 3.20 & 405 \\
\hline 10 & 3.84 & 732 & 3.82 & 821 & 3.49 & 345 & $\begin{array}{l}3.4 \\
3.4\end{array}$ & 500 & $\begin{array}{l}3.35 \\
3.41\end{array}$ & $\begin{array}{l}405 \\
505\end{array}$ & $\begin{array}{l}3.11 \\
3.20\end{array}$ & $\begin{array}{l}366 \\
405\end{array}$ \\
\hline $12 \mathrm{n}$. & 3.75 & 682 & 3.63 & 616 & 3.48 & 540 & $\because 34$ & 470 & 3.34 & 470 & 3.21 & 410 \\
\hline${ }_{4}^{2}$ p.m. & 3.73 & 672 & 3.63 & 616 & 3.42 & 510 & $\begin{array}{l}3.31 \\
3.42\end{array}$ & $\begin{array}{l}455 \\
510\end{array}$ & $\begin{array}{l}3.30 \\
3.34\end{array}$ & $\begin{array}{l}450 \\
470\end{array}$ & $\begin{array}{l}3.10 \\
3.07\end{array}$ & $\begin{array}{l}362 \\
349\end{array}$ \\
\hline 6 & & & & & & & 3.44 & & 3.30 & 450 & 3.18 & $39 t$ \\
\hline & 3.72 & 666 & 3.59 & 595 & 3.40 & 500 & 3.10 & 362 & 3.28 & 441 & 3.21 & +10 \\
\hline $\begin{array}{l}10 \\
12 \mathrm{~m} .\end{array}$ & 3.70 & 655 & 3.48 & 540 & 3.36 & 480 & $\begin{array}{l}3.25 \\
3.30\end{array}$ & $\begin{array}{l}428 \\
450\end{array}$ & $\begin{array}{l}3.24 \\
3.20\end{array}$ & $\begin{array}{l}423 \\
405\end{array}$ & $\begin{array}{l}3.22 \\
3.18\end{array}$ & $\begin{array}{l}414 \\
396\end{array}$ \\
\hline
\end{tabular}

Supplemental records.-July $23,6: 10$ p.m., $8.01 \mathrm{ft}$, 4,390 sec.-ft.; July 28 ,, p.m., $3.76 \mathrm{ft}, 688$ sec.-ft.; July 30,7 a.m., $3.68 \mathrm{ft}$., 644 ser.-ft.; Ang. $1,4: 30$ p.m., $3.51 \mathrm{ft}$, 555 ser.-ft. 
QUTMRBAUG IIVFR AT PUTAAK, CON2T.

Location.-Lat. $41^{\circ} 54^{\prime} 30^{\prime \prime}$, long. $71^{\circ} 54^{\prime} 30^{\prime \prime}$, at Putnam, Windham County, 600 feet downstream from Muddy Brook and 3 miles downstream from French River.

DrAinaGe AREA.-331 square miles.

GAGE-HEIGHT RECORD.-Water-stage recorder graph.

StaGe-Discharge RELATION.-Defined by current-meter measurements below 2,900 second-feet; extended to peak stage on basis of September 1938 determination of flood flow at dam 1 mile above station, combined with inflow from Muddy Brook determined by flow over spillway at dam 2 miles above its mouth.

Maxima.-July 1938: Discharge 10,000 second-feet 2 a.m. July 24 (gage height, 13.51 feet).

1929 to June 1938: Discharge, 17,200 second-feet Mar. 19, 1936 (gage height, 17.28 feet from floodmarks).

REMARKs.-Flood discharge affected by storage in several ponds and reservoirs. City of Putnam diverts about $1,000,000$ gallons per day from Muddy Brook for municipal supply.

Mean discharge, in second-feet, 1938

\begin{tabular}{|c|c|c|c|c|c|c|c|c|c|c|c|}
\hline Day & June & July & Aug. & Day & June & July & Aug. & Day & June & July & Aug. \\
\hline $\begin{array}{r}1 \\
2 \\
3 \\
4 \\
5 \\
6 \\
7 \\
8 \\
9 \\
10\end{array}$ & $\begin{array}{l}496 \\
430 \\
386 \\
328 \\
292 \\
472 \\
420 \\
344 \\
329 \\
344\end{array}$ & $\begin{array}{r}1,230 \\
962 \\
772 \\
672 \\
708 \\
606 \\
440 \\
341 \\
342 \\
250\end{array}$ & $\begin{array}{r}1,070 \\
997 \\
918 \\
854 \\
647 \\
638 \\
1,060 \\
990 \\
1,000 \\
962\end{array}$ & $\begin{array}{l}11 \\
12 \\
13 \\
14 \\
15 \\
16 \\
17 \\
18 \\
19 \\
20\end{array}$ & $\begin{array}{r}332 \\
292 \\
2,030 \\
1,660 \\
1,210 \\
962 \\
681 \\
644 \\
384 \\
644\end{array}$ & $\begin{array}{l}340 \\
729 \\
916 \\
878 \\
660 \\
662 \\
429 \\
540 \\
832 \\
889\end{array}$ & $\begin{array}{r}986 \\
1,040 \\
907 \\
566 \\
731 \\
714 \\
633 \\
652 \\
542 \\
598\end{array}$ & $\begin{array}{l}21 \\
22 \\
23 \\
24 \\
25 \\
26 \\
27 \\
28 \\
29 \\
30 \\
31\end{array}$ & $\begin{array}{r}580 \\
349 \\
415 \\
241 \\
367 \\
373 \\
672 \\
1,740 \\
1,940 \\
1,640\end{array}$ & $\begin{array}{l}1,410 \\
4,030 \\
6,170 \\
9,560 \\
7,040 \\
4,240 \\
2,790 \\
2,110 \\
1,760 \\
1,460 \\
1,210\end{array}$ & $\begin{array}{l}314 \\
534 \\
536 \\
423 \\
464 \\
383 \\
300 \\
433 \\
566 \\
434 \\
381\end{array}$ \\
\hline $\begin{array}{l}\text { Mor } \\
\text { Run }\end{array}$ & & & & & & & & & $\begin{array}{r}700 \\
2 \quad 35\end{array}$ & $\begin{array}{r}1.773 \\
6.18\end{array}$ & $\begin{array}{r}686 \\
2.39\end{array}$ \\
\hline
\end{tabular}

Gage-height, in feet, and discharge, in second-feet, at indicated time, 1938

\begin{tabular}{|c|c|c|c|c|c|c|c|c|c|c|c|c|}
\hline \multirow{2}{*}{ Hour } & Feet & Sec.-ft. & Feet & Sec.-ft. & Feet & Sec.ft. & Feet & Sec.-ft. & Feet & Sec.-ft. & Feet & Ser.-ft. \\
\hline & \multicolumn{2}{|c|}{ July 17} & \multicolumn{2}{|c|}{ July 18} & \multicolumn{2}{|c|}{ July 19} & \multicolumn{2}{|c|}{ July 20} & \multicolumn{2}{|c|}{ July 21} & \multicolumn{2}{|c|}{ July 22} \\
\hline 2 a.m. & & & 3.17 & 376 & 3.92 & 649 & 4.29 & 816 & 4.86 & 1,090 & 7.82 & 3,060 \\
\hline & & & 3.13 & 364 & 4.12 & 739 & 3.92 & 649 & 4.77 & 1,040 & 8.09 & 3,300 \\
\hline 6 & & & 3.13 & 364 & 4.32 & 82 & 3.66 & 54 & 4.90 & 1,110 & 8.33 & 3,530 \\
\hline 8 & & & 3.80 & 600 & 4.64 & 980 & 3.62 & 52 & 5.11 & 1,220 & 8.60 & 3,800 \\
\hline 10 & & & 3.79 & 59 & 4.55 & 93 & 3.6 & 55 & 5. & 1,160 & 8.8 & 4,030 \\
\hline $12 \mathrm{n}$. & & & 3.74 & 57 & \pm .45 & & 4.5 & 91 & 4.8 & & 9.12 & 4,340 \\
\hline 21 l.m. & & & 3.76 & 584 & 4.40 & 86 & 4.9 & 1,120 & 4.8 & 1,14 & 9.18 & 4,410 \\
\hline & & & 3.90 & 64 & 4.38 & & 5. & 1,19 & & & 9. & 4,530 \\
\hline ti & & & 3.81 & 60 & 4.35 & 8 & 5.0 & 1,1 & & & & 4,580 \\
\hline 8 & & & 3.80 & 600 & 4.35 & 84 & 4.9 & 1,16 & 6.3 & 1,94 & 9.3 & 4,580 \\
\hline 10 & & & 3.80 & 600 & 4.3 & 84 & 4.9 & 1,1 & & & 9. & 4,580 \\
\hline $12 \mathrm{~m}$. & & & 3.81 & 604 & 4.35 & 842 & 4.82 & 1,070 & 7.46 & 2,760 & 9.32 & 4,560 \\
\hline
\end{tabular}


Gage-height, in feet, and discharge, in second-feet, at indicated time, 1938 -Continued

\begin{tabular}{|c|c|c|c|c|c|c|c|c|c|c|c|c|}
\hline \multirow{2}{*}{ Hour } & Feet & Sec.-ft. & Feet & Sec.-ft. & Feet & Sec.-ft. & Feet & Sec.ft. & Feet & Sec.-ft. & Feet & Sec.-ft. \\
\hline & \multicolumn{2}{|c|}{ July 23} & \multicolumn{2}{|c|}{ July 24} & \multicolumn{2}{|c|}{ July 25} & \multicolumn{2}{|c|}{ July 26} & \multicolumn{2}{|c|}{ July 27} & \multicolumn{2}{|c|}{ July 28} \\
\hline $\begin{array}{l}2 \mathrm{a} . \mathrm{m} . \\
4 \\
6 \\
8 \\
10 \\
12 \mathrm{n} . \\
2 \mathrm{p.m} . \\
4 \\
6 \\
8 \\
10 \\
12 \mathrm{~m} .\end{array}$ & $\begin{array}{r}9.30 \\
9.28 \\
9.28 \\
9.34 \\
9.63 \\
10.12 \\
10.46 \\
11.04 \\
11.67 \\
12.55 \\
13.24 \\
13.43\end{array}$ & $\begin{array}{l}4,540 \\
4,520 \\
4,520 \\
4,580 \\
4,910 \\
5,490 \\
5,900 \\
6,620 \\
7,440 \\
8,640 \\
9,610 \\
9,900\end{array}$ & $\begin{array}{l}13.51 \\
13.49 \\
13.45 \\
13.36 \\
13.26 \\
13.16 \\
13.16 \\
13.12 \\
13.06 \\
12.96 \\
12.82 \\
12.66\end{array}$ & $\begin{array}{r}10,000 \\
9,980 \\
9,920 \\
9,790 \\
9,640 \\
9,490 \\
9,490 \\
9,440 \\
9,350 \\
9,210 \\
9,020 \\
8,790\end{array}$ & $\begin{array}{l}12.46 \\
12.26 \\
12.04 \\
11.86 \\
11.61 \\
11.36 \\
11.16 \\
10.84 \\
10.56 \\
10.40 \\
10.26 \\
10.06\end{array}$ & $\begin{array}{l}8,510 \\
8,230 \\
7,930 \\
7,690 \\
7,360 \\
7,040 \\
6,780 \\
6,360 \\
6,020 \\
5,830 \\
5,660 \\
5,420\end{array}$ & $\begin{array}{l}9.88 \\
9.73 \\
9.54 \\
9.37 \\
9.24 \\
9.08 \\
8.91 \\
8.64 \\
8.33 \\
8.22 \\
8.06 \\
8.03\end{array}$ & & $\begin{array}{l}7.96 \\
7.89 \\
7.79 \\
7.73 \\
7.63 \\
7.50 \\
7.33 \\
7.05 \\
7.12 \\
7.17 \\
7.13 \\
7.03\end{array}$ & & $\begin{array}{l}6.93 \\
6.85 \\
6.79 \\
6.72 \\
6.72 \\
6.65 \\
6.34 \\
6.24 \\
6.30 \\
6.32 \\
6.29 \\
6.18\end{array}$ & $\begin{array}{l}2,370 \\
2,320 \\
2,270 \\
2,220 \\
2,220 \\
2,180 \\
1,960 \\
1,890 \\
1,930 \\
1,940 \\
1,920 \\
1,850\end{array}$ \\
\hline $12 \mathrm{~m}$. & \multicolumn{2}{|c|}{ July 29} & \multicolumn{2}{|c|}{ July 30} & \multicolumn{2}{|c|}{ July 31} & \multicolumn{2}{|c|}{ August 1} & \multicolumn{2}{|c|}{ August 2} & \multicolumn{2}{|c|}{ August 3} \\
\hline $\begin{array}{l}2 \mathrm{a} . \mathrm{m} . \\
4 \\
6 \\
8 \\
10 \\
12 \mathrm{n.} \\
2 \mathrm{p.m} . \\
4 \\
6 \\
8 \\
10 \\
12 \mathrm{~m} .\end{array}$ & $\begin{array}{l}6.17 \\
6.13 \\
6.12 \\
6.12 \\
6.12 \\
6.09 \\
6.06 \\
6.03 \\
5.95 \\
5.60 \\
5.98 \\
5.92\end{array}$ & $\begin{array}{l}1,840 \\
1,820 \\
1,810 \\
1,810 \\
1,810 \\
1,790 \\
1,780 \\
1,760 \\
1,710 \\
1,500 \\
1,730 \\
1,690\end{array}$ & $\begin{array}{l}5.81 \\
5.73 \\
5.70 \\
5.67 \\
5.61 \\
5.59 \\
5.59 \\
5.33 \\
5.29 \\
5.27 \\
5.26 \\
5.22\end{array}$ & $\begin{array}{l}1,630 \\
1,580 \\
1,560 \\
1,540 \\
1,510 \\
1,490 \\
1,490 \\
1,340 \\
1,310 \\
1,300 \\
1,300 \\
1,270\end{array}$ & $\begin{array}{l}5.23 \\
5.22 \\
5.11 \\
5.15 \\
5.11 \\
5.08 \\
5.07 \\
5.06 \\
5.03 \\
5.08 \\
5.01 \\
5.00\end{array}$ & $\begin{array}{l}1,280 \\
1,270 \\
1,220 \\
1,240 \\
1,220 \\
1,200 \\
1,200 \\
1,190 \\
1,180 \\
1,200 \\
1,160 \\
1,160\end{array}$ & $\begin{array}{l}4.96 \\
4.92 \\
4.98 \\
5.01 \\
4.86 \\
4.95 \\
4.96 \\
4.77 \\
4.70 \\
4.70 \\
4.15 \\
4.82\end{array}$ & $\begin{array}{l}1,140 \\
1,120 \\
1,150 \\
1,160 \\
1,090 \\
1,140 \\
1,140 \\
1,040 \\
1,010 \\
1,010 \\
752 \\
1,070\end{array}$ & $\begin{array}{l}4.70 \\
4.67 \\
4.67 \\
4.63 \\
4.66 \\
4.61\end{array}$ & $\begin{array}{r}1,010 \\
9995 \\
9995 \\
9975 \\
990\end{array}$ & $\begin{array}{c}4.56 \\
4.50 \\
4.48 \\
4.43\end{array}$ & 901 \\
\hline
\end{tabular}

Supplemental records.-July 20,7 a.m., $3.29 \mathrm{ft} ., 412$ sec.-ft.

\section{QUTNGBAUG RIVER AT JEWETT CITY, CONN.}

Location.-Lat. $41^{\circ} 35^{\prime} 55^{\prime \prime}$, long. $71^{\circ} 59^{\prime} 05^{\prime \prime}$, at Jewett City, New London County, 1,000 feet downstream from railroad bridge and 570 feet downstream from outlet of canal from Slater Mills (mouth of Pachaug River). Datum of gage is 63.07 feet above mean sea level (general adjustment of 1929).

Drainage area.-711 square miles.

GAGE-HEIGHT RECORD.-Water-stage recorder graph except for periods June 12 to July 4 when record was computed on basis of records for station at Putnam; and 1 a.m. July 24 to 11 a.m. July 26 when record was computed on basis of floodmark, inspection by engineer and observer, hourly gage readings at Aspinook Co. dam 1 mile above station, and inflow from Pachaug River as determined by peak flow computation, and comparison with records for station on Moosup River at Moosup, Conn. Record poor intermittently during period July 29 to Aug. 1 when pen was tearing recorder chart.

Stage-discharge relation.-Defined by current-meter measurements below 15,000 second-feet; extended to peak stage on basis of hourly determinations of flow at dam 1 mile above station during floods of March 1936 and July 1938 and at dam 6 miles below station in September 1938.

Maxima.-July 1938: Discharge, 25,000 second-feet 5 p.m. July 24 (gage height, 22.5 feet, from floodmark).

1918 to June 1938: Discharge, 29,200 second-feet Mar. 19, 1936 (gage height, 24.0 feet, from floodmarks).

Remarks.-Flood discharge affected by unregulated storage in numerous ponds and reservoirs. 
Mean discharge, in second-feet, 1938

\begin{tabular}{|c|c|c|c|c|c|c|c|c|c|c|c|}
\hline Day & June & July & Aug. & Dav & June & July & Aug. & Day & June & July & Aug. \\
\hline $\begin{array}{r}1 \\
2 \\
3 \\
4 \\
5 \\
6 \\
7 \\
8 \\
9 \\
10\end{array}$ & $\begin{array}{r}1,200 \\
1,050 \\
966 \\
716 \\
625 \\
946 \\
992 \\
930 \\
794 \\
701\end{array}$ & $\begin{array}{r}3,600 \\
2,800 \\
2,200 \\
1,800 \\
1,480 \\
1,300 \\
1,080 \\
912 \\
613 \\
616\end{array}$ & $\begin{array}{l}2,640 \\
2,260 \\
2,010 \\
1,800 \\
1,500 \\
1,400 \\
1,910 \\
2,200 \\
2,320 \\
2,080\end{array}$ & $\begin{array}{l}11 \\
12 \\
13 \\
14 \\
15 \\
16 \\
17 \\
18 \\
19 \\
20\end{array}$ & $\begin{array}{r}612 \\
700 \\
2,600 \\
2,800 \\
2,400 \\
2,000 \\
1,800 \\
1,600 \\
800 \\
1,000\end{array}$ & $\begin{array}{r}836 \\
984 \\
1,310 \\
1,400 \\
1,320 \\
1,250 \\
1,020 \\
1,140 \\
1,750 \\
2,850\end{array}$ & $\begin{array}{l}2,350 \\
2,550 \\
2,080 \\
1,530 \\
1,610 \\
1,420 \\
2,120 \\
2,220 \\
1,760 \\
1,450\end{array}$ & $\begin{array}{l}21 \\
22 \\
23 \\
24 \\
25 \\
26 \\
27 \\
28 \\
29 \\
30 \\
31\end{array}$ & $\begin{array}{r}1,100 \\
1,000 \\
950 \\
850 \\
750 \\
650 \\
700 \\
1,800 \\
5,000 \\
4,600\end{array}$ & $\begin{array}{r}3,890 \\
7,230 \\
10,600 \\
21,900 \\
19,100 \\
11,300 \\
7,330 \\
5,370 \\
4,180 \\
3,450 \\
2,810\end{array}$ & $\begin{array}{r}1,180 \\
1,180 \\
1,220 \\
1,100 \\
975 \\
1,030 \\
842 \\
600 \\
1,070 \\
1,030 \\
922\end{array}$ \\
\hline \multicolumn{9}{|c|}{$\begin{array}{l}\text { Monthly mean discharge, in second-feet } \\
\text { Runoff, in inches }\end{array}$} & $\begin{array}{r}1,421 \\
2.23\end{array}$ & $\begin{array}{c}4,110 \\
6.66\end{array}$ & $\begin{array}{r}1,624 \\
2.63\end{array}$ \\
\hline
\end{tabular}

Gage-height, in feet, and discharge, in second-feet, at indicated time, 1938

\begin{tabular}{|c|c|c|c|c|c|c|c|c|c|c|c|c|}
\hline \multirow{2}{*}{ Hour } & Feet & Sec. $-\mathrm{ft}$. & Feet & Sec.-ft. & Feet & Sec.-ft. & Feet & Sec.-ft. & Feet & Sec. $-\mathrm{ft}$. & Feet & Sec.-ft. \\
\hline & \multicolumn{2}{|c|}{ July 17} & \multicolumn{2}{|c|}{ July 18} & \multicolumn{2}{|c|}{ July 19} & \multicolumn{2}{|c|}{ July 20} & \multicolumn{2}{|c|}{ July 21} & \multicolumn{2}{|c|}{ July 22} \\
\hline $\begin{array}{l}2 \text { a.m. } \\
4 \\
6 \\
8 \\
10 \\
12 \mathrm{n} . \\
2 \mathrm{p.m} . \\
4 \\
6 \\
8 \\
10 \\
12 \mathrm{~m} .\end{array}$ & $\begin{array}{l}6.67 \\
6.44 \\
6.30 \\
6.22 \\
6.17 \\
6.21 \\
6.23 \\
6.17 \\
6.15 \\
6.24 \\
6.30 \\
6.17\end{array}$ & $\begin{array}{r}1,240 \\
1,100 \\
1,020 \\
976 \\
948 \\
970 \\
982 \\
948 \\
938 \\
987 \\
1,020 \\
948\end{array}$ & $\begin{array}{l}6.08 \\
6.01 \\
6.43 \\
6.46 \\
6.29 \\
6.49 \\
6.67 \\
6.68 \\
6.60 \\
6.79 \\
6.81 \\
6.96\end{array}$ & $\begin{array}{r}899 \\
860 \\
1,100 \\
1,120 \\
1,010 \\
1,130 \\
1,240 \\
1,250 \\
1,200 \\
1,310 \\
1,330 \\
1,420\end{array}$ & $\begin{array}{l}7.04 \\
7.14 \\
7.68 \\
7.37 \\
7.30 \\
7.47 \\
7.51 \\
7.60 \\
7.69 \\
7.63 \\
7.49 \\
7.59\end{array}$ & $\begin{array}{l}1,480 \\
1,550 \\
1,930 \\
1,710 \\
1,660 \\
1,780 \\
1,810 \\
1,870 \\
1,940 \\
1,890 \\
1,790 \\
1,860\end{array}$ & $\begin{array}{l}7.59 \\
7.56 \\
7.89 \\
8.07 \\
8.41 \\
8.96 \\
9.34 \\
9.52 \\
9.72 \\
9.80 \\
9.66 \\
9.70\end{array}$ & $\begin{array}{l}1,860 \\
1,840 \\
2,100 \\
2,250 \\
2,520 \\
2,980 \\
3,330 \\
3,490 \\
3,670 \\
3,740 \\
3,610 \\
3,650\end{array}$ & $\begin{array}{r}9.66 \\
9.57 \\
9.79 \\
9.53 \\
9.37 \\
9.50 \\
9.52 \\
9.55 \\
10.06 \\
10.72 \\
11.21 \\
11.53\end{array}$ & $\begin{array}{l}3,610 \\
3,530 \\
3,730 \\
3,500 \\
3,350 \\
3,470 \\
3,490 \\
3,520 \\
3,990 \\
4,670 \\
5,210 \\
5,570\end{array}$ & $\begin{array}{l}11.80 \\
12.07 \\
12.50 \\
12.64 \\
12.80 \\
13.10 \\
13.26 \\
13.32 \\
13.40 \\
13.42 \\
13.41 \\
13.38\end{array}$ & $\begin{array}{l}5,890 \\
6,210 \\
6,760 \\
6,940 \\
7,150 \\
7,540 \\
7,760 \\
7,850 \\
7,960 \\
7,990 \\
7,970 \\
7,930\end{array}$ \\
\hline
\end{tabular}

\begin{tabular}{|c|c|c|c|c|c|c|c|c|c|c|c|c|}
\hline \multirow[b]{2}{*}{$\begin{array}{l}2 \text { a.m. } \\
4 \\
6 \\
8 \\
10 \\
12 \mathrm{n} . \\
2 \mathrm{p.m} . \\
4 \\
6 \\
8 \\
10 \\
12 \mathrm{~m} .\end{array}$} & \multicolumn{2}{|c|}{ July 23} & \multicolumn{2}{|c|}{ July 24} & \multicolumn{2}{|c|}{ July 25} & \multicolumn{2}{|c|}{ July 26} & \multicolumn{2}{|c|}{ July 27} & \multicolumn{2}{|c|}{ July 28} \\
\hline & $\begin{array}{l}13.44 \\
13.54 \\
13.85 \\
14.13 \\
14.35 \\
14.84 \\
15.26 \\
15.70 \\
16.10 \\
16.77 \\
17.46 \\
18.07\end{array}$ & $\begin{array}{r}8,020 \\
8,160 \\
8,590 \\
9,000 \\
9,320 \\
10,100 \\
10,700 \\
11,400 \\
12,100 \\
13,200 \\
14,400 \\
15,400\end{array}$ & $\begin{array}{l}18.86 \\
19.60 \\
20.32 \\
20.88 \\
21.39 \\
21.82 \\
22.17 \\
22.46 \\
22.48 \\
22.44 \\
22.34 \\
22.20\end{array}$ & $\begin{array}{l}17,000 \\
18,000 \\
19,500 \\
21,000 \\
22,000 \\
23,000 \\
24,000 \\
24,500 \\
25,000 \\
24,500 \\
24,500 \\
24,000\end{array}$ & $\begin{array}{l}21.98 \\
21.61 \\
21.21 \\
20.85 \\
20.41 \\
20.00 \\
19.59 \\
19.12 \\
18.71 \\
18.30 \\
17.90 \\
17.50\end{array}$ & $\begin{array}{l}23,500 \\
22,500 \\
21,500 \\
21,000 \\
20,000 \\
19,000 \\
18,000 \\
17,500 \\
16,500 \\
16,000 \\
15,000 \\
14,500\end{array}$ & $\begin{array}{l}16 . \overline{70} \\
\overline{1} 6.10 \\
\overline{1} \overline{5} . \overline{70} \\
\overline{1} 5.02 \\
\overline{14.52} \\
14.09\end{array}$ & $\begin{array}{l}13,000 \\
12,000 \\
11,400 \\
10,300 \\
9,580 \\
8,940\end{array}$ & $\mid \begin{array}{l}1 \overline{3} .6 \overline{2} \\
\overline{13} . \overline{34} \\
\overline{12} . \overline{83} \\
\overline{12.50} \\
\overline{12} . \overline{24} \\
11 . \overline{87}\end{array}$ & $\begin{array}{c}8,270 \\
7,880 \\
7,190 \\
6, \overline{7} 60 \\
6,420 \\
5,970\end{array}$ & $\begin{array}{l}11.64 \\
11.60 \\
11.36 \\
11.18 \\
11.0 \\
10.75\end{array}$ & $\begin{array}{r}5,700 \\
5,650 \\
5,380 \\
5,180 \\
5,000 \\
4,700\end{array}$ \\
\hline & \multicolumn{2}{|c|}{ July 29} & \multicolumn{2}{|c|}{ July 30} & \multicolumn{2}{|c|}{ July 31} & \multicolumn{2}{|c|}{ August 1} & \multicolumn{2}{|c|}{ August 2} & \multicolumn{2}{|c|}{ August 3} \\
\hline $\begin{array}{r}2 \text { a.m. } \\
4 \\
6 \\
8 \\
10 \\
12 \mathrm{n} . \\
2 \mathrm{p} . \mathrm{m} . \\
4 \\
6 \\
8 \\
10 \\
12 \mathrm{~m} .\end{array}$ & \begin{tabular}{l}
-10.5 \\
10.25 \\
9.95 \\
\hdashline 9.81
\end{tabular} & $\begin{array}{c}4,400 \\
4,200 \\
3,900 \\
3,750\end{array}$ & $\mid$\begin{tabular}{l}
$-\cdots .7$ \\
$9 . \overline{7}$ \\
\hdashline 9.49 \\
\hdashline $9 . \overline{3}$ \\
\hdashline 9.05
\end{tabular} & \begin{tabular}{c}
$-\cdots, 600$ \\
3,460 \\
3,300 \\
\hdashline 3,100
\end{tabular} & \begin{tabular}{|l}
-1.9 \\
8.9 \\
8.7 \\
8.60 \\
8.58
\end{tabular} & $\begin{array}{c}2,900 \\
2,800 \\
2,670 \\
2,650\end{array}$ & $\begin{array}{c}8.58 \\
8.53 \\
8.80 \\
-8 . \overline{7}^{-} \\
8.4 \\
8.22\end{array}$ & \begin{tabular}{c}
2,650 \\
2,610 \\
2,840 \\
\hdashline 2,800 \\
2,500 \\
2,370
\end{tabular} & $\begin{array}{l}8.20 \\
8.11 \\
8.22 \\
8.19 \\
8.04 \\
8.05 \\
8.20 \\
8.18 \\
7.94 \\
7.99 \\
7.84 \\
7.86\end{array}$ & $\begin{array}{l}2,350 \\
2,280 \\
2,370 \\
2,340 \\
2,220 \\
2,230 \\
2,350 \\
2,330 \\
2,140 \\
2,180 \\
2,060 \\
2,080\end{array}$ & $\begin{array}{l}7.88 \\
7.86 \\
7.89 \\
8.07 \\
7.84 \\
7.70 \\
7.88 \\
7.80 \\
7.56 \\
7.64 \\
7.55 \\
7.49\end{array}$ & $\begin{array}{l}2,090 \\
2,080 \\
2,100 \\
2,250 \\
2,060 \\
1,950 \\
2,090 \\
2,030 \\
1,840 \\
1,900 \\
1,840 \\
1,790\end{array}$ \\
\hline
\end{tabular}

Supplemental records.-July 24, 5 p.m., 22.5 ft., 25,000 sec.-ft. 
FIVA MIIE RIVER AT KIIIINGLY, CONA.

Location.-Lat. $41^{\circ} 50^{\prime} 10^{\prime \prime}$, long. $71^{\circ} 53^{\prime} 09^{\prime \prime}$, at northwest abutment of New York, New Haven \& Hartford Railroad bridge, five-eighths of a mile south of Killingly, Windham County, and 2.7 miles upstream from mouth. Datum of gage is 222.22 feet above mean sea level (general adjustment of 1929).

Drainage AREA.-58.2 square miles.

GAGE-HEIGHT RECORD.-Water-stage recorder graph.

Stage-discharge RELATION.-Defined by current-meter measurements below 1,600 second-feet; extended to peak stage by logarithmic plotting.

Maxima.-July 1938: Discharge, 2,480 second-feet 2 p.m. July 24 (gage height, 8.52 feet).

November 1937 to June 1938: Discharge, 730 second-feet Nov. 29, 1937 (gage height, 4.3 feet).

Remarks.-Flood discharge affected by storage in ponds and reservoirs.

Mean discharge, in second-feet, 1938

\begin{tabular}{r|r|r|r|r|r|r|r|r|r|r|r}
\hline Day & June & July & Aug. & Day & June & July & Aug. & Day & June & July & Aug. \\
\hline 1 & 109 & 310 & 251 & 11 & 51 & 95 & 155 & 21 & 93 & 198 & 101 \\
2 & 95 & 258 & 178 & 12 & 92 & 79 & 15.5 & 22 & 77 & 524 & 108 \\
3 & $\mathbf{8 4}$ & 212 & 148 & 13 & 154 & 91 & 134 & 23 & 77 & 1,000 & 81 \\
4 & 67 & 162 & 138 & 14 & 319 & 92 & 119 & 24 & 74 & 2,370 & 84 \\
5 & 90 & 121 & 125 & 15 & 370 & 88 & 119 & 25 & 53 & 1,740 & 79 \\
6 & 96 & 109 & 127 & 16 & 284 & 70 & 106 & 26 & 69 & 1.080 & 76 \\
7 & 80 & 99 & 172 & 17 & 228 & 73 & 206 & 27 & 144 & 724 & 60 \\
8 & 75 & 93 & 168 & 18 & 182 & 83 & 179 & 28 & 368 & 551 & 74 \\
9 & 68 & 68 & 150 & 19 & 145 & 81 & 147 & 29 & 491 & 449 & $\mathbf{8 8}$ \\
10 & 68 & 80 & 136 & 20 & 109 & 111 & 115 & 30 & 405 & 377 & 75 \\
&
\end{tabular}

Gage-height, in feet, and discharge, in second-feet, at indicated time, 1938

\begin{tabular}{|c|c|c|c|c|c|c|c|c|c|c|c|c|}
\hline \multirow{2}{*}{ Hour } & Feet & Sec.-ft. & Feet & Sec.ft. & Feet & Sec.-ft. & Feet & Sec. $-\mathrm{ft}$. & Feet & Sec.-ft. & Feet & Sec. $f t$. \\
\hline & \multicolumn{2}{|c|}{ July 17} & \multicolumn{2}{|c|}{ July 18} & \multicolumn{2}{|c|}{ July 19} & \multicolumn{2}{|c|}{ July 20} & \multicolumn{2}{|c|}{ July 21} & \multicolumn{2}{|c|}{ July 22 } \\
\hline $\begin{array}{c}2 \mathrm{a} . \mathrm{m} . \\
4 \\
6 \\
8 \\
10 \\
12 \mathrm{n} . \\
2 \mathrm{p.m} . \\
4 \\
6 \\
8 \\
10 \\
12 \mathrm{~m} .\end{array}$ & $\begin{array}{l}1.42 \\
1.41 \\
1.39 \\
1.38\end{array}$ & 69 & $\begin{array}{l}1.38 \\
1.37 \\
1.37 \\
1.38 \\
1.59 \\
1.63 \\
1.66 \\
1.69 \\
1.55 \\
1.37 \\
1.29 \\
1.25\end{array}$ & $\begin{array}{r}69 \\
68 \\
68 \\
69 \\
102 \\
110 \\
115 \\
121 \\
96 \\
68 \\
58 \\
53\end{array}$ & $\begin{array}{l}1.23 \\
1.22 \\
1.23 \\
1.30 \\
1.56 \\
1.70 \\
1.74 \\
1.74 \\
1.58 \\
1.39 \\
1.29 \\
1.25\end{array}$ & $\begin{array}{r}51 \\
49 \\
51 \\
59 \\
97 \\
123 \\
132 \\
132 \\
101 \\
71 \\
58 \\
53\end{array}$ & $\begin{array}{l}1.25 \\
1.34 \\
1.43 \\
1.57 \\
1.80 \\
1.90 \\
1.90 \\
1.89 \\
1.68 \\
1.52 \\
1.53 \\
1.67\end{array}$ & $\begin{array}{r}53 \\
64 \\
76 \\
99 \\
145 \\
170 \\
170 \\
168 \\
119 \\
90 \\
92 \\
117\end{array}$ & $\begin{array}{l}1.74 \\
1.76 \\
1.77 \\
1.86 \\
1.96 \\
1.96 \\
1.96 \\
2.04 \\
1.91 \\
2.38 \\
2.66 \\
2.78\end{array}$ & $\begin{array}{l}132 \\
136 \\
138 \\
160 \\
18.5 \\
185 \\
185 \\
205 \\
172 \\
286 \\
350 \\
376\end{array}$ & $\begin{array}{l}2.84 \\
2.92 \\
3.04 \\
3.19 \\
3.39 \\
3.52 \\
3.66 \\
3.79 \\
3.86 \\
3.95 \\
4.02 \\
4.06\end{array}$ & $\begin{array}{l}390 \\
409 \\
433 \\
463 \\
503 \\
530 \\
562 \\
592 \\
610 \\
632 \\
650 \\
660\end{array}$ \\
\hline & \multicolumn{2}{|c|}{ July 23} & \multicolumn{2}{|c|}{ July 24} & \multicolumn{2}{|c|}{ July 25} & \multicolumn{2}{|c|}{ July 26} & \multicolumn{2}{|c|}{ July 27} & \multicolumn{2}{|c|}{ July 28} \\
\hline $\begin{array}{c}2 \text { a.m. } \\
4 \\
6 \\
8 \\
10 \\
12 \text { n. } \\
2 \text { p.m. } \\
4 \\
6 \\
8 \\
10 \\
12 \mathrm{~m} .\end{array}$ & $\begin{array}{l}4.11 \\
4.15 \\
4.22 \\
4.32 \\
4.47 \\
4.71 \\
5.00 \\
5.23 \\
5.42 \\
5.89 \\
6.75 \\
7.83\end{array}$ & $\begin{array}{r}673 \\
685 \\
706 \\
737 \\
790 \\
874 \\
975 \\
1,060 \\
1,130 \\
1,320 \\
1,660 \\
2,140\end{array}$ & $\begin{array}{l}8.22 \\
8.31 \\
8.32 \\
8.35 \\
8.42 \\
8.46 \\
8.52 \\
8.48 \\
8.37 \\
8.21 \\
8.06 \\
7.86\end{array}$ & $\begin{array}{l}2,330 \\
2,380 \\
2,380 \\
2,400 \\
2,430 \\
2,450 \\
2,480 \\
2,460 \\
2,400 \\
2,320 \\
2,250 \\
2,150\end{array}$ & $\begin{array}{l}7.78 \\
7.60 \\
7.43 \\
7.28 \\
7.12 \\
6.94 \\
6.77 \\
6.57 \\
6.38 \\
6.23 \\
6.07 \\
5.90\end{array}$ & $\begin{array}{l}2,110 \\
2,020 \\
1,940 \\
1,870 \\
1,810 \\
1,740 \\
1,670 \\
1,590 \\
1,510 \\
1,450 \\
1,390 \\
1,320\end{array}$ & $\begin{array}{l}5.80 \\
5.68 \\
5.55 \\
5.45 \\
5.37 \\
5.26 \\
5.17 \\
5.09 \\
4.98 \\
4.90 \\
4.81 \\
4.72\end{array}$ & $\begin{array}{r}1,280 \\
1,230 \\
1,180 \\
1,140 \\
1,110 \\
1,070 \\
1,030 \\
1,010 \\
968 \\
940 \\
908 \\
877\end{array}$ & $\begin{array}{l}4.54 \\
4.39 \\
4.28 \\
4.07 \\
3.94 \\
3.93\end{array}$ & $\begin{array}{c}814 \\
-762- \\
-724 \\
-662 \\
-630 \\
-628\end{array}$ & $\begin{array}{l}3.86 \\
3.80 \\
3.75 \\
3.71 \\
3.76 \\
3.67 \\
3.47 \\
3.45 \\
3.40 \\
3.41 \\
3.38 \\
3.34\end{array}$ & $\begin{array}{l}610 \\
59: \\
582 \\
572 \\
585 \\
564 \\
519 \\
515 \\
505 \\
507 \\
501 \\
493\end{array}$ \\
\hline
\end{tabular}


Gage-height, in feet. and discharge, in second-feet, at indicated time, 1938

--Continued

\begin{tabular}{|c|c|c|c|c|c|c|c|c|c|c|c|c|}
\hline \multirow{2}{*}{ Ho } & Feet & Sec.-ft. & Feet & Sec.-ft. & Feet & See $-\mathrm{ft}$. & Feet & Sec.-ft. & Feet & sec.-ft. & Feet & Sec. ft. \\
\hline & \multicolumn{2}{|c|}{ uly 29} & \multicolumn{2}{|c|}{ July 30} & \multicolumn{2}{|c|}{ July 31} & \multicolumn{2}{|c|}{ August 1} & & \multicolumn{2}{|c|}{ lugi } \\
\hline \multirow{6}{*}{$\begin{array}{l}2 \text { a.m. } \\
4 \\
6 \\
8 \\
10 \\
12 \text { n. } \\
2 \text { p.m. } \\
4 \\
6 \\
8 \\
10\end{array}$} & 3.26 & 477 & 2.87 & 398 & \multirow{2}{*}{2.60} & \multirow{2}{*}{335} & 2.36 & 282 & & & & \\
\hline & 3.20 & 465 & 2.78 & 376 & & & 2.41 & 292 & & & & $\ldots$ \\
\hline & 3.12 & 449 & 2.78 & 376 & 2.53 & 321 & 2.21 & 248 & & & & $\ldots$ \\
\hline & 3.04 & 433 & 2.75 & 370 & & & 2.10 & 220 & & & & -.. \\
\hline & 2.96 & $41 \overline{7}$ & 2.71 & 362 & .48 & 810 & 2.07 & 212 & & & & 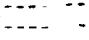 \\
\hline & 2.92 & 409 & 2.66 & 350 & 2.43 & 298 & 2.03 & 202 & & & & $\ldots$ \\
\hline
\end{tabular}

Supplemental record.-July 23,11 p.m., $7.41 \mathrm{ft.} 1920$ sec.-ft.

MOOSUP RIVER AT MOOSUP, CONA.

Location.-Lat. $41^{\circ} 42^{\prime} 40^{\prime \prime}$, long. $71^{\circ} 53^{\prime} 15^{\prime \prime}$, at outlet of tailrace from Aldrich Bros. mill, 100 feet upstream from New York, New Haven \& Hartford Railroad bridge, at Moosup, Windham County, and 31/2 miles upstream from mouth.

Drainage AREA.-83.5 square miles.

GAGE-HEIGHT RECORD.-Water-stage recorder graph.

STAGE-DISCHARGE RELATION.-Defined by current-meter measurements below 1,000 second-feet; extended logarithmically to peak stage on basis of two determinations of flood flow during March 1936 at dam a quarter of a mile above station.

Maxima.-July 1938: Discharge, 4,160 second-feet 7:20 p.m. July 24 (gage height, 8.25 feet), from sharp, short rise of unknown origin, discharge (natural), 4,100 second-feet 5 p. m. July 24 (gage height, 8.20 feet).

1932 to June 1938: Discharge, 4,260 second-feet Mar. 12, 1936 (gage height, 8.25 feet), from a sharp, short rise of unknown origin; discharge (natural), 4,080 second-feet Mar. 12, 1936 (gage height, 8.18 feet). REMARKs.-Flood discharge affected by storage in several ponds.

Mean discharge, in second-feet, 1938

\begin{tabular}{|c|c|c|c|c|c|c|c|c|c|c|c|}
\hline Day & June & July & Aug. & Day & June & July & Aug. & Day & June & July & Aug. \\
\hline $\begin{array}{r}1 \\
2 \\
3 \\
4 \\
5 \\
6 \\
7 \\
8 \\
9 \\
10\end{array}$ & $\begin{array}{r}113 \\
101 \\
96 \\
48 \\
103 \\
131 \\
108 \\
90 \\
70 \\
67\end{array}$ & $\begin{array}{l}451 \\
297 \\
221 \\
179 \\
164 \\
122 \\
102 \\
91 \\
61 \\
75\end{array}$ & $\begin{array}{l}274 \\
230 \\
196 \\
175 \\
162 \\
260 \\
260 \\
222 \\
316 \\
266\end{array}$ & $\begin{array}{l}11 \\
12 \\
13 \\
14 \\
15 \\
16 \\
17 \\
18 \\
19 \\
20\end{array}$ & $\begin{array}{r}53 \\
105 \\
272 \\
245 \\
175 \\
126 \\
112 \\
83 \\
52 \\
106\end{array}$ & $\begin{array}{r}106 \\
115 \\
105 \\
91 \\
132 \\
220 \\
173 \\
189 \\
364 \\
911\end{array}$ & $\begin{array}{l}343 \\
349 \\
262 \\
188 \\
178 \\
127 \\
307 \\
276 \\
225 \\
158\end{array}$ & $\begin{array}{l}21 \\
22 \\
23 \\
24 \\
25 \\
26 \\
27 \\
28 \\
29 \\
30 \\
31\end{array}$ & $\begin{array}{r}70 \\
61 \\
59 \\
70 \\
54 \\
16 \\
118 \\
772 \\
1,080 \\
756\end{array}$ & $\begin{array}{r}998 \\
1,300 \\
1,980 \\
3,500 \\
2,220 \\
1,130 \\
732 \\
570 \\
434 \\
356 \\
298 .\end{array}$ & $\begin{array}{r}137 \\
141 \\
114 \\
95 \\
96 \\
99 \\
65 \\
42 \\
126 \\
90 \\
76\end{array}$ \\
\hline \multicolumn{9}{|c|}{$\begin{array}{l}\text { Monthly mean discharge, in second-feet. } \\
\text { Runoff, in inches }\end{array}$} & $\begin{array}{r}177 \\
2.36\end{array}$ & $\begin{array}{r}571 \\
7.89\end{array}$ & $\begin{array}{r}189 \\
2.61\end{array}$ \\
\hline
\end{tabular}


Gage-height, in feet, and discharge, in second-feet, at indicated time, 1938

\begin{tabular}{|c|c|c|c|c|c|c|c|c|c|c|c|c|}
\hline \multirow{2}{*}{ Hour } & Feet & Sec.ft. & Feet & Sec.ft. & Feet & Sec.-ft. & Feet & Sec.ft. & Feet & Sec.-ft. & Feet & Sec.-ft. \\
\hline & \multicolumn{2}{|c|}{ July 17} & \multicolumn{2}{|c|}{ July 18} & \multicolumn{2}{|c|}{ July 19} & \multicolumn{2}{|c|}{ July 20} & \multicolumn{2}{|c|}{ July 21} & \multicolumn{2}{|c|}{ July 22} \\
\hline $\begin{array}{l}2 \\
4 \\
4 \\
6 \\
8 \\
10 \\
12 \mathrm{n} . \\
2 \mathrm{p.m} . \\
4 \\
6 \\
8 \\
10 \\
12 \mathrm{~m} .\end{array}$ & $\begin{array}{l}2.28 \\
2.25 \\
2.22 \\
2.20 \\
2.17 \\
2.14 \\
2.11 \\
2.09 \\
2.07 \\
2.05 \\
2.01 \\
1.79\end{array}$ & $\begin{array}{r}209 \\
201 \\
193 \\
188 \\
180 \\
173 \\
166 \\
161 \\
156 \\
152 \\
142 \\
98\end{array}$ & $\begin{array}{l}1.79 \\
1.88 \\
1.97 \\
2.21 \\
2.13 \\
2.11 \\
2.09 \\
1.94 \\
2.46 \\
2.56 \\
2.65 \\
2.76\end{array}$ & $\begin{array}{r}98 \\
115 \\
134 \\
191 \\
170 \\
166 \\
161 \\
127 \\
258 \\
288 \\
315 \\
348\end{array}$ & $\begin{array}{l}2.81 \\
2.65 \\
2.80 \\
2.88 \\
2.86 \\
2.86 \\
2.85 \\
2.79 \\
2.81 \\
2.80 \\
2.76 \\
2.69\end{array}$ & $\begin{array}{l}363 \\
315 \\
360 \\
384 \\
378 \\
378 \\
375 \\
357 \\
363 \\
360 \\
348 \\
327\end{array}$ & $\begin{array}{l}2.71 \\
2.54 \\
2.75 \\
4.14 \\
4.60 \\
4.98 \\
5.01 \\
5.01 \\
4.79 \\
4.55 \\
4.38 \\
4.27\end{array}$ & $\begin{array}{r}333 \\
282 \\
345 \\
860 \\
1,110 \\
1,340 \\
1,360 \\
1,360 \\
1,220 \\
1,080 \\
980 \\
925\end{array}$ & $\begin{array}{l}4.16 \\
4.12 \\
4.19 \\
4.20 \\
4.20 \\
4.21 \\
4.30 \\
4.44 \\
4.67 \\
4.75 \\
4.84 \\
5.05\end{array}$ & $\begin{array}{r}870 \\
850 \\
885 \\
890 \\
890 \\
895 \\
940 \\
1,010 \\
1,150 \\
1,200 \\
1,250 \\
1,380\end{array}$ & $\begin{array}{l}5.19 \\
5.10 \\
5.11 \\
5.10 \\
5.06 \\
5.01 \\
4.92 \\
4.80 \\
4.73 \\
4.64 \\
4.55 \\
4.44\end{array}$ & $\begin{array}{l}1,480 \\
1,420 \\
1,430 \\
1,420 \\
1,390 \\
1,360 \\
1,300 \\
1,230 \\
1,190 \\
1,130 \\
1,080 \\
1,010\end{array}$ \\
\hline & \multicolumn{2}{|c|}{ July 23} & \multicolumn{2}{|c|}{ July 24} & \multicolumn{2}{|c|}{ July 25} & \multicolumn{2}{|c|}{ July 26} & \multicolumn{2}{|c|}{ July 27} & \multicolumn{2}{|c|}{ July 28} \\
\hline $\begin{array}{c}2 \mathrm{a} . \mathrm{m} . \\
4 \\
6 \\
8 \\
8 \\
10 \\
12 \mathrm{n} . \\
2 \mathrm{p.m} . \\
4 \\
6 \\
8 \\
10 \\
12 \mathrm{~m} .\end{array}$ & $\begin{array}{r}4.43 \\
4.46 \\
4.57 \\
5.35 \\
5.80 \\
6.03 \\
6.42 \\
6.51 \\
6.42 \\
6.49 \\
7.19 \\
7.43\end{array}$ & $\begin{array}{l}1,010 \\
1,030 \\
1,090 \\
1,600 \\
1,910 \\
2,090 \\
2,410 \\
2,480 \\
2,410 \\
2,460 \\
3,080 \\
3,310\end{array}$ & $\begin{array}{l}7.59 \\
7.55 \\
7.33 \\
7.18 \\
7.17 \\
7.34 \\
7.92 \\
8.16 \\
8.12 \\
7.92 \\
7.61 \\
7.28\end{array}$ & $\begin{array}{l}3,470 \\
3,430 \\
3,210 \\
3,070 \\
3,060 \\
3,220 \\
3,800 \\
4,060 \\
4,010 \\
3,800 \\
3,490 \\
3,160\end{array}$ & $\begin{array}{l}7.02 \\
6.84 \\
6.64 \\
6.49 \\
6.31 \\
6.16 \\
6.01 \\
5.84 \\
5.67 \\
5.50 \\
5.31 \\
5.16\end{array}$ & $\begin{array}{l}2,930 \\
2,770 \\
2,590 \\
2,460 \\
2,320 \\
2,200 \\
2,080 \\
1,940 \\
1,820 \\
1,700 \\
1,570 \\
1,460\end{array}$ & $\begin{array}{l}5.04 \\
4.94 \\
4.84 \\
4.79 \\
4.68 \\
4.64 \\
4.52 \\
4.45 \\
4.37 \\
4.29 \\
4.22 \\
4.16\end{array}$ & $\begin{array}{r}1,380 \\
1,310 \\
1,250 \\
1,220 \\
1,160 \\
1,130 \\
1,060 \\
1,020 \\
975 \\
935 \\
900 \\
870\end{array}$ & $\begin{array}{l}4.09 \\
3.94 \\
4.00 \\
3.97 \\
3.90 \\
3.85 \\
3.80 \\
3.75 \\
3.71 \\
3.66 \\
3.63 \\
3.60\end{array}$ & $\begin{array}{l}836 \\
768 \\
795 \\
782 \\
750 \\
730 \\
710 \\
690 \\
674 \\
654 \\
642 \\
630\end{array}$ & $\begin{array}{l}3.57 \\
3.42 \\
3.58 \\
3.55 \\
3.52 \\
3.48 \\
3.44 \\
3.37 \\
3.35 \\
3.31 \\
3.27 \\
3.23\end{array}$ & $\begin{array}{l}618 \\
562 \\
622 \\
610 \\
598 \\
583 \\
569 \\
544 \\
538 \\
524 \\
510 \\
496\end{array}$ \\
\hline
\end{tabular}

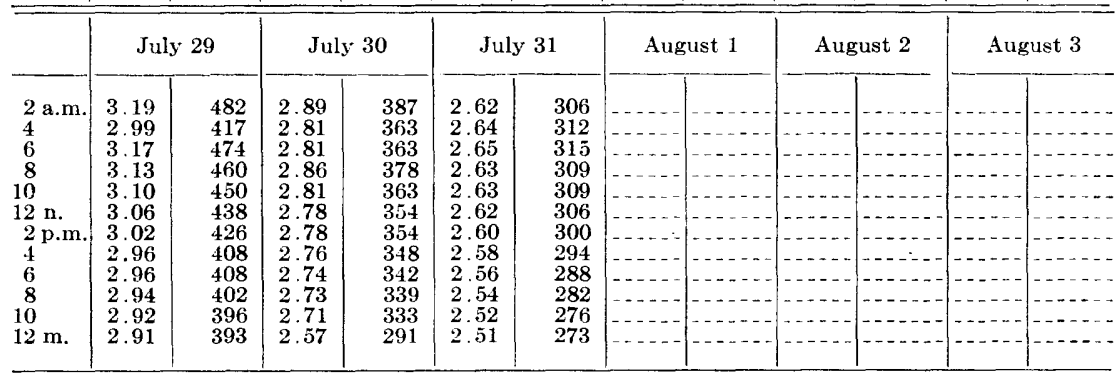

Supplemental records.-July 18,7 a.m., $2.32 \mathrm{ft}$., 219 sec.-ft.; 11 a.m., $1.86 \mathrm{ft}$., 111 sec.-ft.; 3 p.m. $2.21 \mathrm{ft}$., 191 sec.-ft.; July 19, 3 a.m., 2.82 ft., 366 sec.-ft.; 7 a.m., 3.04 ft., 432 sec.-ft.; July 20,3 a.m. $2.71 \mathrm{ft}$., 333 sec.-ft.; 7 a.m., $3.62 \mathrm{ft}$., 638 sec.-ft.; July 24,5 p.m., $8.20 \mathrm{ft}$., 4,100 sec.-ft.; 7 p.m., $8.01 \mathrm{ft}$., 3,890 sec.-ft.; $7: 20$ p.m., 8.25 ft., 4,160 sec.-ft.

YANTIC RIVHE AT YANTIC, CONN.

Location.-Lat. $41^{\circ} 33^{\prime} 35^{\prime \prime}$, long. $72^{\circ} 07^{\prime} 20^{\prime \prime}$, 700 feet downstream from stonearch highway bridge at Yantic, New London County, and 1 mile downstream from Susquetonscut Brook. Datum of gage is 94.46 feet above mean sea level (general adjustment of 1929).

Drainage AREA.-88.6 square miles.

GAGE-HEIGHT RECORD.-Water-stage recorder graph.

StAGE-DiscihaRge RELATION.-Defined by current-meter measurements below 4,600 second-feet; extended to peak stage on basis of determinations of March 1936 and September 1938 flood flows over spillway of dam 21/2 miles above station and determination of September 1938 flood flow over spillway of dam, 3 miles below station. Affected by change in recording conditions 10 p.m. July 23 to 8 p.m. July 24, when water entered gage house through ventilators. 
Maxima.-July 1938: Discharge, 6,980 second-feet 1:20 a.m. July 24 (gage height, 11.47 feet).

1930 to June 1938: Discharge, 6,300 second-feet Mar. 12, 1936 (gage height, 11.32 feet).

Remarks.-Flood discharge affected by storage in a few lakes and ponds.

Mean discharge, in second-feet, 1938

\begin{tabular}{|c|c|c|c|c|c|c|c|c|c|c|c|}
\hline Day & June & July & Aug. & Day & June & July & Aug. & Day & June & July & Aug. \\
\hline $\begin{array}{r}1 \\
2 \\
3 \\
4 \\
5 \\
6 \\
7 \\
8 \\
9 \\
10\end{array}$ & $\begin{array}{r}96 \\
80 \\
117 \\
29 \\
45 \\
94 \\
73 \\
64 \\
67 \\
66\end{array}$ & $\begin{array}{r}262 \\
156 \\
116 \\
85 \\
103 \\
80 \\
67 \\
63 \\
16 \\
17\end{array}$ & $\begin{array}{r}231 \\
191 \\
162 \\
147 \\
83 \\
105 \\
137 \\
152 \\
345 \\
286\end{array}$ & $\begin{array}{l}11 \\
12 \\
13 \\
14 \\
15 \\
16 \\
17 \\
18 \\
19 \\
20\end{array}$ & $\begin{array}{r}19 \\
47 \\
187 \\
161 \\
110 \\
90 \\
79 \\
19 \\
18 \\
63\end{array}$ & $\begin{array}{r}59 \\
77 \\
71 \\
64 \\
67 \\
22 \\
37 \\
92 \\
94 \\
310\end{array}$ & $\begin{array}{l}501 \\
522 \\
345 \\
210 \\
161 \\
132 \\
551 \\
353 \\
249 \\
181\end{array}$ & $\begin{array}{l}21 \\
22 \\
23 \\
24 \\
25 \\
26 \\
27 \\
28 \\
29 \\
30 \\
31\end{array}$ & $\begin{array}{r}56 \\
63 \\
74 \\
68 \\
17 \\
32 \\
100 \\
764 \\
1,090 \\
532\end{array}$ & $\begin{array}{r}750 \\
1,270 \\
2,330 \\
5,180 \\
2,320 \\
1,190 \\
725 \\
495 \\
394 \\
355 \\
277\end{array}$ & $\begin{array}{r}140 \\
137 \\
122 \\
103 \\
86 \\
82 \\
31 \\
58 \\
84 \\
59 \\
60\end{array}$ \\
\hline \multicolumn{9}{|c|}{$\begin{array}{l}\text { Monthly mean discharge, in second-feet } \\
\text { Runoff, in inches }\end{array}$} & $\begin{array}{r}144 \\
1.82\end{array}$ & $\begin{array}{r}553 \\
7 . .19\end{array}$ & $\begin{array}{r}194 \\
2.52\end{array}$ \\
\hline
\end{tabular}

Gage-height, in feet, and discharge, in second-feet, at indicated time, 1938

\begin{tabular}{|c|c|c|c|c|c|c|c|c|c|c|c|c|}
\hline \multirow{2}{*}{ Hour } & Feet & Sec.-ft. & Feet & Sec.-ft. & Feet & Sec.-ft. & Feet & Sec.-ft. & Feet & Sec.-ft. & Feet & Sec.-ft. \\
\hline & \multicolumn{2}{|c|}{ July 17} & \multicolumn{2}{|c|}{ July 18} & \multicolumn{2}{|c|}{ July 19} & \multicolumn{2}{|c|}{ July 20} & \multicolumn{2}{|c|}{ July 21} & \multicolumn{2}{|c|}{ July 22} \\
\hline 2 a.m. & 0.97 & 20 & $1: 41$ & 51 & 1.13 & 30 & 1.85 & 98 & 4.02 & 617 & 5.44 & 1,250 \\
\hline & $\begin{array}{l}0.98 \\
.98\end{array}$ & 21 & $\begin{array}{l}1.41 \\
1.38\end{array}$ & 48 & $\begin{array}{l}1.10 \\
1.13\end{array}$ & $\begin{array}{l}50 \\
30\end{array}$ & $\begin{array}{l}1.85 \\
1.98\end{array}$ & $\begin{array}{r}98 \\
116\end{array}$ & $\begin{array}{l}4.02 \\
4.12\end{array}$ & $\begin{array}{l}617 \\
653\end{array}$ & $\begin{array}{l}5.44 \\
5.39\end{array}$ & $\begin{array}{l}1,200 \\
1,220\end{array}$ \\
\hline & 1.01 & 23 & 1.51 & 60 & 1.13 & 30 & 2.25 & 158 & 4.23 & 697 & 5.46 & 1,260 \\
\hline 8 & 1.06 & 26 & 1.70 & 80 & 1.41 & 51 & 2.66 & 237 & $\begin{array}{l}4.39 \\
\end{array}$ & 761 & 5.76 & 1,440 \\
\hline 10 & 1.16 & 32 & 2.48 & 200 & 2.53 & 210 & 2.87 & 283 & 4.25 & 705 & 5.73 & 1,420 \\
\hline $12 \mathrm{n}$. & 1.27 & 40 & 2.44 & 193 & 2.51 & 206 & 2.81 & 269 & 3. & 572 & 5.54 & 1,300 \\
\hline 2 p.m. & 1.38 & 48 & 2.21 & 152 & 2.38 & 181 & 3.15 & 352 & 4.10 & 645 & 5.76 & 1,440 \\
\hline & 1.41 & 51 & 2.37 & 180 & 2.40 & 185 & 3.41 & 418 & 4.09 & 642 & 5.53 & 1,300 \\
\hline & 1.41 & 51 & 1.52 & 61 & 1.57 & 66 & 3.47 & 436 & 4.20 & 685 & 5.21 & 1,140 \\
\hline 8 & 1.41 & 51 & 1.25 & 38 & 1.33 & 44 & 3.73 & 516 & 4.95 & 1,010 & 5.30 & 1,180 \\
\hline 10 & 1.41 & 51 & 1.18 & 34 & 1.30 & 42 & 3.86 & 561 & 5.31 & 1,180 & 5.23 & 1,140 \\
\hline \multirow[t]{2}{*}{$12 \mathrm{~m}$. } & 1.41 & 51 & 1.15 & 32 & 1.57 & 66 & 3.92 & 582 & 5.47 & 1,260 & 5.14 & 1,100 \\
\hline & \multicolumn{2}{|c|}{ July 23} & \multicolumn{2}{|c|}{ July 24} & \multicolumn{2}{|c|}{ July 25} & \multicolumn{2}{|c|}{ July 26} & \multicolumn{2}{|c|}{ July 27} & \multicolumn{2}{|c|}{ July 28} \\
\hline 2 a.m. & 5.06 & 1,060 & 11.41 & 6,890 & 7.88 & 3,050 & 5.85 & 1,490 & 4.63 & 864 & 3.83 & 550 \\
\hline & 5.06 & 1,060 & 11.07 & & 7.74 & 2,930 & 5.72 & 1,410 & 4.57 & 83 & 3.79 & 536 \\
\hline 6 & 5.44 & 1,250 & 10.73 & & 7.51 & 2,720 & 5.63 & 1,360 & 4.64 & 86 & 3.93 & 586 \\
\hline 8 & & & 10.43 & & 7.43 & & 5.77 & & & & & 665 \\
\hline 10 & & 050 & 10.21 & 5,220 & 7.21 & 2,470 & 5.52 & 1,290 & 4.58 & 8 & 3.92 & 582 \\
\hline $12 \mathrm{n}$. & & & 10.05 & & & 2,230 & 5.09 & 1,0 & & 6 & & 436 \\
\hline 2 p.n & & & 10.05 & & 6.8 & 2,180 & $\tilde{5} .2$ & 1,180 & 4.3 & 7 & 3.76 & 526 \\
\hline & & & 10.04 & 000 & 6.54 & 1,960 & 4.76 & 92 & 3. & 5 & & 380 \\
\hline 6 & & & 9.6 & & 6.39 & 1,8 & 4.80 & 9 & 3.8 & 5 & 3.18 & 360 \\
\hline & & & & 000 & 6.26 & 1,760 & 4.82 & 94 & 3.90 & 57 & 3.35 & 402 \\
\hline 10 & 9.55 & 4,410 & 8.44 & 3,600 & 6.13 & 1,670 & 4.77 & 926 & 3.91 & 578 & 3.41 & 418 \\
\hline $12 \mathrm{~m}$. & 11.30 & 6,720 & 8.08 & 3,240 & 5.99 & 1,570 & 4.70 & 895 & 3.88 & 568 & 3.43 & 424 \\
\hline
\end{tabular}


Gage height, in feet, and discharge, in second-feet, at indicated time, 1938 -Continued

\begin{tabular}{|c|c|c|c|c|c|c|c|c|c|c|c|c|}
\hline \multirow{2}{*}{ Hour } & Feet & Sec.-ft. & Feet & Sec.-ft. & Feet & Sec-ft. & Feet & Sec.-ft. & Feet & Sec. $-\mathrm{ft}$. & Feet & Sec.-ft \\
\hline & \multicolumn{2}{|c|}{ July 29} & \multicolumn{2}{|c|}{ July 30} & \multicolumn{2}{|c|}{ July 31} & \multicolumn{2}{|c|}{ August 1} & \multicolumn{2}{|c|}{ August 2} & \multicolumn{2}{|c|}{ August 3} \\
\hline $2 \mathrm{a.m}$ & 3.42 & 421 & 3.30 & 390 & 2.95 & 302 & 2.65 & 234 & 2.49 & 202 & 2.23 & 155 \\
\hline & 3.41 & 418 & 3.30 & 390 & 2.93 & 298 & 2.64 & 232 & 2.48 & 200 & 2.25 & 158 \\
\hline 6 & 3.56 & 463 & 3.29 & 388 & 2.92 & 295 & 2.64 & 232 & 2.47 & 198 & 2.26 & 160 \\
\hline 8 & 3.79 & 536 & 3.30 & 390 & 2.90 & 290 & 2.89 & 288 & 2.67 & 239 & 2.45 & 195 \\
\hline 10 & 3.59 & 472 & 3.19 & 362 & 2.88 & 285 & 3.13 & 348 & 2.97 & 308 & 2.89 & 288 \\
\hline $12 \mathrm{n}$. & 3.14 & 350 & 3.17 & 358 & 2.86 & 281 & 2.96 & 305 & 2.72 & 249 & 2.70 & 245 \\
\hline $2 \mathrm{p.m}$ & 3.50 & 445 & 3.14 & 350 & 2.84 & 276 & 2.69 & 243 & 2.57 & 21 & 2.37 & 180 \\
\hline & 3.00 & 315 & 3.08 & 335 & 2.81 & 269 & 2.72 & 249 & 2.52 & 208 & 2.51 & 206 \\
\hline 6 & 2.8 & 267 & 3.05 & 32 & 2.76 & 258 & 1.94 & 11 & 1.70 & 80 & 1.67 & 77 \\
\hline 8 & 2.99 & 312 & 3.01 & 318 & 2.72 & 249 & 2.10 & 13 & 1.80 & 92 & 1.3 & 48 \\
\hline 10 & 3.12 & 345 & 2.98 & 310 & 2.69 & 243 & 2.34 & 17. & 2.07 & 130 & 1.70 & 80 \\
\hline $12 \mathrm{~m}$. & & 378 & 2.97 & 308 & 2.6 & 239 & 2.45 & 19 & 2.18 & 147 & 1.93 & 109 \\
\hline
\end{tabular}

Supplemental records.-July 18, 1 p.m., 1.92 ft., 108 sec.-ft.; July 20, 1 p.m., 2.55 ft., 214 sec.ft. July 21, 5 p.m., $3.66 \mathrm{ft}$., 493 sec.-ft.; July 23, 9 p.m., $8.07 \mathrm{ft}$., 3,230 sec.-ft.; July 24, $1: 20$ a.m., $11.47 \mathrm{ft}$. 6,980 sec.-ft.; July 26,3 p.m., 5.19 ft., 1,120 sec.ft.; July 29, 5 p.m., 2.71 ft., 247 sec.-ft.; Aug. 3,9 a.m.. $2.92 \mathrm{ft}$., 295 sec.-ft.

\section{CONNECTICUT RIVER BASIN}

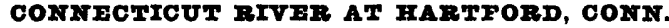

Location.-Lat. $41^{\circ} 46^{\prime} 10^{\prime \prime}$, long. $72^{\circ} 40^{\prime} 00^{\prime \prime}$, at Memorial Bridge in Hartford, Hartford County, three-quarters of a mile upstream from Park River and $1 \frac{1}{2}$ miles upstream from Hockanum River. Datum of gage is 0.55 foot below mean sea level.

Drainage area.- $-10,480$ square miles.

GAGE-HEIGHT RECORD.-Water-stage recorder graph. Gage heights given to tenths.

MахімA.-July 1938: Gage height, 11.2 feet 2:30 a.m. July 25 (discharge, about 40,000 second-feet).

1896 to June 1938: Discharge, 313,000 second-feet Mar, 20, 1936 (augmented by breaching of Hartford dikes); gage height, 37.6 feet Mar. 21, 1936.

1639 to June 1938: Stage known, that of Mar. 21, 1936.

ReMARKs.-Low stages affected by tide. Flow affected by a total storage capacity of $27,000,000,000$ cubic feet (revised) above station. Record furnished by U. S. Weather Bureau.

Gage height, in feet, at 8 a.m., 1938

\begin{tabular}{|c|c|c|c|c|c|c|c|c|c|c|c|}
\hline Day & June & July & Aug. & Day & June & July & Ang. & Day & June & July & Aug. \\
\hline $\begin{array}{r}1 \\
2 \\
3 \\
4 \\
5 \\
6 \\
7 \\
8 \\
9 \\
10\end{array}$ & $\begin{array}{l}4.0 \\
3.8 \\
3.8 \\
3.7 \\
3.6 \\
2.9 \\
2.9 \\
2.6 \\
2.7 \\
2.7\end{array}$ & $\begin{array}{l}5.3 \\
4.7 \\
4.3 \\
4.7 \\
5.4 \\
2.8 \\
2.6 \\
2.5 \\
2.2 \\
1.9\end{array}$ & $\begin{array}{l}9.6 \\
7.9 \\
8.0 \\
8.0 \\
6.7 \\
5.4 \\
4.4 \\
3.3 \\
3.7 \\
4.2\end{array}$ & $\begin{array}{l}11 \\
12 \\
13 \\
14 \\
15 \\
16 \\
17 \\
18 \\
19 \\
20\end{array}$ & $\begin{array}{l}2.8 \\
2.8 \\
3.7 \\
6.4 \\
6.0 \\
5.1 \\
4.3 \\
3.7 \\
3.0 \\
2.7\end{array}$ & $\begin{array}{r}1.8 \\
3.0 \\
3.6 \\
4.1 \\
4.2 \\
3.6 \\
4.0 \\
2.6 \\
3.7 \\
5.3\end{array}$ & $\begin{array}{l}4.6 \\
5.3 \\
5.8 \\
4.5 \\
3.6 \\
3.7 \\
4.0 \\
3.8 \\
3.6 \\
3.5\end{array}$ & $\begin{array}{l}21 \\
22 \\
23 \\
24 \\
25 \\
26 \\
27 \\
28 \\
29 \\
30 \\
31\end{array}$ & $\begin{array}{l}3.0 \\
3.2 \\
2.7 \\
2.6 \\
2.4 \\
1.8 \\
2.1 \\
4.9 \\
9.4 \\
7.5\end{array}$ & $\begin{array}{r}5.0 \\
6.7 \\
9.1 \\
10.5 \\
11.1 \\
9.5 \\
7.5 \\
6.7 \\
6.0 \\
7.1 \\
10.6\end{array}$ & $\begin{array}{l}3.0 \\
2.9 \\
3.0 \\
3.7 \\
3.7 \\
3.8 \\
4.1 \\
4.0 \\
3.1 \\
3.3 \\
3.3\end{array}$ \\
\hline
\end{tabular}


SCANTIC RIVER AT BROAD BROOK, CONT.

Location.—Lat. $41^{\circ} 54^{\prime} 45^{\prime \prime}$, long. $72^{\circ} 34^{\prime} 05^{\prime \prime}, 300$ feet upstream from highway bridge, half a mile downstream from Broad Brook, 1 mile southwest of town of Broad Brook, Hartford County, and 5 $1 / 2$ miles upstream from mouth.

Drainage AREA.- 98.4 square miles.

(iACE-HEIGHT RECORD.-Water-stage recorder graph except period July 4 to Aug. 26 when graph was computed on basis of range line, records for stations on Hockanum River near East Hartford, Farmington River at Riverton, and Willimantic River near South Coventry, and weather records.

STAGE-Discharge relation.-Defined by current-meter measurements below 550 second-feet; extended to peak stage on basis of determinations of flood flows of September 1938 at dams 7 and 9 miles above station.

Maxima.-July 1938: Discharge, 962 second-feet 2 to 4 p.m. July 24 (gage height, 6.85 feet).

1928 to June 1938: Discharge, 1,820 second-feet Mar. 13, 1936 (gage height, 10.17 feet); maximum gage height, 12.31 feet Mar. 21 (backwater from Connecticut River).

REMARKs.-Flood discharge affected by storage in one reservoir and several small ponds.

Mean discharge, in second-feet, 1938

\begin{tabular}{|c|c|c|c|c|c|c|c|c|c|c|c|}
\hline Day & June & July & Aug. & Day & June & July & Aug. & Day & June & July & Aug. \\
\hline $\begin{array}{r}1 \\
2 \\
3 \\
4 \\
5 \\
6 \\
7 \\
8 \\
9 \\
10\end{array}$ & $\begin{array}{r}132 \\
106 \\
104 \\
88 \\
122 \\
138 \\
118 \\
113 \\
108 \\
102\end{array}$ & $\begin{array}{r}309 \\
209 \\
171 \\
130 \\
120 \\
130 \\
100 \\
80 \\
60 \\
90\end{array}$ & $\begin{array}{l}222 \\
240 \\
199 \\
190 \\
150 \\
110 \\
150 \\
200 \\
180 \\
180\end{array}$ & $\begin{array}{l}11 \\
12 \\
13 \\
14 \\
15 \\
16 \\
17 \\
18 \\
19 \\
20\end{array}$ & $\begin{array}{l}111 \\
245 \\
426 \\
698 \\
502 \\
267 \\
204 \\
154 \\
146 \\
140\end{array}$ & $\begin{array}{r}140 \\
130 \\
130 \\
120 \\
130 \\
50 \\
60 \\
150 \\
225 \\
246\end{array}$ & $\begin{array}{r}200 \\
260 \\
200 \\
160 \\
150 \\
140 \\
140 \\
130 \\
130 \\
60\end{array}$ & $\begin{array}{l}21 \\
22 \\
23 \\
24 \\
25 \\
26 \\
27 \\
28 \\
29 \\
30 \\
31\end{array}$ & $\begin{array}{r}121 \\
101 \\
90 \\
85 \\
72 \\
64 \\
200 \\
436 \\
630 \\
547\end{array}$ & $\begin{array}{l}340 \\
541 \\
703 \\
939 \\
823 \\
646 \\
496 \\
409 \\
350 \\
246 \\
200\end{array}$ & $\begin{array}{l}65 \\
90 \\
85 \\
85 \\
85 \\
80 \\
58 \\
66 \\
89 \\
82 \\
77\end{array}$ \\
\hline \multicolumn{9}{|c|}{$\begin{array}{l}\text { Monthly mean discharge, in second-feet } \ldots \ldots \\
\text { Runoff, in inches }\end{array}$} & 212 & $\begin{array}{r}273 \\
3.19\end{array}$ & $\begin{array}{r}137 \\
1.60\end{array}$ \\
\hline
\end{tabular}

Gage-height, in feet, and discharge, in second-feet, at indicated time, 1938

\begin{tabular}{|c|c|c|c|c|c|c|c|c|c|c|c|c|}
\hline \multirow{2}{*}{ Hour } & Feet & Sec.-ft. & Feet & Sec.-ft. & Feet & Sec. $-f t$ & Feet & Sec.-ft. & Feet & Sec. $-\mathrm{ft}$. & Feet & Sec.-ft. \\
\hline & \multicolumn{2}{|c|}{ Iuly 17} & \multicolumn{2}{|c|}{ July 18} & \multicolumn{2}{|c|}{ July 19} & \multicolumn{2}{|c|}{ July 20} & \multicolumn{2}{|c|}{ July 21} & \multicolumn{2}{|c|}{ July 22} \\
\hline $\begin{array}{c}2 \text { a.m. } \\
4 \\
6 \\
8 \\
10 \\
12 \mathrm{n} . \\
2 \mathrm{p} . \mathrm{m} . \\
4 \\
6 \\
8 \\
10 \\
12 \mathrm{~m} .\end{array}$ & $\begin{array}{c}\ldots \\
\ldots . \\
0.90 \\
\cdots \\
\cdots\end{array}$ & $\begin{array}{c}\ldots \ldots \\
\cdots \ldots \\
\cdots \\
\cdots \\
\cdots \\
\cdots \\
\cdots \\
\cdots\end{array}$ & $\begin{array}{r}0.89 \\
.91 \\
.95 \\
.99 \\
1.19 \\
1.59 \\
1.82 \\
1.99 \\
2.09 \\
2.14 \\
2.09 \\
2.04\end{array}$ & $\begin{array}{r}60 \\
62 \\
68 \\
74 \\
110 \\
170 \\
200 \\
220 \\
230 \\
235 \\
230 \\
225\end{array}$ & $\begin{array}{l}1.95 \\
1.86 \\
1.82 \\
1.78 \\
1.82 \\
1.91 \\
2.02 \\
2.18 \\
2.28 \\
2.36 \\
2.40 \\
2.32\end{array}$ & $\begin{array}{l}215 \\
205 \\
200 \\
195 \\
200 \\
210 \\
225 \\
240 \\
250 \\
260 \\
260 \\
250\end{array}$ & $\begin{array}{l}2.17 \\
2.04 \\
1.95 \\
1.89 \\
1.95 \\
2.04 \\
2.18 \\
2.42 \\
2.60 \\
2.70 \\
2.73 \\
2.72\end{array}$ & $\begin{array}{l}235 \\
225 \\
215 \\
210 \\
215 \\
225 \\
240 \\
260 \\
280 \\
290 \\
290 \\
290\end{array}$ & $\begin{array}{l}2.70 \\
2.65 \\
2.60 \\
2.65 \\
2.77 \\
2.94 \\
3.14 \\
3.36 \\
3.56 \\
3.71 \\
3.79 \\
3.80\end{array}$ & $\begin{array}{l}290 \\
280 \\
280 \\
280 \\
300 \\
320 \\
340 \\
370 \\
400 \\
420 \\
430 \\
440\end{array}$ & $\begin{array}{l}3.83 \\
3.89 \\
3.93 \\
3.97 \\
4.02 \\
4.17 \\
4.45 \\
4.75 \\
5.01 \\
5.24 \\
5.41 \\
5.53\end{array}$ & $\begin{array}{l}440 \\
450 \\
460 \\
460 \\
470 \\
490 \\
540 \\
580 \\
640 \\
680 \\
700 \\
720\end{array}$ \\
\hline
\end{tabular}


Gage height in feet, and discharge, in second-feet, at indicated time, 1938-Continued

\begin{tabular}{|c|c|c|c|c|c|c|c|c|c|c|c|c|}
\hline \multirow{2}{*}{ Hour } & Feet & Sec.-ft. & Feet & Sec.-ft. & Fect & Sec.-ft. & Feet & Sec.-ft. & Feet & Sec.-ft. & Feet & Sec.-ft. \\
\hline & \multicolumn{2}{|c|}{ July 23} & \multicolumn{2}{|c|}{ July 24} & \multicolumn{2}{|c|}{ July 25} & \multicolumn{2}{|c|}{ July 26} & \multicolumn{2}{|c|}{ July 27} & \multicolumn{2}{|c|}{ July 28} \\
\hline $\begin{array}{c}2 \text { a.m. } \\
4 \\
6 \\
8 \\
10 \\
12 \mathrm{n} . \\
2 \mathrm{p} . \mathrm{m} . \\
4 \\
6 \\
8 \\
10 \\
12 \mathrm{~m} .\end{array}$ & $\begin{array}{l}5.42 \\
5.29 \\
5.18 \\
5.10 \\
5.06 \\
5.11 \\
5.23 \\
5.40 \\
5.64 \\
5.84 \\
6.04 \\
6.24\end{array}$ & $\begin{array}{l}700 \\
680 \\
660 \\
640 \\
640 \\
640 \\
660 \\
700 \\
740 \\
780 \\
820 \\
840\end{array}$ & $\begin{array}{l}6.42 \\
6.58 \\
6.70 \\
6.77 \\
6.81 \\
6.84 \\
6.85 \\
6.85 \\
6.84 \\
6.82 \\
6.76 \\
6.66\end{array}$ & $\begin{array}{l}880 \\
920 \\
940 \\
940 \\
960 \\
960 \\
962 \\
962 \\
960 \\
960 \\
940 \\
920\end{array}$ & $\begin{array}{l}6.55 \\
6.43 \\
6.31 \\
6.20 \\
6.10 \\
6.03 \\
5.97 \\
5.97 \\
5.93 \\
5.86 \\
5.72 \\
5.53\end{array}$ & $\begin{array}{l}900 \\
880 \\
860 \\
840 \\
820 \\
820 \\
800 \\
800 \\
800 \\
780 \\
760 \\
720\end{array}$ & $\begin{array}{l}5.34 \\
5.22 \\
5.14 \\
5.09 \\
5.06 \\
5.09 \\
5.13 \\
5.12 \\
5.02 \\
4.94 \\
4.82 \\
4.66\end{array}$ & $\begin{array}{l}680 \\
660 \\
660 \\
640 \\
640 \\
640 \\
660 \\
660 \\
640 \\
620 \\
600 \\
580\end{array}$ & $\begin{array}{l}4.46 \\
4.26 \\
4.08 \\
4.02 \\
4.02 \\
4.05 \\
4.12 \\
4.17 \\
4.20 \\
4.20 \\
4.19 \\
4.14\end{array}$ & $\begin{array}{l}540 \\
500 \\
480 \\
470 \\
470 \\
480 \\
490 \\
490 \\
500 \\
500 \\
500 \\
490\end{array}$ & $\begin{array}{l}4.01 \\
3.83 \\
3.63 \\
3.49 \\
3.44 \\
3.36 \\
3.47 \\
3.57 \\
3.63 \\
3.61 \\
3.56 \\
3.49\end{array}$ & $\begin{array}{l}470 \\
440 \\
410 \\
390 \\
380 \\
370 \\
390 \\
400 \\
410 \\
410 \\
400 \\
390\end{array}$ \\
\hline & \multicolumn{2}{|c|}{ July 29} & \multicolumn{2}{|c|}{ July 30} & \multicolumn{2}{|c|}{ July 31} & \multicolumn{2}{|c|}{ August 1} & \multicolumn{2}{|c|}{ August 2} & \multicolumn{2}{|c|}{ August 3} \\
\hline $\begin{array}{c}2 \mathrm{a} . \mathrm{m} . \\
4 \\
6 \\
8 \\
10 \\
12 \mathrm{n} . \\
2 \mathrm{p.m} . \\
4 \\
6 \\
8 \\
10 \\
12 \mathrm{~m} .\end{array}$ & $\begin{array}{l}3.40 \\
3.29 \\
3.19 \\
3.11 \\
3.07 \\
3.06 \\
3.09 \\
3.15 \\
3.24 \\
3.29 \\
3.27 \\
3.21\end{array}$ & $\begin{array}{l}380 \\
360 \\
350 \\
340 \\
330 \\
330 \\
330 \\
340 \\
350 \\
360 \\
360 \\
350\end{array}$ & $\begin{array}{l}3.11 \\
2.85 \\
2.56 \\
2.32 \\
2.17 \\
2.04 \\
1.95 \\
1.91 \\
1.88 \\
1.85 \\
1.83 \\
1.82\end{array}$ & $\begin{array}{l}340 \\
310 \\
280 \\
250 \\
235 \\
225 \\
215 \\
210 \\
210 \\
205 \\
200 \\
200\end{array}$ & 1.82 & $200^{-}$ & $\begin{array}{l}1.82 \\
1.82 \\
1.84 \\
1.87 \\
1.91 \\
1.96 \\
2.04 \\
2.15 \\
2.25 \\
2.30 \\
2.30 \\
2.25\end{array}$ & $\begin{array}{l}200 \\
200 \\
205 \\
205 \\
210 \\
215 \\
225 \\
235 \\
245 \\
250 \\
250 \\
245\end{array}$ & $\begin{array}{l}2.20 \\
2.14 \\
2.09 \\
2.09 \\
2.14 \\
2.20 \\
2.25 \\
2.30 \\
2.30 \\
2.30 \\
2.20 \\
2.06\end{array}$ & $\begin{array}{l}240 \\
235 \\
230 \\
230 \\
235 \\
240 \\
245 \\
250 \\
250 \\
250 \\
240 \\
225\end{array}$ & $\begin{array}{l}1.83 \\
1.70 \\
1.66 \\
1.68 \\
1.75 \\
1.82 \\
1.86 \\
1.92 \\
1.91 \\
1.88 \\
1.85 \\
1.82\end{array}$ & $\begin{array}{l}200 \\
185 \\
180 \\
180 \\
190 \\
200 \\
205 \\
210 \\
210 \\
210 \\
205 \\
200\end{array}$ \\
\hline
\end{tabular}

FARMINGTON RIVER NEAR NEW BOSTON, MASS.

LOCATION.-Lat. $42^{\circ} 04^{\prime} 40^{\prime \prime}$, long. $73^{\circ} 04^{\prime} 25^{\prime \prime}$, at highway bridge a quarter of a mile downstream from Clam River and 1 mile south of New Boston, Berkshire County. Datum of gage is 758.21 feet above mean sea level (general adjustment of 1929).

DraiNAGE AREA.-92.0 square miles.

GAGE-HEIGHT RECORD.-Water-stage recorder graph.

Stage-discharge ReLation.-Defined by current-meter measurements below 1,380 second-feet.

Maxima.-July 1938: Discharge, 1,680 second-feet 10 to 11 p.m. July 29 (gage height, 6.50 feet).

1913 to June 1938: Discharge, 9,080 second-feet Mar. 18, 1936, from rating curve extended above 1,380 second-feet on basis of contractedopening and slope-area; gage height, 11.20 feet Mar. 12, 1936 (ice jam).

Remarks.-Flood discharge regulated by storage in Otis Reservoir (page 234).

Mean discharge, in second-feet, 1938

\begin{tabular}{r|r|r|r||c|c|c|c||c|c|c|c}
\hline Day & June & July & Aug. & Day & June & July & Aug. & Day & June & July & Aug. \\
\hline 1 & 65 & 301 & 431 & 11 & 91 & 104 & 684 & 21 & 88 & 275 & 221 \\
2 & 57 & 286 & 467 & 12 & 166 & 144 & 472 & 22 & 78 & 492 & 215 \\
3 & 65 & 232 & 336 & 13 & 806 & 146 & 319 & 23 & 72 & 496 & 210 \\
4 & 59 & 199 & 244 & 14 & 431 & 118 & 218 & 24 & 65 & 601 & 210 \\
5 & 62 & 176 & 164 & 155 & 250 & 64 & 195 & 25 & 78 & 346 & 184 \\
6 & 60 & 157 & 222 & 16 & 162 & 66 & 218 & 26 & 206 & 235 & 50 \\
7 & 49 & 128 & 364 & 177 & 108 & 204 & 27 & 1,780 & 171 & 61 \\
8 & 59 & 55 & 253 & 18 & 92 & 136 & 197 & 28 & 1,420 & 135 & 179 \\
9 & 61 & 57 & 197 & 19 & 79 & 259 & 121 & 29 & 686 & 710 & 181 \\
10 & 48 & 115 & 259 & 20 & 85 & 174 & 132 & 30 & 403 & 1.070 & 176 \\
&
\end{tabular}


Gage-height, in feet, and discharge, in second-feet, at indicated time, 1938

\begin{tabular}{|c|c|c|c|c|c|c|c|c|c|c|c|c|}
\hline \multirow{2}{*}{ Hour } & Feet & Sec,-ft. & Feet & Sec.-ft. & Feet & Sec.-ft. & Feet & Sec.-ft. & Feet & Sec.-ft. & Feet & Sec.-ft. \\
\hline & \multicolumn{2}{|c|}{ July 17} & \multicolumn{2}{|c|}{ July 18} & \multicolumn{2}{|c|}{ July 19} & \multicolumn{2}{|c|}{ July 20} & \multicolumn{2}{|c|}{ July 21} & \multicolumn{2}{|c|}{ July 22} \\
\hline $\begin{array}{c}6 \mathrm{a} . \mathrm{m} . \\
12 \mathrm{n} . \\
6 \mathrm{p.m} . \\
12 \mathrm{~m} .\end{array}$ & $\begin{array}{l}3.58 \\
3.59 \\
3.55 \\
3.53\end{array}$ & $\begin{array}{l}111 \\
113 \\
106 \\
102\end{array}$ & $\begin{array}{l}3.52 \\
3.56 \\
3.85 \\
3.96\end{array}$ & $\begin{array}{l}101 \\
108 \\
169 \\
199\end{array}$ & $\begin{array}{l}3.94 \\
4.41 \\
4.34 \\
4.07\end{array}$ & $\begin{array}{l}191 \\
328 \\
307 \\
227\end{array}$ & $\begin{array}{l}3.96 \\
3.86 \\
3.79 \\
3.71\end{array}$ & $\begin{array}{l}197 \\
171 \\
155 \\
137\end{array}$ & $\begin{array}{l}3.67 \\
3.99 \\
4.98 \\
4.69\end{array}$ & $\begin{array}{l}129 \\
204 \\
560 \\
431\end{array}$ & $\begin{array}{l}5.05 \\
4.93 \\
4.76 \\
4.64\end{array}$ & $\begin{array}{l}595 \\
535 \\
459 \\
411\end{array}$ \\
\hline & \multicolumn{2}{|c|}{ July 23} & \multicolumn{2}{|c|}{ July 24} & \multicolumn{2}{|c|}{ July 25} & \multicolumn{2}{|c|}{ July 26} & \multicolumn{2}{|c|}{ July 27} & \multicolumn{2}{|c|}{ July 28} \\
\hline $\begin{array}{c}6 \mathrm{a} \text { a.m. } \\
12 \mathrm{n} . \\
6 \mathrm{p.m} . \\
12 \mathrm{~m} .\end{array}$ & $\begin{array}{l}4.50 \\
4.44 \\
5.33 \\
5.41\end{array}$ & $\begin{array}{l}360 \\
339 \\
748 \\
796\end{array}$ & $\begin{array}{l}5.26 \\
5.06 \\
4.83 \\
4.69\end{array}$ & $\begin{array}{l}706 \\
600 \\
488 \\
431\end{array}$ & $\begin{array}{l}4.57 \\
4.46 \\
4.35 \\
4.25\end{array}$ & $\begin{array}{l}384 \\
346 \\
310 \\
280\end{array}$ & $\begin{array}{l}4.18 \\
4.11 \\
4.01 \\
3.95\end{array}$ & $\begin{array}{l}259 \\
238 \\
210 \\
194\end{array}$ & $\begin{array}{l}3.91 \\
3.86 \\
3.80 \\
3.75\end{array}$ & $\begin{array}{l}184 \\
171 \\
157 \\
146\end{array}$ & $\begin{array}{l}3.75 \\
3.71 \\
3.67 \\
3.63\end{array}$ & $\begin{array}{l}142 \\
137 \\
129 \\
121\end{array}$ \\
\hline & \multicolumn{2}{|c|}{ July 29} & \multicolumn{2}{|c|}{ July 30} & \multicolumn{2}{|c|}{ July 31} & \multicolumn{2}{|c|}{ August 1} & \multicolumn{2}{|c|}{ August 2} & \multicolumn{2}{|c|}{ August 3} \\
\hline $\begin{array}{c}6 \mathrm{a} . \mathrm{m} . \\
12 \mathrm{n} . \\
6 \mathrm{p.m} . \\
12 \mathrm{~m} .\end{array}$ & $\begin{array}{l}3.66 \\
5.28 \\
5.60 \\
6.47\end{array}$ & $\begin{array}{r}127 \\
718 \\
920 \\
1,650\end{array}$ & $\begin{array}{l}6.09 \\
5.74 \\
5.46 \\
5.26\end{array}$ & $\begin{array}{r}1,300 \\
1,020 \\
826 \\
706\end{array}$ & $\begin{array}{l}5.08 \\
4.88 \\
4.71 \\
4.61\end{array}$ & $\begin{array}{l}610 \\
511 \\
439 \\
399\end{array}$ & $\begin{array}{l}4.54 \\
4.55 \\
4.48 \\
5.48\end{array}$ & $\begin{array}{l}374 \\
378 \\
353 \\
838\end{array}$ & $\begin{array}{l}5.29 \\
4.9 .4 \\
4.75 \\
4.59\end{array}$ & $\begin{array}{l}724 \\
540 \\
455 \\
392\end{array}$ & $\begin{array}{l}4.51 \\
4.45 \\
4.35 \\
4.29\end{array}$ & $\begin{array}{l}364 \\
342 \\
310 \\
292\end{array}$ \\
\hline & \multicolumn{2}{|c|}{ August 4} & \multicolumn{2}{|c|}{ August 5} & \multicolumn{2}{|c|}{ August 6} & \multicolumn{2}{|c|}{ August 7} & \multicolumn{2}{|c|}{ August 8} & \multicolumn{2}{|c|}{ August 9} \\
\hline $\begin{array}{c}6 \mathrm{a} . \mathrm{m} . \\
12 \mathrm{n} . \\
6 \mathrm{p.m} . \\
12 \mathrm{~m} .\end{array}$ & $\begin{array}{l}4.26 \\
4.09 \\
4.01 \\
3.97\end{array}$ & $\begin{array}{l}283 \\
232 \\
210 \\
199\end{array}$ & $\begin{array}{l}3.95 \\
3.85 \\
3.73 \\
3.67\end{array}$ & $\begin{array}{l}194 \\
169 \\
142 \\
129\end{array}$ & $\begin{array}{l}3.65 \\
3.63 \\
4.37 \\
4.78\end{array}$ & $\begin{array}{l}125 \\
121 \\
316 \\
467\end{array}$ & $\begin{array}{l}4.68 \\
4.46 \\
4.35 \\
4.26\end{array}$ & $\begin{array}{l}427 \\
346 \\
310 \\
283\end{array}$ & $\begin{array}{l}4.20 \\
4.15 \\
4.10 \\
4.10\end{array}$ & $\begin{array}{l}265 \\
250 \\
235 \\
235\end{array}$ & $\begin{array}{l}4.08 \\
3.89 \\
3.77 \\
4.15\end{array}$ & $\begin{array}{l}229 \\
179 \\
150 \\
250\end{array}$ \\
\hline & \multicolumn{2}{|c|}{ August 10} & & & & & & & & & & \\
\hline $\begin{array}{c}6 \mathrm{a} . \mathrm{m} . \\
12 \mathrm{n} . \\
6 \mathrm{p.m} . \\
12 \mathrm{~m} .\end{array}$ & $\begin{array}{l}4.24 \\
4.21 \\
4.10 \\
4.11\end{array}$ & $\begin{array}{l}277 \\
268 \\
235 \\
238\end{array}$ & & & & & & & & & & \\
\hline
\end{tabular}

Supplemental records.--July 23, 3 p.m., 4.49 ft., 356 sec.-ft.; 8 to 9 p.m., 5.48 ft., 838 sec.-ft.; July 29 , 9 a.m., $4.96 \mathrm{ft}$., 550 sec.-ft.; 2 p.m., 5.22 ft., 682 sec.-ft.; 4 p.m., 5.27 ft., 712 sec.-ft.; 8 p.m., $6.42 \mathrm{ft}$., 1,600 sec.-ft.; 10 to 11 p.m., $6.50 \mathrm{ft} ., 1,680$ sec.-ft.; Aug. 6,9 p.m., $4.87 \mathrm{ft}$., 506 sec.-ft.

${ }^{1}$ Adjusted for storage in Otis Reservoir.

\section{FARMINGTON RIVER AT RIVERTON, CONN.}

Location.-Lat. $41^{\circ} 57^{\prime} 15^{\prime \prime}$, long. $73^{\circ} 00^{\prime} 45^{\prime \prime}$, a quarter of a mile downstream from Still River, 1 mile downstream from Riverton, Litchfield County, and 4 miles northeast of Winsted.

Drainage arEa.-216 square miles.

GAGE-HEICHT RECORD.-Water-stage recorder graph.

Stage-discharge ReLATion.-Defined by current-meter measurements.

Maxima.-July 1938: Discharge, 2,610 second-feet 6 to 7 a.m. July 22 (gage height, 5.06 feet).

1929 to June 1938: Discharge, 19,900 second-feet Mar. 18, 1936 (gage height, 13.42 feet).

Remarks.-Flow regulated by storage in Otis Reservoir (page 234). 
Mean discharge, in second-feet, 1938

\begin{tabular}{|c|c|c|c|c|c|c|c|c|c|c|c|}
\hline Day & June & July & Aug. & Day & June & July & Aug. & Day & June & July & Aug. \\
\hline $\begin{array}{r}1 \\
2 \\
3 \\
4 \\
5 \\
6 \\
7 \\
8 \\
9 \\
10\end{array}$ & $\begin{array}{l}180 \\
156 \\
175 \\
165 \\
154 \\
176 \\
154 \\
164 \\
160 \\
126\end{array}$ & $\begin{array}{l}505 \\
540 \\
408 \\
355 \\
330 \\
271 \\
242 \\
162 \\
130 \\
178\end{array}$ & $\begin{array}{l}620 \\
934 \\
572 \\
396 \\
316 \\
340 \\
609 \\
468 \\
470 \\
506\end{array}$ & $\begin{array}{l}11 \\
12 \\
13 \\
14 \\
15 \\
16 \\
17 \\
18 \\
19 \\
20\end{array}$ & $\begin{array}{r}176 \\
338 \\
1.270 \\
764 \\
448 \\
320 \\
251 \\
178 \\
150 \\
162\end{array}$ & $\begin{array}{l}234 \\
344 \\
370 \\
256 \\
210 \\
216 \\
183 \\
309 \\
623 \\
585\end{array}$ & $\begin{array}{r}1.310 \\
991 \\
600 \\
395 \\
\mathbf{3 5 4} \\
347 \\
331 \\
328 \\
300 \\
237\end{array}$ & $\begin{array}{l}21 \\
22 \\
23 \\
24 \\
25 \\
26 \\
27 \\
28 \\
29 \\
30 \\
31\end{array}$ & $\begin{array}{r}158 \\
138 \\
163 \\
154 \\
114 \\
223 \\
2,990 \\
3,320 \\
1.570 \\
892\end{array}$ & $\begin{array}{r}1,280 \\
2,200 \\
1,670 \\
1,720 \\
1,060 \\
703 \\
491 \\
392 \\
776 \\
1,440 \\
795\end{array}$ & $\begin{array}{l}315 \\
309 \\
302 \\
284 \\
268 \\
144 \\
112 \\
185 \\
236 \\
237 \\
224\end{array}$ \\
\hline \multicolumn{9}{|c|}{$\begin{array}{l}\text { Monthly mean discharge, in second-feet } \\
\text { Runoff, in inches }\end{array}$} & $\begin{array}{r}513 \\
2.66\end{array}$ & $\begin{array}{r}615 \\
3.29\end{array}$ & $\begin{array}{r}421 \\
2.25\end{array}$ \\
\hline
\end{tabular}

Gage-height, in feet, and discharge, in second-feet, at indicated time, 1938

\begin{tabular}{|c|c|c|c|c|c|c|c|c|c|c|c|c|}
\hline \multirow{2}{*}{ Hour } & Feet & Sec.ft. & Feet & Sec.-ft. & Feet & Sec. $-\mathrm{ft}$. & Feet & Sec.-ft. & Feet & Sec.-ft. & Feet & Sec.-ft. \\
\hline & \multicolumn{2}{|c|}{ JuJy 17} & \multicolumn{2}{|c|}{ July 18} & \multicolumn{2}{|c|}{ July 19} & \multicolumn{2}{|c|}{ July 20} & \multicolumn{2}{|c|}{ July 21} & \multicolumn{2}{|c|}{ July 22} \\
\hline $\begin{array}{c}2 \mathrm{a} . \mathrm{m} . \\
4 \\
6 \\
8 \\
10 \\
12 \mathrm{n} . \\
2 \mathrm{p} . \mathrm{m} . \\
4 \\
6 \\
8 \\
10 \\
12 \mathrm{~m} .\end{array}$ & $\begin{array}{l}1.45 \\
1.43 \\
1.59 \\
1.64 \\
1.96 \\
1.96 \\
1.66 \\
1.65 \\
1.62 \\
1.61 \\
1.59 \\
1.57\end{array}$ & $\begin{array}{l}134 \\
129 \\
168 \\
181 \\
277 \\
277 \\
186 \\
184 \\
175 \\
173 \\
168 \\
162\end{array}$ & $\begin{array}{l}1.56 \\
1.61 \\
1.63 \\
1.95 \\
1.96 \\
1.76 \\
2.16 \\
2.25 \\
2.40 \\
2.47 \\
2.48 \\
2.30\end{array}$ & $\begin{array}{l}160 \\
173 \\
178 \\
274 \\
277 \\
214 \\
350 \\
385 \\
448 \\
481 \\
486 \\
405\end{array}$ & $\begin{array}{l}2.27 \\
2.27 \\
2.42 \\
2.66 \\
2.69 \\
2.92 \\
3.02 \\
3.01 \\
2.91 \\
3.00 \\
3.06 \\
2.67\end{array}$ & $\begin{array}{l}393 \\
393 \\
457 \\
575 \\
590 \\
722 \\
783 \\
776 \\
716 \\
770 \\
809 \\
580\end{array}$ & $\begin{array}{l}2.63 \\
2.76 \\
2.71 \\
2.83 \\
2.75 \\
2.64 \\
2.77 \\
2.77 \\
2.73 \\
2.56 \\
2.50 \\
2.21\end{array}$ & $\begin{array}{l}560 \\
628 \\
600 \\
668 \\
622 \\
565 \\
634 \\
634 \\
612 \\
525 \\
495 \\
369\end{array}$ & $\begin{array}{l}2.15 \\
2.19 \\
2.39 \\
2.93 \\
2.98 \\
3.12 \\
3.96 \\
4.78 \\
4.86 \\
4.81 \\
4.64 \\
4.53\end{array}$ & $\begin{array}{r}346 \\
361 \\
444 \\
728 \\
758 \\
848 \\
1,500 \\
2,300 \\
2,390 \\
2,330 \\
2,150 \\
2,040\end{array}$ & $\begin{array}{l}4.67 \\
4.96 \\
5.06 \\
5.05 \\
4.95 \\
4.83 \\
4.71 \\
4.59 \\
4.45 \\
4.32 \\
4.23 \\
4.13\end{array}$ & $\begin{array}{l}2,180 \\
2,500 \\
2,610 \\
2,600 \\
2,480 \\
2,350 \\
2,220 \\
2,100 \\
1,960 \\
1,830 \\
1,750 \\
1,660\end{array}$ \\
\hline
\end{tabular}

\begin{tabular}{|c|c|c|c|c|c|c|c|c|c|c|c|c|}
\hline \multirow[b]{2}{*}{$\begin{array}{c}2 \text { a.m. } \\
4 \\
6 \\
8 \\
10 \\
12 \mathrm{n.} \\
2 \mathrm{p.m} . \\
4 \\
6 \\
8 \\
10 \\
12 \mathrm{m.} .\end{array}$} & \multicolumn{2}{|c|}{ July 23} & \multicolumn{2}{|c|}{ July: 24} & \multicolumn{2}{|c|}{ July 25} & \multicolumn{2}{|c|}{ July 26} & \multicolumn{2}{|c|}{ July 27} & \multicolumn{2}{|c|}{ July 28} \\
\hline & $\begin{array}{l}4.04 \\
3.96 \\
3.87 \\
3.86 \\
3.85 \\
3.90 \\
3.93 \\
4.07 \\
4.27 \\
4.72 \\
4.74 \\
4.65\end{array}$ & $\begin{array}{l}1,580 \\
1,500 \\
1,420 \\
1,410 \\
1,400 \\
1,450 \\
1,480 \\
1,600 \\
1,780 \\
2,230 \\
2,250 \\
2,160\end{array}$ & $\begin{array}{l}4.57 \\
4.52 \\
4.45 \\
4.37 \\
4.29 \\
4.20 \\
4.12 \\
4.03 \\
3.95 \\
3.86 \\
3.78 \\
3.72\end{array}$ & $\begin{array}{l}2,080 \\
2,030 \\
1,960 \\
1,880 \\
1,800 \\
1,720 \\
1,650 \\
1,570 \\
1,500 \\
1,410 \\
1,340 \\
1,290\end{array}$ & $\begin{array}{l}3.66 \\
3.61 \\
3.56 \\
3.55 \\
3.52 \\
3.46 \\
3.42 \\
3.34 \\
3.26 \\
3.16 \\
3.10 \\
3.06\end{array}$ & $\begin{array}{r}1,240 \\
1,200 \\
1,160 \\
1,150 \\
1,130 \\
1,080 \\
1,050 \\
998 \\
942 \\
874 \\
835 \\
809\end{array}$ & $\begin{array}{l}3.03 \\
3.00 \\
2.97 \\
2.98 \\
2.98 \\
2.96 \\
2.90 \\
2.83 \\
2.76 \\
2.72 \\
2.67 \\
2.58\end{array}$ & $\begin{array}{l}790 \\
770 \\
752 \\
758 \\
758 \\
746 \\
710 \\
668 \\
628 \\
606 \\
580 \\
535\end{array}$ & $\begin{array}{l}2.58 \\
2.57 \\
2.45 \\
2.59 \\
2.59 \\
2.31 \\
2.57 \\
2.55 \\
2.44 \\
2.40 \\
2.36 \\
2.32\end{array}$ & $\begin{array}{l}535 \\
530 \\
472 \\
540 \\
540 \\
409 \\
530 \\
520 \\
467 \\
448 \\
431 \\
414\end{array}$ & $\begin{array}{l}2.26 \\
2.19 \\
2.10 \\
2.41 \\
2.43 \\
2.23 \\
2.42 \\
2.33 \\
2.17 \\
2.30 \\
2.17 \\
1.95\end{array}$ & $\begin{array}{l}389 \\
361 \\
327 \\
453 \\
462 \\
377 \\
457 \\
418 \\
354 \\
405 \\
354 \\
274\end{array}$ \\
\hline & \multicolumn{2}{|c|}{ July 29} & \multicolumn{2}{|c|}{ July 30} & \multicolumn{2}{|c|}{ July 31} & \multicolumn{2}{|c|}{ August 1} & \multicolumn{2}{|c|}{ August 2} & \multicolumn{2}{|c|}{ August 3} \\
\hline $\begin{array}{l}2 \mathrm{a} . \mathrm{m} . \\
4 \\
6 \\
8 \\
10 \\
12 \mathrm{n} . \\
2 \mathrm{p} .11 . \\
4 \\
6 \\
8 \\
10 \\
12 \mathrm{~m} .\end{array}$ & $\begin{array}{l}1.89 \\
1.86 \\
2.07 \\
2.41 \\
2.37 \\
2.32 \\
3.35 \\
3.15 \\
3.17 \\
3.68 \\
4.38 \\
4.48\end{array}$ & $\begin{array}{r}254 \\
245 \\
316 \\
453 \\
435 \\
414 \\
1,000 \\
868 \\
880 \\
1,250 \\
1,890 \\
1,990\end{array}$ & $\begin{array}{l}4.46 \\
4.24 \\
4.10 \\
4.20 \\
4.09 \\
3.92 \\
3.79 \\
3.60 \\
3.46 \\
3.36 \\
3.40 \\
3.34\end{array}$ & $\begin{array}{r}1,970 \\
1,760 \\
1,630 \\
1,720 \\
1,620 \\
1,470 \\
1,350 \\
1,190 \\
1,080 \\
1,010 \\
1,040 \\
998\end{array}$ & $\begin{array}{l}3.28 \\
3.22 \\
3.17 \\
3.31 \\
3.09 \\
3.18 \\
3.08 \\
2.86 \\
2.72 \\
2.66 \\
2.72 \\
2.73\end{array}$ & $\begin{array}{l}956 \\
914 \\
880 \\
977 \\
828 \\
887 \\
822 \\
686 \\
606 \\
575 \\
606 \\
612\end{array}$ & $\begin{array}{l}2.70 \\
2.69 \\
2.66 \\
2.88 \\
2.84 \\
2.63 \\
2.76 \\
2.79 \\
2.68 \\
2.69 \\
2.73 \\
3.09\end{array}$ & $\begin{array}{l}595 \\
590 \\
575 \\
698 \\
674 \\
560 \\
628 \\
644 \\
585 \\
590 \\
612 \\
828\end{array}$ & $\begin{array}{l}3.45 \\
3.41 \\
3.42 \\
3.57 \\
3.50 \\
3.23 \\
3.28 \\
3.12 \\
3.08 \\
2.98 \\
2.89 \\
2.80\end{array}$ & $\begin{array}{r}1,080 \\
1,050 \\
1,050 \\
1,170 \\
1,110 \\
921 \\
956 \\
848 \\
822 \\
758 \\
704 \\
650\end{array}$ & $\begin{array}{l}2.61 \\
2.58 \\
2.57 \\
2.88 \\
2.85 \\
2.63 \\
2.81 \\
2.67 \\
2.63 \\
2.55 \\
2.47 \\
2.42\end{array}$ & $\begin{array}{l}550 \\
535 \\
530 \\
698 \\
680 \\
560 \\
656 \\
580 \\
560 \\
520 \\
481 \\
457\end{array}$ \\
\hline
\end{tabular}

Supplemental records.-July 17, 5 a.m., $1.43 \mathrm{ft} ., 129$ sec.-ft.; July 22,7 a.m., 506 ft., 2,610 sec.-ft.; July 29, 1 p.m., 3.41 ft.. 1,050 sec.-ft.; Aug. 1, 1 p.m., 2.55 ft., 520 sec.-ft.; Aug. 3,7 a.m., 2.58 ft., 535 sec.-ft. 


\section{FARMINGTON RIVER AT TARIFFVITLE, CONN.}

Location.-Lat. $41^{\circ} 54^{\prime} 35^{\prime \prime}$, long. $72^{\circ} 45^{\prime} 40^{\prime \prime}$, at Tariffille, Hartford County, half a mile upstream from Hartford Electric Light Co.'s plant, threequarters of a mile downstream from Salmon Brook, and 12 miles upstream from mouth.

Drainage aREA.-578 square miles.

GAGE-HEIGHT RECORD.-Water-stage recorder graph.

STAGE-DISCHARGE RELATION.-Varies with number of generators operating at power plant. Base rating curves have been developed for flow through one and two generators operating at full capacity and for flow over spillway of dam with no generators operating. These ratings are correlated by stage relation curves and are defined by discharge measurements and computations of flow over dam. When generators ran at less than full capacity, discharge was determined from gage-height graph adjusted to various ratings. One-generator rating was used June 1-11, 16-26, July 5-10, Aug. 26-31; two-generator rating used for intervening periods.

Maxima.-July 1938: Discharge, 6,020 second-feet 12 p.m. July 22; gage height, 6.98 feet $1: 20$ a.m. July 23 .

1928 to June 1938: Discharge, 26,900 second-feet Mar. 19, 1936 (gage height, 13.4 feet).

REMARKs.-Flood discharge affected by storage and diversion. For information on storage and diversion see records for Otis Reservoir at Cold Spring, Mass., Barkhamsted Reservoir at Barkhamsted, Conn., East Branch Reservoir at New Hartford, Conn., and Nepaug Reservoir near Collinsville, Conn.

Mean discharge, in second-feet, 1938

\begin{tabular}{|c|c|c|c|c|c|c|c|c|c|c|c|}
\hline Day. & June & July & Aug. & Day & June & July & Aug. & Day & June & July & Aug. \\
\hline $\begin{array}{r}1 \\
2 \\
3 \\
4 \\
5 \\
6 \\
7 \\
8 \\
9 \\
10\end{array}$ & $\begin{array}{l}690 \\
665 \\
640 \\
615 \\
512 \\
506 \\
690 \\
715 \\
690 \\
611\end{array}$ & $\begin{array}{r}1,640 \\
1,060 \\
995 \\
898 \\
825 \\
742 \\
715 \\
615 \\
525 \\
528\end{array}$ & $\begin{array}{r}1,870 \\
1,830 \\
1,790 \\
1,420 \\
1,160 \\
995 \\
1,460 \\
1,420 \\
1,340 \\
1,460\end{array}$ & $\begin{array}{l}11 \\
12 \\
13 \\
14 \\
15 \\
16 \\
17 \\
18 \\
19 \\
20\end{array}$ & $\begin{array}{r}582 \\
832 \\
1,310 \\
1,890 \\
1,240 \\
825 \\
770 \\
566 \\
467 \\
438\end{array}$ & $\begin{array}{r}629 \\
1,470 \\
1,200 \\
1,030 \\
832 \\
678 \\
560 \\
581 \\
1,210 \\
2,130\end{array}$ & $\begin{array}{l}2,0 ? 0 \\
3,13) \\
2,340 \\
1,540 \\
1,130 \\
1,130 \\
1,100 \\
1,130 \\
1,200 \\
1,100\end{array}$ & $\begin{array}{l}21 \\
22 \\
23 \\
24 \\
25 \\
26 \\
27 \\
28 \\
29 \\
30 \\
31\end{array}$ & $\begin{array}{r}610 \\
611 \\
532 \\
535 \\
452 \\
359 \\
1,170 \\
4,480 \\
+, 340 \\
2,640\end{array}$ & $\begin{array}{l}2,590 \\
5,710 \\
5,770 \\
5,190 \\
4,470 \\
3,290 \\
2,410 \\
2,590 \\
1,830 \\
2,630 \\
2,530\end{array}$ & $\begin{array}{l}768 \\
768 \\
768 \\
728 \\
702 \\
615 \\
512 \\
409 \\
421 \\
563 \\
546\end{array}$ \\
\hline \multicolumn{9}{|c|}{$\begin{array}{l}\text { Monthly mean discharge, in second-feet } \\
\text { Runof, in inches }\end{array}$} & $\begin{array}{r}1,030 \\
1.99\end{array}$ & $\begin{array}{r}1,870 \\
3.74\end{array}$ & $\begin{array}{r}1,210 \\
2.41\end{array}$ \\
\hline
\end{tabular}


Gage-height, in feet, and discharge, in second-feet, at indicated time, 1938

\begin{tabular}{|c|c|c|c|c|c|c|c|c|c|c|c|c|}
\hline \multirow[b]{2}{*}{ Hour } & Feet & Sec.ft. & Feet & Sec.-ft. & Feet & Sec. $-\mathrm{ft}$. & Feet & Sec.-ft. & Feet & Sec.-ft. & Feet & Sec.-ft. \\
\hline & \multicolumn{2}{|c|}{ July 17} & \multicolumn{2}{|c|}{ July 18} & \multicolumn{2}{|c|}{ July 19} & \multicolumn{2}{|c|}{ July 20} & \multicolumn{2}{|c|}{ July 21} & \multicolumn{2}{|c|}{ July 22} \\
\hline \multirow{6}{*}{$\begin{array}{c}24 \mathrm{a} . \mathrm{m} . \\
4 \\
6 \\
8 \\
10 \\
12 \mathrm{n} . \\
2 \mathrm{p} . \mathrm{m} . \\
4 \\
6 \\
8 \\
10 \\
12 \mathrm{~m} .\end{array}$} & 2.06 & 598 & 1.77 & 490 & 2.40 & 962 & 3.80 & 1,980 & \multirow{6}{*}{$\begin{array}{l}3.79 \\
3.74 \\
3.74 \\
3.69 \\
3.66 \\
3.65 \\
3.75 \\
4.08 \\
4.49 \\
5.01 \\
5.66 \\
6.12\end{array}$} & \multirow{6}{*}{$\begin{array}{l}2,120 \\
2,070 \\
2,030 \\
2,010 \\
1,990 \\
1,980 \\
2,080 \\
2,420 \\
2,880 \\
3,520 \\
4,420 \\
4,990\end{array}$} & 6.45 & 5,370 \\
\hline & 2.00 & 658 & 1.86 & 520 & 2.41 & 995 & 3.87 & 2,200 & & & 6.67 & 5,590 \\
\hline & 1.93 & 622 & 1.82 & 496 & 2.58 & 1,120 & 3.90 & 2,230 & & & 6.83 & 5,810 \\
\hline & 1.83 & 526 & 1.98 & 562 & 2.92 & 1,360 & 3.89 & 2,220 & & & 6.90 & 5,970 \\
\hline & 1.65 & 462 & 2.08 & 722 & 3.14 & 1,530 & 3.89 & 2,220 & & & 6.93 & 6,000 \\
\hline & 1.67 & 462 & 2.38 & 930 & 3.32 & 1,680 & 3.87 & 2,200 & & & 6.95 & 6,020 \\
\hline
\end{tabular}

\begin{tabular}{|c|c|c|c|c|c|c|c|c|c|c|c|c|}
\hline \multirow{2}{*}{$\begin{array}{l}2 \\
4\end{array}$ a.m. } & \multicolumn{2}{|c|}{ July 23} & \multicolumn{2}{|c|}{ July 24} & \multicolumn{2}{|c|}{ Juty 25} & \multicolumn{2}{|c|}{ July 26} & \multicolumn{2}{|c|}{ July 27} & \multicolumn{2}{|c|}{ July 28} \\
\hline & & & & & & & & & & & 4.40 & 2,770 \\
\hline $\begin{array}{l}4 \\
6\end{array}$ & 6.92 & 5,970 & 6.48 & 5,260 & 6.20 & 4,780 & 5.07 & 3,590 & $4.2 \overline{1}$ & 2,560 & 4.54 & 2,940 \\
\hline 8 & -... & $\ldots$ & $\ldots . .$. & & $\cdots$ & $--\infty$ & $\cdots$ & $-\cdots$ & & & 4.50 & 2,890 \\
\hline $12 \mathrm{n}$. & 6.82 & 5,790 & 6.44 & 5,180 & 5.86 & 4,480 & 4.82 & 3,280 & 4.03 & $2, \overline{3} 60$ & $\begin{array}{l}4.45 \\
4.38\end{array}$ & $\begin{array}{l}2,030 \\
2,750\end{array}$ \\
\hline 2 p.m. & $\ldots$ & $\cdots$ & $\cdots$ & $\cdots$ & $\cdots$ & $\ldots$ & $\cdots$ & -1 & & & $\begin{array}{l}4.29 \\
4.16\end{array}$ & $\begin{array}{l}2,650 \\
2,510\end{array}$ \\
\hline 6 & 6.73 & 5,590 & 6.38 & 5,100 & 5.73 & 4,180 & 4.58 & 2,990 & 3.85 & 2,180 & 4.01 & 2,340 \\
\hline 8 & 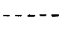 & -1 & $-\ldots$ & - & & & & & & & & 2,180 \\
\hline $12 \mathrm{~m}$. & 6.58 & 5,420 & $6.30^{-}$ & 4,990 & $5 . \overline{3}$ & $3,8 \overline{0}$ & 4.39 & 2,760 & $\begin{array}{l}3.91 \\
4.16\end{array}$ & $\begin{array}{l}2,210 \\
2,510\end{array}$ & $\begin{array}{l}3.71 \\
3.62\end{array}$ & $\begin{array}{l}2,040 \\
1,950\end{array}$ \\
\hline
\end{tabular}

\begin{tabular}{|c|c|c|c|c|c|c|c|c|c|c|c|c|}
\hline \multirow{3}{*}{$\begin{array}{l}2 \text { a.m. } \\
4 \\
6 \\
3\end{array}$} & \multicolumn{2}{|c|}{ July 29} & \multicolumn{2}{|c|}{ July 30} & \multicolumn{2}{|c|}{ July 31} & \multicolumn{2}{|c|}{ August 1} & \multicolumn{2}{|c|}{ August 2} & \multicolumn{2}{|c|}{ August 3} \\
\hline & 3.58 & 1,910 & 3.80 & 2,040 & 4.45 & 2,830 & 3.71 & 2,040 & .3 .38 & 1,730 & 3.65 & 1,980 \\
\hline & $3 . \overline{8}$ & 1,910 & 4.12 & 2,460 & 4.29 & 2,650 & 3.60 & 1,930 & 3.39 & 1,740 & 3.56 & 1,890 \\
\hline $12 \mathrm{n}$. & 3.54 & 1,880 & 4.48 & 2,870 & 4.17 & 2,520 & 3.50 & 1,840 & 3.41 & 1,760 & 3.47 & 1,810 \\
\hline 4 & 3.48 & 1,820 & 4.62 & 3,030 & 4.04 & 2,370 & 3.42 & 1,770 & 3.55 & 1,880 & 3.34 & 1,700 \\
\hline $\begin{array}{l}6 \\
8\end{array}$ & 3.43 & 1,670 & 4.63 & 3,050 & 3.92 & 2,250 & 3.48 & 1,730 & 3.66 & 1,990 & 3.20 & $\overline{1}, \overline{580}$ \\
\hline $12 \mathrm{~m}$. & 3.44 & 1,680 & 4.58 & 2,990 & 3.81 & 2,140 & 3.37 & 1,720 & 3.70 & 2,030 & 3.11 & 1,510 \\
\hline
\end{tabular}

Supplemental records.-July 23, 1:20 p.m., 6.98 feet.

\section{OTIS RESERVOTR AT COID SPRING, MASS.}

Location.-Staff gage at dam, lat. $42^{\circ} 09^{\prime} 35^{\prime \prime}$, long. $73^{\circ} 03^{\prime} 33^{\prime \prime}$, on unnamed stream three-quarters of a mile upstream from its debouchment into Farmington River and 1 mile northeast of Cold Spring, Hampden County. Drainage AREA.-17.2 square miles.

GAGE-HEIGHT RECORD.-One gage reading daily, usually at 7 a. m. Gage-height at midnight computed from graph of gage readings and study of gate operation and weather records.

Stage-Discharge ReLATION.-Outflow computed from records of gate openings and flow over spillway of dam.

REMARKs.- Inflow computed from outflow adjusted for change in contents of reservoir. No adjustments for evaporation from reservoir surface. Records based on data furnished by the Collins Co., Collinsville, Conn. 
Discharge, in second-feet, and change in contents, in equivalent second-feet, 1938

\begin{tabular}{|c|c|c|c|c|c|c|c|c|c|}
\hline \multirow[b]{2}{*}{ Day } & \multicolumn{3}{|c|}{ June } & \multicolumn{3}{|c|}{ July } & \multicolumn{3}{|c|}{ August } \\
\hline & $\begin{array}{c}\text { Observed } \\
\text { Outflow }\end{array}$ & $\begin{array}{c}\text { Change } \\
\text { in } \\
\text { Contents }\end{array}$ & Inflow & $\begin{array}{l}\text { Observed } \\
\text { Outflow }\end{array}$ & $\begin{array}{c}\text { Change } \\
\text { in } \\
\text { Contents }\end{array}$ & Inflow & $\begin{array}{l}\text { Observed } \\
\text { Outflow }\end{array}$ & $\begin{array}{c}\text { Change } \\
\text { in } \\
\text { Contents }\end{array}$ & Inflow \\
\hline $\begin{array}{l}1 \\
2 \\
3 \\
4 \\
5\end{array}$ & $\begin{array}{l}0 \\
0 \\
0 \\
0 \\
0\end{array}$ & $\begin{array}{l}+21 \\
+21 \\
+21 \\
+21 \\
+21\end{array}$ & $\begin{array}{l}21 \\
21 \\
21 \\
21 \\
21\end{array}$ & $\begin{array}{l}82 \\
80 \\
80 \\
80 \\
80\end{array}$ & $\begin{array}{l}-48 \\
-53 \\
-53 \\
-53 \\
-59\end{array}$ & $\begin{array}{l}34 \\
27 \\
27 \\
27 \\
21\end{array}$ & $\begin{array}{r}102 \\
145 \\
90 \\
58 \\
19\end{array}$ & $\begin{array}{l}-32 \\
-64 \\
-48 \\
-21 \\
+53\end{array}$ & $\begin{array}{l}70 \\
81 \\
42 \\
37 \\
72\end{array}$ \\
\hline $\begin{array}{r}6 \\
7 \\
8 \\
9 \\
10\end{array}$ & $\begin{array}{l}0 \\
0 \\
0 \\
0 \\
0\end{array}$ & $\begin{array}{l}+16 \\
+11 \\
+16 \\
+16 \\
+11\end{array}$ & $\begin{array}{l}16 \\
11 \\
16 \\
16 \\
11\end{array}$ & $\begin{array}{r}80 \\
60 \\
0 \\
20 \\
80\end{array}$ & $\begin{array}{r}-59 \\
-43 \\
+11 \\
-11 \\
-48\end{array}$ & $\begin{array}{r}21 \\
17 \\
11 \\
9 \\
32\end{array}$ & $\begin{array}{r}48 \\
102 \\
75 \\
28 \\
17\end{array}$ & $\begin{array}{l}+48 \\
-43 \\
-43 \\
+32 \\
+53\end{array}$ & $\begin{array}{l}96 \\
59 \\
32 \\
60 \\
70\end{array}$ \\
\hline $\begin{array}{l}11 \\
12 \\
13 \\
14 \\
15\end{array}$ & $\begin{array}{l}0 \\
0 \\
0 \\
0 \\
0\end{array}$ & $\begin{array}{r}+16 \\
+43 \\
+112 \\
+37 \\
+16\end{array}$ & $\begin{array}{r}16 \\
43 \\
112 \\
37 \\
16\end{array}$ & $\begin{array}{r}80 \\
80 \\
80 \\
60 \\
0\end{array}$ & $\begin{array}{l}-48 \\
-48 \\
-43 \\
-16 \\
+43\end{array}$ & $\begin{array}{l}32 \\
32 \\
37 \\
44 \\
43\end{array}$ & $\begin{array}{l}86 \\
84 \\
75 \\
26 \\
54\end{array}$ & $\begin{array}{r}-5 \\
-32 \\
-48 \\
-5 \\
-32\end{array}$ & $\begin{array}{l}81 \\
52 \\
27 \\
21 \\
22\end{array}$ \\
\hline $\begin{array}{l}16 \\
17 \\
18 \\
19 \\
20\end{array}$ & $\begin{array}{r}0 \\
0 \\
1 \\
3 \\
30\end{array}$ & $\begin{array}{l}+16 \\
+16 \\
+16 \\
+16 \\
-11\end{array}$ & $\begin{array}{l}16 \\
16 \\
17 \\
19 \\
19\end{array}$ & $\begin{array}{r}20 \\
80 \\
53 \\
0 \\
0\end{array}$ & $\begin{array}{l}+27 \\
-21 \\
+11 \\
+37 \\
+37\end{array}$ & $\begin{array}{l}47 \\
59 \\
64 \\
37 \\
37\end{array}$ & $\begin{array}{r}80 \\
80 \\
60 \\
0 \\
73\end{array}$ & $\begin{array}{r}-59 \\
-58 \\
-32 \\
+16 \\
-59\end{array}$ & $\begin{array}{l}21 \\
22 \\
28 \\
16 \\
14\end{array}$ \\
\hline $\begin{array}{l}21 \\
22 \\
23 \\
24 \\
25\end{array}$ & $\begin{array}{l}42 \\
41 \\
41 \\
40 \\
68\end{array}$ & $\begin{array}{l}-27 \\
-27 \\
-27 \\
-21 \\
-53\end{array}$ & $\begin{array}{l}15 \\
14 \\
14 \\
19 \\
15\end{array}$ & $\begin{array}{l}0 \\
0 \\
0 \\
0 \\
0\end{array}$ & $\begin{array}{r}+101 \\
+106 \\
+69 \\
+69 \\
+64\end{array}$ & $\begin{array}{r}101 \\
106 \\
69 \\
69 \\
64\end{array}$ & $\begin{array}{l}160 \\
158 \\
158 \\
156 \\
110\end{array}$ & $\begin{array}{l}-149 \\
-149 \\
-149 \\
-144 \\
-101\end{array}$ & $\begin{array}{r}11 \\
9 \\
9 \\
12 \\
9\end{array}$ \\
\hline \multirow[t]{2}{*}{$\begin{array}{l}26 \\
27 \\
28 \\
29 \\
30 \\
31\end{array}$} & $\begin{array}{r}67 \\
45 \\
240 \\
86 \\
84\end{array}$ & $\begin{array}{r}-43 \\
+287 \\
-74 \\
-16 \\
-21 \\
\end{array}$ & $\begin{array}{r}24 \\
332 \\
166 \\
70 \\
63\end{array}$ & $\begin{array}{r}1 \\
4 \\
8 \\
32 \\
84 \\
83\end{array}$ & $\begin{array}{l}+48 \\
+27 \\
+32 \\
+48 \\
+27 \\
+32\end{array}$ & $\begin{array}{r}49 \\
31 \\
40 \\
80 \\
111 \\
115\end{array}$ & $\begin{array}{r}0 \\
46 \\
154 \\
154 \\
154 \\
152\end{array}$ & $\begin{array}{r}+11 \\
-37 \\
-149 \\
-149 \\
-149 \\
-144\end{array}$ & $\begin{array}{r}11 \\
9 \\
5 \\
5 \\
5 \\
8\end{array}$ \\
\hline & & & & & & & June & July & August \\
\hline \multicolumn{7}{|c|}{$\begin{array}{l}\text { Nonthly mean outflow, in second-feet } \\
\text { Outflow, in inches } \\
\text { Monthly mean inflow, in second-feet.- } \\
\text { Inflow, in inches. }\end{array}$} & $\begin{array}{l}26.3 \\
1.71 \\
40.6 \\
2.63\end{array}$ & $\begin{array}{l}42.2 \\
2.82 \\
48.2 \\
3.23\end{array}$ & $\begin{array}{l}87.2 \\
5.84 \\
32.8 \\
2.20\end{array}$ \\
\hline
\end{tabular}

BARKMAMSTED RTSFRVOTR NEAR BARKHAMSMFD, CONN.

Location.-Lat. $41^{\circ} 54^{\prime} 55^{\prime \prime}$, long. $72^{\circ} 57^{\prime} 05^{\prime \prime}$, on East Branch of Farmington River, $1 \frac{1 / 4}{4}$ miles south of Barkhamsted, Litchfield County, and $31 / 2$ miles upstream from mouth.

Drainage AREA.-50.5 square miles.

REMARKs.-Elevations of reservoir surface are for $8 \mathrm{a} . \mathrm{m}$. Change in contents is for 24-hour period prior to 8 a.m. except after Sundays and holidays when figure shown is change in contents for total period between readings. Record furnished by Water Bureau of the Metropolitan District Commission, Hartford, Conn. 
Elevation, in feet, and change in contents, in millions of gallons, 1938

\begin{tabular}{|c|c|c|c|c|c|c|}
\hline \multirow[b]{2}{*}{ Day } & \multicolumn{2}{|c|}{ June } & \multicolumn{2}{|c|}{ July } & \multicolumn{2}{|c|}{ August } \\
\hline & Elevation & $\begin{array}{l}\text { Change } \\
\text { in } \\
\text { Contents }\end{array}$ & Nevation & $\begin{array}{c}\text { Change } \\
\text { in } \\
\text { Contents }\end{array}$ & Elevation & $\begin{array}{c}\text { Change } \\
\text { in } \\
\text { Contents }\end{array}$ \\
\hline $\begin{array}{l}1 \\
2 \\
3 \\
4 \\
5\end{array}$ & $\begin{array}{l}431.35 \\
431.08 \\
430.85 \\
430.80\end{array}$ & $\begin{array}{c}-8 \\
-9 \\
-6 \\
-1 \\
\end{array}$ & $\begin{array}{r}440.25 \\
438.80 \\
433.40\end{array}$ & $\begin{array}{r}-70 \\
-78 \\
-257\end{array}$ & $\begin{array}{l}441.45 \\
440.60 \\
439.70 \\
438.50 \\
437.40\end{array}$ & $\begin{array}{r}-180 \\
-47 \\
-49 \\
-64 \\
-57\end{array}$ \\
\hline $\begin{array}{r}6 \\
7 \\
8 \\
9 \\
10\end{array}$ & $\begin{array}{l}430.60 \\
430.50 \\
429.10 \\
427.30 \\
425.85\end{array}$ & $\begin{array}{l}-6 \\
-3 \\
-36 \\
-44 \\
-33\end{array}$ & $\begin{array}{l}431.35 \\
429.65 \\
427.25 \\
425.90\end{array}$ & $\begin{array}{l}-68 \\
-47 \\
-59 \\
-30 \\
-\end{array}$ & $\begin{array}{r}436.00 \\
436.30 \\
435.50 \\
434.50\end{array}$ & $\begin{array}{l}-69 \\
+16 \\
-39 \\
-47\end{array}$ \\
\hline $\begin{array}{l}11 \\
12 \\
13 \\
14 \\
15\end{array}$ & $\begin{array}{r}424.60 \\
426.60 \\
431.50 \\
431.30\end{array}$ & $\begin{array}{r}-27 \\
+45 \\
+124 \\
-6\end{array}$ & $\begin{array}{r}424.50 \\
425.10 \\
425.30 \\
425.35 \\
426.50\end{array}$ & $\begin{array}{r}-31 \\
+12 \\
+5 \\
+1 \\
+26\end{array}$ & $\begin{array}{r}434.65 \\
436.75 \\
435.55 \\
434.50\end{array}$ & $\begin{array}{r}+7 \\
+100 \\
-58 \\
--49\end{array}$ \\
\hline $\begin{array}{l}16 \\
17 \\
18 \\
19 \\
20\end{array}$ & $\begin{array}{r}429.90 \\
428.40 \\
429.45 \\
428.50\end{array}$ & $\begin{array}{l}-39 \\
-37 \\
+26 \\
-21\end{array}$ & $\begin{array}{r}+28.05 \\
+25.70 \\
126.15 \\
+29.10\end{array}$ & $\begin{array}{l}+37 \\
-55 \\
+10 \\
+70\end{array}$ & $\begin{array}{l}433.20 \\
431.80 \\
430.05 \\
429.10 \\
428.20\end{array}$ & $\begin{array}{l}-53 \\
-47 \\
-50 \\
-24 \\
-32\end{array}$ \\
\hline $\begin{array}{l}21 \\
22 \\
23 \\
24 \\
25\end{array}$ & $\begin{array}{l}427.70 \\
425.75 \\
425.30 \\
424.70 \\
424.45\end{array}$ & $\begin{array}{r}-31 \\
-33 \\
-10 \\
-13 \\
-6\end{array}$ & $\begin{array}{r}+31.50 \\
437 \quad 60 \\
441.60 \\
444.55\end{array}$ & $\begin{array}{r}+65 \\
+259 \\
+213 \\
+165\end{array}$ & $\begin{array}{l}425.80 \\
424.90 \\
424.80 \\
424.30\end{array}$ & $\begin{array}{r}-46 \\
-20 \\
-2 \\
-11\end{array}$ \\
\hline \multirow[t]{2}{*}{$\begin{array}{l}26 \\
27 \\
28 \\
29 \\
30 \\
31\end{array}$} & $\begin{array}{l}424.85 \\
437.40 \\
441.70 \\
441.55\end{array}$ & $\begin{array}{r}+10 \\
+412 \\
+230 \\
-10\end{array}$ & $\begin{array}{l}444.35 \\
443.45 \\
443.30 \\
441.15 \\
442.91\end{array}$ & $\begin{array}{r}-12 \\
-50 \\
-8 \\
-119 \\
+197 \\
-\end{array}$ & $\begin{array}{l}424.80 \\
424.20 \\
425.50 \\
424.80 \\
424.10\end{array}$ & $\begin{array}{l}+11 \\
-13 \\
+28 \\
-15 \\
-15\end{array}$ \\
\hline & & & & June & July & August \\
\hline \multicolumn{4}{|c|}{ Change in contents, in miliions of gallons.. } & +465 & +176 & -825 \\
\hline
\end{tabular}

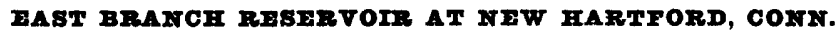

Locatron.-Lat. $41^{\circ} 52^{\prime} 55^{\prime \prime}$, long. $72^{\circ} 57^{\prime} 25^{\prime \prime}$, on East Branch of Farmington River, 1 mile east of New Hartford, Hartford County, and 11/4 miles upstream from mouth.

Drainage AREA.-61.2 square miles.

REMARKs.-Elevations of reservoir surface are for 8 a.m. Crest of spillway at elevation 422.5 feet. Change in contents is for 24 -hour period previous to 8 a.m. except after Sundays and holidays when figure shown is change in contents for total period between readings. Record furnished by Water Bureau of the Metropolitan District Commission, Hartford, Conn. 
Elevation, in feet, and change in contents, in millions of gallons, 1938

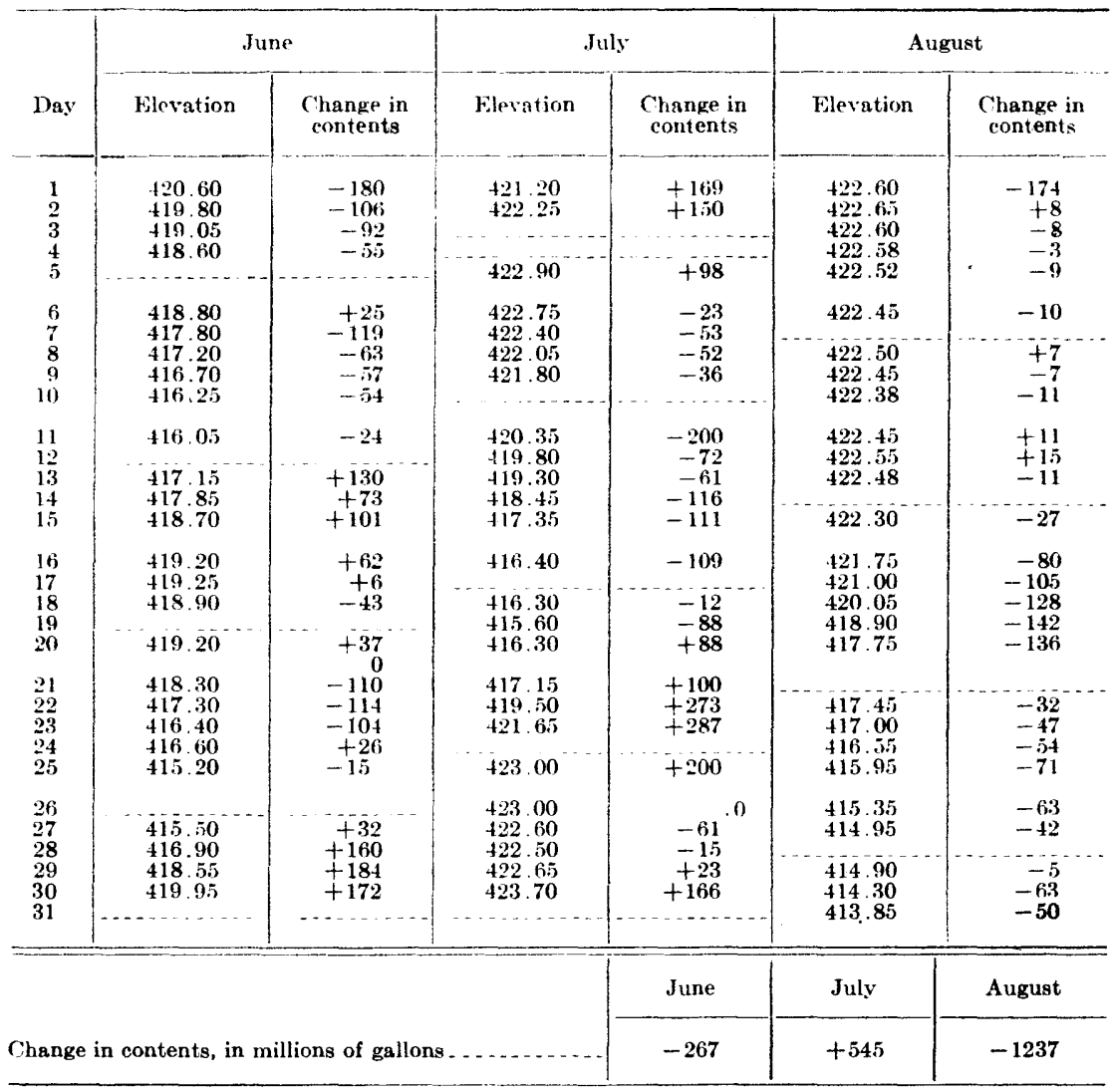

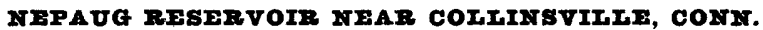

Location.-Lat. $41^{\circ} 49^{\prime} 40^{\prime \prime}$, long. $72^{\circ} 56^{\prime} 05^{\prime \prime}$, on Nepaug River a quarter of a mile upstream from mouth and $1 \frac{1}{2}$ miles northwest of Collinsville, Hartford County.

Drainage area.-32.0 square miles.

REMARKs.-Elevations of reservoir surface are for $8 \mathrm{a.m}$. Crest of spillway at elevation 485.0 feet. Change in contents is for 24 -hour period prior to 8 a.m. Diversions for Hartford municipal supply are for calendar day. Record furnished by Water Bureau of the Metropolitan District Commission, Hartford, Conn. 
Elevation, in feet, change in contents and diversion, in millions of gallons, 1938

\begin{tabular}{|c|c|c|c|c|c|c|c|c|c|}
\hline \multirow[b]{2}{*}{ Day } & \multicolumn{3}{|c|}{ June } & \multicolumn{3}{|c|}{ July } & \multicolumn{3}{|c|}{ August } \\
\hline & Elevation & $\begin{array}{l}\text { Change } \\
\text { in } \\
\text { Contents }\end{array}$ & Diversion & Elevation & $\begin{array}{c}\text { Change } \\
\text { in } \\
\text { Contents }\end{array}$ & Diversion & Elevation & $\begin{array}{c}\text { Change } \\
\text { in } \\
\text { Contents }\end{array}$ & Diversion \\
\hline $\begin{array}{l}1 \\
2 \\
3 \\
4 \\
5\end{array}$ & $\begin{array}{l}485.03 \\
485.00 \\
484.97 \\
484.96 \\
484.96\end{array}$ & $\begin{array}{r}+8.3 \\
-8.3 \\
-8.3 \\
-2.8 \\
.0\end{array}$ & $\begin{array}{l}12.1 \\
23.2 \\
23.5 \\
23.5 \\
23.5\end{array}$ & $\begin{array}{l}484.68 \\
484.68 \\
484.63 \\
484.58 \\
484.53\end{array}$ & $\begin{array}{r}-82.7 \\
-13.0 \\
-13.8 \\
-13.7\end{array}$ & $\begin{array}{l}28.5 \\
28.2 \\
27.8 \\
27.8 \\
28.2\end{array}$ & $\begin{array}{l}485.18 \\
485.14 \\
485.13 \\
485.10 \\
485.04\end{array}$ & $\begin{array}{r}-13.8 \\
-11.1 \\
-2.8 \\
-8.3 \\
-16.6\end{array}$ & $\begin{array}{l}25.0 \\
25.5 \\
25.5 \\
25.5 \\
25.5\end{array}$ \\
\hline $\begin{array}{r}6 \\
7 \\
8 \\
9 \\
10\end{array}$ & $\begin{array}{l}484.95 \\
484.91 \\
484.90 \\
484.92 \\
484.90\end{array}$ & $\begin{array}{r}-2.8 \\
-11.0 \\
-2.8 \\
+5.5 \\
-5.5\end{array}$ & $\begin{array}{l}23.5 \\
24.0 \\
24.0 \\
23.5 \\
23.5\end{array}$ & $\begin{array}{l}484.47 \\
484.41 \\
484.36 \\
484.29 \\
484.27\end{array}$ & $\begin{array}{r}-16.5 \\
-16.5 \\
-13.7 \\
-19.2 \\
-5.5\end{array}$ & $\begin{array}{l}27.5 \\
25.5 \\
24.5 \\
24.0 \\
24.0\end{array}$ & $\begin{array}{l}485.02 \\
485.05 \\
485.05 \\
485.08 \\
485.07\end{array}$ & $\begin{array}{r}-5.5 \\
+8.3 \\
+8.0 \\
-2.8\end{array}$ & $\begin{array}{l}25.5 \\
25.0 \\
25.0 \\
25.0 \\
25.0\end{array}$ \\
\hline $\begin{array}{l}11 \\
12 \\
13 \\
14 \\
15\end{array}$ & $\begin{array}{l}484.86 \\
485.09 \\
485.15 \\
485.17 \\
485.11\end{array}$ & $\begin{array}{r}-11.0 \\
+63.5 \\
+16.6 \\
+5.5 \\
-16.6\end{array}$ & $\begin{array}{l}23.5 \\
23.5 \\
23.5 \\
23.5 \\
23.5\end{array}$ & $\begin{array}{l}484.24 \\
484.56 \\
484.75 \\
484.85 \\
484.86\end{array}$ & $\begin{array}{r}-8.2 \\
+87.8 \\
+52.3 \\
+27.6 \\
+2.8\end{array}$ & $\begin{array}{l}26.0 \\
28.0 \\
26.8 \\
26.0 \\
26.0\end{array}$ & $\begin{array}{l}485.19 \\
485.26 \\
485.04 \\
485.00 \\
485.01\end{array}$ & $\begin{array}{r}+33.2 \\
+19.4 \\
-60.9 \\
-11.1 \\
+2.8\end{array}$ & $\begin{array}{l}25.0 \\
25.0 \\
25.5 \\
25.0 \\
25.0\end{array}$ \\
\hline $\begin{array}{l}16 \\
17 \\
18 \\
19 \\
20\end{array}$ & $\begin{array}{l}485.05 \\
485.03 \\
484.97 \\
484.93 \\
484.88\end{array}$ & $\begin{array}{r}-16.6 \\
-5.5 \\
-16.6 \\
-11.1 \\
-13.8\end{array}$ & $\begin{array}{l}23.5 \\
23.5 \\
23.5 \\
23.5 \\
24.5\end{array}$ & $\begin{array}{l}484.84 \\
484.79 \\
484.74 \\
484.74 \\
484.97\end{array}$ & $\begin{array}{r}-5.5 \\
-13.8 \\
-13.8 \\
+63.0\end{array}$ & $\begin{array}{l}26.0 \\
25.5 \\
25.0 \\
25.0 \\
25.0\end{array}$ & $\begin{array}{l}485.00 \\
484.99 \\
484.98 \\
484.98 \\
484.95\end{array}$ & $\begin{array}{r}-2.8 \\
-2.8 \\
-2.8 \\
-8.0\end{array}$ & $\begin{array}{l}25.5 \\
25.0 \\
25.0 \\
25.5 \\
25.5\end{array}$ \\
\hline $\begin{array}{l}21 \\
22 \\
23 \\
24 \\
25\end{array}$ & $\begin{array}{l}484.83 \\
484.78 \\
484.70 \\
484.68 \\
484.63\end{array}$ & $\begin{array}{r}-13.8 \\
-13.8 \\
-22.0 \\
-5.5 \\
-13.8\end{array}$ & $\begin{array}{l}25.0 \\
26.3 \\
28.0 \\
28.5 \\
28.5\end{array}$ & $\begin{array}{l}485.14 \\
486.47 \\
485.81 \\
485.62 \\
485.44\end{array}$ & $\begin{array}{r}+47.0 \\
+370.9 \\
-184.7 \\
-52.9 \\
-50.0\end{array}$ & $\begin{array}{l}25.0 \\
25.5 \\
25.5 \\
25.0 \\
25.0\end{array}$ & $\begin{array}{l}484.94 \\
484.90 \\
484.86 \\
484.81 \\
484.75\end{array}$ & $\begin{array}{r}-2.8 \\
-11.0 \\
-11.0 \\
-13.8 \\
-16.5\end{array}$ & $\begin{array}{l}25.0 \\
25.0 \\
25.0 \\
25.0 \\
25.0\end{array}$ \\
\hline \multirow[t]{2}{*}{$\begin{array}{l}26 \\
27 \\
28 \\
29 \\
30 \\
31\end{array}$} & $\begin{array}{l}484.57 \\
484.56 \\
485.01 \\
485.14 \\
484.98\end{array}$ & $\begin{array}{r}-16.5 \\
+2.8 \\
+124.1 \\
+35.9 \\
-44.2 \\
\end{array}$ & $\begin{array}{l}28.0 \\
28.0 \\
28.5 \\
28.5 \\
28.2\end{array}$ & $\begin{array}{l}485.20 \\
485.02 \\
485.05 \\
485.09 \\
485.18 \\
485.23\end{array}$ & $\begin{array}{r}-66.6 \\
-49.8 \\
+8.3 \\
+11.1 \\
+24.9 \\
+13.8\end{array}$ & $\begin{array}{l}25.5 \\
25.5 \\
25.5 \\
25.5 \\
25.0 \\
25.0\end{array}$ & $\begin{array}{l}484.69 \\
484.61 \\
484.57 \\
484.50 \\
484.45 \\
484.39\end{array}$ & $\begin{array}{l}-16.5 \\
-22.0 \\
-11.0 \\
-19.2 \\
-13.7 \\
-16.5\end{array}$ & $\begin{array}{l}25.5 \\
25.5 \\
25.0 \\
25.0 \\
25.0 \\
25.0\end{array}$ \\
\hline & & & & & & & June & July & August \\
\hline \multicolumn{7}{|c|}{$\begin{array}{l}\text { Change in contents, in millions of yallons } \\
\text { Diversion, in millions of gallons }\end{array}$} & $\begin{array}{r}-5.7 \\
737.8\end{array}$ & $\begin{array}{r}+69.3 \\
803.3\end{array}$ & $\begin{array}{r}-231.6 \\
780.5\end{array}$ \\
\hline
\end{tabular}

BURIINGTON BROOK NEAR BURITNGTON, CONN.

Location.-Lat. $41^{\circ} 47^{\prime} 10^{\prime \prime}$, long. $72^{\circ} 57^{\prime} 55^{\prime \prime}$, $1 \frac{1}{4}$ miles north of Burlington, Hartford County, $2 \frac{1}{2}$ miles upstream from mouth, and 3 miles southwest of Collinsville.

Drainage area.- 4.1 square miles.

GAGE-HEIGHT RECORD.-Water-stage recorder graph.

STAGE-DischaRge RELATION.-Artificial control consists of a sharp-edged orifice

1 foot square and a sharp-crested rectangular weir 12 feet long with end contractions 5 feet high. Crest of weir is at gage height 1.02 feet and 1.02 feet above bottom edge of orifice. Rating curve which was developed from formula and coefficients checked by current-meter measurements below 49 second-feet. Discharge computed on basis of gage-height graph when record was affected by backwater from trash in orifice June 1-4, 2 p.m. July 17 to 3 p.m. Aug. 1, Aug. 29-31.

Maxima.-July 1938: Discharge, 357 second-feet 5:30 p.m. July 21 (gage height, 5.54 feet).

1931 to June 1938: Discharge, 503 second-feet Mar. 12, 1936 (gage height, 6.58 feet).

REMARKs.-Flood discharge not affected by artificial storage. 
Mean discharge, in second-feet, 1938

\begin{tabular}{r|c|c|c||c|c|c|c||c|c|c|c}
\hline Day & June & July & Aug. & Day & June & July & Aug. & Day & June & July & Aug. \\
\hline 1 & 3.29 & 2.95 & 6.50 & 11 & 8.74 & 9.01 & 39.3 & & & & \\
1 & & & 21 & 2.37 & 97 & \\
2 & 4.55 & 3.57 & 9.05 & 12 & 9.60 & 24.2 & 13.8 & 22 & 2.09 & 73 & 3.42 \\
3 & 4.78 & 3.11 & 6.05 & 13 & 13.4 & 10.1 & 7.41 & 23 & 1.97 & 46.0 & 2.97 \\
4 & 4.33 & 2.71 & 5.02 & 14 & 6.85 & 4.55 & 5.77 & 24 & 1.89 & 44.4 & 2.76 \\
5 & 4.13 & 2.33 & 4.78 & 15 & 4.78 & 4.55 & 5.02 & 25 & 1.85 & 22.0 & 2.22 \\
6 & 3.57 & 1.97 & 4.78 & 16 & 3.74 & 3.29 & 4.33 & 26 & 2.31 & 15.5 & 2.50 \\
7 & 3.29 & 1.85 & 5.02 & 17 & 3.42 & 2.86 & 4.13 & 27 & 15.2 & 12.1 & 2.46 \\
8 & 7.48 & 1.82 & 5.26 & 18 & 3.15 & 3.58 & 5.02 & 28 & 28.5 & 8.69 & 2.42 \\
9 & 5.52 & 1.70 & 8.32 & 19 & 2.89 & 7.80 & 5.77 & 29 & 13.1 & 8.68 & 2.95 \\
10 & 3.93 & 2.58 & 5.52 & 20 & 4.62 & 31.4 & 4.13 & 30 & 5.26 & 10.1 & 2.42 \\
&
\end{tabular}

Gage-height, in feet, and discharge, in second-feet, at indicated time, 1938

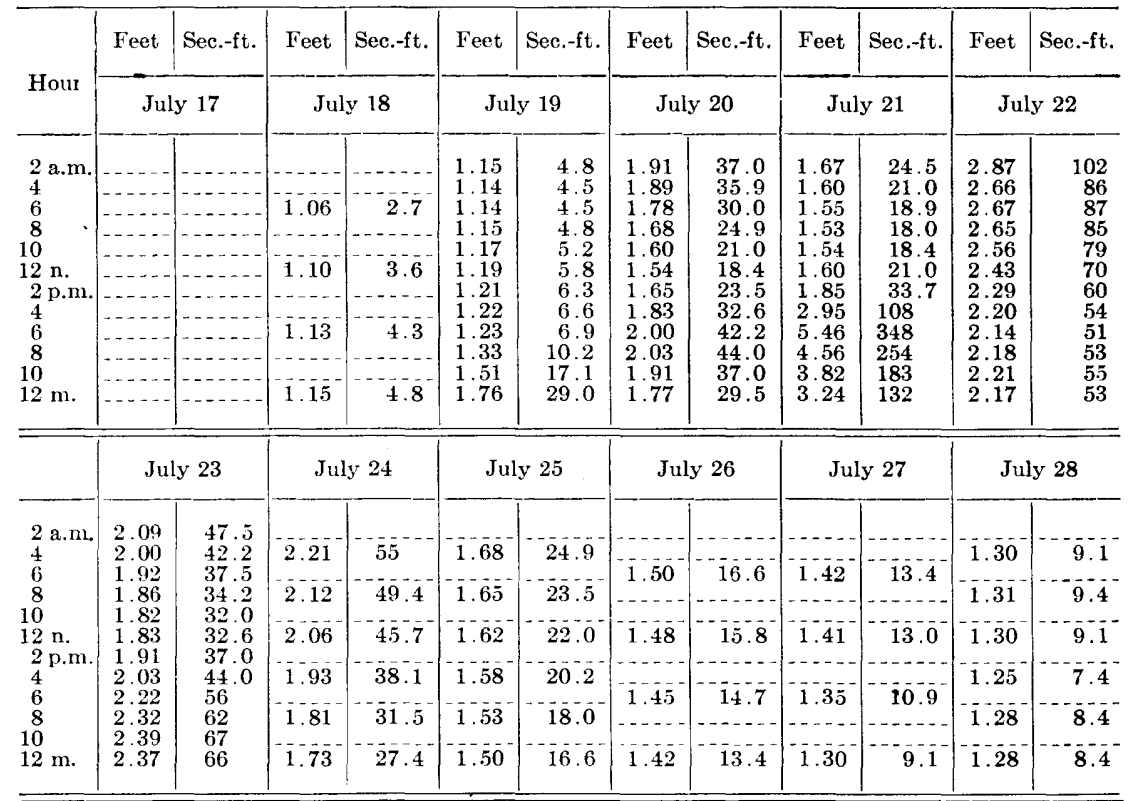

\begin{tabular}{|c|c|c|c|c|c|c|c|c|c|c|c|c|}
\hline & \multicolumn{2}{|c|}{ July 29} & \multicolumn{2}{|c|}{ July 30} & \multicolumn{2}{|c|}{ July 31} & \multicolumn{2}{|c|}{ August 1} & \multicolumn{2}{|c|}{ August 2} & \multicolumn{2}{|c|}{ August 3} \\
\hline \multirow{7}{*}{$\begin{array}{l}2 \mathrm{a} \cdot \mathrm{m} \\
4 \\
6 \\
8 \\
10 \\
12 \mathrm{n} . \\
2 \mathrm{p} . \mathrm{m} \\
4 \\
6 \\
8 \\
10 \\
12 \mathrm{~m} .\end{array}$} & 128 & & & & & & 101 & & & & & \\
\hline & 1.20 & 0.4 & 1.37 & 11.6 & 1.26 & $7 . \overline{8}$ & 1.21 & 0.0 & 1.52 & 11.0 & 1.18 & 6.57 \\
\hline & 1.28 & 8.4 & & & & & 1.21 & 6.3 & 1.30 & 10.3 & $\ldots$ & \\
\hline & 1.28 & $8 . \overline{4}$ & 1.34 & 10.5 & 1.25 & 7.4 & 1.22 & 6.6 & 1.28 & 9.60 & 1.17 & 6.30 \\
\hline & 1.28 & $8 . \overline{4}$ & & & & & 1.17 & 6.30 & 1.26 & $8 . \overline{9}$ & & \\
\hline & 1.29 & $8 . \overline{7}$ & 1.29 & 8.7 & 1.23 & 6.9 & 1.16 & 6.03 & 1.19 & 6.85 & 1.14 & 5.52 \\
\hline & 1.36 & 11.2 & 1.26 & 7.8 & 1.21 & 6.3 & 1.25 & 8.63 & 1.18 & 6.57 & 1.12 & 5.02 \\
\hline
\end{tabular}

Supplemental records.-July 20, 3 a.m., $1.92 \mathrm{ft}$., $37.5 \mathrm{sec} . \mathrm{ft}$.; July 21, 3 p.m., $2.02 \mathrm{ft} ., 43.4$ sec.-ft.; 3:30 p.m., 2.15 ft., 51.3 sec.-ft.; 5 p.m., 5.30 ft., 331 sec.-ft.; $5: 30$ p.m., 5.54 ft., 357 sec.-ft.; July 25 , 6 p.m., $1.61 \mathrm{ft} ., 21.5$ sec.-ft. 
SOUTH BRANCF OF PABK EIVER AT HARTFORD, CONN.

Location.-Lat. $41^{\circ} 44^{\prime} 02^{\prime \prime}$, long. $72^{\circ} 42^{\prime} 51^{\prime \prime}$, at Newfield Avenue bridge, Hartford, Hartford County, 0.7 mile downstream from Trout Brook, and 3.3 miles upstream from confluence with North Branch of Park River. Datum of gage is 31.07 feet above mean sea level (general adjustment of 1929). Drainage area.- -40.6 square miles.

GAGE-height RECORD.-Water-stage recorder graph.

Stage-discharge ReLATION.- Affected by rate of change of stage above gage height about 5 feet. Shift in low-water rating occurred 5 p.m. June 11; low-water curve used prior to that time well defined by current-meter measurements and low-water curve used after that time fairly well defined. Base rating for high stages defined by current-meter measurements (adjusted for changing stage) below 1,300 second-feet and extended to peak stage on basis of comparison with records for stations on North Branch of Park River and Park River. Above gage height about 5 feet, rather poorly defined rating curve developed for different rates of changing stage on basis of several measurements. Correction applied for backwater from unknown source Aug. 21-31.

Maxima.-July 1938: Discharge, 800 second-feet 2 to 4 a.m. July 24; gage height, 7.84 feet 4 to 6 a.m. July 24 .

1936 to June 1938: Discharge, 2,860 second-feet Jan. 25, 1938; gage height, 12.65 feet Jan. 25, 1938, 1 hour later than maximum discharge. Flood of Mar. 12, 1936, reached a stage of 12.1 feet as determined from floodmarks by city engineers of Hartford (discharge not determined).

REMARKs.-Flood discharge not appreciably affected by artificial storage.

Mean discharge, in second-feet, 1938

\begin{tabular}{|c|c|c|c|c|c|c|c|c|c|c|c|}
\hline Day & June & July & Ang. & Day: & June & July & Aug. & Day & June & July & Aug. \\
\hline $\begin{array}{r}1 \\
2 \\
3 \\
4 \\
5 \\
6 \\
7 \\
8 \\
9 \\
10\end{array}$ & $\begin{array}{l}32 \\
30 \\
44 \\
39 \\
41 \\
36 \\
33 \\
46 \\
35 \\
31\end{array}$ & $\begin{array}{l}47 \\
43 \\
44 \\
48 \\
48 \\
42 \\
30 \\
24 \\
23 \\
30\end{array}$ & $\begin{array}{l}60 \\
53 \\
48 \\
41 \\
36 \\
33 \\
33 \\
47 \\
85 \\
96\end{array}$ & $\begin{array}{l}11 \\
12 \\
13 \\
14 \\
15 \\
16 \\
17 \\
18 \\
19 \\
20\end{array}$ & $\begin{array}{r}47 \\
+9 \\
125 \\
50 \\
34 \\
35 \\
30 \\
26 \\
23 \\
21\end{array}$ & $\begin{array}{r}26 \\
38 \\
39 \\
37 \\
31 \\
27 \\
24 \\
108 \\
186 \\
222\end{array}$ & $\begin{array}{r}339 \\
208 \\
90 \\
63 \\
46 \\
40 \\
36 \\
35 \\
32 \\
28\end{array}$ & $\begin{array}{l}21 \\
22 \\
23 \\
24 \\
25 \\
26 \\
27 \\
28 \\
29 \\
30 \\
31\end{array}$ & $\begin{array}{r}21 \\
21 \\
20 \\
22 \\
24 \\
33 \\
140 \\
298 \\
140 \\
62\end{array}$ & $\begin{array}{r}312 \\
474 \\
505 \\
665 \\
347 \\
207 \\
131 \\
150 \\
114 \\
133 \\
69\end{array}$ & $\begin{array}{l}26 \\
29 \\
29 \\
28 \\
26 \\
25 \\
23 \\
22 \\
24 \\
24 \\
24\end{array}$ \\
\hline \multicolumn{9}{|c|}{$\begin{array}{l}\text { Monthly mean discharge, in second-fret } \ldots \\
\text { Runoff, in inches. }\end{array}$} & $\begin{array}{l}52.9 \\
1.45\end{array}$ & $\begin{array}{r}136 \\
3.86\end{array}$ & $\frac{\pi 5.8}{1.58}$ \\
\hline
\end{tabular}

Gage-height, in feet, and discharge, in second-feet, at indicated time, 1938

\begin{tabular}{|c|c|c|c|c|c|c|c|c|c|c|c|c|}
\hline \multirow{2}{*}{ Hour } & Feet & Sec.-ft. & Feet & Sec.ft. & Feet & Sec.-ft. & Feet & Sec.-ft. & Feet & Sec.-ft. & Feet & Sec.-ft. \\
\hline & \multicolumn{2}{|c|}{ July 17} & \multicolumn{2}{|c|}{ July 18} & \multicolumn{2}{|c|}{ July 19} & \multicolumn{2}{|c|}{ July 20} & \multicolumn{2}{|c|}{ July 21} & \multicolumn{2}{|c|}{ July 2:2 } \\
\hline 2 a.m. & & & 1.81 & 24 & 5.27 & 287 & 3.07 & 96 & 6.30 & $3: 20$ & & \\
\hline $4^{0}$ & 1.77 & 23 & 1.80 & 24 & 5.23 & 270 & 3.01 & 91 & 6.09 & 300 & 6.54 & 470 \\
\hline $\begin{array}{l}6 \\
8\end{array}$ & 100 & $\bar{a}=$ & 1.80 & 24 & 71 & 020 & 2.95 & 86 & 5.85 & 280 & & \\
\hline 10 & 1.82 & 25 & $\begin{array}{l}1.82 \\
1.87\end{array}$ & 27 & 4.81 & 220 & 3.04 & 93 & $\begin{array}{l}3.58 \\
5.27\end{array}$ & 年 & $\begin{array}{l}0.85 \\
6.95\end{array}$ & 520 \\
\hline $12 \mathrm{n}$. & 1.82 & 25 & 1.90 & 28 & 4.03 & 178 & 3.26 & 111 & 4.99 & 245 & 7.00 & 520 \\
\hline & 1.81 & 24 & 3.95 & 170 & 3.60 & 139 & 5.00 & 290 & 5.14 & 300 & 6.95 & 485 \\
\hline 6 & - & & 4.49 & 224 & 7 & 18 & & 510 & $\tilde{\tilde{o}} .61$ & 370 & 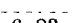 & - \\
\hline $\begin{array}{r}8 \\
10\end{array}$ & 1.80 & 24 & $\begin{array}{l}4.87 \\
5.13\end{array}$ & 260 & 3.27 & 112 & 6.64 & 505 & 5.95 & 400 & 6.83 & 40 \\
\hline $12 \mathrm{~m}$. & 1.82 & 25 & 5.21 & 290 & 3.13 & 100 & 6.48 & 345 & 6.23 & 410 & 6.67 & $400^{\circ}$ \\
\hline
\end{tabular}


Gage height in feet, and discharge, in second-feet, at indicated time, 1938-Continued

\begin{tabular}{|c|c|c|c|c|c|c|c|c|c|c|c|c|}
\hline \multirow{2}{*}{ Hour } & Feet & Sec.ft. & Feet & Sec.-ft. & Feet & Sec.-ft. & Feet & Sec.-ft. & Feet & Sec.ftt. & Feet & Sec.-ft. \\
\hline & \multicolumn{2}{|c|}{ July 23} & \multicolumn{2}{|c|}{ July 24} & \multicolumn{2}{|c|}{ July 25} & \multicolumn{2}{|c|}{ July 26} & \multicolumn{2}{|c|}{ July 27} & \multicolumn{2}{|c|}{ July 28} \\
\hline \multirow{8}{*}{$\begin{array}{l}2 \mathrm{a} . \mathrm{m} . \\
4 \\
6 \\
8 \\
10 \\
12 \mathrm{n} . \\
2 \mathrm{p.m} . \\
4 \\
6 \\
8 \\
10 \\
12 \mathrm{~m} .\end{array}$} & \multirow{8}{*}{$\begin{array}{l}6.56 \\
\text { i. } .45 \\
1.32 \\
6.17 \\
6.07 \\
6.23 \\
6.49 \\
6.83 \\
7.14 \\
7.38 \\
7.57 \\
7.70\end{array}$} & \multirow{8}{*}{$\begin{array}{l}385 \\
370 \\
355 \\
340 \\
357 \\
430 \\
505 \\
590 \\
670 \\
715 \\
750 \\
780\end{array}$} & \multirow{8}{*}{$\begin{array}{l}7.79 \\
7.84 \\
7.84 \\
7.82 \\
7.75 \\
7.67 \\
7.57 \\
7.45 \\
7.34 \\
7.23 \\
7.10 \\
6.97\end{array}$} & \multirow{8}{*}{$\begin{array}{l}800 \\
800 \\
790 \\
765 \\
725 \\
675 \\
635 \\
595 \\
560 \\
530 \\
490 \\
460\end{array}$} & \multirow[b]{2}{*}{6.71} & \multirow[b]{2}{*}{+10} & & \multirow[b]{2}{*}{240} & & \multirow[b]{2}{*}{139} & \multirow{2}{*}{$\begin{array}{l}3.81 \\
3.90\end{array}$} & \multirow{2}{*}{$\begin{array}{l}1,58 \\
16 t\end{array}$} \\
\hline & & & & & & & 4.89 & & & & & \\
\hline & & & & & 6.48 & 375 & 4.59 & & 3.50 & & 3.82 & 159 \\
\hline & & & & & 6.22 & 345 & 4.35 & 205 & 3.44 & 125 & $\begin{array}{l}3.82 \\
-.0 .0\end{array}$ & $\begin{array}{c}159 \\
\ldots\end{array}$ \\
\hline & & & & & & & & & & & 3.76 & 153 \\
\hline & & & & & 5. 93 & 310 & 4.17 & 190 & 3.42 & 124 & 3.72 & 150 \\
\hline & & & & & 5.62 & 280 & 3.97 & 172 & 3.35 & 118 & 3.57 & 136 \\
\hline & & & & & 5.25 & 260 & 3.78 & 155 & $\begin{array}{l}3.50 \\
3.58\end{array}$ & $\begin{array}{l}130 \\
137\end{array}$ & 3.40 & 122 \\
\hline & & & $J u l$ & 30 & $J u l$ & 31 & $\mathbf{A u}$ & just 1 & $A u_{1}$ & ust 2 & Aue & ust 3 \\
\hline 2 a.m. & & & 3.88 & & & & & & & & & \\
\hline & $\begin{array}{l}3 . \\
3 .\end{array}$ & & & & 2.77 & 64 & & & & & & \\
\hline 8 & & 10 & 3.74 & 152 & & & & & & & & \\
\hline 10 & & & & & & & & & & & & \\
\hline $\begin{array}{r}12 \mathrm{n} . \\
2 \mathrm{p.m} .\end{array}$ & & & 3.59 & 138 & 2.68 & 68 & & & & & & \\
\hline s.1n. & $\begin{array}{l}3.15 \\
3.14\end{array}$ & & $3.36^{-}$ & 119 & & & & & & & & \\
\hline $\begin{array}{l}6 \\
8\end{array}$ & 3.20 & 10 & & & 2.58 & 62 & & & & & & \\
\hline $\begin{array}{r}8 \\
10\end{array}$ & $\begin{array}{l}3.35 \\
3.70\end{array}$ & & 3.14 & 101 & & & & & & & & \\
\hline $12 \mathrm{~m}$. & & 162 & 2.97 & 88 & 2.50 & 57 & & & & & & \\
\hline
\end{tabular}

Supplemental records.--July 18, 3 p.m. 3.28 feet, 112 sec.-ft.; 5 p.m., 4.36 feet, 211 sec.-ft.; July 20 , 5 p.m., 5.70 feet, 420 sec.-ft.; 7 p.m., 6.51 fert, 530 sec.-ft.; 9 p.m., 6.66 feet, 442 sec.-ft.; July 29,5 p.m., 3.12 feet, 100 sec. - t.

PARK RIVIE AT FARTPOED, CONR.

Location,-Lat. $41^{\circ} 45^{\prime} 36^{\prime \prime}$, long. $72^{\circ} 41^{\prime} 42^{\prime \prime}$, at plate-girder footbridge on Riverside Street in Hartford, Hartford County, 1,300 feet downstream from confluence of North and South Branches of Park River, and 2.3 miles upstream from mouth. Datum of gage is 27.13 feet above mean sea level, (general adjustment of 1929).

Drainage area. - 74.0 square miles.

GAGE-HEIGHT RECORD.-Water-stage recorder graph.

StaGe-discharge RELATion.-Defined by current-meter measurements.

Maxima.-July 1938: Discharge, 1,320 second-feet 8 a.m. July 24 (gage height, 4.99 feet).

1936 to June 1938: Discharge, 5,650 second-feet Jan. 25, 1938 (gage height, 9.16 feet).

Flood of Mar. 12, 1936, reached a stage of 9.0 feet as determined from floodmarks by city engineers of Hartford (discharge, 5,400 second-feet). Backwater from Connecticut River on Mar. 21, 1936, caused a stage of 10.7 feet as determined from floodmarks.

Remarks.-Flood discharge probably not appreciably affected by artificial storage. 
Mean discharge, in second-feet, 1938

\begin{tabular}{|c|c|c|c|c|c|c|c|c|c|c|c|}
\hline Day & June & July & Aug. & Day & June & July & Aug. & Iay- & June & July & Aug. \\
\hline $\begin{array}{r}1 \\
2 \\
3 \\
4 \\
5 \\
6 \\
7 \\
8 \\
9 \\
10\end{array}$ & $\begin{array}{l}37 \\
35 \\
51 \\
46 \\
56 \\
46 \\
42 \\
59 \\
46 \\
35\end{array}$ & $\begin{array}{l}76 \\
61 \\
56 \\
51 \\
51 \\
46 \\
37 \\
35 \\
35 \\
42\end{array}$ & $\begin{array}{r}95 \\
86 \\
72 \\
59 \\
49 \\
46 \\
46 \\
65 \\
121 \\
134\end{array}$ & $\begin{array}{l}11 \\
12 \\
13 \\
14 \\
15 \\
16 \\
17 \\
18 \\
19 \\
20\end{array}$ & $\begin{array}{r}88 \\
176 \\
365 \\
150 \\
73 \\
51 \\
46 \\
40 \\
35 \\
31\end{array}$ & $\begin{array}{r}40 \\
150 \\
89 \\
54 \\
40 \\
33 \\
27 \\
132 \\
201 \\
393\end{array}$ & $\begin{array}{r}500 \\
406 \\
145 \\
93 \\
64 \\
59 \\
54 \\
49 \\
46 \\
40\end{array}$ & $\begin{array}{l}21 \\
22 \\
23 \\
24 \\
25 \\
26 \\
27 \\
28 \\
29 \\
30 \\
31\end{array}$ & $\begin{array}{r}29 \\
27 \\
27 \\
27 \\
25 \\
42 \\
193 \\
540 \\
291 \\
123\end{array}$ & $\begin{array}{r}626 \\
1,020 \\
825 \\
1,190 \\
566 \\
282 \\
190 \\
222 \\
183 \\
221 \\
130\end{array}$ & $\begin{array}{l}37 \\
37 \\
37 \\
35 \\
31 \\
33 \\
33 \\
31 \\
3.3 \\
33 \\
33\end{array}$ \\
\hline \multicolumn{9}{|c|}{$\begin{array}{l}\text { Monthly mean discharge, in second-feet } \\
\text { Runoff, in inches. }\end{array}$} & $\begin{array}{l}94.4 \\
1.43\end{array}$ & $\begin{array}{r}229 \\
3.56\end{array}$ & $\begin{array}{l}83.9 \\
1.30\end{array}$ \\
\hline
\end{tabular}

Gage-height, in feet, and discharge, in second-feet, at indicated time, 1938

\begin{tabular}{|c|c|c|c|c|c|c|c|c|c|c|c|c|}
\hline \multirow{2}{*}{ Hour } & Feet & Sec. $-\mathrm{ft}$. & Feet & Sec. $-\mathrm{ft}$. & Feet & Sec.-ft. & Feet & Sec.-ft. & Feet & Sec.-ft. & Feet & Sec. $-\mathrm{ft}$. \\
\hline & \multicolumn{2}{|c|}{ July 17} & \multicolumn{2}{|c|}{ July 18} & \multicolumn{2}{|c|}{ July 19} & \multicolumn{2}{|c|}{ July 20} & \multicolumn{2}{|c|}{ July 21} & \multicolumn{2}{|c|}{ July 22} \\
\hline $\begin{array}{l}2 \mathrm{a} . \mathrm{m} . \\
4 \\
6 \\
8 \\
10 \\
12 \mathrm{n} . \\
2 \mathrm{p} . \mathrm{m} . \\
4 \\
6 \\
8 \\
10 \\
12 \mathrm{~m} .\end{array}$ & \begin{tabular}{|c}
2.43 \\
$-\overline{3}$ \\
\hdashline$\overline{2} .43$ \\
\hdashline$\overline{2} . \overline{4}$ \\
\hdashline$\overline{2} . \overline{3}$
\end{tabular} & $\begin{array}{r}-\cdots \\
-\cdots \\
-\cdots \\
-\cdots \\
-\cdots \\
-\cdots \\
-\cdots\end{array}$ & $\begin{array}{l}2.43 \\
2.42 \\
2.42 \\
2.42 \\
2.47 \\
2.46 \\
3.03 \\
3.22 \\
3.16 \\
3.12 \\
3.11 \\
3.11\end{array}$ & $\begin{array}{r}27 \\
25 \\
25 \\
25 \\
35 \\
33 \\
214 \\
294 \\
268 \\
251 \\
246 \\
246\end{array}$ & $\begin{array}{l}3.12 \\
3.13 \\
3.13 \\
3.11 \\
3.06 \\
3.00 \\
2.94 \\
2.90 \\
2.87 \\
2.84 \\
2.82 \\
2.80\end{array}$ & $\begin{array}{l}251 \\
255 \\
255 \\
246 \\
226 \\
202 \\
179 \\
164 \\
154 \\
143 \\
146 \\
129\end{array}$ & $\begin{array}{l}2.79 \\
2.77 \\
2.76 \\
2.78 \\
2.78 \\
2.78 \\
3.63 \\
3.91 \\
4.18 \\
4.25 \\
4.22 \\
4.19\end{array}$ & $\begin{array}{l}126 \\
119 \\
116 \\
122 \\
122 \\
122 \\
485 \\
630 \\
783 \\
825 \\
807 \\
789\end{array}$ & $\begin{array}{l}4.14 \\
4.06 \\
3.95 \\
3.82 \\
3.69 \\
3.62 \\
3.54 \\
3.78 \\
3.85 \\
3.97 \\
4.10 \\
4.25\end{array}$ & $\begin{array}{l}759 \\
713 \\
652 \\
581 \\
515 \\
480 \\
440 \\
560 \\
598 \\
664 \\
735 \\
825\end{array}$ & $\begin{array}{l}4.52 \\
4.50 \\
4.63 \\
4.68 \\
4.70 \\
4.71 \\
4.69 \\
4.63 \\
4.54 \\
4.43 \\
4.33 \\
4.22\end{array}$ & $\begin{array}{r}998 \\
985 \\
1,070 \\
1,110 \\
1,120 \\
1,130 \\
1,110 \\
1,070 \\
1,010 \\
940 \\
874 \\
807\end{array}$ \\
\hline
\end{tabular}

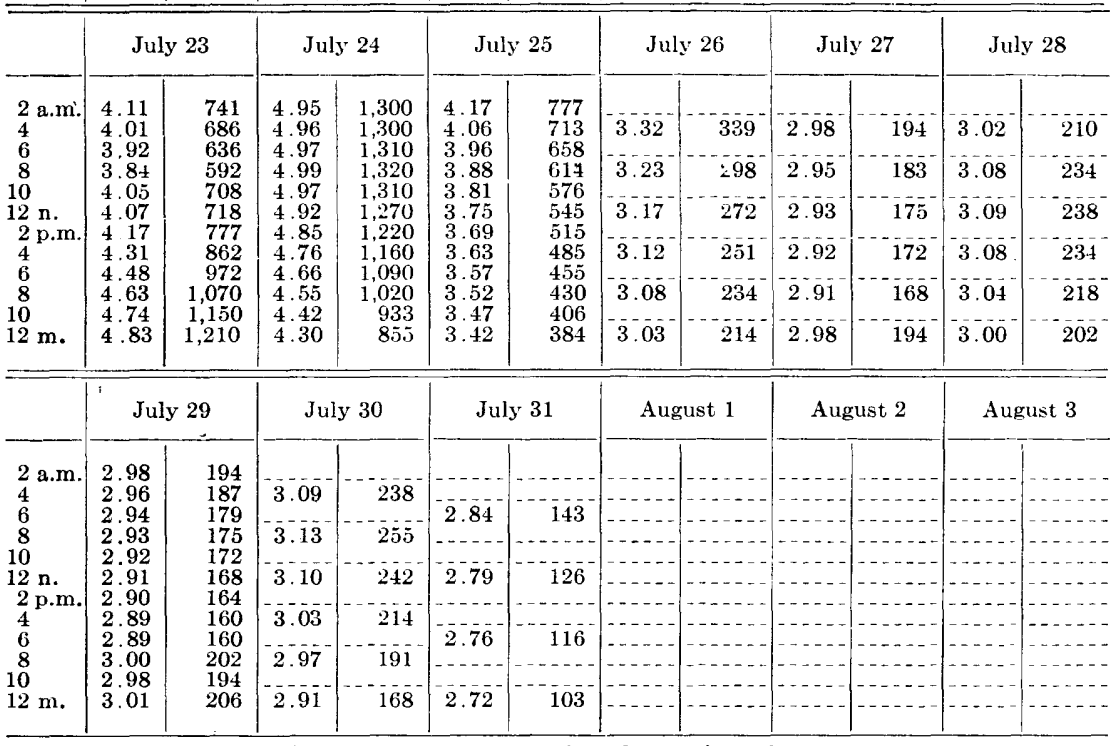

Supplemental records.-July $18,1: 30$ p.m., 2.45 feet, 31 sec.-ft.; 2:30 p.m., 3.42 feet, 384 sec.-ft.; July 21, 5 p.m., 3.85 feet, 598 sec.-ft.; July 22, 1 a.m., 4.38 ft., 907 sec.-ft.; July $23,8: 30$ a.m., 3.82 feet, 581 sec.-ft.; July 27,9 p.m., 3.15 feet, 264 sec.-ft.; July $29,6: 30$ p.m., 3.08 feet, 234 sec.-ft. 
NORTF BRANCF OF PARK RIVIR AT HARTFORD, CONN.

Location.-Lat. $41^{\circ} 47^{\prime} 03^{\prime \prime}$, long. 72 $42^{\prime} 31^{\prime \prime}, 60$ feet downstream from stone arch bridge on Albany Avenue, Hartford, Hartford County, and 3 miles upstream from confluence with South Branch of Park River. Datum of gage is 34.20 feet above mean sea level, (general adjustment of 1929).

Drainage AREA.-25.3 square miles.

GAGE-HEIGHT RECORD.-Water-stage recorder graph.

Stage-discharge relation.-Defined by current-meter measurements. Below gage-height 3.2 feet, affected slightly by backwater from trash on masonry control, 8 a.m. July 7 to $4: 30$ p.m. Aug. 1 .

Maxima.-July 1938: Discharge, 623 second-feet 3:30 p.m. July 20 (gage height, 5.52 feet).

1936 to June 1938: Discharge, 1,640 second-feet Jan. 25, 1938 (gage height, 11.81 feet).

Flood of Mar. 12, 1936, reached a stage of 11.2 feet as determined from floodmarks by city engineers of Hartford (discharge, probably 1,520 second-feet).

REMARKs.-Flood discharge probably not appreciably affected by artificial storage.

Mean discharge, in second-feet, 1938

\begin{tabular}{|c|c|c|c|c|c|c|c|c|c|c|c|}
\hline Day & June & $J_{\text {uly }}$ & Aug. & Day & June & July & Aug. & Day & June & July & Aug. \\
\hline $\begin{array}{r}1 \\
2 \\
3 \\
4 \\
5 \\
6 \\
7 \\
8 \\
9 \\
10\end{array}$ & $\begin{array}{c}9.6 \\
8.4 \\
9.9 \\
11 \\
16 \\
13 \\
9.3 \\
13 \\
12 \\
7.8\end{array}$ & $\begin{array}{l}21 \\
16 \\
12 \\
9.3 \\
8.4 \\
7.1 \\
6.2 \\
6.0 \\
5.6 \\
6.0\end{array}$ & $\begin{array}{l}31 \\
33 \\
24 \\
18 \\
16 \\
14 \\
16 \\
16 \\
20 \\
27\end{array}$ & $\begin{array}{l}11 \\
12 \\
13 \\
14 \\
15 \\
16 \\
17 \\
18 \\
19 \\
20\end{array}$ & $\begin{array}{c}56 \\
102 \\
248 \\
68 \\
28 \\
16 \\
13 \\
12 \\
9.6 \\
7.5\end{array}$ & $\begin{array}{c}13 \\
131 \\
46 \\
21 \\
14 \\
11 \\
8.4 \\
15 \\
18 \\
263\end{array}$ & $\begin{array}{r}190 \\
94 \\
35 \\
20 \\
16 \\
13 \\
12 \\
12 \\
12 \\
9.9\end{array}$ & $\begin{array}{l}21 \\
22 \\
23 \\
24 \\
25 \\
26 \\
27 \\
28 \\
29 \\
30 \\
31\end{array}$ & $\begin{array}{c}6.4 \\
5.1 \\
5.4 \\
5.4 \\
5.0 \\
5.6 \\
78 \\
262 \\
128 \\
41\end{array}$ & $\begin{array}{r}340 \\
504 \\
336 \\
396 \\
137 \\
68 \\
47 \\
80 \\
62 \\
86 \\
44\end{array}$ & $\begin{array}{l}8.7 \\
7.8 \\
7.3 \\
6.4 \\
5.3 \\
5.2 \\
5.1 \\
5.1 \\
5.1 \\
4.7 \\
4.6\end{array}$ \\
\hline \multicolumn{9}{|c|}{$\begin{array}{l}\text { Monthly mean discharge, in second-feet, } \\
\text { Runoff, in inches }\end{array}$} & $\begin{array}{l}40.4 \\
1.78\end{array}$ & $\begin{array}{l}88.3 \\
4.02\end{array}$ & $\begin{array}{l}22: 4 \\
1.02\end{array}$ \\
\hline
\end{tabular}

Gage-height, in feet, and discharge, in second-feet, at indicated time, 1938

\begin{tabular}{|c|c|c|c|c|c|c|c|c|c|c|c|c|}
\hline & Feet & Sec.-ft. & Feet & Sec.-ft. & Feet & Sec.-ft. & Feet & Sec.-ft. & Feet & Sec.-ft. & Feet & Sec.-ft. \\
\hline & \multicolumn{2}{|c|}{ July 17} & \multicolumn{2}{|c|}{ July 18} & \multicolumn{2}{|c|}{ July 19} & \multicolumn{2}{|c|}{ July 20} & \multicolumn{2}{|c|}{ July 21} & \multicolumn{2}{|c|}{ July 22} \\
\hline $2 \mathrm{a} . \mathrm{m}$ & & & 1.58 & 7.8 & & & 1.90 & 22 & 3.55 & 368 & 5.10 & 565 \\
\hline & & & 1.58 & 7.8 & & & 1.91 & 23 & 3.30 & 300 & 5.30 & 595 \\
\hline 6 & & & 1.58 & 7.8 & 1.83 & 18 & 1.94 & 24 & 3.10 & 243 & 5.45 & 615 \\
\hline 8 & & & 1.58 & 7.8 & & & 1.98 & 27 & 2.99 & 213 & 5.39 & 608 \\
\hline 10 & 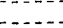 & & 1.58 & 7.8 & & & 2.01 & 29 & 2.91 & 190 & 5.21 & 582 \\
\hline $12 \mathrm{n}$. & & & 1.59 & 8.1 & 1.83 & 18 & 2.03 & 31 & 2.91 & 190 & 4.92 & 547 \\
\hline $2 \mathrm{p.m}$. & 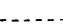 & & 2.34 & 62 & $\ldots$ & $\ldots$ & 5.05 & 560 & 3.05 & 230 & 4.58 & 508 \\
\hline & & & 1.98 & 27 & & & 5.50 & 620 & 3.61 & 382 & 4.22 & 467 \\
\hline 6 & & & 1.87 & 20 & 1.82 & 17 & 5.0 & 56 & 4.04 & 449 & & 428 \\
\hline 8 & & & 1.80 & 16 & & & 4.48 & 498 & 4.46 & 496 & 3.62 & 384 \\
\hline 10 & & & & 16 & & & 4.0 & 44 & 4.78 & 53 & 3.40 & 380 \\
\hline $12 \mathrm{~m}$. & & & 1.7 & 16 & 1.88 & 21 & 3.77 & 410 & 4.98 & 553 & 3.25 & 286 \\
\hline
\end{tabular}


Gage height in feet, and discharge, in second-feet, at indicated time, 1938--Continued

\begin{tabular}{|c|c|c|c|c|c|c|c|c|c|c|c|c|}
\hline \multirow{2}{*}{ Hour } & Feet & Sec.-ft. & Feet & Sec.-ft. & Feet & Sec.-ft. & Feet & Sec.-ft. & Feet & Sec.-ft. & Feet & Sec.-ft. \\
\hline & \multicolumn{2}{|c|}{ July 23} & \multicolumn{2}{|c|}{ July 24} & \multicolumn{2}{|c|}{ July 25} & \multicolumn{2}{|c|}{ July 26} & \multicolumn{2}{|c|}{ July 27} & \multicolumn{2}{|c|}{ July 28} \\
\hline 2 a.m. & 3.13 & 249 & 4.19 & 464 & & & & & & & & \\
\hline & 3.06 & 230 & 4.21 & +66 & 2.85 & 172 & & & 2.23 & 48 & 2.43 & 78 \\
\hline 6 & 3.00 & 213 & 4.25 & 470 & & & 2.41 & 75 & & & & \\
\hline $\begin{array}{r}8 \\
10\end{array}$ & $\begin{array}{l}2.93 \\
3.20\end{array}$ & 19.5 & $\begin{array}{l}4.23 \\
4.12\end{array}$ & $\begin{array}{l}468 \\
+57\end{array}$ & 2.76 & 150 & & & 2.21 & $4 i$ & 2.50 & 91 \\
\hline $12 \mathrm{n}$. & $\begin{array}{l}0.20 \\
3.37\end{array}$ & 321 & 3.97 & 440 & 2.68 & 131 & 2.37 & 67 & 2.20 & 45 & 2.50 & 91 \\
\hline 2 p.m. & 3.65 & 390 & 3.80 & 415 & & & & & & & & \\
\hline & 3.87 & +26 & 3.61 & 382 & 2.62 & 116 & 930 & 50 & 2.18 & 43 & 2.45 & 82 \\
\hline & $\begin{array}{r}3.98 \\
4.10\end{array}$ & $\begin{array}{l}442 \\
455\end{array}$ & $\begin{array}{l}3.41 \\
3.24\end{array}$ & $\begin{array}{l}3.32 \\
283\end{array}$ & 2.56 & 103 & 2.32 & 59 & 2.17 & 42 & 2.41 & 75 \\
\hline 10 & 4.19 & 464 & 3.10 & 243 & & & & & & & & \\
\hline $12 \mathrm{~m}$. & 420 & 465 & 2.99 & 211 & 2.49 & 89 & 2.27 & 53 & 2.31 & 58 & 2.38 & 68 \\
\hline
\end{tabular}

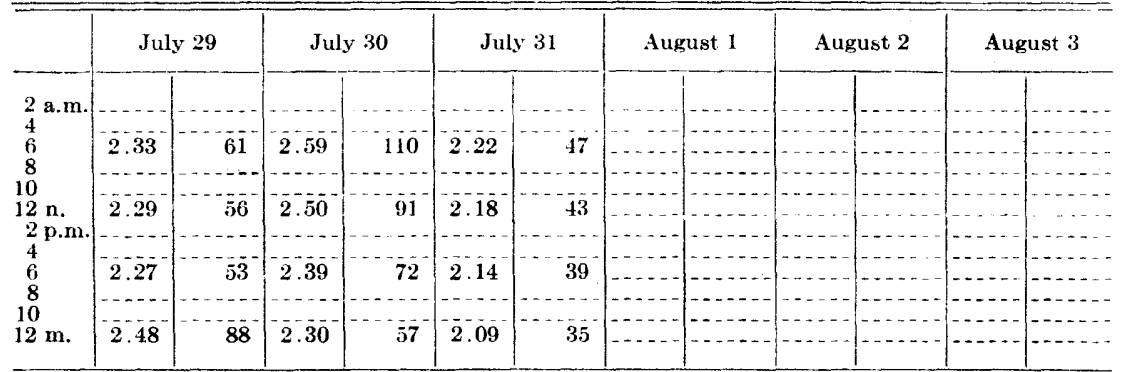

Supplemental records.-July 18, 1 p.m., 1.59 feet, 8.4 sec.-ft.; 3 p.m., 1.98 feet, 27 sec.-ft. July 20 1 p.m., 4.11 feet. 456 sec.ft.; 3 p.m., 5.49 feet, 619 sec.-ft., $3: 30$ p.m., 5.52 ft., 623 see.ft. (published to limits as 620 see.-ft. in W.S. P. 851 ).

\section{HOCKANUM RIVRE AT OUTIET OF STENTPSIT IAKE, AT ROCKVIIIE, CONN.}

Location.-Lat. $41^{\circ} 52^{\prime} 06^{\prime \prime}$, long. $72^{\circ} 25^{\prime} 56^{\prime \prime}$, three-quarters of a mile east of Rockville, Tolland County.

Drainage AREA.-16.5 square miles.

GAGE-HEICHT RECORD.-One reservoir gage reading daily in morning except Sundays. Gage height at midnight determined from graph of gage readings.

STAGE-Discharge RELATION.-Observed discharge computed from flow over spillway and through pumps, venturi meter, wheel, and gate.

ReMarks.-Daily and monthly mean discharges adjusted for change in contents of Shenipsit Lake. No corrections made for evaporation from lake surface. Basic data furnished by Rockville Water \& Aqueduct Co.

Discharge, in second-feet, and change in contents, in equivalent second-feet, 1938

\begin{tabular}{|c|c|c|c|c|c|c|c|c|c|}
\hline \multirow[b]{2}{*}{ Day } & \multicolumn{3}{|c|}{ June } & \multicolumn{3}{|c|}{ July } & \multicolumn{3}{|c|}{ August } \\
\hline & Observed & $\begin{array}{c}\text { Change } \\
\text { in } \\
\text { Contents }\end{array}$ & Adjusted & Observed & $\begin{array}{c}\text { Change } \\
\text { in } \\
\text { Contents }\end{array}$ & Adjusted & Observed & $\begin{array}{c}\text { Change } \\
\text { in } \\
\text { Contents }\end{array}$ & Adjusted \\
\hline $\begin{array}{l}1 \\
2 \\
3 \\
4 \\
5\end{array}$ & $\begin{array}{r}33 \\
31 \\
34 \\
10 \\
9\end{array}$ & $\begin{array}{r}-13 \\
-9 \\
-9 \\
+13 \\
+13\end{array}$ & $\begin{array}{l}20 \\
22 \\
25 \\
23 \\
22\end{array}$ & $\begin{array}{l}42 \\
22 \\
11 \\
20 \\
36\end{array}$ & $\begin{array}{r}-22 \\
-3 \\
+3 \\
-9 \\
-28\end{array}$ & $\begin{array}{r}20 \\
19 \\
14 \\
11 \\
8\end{array}$ & $\begin{array}{l}33 \\
33 \\
33 \\
33 \\
44\end{array}$ & $\begin{array}{l}-22 \\
-22 \\
-22 \\
-22 \\
-35\end{array}$ & $\begin{array}{l}11 \\
11 \\
11 \\
11 \\
9\end{array}$ \\
\hline
\end{tabular}


Discharge, in second-feet, and change in contents in equivalent second-feet, 1938 -Continued

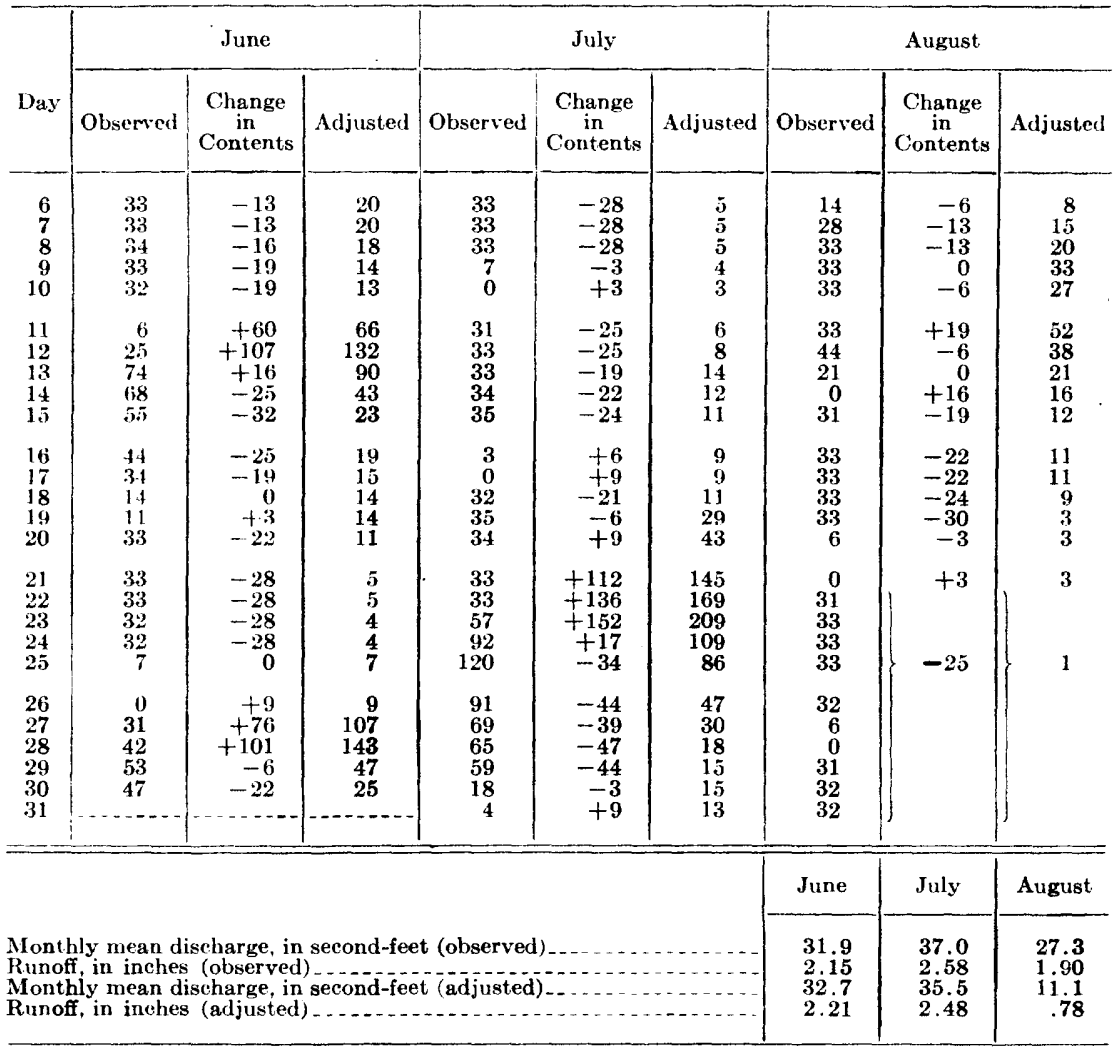

HOCKANUM RIVIR NEAR FAST FARTFORD, CONN.

Location,-Lat. $41^{\circ} 46^{\prime} 57^{\prime \prime}$, long. $72^{\circ} 35^{\prime} 20^{\prime \prime}$, at Case \& Marshall paper mill, $1 \frac{1}{2}$ miles downstream from South Branch of Hockanum River, and 23/4 miles east of East Hartford, Hartford County. Datum of gage is $\mathbf{5 4 . 5}$ feet above mean sea level, (general adjustment of 1929 , levels by Department of Engineering, City of Hartford).

DRAINAGE AREA.- 74.5 square miles.

GAGE-HEIGHT RECORD.-Water-stage recorder graph.

StaGe-discharge relation.-Defined by current-meter measurements.

Maxima.-July 1938: Discharge, 781 second-feet 1 to 2 a.m. July 24 (gage height, 5.39 feet).

1919-21, 1928 to June 1938: Discharge, 2,140 second-feet Jan. 25, 1938 gage height, 8.79 feet).

Remarks.-Flow affected by storage in Shenipsit Lake (see record for Hockanum River at outlet of Shenipsit Lake, at Rockville, Conn.). 
Mean discharge, in second-feet, 1938

\begin{tabular}{|c|c|c|c|c|c|c|c|c|c|c|c|}
\hline Day & June & July & Aug. & Day & June & July & Aug. & Day & June & July & Aug. \\
\hline $\begin{array}{r}1 \\
2 \\
3 \\
4 \\
5 \\
6 \\
7 \\
8 \\
9 \\
10\end{array}$ & $\begin{array}{r}127 \\
121 \\
142 \\
123 \\
51 \\
83 \\
112 \\
149 \\
128 \\
91\end{array}$ & $\begin{array}{r}173 \\
101 \\
43 \\
73 \\
151 \\
144 \\
81 \\
82 \\
58 \\
33\end{array}$ & $\begin{array}{r}219 \\
158 \\
132 \\
130 \\
125 \\
99 \\
48 \\
148 \\
177 \\
148\end{array}$ & $\begin{array}{l}11 \\
12 \\
13 \\
14 \\
15 \\
16 \\
17 \\
18 \\
19 \\
20\end{array}$ & $\begin{array}{r}61 \\
55 \\
193 \\
208 \\
188 \\
168 \\
188 \\
106 \\
41 \\
75\end{array}$ & $\begin{array}{r}100 \\
75 \\
99 \\
130 \\
143 \\
77 \\
20 \\
103 \\
168 \\
173\end{array}$ & $\begin{array}{r}208 \\
211 \\
109 \\
59 \\
139 \\
119 \\
114 \\
124 \\
133 \\
83\end{array}$ & $\begin{array}{l}21 \\
22 \\
23 \\
24 \\
25 \\
26 \\
27 \\
28 \\
29 \\
30 \\
31\end{array}$ & $\begin{array}{r}104 \\
93 \\
89 \\
108 \\
89 \\
46 \\
112 \\
264 \\
252 \\
222\end{array}$ & $\begin{array}{l}291 \\
457 \\
510 \\
674 \\
541 \\
425 \\
368 \\
307 \\
271 \\
181 \\
155\end{array}$ & $\begin{array}{l}44 \\
79 \\
83 \\
82 \\
62 \\
97 \\
65 \\
41 \\
58 \\
60 \\
72\end{array}$ \\
\hline \multicolumn{9}{|c|}{$\begin{array}{l}\text { Monthly mean discharge, in second-feet } \\
\text { Runoff, in inches }\end{array}$} & $\begin{array}{r}126 \\
1.89\end{array}$ & $\begin{array}{r}200 \\
3.09\end{array}$ & $\begin{array}{r}111 \\
1.72\end{array}$ \\
\hline
\end{tabular}

Gage-height, in feet, and discharge, in second-feet, at indicated time, 1938

\begin{tabular}{|c|c|c|c|c|c|c|c|c|c|c|c|c|}
\hline \multirow[b]{2}{*}{ Hour } & Feet & Sec.-ft. & Feet & Sec.-ft. & Feet & Sec. $-\mathrm{ft}$. & Feet & Sec.-ft. & Feet & Sec.-ft. & Feet & Sec.-ft. \\
\hline & \multicolumn{2}{|c|}{ July 17} & \multicolumn{2}{|c|}{ July 18} & \multicolumn{2}{|c|}{ July 19} & \multicolumn{2}{|c|}{ July 20} & \multicolumn{2}{|c|}{ July 21} & \multicolumn{2}{|c|}{ July 22} \\
\hline $\begin{array}{l}2 \text { a.m. } \\
4 \\
6 \\
8 \\
10 \\
12 \mathrm{n} . \\
2 \mathrm{p} . \mathrm{m} . \\
4 \\
6 \\
8 \\
10 \\
12 \mathrm{~m} .\end{array}$ & $\begin{array}{r}1.45 \\
1.45 \\
1.01 \\
.94 \\
.90 \\
.88 \\
.86 \\
.85 \\
.84 \\
.85 \\
.86 \\
.89\end{array}$ & $\begin{array}{r}52 \\
52 \\
18 \\
13 \\
11 \\
10 \\
9 \\
8 \\
8 \\
8 \\
9 \\
11\end{array}$ & $\begin{array}{r}0.91 \\
.93 \\
.95 \\
1.78 \\
1.77 \\
1.82 \\
1.94 \\
2.45 \\
2.67 \\
2.68 \\
2.60 \\
2.46\end{array}$ & $\begin{array}{r}12 \\
13 \\
14 \\
83 \\
82 \\
87 \\
101 \\
166 \\
198 \\
200 \\
188 \\
167\end{array}$ & $\begin{array}{l}2.35 \\
2.20 \\
2.08 \\
1.99 \\
2.15 \\
2.52 \\
2.86 \\
3.04 \\
2.93 \\
2.59 \\
2.32 \\
2.14\end{array}$ & $\begin{array}{l}152 \\
132 \\
118 \\
107 \\
126 \\
176 \\
228 \\
256 \\
239 \\
186 \\
148 \\
125\end{array}$ & $\begin{array}{l}2.01 \\
1.88 \\
1.86 \\
1.81 \\
1.92 \\
2.34 \\
2.76 \\
3.14 \\
3.15 \\
3.12 \\
3.00 \\
2.73\end{array}$ & $\begin{array}{r}109 \\
94 \\
92 \\
86 \\
98 \\
151 \\
212 \\
273 \\
275 \\
270 \\
250 \\
208\end{array}$ & $\begin{array}{l}2.50 \\
2.53 \\
2.62 \\
2.72 \\
3.00 \\
3.27 \\
3.42 \\
3.60 \\
3.73 \\
3.81 \\
3.86 \\
3.87\end{array}$ & $\begin{array}{l}173 \\
178 \\
191 \\
206 \\
250 \\
297 \\
324 \\
360 \\
386 \\
402 \\
412 \\
414\end{array}$ & $\begin{array}{l}3.66 \\
3.44 \\
3.69 \\
3.80 \\
4.13 \\
4.34 \\
4.46 \\
4.48 \\
4.32 \\
4.25 \\
4.17 \\
4.09\end{array}$ & $\begin{array}{l}372 \\
328 \\
378 \\
400 \\
469 \\
518 \\
546 \\
551 \\
513 \\
496 \\
477 \\
460\end{array}$ \\
\hline
\end{tabular}

\begin{tabular}{|c|c|c|c|c|c|c|c|c|c|c|c|c|}
\hline \multirow[b]{2}{*}{2 a.m. } & \multicolumn{2}{|c|}{ July 23} & \multicolumn{2}{|c|}{ July 24} & \multicolumn{2}{|c|}{ July 25} & \multicolumn{2}{|c|}{ July 26} & \multicolumn{2}{|c|}{ July 27} & \multicolumn{2}{|c|}{ July 28} \\
\hline & 3.90 & 420 & 5.39 & 781 & 4.61 & 582 & 4.00 & 140 & 3.61 & 362 & 3.49 & 338 \\
\hline & 3.73 & 386 & 5.31 & 761 & 4.56 & 570 & 3.89 & 418 & 3.46 & 332 & 3.36 & 313 \\
\hline 6 & 3.66 & 372 & 5.20 & 732 & 4.49 & 554 & 3.86 & +12 & 3.42 & 324 & 3.20 & 284 \\
\hline 8 & 3.62 & 364 & 5.09 & 703 & 4.47 & 549 & 4.11 & 464 & 3.70 & 380 & 3.09 & 264 \\
\hline 10 & 3. 62 & 364 & 4.99 & 677 & 4.55 & 568 & 4.10 & 462 & 3.73 & 386 & 3.11 & 268 \\
\hline $12 \mathrm{n}$. & 3.93 & 426 & 4.90 & 654 & 4.60 & 580 & 4.11 & 464 & 3.79 & 398 & 3.18 & 280 \\
\hline 2 p.m. & 4.27 & 501 & 4.84 & 638 & 4.55 & 568 & 4.06 & 453 & 3.76 & 392 & 3.27 & 297 \\
\hline & 4. 61 & 582 & 4.79 & 626 & 4.44 & 542 & 3.86 & 412 & 3.72 & 384 & 3.37 & 315 \\
\hline 6 & 4.84 & 638 & 4.76 & 618 & 4.26 & 498 & 3.73 & 386 & 3.67 & 374 & 3.42 & 324 \\
\hline 8 & 5.08 & 701 & 4.72 & 609 & 4.18 & 480 & 3,71 & 382 & 3.60 & 360 & 3.43 & 326 \\
\hline 10 & 5.27 & 750 & 4.69 & 602 & 4.14 & 471 & 3.71 & 382 & 3.59 & 358 & 3.45 & 330 \\
\hline $12 \mathrm{~m}$. & 5.37 & 776 & 4.65 & 592 & 4.10 & 462 & 3.70 & 380 & 3.57 & 354 & 3.45 & 330 \\
\hline
\end{tabular}

\begin{tabular}{|c|c|c|c|c|c|c|c|c|c|c|c|c|}
\hline & \multicolumn{2}{|c|}{ July 29} & \multicolumn{2}{|c|}{ July 30} & \multicolumn{2}{|c|}{ July 31} & \multicolumn{2}{|c|}{ August 1} & \multicolumn{2}{|c|}{ August 2} & \multicolumn{2}{|c|}{ August 3} \\
\hline & 3.37 & 315 & 3.23 & 289 & 2.21 & 133 & 2.37 & 155 & 2.57 & 184 & 2.10 & 120 \\
\hline & 3.23 & 289 & 3.07 & 261 & 2.27 & 141 & 2.36 & 153 & 2.41 & 160 & 2.01 & 109 \\
\hline & 3.11 & 268 & 2.95 & 242 & 2.33 & 149 & 2.35 & 152 & 2.27 & 141 & 1.93 & 100 \\
\hline 8 & 3.01 & 252 & 2.68 & 200 & 2.36 & 153 & 2.66 & 197 & 2.15 & 126 & 1.87 & 93 \\
\hline 10 & 3.00 & 250 & 2.61 & 190 & 2.39 & 158 & 2.77 & 214 & 2.15 & 126 & 1.90 & 96 \\
\hline $12 \mathrm{n}$. & 3.01 & 252 & 2.51 & 174 & 2.43 & 163 & 2.95 & 242 & 2.26 & 140 & 2.04 & 113 \\
\hline 2 p.m. & 3.02 & 253 & 2.39 & 158 & 2.45 & 166 & 3.06 & 260 & 2.37 & $15 \tilde{5}$ & 2.19 & 131 \\
\hline & 3.00 & 250 & 2.07 & 116 & 2.45 & 166 & 3.14 & 273 & 2.54 & 179 & 2.37 & 155 \\
\hline & 2.98 & 247 & 2.03 & 112 & 2.44 & 165 & 3.16 & 277 & 2.61 & 190 & 2.59 & 186 \\
\hline 8 & 3.08 & 263 & 2.03 & 112 & 2.43 & 163 & 3.10 & 266 & 2.48 & 170 & 2.54 & 179 \\
\hline & 3.22 & 288 & 2.08 & 118 & 2.41 & 160 & 2.87 & 229 & 2.35 & 152 & 2.41 & 160 \\
\hline $12 \mathrm{~m}$. & 3.34 & 309 & 2. 15 & 126 & 2.39 & 158 & 2.73 & 208 & 2.22 & 135 & 2.27 & 141 \\
\hline
\end{tabular}

Supplemental records.-July 17, $5: 30$ a.m., 1.45 ft., 52 sec.-ft.; July 20,9 a.m., 1.80 ft., 85 sec.-ft.; 5 p.m., 3.20 ft., 284 sec.-ft.; July 30, 2:20 p.m., 2.13 ft., 124 sec.ft.; Aug. 1, $6: 20$ a.m., 2.75 ft., 210 sec.-ft. 
SAIMON RIVIR NGAR FAST GAMPTON, CONN.

Location.-Lat. $41^{\circ} 33^{\prime} 14^{\prime \prime}$, long. $72^{\circ} 27^{\prime} 00^{\prime \prime}$, at Comstock Bridge, on HartfordMiddlesex County line, 0.7 mile downstream from Dickinson Creek, 31/2 miles southeast of East Hampton, Middlesex County.

Drainage area. - 105 square miles.

GAGE-HEIGH T RECORD.-Water-stage recorder graph except for periods when records were destroyed by mice, June 24 to July 4, July 15 to 11 a.m. Aug. 2, and Aug. 12; graph computed on basis of fragmentary records, hourly records of operation of Connecticut Light and Power Co. plant 4 miles below station, records for East Branch of Eightmile River near North Lyme, floodmark, and shape of previous peaks.

Stage-discharge relation.-Defined by current meter measurements below 500 second-feet; extended to peak stage on basis of shape of previous and subsequent rating curves.

Maxima.-July 1938: Discharge, 6,300 second-feet 8 p.m. July 23 (gage height, 6.5 feet, from floodmark).

1905-6, 1928 to June 1938: Discharge, 6,250 second-feet Mar. 12, 1936 (gage height, 6.98 feet, ice jam).

Remarks.-Flood discharge not materially affected by storage.

Mean discharge, in second-feet, 1938

\begin{tabular}{|c|c|c|c|c|c|c|c|c|c|c|c|}
\hline Day & June & $\mathbf{J}$ ully & Aug. & Day & June & July & Aug. & Day & June & July & Aug. \\
\hline $\begin{array}{r}1 \\
2 \\
3 \\
4 \\
5 \\
6 \\
7 \\
8 \\
9 \\
10\end{array}$ & $\begin{array}{r}145 \\
123 \\
120 \\
123 \\
159 \\
133 \\
108 \\
103 \\
95 \\
80\end{array}$ & $\begin{array}{r}240 \\
200 \\
170 \\
130 \\
101 \\
82 \\
71 \\
64 \\
57 \\
67\end{array}$ & $\begin{array}{l}217 \\
189 \\
161 \\
142 \\
131 \\
131 \\
136 \\
494 \\
716 \\
390\end{array}$ & $\begin{array}{l}11 \\
12 \\
13 \\
14 \\
15 \\
16 \\
17 \\
18 \\
19 \\
20\end{array}$ & $\begin{array}{r}109 \\
178 \\
278 \\
191 \\
123 \\
97 \\
86 \\
80 \\
73 \\
62\end{array}$ & $\begin{array}{r}60 \\
67 \\
64 \\
57 \\
100 \\
135 \\
111 \\
126 \\
252 \\
642\end{array}$ & $\begin{array}{l}903 \\
550 \\
320 \\
230 \\
188 \\
180 \\
371 \\
282 \\
208 \\
165\end{array}$ & $\begin{array}{l}21 \\
22 \\
23 \\
24 \\
25 \\
26 \\
27 \\
28 \\
29 \\
30 \\
31\end{array}$ & $\begin{array}{r}54 \\
49 \\
49 \\
48 \\
48 \\
50 \\
390 \\
1,200 \\
950 \\
380\end{array}$ & $\begin{array}{r}873 \\
933 \\
3,120 \\
2,660 \\
746 \\
502 \\
401 \\
348 \\
310 \\
279 \\
245\end{array}$ & $\begin{array}{r}142 \\
128 \\
113 \\
103 \\
93 \\
86 \\
86 \\
80 \\
75 \\
69 \\
67\end{array}$ \\
\hline \multicolumn{9}{|c|}{$\begin{array}{l}\text { Monthly mean discharge, in second-feet } \\
\text { Runoff, in inches }\end{array}$} & $\begin{array}{r}189 \\
2.01\end{array}$ & $\begin{array}{r}426 \\
4.68\end{array}$ & $\begin{array}{r}231 \\
2.54\end{array}$ \\
\hline
\end{tabular}

Gage-height, in feet, and discharge, in second-feet, at indicated time, 1938

\begin{tabular}{|c|c|c|c|c|c|c|c|c|c|c|c|c|}
\hline & Feet & Sec.-ft. & Feet & Sec.-ft. & Feet & Sec.-ft. & Feet & Sec.-ft. & Feet & Sec.-ft. & Feet & Sec.-ft. \\
\hline Hour & \multicolumn{2}{|c|}{ July 17} & \multicolumn{2}{|c|}{ July 18} & \multicolumn{2}{|c|}{ July 19} & \multicolumn{2}{|c|}{ July 20} & \multicolumn{2}{|c|}{ July 21} & \multicolumn{2}{|c|}{ July 22} \\
\hline $\begin{array}{l}2 \\
4\end{array}$ & 1.07 & 120 & 0.98 & 98 & 1.25 & 170 & 1.43 & 230 & 2.30 & 660 & $280^{\circ}$ & 1.050 \\
\hline $\begin{array}{l}0 \\
8\end{array}$ & 1.06 & 115 & 97 & 96 & 1.67 & 330 & 1.85 & 420 & 2.23 & 620 & 2.80 & 1,050 \\
\hline $12 \mathrm{n}$. & 1.04 & 110 & 1.00 & 100 & 1.58 & 290 & 2.75 & 1,000 & 2.19 & 600 & 2.72 & 980 \\
\hline & 1.02 & 105 & 1.19 & 150 & 1.54 & 270 & 2.65 & 920 & 3.00 & 1,200 & 2.57 & 860 \\
\hline 8 & 1.01 & 105 & 1.29 & 180 & 1. 49 & 250 & 2.50 & 800 & 3.05 & 1,250 & 2.45 & 760 \\
\hline $12 \mathrm{~m}$. & 1.00 & 100 & 1.22 & 160 & 1.46 & 240 & 2.38 & 720 & 2.90 & 1,100 & $\overline{2} . \overline{35}$ & 700 \\
\hline
\end{tabular}


Gage-height, in feet, and discharge, in second-feet, at indicated time, 1938-Continued

\begin{tabular}{|c|c|c|c|c|c|c|c|c|c|c|c|c|}
\hline \multirow{2}{*}{ Hour } & Feet & Sec.-ft. & Feet & Sec.-ft. & Feet & Sec.-ft. & Feet & Sec.ft. & Feet & Sec.-ft. & Feet & Sec.-ft. \\
\hline & \multicolumn{2}{|c|}{ July 23} & \multicolumn{2}{|c|}{ July 24} & \multicolumn{2}{|c|}{ July 25} & \multicolumn{2}{|c|}{ July 26} & \multicolumn{2}{|c|}{ July 27} & \multicolumn{2}{|c|}{ July 28} \\
\hline \multirow{9}{*}{$\begin{array}{l}2 \mathrm{a} \cdot \mathrm{m} . \\
4 \\
6 \\
8 \\
10 . \\
12 \mathrm{n} . \\
2 \mathrm{p} . \mathrm{m} . \\
4 \\
6 \\
8 \\
10 \\
12 \mathrm{~m} .\end{array}$} & \multirow{9}{*}{$\begin{array}{l}2.32 \\
2.28 \\
2.47 \\
3.00 \\
3.70 \\
.35 \\
5.0 \\
5.65 \\
6.15 \\
6.5 \\
6.45 \\
6.15\end{array}$} & \multirow{9}{*}{$\begin{array}{r}680 \\
660 \\
780 \\
1,200 \\
1,900 \\
2,700 \\
3,600 \\
4,700 \\
5,600 \\
6,300 \\
6,200 \\
5,600\end{array}$} & \multirow{9}{*}{$\begin{array}{l}5.8 \\
5.4 \\
5.0 \\
4.7 \\
4.35 \\
4.05 \\
3.80 \\
3.50 \\
3.25 \\
3.05 \\
2.95 \\
2.80\end{array}$} & \multirow{2}{*}{$\begin{array}{l}5,000 \\
4,300 \\
3,600\end{array}$} & \multirow[b]{2}{*}{2.60} & \multirow[b]{2}{*}{880} & & \multirow[b]{2}{*}{540} & \multirow[b]{2}{*}{1.87} & \multirow[b]{2}{*}{420} & \multirow[b]{2}{*}{$1 . \overline{74}$} & \multirow[b]{2}{*}{360} \\
\hline & & & & & & & 2.10 & & & & & \\
\hline & & & & \multirow{2}{*}{$\begin{array}{l}3.200 \\
2,700\end{array}$} & 2.47 & 780 & 205 & 520 & \multirow{2}{*}{1.84} & +10 & 1.72 & \multirow{2}{*}{350} \\
\hline & & & & & & & & \multirow[b]{2}{*}{500} & & & 1.72 & \\
\hline & & & & $\begin{array}{l}2,300 \\
2,000\end{array}$ & 2.38 & 720 & 2.01 & & 1.82 & 400 & 1.71 & 350 \\
\hline & & & & 1,700 & 2.29 & 660 & 1.98 & 480 & 1.80 & 390 & 1.70 & . \\
\hline & & & & $\begin{array}{l}1,450 \\
1,250\end{array}$ & 2.22 & 620 & 1.94 & 460 & 1.78 & 380 & 1.69 & $\overline{3} 40$ \\
\hline & & & & 1,150 & & & & & & & & \\
\hline & & & & 1,050 & 2.16 & 580 & 1.90 & 440 & 1.76 & 370 & 1.67 & 330 \\
\hline & & & $\mathrm{Jul}$ & y 30 & & y 31 & Au & rust 1 & $A u$ & ust 2 & $\mathrm{Au}$ & ist 3 \\
\hline & & & & & & & & & & & & $\cdots$ \\
\hline $\begin{array}{l}6 \\
8 \\
8\end{array}$ & 1.65 & 320 & 1.57 & 290 & 1.49 & 250 & 1.41 & 225 & 1.34 & 200 & 1.26 & 172 \\
\hline 10 & & & & & & & & & & & & \\
\hline $12 \mathrm{n}$. & 1.63 & 310 & 1.55 & 280 & 1.47 & 245 & 1.39 & 215 & 1.32 & 191 & 1.23 & 162 \\
\hline $\begin{array}{l}2 \text { J.M. } \\
4\end{array}$ & & -1 & & & & & & & & & & \\
\hline & 1.61 & 300 & 1.53 & 270 & 1.45 & 240 & 1.37 & 210 & 1.27 & 175 & 1.20 & 153 \\
\hline 10 & & & & & & & & & & & & \\
\hline $12 \mathrm{~m}$ & 1.59 & 290 & 1.51 & 260 & 1.43 & 230 & 1.36 & 205 & 1.26 & 172 & 1.17 & 145 \\
\hline
\end{tabular}

GAST BRANCE OF EIGHTMIIE RIVER XEAR NORTH IYME, CONT.

Location.-Lat. $41^{\circ} 25^{\prime} 40^{\prime \prime}$, long. $72^{\circ} 20^{\prime} 05^{\prime \prime}$, at highway bridge 0.4 mile upstream from confluence with West Branch of Eightmile River, 1.1 miles north of North Lyme, New London County, and 51/2 miles upstream from mouth of Eightmile River.

Drainage area.-22.0 square miles.

GAGE-HEIGHT RECORD.-Water-stage recorder graph.

Stage-Discharge RELATION.-Defined by current-meter measurements below 300 second-feet; extended to peak stage on basis of flow characteristics at control section.

Maxima.-July 1938: Discharge, 897 second-feet noon July 24 (gage height, 4.92 feet).

September 1937 to June 1938: Discharge, 1,010 second-feet Nov. 29, 1937 (gage height, 5.25 feet).

REMARKs.-Flood discharge affected by storage in several small ponds.

Mean discharge, in second-feet, 1938

\begin{tabular}{|c|c|c|c|c|c|c|c|c|c|c|c|}
\hline Day & June & July & Aug. & $D_{a 1}$ & June & July & Aug. & Day & June & July & Aug. \\
\hline $\begin{array}{r}1 \\
2 \\
3 \\
4 \\
5 \\
6 \\
7 \\
8 \\
9 \\
10\end{array}$ & $\begin{array}{l}27 \\
24 \\
23 \\
24 \\
29 \\
30 \\
24 \\
21 \\
19 \\
16\end{array}$ & $\begin{array}{l}78 \\
54 \\
44 \\
36 \\
29 \\
24 \\
20 \\
18 \\
16 \\
22\end{array}$ & $\begin{array}{r}52 \\
46 \\
40 \\
35 \\
37 \\
52 \\
67 \\
59 \\
114 \\
90\end{array}$ & $\begin{array}{l}11 \\
12 \\
13 \\
14 \\
15 \\
16 \\
17 \\
18 \\
19 \\
20\end{array}$ & $\begin{array}{l}17 \\
41 \\
50 \\
40 \\
27 \\
21 \\
19 \\
17 \\
16 \\
14\end{array}$ & $\begin{array}{l}21 \\
17 \\
16 \\
15 \\
28 \\
29 \\
20 \\
21 \\
28 \\
35\end{array}$ & $\begin{array}{r}116 \\
159 \\
86 \\
57 \\
45 \\
40 \\
95 \\
130 \\
82 \\
59\end{array}$ & $\begin{array}{l}21 \\
22 \\
23 \\
24 \\
25 \\
26 \\
27 \\
28 \\
29 \\
30 \\
31\end{array}$ & $\begin{array}{r}12 \\
11 \\
10 \\
10 \\
10 \\
10 \\
22 \\
137 \\
278 \\
162\end{array}$ & $\begin{array}{r}55 \\
107 \\
188 \\
794 \\
544 \\
245 \\
155 \\
112 \\
88 \\
76 \\
63\end{array}$ & $\begin{array}{l}45 \\
38 \\
34 \\
30 \\
26 \\
23 \\
21 \\
21 \\
18 \\
17 \\
16\end{array}$ \\
\hline $\begin{array}{l}\text { Lor } \\
\text { un }\end{array}$ & $\mathrm{m}$ & & & & & & & & $\begin{array}{l}38.7 \\
1.96\end{array}$ & $\begin{array}{l}96.9 \\
5.07\end{array}$ & $\begin{array}{l}56 . j \\
2.96\end{array}$ \\
\hline
\end{tabular}


Gage-height, in feet, and discharge, in second-feet, at indicated time, 1938

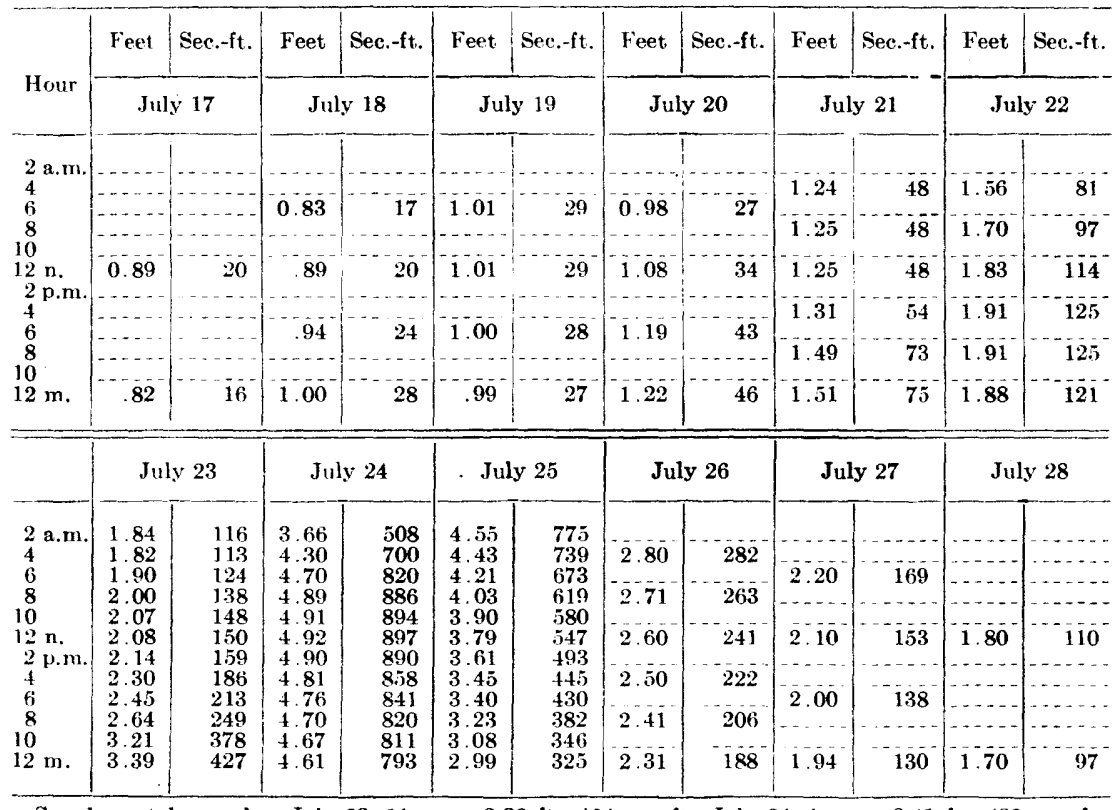

Supplemental records.-July 23,11 p.m., $3.38 \mathrm{ft} ., 424$ sec.-ft.; July 24,1 a.m., $3.41 \mathrm{ft} . .433$ sec.-ft.: 5 a.m., 4.59 ft., 787 sec.-ft.; 11 a.m., $4.90 \mathrm{ft}$., 890 sec.-ft.; July 25,5 p.m., 3.39 ft., 427 sec.-ft.

\section{WEST BRANCE OF FIGHTMITE RIVEE NEAR NORTH IYME, CONA.}

Location.-Lat. $41^{\circ} 25^{\prime} 55^{\prime \prime}$, long. $72^{\circ} 20^{\prime} 10^{\prime \prime}$, on highway bridge, 300 feet upstream from confluence with East Branch of Eightmile River, 11/2 miles north of North Lyme, New London County, and 5 $1 / 2$ miles upstream from mouth of Eightmile River.

Drainage AREA.-19.2 square miles.

GAGE-HEIGHT RECORD.-Staff gage read once or twice daily. Gage-height graph based on gage readings and comparison with record for station on East Branch used June 4, 6, 11, 14, 15, 26-30, July 1, 3, 6-31, Aug. 1-27.

StaGe-discharge RELATion.-Defined by current-meter measurements below 225 second-feet; extended to peak stage on basis of determination of September 1938 peak flow at bridge half a mile above station.

Maxima.-July 1938: Discharge, 785 second-feet 8 a.m. July 24 (gage height, 6.20 feet, from graph based on gage readings).

September 1937 to June 1938: Discharge, 1,020 second-feet Nov. 29, 1937 (gage height, 6.8 feet, from floodmarks).

REMARKs.-Flood discharge not affected by artificial storage. Shaw Lake - (Lake Hayward) controls headwater discharge to some extent. 
Mean discharge, in second-feet, 1938

\begin{tabular}{r|r|r|r|r|r|r|r|r|r|r|r}
\hline Day & June & July & Aug. & Day & June & July & Aug. & Day & June & July & Aug. \\
\hline 1 & 29 & 61 & 55 & 11 & 22 & 19 & 176 & 21 & 12 & 74 & 45 \\
2 & 25 & 44 & 48 & 12 & 41 & 18 & 147 & 22 & 10 & 114 & 40 \\
3 & 23 & 36 & 41 & 13 & 52 & 16 & 89 & 23 & 10 & 253 & 33 \\
4 & 24 & 29 & 37 & 14 & 31 & 16 & 63 & 24 & 10 & 732 & 32 \\
5 & 31 & 26 & 56 & 15 & 22 & 24 & 49 & 25 & 9.5 & 410 & 26 \\
6 & 29 & 22 & 72 & 16 & 19 & 23 & 44 & 26 & 9.8 & 214 & 23 \\
7 & 24 & 18 & 70 & 17 & 18 & 16 & 136 & 27 & 33 & 150 & 18 \\
8 & 22 & 16 & 56 & 18 & 16 & 19 & 119 & 28 & 145 & 118 & 18 \\
9 & 19 & 14 & 198 & 19 & 15 & 23 & 78 & 29 & 248 & 97 & 17 \\
10 & 16 & 26 & 78 & 20 & 13 & 32 & 56 & 30 & 122 & 79 & 15 \\
&
\end{tabular}

Gage-height, in feet, and discharge, in second-feet, at indicated time, 1938

\begin{tabular}{|c|c|c|c|c|c|c|c|c|c|c|c|c|}
\hline \multirow{2}{*}{ Hour } & Feet & Sec.-ft. & Feet & Sec.-ft. & Feet & Sec.-ft. & Feet & Sec.-ft. & Feet & Sec.-ft. & Feet & Sec.ft. \\
\hline & \multicolumn{2}{|c|}{ July 17} & \multicolumn{2}{|c|}{ July 18} & \multicolumn{2}{|c|}{ July 19} & \multicolumn{2}{|c|}{ July 20} & \multicolumn{2}{|c|}{ July 21} & \multicolumn{2}{|c|}{ July 22} \\
\hline \multirow{5}{*}{$\begin{array}{l}2 \mathrm{a} . \mathrm{m} . \\
4 \\
6 \\
8 \\
10 \\
12 \mathrm{n} . \\
2 \mathrm{p.m} . \\
4 \\
6 \\
8 \\
10 \\
12 \mathrm{~m} .\end{array}$} & & & $\begin{array}{l}1.05 \\
a 1.06\end{array}$ & $\begin{array}{l}16 \\
16\end{array}$ & $a 1.16$ & 22 & $\begin{array}{l}1.18 \\
a 1.18\end{array}$ & $\begin{array}{l}23 \\
23\end{array}$ & $\begin{array}{r}1.38 \\
a 1.36 \\
1.37\end{array}$ & $\begin{array}{l}36 \\
34 \\
35\end{array}$ & $\begin{array}{r}2.06 \\
c 2.34 \\
2.37\end{array}$ & $\begin{array}{r}96 \\
122 \\
125\end{array}$ \\
\hline & 1.07 & 16 & 1.12 & 19 & 1.16 & 22 & 1.28 & 29 & 1.65 & 56 & 2.52 & $1 \overline{3} \overline{5}$ \\
\hline & & & & & & & & & 2.24 & 114 & 2.35 & 123 \\
\hline & 1.02 & 14 & $\begin{array}{l}1.19 \\
1.20\end{array}$ & $\begin{array}{l}23 \\
24\end{array}$ & $b 1.16$ & 22 & $\begin{array}{l}1.50 \\
1.52\end{array}$ & $\begin{array}{l}44 \\
46\end{array}$ & 2.42 & 128 & 2.16 & 106 \\
\hline & 1.01 & 14 & $\overline{1} . \overline{1}$ & 25 & 1.16 & 22 & 1.48 & 43 & 2.13 & 103 & 2.10 & 100 \\
\hline & \multicolumn{2}{|c|}{ July 23} & \multicolumn{2}{|c|}{ July 24} & \multicolumn{2}{|c|}{ July 25} & \multicolumn{2}{|c|}{ July 26} & \multicolumn{2}{|c|}{ July 27} & \multicolumn{2}{|c|}{ July 28} \\
\hline \multirow{6}{*}{$\begin{array}{l}2 \mathrm{a} . \mathrm{m} . \\
4 \\
6 \\
8 \\
10 \\
12 \mathrm{n} . \\
2 \mathrm{p} . \mathrm{m} . \\
4 \\
6 \\
8 \\
10 \\
12 \mathrm{~m} .\end{array}$} & 2.20 & 110 & 6.15 & 768 & & & & & & & & \\
\hline & 2.55 & 138 & 6.20 & 785 & $\begin{array}{c}5.2 \\
c 5.04\end{array}$ & $\begin{array}{l}495 \\
458\end{array}$ & $a 3.60$ & 230 & & & & \\
\hline & $2.7 \overline{5}$ & $\overline{153}$ & 6.15 & 768 & 4.7 & 391 & 3.4 & 209 & 2.7 & 149 & 2.3 & 119 \\
\hline & 3.65 & 236 & 6.05 & 732 & & & & & & & & \\
\hline & 5.14 & 480 & 5.90 & 685 & 4.10 & $\begin{array}{l}090 \\
294\end{array}$ & 3.14 & 185 & 2.50 & 134 & 2.20 & 110 \\
\hline & 5.95 & $700^{-}$ & $5.65^{-}$ & 610 & $3 . \overline{9}$ & 267 & 3.0 & 173 & 2.45 & 130 & 2.15 & 105 \\
\hline
\end{tabular}

$a$ Gage height at 7:00 a.m.

$b$ Gage height at $6: 45$ a.m.

$c$ Gage height at $7: 30$ a.m.

NoTE.-All gage readings are included in above table.

\section{QUINNIPIAC RIVER BASIN}

\section{QUINNIPIAC RIVER AT WATIINGFORD, CONN.}

Location.-Lat. $41^{\circ} 26^{\prime} 58^{\prime \prime}$, long. 72 $50^{\prime} 29^{\prime \prime}, 0.4$ mile downstream from Quinnipiac Street bridge in Wallingford, New Haven County and 2 miles upstream from Worton Brook.

Drainage AREA.-109 square miles.

GAGE-HEIGHT RECORD.-Water-stage recorder graph.

Stage-discharge Relation.-Defined by current-meter measurements.

Maxima.-July 1938: Discharge, 1,460 second-feet 9 p.m. July 24 (gage height, 6.00 feet).

1930 to June 1938: Discharge, 3,240 second-feet Mar. 12, 1936 (gage height, 8.2 feet). 
Remarks.-Flood discharge affected by storage and regulation in several small ponds.

Mean discharge, in second-feet, 1938

\begin{tabular}{r|c|c|c|c|c|c|c|c|c|c|c}
\hline Day & June & July & Aug. & Day & June & July & Aug. & Day & June & July & Aug. \\
\hline 1 & 187 & 254 & 322 & 11 & 199 & 169 & 437 & 21 & 159 & 336 & 202 \\
2 & 179 & 222 & 305 & 12 & 229 & 176 & 540 & 22 & 156 & 411 & 200 \\
3 & 183 & 210 & 267 & 13 & 249 & 78 & 375 & 23 & 152 & 800 & 190 \\
4 & 194 & 205 & 210 & 14 & 257 & 58 & 281 & 24 & 142 & 1,320 & 182 \\
5 & 205 & 196 & 210 & 15 & 210 & 52 & 252 & 25 & 138 & 1.120 & 172 \\
6 & 203 & 192 & 215 & 16 & 193 & 50 & 265 & 26 & 151 & 681 & 161 \\
7 & 193 & 190 & 220 & 17 & 181 & 112 & 295 & 27 & 198 & 468 & 150 \\
8 & 199 & 184 & 218 & 18 & 187 & 137 & 277 & 28 & 388 & 404 & 150 \\
9 & 190 & 182 & 254 & 19 & 187 & 281 & 254 & 29 & 554 & 364 & 153 \\
10 & 181 & 185 & 285 & 20 & 172 & 360 & 215 & 30 & 359 & 350 & 156 \\
&
\end{tabular}

Gage-height, in feet, and discharge, in second-feet, at indicated time, 1938

\begin{tabular}{|c|c|c|c|c|c|c|c|c|c|c|c|c|}
\hline \multirow{2}{*}{ Hour } & Feet & Sec.-ft. & Feet & Sec.-ft. & Feet & Sec. $-\mathrm{ft}$. & Feet & Sec.-ft. & Feet & Sec.-ft. & Feet & Sec.-ft. \\
\hline & \multicolumn{2}{|c|}{ July 17} & \multicolumn{2}{|c|}{ July 18} & \multicolumn{2}{|c|}{ July 19} & \multicolumn{2}{|c|}{ July 20} & \multicolumn{2}{|c|}{ July 21} & \multicolumn{2}{|c|}{ July 22} \\
\hline $2 \mathrm{a} . \mathrm{m}$ & 1.23 & 96 & 1.29 & 111 & 1.77 & 236 & 2.23 & 332 & 2.34 & 355 & 2.28 & 343 \\
\hline & 1.28 & 109 & 1.29 & 111 & 1.87 & 258 & 2.26 & 339 & 2.30 & 347 & 2.25 & 336 \\
\hline 6 & 1.30 & 114 & 1.30 & 114 & 1.91 & 267 & 2.26 & 339 & 2.25 & 336 & 2.33 & 353 \\
\hline 8 & 1.31 & 117 & 1.30 & 114 & 1.93 & 271 & 2.33 & 353 & 2.22 & 330 & 2.42 & 372 \\
\hline 10 & 1.33 & 122 & 1.44 & 153 & 2.14 & 313 & 2.35 & 358 & 2.37 & 362 & 2.56 & 402 \\
\hline $12 \mathrm{n}$. & 1.34 & 125 & 1.50 & 169 & 2.12 & 309 & 2.41 & 370 & 2.30 & 347 & 2.67 & 424 \\
\hline 2 p.m & 1.33 & 122 & 1.52 & 174 & 1.88 & 261 & 2.57 & 404 & 2.10 & 305 & 2.74 & 438 \\
\hline & 1.31 & 117 & 1.58 & 190 & 2.12 & 309 & 2.57 & 404 & 2.15 & 316 & 2.82 & 454 \\
\hline 6 & 1.29 & 111 & 1.29 & 111 & 1.97 & 279 & 2.37 & 362 & 2.19 & 324 & 2.84 & 458 \\
\hline 8 & 1.29 & 111 & 1.20 & 88 & 2.03 & 291 & 2.34 & 355 & 2.21 & 328 & 2.89 & 468 \\
\hline 10 & 1.29 & 111 & 1.43 & 150 & 2.11 & 307 & 2.37 & 362 & 2.23 & 332 & 2.94 & 478 \\
\hline $12 \mathrm{~m}$. & 1.29 & 111 & 1.71 & 222 & 2.18 & 322 & 2.37 & 362 & 2.21 & 328 & 2.96 & 482 \\
\hline
\end{tabular}

\begin{tabular}{|c|c|c|c|c|c|c|c|c|c|c|c|c|}
\hline \multirow[b]{2}{*}{2 a.m. } & \multicolumn{2}{|c|}{ July 23} & \multicolumn{2}{|c|}{ July 24} & \multicolumn{2}{|c|}{ July 25} & \multicolumn{2}{|c|}{ July 26} & \multicolumn{2}{|c|}{ July 27} & \multicolumn{2}{|c|}{ July 28} \\
\hline & 2.98 & 486 & 5.54 & 1,230 & 5.84 & 1,380 & 4.45 & 825 & 3.19 & 528 & 2.65 & 420 \\
\hline & 3.01 & 492 & 5.53 & 1,220 & 5.74 & 1,330 & 4.34 & 792 & 3.11 & 512 & 2.64 & 418 \\
\hline 6 & 3.01 & 492 & 5.53 & 1,220 & 5.64 & 1,280 & 4.22 & 756 & 3.03 & 496 & 2.63 & 416 \\
\hline 8 & 3.08 & 506 & 5.55 & 1,240 & 5.52 & 1,220 & 4.09 & 722 & 2.96 & 482 & 2.63 & 416 \\
\hline 10 & 3.74 & 643 & 5.61 & 1,260 & 5.46 & 1,190 & 3.97 & 693 & 2.90 & 470 & 2.63 & 416 \\
\hline $12 \mathrm{n}$. & 3.86 & 669 & 5.65 & 1,280 & 5.25 & 1,100 & 3.86 & 669 & 2.87 & 464 & 2.65 & 420 \\
\hline 2 p.m. & 4.39 & 807 & 5.72 & 1,320 & 5.14 & 1,060 & 3.75 & 645 & 2.82 & 454 & 2.74 & 438 \\
\hline & 5.08 & 1,030 & 5.80 & 1,360 & 5.03 & 1,010 & 3.64 & 621 & 2.77 & 444 & 2.58 & 406 \\
\hline 6 & 5.38 & 1,150 & 5.90 & 1,410 & 4.91 & 964 & 3.54 & 599 & 2.73 & 436 & 2.49 & 387 \\
\hline 8 & 5.54 & 1,230 & 5.99 & 1,460 & 4.79 & 927 & 3.45 & 580 & 2.68 & 426 & 2.42 & 372 \\
\hline 10 & 5.57 & 1,240 & 5.99 & 1,460 & 4.68 & 894 & 3.36 & 562 & 2.66 & 422 & 2.35 & 358 \\
\hline $12 \mathrm{~m}$. & 5.54 & 1,230 & 5.93 & 1,420 & 4.57 & 861 & 3.27 & 544 & 2.65 & 420 & 2.33 & 353 \\
\hline
\end{tabular}

\begin{tabular}{|c|c|c|c|c|c|c|c|c|c|c|c|c|}
\hline & \multicolumn{2}{|c|}{ July 29} & \multicolumn{2}{|c|}{ July 30} & \multicolumn{2}{|c|}{ July 31} & \multicolumn{2}{|c|}{ August 1} & \multicolumn{2}{|c|}{ August 2} & \multicolumn{2}{|c|}{ August 3} \\
\hline \multirow{8}{*}{$\begin{array}{c}2 \mathrm{a} . \mathrm{m} . \\
4 \\
6 \\
8 \\
10 \\
12 \mathrm{n} . \\
2 \mathrm{p} . \mathrm{m} . \\
4 \\
6 \\
8 \\
8 \\
10 \\
12 \mathrm{~m} .\end{array}$} & & & & & & & & & 2.13 & 311 & & \\
\hline & 2.31 & 349 & 2.38 & 364 & 2.25 & 336 & 2.21 & 328 & 2.1 & 311 & 2.03 & 291 \\
\hline & 2.36 & 360 & 2.36 & 360 & 2.25 & 336 & 2.20 & 326 & 2.14 & 313 & 2.03 & 291 \\
\hline & 2.43 & 374 & 2.31 & 349 & 2.25 & 336 & 2.21 & 328 & 2.15 & 316 & 2.03 & 291 \\
\hline & 2.42 & 372 & 2.27 & 341 & 2.23 & 332 & 2.17 & 320 & 2.13 & 311 & 1.90 & 265 \\
\hline & 2.40 & 368 & 2.25 & 336 & 2.22 & 330 & 2.13 & 311 & $\begin{array}{l}1.90 \\
1.97\end{array}$ & 279 & 1.68 & 215 \\
\hline & 2.40 & 368 & 2.25 & 336 & 2.22 & 330 & 2.13 & 311 & $\begin{array}{l}2.00 \\
2.02\end{array}$ & $\begin{array}{l}280 \\
289\end{array}$ & 1.65 & 208 \\
\hline & & & & & & & & & & & & \\
\hline
\end{tabular}

Supplemental records.-July 18, 1:20 p.m., 1.31 ft., 117 sec.-ft.; $5: 15$ p.m., 1.55 ft., 182 ,sec.-ft.; Juiy 24,9 p.m., $6.00 \mathrm{ft} ., 1,460$ sec.-ft. 


\section{HOUSATONIC RIVER BASIN \\ HOUSATONIC RIVER AT COITSVIILE, MAgS.}

Location.-Lat. $42^{\circ} 28^{\prime} 10^{\prime \prime}$, long. $73^{\circ} 11^{\prime} 50^{\prime \prime}$, in Coltsville, Berkshire County, 1 mile upstream from Unkamet Brook and 2 miles northeast of Pittsfield. Datum of gage is 993.49 feet above mean sea level (general adjustment of 1929).

Drainage area. - 57.1 square miles.

GACE-HEICHT RECORD.-Water-stage recorder graph.

Stage-discharge RELATION.-Defined by current-meter measurements.

Maxima.-July 1938: Discharge, 2,060 second-feet 4 p.m. July 23 (gage height, 7.65 feet).

1936 to June 1938: Discharge, 6,000 second-feet Mar. 18, 1936 (gage height, 10.14 feet), from rating curve extended on basis of computation of flow over dam.

Remarks.-Flood discharge not materially affected by artificial or natural storage.

Mean discharge, in second-feet, 1938

\begin{tabular}{|c|c|c|c|c|c|c|c|c|c|c|c|}
\hline Day & June & July & Aug. & Day & June & July & Aug. & Day & June & July & Atug. \\
\hline $\begin{array}{r}1 \\
2 \\
3 \\
4 \\
5 \\
6 \\
7 \\
8 \\
9 \\
10\end{array}$ & $\begin{array}{l}\mathbf{5 0} \\
\mathbf{4 3} \\
\mathbf{5 0} \\
\mathbf{3 4} \\
\mathbf{3 9} \\
\mathbf{3 8} \\
\mathbf{5 6} \\
\mathbf{7 4} \\
\mathbf{7 3} \\
\mathbf{3 9}\end{array}$ & $\begin{array}{l}63 \\
65 \\
64 \\
47 \\
52 \\
50 \\
38 \\
41 \\
34 \\
50\end{array}$ & $\begin{array}{r}141 \\
218 \\
134 \\
95 \\
90 \\
54 \\
132 \\
144 \\
135 \\
159\end{array}$ & $\begin{array}{l}11 \\
12 \\
13 \\
14 \\
15 \\
16 \\
17 \\
18 \\
19 \\
20\end{array}$ & $\begin{array}{r}62 \\
464 \\
814 \\
373 \\
164 \\
101 \\
87 \\
54 \\
54 \\
74\end{array}$ & $\begin{array}{r}43 \\
173 \\
102 \\
65 \\
65 \\
60 \\
48 \\
138 \\
272 \\
304\end{array}$ & $\begin{array}{r}417 \\
274 \\
125 \\
96 \\
103 \\
108 \\
101 \\
109 \\
114 \\
57\end{array}$ & $\begin{array}{l}21 \\
22 \\
23 \\
24 \\
25 \\
26 \\
27 \\
28 \\
29 \\
30 \\
31\end{array}$ & $\begin{array}{r}61 \\
58 \\
55 \\
52 \\
29 \\
35 \\
199 \\
285 \\
147 \\
79\end{array}$ & $\begin{array}{r}372 \\
751 \\
1,160 \\
732 \\
328 \\
196 \\
132 \\
118 \\
228 \\
274 \\
169\end{array}$ & $\begin{array}{r}60 \\
90 \\
88 \\
103 \\
91 \\
78 \\
36 \\
41 \\
77 \\
58 \\
51\end{array}$ \\
\hline 1 & & & & & & & & & $\begin{array}{r}125 \\
2.44\end{array}$ & $\begin{array}{l}2.01 \\
4.06\end{array}$ & $\begin{array}{r}115 \\
2.32\end{array}$ \\
\hline
\end{tabular}

Gage-height, in feet, and discharge, in second-feet, at indicated time, 1938

\begin{tabular}{|c|c|c|c|c|c|c|c|c|c|c|c|c|}
\hline \multirow{2}{*}{ Hour } & Feet & Sec.-ft. & Feet & Sec.-ft. & Feet & Sec.-ft. & Feet & Sec.-ft. & Feet & Sec.-ft. & Feet & Sec.-ft. \\
\hline & \multicolumn{2}{|c|}{ July 17} & \multicolumn{2}{|c|}{ July 18} & \multicolumn{2}{|c|}{ July 19} & \multicolumn{2}{|c|}{ July 20} & \multicolumn{2}{|c|}{ July 21} & \multicolumn{2}{|c|}{ July 22} \\
\hline \multirow[t]{2}{*}{$\begin{array}{l}6 \mathrm{a} . \mathrm{m} . \\
12 \mathrm{n} . \\
6 \mathrm{p.m} . \\
12 \mathrm{~m} .\end{array}$} & $\begin{array}{l}2.65 \\
2.61 \\
2.64 \\
2.84\end{array}$ & $\begin{array}{l}48 \\
45 \\
47 \\
66\end{array}$ & $\begin{array}{l}2.68 \\
2.73 \\
3.88 \\
4.10\end{array}$ & $\begin{array}{r}50 \\
55 \\
249 \\
303\end{array}$ & $\begin{array}{l}4.07 \\
4.06 \\
3.88 \\
3.75\end{array}$ & $\begin{array}{l}296 \\
293 \\
249 \\
220\end{array}$ & $\begin{array}{l}3.66 \\
4.46 \\
4.24 \\
3.96\end{array}$ & $\begin{array}{l}200 \\
405 \\
341 \\
268\end{array}$ & $\begin{array}{l}3.70 \\
4.72 \\
4.74 \\
4.30\end{array}$ & $\begin{array}{l}209 \\
486 \\
493 \\
358\end{array}$ & $\begin{array}{l}4.44 \\
5.80 \\
6.20 \\
5.42\end{array}$ & $\begin{array}{r}399 \\
915 \\
1,110 \\
748\end{array}$ \\
\hline & \multicolumn{2}{|c|}{ July 23} & \multicolumn{2}{|c|}{ July 24} & \multicolumn{2}{|c|}{ July 25} & \multicolumn{2}{|c|}{ July 26} & \multicolumn{2}{|c|}{ July 27} & \multicolumn{2}{|c|}{ July 28} \\
\hline $\begin{array}{c}6 \mathrm{a.m} . \\
12 \mathrm{n} . \\
6 \mathrm{p.m} . \\
12 \mathrm{~m} .\end{array}$ & $\begin{array}{l}4.84 \\
6.12 \\
7.52 \\
6.32\end{array}$ & $\begin{array}{r}525 \\
1,070 \\
1,960 \\
1,180\end{array}$ & $\begin{array}{l}5.69 \\
5.38 \\
4.94 \\
4.62\end{array}$ & $\begin{array}{l}866 \\
732 \\
559 \\
4 \overline{5} 4\end{array}$ & $\begin{array}{l}4.48 \\
4.22 \\
3.87 \\
3.76\end{array}$ & $\begin{array}{l}411 \\
336 \\
247 \\
222\end{array}$ & $\begin{array}{l}3.73 \\
3.65 \\
3.57 \\
3.55\end{array}$ & $\begin{array}{l}216 \\
198 \\
181 \\
176\end{array}$ & $\begin{array}{l}3.52 \\
2.97 \\
3.35 \\
3.31\end{array}$ & $\begin{array}{r}170 \\
80 \\
137 \\
130\end{array}$ & $\begin{array}{l}3.26 \\
3.25 \\
3.21 \\
3.24\end{array}$ & $\begin{array}{l}122 \\
120 \\
114 \\
118\end{array}$ \\
\hline
\end{tabular}

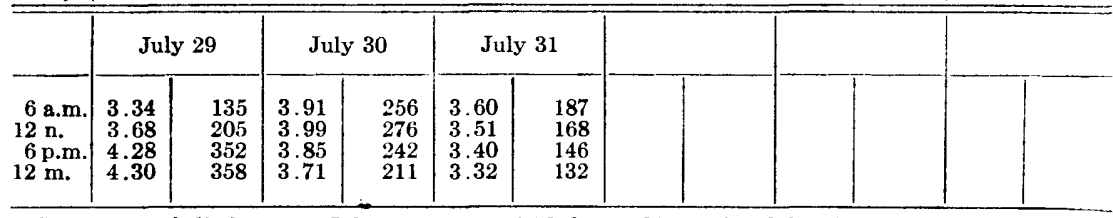

Supplemental discharges.-July 22, 2 p.m., 6.50 ft., 1,280 sec.-ft.; July 23, 6:40 a.m., 4.55 ft., 432 sec.-ft.; 9:00 a.m., 5.23 ft., 672 sec.-ft.; 4 p.m., 7.65 ft., 2,060 sec.-ft.; 9 p.m., $6.47 \mathrm{ft} ., 1,250$ sec.-ft.; July 24,3 a.m., 5.92 ft., 970 sec.-ft. 
HOUSATONIC IIVER TEAR GREAT BAERINGTON, MASS.

Location.-Lat. $42^{\circ} 13^{\prime} 45^{\prime \prime}$, long. $73^{\circ} 21^{\prime} 35^{\prime \prime}$, just upstream from Williams River, and highway bridge at Van Deusenville and 2 miles north of Great Barrington, Berkshire County. Datum of gage is 683.04 feet above mean sea level (general adjustment of 1929).

Drainage AREA.-280 square miles.

GAGE-HEIGHT RECORD.-Water-stage recorder graph.

Stage-discharge Relation.-Defined by current-meter measurements.

Maxima.-July 1938: Discharge, 3,420 second-feet 2 a.m. to 6 a.m. July 25 (gage height, 7.10 feet).

1913 to June 1938: Discharge, 8,990 second-feet Mar. 19, 1936 (gage height, 10.60 feet), from rating curve extended on basis of computation of flow over dam.

Remarks.-Flood discharge affected by artificial and natural storage.

Mean discharge, in second-feet, 1938

\begin{tabular}{|c|c|c|c|c|c|c|c|c|c|c|c|}
\hline .Jay & June & July & Aug. & Day & June & July & Aug. & Day & June & July & Ang. \\
\hline $\begin{array}{r}1 \\
2 \\
3 \\
4 \\
5 \\
6 \\
7 \\
8 \\
9 \\
10\end{array}$ & $\begin{array}{l}466 \\
425 \\
370 \\
283 \\
124 \\
153 \\
246 \\
368 \\
380 \\
360\end{array}$ & $\begin{array}{l}544 \\
427 \\
321 \\
160 \\
292 \\
344 \\
280 \\
233 \\
302 \\
343\end{array}$ & $\begin{array}{r}1,180 \\
1,460 \\
1,180 \\
945 \\
797 \\
652 \\
476 \\
546 \\
690 \\
779\end{array}$ & $\begin{array}{l}11 \\
12 \\
13 \\
14 \\
15 \\
16 \\
17 \\
18 \\
19 \\
20\end{array}$ & $\begin{array}{r}364 \\
504 \\
1,470 \\
2,010 \\
1,570 \\
1,050 \\
790 \\
599 \\
356 \\
291\end{array}$ & $\begin{array}{l}147 \\
315 \\
458 \\
471 \\
391 \\
272 \\
137 \\
249 \\
572 \\
693\end{array}$ & $\begin{array}{r}1,170 \\
1,380 \\
1,180 \\
809 \\
691 \\
640 \\
570 \\
568 \\
660 \\
487\end{array}$ & $\begin{array}{l}21 \\
22 \\
23 \\
24 \\
25 \\
26 \\
27 \\
28 \\
29 \\
30 \\
31\end{array}$ & $\begin{array}{r}414 \\
422 \\
280 \\
252 \\
280 \\
222 \\
468 \\
1,140 \\
1,050 \\
779\end{array}$ & $\begin{array}{r}694 \\
1,020 \\
1,780 \\
3,030 \\
3,220 \\
2,380 \\
1,490 \\
1,050 \\
1,130 \\
1,900 \\
1,460\end{array}$ & $\begin{array}{r}210 \\
298 \\
398 \\
418 \\
430 \\
450 \\
226 \\
32 \\
304 \\
322 \\
319\end{array}$ \\
\hline \multicolumn{9}{|c|}{$\begin{array}{l}\text { Monthly mean discharge, in second-feet } \\
\text { Runoff, in inches }\end{array}$} & $\begin{array}{r}583 \\
2.32\end{array}$ & $\begin{array}{r}842 \\
3.47\end{array}$ & $\begin{array}{r}654 \\
2.70\end{array}$ \\
\hline
\end{tabular}

Gage-height, in feet, and discharge, in second-feet, at indicated time, 1938

\begin{tabular}{|c|c|c|c|c|c|c|c|c|c|c|c|c|}
\hline \multirow{2}{*}{ Hour } & Feet & Sec.-ft. & Feet & Sec.-ft. & Feet & Sec.-ft. & Feet & Sec.-ft. & Feet & Sec,-ft. & Feet & Sec.-ft. \\
\hline & \multicolumn{2}{|c|}{ July 17} & \multicolumn{2}{|c|}{ July 18} & \multicolumn{2}{|c|}{ July 19} & \multicolumn{2}{|c|}{ July 20} & \multicolumn{2}{|c|}{ July 21} & \multicolumn{2}{|c|}{ July 22} \\
\hline \multirow[t]{2}{*}{$\begin{array}{c}6 \mathrm{a} . \mathrm{m} . \\
12 \mathrm{n.} \\
6 \mathrm{p.m} . \\
12 \mathrm{~m} .\end{array}$} & $\begin{array}{l}2.20 \\
2.12 \\
2.33 \\
2.37\end{array}$ & $\begin{array}{r}113 \\
97 \\
148 \\
161\end{array}$ & $\begin{array}{l}2.21 \\
2.62 \\
2.71 \\
2.94\end{array}$ & $\begin{array}{l}116 \\
248 \\
286 \\
395\end{array}$ & $\begin{array}{l}3.04 \\
3.21 \\
3.44 \\
3.50\end{array}$ & $\begin{array}{l}445 \\
536 \\
669 \\
705\end{array}$ & $\begin{array}{l}3.45 \\
3.48 \\
3.45 \\
3.39\end{array}$ & $\begin{array}{l}675 \\
693 \\
675 \\
639\end{array}$ & $\begin{array}{l}3.33 \\
3.37 \\
3.60 \\
3.70\end{array}$ & $\begin{array}{l}603 \\
627 \\
765 \\
825\end{array}$ & $\begin{array}{l}3.83 \\
4.09 \\
4.15 \\
4.36\end{array}$ & $\begin{array}{r}904 \\
1,070 \\
1,110 \\
1,250\end{array}$ \\
\hline & \multicolumn{2}{|c|}{ July 23} & \multicolumn{2}{|c|}{ July 24} & \multicolumn{2}{|c|}{ July 25} & \multicolumn{2}{|c|}{ July 26} & \multicolumn{2}{|c|}{ July 27} & \multicolumn{2}{|c|}{ July 28} \\
\hline $\begin{array}{c}6 \mathrm{a} . \mathrm{m} . \\
12 \mathrm{n} . \\
6 \mathrm{p.n.} \\
12 \mathrm{~m} .\end{array}$ & $\begin{array}{l}4.58 \\
4.82 \\
5.65 \\
6.15\end{array}$ & $\begin{array}{l}1,410 \\
1,580 \\
2,200 \\
2,580\end{array}$ & $\begin{array}{l}6.49 \\
6.73 \\
6.91 \\
7.08\end{array}$ & $\begin{array}{l}2,850 \\
3,060 \\
3,230 \\
3,400\end{array}$ & $\begin{array}{l}7.10 \\
7.02 \\
6.80 \\
6.55\end{array}$ & $\begin{array}{l}3,420 \\
3,340 \\
3,120 \\
2,900\end{array}$ & $\begin{array}{l}6.24 \\
5.89 \\
5.54 \\
5.26\end{array}$ & $\begin{array}{l}2,650 \\
2,380 \\
2,120 \\
1,900\end{array}$ & $\begin{array}{l}4.95 \\
4.72 \\
4.37 \\
4.22\end{array}$ & $\begin{array}{l}1,670 \\
1,500 \\
1,260 \\
1,160\end{array}$ & $\begin{array}{l}4.17 \\
4.10 \\
3.96 \\
3.38\end{array}$ & $\begin{array}{r}1,130 \\
1,080 \\
988 \\
937\end{array}$ \\
\hline & \multicolumn{2}{|c|}{ July 29} & \multicolumn{2}{|c|}{ July 30} & \multicolumn{2}{|c|}{ July 31} & \multicolumn{2}{|c|}{ August 1} & \multicolumn{2}{|c|}{ August 2} & \multicolumn{2}{|c|}{ August 3} \\
\hline \multirow[t]{2}{*}{$\begin{array}{c}6 \mathrm{~g} . \mathrm{m} . \\
12 \mathrm{n} . \\
6 \mathrm{p.m} . \\
12 \mathrm{~m} .\end{array}$} & $\begin{array}{l}3.93 \\
4.05 \\
4.30 \\
4.91\end{array}$ & $\begin{array}{r}970 \\
1,050 \\
1,210 \\
1,640\end{array}$ & $\begin{array}{l}5.27 \\
5.35 \\
5.22 \\
5.03\end{array}$ & $\begin{array}{l}1,910 \\
1,970 \\
1,880 \\
1,730\end{array}$ & $\begin{array}{l}4.84 \\
4.68 \\
4.50 \\
4.32\end{array}$ & $\begin{array}{l}1,590 \\
1,480 \\
1,350 \\
1,220\end{array}$ & $\begin{array}{l}4.20 \\
4.17 \\
4.20 \\
4.55\end{array}$ & $\begin{array}{l}1,140 \\
1,130 \\
1,140 \\
1,380\end{array}$ & $\begin{array}{l}4.71 \\
4.64 \\
4.57 \\
4.46\end{array}$ & $\begin{array}{l}1,500 \\
1,450 \\
1,400 \\
1,320\end{array}$ & $\begin{array}{l}4.36 \\
4.27 \\
4.18 \\
4.00\end{array}$ & $\begin{array}{l}1,250 \\
1,190 \\
1,130 \\
1,020\end{array}$ \\
\hline & \multicolumn{2}{|c|}{ August 4} & \multicolumn{2}{|c|}{ August 5} & \multicolumn{2}{|c|}{ August 6} & \multicolumn{2}{|c|}{ August 7} & & & & \\
\hline $\begin{array}{c}6 \mathrm{a} . \mathrm{m} . \\
12 \mathrm{n} . \\
6 \mathrm{p} . \mathrm{m} . \\
12 \mathrm{~m} .\end{array}$ & $\begin{array}{l}3.90 \\
3.85 \\
3.85 \\
3.72\end{array}$ & $\begin{array}{l}950 \\
918 \\
918 \\
837\end{array}$ & $\begin{array}{l}3.65 \\
3.63 \\
3.64 \\
3.54\end{array}$ & $\begin{array}{l}795 \\
783 \\
789 \\
729\end{array}$ & $\begin{array}{l}3.57 \\
3.47 \\
3.35 \\
3.20\end{array}$ & $\begin{array}{l}747 \\
687 \\
615 \\
530\end{array}$ & $\begin{array}{l}3.04 \\
3.11 \\
3.14 \\
3.12\end{array}$ & $\begin{array}{l}445 \\
480 \\
497 \\
486\end{array}$ & & & & \\
\hline
\end{tabular}


HOUSATONIC RIVER AT FAIIS VIILAGF, CONT.

Location.-Lat. $41^{\circ} 57^{\prime} 15^{\prime \prime}$, long. $73^{\circ} 22^{\prime} 05^{\prime \prime}$, at Falls Village, Litchfield County, half a mile downstream from power plant of Connecticut Power

Co., and 11/4 miles downstream from Hollenbeck River. Datum of gage is 522.41 feet above mean sea level (general adjustment of 1929).

JRAINAGE AREA.-632 square miles.

GAGE-HEIGHT RECORD.-Water-stage recorder graph.

STAGE-DisCHARGE RELATION.-Defined by current-meter measurements.

Maxima.-July 1938: Discharge, 4,580 second-feet 6 p.m. July 25 (gage height, 8.72 feet).

1912 to June 1938: Discharge, 14,500 second-feet Mar. 20, 1936 (gage height, 17.41 feet).

Remarks.-Flood discharge affected by storage.

Mean discharge, in second-feet, 1938

\begin{tabular}{|c|c|c|c|c|c|c|c|c|c|c|c|}
\hline Day & June & July & Aug. & Day & June & July & Aug. & Day & June & July & Aug. \\
\hline $\begin{array}{r}1 \\
2 \\
3 \\
4 \\
5 \\
6 \\
7 \\
8 \\
9 \\
10\end{array}$ & $\begin{array}{l}520 \\
691 \\
598 \\
610 \\
468 \\
389 \\
338 \\
608 \\
630 \\
636\end{array}$ & $\begin{array}{r}1,930 \\
1,260 \\
1,100 \\
950 \\
650 \\
542 \\
621 \\
596 \\
571 \\
592\end{array}$ & $\begin{array}{l}2,920 \\
2,870 \\
2,840 \\
2,390 \\
1,990 \\
1,580 \\
1,380 \\
1,170 \\
1,630 \\
1,940\end{array}$ & $\begin{array}{l}11 \\
12 \\
13 \\
14 \\
15 \\
16 \\
17 \\
18 \\
19 \\
20\end{array}$ & $\begin{array}{r}680 \\
861 \\
1,140 \\
2,190 \\
2,470 \\
2,170 \\
1,540 \\
1,230 \\
1,060 \\
768\end{array}$ & $\begin{array}{l}678 \\
607 \\
810 \\
960 \\
868 \\
832 \\
576 \\
430 \\
747 \\
923\end{array}$ & $\begin{array}{l}2,540 \\
3,170 \\
2,820 \\
2,300 \\
1,830 \\
1,580 \\
1,220 \\
1,150 \\
1,240 \\
1,220\end{array}$ & $\begin{array}{l}21 \\
22 \\
23 \\
24 \\
25 \\
26 \\
27 \\
28 \\
29 \\
30 \\
31\end{array}$ & $\begin{array}{r}551 \\
554 \\
580 \\
472 \\
414 \\
584 \\
1,600 \\
4,000 \\
3,720 \\
2,740\end{array}$ & $\begin{array}{l}1,300 \\
2,200 \\
3,230 \\
4,120 \\
4,420 \\
4,360 \\
3,790 \\
2,880 \\
2,160 \\
2,820 \\
3,260\end{array}$ & $\begin{array}{r}1,110 \\
840 \\
634 \\
667 \\
697 \\
700 \\
706 \\
534 \\
352 \\
393 \\
460\end{array}$ \\
\hline \multicolumn{9}{|c|}{$\begin{array}{l}\text { Monthly mean discharge, in second-feet } \\
\text { Runoff, in inches }\end{array}$} & $\begin{array}{r}1.160 \\
2.05\end{array}$ & $\begin{array}{r}1,638 \\
2.99\end{array}$ & $\begin{array}{r}1,512 \\
2.76\end{array}$ \\
\hline
\end{tabular}

Gage height, in feet, and discharge, in second-feet, at indicated time, 1938

\begin{tabular}{|c|c|c|c|c|c|c|c|c|c|c|c|c|}
\hline \multirow{2}{*}{ Hour } & Feet & Sec.-ft. & Feet & Sec.-ft. & Feet & Sec.-ft. & Feet & Sec.-ft. & Feet & Sec.-ft. & Feet & Sec. $-\mathrm{ft}$. \\
\hline & \multicolumn{2}{|c|}{ July 17} & \multicolumn{2}{|c|}{ July 18} & \multicolumn{2}{|c|}{ July 19} & \multicolumn{2}{|c|}{ July 20} & \multicolumn{2}{|c|}{ July 21} & \multicolumn{2}{|c|}{ July 22} \\
\hline \multirow[t]{2}{*}{$\begin{array}{c}2 \text { a.m. } \\
4 \\
6 \\
8 \\
10 \\
12 \mathrm{n} . \\
2 \mathrm{p.m} . \\
4 \\
6 \\
8 \\
10 \\
12 \mathrm{~m} .\end{array}$} & 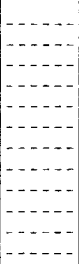 & \begin{tabular}{|}
-- \\
-- \\
-- \\
-
\end{tabular} & 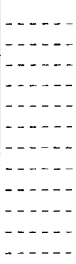 & \begin{tabular}{c}
$-\ldots-$ \\
$-\cdots$ \\
$-\ldots$ \\
\hdashline- \\
-
\end{tabular} & 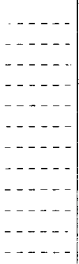 & $\begin{array}{c}\ldots \\
\ldots \\
\ldots\end{array}$ & $\begin{array}{l} \\
\ldots .55 \\
3.55 \\
3.56 \\
3.64 \\
3.67 \\
3.68\end{array}$ & \begin{tabular}{c}
$\ldots$ \\
$\cdots$ \\
\hdashline \\
\hdashline \\
1,160 \\
1,160 \\
1,160 \\
1,200 \\
1,220 \\
1,220
\end{tabular} & $\begin{array}{l}3.69 \\
3.70 \\
3.36 \\
3.74 \\
3.81 \\
3.86 \\
3.96 \\
4.04 \\
4.06 \\
4.03 \\
3.99 \\
3.97\end{array}$ & $\begin{array}{l}1,220 \\
1,230 \\
1,060 \\
1,250 \\
1,280 \\
1,310 \\
1,370 \\
1,410 \\
1,430 \\
1,410 \\
1,380 \\
1,370\end{array}$ & $\begin{array}{l}4.08 \\
4.48 \\
4.77 \\
4.96 \\
5.09 \\
5.27 \\
5.74 \\
5.97 \\
6.08 \\
6.17 \\
6.26 \\
6.34\end{array}$ & $\begin{array}{l}1,440 \\
1,680 \\
1,850 \\
1,970 \\
2,040 \\
2,150 \\
2,430 \\
2,580 \\
2,660 \\
2,720 \\
2,780 \\
2,840\end{array}$ \\
\hline & \multicolumn{2}{|c|}{ July 23} & \multicolumn{2}{|c|}{ July 24} & \multicolumn{2}{|c|}{ July 25} & \multicolumn{2}{|c|}{ July 26} & \multicolumn{2}{|c|}{ July 27} & \multicolumn{2}{|c|}{ July 28} \\
\hline $\begin{array}{c}2 \text { a.m. } \\
4 \\
6 \\
8 \\
10 \\
12 \mathrm{n} . \\
2 \text { p.m. } \\
4 \\
6 \\
8 \\
10 \\
12 \mathrm{~m} .\end{array}$ & $\begin{array}{l}6.37 \\
6.40 \\
6.42 \\
6.43 \\
6.41 \\
6.45 \\
6.78 \\
7.17 \\
7.62 \\
7.83 \\
7.86 \\
7.87\end{array}$ & $\begin{array}{l}2,860 \\
2,880 \\
2,890 \\
2,900 \\
2,890 \\
2,920 \\
3,150 \\
3,420 \\
3,730 \\
3,880 \\
3,900 \\
3,910\end{array}$ & $\begin{array}{l}7.88 \\
7.89 \\
7.94 \\
8.01 \\
8.10 \\
8.17 \\
8.24 \\
8.29 \\
8.34 \\
8.38 \\
8.40 \\
8.44\end{array}$ & $\begin{array}{l}3,920 \\
3,920 \\
3,960 \\
4,010 \\
4,080 \\
4,140 \\
4,190 \\
4,230 \\
4,270 \\
4,300 \\
4,320 \\
4,350\end{array}$ & $\begin{array}{l}8.45 \\
8.48 \\
8.48 \\
8.48 \\
8.48 \\
8.48 \\
8.49 \\
8.53 \\
8.72 \\
8.65 \\
8.58 \\
8.57\end{array}$ & $\begin{array}{l}4,360 \\
4,380 \\
4,380 \\
4,380 \\
4,380 \\
4,380 \\
4,390 \\
4,420 \\
4,580 \\
4,520 \\
4,460 \\
4,460\end{array}$ & $\begin{array}{l}8.57 \\
8.56 \\
8.55 \\
8.53 \\
8.50 \\
8.49 \\
8.46 \\
8.41 \\
8.38 \\
8.31 \\
8.26 \\
8.19\end{array}$ & $\begin{array}{l}4,460 \\
4,450 \\
4,440 \\
4,420 \\
4,400 \\
4,390 \\
4,370 \\
4,330 \\
4,300 \\
4,250 \\
4,210 \\
4,150\end{array}$ & $\begin{array}{l}8.14 \\
8.08 \\
7.99 \\
7.93 \\
7.83 \\
7.73 \\
7.65 \\
7.52 \\
7.41 \\
7.29 \\
7.16 \\
7.01\end{array}$ & $\begin{array}{l}4,110 \\
4,060 \\
3,990 \\
3,950 \\
3,880 \\
3,810 \\
3,760 \\
3,660 \\
3,590 \\
3,500 \\
3,410 \\
3,310\end{array}$ & $\begin{array}{l}6.90 \\
6.80 \\
6.71 \\
6.60 \\
6.50 \\
6.37 \\
6.25 \\
6.16 \\
6.11 \\
6.04 \\
5.96 \\
5.86\end{array}$ & $\begin{array}{l}3,230 \\
3,160 \\
3,100 \\
3,020 \\
2,950 \\
2,860 \\
2,780 \\
2,710 \\
2,680 \\
2,630 \\
2,570 \\
2,510\end{array}$ \\
\hline
\end{tabular}


Gage height in feet, and discharge, in second-feet, at indicated time, 1938-Continued

\begin{tabular}{|c|c|c|c|c|c|c|c|c|c|c|c|c|}
\hline \multirow{2}{*}{ Hour } & Feet & Sec.-ft. & Feet & Sec.-ft. & Feet & Sec.-ft. & Feet & Sec.-ft. & Feet & Sec.-ft. & Feet & Sec.-ft. \\
\hline & \multicolumn{2}{|c|}{ July 29} & \multicolumn{2}{|c|}{ July 30} & \multicolumn{2}{|c|}{ July 31} & \multicolumn{2}{|c|}{ August 1} & \multicolumn{2}{|c|}{ August 2} & \multicolumn{2}{|c|}{ August 3} \\
\hline 2 a.m. & 5.78 & 2,460 & 5.48 & 2.280 & 7.00 & 3,300 & 6.68 & 3,080 & & & & \\
\hline & 5.67 & 2,390 & 5.63 & 2.370 & 7.03 & 3,320 & 6.65 & 3,060 & & & & \\
\hline 6 & 5.56 & 2,330 & 5.82 & 2,480 & 7.03 & 3,320 & 6.58 & 3,010 & & & & \\
\hline 8 & 5.40 & 2,230 & 6.02 & 2,610 & 7.00 & 3,300 & 6.55 & 2,980 & & & & \\
\hline 10 & 5.09 & 2,040 & 6.33 & 2,830 & 7.01 & 3,310 & 6.36 & 2,850 & & & & \\
\hline $12 \mathrm{n}$. & 4.95 & 1,960 & 6.48 & 2,940 & 6.97 & 3,280 & 6.32 & 2,820 & & & & \\
\hline 2 p.m. & 4.92 & 1,940 & 6.59 & 3,010 & 6.97 & 3,280 & 6.38 & 2,870 & & & & \\
\hline & 4.93 & 1,950 & 6.67 & 3,070 & 6.95 & 3,260 & 6.33 & 2,830 & & & & \\
\hline 6 & 5.12 & 2,060 & 6.74 & 3,120 & 6.93 & 3,250 & 6.22 & 2,750 & & & & \\
\hline 8 & 5.12 & 2,060 & 6.8 & 3,17 & 6.84 & 3,1 ? & 6.47 & 2,9 & & & -. & \\
\hline & & 2,100 & 6.8 & 3,210 & 6.7 & 3,120 & 6.41 & 2,8 & & & & \\
\hline $12 \mathrm{~m}$. & 5.35 & 2,200 & 6.98 & 3,290 & 6.74 & 3,120 & 6.35 & 2,840 & & & & \\
\hline
\end{tabular}

ZOAR IAKE AT STEVENSON, CONN.

Location.-Staff gage, lat. $41^{\circ} 22^{\prime} 55^{\prime \prime}$, long. $73^{\circ} 10^{\prime} 05^{\prime \prime}$, on Housatonic River at Stevenson Dam of Connecticut Light \& Power Co., at Stevenson, Fairfield County.

Drainage AREA.-1,544 square miles.

Remarks.- Change of contents in equivalent second-feet computed from elevations of lake at midnight as furnished by Connecticut Light \& Power Co., Waterbury, Conn.

Change in contents, in equivalent second-feet, 1938

\begin{tabular}{|c|c|c|c|c|}
\hline Day & June & July & & August \\
\hline $\begin{array}{r}1 \\
2 \\
3 \\
4 \\
5 \\
6 \\
7 \\
8 \\
9 \\
10 \\
11 \\
12 \\
13 \\
14 \\
15 \\
16 \\
17 \\
18 \\
19 \\
20 \\
21 \\
22 \\
23 \\
24 \\
25 \\
26 \\
27 \\
28 \\
29 \\
30 \\
31\end{array}$ & $\begin{array}{r}-205 \\
+102 \\
+155 \\
-614 \\
+771 \\
+52 \\
0 \\
-312 \\
-51 \\
-307 \\
0 \\
+932 \\
-157 \\
+263 \\
+53 \\
-159 \\
-727 \\
+257 \\
+470 \\
-624 \\
0 \\
-51 \\
+154 \\
0 \\
0 \\
-51 \\
+312 \\
+1060 \\
+216 \\
-592\end{array}$ & $\begin{array}{r}-738 \\
+366 \\
-53 \\
+106 \\
0 \\
-472 \\
-310 \\
+51 \\
-51 \\
+782 \\
-211 \\
0 \\
-209 \\
-311 \\
-102 \\
+414 \\
+157 \\
-104 \\
-104 \\
+104 \\
+1500 \\
-55 \\
+220 \\
-274 \\
+220 \\
-274 \\
0 \\
-108 \\
-270 \\
-54 \\
0\end{array}$ & & $\begin{array}{r}-267 \\
-53 \\
-53 \\
-474 \\
+157 \\
+105 \\
-105 \\
-104 \\
-157 \\
+261 \\
+1340 \\
-165 \\
-325 \\
-323 \\
-372 \\
-419 \\
+313 \\
-209 \\
+315 \\
-884 \\
-306 \\
+152 \\
-152 \\
+255 \\
+51 \\
+517 \\
0 \\
+52 \\
+52 \\
-52 \\
-209\end{array}$ \\
\hline \multicolumn{2}{|l|}{$=$} & June & July & August \\
\hline \multicolumn{2}{|c|}{ Change in contents, in equiralent second-feet } & +31.6 & +7.10 & -34.2 \\
\hline
\end{tabular}


HOUSATONIC RIVER AT STEVERSON, CONM.

Location.-Lat. $41^{\circ} 23^{\prime} 05^{\prime \prime}$, long. $73^{\circ} 09^{\prime} 55^{\prime \prime}$, in New Haven County, a quarter of a mile upstream from Eightmile Brook and a quarter of a mile downstream from Stevenson Dam of Connecticut Light \& Power Co. at Stevenson, Fairfield County. Datum of gage is 24.98 feet above mean sea level (general adjustment of 1929), levels by Corps of Engineers, U. S. Army.

Drainage area.-1,545 square miles.

GAGE-HEIGHT RECORD.-Water-stage recorder graph.

STAGE-Discharge RELATION.-Defined by current-meter measurements.

Maxima.-July 1938: Discharge, 18,700 second-feet 6 a.m. July 24 (gage height, 12.84 feet).

1928 to June 1938: Discharge, 69,500 second-feet Mar. 12, 1936 (gage height, 23.5 feet, from floodmarks).

REMARKs.-Flow affected by artificial storage and diversion. For information on storage and diversion see records for Zoar Lake at Stevenson, Conn., Rocky River at outlet of Candlewood Lake, near New Milford, Conn., and for Shepaug River at outlet of Shepaug Reservoir, at Woodville, Conn.

Mean discharge, in second-feet, 1938

\begin{tabular}{|c|c|c|c|c|c|c|c|c|c|c|c|}
\hline Day & June & July & Aug. & Day & June & July & Aug. & Day & June & July & Aug. \\
\hline $\begin{array}{r}1 \\
2 \\
3 \\
4 \\
5 \\
6 \\
7 \\
8 \\
9 \\
10\end{array}$ & $\begin{array}{r}1,420 \\
1,130 \\
1,590 \\
2,160 \\
712 \\
1,410 \\
1,200 \\
1,980 \\
1,540 \\
1,750\end{array}$ & $\begin{array}{r}5,120 \\
3,340 \\
2,930 \\
2,390 \\
1,980 \\
2,190 \\
1,710 \\
1,460 \\
1,520 \\
987\end{array}$ & $\begin{array}{l}6,050 \\
5,850 \\
5,300 \\
5,140 \\
3,910 \\
3,800 \\
4,140 \\
3,680 \\
4,740 \\
4,140\end{array}$ & $\begin{array}{l}11 \\
12 \\
13 \\
14 \\
15 \\
16 \\
17 \\
18 \\
19 \\
20\end{array}$ & $\begin{array}{l}1,410 \\
3,130 \\
3,760 \\
3,260 \\
3,870 \\
3,800 \\
3,720 \\
2,040 \\
1,500 \\
2,340\end{array}$ & $\begin{array}{l}1,740 \\
1,730 \\
2,120 \\
2,160 \\
2,180 \\
1,410 \\
1,340 \\
1,400 \\
2,380 \\
2,850\end{array}$ & $\begin{array}{r}10,600 \\
10100 \\
7,710 \\
6,220 \\
5,280 \\
4,560 \\
3,620 \\
3,310 \\
3,300 \\
3,980\end{array}$ & $\begin{array}{l}21 \\
22 \\
23 \\
24 \\
25 \\
26 \\
27 \\
28 \\
29 \\
30 \\
31\end{array}$ & $\begin{array}{l}1,780 \\
1,400 \\
1,020 \\
1,310 \\
1,260 \\
1,200 \\
2,710 \\
8,020 \\
8,070 \\
6,530\end{array}$ & $\begin{array}{r}5,060 \\
15,600 \\
13,700 \\
16,200 \\
12,000 \\
10,400 \\
8,610 \\
8,800 \\
6,830 \\
6,370 \\
6,120\end{array}$ & $\begin{array}{l}2,980 \\
2,250 \\
2,230 \\
1,500 \\
1,760 \\
1,400 \\
1,500 \\
1,390 \\
1,170 \\
1,280 \\
1,400\end{array}$ \\
\hline \multicolumn{9}{|c|}{$\begin{array}{l}\text { Monthly mean discharge, in second-feet } \\
\text { Runoff, in inches. }\end{array}$} & $\begin{array}{r}2,567 \\
1.85\end{array}$ & $\begin{array}{r}4,923 \\
3.68\end{array}$ & $\begin{array}{r}4,009 \\
2.99\end{array}$ \\
\hline
\end{tabular}

Gage-height, in feet, and discharge, in second-feet, at indicated time, 1938

\begin{tabular}{|c|c|c|c|c|c|c|c|c|c|c|c|c|}
\hline \multirow{2}{*}{ Hour } & Feet & Sec.-ft. & Feet & Sec.-ft. & Feet & Sec.-ft. & Feet & Sec.-ft. & Feet & Sec.-ft. & Feet & Sec.-ft. \\
\hline & \multicolumn{2}{|c|}{ July 17} & \multicolumn{2}{|c|}{ July 18} & \multicolumn{2}{|c|}{ July 19} & \multicolumn{2}{|c|}{ July 20} & \multicolumn{2}{|c|}{ July 21} & \multicolumn{2}{|c|}{ July 22} \\
\hline $\begin{array}{l}2 \text { a.m. } \\
4 \\
6 \\
8 \\
10 \\
12 \mathrm{n} . \\
2 \text { p.m. } \\
4 \\
6 \\
8 \\
10 \\
12 \mathrm{~m} .\end{array}$ & $\begin{array}{r}1.50 \\
.80 \\
.73 \\
4.80 \\
4.70 \\
5.63 \\
3.85 \\
2.60 \\
3.91 \\
5.00 \\
5.50 \\
2.99\end{array}$ & a1,340 & $\begin{array}{r}2.00 \\
.85 \\
3.14 \\
5.93 \\
7.13 \\
2.30 \\
6.10 \\
3.50 \\
.81 \\
.73 \\
.69 \\
4.18\end{array}$ & $\begin{array}{l}\ldots \ldots \\
a 1,400 \\
0.1 \\
\end{array}$ & $\begin{array}{l}2.90 \\
3.20 \\
3.30 \\
6.86 \\
5.90 \\
3.67 \\
7.16 \\
4.76 \\
3.60 \\
6.82 \\
6.50 \\
2.30\end{array}$ & 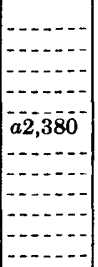 & $\begin{array}{r}0.80 \\
.70 \\
.68 \\
7.16 \\
7.22 \\
2.20 \\
7.18 \\
6.50 \\
6.50 \\
5.65 \\
5.65 \\
3.12\end{array}$ & 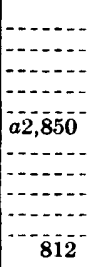 & $\begin{array}{r}3.35 \\
3.43 \\
3.60 \\
7.05 \\
7.20 \\
4.55 \\
7.21 \\
7.23 \\
8.00 \\
8.55 \\
10.10 \\
11.54\end{array}$ & $\begin{array}{r}955 \\
1,010 \\
1,130 \\
5,060 \\
5,300 \\
1,900 \\
5,320 \\
5,350 \\
6,680 \\
7,720 \\
10,900 \\
14,400\end{array}$ & $\begin{array}{l}12.20 \\
11.91 \\
10.89 \\
12.30 \\
12.23 \\
12.19 \\
12.11 \\
12.02 \\
11.90 \\
11.75 \\
11.55 \\
11.39\end{array}$ & $\begin{array}{l}16,500 \\
15,500 \\
12,800 \\
16,800 \\
16,600 \\
16,500 \\
16,200 \\
15,900 \\
15,500 \\
15,000 \\
14,400 \\
14,000\end{array}$ \\
\hline
\end{tabular}


Gage-height, in feet, and discharge, in second-feet, at indicated time, 1938-Continued

\begin{tabular}{|c|c|c|c|c|c|c|c|c|c|c|c|c|}
\hline \multirow{2}{*}{ Hour } & Feet & Sec.-ft. & Feet & Sec.-ft. & Feet & Sec.-ft. & Feet & Sec.-ft. & Feet & Sec.-ft. & Feet & Sec.-ft. \\
\hline & \multicolumn{2}{|c|}{ July 23} & \multicolumn{2}{|c|}{ July 24} & \multicolumn{2}{|c|}{ July 25} & \multicolumn{2}{|c|}{ July 25} & \multicolumn{2}{|c|}{ July 27} & \multicolumn{2}{|c|}{ July 28} \\
\hline $\begin{array}{c}2 \text { a.m. } \\
4 \\
6 \\
8 \\
10 \\
12 \text { n. } \\
2 \text { p.m. } \\
4 \\
6 \\
8 \\
10 \\
12 \mathrm{~m} .\end{array}$ & $\begin{array}{l}11.00 \\
10.77 \\
10.70 \\
10.84 \\
10.93 \\
10.93 \\
11.00 \\
11.16 \\
11.40 \\
11.89 \\
12.25 \\
12.43\end{array}$ & $\begin{array}{l}13,000 \\
12,500 \\
12,300 \\
12,600 \\
12,900 \\
12,900 \\
13,000 \\
13,400 \\
14,000 \\
15,500 \\
16,700 \\
17,300\end{array}$ & $\begin{array}{l}12.30 \\
12.37 \\
12.84 \\
12.65 \\
12.36 \\
12.15 \\
12.04 \\
11.88 \\
11.71 \\
11.64 \\
11.50 \\
11.20\end{array}$ & $\begin{array}{l}16,800 \\
17,100 \\
18,700 \\
18,100 \\
17,100 \\
16,300 \\
15,900 \\
15,400 \\
14,900 \\
14,700 \\
14,300 \\
13,600\end{array}$ & $\begin{array}{r}11.00 \\
11.03 \\
10.90 \\
11.17 \\
11.01 \\
10.37 \\
10.20 \\
9.20 \\
9.65 \\
10.49 . \\
10.33 \\
10.25\end{array}$ & $\begin{array}{r}13,000 \\
13,100 \\
12,800 \\
13,500 \\
13,100 \\
11,500 \\
11,100 \\
9,000 \\
9,930 \\
11,800 \\
11,400 \\
11,200\end{array}$ & $\begin{array}{r}10.19 \\
10.03 \\
9.76 \\
9.84 \\
10.03 \\
9.90 \\
9.87 \\
9.80 \\
9.73 \\
9.66 \\
9.55 \\
9.52\end{array}$ & $\begin{array}{r}11,100 \\
10,800 \\
10,200 \\
10,300 \\
10,800 \\
10,500 \\
10,400 \\
10,300 \\
10,100 \\
\mathbf{9 , 9 5 0} \\
\mathbf{9 , 7 1 0} \\
9,640\end{array}$ & $\begin{array}{l}9.46 \\
9.08 \\
9.03 \\
9.43 \\
9.30 \\
9.26 \\
8.64 \\
8.73 \\
8.77 \\
8.82 \\
8.80 \\
8.90\end{array}$ & & $\begin{array}{l}8.87 \\
9.06 \\
9.33 \\
9.56 \\
9.88 \\
9.60 \\
9.37 \\
9.19 \\
8.44 \\
8.48 \\
8.45 \\
8.40\end{array}$ & $\begin{array}{r}\mathbf{8 , 3 4 0} \\
\mathbf{8 , 7 2 0} \\
9,260 \\
\mathbf{9 , 7 3 0} \\
10,400 \\
\mathbf{9 , 8 2 0} \\
\mathbf{9 , 3 4 0} \\
\mathbf{8 , 9 8 0} \\
\mathbf{7 , 5 1 0} \\
\mathbf{7 , 5 8 0} \\
\mathbf{7 , 5 2 0} \\
\mathbf{7 , 4 3 0}\end{array}$ \\
\hline $12 \mathrm{~m}$. & \multicolumn{2}{|c|}{ July 29} & \multicolumn{2}{|c|}{ July 30} & \multicolumn{2}{|c|}{ July 31} & \multicolumn{2}{|c|}{ August 1} & \multicolumn{2}{|c|}{ August 2} & \multicolumn{2}{|c|}{ August 3} \\
\hline $\begin{array}{c}2 \text { a.m. } \\
4 \\
6 \\
8 \\
10 \\
12 \text { n. } \\
2 \text { p.m. } \\
4 \\
6 \\
8 \\
10 \\
12 \mathrm{~m} .\end{array}$ & $\begin{array}{l}8.34 \\
8.27 \\
7.95 \\
8.32 \\
8.04 \\
7.97 \\
7.98 \\
7.93 \\
7.95 \\
7.98 \\
8.00 \\
8.00\end{array}$ & $\begin{array}{l}7,320 \\
7,180 \\
6,590 \\
7,280 \\
6,750 \\
6,630 \\
6,640 \\
6,550 \\
6,590 \\
6,640 \\
6,680 \\
6,680\end{array}$ & $\begin{array}{l}7.90 \\
7.72 \\
7.72 \\
7.74 \\
7.77 \\
7.78 \\
7.92 \\
7.92 \\
7.89 \\
7.89 \\
7.88 \\
7.57\end{array}$ & & $\begin{array}{l}7.15 \\
7.10 \\
7.25 \\
7.95 \\
7.83 \\
7.89 \\
7.80 \\
7.97 \\
7.77 \\
7.90 \\
7.83 \\
7.83\end{array}$ & $\begin{array}{l}\mathbf{5 , 2 2 0} \\
\mathbf{5 , 1 4 0} \\
5,380 \\
\mathbf{6 , 5 9 0} \\
\mathbf{6 , 3 7 0} \\
6,480 \\
6,320 \\
6,630 \\
6,270 \\
6,500 \\
6,370 \\
6,370\end{array}$ & $\begin{array}{l}5.85 \\
7.75 \\
7.82 \\
7.82 \\
7.77 \\
7.80 \\
7.80 \\
7.76 \\
7.78 \\
7.77 \\
7.79 \\
7.80\end{array}$ & $\begin{array}{l}3,340 \\
6,230 \\
6,360 \\
6,360 \\
6,270 \\
6,320 \\
6,320 \\
6,250 \\
6,280 \\
6,270 \\
6,300 \\
7,320\end{array}$ & $\begin{array}{l}7.28 \\
7.20 \\
7.33 \\
7.66 \\
7.73 \\
7.40 \\
7.70 \\
7.60 \\
7.77 \\
7.72 \\
7.72 \\
7.79\end{array}$ & \begin{tabular}{l}
$\ldots \ldots$ \\
$\mathbf{a} 5, \mathbf{8 5 0}$ \\
\hdashline \\
\hdashline \\
\\
\hdashline
\end{tabular} & $\begin{array}{l}7.79 \\
7.59 \\
6.20 \\
7.29 \\
7.29 \\
7.00 \\
7.72 \\
7.45 \\
6.78 \\
7.28 \\
7.10 \\
7.27\end{array}$ & $\begin{array}{l}0,300 \\
05 \\
\end{array}$ \\
\hline
\end{tabular}

Supplemental records.-July 17, 7 a.m., 0.70 ft.; 7 p.m., 2.86 ft.; 9 p.m., 6.60 ft.; July 18, 1 a.m., 3.60 ft.; $5: 30$ a.m., 0.82 ft.; $6: 30$ a.m., 2.04 ft.; 11 a.m., 7.13 ft.; 1 p.m., 6.30 ft.; 11 p.m., 0.68 ft.; July 19, 3 a.m., $2.46 \mathrm{ft} . ; 6: 30$ a.m., $1.88 \mathrm{ft}$.; $8: 30$ a.m., $4.60 \mathrm{ft} . ; 1$ p.m., $7.10 \mathrm{ft} . ; 3$ p.m., $7.24 \mathrm{ft}$.; 7 p.m. $2.51 \mathrm{ft}$., 11 p.m. 6.50 ft.; July 20, 11 a.m., 7.23 ft., 1 p.m., 7.10 ft., 7 p.m., 5.64 ft.; 9 p.m., 6.48 ft.; July 21, $12: 30$ a.m., 4.51 ft., 1,870 sec.-ft.; $6: 30$ a.m., $2.10 \mathrm{ft}$., 370 sec.-ft.; $11: 30$ a.m., 7.22 ft., 5,330 sec.-ft.; 1 p.m., 7.15 ft., 5.220 sec.-ft.-ft.; July 22,3 a.m., 12.49 ft., 17,500 sec.-ft.; 7 a.m., $12.38 \mathrm{ft}$., 17,100 see.-ft.; July 24, 6:30 a.m., 12.43 ft., 17,300 sec.-ft.; July 25, 6:30 a.m., 11.27 ft., 13,700 sec.-ft.; 11 a.m., $10.96 \mathrm{ft}$,, 13,000 sec.-ft.; 7 p.m., 10.53 ft., 11,900 sec.-ft.; July 27,7 a.m. 9.50 ft., 9,600 sec.-ft.; 1 p.m., 8.60 ft,, 7.810 sec.-ft.; 10:30 p.m., 7.96 ft., 6,610 sec.-ft.: July 28, 8:30 a.m., 10.10 ft., 10,900 sec.-ft.; July 31. 6:30 a.m., $8.01 \mathrm{ft} ., 6,700$ sec.-ft.; 11 p.m., $7.25 \mathrm{ft} ., 5,380$ sec.-ft.; Aug. 2, $11: 20$ a.m., $4.70 \mathrm{ft}$.; Aug. 3, $11: 20$ a.m., $4.80 \mathrm{ft}$.

ailean for the day.

\section{TENMITE RIVER MEAE GAYTORDSVIIIE, CONN.}

Locatron.-Lat. $41^{\circ} 39^{\prime} 35^{\prime \prime}$, long. $73^{\circ} 31^{\prime} 45^{\prime \prime}, 1$ mile upstream from ConnecticutNew York State line, 11/2 miles upstream from mouth, and 21/2 miles northwest of Gaylordsville, Litchfield County.

Drainage AREA.-204 square miles.

GAGE-HEIGHT RECORD.-Water-stage recorder graph.

Stage-discharge Relation,-Defined by current-meter measurements.

Maxima.-July 1938: Discharge, 5,660 second-feet 9 a.m. July 22 (gage height, 8.79 feet).

1929 to June 1938: Discharge, 10,200 second-feet Mar. 12, 1936 (gage height, 11.61 feet).

Remarks.-Flood discharge may be slightly affected by storage in several small ponds. 
Mean discharge, in second-feet, 1938

\begin{tabular}{|c|c|c|c|c|c|c|c|c|c|c|c|}
\hline Day & June & July & Aug. & Day & June & July & Aug. & Day & June & July & Aug. \\
\hline $\begin{array}{r}1 \\
2 \\
3 \\
4 \\
5 \\
6 \\
7 \\
8 \\
9 \\
10\end{array}$ & $\begin{array}{l}148 \\
140 \\
146 \\
148 \\
140 \\
134 \\
122 \\
163 \\
161 \\
130\end{array}$ & $\begin{array}{l}810 \\
688 \\
557 \\
453 \\
388 \\
330 \\
276 \\
250 \\
236 \\
330\end{array}$ & $\begin{array}{l}658 \\
880 \\
666 \\
522 \\
453 \\
416 \\
438 \\
416 \\
502 \\
529\end{array}$ & $\begin{array}{l}11 \\
12 \\
13 \\
14 \\
15 \\
16 \\
17 \\
18 \\
19 \\
20\end{array}$ & $\begin{array}{l}150 \\
658 \\
665 \\
522 \\
391 \\
304 \\
253 \\
210 \\
181 \\
159\end{array}$ & $\begin{array}{l}302 \\
377 \\
427 \\
343 \\
285 \\
236 \\
199 \\
180 \\
315 \\
397\end{array}$ & $\begin{array}{r}1,770 \\
1,730 \\
1,020 \\
810 \\
665 \\
572 \\
522 \\
514 \\
600 \\
460\end{array}$ & $\begin{array}{l}21 \\
22 \\
23 \\
24 \\
25 \\
26 \\
27 \\
28 \\
29 \\
30 \\
31\end{array}$ & $\begin{array}{r}140 \\
128 \\
171 \\
228 \\
148 \\
135 \\
896 \\
2,040 \\
1,700 \\
1,140\end{array}$ & $\begin{array}{r}1,980 \\
5,000 \\
3,540 \\
3,660 \\
2,600 \\
1,770 \\
1,420 \\
1,090 \\
938 \\
871 \\
702\end{array}$ & $\begin{array}{l}388 \\
336 \\
297 \\
261 \\
233 \\
210 \\
200 \\
185 \\
172 \\
165 \\
159\end{array}$ \\
\hline & & & & & & & & & $\begin{array}{r}388 \\
2.12\end{array}$ & $\begin{array}{r}998 \\
5.64\end{array}$ & $\begin{array}{r}540 \\
3.06\end{array}$ \\
\hline
\end{tabular}

Gage-height, in feet, and discharge, in second-feet, at indicated time, 1938

\begin{tabular}{|c|c|c|c|c|c|c|c|c|c|c|c|c|}
\hline \multirow{2}{*}{ Hour } & Feet & Sec.-ft. & Feet & Sec.-ft. & Feet & Sec.-ft. & Feet & Sec.-ft. & Feet & Sec. $-\mathrm{ft}$. & Feet & Sec.-ft. \\
\hline & \multicolumn{2}{|c|}{ July 17} & \multicolumn{2}{|c|}{ July 18} & \multicolumn{2}{|c|}{ July 19} & \multicolumn{2}{|c|}{ July 20} & \multicolumn{2}{|c|}{ July 21} & \multicolumn{2}{|c|}{ July 22} \\
\hline 2 a.m. & & & & & & & 2.71 & 468 & 2.29 & 320 & 8.34 & 5.070 \\
\hline & & & $1.7 \overline{8}$ & 179 & 1.99 & 230 & 2.68 & $\begin{array}{l}400 \\
457\end{array}$ & $\begin{array}{l}2.29 \\
2.29\end{array}$ & $\begin{array}{l}520 \\
320\end{array}$ & $\begin{array}{l}0.04 \\
8.39\end{array}$ & 5,140 \\
\hline 6 & 1.90 & 207 & & & & & & & 2.39 & 353 & 8.61 & 5,420 \\
\hline 8 & $\ldots$ & $\ldots \ldots$ & 1.77 & 176 & 2.13 & 270 & 2.58 & 420 & 2.79 & 498 & 8.77 & 5,630 \\
\hline 10 & & $\ldots \ldots$ & & & & & & & 3.74 & 930 & 8.76 & 5,620 \\
\hline $12 \mathrm{n}$. & 1.87 & 200 & 1.76 & 174 & 2.24 & 304 & 2.49 & 388 & 4.98 & 1,720 & 8.60 & 5,410 \\
\hline$\frac{2}{4}$ p.m. & $-\cdots \cdots$ & ----- & $\overline{7}$ & 176 & 38 & 340 & $-\overline{13}$ & 36 & 5.75 & 2,320 & 8.40 & 5,150 \\
\hline $\begin{array}{l}4 \\
6\end{array}$ & 1.83 & 190 & 1.78 & 170 & 2.38 & 349 & 2.43 & 366 & $\begin{array}{l}6.18 \\
6.73\end{array}$ & $\begin{array}{l}2,710 \\
3,240\end{array}$ & $\begin{array}{l}8.19 \\
7.98\end{array}$ & $\begin{array}{l}4,880 \\
4,630\end{array}$ \\
\hline 8 & $\ldots . .-$ & $-\ldots+\ldots$ & 1.80 & 183 & 2.54 & 405 & 2.38 & 349 & 7.62 & 4,190 & 7.81 & 4.420 \\
\hline 10 & $-7--\overline{0}$ & $---\overline{10}$ & $---\overline{0}$ & ---10 & $-\overline{0}-\overline{-}-$ & & $-\overline{0}$ & $-\overline{0}--$ & 8.01 & 4,660 & 7.64 & 4,220 \\
\hline $12 \mathrm{~m}$. & 1.80 & 183 & 1.89 & 205 & 2.70 & 464 & 2.32 & 330 & 8.02 & 4,670 & 7.47 & 4,030 \\
\hline
\end{tabular}

\begin{tabular}{|c|c|c|c|c|c|c|c|c|c|c|c|c|}
\hline \multirow[b]{2}{*}{2 a.m. } & \multicolumn{2}{|c|}{ July 23} & \multicolumn{2}{|c|}{ July 24} & \multicolumn{2}{|c|}{ July 25} & \multicolumn{2}{|c|}{ July 26} & \multicolumn{2}{|c|}{ July 27} & \multicolumn{2}{|c|}{ July 28} \\
\hline & 7.29 & 3,830 & 7.30 & 3,840 & & & & & 4.65 & 1,480 & & \\
\hline & 7.12 & 3,640 & 7.26 & 3,800 & 6.46 & 2,970 & 5.30 & 1,960 & 4.60 & 1,450 & 4.18 & 1,190 \\
\hline 6 & 6.98 & 3,490 & 7.25 & 3,780 & & & & & 4.55 & 1,420 & & \\
\hline 8 & 6.86 & 3,370 & 7.26 & 3,800 & 6.25 & 2,780 & 5.17 & 1,860 & 4.53 & 1,400 & 4.09 & 1,130 \\
\hline 10 & 6.72 & 3,230 & 7.25 & 3,780 & & & & & 4.60 & 1,450 & & \\
\hline $12 \mathrm{n}$. & 6.68 & 3,190 & 7.22 & 3,750 & 6.03 & 2,580 & 5.03 & 1,750 & 4.65 & 1,480 & 4.01 & 1,090 \\
\hline 2 p.m. & 6.69 & 3,200 & 7.19 & 3,720 & & & & & 4.66 & 1,490 & & \\
\hline & 6.78 & 3,290 & 7.12 & 3,640 & 5.82 & 2,390 & 4.91 & 1,670 & 4.61 & 1,460 & 3.92 & 1,030 \\
\hline 6 & 6.95 & 3,460 & 7.02 & 3,530 & & & & & 4.51 & 1,390 & & $\ldots$ \\
\hline 8 & 7.27 & 3,810 & 6.92 & 3,430 & 5.64 & 2,230 & 4.80 & 1,590 & 4.41 & 1,330 & 3.87 & 1,000 \\
\hline 10 & 7.42 & 3,970 & 6.81 & 3,320 & -ラー・ー & & $--\overline{-1}$ & $---5=--$ & 4.37 & $1,300^{\circ}$ & $---\overline{-}$ & $\cdots$ \\
\hline $12 \mathrm{~m}$. & 7.38 & 3,930 & 6.69 & 3,200 & 5.47 & 2,100 & 4.70 & 1,520 & 4.28 & 1,250 & 3.82 & 972 \\
\hline
\end{tabular}

\begin{tabular}{|c|c|c|c|c|c|c|c|c|c|c|c|c|}
\hline \multirow[b]{2}{*}{2 a.m. } & \multicolumn{2}{|c|}{ July 29} & \multicolumn{2}{|c|}{ July 30} & \multicolumn{2}{|c|}{ July 31} & \multicolumn{2}{|c|}{ August 1} & \multicolumn{2}{|c|}{ August 2} & \multicolumn{2}{|c|}{ August 3} \\
\hline & & & & & & & 3.21 & 670 & 3.43 & 775 & & \\
\hline & 3.79 & 955 & 3.77 & 945 & 3.37 & 745 & 3.18 & 656 & 3.49 & 805 & 3.36 & 740 \\
\hline 6 & $-2-2=-$ & $\cdots--\overline{0}=-$ & 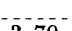 & $-+-\overline{0}$ & 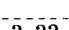 & $---\bar{z}=$ & .3 .19 & 660 & 3.54 & 830 & $-1-$. & - . \\
\hline 8 & 3.75 & 935 & 3.70 & 910 & 3.33 & 725 & 3.21 & 670 & 3.63 & 875 & 3.26 & 692 \\
\hline $\begin{array}{l}10 \\
12 \mathrm{n} .\end{array}$ & 3.71 & $-\overline{915}$ & $-\overline{3} . \overline{6}-$ & 870 & $3 . \overline{28}$ & 701 & $\begin{array}{l}3.20 \\
3.10\end{array}$ & $\begin{array}{l}665 \\
660\end{array}$ & $\begin{array}{l}3.73 \\
3.79\end{array}$ & 925 & 318 & $--\overline{656}$ \\
\hline 2 p.m. & 3.69 & 905 & & & & 101 & 3.18 & 656 & 3.81 & 966 & & $\ldots$ \\
\hline & 3.71 & 915 & 3.55 & 835 & 3.23 & 678 & 3.16 & 647 & 3.80 & 960 & 3.11 & 624 \\
\hline $\begin{array}{l}6 \\
8\end{array}$ & $37 \overline{7}$ & 015 & 348 & 800 & $3-10$ & 660 & & 638 & $\begin{array}{l}3.76 \\
3.69\end{array}$ & 940 & 303 & $--\overline{50}$ \\
\hline 10 & & $9 \pm 3$ & 0.40 & 000 & 0.19 & 000 & 3.17 & $\begin{array}{l}032 \\
652\end{array}$ & 3.61 & 865 & & \\
\hline $12 \mathrm{~m}$. & 3.81 & 966 & 3.41 & 765 & 3.15 & 642 & 3.30 & 710 & 3.51 & 815 & 2.97 & 568 \\
\hline
\end{tabular}

Supplemental records.-July 22, 9 a.m., $8.79 \mathrm{ft} ., 5,660 \mathrm{sec} .-\mathrm{ft}$.

ROCKY RIVER AT OUTIET OF CANDIEWOOD IAKE, NEAR NEW MILFORD, CONN.

Location.-Nonrecording gage and venturi meter, lat. $41^{\circ} 35^{\prime} 00^{\prime \prime}$, long. $73^{\circ}$ 26'00", at Rocky River plant of Connecticut Light \& Power Co., 11/2 miles northwest of New Milford, Litchfield County. 
Drainage AREA.-40.4 square miles.

GAGE-HEIGHT RECORD.-One lake-gage reading usually daily at about 8 a.m. Gage height at midnight computed from gage readings.

Stage-discharge RELATION.-Observed discharge computed from flow through venturi meters.

Remarks.-Power plant is of pumped-storage type. Candlewood Lake stores flow of Rocky River and water pumped from Housatonic River, into which tailrace of plant discharges. Plus sign before observed discharge indicates water passed from lake through generators into Housatonic River; minus sign indicates water pumped from Housatonic River into lake. Daily and monthly mean discharges adjusted for change in contents of Candlewood Lake. No corrections for evaporation from reservoir surface, which is about 8 square miles. Negative adjusted discharge figures indicate that evaporation and seepage from reservoir exceeded the inflow. Record based on data furnished by the Connecticut Light \& Power Co.

Discharge, in second-feet, and change in contents, in equivalent second-feet, 1938

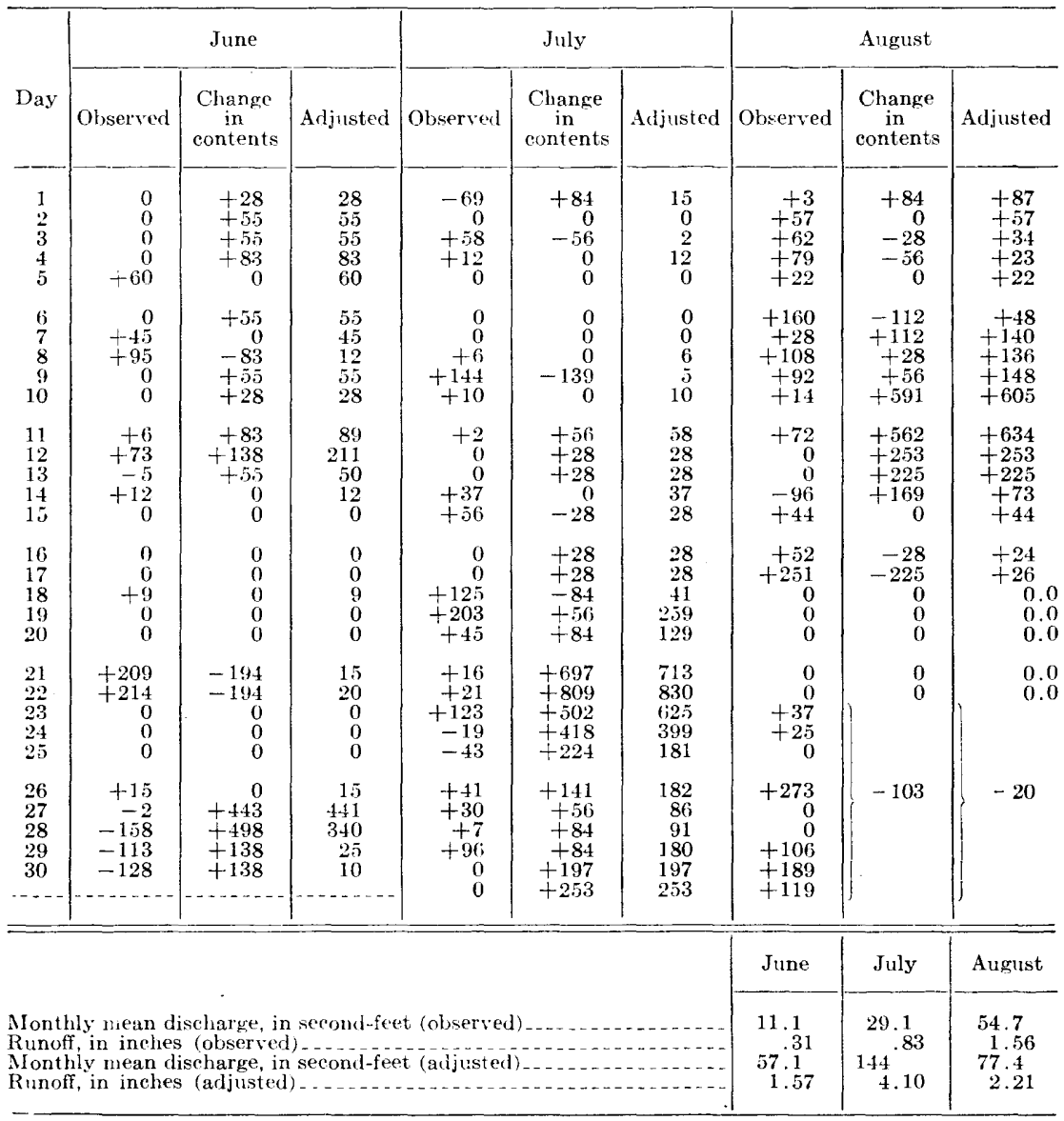


GTIIT RIVER MFAR IAMESVIIIR, CONA.

Location.-Lat. $41^{\circ} 31^{\prime} 14^{\prime \prime}$, long. $73^{\circ} 25^{\prime} 09^{\prime \prime}$, at highway bridge $1{ }^{\prime \prime} / 2$ miles south of Lanesville, Litchfield County, 2 miles upstream from mouth, and 4 miles south of New Milford. Datum of gage is 213.05 feet above mean sea level (general adjustment of 1929), levels by Corps of Engineers, U. S. Army.

Drainage AREA. - 68.5 square miles.

GAGE-Height RECORD.-Water-stage recorder graph except period Aug. 12-25 when record was based on range line and records for Tenmile River near Gaylordsville and Shepaug River near Roxbury.

Stage-discharge relation.-Defined by current-meter measurements.

Maxima.-July 1938: Discharge, 920 second-feet 10 to 12 p.m. July 24 (gage height, 7.64 feet).

1931 to June 1938: Discharge, 3,930 second-feet Mar. 12, 1936 (gage height, 10.58 feet).

Remarks.-Flood discharge not appreciably affected by storage or regulation.

Mean discharge, in second-feet, 1938

\begin{tabular}{|c|c|c|c|c|c|c|c|c|c|c|c|}
\hline Day & June & July & Aug. & Day & June & July & Aug. & Day & June & July & Aug. \\
\hline $\begin{array}{r}1 \\
2 \\
3 \\
4 \\
5 \\
6 \\
7 \\
8 \\
9 \\
10\end{array}$ & $\begin{array}{l}59 \\
54 \\
60 \\
64 \\
58 \\
69 \\
57 \\
66 \\
72 \\
54\end{array}$ & $\begin{array}{r}106 \\
83 \\
66 \\
53 \\
44 \\
40 \\
36 \\
34 \\
32 \\
35\end{array}$ & $\begin{array}{l}255 \\
191 \\
155 \\
129 \\
117 \\
190 \\
265 \\
275 \\
214 \\
260\end{array}$ & $\begin{array}{l}11 \\
12 \\
13 \\
14 \\
15 \\
16 \\
17 \\
18 \\
19 \\
20\end{array}$ & $\begin{array}{r}59 \\
108 \\
88 \\
80 \\
66 \\
57 \\
50 \\
45 \\
40 \\
35\end{array}$ & $\begin{array}{r}37 \\
38 \\
74 \\
73 \\
58 \\
49 \\
40 \\
37 \\
63 \\
183\end{array}$ & $\begin{array}{l}496 \\
950 \\
500 \\
400 \\
340 \\
300 \\
260 \\
260 \\
280 \\
220\end{array}$ & $\begin{array}{l}21 \\
22 \\
23 \\
24 \\
25 \\
26 \\
27 \\
28 \\
29 \\
30 \\
31\end{array}$ & $\begin{array}{r}34 \\
32 \\
\mathbf{3 3} \\
\mathbf{3 1} \\
29 \\
\mathbf{2 9} \\
98 \\
198 \\
250 \\
177\end{array}$ & $\begin{array}{l}260 \\
394 \\
515 \\
773 \\
802 \\
592 \\
456 \\
336 \\
272 \\
343 \\
380\end{array}$ & $\begin{array}{r}150 \\
120 \\
100 \\
90 \\
80 \\
70 \\
68 \\
64 \\
59 \\
56 \\
57\end{array}$ \\
\hline \multicolumn{9}{|c|}{$\begin{array}{l}\text { Monthly miean discharge, in second-feet } \\
\text { Runoff, in inches }\end{array}$} & $\begin{array}{l}71.7 \\
1.17\end{array}$ & $\begin{array}{r}203 \\
3.41\end{array}$ & $\begin{array}{r}225 \\
3.78\end{array}$ \\
\hline
\end{tabular}

Gage height, in feet, and discharge, in second-feet, at indicated time, 1938

\begin{tabular}{|c|c|c|c|c|c|c|c|c|c|c|c|c|}
\hline \multirow{2}{*}{ Hour } & Feet & See.-ft. & Feet & Sec.-ft & Feet & Sec. $-\mathrm{ft}$. & Feet & Sec.-ft. & Feet & Sec.-ft. & Feet & Sec.-ft. \\
\hline & \multicolumn{2}{|c|}{ July 17} & \multicolumn{2}{|c|}{ July 18} & \multicolumn{2}{|c|}{ July 19} & \multicolumn{2}{|c|}{ July 20} & \multicolumn{2}{|c|}{ July 21} & \multicolumn{2}{|c|}{ July 22} \\
\hline $\begin{array}{l}2 \text { a.m. } \\
4 \\
6 \\
8 \\
10 \\
12 \mathrm{n} . \\
2 \mathrm{p} . \mathrm{m} . \\
4 \\
6 \\
8 \\
10 \\
12 \mathrm{~m} .\end{array}$ & $\begin{array}{c}1.64 \\
1.59 \\
1.49 \\
1.44\end{array}$ & $\begin{array}{r}43 \\
41 \\
37 \\
35\end{array}$ & $\begin{array}{l}1.45 \\
1.45 \\
1.44 \\
1.55 \\
1.58 \\
1.51\end{array}$ & $\begin{array}{r}35 \\
35 \\
35 \\
39 \\
40 \\
37\end{array}$ & $\begin{array}{l}1.73 \\
1.92 \\
2.04 \\
2.02 \\
1.99 \\
2.18 \\
2.55 \\
2.71 \\
2.74\end{array}$ & $\begin{array}{r}56 \\
662 \\
61 \\
60 \\
69 \\
88 \\
98 \\
99\end{array}$ & $\begin{array}{l}2.86 \\
3.21 \\
3.59 \\
3.88 \\
4.07 \\
4.21 \\
4.30 \\
4.35 \\
4.39 \\
4.42 \\
4.44 \\
4.46\end{array}$ & $\begin{array}{l}106 \\
127 \\
152 \\
174 \\
190 \\
201 \\
209 \\
214 \\
217 \\
220 \\
222 \\
223\end{array}$ & $\begin{array}{l}4.48 \\
4.49 \\
4.49 \\
4.47 \\
4.43 \\
4.54 \\
4.87 \\
5.16 \\
5.30 \\
5.33 \\
5.34 \\
5.36\end{array}$ & $\begin{array}{l}225 \\
226 \\
226 \\
224 \\
221 \\
231 \\
262 \\
294 \\
311 \\
315 \\
316 \\
318\end{array}$ & $\begin{array}{l}5.41 \\
5.54 \\
5.67 \\
5.77 \\
5.84 \\
5.90 \\
5.96 \\
6.02 \\
6.07 \\
6.13 \\
6.17 \\
6.20\end{array}$ & $\begin{array}{l}324 \\
341 \\
360 \\
376 \\
388 \\
399 \\
410 \\
421 \\
430 \\
442 \\
150 \\
4.56\end{array}$ \\
\hline
\end{tabular}


Gage height in feet, and discharge, in second-feet, at indicated time, 1938-Continued

\begin{tabular}{|c|c|c|c|c|c|c|c|c|c|c|c|c|}
\hline \multirow{2}{*}{ Hour } & Feet & Sec.-ft. & Feet & Sec.-ft. & Feet & Sec.-ft. & Feet & Sec.-ft. & Feet & Sec.-ft. & Feet & Sec.-ft. \\
\hline & \multicolumn{2}{|c|}{ July 23} & \multicolumn{2}{|c|}{ July 24} & \multicolumn{2}{|c|}{ July 25} & \multicolumn{2}{|c|}{ July 26} & \multicolumn{2}{|c|}{ July 27} & \multicolumn{2}{|c|}{ July 28} \\
\hline \multirow{10}{*}{$\begin{array}{c}2 \text { a.m. } \\
4 \\
6 \\
8 \\
10 \\
12 \mathrm{n.} . \\
2 \mathrm{p} . \mathrm{m} . \\
4 \\
6 \\
8 \\
10 \\
12 \mathrm{~m} .\end{array}$} & 6.23 & 462 & 6.92 & 627 & 7.61 & 905 & & & & & & \\
\hline & 26 & & 6.97 & 6 & 7.57 & & & & & & & \\
\hline & 28 & & 7.03 & & 7.53 & 865 & 6.93 & 630 & 6.35 & 486 & 5.69 & 362 \\
\hline & 6 & & 7.11 & & $\begin{array}{r}7.47 \\
7.3\end{array}$ & 838 & & & & & & \\
\hline & & & 7.28 & 76 & 7.38 & 802 & 6.79 & 588 & 6.20 & 456 & 5.48 & 333 \\
\hline & .47 & & 7.40 & 81 & 7.33 & 782 & . & & . & & $\ldots .$. & 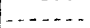 \\
\hline & & & 7.51 & 8 & 7.28 & 762 & 6 & 551 & 04 & 495 & $\overline{5}-\overline{8}$ & $=0$ \\
\hline & 6 & & $\begin{array}{l}7.08 \\
7.63\end{array}$ & 91 & 7.18 & 722 & 0.04 & & 0.04 & & 0.28 & \\
\hline & 6.84 & 602 & 7.64 & 920 & 7.13 & 702 & & & & & & \\
\hline & 6.88 & & 7.64 & 920 & 7.08 & 683 & 6.50 & 519 & 5.86 & 392 & 5.11 & 288 \\
\hline & \multicolumn{2}{|c|}{ July 29} & \multicolumn{2}{|c|}{ July 30} & \multicolumn{2}{|c|}{ July 31} & \multicolumn{2}{|c|}{ August 1} & \multicolumn{2}{|c|}{ August 2} & \multicolumn{2}{|c|}{ August 3} \\
\hline \multicolumn{13}{|l|}{$\frac{2}{4} \mathrm{a} \cdot \mathrm{m}}$. \\
\hline 6 & 4.99 & 275 & 5.28 & 309 & 5.93 & 404 & 5.04 & 280 & 4.22 & 202 & 3.74 & 163 \\
\hline \multirow{6}{*}{$\begin{array}{l}10 \\
12 \mathrm{n} . \\
2 \mathrm{p.m} . \\
4 \\
6 \\
8 \\
10 \\
12 \mathrm{~m} .\end{array}$} & & & & & & & & & & & & \\
\hline & 4.90 & 265 & 5.57 & $3 \overline{4} 5$ & 5.87 & 394 & 4.72 & 247 & 4.09 & 191 & 3.61 & 154 \\
\hline & & & & & & & & & & & & \\
\hline & 4.87 & 262 & 5.78 & 378 & 5.68 & 361 & 4.49 & 226 & 3.94 & 179 & 3.48 & $14 \overline{5}$ \\
\hline & & & & & & & & & & & & \\
\hline & 5.04 & 280 & 5.89 & 397 & 5.38 & 321 & 4.34 & 213 & 3.85 & 172 & 3.43 & 141 \\
\hline
\end{tabular}

supplemental records.-July 19,5 p.m., $1.99 \mathrm{ft} ., 60$ sec.-ft.

\section{SHPPAUG RIVER AT OUTTET OF SHFPAUG REgERVOTR, AT WOODVIIIE, CONA.}

LOCATION.-Nonrecording gages at dam at outlet of Shepaug Reservoir, lat. $41^{\circ} 43^{\prime} 16^{\prime \prime}$, long. $73^{\circ} 17^{\circ} 40^{\prime \prime}, 1$ mile north of Woodville, Litchfield County, and 3 miles upstream from Bantam River.

Drainage area. - 38.0 square miles.

GAGE-HEIGHT RECORD.-One reservoir gage reading daily at noon; gage height at midnight determined from graph constructed from gage readings.

Stage-discharge Relation.-Observed discharge computed from flow over spillway and through fountain for time when reservoir gage was read. During periods of rapid change in discharge, mean daily discharge computed from graphs constructed from determinations of discharge at noon and records for stations near Roxbury, Pomperaug River at Southbury, and Naugatuck River near Thomaston.

Maxima.-July 1938: Discharge, 2,400 second-feet about 8 p.m. July 21, from graph developed from noon determinations of discharge and records for adjacent stations.

1935 to June 1938: Discharge, 4,100 second-feet Jan. 25, 1938, from graph of noon determinations of discharge and record for station near Roxbury.

Remarks.-Daily and monthly mean discharges adjusted for change in contents of Shepaug Reservoir and diversion to Naugatuck River drainage through Morris Reservoir. No corrections for evaporation from reservoir surface. Minimum flow of 2.35 second-feet maintained below reservoir at all times. Basic data furnished by Bureau of Engineering, City of Waterbury. 
Discharge, in second-feet, and change in contents, in equivalent second-feet, 1938

\begin{tabular}{|c|c|c|c|c|c|c|c|c|c|}
\hline \multirow[b]{2}{*}{ Day } & \multicolumn{3}{|c|}{ June } & \multicolumn{3}{|c|}{ July } & \multicolumn{3}{|c|}{ Auguist } \\
\hline & Observed & $\begin{array}{c}\text { Change } \\
\text { in } \\
\text { contents }\end{array}$ & Adjusted & Observed & $\begin{array}{l}\text { Change } \\
\text { in } \\
\text { contents }\end{array}$ & Adjusted & Observed & $\begin{array}{l}\text { Change } \\
\text { in } \\
\text { contents }\end{array}$ & Adjusted \\
\hline $\begin{array}{l}1 \\
2 \\
3 \\
4 \\
5\end{array}$ & $\begin{array}{l}31 \\
29 \\
35 \\
42 \\
35\end{array}$ & $\begin{array}{r}-1 \\
0 \\
+2 \\
0 \\
-1\end{array}$ & $\begin{array}{l}30 \\
29 \\
37 \\
42 \\
34\end{array}$ & $\begin{array}{r}90 \\
1.11 \\
69 \\
51 \\
44\end{array}$ & $\begin{array}{r}0 \\
-2 \\
-8 \\
-3 \\
-1\end{array}$ & $\begin{array}{r}90 \\
139 \\
61 \\
48 \\
43\end{array}$ & $\begin{array}{r}95 \\
128 \\
90 \\
35 \\
23\end{array}$ & $\begin{array}{r}0 \\
-1 \\
-9 \\
a+4 \\
a+60\end{array}$ & $\begin{array}{r}95 \\
127 \\
81 \\
39 \\
83\end{array}$ \\
\hline $\begin{array}{r}6 \\
7 \\
8 \\
9 \\
10\end{array}$ & $\begin{array}{l}31 \\
26 \\
44 \\
46 \\
26\end{array}$ & $\begin{array}{l}-1 \\
+2 \\
+3 \\
-3 \\
-2\end{array}$ & $\begin{array}{l}30 \\
28 \\
47 \\
43 \\
24\end{array}$ & $\begin{array}{c}38 \\
18 \\
13 \\
9.8 \\
38\end{array}$ & $\begin{array}{r}-4 \\
a+4 \\
a+10 \\
a+19 \\
a+18\end{array}$ & $\begin{array}{l}34 \\
22 \\
23 \\
29 \\
56\end{array}$ & $\begin{array}{r}42 \\
202 \\
138 \\
125 \\
79\end{array}$ & $\begin{array}{r}a+17 \\
+17 \\
-5 \\
-5 \\
-5\end{array}$ & $\begin{array}{r}59 \\
219 \\
133 \\
120 \\
74\end{array}$ \\
\hline $\begin{array}{l}11 \\
12 \\
13 \\
14 \\
15\end{array}$ & $\begin{array}{r}29 \\
263 \\
128 \\
92 \\
57\end{array}$ & $\begin{array}{r}+3 \\
+21 \\
-7 \\
-6 \\
-6\end{array}$ & $\begin{array}{r}32 \\
284 \\
121 \\
86 \\
51\end{array}$ & $\begin{array}{l}33 \\
38 \\
40 \\
28 \\
24\end{array}$ & $\begin{array}{r}0 \\
+1 \\
-1 \\
-2 \\
-1\end{array}$ & $\begin{array}{l}33 \\
39 \\
39 \\
26 \\
23\end{array}$ & $\begin{array}{r}700 \\
473 \\
224 \\
148 \\
84\end{array}$ & $\begin{array}{r}+56 \\
-25 \\
-13 \\
-10 \\
-5\end{array}$ & $\begin{array}{r}756 \\
448 \\
211 \\
138 \\
79\end{array}$ \\
\hline $\begin{array}{l}16 \\
17 \\
18 \\
19 \\
20\end{array}$ & $\begin{array}{l}37 \\
29 \\
28 \\
24 \\
20\end{array}$ & $\begin{array}{r}-3 \\
-1 \\
0 \\
-1 \\
-2\end{array}$ & $\begin{array}{l}34 \\
28 \\
28 \\
23 \\
18\end{array}$ & $\begin{array}{l}20 \\
6.9 \\
18 \\
63 \\
90\end{array}$ & $\begin{array}{r}-3 \\
a+9 \\
a+23 \\
+26 \\
-17\end{array}$ & $\begin{array}{l}17 \\
16 \\
41 \\
89 \\
73\end{array}$ & $\begin{array}{l}84 \\
76 \\
67 \\
98 \\
62\end{array}$ & $\begin{array}{r}-1 \\
-1 \\
+2 \\
0 \\
-5\end{array}$ & $\begin{array}{l}83 \\
75 \\
69 \\
98 \\
57\end{array}$ \\
\hline $\begin{array}{l}21 \\
22 \\
23 \\
24 \\
25\end{array}$ & $\begin{array}{c}11 \\
8.8 \\
12 \\
36 \\
24\end{array}$ & $\begin{array}{r}a+6 \\
a+8 \\
a+14 \\
a+12 \\
a+4\end{array}$ & $\begin{array}{l}17 \\
17 \\
26 \\
48 \\
28\end{array}$ & $\begin{array}{r}979 \\
1310 \\
918 \\
820 \\
416\end{array}$ & $\begin{array}{l}+99 \\
-37 \\
+14 \\
-27 \\
-14\end{array}$ & $\begin{array}{r}1080 \\
1270 \\
932 \\
793 \\
402\end{array}$ & $\begin{array}{l}49 \\
40 \\
37 \\
26 \\
26\end{array}$ & $\begin{array}{l}-2 \\
-1 \\
-2 \\
-1 \\
-1\end{array}$ & $\begin{array}{l}47 \\
39 \\
35 \\
25 \\
25\end{array}$ \\
\hline \multirow[t]{2}{*}{$\begin{array}{l}26 \\
27 \\
28 \\
29 \\
30 \\
31\end{array}$} & $\begin{array}{r}11 \\
135 \\
522 \\
250 \\
135\end{array}$ & $\begin{array}{r}a+19 \\
a+41 \\
-2 \\
-17 \\
-11\end{array}$ & $\begin{array}{r}30 \\
176 \\
520 \\
233 \\
124\end{array}$ & $\begin{array}{l}268 \\
191 \\
296 \\
156 \\
282 \\
135\end{array}$ & $\begin{array}{r}-10 \\
-5 \\
-4 \\
+24 \\
-20 \\
-10\end{array}$ & $\begin{array}{l}258 \\
186 \\
292 \\
180 \\
262 \\
125\end{array}$ & $\begin{array}{c}20 \\
13 \\
6.9 \\
14 \\
14 \\
18\end{array}$ & $\begin{array}{r}a 0 \\
a+12 \\
a+14 \\
a+3 \\
0 \\
+1\end{array}$ & $\begin{array}{l}20 \\
25 \\
21 \\
17 \\
14 \\
19\end{array}$ \\
\hline & & & & & & & June & July & August \\
\hline \multicolumn{7}{|c|}{$\begin{array}{l}\text { Monthly mean discharge, in second-feet (observed) } \\
\text { Runoff, in inches (observed) } \\
\text { Monthly mean discharge, in second-feet (adjusted) } \\
\text { Runoff, in inches (adjusted) }\end{array}$} & $\begin{array}{l}73.2 \\
2.15 \\
75.6 \\
2.22\end{array}$ & $\begin{array}{r}214 \\
6.49 \\
217 \\
6.58\end{array}$ & $\begin{array}{r}104 \\
3.16 \\
107 \\
3.25\end{array}$ \\
\hline
\end{tabular}

a Includes diversion for city of Waterbury municiral supply.

SHEPAUG RIVER NEAR ROXBURY, CONN.

Location.-Lat. $41^{\circ} 32^{\prime} 53^{\prime \prime}$, long. $73^{\circ} 19^{\prime} 51^{\prime \prime}$, at highway bridge 0.7 mile downstream from Roxbury Station, 1/1/4 miles southwest of Village of Roxbury, Litchfield County, and 2 miles upstream from Jacks Brook. Datum of gage is 282.07 feet above mean sea level (general adjustment of 1929).

Drainage AREA.-133 square miles.

GAGE-HEIGHT RECORD.-Water-stage recorder graph except period 4 p.m. July 21 to 1 a.m. July 22 when bead on float wire was caught. Graph for period of no gage-height record determined on basis of shape of graphs for previous peaks.

Stage-discharge RELATION.-Defined by current-meter measurements.

Maxima.-July 1938: Discharge, 3,600 second-feet 8 p.m. July 21 (gage height, 7.73 feet, from fragmentary record and shape of graphs of previous peaks).

1930 to June 1938: Discharge, 7,000 second-feet Mar. 12, 1936 (gage height, 10.77 feet). 
Remarks.-Flood discharge affected by storage in Shepaug Reservoir at Woodville (see p. 261) and in Bantam Lake (drainage area outlet, 33.2 square miles).

Mean discharge, in second-feet, 1938

\begin{tabular}{|c|c|c|c|c|c|c|c|c|c|c|c|}
\hline Day & June & July & Aug. & Day & June & July & Aug. & Day & June & July & Ang. \\
\hline $\begin{array}{r}1 \\
2 \\
3 \\
4 \\
5 \\
6 \\
7 \\
8 \\
9 \\
10\end{array}$ & $\begin{array}{l}130 \\
120 \\
150 \\
150 \\
135 \\
122 \\
108 \\
159 \\
143 \\
113\end{array}$ & $\begin{array}{l}294 \\
301 \\
265 \\
228 \\
199 \\
173 \\
143 \\
125 \\
117 \\
135\end{array}$ & $\begin{array}{l}542 \\
533 \\
448 \\
367 \\
294 \\
309 \\
454 \\
426 \\
416 \\
332\end{array}$ & $\begin{array}{l}11 \\
12 \\
13 \\
14 \\
1.5 \\
16 \\
17 \\
18 \\
19 \\
20\end{array}$ & $\begin{array}{l}164 \\
666 \\
446 \\
316 \\
234 \\
196 \\
173 \\
159 \\
145 \\
122\end{array}$ & $\begin{array}{r}135 \\
173 \\
167 \\
132 \\
125 \\
108 \\
89 \\
120 \\
165 \\
280\end{array}$ & $\begin{array}{r}1,900 \\
1,020 \\
660 \\
548 \\
467 \\
408 \\
363 \\
359 \\
351 \\
290\end{array}$ & $\begin{array}{l}21 \\
22 \\
23 \\
24 \\
25 \\
26 \\
27 \\
28 \\
29 \\
30 \\
31\end{array}$ & $\begin{array}{r}110 \\
92 \\
88 \\
88 \\
108 \\
99 \\
396 \\
810 \\
520 \\
359\end{array}$ & $\begin{array}{r}1,600 \\
2,360 \\
1,940 \\
1,980 \\
1,280 \\
970 \\
774 \\
1,560 \\
842 \\
833 \\
632\end{array}$ & $\begin{array}{r}248 \\
218 \\
199 \\
175 \\
153 \\
137 \\
117 \\
103 \\
99 \\
95 \\
88\end{array}$ \\
\hline $\begin{array}{l}\text { Mon } \\
\text { Run }\end{array}$ & $n$ in & - & & & & & & & $\begin{array}{r}221 \\
1.85\end{array}$ & $\begin{array}{r}589 \\
5.11\end{array}$ & $\begin{array}{r}391 \\
3.39\end{array}$ \\
\hline
\end{tabular}

Gage-height, in feet, and discharge, in second-feet, at indicated time, 1938

\begin{tabular}{|c|c|c|c|c|c|c|c|c|c|c|c|c|}
\hline \multirow{2}{*}{ Hour } & Feet & Sec.-ft. & Feet & Sec.-ft. & Feet & Sec.-ft. & Feet & Sec.-ft. & Feet & Sec.-ft. & Feet & Sec.-ft. \\
\hline & \multicolumn{2}{|c|}{ July 17} & \multicolumn{2}{|c|}{ July 18} & \multicolumn{2}{|c|}{ July 19} & \multicolumn{2}{|c|}{ July 20} & \multicolumn{2}{|c|}{ July 21} & \multicolumn{2}{|c|}{ July 22} \\
\hline 2 a.m. & & & 2.18 & 78 & & & & & 2.82 & 251 & 7.13 & 3,020 \\
\hline & 2.22 & 86 & 2.16 & 75 & 2.30 & 103 & 2.89 & 276 & 2.82 & 251 & 7.00 & 2,900 \\
\hline $\begin{array}{l}6 \\
8\end{array}$ & 2.33 & 110 & $\begin{array}{l}2.12 \\
2.25\end{array}$ & $\begin{array}{l}68 \\
92\end{array}$ & 248 & 148 & 294 & 294 & $\begin{array}{l}2.83 \\
2.75\end{array}$ & $\begin{array}{l}254 \\
228\end{array}$ & $\begin{array}{l}6.81 \\
6.52\end{array}$ & $\begin{array}{l}2,730 \\
2,480\end{array}$ \\
\hline 10 & & & 2.32 & 108 & & & & & 3.10 & 355 & 6.32 & 2,320 \\
\hline $12 \mathrm{n}$. & 2.28 & 99 & 2.23 & 88 & 2.43 & 135 & 2.91 & 283 & 3.53 & 538 & 6.22 & 2,240 \\
\hline 4 & 2.19 & 80 & 2.25 & 92 & 2.36 & 117 & 2.91 & 283 & 7.14 & 3,030 & 6.10 & 2,140 \\
\hline 6 & & & 2.83 & 254 & & & & & 7.52 & 3,400 & 6.00 & 2,060 \\
\hline $\begin{array}{r}8 \\
10\end{array}$ & 2.12 & 68 & 2.57 & 173 & $2.8 i$ & 258 & 2.89 & 276 & 7.73 & 3,600 & 5.83 & 1,920 \\
\hline $12 \mathrm{~m}$. & 2.18 & 78 & 2.39 & 125 & 2.90 & 279 & 2.82 & 251 & 7.42 & 3,300 & 5.58 & 1,750 \\
\hline
\end{tabular}

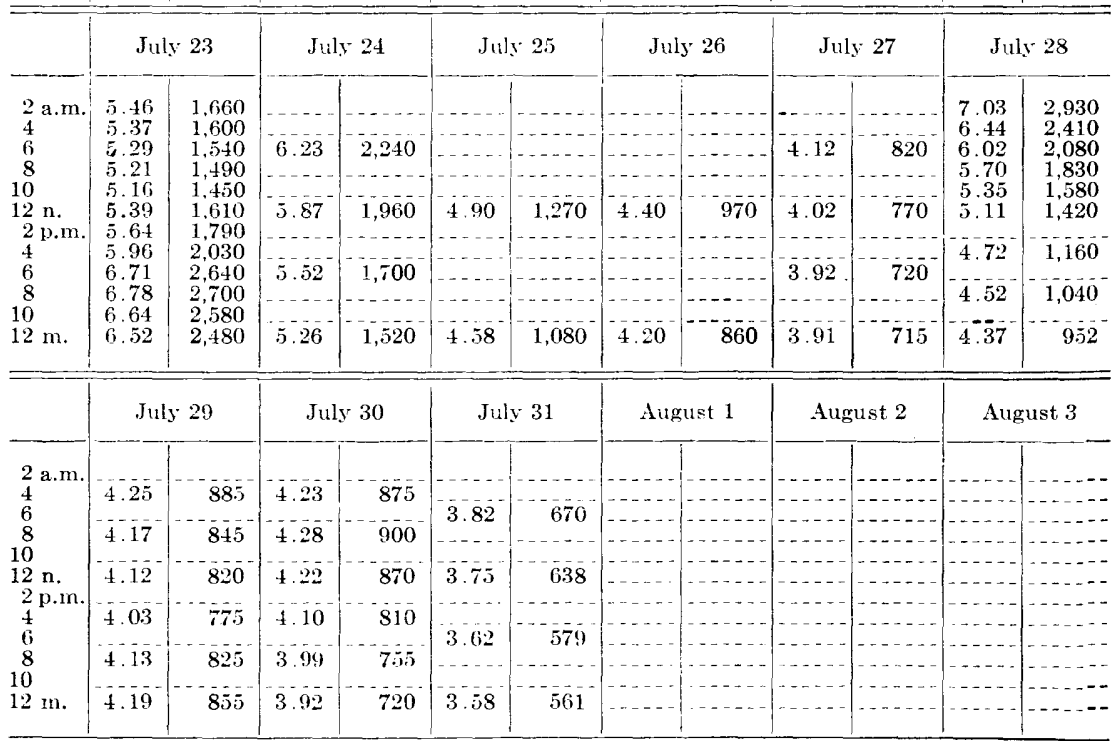

Supplemental records.-July $18,4: 30$ p.m., $3.03 \mathrm{ft} ., 328$ sec.-ft.; July 19,9 p.m., $3.01 \mathrm{ft} ., 320$ sec.-ft.; July 23,7 p.m., $6.90 \mathrm{ft}$., 2,810 see.-ft.; July $28,2: 20$ a.m., $7.09 \mathrm{ft}$., 2,980 sec.-ft. 
PONTERAUG RIVER AT BOUTHBURY, CONT.

Location.-Lat. $41^{\circ} 28^{\prime} 50^{\prime \prime}$, long. $73^{\circ} 13^{\prime} 30^{\prime \prime}$, 200 feet upstream from highway bridge, three-quarters of a mile west of Southbury, New Haven County, and $5 \frac{1}{2}$ miles upstream from mouth.

Drainage area.- 75.3 square miles.

Gage-height ReCord.-Water-stage recorder graph. Adjustments made for intake lag during part of day June $12,27,28,8$ to 9 p.m. July 19,12 n. to 1 p.m., 4 to 12 p.m. July 21, 7 to 12 p.m. July 23, 2 to 6 a.m. July 28, Aug. $8,9,11$. 3

Stage-discharge RELATION.--Defined by current-meter measurements below 1200 second-feet; extended to peak stage on basis of September 1938 peak flow determination at dam 2 miles below station.

Maxima.-July 1938: Discharge, 1,750 second-feet 9 p.m. July 21 (gage height, 7.7 feet, from floodmark).

1932 to June 1938: Discharge, 5,990 second-feet Mar. 12, 1936 (gage height, 14.13 feet, from floodmark), and 5,980 second-feet Jan, 25, 1938 (gage height, 14.12 feet, from floodmark).

Remarks.-Flood discharge not affected by artificial storage.

Mean discharge, in second-feet, 1938

\begin{tabular}{r|r|r|r|r|r|r|r|r|r|r|r}
\hline Day & June & July & Aug. & Day & June & July & Aug. & Day & June & July & Aug. \\
\hline 1 & 64 & 98 & 216 & 11 & 108 & 43 & 1,240 & 21 & 57 & 672 & 113 \\
2 & 58 & 92 & 202 & 12 & 532 & 73 & 467 & 22 & 52 & 1,060 & 104 \\
3 & 87 & 76 & 165 & 13 & 298 & 72 & 284 & 23 & 50 & 901 & 96 \\
4 & 78 & 64 & 149 & 14 & 196 & 54 & 222 & 24 & 48 & 1,030 & 86 \\
5 & 79 & 57 & 140 & 15 & 139 & 63 & 188 & 25 & 44 & 514 & 78 \\
6 & 72 & 50 & 142 & 16 & 113 & 48 & 167 & 26 & 47 & 360 & 72 \\
7 & 56 & 44 & 189 & 17 & 98 & 41 & 156 & 27 & 277 & 283 & 69 \\
8 & 98 & 43 & 196 & 18 & 89 & 133 & 160 & 28 & 417 & 792 & 65 \\
9 & 80 & 41 & 376 & 19 & 78 & 230 & 175 & 29 & 213 & 401 & 62 \\
10 & 59 & 48 & 182 & 20 & 66 & 362 & 132 & 30 & 129 & 409 & 58 \\
&
\end{tabular}

Gage-height, in feet, and discharge, in second-feet, at indicated time, 1938

\begin{tabular}{|c|c|c|c|c|c|c|c|c|c|c|c|c|}
\hline \multirow{2}{*}{ Hour } & Feet & Sec.-ft. & Feet & Sec.-ft. & Feet & Sec. $-\mathrm{ft}$. & Feet & Sec.-ft. & Feet & Sec.-ft. & Feet & Sec.-ft. \\
\hline & \multicolumn{2}{|c|}{ July 17} & \multicolumn{2}{|c|}{ July 18} & \multicolumn{2}{|c|}{ July 19} & \multicolumn{2}{|c|}{ July 20} & \multicolumn{2}{|c|}{ July 21} & \multicolumn{2}{|c|}{ July 22} \\
\hline $\begin{array}{c}2 \text { a.m. } \\
4 \\
6 \\
8 \\
10 \\
12 \mathrm{n} . \\
2 \text { p.m. } \\
4 \\
6 \\
8 \\
10 \\
12 \mathrm{n.} .\end{array}$ & $\begin{array}{l}3.05 \\
3.04 \\
3.03 \\
3.02 \\
3.02 \\
3.02 \\
3.02 \\
3.01 \\
3.00 \\
3.00 \\
3.00 \\
3.00\end{array}$ & $\begin{array}{l}44 \\
43 \\
42 \\
41 \\
41 \\
41 \\
41 \\
40 \\
39 \\
39 \\
39 \\
39\end{array}$ & $\begin{array}{l}3.00 \\
3.00 \\
2.99 \\
3.00 \\
3.03 \\
3.02 \\
3.01 \\
3.06 \\
3.16 \\
5.15 \\
5.12 \\
4.70\end{array}$ & $\begin{array}{r}39 \\
39 \\
38 \\
39 \\
42 \\
41 \\
40 \\
44 \\
55 \\
502 \\
490 \\
355\end{array}$ & $\begin{array}{l}4.40 \\
4.20 \\
+.05 \\
3.94 \\
3.86 \\
3.83 \\
3.84 \\
3.87 \\
3.97 \\
4.30 \\
4.67 \\
5.40\end{array}$ & $\begin{array}{l}276 \\
229 \\
196 \\
175 \\
160 \\
154 \\
156 \\
162 \\
180 \\
250 \\
350 \\
600\end{array}$ & $\begin{array}{l}5.45 \\
5.11 \\
4.82 \\
4.72 \\
4.69 \\
4.62 \\
4.54 \\
4.46 \\
4.37 \\
4.32 \\
4.25 \\
4.17\end{array}$ & $\begin{array}{l}620 \\
487 \\
391 \\
361 \\
352 \\
333 \\
311 \\
291 \\
269 \\
257 \\
240 \\
222\end{array}$ & $\begin{array}{l}4.11 \\
4.06 \\
4.01 \\
3.97 \\
3.99 \\
4.11 \\
4.43 \\
5.90 \\
7.40 \\
7.67 \\
7.62 \\
7.13\end{array}$ & $\begin{array}{r}209 \\
199 \\
188 \\
180 \\
184 \\
210 \\
284 \\
820 \\
1,550 \\
1,700 \\
1,700 \\
1,400\end{array}$ & $\begin{array}{l}6.72 \\
6.56 \\
6.80 \\
6.96 \\
6.88 \\
6.47 \\
6.16 \\
6.06 \\
5.97 \\
6.02 \\
5.93 \\
5.70\end{array}$ & $\begin{array}{r}1,210 \\
1,130 \\
1,250 \\
1,130 \\
1,290 \\
1,080 \\
937 \\
892 \\
852 \\
874 \\
834 \\
730\end{array}$ \\
\hline
\end{tabular}


Gage height in jeet, and discharge, in second-feet, at indicated time, 1938-Continued

\begin{tabular}{|c|c|c|c|c|c|c|c|c|c|c|c|c|}
\hline \multirow[b]{2}{*}{ Hour } & Feei & Sec.-ft. & Feet & Sec.-ft. & Feet & Sec, $-\mathrm{ft}$. & Feet & Sec.-ft. & Feet & Sec.-ft. & Feet & Sec.-ft. \\
\hline & \multicolumn{2}{|c|}{ July 23} & \multicolumn{2}{|c|}{ July 24} & \multicolumn{2}{|c|}{ July 25} & \multicolumn{2}{|c|}{ July 26} & \multicolumn{2}{|c|}{ July 27} & \multicolumn{2}{|c|}{ July 28} \\
\hline $\begin{array}{c}2 \text { a.m. } \\
4 \\
t \\
8 \\
10 \\
12 \mathrm{n} . \\
2 \\
4 \\
4 \\
6 \\
8 \\
10 \\
12 \mathrm{nt} .\end{array}$ & $\begin{array}{l}5.54 \\
5.42 \\
5.32 \\
5.23 \\
5.26 \\
5.53 \\
5.82 \\
6.30 \\
6.74 \\
7.18 \\
7.48 \\
7.48\end{array}$ & $\begin{array}{r}658 \\
608 \\
568 \\
532 \\
544 \\
654 \\
784 \\
1,000 \\
1,220 \\
1,450 \\
1,600 \\
1,600\end{array}$ & $\begin{array}{l}7.20 \\
6.86 \\
6.69 \\
6.60 \\
6.48 \\
6.36 \\
6.18 \\
6.00 \\
5.86 \\
5.72 \\
5.61 \\
5.52\end{array}$ & $\begin{array}{r}1,460 \\
1,280 \\
1,200 \\
1,150 \\
1,090 \\
1,030 \\
946 \\
8655 \\
802 \\
739 \\
690 \\
649\end{array}$ & $\begin{array}{l}5.44 \\
5.37 \\
5.33 \\
5.27 \\
5.23 \\
5.18 \\
5.14 \\
5.08 \\
5.02 \\
4.95 \\
4.90 \\
4.86\end{array}$ & $\begin{array}{l}616 \\
588 \\
572 \\
548 \\
532 \\
513 \\
498 \\
476 \\
456 \\
432 \\
416 \\
404\end{array}$ & $\begin{array}{l}4.83 \\
4.81 \\
4.80 \\
4.78 \\
4.76 \\
4.74 \\
4.72 \\
4.68 \\
4.64 \\
4.58 \\
4.55 \\
4.52\end{array}$ & $\begin{array}{l}394 \\
388 \\
385 \\
379 \\
373 \\
367 \\
361 \\
349 \\
338 \\
322 \\
314 \\
306\end{array}$ & $\begin{array}{l}4.50 \\
4.49 \\
4.48 \\
4.48 \\
4.47 \\
4.45 \\
4.43 \\
4.41 \\
4.37 \\
4.32 \\
4.29 \\
4.35\end{array}$ & $\begin{array}{l}301 \\
298 \\
296 . \\
296 \\
294 \\
288 \\
284 \\
278 \\
269 \\
257 \\
250 \\
264\end{array}$ & $\begin{array}{l}4.70 \\
7.10 \\
7.22 \\
6.84 \\
6.30 \\
5.87 \\
5.62 \\
5.42 \\
5.26 \\
5.14 \\
5.08 \\
5.05\end{array}$ & $\begin{array}{r}360 \\
1,400 \\
1,450 \\
1,270 \\
1,000 \\
806 \\
694 \\
608 \\
544 \\
498 \\
476 \\
466\end{array}$ \\
\hline
\end{tabular}

\begin{tabular}{|c|c|c|c|c|c|c|c|c|c|c|c|c|}
\hline \multirow{5}{*}{$\begin{array}{l}2 \text { a.m. } \\
4 \\
6 \\
8\end{array}$} & \multicolumn{2}{|c|}{ July 29} & \multicolumn{2}{|c|}{ July 30} & \multicolumn{2}{|c|}{ July 31} & \multicolumn{2}{|c|}{ August 1} & \multicolumn{2}{|c|}{ August 2} & \multicolumn{2}{|c|}{ August 3} \\
\hline & 4.98 & 442 & 5.25 & 540 & 4.44 & 286 & 4.16 & 220 & 4.05 & 196 & 3.92 & 171 \\
\hline & 4.92 & 423 & 5.16 & 505 & 4.42 & 281 & 4.16 & 220 & 4.13 & 214 & 3.92 & 171 \\
\hline & 4.86 & 404 & 5.07 & 473 & 4.41 & 278 & 4.16 & 220 & 4.16 & 220 & 3.92 & 171 \\
\hline & 4.82 & 391 & 5.01 & 452 & 4.40 & 276 & 4.16 & 220 & 4. 16 & 220 & 3.92 & 171 \\
\hline 10 & 4.77 & 376 & 4.94 & 429 & 4.39 & 274 & 4.17 & 222 & 4.15 & 218 & 3.92 & 171 \\
\hline $12 \mathrm{n}$. & +.73 & 364 & 4.86 & 404 & 4.38 & 271 & 4.17 & 222 & 4.13 & 214 & 3.92 & 171 \\
\hline 2 p.m. & 4.70 & $35 \overline{5}$ & 4.79 & 382 & 4.36 & 266 & 4.16 & 220 & 4.10 & 207 & 3.91 & 169 \\
\hline 4 & 4.66 & 344 & 4.73 & 364 & 4.33 & 259 & 4.14 & 216 & 4.07 & 201 & 3.89 & 165 \\
\hline 6 & +.67 & 347 & 4.62 & 333 & 4.27 & 245 & 4.12 & 211 & 4.03 & 192 & 3.86 & 160 \\
\hline 8 & 4.84 & 397 & 4.55 & 314 & 4.23 & 236 & 4.10 & 207 & 3.98 & $18 \%$ & 3.82 & 152 \\
\hline 10 & 5.06 & 469 & 4.50 & 301 & 4.19 & 227 & 4.07 & 201 & $3.9 \overline{5}$ & 176 & 3.78 & 146 \\
\hline $12 \mathrm{~m}$. & 5.22 & 528 & 4.46 & 291 & 4.17 & 222 & 4.04 & 194 & 3.93 & 173 & 3.77 & 144 \\
\hline
\end{tabular}

Supplemental records.-July 18, 7 p.m., $4.45 \mathrm{ft}$., 288 sec.-ft.; 9 p.m., 5.24 ft., 536 sec.-ft.; July 20,1 a.m., 5.55 ft., 660 sec.-ft.; July 21,9 p.m., 7.70 ft., 1,750 sec.-ft.; July 23 , 11 p.m., 7.52 ft., 1,650 sec.-ft.; July 28,5 a.m., 7.27 ft., 1,500 sec.-ft.

MAUGATUCK RIVER NPAR THONABTON, CONA.

location.-Lat. $41^{\circ} 42^{\prime} 11^{\prime \prime}$, long. $73^{\circ} 03^{\prime} 56^{\prime \prime}$, at highway bridge half a mile upstream from Leadmine Brook and 2 miles north of Thomaston, Litchfield County. Datum of gage is 389.44 feet above mean sea level (general adjustment of 1929).

Drainage arEa.-71.9 square miles.

GAGE-HEIGHT RECORD.-Water-stage recorder graph.

StaGE-Discharge RELATION.-Defined by current-meter measurements.

Maxima.-July 1938: Discharge, 5,630 second-feet 6:20 p.m. July 21 (gage height, 8.57 feet).

1930 to June 1938: Discharge, 6,830 second-feet Jan. 25, 1938 (gage height, 9.57 feet).

Remarks.-Flood discharge slightly affected by storage in small ponds and reservoirs.

Mean discharge, in second-feet, 1938

\begin{tabular}{|c|c|c|c|c|c|c|c|c|c|c|c|}
\hline Day & June & July & Aug. & Day & June & July & Aug. & Day & June & July & Alig. \\
\hline $\begin{array}{r}1 \\
2 \\
3 \\
4 \\
5 \\
6 \\
7 \\
8 \\
9 \\
10\end{array}$ & $\begin{array}{l}55 \\
50 \\
68 \\
65 \\
64 \\
58 \\
49 \\
86 \\
66 \\
47\end{array}$ & $\begin{array}{r}99 \\
102 \\
81 \\
66 \\
58 \\
50 \\
40 \\
38 \\
36 \\
56\end{array}$ & $\begin{array}{r}141 \\
186 \\
128 \\
97 \\
84 \\
93 \\
149 \\
128 \\
192 \\
158\end{array}$ & $\begin{array}{l}11 \\
12 \\
13 \\
14 \\
15 \\
16 \\
17 \\
18 \\
19 \\
20\end{array}$ & $\begin{array}{r}118 \\
205 \\
211 \\
144 \\
82 \\
70 \\
60 \\
40 \\
35 \\
34\end{array}$ & $\begin{array}{r}64 \\
146 \\
137 \\
81 \\
64 \\
52 \\
46 \\
48 \\
129 \\
259\end{array}$ & $\begin{array}{r}1,090 \\
422 \\
199 \\
139 \\
108 \\
93 \\
88 \\
95 \\
100 \\
74\end{array}$ & $\begin{array}{l}21 \\
22 \\
23 \\
24 \\
25 \\
26 \\
27 \\
28 \\
29 \\
30 \\
31\end{array}$ & $\begin{array}{r}33 \\
33 \\
34 \\
49 \\
33 \\
33 \\
278 \\
794 \\
311 \\
148\end{array}$ & $\begin{array}{r}2,210 \\
1,710 \\
1,070 \\
962 \\
483 \\
320 \\
239 \\
212 \\
227 \\
301 \\
162\end{array}$ & $\begin{array}{l}62 \\
56 \\
51 \\
49 \\
44 \\
42 \\
39 \\
38 \\
36 \\
35 \\
35\end{array}$ \\
\hline \multicolumn{9}{|c|}{$\begin{array}{l}\text { Monthly mean discharge, in second-feet } \\
\text { Runof, in inches }\end{array}$} & $\begin{array}{r}112 \\
1.74\end{array}$ & $\begin{array}{r}308 \\
4.93\end{array}$ & $\begin{array}{r}137 \\
2.20\end{array}$ \\
\hline
\end{tabular}


Gage-height, in feet, and discharge, in second-feet, at indicated time, 1938

\begin{tabular}{|c|c|c|c|c|c|c|c|c|c|c|c|c|}
\hline \multirow{2}{*}{ Hour } & Feet & Sec.-ft. & Feet & Sec.-ft. & Fret & Sec.-ft. & Feet & Sec.ft. & Feet & Sec.-ft. & Feet & Sec.-ft. \\
\hline & \multicolumn{2}{|c|}{ July 17} & \multicolumn{2}{|c|}{ July 18} & \multicolumn{2}{|c|}{ July 19} & \multicolumn{2}{|c|}{ July 20} & \multicolumn{2}{|c|}{ July 21} & \multicolumn{2}{|c|}{ July 22} \\
\hline $\begin{array}{l}2 \mathrm{a} . \mathrm{m} . \\
4 \\
6 \\
8 \\
10 \\
12 \mathrm{n} . \\
2 \mathrm{p} . \mathrm{m} . \\
4 \\
6 \\
8 \\
10 \\
12 \mathrm{~m} .\end{array}$ & & & $\begin{array}{l}1.37 \\
1.37 \\
1.37 \\
1.38 \\
1.39 \\
1.38 \\
1.40 \\
1.49 \\
1.48 \\
1.46 \\
1.42 \\
1.42\end{array}$ & $\begin{array}{l}43 \\
43 \\
43 \\
44 \\
45 \\
44 \\
46 \\
58 \\
56 \\
54 \\
49 \\
49\end{array}$ & $\begin{array}{l}1.42 \\
1.45 \\
1.48 \\
1.56 \\
1.54 \\
1.61 \\
1.73 \\
1.78 \\
1.90 \\
2.00 \\
2.75 \\
2.73\end{array}$ & $\begin{array}{r}49 \\
52 \\
56 \\
68 \\
65 \\
76 \\
97 \\
106 \\
132 \\
156 \\
450 \\
440\end{array}$ & $\begin{array}{l}2.58 \\
2.50 \\
2.39 \\
2.30 \\
2.23 \\
2.20 \\
2.17 \\
2.31 \\
2.29 \\
2.22 \\
2.17 \\
2.12\end{array}$ & $\begin{array}{l}366 \\
330 \\
284 \\
249 \\
224 \\
214 \\
205 \\
253 \\
246 \\
221 \\
205 \\
189\end{array}$ & $\begin{array}{l}2.06 \\
2.04 \\
2.03 \\
3.58 \\
3.71 \\
4.07 \\
6.40 \\
7.96 \\
8.54 \\
7.60 \\
6.10 \\
5.32\end{array}$ & $\begin{array}{r}172 \\
167 \\
164 \\
966 \\
1,060 \\
1,310 \\
3,300 \\
4,960 \\
5,600 \\
4,560 \\
3,000 \\
2,300\end{array}$ & $\begin{array}{l}5.00 \\
5.17 \\
5.25 \\
5.04 \\
4.77 \\
4.53 \\
4.36 \\
4.32 \\
4.17 \\
4.01 \\
3.86 \\
3.70\end{array}$ & $\begin{array}{l}2,040 \\
2,180 \\
2,240 \\
2,070 \\
1,860 \\
1,660 \\
1,530 \\
1,500 \\
1,380 \\
1,270 \\
1,160 \\
1,050\end{array}$ \\
\hline & \multicolumn{2}{|c|}{ July 23} & \multicolumn{2}{|c|}{ July 24} & \multicolumn{2}{|c|}{ July 25} & \multicolumn{2}{|c|}{ July 26} & \multicolumn{2}{|c|}{ July 27} & \multicolumn{2}{|c|}{ July 28} \\
\hline $\begin{array}{l}2 \mathrm{a} . \mathrm{m} . \\
4 \\
6 \\
3 \\
3 \\
10 \\
12 \mathrm{n} . \\
2 \mathrm{p.m} . \\
4 \\
6 \\
8 \\
10 \\
12 \mathrm{~m} .\end{array}$ & $\begin{array}{l}3.57 \\
3.47 \\
3.37 \\
3.29 \\
3.23 \\
3.36 \\
3.56 \\
3.65 \\
3.97 \\
4.54 \\
4.45 \\
4.26\end{array}$ & $\begin{array}{r}959 \\
889 \\
819 \\
764 \\
728 \\
812 \\
952 \\
1,020 \\
1,240 \\
1,670 \\
1,600 \\
1,450\end{array}$ & $\begin{array}{l}4.09 \\
3.98 \\
3.88 \\
3.76 \\
3.64 \\
3.54 \\
3.43 \\
3.34 \\
3.24 \\
3.16 \\
3.10 \\
3.04\end{array}$ & $\begin{array}{r}1,320 \\
1,250 \\
1,180 \\
1.090 \\
1.010 \\
938 \\
861 \\
798 \\
734 \\
686 \\
650 \\
614\end{array}$ & $\begin{array}{l}2.89 \\
2.81 \\
2.73 \\
2.64 \\
2.59\end{array}$ & $\begin{array}{r}524 \\
480 \\
440 \\
395\end{array}$ & $\begin{array}{l}2.55 \\
2.53 \\
2.50 \\
2.44 \\
2.37 \\
2.33\end{array}$ & $\begin{array}{r}352 \\
344 \\
330 \\
305\end{array}$ & $\begin{array}{l}2.31 \\
2.30 \\
2.29 \\
2.22\end{array}$ & $\begin{array}{r}249 \\
-246 \\
221 \\
214\end{array}$ & $\begin{array}{l}2.27 \\
2.23 \\
2.20\end{array}$ & $\begin{array}{l}238 \\
224 \\
214 \\
202 \\
183 \\
178\end{array}$ \\
\hline & Jul & & & & & & Au: & ust 1 & Aug & ist 2 & & ist 3 \\
\hline 2 a.m. & 2.07 & $1 \overline{7}$ & 2.62 & $385^{\circ}$ & 2.09 & 180 & $19 \overline{1}$ & 134 & 2.16 & 202 & 1.93 & $139^{-}$ \\
\hline & 2.07 & 175 & 2.50 & 330 & 2.06 & 172 & 1.93 & 139 & 2.19 & 211 & 1.91 & 134 \\
\hline $12 \mathrm{n}$. & 2.06 & .172 & 2.41 & 292 & 2.04 & 167 & 1.94 & 142 & 2.16 & 202 & $1.90^{\circ}$ & 132 \\
\hline & 2.05 & 170 & 2.29 & 246 & 2.00 & 156 & 1.93 & 139 & 2.10 & 183 & 1.88 & 128 \\
\hline & 2.71 & 430 & 2.20 & 214 & 1.92 & 137 & 1.91 & 134 & 1.99 & 154 & 1.80 & 110 \\
\hline & 2.82 & 486 & 2.13 & 192 & 1.91 & 134 & 2.08 & 178 & 1.96 & 146 & 1.76 & 102 \\
\hline
\end{tabular}

Supplemental reeords.-July $21, y$ a.m., $3.42 \mathrm{ft} ., 854$ sec.-ft.; $6: 20$ p.m., 8.57 ft., 5,630 sec.-ft.; July 23,7 p.m., 4.59 ft., 1,710 sec.-ft.; July 29,7 p.m., $2.08 \mathrm{ft}$., i 78 sec.-ft.

NAUGATUCK RIVER NEAR NAUGATUCK, CONN.

Location.-Lat. $41^{\circ} 28^{\prime} 15^{\prime \prime}$, long. $73^{\circ} 03^{\prime} 10^{\prime \prime}$, 0.2 mile upstream from Beacon Hill Brook, 1.3 miles downstream from Naugatuck, New Haven County, and 12 miles upstream from mouth. Datum of gage is 155.17 feet above mean sea level (general adjustment of 1929).

DRAINAGE AREA.—246 square miles.

Gage-height RECORD.-Water-stage recorder graph.

Stace-Discharge Relation.-Defined by current-meter measurements below 4,700 second-feet; extended logarithmically to peak stage on basis of records for flood of September 1938 at stations on Leadmine Brook near Thomaston and Naugatuck River near Thomaston. 
Maxima.-July 1938: Discharge, 7,760 second-feet 9 p.m. July 21 (gage height, 7.89 feet).

1918-24, 1928 to June 1938: Gage height, 12.08 feet Apr. 7, 1924 (discharge uncertain; previously published figure probably too low).

Flood of November 1927 reached a stage of about 14 feet (discharge, about 18,300 second-feet).

REMARKs.-Discharge affected by storage in Wigwam and Morris Reservoirs ( see record for Branch of Naugatuck River at outlet of Wigwam Reservoir, near Thomaston, Conn.) and diversion from Shepaug River at outlet of Shepaug Reservoir (p. 261).

Mean discharge, in second-feet, 1938

\begin{tabular}{|c|c|c|c|c|c|c|c|c|c|c|c|}
\hline Day & June & July & Aug. & Dav & June & July & Aug. & Day & June & July & Aug. \\
\hline $\begin{array}{r}1 \\
2 \\
3 \\
4 \\
5 \\
6 \\
7 \\
8 \\
9 \\
10\end{array}$ & $\begin{array}{l}221 \\
199 \\
239 \\
252 \\
262 \\
245 \\
209 \\
291 \\
286 \\
196\end{array}$ & $\begin{array}{l}350 \\
297 \\
252 \\
202 \\
182 \\
154 \\
136 \\
126 \\
113 \\
133\end{array}$ & $\begin{array}{r}642 \\
560 \\
461 \\
384 \\
354 \\
338 \\
454 \\
583 \\
1,060 \\
592\end{array}$ & $\begin{array}{l}11 \\
12 \\
13 \\
14 \\
15 \\
16 \\
17 \\
18 \\
19 \\
20\end{array}$ & $\begin{array}{l}230 \\
882 \\
761 \\
571 \\
367 \\
274 \\
248 \\
205 \\
179 \\
170\end{array}$ & $\begin{array}{r}138 \\
353 \\
317 \\
252 \\
199 \\
146 \\
119 \\
351 \\
707 \\
1,140\end{array}$ & $\begin{array}{r}2.860 \\
1,600 \\
822 \\
589 \\
485 \\
414 \\
388 \\
395 \\
422 \\
326\end{array}$ & $\begin{array}{l}21 \\
22 \\
23 \\
24 \\
25 \\
26 \\
27 \\
28 \\
29 \\
30 \\
31\end{array}$ & $\begin{array}{r}156 \\
138 \\
138 \\
152 \\
133 \\
141 \\
568 \\
1,750 \\
968 \\
513\end{array}$ & $\begin{array}{r}2,850 \\
4,050 \\
3,140 \\
3,380 \\
1,700 \\
1,130 \\
901 \\
2,130 \\
1,030 \\
1,120 \\
809\end{array}$ & $\begin{array}{l}270 \\
252 \\
231 \\
209 \\
187 \\
179 \\
165 \\
159 \\
156 \\
151 \\
151\end{array}$ \\
\hline \multicolumn{9}{|c|}{$\begin{array}{l}\text { Monthly mean discharge, in second-feet } \\
\text { Runoff, in inches }\end{array}$} & $\begin{array}{r}365 \\
1.65\end{array}$ & $\begin{array}{r}900 \\
4.22\end{array}$ & $\begin{array}{r}511 \\
2.40\end{array}$ \\
\hline
\end{tabular}

Gage-height, in feet, and discharge, in second-feet, at indicated time, 1938

\begin{tabular}{|c|c|c|c|c|c|c|c|c|c|c|c|c|}
\hline \multirow{2}{*}{ Hour } & Feet & Sec.-ft. & Feet & Sec.-ft. & Feet & Sec.-ft. & Feet & Sec.-ft. & Feet & Sec.-ft. & Feet & Sec.-ft. \\
\hline & \multicolumn{2}{|c|}{ July 17} & \multicolumn{2}{|c|}{ July 18} & \multicolumn{2}{|c|}{ July 19} & \multicolumn{2}{|c|}{ July 20} & \multicolumn{2}{|c|}{ July 21} & \multicolumn{2}{|c|}{ July 22} \\
\hline $\begin{array}{c}2 \mathrm{a} . \mathrm{m} . \\
4 \\
6 \\
8 \\
10 \\
12 \mathrm{n} . \\
2 \\
4 \\
6 \\
8 \\
8 \\
10 \\
12 \mathrm{~m} . \mathrm{m} .\end{array}$ & $\begin{array}{c}0.74 \\
-73 \\
.72 \\
.70 \\
.70 \\
.71 \\
.71 \\
.69 \\
.69 \\
.68 \\
.68 \\
.68\end{array}$ & $\begin{array}{l}128 \\
126 \\
123 \\
118 \\
118 \\
120 \\
120 \\
116 \\
116 \\
113 \\
113 \\
113\end{array}$ & $\begin{array}{r}0.72 \\
-68 \\
.67 \\
.89 \\
.80 \\
.88 \\
.95 \\
.93 \\
1.72 \\
2.34 \\
2.98 \\
2.75\end{array}$ & $\begin{array}{r}123 \\
113 \\
111 \\
167 \\
143 \\
165 \\
184 \\
179 \\
123 \\
820 \\
1,240 \\
1,080\end{array}$ & $\begin{array}{l}2.36 \\
2.17 \\
2.03 \\
1.93 \\
1.88 \\
1.77 \\
1.71 \\
1.74 \\
2.04 \\
2.52 \\
2.48 \\
2.70\end{array}$ & $\begin{array}{r}831 \\
721 \\
642 \\
589 \\
563 \\
509 \\
481 \\
495 \\
648 \\
927 \\
903 \\
1,040\end{array}$ & $\begin{array}{l}2.94 \\
3.26 \\
3.14 \\
3.13 \\
3.04 \\
2.88 \\
2.75 \\
2.64 \\
2.54 \\
2.49 \\
2.54 \\
2.46\end{array}$ & $\begin{array}{r}1,210 \\
1,470 \\
1.370 \\
1,360 \\
1,290 \\
1.170 \\
1,080 \\
1,000 \\
939 \\
909 \\
939 \\
891\end{array}$ & $\begin{array}{l}2.36 \\
2.26 \\
2.19 \\
2.14 \\
2.14 \\
2.24 \\
3.35 \\
5.00 \\
6.97 \\
7.75 \\
7.76 \\
6.84\end{array}$ & $\begin{array}{r}831 \\
773 \\
732 \\
704 \\
704 \\
761 \\
1,540 \\
3,310 \\
6,250 \\
7,520 \\
7,540 \\
6,040\end{array}$ & $\begin{array}{l}6.23 \\
6.06 \\
6.01 \\
5.89 \\
5.73 \\
5.50 \\
5.29 \\
5.13 \\
4.97 \\
4.90 \\
4.73 \\
4.54\end{array}$ & $\begin{array}{l}5,100 \\
4,840 \\
4,760 \\
4,580 \\
4,340 \\
4,000 \\
3,710 \\
3,480 \\
3,270 \\
3,180 \\
2,970 \\
2,740\end{array}$ \\
\hline $12 \mathrm{~m}$. & \multicolumn{2}{|c|}{ July 23} & \multicolumn{2}{|c|}{ July 24} & \multicolumn{2}{|c|}{ July 25} & \multicolumn{2}{|c|}{ July 26} & \multicolumn{2}{|c|}{ July 27} & \multicolumn{2}{|c|}{ July 28} \\
\hline $\begin{array}{c}2 \mathrm{a} . \mathrm{m} . \\
4 \\
6 \\
8 \\
10 \\
12 \mathrm{n} . \\
2 \mathrm{p} . \mathrm{m} . \\
4 \\
6 \\
8 \\
10 \\
12 \mathrm{~m} .\end{array}$ & $\begin{array}{l}4.35 \\
4.18 \\
4.02 \\
3.96 \\
4.69 \\
4.62 \\
4.71 \\
4.98 \\
5.50 \\
5.69 \\
5.94 \\
5.95\end{array}$ & $\begin{array}{l}2,520 \\
2,340 \\
2,180 \\
2,120 \\
2,920 \\
2,830 \\
2,940 \\
3,280 \\
4,000 \\
4,280 \\
4,660 \\
4,680\end{array}$ & $\begin{array}{l}5.98 \\
5.69 \\
5.51 \\
5.38 \\
5.20 \\
5.03 \\
4.83 \\
4.65 \\
4.47 \\
4.30 \\
4.14 \\
4.01\end{array}$ & $\begin{array}{l}4,720 \\
4,280 \\
4,020 \\
3,830 \\
3,580 \\
3,350 \\
3,090 \\
2,870 \\
2,660 \\
2,470 \\
2,300 \\
2,170\end{array}$ & $\begin{array}{l}3.90 \\
3.80 \\
3.71 \\
3.65 \\
3.59 \\
3.51 \\
3.43 \\
3.37 \\
3.27 \\
3.20 \\
3.13 \\
3.06\end{array}$ & $\begin{array}{l}2,060 \\
1,960 \\
1,870 \\
1,820 \\
1,760 \\
1,690 \\
1,620 \\
1,560 \\
1,480 \\
1,420 \\
1,360 \\
1,310\end{array}$ & $\begin{array}{l}3.00 \\
2.96 \\
2.93 \\
2.91 \\
2.90 \\
2.85 \\
2.81 \\
2.76 \\
2.71 \\
2.66 \\
2.61 \\
2.57\end{array}$ & $\begin{array}{r}1,260 \\
1,230 \\
1,200 \\
1,190 \\
1,180 \\
1,140 \\
1,120 \\
1,080 \\
1,050 \\
1,010 \\
982 \\
957\end{array}$ & $\begin{array}{l}2.53 \\
2.50 \\
2.48 \\
2.48 \\
2.48 \\
2.47 \\
2.43 \\
2.40 \\
2.34 \\
2.29 \\
2.38 \\
3.17\end{array}$ & $\begin{array}{r}933 \\
915 \\
903 \\
903 \\
903 \\
897 \\
873 \\
855 \\
820 \\
790 \\
843 \\
1,400\end{array}$ & $\begin{array}{l}3.40 \\
5.44 \\
5.02 \\
4.58 \\
4.20 \\
3.94 \\
3.71 \\
3.52 \\
3.35 \\
3.20 \\
3.09 \\
2.98\end{array}$ & $\begin{array}{l}1,590 \\
3,920 \\
3,340 \\
2,790 \\
2,360 \\
2,100 \\
1,870 \\
1,700 \\
1,540 \\
1,420 \\
1,330 \\
1,240\end{array}$ \\
\hline
\end{tabular}


Gage-height, in feet, and discharge, in second-feet, at indicated time, 1938-Continued

\begin{tabular}{|c|c|c|c|c|c|c|c|c|c|c|c|c|}
\hline \multirow{2}{*}{ Hour } & Feet & Sec.-ft. & Feet & Sec.-ft. & Feet & Sec..ft. & Feet & Sec.-ft. & Feet & Sec.-ft. & Feet & Sec.-ft. \\
\hline & \multicolumn{2}{|c|}{ July 29} & \multicolumn{2}{|c|}{ July 30} & \multicolumn{2}{|c|}{ July 31} & \multicolumn{2}{|c|}{ August 1} & \multicolumn{2}{|c|}{ August 2} & \multicolumn{2}{|c|}{ August, 3} \\
\hline 2 a.m. & 2.89 & 1,170 & & & & & & & & & & \\
\hline & 2.82 & 1,120 & 3.00 & 1,260 & 2.41 & 861 & 2.08 & 670 & 1.76 & 504 & 1.71 & 481 \\
\hline 8 & 2.72 & 1,050 & 2.98 & 1,240 & 2.36 & 831 & 2.06 & 659 & 1.89 & 568 & 1.67 & 462 \\
\hline $\begin{array}{l}10 \\
12 \mathrm{n} .\end{array}$ & $\begin{array}{l}2.70 \\
2.67\end{array}$ & $\begin{array}{l}1,040 \\
1,020\end{array}$ & 2.87 & 1,160 & 2.34 & 820 & 2.11 & 687 & 1.98 & 615 & 1.69 & 472 \\
\hline $2 \mathrm{p.m}$. & 2.62 & 988 & & & & & & & & & & \\
\hline $\begin{array}{l}4 \\
6\end{array}$ & $\begin{array}{l}2.58 \\
2.54\end{array}$ & $\begin{array}{l}963 \\
939\end{array}$ & 2.75 & 1,080 & 2.28 & 784 & 2.05 & 654 & 1.95 & 600 & 1.66 & 458 \\
\hline 8 & 60 & 975 & 2.65 & 1.010 & 2.21 & 744 & 1.88 & 563 & 1.86 & 553 & 1.60 & 431 \\
\hline $12 \mathrm{~m}$. & $\begin{array}{l}2.57 \\
2.62\end{array}$ & $\begin{array}{l}957 \\
988\end{array}$ & 2.52 & 927 & 2.14 & 704 & 1.81 & 528 & 1.78 & 514 & 1.54 & 405 \\
\hline
\end{tabular}

Supplemental records.-July 18, 5 p.m., $0.98 \mathrm{ft} ., 193$ sec.-ft.; 7 p.m., $1.50 \mathrm{ft} ., 388$ sec.-ft.; 9 p.m., 337 ; ft., 1,560 sec.-ft.; July 19, 7 p.m., 2.67 ft., 1,020 sec.-ft.; July 21,9 p.m., 7.89 ft., 7,760 sec.-ft.; July 23 , 9 a.m., 4.09 ft., 2,250 sec.-ft.; 10:30 p.m., $6.00 \mathrm{ft} ., 4,750$ sec.-ft.; July 28 , 1 a.m., $3.02 \mathrm{ft.,} 1,280$ sec.-ft..

3 a.m., $5.10 \mathrm{ft}$., 3,440 sec. $\mathrm{ft}$.

IEADMINE BEOOK NEAR THOMASTON, CONN.

Location.-Lat. $41^{\circ} 42^{\prime} 10^{\prime \prime}$, long. $73^{\circ} 03^{\prime} 36^{\prime \prime}$, at highway bridge half a mile upstream from mouth and $21 / 4$ miles northeast of Thomaston, Litchfield County. Datum of gage is 401.23 feet above mean sea level, (general adjustment of 1929).

Drainage area.-24.0 square miles.

GAGE-HEIGHT RECORD.-Water-stage recorder graph.

Stage-Discharce RELATION.-Defined by current-meter measurements below 500 second-feet; extended to peak stage on basis of logarithmic plotting and comparison with records for stations on Naugatuck River.

Maxima.-July 1938: Discharge, 2,270 second-feet 4:30 p.m. July 21 (gage height, 9.60 feet).

1930 to June 1938: Discharge, about 2,800 second-feet Sept. 17, 1934 (gage height, 11.2 feet; from floodmarks).

Remarks.-Flood discharge not affected by artificial storage.

Mean discharge, in second-feet, 1938

\begin{tabular}{|c|c|c|c|c|c|c|c|c|c|c|c|}
\hline Day & June & July & Aug. & Day & June & July & Aug. & Day & June & July & Aug. \\
\hline $\begin{array}{r}1 \\
2 \\
3 \\
4 \\
5 \\
6 \\
7 \\
8 \\
9 \\
10\end{array}$ & $\begin{array}{l}18 \\
16 \\
26 \\
22 \\
22 \\
19 \\
16 \\
32 \\
22 \\
16\end{array}$ & $\begin{array}{c}30 \\
27 \\
19 \\
15 \\
12 \\
9.7 \\
8.2 \\
7.1 \\
6.5 \\
11\end{array}$ & $\begin{array}{l}55 \\
66 \\
42 \\
33 \\
30 \\
29 \\
46 \\
38 \\
72 \\
48\end{array}$ & $\begin{array}{l}11 \\
12 \\
13 \\
14 \\
15 \\
16 \\
17 \\
18 \\
19 \\
20\end{array}$ & $\begin{array}{l}54 \\
82 \\
80 \\
49 \\
30 \\
22 \\
18 \\
17 \\
14 \\
11\end{array}$ & $\begin{array}{r}37 \\
96 \\
53 \\
28 \\
24 \\
17 \\
13 \\
17 \\
5.57 \\
173\end{array}$ & $\begin{array}{r}327 \\
127 \\
70 \\
50 \\
38 \\
33 \\
31 \\
31 \\
36 \\
26\end{array}$ & $\begin{array}{l}21 \\
22 \\
23 \\
24 \\
25 \\
26 \\
27 \\
28 \\
29 \\
30 \\
31\end{array}$ & $\begin{array}{r}8.7 \\
7.1 \\
11 \\
23 \\
13 \\
11 \\
118 \\
199 \\
92 \\
47\end{array}$ & $\begin{array}{r}798 \\
571 \\
366 \\
325 \\
170 \\
121 \\
96 \\
85 \\
75 \\
97 \\
59\end{array}$ & $\begin{array}{c}21 \\
19 \\
17 \\
15 \\
13 \\
11 \\
10 \\
9.3 \\
8.7 \\
7.9 \\
7.1\end{array}$ \\
\hline \multicolumn{9}{|c|}{$\begin{array}{l}\text { Monthly mean discharge, in second-feet } \\
\text { Runoff, in inches }\end{array}$} & $\begin{array}{l}37.2 \\
1.73\end{array}$ & $\begin{array}{r}110 \\
5.28\end{array}$ & $\stackrel{44}{2.11}$ \\
\hline
\end{tabular}


Gage-height, in feet, and discharge, in second-feet, at indicated time, 1938

\begin{tabular}{|c|c|c|c|c|c|c|c|c|c|c|c|c|}
\hline \multirow{2}{*}{ Hour } & Feet & Sec. $-\mathrm{ft}$. & Feet & Sec.-ft. & Feet & Sec.-ft. & Feet & Sec.-ft. & Feet & Sec.-ft. & Feet & Sec. $-\mathrm{ft}$. \\
\hline & \multicolumn{2}{|c|}{ July 17} & \multicolumn{2}{|c|}{ July 18} & \multicolumn{2}{|c|}{ July 19} & \multicolumn{2}{|c|}{ July 20} & \multicolumn{2}{|c|}{ July 21} & \multicolumn{2}{|c|}{ July 22} \\
\hline $\begin{array}{l}2 \mathrm{a.m} . \\
4 \\
6 \\
8 \\
10 \\
12 \mathrm{n} . \\
2 \mathrm{p.m} . \\
4 \\
6 \\
8 \\
10 \\
12 \mathrm{~m} .\end{array}$ & $\begin{array}{l}2.52 \\
2.51 \\
2.46 \\
2.44\end{array}$ & $\begin{array}{c}14 \\
13 \\
15 \\
11\end{array}$ & $\begin{array}{l}2.43 \\
2.43 \\
2.43 \\
2.45 \\
2.52 \\
2.56 \\
2.58 \\
2.79 \\
2.75 \\
2.77 \\
2.73 \\
2.71\end{array}$ & $\begin{array}{l}10 \\
10 \\
10 \\
11 \\
14 \\
15 \\
16 \\
26 \\
24 \\
24 \\
22 \\
22\end{array}$ & $\begin{array}{l}2.69 \\
2.68 \\
2.68 \\
2.71 \\
2.81 \\
2.83 \\
2.83 \\
2.85 \\
3.01 \\
3.48 \\
4.28 \\
4.48\end{array}$ & $\begin{array}{r}21 \\
20 \\
20 \\
20 \\
27 \\
28 \\
28 \\
29 \\
29 \\
40 \\
8.5 \\
207 \\
248\end{array}$ & $\begin{array}{l}4.40 \\
4.38 \\
4.26 \\
4.08 \\
3.94 \\
3.84 \\
3.80 \\
4.15 \\
4.08 \\
3.97 \\
3.86 \\
3.77\end{array}$ & $\begin{array}{l}231 \\
227 \\
203 \\
171 \\
147 \\
132 \\
126 \\
183 \\
171 \\
152 \\
135 \\
122\end{array}$ & $\begin{array}{l}3.70 \\
3.64 \\
3.63 \\
3.88 \\
4.30 \\
4.74 \\
7.20 \\
9.55 \\
9.30 \\
7.97 \\
6.98 \\
6.33\end{array}$ & $\begin{array}{r}112 \\
104 \\
103 \\
138 \\
211 \\
310 \\
1,180 \\
2,240 \\
2,120 \\
1,510 \\
1,090 \\
832\end{array}$ & $\begin{array}{l}6.21 \\
6.11 \\
5.99 \\
5.82 \\
5.65 \\
5.46 \\
5.29 \\
5.40 \\
5.31 \\
5.18 \\
5.04 \\
4.92\end{array}$ & $\begin{array}{l}784 \\
748 \\
706 \\
647 \\
588 \\
521 \\
467 \\
500 \\
473 \\
434 \\
392 \\
356\end{array}$ \\
\hline $12 \mathrm{~m}$ & \multicolumn{2}{|c|}{ July 23} & \multicolumn{2}{|c|}{ July 24} & \multicolumn{2}{|c|}{ July $2 \tilde{5}$} & \multicolumn{2}{|c|}{ July 26} & \multicolumn{2}{|c|}{ July 27} & \multicolumn{2}{|c|}{ July 28} \\
\hline $\begin{array}{l}2 \mathrm{am} . \mathrm{m} . \\
4 \\
6 \\
8 \\
10 \\
12 \mathrm{n} . \\
2 \mathrm{p.m} . \\
4 \\
6 \\
8 \\
10 \\
12 \mathrm{~m} .\end{array}$ & $\begin{array}{l}4.81 \\
4.71 \\
4.62 \\
4.55 \\
4.51 \\
4.78 \\
5.06 \\
5.11 \\
5.21 \\
5.32 \\
5.38 \\
5.34\end{array}$ & $\begin{array}{l}328 \\
302 \\
280 \\
264 \\
254 \\
320 \\
398 \\
413 \\
443 \\
476 \\
494 \\
482\end{array}$ & $\begin{array}{l}5.14 \\
4.96 \\
4.76 \\
4.57 \\
4.40 \\
4.29\end{array}$ & $\begin{array}{c}422 \\
368 \\
315 \\
268 \\
231 \\
209\end{array}$ & $\begin{array}{l}4.18 \\
4.08 \\
3.95\end{array}$ & $\begin{array}{c}171 \\
149 \\
138\end{array}$ & $\begin{array}{r}\overline{3.82} \\
3.79 \\
3.68 \\
3.63\end{array}$ & $\begin{array}{c}129 \\
125 \\
109 \\
103\end{array}$ & $\begin{array}{l}3.63 \\
3.62 \\
3.61 \\
3.61 \\
3.60 \\
3.59 \\
3.55 \\
3.51 \\
3.49 \\
3.46 \\
3.62 \\
3.60\end{array}$ & $\begin{array}{r}103 \\
102 \\
100 \\
100 \\
99 \\
98 \\
93 \\
88 \\
86 \\
83 \\
102 \\
99\end{array}$ & $\begin{array}{l}3.55 \\
3.50 \\
3.40 \\
3.34\end{array}$ & $\begin{array}{r}93 \\
87 \\
76 \\
70\end{array}$ \\
\hline
\end{tabular}

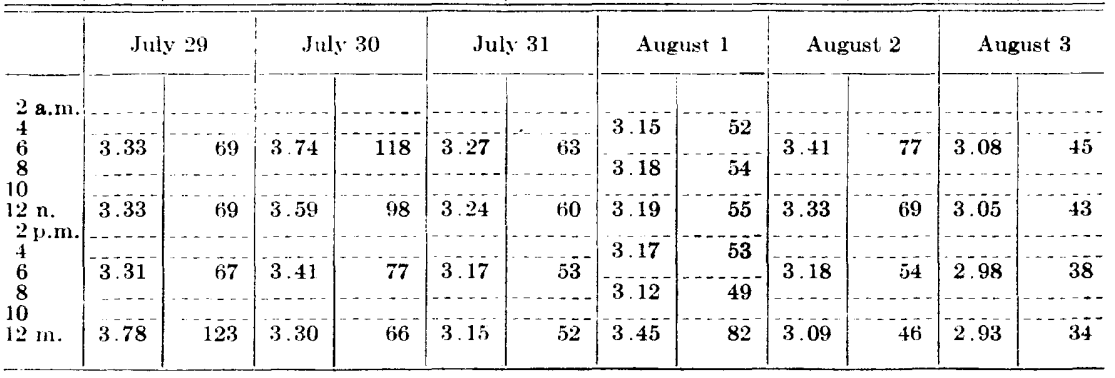

Supplemental records.-July 18, 3:30 p.m., 2.84 ft., 28 sec.-ft.; July 19, 5 p.m., 2.87 ft., 30 sec.-ft.; July 20, 3 p.m., 4.12 ft., 178 sec.-ft.; July 21,1 p.m., 5.80 ft., 640 sec.-ft.; 3 p.m., 8.40 ft., 1,700 sec.-ft.; $4: 30$ p.m., 9.60 ft., 2,270 sec.-ft.: 5 p.m., 9.57 ft., 2,260 sec.-ft.

BRATCE OF NAUGATUCK EIVER AT OUTIET OF WIGWAM RESBRVOM; NHAR THOMaston, cons.

Location.-Nonrecording gage and venturi meter at dam, lat. $41^{\circ} 39^{\prime} 45^{\prime \prime}$, long. $73^{\circ} 07^{\prime} 35^{\prime \prime}, 2 \frac{1}{2}$ miles west of Thomaston, Litchfield County, and 3 miles upstream from mouth.

Drainage area.-18.0 square miles.

GACE-HEIGHT RECORD.-Three reservoir gage readings daily; gage height at midnight determined from graph constructed from gage readings.

Stage-discharge Relation.-Observed discharge computed from flow over spillways and through venturi meter.

Maxima.-July 1938: Discharge observed, 2,380 second-feet 10:30 p.m. July 27.

REMARKs.-Daily and monthly mean discharges adjusted for change in contents of Wigwam and Morris Reservoirs and for diversions from Shepaug River Basin to Morris Reservoir. No corrections for evaporation from reservoir surfaces. Basic data furnished by Bureau of Engineering, City of Waterbury. 
Discharge, in second-feet, and change in contents, in equivalent second-feet, 1938

\begin{tabular}{|c|c|c|c|c|c|c|c|c|c|}
\hline \multirow[b]{2}{*}{ Day } & \multicolumn{3}{|c|}{ June } & \multicolumn{3}{|c|}{ July } & \multicolumn{3}{|c|}{ August } \\
\hline & Observed & $\begin{array}{l}\text { Change } \\
\text { in } \\
\text { contents }\end{array}$ & Adjusted & Observed & $\begin{array}{l}\text { Change } \\
\text { in } \\
\text { contents }\end{array}$ & Adjusted & Observed & $\begin{array}{l}\text { Change } \\
\text { in } \\
\text { contents }\end{array}$ & Adjusted \\
\hline $\begin{array}{r}1 \\
2 \\
3 \\
4 \\
5 \\
6 \\
7 \\
8 \\
9 \\
10 \\
11 \\
12 \\
13 \\
14 \\
15 \\
16 \\
17 \\
18 \\
19 \\
20 \\
21 \\
22 \\
23 \\
24 \\
25 \\
26 \\
27 \\
28 \\
29 \\
30 \\
31\end{array}$ & $\begin{array}{r}15 \\
13 \\
14 \\
15 \\
13 \\
12 \\
13 \\
17 \\
16 \\
13 \\
39 \\
70 \\
59 \\
34 \\
17 \\
15 \\
14 \\
12 \\
11 \\
11 \\
13 \\
13 \\
13 \\
12 \\
13 \\
11 \\
89 \\
134 \\
71 \\
24 \\
----\end{array}$ & $\begin{array}{r}-3 \\
-3 \\
+6 \\
+1 \\
-3 \\
-3 \\
+3 \\
+10 \\
-7 \\
-5 \\
+33 \\
-6 \\
-5 \\
-7 \\
-8 \\
-4 \\
-3 \\
-4 \\
-4 \\
-6 \\
a-7 \\
a-10 \\
a-5 \\
a-5 \\
a-10 \\
a-2 \\
+58 \\
-21 \\
-18 \\
-7 \\
---.\end{array}$ & $\begin{array}{r}12 \\
10 \\
20 \\
16 \\
10 \\
9 \\
16 \\
27 \\
9 \\
8 \\
72 \\
64 \\
54 \\
27 \\
9 \\
11 \\
11 \\
8 \\
7 \\
5 \\
6 \\
3 \\
8 \\
7 \\
3 \\
9 \\
147 \\
113 \\
53 \\
17 \\
----\end{array}$ & $\begin{array}{l}17 \\
16 \\
14 \\
11 \\
10 \\
12 \\
12 \\
12 \\
12 \\
11 \\
11 \\
17 \\
16 \\
14 \\
12 \\
13 \\
11 \\
27 \\
54 \\
75 \\
513 \\
347 \\
344 \\
226 \\
128 \\
78 \\
361 \\
632 \\
142 \\
147 \\
153\end{array}$ & $\begin{array}{r}-4 \\
-2 \\
-2 \\
-6 \\
-6 \\
-7 \\
a-8 \\
a-8 \\
a-10 \\
a-9 \\
+8 \\
+7 \\
-7 \\
-9 \\
-6 \\
-8 \\
a-4 \\
a+23 \\
+17 \\
-29 \\
+91 \\
-43 \\
+13 \\
-23 \\
-15 \\
-11 \\
+197 \\
-164 \\
-30 \\
-59 \\
-93\end{array}$ & $\begin{array}{r}13 \\
14 \\
12 \\
5 \\
4 \\
5 \\
4 \\
4 \\
2 \\
2 \\
19 \\
24 \\
9 \\
5 \\
6 \\
5 \\
7 \\
50 \\
71 \\
46 \\
604 \\
304 \\
357 \\
203 \\
113 \\
67 \\
558 \\
468 \\
112 \\
88 \\
60\end{array}$ & $\begin{array}{r}70 \\
17 \\
14 \\
13 \\
13 \\
14 \\
35 \\
25 \\
36 \\
24 \\
458 \\
118 \\
56 \\
41 \\
30 \\
31 \\
30 \\
37 \\
30 \\
19 \\
16 \\
15 \\
15 \\
13 \\
13 \\
13 \\
12 \\
11 \\
11 \\
13 \\
13\end{array}$ & $\begin{array}{c}-18 \\
+34 \\
+20 \\
a+12 \\
a+5 \\
a+3 \\
+2 \\
+1 \\
-5 \\
0 \\
+61 \\
-42 \\
-10 \\
-7 \\
-3 \\
-1 \\
-1 \\
+4 \\
-2 \\
-3 \\
-4 \\
-3 \\
-7 \\
-5 \\
-5 \\
a-7 \\
a-6 \\
a-6 \\
a-5 \\
-7 \\
-7\end{array}$ & $\begin{array}{r}52 \\
51 \\
34 \\
25 \\
18 \\
17 \\
37 \\
26 \\
31 \\
24 \\
519 \\
76 \\
46 \\
34 \\
27 \\
30 \\
29 \\
41 \\
28 \\
16 \\
12 \\
12 \\
8 \\
8 \\
5 \\
6 \\
6 \\
5 \\
6 \\
6 \\
6\end{array}$ \\
\hline & & & & & & & June & July & August \\
\hline $\begin{array}{l}\text { Mont } \\
\text { Runo } \\
\text { Mont } \\
\text { Runo }\end{array}$ & $\begin{array}{l}\text { hly mean d } \\
\text { fl, in inche } \\
\text { hly mean d } \\
\text { ff, in inche }\end{array}$ & $\begin{array}{l}\text { scharge, in } \\
\text { (observed } \\
\text { scharge, in } \\
\text { (adjusted }\end{array}$ & $\begin{array}{l}\text { second-fee } \\
\text { second-fee }\end{array}$ & et (observed & & & $\begin{array}{l}27.2 \\
1.68 \\
25.7 \\
1.60\end{array}$ & $\begin{array}{r}111 \\
7.11 \\
105 \\
6.72\end{array}$ & $\begin{array}{l}40.5 \\
2.59 \\
40.0 \\
2.56\end{array}$ \\
\hline
\end{tabular}

$a$ Does not include diversion from Sheraug Reservoir to Naugatuck River Basin.

\section{SAUGATUCK RIVER BASIN}

SAUGATUCK RIVER NEAR WESTPORT, CONAT.

Location.-Lat. $41^{\circ} 10^{\prime} 15^{\prime \prime}$, long. $73^{\circ} 22^{\prime} 00^{\prime \prime}$, on old Ford Road (Clinton Ave.), 400 feet downstream from West Branch of Saugatuck River, 600 feet downstream from dam of Dorr Co., and 2 miles north of Westport, Fairfield County.

Drainage area.-77.5 square miles.

GAGE-HEIGHT RECORD.-Water-stage recorder graph.

STAGE-DISCHARGE RELATION.-Defined by current-meter measurements below 1,700 second-feet; extended to peak stage on basis of September 1938 flood flow determination at Dorr Co's. dam.

Maxima.-July 1938: Discharge, 3,120 second-feet 2 a.m. July 24 (gage height, 8.77 feet).

1932 to June 1938: Discharge, 5,310 second-feet Mar. 12, 1936 (gage height, 11.30 feet).

Remarks.-Bridgeport Hydraulic Co. occasionally diverts the flow from 17 square miles of the Aspetuck River Basin. Water for diversion is stored in Aspetuck Reservoir and diverted by canal into Hemlocks Reservoir 
in Mill River Basin from which it is released for water supply. Daily and monthly mean discharges not adjusted for diversions. Run-off computations are based on total drainage area above station.

Mean discharge, in second-feet, 1938

\begin{tabular}{|c|c|c|c|c|c|c|c|c|c|c|c|}
\hline Day & June & July & Aug. & Day & June & July & Aug. & Day & June & July & Aug. \\
\hline $\begin{array}{r}1 \\
2 \\
3 \\
4 \\
5 \\
6 \\
7 \\
8 \\
9 \\
10\end{array}$ & $\begin{array}{r}64 \\
56 \\
69 \\
72 \\
70 \\
63 \\
53 \\
105 \\
85 \\
63\end{array}$ & $\begin{array}{r}157 \\
124 \\
97 \\
78 \\
62 \\
51 \\
43 \\
40 \\
39 \\
96\end{array}$ & $\begin{array}{l}210 \\
177 \\
142 \\
118 \\
116 \\
153 \\
206 \\
179 \\
159 \\
157\end{array}$ & $\begin{array}{l}11 \\
12 \\
13 \\
14 \\
15 \\
16 \\
17 \\
18 \\
19 \\
20\end{array}$ & $\begin{array}{r}90 \\
145 \\
130 \\
95 \\
72 \\
57 \\
51 \\
47 \\
44 \\
40\end{array}$ & $\begin{array}{r}62 \\
74 \\
339 \\
174 \\
168 \\
137 \\
87 \\
80 \\
146 \\
306\end{array}$ & $\begin{array}{r}670 \\
525 \\
290 \\
206 \\
155 \\
130 \\
115 \\
102 \\
99 \\
82\end{array}$ & $\begin{array}{l}21 \\
22 \\
23 \\
24 \\
25 \\
26 \\
27 \\
28 \\
29 \\
30 \\
31\end{array}$ & $\begin{array}{r}33 \\
31 \\
28 \\
28 \\
27 \\
28 \\
134 \\
584 \\
471 \\
248\end{array}$ & $\begin{array}{r}316 \\
524 \\
1,140 \\
2,210 \\
1,070 \\
681 \\
497 \\
391 \\
318 \\
302 \\
253\end{array}$ & $\begin{array}{l}70 \\
62 \\
57 \\
52 \\
47 \\
44 \\
43 \\
41 \\
39 \\
35 \\
33\end{array}$ \\
\hline \multicolumn{9}{|c|}{$\begin{array}{l}\text { Monthly mean discharge, in second-feet } \\
\text { Runoff, in inches }\end{array}$} & $\begin{array}{r}103 \\
1.48\end{array}$ & $\begin{array}{r}325 \\
4.83\end{array}$ & 2.176 \\
\hline
\end{tabular}

Gage-height, in feet, and discharge, in second-feet, at indicated time, 1938

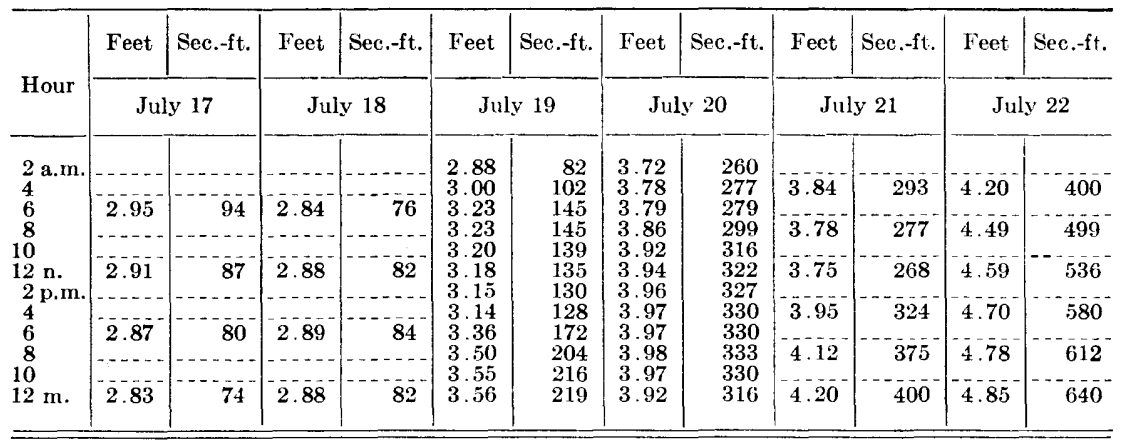

\begin{tabular}{|c|c|c|c|c|c|c|c|c|c|c|c|c|}
\hline \multirow[b]{2}{*}{$\begin{array}{c}2 \text { a.m. } \\
4 \\
6 \\
8 \\
10 \\
12 \mathrm{n} . \\
2 \mathrm{p.m} . \\
4 \\
6 \\
8 \\
10 \\
12 \mathrm{~m} .\end{array}$} & \multicolumn{2}{|c|}{ July 23} & \multicolumn{2}{|c|}{ July 24} & \multicolumn{2}{|c|}{ July 25} & \multicolumn{2}{|c|}{ July 26} & \multicolumn{2}{|c|}{ July 27} & \multicolumn{2}{|c|}{ July 28} \\
\hline & $\begin{array}{l}4.85 \\
4.81 \\
4.78 \\
4.75 \\
4.81 \\
5.13 \\
5.60 \\
6.09 \\
6.68 \\
7.25 \\
7.85 \\
8.43\end{array}$ & $\begin{array}{r}640 \\
624 \\
612 \\
600 \\
624 \\
754 \\
970 \\
1,230 \\
1,590 \\
1,960 \\
2,380 \\
2,840\end{array}$ & $\begin{array}{l}8.77 \\
8.61 \\
8.28 \\
7.94 \\
7.68 \\
7.45 \\
7.26 \\
7.10 \\
6.91 \\
6.74 \\
6.58 \\
6.41\end{array}$ & $\begin{array}{l}3,120 \\
2,990 \\
2,720 \\
2,450 \\
2,270 \\
2,100 \\
1,970 \\
1,860 \\
1,730 \\
1,620 \\
1,530 \\
1,430\end{array}$ & $\begin{array}{c}-6.16 \\
5 . \overline{9} \\
5.76 \\
5.58 \\
5.4 \overline{2} \\
5 . \overline{2}\end{array}$ & $\begin{array}{c}1,280 \\
1,150 \\
1,050 \\
960 \\
884 \\
816\end{array}$ & $\begin{array}{c}\overline{5} .14 \\
5.04 \\
4.95 \\
4.85 \\
4.75 \\
4.68\end{array}$ & \begin{tabular}{r}
$-\overline{758}$ \\
\hdashline 716 \\
-680 \\
-640 \\
-600 \\
-572
\end{tabular} & \begin{tabular}{c}
----- \\
-4.57 \\
.--- \\
4.49 \\
\hdashline 4.38 \\
4.28
\end{tabular} & $\begin{array}{c}- \\
529 \\
-499 \\
-460 \\
-426\end{array}$ & \begin{tabular}{c}
4.21 \\
\hdashline 4.21 \\
\hdashline 4.11 \\
4.03
\end{tabular} & $\begin{array}{r}-403 \\
403 \\
-37 \overline{2} \\
-348\end{array}$ \\
\hline & \multicolumn{2}{|c|}{ July 29} & \multicolumn{2}{|c|}{ July 30} & \multicolumn{2}{|c|}{ July 31} & \multicolumn{2}{|c|}{ August 1} & \multicolumn{2}{|c|}{ August 2} & \multicolumn{2}{|c|}{ August 3} \\
\hline $\begin{array}{c}2 \mathrm{a} . \mathrm{m} . \\
4 \\
6 \\
8 \\
10 \\
12 \mathrm{n} . \\
2 \mathrm{p.m} . \\
4 \\
6 \\
8 \\
10 \\
12 \mathrm{~m} .\end{array}$ & $\begin{array}{c}3.98 \\
3.93 \\
3.85 \\
3.85\end{array}$ & $\begin{array}{r}333 \\
319 \\
296 \\
296\end{array}$ & \begin{tabular}{c}
3.90 \\
\hdashline 3.91 \\
\hdashline 3.86 \\
\hdashline 3.79
\end{tabular} & $\begin{array}{r}310 \\
313 \\
299 \\
279\end{array}$ & 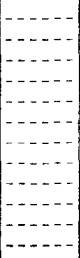 & 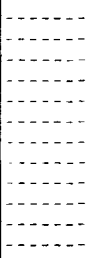 & 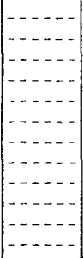 & 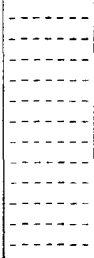 & 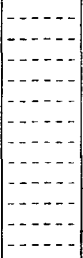 & 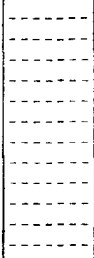 & 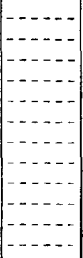 & 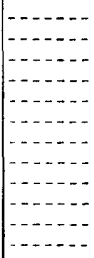 \\
\hline
\end{tabular}


SCIOHARIF CREFX AT PRATTSVIIIE, N. $Y$.

Location.-Lat. $42^{\circ} 19^{\prime} 25^{\prime \prime}$, long. $74^{\circ} 26^{\prime} 05^{\prime \prime}$, a quarter of a mile downstream from highway bridge in Prattsville, Greene County. Datum of gage is 1,130.01 feet above mean sea level (general adjustment of 1912).

Drainage AREa.-236 square miles.

GAGE-hEight RECORD.-Water-stage recorder graph.

Stage-discharge relation.-Defined by current-meter measurements to 4,600 second-feet; extended to peak stage on basis of area-velocity study.

Maxima.-July-August 1938: Discharge, 6,060 second-feet 2 p.m. July 23 (gage height, 6.46 feet).

1902 to June 1938: Discharge, 42,300 second-feet Nov. 16, 1926 (gage height, 19.5 feet, site and datum then in use), from records of New York City Board of Water Supply.

Remarks.-Flood discharge not affected by storage or diversion. Records collected in cooperation with New York City Board of Water Supply.

Mean discharge, in second-feet, 1938

\begin{tabular}{|c|c|c|c|c|c|c|c|c|c|c|c|}
\hline Day & July & August & Day & July & August & Day & Jily & August & Day & July & August \\
\hline $\begin{array}{l}1 \\
2 \\
3 \\
4 \\
5 \\
6 \\
7 \\
8\end{array}$ & $\begin{array}{l}553 \\
547 \\
415 \\
332 \\
282 \\
299 \\
248 \\
222\end{array}$ & $\begin{array}{l}386 \\
444 \\
331 \\
263 \\
222 \\
195 \\
196 \\
182\end{array}$ & $\begin{array}{r}9 \\
10 \\
11 \\
12 \\
13 \\
14 \\
15 \\
16\end{array}$ & $\begin{array}{l}196 \\
175 \\
246 \\
383 \\
246 \\
199 \\
193 \\
154\end{array}$ & $\begin{array}{l}192 \\
162 \\
485 \\
344 \\
241 \\
198 \\
168 \\
148\end{array}$ & $\begin{array}{l}17 \\
18 \\
19 \\
20 \\
21 \\
22 \\
23 \\
24\end{array}$ & $\begin{array}{r}125 \\
240 \\
403 \\
388 \\
737 \\
2,400 \\
4,600 \\
2,230\end{array}$ & $\begin{array}{r}159 \\
147 \\
179 \\
133 \\
108 \\
9.5 \\
84 \\
74\end{array}$ & $\begin{array}{l}25 \\
26 \\
27 \\
28 \\
29 \\
30 \\
31\end{array}$ & $\begin{array}{r}1,460 \\
1,080 \\
846 \\
678 \\
644 \\
663 \\
451\end{array}$ & $\begin{array}{l}66 \\
62 \\
58 \\
53 \\
48 \\
46 \\
44\end{array}$ \\
\hline \multicolumn{11}{|c|}{$\begin{array}{l}\text { Monthly mean discharge, in second-feet } \\
\text { Runoff, in inches }\end{array}$} & $\begin{array}{l}178 \\
.87\end{array}$ \\
\hline
\end{tabular}

Peak discharge-Aug. $11,(2$ p.m.) 634 sec.-ft.

\section{SCHOHARIF CREDK AT GITBOA DAM, AT GIIBOA, T. Y.}

Location.-Lat. $42^{\circ} 23^{\prime} 30^{\prime \prime}$, long. $74^{\circ} 27^{\prime} 05^{\prime \prime}$, at Gilboa Dam, 6 miles south of North Blenheim, Schoharie County.

Drainage area.-314 square miles.

GAGE-height RECORD.-Water-stage recorder graph.

Maxima.-July 1938: Discharge, 5,880 second-feet 4 p.m. July 23 (elevation, $1,131.40$ feet).

August 1938: Discharge, 308 second-feet 10 a. m. Aug. 2 (elevation, $1,130.21$ feet).

1927 to June 1938: Discharge, 32,000 second-feet Mar. 18, 1936 (elevation, $1,134.38$ feet).

Remarks.-Discharge of Schoharie Creek is the sum of the flow passing Gilboa Dam and the flow diverted through Shandaken Tunnel into Esopus Creek above Ashokan Reservoir for New York City municipal supply. Monthly mean discharge adjusted for change in contents of Schoharie Reservoir and diversion through Shandaken Tunnel into Esopus Creek. Records collected by New York City Department of Water Supply, Gas, and Electricity and furnished by that organization and New York City Board of Water Supply. 
Mean discharge, in second-feet, 1938

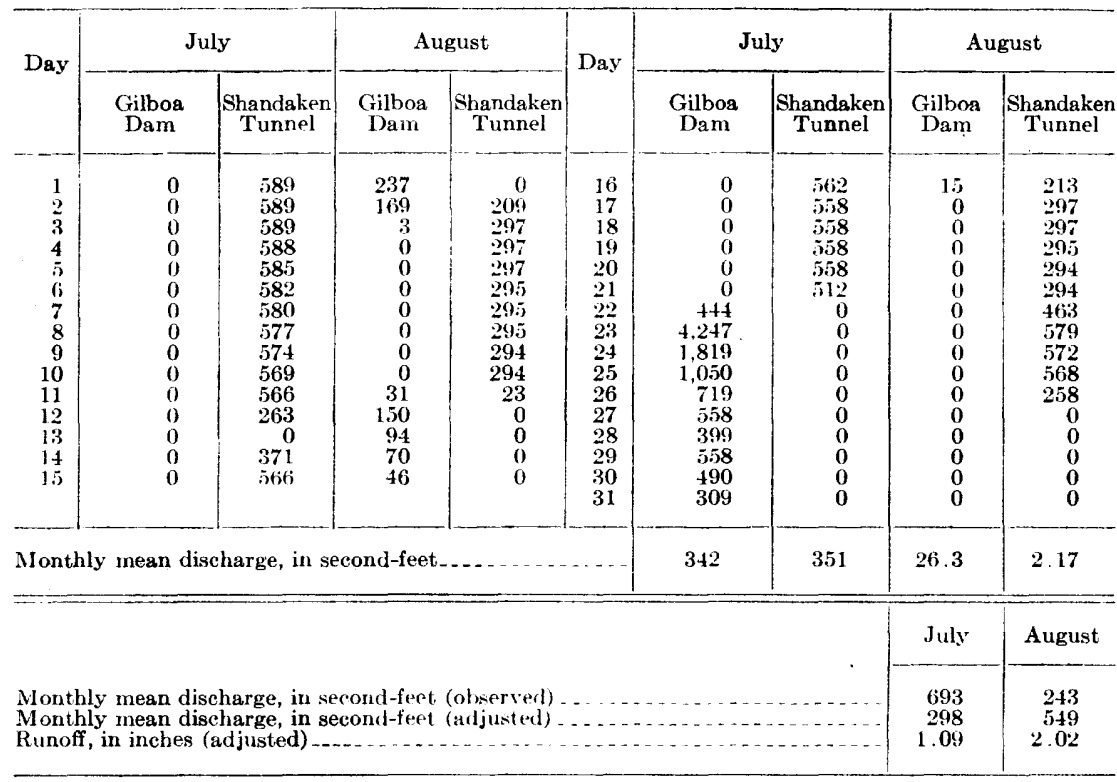

CATSKIII CRISK AT OAK HIIr, N. $\mathbf{Y}$.

LoCATION.-Lat. $42^{\circ} 24^{\prime} 20^{\prime \prime}$, long. $74^{\circ} 09^{\prime} 05^{\prime \prime}$, just downstream from highway bridge in southernmost part of Oak Hill, Greene County.

Drainage AREA.-98 square miles.

GaGE-HEIGHT RECORD.-Water-stage recorder graph.

Stage-discharge nelation.-Defined by current-meter measurements below 1,450 second-feet; extended to peak stage on basis of slope-area determination.

Maxima.-July-August 1938: Discharge, 1,390 second-feet 8:30 a.m. July 23 (gage height, 5.70 feet).

1929 to June 1938: Discharge, 8,880 second-feet Mar. 18, 1936 (gage height, 12.83 feet, from flood marks), from rating curve extended on basis of slope-area determination.

New York City Board of Water Supply reports a maximum discharge of 12,300 second-feet occurred on Nov. 9, 1913.

Remarks.-Flood discharge not affected by storage or diversion.

Mean discharge, in second-feet, 1938

\begin{tabular}{l|c|c|c|c|c|c||c|c|c||c|c|c}
\hline Day & July & August & Day & July & August & Day & July & August & Day & July & August \\
\hline 1 & 40 & 115 & 9 & 8.5 & 48 & 17 & 13 & 41 & 25 & 208 & 15 \\
2 & 40 & 104 & 10 & 82 & 46 & 18 & 62 & 38 & 26 & 143 & 12 \\
3 & 32 & 79 & 11 & 27 & 170 & 19 & 102 & 37 & 27 & 150 & 9.2 \\
4 & 25 & 64 & 12 & 64 & 97 & 20 & 89 & 29 & 28 & 116 & 6.9 \\
5 & 21 & 52 & 13 & 36 & 66 & 21 & 116 & 23 & 29 & 214 & 6.2 \\
6 & 17 & 41 & 14 & 25 & 55 & 22 & 280 & 18 & 30 & 228 & 5.8 \\
8 & 13 & 66 & 15 & 23 & 46 & 23 & 740 & 16 & 31 & 137 & 5.3 \\
\hline
\end{tabular}

Peak disikarge.-Aug. 11 (9 a.m.) 271 sea.-ft. 
ISOPUS CREFK AT COIDBROOK, N. Y.

Location.-Lat. $42^{\circ} 00^{\prime} 45^{\prime \prime}$, long. $74^{\circ} 16^{\prime} 10^{\prime \prime}$, at highway bridge at Coldbrook, Uster County and 11/2 miles upstream from Ashokan Reservoir.

Drainage area.-192 square miles.

GAGE-HEICHT RECORD.-Water-stage recorder graph. Gage heights used to hundredths.

Stage-discharge relation.-Defined by current-meter measurements below 7,100 second-feet; extended logarithmically to peak stage.

Maxima.-July-August 1938: Discharge, 8,830 second-feet 8:40 a.m. July 22 (gage height, 10.68 feet).

1914 to June 1938: Discharge, 55,000 second-feet Aug. 24, 1933 (gage height, 20.40 feet), from rating curve extended above 7,100 second-feet by logarithmic plotting.

REMARKs.-Water diverted from Schoharie Creek through Shandaken Tunnel enters Esopus Creek about 6 miles above this station. Flood peak not affected by diversion as Shandaken Tunnel was not operated during high-water periods. For information on diversion see record for Schoharie Creek at Gilboa Dam, at Gilboa, N. Y. Records collected in cooperation with New York City Board of Water Supply.

Mean discharge, in second-feet, 1938

\begin{tabular}{|c|c|c|c|c|c|c|c|c|c|c|c|}
\hline Day & July & August & Day & July & August & Day & July & August & Day & July & August \\
\hline $\begin{array}{l}1 \\
2 \\
3 \\
4 \\
5 \\
6 \\
7 \\
8\end{array}$ & $\begin{array}{r}1,080 \\
1,060 \\
1,020 \\
980 \\
944 \\
924 \\
903 \\
891\end{array}$ & $\begin{array}{l}602 \\
753 \\
872 \\
808 \\
755 \\
702 \\
704 \\
763\end{array}$ & $\begin{array}{r}9 \\
10 \\
11 \\
12 \\
13 \\
14 \\
15 \\
16\end{array}$ & $\begin{array}{l}894 \\
847 \\
838 \\
849 \\
297 \\
208 \\
726 \\
714\end{array}$ & $\begin{array}{r}742 \\
655 \\
2,000 \\
988 \\
670 \\
530 \\
439 \\
398\end{array}$ & $\begin{array}{l}17 \\
18 \\
19 \\
20 \\
21 \\
22 \\
23 \\
24\end{array}$ & $\begin{array}{r}707 \\
713 \\
802 \\
813 \\
936 \\
4,250 \\
5,340 \\
2,850\end{array}$ & $\begin{array}{l}688 \\
748 \\
692 \\
635 \\
594 \\
606 \\
848 \\
822\end{array}$ & $\begin{array}{l}25 \\
26 \\
27 \\
28 \\
29 \\
30 \\
31\end{array}$ & $\begin{array}{r}1,520 \\
1,140 \\
854 \\
752 \\
859 \\
772 \\
594\end{array}$ & $\begin{array}{l}798 \\
774 \\
188 \\
128 \\
117 \\
107 \\
102\end{array}$ \\
\hline \multicolumn{10}{|c|}{$\begin{array}{l}\text { Monthly mean discharge, in second-feat (adjusted for diversion } \dagger \text { ) } \\
\text { Runoff, in inches (adjusted for diversion } \dagger \text { ) }\end{array}$} & $\begin{array}{r}812 \\
4.88\end{array}$ & $\begin{array}{r}435 \\
2.62\end{array}$ \\
\hline
\end{tabular}

†Adjusted for diversion from Schoharie Creek.

l'eak discharge.-July 23 (4 p.m.) 7,100 sec.-ft.; Aug. 11 (10 a.m.) 3,160 sec.-ft.

\section{RONDOUT CRFFK NEAR IOWTS CORNERS, N. $\mathbf{Y}$.}

Location.--Lat. $41^{\circ} 51^{\prime} 55^{\prime \prime}$, long. $74^{\circ} 29^{\prime} 10^{\prime \prime}$, at highway bridge 1.1 miles upstream from Lowes Corners, Sullivan County and about $23 / 4$ miles upstream from Chestnut Creek.

Drainage area.-38.5 square miles.

GAGE-HEIGHT RECORD.-Chain gage read to hundredths twice daily and more frequently during floods. Graph based on chain gage readings used July 19-24, 26-29, August 1, 2, 6-12.

Stage-discharge relation.-Defined by current-meter measurements below 2,030 second-feet; extended logarithmically to peak stage.

Maxıma.-July-August 1938: Discharge, 7,600 second-feet 8 a.m. July 22 (gage height, 8.2 feet).

1937 to June 1938: Discharge, 5,700 second-feet Oct. 23, 1937 (gage height, 7.0 feet from graph based on gage readings).

Remarks.--Flood discharge not affected by storage or diversion. 
Mean discharge, in second-feet, 1938

\begin{tabular}{c|c|c||c|c|c||c|c|c||c|c|c}
\hline Day & July & August & Day & July & August & Day & July & August & Day & July & August \\
\hline 1 & 82 & 332 & 9 & 80 & 188 & 17 & 35 & 132 & 25 & 430 & 57 \\
2 & 92 & 259 & 10 & 71 & 134 & 18 & 36 & 132 & 26 & 258 & 52 \\
3 & 70 & 173 & 11 & 66 & 2,100 & 19 & 51 & 121 & 27 & 272 & 47 \\
4 & 56 & 173 & 12 & 64 & 574 & 20 & 51 & 100 & 28 & 258 & 44 \\
5 & 52 & 138 & 13 & 55 & 310 & 21 & 372 & 82 & 29 & 282 & 42 \\
6 & 51 & 408 & 14 & 44 & 232 & 22 & 2,090 & 77 & 30 & 214 & 42 \\
7 & 46 & 239 & 15 & 40 & 171 & 23 & 1,880 & 68 & 31 & 192 & 40 \\
8 & 44 & 326 & 16 & 37 & 144 & 24 & 799 & 60 & & & \\
\hline
\end{tabular}

Gage-height, in feet, and discharge, in second-feet, at indicated time, 1938

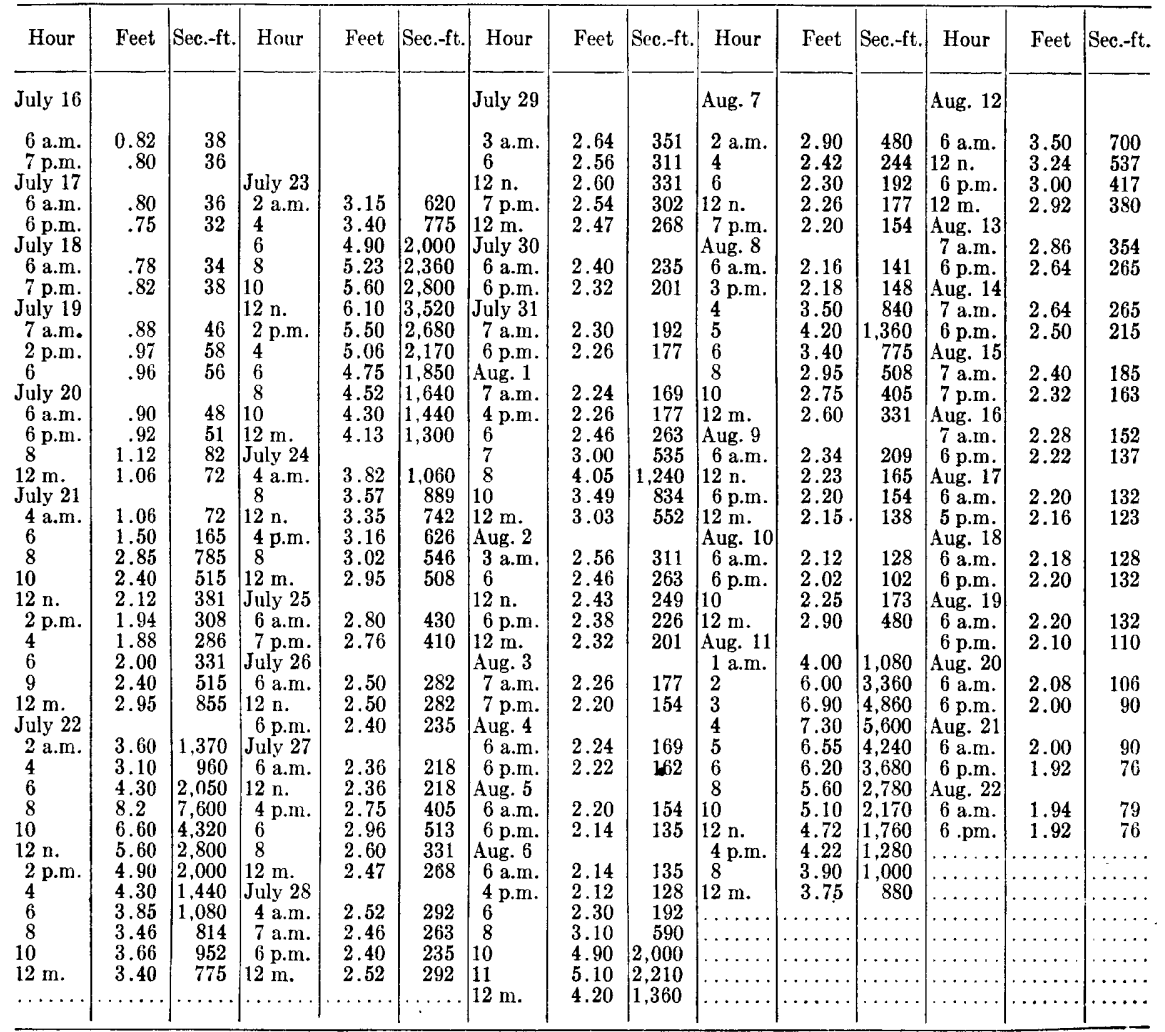


RONDOUT CRERK MEAR IACKAWACK, N. $Y$.

Location.-Lat. $41^{\circ} 46^{\prime} 25^{\prime \prime}$, long. $74^{\circ} 23^{\prime} 35^{\prime \prime}$, half a mile downstream from highway bridge known as Wilburs Bridge and $23 / 4$ miles southeast of Lackawack, Ulster County. Datum of gage is $\mathbf{5 8 7 . 6 7}$ feet above mean sea level (general adjustment of 1912).

Drainage area.-100 square miles.

GAGE-HEIGHT RECORD.-Water-stage recorder graph. Gage heights used to hundredths.

STAGE-DISCHARGE RELATION.-Defined by current-meter measurements below 10,260 second-feet; extended to peak stage on basis of logarithmic plotting and slope-area determination of peak discharge.

MaхıмA.-July-August 1938: Discharge, 17,700 second-feet 9:30 a.m. July 22. (gage height, 14.00 feet).

1906 to June 1938: Discharge, 26,700 second-feet Aug. 26, 1928, from slope-area determination by engineers of New York City Board of Water Supply.

Remarks.-Flood discharge not affected by storage or diversion. Records collected in cooperation with New York City Board of Water Supply.

Mean discharge, in second-feet, 1938

\begin{tabular}{|c|c|c|c|c|c|c|c|c|c|c|c|}
\hline Day & July & August & Day & July & August & Day & July & August & Day & July & August \\
\hline $\begin{array}{l}1 \\
2 \\
3 \\
4 \\
5 \\
6 \\
7 \\
8\end{array}$ & $\begin{array}{l}172 \\
196 \\
152 \\
134 \\
121 \\
112 \\
103 \\
100\end{array}$ & $\begin{array}{r}431 \\
545 \\
326 \\
268 \\
235 \\
\mathbf{8 8 2} \\
1,180 \\
\mathbf{8 7 2}\end{array}$ & $\begin{array}{r}9 \\
10 \\
11 \\
12 \\
13 \\
14 \\
15 \\
16\end{array}$ & $\begin{array}{r}172 \\
173 \\
136 \\
159 \\
122 \\
106 \\
98 \\
87\end{array}$ & $\begin{array}{r}808 \\
490 \\
5,170 \\
1.370 \\
832 \\
668 \\
569 \\
482\end{array}$ & $\begin{array}{l}17 \\
18 \\
19 \\
23 \\
21 \\
22 \\
23 \\
24\end{array}$ & $\begin{array}{r}85 \\
80 \\
117 \\
158 \\
1,380 \\
6,300 \\
4,260 \\
1,910\end{array}$ & $\begin{array}{l}414 \\
415 \\
373 \\
279 \\
237 \\
206 \\
180 \\
159\end{array}$ & $\begin{array}{l}25 \\
26 \\
27 \\
28 \\
29 \\
30 \\
31\end{array}$ & $\begin{array}{r}1,010 \\
701 \\
558 \\
537 \\
520 \\
411 \\
309\end{array}$ & $\begin{array}{r}146 \\
133 \\
125 \\
117 \\
110 \\
102 \\
96\end{array}$ \\
\hline \multicolumn{10}{|c|}{$\begin{array}{l}\text { Monthly mean discharge, in second-feet } \\
\text { Runoff, in inches }\end{array}$} & $\begin{array}{r}661 \\
7.62\end{array}$ & $\begin{array}{r}588 \\
6.78\end{array}$ \\
\hline
\end{tabular}


Gage-height, in feet, and discharge, in second-feet, at indicated time, 1938

\begin{tabular}{|c|c|c|c|c|c|c|c|c|c|c|c|c|c|c|}
\hline Hour & Feet & Sec.-ft. & Hour & Feet & Sec.-ft. & Hour & Feet & Sec. $-\mathrm{ft}$. & Hour & Feet & Sec.-ft. & Hour & Feet & Sec.-ft. \\
\hline & & & July 22 & & & July 27 & & & Aug. 6 & & & Aug. 11 & & \\
\hline & & & & 10.30 & 9,870 & & 2.72 & 673 & & 2.04 & 270 & & 11.20 & 11,600 \\
\hline & 1.29 & 90 & & 8.70 & & & & 673 & & & 428 & & 9.80 & \\
\hline & 1.27 & 85 & & 7.92 & 6,1 & 12 & & 56 & & 3. & 1,210 & 8 & 50 & 8,450 \\
\hline & 1727 & 85 & 3 & 7.30 & 5, & & & & 8 & 8 & 86 & 1 & 8.40 & \\
\hline & 1.27 & 85 & 4 & 6. & & 4 & 2.52 & $\begin{array}{l}543 \\
582\end{array}$ & 9 & & 1,180 & 12 & 7.05 & \\
\hline $\operatorname{ly} 18$ & 26 & 0 & 6 & $\begin{array}{l}0.50 \\
5.95\end{array}$ & $\begin{array}{l}4,0 \\
3,6\end{array}$ & $12 \mathrm{n}$ & $\begin{array}{l}2.58 \\
2.52\end{array}$ & & $\begin{array}{l}10 \\
11\end{array}$ & & & 4 & $\begin{array}{l}0.10 \\
5.40\end{array}$ & 380 \\
\hline n. & 1.21 & 70 & 8 & 5.42 & 3,010 & $8 \mathrm{r}$ & 2.44 & & $12 \mathrm{~m}$. & 5 & 5,21 & 6 & & 330 \\
\hline & 1.27 & 85 & 10 & 5.60 & 3,2 & 12 & 2.46 & 506 & Aug & & & 8 & 4.80 & 340 \\
\hline & & & $12 \mathrm{I}$ & 5.50 & 3,100 & July 29 & & & & 5.30 & 2,870 & 10 & & 90 \\
\hline n. & 1.29 & 90 & July 23 & & & 8 a.m. & 2.43 & 488 & 2 & 4.75 & 2.290 & $12 n$ & 4.40 & 1,950 \\
\hline & 1.49 & 147 & 2 a.m. & 4.96 & 2,500 & $12 \mathrm{n}$. & 2.70 & 660 & 4 & 4. & 1,790 & Aug. 12 & & \\
\hline & 1.51 & 154 & & 4.80 & 2,340 & $4 p$ & 2.55 & 562 & 6 & 3. & 1,370 & $6 \mathrm{am}$ & 3.97 & 1,670 \\
\hline m. & 1.46 & 137 & 6 & 5.50 & 3,100 & 6 & 2.42 & 48 & 8 & 3.43 & 1,160 & 12 & 3.55 & 1.330 \\
\hline $\operatorname{ly} 20$ & & & 8 & 5.85 & 3.520 & $12 \mathrm{~m}$. & 2.46 & 506 & 10 & 3.22 & 1,010 & 6 p.m. & 3.20 & 1.070 \\
\hline n. & 1.40 & 118 & 10 & 6.50 & 4,300 & July $\mathbf{3 0}$ & & & $12 \mathrm{n}$ & 3.06 & 902 & $12 \mathrm{~m}$. & 3.02 & 935 \\
\hline p.m. & 1.38 & 113 & 11 & 7.50 & 5,530 & $12 i$ & 2.30 & 410 & 4 p.m. & 2. & 699 & Aug. 13 & & \\
\hline & 1.42 & 124 & $12 \mathrm{n}$. & 8.82 & 7,430 & $12 \mathrm{~m}$ & 2.18 & 342 & $8^{\circ}$ & 2. & 576 & 6 a.m. & 2.92 & 864 \\
\hline & 1.89 & 325 & 1 p.m. & 8.60 & 7,100 & July 31 & & & $12 n$ & 2. & 518 & 12 & 2.89 & 843 \\
\hline & 1.73 & 250 & & 8.25 & 6,580 & $12 \mathrm{n}$. & 2.15 & 326 & Aug. 8 & & & $\mathrm{~m}$ & 2.82 & 794 \\
\hline m 21 & 1.68 & 226 & & $\begin{array}{l}7.65 \\
7.30\end{array}$ & $\begin{array}{l}5,720 \\
5,280\end{array}$ & $\begin{array}{l}12 \mathrm{~m} . \\
\text { Aug. } 1\end{array}$ & 2.04 & 27 & $\begin{array}{l}8 \text { a.m. } \\
4 \text { p.m. }\end{array}$ & $\begin{array}{l}2.37 \\
2.28\end{array}$ & $\begin{array}{l}452 \\
399\end{array}$ & $\begin{array}{l}12 \mathrm{~m} . \\
\text { Aug. 14 }\end{array} \mid$ & 2.71 & 722 \\
\hline a.n & 1.60 & 190 & 8 & 6.45 & 4,2 & $6 a$ & 2.05 & 275 & 5 & 2.35 & 440 & $12 \mathrm{n}$. & 2. & 673 \\
\hline & 1.75 & 258 & 10 & 5.8 & & & 2.30 & 41 & 6 & 2.80 & 725 & & 52 & 611 \\
\hline & 4.75 & 2.340 & $12 \mathrm{~m}$. & 5. & 3,040 & 9 & 2.10 & 30 & 7 & 6. & 3,820 & Aug. 15 & & \\
\hline & 7.12 & 5,280 & July 24 & & & 6 p.m. & 2.06 & 280 & 8 & 5.05 & & 12 n. & 2.46 & 578 \\
\hline t & 6.65 & 4,480 & 2 a.m. & 5.15 & 2,700 & 8 & 2.50 & 530 & 10 & 4.1 & & $12 \mathrm{~m}$. & 2.34 & 512 \\
\hline & 5.80 & 3,460 & 4 & 4.97 & 2.5 & 9 & 3.58 & 1,270 & $12 \mathrm{nt}$. & 3.72 & 1.370 & Aug. 16 & & \\
\hline & 5.00 & 2,580 & 6 & 4.75 & 2290 & $12 \mathrm{~m}$ & 3,18 & 98 & Aug. 9 & & & $12 \mathrm{n}$. & 2.29 & 484 \\
\hline n. & 4.53 & 2,150 & 8 & 4.54 & 2,080 & Aug. 2 & & & $2 a$ & 3.45 & & $12 \mathrm{~m}$. & 2.22 & 446 \\
\hline p.m. & 3.8 & 1,590 & 10 & 4.37 & 1,920 & 4 a.m. & 2.77 & 70 & 4 & 3. & 940 & Aug. 17 & & \\
\hline$?$ & 3.20 & 1,070 & $12 \mathrm{n}$. & 4.22 & 1.790 & 8 & 2.58 & & 6 & 3.12 & 944 & $12 \mathrm{n}$. & 2.17 & 418 \\
\hline$f$ & 2.8 & 892 & 2 p.m. & 4.10 & 1,680 & $12 \mathrm{n}$. & 2.47 & 51 & 8 & 3. & 881 & 12 & .12 & 391 \\
\hline 8 & 2.72 & 772 & & 3.9 & 1,570 & 4 p.m. & 2.36 & 446 & 10 & & 825 & Aug. 18. & & \\
\hline & 2 & 700 & 6 & 3.9 & 1,510 & & 2.2 & 38 & $12 \mathrm{n}$. & 2. & 764 & $12 \mathrm{n}$. & 2.10 & 380 \\
\hline & 2 & 772 & 8 & 3.7 & 1.420 & $12 \mathrm{~m}$ & 2.22 & 364 & 4 p.m. & 2. & 640 & 4 p.m. & .22 & 446 \\
\hline $\mathrm{m}$. & 4 & 1,690 & $12 \mathrm{~m}$. & $3 . t$ & 1,280 & 3 & & & & 2. & 595 & & 2.28 & $47 ?$ \\
\hline & & & July & & & 12 & 2.17 & 337 & $12 \mathrm{~m}$. & & 550 & $12 \mathrm{~m}$. & 2.22 & 446 \\
\hline 1 a.m. & 6.35 & 4,120 & $6 a$ & 3. & 1,130 & m. & 2.09 & 29 & Aug. 10 & & & Aug. 19 & & \\
\hline & & & 12 & & & $12 \mathrm{I}$ & & & $12 \mathrm{n}$. & 2 . & 470 & 12 & 2.08 & 370 \\
\hline & & & & & & & & & & & 399 & $12 \mathrm{~m}$ & 1.97 & \\
\hline & & & & & & $12 \mathrm{I}$ & & & & 2. & 440 & 20 & & \\
\hline & 7.2 & & & $?$ & & & & & & & & & & \\
\hline & 9.0 & & & & & & & & & & & & & \\
\hline & & & & 2.1 & 000 & 1211. & & 29 & & 5.30 & & 21 & & \\
\hline & & & & & 80 & $2 \mathrm{~m}$. & 1.9 & 21 & 3 & 8.10 & 5020 & & 1.81 & 242 \\
\hline & & & 8 a.m. & 2.5 & 536 & & 1.92 & 21 & 4 & 10.50 & & 22 & & \\
\hline & & & 4 p.m. & 2.46 & 506 & 3 p.m. & 1.92 & 214 & 5 & 11.50 & 12,200 & & 1.74 & 214 \\
\hline & & & & & & & & & & & & & & 198 \\
\hline
\end{tabular}

RONDOUT CREEK AT ROSENDATE, X. $\mathbf{x}$

Location.-Lat. $41^{\circ} 50^{\prime} 35^{\prime \prime}$, long. $74^{\circ} 05^{\prime} 10^{\prime \prime}, 150$ feet upstream from highway bridge in Rosendale, Ulster County. Datum of gage is 42.81 feet above mean sea level (general adjustment of 1912).

Drainage arEa.-386 square miles.

GAGE-HEIGHT RECORD.-Water-stage recorder graph. Gage heights used to hundredths.

STAGE-Discharge RELATION.-Defined by current-meter measurements to 15,000 second-feet; extended logarithmically to peak stage.

Maxima.-July-August 1938: Discharge, 16,400 second-feet 3 p.m. Aug. 11 (gage height, 14.53 feet).

1901-03, 1906-19, 1926 to June 1938: Discharge, 27,300 second-feet Aug. 27, 1928 (gage height, 21.9 feet).

Remarks.-Flood discharge not affected by storage or diversion. Diurnal fluctuations during periods of low flow caused by operation of power plants above station. 
Mean discharge, in second-feet, 1938

\begin{tabular}{c|c|c||c|c|c||c|c|c||c|c|c}
\hline Day & July & August & Day & July & August & Day & July & August & Day & July & August \\
\hline & & & & & & & \\
1 & 660 & 670 & 9 & 240 & 2,400 & 17 & 164 & 720 & 25 & 3,300 & 305 \\
2 & 610 & 1,140 & 10 & 440 & 1,180 & 18 & 166 & 680 & 26 & 1,920 & 280 \\
3 & 530 & 770 & 11 & 320 & 9,900 & 19 & 178 & 680 & 27 & 1,280 & 270 \\
4 & 390 & 620 & 12 & 385 & 4,500 & 20 & 300 & 530 & 28 & 1,200 & 239 \\
5 & 385 & 530 & 13 & 335 & 2,180 & 21 & 1,560 & 470 & 29 & 1,100 & 216 \\
6 & 330 & 520 & 14 & 275 & 1,280 & 22 & 7.400 & 365 & 30 & 1,080 & 210 \\
7 & 280 & 3,400 & 15 & 220 & 1,000 & 23 & 12,200 & 350 & 31 & 810 & 214 \\
8 & 230 & 1,720 & 16 & 200 & 800 & 24 & 8,000 & 330 & & & \\
\hline
\end{tabular}

Gage height, in feet, and discharge, in second-feet, at indicated time, 1938

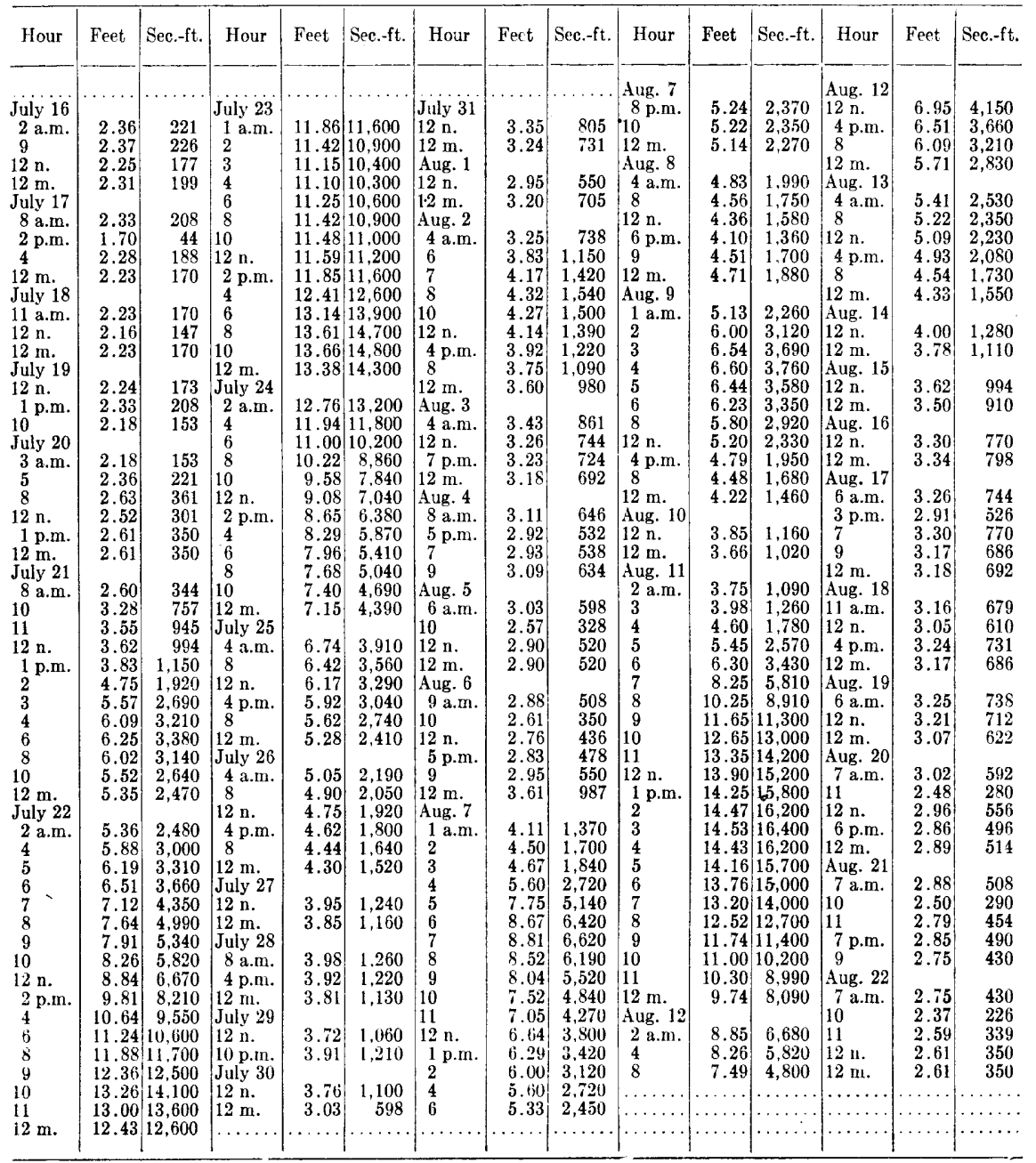


CHFSTUUT CRFEK ABOVE RED BROOK, AT GRAFAMSVIIIT, N. $Y$.

Location.-Lat. $41^{\circ} 50^{\prime} 45^{\prime \prime}$, long. $74^{\circ} 32^{\prime} 50^{\prime \prime}$, about 300 feet upstream from bridge on State Highway 42 in Grahamsville, Sullivan County, and a quarter of a mile upstream from Red Brook.

Drainage area.-12.2 square miles.

Gage-Height RECORD.-Staff gage read to hundredths twice daily and more frequently during floods. Record for periods July 19-23, 28, Aug. 1, 2, 6-11 determined from graph based on gage readings.

Stage-discharge RELATION.-Defined by current-meter measurements to $\mathbf{5 5 0}$ second-feet; extended to peak stage on basis of computations of discharge through contracted section and by logarithmic plotting,

Maxima.-July-August 1938: Discharge, 2,600 second-feet 8 a.m. July 22 (gage height, 5.8 feet, observed during flood).

1937 to June 1938: Discharge, 1,250 second-feet Oct. 23, 1937 (gage height, 4.0 feet, from graph based on gage readings).

REMARKs.-Flood discharge not affected by storage or diversion.

Mean discharge, in second-feet, 1938

\begin{tabular}{c|c|c||c|c|c|c|c|c||c|c|c}
\hline Day & July & Augi st & Day & July & Algust & Day & July & August & Day & July & August \\
\hline 1 & 14 & 77 & 9 & 53 & 126 & 17 & 9.5 & 42 & 25 & 95 & 20 \\
2 & 17 & 77 & 10 & 22 & 78 & 18 & 9.5 & 42 & 26 & 68 & 20 \\
3 & 13 & 39 & 11 & 16 & 656 & 19 & 21 & 36 & 27 & 58 & 18 \\
4 & 12 & 34 & 12 & 15 & 134 & 20 & 17 & 32 & 28 & 65 & 17 \\
5 & 10 & 29 & 13 & 12 & 75 & 21 & 109 & 27 & 29 & 74 & 17 \\
6 & 9.5 & 170 & 14 & 12 & 57 & 22 & 798 & 25 & 30 & 45 & 16 \\
7 & 9 & 172 & 15 & 10 & 47 & 23 & 265 & 23 & 31 & 37 & 16 \\
8 & 9 & 208 & 16 & 10 & 42 & 24 & 173 & 21 & & & \\
\hline
\end{tabular}


Gage height, in feet, and discharge, in second-feet, at indicated time, 1938

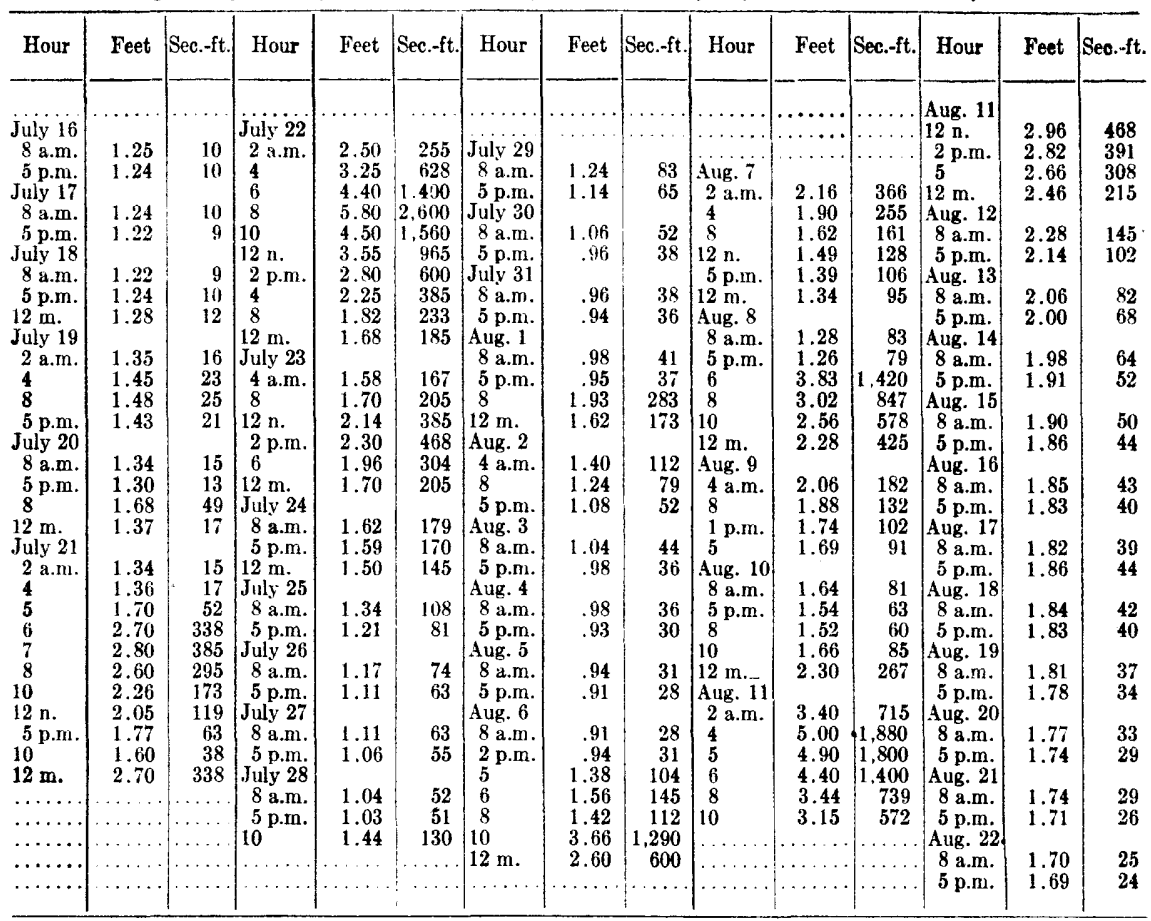

WAITKIII RIVER NEAR UNIONVITIF, N. $\mathbf{x}$.

Location.-Lat. $41^{\circ} 15^{\prime} 35^{\prime \prime}$, long. $74^{\circ} 32^{\prime} 55^{\prime \prime}$, at bridge on Quarryville-Milton road, about 2 miles south of New York-New Jersey State line, and 3 miles south of Unionville, Orange County.

Drainage. - 144 square miles.

GAGE-HEIGHT RECORD.-Wire-weight gage read to hundredths twice daily.

Stage-discharge RELA'TION.-Defined by current-meter measurements to 900 second-feet; and extended logarithmically to peak stage.

Maxima.-July-August 1938: Discharge, 1,050 secorid-feet 3 a.m. July 25 (gage height, 10.87 feet, from graph based on gage readings).

1937 to June 1938: Discharge, 1,710 second-feet Jan. 26, 1938 (gage height, 10.06 feet, from graph based on gage readings).

Remarks.-No regulation or diversion. Natural storage occurs in small lakes and swampy areas above station.

Mean discharge, in second-feet, 1938

\begin{tabular}{c|c|c||c|c|c|c|c|c|c|c|c}
\hline Day & July & August & Day & July & August & Day & July & August & Day & July & August \\
\hline 1 & 774 & 625 & 9 & 130 & 302 & 17 & 106 & 124 & 25 & 1,030 & 61 \\
2 & 710 & 565 & 10 & 110 & 261 & 18 & 97 & 147 & 26 & 960 & 56 \\
3 & 650 & 546 & 11 & 102 & 316 & 19 & 106 & 244 & 27 & 864 & 55 \\
4 & 593 & 491 & 12 & 150 & 361 & 20 & 120 & 197 & 28 & 794 & 50 \\
5 & 502 & 440 & 13 & 190 & 331 & 21 & 242 & 124 & 29 & 728 & 49 \\
6 & 418 & 408 & 14 & 162 & 261 & 22 & 521 & 89 & 30 & 686 & 46 \\
7 & 296 & 392 & 15 & 135 & 173 & 23 & 765 & 78 & 31 & 645 & 45 \\
8 & 178 & 361 & 16 & 110 & 156 & 24 & 984 & 70 & & & \\
\hline
\end{tabular}


WAITKIII RIVER AT PXILETS ISIAND MOUNTAIN, $N$. $x$.

LoCATION.-Lat. $41^{\circ} 22^{\prime} 50^{\prime \prime}$, long. $74^{\circ} 24^{\prime} 50^{\prime \prime}$, just downstream from highway bridge at Pellets Island Mountain, Orange County and $41 / 2$ miles south of Middletown. Datum of gage is 357.43 feet above mean sea level( general adjustment of 1912).

Drainage AREA.-385 square miles.

GAGE-HEIGHT RECORD.-Water-stage recorder graph.

Stage-discharge relation.-Defined by current-meter measurements to 4,000 second-feet; extended logarithmically to peak stage.

Maxima.-July-August 1938: Discharge, 4,880 second-feet 5 p.m. July 24 (gage height, 13.81 feet).

1919 to June 1938: Discharge, 12,400 second-feet Mar. 14, 1936 (gage height, 20.0 feet, present site and datum), from rating curve extended above 9,000 second-feet; gage height, 25.7 feet (present datum) Mar. $16,1920$.

Remarks.-Discharge affected by no known diversions but natural storage occurs in large swampy areas and small lakes above Pellets Island Mountain.

Mean discharge, in second-feet, 1938

\begin{tabular}{|c|c|c|c|c|c|c|c|c|c|c|c|}
\hline Day & July & August & Day & July & August & Day & July & August & Day & July & August \\
\hline $\begin{array}{l}1 \\
2 \\
3 \\
4 \\
5 \\
6 \\
6 \\
7 \\
8\end{array}$ & $\begin{array}{r}2,220 \\
1,960 \\
1,570 \\
1,270 \\
1,030 \\
848 \\
644 \\
450\end{array}$ & $\begin{array}{r}1,370 \\
1,700 \\
1,210 \\
954 \\
817 \\
769 \\
718 \\
680\end{array}$ & $\begin{array}{r}9 \\
10 \\
11 \\
12 \\
13 \\
14 \\
15 \\
16\end{array}$ & $\begin{array}{l}325 \\
258 \\
222 \\
295 \\
411 \\
370 \\
311 \\
269\end{array}$ & $\begin{array}{r}796 \\
712 \\
1.090 \\
1.060 \\
817 \\
628 \\
485 \\
397\end{array}$ & $\begin{array}{l}17 \\
18 \\
19 \\
20 \\
21 \\
22 \\
23 \\
24\end{array}$ & $\begin{array}{r}219 \\
186 \\
302 \\
302 \\
735 \\
2,740 \\
3,620 \\
4,740\end{array}$ & $\begin{array}{r}386 \\
425 \\
485 \\
478 \\
a 353 \\
a 274 \\
a 225 \\
a 194\end{array}$ & $\begin{array}{l}25 \\
26 \\
27 \\
28 \\
29 \\
30 \\
31\end{array}$ & $\begin{array}{l}4,500 \\
3,820 \\
2,960 \\
2,510 \\
2,050 \\
2,000 \\
1,620\end{array}$ & $\begin{array}{r}171 \\
151 \\
146 \\
a 132 \\
a 124 \\
119 \\
113\end{array}$ \\
\hline \multicolumn{11}{|c|}{$\begin{array}{l}\text { Monthly mean discharge, in second-feet } \\
\text { Runoff, in inches }\end{array}$} & $\begin{array}{r}580 \\
1.74\end{array}$ \\
\hline
\end{tabular}

$a$ Fragmentary gage-height record; discharge estimated.

Peak discharge.-Âug. 11 (4 p.m.) 1.300 sec.-ft.

WAITKIII RTVER AT GARDINER, N. $\mathbf{Y}$.

LoCATION.-Lat. $41^{\circ} 41^{\prime} 10^{\prime \prime}$, long. $74^{\circ} 09^{\prime} 55^{\prime \prime}$, at highway bridge 500 feet downstream from Shawangunk Kill and three-quarters of a mile northwest of Gardiner, Ulster County. Datum of gage is 185.70 feet above sea level (general adjustment of 1912).

Drainage area.-711 square miles.

GAGE-HEIGHT RECORD.-Water-stage recorder graph.

Stage-discharge RELATION.-Defined by current-meter measurements to 11,200 second-feet; extended logarithmically to peak stage.

Maxima.-July-August 1938: Discharge, 9,720 second-feet 7 p.m. July 23 (gage height, 10.75 feet).

1924 to June 1938: Discharge, 18,000 second-feet Mar. 12, 1936 (gage height, 15.16 feet), from rating curve extended logarithmically above 11,200 second-feet; gage height, 16.42 feet Mar. 12, 1936, result of ice jam.

Remarks.-Large diurnal fluctuations during low and medium stages caused by power-plant operation. Natural storage occurs in swampy areas and small lakes above Pellets Island Mountain, and both artificial and natural storage occurs in lakes and ponds in the area between Pellets Island Mountain and station. 
Mean discharge, in second-feet, 1938

\begin{tabular}{c|c|c||c|c|c||c|c|c|c|c|c}
\hline Day & July & August & Day & July & August & Day & July & August & Day & July & August \\
\cline { 3 - 6 } 1 & 2,870 & 2,000 & 9 & 565 & 1,300 & 17 & 342 & 649 & 25 & 6,350 & 328 \\
2 & 2,660 & 2,450 & 10 & 491 & 1,120 & 18 & 300 & 671 & 26 & 5,140 & 295 \\
3 & 2,200 & 2,090 & 11 & 391 & 6,620 & 19 & 299 & 784 & 27 & 4,150 & 253 \\
4 & 1,750 & 1,490 & 12 & 366 & 3,350 & 20 & 464 & 776 & 28 & 3,900 & 256 \\
5 & 1,410 & 1,200 & 13 & 482 & 1,890 & 21 & 1,070 & 634 & 29 & 3,120 & 261 \\
6 & 1,160 & 1,050 & 14 & 528 & 1,300 & 22 & 7,210 & 527 & 30 & 2,990 & 213 \\
7 & 944 & 1,070 & 15 & 463 & 974 & 23 & 7,950 & 397 & 31 & 2,610 & 219 \\
8 & 732 & 1,170 & 16 & 391 & 761 & 24 & 8,180 & 374 & & & \\
\hline
\end{tabular}

Peak discharge.-Aug. 11 (1:30 p.m.) 7,920 sec.-ft.

\section{HACKENSACK RIVER BASIN}

\section{ORADETI RESERVOTR AT ORADETI, N. J.}

Location.-Lat. $40^{\circ} 57^{\prime} 24^{\prime \prime}$, long. $74^{\circ} 01^{\prime} 43^{\prime \prime}$, at Oradell Dam, Oradell, Bergen County. Gage heights are elevations above mean sea level (general adjustment of 1929).

Drainage area.-113 square miles.

GAGE-HEIGH RECORD.-Water-stage recorder graph. Gage heights shown in table are at 8 a.m. readings.

Remarks.-Capacity, 381,000,000 cubic feet. Records furnished by Hackensack Water Co.

Gage height, in feet, and contents, in millions of cubic feet, 1938

\begin{tabular}{|c|c|c|c|c|c|c|}
\hline \multirow[b]{2}{*}{ Day } & \multicolumn{2}{|c|}{ June } & \multicolumn{2}{|c|}{ July } & \multicolumn{2}{|c|}{ August } \\
\hline & Gage Height & Contents & Gage Height & Contents & Gage Height & Contents \\
\hline $\begin{array}{r}1 \\
2 \\
3 \\
4 \\
5 \\
6 \\
7 \\
8 \\
9 \\
10 \\
11 \\
12 \\
13 \\
14 \\
15 \\
16 \\
17 \\
18 \\
19 \\
20 \\
21 \\
22 \\
23 \\
24 \\
25 \\
26 \\
27 \\
28 \\
29 \\
30 \\
31\end{array}$ & $\begin{array}{l}22.67 \\
22.68 \\
22.73 \\
22.66 \\
22.67 \\
22.67 \\
22.69 \\
22.70 \\
22.51 \\
22.58 \\
22.65 \\
22.57 \\
22.71 \\
22.68 \\
22.57 \\
22.55 \\
22.55 \\
22.77 \\
22.83 \\
22.79 \\
22.77 \\
22.75 \\
22.71 \\
22.70 \\
22.77 \\
22.75 \\
22.71 \\
22.79 \\
22.52 \\
22.88 \\
-2 .----\end{array}$ & $\begin{array}{l}381 \\
382 \\
383 \\
381 \\
381 \\
381 \\
382 \\
382 \\
377 \\
379 \\
381 \\
378 \\
382 \\
382 \\
378 \\
378 \\
378 \\
384 \\
386 \\
385 \\
384 \\
384 \\
382 \\
382 \\
384 \\
384 \\
382 \\
385 \\
377 \\
387 \\
--- \\
--\end{array}$ & $\begin{array}{l}22.86 \\
22.80 \\
22.77 \\
22.75 \\
22.76 \\
22.77 \\
22.76 \\
22.74 \\
22.74 \\
22.87 \\
22.81 \\
22.81 \\
22.75 \\
22.83 \\
22.79 \\
22.60 \\
22.59 \\
22.60 \\
22.64 \\
22.58 \\
22.65 \\
22.70 \\
21.75 \\
21.88 \\
21.47 \\
22.00 \\
22.03 \\
22.07 \\
22.08 \\
22.09 \\
22.15\end{array}$ & $\begin{array}{l}387 \\
385 \\
384 \\
384 \\
384 \\
384 \\
384 \\
383 \\
383 \\
387 \\
385 \\
385 \\
384 \\
386 \\
385 \\
379 \\
379 \\
379 \\
380 \\
379 \\
381 \\
382 \\
355 \\
359 \\
347 \\
362 \\
363 \\
364 \\
364 \\
365 \\
366\end{array}$ & $\begin{array}{l}22.11 \\
22.20 \\
22.53 \\
22.83 \\
22.87 \\
22.88 \\
22.87 \\
22.87 \\
22.76 \\
22.72 \\
22.80 \\
22.00 \\
22.00 \\
22.06 \\
22.05 \\
22.19 \\
22.41 \\
22.56 \\
22.71 \\
22.74 \\
22.74 \\
22.73 \\
22.74 \\
22.72 \\
22.69 \\
22.70 \\
22.71 \\
22.71 \\
22.71 \\
22.71 \\
22.69\end{array}$ & $\begin{array}{l}365 \\
368 \\
377 \\
386 \\
387 \\
387 \\
387 \\
387 \\
384 \\
383 \\
385 \\
362 \\
362 \\
364 \\
363 \\
368 \\
374 \\
378 \\
382 \\
383 \\
383 \\
383 \\
383 \\
383 \\
382 \\
382 \\
382 \\
382 \\
382 \\
382 \\
382\end{array}$ \\
\hline & & & & June & July & August \\
\hline $\begin{array}{l}\text { Change in } \\
\text { Change in }\end{array}$ & $\begin{array}{l}\text { contents, in mill } \\
\text { contents, in equ }\end{array}$ & $\begin{array}{l}\text { ions of cubic fee } \\
\text { ivalent second-f }\end{array}$ & t........ & $\begin{array}{r}+6 \\
+2.31\end{array}$ & $\begin{array}{r}-22 \\
-8.21\end{array}$ & $\begin{array}{r}+18 \\
+6.71\end{array}$ \\
\hline
\end{tabular}


HACKENSACK RIVER AT NEW MITFORD, N. J.

Location.-Lat. $40^{\circ} 56^{\prime} 52^{\prime \prime}$, long. $74^{\circ} 01^{\prime} 34^{\prime \prime}$, at pumping plant of Hackensack Water Co., New Milford, Bergen County, 31/2 miles downstream from Dwars Kill. Datum of gage is 6.25 feet above mean sea level. (general adjustment of 1929).

Drainage area.-113 square miles.

GAGE-HEIGHT RECORD.-Water-stage recorder graph.

Stage-discharge Relation.-Defined by current-meter measurements.

Maxima.-July 1938: Discharge, 2,350 second-feet 11 a.m. to 2 p.m. July 24 (gage height, 4.51 feet).

1921 to June 1938: Discharge, 2,800 second-feet Mar. 12, 13, 1936 (gage height, 5.08 feet).

Remarks.-Monthly mean discharge, and run-off, in inches, adjusted for diversions and for storage in Oradell Reservoir and Woodcliff Lake. Monthly mean diversion at West Nyack, N. Y.: June, 1.2 second-feet; July, 1.1 second-feet; August, 1.2 second-feet. Monthly mean diversion at New Milford: June, 52.3 second-feet; July, j0.7 second-feet; August, 53.8 second-feet. For daily changes in contents of reservoirs see records for Oradell Reservoir at Oradell, N. J., and Woodcliff Lake at Hillsdale, N. J. Water-stage recorder inspected by employees of Hackensack Water Co., and records of diversions and contents of reservoirs furnished by that company.

Mean discharge, in second-feet, 1938

\begin{tabular}{|c|c|c|c|c|c|c|c|c|c|c|c|}
\hline Day & June & July & Aug. & Day. & June & July & Aug. & Day & June & July & Aug. \\
\hline $\begin{array}{r}1 \\
2 \\
3 \\
4 \\
5 \\
6 \\
7 \\
8 \\
9 \\
10\end{array}$ & $\begin{array}{r}33 \\
20 \\
98 \\
70 \\
65 \\
37 \\
59 \\
411 \\
103 \\
36\end{array}$ & $\begin{array}{r}407 \\
360 \\
258 \\
172 \\
104 \\
78 \\
65 \\
40 \\
37 \\
92\end{array}$ & $\begin{array}{r}204 \\
114 \\
36 \\
108 \\
120 \\
129 \\
124 \\
210 \\
342 \\
137\end{array}$ & $\begin{array}{l}11 \\
12 \\
13 \\
14 \\
15 \\
16 \\
17 \\
18 \\
19 \\
20\end{array}$ & $\begin{array}{r}255 \\
208 \\
290 \\
514 \\
224 \\
154 \\
65 \\
78 \\
104 \\
78\end{array}$ & $\begin{array}{r}63 \\
96 \\
155 \\
181 \\
343 \\
163 \\
120 \\
87 \\
180 \\
223\end{array}$ & $\begin{array}{c}752 \\
281 \\
120 \\
120 \\
78 \\
12.2 \\
15.6 \\
15.6 \\
32 \\
36\end{array}$ & $\begin{array}{l}21 \\
22 \\
23 \\
24 \\
25 \\
26 \\
27 \\
28 \\
29 \\
30 \\
31\end{array}$ & $\begin{array}{r}48 \\
45 \\
38 \\
22 \\
60 \\
109 \\
469 \\
1,110 \\
647 \\
431\end{array}$ & $\begin{array}{r}466 \\
1,150 \\
1,900 \\
2,160 \\
1,010 \\
656 \\
580 \\
475 \\
383 \\
322 \\
289\end{array}$ & $\begin{array}{r}3.5 \\
33 \\
30 \\
26 \\
13.5 \\
12.0 \\
12.9 \\
14.1 \\
12.8 \\
10.0 \\
7.4\end{array}$ \\
\hline \multicolumn{9}{|c|}{$\begin{array}{l}\text { Monthly mean discharge, in second-feet (observed) } \\
\text { Monthly mean discharge, in second-feet (adjusted) } \\
\text { Runoff, in inches (adjusted) }\end{array}$} & $\begin{array}{r}196 \\
252 \\
2.49\end{array}$ & $\begin{array}{r}407 \\
451 \\
4.60\end{array}$ & $\begin{array}{r}103 \\
164 \\
1.67\end{array}$ \\
\hline
\end{tabular}

Gage height, in feet, and discharge, in second-feet, at indicated time, 1938

\begin{tabular}{|c|c|c|c|c|c|c|c|c|c|c|c|c|}
\hline \multirow{2}{*}{ Hour } & Feet & Sec.-ft. & Feet & Sec.-ft. & Feet & Sec.-ft. & Feet & Sec. $-\mathrm{ft}$. & Feet & Sec.-ft. & Feet & Sec.-ft. \\
\hline & \multicolumn{2}{|c|}{ July 17} & \multicolumn{2}{|c|}{ July 18} & \multicolumn{2}{|c|}{ July 19} & \multicolumn{2}{|c|}{ July 20} & \multicolumn{2}{|c|}{ July 21} & \multicolumn{2}{|c|}{ July 22} \\
\hline 2 a.m. & 1.57 & 145 & 1.47 & 104 & 1.34 & 59 & 1.54 & 133 & 1.79 & 248 & 2.77 & 887 \\
\hline & 1.56 & 141 & 1.48 & 108 & 1.33 & 56 & 1.54 & 133 & 1.79 & 248 & 2.81 & 918 \\
\hline & 1.56 & 141 & 1.48 & 108 & 1.33 & 56 & 1.54 & 133 & 1.78 & 24 & 2.81 & 918 \\
\hline 8 & 1.56 & 141 & 1.46 & 100 & 1.33 & 56 & 1.54 & 133 & 1.79 & 248 & 2.74 & 863 \\
\hline 10 & 1.47 & 104 & 1.43 & 88 & 1.33 & 56 & 1.54 & 13 & 1.79 & 24 & 2.75 & 871 \\
\hline $12 \mathrm{n}$. & 1.46 & 100 & 1.43 & 88 & 1.33 & 56 & 1.91 & 31 & 1.88 & 29 & 3.14 & 1,190 \\
\hline $2 \mathrm{p.m}$. & 1.46 & 100 & 1.45 & 96 & 1.36 & 65 & 1.94 & 327 & 2.53 & 706 & 3.12 & 1,170 \\
\hline & 1.48 & 108 & 1.45 & 96 & 2.12 & 431 & 1.9 & 34 & 2. & 68 & 3.4 & 1,410 \\
\hline 6 & 1.49 & 112 & 1.34 & 59 & 2.12 & 431 & 1.9 & 34 & 2.5 & 691 & 3.4 & 1,410 \\
\hline 8 & 1.49 & 112 & 1.32 & 53 & 2.12 & 431 & 1.97 & 34 & 2.5 & 691 & 3.39 & 1,400 \\
\hline & 1.49 & 11 & 1.33 & 56 & $1.8 \mathrm{~s}$ & 300 & 1.8 & 25 & 2.5 & 684 & 3. & 1,390 \\
\hline $12 \mathrm{~m}$. & 1.47 & 104 & 1.33 & 56 & 1.80 & 253 & 1.79 & 248 & 2.68 & 817 & 3.38 & 1,390 \\
\hline
\end{tabular}


Gage-height, in feet, and discharge, in second-feet, at indicated time, 1938-Continued

\begin{tabular}{|c|c|c|c|c|c|c|c|c|c|c|c|c|}
\hline \multirow{2}{*}{ Hour } & Feet & Sec.-ft. & Feet & Sec.-ft. & Feet & Sec.fft. & Feet & Sec.-ft. & Feet & Sec.-ft. & Feet & Sec.-ft. \\
\hline & \multicolumn{2}{|c|}{ July 23} & \multicolumn{2}{|c|}{ July 24} & \multicolumn{2}{|c|}{ July 25} & \multicolumn{2}{|c|}{ July 26} & \multicolumn{2}{|c|}{ July 27} & \multicolumn{2}{|c|}{ July 28} \\
\hline \multirow[t]{2}{*}{$\begin{array}{c}2 \mathrm{a} . \mathrm{m} . \\
4 \\
6 \\
8 \\
10 \\
12 \mathrm{n} . \\
2 \mathrm{p} . \mathrm{m} . \\
4 \\
6 \\
8 \\
10 \\
12 \mathrm{~m} .\end{array}$} & $\begin{array}{l}3.37 \\
3.36 \\
3.36 \\
3.45 \\
4.18 \\
4.35 \\
4.32 \\
4.25 \\
4.29 \\
4.33 \\
4.30 \\
4.24\end{array}$ & $\begin{array}{l}1,380 \\
1,370 \\
1,370 \\
1,450 \\
2,070 \\
2,220 \\
2,190 \\
2,130 \\
2,160 \\
2,200 \\
2,170 \\
2,120\end{array}$ & $\begin{array}{l}4.20 \\
4.18 \\
4.19 \\
4.21 \\
4.50 \\
4.51 \\
4.51 \\
4.49 \\
4.49 \\
4.50 \\
3.84 \\
3.63\end{array}$ & $\begin{array}{l}2,090 \\
2,070 \\
2,080 \\
2,100 \\
2,340 \\
2,350 \\
2,350 \\
2,330 \\
2,330 \\
2,340 \\
1,780 \\
1,600\end{array}$ & $\begin{array}{l}3.48 \\
3.32 \\
3.30 \\
3.28 \\
2.89 \\
2.90 \\
2.91 \\
2.50 \\
2.50 \\
2.50 \\
2.50 \\
2.50\end{array}$ & $\begin{array}{r}1,470 \\
1,340 \\
1,320 \\
1.300 \\
982 \\
990 \\
998 \\
684 \\
684 \\
684 \\
684 \\
684\end{array}$ & $\begin{array}{l}2.37 \\
2.30 \\
2.22 \\
2.56 \\
2.57 \\
2.57 \\
2.57 \\
2.52 \\
2.52 \\
2.52 \\
2.52 \\
2.52\end{array}$ & $\begin{array}{l}594 \\
546 \\
494 \\
728 \\
735 \\
735 \\
735 \\
699 \\
699 \\
699 \\
699 \\
699\end{array}$ & $\begin{array}{l}2.42 \\
2.38 \\
2.37 \\
2.36 \\
2.36 \\
2.36 \\
2.36 \\
2.36 \\
2.36 \\
2.35 \\
2.11 \\
2.09\end{array}$ & $\begin{array}{l}628 \\
600 \\
594 \\
587 \\
587 \\
587 \\
587 \\
587 \\
587 \\
580 \\
425 \\
413\end{array}$ & $\begin{array}{l}2.09 \\
2.09 \\
2.09 \\
2.09 \\
2.09 \\
2.09 \\
2.09 \\
2.09 \\
2.09 \\
2.09 \\
2.09 \\
2.10\end{array}$ & $\begin{array}{l}413 \\
413 \\
413 \\
413 \\
413 \\
413 \\
413 \\
413 \\
413 \\
413 \\
413 \\
419\end{array}$ \\
\hline & \multicolumn{2}{|c|}{ July 29} & \multicolumn{2}{|c|}{ July 30} & \multicolumn{2}{|c|}{ July 31} & \multicolumn{2}{|c|}{ August 1} & \multicolumn{2}{|c|}{ August 2} & \multicolumn{2}{|c|}{ August 3} \\
\hline $\begin{array}{c}2 \text { a.m. } \\
4 \\
6 \\
8 \\
10 \\
12 \mathrm{n} . \\
2 \mathrm{p} . \mathrm{m} . \\
4 \\
6 \\
8 \\
10 \\
12 \mathrm{~m} .\end{array}$ & $\begin{array}{l}2.10 \\
2.10 \\
2.10 \\
2.09 \\
2.09 \\
2.09 \\
2.08 \\
2.07 \\
1.93 \\
1.93 \\
1.93 \\
1.94\end{array}$ & $\begin{array}{l}419 \\
419 \\
419 \\
413 \\
413 \\
413 \\
407 \\
401 \\
322 \\
322 \\
322 \\
327\end{array}$ & $\begin{array}{l}1.94 \\
1.94 \\
1.93 \\
1.92 \\
1.93 \\
1.92 \\
1.92 \\
1.92 \\
1.92 \\
1.93 \\
1.94 \\
1.94\end{array}$ & $\begin{array}{l}327 \\
327 \\
322 \\
316 \\
322 \\
316 \\
316 \\
316 \\
316 \\
322 \\
327 \\
327\end{array}$ & $\begin{array}{l}1.94 \\
1.95 \\
1.94 \\
1.93 \\
1.92 \\
1.92 \\
1.93 \\
1.77 \\
1.77 \\
1.77 \\
1.77 \\
1.77\end{array}$ & $\begin{array}{l}327 \\
332 \\
327 \\
322 \\
316 \\
316 \\
322 \\
238 \\
238 \\
238 \\
238 \\
238\end{array}$ & $\begin{array}{l}1.77 \\
1.77 \\
1.76 \\
1.75 \\
1.75 \\
1.75 \\
1.75 \\
1.60 \\
1.59 \\
1.59 \\
1.59 \\
1.59\end{array}$ & $\begin{array}{l}238 \\
238 \\
233 \\
228 \\
228 \\
228 \\
228 \\
158 \\
154 \\
154 \\
154 \\
154\end{array}$ & $\begin{array}{l}1.60 \\
1.60 \\
1.60 \\
1.58 \\
1.58 \\
1.57 \\
1.49 \\
1.36 \\
1.27 \\
1.27 \\
1.21 \\
1.28\end{array}$ & $\begin{array}{r}158 \\
158 \\
158 \\
150 \\
150 \\
145 \\
112 \\
65 \\
41 \\
41 \\
41 \\
43\end{array}$ & $\begin{array}{l}1.30 \\
1.31 \\
1.28 \\
1.28 \\
1.18 \\
1.13 \\
1.13 \\
1.15 \\
1.21 \\
1.25 \\
1.34 \\
1.43\end{array}$ & $\begin{array}{r}48 \\
50 \\
43 \\
43 \\
22 \\
14.2 \\
14.2 \\
17.1 \\
28 \\
36 \\
59 \\
88\end{array}$ \\
\hline
\end{tabular}

WOODCLIFF IAKE AT HILISDALE, N. J.

Location.-Lat. $41^{\circ} 00^{\prime} 42^{\prime \prime}$, long. $74^{\circ} 02^{\prime} 55^{\prime \prime}$, at Woodcliff Lake Dam in Hillsdale, Bergen County. Gage heights are elevations above mean sea level (general adjustment of 1929).

Drainage AREA.-20.2 square miles.

GAGE-HEIGHT RECORD.-Gage read twice daily to hundredths. Gage heights shown in table are readings at 8 a.m.

Remarks.-Capacity, 112,000,000 cubic feet. Records furnished by Hackensack Water Co. 
Gage height, in feet, and contents, in millions of cubic feet, 1938

\begin{tabular}{|c|c|c|c|c|c|c|c|}
\hline \multirow{2}{*}{ Day } & \multicolumn{2}{|c|}{ June } & \multicolumn{2}{|c|}{ July } & \multicolumn{3}{|c|}{ August } \\
\hline & Gage height & Contents & Gage height & Contents & Gag & ght & Contents \\
\hline $\begin{array}{l}\mathbf{1} \\
\mathbf{2} \\
\mathbf{3} \\
4 \\
\tilde{5}\end{array}$ & $\begin{array}{l}94.53 \\
94.53 \\
94.53 \\
94.63 \\
94.53\end{array}$ & $\begin{array}{l}113 \\
113 \\
113 \\
114 \\
113\end{array}$ & $\begin{array}{l}94.63 \\
94.63 \\
94.63 \\
94.63 \\
94.53\end{array}$ & $\begin{array}{l}114 \\
114 \\
114 \\
114 \\
113\end{array}$ & & & $\begin{array}{l}114 \\
114 \\
114 \\
114 \\
114\end{array}$ \\
\hline $\begin{array}{r}6 \\
7 \\
8 \\
9 \\
10\end{array}$ & $\begin{array}{l}94.53 \\
94.53 \\
94.63 \\
94.63 \\
94.53\end{array}$ & $\begin{array}{l}113 \\
113 \\
114 \\
114 \\
113\end{array}$ & $\begin{array}{l}94.53 \\
94.53 \\
94.53 \\
94.53 \\
94.53\end{array}$ & $\begin{array}{l}113 \\
113 \\
113 \\
113 \\
113\end{array}$ & & & $\begin{array}{l}114 \\
114 \\
114 \\
113 \\
114\end{array}$ \\
\hline $\begin{array}{l}11 \\
12 \\
13 \\
14 \\
15\end{array}$ & $\begin{array}{l}94.53 \\
94.63 \\
94.73 \\
94.73 \\
94.73\end{array}$ & $\begin{array}{l}113 \\
114 \\
114 \\
114 \\
114\end{array}$ & $\begin{array}{l}94.53 \\
94.53 \\
94.83 \\
94.73 \\
94.63\end{array}$ & $\begin{array}{l}113 \\
113 \\
115 \\
114 \\
114\end{array}$ & & & $\begin{array}{l}115 \\
115 \\
114 \\
114 \\
113\end{array}$ \\
\hline $\begin{array}{l}16 \\
17 \\
18 \\
19 \\
20\end{array}$ & $\begin{array}{l}94.53 \\
94.53 \\
94.53 \\
94.53 \\
94.53\end{array}$ & $\begin{array}{l}113 \\
113 \\
113 \\
113 \\
113\end{array}$ & $\begin{array}{l}94.63 \\
94.53 \\
94.53 \\
94.53 \\
94.63\end{array}$ & $\begin{array}{l}114 \\
113 \\
113 \\
113 \\
114\end{array}$ & & & $\begin{array}{l}113 \\
113 \\
113 \\
113 \\
112\end{array}$ \\
\hline $\begin{array}{l}21 \\
22 \\
23 \\
24 \\
25\end{array}$ & $\begin{array}{l}94.53 \\
94.43 \\
94.43 \\
94.43 \\
94.43\end{array}$ & $\begin{array}{l}113 \\
112 \\
112 \\
112 \\
112\end{array}$ & $\begin{array}{l}94.83 \\
95.33 \\
95.03 \\
95.63 \\
95.03\end{array}$ & $\begin{array}{l}115 \\
119 \\
117 \\
121 \\
117\end{array}$ & & & $\begin{array}{l}113 \\
113 \\
113 \\
113 \\
112\end{array}$ \\
\hline \multirow[t]{2}{*}{$\begin{array}{l}26 \\
27 \\
28 \\
29 \\
\mathbf{3 0} \\
\mathbf{3 1}\end{array}$} & $\begin{array}{l}94.53 \\
94.93 \\
95.53 \\
95.03 \\
94.73\end{array}$ & $\begin{array}{l}113 \\
116 \\
120 \\
117 \\
114\end{array}$ & $\begin{array}{l}94.83 \\
94.73 \\
94.73 \\
94.73 \\
94.83 \\
94.73\end{array}$ & $\begin{array}{l}115 \\
114 \\
114 \\
114 \\
115 \\
114\end{array}$ & & & $\begin{array}{l}112 \\
112 \\
112 \\
112 \\
112 \\
112\end{array}$ \\
\hline & & & & & & July & August \\
\hline $\begin{array}{l}\text { Change } \\
\text { Change }\end{array}$ & $\begin{array}{l}\text { ntents, in mi } \\
\text { ntents, in equ }\end{array}$ & $\begin{array}{l}\text { is of cubic } \\
\text { lent secon }\end{array}$ & 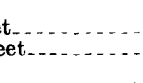 & $\cdots$ & .39 & $\begin{array}{l}0 \\
0\end{array}$ & $\begin{array}{l}-1 \\
-0.37\end{array}$ \\
\hline
\end{tabular}

PASCACK BROOK AT WTSTWOOD, T. J.

Location.-Lat. $40^{\circ} 59^{\prime} 33^{\prime \prime}$, long. $74^{\circ} 01^{\prime} 19^{\prime \prime}, 75$ feet upstream from Harrington Avenue, Westwood, Bergen County, 500 feet downstream from Musquapsink Creek. Datum of gage is 28.62 feet above mean sea level (general adjustment of 1929).

DRAinAGE AREA.-29.6 square miles.

GAGE-HEIGHT RECORD.-Water-stage recorder graph except for periods June 1-10, Aug. 3-5, 15-19 when graph is based on once daily staff-gage readings and range of stage.

StAGE-Discharge RELATron.-Defined by current-meter measurements below 500 second-feet: extended to peak stage on basis of study of run-off at stations on nearby streams.

Maxima.-July 1938: Discharge, 600 second-feet 9 to 10 a.m. July 24 (gage height, 4.05 feet).

1934 to June 1938: Discharge, 1,190 second-feet March 12, 1936 (gage height, 5.53 feet).

REMarks.-Monthly mean discharge and run-off, in inches, adjusted for storage in Woodcliff Lake (see p. 284). Recorder operated and storage data furnished by Hackensack Water Co. 
Mean discharge, in second-feet, 1938

\begin{tabular}{|c|c|c|c|c|c|c|c|c|c|c|c|}
\hline Day & June & July & Aug. & Day & June & July & Aug. & Day & June & July & Aug. \\
\hline $\begin{array}{r}1 \\
2 \\
3 \\
4 \\
5 \\
6 \\
7 \\
8 \\
9 \\
10\end{array}$ & $\begin{array}{l}20 \\
18.2 \\
42 \\
44 \\
35 \\
28 \\
24 \\
61 \\
51 \\
32\end{array}$ & $\begin{array}{l}54 \\
46 \\
41 \\
28 \\
28 \\
23 \\
25 \\
20 \\
30 \\
37\end{array}$ & $\begin{array}{l}56 \\
56 \\
49 \\
43 \\
46 \\
47 \\
41 \\
47 \\
54 \\
47\end{array}$ & $\begin{array}{l}11 \\
12 \\
13 \\
14 \\
15 \\
16 \\
17 \\
18 \\
19 \\
20\end{array}$ & $\begin{array}{l}49 \\
56 \\
74 \\
81 \\
57 \\
32 \\
32 \\
34 \\
32 \\
24\end{array}$ & $\begin{array}{l}35 \\
54 \\
81 \\
60 \\
54 \\
42 \\
32 \\
28 \\
38 \\
55\end{array}$ & $\begin{array}{r}116 \\
90 \\
51 \\
39 \\
29 \\
32 \\
28 \\
27 \\
33 \\
24\end{array}$ & $\begin{array}{l}21 \\
22 \\
23 \\
24 \\
25 \\
26 \\
27 \\
28 \\
29 \\
30 \\
31\end{array}$ & $\begin{array}{l}23 \\
17.0 \\
20 \\
20 \\
18.2 \\
36 \\
142 \\
362 \\
172 \\
82\end{array}$ & $\begin{array}{r}135 \\
313 \\
339 \\
518 \\
209 \\
112 \\
85 \\
74 \\
72 \\
93 \\
70\end{array}$ & $\begin{array}{l}24 \\
32 \\
24 \\
26 \\
19.4 \\
23 \\
17.6 \\
17.0 \\
22 \\
17.0 \\
17.0\end{array}$ \\
\hline \multicolumn{9}{|c|}{$\begin{array}{l}\text { Monthly mean discharge, in second-feet (observed) } \\
\text { Monthly mean discharge, in second-feet (adjusted) } \\
\text { Runoff, in inches (adjusted) }\end{array}$} & $\begin{array}{l}57.3 \\
57.6 \\
2.18\end{array}$ & $\begin{array}{l}91.3 \\
91.3 \\
3.55\end{array}$ & $\begin{array}{l}38.5 \\
38.2 \\
1.49\end{array}$ \\
\hline
\end{tabular}

Gage height, in feet, and discharge, in second-feet, at indicated time, 1938

\begin{tabular}{|c|c|c|c|c|c|c|c|c|c|c|c|c|}
\hline \multirow[t]{2}{*}{ Hour } & Feet & Sec.-ft. & Feet & Sec.-ft. & Feet & Sec.-ft. & Feet & Sec.-ft. & Feet & Sec.-ft. & Feet & Sec. $-\mathrm{ft}$. \\
\hline & \multicolumn{2}{|c|}{ July 17} & \multicolumn{2}{|c|}{ July 18} & \multicolumn{2}{|c|}{ July 19} & \multicolumn{2}{|c|}{ July 20} & \multicolumn{2}{|c|}{ July 21} & \multicolumn{2}{|c|}{ July 22} \\
\hline \multirow[t]{2}{*}{$\begin{array}{l}2 \text { a.m. } \\
4 \\
6 \\
8 \\
10 \\
12 \mathrm{n} . \\
2 \mathrm{p.m} . \\
4 \\
6 \\
8 \\
10 \\
12 \mathrm{~m} .\end{array}$} & 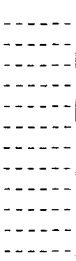 & 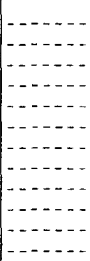 & 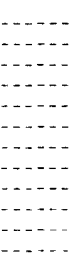 & $\begin{array}{l}- \\
-\end{array}$ & $\begin{array}{l}1.71 \\
1.71 \\
1.72 \\
1.73 \\
1.73 \\
1.74 \\
1.85 \\
1.91 \\
1.83 \\
1.82 \\
1.81 \\
1.81\end{array}$ & $\begin{array}{l}31 \\
31 \\
32 \\
33 \\
33 \\
34 \\
46 \\
52 \\
43 \\
42 \\
41 \\
41\end{array}$ & $\begin{array}{l}1.81 \\
1.81 \\
1.86 \\
1.90 \\
1.98 \\
2.02 \\
1.99 \\
1.98 \\
1.98 \\
1.98 \\
1.98 \\
1.99\end{array}$ & $\begin{array}{l}41 \\
41 \\
47 \\
51 \\
61 \\
67 \\
63 \\
61 \\
61 \\
61 \\
61 \\
63\end{array}$ & $\begin{array}{l}2.00 \\
2.09 \\
2.14 \\
2.20 \\
2.39 \\
2.47 \\
2.55 \\
2.59 \\
2.62 \\
2.67 \\
2.73 \\
2.83\end{array}$ & $\begin{array}{r}64 \\
78 \\
85 \\
95 \\
129 \\
146 \\
163 \\
172 \\
179 \\
190 \\
204 \\
228\end{array}$ & $\begin{array}{l}2.95 \\
3.01 \\
3.08 \\
3.16 \\
3.22 \\
3.25 \\
3.26 \\
3.26 \\
3.26 \\
3.25 \\
3.19 \\
3.13\end{array}$ & $\begin{array}{l}259 \\
275 \\
294 \\
316 \\
333 \\
342 \\
344 \\
344 \\
344 \\
342 \\
324 \\
307\end{array}$ \\
\hline & \multicolumn{2}{|c|}{ July 23} & \multicolumn{2}{|c|}{ July 24} & \multicolumn{2}{|c|}{ July 25} & \multicolumn{2}{|c|}{ July 26} & \multicolumn{2}{|c|}{ July 27} & \multicolumn{2}{|c|}{ July 28} \\
\hline $\begin{aligned} & 2 \text { a.m. } \\
& 4 \\
& 6 \\
& 8 \\
& 10 \\
& 12 \mathrm{n.} \\
& 2 \mathrm{p.m} . \\
& 4 \\
& 6 \\
& 8 \\
& 10 \\
& 12 \mathrm{~m} .\end{aligned}$ & $\begin{array}{l}3.03 \\
2.93 \\
2.86 \\
2.87 \\
3.10 \\
3.21 \\
3.27 \\
3.41 \\
3.55 \\
3.60 \\
3.62 \\
3.70\end{array}$ & $\begin{array}{l}280 \\
254 \\
236 \\
238 \\
299 \\
330 \\
347 \\
389 \\
432 \\
448^{\circ} \\
454 \\
480\end{array}$ & $\begin{array}{l}3.80 \\
3.90 \\
3.99 \\
4.04 \\
4.05 \\
4.01 \\
3.94 \\
3.81 \\
3.69 \\
3.55 \\
3.41 \\
3.29\end{array}$ & $\begin{array}{l}513 \\
547 \\
578 \\
596 \\
600 \\
586 \\
561 \\
516 \\
477 \\
432 \\
389 \\
353\end{array}$ & $\begin{array}{l}3.13 \\
3.00 \\
2.89 \\
2.81 \\
2.74 \\
2.68 \\
2.61 \\
2.56 \\
2.53 \\
2.50 \\
2.46 \\
2.43\end{array}$ & $\begin{array}{l}307 \\
272 \\
244 \\
224 \\
207 \\
192 \\
176 \\
165 \\
159 \\
152 \\
144 \\
137\end{array}$ & $\begin{array}{l}2.40 \\
2.37 \\
2.35 \\
2.33 \\
2.31 \\
2.29 \\
2.27 \\
2.26 \\
2.24 \\
2.22 \\
2.21 \\
2.20\end{array}$ & $\begin{array}{r}131 \\
125 \\
122 \\
118 \\
114 \\
110 \\
107 \\
105 \\
102 \\
98 \\
97 \\
95\end{array}$ & $\begin{array}{l}2.19 \\
2.18 \\
2.17 \\
2.16 \\
2.15 \\
2.15 \\
2.14 \\
2.12 \\
2.11 \\
2.11 \\
2.10 \\
2.09\end{array}$ & $\begin{array}{l}93 \\
92 \\
90 \\
89 \\
87 \\
87 \\
85 \\
82 \\
81 \\
81 \\
79 \\
78\end{array}$ & $\begin{array}{l}2.08 \\
2.05 \\
2.06 \\
2.06 \\
2.07 \\
2.09 \\
2.09 \\
2.08 \\
2.07 \\
2.06 \\
2.05 \\
2.05\end{array}$ & $\begin{array}{l}76 \\
73 \\
73 \\
73 \\
74 \\
78 \\
78 \\
76 \\
74 \\
73 \\
72 \\
72\end{array}$ \\
\hline
\end{tabular}

\begin{tabular}{|c|c|c|c|c|c|c|c|c|c|c|c|c|}
\hline \multirow[b]{2}{*}{2 a.m. } & \multicolumn{2}{|c|}{ July 29} & \multicolumn{2}{|c|}{ July 30} & \multicolumn{2}{|c|}{ July 31} & \multicolumn{2}{|c|}{ August 1} & \multicolumn{2}{|c|}{ August 2} & \multicolumn{2}{|c|}{ August 3} \\
\hline & 2.04 & 70 & 2.21 & 97 & 2.10 & 79 & & & & & & \\
\hline & 2.04 & 70 & 2.21 & 97 & 2.09 & 78 & - - & & & & $-x_{-1}$ & $\ldots$ \\
\hline 6 & 2.04 & 70 & 2.22 & 98 & 2.08 & 76 & $-\ldots$ & & $\ldots \ldots$ & $\ldots$ & $\ldots$ & _. . . \\
\hline 8 & 2.04 & 70 & 2.23 & 100 & 2.07 & 74 & $\ldots \ldots$ & $-\ldots$ & $-\ldots$ & $\ldots$ & $-\ldots$ & $\ldots$ \\
\hline 10 & 2.04 & 70 & 2.23 & 100 & $20 \tilde{J}$ & 72 & - & - & - $\ldots .$. & $\ldots$ & $\ldots$ & $\ldots$ \\
\hline $12 \mathrm{n}$. & 2.03 & 68 & 2.23 & 100 & 2.03 & $6 \overline{8}$ & $\ldots \ldots$ & - . - - & $\ldots . .$. & $\ldots$ & $\ldots$ & $\ldots$ \\
\hline 2 p.m. & 2.03 & 68 & 2.21 & 97 & 2.01 & 66 & $\ldots \ldots$ & $\ldots \ldots$ & $\ldots .$. & $\ldots \ldots$ & $\ldots \ldots$ & $\ldots \ldots$ \\
\hline & 2.03 & 68 & 2.18 & 92 & 2.00 & 64 & $\ldots .$. & $\ldots \ldots$ & $\ldots$ & $\ldots \ldots$ & $-\ldots .$. & $\ldots \ldots$ \\
\hline 6 & 2.03 & 68 & 2.16 & 89 & 2.00 & 64 & $\ldots .$. & $\ldots \ldots$ & $\ldots$ & $\ldots \ldots$ & $\ldots$. & $\ldots \ldots$ \\
\hline 8 & 2.10 & 79 & 2.14 & 85 & 1.99 & 633 & $\ldots \ldots$ & $\ldots . .$. & $\ldots . .$. & $\ldots \ldots$ & $\ldots .$. & $\ldots \ldots$ \\
\hline 10 & 2.14 & 85 & 2.13 & 84 & 1.98 & 01 & $\ldots .$. & $\ldots \ldots$ & $\ldots$ & $\ldots \ldots$ & $\ldots .$. & $\ldots \ldots$ \\
\hline $12 \mathrm{~m}$ & & 92 & 2.11 & 81 & 1.98 & 61 & $\ldots \ldots$ & $\ldots \ldots$ & $\ldots \ldots$ & $\ldots \ldots$ & $\ldots \ldots$ & $\ldots . . .$. \\
\hline
\end{tabular}




\section{PASSAIC RIVER BASIN}

ROCKAWAY RIVER ABOVE RESFRVOIR AT BOONTON, N. J.

Location.-Lat. 40 54'06", long. 74 24:40", at Morris Avenue, Boonton, Morris County and 1.8 miles upstream from Boonton Reservoir dam. Datum of gage is 364.47 feet above mean sea level (New Jersey Geological Survey bench mark).

Drainace area.—116 square miles.

GAGE-HEIGHT RECORD.-Water-stage recorder graph.

Stage-discharge relation.-Defined by current-meter measurements.

Maxima.-July 1938: Discharge, 2,120 second-feet 11 a.m. to 2 p.m. July 24 (gage height, 5.43 feet).

1937 to June 1938: Discharge, 1,900 second-feet Nov. 14, 1937, and Jan. 25, 1938 (gage height, 5.15 feet).

REMARKs.-Discharge not materially affected by storage. Monthly mean discharge and runoff in inches, adjusted for water diverted above station by trunk sewer. Monthly mean diversions were: June, 4.2 second-feet; July, 5.2 second-feet; August, 4.7 second-feet. Water-stage recorder inspected by employees of Department of Streets and Public Improvements, Bureau of Water, Jersey City.

Mean discharge, in second-feet, 1938

\begin{tabular}{r|r|r|r|r|r|r|r|r|r|r|r}
\hline Day & June & July & Aug. & Day & June & July & Aug. & Day & June & July & Aug. \\
\hline & & & & & & & & \\
1 & 100 & 589 & 476 & 11 & 91 & 105 & 377 & 21 & 66 & 476 & 105 \\
2 & 76 & 448 & 420 & 12 & 115 & 125 & 377 & 22 & 62 & 1,020 & 100 \\
3 & 105 & 335 & 341 & 13 & 154 & 134 & 281 & 23 & 77 & 1,160 & 91 \\
4 & 102 & 262 & 291 & 14 & 145 & 128 & 208 & 24 & 248 & 1,980 & 85 \\
5 & 105 & 208 & 253 & 15 & 116 & 134 & 176 & 25 & 154 & 1,550 & 78 \\
6 & 80 & 170 & 281 & 16 & 113 & 113 & 150 & 26 & 138 & 1,160 & 74 \\
7 & 85 & 140 & 351 & 17 & 94 & 89 & 134 & 27 & 623 & 888 & 70 \\
8 & 173 & 122 & 296 & 18 & 98 & 80 & 134 & 28 & 930 & 738 & 69 \\
9 & 140 & 120 & 262 & 19 & 91 & 89 & 128 & 29 & 944 & 627 & 64 \\
10 & 92 & 96 & 248 & 20 & 70 & 225 & 115 & 30 & 785 & 685 & 64 \\
&
\end{tabular}

Gage height, in feet, and discharge, in second-feet, at indicated time, 1938

\begin{tabular}{|c|c|c|c|c|c|c|c|c|c|c|c|c|}
\hline \multirow{2}{*}{ Hour } & Feet & Sec.-ft. & Feet & Sec. $-\mathrm{ft}$. & Feet & Sec.-ft. & Feet & Sec.-ft. & Feet & Sec.-ft. & Feet & Sec.-ft. \\
\hline & \multicolumn{2}{|c|}{ July 17} & \multicolumn{2}{|c|}{ July 18} & \multicolumn{2}{|c|}{ July 19} & \multicolumn{2}{|c|}{ Jйу 20} & \multicolumn{2}{|c|}{ July 21} & \multicolumn{2}{|c|}{ July 22} \\
\hline $\begin{array}{c}2 \text { a.m. } \\
4 \\
6 \\
8 \\
10 \\
12 \mathrm{n} . \\
2 \text { p.m. } \\
4 \\
6 \\
8 \\
10 \\
12 \mathrm{~m} .\end{array}$ & $\begin{array}{l}2.19 \\
2.18 \\
2.17 \\
2.20 \\
2.27 \\
2.33 \\
2.35 \\
2.33 \\
2.28 \\
2.24 \\
2.22 \\
2.20\end{array}$ & $\begin{array}{r}76 \\
74 \\
72 \\
78 \\
93 \\
108 \\
112 \\
108 \\
96 \\
87 \\
82 \\
78\end{array}$ & $\begin{array}{l}2.18 \\
2.17 \\
2.15 \\
2.15 \\
2.15 \\
2.16 \\
2.17 \\
2.18 \\
2.25 \\
2.32 \\
2.35 \\
2.38\end{array}$ & $\begin{array}{r}74 \\
72 \\
69 \\
69 \\
69 \\
70 \\
72 \\
74 \\
89 \\
105 \\
112 \\
120\end{array}$ & $\begin{array}{l}2.38 \\
2.35 \\
2.28 \\
2.24 \\
2.20 \\
2.18 \\
2.20 \\
2.18 \\
2.18 \\
2.20 \\
2.21 \\
2.22\end{array}$ & $\begin{array}{r}120 \\
112 \\
96 \\
87 \\
78 \\
74 \\
78 \\
74 \\
74 \\
78 \\
80 \\
82\end{array}$ & $\begin{array}{l}2.29 \\
2.34 \\
2.36 \\
2.36 \\
2.50 \\
2.59 \\
2.75 \\
2.89 \\
2.97 \\
3.02 \\
3.03 \\
3.02\end{array}$ & $\begin{array}{r}98 \\
110 \\
115 \\
115 \\
154 \\
183 \\
253 \\
320 \\
361 \\
388 \\
393 \\
388\end{array}$ & $\begin{array}{l}3.01 \\
2.99 \\
2.97 \\
2.97 \\
2.98 \\
3.06 \\
3.11 \\
3.17 \\
3.27 \\
3.52 \\
3.63 \\
3.77\end{array}$ & $\begin{array}{l}382 \\
372 \\
361 \\
361 \\
367 \\
409 \\
437 \\
470 \\
528 \\
685 \\
758 \\
853\end{array}$ & $\begin{array}{l}3.84 \\
3.88 \\
3.94 \\
3.99 \\
4.04 \\
4.06 \\
4.09 \\
4.10 \\
4.10 \\
4.10 \\
4.09 \\
4.08\end{array}$ & $\begin{array}{r}902 \\
930 \\
974 \\
1,010 \\
1,050 \\
1,060 \\
1,080 \\
1,090 \\
1,090 \\
1,090 \\
1,080 \\
1,080\end{array}$ \\
\hline
\end{tabular}


Gage-height, in feet, and discharge, in second-feet, at indicated time, 1938-Continued

\begin{tabular}{|c|c|c|c|c|c|c|c|c|c|c|c|c|}
\hline \multirow{2}{*}{ Hour } & Feet & Sec.-ft. & Feet & Sec. $-\mathrm{ft}$. & Feet & Sec.-ft. & Feet & Sec.-ft. & Feet & Sec.-ft. & Feet & Sec.-ft. \\
\hline & \multicolumn{2}{|c|}{ July 23} & \multicolumn{2}{|c|}{ July 24} & \multicolumn{2}{|c|}{ July 25} & \multicolumn{2}{|c|}{ July 26} & \multicolumn{2}{|c|}{ July 27} & \multicolumn{2}{|c|}{ July 28} \\
\hline $\begin{array}{c}2 \mathrm{a} . \mathrm{m} . \\
4 \\
6 \\
8 \\
8 \\
12 \\
12 \mathrm{n} . \\
22 \mathrm{p.m} . \\
4 \\
6 \\
8 \\
10 \\
12 \mathrm{~m} .\end{array}$ & $\begin{array}{l}4.07 \\
4.06 \\
4.05 \\
4.05 \\
4.06 \\
4.10 \\
4.16 \\
4.27 \\
4.32 \\
4.40 \\
4.52 \\
4.72\end{array}$ & $\begin{array}{l}1,070 \\
1,060 \\
1,060 \\
1,060 \\
1,060 \\
1,090 \\
1,130 \\
1,220 \\
1,250 \\
1,310 \\
1,410 \\
1,560\end{array}$ & $\begin{array}{l}4.93 \\
5.11 \\
5.25 \\
5.37 \\
5.41 \\
5.43 \\
5.42 \\
5.37 \\
5.32 \\
5.26 \\
5.21 \\
5.14\end{array}$ & $\begin{array}{l}1,720 \\
1,870 \\
1,980 \\
2,080 \\
2,110 \\
2,120 \\
2,120 \\
2,080 \\
2,040 \\
1,990 \\
1,950 \\
1,890\end{array}$ & $\begin{array}{l}3.07 \\
4.97 \\
4.89 \\
4.81 \\
+.74 \\
4.67 \\
4.63 \\
4.55 \\
4.52 \\
4.50 \\
4.49 \\
4.45\end{array}$ & $\begin{array}{l}1,840 \\
1,760 \\
1,690 \\
1,630 \\
1,580 \\
1,530 \\
1,490 \\
1,430 \\
1,410 \\
1,390 \\
1,380 \\
1,350\end{array}$ & $\begin{array}{l}4.40 \\
4.35 \\
4.30 \\
4.26 \\
4.23 \\
4.19 \\
4.16 \\
4.13 \\
4.08 \\
4.04 \\
4.00 \\
3.97\end{array}$ & $\begin{array}{r}1,310 \\
1,280 \\
1,240 \\
1,210 \\
1,180 \\
1,150 \\
1,130 \\
1,110 \\
1,080 \\
1,050 \\
1,020 \\
997\end{array}$ & $\begin{array}{l}3.93 \\
3.91 \\
3.88 \\
3.86 \\
3.83 \\
3.80 \\
3.78 \\
3.76 \\
3.82 \\
3.78 \\
3.76 \\
3.73\end{array}$ & $\begin{array}{l}967 \\
952 \\
930 \\
916 \\
895 \\
\mathbf{8 7 4} \\
\mathbf{8 6 0} \\
846 \\
\mathbf{8 8 8} \\
\mathbf{8 6 0} \\
\mathbf{8 4 6} \\
\mathbf{8 2 6}\end{array}$ & $\begin{array}{l}3.70 \\
3.68 \\
3.67 \\
3.65 \\
3.63 \\
3.61 \\
3.59 \\
3.57 \\
3.53 \\
3.51 \\
3.49 \\
3.48\end{array}$ & $\begin{array}{l}805 \\
792 \\
785 \\
772 \\
758 \\
745 \\
731 \\
718 \\
692 \\
679 \\
666 \\
659\end{array}$ \\
\hline $12 \mathrm{~m}$. & \multicolumn{2}{|c|}{ July 29} & \multicolumn{2}{|c|}{ July 30} & \multicolumn{2}{|c|}{ July 31} & \multicolumn{2}{|c|}{ August 1} & \multicolumn{2}{|c|}{ August 2} & \multicolumn{2}{|c|}{ August 3} \\
\hline $\begin{array}{l}2 \mathrm{a} . \mathrm{m} . \\
4 \\
6 \\
8 \\
10 \\
12 \mathrm{n} . \\
22 \mathrm{p.m} . \\
4 \\
6 \\
8 \\
10 \\
12 \mathrm{~m} .\end{array}$ & $\begin{array}{l}3.47 \\
3.45 \\
3.44 \\
3.42 \\
3.40 \\
3.37 \\
3.35 \\
3.43 \\
3.45 \\
3.45 \\
3.47 \\
3.48\end{array}$ & $\begin{array}{l}653 \\
640 \\
634 \\
621 \\
608 \\
589 \\
577 \\
627 \\
640 \\
640 \\
653 \\
659\end{array}$ & $\begin{array}{l}3.50 \\
3.53 \\
3.55 \\
3.57 \\
3.57 \\
3.57 \\
3.55 \\
3.53 \\
3.51 \\
3.50 \\
3.48 \\
3.46\end{array}$ & $\begin{array}{l}672 \\
692 \\
705 \\
718 \\
718 \\
718 \\
705 \\
692 \\
679 \\
672 \\
659 \\
646\end{array}$ & $\begin{array}{l}3.43 \\
3.41 \\
3.37 \\
3.35 \\
3.33 \\
3.30 \\
3.27 \\
3.26 \\
3.25 \\
3.24 \\
3.24 \\
3.24\end{array}$ & $\begin{array}{l}627 \\
614 \\
589 \\
577 \\
565 \\
546 \\
528 \\
522 \\
516 \\
511 \\
511 \\
511\end{array}$ & $\begin{array}{l}3.24 \\
3.24 \\
3.23 \\
3.22 \\
3.21 \\
3.19 \\
3.18 \\
3.16 \\
3.15 \\
3.13 \\
3.12 \\
3.11\end{array}$ & $\begin{array}{l}511 \\
511 \\
505 \\
499 \\
493 \\
481 \\
476 \\
465 \\
459 \\
448 \\
442 \\
437\end{array}$ & $\begin{array}{l}3.11 \\
3.12 \\
3.12 \\
3.12 \\
3.10 \\
3.08 \\
3.07 \\
3.05 \\
3.03 \\
3.02 \\
3.01 \\
3.00\end{array}$ & $\begin{array}{l}437 \\
442 \\
442 \\
442 \\
431 \\
420 \\
415 \\
404 \\
393 \\
388 \\
382 \\
377\end{array}$ & $\begin{array}{l}2.98 \\
2.97 \\
2.95 \\
2.95 \\
2.94 \\
2.93 \\
2.93 \\
2.93 \\
2.92 \\
2.91 \\
2.88 \\
2187\end{array}$ & $\begin{array}{l}367 \\
361 \\
351 \\
351 \\
346 \\
341 \\
341 \\
341 \\
335 \\
330 \\
315 \\
310\end{array}$ \\
\hline
\end{tabular}

Supplemental records.-July $27,5: 30$ p.m., 3.74 ft., 833 sec.-ft.; 5:45 p.m., $3.86 \mathrm{ft} ., 916$ sec.-ft.; July $29,3: 45$ p.m., $3.33 \mathrm{ft} ., 565$ sec.-ft.

BOONTON EESERVOIR AT BOONTON, 2. J.

Location.-Lat. $40^{\circ} 53^{\prime} 35^{\prime \prime}$, long. 74 $23^{\prime} 55^{\prime \prime}$, at Boonton Reservoir dam, Boonton, Morris County. Datum of gage is 305.25 feet above mean sea level (New Jersey Geological Survey bench mark).

Drainage AREA.-119 square miles.

GAGE-HEIGHT RECORD.-One gage reading daily, usually about 8 a.m.

Remarks.-Usable capacity, $870,000,000$ cubic feet. Crest of spillway is at gage datum. Flash boards used on spillway. Records furnished by Department of Streets and Public Improvements, Bureau of Water, Jersey City.

Gage height, in feet, and contents, in millions of cubic feet, 1938

\begin{tabular}{|c|c|c|c|c|c|c|}
\hline \multirow{2}{*}{ Day } & \multicolumn{2}{|c|}{ June } & \multicolumn{2}{|c|}{ July } & \multicolumn{2}{|c|}{ August } \\
\hline & Gage height & Contents & Gage height & Contents & Gage height & Contents \\
\hline $\begin{array}{l}\mathbf{1} \\
\mathbf{2} \\
\mathbf{3} \\
\mathbf{4} \\
\mathbf{5}\end{array}$ & $\begin{array}{l}1.86 \\
1.81 \\
1.78 \\
1.87 \\
1.82\end{array}$ & $\begin{array}{l}1,083 \\
1,082 \\
1,081 \\
1,084 \\
1,082\end{array}$ & $\begin{array}{l}2.35 \\
2.25 \\
2.17 \\
2.09 \\
2.02\end{array}$ & $\begin{array}{l}1,100 \\
1,097 \\
1,094 \\
1,091 \\
1,089\end{array}$ & $\begin{array}{l}2.26 \\
2.22 \\
2.16 \\
2.08 \\
2.04\end{array}$ & $\begin{array}{l}1,097 \\
1,096 \\
1,094 \\
1,091 \\
1,090\end{array}$ \\
\hline $\begin{array}{r}6 \\
7 \\
8 \\
9 \\
10\end{array}$ & $\begin{array}{l}1.82 \\
1.76 \\
1.83 \\
1.89 \\
1.88\end{array}$ & $\begin{array}{l}1,082 \\
1,080 \\
1,082 \\
1,084 \\
1,084\end{array}$ & $\begin{array}{l}1.96 \\
1.90 \\
1.89 \\
1.88 \\
1.84\end{array}$ & $\begin{array}{l}1,087 \\
1,085 \\
1,084 \\
1,084 \\
1,083\end{array}$ & $\begin{array}{l}2.02 \\
2.06 \\
2.09 \\
2.06 \\
2.04\end{array}$ & $\begin{array}{l}1,089 \\
1,090 \\
1,091 \\
1,090 \\
1,090\end{array}$ \\
\hline $\begin{array}{l}11 \\
12 \\
13 \\
14 \\
15\end{array}$ & $\begin{array}{l}1.82 \\
1.86 \\
1.88 \\
1.94 \\
1.90\end{array}$ & $\begin{array}{l}1,082 \\
1,083 \\
1,084 \\
1,086 \\
1,085\end{array}$ & $\begin{array}{l}1.82 \\
1.84 \\
1.86 \\
1.86 \\
1.91\end{array}$ & $\begin{array}{l}1,082 \\
1,083 \\
1,083 \\
1,083 \\
1,085\end{array}$ & $\begin{array}{l}2.09 \\
2.17 \\
2.12 \\
2.03 \\
1.98\end{array}$ & $\begin{array}{l}1,091 \\
1,094 \\
1,092 \\
1,089 \\
1,087\end{array}$ \\
\hline
\end{tabular}


Gage height, in feet, and contents, in millions of cubic feet, 1938-Continued

\begin{tabular}{|c|c|c|c|c|c|c|c|}
\hline \multirow{2}{*}{ Day } & \multicolumn{2}{|c|}{ June } & \multicolumn{2}{|c|}{ July } & \multicolumn{3}{|c|}{ August } \\
\hline & Gage height & Contents & Gage height & Contents & $\mathrm{Ga}$ & height & Contents \\
\hline $\begin{array}{l}16 \\
17 \\
18 \\
19 \\
20\end{array}$ & $\begin{array}{l}1.84 \\
1.81 \\
1.84 \\
1.85 \\
1.80\end{array}$ & $\begin{array}{l}1,083 \\
1,082 \\
1,083 \\
1,083 \\
1,081\end{array}$ & $\begin{array}{l}1.88 \\
1.83 \\
1.80 \\
1.80 \\
2.11\end{array}$ & $\begin{array}{l}1.084 \\
1,082 \\
1,081 \\
1,081 \\
1,092\end{array}$ & & $\begin{array}{l}.93 \\
.90 \\
.87 \\
.88 \\
.87\end{array}$ & $\begin{array}{l}1,086 \\
1,083 \\
1,084 \\
1,084 \\
1,084\end{array}$ \\
\hline $\begin{array}{l}21 \\
22 \\
23 \\
24 \\
25\end{array}$ & $\begin{array}{l}1.75 \\
1.68 \\
1.63 \\
1.75 \\
1.95\end{array}$ & $\begin{array}{l}1,079 \\
1,077 \\
1,075 \\
1,079 \\
1,086\end{array}$ & $\begin{array}{l}1.82 \\
2.45 \\
2.55 \\
2.95 \\
3.05\end{array}$ & $\begin{array}{l}1,082 \\
1,104 \\
1,107 \\
1,121 \\
1,125\end{array}$ & & $\begin{array}{l}.86 \\
.84 \\
.81 \\
.78 \\
.74\end{array}$ & $\begin{array}{l}1,083 \\
1,083 \\
1,082 \\
1,081 \\
1,079\end{array}$ \\
\hline \multirow[t]{2}{*}{$\begin{array}{l}26 \\
27 \\
28 \\
29 \\
30 \\
.31\end{array}$} & $\begin{array}{l}1.87 \\
2.10 \\
2.41 \\
2.48 \\
2.41\end{array}$ & $\begin{array}{l}1.084 \\
1.092 \\
1,102 \\
1.105 \\
1.102\end{array}$ & $\begin{array}{l}2.74 \\
2.50 \\
2.42 \\
2.34 \\
2.36 \\
2.32\end{array}$ & $\begin{array}{l}1.114 \\
1.106 \\
1,103 \\
1,100 \\
1,101 \\
1,099\end{array}$ & & $\begin{array}{l}66 \\
.62 \\
.59 \\
.54 \\
.47 \\
.40\end{array}$ & $\begin{array}{l}1,076 \\
1,075 \\
1,074 \\
1,072 \\
1,070 \\
1,067\end{array}$ \\
\hline & & & & & ine & July & August \\
\hline \multicolumn{5}{|c|}{$\begin{array}{l}\text { Change in contents, in millions of cubic feet.- } \\
\text { Change in contents, in equivalent second-feet. }\end{array}$} & & $\begin{array}{l}-3 \\
-1.1\end{array}$ & $\begin{array}{l}-30 \\
-11.2\end{array}$ \\
\hline
\end{tabular}

ROCKA WAY RIVER BEIOW RESERVOTR AT BOONTON, N. J.

[Formerly Rockaway River at Boonton, N. J.]

Location.-Lat. $40^{\circ} 53^{\prime} 47^{\prime \prime}$, long. $74^{\circ} 23^{\prime} 36^{\prime \prime}, 1,500$ feet downstream from dam of Boonton Reservoir, Boonton, Morris County. Datum of gage is 195.68 feet above mean sea level (New Jersey Geological Survey bench mark). Drainage AREA.-119 square miles.

GAGE-HEIGHT RECORD.-Water-stage recorder graph.

Stage-discharce RELation.-Defined by current-meter measurements below 1,300 second-feet; extended to peak stage on basis of logarithmic plotting and determination of flow over Boonton Reservoir dam.

Maxima.-July 1938: Discharge, 1,730 second-feet 8 to 11 p.m. July 24 (gage height, 5.87 feet).

1903-4, 1906 to June 1938: Daily discharge recorded, 7,560 second-feet Oct. 10, 1903.

REMARKs.-Observed discharge represents total flow over Boonton Reservoir dam, through waste gate, and effluent from sewage-disposal plant. Monthly mean discharge and run-off in inches, adjusted for diversion from and effect of storage in Boonton Reservoir. Monthly mean diversions were: June, 80.7 second-feet; July, 79.6 second-feet; August, 86.2 secondfeet. For information on storage see record for Boonton Reservoir at Boonton, N. J. Water-stage recorder inspected by employees of Department of Streets and Public Improvements, Bureau of Water, Jersey City. 
Mean discharge, in second-feet, 1938

\begin{tabular}{rl|c|c||c|c|c|c||c|c|c|c}
\hline Day & June & July & Aug. & Day & June & July & Aug. & Day & June & July & Aug. \\
\hline & & & & & & & & \\
1 & 34 & 483 & 386 & 11 & 23 & 14.5 & 239 & 21 & 4.8 & 309 & 32 \\
2 & 23 & 362 & 330 & 12 & 38 & 23 & 276 & 22 & 4.3 & 766 & 21 \\
3 & 10.5 & 269 & 269 & 13 & 51 & 30 & 225 & 23 & 4.3 & 947 & 13.8 \\
4 & 19.8 & 201 & 210 & 14 & 69 & 40 & 163 & 24 & 34 & 1,510 & 9.1 \\
5 & 22 & 142 & 168 & 15 & 44 & 55 & 103 & 25 & 88 & 1,480 & 5.8 \\
6 & 23 & 92 & 168 & 16 & 30 & 43 & 68 & 26 & 62 & 1,050 & 5.4 \\
7 & 20 & 64 & 239 & 17 & 29 & 20 & 49 & 27 & 338 & 792 & 5.5 \\
8 & 39 & 43 & 219 & 18 & 25 & 12.1 & 40 & 28 & 692 & 620 & 4.8 \\
9 & 68 & 45 & 185 & 19 & 21 & 7.7 & 38 & 29 & 741 & 506 & 4.4 \\
10 & 36 & 23 & 171 & 20 & 9.2 & 51 & 34 & 30 & 644 & 524 & 4.6 \\
\end{tabular}

Gage height, in feet, and discharge, in second-feet, at indicated time, 1938

\begin{tabular}{|c|c|c|c|c|c|c|c|c|c|c|c|c|}
\hline \multirow{2}{*}{ Hour } & Feet & Sec.-ft. & Feet & Sec.-ft. & Feet & Sec.-ft. & Feet & Sec.-ft. & Feet & Sec.-ft. & Feet & Sec. ft. \\
\hline & \multicolumn{2}{|c|}{ July 17} & \multicolumn{2}{|c|}{ July 18} & \multicolumn{2}{|c|}{ July 19} & \multicolumn{2}{|c|}{ July 20} & \multicolumn{2}{|c|}{ July 21} & \multicolumn{2}{|c|}{ July 22} \\
\hline $\begin{array}{c}2 \text { a.m. } \\
4 \\
6 \\
8 \\
10 \\
12 \mathrm{n} . \\
2 \mathrm{p.m} . \\
4 \\
6 \\
8 \\
10 \\
12 \mathrm{~m} .\end{array}$ & $\begin{array}{l}1.72 \\
1.69 \\
1.65 \\
1.62 \\
1.61 \\
1.78 \\
1.83 \\
1.80 \\
1.81 \\
1.70 \\
1.63 \\
1.61\end{array}$ & $\begin{array}{l}21 \\
18.9 \\
16.7 \\
15.3 \\
14.8 \\
24 \\
28 \\
26 \\
27 \\
19.5 \\
15.7 \\
14.8\end{array}$ & $\begin{array}{l}1.59 \\
1.54 \\
1.50 \\
1.46 \\
1.40 \\
1.81 \\
1.72 \\
1.57 \\
1.40 \\
1.27 \\
1.41 \\
1.34\end{array}$ & $\begin{array}{r}13.8 \\
11.8 \\
10.3 \\
9.0 \\
7.4 \\
27 \\
20 \\
13.0 \\
7.4 \\
5.0 \\
7.6 \\
6.1\end{array}$ & $\begin{array}{l}1.30 \\
1.34 \\
1.47 \\
1.54 \\
1.50 \\
1.37 \\
1.44 \\
1.42 \\
1.39 \\
1.37 \\
1.36 \\
1.34\end{array}$ & $\begin{array}{r}5.6 \\
6.3 \\
9.5 \\
12.0 \\
10.5 \\
6.9 \\
8.6 \\
8.1 \\
7.3 \\
6.9 \\
6.7 \\
6.3\end{array}$ & $\begin{array}{l}1.34 \\
1.34 \\
1.64 \\
1.79 \\
1.81 \\
1.85 \\
1.95 \\
2.10 \\
2.25 \\
2.40 \\
2.52 \\
2.64\end{array}$ & $\begin{array}{r}6.3 \\
6.3 \\
16.2 \\
25 \\
27 \\
30 \\
38 \\
55 \\
78 \\
106 \\
134 \\
167\end{array}$ & $\begin{array}{l}2.75 \\
2.81 \\
2.82 \\
2.85 \\
2.90 \\
3.05 \\
3.10 \\
3.09 \\
3.09 \\
3.74 \\
3.68 \\
3.75\end{array}$ & $\begin{array}{l}199 \\
216 \\
219 \\
227 \\
242 \\
288 \\
304 \\
301 \\
301 \\
568 \\
541 \\
573\end{array}$ & $\begin{array}{l}3.86 \\
3.93 \\
4.00 \\
4.08 \\
4.10 \\
4.19 \\
4.21 \\
4.24 \\
4.27 \\
4.29 \\
4.31 \\
4.32\end{array}$ & $\begin{array}{l}625 \\
658 \\
692 \\
731 \\
741 \\
786 \\
796 \\
811 \\
827 \\
837 \\
847 \\
852\end{array}$ \\
\hline & \multicolumn{2}{|c|}{ July 23} & \multicolumn{2}{|c|}{ July 24} & \multicolumn{2}{|c|}{ July 25} & \multicolumn{2}{|c|}{ July 26} & \multicolumn{2}{|c|}{ July 27} & \multicolumn{2}{|c|}{ July 28} \\
\hline $\begin{array}{c}2 \mathrm{a} . \mathrm{m} . \\
4 \\
6 \\
8 \\
10 \\
12 \mathrm{n} . \\
2 \mathrm{p} . \mathrm{m} . \\
4 \\
6 \\
8 \\
10 \\
12 \mathrm{~m} .\end{array}$ & $\begin{array}{l}4.32 \\
4.33 \\
4.33 \\
4.35 \\
4.47 \\
4.48 \\
4.50 \\
4.61 \\
4.61 \\
4.61 \\
4.65 \\
4.70\end{array}$ & $\begin{array}{r}853 \\
859 \\
859 \\
869 \\
931 \\
937 \\
947 \\
1,000 \\
1,000 \\
1,000 \\
1,030 \\
1,050\end{array}$ & $\begin{array}{l}4.83 \\
4.97 \\
5.14 \\
5.32 \\
5.49 \\
5.63 \\
5.74 \\
5.82 \\
5.85 \\
5.87 \\
5.87 \\
5.84\end{array}$ & $\begin{array}{l}1,130 \\
1,200 \\
1,290 \\
1,400 \\
1,500 \\
1,590 \\
1,660 \\
1,710 \\
1,720 \\
1,730 \\
1,730 \\
1,720\end{array}$ & $\begin{array}{l}5.80 \\
5.74 \\
5.66 \\
5.58 \\
5.52 \\
5.46 \\
5.38 \\
5.30 \\
5.24 \\
5.16 \\
5.10 \\
5.04\end{array}$ & $\begin{array}{l}1,700 \\
1,660 \\
1,610 \\
1,560 \\
1,520 \\
1,490 \\
1,440 \\
1,390 \\
1,350 \\
1,310 \\
1,270 \\
1,240\end{array}$ & $\begin{array}{l}4.98 \\
4.91 \\
4.85 \\
4.79 \\
4.73 \\
4.69 \\
4.65 \\
4.61 \\
4.56 \\
4.49 \\
4.44 \\
4.37\end{array}$ & $\begin{array}{r}1,210 \\
1,170 \\
1,130 \\
1,100 \\
1,070 \\
1,050 \\
1,030 \\
1,010 \\
980 \\
943 \\
917 \\
880\end{array}$ & $\begin{array}{l}4.34 \\
4.27 \\
4.25 \\
4.20 \\
4.16 \\
4.12 \\
4.08 \\
4.05 \\
3.99 \\
4.33 \\
4.20 \\
4.10\end{array}$ & $\begin{array}{l}864 \\
828 \\
812 \\
792 \\
772 \\
752 \\
732 \\
717 \\
688 \\
859 \\
792 \\
742\end{array}$ & $\begin{array}{l}4.06 \\
4.03 \\
4.01 \\
3.95 \\
3.90 \\
3.85 \\
3.81 \\
3.79 \\
3.77 \\
3.71 \\
3.68 \\
3.67\end{array}$ & $\begin{array}{l}721 \\
707 \\
697 \\
668 \\
644 \\
620 \\
602 \\
592 \\
583 \\
5.36 \\
542 \\
538\end{array}$ \\
\hline
\end{tabular}

\begin{tabular}{|c|c|c|c|c|c|c|c|c|c|c|c|c|}
\hline \multirow[b]{2}{*}{2 a.m. } & \multicolumn{2}{|c|}{ July 29} & \multicolumn{2}{|c|}{ July 30} & \multicolumn{2}{|c|}{ July 31} & \multicolumn{2}{|c|}{ August 1} & \multicolumn{2}{|c|}{ August 2} & \multicolumn{2}{|c|}{ August 3} \\
\hline & 3.65 & 528 & 3.65 & 528 & 3.62 & 515 & 3.37 & 407 & & & & $\ldots$ \\
\hline & 3.63 & 520 & 3.63 & 520 & 2.60 & 506 & 3.34 & 394 & & & $-\ldots$ & --1 \\
\hline 6 & 3.62 & 515 & 3.63 & 520 & 3.57 & 493 & 3.33 & 390 & & & $-\ldots$ & 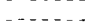 \\
\hline 8 & 3.59 & 502 & 3.63 & 520 & 3.55 & 484 & 3.32 & 386 & $\ldots \ldots$ & $\ldots \ldots$ & $\ldots$ & $\ldots$ \\
\hline 10 & 3.57 & 493 & 3.63 & 520 & 3.53 & 475 & 3.31 & 382 & $\ldots$ & $\ldots \ldots$ & $\ldots \ldots$ & $-\ldots$ \\
\hline $12 \mathrm{n}$. & 3.57 & 493 & 3.64 & 524 & 3.51 & 466 & 3.31 & 382 & $\ldots$ & $\ldots . .$. & $\ldots \ldots$ & $\ldots \ldots$ \\
\hline 2 p.m. & 3.53 & 475 & 3.65 & 528 & 3.49 & 458 & 3.30 & 378 & $\ldots$ & $\ldots \ldots$ & $\ldots \ldots$ & $\ldots \ldots$ \\
\hline & 3.50 & 462 & 3.66 & 533 & 3.47 & 449 & 3.31 & 382 & $\ldots \ldots$ & $\ldots \ldots$ & $\ldots \ldots$ & $\ldots \ldots$ \\
\hline 6 & 3.50 & 462 & 3.66 & 533 & 3.53 & 475 & 3.27 & 367 & $\cdots-$ & $\ldots \ldots$ & $\ldots .$. & $\ldots \ldots$ \\
\hline 8 & 3.64 & 524 & 3.65 & 528 & 3.47 & 449 & 3.28 & 370 & $\ldots-$. & $-\ldots-\ldots$ & $\ldots .$. & $\ldots \ldots$ \\
\hline 10 & 3.59 & 502 & 3.65 & 528 & 3.43 & 432 & 3.32 & 386 & $\ldots \ldots$ & $\ldots \ldots$ & $\ldots .$. & $-\ldots-.-$ \\
\hline $12 \mathrm{~m}$. & 3.68 & 542 & 3.63 & 520 & 3.39 & $41 \overline{5}$ & 3.28 & 370 & $\ldots-\ldots$ & $-\ldots .$. & $\ldots-\ldots$ & $\ldots$ \\
\hline
\end{tabular}


SADDTE RIVFR AT IODI, N. J.

Location.-Lat. $40^{\circ} 53^{\prime} 24^{\prime \prime}$, long. $74^{\circ} 04^{\prime} 50^{\prime \prime}$, at highway bridge 1 mile upstream from Lodi, Bergen County, and $3 \frac{1}{4}$ miles upstream from mouth. Datum of gage is 22.46 feet above mean sea level (general adjustment of 1929).

Drainage AREa. - 54.6 square miles.

GAGE-height RECORD.-Water-stage recorder graph.

Stage-Discharge RELATION.-Defined by current-meter measurements below 700 second-feet; extended to peak stage on basis of comparison with records for Pascack Brook at Westwood.

Maxima.-July 1938: Discharge, 1,060 second-feet 6 p.m. July 24 (gageheight, 4.75 feet).

1923 to June 1938: Discharge, 2,200 second-feet Mar. 12, 1936 (gageheight, 6.27 feet).

RemARKs.- Run-off not materially affected by storage.

Mean discharge, in second-feet, 1938

\begin{tabular}{r|r|r|r|r|r|r|r||r|r|r|r}
\hline Day & June & July & Aug. & Day & June & July & Aug. & Day & June & July & A ug. \\
\hline & & & & & & \\
1 & 48 & 100 & 108 & 11 & 120 & 49 & 199 & 21 & 46 & 189 & 50 \\
2 & 43 & 91 & 109 & 12 & 138 & 78 & 215 & 22 & 45 & 395 & 48 \\
3 & 60 & 78 & 98 & 13 & 136 & 92 & 96 & 23 & 45 & 801 & 46 \\
4 & 71 & 65 & 84 & 14 & 158 & 76 & 76 & 24 & 43 & 917 & 42 \\
5 & 61 & 56 & 82 & 15 & 103 & 82 & 67 & 25 & 43 & 616 & 38 \\
6 & 59 & 52 & 100 & 16 & 73 & 73 & 63 & 26 & 55 & 257 & 37 \\
7 & 52 & 46 & 100 & 17 & 57 & 61 & 61 & 27 & 196 & 155 & 36 \\
8 & 149 & 42 & 100 & 18 & 73 & 52 & 63 & 28 & 453 & 134 & 40 \\
9 & 95 & 42 & 109 & 19 & 80 & $\mathbf{7 4}$ & 61 & 29 & 608 & 116 & 43 \\
10 & 56 & 65 & 91 & 20 & 56 & 110 & 54 & 30 & 240 & 149 & 39 \\
\end{tabular}

Gage height, in feet, and discharge, in second-feet, at indicated time, 1938

\begin{tabular}{|c|c|c|c|c|c|c|c|c|c|c|c|c|}
\hline \multirow[b]{2}{*}{ Hour } & Feet & Sec. $-\mathrm{ft}$. & Feet & Sec.-ft. & Feet & Sec.-ft. & Feet & Sec. $-f \mathbf{t}$. & Feet & Sec.-ft. & Feet & Sec.-ft. \\
\hline & \multicolumn{2}{|c|}{ July 17} & \multicolumn{2}{|c|}{ July 18} & \multicolumn{2}{|c|}{ July 19} & \multicolumn{2}{|c|}{ July 20} & \multicolumn{2}{|c|}{ July 21} & \multicolumn{2}{|c|}{ July 22} \\
\hline \multirow[t]{2}{*}{$\begin{array}{l}2 \mathrm{a} . \mathrm{m} . \\
4 \\
6 \\
8 \\
10 \\
12 \mathrm{n} . \\
2 \mathrm{p} . \mathrm{m} . \\
4 \\
6 \\
8 \\
10 \\
12 \mathrm{~m} .\end{array}$} & 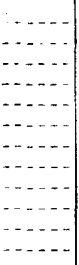 & 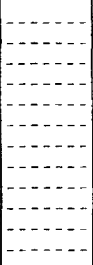 & $\begin{array}{l}1.89 \\
1.88 \\
1.86 \\
1.85 \\
1.85 \\
1.85 \\
1.88 \\
1.88 \\
1.90 \\
1.93 \\
1.93 \\
1.93\end{array}$ & $\begin{array}{l}52 \\
50 \\
48 \\
46 \\
46 \\
46 \\
50 \\
50 \\
54 \\
59 \\
59 \\
59\end{array}$ & $\begin{array}{l}1.92 \\
1.92 \\
1.90 \\
1.90 \\
1.89 \\
1.90 \\
2.08 \\
2.17 \\
2.18 \\
2.15 \\
2.13 \\
2.12\end{array}$ & $\begin{array}{l}57 \\
57 \\
54 \\
54 \\
52 \\
54 \\
85 \\
98 \\
99 \\
95 \\
92 \\
91\end{array}$ & $\begin{array}{l}2.12 \\
2.12 \\
2.12 \\
2.13 \\
2.16 \\
2.21 \\
2.26 \\
2.31 \\
2.37 \\
2.42 \\
2.45 \\
2.49\end{array}$ & $\begin{array}{r}91 \\
91 \\
91 \\
92 \\
96 \\
103 \\
109 \\
115 \\
124 \\
133 \\
138 \\
145\end{array}$ & $\begin{array}{l}2.52 \\
2.54 \\
2.55 \\
2.57 \\
2.64 \\
2.72 \\
2.77 \\
2.81 \\
2.81 \\
2.82 \\
2.82 \\
2.86\end{array}$ & $\begin{array}{l}151 \\
155 \\
158 \\
162 \\
177 \\
196 \\
208 \\
219 \\
219 \\
221 \\
221 \\
232\end{array}$ & $\begin{array}{l}2.90 \\
2.97 \\
3.01 \\
3.10 \\
3.19 \\
3.35 \\
3.45 \\
3.55 \\
3.65 \\
3.74 \\
3.82 \\
3.90\end{array}$ & $\begin{array}{l}243 \\
263 \\
275 \\
303 \\
333 \\
388 \\
425 \\
464 \\
505 \\
543 \\
578 \\
614\end{array}$ \\
\hline & \multicolumn{2}{|c|}{ July 23} & \multicolumn{2}{|c|}{ July 24} & \multicolumn{2}{|c|}{ July 25} & \multicolumn{2}{|c|}{ July 26} & \multicolumn{2}{|c|}{ July 27} & \multicolumn{2}{|c|}{ July 28} \\
\hline $\begin{array}{c}2 \text { a.m. } \\
4 \\
6 \\
8 \\
10 \\
12 \mathrm{n} . \\
2 \mathrm{p.m} . \\
4 \\
6 \\
8 \\
10 \\
12 \mathrm{~m} .\end{array}$ & $\begin{array}{l}3.95 \\
3.96 \\
3.97 \\
4.28 \\
4.30 \\
4.50 \\
4.46 \\
4.47 \\
4.52 \\
4.46 \\
4.40 \\
4.35\end{array}$ & $\begin{array}{l}637 \\
642 \\
646 \\
798 \\
808 \\
914 \\
892 \\
898 \\
925 \\
892 \\
860 \\
834\end{array}$ & $\begin{array}{l}4.30 \\
4.26 \\
4.26 \\
4.30 \\
4.40 \\
4.52 \\
4.65 \\
4.73 \\
4.75 \\
4.73 \\
4.66 \\
4.56\end{array}$ & $\begin{array}{r}808 \\
788 \\
788 \\
808 \\
860 \\
925 \\
1,000 \\
1,050 \\
1,060 \\
1,050 \\
1,010 \\
948\end{array}$ & $\begin{array}{l}4.45 \\
4.33 \\
4.20 \\
4.07 \\
3.95 \\
3.83 \\
3.72 \\
3.61 \\
3.52 \\
3.44 \\
3.36 \\
3.29\end{array}$ & $\begin{array}{l}887 \\
824 \\
757 \\
694 \\
637 \\
582 \\
535 \\
488 \\
452 \\
421 \\
392 \\
367\end{array}$ & $\begin{array}{l}3.23 \\
3.16 \\
3.10 \\
3.05 \\
2.99 \\
2.94 \\
2.87 \\
2.82 \\
2.78 \\
2.72 \\
2.69 \\
2.66\end{array}$ & $\begin{array}{l}346 \\
323 \\
303 \\
288 \\
269 \\
255 \\
235 \\
221 \\
211 \\
196 \\
189 \\
182\end{array}$ & $\begin{array}{l}2.63 \\
2.62 \\
2.59 \\
2.56 \\
2.55 \\
2.53 \\
2.51 \\
2.50 \\
2.49 \\
2.48 \\
2.46 \\
2.45\end{array}$ & $\begin{array}{l}175 \\
173 \\
166 \\
160 \\
158 \\
153 \\
149 \\
147 \\
14.5 \\
113 \\
140 \\
138\end{array}$ & $\begin{array}{l}2.44 \\
2.43 \\
2.42 \\
2.41 \\
2.41 \\
2.42 \\
2.44 \\
2.43 \\
2.44 \\
2.44 \\
2.43 \\
2.42\end{array}$ & $\begin{array}{l}136 \\
134 \\
133 \\
131 \\
131 \\
133 \\
136 \\
134 \\
136 \\
136 \\
134 \\
133\end{array}$ \\
\hline
\end{tabular}


Gage-height, in feet, and discharge, in second-feet, at indicated time, 1938-Continued

\begin{tabular}{|c|c|c|c|c|c|c|c|c|c|c|c|c|}
\hline \multirow{2}{*}{ Hour } & Feet & Sec.-ft. & Feet & Sec.-ft. & Feet & Sec.-ft. & Feet & Sec.-ft. & Feet & Sec.-ft. & Feet & Sec.-ft. \\
\hline & \multicolumn{2}{|c|}{ July 29} & \multicolumn{2}{|c|}{ July 30} & \multicolumn{2}{|c|}{ July 31} & \multicolumn{2}{|c|}{ August 1} & \multicolumn{2}{|c|}{ August 2} & \multicolumn{2}{|c|}{ August 3} \\
\hline $\begin{array}{c}2 \mathrm{a} . \mathrm{m} . \\
4 \\
6 \\
8 \\
10 \\
12 \mathrm{n} . \\
2 \mathrm{p} . \mathrm{m} . \\
4 \\
6 \\
8 \\
10 \\
12 \mathrm{~m} .\end{array}$ & $\begin{array}{l}2.40 \\
2.38 \\
2.36 \\
2.35 \\
2.35 \\
2.34 \\
1.99 \\
2.30 \\
2.31 \\
2.30 \\
2.30 \\
2.31\end{array}$ & $\begin{array}{r}129 \\
125 \\
122 \\
120 \\
120 \\
119 \\
71 \\
114 \\
115 \\
114 \\
114 \\
115\end{array}$ & $\begin{array}{l}2.35 \\
2.40 \\
2.43 \\
2.47 \\
2.50 \\
2.52 \\
2.55 \\
2.57 \\
2.59 \\
2.60 \\
2.63 \\
2.64\end{array}$ & $\begin{array}{l}120 \\
129 \\
134 \\
142 \\
147 \\
151 \\
158 \\
162 \\
166 \\
168 \\
175 \\
177\end{array}$ & $\begin{array}{l}2.65 \\
2.65 \\
2.62 \\
2.57 \\
2.51 \\
2.46 \\
2.44 \\
2.40 \\
2.37 \\
2.35 \\
2.33 \\
2.30\end{array}$ & $\begin{array}{l}180 \\
180 \\
173 \\
162 \\
149 \\
140 \\
136 \\
129 \\
124 \\
120 \\
117 \\
114\end{array}$ & & & & & $\ldots$ & 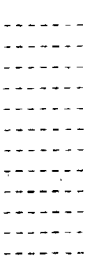 \\
\hline
\end{tabular}

Supplemental records.-July 29,1 p.m., $2.10 \mathrm{ft}$., 88 sec.-ft.

ELIZABETH RIVER BASIN

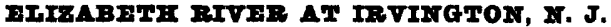

Location.-Lat. $40^{\circ} 44^{\prime} 10^{\prime \prime}$, long. $74^{\circ} 13^{\prime} 46^{\prime \prime}$, just downstream from Valley Avenue (formerly published as Orange Avenue) in Irvington, Essex County.

Drainage area.-2.91 square miles (revised).

GAGE-HEIGHT RECORD.-Water-stage recorder graph.

Stage-discharge relation.-Defined by current-meter measurements below 750 second-feet; extended to peak stage on basis of velocity-area studies.

Maxima.-July 1938: Discharge, 1,750 second-feet 8 a.m. July 23 (gage height, 12.1 feet, from floodmark).

1930 to June 1938: Discharge, about 1,460 second-feet Aug. 6, 1932 (gage height, 10.52 feet) from rating curve extended above 800 secondfeet.

Remarks.-Recorder graph good only for stages above upper intake pipe (gage height, 1.90 feet), owing to debris in channel covering lower intake pipe.

Gage height, in feet, and discharge, in second-feet, at indicated time, 1938

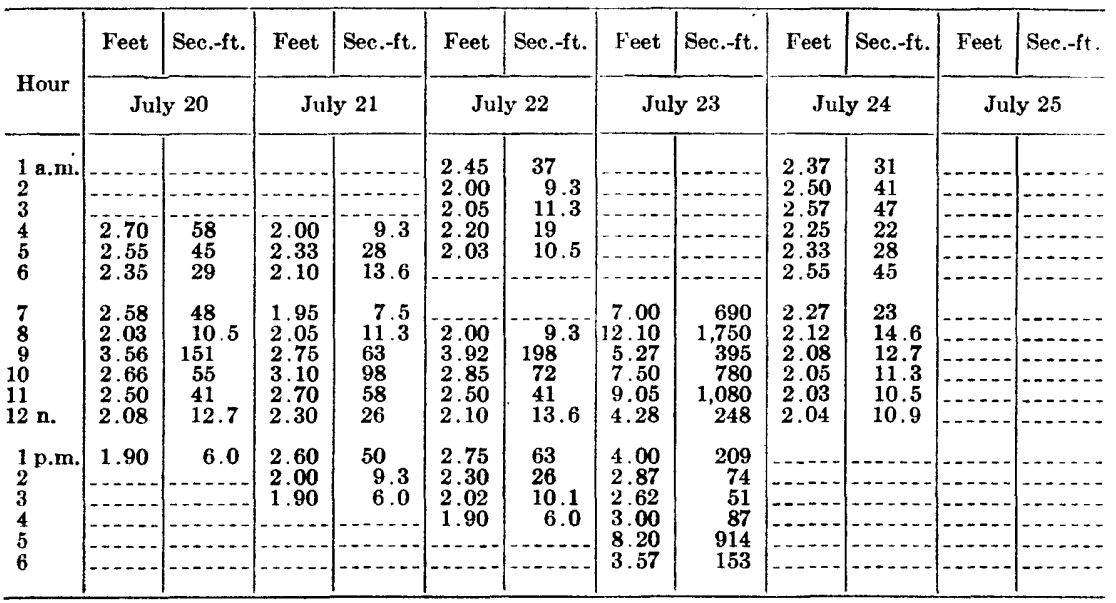


Gage-height, in feet, and discharge, in second-feet, at indicated time, 1938-Continued

\begin{tabular}{|c|c|c|c|c|c|c|c|c|c|c|c|c|}
\hline \multirow{2}{*}{ Hour } & Feet & Sec.-ft. & Feet & Sec.-ft. & Feet & Sec.-ft. & Feet & Sec.-ft. & Feet & Sec.-ft. & Feet & Sec.-ft. \\
\hline & \multicolumn{2}{|c|}{ July 20} & \multicolumn{2}{|c|}{ July 21} & \multicolumn{2}{|c|}{ July 22} & \multicolumn{2}{|c|}{ July 23} & \multicolumn{2}{|c|}{ July 24} & \multicolumn{2}{|c|}{ July 25} \\
\hline $\begin{array}{r}7 \\
8 \\
9 \\
10 \\
11 \\
12 \mathrm{~m} .\end{array}$ & & & $\begin{array}{r}2.80 \\
2.10 \\
1.87 \\
2.35\end{array}$ & $\begin{array}{r}68 \\
13.6 \\
5.2 \\
29\end{array}$ & & & $\begin{array}{l}3.05 \\
2.57 \\
2.44 \\
2.35 \\
2.28 \\
2.23\end{array}$ & $\begin{array}{l}92 \\
47 \\
36 \\
29 \\
24 \\
21\end{array}$ & & & & $\cdots$ \\
\hline & \multicolumn{2}{|c|}{ July 26} & \multicolumn{2}{|c|}{ July 27} & \multicolumn{2}{|c|}{ July 28} & \multicolumn{2}{|c|}{ July 29} & \multicolumn{2}{|c|}{ July 30} & \multicolumn{2}{|c|}{ July $\mathbf{3 1}$} \\
\hline $\begin{array}{l}1 \text { a.m. } \\
2 \\
3 \\
4 \\
5 \\
6\end{array}$ & & & & & & & & & & & & \\
\hline $\begin{array}{c}7 \\
8 \\
9 \\
10 \\
11 \\
12 \mathrm{n} .\end{array}$ & & $\begin{array}{c}\cdots \\
\cdots \\
\cdots- \\
\cdots- \\
-\cdots\end{array}$ & & & & & $\begin{array}{l}\ldots \\
\cdots \\
\cdots \\
\cdots \\
\cdots\end{array}$ & ' & $\begin{array}{l}\cdots \\
\cdots \\
\cdots\end{array}$ & & & {$\left[\begin{array}{c}-1 \ldots \\
\hdashline \\
\hdashline\end{array}\right.$} \\
\hline $\begin{array}{l}1 \\
1 \\
2 \\
3 \\
4 \\
4 \\
5 \\
6\end{array}$ & & & & & 2.06 & $\begin{array}{r}11.8 \\
0\end{array}$ & 2.00 & 9.3 & $-\ldots$. & $\begin{array}{c}\cdots \\
\cdots\end{array}$ & $\begin{array}{l}1.90 \\
6.02 \\
2.30 \\
1.95 \\
\end{array}$ & $\begin{array}{c}6.0 \\
518 \\
26 \\
7.5\end{array}$ \\
\hline $\begin{array}{r}7 \\
8 \\
9 \\
10 \\
11 \\
12 \mathrm{~m} .\end{array}$ & & 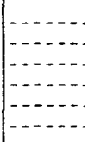 & \begin{tabular}{r}
2.05 \\
2.05 \\
\hdashline \\
\end{tabular} & $\begin{array}{r}11.3 \\
11.3 \\
\end{array}$ & & 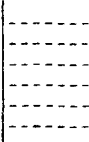 & $\begin{array}{l}2.35 \\
2.00 \\
2.04 \\
2.20 \\
2.42 \\
2.05\end{array}$ & $\begin{array}{c}29 \\
9.3 \\
10.9 \\
19 \\
35 \\
11.3\end{array}$ & 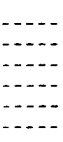 & {$\left[\begin{array}{l}-1 \\
\hdashline-1\end{array}\right.$} & ' & {$\left[\begin{array}{l}{[-1} \\
\hdashline-1\end{array}\right.$} \\
\hline
\end{tabular}

Supplemental records.-July 20, 4:20 a.m., $3.26 \mathrm{ft}$., 115 sec.-ft.; 5:30 a.m., $2.24 \mathrm{ft}$., 21 sec.-ft.; 10:20 a.m. 2.76 ft., 64 sec.-ft.; July 21, 9:20 a.m., 3.57 ft., 153 sec.-ft.; $12: 30$ p.m., 3.47 ft., 140 sec.-ft.; July 22, 12:30 a.m., $2.78 \mathrm{ft}$., 66 sec.-ft.; 10:40 a.m., $2.32 \mathrm{ft}$., 27 sec-ft.; July 23, $7: 30$ a.m., $11.12 \mathrm{ft}$., 1500 sec.-ft.; 7:40 a.m., 10.95 ft., 1,460 sec.-ft.; $9: 30$ a.m., 9.78 ft., 1,230 sec.-ft.; 10:40 a.m., 4.60 ft., 294 sec.-ft.; 12:30 p.m., 4.78 ft., 320 sec.-ft.; $3: 30$ p.m., 2.58 ft., 48 sec.-ft.; $3: 40$ p.m., 3.22 ft., 111 sec.-ft.; $4: 30$ p.m. $2.66 \mathrm{ft}$., 55 sec.ft.; $6: 30$ p.m., $3.64 \mathrm{ft}$., 162 sec.-ft.; July 27, $7: 30$ p.m., $2.15 \mathrm{ft}$., 16.0 sec.-ft.; July 29 , $6: 40$ p.m., 2.49 ft., 40 sec.-ft.; $8: 30$ p.m. 1.95 ft., 7.5 sec.-ft.

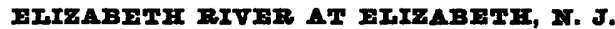

Location.-Lat. $40^{\circ} 40^{\prime} 03^{\prime \prime}$, long. $74^{\circ} 13^{\prime} 09^{\prime \prime}$, just upstream from Westfield Avenue bridge, Elizabeth, Union County, and $3 \frac{114}{4}$ miles upstream from mouth. Datum of gage is $\mathbf{5 . 2 3}$ feet above mean sea level (general adjustment of 1929).

Drainage area.- $\mathbf{1 8 . 0}$ square miles.

GAGE-HEIGhT RECORD.-Water-stage recorder graph except June 18-20, 11 a.m. July 23 to 10 a.m. July 28. Staff-gage readings made on July 23 from $4: 45$ to $5: 45$ p.m.

Stage-discharge relation.-Defined by current-meter measurements below 190 second-feet; extended to peak stage on basis of determinations of flood flow by contracted-opening method.

Maxima.-July 1938: Discharge, about 2,720 second-feet 1 p.m. July 23 (gage height, 13.05 feet, from floodmark).

1921 to June 1938: Discharge, about 2,640 second-feet Sept. 1, 1927, and Nov. 19, 1932 (gage height, 9.73 feet).

Remarks.-Discharge affected by diversions for municipal supply. Records during periods of no gage-height record computed on basis of floodmark, several gage readings, and record for Rahway River at Rahway. Monthly 
mean discharge and run-off, in inches, adjusted for diversion. Monthly mean diversions were: June, 4.2 second-feet; July, 4.1 second-feet; August, 4.4 second-feet.

Mean discharge, in second-feet, 1938

\begin{tabular}{|c|c|c|c|c|c|c|c|c|c|c|c|}
\hline Day & June & July & Aug. & Das & June & July & Aug. & Day. & June & July & Aug. \\
\hline $\begin{array}{r}1 \\
2 \\
3 \\
4 \\
5 \\
6 \\
7 \\
8 \\
9 \\
10\end{array}$ & $\begin{array}{r}6.1 \\
7.1 \\
16.8 \\
7.3 \\
15.7 \\
10.1 \\
26 \\
171 \\
1.9 \\
7.8\end{array}$ & $\begin{array}{r}17.0 \\
13.1 \\
10.7 \\
8.7 \\
8.2 \\
7.6 \\
7.3 \\
7.6 \\
7.6 \\
15.0\end{array}$ & $\begin{array}{l}27 \\
21 \\
17.0 \\
15.7 \\
13.6 \\
41 \\
15.1 \\
83 \\
34 \\
26\end{array}$ & $\begin{array}{l}11 \\
12 \\
13 \\
14 \\
15 \\
16 \\
17 \\
18 \\
19 \\
20\end{array}$ & $\begin{array}{c}18.0 \\
15.5 \\
89 \\
24 \\
10.7 \\
10.3 \\
9.0 \\
58 \\
12 \\
9\end{array}$ & $\begin{array}{l}71 \\
15.3 \\
10.0 \\
18.0 \\
30 \\
10.4 \\
30.4 \\
11.8 \\
13.2 \\
78\end{array}$ & $\begin{array}{r}54 \\
14.0 \\
11.7 \\
10.3 \\
10.0 \\
10.0 \\
10.7 \\
16.8 \\
10.0 \\
8.2\end{array}$ & $\begin{array}{l}21 \\
22 \\
23 \\
24 \\
25 \\
26 \\
27 \\
28 \\
29 \\
30 \\
31\end{array}$ & $\begin{array}{r}7.9 \\
7.3 \\
8.2 \\
8.0 \\
6.5 \\
77 \\
97 \\
222 \\
26 \\
23\end{array}$ & $\begin{array}{r}56 \\
77 \\
1,000 \\
180 \\
60 \\
45 \\
36 \\
37 \\
34 \\
31 \\
47\end{array}$ & $\begin{array}{l}7.6 \\
7.6 \\
7.9 \\
7.6 \\
7.1 \\
7.9 \\
7.3 \\
6.3 \\
6.5 \\
7.1 \\
7.1\end{array}$ \\
\hline \multicolumn{9}{|c|}{$\begin{array}{l}\text { Monthly mean discharge, in second-feet (observed) } \\
\text { Monthy mean discharge, in second-feet (adjusted) } \\
\text { Runoff, in inches (adjusted) }\end{array}$} & $\begin{array}{l}33.6 \\
37.8 \\
2.34\end{array}$ & $\begin{array}{l}64.3 \\
68.4 \\
4.38\end{array}$ & $\begin{array}{l}17.1 \\
21.5 \\
1.37\end{array}$ \\
\hline
\end{tabular}

Gage height, in feet, and discharge, in second-feet, at indicated time, 1938

\begin{tabular}{|c|c|c|c|c|c|c|c|c|c|c|c|c|}
\hline \multirow{2}{*}{ Hour } & Feet & Sec. $-\mathrm{ft}$. & Feet & Sec.-ft. & Feet & Sec. $-\mathrm{ft}$. & Feet & Sec.-ft. & Feet & Sec.-ft. & Feet & Sec-ft. \\
\hline & \multicolumn{2}{|c|}{ July 20} & \multicolumn{2}{|c|}{ July 20} & \multicolumn{2}{|c|}{ July 21} & \multicolumn{2}{|c|}{ July 23} & \multicolumn{2}{|c|}{ July 24} & \multicolumn{2}{|c|}{ July 25 } \\
\hline $\begin{array}{l}1 \text { a.m. } \\
2 \\
3 \\
4 \\
5 \\
6\end{array}$ & $\begin{array}{l}2.93 \\
2.90 \\
2.88 \\
2.87 \\
3.10 \\
3.55\end{array}$ & $\begin{array}{l}14.0 \\
12.7 \\
12.0 \\
11.7 \\
22 \\
56\end{array}$ & $\begin{array}{l}2.71 \\
2.71 \\
2.70 \\
2.72 \\
2.73 \\
2.73\end{array}$ & $\begin{array}{l}6.8 \\
6.8 \\
6.5 \\
7.1 \\
7.3 \\
7.3\end{array}$ & $\begin{array}{l}3.48 \\
3.73 \\
3.71 \\
3.56 \\
3.46 \\
3.42\end{array}$ & $\begin{array}{l}49 \\
76 \\
73 \\
57 \\
48 \\
45\end{array}$ & $\begin{array}{l}3.18 \\
3.16 \\
3.15 \\
3.14 \\
3.14 \\
3.14\end{array}$ & $\begin{array}{l}27 \\
26 \\
25 \\
24 \\
.24 \\
24\end{array}$ & 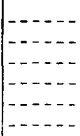 & 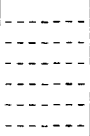 & 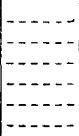 & $\mid \begin{array}{c}\cdots \\
\cdots \\
-\ldots \\
-\cdots \\
\cdots \\
\cdots \\
\cdots \\
\cdots\end{array}$ \\
\hline $\begin{array}{r}7 \\
8 \\
9 \\
10 \\
11 \\
12 \mathrm{n} .\end{array}$ & $\begin{array}{l}4.03 \\
3.90 \\
3.84 \\
4.04 \\
5.14 \\
5.20\end{array}$ & $\begin{array}{r}116 \\
97 \\
89 \\
117 \\
376 \\
396\end{array}$ & $\begin{array}{l}2.73 \\
2.73 \\
2.75 \\
2.77 \\
3.60 \\
4.30\end{array}$ & $\begin{array}{r}7.3 \\
7.3 \\
7.9 \\
8.5 \\
61 \\
161\end{array}$ & $\begin{array}{l}3.39 \\
3.34 \\
3.70 \\
4.65 \\
4.65 \\
4.32\end{array}$ & $\begin{array}{r}42 \\
38 \\
72 \\
237 \\
237 \\
165\end{array}$ & $\begin{array}{r}4.30 \\
5.46 \\
5.58 \\
6.40 \\
10.30 \\
-. . .-\end{array}$ & $\begin{array}{r}161 \\
486 \\
528 \\
880 \\
2.250 \\
\end{array}$ & 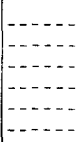 & 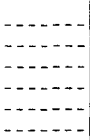 & 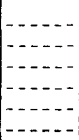 & 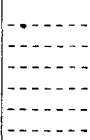 \\
\hline $\begin{array}{l}1 \text { p.m. } \\
2 \\
3 \\
4 \\
5 \\
6\end{array}$ & $\begin{array}{l}4.90 \\
4.30 \\
3.34 \\
2.81 \\
2.72 \\
2.71\end{array}$ & $\begin{array}{r}303 \\
161 \\
38 \\
9.6 \\
7.1 \\
6.8\end{array}$ & $\begin{array}{l}4.31 \\
4.32 \\
3.98 \\
3.69 \\
3.48 \\
3.80\end{array}$ & $\begin{array}{r}163 \\
165 \\
108 \\
71 \\
49 \\
84\end{array}$ & $\begin{array}{l}4.08 \\
3.94 \\
3.92 \\
3.76 \\
3.60 \\
3.48\end{array}$ & $\begin{array}{r}123 \\
103 \\
100 \\
79 \\
61 \\
49\end{array}$ & 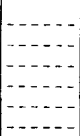 & $a 1,500$ & 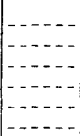 & 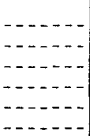 & 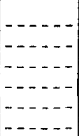 & $\mid \begin{array}{l}-\cdots \\
-\cdots \\
-\cdots\end{array}$ \\
\hline $\begin{array}{r}7 \\
8 \\
9 \\
10 \\
11 \\
12 \mathrm{~m} .\end{array}$ & $\begin{array}{l}2.71 \\
2.71 \\
2.70 \\
2.70 \\
2.70 \\
2.70\end{array}$ & $\begin{array}{l}6.8 \\
6.8 \\
6.5 \\
6.5 \\
6.5 \\
6.5\end{array}$ & $\begin{array}{l}3.92 \\
3.73 \\
3.79 \\
3.61 \\
3.47 \\
3.41\end{array}$ & $\begin{array}{r}100 \\
76 \\
83 \\
62 \\
49 \\
44\end{array}$ & $\begin{array}{l}3.40 \\
3.33 \\
3.28 \\
3.25 \\
3.22 \\
3.20\end{array}$ & $\begin{array}{l}43 \\
37 \\
34 \\
32 \\
29 \\
28\end{array}$ & 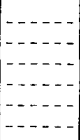 & 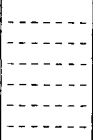 & 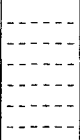 & 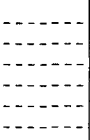 & 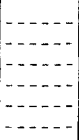 & 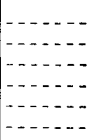 \\
\hline & \multicolumn{2}{|c|}{ July 26} & \multicolumn{2}{|c|}{ July 27} & \multicolumn{2}{|c|}{ July 28} & \multicolumn{2}{|c|}{ July 29} & \multicolumn{2}{|c|}{ July 30} & \multicolumn{2}{|c|}{ July 31} \\
\hline $\begin{array}{l}2 \text { a.m. } \\
4 \\
6 \\
8 \\
10 \\
12 \mathrm{n} . \\
2 \mathrm{p.m} . \\
4 \\
6 \\
8 \\
10 \\
12 \mathrm{~m} .\end{array}$ & 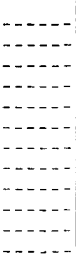 & 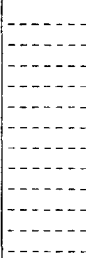 & 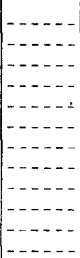 & \begin{tabular}{|l}
$-\cdots-$ \\
---- \\
---
\end{tabular} & $\begin{array}{l}\ldots .29 \\
3.29 \\
3.28 \\
3.28 \\
3.32 \\
3.46 \\
3.38 \\
3.30\end{array}$ & $\begin{array}{l}34 \\
34 \\
34 \\
34 \\
37 \\
48 \\
41 \\
35\end{array}$ & $\begin{array}{l}3.27 \\
3.25 \\
3.24 \\
3.23 \\
3.23 \\
3.23 \\
3.25 \\
3.17 \\
3.25 \\
3.40 \\
3.55 \\
3.49\end{array}$ & $\begin{array}{l}33 \\
32 \\
31 \\
30 \\
30 \\
30 \\
32 \\
26 \\
32 \\
43 \\
56 \\
50\end{array}$ & $\begin{array}{l}3.57 \\
3.42 \\
3.28 \\
3.21 \\
3.18 \\
3.15 \\
3.14 \\
3.12 \\
3.11 \\
3.10 \\
3.11 \\
3.11\end{array}$ & $\begin{array}{r}58 \\
45 \\
34 \\
29 \\
27 \\
25 \\
24 \\
23 \\
23 \\
22 \\
23 \\
23\end{array}$ & $\begin{array}{l}3.09 \\
3.08 \\
3.07 \\
3.07 \\
3.07 \\
3.07 \\
3.10 \\
3.90 \\
4.32 \\
3.62 \\
3.35 \\
3.24\end{array}$ & $\begin{array}{r}22 \\
21 \\
20 \\
20 \\
20 \\
20 \\
22 \\
97 \\
165 \\
63 \\
39 \\
31\end{array}$ \\
\hline
\end{tabular}

Supplemental records.-July 20, $11: 30$ a.m., $5.26 \mathrm{ft}, 416$ sec.-ft.; July $21,1: 30$ p.m., $4.37 \mathrm{ft} ., 175$ sec., $\mathrm{ft}$. $6: 30$ p.m., 4.04 ft., 117 sec.-ft.; July $22,10: 30$ a.m., 4.72 ft., 254 sec.-ft.; July $23,4: 45$ p.m., $8.45 \mathrm{ft} ., 1,800$ sec.-ft.; $5: 35$ p.m., 7.7 ft., 1,530 sec.-ft.; $5: 45$ p.m., 7.2 ft., 1,300 sec.-ft.; July 31,3 p.m.. 4.25 ft .. 152 sec-ft.; $4: 30$ p.in., $3.79 \mathrm{ft}$., 83 sec.-ft.; $5: 30$ p.m., 4.41 ft., 183 sec.-ft.

$a$ Estimated ruean for 13 hours. 


\section{RAHWAY RIVER BASIN}

RAHWAY RIVER NTAR SPRINGTIETD, N. J.

Location.-Lat. $40^{\circ} 41^{\prime} 11^{\prime \prime}$, long. $74^{\circ} 18^{\prime} 44^{\prime \prime}$, 50 feet downstream from State Highway 29, 100 feet downstream from Pope Brook, and 11/2 miles south of Springfield, Union County. Datum of gage is 66.17 feet above mean sea level (general adjustment of 1929).

Drainage area.-25.5 square miles.

GAGE-HEIGHT RECORD.-Water-stage recorder graph.

Stage-Discharge RELATION.-Defined by current-meter measurements below 900 second-feet; extended to peak stage on basis of logarithmic plotting and determination of discharge by contracted-opening method at stage of 7.29 feet.

Maxıma.-July 1938: Discharge, 1,940 second-feet 1:15 p.m. July 23 (gage height, 7.41 feet).

REMARKs.-Discharge affected by diversions for municipal supply. Record started July 7, 1938. Monthly mean discharge and run-off, in inches, adjusted for diversion. Monthly mean diversion for August, 14.6 second-feet.

Mean discharge, in second-feet, 1938

\begin{tabular}{|c|c|c|c|c|c|c|c|c|c|c|}
\hline Day & June & July & Aug. & Day & June & July & Aug. & Day June & July & Aug. \\
\hline $\begin{array}{r}1 \\
2 \\
3 \\
4 \\
5 \\
6 \\
7 \\
8 \\
9 \\
10\end{array}$ & 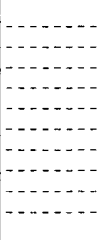 & $\begin{array}{r}10.0 \\
10.0 \\
9.5 \\
9.1\end{array}$ & $\begin{array}{c}33 \\
23 \\
19.6 \\
17.0 \\
15.4 \\
96 \\
102 \\
42 \\
93 \\
29\end{array}$ & $\begin{array}{l}11 \\
12 \\
13 \\
14 \\
15 \\
16 \\
17 \\
18 \\
19 \\
20\end{array}$ & 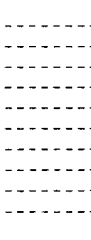 & $\begin{array}{l}19.6 \\
15.4 \\
11.5 \\
11.8 \\
27.8 \\
12.2 \\
21.2 \\
14.2 \\
15.1 \\
35\end{array}$ & $\begin{array}{l}66 \\
27 \\
18.7 \\
16.2 \\
15.4 \\
14.0 \\
14.0 \\
15.4 \\
13.2 \\
11.1\end{array}$ & $\begin{array}{ll}21 & \ldots \\
22 & \ldots \\
23 & \ldots \\
24 & \ldots \\
25 & \cdots \\
26 & \cdots \\
27 & \ldots \\
28 & \cdots \\
29 & \cdots \\
30 & \cdots \\
31 & \end{array}$ & $\begin{array}{r}65 \\
98 \\
1,160 \\
755 \\
136 \\
63 \\
53 \\
67 \\
42 \\
37 \\
40\end{array}$ & $\begin{array}{r}11.8 \\
10.5 \\
10.0 \\
10.0 \\
10.0 \\
9.1 \\
9.5 \\
8.6 \\
8.6 \\
6.5 \\
6.5\end{array}$ \\
\hline \multicolumn{9}{|c|}{$\begin{array}{l}\text { Monthly mean discharge, in second-feet (observed) } \\
\text { Monthly mean discharge, in second-feet (adjusted) } \\
\text { Runoff, in inches (adjusted) }\end{array}$} & & $\begin{array}{l}25.2 \\
39.8 \\
1.80\end{array}$ \\
\hline
\end{tabular}

Gage height, in feet, and discharge, in second-feet, at indicated time, 1938

\begin{tabular}{|c|c|c|c|c|c|c|c|c|c|c|c|c|}
\hline \multirow{2}{*}{ Hour } & Feet & Sec.-ft. & Feet & Sec.-ft. & Feet & Sec.-ft. & Feet & Sec.-ft. & Feet & Sec.-ft. & Feet & Sec.-ft. \\
\hline & \multicolumn{2}{|c|}{ July 17} & \multicolumn{2}{|c|}{ July 18} & \multicolumn{2}{|c|}{ July 19} & \multicolumn{2}{|c|}{ July 20} & \multicolumn{2}{|c|}{ July 21} & \multicolumn{2}{|c|}{ July 22} \\
\hline 2 a.m. & 1.51 & 10.0 & 1.63 & 18.7 & 1.52 & 10.5 & 1.61 & 17.0 & 1.61 & 17.0 & 2.04 & 73 \\
\hline & 1.51 & 10.0 & 1.60 & 16.2 & 1.52 & 10.5 & $1 . \tilde{9} 9$ & 15.4 & 1.61 & 17.0 & 2.06 & 76 \\
\hline & 1.51 & 10.0 & 1.59 & 15.4 & 1.53 & 11.1 & 1.59 & 15. & 1.67 & 22 & 2.07 & 78 \\
\hline & 1.51 & 10.0 & 1.61 & 17.0 & 1.56 & 13.2 & 1.77 & 32 & 1.82 & 39 & 2.04 & 73 \\
\hline & 1.53 & 11.1 & 1.60 & 16.2 & 1.58 & 14.7 & 1.97 & 60 & 1.89 & 48 & 2.13 & 91 \\
\hline $12 \mathrm{n}$. & 1.53 & 11.1 & 1.50 & 9.5 & 1.56 & 13.2 & 2.03 & 71 & 2.16 & 98 & 2.3 & 146 \\
\hline 2 p.m. & 1.51 & 10.0 & 1.58 & 14.7 & 1.54 & 11.8 & 2.03 & 71 & 2.25 & 122 & 2.35 & 149 \\
\hline & 1.55 & 12. & $1 . \tilde{5}$ & 11.8 & 1.5 & 11. & 1.8 & 42 & 2.21 & 111 & 2.3 & 157 \\
\hline 6 & 1.88 & 46 & 1.5 & 11.1 & 1.54 & 11.8 & 1.7 & 30 & 2.09 & 82 & 2.21 & 111 \\
\hline & 2.01 & 67 & 1.5 & & & 30 & 1.6 & 23 & 2.07 & 78 & 2.12 & 89 \\
\hline & 1.87 & 45 & 1.5 & 10 & 1.7 & 28 & 1.63 & 18.7 & 2.14 & 94 & 2.02 & 64 \\
\hline $12 \mathrm{~m}$ & 1.7 & 26 & & & & 20 & 1.61 & 17 & 2.11 & 86 & 1.93 & 54 \\
\hline
\end{tabular}


Gage height in feet, and discharge, in second-feet, at indicated time, 1938-Continued

\begin{tabular}{|c|c|c|c|c|c|c|c|c|c|c|c|c|}
\hline \multirow{2}{*}{ Hour } & Feet & Sec.-ft. & Feet & Sec.-ft. & Feet & Sec.-ft. & Feet & Sec.-ft. & Feet & Sec.-ft. & Feet & Sec.-ft. \\
\hline & \multicolumn{2}{|c|}{ July 23} & \multicolumn{2}{|c|}{ July 24} & \multicolumn{2}{|c|}{ July 25} & \multicolumn{2}{|c|}{ July 26} & \multicolumn{2}{|c|}{ July 27} & \multicolumn{2}{|c|}{ July 28} \\
\hline $\begin{array}{c}2 \mathrm{a} . \mathrm{m} . \\
4 \\
6 \\
8 \\
10 \\
12 \mathrm{n} . \\
2 \mathrm{p} . \mathrm{m} . \\
4 \\
6 \\
8 \\
10 \\
12 \mathrm{~m} .\end{array}$ & $\begin{array}{l}1.88 \\
1.84 \\
1.85 \\
3.20 \\
6.50 \\
7.33 \\
7.36 \\
7.32 \\
7.30 \\
7.22 \\
6.97 \\
6.64\end{array}$ & $\begin{array}{r}46 \\
41 \\
42 \\
393 \\
1,500 \\
1,900 \\
1,910 \\
1,890 \\
1,880 \\
1,840 \\
1,720 \\
1,560\end{array}$ & $\begin{array}{l}6.23 \\
5.82 \\
5.41 \\
5.02 \\
4.65 \\
4.26 \\
3.87 \\
3.52 \\
3.25 \\
3.01 \\
2.81 \\
2.65\end{array}$ & $\begin{array}{r}1,380 \\
1,220 \\
1,060 \\
926 \\
802 \\
681 \\
570 \\
478 \\
407 \\
.340 \\
282 \\
236\end{array}$ & $\begin{array}{l}2.54 \\
2.46 \\
2.40 \\
2.34 \\
2.30 \\
2.27 \\
2.25 \\
2.21 \\
2.18 \\
2.15 \\
2.11 \\
2.09\end{array}$ & $\begin{array}{r}204 \\
180 \\
163 \\
146 \\
135 \\
127 \\
122 \\
111 \\
103 \\
96 \\
86 \\
82\end{array}$ & $\begin{array}{l}2.07 \\
2.05 \\
2.03 \\
2.01 \\
1.99 \\
1.98 \\
1.97 \\
1.95 \\
1.94 \\
1.92 \\
1.90 \\
1.89\end{array}$ & $\begin{array}{l}78 \\
74 \\
71 \\
67 \\
63 \\
62 \\
60 \\
57 \\
55 \\
52 \\
49 \\
48\end{array}$ & $\begin{array}{l}1.88 \\
1.88 \\
1.87 \\
1.87 \\
1.86 \\
1.85 \\
1.80 \\
1.77 \\
1.75 \\
1.87 \\
2.30 \\
2.25\end{array}$ & $\begin{array}{r}46 \\
46 \\
45 \\
45 \\
44 \\
42 \\
36 \\
32 \\
30 \\
45 \\
135 \\
122\end{array}$ & $\begin{array}{l}2.14 \\
2.04 \\
1.98 \\
1.95 \\
1.91 \\
1.89 \\
1.65 \\
1.79 \\
2.31 \\
2.18 \\
2.05 \\
1.96\end{array}$ & $\begin{array}{r}94 \\
73 \\
62 \\
57 \\
51 \\
48 \\
20 \\
35 \\
138 \\
103 \\
74 \\
59\end{array}$ \\
\hline & \multicolumn{2}{|c|}{ July 29} & \multicolumn{2}{|c|}{ July 30} & \multicolumn{2}{|c|}{ July 31} & \multicolumn{2}{|c|}{ August 1} & \multicolumn{2}{|c|}{ August 2} & \multicolumn{2}{|c|}{ August 3} \\
\hline $\begin{array}{c}2 \mathrm{a} . \mathrm{m} . \\
4 \\
6 \\
8 \\
10 \\
12 \mathrm{n} . \\
2 \mathrm{p} . \mathrm{m} . \\
4 \\
6 \\
8 \\
10 \\
12 \mathrm{~m} .\end{array}$ & $\begin{array}{l}1.91 \\
1.89 \\
1.87 \\
1.85 \\
1.85 \\
1.84 \\
1.80 \\
1.97 \\
1.80 \\
1.78 \\
1.83 \\
1.86\end{array}$ & $\begin{array}{l}\mathbf{5 1} \\
48 \\
45 \\
42 \\
42 \\
41 \\
36 \\
60 \\
36 \\
33 \\
40 \\
44\end{array}$ & $\begin{array}{l}1.94 \\
1.92 \\
1.89 \\
1.85 \\
1.82 \\
1.78 \\
1.76 \\
1.74 \\
1.73 \\
1.71 \\
1.70 \\
1.70\end{array}$ & $\begin{array}{l}55 \\
52 \\
48 \\
42 \\
39 \\
33 \\
31 \\
29 \\
28 \\
26 \\
25 \\
25\end{array}$ & $\begin{array}{l}1.70 \\
1.70 \\
1.70 \\
1.71 \\
1.71 \\
1.69 \\
1.69 \\
1.77 \\
1.79 \\
2.17 \\
2.12 \\
1.99\end{array}$ & $\begin{array}{r}25 \\
25 \\
25 \\
26 \\
26 \\
24 \\
24 \\
32 \\
35 \\
101 \\
89 \\
63\end{array}$ & $\begin{array}{l}1.90 \\
1.84 \\
1.81 \\
1.80 \\
1.79 \\
1.76 \\
1.74 \\
1.72 \\
1.70 \\
1.70 \\
1.70 \\
1.72\end{array}$ & $\begin{array}{l}49 \\
41 \\
37 \\
36 \\
35 \\
31 \\
29 \\
27 \\
25 \\
25 \\
25 \\
27\end{array}$ & $\begin{array}{l}1.74 \\
1.72 \\
1.70 \\
1.70 \\
1.70 \\
1.52 \\
1.67 \\
1.66 \\
1.67 \\
1.61 \\
1.67 \\
1.65\end{array}$ & $\begin{array}{l}29 \\
27 \\
25 \\
25 \\
25 \\
10.5 \\
22 \\
21 \\
22 \\
17.0 \\
22 \\
20\end{array}$ & $\begin{array}{l}1.65 \\
1.65 \\
1.65 \\
1.67 \\
1.66 \\
1.67 \\
1.63 \\
1.64 \\
1.68 \\
1.63 \\
1.62 \\
1.62\end{array}$ & $\begin{array}{l}20 \\
20 \\
20 \\
22 \\
21 \\
22 \\
18.7 \\
19.6 \\
23 \\
18.7 \\
17.9 \\
17.9\end{array}$ \\
\hline
\end{tabular}

Supplemental records.-July 23, $1: 15$ p.m., $7.41 \mathrm{ft}$, 1,940 sec.-ft.; July 28,1 p.m., $1.87 \mathrm{ft} ., 45$ sec-ft. July 29, 1 :30 p.m., 1.68 ft., 23 sec-ft.; 3 p.m., 1.64 ft., 19.6 sec.-ft.

RAFWAX RIVER AT RAEWAY, IT. J.

Location.-Lat. $40^{\circ} 37^{\prime} 05^{\prime \prime}$, long. $74^{\circ} 17^{\prime} 00^{\prime \prime}, 100$ feet upstream from St. George Avenue Bridge in Rahway, Union County, and 1 mile upstream from Robinsons Branch of Rahway River. Datum of gage is 8.77 feet above mean sea level (general adjustment of 1929).

Drainage area.-40.9 square miles.

GAGE-HEIGHT RECORD.-Water-stage recorder graph except for periods July 1, 8-13, July 15 to 7 a.m. July 21, Aug. 20-31.

Stace-Discharge relation.-Defined by current-meter measurements below 500 second-feet; extended to peak stage on basis of logarithmic plotting and laboratory rating of control.

Maxima.-July 1938: Discharge, 3,140 second-feet 1:15 a.m. July 24 (gage height, 6.35 feet).

1908-15, 1921 to June 1938: Discharge, about 1,740 second-feet Aug. 2, 1927 (gage height, 6.0 feet, site and datum then in use).

Remarks.-Discharge affected by diversions for municipal supply. Discharge for periods of no gage-heights record computed on basis of recorded ranges in stage and record for station near Springfield. Monthly mean discharge and runoff, in inches, adjusted for diversions. Monthly mean diversions were: June, 19.9 second-feet; July, 19.3 second-feet; August, 20.0 second-feet. 
Mean discharge, in second-feet, 1938

\begin{tabular}{|c|c|c|c|c|c|c|c|c|c|c|c|}
\hline Day & June & July & Aug. & Day & June & July & Aug. & Day & June & July & Aug. \\
\hline $\begin{array}{r}1 \\
2 \\
3 \\
4 \\
5 \\
6 \\
7 \\
8 \\
9 \\
10\end{array}$ & $\begin{array}{c}14.6 \\
14.5 \\
17.1 \\
15.8 \\
16.7 \\
26 \\
17.8 \\
227 \\
83 \\
23\end{array}$ & $\begin{array}{l}30 \\
27 \\
23 \\
19.2 \\
19.0 \\
16.1 \\
15.2 \\
15 \\
15 \\
15\end{array}$ & $\begin{array}{r}69 \\
43 \\
34 \\
30 \\
28 \\
35 \\
158 \\
57 \\
102 \\
54\end{array}$ & $\begin{array}{l}11 \\
12 \\
13 \\
14 \\
15 \\
16 \\
17 \\
18 \\
19 \\
20\end{array}$ & $\begin{array}{l}25 \\
28 \\
50 \\
47 \\
20 \\
15.6 \\
15.6 \\
48 \\
27 \\
18.2\end{array}$ & $\begin{array}{l}40 \\
30 \\
20 \\
19.2 \\
45 \\
21 \\
32 \\
26 \\
24 \\
55\end{array}$ & $\begin{array}{l}79 \\
48 \\
32 \\
30 \\
28 \\
27 \\
26 \\
26 \\
27 \\
19\end{array}$ & $\begin{array}{l}21 \\
22 \\
23 \\
24 \\
25 \\
26 \\
27 \\
28 \\
29 \\
30 \\
31\end{array}$ & $\begin{array}{c}14.5 \\
11.1 \\
14.8 \\
15.0 \\
14 \\
100 \\
140 \\
340 \\
100 \\
45\end{array}$ & $\begin{array}{r}100 \\
168 \\
1,140 \\
2,270 \\
581 \\
140 \\
80 \\
114 \\
91 \\
66 \\
46\end{array}$ & $\begin{array}{l}19 \\
18 \\
17 \\
17 \\
17 \\
16 \\
16 \\
16 \\
15 \\
14 \\
14\end{array}$ \\
\hline \multicolumn{9}{|c|}{$\begin{array}{l}\text { Monthly mean discharge, in second-feet (observed) } \\
\text { Monthly mean discharge, in second-feet (adjusted) } \\
\text { Runoff, in inches (adjusted) }\end{array}$} & $\begin{array}{l}51.5 \\
71.4 \\
1.95\end{array}$ & $\begin{array}{r}171 \\
190 \\
5.36\end{array}$ & $\begin{array}{l}36.5 \\
56.5 \\
1.59\end{array}$ \\
\hline
\end{tabular}

Gage height, in feet, and discharge, in second-feet, at indicated time, 1938

\begin{tabular}{|c|c|c|c|c|c|c|c|c|c|c|c|c|}
\hline \multirow{2}{*}{ Hour } & Feet & Sec.-ft. & Feet & Sec.-ft. & Feet & Sec. $-\mathrm{ft}$. & Feet & Sec.-ft. & Feet & Sec.-ft. & Feet & Sec.-ft. \\
\hline & \multicolumn{2}{|c|}{ July 17} & \multicolumn{2}{|c|}{ July 18} & \multicolumn{2}{|c|}{$J_{11} l y 19$} & \multicolumn{2}{|c|}{ July 20} & \multicolumn{2}{|c|}{ July 21} & \multicolumn{2}{|c|}{ July 22} \\
\hline \multirow[t]{2}{*}{$\begin{array}{c}2 \text { a.m. } \\
4 \\
6 \\
8 \\
10 \\
12 \mathrm{n} . \\
2 \mathrm{p} . \mathrm{m} . \\
4 \\
6 \\
8 \\
10 \\
12 \mathrm{~m} .\end{array}$} & 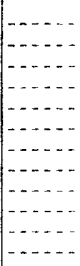 & \begin{tabular}{|c}
- \\
$\cdots$ \\
$\cdots$
\end{tabular} & 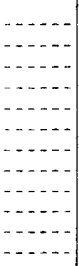 & $\begin{array}{c}-- \\
-- \\
-\ldots \\
-\ldots\end{array}$ & 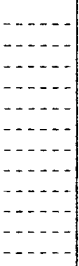 & $\begin{array}{c}--1 \\
-- \\
- \\
-\end{array}$ & 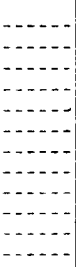 & 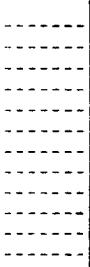 & $\begin{array}{l}1.66 \\
1.65 \\
1.65 \\
1.64 \\
1.64 \\
1.73 \\
1.86 \\
1.95 \\
2.05 \\
2.35 \\
2.32 \\
2.20\end{array}$ & $\begin{array}{r}51 \\
50 \\
50 \\
48 \\
48 \\
64 \\
90 \\
110 \\
134 \\
226 \\
215 \\
176\end{array}$ & $\begin{array}{l}2.12 \\
2.10 \\
2.07 \\
2.03 \\
2.05 \\
2.23 \\
2.31 \\
2.25 \\
2.23 \\
2.23 \\
2.22 \\
2.20\end{array}$ & $\begin{array}{l}153 \\
147 \\
139 \\
129 \\
134 \\
186 \\
212 \\
192 \\
186 \\
186 \\
182 \\
176\end{array}$ \\
\hline & \multicolumn{2}{|c|}{ July 23} & \multicolumn{2}{|c|}{ July 24} & \multicolumn{2}{|c|}{ July 25} & \multicolumn{2}{|c|}{ July 26} & \multicolumn{2}{|c|}{ July 27} & \multicolumn{2}{|c|}{ July 28} \\
\hline $\begin{array}{c}2 \mathrm{a} . \mathrm{m} . \\
4 \\
6 \\
8 \\
10 \\
12 \mathrm{n} . \\
2 \mathrm{p.m} . \\
4 \\
6 \\
8 \\
10 \\
12 \mathrm{~m} .\end{array}$ & $\begin{array}{l}2.14 \\
2.07 \\
2.00 \\
1.99 \\
2.77 \\
3.62 \\
4.28 \\
4.56 \\
5.04 \\
6.01 \\
6.16 \\
6.20\end{array}$ & $\begin{array}{r}159 \\
139 \\
121 \\
119 \\
390 \\
829 \\
1,270 \\
1,470 \\
1,870 \\
2,780 \\
2,940 \\
2,980\end{array}$ & $\begin{array}{l}6.22 \\
6.24 \\
6.15 \\
6.02 \\
5.82 \\
5.61 \\
5.37 \\
5.12 \\
4.87 \\
4.60 \\
4.37 \\
4.14\end{array}$ & $\begin{array}{l}3,000 \\
3,020 \\
2,930 \\
2,790 \\
2,590 \\
2,380 \\
2,150 \\
1,940 \\
1,720 \\
1,500 \\
1,330 \\
1,170\end{array}$ & $\begin{array}{l}3.91 \\
3.72 \\
3.54 \\
3.38 \\
3.22 \\
3.06 \\
2.92 \\
2.80 \\
2.70 \\
2.62 \\
2.52 \\
2.43\end{array}$ & $\begin{array}{r}1,010 \\
889 \\
782 \\
692 \\
606 \\
524 \\
457 \\
403 \\
360 \\
327 \\
288 \\
254\end{array}$ & $\begin{array}{l}2.35 \\
2.27 \\
2.19 \\
2.12 \\
2.07 \\
2.02 \\
1.99 \\
1.96 \\
1.93 \\
1.91 \\
1.89 \\
1.88\end{array}$ & $\begin{array}{r}226 \\
198 \\
173 \\
153 \\
139 \\
126 \\
119 \\
112 \\
105 \\
100 \\
96 \\
94\end{array}$ & $\begin{array}{l}1.85 \\
1.84 \\
1.82 \\
1.80 \\
1.80 \\
1.78 \\
1.77 \\
1.76 \\
1.75 \\
1.79 \\
1.86 \\
2.05\end{array}$ & $\begin{array}{r}88 \\
85 \\
81 \\
77 \\
77 \\
73 \\
71 \\
69 \\
68 \\
75 \\
90 \\
134\end{array}$ & $\begin{array}{l}2.05 \\
2.08 \\
2.11 \\
2.10 \\
2.06 \\
1.99 \\
1.92 \\
1.88 \\
1.87 \\
1.85 \\
1.83 \\
1.82\end{array}$ & $\begin{array}{l}134 \\
142 \\
150 \\
147 \\
137 \\
119 \\
103 \\
94 \\
92 \\
88 \\
83 \\
81\end{array}$ \\
\hline
\end{tabular}

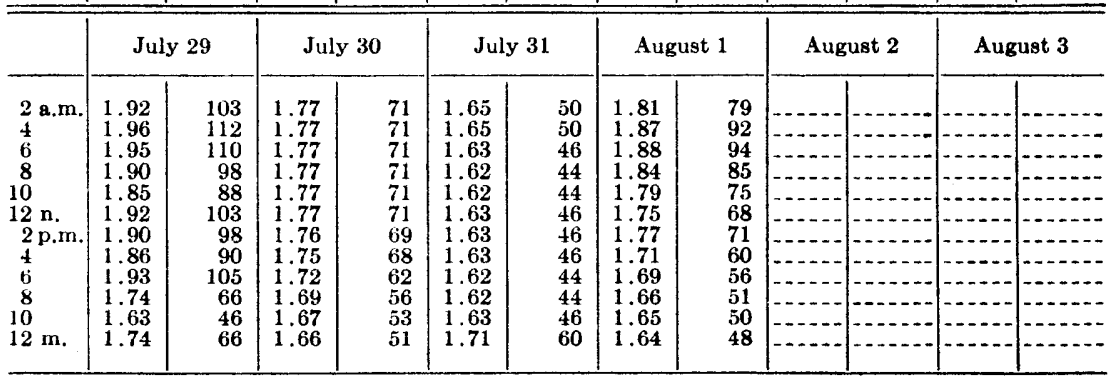

Supplemental records.-July 21, 9 p.m., 2.37 ft., 232 sec.-ft.; July 24, 1 :15 a.m., 6.35 ft., 3,140 sec.-ft.; $1: 45$ a.m., $6.20 \mathrm{ft}$., 2,980 sec.-ft. 


\section{RARITAN RIVER BASIN}

SOUTH BRANCH OF RARITAN RIVER AT STANTON, N. J.

Location.-Lat. $40^{\circ} 34^{\prime} 21^{\prime \prime}$, long. $74^{\circ} 52^{\prime} 10^{\prime \prime}$, at highway bridge near Stanton railroad station, Reading Township, Hunterdon County, and half a mile upstream from Prescott Brook. Datum of gage is 125.01 feet above mean sea level (general adjustment of 1929).

Drainace aREA.-147 square miles.

GAGE-HEIGHT RECORD.-Water-stage recorder graph except June 10, 11.

StAGE-Discharge RELATION.-Defined by current-meter measurements below 1,200 second-feet; extended to peak stage on basis of slope-area measurement and computation of flow over dam.

Maxima.-July 1938: Discharge, 4,600 second-feet 10 p.m. July 23 (gage height, 8.51 feet).

1903-6, 1919 to June 1938: Discharge, about 8,280 second-feet July 9, 1935 (gage height, 10.80 feet).

REMARKs.-Flow not materially affected by storage. Discharge for period of no gage-height record computed on basis of record for station near High Bridge.

Mean discharge, in second-feet, 1938

\begin{tabular}{|c|c|c|c|c|c|c|c|c|c|c|c|}
\hline Day & June & July & Aug. & Day & June & July & Aug. & Day & June & July & Aug. \\
\hline $\begin{array}{r}1 \\
2 \\
3 \\
4 \\
5 \\
6 \\
7 \\
8 \\
9 \\
10\end{array}$ & $\begin{array}{r}107 \\
99 \\
97 \\
109 \\
105 \\
105 \\
100 \\
413 \\
177 \\
120\end{array}$ & $\begin{array}{l}266 \\
256 \\
216 \\
196 \\
174 \\
155 \\
152 \\
135 \\
130 \\
135\end{array}$ & $\begin{array}{l}387 \\
387 \\
313 \\
279 \\
262 \\
501 \\
423 \\
306 \\
259 \\
234\end{array}$ & $\begin{array}{l}11 \\
12 \\
13 \\
14 \\
15 \\
16 \\
17 \\
18 \\
19 \\
20\end{array}$ & $\begin{array}{l}130 \\
148 \\
185 \\
275 \\
163 \\
128 \\
106 \\
458 \\
182 \\
132\end{array}$ & $\begin{array}{l}128 \\
155 \\
150 \\
138 \\
155 \\
145 \\
121 \\
152 \\
136 \\
671\end{array}$ & $\begin{array}{l}324 \\
256 \\
188 \\
185 \\
182 \\
168 \\
218 \\
243 \\
174 \\
152\end{array}$ & $\begin{array}{l}21 \\
22 \\
23 \\
24 \\
25 \\
26 \\
27 \\
28 \\
29 \\
30 \\
31\end{array}$ & $\begin{array}{r}121 \\
109 \\
195 \\
199 \\
135 \\
195 \\
885 \\
1,200 \\
526 \\
332\end{array}$ & $\begin{array}{r}939 \\
1,310 \\
1,830 \\
2,180 \\
896 \\
653 \\
560 \\
726 \\
549 \\
694 \\
426\end{array}$ & $\begin{array}{r}148 \\
140 \\
132 \\
128 \\
114 \\
121 \\
130 \\
94 \\
116 \\
107 \\
99\end{array}$ \\
\hline \multicolumn{9}{|c|}{$\begin{array}{l}\text { Monthly mean discharge, in second-feet, } \\
\text { Runoff, in inchess }\end{array}$} & $\begin{array}{r}241 \\
1.83\end{array}$ & $\begin{array}{r}469 \\
\mathbf{3 . 6 8}\end{array}$ & $\begin{array}{r}218 \\
1.71\end{array}$ \\
\hline
\end{tabular}

Gage height, in feet, and discharge, in second-feet, at indicated time, 1938

\begin{tabular}{|c|c|c|c|c|c|c|c|c|c|c|c|c|}
\hline \multirow{2}{*}{ Hour } & Feet & Sec.-ft. & Feet & Sec.-ft. & Feet & Sec. $-\mathrm{ft}$. & Feet & Sec. $-\mathrm{ft}$. & Feet & Sec.-ft. & Feet & Sec.-ft. \\
\hline & \multicolumn{2}{|c|}{ July 17} & \multicolumn{2}{|c|}{ July 18} & \multicolumn{2}{|c|}{ July 19} & \multicolumn{2}{|c|}{ July 20} & \multicolumn{2}{|c|}{ July 21} & \multicolumn{2}{|c|}{ July 22} \\
\hline $2 \mathrm{a} . \mathrm{r}$ & 2.60 & 130 & 2.77 & 174 & 2.47 & 101 & 2.64 & 140 & 3.84 & 593 & 5.24 & 1.510 \\
\hline $4^{\mathrm{a} .1}$ & 2.60 & 130 & 2.73 & 163 & 2.37 & 81 & 2.70 & 155 & 3.63 & 486 & 5.17 & 1,460 \\
\hline & 2.60 & 130 & 2.69 & 152 & 2.42 & 90 & 2.84 & 193 & 3.4 & 40 & 5.0 & 1,390 \\
\hline 8 & 2.59 & 128 & 2.66 & 145 & 2.59 & 128 & 3.31 & 347 & 3.39 & 379 & 4.96 & 1,310 \\
\hline 10 & 2.59 & 128 & 2.64 & 140 & 2.63 & 138 & 3.70 & 520 & 3. & 44 & 4.7 & 1,180 \\
\hline $12 \mathrm{n}$. & 2.59 & 128 & 2.65 & 142 & 2.79 & 179 & 4.52 & 1,009 & 4.02 & 693 & 4.75 & $\begin{array}{l}1,160 \\
1,160\end{array}$ \\
\hline 2 p.m. & 2.60 & 130 & 2.7 & 171 & 2.81 & 18 & 4.84 & 1,230 & & 1,4 & 4. & 1,300 \\
\hline & 2.54 & 116 & 2.7 & 163 & 2.7 & 17 & 4.5 & 1,020 & & 1,8 & & 1,420 \\
\hline & 2.43 & 92 & 2.7 & 160 & 2.7 & 16 & 4.4 & 962 & 5.1 & 1,47 & 5.0 & 1,340 \\
\hline & 2.38 & 82 & 2.6 & 13 & 2.6 & 15 & 4. & 1,030 & & 1,2 & 4. & 1,150 \\
\hline & 2.51 & 109 & 2.6 & 130 & & 118 & 4. & 942 & & 1,280 & 4. & 1,040 \\
\hline & & 16 & & 130 & & 9 & & 740 & 5.11 & 1,420 & 4.47 & 976 \\
\hline
\end{tabular}


Gage height in feet, and discharge, in second-feet, at indicated time, 1938-Continued

\begin{tabular}{|c|c|c|c|c|c|c|c|c|c|c|c|c|}
\hline \multirow{2}{*}{ Hour } & Feet & Sec.-ft. & Feet & Sec.ft. & Feet & Sec.-ft. & Feet & Sec.-ft. & Feet & Sec.-ft. & Feet & Sec.-ft. \\
\hline & \multicolumn{2}{|c|}{ July 23} & \multicolumn{2}{|c|}{ July 24} & \multicolumn{2}{|c|}{ July 25} & \multicolumn{2}{|c|}{ July 26} & \multicolumn{2}{|c|}{ July 27} & \multicolumn{2}{|c|}{ July 28} \\
\hline 2 a.m. & 4.34 & 890 & 7.23 & 3,120 & 4.60 & 1,060 & 4.07 & 722 & 3.79 & 566 & 5.03 & 1,360 \\
\hline & 4.21 & 807 & 7.25 & 140 & $\begin{array}{l}4.54 \\
\end{array}$ & 1,020 & 4.05 & 710 & 3.77 & 556 & 4.44 & 956 \\
\hline & 4.11 & 746 & 7.23 & 3,120 & $\begin{array}{l}4.48 \\
4.48\end{array}$ & 983 & $\begin{array}{l}4.02 \\
\end{array}$ & 693 & 3.7 & 551 & 4.11 & 746 \\
\hline 8 & 4.07 & 722 & 6.95 & 2,840 & 4.43 & 949 & 4.00 & 681 & 3.75 & 546 & 3.97 & 664 \\
\hline 10 & 4.13 & 758 & 6.55 & 2,500 & 4.4 & 92 & 3.9 & 66 & 3.7 & 540 & 3.92 & 636 \\
\hline $12 \mathrm{n}$. & 4.32 & 877 & 5.94 & 2,020 & 4.32 & 87 & 3.9 & 65 & 3.7 & 53 & 3.8 & 620 \\
\hline 2 p.m. & 4.70 & 1,130 & 5.46 & 1,660 & 4.33 & 88 & 3.9 & 642 & 3.72 & 530 & 3.82 & 582 \\
\hline & 5.98 & 2,050 & 5.15 & 1,440 & 4.26 & 83 & 3. & 63 & 3. & 52 & 3.7 & 556 \\
\hline & 7.02 & 2,910 & 4.97 & 1,320 & 4.21 & 80 & 3. & 61 & & 50 & & 510 \\
\hline 8 & 7.96 & 3,910 & 4.85 & 1,240 & 4.17 & 783 & 3.8 & 59 & 3.6 & 482 & 3.72 & 530 \\
\hline & 8.51 & 4,600 & 4.7 & 1.160 & 4.1 & 764 & 3. & 58 & & 491 & 3.66 & 501 \\
\hline $12 \mathrm{~m}$. & 7.9 & 3,950 & 4.67 & 1,110 & 4.1 & 740 & 3.8 & 576 & 5.35 & 1,580 & 3.57 & 458 \\
\hline
\end{tabular}

\begin{tabular}{|c|c|c|c|c|c|c|c|c|c|c|c|c|}
\hline & \multicolumn{2}{|c|}{ July 29} & \multicolumn{2}{|c|}{ July 30} & \multicolumn{2}{|c|}{ July 31} & \multicolumn{2}{|c|}{ August 1} & \multicolumn{2}{|c|}{ August 2} & \multicolumn{2}{|c|}{ August 3} \\
\hline & 3.65 & 496 & 4.38 & 916 & 3.58 & 463 & 3.43 & 396 & 3.42 & 392 & 3.27 & 332 \\
\hline & 3.70 & 520 & 4.12 & 752 & 3.56 & 454 & 3.42 & 392 & 3.43 & 396 & 3.26 & 328 \\
\hline 6 & 3.70 & 520 & 4.11 & 746 & 3.54 & 444 & 3.42 & 392 & 3.43 & 396 & 3.24 & 321 \\
\hline 8 & 3.68 & 510 & 4.15 & 770 & 3.52 & 435 & 3.42 & 392 & 3.45 & 404 & 3.23 & 317 \\
\hline 10 & 3.67 & 506 & 4.08 & 728 & 3.51 & 431 & 3.43 & 396 & 3.50 & 426 & 3.22 & 313 \\
\hline $12 \mathrm{n}$. & 3.66 & 501 & 4.00 & 681 & 3.50 & 426 & 3.43 & 396 & 3.47 & 413 & 3.22 & 313 \\
\hline $2 \mathrm{p.m}$. & 3.61 & 477 & 3.91 & 631 & 3.48 & 417 & 3.41 & 387 & 3.50 & 42 & 3.21 & 310 \\
\hline & 3.59 & 467 & 3.84 & 593 & 3.47 & 413 & 3.40 & 383 & 3.44 & 400 & 3.19 & 303 \\
\hline & 3.94 & 647 & 3.76 & 551 & 3.44 & 400 & 3.37 & 371 & 3.40 & 38 & 3.17 & 296 \\
\hline & 4.20 & 801 & 3.70 & 520 & 3.34 & 359 & 3.37 & 371 & 3.35 & 363 & 3.13 & 282 \\
\hline 10 & 4.60 & 1,060 & 3.64 & 491 & 3.42 & 392 & 3.35 & 363 & 3.32 & 351 & 3.13 & 282 \\
\hline $12 \mathrm{~m}$. & 4.77 & 1,180 & 3.62 & 482 & 3.51 & 431 & 3.35 & 363 & 3.28 & 336 & 3.13 & 282 \\
\hline
\end{tabular}

RARITAN RIVER AT MANVIIIE, N. J.

LocAtion.-Lat. $40^{\circ} 33^{\prime} 18^{\prime \prime}$, long. $74^{\circ} 35^{\prime} 02^{\prime \prime}$, at highway bridge in Manville, Somerset County, $1 \frac{114}{4}$ miles upstream from Millstone River. Datum of gage is 20.61 feet above mean sea level (general adjustment of 1929).

Drainage area.-490 square miles.

GACE-HEIGHT RECORD.-Water-stage recorder graph.

Stage-discharge Relation.-Defined by current-meter measurements below 14,000 second-feet; extended to peak stage on basis of two slope-area determinations.

Maxima.-July 1938: Discharge, 26,000 second-feet 10 p.m. July 23 (gage height, 17.75 feet).

1903-7, 1921 to June 1938: Discharge, about 21,000 second-feet Aug. 24, 1933 (gage height, 16.22 feet).

Remarks.-Discharges below 3,100 second-feet computed by shifting-control method on basis of three current-meter measurements and records for other stations in Raritan River Basin.

Mean discharge, in second-feet, 1938

\begin{tabular}{|c|c|c|c|c|c|c|c|c|c|c|c|}
\hline Day & June & July & Aug. & Day & June & July & Atug. & Day & June & July & Aug. \\
\hline $\begin{array}{r}1 \\
2 \\
3 \\
4 \\
5 \\
6 \\
7 \\
8 \\
9 \\
10\end{array}$ & $\begin{array}{r}235 \\
235 \\
240 \\
269 \\
269 \\
258 \\
229 \\
1.840 \\
649 \\
352\end{array}$ & $\begin{array}{l}908 \\
803 \\
660 \\
527 \\
443 \\
376 \\
329 \\
309 \\
282 \\
289\end{array}$ & $\begin{array}{r}896 \\
860 \\
681 \\
577 \\
537 \\
1,210 \\
2,390 \\
896 \\
692 \\
567\end{array}$ & $\begin{array}{l}11 \\
12 \\
13 \\
14 \\
15 \\
16 \\
17 \\
18 \\
19 \\
20\end{array}$ & $\begin{array}{r}344 \\
498 \\
968 \\
872 \\
607 \\
376 \\
316 \\
1,390 \\
660 \\
400\end{array}$ & $\begin{array}{r}276 \\
289 \\
336 \\
309 \\
416 \\
425 \\
309 \\
712 \\
344 \\
2,870\end{array}$ & $\begin{array}{r}791 \\
724 \\
471 \\
384 \\
368 \\
344 \\
360 \\
1,010 \\
425 \\
323\end{array}$ & $\begin{array}{l}21 \\
22 \\
23 \\
24 \\
25 \\
26 \\
27 \\
28 \\
29 \\
30 \\
31\end{array}$ & $\begin{array}{r}316 \\
282 \\
537 \\
803 \\
392 \\
434 \\
3,340 \\
4,840 \\
2,740 \\
1,300\end{array}$ & $\begin{array}{r}3,590 \\
7,980 \\
14,900 \\
16,600 \\
4,660 \\
2,650 \\
1,700 \\
2,090 \\
1,260 \\
2,240 \\
1,070\end{array}$ & $\begin{array}{l}296 \\
269 \\
246 \\
235 \\
218 \\
203 \\
212 \\
212 \\
184 \\
184 \\
179\end{array}$ \\
\hline \multicolumn{9}{|c|}{$\begin{array}{l}\text { Monthly mean discharge, in second-feet } \\
\text { Runoff, in inches. }\end{array}$} & $\begin{array}{r}866 \\
1.98\end{array}$ & $\begin{array}{r}2,257 \\
5.32\end{array}$ & $\begin{array}{r}547 \\
1.29\end{array}$ \\
\hline
\end{tabular}


Gage height, in feet, and discharge, in second-feet, at indicated time, 1938

\begin{tabular}{|c|c|c|c|c|c|c|c|c|c|c|c|c|}
\hline \multirow[b]{2}{*}{ Hour } & Feet & Sec.-ft. & Feet & Sec. - ft. & Feet & Sec.-ft. & Feet & Sec.-ft. & Feet & Sec.-ft. & Feet & Sec-ft. \\
\hline & \multicolumn{2}{|c|}{ July 17} & \multicolumn{2}{|c|}{ July 18} & \multicolumn{2}{|c|}{ July 19} & \multicolumn{2}{|c|}{ July 20} & \multicolumn{2}{|c|}{ July 21} & \multicolumn{2}{|c|}{ July 22} \\
\hline \multirow[t]{2}{*}{$\begin{array}{c}2 \text { a.m. } \\
4 \\
6 \\
8 \\
10 \\
12 \mathrm{n} . \\
2 \text { p.m. } \\
4 \\
6 \\
8 \\
10 \\
12 \mathrm{~m} .\end{array}$} & $\begin{array}{l}4.42 \\
4.41 \\
4.40 \\
4.40 \\
4.40 \\
4.40 \\
4.39 \\
4.39 \\
4.40 \\
4.40 \\
4.40 \\
4.95\end{array}$ & $\begin{array}{l}316 \\
309 \\
302 \\
302 \\
302 \\
302 \\
296 \\
296 \\
302 \\
302 \\
302 \\
825\end{array}$ & $\begin{array}{l}5.61 \\
5.30 \\
5.02 \\
4.83 \\
4.74 \\
4.70 \\
4.65 \\
4.63 \\
4.57 \\
4.54 \\
4.52 \\
4.50\end{array}$ & $\begin{array}{r}1,700 \\
1,260 \\
896 \\
681 \\
587 \\
547 \\
498 \\
480 \\
425 \\
400 \\
384 \\
368\end{array}$ & $\begin{array}{l}4.49 \\
4.49 \\
4.48 \\
4.48 \\
4.47 \\
4.47 \\
4.45 \\
4.43 \\
4.43 \\
4.43 \\
4.44 \\
4.44\end{array}$ & $\begin{array}{l}360 \\
360 \\
352 \\
352 \\
344 \\
344 \\
329 \\
316 \\
316 \\
316 \\
323 \\
323\end{array}$ & $\begin{array}{l}4.49 \\
4.56 \\
4.67 \\
4.85 \\
7.20 \\
8.87 \\
9.11 \\
8.50 \\
7.65 \\
7.08 \\
6.68 \\
6.32\end{array}$ & $\begin{array}{r}360 \\
416 \\
517 \\
702 \\
3,630 \\
5,500 \\
5,860 \\
4,990 \\
4,050 \\
3,540 \\
3,250 \\
2,720\end{array}$ & $\begin{array}{l}6.07 \\
5.96 \\
5.87 \\
5.75 \\
5.64 \\
5.78 \\
6.43 \\
8.30 \\
9.57 \\
9.75 \\
9.30 \\
8.75\end{array}$ & $\begin{array}{l}2,380 \\
2,220 \\
2,080 \\
1,900 \\
1,740 \\
1,950 \\
2,850 \\
4,730 \\
6,560 \\
6,850 \\
6,150 \\
5,330\end{array}$ & $\begin{array}{r}8.35 \\
8.92 \\
10.05 \\
10.66 \\
11.03 \\
11.06 \\
11.03 \\
11.13 \\
11.28 \\
11.20 \\
10.83 \\
10.23\end{array}$ & $\begin{array}{l}4,800 \\
5,580 \\
7,330 \\
8,350 \\
8,990 \\
9,050 \\
8,990 \\
9,170 \\
9,440 \\
9,300 \\
\mathbf{8 , 6 4 0} \\
7,620\end{array}$ \\
\hline & \multicolumn{2}{|c|}{ July 23} & \multicolumn{2}{|c|}{ July 24} & \multicolumn{2}{|c|}{ July 25} & \multicolumn{2}{|c|}{ July 26} & \multicolumn{2}{|c|}{ July 27} & \multicolumn{2}{|c|}{ July 28} \\
\hline $\begin{array}{l}2 \mathrm{a} . \mathrm{m} . \\
4 \\
6 \\
8 \\
10 \\
12 \mathrm{n} . \\
2 \mathrm{p} . \mathrm{m} . \\
4 \\
6 \\
8 \\
10 \\
12 \mathrm{~m} .\end{array}$ & $\begin{array}{r}9.54 \\
8.95 \\
8.60 \\
9.88 \\
11.65 \\
13.70 \\
14.95 \\
16.30 \\
17.27 \\
17.68 \\
17.75 \\
17.53\end{array}$ & $\begin{array}{r}6,510 \\
5,620 \\
5,120 \\
7,060 \\
10,100 \\
14,600 \\
17,400 \\
21,300 \\
24,400 \\
25,700 \\
26,000 \\
25,300\end{array}$ & $\begin{array}{l}17.27 \\
16.97 \\
16.55 \\
15.98 \\
15.27 \\
14.48 \\
13.73 \\
13.00 \\
12.35 \\
11.67 \\
11.04 \\
10.41\end{array}$ & $\begin{array}{r}24,400 \\
23,400 \\
22,100 \\
20,300 \\
18,300 \\
16,500 \\
14,700 \\
13,000 \\
11,600 \\
10,100 \\
9,010 \\
7,930\end{array}$ & $\begin{array}{l}9.75 \\
9.18 \\
8.75 \\
8.43 \\
8.15 \\
7.92 \\
7.70 \\
7.50 \\
7.27 \\
7.09 \\
6.93 \\
6.77\end{array}$ & $\begin{array}{l}6,850 \\
5,970 \\
5,330 \\
4,900 \\
4,560 \\
4,320 \\
4,100 \\
3,900 \\
3,690 \\
3,540 \\
3,430 \\
3,320\end{array}$ & $\begin{array}{l}6.63 \\
6.51 \\
6.42 \\
6.33 \\
6.25 \\
6.18 \\
6.08 \\
6.01 \\
5.94 \\
5.87 \\
5.80 \\
5.73\end{array}$ & $\begin{array}{l}3,210 \\
3,110 \\
2,920 \\
2,820 \\
2,720 \\
2,640 \\
2,500 \\
2,400 \\
2,300 \\
2,190 \\
2,080 \\
1,980\end{array}$ & $\begin{array}{l}5.68 \\
5.63 \\
5.60 \\
5.58 \\
5.56 \\
5.53 \\
5.47 \\
5.48 \\
5.44 \\
5.45 \\
5.46 \\
5.53\end{array}$ & $\begin{array}{l}1,900 \\
1,830 \\
1,780 \\
1,760 \\
1,720 \\
1,680 \\
1,590 \\
1,610 \\
1,550 \\
1,560 \\
1,580 \\
1,680\end{array}$ & $\begin{array}{l}5.56 \\
5.79 \\
6.10 \\
6.62 \\
6.40 \\
6.03 \\
5.75 \\
5.65 \\
5.56 \\
5.48 \\
5.41 \\
5.35\end{array}$ & $\begin{array}{l}1,720 \\
2,070 \\
2,530 \\
3,200 \\
2,900 \\
2,430 \\
2,010 \\
1,860 \\
1,720 \\
1,610 \\
1,510 \\
1,420\end{array}$ \\
\hline $12 \mathrm{~m}$. & \multicolumn{2}{|c|}{ July 29} & \multicolumn{2}{|c|}{ July 30} & \multicolumn{2}{|c|}{ July 31} & \multicolumn{2}{|c|}{ August 1} & \multicolumn{2}{|c|}{ August 2} & \multicolumn{2}{|c|}{ August 3} \\
\hline $\begin{array}{l}2 \mathrm{a} . \mathrm{m} . \\
4 \\
6 \\
8 \\
10 \\
12 \mathrm{n} . \\
2 \mathrm{p.m} . \\
4 \\
6 \\
8 \\
10 \\
12 \mathrm{~m} .\end{array}$ & $\begin{array}{l}5.30 \\
5.27 \\
5.25 \\
5.24 \\
5.30 \\
5.25 \\
5.20 \\
5.20 \\
5.19 \\
5.18 \\
5.19 \\
5.35\end{array}$ & $\begin{array}{l}1,350 \\
1,310 \\
1,280 \\
1,270 \\
1,350 \\
1,280 \\
1,210 \\
1,210 \\
1,200 \\
1,190 \\
1,200 \\
1,420\end{array}$ & $\begin{array}{l}5.98 \\
6.55 \\
6.74 \\
6.54 \\
6.18 \\
5.88 \\
5.73 \\
5.63 \\
5.53 \\
5.42 \\
5.35 \\
5.27\end{array}$ & $\begin{array}{l}2,360 \\
3,140 \\
3,300 \\
3,130 \\
2,640 \\
2,200 \\
1,980 \\
1,830 \\
1,680 \\
1,520 \\
1,420 \\
1,310\end{array}$ & $\begin{array}{l}5.22 \\
5.17 \\
5.13 \\
5.08 \\
5.07 \\
5.06 \\
5.05 \\
5.04 \\
5.03 \\
5.02 \\
5.01 \\
4.98\end{array}$ & $\begin{array}{r}1,240 \\
1,170 \\
1,120 \\
1,060 \\
1,040 \\
1,030 \\
1,020 \\
1,010 \\
994 \\
981 \\
968 \\
931\end{array}$ & $\begin{array}{l}4.97 \\
4.96 \\
4.94 \\
4.97 \\
4.98 \\
4.98 \\
4.97 \\
4.95 \\
4.93 \\
4.92 \\
4.91 \\
4.90\end{array}$ & $\begin{array}{l}919 \\
908 \\
884 \\
919 \\
931 \\
931 \\
919 \\
896 \\
872 \\
860 \\
849 \\
837\end{array}$ & $\begin{array}{l}4.89 \\
4.90 \\
4.92 \\
4.95 \\
4.95 \\
4.95 \\
4.94 \\
4.93 \\
4.91 \\
4.90 \\
4.88 \\
4.87\end{array}$ & $\begin{array}{l}825 \\
837 \\
860 \\
896 \\
896 \\
896 \\
884 \\
872 \\
849 \\
837 \\
814 \\
803\end{array}$ & $\begin{array}{l}4.83 \\
4.81 \\
4.78 \\
4.77 \\
4.77 \\
4.76 \\
4.75 \\
4.75 \\
4.73 \\
4.72 \\
4.71 \\
4.69\end{array}$ & $\begin{array}{l}758 \\
735 \\
702 \\
692 \\
692 \\
681 \\
671 \\
671 \\
649 \\
639 \\
628 \\
607\end{array}$ \\
\hline
\end{tabular}

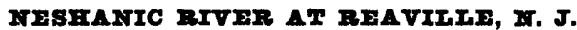

LocAtion.-Lat. $40^{\circ} 28^{\prime} 18^{\prime \prime}$, long. $74^{\circ} 49^{\prime} 42^{\prime \prime}$, at highway bridge half a mile southwest of Reaville, Hunterdon County. Datum of gage is 109.46 feet above mean sea level (unadjusted).

Drainage AREA. - 25.7 square miles.

GAGE-HEIGHT RECORD.-Water-stage recorder graph.

Stage-discharge RELATION.-Defined by current-meter measurements below 1,700 second-feet; extended to peak stage by logarithmic plotting.

Maxima.-July 1938: Discharge, 2,960. second-feet 10:30 a.m. July 23 (gage height, 9.12 feet).

1930 to June 1938: Discharge, 4,370 second-feet Aug. 23, 1933 (gage height, 10.80 feet). 
Mean discharge, in second-feet, 1938

\begin{tabular}{|c|c|c|c|c|c|c|c|c|c|c|c|}
\hline Day & June & July & Aug. & Day & Junè & July & Aug. & Day & June & July & Aug. \\
\hline $\begin{array}{r}1 \\
2 \\
3 \\
4 \\
5 \\
6 \\
7 \\
8 \\
9 \\
10\end{array}$ & $\begin{array}{r}3.6 \\
3.4 \\
3.4 \\
3.4 \\
4.1 \\
4.6 \\
5.7 \\
98 \\
13.9 \\
8.9\end{array}$ & $\begin{array}{l}31 \\
26 \\
18.5 \\
13.3 \\
10.9 \\
8.9 \\
7.5 \\
6.6 \\
6.3 \\
5.7\end{array}$ & $\begin{array}{l}38 \\
33 \\
23 \\
19.8 \\
17.3 \\
18.2 \\
18.5 \\
15.0 \\
12.8 \\
10.1\end{array}$ & $\begin{array}{l}11 \\
12 \\
13 \\
14 \\
15 \\
16 \\
17 \\
18 \\
19 \\
20\end{array}$ & $\begin{array}{l}17.7 \\
28 \\
87 \\
89 \\
27 \\
18.5 \\
15.0 \\
31 \\
13.9 \\
10.1\end{array}$ & $\begin{array}{c}5.4 \\
7.8 \\
5.7 \\
7.6 \\
6.0 \\
4.9 \\
30 \\
24 \\
8.5 \\
545\end{array}$ & $\begin{array}{r}11.4 \\
8.9 \\
7.5 \\
6.9 \\
6.6 \\
6.3 \\
49 \\
19.7 \\
8.2 \\
6.6\end{array}$ & $\begin{array}{l}21 \\
22 \\
23 \\
24 \\
25 \\
26 \\
27 \\
28 \\
29 \\
30 \\
31\end{array}$ & $\begin{array}{r}8.5 \\
7.5 \\
7.8 \\
6.6 \\
5.4 \\
6.2 \\
110 \\
214 \\
76 \\
43\end{array}$ & $\begin{array}{r}329 \\
630 \\
1,500 \\
318 \\
129 \\
82 \\
60 \\
154 \\
133 \\
102 \\
47\end{array}$ & $\begin{array}{l}5.7 \\
5.2 \\
4.6 \\
4.4 \\
3.8 \\
3.8 \\
4.9 \\
6.1 \\
3.8 \\
3.4 \\
3.2\end{array}$ \\
\hline \multicolumn{9}{|c|}{$\begin{array}{l}\text { Monthly mean discharge, in second-feet- } \\
\text { Runoff, in inches }\end{array}$} & $\begin{array}{l}32.4 \\
1.41\end{array}$ & $\begin{array}{r}138 \\
6.19\end{array}$ & $\begin{array}{r}12.4 \\
.56\end{array}$ \\
\hline
\end{tabular}

Gage height, in feet, and discharge, in second-feet, at indicated time, 1938

\begin{tabular}{|c|c|c|c|c|c|c|c|c|c|c|c|c|}
\hline \multirow{2}{*}{ Hour } & Feet & Sre.ft. & Feet & Sec. $-\mathrm{ft}$. & Feet & Sec.-ft. & Feet & Sec.-ft. & Feet & Ser.-ft. & Feet & Sec.-ft. \\
\hline & \multicolumn{2}{|c|}{ July 17} & \multicolumn{2}{|c|}{ July 18} & \multicolumn{2}{|c|}{ July 19} & \multicolumn{2}{|c|}{ July 20} & \multicolumn{2}{|c|}{ July 21} & \multicolumn{2}{|c|}{ July 22} \\
\hline $\begin{array}{l}2 \mathrm{a} . \mathrm{m} . \\
4 \\
6 \\
8 \\
10 \\
12 \mathrm{n} . \\
2 \mathrm{p.m} . \\
4 \\
6 \\
8 \\
10 \\
12 \mathrm{~m} .\end{array}$ & $\begin{array}{l}2.41 \\
2.41 \\
2.41 \\
2.40 \\
2.40 \\
2.40 \\
2.40 \\
2.40 \\
2.56 \\
3.20 \\
3.84 \\
3.52\end{array}$ & $\begin{array}{r}4.1 \\
4.1 \\
4.1 \\
3.8 \\
3.8 \\
3.8 \\
3.8 \\
3.8 \\
8.5 \\
60 \\
190 \\
112\end{array}$ & $\begin{array}{l}3.18 \\
2.98 \\
2.85 \\
2.76 \\
2.72 \\
2.70 \\
2.68 \\
2.65 \\
2.64 \\
2.62 \\
2.60 \\
2.58\end{array}$ & $\begin{array}{l}58 \\
36 \\
25 \\
18.5 \\
16.1 \\
15.0 \\
13.9 \\
12.3 \\
11.8 \\
10.9 \\
10.1 \\
9.3\end{array}$ & $\begin{array}{l}2.57 \\
2.56 \\
2.56 \\
2.56 \\
2.55 \\
2.54 \\
2.55 \\
2.55 \\
2.55 \\
2.55 \\
2.55 \\
2.55\end{array}$ & $\begin{array}{l}8.9 \\
8.5 \\
8.5 \\
8.5 \\
8.2 \\
7.8 \\
8.2 \\
8.2 \\
8.2 \\
8.2 \\
8.2 \\
8.2\end{array}$ & $\begin{array}{l}2.55 \\
2.55 \\
3.20 \\
8.40 \\
8.44 \\
5.28 \\
4.16 \\
3.80 \\
3.63 \\
3.49 \\
3.41 \\
3.35\end{array}$ & $\begin{array}{r}8.2 \\
8.2 \\
60 \\
2,440 \\
2,470 \\
744 \\
294 \\
178 \\
136 \\
106 \\
92 \\
82\end{array}$ & $\begin{array}{l}3.30 \\
3.27 \\
3.25 \\
3.27 \\
3.82 \\
6.30 \\
6.00 \\
4.56 \\
4.07 \\
3.86 \\
3.71 \\
4.56\end{array}$ & $\begin{array}{r}74 \\
70 \\
67 \\
.70 \\
184 \\
1,200 \\
1,060 \\
456 \\
262 \\
195 \\
155 \\
456\end{array}$ & $\begin{array}{l}6.06 \\
6.70 \\
5.00 \\
4.38 \\
4.56 \\
5.91 \\
5.34 \\
4.72 \\
4.34 \\
4.13 \\
3.99 \\
3.89\end{array}$ & $\begin{array}{r}1,080 \\
1,400 \\
632 \\
381 \\
456 \\
1,020 \\
769 \\
520 \\
364 \\
283 \\
235 \\
204\end{array}$ \\
\hline & \multicolumn{2}{|c|}{ - July 23} & \multicolumn{2}{|c|}{ July $2+$} & \multicolumn{2}{|c|}{ July 25} & \multicolumn{2}{|c|}{ July 26} & \multicolumn{2}{|c|}{ July 27} & \multicolumn{2}{|c|}{ July 28} \\
\hline $\begin{array}{l}2 \text { a.m. } \\
4 \\
6 \\
8 \\
10 \\
12 \mathrm{n} . \\
2 \mathrm{p} . \mathrm{m} . \\
4 \\
6 \\
8 \\
80 \\
12 \mathrm{~m} .\end{array}$ & $\begin{array}{l}3.83 \\
3.81 \\
3.94 \\
7.80 \\
9.00 \\
8.90 \\
8.66 \\
7.59 \\
8.22 \\
7.02 \\
5.33 \\
4.84\end{array}$ & $\begin{array}{r}187 \\
181 \\
219 \\
2,040 \\
2,870 \\
2,790 \\
2,620 \\
1,910 \\
2,310 \\
1,570 \\
766 \\
568\end{array}$ & $\begin{array}{l}4.58 \\
4.52 \\
4.63 \\
4.46 \\
4.27 \\
4.14 \\
4.05 \\
3.96 \\
3.88 \\
3.84 \\
3.79 \\
3.76\end{array}$ & $\begin{array}{l}464 \\
439 \\
484 \\
414 \\
336 \\
287 \\
255 \\
226 \\
201 \\
190 \\
175 \\
168\end{array}$ & $\begin{array}{l}3.73 \\
3.70 \\
3.67 \\
3.65 \\
3.63 \\
3.60 \\
3.56 \\
3.53 \\
3.50 \\
3.48 \\
3.46 \\
3.44\end{array}$ & $\begin{array}{r}160 \\
152 \\
145 \\
140 \\
136 \\
129 \\
121 \\
114 \\
108 \\
104 \\
101 \\
97\end{array}$ & $\begin{array}{l}3.43 \\
3.42 \\
3.41 \\
3.40 \\
3.39 \\
3.36 \\
3.33 \\
3.31 \\
3.28 \\
3.27 \\
3.26 \\
3.25\end{array}$ & $\begin{array}{l}95 \\
94 \\
92 \\
90 \\
88 \\
84 \\
79 \\
76 \\
71 \\
70 \\
68 \\
67\end{array}$ & $\begin{array}{l}3.25 \\
3.24 \\
3.24 \\
3.23 \\
3.23 \\
3.21 \\
3.19 \\
3.17 \\
3.14 \\
3.12 \\
3.10 \\
3.50\end{array}$ & $\begin{array}{r}67 \\
66 \\
66 \\
64 \\
64 \\
61 \\
59 \\
56 \\
53 \\
50 \\
48 \\
108\end{array}$ & $\begin{array}{l}5.08 \\
3.94 \\
3.60 \\
3.46 \\
3.39 \\
3.35 \\
3.32 \\
3.26 \\
3.19 \\
3.17 \\
3.15 \\
3.14\end{array}$ & $\begin{array}{r}664 \\
219 \\
129 \\
101 \\
88 \\
82 \\
77 \\
68 \\
59 \\
56 \\
54 \\
53\end{array}$ \\
\hline $12 \mathrm{~m}$ & \multicolumn{2}{|c|}{ July 29} & \multicolumn{2}{|c|}{ July 30} & \multicolumn{2}{|c|}{$J_{u l l y} 31$} & \multicolumn{2}{|c|}{ August 1} & \multicolumn{2}{|c|}{ August 2} & \multicolumn{2}{|c|}{ August 3} \\
\hline $\begin{array}{l}2 \mathrm{p} . \mathrm{m} . \\
4 \\
6 \\
8 \\
10 \\
12 \mathrm{n} . \\
2 \mathrm{p.m} . \\
4 \\
6 \\
8 \\
10 \\
12 \mathrm{~m} .\end{array}$ & $\begin{array}{l}3.14 \\
3.14 \\
3.13 \\
3.13 \\
3.12 \\
3.11 \\
3.10 \\
3.08 \\
3.06 \\
4.50 \\
4.78 \\
4.05\end{array}$ & $\begin{array}{r}53 \\
53 \\
52 \\
52 \\
50 \\
49 \\
48 \\
46 \\
44 \\
431 \\
544 \\
255\end{array}$ & $\begin{array}{l}4.00 \\
3.70 \\
3.54 \\
3.46 \\
3.41 \\
3.35 \\
3.26 \\
3.25 \\
3.19 \\
3.16 \\
3.13 \\
3.12\end{array}$ & $\begin{array}{r}238 \\
152 \\
116 \\
101 \\
92 \\
82 \\
68 \\
67 \\
59 \\
55 \\
52 \\
50\end{array}$ & & & & & & $\cdots$ & & 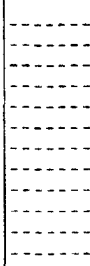 \\
\hline
\end{tabular}

Supplemental records. - July 20, 9 à.m., $900 \mathrm{ft}$; 2,870 sec.-ft.; July 21, $12: 45$ p.m., 6.94 ft., 1,530 sec.-ft.; July $22,3: 15$ a.m., 7.24 ft., 1,700 sec.-ft.; 9 a.m., 4.32 ft., 356 sec.-ft.; July $23,10: 30$ a.m., 9.12 ft. 2,960 sec.-ft.; July 28, 1 a.m., 5.76 ft., 952 sec.-ft.; July 29, 9 p.m., 5.10 ft., 672 sec.-ft.; .July $30,1: 30$ s.m., 4.06 ft., 258 sec.-ft. 
NORTI BRANCH OF RARITAN RIVER AT MILITOWN, N. J.

Location.-Lat. $40^{\circ} 34^{\prime} 10^{\prime \prime}$, long. $74^{\circ} 40^{\prime} 45^{\prime \prime}$, at Milltown, Somerset County,

$1 \frac{1 / 2}{2}$ miles upstream from confluence of North and South Branches of

Raritan River. Datum of gage is 50.43 feet above mean sea level (general adjustment of 1929).

Drainage area.—190 square miles.

GaGe-height RECORD.-Water-stage recorder graph.

Stage-discharge Relation.-Defined by current-meter measurements below 2,100 second-feet; extended to peak stage on basis of two slope-area measurements.

Maxima.-July 1938: Discharge, 7,900 second-feet 4 p.m. July 23 (gage height, 8.92 feet).

1923 to June 1938: Discharge, about 14,400 second-feet Jan. 3, 1936 (gage height, 11.35 feet, from floodmark).

REMARKs.-Flow not materially affected by storage.

Mean discharge, in second-feet, 1938

\begin{tabular}{|c|c|c|c|c|c|c|c|c|c|c|c|}
\hline Day & June & July & Aug. & Day & June & July & Aug. & Day & June & July & Aug. \\
\hline $\begin{array}{r}1 \\
2 \\
3 \\
4 \\
5 \\
6 \\
7 \\
8 \\
9 \\
10\end{array}$ & $\begin{array}{r}102 \\
99 \\
106 \\
109 \\
102 \\
102 \\
93 \\
766 \\
209 \\
146\end{array}$ & $\begin{array}{r}307 \\
274 \\
-221 \\
185 \\
158 \\
137 \\
123 \\
119 \\
116 \\
109\end{array}$ & $\begin{array}{r}342 \\
342 \\
268 \\
244 \\
232 \\
1,530 \\
1,110 \\
515 \\
388 \\
314\end{array}$ & $\begin{array}{l}11 \\
12 \\
13 \\
14 \\
15 \\
16 \\
17 \\
18 \\
19 \\
20\end{array}$ & $\begin{array}{l}201 \\
195 \\
330 \\
262 \\
175 \\
141 \\
123 \\
771 \\
222 \\
158\end{array}$ & $\begin{array}{l}109 \\
119 \\
126 \\
116 \\
206 \\
157 \\
113 \\
123 \\
123 \\
671 \\
-\end{array}$ & $\begin{array}{l}596 \\
357 \\
256 \\
226 \\
211 \\
160 \\
275 \\
447 \\
211 \\
175\end{array}$ & $\begin{array}{l}21 \\
22 \\
23 \\
24 \\
25 \\
26 \\
27 \\
28 \\
29 \\
30 \\
31\end{array}$ & $\begin{array}{r}133 \\
119 \\
325 \\
244 \\
133 \\
649 \\
1,360 \\
1,770 \\
640 \\
380\end{array}$ & $\begin{array}{r}1,230 \\
2,440 \\
4,810 \\
2,560 \\
898 \\
658 \\
555 \\
644 \\
458 \\
722 \\
349\end{array}$ & $\begin{array}{l}162 \\
154 \\
141 \\
133 \\
126 \\
123 \\
119 \\
116 \\
113 \\
109 \\
106\end{array}$ \\
\hline \multicolumn{9}{|c|}{$\begin{array}{l}\text { Monthly mean discharge, in second-feet } \\
\text { Runoff, in inches }\end{array}$} & $\begin{array}{r}339 \\
1.99\end{array}$ & 611. & $\begin{array}{r}311 \\
1.89\end{array}$ \\
\hline
\end{tabular}

Gage height, in feet, and discharge, in second-feet, at indicated time, 1938

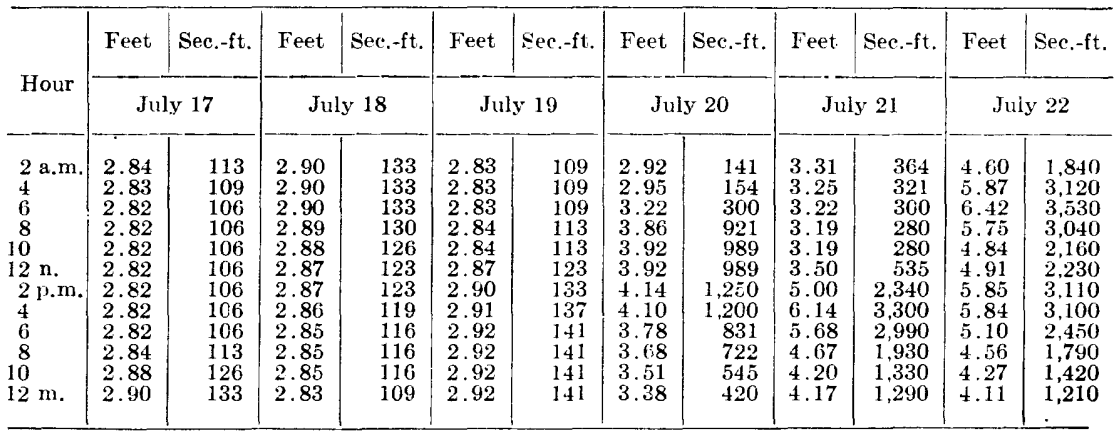


Gage height in feet, and discharge, in second-feet, at indicated time, 1938-Continued

\begin{tabular}{|c|c|c|c|c|c|c|c|c|c|c|c|c|}
\hline \multirow{2}{*}{ Hour } & Feet & Sec. $-\mathrm{ft}$. & Feet & Sec.-ft. & Feet & Sec. $-\mathrm{ft}$. & Feet & Sec.-ft. & Feet & Sec.-it. & Feet & Sec. $-\mathrm{ft}$. \\
\hline & \multicolumn{2}{|c|}{ July 23} & \multicolumn{2}{|c|}{ July 24} & \multicolumn{2}{|c|}{ July 25} & \multicolumn{2}{|c|}{ July 26} & \multicolumn{2}{|c|}{ July 27} & \multicolumn{2}{|c|}{ July 28} \\
\hline $\begin{array}{l}2 \mathrm{a} . \mathrm{m} . \\
4 \\
6 \\
8 \\
10 \\
12 \mathrm{n} . \\
2 \mathrm{p.m} . \\
4 \\
6 \\
8 \\
10 \\
12 \mathrm{~m} .\end{array}$ & $\begin{array}{l}3.98 \\
3.89 \\
3.86 \\
4.23 \\
7.20 \\
8.22 \\
8.75 \\
8.92 \\
8.81 \\
8.72 \\
8.75 \\
8.71\end{array}$ & $\begin{array}{r}1,060 \\
955 \\
921 \\
1,370 \\
4,490 \\
6,400 \\
7,520 \\
7,900 \\
7,650 \\
7,560 \\
7,520 \\
7,430\end{array}$ & $\begin{array}{l}8.42 \\
7.10 \\
5.53 \\
4.95 \\
4.66 \\
4.50 \\
4.36 \\
4.28 \\
4.18 \\
4.10 \\
4.04 \\
3.99\end{array}$ & $\begin{array}{l}6,810 \\
4,330 \\
2,870 \\
2,280 \\
1,920 \\
1,710 \\
1,530 \\
1,430 \\
1,300 \\
1,200 \\
1,130 \\
1,070\end{array}$ & $\begin{array}{l}3.96 \\
3.93 \\
3.92 \\
3.90 \\
3.87 \\
3.85 \\
3.83 \\
3.79 \\
3.77 \\
3.74 \\
3.71 \\
3.69\end{array}$ & $\begin{array}{r}1.030 \\
1.000 \\
989 \\
966 \\
932 \\
910 \\
887 \\
842 \\
820 \\
787 \\
754 \\
732\end{array}$ & $\begin{array}{l}3.68 \\
3.67 \\
3.66 \\
3.65 \\
3.65 \\
3.64 \\
3.63 \\
3.61 \\
3.59 \\
3.57 \\
3.54 \\
3.54\end{array}$ & $\begin{array}{l}722 \\
711 \\
701 \\
690 \\
690 \\
679 \\
669 \\
648 \\
627 \\
606 \\
576 \\
576\end{array}$ & $\begin{array}{l}3.53 \\
3.52 \\
3.52 \\
3.52 \\
3.51 \\
3.51 \\
3.50 \\
3.47 \\
3.46 \\
3.45 \\
3.63 \\
3.68\end{array}$ & $\begin{array}{r}566 \\
555 \\
555 \\
555 \\
545 \\
545 \\
535 \\
505 \\
495 \\
486 \\
669 \\
722\end{array}$ & $\begin{array}{l}4.00 \\
3.80 \\
3.68 \\
3.63 \\
3.58 \\
3.55 \\
3.53 \\
3.50 \\
3.47 \\
3.45 \\
3.43 \\
3.42\end{array}$ & $\begin{array}{r}1,080 \\
853 \\
722 \\
669 \\
617 \\
586 \\
566 \\
535 \\
505 \\
486 \\
466 \\
456\end{array}$ \\
\hline
\end{tabular}

\begin{tabular}{|c|c|c|c|c|c|c|c|c|c|c|c|c|}
\hline & \multicolumn{2}{|c|}{ July 29} & \multicolumn{2}{|c|}{ July 30} & \multicolumn{2}{|c|}{ July 31} & \multicolumn{2}{|c|}{ August 1} & \multicolumn{2}{|c|}{ August 2} & \multicolumn{2}{|c|}{ August 3} \\
\hline 2 a.m. & 3.41 & 446 & 4.16 & 1,280 & 3.33 & 380 & 3.27 & 335 & 3.33 & 380 & 3.18 & 274 \\
\hline & 3.41 & 446 & 4.10 & 1,200 & 3.32 & 372 & 3.30 & 356 & 3.33 & 380 & 3.18 & 274 \\
\hline 6 & 3.40 & 436 & 3.93 & 1,000 & 3.31 & 364 & 3.31 & 364 & 3.32 & 377 & 3.18 & 274 \\
\hline 8 & 3.40 & 436 & 3.78 & 831 & 3.31 & 364 & 3.30 & 356 & 3.31 & 364 & 3.18 & 274 \\
\hline 10 & 3.39 & 428 & 3.68 & 722 & 3.31 & 364 & 3.29 & 349 & 3.30 & 356 & 3.18 & 274 \\
\hline $12 \mathrm{n}$ & 3.38 & 420 & 3.60 & $63 \overline{7}$ & 3.30 & 356 & 3.30 & 356 & 3.28 & 342 & 3.18 & 274 \\
\hline 2 p.m. & 3.37 & 412 & 3.53 & 566 & 3.30 & 356 & 3.29 & 349 & 3.28 & 342 & 3.18 & 274 \\
\hline & 3.37 & 412 & 3.48 & 515 & 3.29 & 349 & 3.28 & 342 & 3.27 & 335 & 3.18 & 274 \\
\hline 6 & 3.37 & 412 & 3.43 & 466 & 3.28 & 342 & 3.27 & 335 & 3.25 & 321 & 3.17 & 268 \\
\hline 8 & 3.37 & 412 & 3.38 & 420 & 3.28 & 342 & 3.27 & 335 & 3.23 & 307 & 3.16 & 262 \\
\hline & 3.48 & 515 & 3.36 & 404 & 3.27 & 335 & 3.25 & 321 & 3.21 . & 293 & 3.14 & 250 \\
\hline $12 \mathrm{~m}$. & 3.90 & 966 & 3.34 & 388 & 3.27 & $33 \tilde{5}$ & 3.28 & 342 & 3.18 & 274 & 3.13 & 244 \\
\hline
\end{tabular}

Supplemental records.-July 22,3 p.m., 5.99 feet, 3,190 sec.-ft.

IAKE CARNEGIE AT PRINCFTON, N. J.

Location.-Lat. $40^{\circ} 22^{\prime} 10^{\prime \prime}$, long. 74 $37^{\prime} 20^{\prime \prime}$, at Kingston Dam on Millstone River, 2 miles northeast of Princeton, Mercer County.

Drainage AREA.-159 square miles.

GAGE-HEIGHT RECORD.-One staff gage reading daily, usually about 8 a.m.

Remarks.-Only contents above crest of spillway are given in table. Crest of lower spillway is gage datum. Records furnished by Princeton University.

Gage height, in feet, and contents, in millions of cubic feet, 1938

\begin{tabular}{|c|c|c|c|c|c|c|}
\hline \multirow{2}{*}{ Day } & \multicolumn{2}{|c|}{ June } & \multicolumn{2}{|c|}{ July } & \multicolumn{2}{|c|}{ August } \\
\hline & Crage height & Contents & Gage height & Contents & Gage height & Contents \\
\hline $\begin{array}{r}1 \\
2 \\
3 \\
4 \\
5 \\
6 \\
7 \\
8 \\
9 \\
10 \\
11 \\
12 \\
13 \\
14 \\
15 \\
16 \\
17 \\
18 \\
19\end{array}$ & $\begin{array}{r}0.34 \\
.34 \\
.34 \\
.34 \\
.32 \\
.34 \\
.38 \\
.89 \\
.52 \\
.42 \\
.38 \\
.42 \\
.50 \\
.56 \\
.60 \\
.56 \\
.48 \\
.38 \\
.38\end{array}$ & $\begin{array}{l}3.56 \\
3.56 \\
3.56 \\
3156 \\
3.36 \\
3.56 \\
3.99 \\
9.33 \\
5.45 \\
4.40 \\
3.98 \\
4.40 \\
5.24 \\
5.87 \\
6.29 \\
5.87 \\
5.03 \\
3.98 \\
3.98\end{array}$ & $\begin{array}{r}0.76 \\
.68 \\
.52 \\
.48 \\
.46 \\
.42 \\
.42 \\
.36 \\
.36 \\
.32 \\
.32 \\
.32 \\
.30 \\
.30 \\
.50 \\
.40 \\
.38 \\
.50 \\
.40\end{array}$ & $\begin{array}{l}7.97 \\
7.13 \\
5.45 \\
5.03 \\
4.82 \\
4.40 \\
4.40 \\
3.78 \\
3.78 \\
3.36 \\
3.36 \\
3.36 \\
3.15 \\
3.15 \\
5.24 \\
4.19 \\
3.98 \\
5.24 \\
4.19\end{array}$ & $\begin{array}{r}0.50 \\
.48 \\
.42 \\
.40 \\
.38 \\
.38 \\
.56 \\
.58 \\
.54 \\
.54 \\
.52 \\
.46 \\
.38 \\
.38 \\
.36 \\
.34 \\
.34 \\
.58 \\
.42\end{array}$ & $\begin{array}{l}5.24 \\
5.03 \\
4.40 \\
4.19 \\
3.98 \\
3.98 \\
5.87 \\
6.08 \\
5.66 \\
5.66 \\
5.45 \\
4.82 \\
3.98 \\
3.98 \\
3.78 \\
3.56 \\
3.56 \\
6.08 \\
4.40\end{array}$ \\
\hline
\end{tabular}


Gage height, in feet, and contents, in millions of cubic feet, 1938-Continued

\begin{tabular}{|c|c|c|c|c|c|c|c|}
\hline \multirow{2}{*}{ Day } & \multicolumn{2}{|c|}{ June } & \multicolumn{2}{|c|}{ July } & \multicolumn{3}{|c|}{ August } \\
\hline & Gage height & Contents & Gage height & Contents & Gage & ight & Contents \\
\hline \multirow[t]{2}{*}{$\begin{array}{l}20 \\
21 \\
22 \\
23 \\
24 \\
25 \\
26 \\
27 \\
28 \\
29 \\
30 \\
31\end{array}$} & $\begin{array}{r}.38 \\
.36 \\
.34 \\
.32 \\
.52 \\
.50 \\
.58 \\
.82 \\
1.42 \\
1.09 \\
.96\end{array}$ & $\begin{array}{r}3.98 \\
-3.78 \\
3.56 \\
3.36 \\
5.45 \\
5.24 \\
6.08 \\
8.60 \\
14.89 \\
11.43 \\
10.07\end{array}$ & $\begin{array}{r}.82 \\
.98 \\
1.50 \\
1.09 \\
1.79 \\
1.62 \\
1.08 \\
.84 \\
.64 \\
.64 \\
.60 \\
.60\end{array}$ & $\begin{array}{r}8.60 \\
10.28 \\
15.73 \\
11.43 \\
18.77 \\
16.99 \\
11.32 \\
8.81 \\
6.71 \\
6.71 \\
6.29 \\
6.29\end{array}$ & & & $\begin{array}{l}3.56 \\
3.36 \\
3.15 \\
2.94 \\
2.94 \\
2.73 \\
2.94 \\
3.56 \\
3.15 \\
2.94 \\
2.94 \\
2.73\end{array}$ \\
\hline & & & & & June & $\mathrm{Ju}$ & August \\
\hline \multicolumn{5}{|c|}{$\begin{array}{l}\text { Change in contents, in millions of cubic feet } \\
\text { Change in contents, in equivalent second-feet }\end{array}$} & $\begin{array}{l}+4.41 \\
+1.70\end{array}$ & $\begin{array}{l}-2.73 \\
-1.02\end{array}$ & $\begin{array}{l}-2.51 \\
-0.94\end{array}$ \\
\hline
\end{tabular}

MIIISTONE RTVER TEAR KRMGSTON, N. J.

Location.-Lat. $40^{\circ} 23^{\prime} 05^{\prime \prime}$, long. $74^{\circ} 37^{\prime} 29^{\prime \prime}$, at Princeton sewage-disposal plant, 1 mile downstream from Heathcots Brook near Kingston, Middlesex County. Datum of gage is 38.00 feet above mean sea level. (New Jersey Geological Survey bench mark.)

Drainage area.-171 square miles.

GAGE-HEIGHT RECORD.-Water-stage recorder graph except for period 6 p.m. July 23 to 10 a.m. July 29 when record was based on floodmark, shape of available recorder graph, and records for station at Blackwells Mills.

StAGE-DISCHARGe RELATION.-Defined by current-meter measurements below. 2,100 second-feet; extended to peak stage on basis of logarithmic plotting and record for station at Blackwells Mills.

Maxima.-July 1938: Discharge, 8,600 second-feet about 10 p.m. July 23 (gage height, 13.37 feet, from floodmark).

1933 to June 1938: Discharge, about 4,950 second-feet Aug. 24, 1933 (gage height, 10.60 feet).

REMARKs.-Discharge below 255 second-feet computed by shifting-control method on basis of three current-meter measurements. Delaware \& Raritan Canal may divert a small amount of water from the Delaware River into the Millstone River. Flow regulated slightly by storage in Lake Carnegie (see p. 303). Water-stage recorder inspected by employee of Borough of Princeton.

Mean discharge, in second-feet, 1938

\begin{tabular}{r|r|c|c|c|c|c|c||c|c|c|c}
\hline Das & June & July & Aug. & Day & June & July & Aug. & Day & June & July & Aug. \\
\hline 1 & 144 & 450 & 255 & 11 & 176 & 122 & 242 & 21 & 135 & 1,850 & 113 \\
2 & 144 & 312 & 234 & 12 & 168 & 125 & 178 & 22 & 133 & 3,400 & 112 \\
3 & 132 & 271 & 224 & 13 & 238 & 127 & 149 & 23 & 211 & 4,300 & 114 \\
4 & 125 & 231 & 191 & 14 & 286 & 279 & 133 & 24 & 278 & 6,000 & 110 \\
5 & 127 & 206 & 187 & 15 & 321 & 279 & 124 & 25 & 233 & 2,700 & 104 \\
6 & 132 & 178 & 216 & 16 & 271 & 185 & 120 & 26 & 191 & 1,300 & 108 \\
7 & 130 & 159 & 330 & 17 & 216 & 163 & 155 & 27 & 747 & 880 & 106 \\
8 & $\mathbf{5 4 1}$ & 144 & 294 & 18 & 174 & 214 & 334 & 28 & 1,960 & 640 & 90 \\
9 & 279 & 135 & 286 & 19 & 142 & 232 & 172 & 29 & 1,740 & 370 & 112 \\
10 & 208 & 124 & 286 & 20 & 136 & 891 & 140 & 30 & 894 & 321 & 114 \\
&
\end{tabular}


Gage height, in feet, and discharge, in second-feet, at indicated time, 1938

\begin{tabular}{|c|c|c|c|c|c|c|c|c|c|c|c|c|}
\hline \multirow{2}{*}{ Hour } & Feet & Sec.-ft. & Feet & Sec.-ft. & Feet & Sec.-ft. & Feet & Sec.-ft. & Feet & Sec.-ft. & Feet & Sec.-ft. \\
\hline & \multicolumn{2}{|c|}{ July 17} & \multicolumn{2}{|c|}{ July 18} & \multicolumn{2}{|c|}{ July 19} & \multicolumn{2}{|c|}{ July 20} & \multicolumn{2}{|c|}{ July 21} & \multicolumn{2}{|c|}{ July 22} \\
\hline $\begin{array}{c}2 \mathrm{a} . \mathrm{m} . \\
4 \\
6 \\
8 \\
10 \\
12 \mathrm{n} . \\
2 \mathrm{p.m} . \\
4 \\
6 \\
8 \\
10 \\
12 \mathrm{~m} .\end{array}$ & & $\begin{array}{c}1 \\
\end{array}$ & $\begin{array}{l}2.12 \\
2.18 \\
2.24 \\
2.37 \\
2.57 \\
2.52 \\
2.51 \\
2.44 \\
2.30 \\
2.38 \\
2.35 \\
2.32\end{array}$ & $\begin{array}{l}165 \\
178 \\
191 \\
218 \\
253 \\
245 \\
243 \\
231 \\
204 \\
220 \\
214 \\
208\end{array}$ & $\begin{array}{l}2.28 \\
2.25 \\
2.23 \\
2.20 \\
2.20 \\
2.15 \\
2.13 \\
2.30 \\
2.87 \\
3.07 \\
3.22 \\
3.60\end{array}$ & $\begin{array}{l}200 \\
193 \\
189 \\
182 \\
182 \\
172 \\
168 \\
204 \\
282 \\
315 \\
344 \\
426\end{array}$ & $\begin{array}{l}3.72 \\
3.58 \\
3.47 \\
3.56 \\
3.62 \\
4.45 \\
5.35 \\
5.86 \\
6.18 \\
6.45 \\
6.60 \\
6.46\end{array}$ & $\begin{array}{r}455 \\
421 \\
396 \\
+15 \\
431 \\
664 \\
1,000 \\
1,230 \\
1,390 \\
1,520 \\
1,610 \\
1,530\end{array}$ & $\begin{array}{l}5.97 \\
5.48 \\
5.25 \\
5.28 \\
5.56 \\
6.21 \\
6.96 \\
7.54 \\
8.00 \\
8.42 \\
9.10 \\
9.57\end{array}$ & $\begin{array}{r}1,280 \\
1,060 \\
960 \\
973 \\
1,090 \\
1,400 \\
1,820 \\
2,180 \\
2,510 \\
2,840 \\
3,410 \\
3,840\end{array}$ & $\begin{array}{l}9.63 \\
9.39 \\
9.06 \\
8.84 \\
8.75 \\
8.83 \\
8.88 \\
8.89 \\
8.96 \\
9.29 \\
9.47 \\
9.28\end{array}$ & $\begin{array}{l}3,900 \\
3,670 \\
3,370 \\
3,180 \\
3,100 \\
3,170 \\
3,210 \\
3,220 \\
3,280 \\
3,580 \\
3,750 \\
3,570\end{array}$ \\
\hline
\end{tabular}

\begin{tabular}{|c|c|c|c|c|c|c|c|c|c|c|c|c|}
\hline \multirow[b]{2}{*}{$\begin{array}{l}2 \mathrm{a} . \mathrm{m} . \\
4 \\
6 \\
8 \\
10 \\
12 \mathrm{n} . \\
2 \mathrm{p.m} . \\
4 \\
6 \\
8 \\
10 \\
12 \mathrm{~m} .\end{array}$} & \multicolumn{2}{|c|}{ July 23} & \multicolumn{2}{|c|}{ July 24} & \multicolumn{2}{|c|}{ July 25} & \multicolumn{2}{|c|}{ July 26} & \multicolumn{2}{|c|}{ July 27} & \multicolumn{2}{|c|}{ July 28} \\
\hline & \begin{tabular}{r}
8.89 \\
8.38 \\
7.87 \\
7.49 \\
7.26 \\
7.68 \\
9.23 \\
10.00 \\
\hdashline \\
\\
\\
\end{tabular} & $\begin{array}{l}3,220 \\
2,740 \\
2,070 \\
2,150 \\
2,010 \\
2,280 \\
3,530 \\
4,270 \\
6,700 \\
8,100 \\
8,600 \\
8,500\end{array}$ & & $\begin{array}{l}8,200 \\
7,700 \\
7,200 \\
6,800 \\
6,300 \\
5,900 \\
5,400 \\
5,000 \\
4,600 \\
4,300 \\
4,000 \\
3,800\end{array}$ & & $\begin{array}{l}3,600 \\
3,400 \\
3,200 \\
3,000 \\
2,800 \\
2,600 \\
2,500 \\
2,300 \\
2,200 \\
2,100 \\
2,000 \\
1,900\end{array}$ & & $\begin{array}{r}1,700 \\
1,600 \\
1,500 \\
1,500 \\
1,400 \\
1,300 \\
1,200 \\
1,100 \\
1,100 \\
1,000 \\
960 \\
900\end{array}$ & 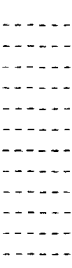 & $\begin{array}{r}840 \\
800 \\
760 \\
730 \\
720 \\
720 \\
760 \\
1,000 \\
1,200 \\
1,200 \\
970 \\
870\end{array}$ & & $\begin{array}{l}820 \\
780 \\
740 \\
700 \\
660 \\
640 \\
600 \\
570 \\
540 \\
520 \\
490 \\
470\end{array}$ \\
\hline & \multicolumn{2}{|c|}{ July 29} & \multicolumn{2}{|c|}{ July 30} & \multicolumn{2}{|c|}{ July 31} & \multicolumn{2}{|c|}{ August 1} & \multicolumn{2}{|c|}{ August 2} & \multicolumn{2}{|c|}{ August 3} \\
\hline $\begin{array}{c}2 \text { a.m. } \\
4 \\
6 \\
8 \\
10 \\
12 \mathrm{n} . \\
2 \mathrm{p} . \mathrm{m} . \\
4 \\
6 \\
8 \\
10 \\
12 \mathrm{~m} .\end{array}$ & $\begin{array}{l}3.30 \\
3.29 \\
3.28 \\
3.26 \\
3.15 \\
3.17 \\
3.24 \\
3.10\end{array}$ & $\begin{array}{l}440 \\
420 \\
400 \\
380 \\
360 \\
358 \\
356 \\
352 \\
330 \\
334 \\
348 \\
321\end{array}$ & $\begin{array}{l}3.10 \\
3.08 \\
3.06 \\
3.12 \\
3.10 \\
3.13 \\
3.13 \\
3.12 \\
3.06 \\
2.97 \\
3.00 \\
2.97\end{array}$ & $\begin{array}{l}321 \\
317 \\
314 \\
325 \\
321 \\
327 \\
327 \\
325 \\
314 \\
298 \\
303 \\
298\end{array}$ & $\begin{array}{l}2.93 \\
2.91 \\
2.89 \\
2.87 \\
2.87 \\
2.85 \\
2.80 \\
2.78 \\
2.70 \\
2.68 \\
2.67 \\
2.65\end{array}$ & $\begin{array}{l}291 \\
288 \\
284 \\
282 \\
282 \\
278 \\
271 \\
268 \\
276 \\
272 \\
271 \\
268\end{array}$ & $\begin{array}{l}2.64 \\
2.61 \\
2.59 \\
2.61 \\
2.70 \\
2.65 \\
2.67 \\
2.66 \\
2.56 \\
2.44 \\
2.44 \\
2.35\end{array}$ & $\begin{array}{l}265 \\
260 \\
257 \\
260 \\
274 \\
266 \\
269 \\
268 \\
252 \\
231 \\
231 \\
214\end{array}$ & $\begin{array}{l}2.48 \\
2.46 \\
2.45 \\
2.44 \\
2.48 \\
2.53 \\
2.46 \\
2.46 \\
2.46 \\
2.47 \\
2.47 \\
2.36\end{array}$ & $\begin{array}{l}238 \\
234 \\
233 \\
231 \\
238 \\
246 \\
234 \\
234 \\
234 \\
236 \\
236 \\
216\end{array}$ & $\begin{array}{l}2.46 \\
2.46 \\
2.44 \\
2.44 \\
2.48 \\
2.42 \\
2.42 \\
2.43 \\
2.43 \\
2.40 \\
2.34 \\
2.24\end{array}$ & $\begin{array}{l}234 \\
234 \\
231 \\
231 \\
238 \\
227 \\
227 \\
229 \\
229 \\
224 \\
212 \\
191\end{array}$ \\
\hline
\end{tabular}

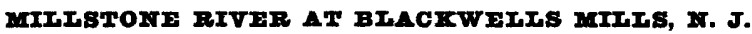

Location.-Lat. $40^{\circ} 28^{\prime} 30^{\prime \prime}$, long. $74^{\circ} 34^{\prime} 34^{\prime \prime}$, at highway bridge in Blackwells Mills, Somerset County, a quarter of a mile downstream from Middlebrush Brook. Datum of gage is 26.97 feet above mean sea level (general adjustment of 1929).

Drainace AREA.-258 square miles; 159 square miles affected by storage in Lake Carnegie.

GAGE-hEIGHT RECORD.-Water-stage recorder 'graph except for period 2:10 a.m. July 23 to $2: 30$ p.m. July 24 when record is based on floodmark and shape of available recorder graph.

StAGE-DISCHARGE RELATION.-Defined by current-meter measurements below 4,000 second-feet; extended to peak stage on basis of a slope-area measurement.

Maxima.-July 1938: Discharge, about 12,400 second-feet 11 p.m. July 23 (gage height, 13.22 feet, from floodmark).

1921 to June 1938: Discharge, about 7,000 second-feet Oct. 18, 1927; gage height, about 11 feet Apr. 7, 1924, and Sept. 7, 1926. 
Remarks.-Delaware \& Raritan Canal parallels .river for some distance; there may be a small amount of water diverted to the river. Flow regulated slightly by storage in Lake Carnegie (see p. 303).

Mean discharge, in second-feet, 1938

\begin{tabular}{r|r|c|c||c|c|c|c|c|c|c|c}
\hline Day & June & July & Aug. & Day & June & July & Aug. & Dav & June & July & Aug. \\
\hline 1 & 171 & 819 & 347 & 11 & 222 & 160 & 302 & 21 & 168 & 2,180 & 153 \\
2 & 171 & 511 & 307 & 12 & 213 & 164 & 213 & 22 & 153 & 4,710 & 142 \\
3 & 156 & 388 & 283 & 13 & 367 & 164 & 192 & 23 & 317 & 8,020 & 145 \\
4 & 149 & 312 & 245 & 14 & 394 & 286 & 168 & 24 & 497 & 9,260 & 142 \\
5 & 145 & 273 & 231 & 15 & 404 & 439 & 164 & 25 & 273 & 4,880 & 128 \\
6 & 156 & 235 & 258 & 16 & 342 & 240 & 153 & 26 & 235 & 2,600 & 132 \\
7 & 149 & 209 & 445 & 17 & 273 & 217 & 207 & 27 & 1,270 & 1,390 & 132 \\
8 & 1,050 & 192 & 399 & 18 & 273 & 322 & 472 & 28 & 2,320 & 1.160 & 135 \\
9 & 460 & 179 & 367 & 19 & 204 & 275 & 231 & 29 & 2,780 & 621 & 132 \\
10 & 263 & 164 & 352 & 20 & 175 & 1,340 & 179 & 30 & 1.730 & 505 & 142 \\
&
\end{tabular}

Gage height, in feet, and discharge, in second-feet, at indicated time, 1938

\begin{tabular}{|c|c|c|c|c|c|c|c|c|c|c|c|c|}
\hline \multirow{2}{*}{ Hour } & Feet & Sec.-ft. & Feet & Sec, $-\mathrm{ft}$. & Feet & Sec. $-\mathrm{ft}$. & Feet & Sec.-ft. & Feet & Sec.-ft. & Feet & Sec.-ft. \\
\hline & \multicolumn{2}{|c|}{ July 17} & \multicolumn{2}{|c|}{ July 18} & \multicolumn{2}{|c|}{ July 19} & \multicolumn{2}{|c|}{ July 20} & \multicolumn{2}{|c|}{ July 21} & \multicolumn{2}{|c|}{ July 22} \\
\hline $\begin{array}{l}2 \text { a.m. } \\
4 \\
6 \\
8 \\
10 \\
12 \mathrm{n} . \\
2 \mathrm{p.m} . \\
4 \\
6 \\
8 \\
10 \\
12 \mathrm{~m} .\end{array}$ & $\begin{array}{l}1.97 \\
1.97 \\
1.97 \\
1.96 \\
1.95 \\
1.95 \\
1.94 \\
2.00 \\
2.04 \\
2.10 \\
2.16 \\
2.20\end{array}$ & $\begin{array}{l}204 \\
204 \\
204 \\
200 \\
196 \\
196 \\
192 \\
217 \\
235 \\
263 \\
292 \\
312\end{array}$ & $\begin{array}{l}2.25 \\
2.26 \\
2.27 \\
2.27 \\
2.26 \\
2.25 \\
2.25 \\
2.23 \\
2.18 \\
2.15 \\
2.13 \\
2.12\end{array}$ & $\begin{array}{l}337 \\
342 \\
347 \\
347 \\
342 \\
337 \\
337 \\
327 \\
302 \\
288 \\
278 \\
273\end{array}$ & $\begin{array}{l}2.10 \\
2.08 \\
2.07 \\
2.04 \\
2.04 \\
2.03 \\
2.02 \\
2.02 \\
2.05 \\
2.18 \\
2.42 \\
2.58\end{array}$ & $\begin{array}{l}263 \\
254 \\
249 \\
235 \\
235 \\
231 \\
226 \\
226 \\
240 \\
302 \\
427 \\
523\end{array}$ & $\begin{array}{l}2.68 \\
2.79 \\
2.99 \\
3.50 \\
4.31 \\
4.82 \\
5.02 \\
5.13 \\
5.17 \\
5.17 \\
5.17 \\
5.18\end{array}$ & $\begin{array}{r}587 \\
663 \\
789 \\
1,080 \\
1,430 \\
1,640 \\
1,720 \\
1,760 \\
1,780 \\
1,780 \\
1,780 \\
1,790\end{array}$ & $\begin{array}{l}5.20 \\
5.22 \\
5.20 \\
5.18 \\
5.24 \\
5.51 \\
5.82 \\
6.09 \\
6.43 \\
6.90 \\
7.25 \\
7.51\end{array}$ & $\begin{array}{l}1,800 \\
1,810 \\
1,800 \\
1,790 \\
1,820 \\
1,960 \\
2,110 \\
2,250 \\
2,460 \\
2,810 \\
3,100 \\
3,330\end{array}$ & $\begin{array}{l}7.75 \\
7.98 \\
8.22 \\
8.41 \\
8.58 \\
8.75 \\
9.05 \\
9.40 \\
9.56 \\
9.63 \\
9.56 \\
9.45\end{array}$ & $\begin{array}{l}3,550 \\
3,780 \\
4,020 \\
4,220 \\
4,410 \\
4,600 \\
4,980 \\
5,430 \\
5,650 \\
5,750 \\
5,650 \\
5,500\end{array}$ \\
\hline & \multicolumn{2}{|c|}{ July 23} & \multicolumn{2}{|c|}{ July 24} & \multicolumn{2}{|c|}{ July 25} & \multicolumn{2}{|c|}{ July 26} & \multicolumn{2}{|c|}{ July 27} & \multicolumn{2}{|c|}{ July 28} \\
\hline $\begin{array}{l}2 \text { a.m. } \\
4 \\
6 \\
8 \\
10 \\
12 \mathrm{n} . \\
2 \mathrm{p.m} . \\
4 \\
6 \\
8 \\
10 \\
12 \mathrm{~m} .\end{array}$ & $\begin{array}{r}9.32 \\
9.16 \\
9.00 \\
9.08 \\
9.32 \\
10.00 \\
11.35 \\
12.35 \\
12.90 \\
13.15 \\
13.20 \\
13.15\end{array}$ & $\begin{array}{r}5,330 \\
5,120 \\
4,910 \\
5,010 \\
5,330 \\
6,270 \\
8,530 \\
10,500 \\
11,700 \\
12,300 \\
12,400 \\
12,300\end{array}$ & $\begin{array}{l}12.95 \\
12.70 \\
12.45 \\
12.20 \\
11.95 \\
11.70 \\
11.48 \\
11.19 \\
10.90 \\
10.62 \\
10.37 \\
10.15\end{array}$ & $\begin{array}{r}11,800 \\
11,200 \\
10,700 \\
10,200 \\
9,700 \\
9,200 \\
8,770 \\
8,240 \\
7,720 \\
7,230 \\
6,820 \\
6,480\end{array}$ & $\begin{array}{l}9.95 \\
9.75 \\
9.52 \\
9.32 \\
9.12 \\
8.92 \\
8.72 \\
8.52 \\
8.30 \\
8.10 \\
7.90 \\
7.70\end{array}$ & $\begin{array}{l}6,200 \\
5,920 \\
5,600 \\
5,330 \\
5,070 \\
4,810 \\
4,560 \\
4,340 \\
4,100 \\
3,900 \\
3,700 \\
3,500\end{array}$ & $\begin{array}{l}7.50 \\
7.31 \\
7.13 \\
6.95 \\
6.77 \\
6.58 \\
6.40 \\
6.20 \\
6.02 \\
5.77 \\
5.50 \\
5.20\end{array}$ & $\begin{array}{l}3,320 \\
3,150 \\
2,990 \\
2,850 \\
2,710 \\
2,570 \\
2,440 \\
2,370 \\
2,210 \\
2,080 \\
1,950 \\
1,800\end{array}$ & $\begin{array}{l}4.89 \\
4.62 \\
4.36 \\
4.17 \\
3.98 \\
3.84 \\
3.70 \\
3.58 \\
3.48 \\
3.60 \\
5.00 \\
5.30\end{array}$ & $\begin{array}{l}1,670 \\
1,560 \\
1,450 \\
1,380 \\
1,300 \\
1,250 \\
1,180 \\
1,120 \\
1,070 \\
1,130 \\
1,710 \\
1,850\end{array}$ & $\begin{array}{l}4.94 \\
4.55 \\
4.12 \\
3.79 \\
3.57 \\
3.47 \\
3.37 \\
3.28 \\
3.20 \\
3.14 \\
3.04 \\
2.93\end{array}$ & $\begin{array}{r}1,680 \\
1,530 \\
1,360 \\
1,220 \\
1,120 \\
1,060 \\
1,000 \\
959 \\
915 \\
879 \\
819 \\
753\end{array}$ \\
\hline $12 \mathrm{~m}$ & \multicolumn{2}{|c|}{ July 29} & \multicolumn{2}{|c|}{ July 30} & \multicolumn{2}{|c|}{ July 31} & \multicolumn{2}{|c|}{ August 1} & \multicolumn{2}{|c|}{ August 2} & \multicolumn{2}{|c|}{ August 3} \\
\hline $\begin{array}{l}2 \text { a.m. } \\
4 \\
6 \\
8 \\
10 \\
12 \mathrm{n} . \\
2 \mathrm{p.m} . \\
4 \\
6 \\
8 \\
10 \\
12 \mathrm{~m} .\end{array}$ & $\begin{array}{l}2.87 \\
2.83 \\
2.80 \\
2.78 \\
2.74 \\
2.70 \\
2.68 \\
2.65 \\
2.64 \\
2.62 \\
2.61 \\
2.60\end{array}$ & $\begin{array}{l}716 \\
690 \\
670 \\
656 \\
628 \\
600 \\
587 \\
568 \\
561 \\
548 \\
542 \\
535\end{array}$ & $\begin{array}{l}2.60 \\
2.58 \\
2.58 \\
2.57 \\
2.56 \\
2.55 \\
2.55 \\
2.54 \\
2.53 \\
2.51 \\
2.48 \\
2.46\end{array}$ & $\begin{array}{l}535 \\
523 \\
523 \\
517 \\
511 \\
505 \\
505 \\
499 \\
493 \\
481 \\
463 \\
451\end{array}$ & $\begin{array}{l}2.45 \\
2.44 \\
2.43 \\
2.42 \\
2.40 \\
2.39 \\
2.38 \\
2.37 \\
2.36 \\
2.36 \\
2.35 \\
2.33\end{array}$ & $\begin{array}{l}445 \\
439 \\
433 \\
427 \\
415 \\
410 \\
404 \\
399 \\
394 \\
394 \\
388 \\
378\end{array}$ & $\begin{array}{l}2.32 \\
2.30 \\
2.29 \\
2.29 \\
2.28 \\
2.27 \\
2.27 \\
2.27 \\
2.27 \\
2.26 \\
2.24 \\
2.22\end{array}$ & $\begin{array}{l}373 \\
362 \\
357 \\
357 \\
352 \\
347 \\
347 \\
347 \\
347 \\
342 \\
332 \\
322\end{array}$ & 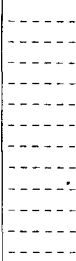 & 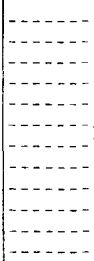 & 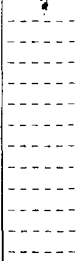 & $\mid$\begin{tabular}{l}
$-\ldots-$ \\
$-\cdots$ \\
\hdashline- \\
-
\end{tabular} \\
\hline
\end{tabular}

Supplemental records.-July 23, 11 p.m., 13.22 ft, 12,400 sec.-ft July 27, 7:30 p.m., 3.40 ft., 1,020 sec.-tt. 
GREEN BROOK AT PIAINFIEID, N. J.

Location.-Lat. $40^{\circ} 36^{\prime} 50^{\prime \prime}$, long. $74^{\circ} 25^{\prime} 55^{\prime \prime}$, just downstream from Sycamore Avenue, Plainfield, Union County, and 1 mile upstream from Stoney Brook. Datum of gage is 70.37 feet above mean sea level (general adjustment of 1929).

Drainage area.-9.75 square miles.

GAGE-HEIGHT RECORD.-Water-stage recorder graph.

Stage-discharge Relation.-Defined by current-meter measurements below 200 second-feet; extended to peak stage by averaging two contractedopening determinations of flood flow.

Maxima.-July 1938: Discharge, 2,890 second-feet 11:30 a.m. July 23 (gage height, 5.82 feet).

Remarks.-Record started May 15, 1938. Discharge affected by diversion for municipal supply. Monthly mean discharge and run-off, in inches, adjusted for diversion. Monthly mean diversions were: June, 2.53 secondfeet; July, 2.45 second-feet; August, 2.53 second-feet.

Mean discharge, in second-feet, 1938

\begin{tabular}{r|r|r|r|r|r|r|r||r|r|r|r}
\hline Day & June & July & Aug. & Day & June & July & Aug. & Day & June & July & Aug. \\
\hline & & & & & & & & \\
1 & 3.6 & 9.5 & 13.5 & 11 & 6.8 & 7.9 & 11.0 & 21 & 3.2 & 41 & 2.6 \\
2 & 2.4 & 9.0 & 10.4 & 12 & 6.9 & 5.2 & 6.6 & 22 & 4.3 & 69 & 2.6 \\
3 & 4.0 & 7.5 & 9.5 & 13 & 12.7 & 5.2 & 4.2 & 23 & 3.4 & 911 & 2.6 \\
4 & 3.4 & 6.2 & 8.3 & 14 & 6.9 & 5.9 & 3.9 & 24 & 3.1 & 168 & 2.4 \\
5 & 2.6 & 5.8 & 7.5 & 15 & 5.7 & 9.1 & 3.6 & 25 & 4.0 & 64 & 2.2 \\
6 & 3.6 & $\mathbf{4 . 8}$ & 10.6 & 16 & 4.1 & 6.3 & 3.4 & 26 & 9.2 & 40 & 2.6 \\
7 & 10.7 & 3.6 & 8.7 & 17 & 4.5 & 23 & 3.4 & 27 & 32 & 42 & 2.0 \\
8 & 55 & 3.4 & 7.7 & 18 & 7.9 & 9.7 & 3.2 & 28 & 109 & 44 & 1.7 \\
9 & 12.6 & 3.6 & 8.0 & 19 & 4.3 & 6.4 & 3.2 & 29 & 33 & 27 & 2.4 \\
10 & 6.2 & 3.6 & 8.7 & 20 & 3.6 & 18.5 & 2.9 & 30 & 19.8 & 21 & 2.2 \\
&
\end{tabular}

Gage height, in feet, and discharge, in second-feet, at indicated time, 1938

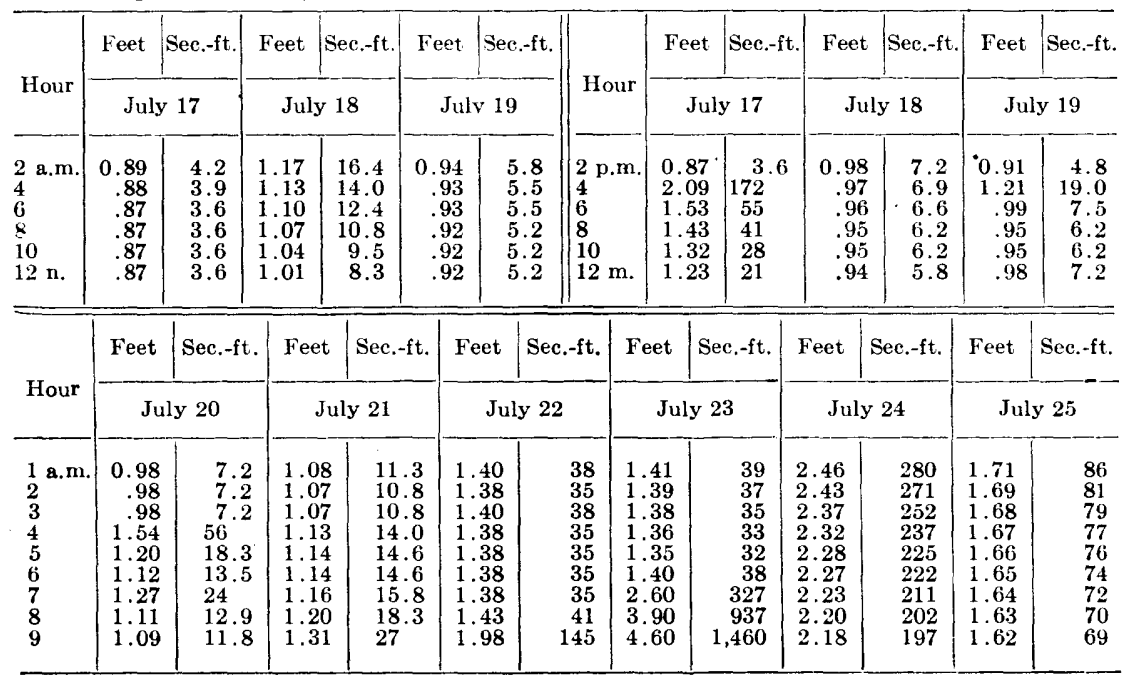

$748116--48-21$ 
Gage height in feet, and discharge, in second-feet, at indicated time, 1938-Continued

\begin{tabular}{|c|c|c|c|c|c|c|c|c|c|c|c|c|}
\hline \multirow{2}{*}{ Hour } & Feet & Sec.-ft. & Feet & Sec.-ft. & Feet & Sec.-ft. & Feet & Sec. $-\mathrm{ft}$. & Feet & Sec.-ft. & Feet & Sec.-ft. \\
\hline & \multicolumn{2}{|c|}{ July 20} & \multicolumn{2}{|c|}{ July 21} & \multicolumn{2}{|c|}{ July 22} & \multicolumn{2}{|c|}{ July 23} & \multicolumn{2}{|c|}{ July 24} & \multicolumn{2}{|c|}{ July 25} \\
\hline 10 & 1.32 & 28 & 1.29 & 25 & 1.65 & $7 \pm$ & 5.24 & 2,130 & 2.14 & $18 \pi$ & 1.61 & 67 \\
\hline 11 & 1.29 & 25 & 1.30 & 26 & 1.90 & 126 & 5.70 & 2,720 & 2.08 & 370 & 1.60 & 66 \\
\hline $12 \mathrm{n}$ & 1.27 & 24 & 1.64 & 72 & 1.87 & 119 & 5.72 & 2,750 & 2.04 & 100 & 1.58 & 62 \\
\hline 1 p.m. & 1.27 & 24 & 1.56 & 59 & 1.87 & 119 & 5.34 & 2,250 & 1.99 & 148 & 1.57 & 61 \\
\hline & 1.27 & 24 & 1.65 & 74 & 1.84 & 113 & 4.70 & 1.550 & 1.96 & 14 & 1.56 & 59 \\
\hline & 1.27 & 24 & 1.73 & 90 & 1.78 & 100 & 4.20 & $1,1,40$ & 1.92 & 131 & 1.50 & 59 \\
\hline 4 & 1.27 & 24 & 1.72 & 88 & 1.77 & 98 & 3.60 & 762 & 1.89 & 12 & 1.25 & 58 \\
\hline 5 & 1.26 & 23 & 1.65 & 74 & 1.72 & 88 & 3.76 & 853 & 1.86 & 11 & 1.54 & 56 \\
\hline 6 & 1.24 & 21 & 2.04 & 160 & 1.67 & 77 & 3.86 & 913 & 1.83 & 1. & 1.52 & $5+$ \\
\hline 7 & 1.21 & 19.0 & 1.50 & 51 & 1. 61 & 67 & 3.94 & 962 & 1.80 & 104 & 1.51 & 52 \\
\hline 8 & 1.18 & 17.1 & 1.44 & 43 & 1.56 & 59 & 3.8 & 876 & 1.78 & 10 & 1.50 & 51 \\
\hline 9 & 1.16 & 15.8 & 1.40 & 38 & 1.52 & 54 & 3.42 & 668 & 1.76 & 96 & 1.50 & 51 \\
\hline 10 & 1.14 & 14.6 & 1.37 & 34 & 1.49 & 49 & 3.06 & 503 & 1.75 & 94 & 1.9 & 49 \\
\hline & & 13.5 & 1.35 & 32 & 1.45 & 44 & 2.75 & 380 & 1.73 & (61) & 4.48 & -18 \\
\hline & & 12.4 & 1.48 & 48 & 1.43 & 41 & 2.60 & 327 & 1.72 & 88 & 1.48 & 48 \\
\hline
\end{tabular}

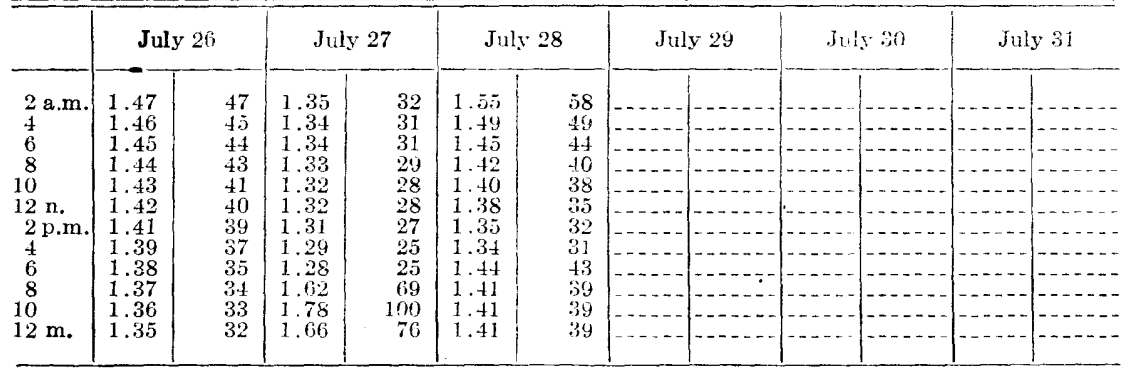

Supplemental records.-July $21,11: 45$ a.m., $1.94 \mathrm{ft}$., 136 sec.-ft.; $12: 30$ p.m., $1.50 \mathrm{ft} ., 51 \mathrm{krc}$ - ft.; July 22 , $12: 20$ a.m., $1.50 \mathrm{ft}$, 51 sec.-ft.; July $23,9: 30$ a.m., $5.4+\mathrm{ft}_{\text {., }} 2,370 \mathrm{sec}$-ft.; $11: 30$ a.m., $5.82 \mathrm{ft}$., 2,890 sec.-ft.; $4: 40$ p.m., $3.92 \mathrm{ft}$., 950 sec.-ft.; July $27,7: 00$ p.m., $2.10 \mathrm{ft},, 175$ sec.-ft.; $7: 30$ p.m., 1.52 ft., $\tilde{5} 4$ sec.-ft.; July 28, 4:30 p.m., $2.07 \mathrm{ft} ., 168$ sec.-ft.

RESERVOTR ON IAWRENCE BROOK AT FARRINGTON DAM, N. J.

Locatron.-Lat. $40^{\circ} 27^{\prime} 00^{\prime \prime}$, long. $74^{\circ} 27^{\prime} 05^{\prime \prime}$, on Lawrence Brook at Farrington Dam, half a mile southwest of Milltown, Middlesex County.

Drainage AREA.-34.4 square miles.

GAGE-HEIGHT RECORD.-Water-stage recorder graph.

Remarks.-Usable capacity, $87,600,000$ cubic feet. Crest of notch in dam is at gage height 24.00 feet.

Gage height, in feet, and contents, in millions of cubic feet, 1938

\begin{tabular}{|c|c|c|c|c|c|c|}
\hline \multirow{2}{*}{ Day } & \multicolumn{2}{|c|}{ June } & \multicolumn{2}{|c|}{ July } & \multicolumn{2}{|c|}{ August } \\
\hline & Gage height & Contents & Gage height & Contents & Gage height & Contents \\
\hline $\begin{array}{r}1 \\
2 \\
3 \\
4 \\
5 \\
6 \\
7 \\
8 \\
9 \\
10 \\
11 \\
12 \\
13 \\
14 \\
15 \\
16\end{array}$ & $\begin{array}{l}24.50 \\
24.49 \\
24.49 \\
24.49 \\
24.50 \\
24.48 \\
24.65 \\
24.67 \\
24.58 \\
24.54 \\
24.54 \\
24.54 \\
24.54 \\
24.54 \\
24.52 \\
24.50\end{array}$ & $\begin{array}{l}92.2 \\
92.1 \\
92.1 \\
92.1 \\
92.2 \\
92.1 \\
93.6 \\
93.8 \\
93 \\
92.6 \\
92.6 \\
92.6 \\
92.6 \\
92.6 \\
92.4 \\
92.2\end{array}$ & $\begin{array}{l}24.56 \\
24.55 \\
24.52 \\
24.51 \\
24.49 \\
24.48 \\
24.47 \\
24.46 \\
24.48 \\
24.48 \\
24.47 \\
24.46 \\
24.45 \\
24.55 \\
24.52 \\
24.50\end{array}$ & $\begin{array}{l}92.8 \\
92.8 \\
92.4 \\
92.4 \\
92.1 \\
92.1 \\
92.1 \\
91.8 \\
92.1 \\
92.1 \\
92 \\
91.8 \\
91.7 \\
92.8 \\
92.4 \\
92.2\end{array}$ & $\begin{array}{l}24.56 \\
24.55 \\
24.53 \\
24.54 \\
24.52 \\
24.61 \\
24.59 \\
24.56 \\
24.54 \\
24.54 \\
24.54 \\
24.52 \\
24.52 \\
24.52 \\
24.52 \\
24.52\end{array}$ & $\begin{array}{l}92.8 \\
92.8 \\
92.5 \\
92.6 \\
92.4 \\
93.2 \\
93.0 \\
92.8 \\
92.6 \\
92.6 \\
92.6 \\
92.4 \\
92.4 \\
92.4 \\
92.4 \\
92.4\end{array}$ \\
\hline
\end{tabular}


Gage height, in feet, and contents, in millions of cubic feet, 1938-Continued

\begin{tabular}{|c|c|c|c|c|c|c|c|}
\hline \multirow{2}{*}{ Day } & \multicolumn{2}{|c|}{ June } & \multicolumn{2}{|c|}{ July } & \multicolumn{3}{|c|}{ August } \\
\hline & Gage height & Contents & Gage height & Contents & \multicolumn{2}{|c|}{ Gage height } & Contents \\
\hline $\begin{array}{l}17 \\
18 \\
19 \\
20 \\
21 \\
22 \\
23 \\
24 \\
25 \\
26 \\
27 \\
28 \\
29 \\
30 \\
31\end{array}$ & $\begin{array}{l}24.50 \\
24.51 \\
24.50 \\
24.48 \\
24.48 \\
24.48 \\
24.48 \\
24.48 \\
24.46 \\
24.57 \\
24.84 \\
24.78 \\
24.66 \\
24.59\end{array}$ & $\begin{array}{l}92.2 \\
92.4 \\
92.2 \\
92.1 \\
92.1 \\
92.1 \\
92.1 \\
92.1 \\
91.8 \\
92.9 \\
95.4 \\
94.9 \\
93.7 \\
93\end{array}$ & $\begin{array}{l}24.50 \\
24.52 \\
24.53 \\
24.74 \\
24.94 \\
24.83 \\
25.35 \\
24.94 \\
24.74 \\
24.69 \\
24.65 \\
24.65 \\
24.61 \\
24.58 \\
24.57\end{array}$ & $\begin{array}{r}92.2 \\
92.4 \\
92.5 \\
94.5 \\
96.4 \\
95.3 \\
100.7 \\
96.4 \\
94.6 \\
94 \\
93.6 \\
93.6 \\
93.3 \\
93.0 \\
92.9\end{array}$ & \multicolumn{2}{|c|}{$\begin{array}{l}24.52 \\
24.52 \\
24.52 \\
24.52 \\
24.50 \\
24.50 \\
24.49 \\
24.48 \\
24.48 \\
24.49 \\
24.56 \\
24.52 \\
24.50 \\
24.49 \\
24.48\end{array}$} & $\begin{array}{l}92.4 \\
92.4 \\
92.4 \\
92.4 \\
92.2 \\
92.2 \\
92.1 \\
92.1 \\
92.1 \\
92.1 \\
92.8 \\
92.4 \\
92.2 \\
92.1 \\
92.1\end{array}$ \\
\hline $\begin{array}{l}30 \\
31\end{array}$ & & & $\bullet$ & & June & Juls & August \\
\hline \multicolumn{5}{|c|}{$\begin{array}{l}\text { Change in contents, in millions of cubic feet } \\
\text { Change in contents, in equivalent second-feet }\end{array}$} & $\begin{array}{l}+0.6 \\
+0.23\end{array}$ & $\begin{array}{l}-0.1 \\
-0.04\end{array}$ & $\begin{array}{l}-0.8 \\
-0.30\end{array}$ \\
\hline
\end{tabular}

IAWRENCE BROOK AT EARRINGTON DAM, N. J.

Location,--Lat. $40^{\circ} 27^{\prime} 00^{\prime \prime}$, long. $74^{\circ} 27^{\prime} 05^{\prime \prime}$, at Farrington Dam, half a mile southwest of Milltown, Middlesex County, and 43/4 miles upstream from mouth.

Drainage ARea.-34.4 square miles.

GAGE-HEIGHT RECORD.-Water-stage recorder graph.

STAGE-DISCHARGe reLATION.-Defined by current-meter measurements below 500 second-feet; extended to peak stage by weir formula.

Maxima.-July 1938: Discharge, 1,050 second-feet 7 to 9 p.m. July 23 (gage height, 25.40 feet).

1927 to June 1938: Discharge, about 1,900 second-feet July 6, 1928 (gage-height, 25.84 feet).

Remarks.-Flow affected by storage in reservoir at Farrington Dam (see p. 308). Monthly mean discharge and runoff, in inches, adjusted for storage in reservoir. Water-stage recorder inspected by employee of City of New Brunswick.

Mean discharge, in second-feet, 1938

\begin{tabular}{|c|c|c|c|c|c|c|c|c|c|c|c|}
\hline Day & June & July & Alug. & Day & June & July & Aug. & Day & June & July & Aug. \\
\hline $\begin{array}{r}1 \\
2 \\
3 \\
4 \\
5 \\
6 \\
7 \\
8 \\
9 \\
10\end{array}$ & $\begin{array}{r}19.4 \\
17.1 \\
15.0 \\
15.0 \\
15.0 \\
15.0 \\
17.8 \\
142 \\
68 \\
36\end{array}$ & $\begin{array}{l}46 \\
32 \\
25 \\
19.4 \\
17.1 \\
13.1 \\
11.5 \\
11.5 \\
10.0 \\
13.1\end{array}$ & $\begin{array}{l}41 \\
32 \\
29 \\
25 \\
25 \\
36 \\
62 \\
41 \\
32 \\
29\end{array}$ & $\begin{array}{l}11 \\
12 \\
13 \\
14 \\
15 \\
16 \\
17 \\
18 \\
19 \\
20\end{array}$ & $\begin{array}{l}29 \\
25 \\
25 \\
29 \\
22 \\
19.4 \\
17.1 \\
19.4 \\
19.4 \\
15.0\end{array}$ & $\begin{array}{l}11.5 \\
11.5 \\
10.0 \\
21 \\
29 \\
19.4 \\
15.0 \\
22 \\
22 \\
93\end{array}$ & $\begin{array}{l}29 \\
25 \\
22 \\
22 \\
22 \\
22 \\
22 \\
22 \\
22 \\
19.1\end{array}$ & $\begin{array}{l}21 \\
22 \\
23 \\
24 \\
25 \\
26 \\
27 \\
28 \\
29 \\
30 \\
31\end{array}$ & $\begin{array}{r}13.1 \\
11.5 \\
11.5 \\
13.1 \\
11.5 \\
12.6 \\
125 \\
241 \\
134 \\
68\end{array}$ & $\begin{array}{r}300 \\
285 \\
586 \\
668 \\
253 \\
142 \\
94 \\
118 \\
68 \\
51 \\
41\end{array}$ & $\begin{array}{l}17.1 \\
15.0 \\
15.0 \\
13.1 \\
13.1 \\
13.1 \\
15.4 \\
25 \\
17.1 \\
17.1 \\
15.0\end{array}$ \\
\hline \multicolumn{9}{|c|}{$\begin{array}{l}\text { Monthly mean discharge, in second-feet (observed) } \\
\text { Montbly mean discharge, in second-feet (adjusted) } \\
\text { Runoff, in inches (adjusted) }\end{array}$} & $\begin{array}{l}40.7 \\
41.0 \\
1.33\end{array}$ & $\begin{array}{l}98.7 \\
98.7 \\
3.31\end{array}$ & $\begin{array}{r}24.4 \\
24.0 \\
.80\end{array}$ \\
\hline
\end{tabular}


Gage height, in feet, and discharge, in second-feet, at indicated time, 1938

\begin{tabular}{|c|c|c|c|c|c|c|c|c|c|c|c|c|}
\hline \multirow{2}{*}{ Hour } & Feet & Sec. $-\mathrm{ft}$. & Feet & Sec.-ft. & Feet & Sec. $-\mathrm{ft}$. & Feet & Sec.-ft. & Feet & Sec.-ft. & Feet & Sec.-ft. \\
\hline & \multicolumn{2}{|c|}{ July 17} & \multicolumn{2}{|c|}{ July 18} & \multicolumn{2}{|c|}{ July 19} & \multicolumn{2}{|c|}{ July 20} & \multicolumn{2}{|c|}{ July 21} & \multicolumn{2}{|c|}{ July 22} \\
\hline \multirow[t]{2}{*}{$\begin{array}{c}2 \mathrm{a} . \mathrm{m} . \\
4 \\
6 \\
8 \\
10 \\
12 \mathrm{n} . \\
2 \mathrm{p.m} . \\
4 \\
6 \\
8 \\
10 \\
12 \mathrm{~m} .\end{array}$} & 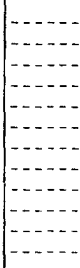 & 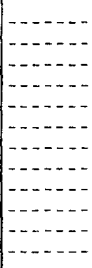 & 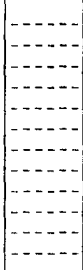 & 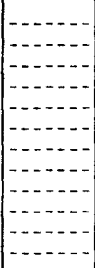 & 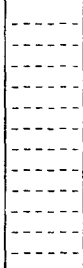 & 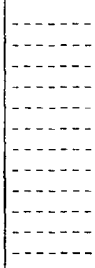 & $\begin{array}{l}24.53 \\
24.54 \\
24.57 \\
24.57 \\
24.62 \\
24.66 \\
24.69 \\
24.72 \\
24.74 \\
24.75 \\
24.75 \\
24.74\end{array}$ & $\begin{array}{r}25 \\
29 \\
41 \\
41 \\
68 \\
94 \\
117 \\
142 \\
160 \\
170 \\
170 \\
160\end{array}$ & $\begin{array}{l}24.75 \\
24.77 \\
24.79 \\
24.82 \\
24.85 \\
24.90 \\
24.92 \\
24.94 \\
24.95 \\
24.95 \\
24.99 \\
24.94\end{array}$ & $\begin{array}{l}170 \\
190 \\
210 \\
241 \\
273 \\
331 \\
355 \\
379 \\
391 \\
391 \\
441 \\
379\end{array}$ & $\begin{array}{l}24.91 \\
24.89 \\
24.87 \\
24.85 \\
24.84 \\
24.83 \\
24.83 \\
24.83 \\
24.84 \\
24.84 \\
24.84 \\
24.83\end{array}$ & $\begin{array}{l}343 \\
319 \\
296 \\
273 \\
262 \\
252 \\
252 \\
252 \\
262 \\
262 \\
262 \\
252\end{array}$ \\
\hline & \multicolumn{2}{|c|}{ July 23} & \multicolumn{2}{|c|}{ July 24} & \multicolumn{2}{|c|}{ July 25} & \multicolumn{2}{|c|}{ - July 26} & \multicolumn{2}{|c|}{ July 27} & \multicolumn{2}{|c|}{ July 28} \\
\hline \multirow[t]{2}{*}{$\begin{array}{c}2 \text { a.m. } \\
4 \\
6 \\
8 \\
10 \\
12 \mathrm{n} . \\
2 \mathrm{p.m} . \\
4 \\
6 \\
8 \\
10 \\
12 \mathrm{~m} .\end{array}$} & $\begin{array}{l}24.81 \\
24.79 \\
24.78 \\
24.77 \\
24.77 \\
25.08 \\
25.21 \\
25.32 \\
25.38 \\
25.40 \\
25.39 \\
25.35\end{array}$ & $\begin{array}{r}231 \\
210 \\
200 \\
190 \\
190 \\
560 \\
750 \\
920 \\
1,020 \\
1,050 \\
1,040 \\
970\end{array}$ & $\begin{array}{l}25.30 \\
25.28 \\
25.25 \\
25.22 \\
25.20 \\
25.16 \\
25.13 \\
25.09 \\
25.05 \\
25.00 \\
24.97 \\
24.94\end{array}$ & $\begin{array}{l}890 \\
860 \\
810 \\
765 \\
735 \\
675 \\
630 \\
575 \\
520 \\
454 \\
416 \\
379\end{array}$ & $\begin{array}{l}24.91 \\
24.89 \\
24.87 \\
24.85 \\
24.84 \\
24.82 \\
24.81 \\
24.79 \\
24.79 \\
24.78 \\
24.77 \\
24.76\end{array}$ & $\begin{array}{l}343 \\
319 \\
296 \\
273 \\
262 \\
241 \\
231 \\
210 \\
210 \\
200 \\
190 \\
180\end{array}$ & $\begin{array}{l}24.75 \\
24.74 \\
24.74 \\
24.73 \\
24.72 \\
24.72 \\
24.71 \\
24.70 \\
24.70 \\
24.69 \\
24.69 \\
24.69\end{array}$ & $\begin{array}{l}170 \\
160 \\
160 \\
151 \\
142 \\
142 \\
134 \\
125 \\
125 \\
117 \\
117 \\
117\end{array}$ & $\begin{array}{l}24.68 \\
24.68 \\
24.67 \\
24.67 \\
24.67 \\
24.66 \\
24.66 \\
24.65 \\
24.64 \\
24.64 \\
24.65 \\
24.65\end{array}$ & $\begin{array}{r}109 \\
109 \\
102 \\
102 \\
102 \\
94 \\
94 \\
87 \\
80 \\
80 \\
87 \\
87\end{array}$ & $\begin{array}{l}24.67 \\
24.69 \\
24.72 \\
24.73 \\
24.73 \\
24.72 \\
24.70 \\
24.69 \\
24.68 \\
24.67 \\
24.66 \\
24.65\end{array}$ & $\begin{array}{l}102 \\
117 \\
142 \\
151 \\
151 \\
142 \\
125 \\
117 \\
109 \\
102 \\
94 \\
87\end{array}$ \\
\hline & \multicolumn{2}{|c|}{ July 29} & \multicolumn{2}{|c|}{ July $\mathbf{3 0}$} & \multicolumn{2}{|c|}{ July 31} & \multicolumn{2}{|c|}{ August 1} & \multicolumn{2}{|c|}{ August 2} & \multicolumn{2}{|c|}{ August 3} \\
\hline $\begin{array}{l}2 \text { a.m. } \\
4 \\
6 \\
8 \\
10 \\
12 \mathrm{n.} \\
2 \mathrm{p.m} . \\
4 \\
6 \\
8 \\
10 \\
12 \mathrm{~m} .\end{array}$ & $\begin{array}{l}24.64 \\
24.64 \\
24.63 \\
24.63 \\
24.62 \\
24.62 \\
24.61 \\
24.61 \\
24.62 \\
24.61 \\
24.61 \\
24.61\end{array}$ & $\begin{array}{l}80 \\
80 \\
74 \\
74 \\
68 \\
68 \\
62 \\
62 \\
68 \\
62 \\
62 \\
62\end{array}$ & $\begin{array}{l}24.61 \\
24.60 \\
24.60 \\
24.60 \\
24.60 \\
24.59 \\
24.59 \\
24.59 \\
24.59 \\
24.58 \\
24.58 \\
24.58\end{array}$ & $\begin{array}{l}62 \\
56 \\
56 \\
56 \\
56 \\
51 \\
51 \\
51 \\
51 \\
46 \\
46 \\
46\end{array}$ & $\left\{\begin{array}{l}- \\
- \\
- \\
- \\
- \\
- \\
- \\
-\end{array}\right.$ & $\begin{array}{l}-- \\
-\cdots \\
-- \\
-\cdots \\
-- \\
- \\
-- \\
- \\
-- \\
-- \\
--\end{array}$ & $\begin{array}{l}\cdots \\
\cdots \\
\cdots \\
\cdots \\
\cdots \\
\cdots \\
\cdots \\
\cdots\end{array}$ & 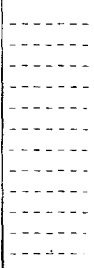 & 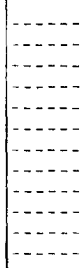 & \begin{tabular}{l}
--- \\
--- \\
\hdashline-
\end{tabular} & 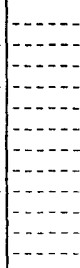 & 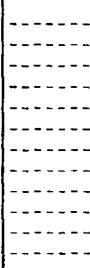 \\
\hline
\end{tabular}

Supplemental records.-July 21, 9:45 p.m., 24.94 ft., 379 sec.-ft.; July 22, $12: 15$ a.m., 24.95 ft., 391 sec.-ft.; July 23,7 to 9 p.m., $25.40 \mathrm{ft}$., 1,050 sec.-ft.

DEEP RUN MEAR BROWNTON, N. J.

Location.-Lat. $40^{\circ} 22^{\prime} 32^{\prime \prime}$, long. $74^{\circ} 18^{\prime} 08^{\prime \prime}$, half a mile downstream from Middlesex-Monmouth county line and $13 / 4$ miles south of Browntown, Middlesex County.

Drainage area.-8.07 square miles.

GAGE-HEIGHT RECORD.-Water-stage recorder graph.

Stage-discharge relation.-Defined by current-meter measurements below 400 second-feet.

Maxima.-June 1938: Discharge, 710 second-feet $11^{\prime}$ p.m. June 27 (gage height, 7.47 feet).

July 1938: Discharge, 541 second-feet 5:30 p.m., July 20 (gage height, 6.79 feet).

1932 to May 1938: Discharge, 917 second-feet Sept. 9, 1934 (gage height, 8.27 feet). 
Mean discharge, in second-feet, 1938

\begin{tabular}{r|r|r|r||r|r|r|r|r|r|r|r}
\hline Day & June & July & Aug. & Day & June & July & Aug. & Day & June & July & Aug. \\
\hline & 5.4 & 16.1 & 15.0 & 11 & 4.6 & 4.9 & 10.8 & 21 & 5.2 & 141 & 4.2 \\
2 & 4.6 & 12.9 & 11.3 & 12 & 7.9 & 5.2 & 13.6 & 22 & 4.3 & 79 & 4.0 \\
3 & 4.1 & 10.8 & 9.4 & 13 & 14.4 & 4.6 & 8.3 & 23 & 40 & 70 & 3.5 \\
4 & 4.1 & 9.3 & 8.6 & 14 & 14.1 & 6.6 & 6.6 & 24 & 36 & 213 & 3.3 \\
5 & 4.6 & 7.9 & 9.4 & 15 & 8.2 & 10.7 & 5.8 & 25 & 12.8 & 50 & 3.1 \\
6 & 5.2 & 6.6 & 8.6 & 16 & 6.3 & 6.0 & 5.5 & 26 & 8.1 & 27 & 2.9 \\
7 & 3.8 & 6.0 & 10.9 & 17 & 5.4 & 4.9 & 5.5 & 27 & 185 & 22 & 2.9 \\
8 & 15.7 & 5.4 & 14.2 & 18 & 18.4 & 4.9 & 5.8 & 28 & 211 & 18.2 & 5.7 \\
9 & 8.2 & 4.6 & 10.9 & 19 & 10.2 & 9.5 & 5.8 & 29 & 44 & 15.4 & 4.0 \\
10 & 4.9 & 4.9 & 8.6 & 20 & 6.3 & 173 & 4.4 & 30 & 23 & 12.5 & 3.3 \\
&
\end{tabular}

Gage-height, in feet, and discharge, in second-feet, at indicated time, June 1938

\begin{tabular}{|c|c|c|c|c|c|c|c|c|c|c|c|c|}
\hline \multirow{2}{*}{ Hour } & Feet & Sec.-ft. & Feet & Sec. $-\mathrm{ft}$. & Feet & Sec.-ft. & Feet & Sec.-ft. & Feet & Sec.-ft. & Feet & Sec.-ft. \\
\hline & \multicolumn{2}{|c|}{ June 23} & \multicolumn{2}{|c|}{ June 24} & \multicolumn{2}{|c|}{ June 25} & \multicolumn{2}{|c|}{ June 26} & \multicolumn{2}{|c|}{ June 27} & \multicolumn{2}{|c|}{ June 28} \\
\hline 2 a.m. & 1.54 & 4.3 & 3.10 & 71 & 1.85 & 15.6 & 1.68 & 8.6 & 2.11 & 28 & 6.50 & 474 \\
\hline $4^{a .114}$ & 1.54 & 4.3 & 2.74 & 54 & 1.84 & $\begin{array}{l}15.0 \\
15.2\end{array}$ & $\begin{array}{l}1.00 \\
1.68\end{array}$ & 8.6 & $\begin{array}{l}2.11 \\
2.43\end{array}$ & $\begin{array}{l}20 \\
42\end{array}$ & $\begin{array}{l}0.00 \\
5.94\end{array}$ & 360 \\
\hline 6 & 1.54 & 4.3 & 2.44 & 42 & 1.83 & 14.7 & 1.68 & 8. & 2.78 & 55 & 5.51 & 288 \\
\hline 8 & 1.54 & 4.3 & 2.27 & 36 & 1.82 & 14.2 & 1.68 & 8. & 3.38 & 87 & 5.12 & 237 \\
\hline 10 & 1.54 & 4.3 & 2.19 & 32 & 1.81 & 13.8 & 1.68 & 8. & 3.64 & 103 & 4.77 & 198 \\
\hline $12 \mathrm{n}$. & 1.54 & 4.3 & 2.14 & 29 & 1.80 & 13.3 & 1.67 & 8 & 3.63 & 102 & 4.38 & 159 \\
\hline 2 p.m & 2.50 & 44 & 2.09 & 27 & 1.78 & 12.4 & 1.66 & 7 & 3. & $1]$ & 3.96 & 125 \\
\hline & 3.90 & 121 & 2.04 & 25 & 1.76 & 11. & 1.65 & 7. & 4.1 & $136^{\circ}$ & 3.65 & 104 \\
\hline & 3.42 & 89 & 1.99 & 2 & 1.7 & 10. & 1.64 & 7 & 4. & 2 & 3.43 & 90 \\
\hline & 3.23 & 78 & 1.94 & & 1.7 & 9 & 1.63 & 6. & 5.6 & 310 & 3.29 & 81 \\
\hline & 3.31 & 83 & 1.90 & 18.0 & 1.7 & 9. & 1.63 & 6. & 7.3 & 687 & 3.16 & 74 \\
\hline $12 \mathrm{~m}$. & 3.3 & 82 & 1.87 & 16.6 & 1.69 & 8 & 1.87 & 16.6 & 7.24 & 652 & 3.02 & 67 \\
\hline
\end{tabular}

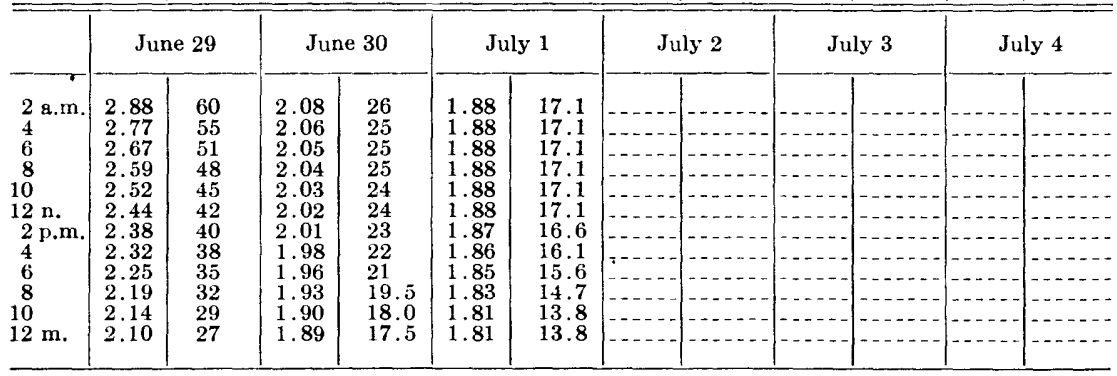

Gage-height, in feet, and discharge, in second-feet, at indicated time, 1938

\begin{tabular}{|c|c|c|c|c|c|c|c|c|c|c|c|c|}
\hline \multirow{2}{*}{ Hour } & Feet & Sec.-ft. & Feet & Sec.-ft. & Feet & Sec.-ft. & Feet & Sec.-ft. & Feet & Sec.-ft. & Feet & Sec.-ft. \\
\hline & \multicolumn{2}{|c|}{ July 17} & \multicolumn{2}{|c|}{ July 18} & \multicolumn{2}{|c|}{ July 19} & \multicolumn{2}{|c|}{ July 20} & \multicolumn{2}{|c|}{ July 21} & \multicolumn{2}{|c|}{ July 22} \\
\hline $\begin{array}{c}2 \mathrm{a} . \mathrm{m} \\
4 \\
6 \\
8 \\
10 \\
12 \mathrm{n} . \\
2 \mathrm{p} . \mathrm{m} \\
4 \\
6 \\
8 \\
10 \\
12 \mathrm{~m} .\end{array}$ & & & & & $\begin{array}{l}1.55 \\
1.55 \\
1.55 \\
1.55 \\
1.55 \\
1.55 \\
1.56 \\
1.68 \\
1.68 \\
1.98 \\
2.13 \\
2.08\end{array}$ & $\begin{array}{c}4.6 \\
4.6 \\
4.6 \\
4.6 \\
4.6 \\
4.6 \\
4.9 \\
8.6 \\
8.6 \\
22 \\
29 \\
26\end{array}$ & $\begin{array}{l}1.95 \\
1.88 \\
1.87 \\
1.96 \\
2.15 \\
3.24 \\
4.30 \\
5.80 \\
6.70 \\
6.04 \\
5.50 \\
5.03\end{array}$ & $\begin{array}{l}20 \\
17.1 \\
16.6 \\
21 \\
30 \\
78 \\
152 \\
335 \\
519 \\
379 \\
287 \\
227\end{array}$ & $\begin{array}{l}4.46 \\
3.70 \\
3.32 \\
3.24 \\
3.19 \\
3.18 \\
3.69 \\
3.80 \\
4.14 \\
4.92 \\
5.10 \\
4.73\end{array}$ & $\begin{array}{r}171 \\
116 \\
93 \\
88 \\
85 \\
85 \\
115 \\
122 \\
145 \\
214 \\
235 \\
195\end{array}$ & $\begin{array}{l}4.00 \\
3.20 \\
2.85 \\
2.65 \\
2.53 \\
2.72 \\
2.79 \\
2.82 \\
3.03 \\
3.16 \\
3.11 \\
2.93\end{array}$ & $\begin{array}{r}135 \\
86 \\
67 \\
56 \\
50 \\
60 \\
64 \\
65 \\
76 \\
84 \\
81 \\
71\end{array}$ \\
\hline
\end{tabular}


Gage-height, in feet, and discharge, in second-feet, at indicated time, 1938-Continued

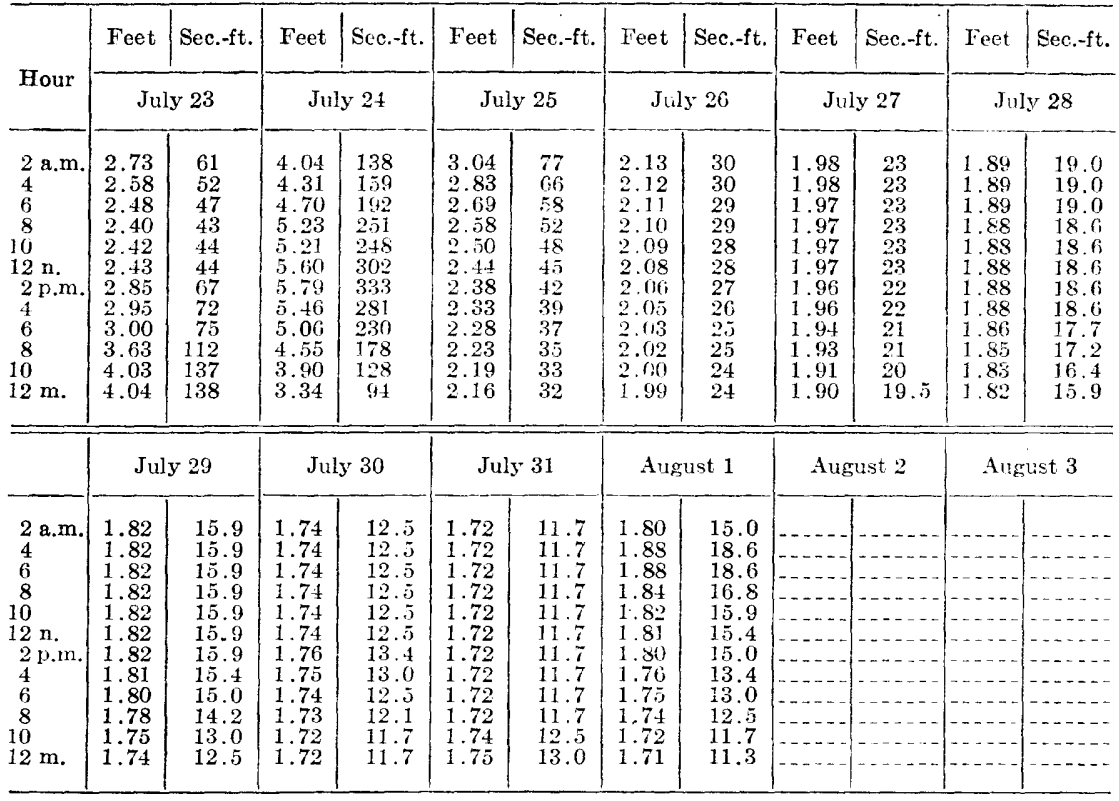

Supplemental records.-June 27,11 p.m., 7.47 ft., 710 sec.-ft.; July $20,5: 30$ p.m., 6.79 ft., 5.11 sec.-ft.; July 21, $3: 30$ p.m., 3.81 ft., 123 sec.-ft.; $4: 30$ p.m., 3.78 ft., 121 sec.-ft.; $9: 30$ p.m., 5.13 ft., 259 sec.-ft.: July 22, 11 a.m., 2.49 ft., 47 sec.-ft.; J.1y $24,1: 30$ p.m., $5 . \$ 3$ ft., 340 sec.ft.

\section{COASTAL BASINS IN NEW JERSEY}

TINTON FAILS RESERVOIR NEAR RED BANK, N. J.

Location.-Lat. $40^{\circ} 19^{\prime} 03^{\prime \prime}$, long. $74^{\circ} 06^{\prime} 57^{\prime \prime}$, on Swimming River upstream from dam of Monmouth Consolidated Water Co., 4 miles upstream from Red Bank, Monmouth County.

Drainage area. - 48.5 square miles.

GACE-HEIGHT RECORD.-Water-stage recorder graph. Gage heights shown in table are those for midnight.

Remarks.-Contents above zero gage height are given in table. Spillway crest at gage height 2.36 feet.

Gage height, in feet, and contents, in millions of cubic feet, 1938 .

\begin{tabular}{|c|c|c|c|c|c|c|}
\hline \multirow{2}{*}{ Day } & \multicolumn{2}{|c|}{ June } & \multicolumn{2}{|c|}{ July } & \multicolumn{2}{|c|}{ August } \\
\hline & Gage height & Contents & Gage beight & Contents & Gage height & Contents \\
\hline $\begin{array}{r}1 \\
2 \\
3 \\
4 \\
5 \\
6 \\
7 \\
8 \\
9 \\
10 \\
11 \\
12 \\
13 \\
14 \\
15 \\
16 \\
17\end{array}$ & $\begin{array}{l}2.57 \\
2.55 \\
2.54 \\
2.56 \\
2.57 \\
2.57 \\
2.54 \\
2.58 \\
2.53 \\
2.52 \\
2.53 \\
2.78 \\
2.86 \\
2.72 \\
2.62 \\
2.58 \\
2.57\end{array}$ & $\begin{array}{l}11.86 \\
11.76 \\
11.72 \\
11.80 \\
11.86 \\
11.86 \\
11.72 \\
11.90 \\
11.67 \\
11.63 \\
11.67 \\
12.82 \\
13.19 \\
12.55 \\
12.08 \\
11.90 \\
11.86\end{array}$ & $\begin{array}{l}2.70 \\
2.67 \\
2.64 \\
2.63 \\
2.61 \\
2.60 \\
2.58 \\
2.57 \\
2.56 \\
2.57 \\
2.58 \\
2.59 \\
2.56 \\
2.64 \\
2.91 \\
2.64 \\
2.65\end{array}$ & $\begin{array}{l}12.46 \\
12.31 \\
12.18 \\
12.14 \\
12.01 \\
11.49 \\
11.90 \\
11.86 \\
11.80 \\
11.86 \\
11.90 \\
11.95 \\
11.80 \\
12.18 \\
13.42 \\
12.18 \\
12.22\end{array}$ & $\begin{array}{l}2.77 \\
2.72 \\
2.69 \\
2.70 \\
2.70 \\
2.76 \\
3.46 \\
2.98 \\
2.84 \\
2.77 \\
2.83 \\
2.76 \\
2.70 \\
2.68 \\
2.67 \\
2.66 \\
2.67\end{array}$ & $\begin{array}{l}12.78 \\
12.55 \\
12.41 \\
12.46 \\
12.46 \\
12.73 \\
1.5 .46 \\
13.71 \\
13.10 \\
12.78 \\
13.06 \\
12.73 \\
12.46 \\
12.37 \\
12.31 \\
12.27 \\
12.31\end{array}$ \\
\hline
\end{tabular}


Gage height, in feet, and contents, in millions of cubic feet, 1938-Continued

\begin{tabular}{|c|c|c|c|c|c|c|c|}
\hline \multirow{2}{*}{ Day } & \multicolumn{2}{|c|}{ June } & \multicolumn{2}{|c|}{ July } & \multicolumn{3}{|c|}{ August } \\
\hline & Gage height & Contents & Gage height & Contents & Gage & ight & Contents \\
\hline $\begin{array}{l}18 \\
19 \\
20 \\
21 \\
22 \\
23 \\
24 \\
25 \\
26 \\
27 \\
28 \\
29 \\
30 \\
31\end{array}$ & $\begin{array}{r}2.65 \\
2.57 \\
2.54 \\
2.53 \\
2.55 \\
2.54 \\
2.50 \\
2.52 \\
2.07 \\
4.18 \\
3.80 \\
2.88 \\
2.75\end{array}$ & $\begin{array}{l}12.22 \\
11.86 \\
11.72 \\
11.67 \\
11.76 \\
11.72 \\
11.76 \\
11.63 \\
12.31 \\
19.28 \\
15.23 \\
13.29 \\
12.69\end{array}$ & $\begin{array}{l}2.73 \\
3.17 \\
4.14 \\
3.82 \\
3.21 \\
3.60 \\
3.67 \\
2.99 \\
2.89 \\
2.84 \\
2.81 \\
2.77 \\
2.75 \\
2.73\end{array}$ & $\begin{array}{l}12.59 \\
14.62 \\
19.09 \\
17.83 \\
14.81 \\
16.88 \\
16.92 \\
13.80 \\
13.33 \\
13.10 \\
12.97 \\
12.78 \\
12.69 \\
12.59\end{array}$ & & & $\begin{array}{l}12.41 \\
12.27 \\
12.18 \\
12.08 \\
12.08 \\
11.99 \\
11.99 \\
11.95 \\
11.95 \\
11.95 \\
12.08 \\
11.99 \\
11.90 \\
11.95\end{array}$ \\
\hline & & & & & June & July & August \\
\hline \multicolumn{5}{|c|}{$\begin{array}{l}\text { Change in contents, in millions of cubic feet } \\
\text { Change in contents, in equivalent second-feet. }\end{array}$} & $\begin{array}{l}+0.79 \\
+0.30\end{array}$ & $\begin{array}{l}-0 . \\
-0\end{array}$ & $\begin{array}{l}-0.64 \\
-0.24\end{array}$ \\
\hline
\end{tabular}

SWIMMING RIVER NEAR RED BANK, N. J.

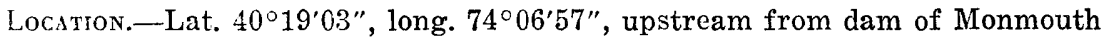
Consolidated Water Co., 4 miles upstream from Red Bank, Monmouth County.

Drainage area. - 48.5 square miles.

GAGE-HEIGHT RECORD.-Water-stage recorder graph.

StaGe-discharge Relation.-Defined by current-meter measurements below 500 second-feet; extended to peak stage on basis of weir formula.

Maxima.-June 1938: Discharge, 1,610 second-feet 2 to 3 a.m. June 28 (gage height, 4.60 feet).

July 1938: Discharge, 1,500 second-feet 7:30 p.m. July 20 (gage height, 4.49 feet).

1922 to May 1938: Discharge, 2,930 second-feet Sept. 9, 1934 (gage height, 5.65 feet).

Remarks.-Flow affected by storage in Tinton Falls Reservoir and includes discharge over spillway and diversion for municipal supply. Monthly. mean discharge and run-off adjusted for storage in Tinton Falls Reservoir (see p. 312). Water-stage recorder inspected and record of diversion furnished by Monmouth Consolidated Water Company.

Mean discharge, in second-feet, 1938

\begin{tabular}{|c|c|c|c|c|c|c|c|c|c|c|c|}
\hline Day & June & July & Aug. & Day & June & July & Aug. & Day & June & July & Aug. \\
\hline $\begin{array}{r}1 \\
2 \\
3 \\
4 \\
5 \\
6 \\
7 \\
8 \\
9 \\
10\end{array}$ & $\begin{array}{l}45 \\
43 \\
40 \\
43 \\
48 \\
51 \\
44 \\
45 \\
43 \\
36\end{array}$ & $\begin{array}{l}94 \\
82 \\
75 \\
66 \\
61 \\
58 \\
53 \\
54 \\
50 \\
49\end{array}$ & $\begin{array}{r}116 \\
100 \\
94 \\
85 \\
89 \\
93 \\
221 \\
576 \\
184 \\
116\end{array}$ & $\begin{array}{l}11 \\
12 \\
13 \\
14 \\
15 \\
16 \\
17 \\
18 \\
19 \\
20\end{array}$ & $\begin{array}{r}36 \\
54 \\
200 \\
122 \\
68 \\
53 \\
48 \\
56 \\
57 \\
46\end{array}$ & $\begin{array}{r}52 \\
52 \\
49 \\
53 \\
138 \\
117 \\
60 \\
97 \\
132 \\
887\end{array}$ & $\begin{array}{r}131 \\
132 \\
97 \\
85 \\
83 \\
75 \\
78 \\
81 \\
81 \\
72\end{array}$ & $\begin{array}{l}21 \\
22 \\
23 \\
24 \\
25 \\
26 \\
27 \\
28 \\
29 \\
30 \\
31\end{array}$ & $\begin{array}{r}41 \\
40 \\
41 \\
45 \\
40 \\
39 \\
373 \\
981 \\
260 \\
127\end{array}$ & $\begin{array}{l}613 \\
466 \\
358 \\
908 \\
359 \\
190 \\
156 \\
137 \\
120 \\
113 \\
105\end{array}$ & $\begin{array}{l}66 \\
63 \\
60 \\
58 \\
55 \\
56 \\
54 \\
61 \\
59 \\
54 \\
50\end{array}$ \\
\hline \multicolumn{9}{|c|}{$\begin{array}{l}\text { Monthly mean discharge, in second-feet (observed) } \\
\text { Monthly mean discharge, in second-feet (adjusted) } \\
\text { Runoff, in inches (adjusted) }\end{array}$} & $\begin{array}{r}106 \\
106 \\
2.44\end{array}$ & $\begin{array}{r}187 \\
187 \\
4.45\end{array}$ & $\begin{array}{r}104 \\
104 \\
2.47\end{array}$ \\
\hline
\end{tabular}


Gage-height, in feet, and discharge, in second-feet, at indicated time, 1938

\begin{tabular}{|c|c|c|c|c|c|c|c|c|c|c|c|c|}
\hline \multirow{2}{*}{ Hour } & Feet & Sec.-ft. & Feet & Sec.-ft. & Feet & Sec.-ft. & Feet & Sec. $-\mathrm{ft}$. & Feet & Sec.-ft. & Feet & Sec.-ft. \\
\hline & \multicolumn{2}{|c|}{ June 23} & \multicolumn{2}{|c|}{ June 24} & \multicolumn{2}{|c|}{ June 25} & \multicolumn{2}{|c|}{ June 26} & \multicolumn{2}{|c|}{ June 27} & \multicolumn{2}{|c|}{ June 28} \\
\hline \multirow[t]{2}{*}{$\begin{array}{l}2 \text { a.m. } \\
4 \\
6 \\
8 \\
10 \\
12 \mathrm{n} . \\
2 \text { p.m. } \\
4 \\
6 \\
8 \\
10 \\
12 \mathrm{~m} .\end{array}$} & & & & & & & $\begin{array}{l}2.52 \\
2.52 \\
2.52 \\
2.51 \\
2.51 \\
2.50 \\
2.51 \\
2.52 \\
2.52 \\
2.52 \\
2.64 \\
2.67\end{array}$ & $\begin{array}{l}37 \\
37 \\
37 \\
35 \\
35 \\
32 \\
35 \\
37 \\
37 \\
37 \\
69 \\
78\end{array}$ & $\begin{array}{l}2.71 \\
2.77 \\
2.87 \\
3.00 \\
3.09 \\
3.18 \\
3.26 \\
3.36 \\
3.44 \\
3.58 \\
3.69 \\
4.18\end{array}$ & $\begin{array}{r}93 \\
110 \\
160 \\
225 \\
276 \\
332 \\
386 \\
456 \\
515 \\
625 \\
716 \\
1,170\end{array}$ & $\begin{array}{l}4.60 \\
4.54 \\
4.37 \\
4.16 \\
4.00 \\
3.84 \\
3.69 \\
3.58 \\
3.50 \\
3.46 \\
3.37 \\
3.30\end{array}$ & $\begin{array}{r}1,610 \\
1,540 \\
1,360 \\
1,150 \\
995 \\
848 \\
717 \\
626 \\
562 \\
532 \\
464 \\
414\end{array}$ \\
\hline & \multicolumn{2}{|c|}{ June 29} & \multicolumn{2}{|c|}{ June 30} & \multicolumn{2}{|c|}{ July 1} & \multicolumn{2}{|c|}{ July 2} & \multicolumn{2}{|c|}{ July 3} & \multicolumn{2}{|c|}{ July 4} \\
\hline $\begin{array}{c}2 \text { a.m. } \\
4 \\
6 \\
8 \\
10 \\
12 \mathrm{n} . \\
2 \mathrm{p.m} . \\
4 \\
6 \\
8 \\
10 \\
12 \mathrm{~m} .\end{array}$ & $\begin{array}{l}3.25 \\
3.20 \\
3.16 \\
3.12 \\
3.07 \\
3.04 \\
3.01 \\
2.97 \\
2.95 \\
2.92 \\
2.90 \\
2.88\end{array}$ & $\begin{array}{l}380 \\
346 \\
320 \\
296 \\
266 \\
248 \\
232 \\
210 \\
200 \\
184 \\
174 \\
166\end{array}$ & $\begin{array}{l}2.87 \\
2.85 \\
2.84 \\
2.82 \\
2.80 \\
2.79 \\
2.78 \\
2.78 \\
2.77 \\
2.77 \\
2.75 \\
2.75\end{array}$ & $\begin{array}{l}160 \\
151 \\
146 \\
136 \\
127 \\
123 \\
119 \\
119 \\
116 \\
116 \\
108 \\
108\end{array}$ & $\begin{array}{l}2.74 \\
2.74 \\
2.73 \\
2.72 \\
2.71 \\
2.71 \\
2.70 \\
2.70 \\
2.70 \\
2.70 \\
2.70 \\
2.70\end{array}$ & $\begin{array}{r}104 \\
104 \\
100 \\
98 \\
94 \\
94 \\
90 \\
90 \\
90 \\
90 \\
90 \\
90\end{array}$ & $\begin{array}{l}2.70 \\
2.70 \\
2.70 \\
2.69 \\
2.68 \\
2.68 \\
2.67 \\
2.67 \\
2.67 \\
2.67 \\
2.67 \\
2.67\end{array}$ & $\begin{array}{l}90 \\
90 \\
90 \\
86 \\
82 \\
82 \\
78 \\
78 \\
78 \\
78 \\
78 \\
78\end{array}$ & $\begin{array}{l}2.67 \\
2.67 \\
2.67 \\
2.66 \\
2.66 \\
2.65 \\
2.65 \\
2.65 \\
2.65 \\
2.65 \\
2.65 \\
2.64\end{array}$ & $\begin{array}{l}78 \\
78 \\
78 \\
75 \\
75 \\
72 \\
72 \\
72 \\
72 \\
72 \\
72 \\
69\end{array}$ & 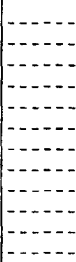 & 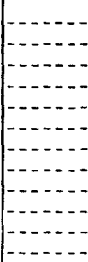 \\
\hline
\end{tabular}

Gage-height, in feet, and discharge, in second-feet, at indicated time, 1938

\begin{tabular}{|c|c|c|c|c|c|c|c|c|c|c|c|c|}
\hline \multirow{2}{*}{ Hour } & Feet & Sec.-ft, & Feet & Sec.-ft. & Feet & Sec.fft. & Feet & Sec.-ft. & Feet & Sec.-ft. & Feet & Sec.-ft. \\
\hline & \multicolumn{2}{|c|}{ July 17} & \multicolumn{2}{|c|}{ July 18} & \multicolumn{2}{|c|}{ July 19} & \multicolumn{2}{|c|}{ July 20} & \multicolumn{2}{|c|}{ July 21} & \multicolumn{2}{|c|}{ July 22} \\
\hline $\begin{array}{c}2 \text { a.m. } \\
4 \\
6 \\
8 \\
10 \\
12 \mathrm{n} . \\
2 \mathrm{p.m} . \\
4 \\
6 \\
8 \\
10 \\
12 \mathrm{~m} .\end{array}$ & $\begin{array}{l}2.63 \\
2.63 \\
2.61 \\
2.61 \\
2.60 \\
2.62 \\
2.61 \\
2.60 \\
2.60 \\
2.61 \\
2.63 \\
2.65\end{array}$ & $\begin{array}{l}66 \\
66 \\
60 \\
60 \\
56 \\
62 \\
60 \\
56 \\
56 \\
60 \\
66 \\
72\end{array}$ & $\begin{array}{l}2.69 \\
2.71 \\
2.73 \\
2.73 \\
2.73 \\
2.72 \\
2.71 \\
2.70 \\
2.72 \\
2.74 \\
2.73 \\
2.73\end{array}$ & $\begin{array}{r}85 \\
93 \\
100 \\
100 \\
100 \\
97 \\
93 \\
89 \\
97 \\
104 \\
100 \\
100\end{array}$ & $\begin{array}{l}2.73 \\
2.73 \\
2.73 \\
2.73 \\
2.72 \\
2.71 \\
2.70 \\
2.79 \\
2.87 \\
2.94 \\
3.02 \\
3.17\end{array}$ & $\begin{array}{r}100 \\
100 \\
100 \\
100 \\
97 \\
93 \\
89 \\
123 \\
160 \\
194 \\
236 \\
326\end{array}$ & $\begin{array}{l}3.33 \\
3.47 \\
3.51 \\
3.52 \\
3.67 \\
3.81 \\
3.92 \\
4.14 \\
4.44 \\
4.48 \\
4.33 \\
4.14\end{array}$ & $\begin{array}{r}436 \\
539 \\
570 \\
-\quad 578 \\
700 \\
821 \\
921 \\
1,130 \\
1,430 \\
1,480 \\
1,320 \\
1,130\end{array}$ & $\begin{array}{l}3.96 \\
3.80 \\
3.65 \\
3.51 \\
3.40 \\
3.33 \\
3.27 \\
3.23 \\
3.20 \\
3.50 \\
3.82 \\
3.82\end{array}$ & $\begin{array}{l}958 \\
812 \\
684 \\
570 \\
486 \\
436 \\
394 \\
366 \\
346 \\
562 \\
830 \\
830\end{array}$ & $\begin{array}{l}3.70 \\
3.58 \\
3.46 \\
3.36 \\
3.32 \\
3.31 \\
3.27 \\
3.23 \\
3.22 \\
3.22 \\
3.22 \\
3.21\end{array}$ & $\begin{array}{l}725 \\
626 \\
532 \\
457 \\
428 \\
421 \\
394 \\
366 \\
360 \\
360 \\
360 \\
353\end{array}$ \\
\hline & \multicolumn{2}{|c|}{ July 23} & \multicolumn{2}{|c|}{ July 24} & \multicolumn{2}{|c|}{ July 25} & \multicolumn{2}{|c|}{ July 26} & \multicolumn{2}{|c|}{ July 27} & \multicolumn{2}{|c|}{ July 28} \\
\hline $\begin{array}{l}2 \mathrm{a} . \mathrm{m} . \\
4 \\
6 \\
8 \\
10 \\
12 \mathrm{n} . \\
2 \mathrm{p.m} . \\
4 \\
6 \\
8 \\
10 \\
12 \mathrm{~m} .\end{array}$ & $\begin{array}{l}3.19 \\
3.16 \\
3.14 \\
3.11 \\
3.09 \\
3.08 \\
3.09 \\
3.12 \\
3.22 \\
3.37 \\
3.52 \\
3.66\end{array}$ & $\begin{array}{l}340 \\
321 \\
308 \\
289 \\
277 \\
272 \\
277 \\
296 \\
360 \\
464 \\
578 \\
692\end{array}$ & $\begin{array}{l}3.69 \\
3.70 \\
3.74 \\
3.73 \\
3.75 \\
4.02 \\
4.34 \\
4.27 \\
4.10 \\
3.94 \\
3.80 \\
3.67\end{array}$ & $\begin{array}{r}716 \\
724 \\
760 \\
750 \\
768 \\
1,010 \\
1,340 \\
1,260 \\
1,090 \\
938 \\
812 \\
700\end{array}$ & $\begin{array}{l}3.54 \\
3.42 \\
3.33 \\
.3 .26 \\
3.21 \\
3.16 \\
3.12 \\
3.08 \\
3.04 \\
3.02 \\
3.00 \\
2.99\end{array}$ & $\begin{array}{l}594 \\
501 \\
436 \\
487 \\
353 \\
321 \\
296 \\
272 \\
249 \\
237 \\
226 \\
221\end{array}$ & $\begin{array}{l}2.97 \\
2.97 \\
2.96 \\
2.94 \\
2.93 \\
2.92 \\
2.91 \\
2.91 \\
2.90 \\
2.90 \\
2.90 \\
2.89\end{array}$ & $\begin{array}{l}211 \\
211 \\
206 \\
195 \\
190 \\
185 \\
180 \\
180 \\
175 \\
175 \\
175 \\
170\end{array}$ & $\begin{array}{l}2.89 \\
2.89 \\
2.88 \\
2.87 \\
2.87 \\
2.86 \\
2.86 \\
2.86 \\
2.86 \\
2.84 \\
2.84 \\
2.84\end{array}$ & $\begin{array}{l}170 \\
170 \\
166 \\
161 \\
161 \\
156 \\
156 \\
156 \\
156 \\
147 \\
147 \\
147\end{array}$ & $\begin{array}{l}2.84 \\
2.84 \\
2.83 \\
2.83 \\
2.82 \\
2.82 \\
2.81 \\
2.81 \\
2.81 \\
2.81 \\
2.81 \\
2.81\end{array}$ & $\begin{array}{l}147 \\
147 \\
142 \\
142 \\
137 \\
137 \\
133 \\
133 \\
133 \\
133 \\
133 \\
133\end{array}$ \\
\hline
\end{tabular}


Gage-height, in feet, and discharge, in second-feet, at indicated time, 1938-Continued

\begin{tabular}{|c|c|c|c|c|c|c|c|c|c|c|c|c|}
\hline \multirow{2}{*}{ Hour } & Feet & Sec.-ft. & Feet & Sec.-ft. & Feet & Sec. $\mathrm{ft}$. & Feet & Sec.-ft. & Feet & Sec.-ft. & Feet & Sec.-ft. \\
\hline & \multicolumn{2}{|c|}{ July 29} & \multicolumn{2}{|c|}{ July 30} & \multicolumn{2}{|c|}{ July 31} & \multicolumn{2}{|c|}{ August 1} & \multicolumn{2}{|c|}{ August 2} & \multicolumn{2}{|c|}{ August 3} \\
\hline 2 a.m. & 2.80 & 128 & 2.77 & 117 & 2.75 & 109 & 2.74 & 104 & 2.77 & 116 & & \\
\hline & 2.80 & 128 & 2.77 & 117 & 2.75 & 109 & 2.75 & 108 & 2.75 & 108 & & \\
\hline 6 & 2.79 & 124 & 2.77 & 117 & 2.75 & 109 & 2.77 & 116 & 2.74 & 104 & & \\
\hline 8 & 2.79 & 124 & 2.76 & - 114 & 2.74 & 105 & 2.78 & 119 & 2.73 & 100 & & \\
\hline 10 & 2.78 & 120 & 2.75 & 109 & 2.74 & 105 & 2.79 & 123 & 2.72 & 97 & & \\
\hline $12 \mathrm{n}$. & 2.78 & 120 & 2.75 & 109 & 2.73 & 101 & 2.79 & 123 & 2.72 & 97 & & \\
\hline 2 p.m. & 2.77 & 117 & 2.75 & 109 & 2.73 & 101. & 2.79 & 123 & 2.72 & 97 & & \\
\hline & 2.77 & 117 & 2.75 & 109 & 2.73 & 101 & 2.79 & 123 & 2.72 & 97 & & \\
\hline 6 & 2.77 & 117 & 275 & 109 & 2.73 & 101 & 2.7 & 11 & 2.72 & 97 & & \\
\hline 8 & 2.77 & 117 & 2.75 & 109 & 2.73 & 101 & 2.77 & 116 & 2.72 & 97 & & \\
\hline & 2.77 & & 27 & 109 & 2.73 & 101 & 2.77 & 116 & 2.72 & 97 & & \\
\hline & & & & 109 & 2.73 & 101 & 2.77 & 116 & 2.72 & 97 & & \\
\hline
\end{tabular}

MATASQUAN RTVER AT SQUANKUM, N. J.

Location.-Lat. $40^{\circ} 09^{\prime} 47^{\prime \prime}$, long. $74^{\circ} 09^{\prime} 21^{\prime \prime}$, at Farmingdale-Lakewood highway bridge in Squankum, Monmouth County, half a mile downstream from Marshbog Brook.

Drainage area.-43.4 square miles.

GAGE-HEIGHT RECORD.-Water-stage recorder graph except for period 9:30 a.m. July 31 to $12: 30$ p.m. Aug. 16, Aug. 17-28, when recorder graph is missing.

STAGE-DISCHARGE RELATION.-Defined by current-meter measurements below 750 second-feet; extended to peak stage on basis of discharge determined by contracted-opening method.

Maxima.-June 1938: Discharge, 1,550 second-feet 8 a.m. June 28 (gage height, 10.09 feet).

July 1938: Discharge, 1,480 second-feet 9 p.m. July 20 (gage height, 9.96 feet).

1931 to May 1938: Discharge, 1,020 second-feet Jan. 3, 1936 (gage height, 9.22 feet).

Remarks.-Flow not affected by storage. Discharge for period of no gageheight record, July 31 to Aug. 28, computed on basis of recorded range in stage and records for Swimming River near Red Bank.

Mean discharge, in second-feet, 1938

\begin{tabular}{|c|c|c|c|c|c|c|c|c|c|c|c|}
\hline Day & June & July & Aug. & Day & June & July & - Aug. & Day & June & July & Aug. \\
\hline $\begin{array}{r}1 \\
2 \\
3 \\
4 \\
5 \\
6 \\
7 \\
8 \\
9 \\
10\end{array}$ & $\begin{array}{r}48 \\
44 \\
39 \\
39 \\
42 \\
40 \\
35 \\
37 \\
36 \\
33\end{array}$ & $\begin{array}{r}104 \\
90 \\
78 \\
70 \\
62 \\
58 \\
54 \\
52 \\
48 \\
57\end{array}$ & $\begin{array}{r}105 \\
92 \\
86 \\
78 \\
80 \\
84 \\
220 \\
580 \\
190 \\
120\end{array}$ & $\begin{array}{l}11 \\
12 \\
13 \\
14 \\
15 \\
16 \\
17 \\
18 \\
19 \\
20\end{array}$ & $\begin{array}{r}34 \\
43 \\
99 \\
147 \\
86 \\
60 \\
50 \\
44 \\
41 \\
37\end{array}$ & $\begin{array}{r}54 \\
54 \\
50 \\
58 \\
98 \\
76 \\
67 \\
75 \\
120 \\
932\end{array}$ & $\begin{array}{r}125 \\
125 \\
90 \\
74 \\
70 \\
60 \\
62 \\
64 \\
58 \\
52\end{array}$ & $\begin{array}{l}21 \\
22 \\
23 \\
24 \\
25 \\
26 \\
27 \\
28 \\
29 \\
30 \\
31\end{array}$ & $\begin{array}{r}35 \\
34 \\
38 \\
120 \\
53 \\
39 \\
364 \\
1,060 \\
380 \\
155\end{array}$ & $\begin{array}{l}826 \\
463 \\
482 \\
836 \\
515 \\
224 \\
159 \\
133 \\
114 \\
106 \\
100\end{array}$ & $\begin{array}{l}49 \\
47 \\
45 \\
43 \\
41 \\
41 \\
40 \\
42 \\
40 \\
39 \\
38\end{array}$ \\
\hline $\begin{array}{l}\text { Mon } \\
\text { Run }\end{array}$ & & & & re & & & & & $\begin{array}{r}110 \\
2.82\end{array}$ & $\begin{array}{r}200 \\
5.32\end{array}$ & $\begin{array}{l}92.9 \\
2.47\end{array}$ \\
\hline
\end{tabular}


Gage-height, in feet, and discharge, in second-feet, at indicated time, 1938

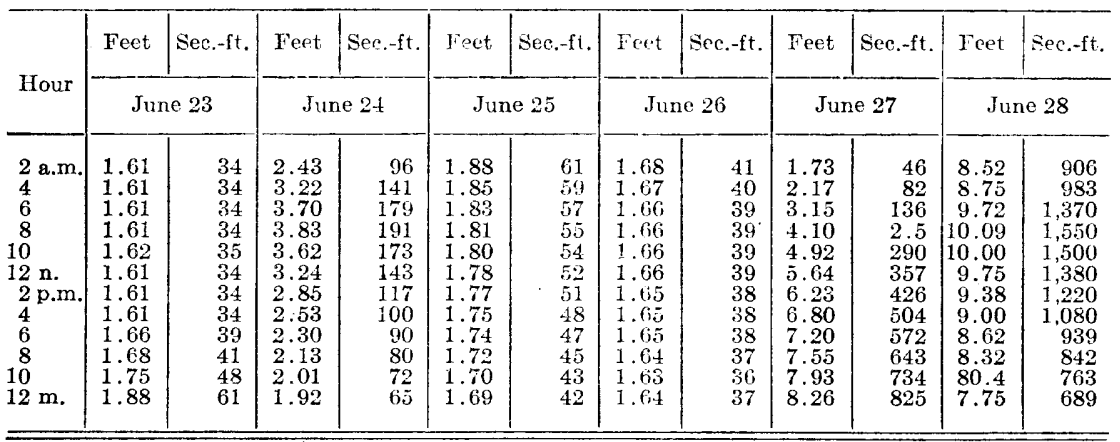

\begin{tabular}{|c|c|c|c|c|c|c|c|c|c|c|c|c|}
\hline \multirow[b]{2}{*}{$\begin{array}{c}2 \text { a.m. } \\
4 \\
6 \\
8 \\
10 \\
12 \mathrm{n.} \\
2 \mathrm{p.m} . \\
4 \\
6 \\
8 \\
10 \\
12 \mathrm{~m} .\end{array}$} & \multicolumn{2}{|c|}{ June 29} & \multicolumn{2}{|c|}{ June 30} & \multicolumn{2}{|c|}{ July 1} & \multicolumn{2}{|c|}{ July 2} & \multicolumn{2}{|c|}{ July 3} & \multicolumn{2}{|c|}{ July 4} \\
\hline & $\begin{array}{l}7.38 \\
7.00 \\
6.62 \\
6.27 \\
5.90 \\
5.58 \\
5.30 \\
5.02 \\
4.74 \\
4.50 \\
4.30 \\
4.10\end{array}$ & $\begin{array}{l}607 \\
537 \\
478 \\
431 \\
386 \\
351 \\
325 \\
300 \\
274 \\
251 \\
233 \\
215\end{array}$ & $\begin{array}{l}3.94 \\
3.80 \\
3.67 \\
3.57 \\
3.47 \\
3.37 \\
3.27 \\
3.17 \\
3.07 \\
2.98 \\
2.88 \\
2.82\end{array}$ & $\begin{array}{l}201 \\
188 \\
177 \\
169 \\
161 \\
153 \\
145 \\
138 \\
131 \\
125 \\
119 \\
115\end{array}$ & $\begin{array}{l}2.77 \\
2.72 \\
2.70 \\
2.67 \\
2.65 \\
2.62 \\
2.58 \\
2.55 \\
2.50 \\
2.45 \\
2.41 \\
2.38\end{array}$ & $\begin{array}{r}112 \\
110 \\
109 \\
108 \\
106 \\
105 \\
103 \\
102 \\
99 \\
97 \\
95 \\
94\end{array}$ & $\begin{array}{l}2.36 \\
2.35 \\
2.35 \\
2.35 \\
2.35 \\
2.34 \\
2.32 \\
2.29 \\
2.26 \\
2.24 \\
2.22 \\
2.20\end{array}$ & $\begin{array}{l}93 \\
92 \\
92 \\
92 \\
92 \\
92 \\
91 \\
89 \\
88 \\
86 \\
85 \\
84\end{array}$ & $\begin{array}{l}2.19 \\
2.18 \\
2.17 \\
2.17 \\
2.16 \\
2.15 \\
2.13 \\
2.10 \\
2.07 \\
2.05 \\
2.03 \\
2.02\end{array}$ & $\begin{array}{l}83 \\
83 \\
82 \\
82 \\
82 \\
81 \\
80 \\
78 \\
76 \\
74 \\
73 \\
72\end{array}$ & 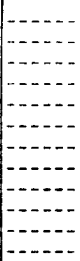 & 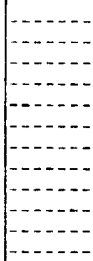 \\
\hline
\end{tabular}

Gage-height, in feet, and discharge, in second-feet, at indicated time, 1938

\begin{tabular}{|c|c|c|c|c|c|c|c|c|c|c|c|c|}
\hline \multirow{2}{*}{ Hour } & Feet & Sec.-ft. & Feet & Sec.-ft. & Feet & Sec.-ft. & Feet & Sec.-ft. & Feet & Sec, $-\mathrm{ft}$. & Feet & Sec.-ft. \\
\hline & \multicolumn{2}{|c|}{ July 17} & \multicolumn{2}{|c|}{ July 18} & \multicolumn{2}{|c|}{ July 19} & \multicolumn{2}{|c|}{ July 20} & \multicolumn{2}{|c|}{ July 21} & \multicolumn{2}{|c|}{ July 22} \\
\hline $\begin{array}{c}2 \text { a.m. } \\
4 \\
6 \\
8 \\
10 \\
12 \mathrm{n} . \\
2 \mathrm{p} . \mathrm{m} . \\
4 \\
6 \\
8 \\
10 \\
12 \mathrm{~m} .\end{array}$ & $\begin{array}{l}1.84 \\
1.83 \\
1.82 \\
1.82 \\
1.81 \\
1.80 \\
1.83 \\
1.95 \\
2.15 \\
2.22 \\
2.25 \\
2.32\end{array}$ & $\begin{array}{l}58 \\
57 \\
56 \\
56 \\
55 \\
54 \\
57 \\
67 \\
81 \\
85 \\
87 \\
91\end{array}$ & $\begin{array}{l}2.35 \\
2.30 \\
2.18 \\
2.07 \\
2.00 \\
1.96 \\
1.94 \\
1.91 \\
1.91 \\
1.95 \\
1.98 \\
2.00\end{array}$ & $\begin{array}{l}92 \\
90 \\
83 \\
76 \\
71 \\
68 \\
66 \\
64 \\
64 \\
67 \\
70 \\
71\end{array}$ & $\begin{array}{l}2.01 \\
2.02 \\
2.00 \\
1.98 \\
1.96 \\
1.94 \\
1.93 \\
1.96 \\
3.53 \\
4.43 \\
4.75 \\
5.00\end{array}$ & $\begin{array}{r}72 \\
72 \\
71 \\
70 \\
68 \\
66 \\
66 \\
68 \\
165 \\
245 \\
274 \\
248\end{array}$ & $\begin{array}{l}5.40 \\
5.95 \\
6.70 \\
7.57 \\
8.35 \\
8.90 \\
9.27 \\
9.52 \\
9.75 \\
9.93 \\
9.94 \\
9.80\end{array}$ & $\begin{array}{r}335 \\
392 \\
489 \\
647 \\
852 \\
1,040 \\
1,180 \\
1,290 \\
1,380 \\
1,460 \\
1,470 \\
1,410\end{array}$ & $\begin{array}{l}9.55 \\
9.24 \\
8.90 \\
8.58 \\
8.32 \\
8.06 \\
7.80 \\
7.54 \\
7.34 \\
7.16 \\
7.03 \\
6.87\end{array}$ & $\begin{array}{r}1,300 \\
1,170 \\
1,040 \\
925 \\
842 \\
768 \\
701 \\
641 \\
599 \\
565 \\
542 \\
515\end{array}$ & $\begin{array}{l}6.69 \\
6.42 \\
6.10 \\
5.70 \\
5.40 \\
5.50 \\
6.37 \\
6.85 \\
7.06 \\
7.14 \\
7.14 \\
7.11\end{array}$ & $\begin{array}{l}488 \\
451 \\
410 \\
363 \\
335 \\
352 \\
444 \\
512 \\
547 \\
561 \\
561 \\
556\end{array}$ \\
\hline & \multicolumn{2}{|c|}{ July 23} & \multicolumn{2}{|c|}{ July 24} & \multicolumn{2}{|c|}{ July 25} & \multicolumn{2}{|c|}{ July 26} & \multicolumn{2}{|c|}{ July 27} & \multicolumn{2}{|c|}{ July 28} \\
\hline $\begin{array}{c}2 \text { a.m. } \\
4 \\
6 \\
8 \\
10 \\
12 \mathrm{n} . \\
2 \mathrm{p} . \mathrm{m} . \\
4 \\
6 \\
8 \\
10 \\
12 \mathrm{~m} .\end{array}$ & $\begin{array}{l}7.03 \\
6.90 \\
6.67 \\
6.40 \\
6.08 \\
5.75 \\
5.67 \\
6.04 \\
6.70 \\
7.27 \\
7.64 \\
7.80\end{array}$ & $\begin{array}{l}542 \\
520 \\
485 \\
448 \\
408 \\
368 \\
360 \\
403 \\
489 \\
585 \\
663 \\
701\end{array}$ & $\begin{array}{l}7.82 \\
7.80 \\
7.87 \\
8.00 \\
8.10 \\
8.15 \\
8.22 \\
8.45 \\
8.87 \\
9.08 \\
9.00 \\
8.75\end{array}$ & $\begin{array}{r}706 \\
701 \\
718 \\
752 \\
779 \\
793 \\
813 \\
883 \\
1,030 \\
1,100 \\
1,080 \\
983\end{array}$ & $\begin{array}{l}8.45 \\
8.14 \\
7.80 \\
7.35 \\
6.88 \\
6.48 \\
6.13 \\
5.82 \\
5.55 \\
5.33 \\
5.14 \\
4.92\end{array}$ & $\begin{array}{l}883 \\
790 \\
701 \\
601 \\
517 \\
458 \\
414 \\
376 \\
348 \\
328 \\
311 \\
290\end{array}$ & $\begin{array}{l}4.74 \\
4.60 \\
4.48 \\
4.37 \\
4.30 \\
4.20 \\
4.11 \\
4.01 \\
3.91 \\
3.82 \\
3.74 \\
3.68\end{array}$ & $\begin{array}{l}274 \\
261 \\
249 \\
239 \\
233 \\
224 \\
216 \\
207 \\
198 \\
190 \\
183 \\
177\end{array}$ & $\begin{array}{l}3.64 \\
3.61 \\
3.58 \\
3.55 \\
3.51 \\
3.48 \\
3.45 \\
3.41 \\
3.36 \\
3.30 \\
3.26 \\
3.21\end{array}$ & $\begin{array}{l}174 \\
172 \\
169 \\
167 \\
164 \\
161 \\
159 \\
156 \\
152 \\
147 \\
144 \\
141\end{array}$ & $\begin{array}{l}3.19 \\
3.18 \\
3.16 \\
3.15 \\
3.14 \\
3.13 \\
3.10 \\
3.08 \\
3.03 \\
3.00 \\
2.93 \\
2.90\end{array}$ & $\begin{array}{l}139 \\
139 \\
137 \\
136 \\
136 \\
135 \\
133 \\
132 \\
128 \\
126 \\
122 \\
120\end{array}$ \\
\hline
\end{tabular}

TOMS RIVER NEAR TOMS RIVIR, N. J.

Location.-Lat. $39^{\circ} 59^{\prime} 10^{\prime \prime}$, long. $74^{\circ} 13^{\prime} 29^{\prime \prime}, 1$ mile downstream from Union Branch and $2 \frac{1}{2}$ miles northwest of village of Toms River, Ocean County. 
Datum of gage is 8.10 feet above mean sea level (general adjustment of 1929).

Drainage area.-124 square miles.

GAGE-HEIGHT RECORD.-Water-stage recorder graph except for period 1 p.m. June 29 to 3 a.m. June 30 when record was computed on basis of shape of available recorder graph.

StAGE-DISCHARGE RELATION.-Defined by current-meter measurements below 610 second-feet; extended to peak stage by logarithmic plotting.

Maxima.-June 1938: Discharge, 1,240 second-feet 4 to 5 p.m. June 29 (gage height, 11.1 feet).

July 1938: Discharge, 1,050 second-feet 2 a.m. July 26 (gage height, 10.15 feet).

1928 to May 1938: Discharge, 851 second-feet April 18, 1929 (gage height, 8.95 feet).

Mean discharge, in second-feet, 1938

\begin{tabular}{|c|c|c|c|c|c|c|c|c|c|c|c|}
\hline Day & June & July & Aug. & Day & June & July & Aug. & Day & June & July & Aug. \\
\hline $\begin{array}{r}1 \\
2 \\
3 \\
4 \\
5 \\
6 \\
7 \\
8 \\
9 \\
10\end{array}$ & $\begin{array}{l}210 \\
198 \\
192 \\
174 \\
174 \\
186 \\
186 \\
174 \\
167 \\
158\end{array}$ & $\begin{array}{l}698 \\
514 \\
389 \\
317 \\
282 \\
247 \\
222 \\
204 \\
192 \\
180\end{array}$ & $\begin{array}{l}317 \\
287 \\
282 \\
270 \\
270 \\
287 \\
339 \\
486 \\
647 \\
572\end{array}$ & $\begin{array}{l}11 \\
12 \\
13 \\
14 \\
15 \\
16 \\
17 \\
18 \\
19 \\
20\end{array}$ & $\begin{array}{l}157 \\
180 \\
210 \\
282 \\
351 \\
389 \\
351 \\
276 \\
229 \\
210\end{array}$ & $\begin{array}{l}180 \\
186 \\
180 \\
186 \\
229 \\
241 \\
265 \\
328 \\
339 \\
377\end{array}$ & $\begin{array}{l}472 \\
363 \\
317 \\
282 \\
253 \\
235 \\
229 \\
229 \\
229 \\
216\end{array}$ & $\begin{array}{l}21 \\
22 \\
23 \\
24 \\
25 \\
26 \\
27 \\
28 \\
29 \\
30 \\
31\end{array}$ & $\begin{array}{r}186 \\
158 \\
156 \\
186 \\
222 \\
259 \\
282 \\
432 \\
1,080 \\
1,030\end{array}$ & $\begin{array}{r}514 \\
881 \\
902 \\
953 \\
1,010 \\
989 \\
771 \\
587 \\
486 \\
416 \\
351\end{array}$ & $\begin{array}{l}204 \\
192 \\
186 \\
180 \\
174 \\
174 \\
168 \\
166 \\
162 \\
159 \\
156\end{array}$ \\
\hline \multicolumn{9}{|c|}{$\begin{array}{l}\text { Monthly mean discharge, in second-feet } \\
\text { Runoff, in inches }\end{array}$} & $\begin{array}{r}282 \\
2.53\end{array}$ & $\begin{array}{r}439 \\
4.08\end{array}$ & $\begin{array}{r}274 \\
2.55\end{array}$ \\
\hline
\end{tabular}

Gage-height, in feet, and discharge, in second-feet, at indicated time, 1938

\begin{tabular}{|c|c|c|c|c|c|c|c|c|c|c|c|c|}
\hline \multirow{2}{*}{ Hour } & Feet & Sec.-ft. & Feet & Sec.-ft. & Feet & Sec.-ft. & Feet & Sec.-ft. & Feet & Sec.-ft. & Feet & Sec.-ft. \\
\hline & \multicolumn{2}{|c|}{ June 23} & \multicolumn{2}{|c|}{ June 24} & \multicolumn{2}{|c|}{ June 25} & \multicolumn{2}{|c|}{ June 26} & \multicolumn{2}{|c|}{ June 27} & \multicolumn{2}{|c|}{ June 28} \\
\hline $\begin{array}{l}2 \mathrm{a} . \mathrm{m} . \\
4 \\
6 \\
8 \\
10 \\
12 \mathrm{n} . \\
2 \mathrm{p} . \mathrm{m} . \\
4 \\
6 \\
8 \\
10 \\
12 \mathrm{~m} .\end{array}$ & $\begin{array}{l}3.90 \\
3.89 \\
3.89 \\
3.88 \\
3.87 \\
3.87 \\
3.86 \\
3.85 \\
3.87 \\
3.89 \\
3.91 \\
3.97\end{array}$ & $\begin{array}{l}157 \\
156 \\
156 \\
155 \\
154 \\
154 \\
153 \\
152 \\
154 \\
156 \\
158 \\
165\end{array}$ & $\begin{array}{l}4.05 \\
4.13 \\
4.18 \\
4.22 \\
4.23 \\
4.24 \\
4.23 \\
4.20 \\
4.18 \\
4.17 \\
4.17 \\
4.17\end{array}$ & $\begin{array}{l}174 \\
184 \\
190 \\
194 \\
196 \\
197 \\
196 \\
192 \\
190 \\
188 \\
188 \\
188\end{array}$ & $\begin{array}{l}4.20 \\
4.23 \\
4.28 \\
4.35 \\
4.42 \\
4.48 \\
4.52 \\
4.57 \\
4.60 \\
4.63 \\
4.65 \\
4.68\end{array}$ & $\begin{array}{l}192 \\
196 \\
202 \\
210 \\
219 \\
226 \\
231 \\
237 \\
241 \\
245 \\
247 \\
251\end{array}$ & $\begin{array}{l}4.69 \\
4.71 \\
4.72 \\
4.73 \\
4.74 \\
4.75 \\
4.75 \\
4.75 \\
4.75 \\
4.75 \\
4.75 \\
4.74\end{array}$ & $\begin{array}{l}252 \\
254 \\
255 \\
257 \\
258 \\
259 \\
259 \\
259 \\
259 \\
259 \\
259 \\
258\end{array}$ & $\begin{array}{l}4.74 \\
4.76 \\
4.76 \\
4.78 \\
4.83 \\
4.95 \\
5.05 \\
5.07 \\
5.08 \\
5.15 \\
5.24 \\
5.37\end{array}$ & $\begin{array}{l}258 \\
260 \\
260 \\
263 \\
268 \\
282 \\
292 \\
294 \\
295 \\
302 \\
311 \\
325\end{array}$ & $\begin{array}{l}5.48 \\
5.57 \\
5.65 \\
5.75 \\
5.85 \\
5.97 \\
6.13 \\
6.34 \\
6.56 \\
6.91 \\
7.41 \\
8.00\end{array}$ & $\begin{array}{l}337 \\
347 \\
357 \\
370 \\
382 \\
398 \\
420 \\
450 \\
480 \\
529 \\
604 \\
692\end{array}$ \\
\hline & \multicolumn{2}{|c|}{ June 29} & \multicolumn{2}{|c|}{ June 30} & \multicolumn{2}{|c|}{ July 1} & \multicolumn{2}{|c|}{ July 2} & \multicolumn{2}{|c|}{ July 3} & \multicolumn{2}{|c|}{ July 4} \\
\hline $\begin{array}{l}2 \mathrm{a} . \mathrm{m} . \\
4 \\
6 \\
8 \\
10 \\
12 \mathrm{n} . \\
2 \mathrm{p} . \mathrm{m} . \\
4 \\
6 \\
8 \\
10 \\
12 \mathrm{~m} .\end{array}$ & $\begin{array}{r}8.57 \\
9.05 \\
9.55 \\
10.02 \\
10.44 \\
10.70 \\
11.02 \\
11.1 \\
11.09 \\
11.05 \\
10.98 \\
10.88\end{array}$ & $\begin{array}{r}782 \\
860 \\
944 \\
1,030 \\
1,110 \\
1,160 \\
1,220 \\
1,240 \\
1,230 \\
1,230 \\
1,220 \\
1,200\end{array}$ & $\begin{array}{r}10.78 \\
10.67 \\
10.57 \\
10.45 \\
10.30 \\
10.10 \\
9.88 \\
9.69 \\
9.48 \\
9.29 \\
9.10 \\
8.94\end{array}$ & $\begin{array}{r}1,180 \\
1,150 \\
1,130 \\
1,110 \\
1,080 \\
1,040 \\
1,010 \\
970 \\
933 \\
900 \\
868 \\
841\end{array}$ & $\begin{array}{l}8.74 \\
8.58 \\
8.43 \\
8.28 \\
8.14 \\
8.00 \\
7.85 \\
7.72 \\
7.58 \\
7.46 \\
7.34 \\
7.24\end{array}$ & $\begin{array}{l}809 \\
784 \\
760 \\
736 \\
713 \\
692 \\
670 \\
650 \\
629 \\
611 \\
593 \\
578\end{array}$ & $\begin{array}{l}7.14 \\
7.05 \\
6.96 \\
6.88 \\
6.80 \\
6.74 \\
6.65 \\
6.59 \\
6.52 \\
6.45 \\
6.39 \\
6.32\end{array}$ & $\begin{array}{l}563 \\
550 \\
536 \\
525 \\
514 \\
506 \\
493 \\
485 \\
475 \\
465 \\
457 \\
447\end{array}$ & $\begin{array}{l}6.26 \\
6.19 \\
6.13 \\
6.06 \\
5.99 \\
5.92 \\
5.86 \\
5.79 \\
5.73 \\
5.66 \\
5.60 \\
5.54\end{array}$ & $\begin{array}{l}438 \\
429 \\
420 \\
410 \\
401 \\
392 \\
384 \\
375 \\
367 \\
358 \\
351 \\
344\end{array}$ & $\begin{array}{l}5.49 \\
5.44 \\
5.40 \\
5.37 \\
5.32 \\
5.28 \\
5.25 \\
5.23 \\
5.19 \\
5.17 \\
5.13 \\
5.10\end{array}$ & $\begin{array}{l}338 \\
332 \\
328 \\
325 \\
319 \\
315 \\
312 \\
310 \\
306 \\
304 \\
300 \\
297\end{array}$ \\
\hline
\end{tabular}


Gage-height, in feet, and discharge, in second-feet, at indicated time, 1938

\begin{tabular}{|c|c|c|c|c|c|c|c|c|c|c|c|c|}
\hline \multirow{2}{*}{ Hour } & Feet & Ser.eft. & Feet & Sec.-ft. & Feet & Sec-ft. & Feet & Sec. $-\mathrm{ft}$. & Feet & Sec, $-\mathrm{ft}$. & Feet & Sec. $-\mathrm{ft}$. \\
\hline & \multicolumn{2}{|c|}{ July 17} & \multicolumn{2}{|c|}{ July 18} & \multicolumn{2}{|c|}{ July 19} & \multicolumn{2}{|c|}{ July 19} & \multicolumn{2}{|c|}{ July 21} & \multicolumn{2}{|c|}{ July 22} \\
\hline $\begin{array}{c}2 \mathrm{a} . \mathrm{m} . \\
4 \\
6 \\
8 \\
10 \\
12 \mathrm{n} . \\
2 \mathrm{p} . \mathrm{m} . \\
4 \\
6 \\
8 \\
10 \\
12 \mathrm{~m} .\end{array}$ & $\begin{array}{l}4.60 \\
4.60 \\
4.59 \\
4.58 \\
4.57 \\
4.56 \\
4.75 \\
5.10 \\
5.20 \\
5.21 \\
5.20 \\
5.19\end{array}$ & $\begin{array}{l}241 \\
241 \\
240 \\
239 \\
237 \\
236 \\
259 \\
297 \\
307 \\
308 \\
307 \\
306\end{array}$ & $\begin{array}{l}5.18 \\
5.20 \\
5.23 \\
5.28 \\
5.33 \\
5.39 \\
5.45 \\
5.50 \\
5.61 \\
5.70 \\
5.73 \\
5.72\end{array}$ & $\begin{array}{l}305 \\
307 \\
310 \\
315 \\
320 \\
327 \\
334 \\
339 \\
352 \\
363 \\
367 \\
366\end{array}$ & $\begin{array}{l}5.69 \\
5.65 \\
5.60 \\
5.56 \\
5.52 \\
5.49 \\
5.45 \\
5.42 \\
5.45 \\
5.48 \\
5.47 \\
5.44\end{array}$ & $\begin{array}{l}362 \\
357 \\
351 \\
346 \\
341 \\
338 \\
334 \\
330 \\
334 \\
337 \\
336 \\
332\end{array}$ & $\begin{array}{l}5.42 \\
5.40 \\
5.46 \\
5.49 \\
5.51 \\
5.55 \\
5.84 \\
6.04 \\
6.19 \\
6.27 \\
6.34 \\
6.40\end{array}$ & $\begin{array}{l}330 \\
328 \\
335 \\
338 \\
340 \\
345 \\
381 \\
408 \\
429 \\
440 \\
450 \\
458\end{array}$ & $\begin{array}{l}6.47 \\
6.52 \\
6.58 \\
6.63 \\
6.69 \\
6.74 \\
6.80 \\
6.96 \\
7.08 \\
7.20 \\
7.40 \\
7.73\end{array}$ & $\begin{array}{l}468 \\
475 \\
483 \\
490 \\
499 \\
506 \\
514 \\
536 \\
554 \\
572 \\
602 \\
652\end{array}$ & $\begin{array}{l}8.16 \\
8.53 \\
8.80 \\
9.02 \\
9.18 \\
9.40 \\
9.55 \\
9.62 \\
9.65 \\
9.64 \\
9.60 \\
9.55\end{array}$ & $\begin{array}{l}717 \\
776 \\
819 \\
854 \\
882 \\
919 \\
944 \\
957 \\
962 \\
960 \\
953 \\
944\end{array}$ \\
\hline $12 \mathrm{~m}$ & \multicolumn{2}{|c|}{ July 23} & \multicolumn{2}{|c|}{ July 24} & \multicolumn{2}{|c|}{ July 25} & \multicolumn{2}{|c|}{ July 26} & \multicolumn{2}{|c|}{ July 27} & \multicolumn{2}{|c|}{ July 28} \\
\hline $\begin{array}{c}2 \mathrm{a} . \mathrm{m} . \\
4 \\
6 \\
8 \\
10 \\
12 \mathrm{n} . \\
2 \mathrm{p} . \mathrm{m} . \\
4 \\
6 \\
8 \\
10 \\
12 \mathrm{~m} .\end{array}$ & $\begin{array}{l}9.48 \\
9.43 \\
9.37 \\
9.32 \\
9.28 \\
9.26 \\
9.23 \\
9.21 \\
9.20 \\
9.33 \\
9.37 \\
9.40\end{array}$ & $\begin{array}{l}933 \\
924 \\
914 \\
905 \\
899 \\
895 \\
890 \\
887 \\
885 \\
907 \\
914 \\
919\end{array}$ & $\begin{array}{l}9.43 \\
9.44 \\
9.45 \\
9.47 \\
9.53 \\
9.58 \\
9.63 \\
9.68 \\
9.70 \\
9.74 \\
9.75 \\
9.75\end{array}$ & $\begin{array}{l}924 \\
926 \\
928 \\
931 \\
941 \\
950 \\
958 \\
967 \\
971 \\
978 \\
980 \\
980\end{array}$ & $\begin{array}{r}9.76 \\
9.77 \\
9.78 \\
9.80 \\
9.83 \\
9.86 \\
9.90 \\
9.95 \\
10.02 \\
10.07 \\
10.11 \\
10.14\end{array}$ & $\begin{array}{r}982 \\
984 \\
985 \\
989 \\
995 \\
1,000 \\
1,010 \\
1,020 \\
1,030 \\
1,040 \\
1,040 \\
1,050\end{array}$ & $\begin{array}{r}10.15 \\
10.14 \\
10.11 \\
10.08 \\
10.03 \\
9.95 \\
9.86 \\
9.75 \\
9.65 \\
9.50 \\
9.38 \\
9.25\end{array}$ & $\begin{array}{r}1,050 \\
1,050 \\
1,040 \\
1,040 \\
1,030 \\
1,020 \\
1,000 \\
980 \\
962 \\
936 \\
916 \\
894\end{array}$ & $\begin{array}{l}9.13 \\
8.98 \\
8.85 \\
8.72 \\
8.60 \\
8.46 \\
8.34 \\
8.21 \\
8.11 \\
8.05 \\
7.94 \\
7.83\end{array}$ & $\begin{array}{l}873 \\
848 \\
827 \\
806 \\
787 \\
765 \\
745 \\
725 \\
709 \\
700 \\
683 \\
666\end{array}$ & $\begin{array}{l}7.73 \\
7.63 \\
7.53 \\
7.45 \\
7.37 \\
7.29 \\
7.23 \\
7.16 \\
7.09 \\
7.03 \\
6.97 \\
6.91\end{array}$ & $\begin{array}{l}652 \\
636 \\
622 \\
610 \\
598 \\
586 \\
576 \\
566 \\
556 \\
546 \\
538 \\
529\end{array}$ \\
\hline
\end{tabular}

CHDAR CIFET AT IANOKA marBor, N. J.

LOCATION.-Lat. $39^{\circ} 52^{\prime} 05^{\prime \prime}$, long. $74^{\circ} 10^{\prime} 06^{\prime \prime}$, at highway bridge in village of Lanoka Harbor, Ocean County. Datum of gage is at mean sea level (New Jersey Geological Survey bench mark).

Drainage area.- 56.0 square miles.

GAGE-HEIGHT RECORD.-Water-stage recorder graph.

STAGE-Discharge RELATION.-Defined by current-meter measurements below 350 second-feet.

Maxima.-June 1938: Discharge, 248 second-feet 7 to 10 p.m. June 28; gage height, 3.52 feet 1 to 2 a.m. June 29 .

July 1938: Discharge, 367 second-feet 3 a.m. to 1 p.m. July 25 (gage height, 4.12 feet).

1932 to May 1938: Gage height, 6.45 feet Feb. 16, 1936 (discharge not determined).

Remarks.-High tides cause backwater at this station for medium and high stages of the creek. During these periods the discharges are computed on basis of an effective gage-height graph determined by estimating a curve between the parts of the recorder graph which are not affected by tide. Shifting-control method was used June 7 and thereafter for discharges below 134 second-feet. 
Mean discharge, in second-feet, 1938

\begin{tabular}{r|r|r|r|r|r|r|r|r|r|r|r}
\hline Day & June & July & Aug. & Day & June & July & Aur. & Day & June & July & Aug. \\
\cline { 3 - 9 } 1 & 36 & 182 & 182 & 11 & 70 & 70 & 322 & 21 & 72 & 340 & 150 \\
2 & 36 & 139 & 168 & 12 & 70 & 82 & 244 & 22 & 68 & 352 & 146 \\
3 & 88 & 108 & 154 & 13 & 80 & 85 & 206 & 23 & 68 & 352 & 139 \\
4 & 184 & 99 & 148 & 14 & 99 & 85 & 182 & 24 & 65 & 341 & 129 \\
5 & 102 & 88 & 163 & 15 & 94 & 88 & 171 & 25 & 65 & 362 & 126 \\
6 & 96 & 82 & 251 & 16 & 108 & 94 & 162 & 26 & 63 & 311 & 126 \\
7 & 88 & 78 & 324 & 17 & 94 & 88 & 160 & 27 & 80 & 284 & 123 \\
8 & 82 & 91 & 409 & 18 & 85 & 94 & 168 & 28 & 220 & 244 & 123 \\
9 & 78 & 99 & 447 & 19 & 78 & 148 & 164 & 29 & 230 & 206 & 120 \\
10 & 72 & 75 & 434 & 20 & 72 & 203 & 156 & 30 & 217 & .189 & 117 \\
&
\end{tabular}

Gage-height, in feet, and discharge, in second-feet, at indicated time, 1938

\begin{tabular}{|c|c|c|c|c|c|c|c|c|c|c|c|c|}
\hline \multirow{2}{*}{ Hour } & Feet & Sec.-ft. & Feet & Sec.-ft. & Feet & Sec.-ft. & Feet & Sec.-ft. & Feet & Sec.-ft. & Feet & Sec.-ft. \\
\hline & \multicolumn{2}{|c|}{ June 23} & \multicolumn{2}{|c|}{ June 24} & \multicolumn{2}{|c|}{ June 25} & \multicolumn{2}{|c|}{ June 26} & \multicolumn{2}{|c|}{ June 27} & \multicolumn{2}{|c|}{ June 28} \\
\hline \multirow[t]{2}{*}{$\begin{array}{c}2 \mathrm{a} . \mathrm{m} . \\
4 \\
6 \\
8 \\
10 \\
12 \mathrm{n} . \\
2 \mathrm{p.m} . \\
4 \\
6 \\
8 \\
10 \\
12 \mathrm{~m} .\end{array}$} & & & & & & & & & $\begin{array}{l}2.44 \\
2.44 \\
2.44 \\
2.44 \\
2.46 \\
2.48 \\
2.50 \\
2.50 \\
2.52 \\
2.64 \\
2.73 \\
2.88\end{array}$ & $\begin{array}{r}60 \\
60 \\
60 \\
60 \\
63 \\
65 \\
68 \\
75 \\
80 \\
114 \\
144 \\
164\end{array}$ & $\begin{array}{l}2.93 \\
2.97 \\
3.05 \\
3.17 \\
3.30 \\
3.40 \\
3.44 \\
3.45 \\
3.47 \\
3.48 \\
3.50 \\
3.51\end{array}$ & $\begin{array}{l}177 \\
185 \\
194 \\
207 \\
219 \\
228 \\
236 \\
242 \\
246 \\
248 \\
248 \\
246\end{array}$ \\
\hline & \multicolumn{2}{|c|}{ June 29} & \multicolumn{2}{|c|}{ June 30} & \multicolumn{2}{|c|}{ July 1} & \multicolumn{2}{|c|}{ July 2} & \multicolumn{2}{|c|}{ July 3} & \multicolumn{2}{|c|}{ July 4} \\
\hline $\begin{array}{l}2 \mathrm{a} . \mathrm{m} . \\
4 \\
6 \\
8 \\
10 \\
12 \mathrm{n} . \\
2 \mathrm{p} . \mathrm{m} . \\
4 \\
6 \\
8 \\
10 \\
12 \mathrm{~m} .\end{array}$ & $\begin{array}{l}3.52 \\
3.45 \\
3.40 \\
3.38 \\
3.38 \\
3.39 \\
3.39 \\
3.34 \\
3.29 \\
3.27 \\
3.28 \\
3.35\end{array}$ & $\begin{array}{l}244 \\
239 \\
235 \\
232 \\
230 \\
227 \\
224 \\
223 \\
221 \\
219 \\
219 \\
221\end{array}$ & $\begin{array}{l}3.35 \\
3.34 \\
3.31 \\
3.29 \\
3.30 \\
3.31 \\
3.30 \\
3.26 \\
3.22 \\
3.19 \\
3.19 \\
3.19\end{array}$ & $\begin{array}{l}221 \\
221 \\
222 \\
222 \\
221 \\
219 \\
217 \\
215 \\
212 \\
209 \\
206 \\
202\end{array}$ & $\begin{array}{l}3.19 \\
3.13 \\
3.07 \\
3.02 \\
3.00 \\
3.00 \\
3.00 \\
2.96 \\
2.92 \\
2.89 \\
2.88 \\
2.88\end{array}$ & $\begin{array}{l}199 \\
196 \\
193 \\
191 \\
188 \\
185 \\
182 \\
180 \\
177 \\
174 \\
171 \\
168\end{array}$ & $\begin{array}{l}2.89 \\
2.86 \\
2.79 \\
2.74 \\
2.71 \\
2.69 \\
2.67 \\
2.65 \\
2.64 \\
2.63 \\
2.63 \\
2.63\end{array}$ & $\begin{array}{l}164 \\
158 \\
152 \\
146 \\
139 \\
129 \\
123 \\
117 \\
114 \\
111 \\
111 \\
111\end{array}$ & $\begin{array}{l}2.63 \\
2.63 \\
2.63 \\
2.63 \\
2.63 \\
2.62 \\
2.62 \\
2.62 \\
2.62 \\
2.61 \\
2.61 \\
2.60\end{array}$ & $\begin{array}{l}111 \\
111 \\
111 \\
111 \\
111 \\
108 \\
108 \\
108 \\
108 \\
105 \\
105 \\
102\end{array}$ & $\begin{array}{l}2.60 \\
2.60 \\
2.60 \\
2.60 \\
2.59 \\
2.59 \\
2.58 \\
2.58 \\
2.58 \\
2.57 \\
2.57 \\
2.57\end{array}$ & $\begin{array}{r}102 \\
102 \\
102 \\
102 \\
99 \\
99 \\
96 \\
96 \\
96 \\
94 \\
94 \\
94\end{array}$ \\
\hline & \multicolumn{2}{|c|}{ July 5} & \multicolumn{2}{|c|}{ July 6} & \multicolumn{2}{|c|}{ July 7} & \multicolumn{2}{|c|}{ July 8} & \multicolumn{2}{|c|}{ July 9} & \multicolumn{2}{|c|}{ July 10} \\
\hline $\begin{array}{l}2 \mathrm{a} . \mathrm{m} . \\
4 \\
6 \\
8 \\
10 \\
12 \mathrm{n} . \\
2 \mathrm{p.m} . \\
4 \\
6 \\
8 \\
10 \\
12 \mathrm{~m} .\end{array}$ & $\begin{array}{l}2.56 \\
2.56 \\
2.56 \\
2.55 \\
2.55 \\
2.54 \\
2.54 \\
2.54 \\
2.54 \\
2.54 \\
2.54 \\
2.54\end{array}$ & $\begin{array}{l}91 \\
91 \\
91 \\
88 \\
88 \\
85 \\
85 \\
85 \\
85 \\
85 \\
85 \\
85\end{array}$ & $\begin{array}{l}2.54 \\
2.54 \\
2.53 \\
2.53 \\
2.53 \\
2.53 \\
2.53 \\
2.52 \\
2.52 \\
2.52 \\
2.52 \\
2.52\end{array}$ & $\begin{array}{l}85 \\
85 \\
82 \\
82 \\
82 \\
82 \\
82 \\
80 \\
80 \\
80 \\
80 \\
80\end{array}$ & $\begin{array}{l}2.52 \\
2.52 \\
2.52 \\
2.52 \\
2.52 \\
2.52 \\
2.52 \\
2.52 \\
2.51 \\
2.51 \\
2.51 \\
2.51\end{array}$ & $\begin{array}{l}80 \\
80 \\
80 \\
80 \\
80 \\
80 \\
80 \\
80 \\
78 \\
78 \\
78 \\
78\end{array}$ & $\begin{array}{l}2.51 \\
2.51 \\
2.52 \\
2.53 \\
2.54 \\
2.55 \\
2.57 \\
2.58 \\
2.60 \\
2.62 \\
2.63 \\
2.64\end{array}$ & $\begin{array}{r}78 \\
78 \\
80 \\
82 \\
85 \\
88 \\
94 \\
96 \\
102 \\
108 \\
111 \\
114\end{array}$ & $\begin{array}{l}2.65 \\
2.65 \\
2.65 \\
2.64 \\
2.62 \\
2.59 \\
2.57 \\
2.56 \\
2.55 \\
2.54 \\
2.53 \\
2.52\end{array}$ & $\begin{array}{r}117 \\
117 \\
117 \\
114 \\
108 \\
99 \\
94 \\
91 \\
88 \\
85 \\
82 \\
80\end{array}$ & 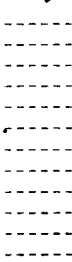 & 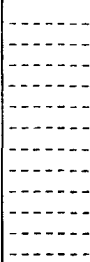 \\
\hline
\end{tabular}


Gage-height, in feet, and discharge, in second-feet, at indicated time, 1938

\begin{tabular}{|c|c|c|c|c|c|c|c|c|c|c|c|c|}
\hline \multirow{2}{*}{ Hour } & Feet & Sec.ft. & Feet & Sec-ft. & Feet & Sec. $f t$. & Feet & Sec.-ft. & Feet & See, $f \mathrm{t}$. & Feet & Sec.-ft. \\
\hline & \multicolumn{2}{|c|}{ July 17} & \multicolumn{2}{|c|}{ July 18} & \multicolumn{2}{|c|}{ July 19} & \multicolumn{2}{|c|}{ July 20} & \multicolumn{2}{|c|}{ July 21} & \multicolumn{2}{|c|}{ July 22} \\
\hline $\begin{array}{c}2 \mathrm{a} . \mathrm{m} . \\
4 \\
6 \\
8 \\
10 \\
12 \mathrm{n} . \\
2 \mathrm{p.m} . \\
4 \\
6 \\
8 \\
10 \\
12 \mathrm{~m} .\end{array}$ & & & $\begin{array}{l}2.54 \\
2.54 \\
2.54 \\
2.54 \\
2.54 \\
2.54 \\
2.54 \\
2.55 \\
2.62 \\
2.64 \\
2.66 \\
2.68\end{array}$ & $\begin{array}{r}85 \\
85 \\
85 \\
85 \\
85 \\
85 \\
85 \\
88 \\
108 \\
111 \\
120 \\
126\end{array}$ & $\begin{array}{l}2.70 \\
2.71 \\
2.72 \\
2.73 \\
2.74 \\
2.76 \\
2.78 \\
2.80 \\
2.80 \\
2.80 \\
2.81 \\
2.83\end{array}$ & $\begin{array}{l}136 \\
139 \\
141 \\
144 \\
146 \\
148 \\
150 \\
152 \\
156 \\
158 \\
160 \\
164\end{array}$ & $\begin{array}{l}2.86 \\
2.90 \\
2.93 \\
2.95 \\
2.98 \\
3.06 \\
3.28 \\
3.32 \\
3.33 \\
3.36 \\
3.44 \\
3.56\end{array}$ & $\begin{array}{l}170 \\
173 \\
177 \\
181 \\
185 \\
196 \\
221 \\
222 \\
226 \\
231 \\
242 \\
261\end{array}$ & $\begin{array}{l}3.69 \\
3.81 \\
3.89 \\
3.96 \\
4.01 \\
4.03 \\
4.06 \\
4.10 \\
4.11 \\
4.11 \\
4.11 \\
4.11\end{array}$ & $\begin{array}{l}282 \\
304 \\
319 \\
333 \\
343 \\
347 \\
354 \\
362 \\
364 \\
364 \\
364 \\
364\end{array}$ & $\begin{array}{l}4.10 \\
4.09 \\
4.08 \\
4.06 \\
4.04 \\
4.02 \\
4.02 \\
4.03 \\
4.04 \\
4.04 \\
4.05 \\
4.05\end{array}$ & $\begin{array}{l}362 \\
360 \\
358 \\
354 \\
349 \\
345 \\
345 \\
347 \\
349 \\
349 \\
352 \\
352\end{array}$ \\
\hline & \multicolumn{2}{|c|}{ July 23} & \multicolumn{2}{|c|}{ July 24} & \multicolumn{2}{|c|}{ July 25} & \multicolumn{2}{|c|}{ July 26} & \multicolumn{2}{|c|}{ July 27} & \multicolumn{2}{|c|}{ July 28} \\
\hline $\begin{array}{c}2 \mathrm{a} . \mathrm{m} . \\
4 \\
6 \\
8 \\
10 \\
12 \mathrm{n} . \\
2 \mathrm{p} . \mathrm{m} . \\
4 \\
6 \\
8 \\
10 \\
12 \mathrm{~m} .\end{array}$ & $\begin{array}{l}4.05 \\
4.07 \\
4.07 \\
4.07 \\
4.06 \\
4.04 \\
4.03 \\
4.02 \\
4.01 \\
4.02 \\
4.02 \\
4.01\end{array}$ & $\begin{array}{l}352 \\
352 \\
349 \\
349 \\
347 \\
347 \\
345 \\
345 \\
343 \\
343 \\
341 \\
341\end{array}$ & $\begin{array}{l}3.99 \\
3.99 \\
3.99 \\
3.99 \\
4.00 \\
4.01 \\
4.01 \\
4.02 \\
4.04 \\
4.07 \\
4.09 \\
4.11\end{array}$ & $\begin{array}{l}339 \\
339 \\
339 \\
339 \\
341 \\
343 \\
343 \\
345 \\
349 \\
356 \\
360 \\
364\end{array}$ & $\begin{array}{l}4.11 \\
1.12 \\
4.12 \\
4.12 \\
4.12 \\
4.12 \\
4.11 \\
4.10 \\
4.09 \\
4.08 \\
4.07 \\
4.05\end{array}$ & $\begin{array}{l}364 \\
367 \\
367 \\
367 \\
367 \\
367 \\
364 \\
362 \\
360 \\
358 \\
356 \\
352\end{array}$ & $\begin{array}{l}4.03 \\
4.00 \\
3.96 \\
3.92 \\
3.86 \\
3.81 \\
3.77 \\
3.75 \\
3.75 \\
3.76 \\
3.78 \\
3.79\end{array}$ & $\begin{array}{l}347 \\
341 \\
333 \\
325 \\
313 \\
304 \\
297 \\
293 \\
293 \\
295 \\
295 \\
295\end{array}$ & $\begin{array}{l}3.79 \\
3.79 \\
3.77 \\
3.76 \\
3.76 \\
3.74 \\
3.71 \\
3.68 \\
3.66 \\
3.64 \\
3.64 \\
3.61\end{array}$ & $\begin{array}{l}295 \\
297 \\
297 \\
295 \\
295 \\
291 \\
286 \\
281 \\
277 \\
272 \\
267 \\
264\end{array}$ & $\begin{array}{l}3.60 \\
3.56 \\
3.51 \\
3.48 \\
3.48 \\
3.48 \\
3.44 \\
3.41 \\
3.36 \\
3.34 \\
3.34 \\
3.34\end{array}$ & $\begin{array}{l}261 \\
256 \\
253 \\
248 \\
244 \\
240 \\
238 \\
235 \\
231 \\
227 \\
224 \\
221\end{array}$ \\
\hline
\end{tabular}

BATSTO RIVER AT BATSTO, N. J.

Location.-Lat. $39^{\circ} 38^{\prime} 33^{\prime \prime}$, long. $74^{\circ} 39^{\prime} 00^{\prime \prime}, 30$ feet downstream from highway bridge in Batsto, Burlington County, and 1 mile upstream from mouth.

Drainage area.-70.5 square miles.

GAGE-HEIGHT RECORD.-Water-stage recorder graph except for periods June 29, 30, July 17-24, Aug. 11-16.

StAGE-Discharge RELATION.-Defined by current-meter measurements below 670 second-feet.

Maxima.-June 1938: Daily discharge, 641 second-feet June 29, 30.

July 1938: Discharge, 579 second-feet 10 p.m. July 25 (gage height, 5.27 feet).

1927 to May 1938: Daily discharge, about 824 second-feet Aug. 24, 1933.

Remarks.-Discharge for periods of no gage-height record computed on basis of records for East Branch of Wading River at Harrisville.

Mean discharge, in second-feet, 1938

\begin{tabular}{|c|c|c|c|c|c|c|c|c|c|c|c|}
\hline Day & June & July & Aug. & Day & June & July & Aug. & Day & June & July & Aug. \\
\hline $\begin{array}{r}1 \\
2 \\
3 \\
4 \\
5 \\
6 \\
7 \\
8 \\
9 \\
10\end{array}$ & $\begin{array}{r}80 \\
86 \\
94 \\
99 \\
102 \\
103 \\
100 \\
94 \\
87 \\
83\end{array}$ & $\begin{array}{r}485 \\
364 \\
261 \\
229 \\
184 \\
155 \\
119 \\
119 \\
112 \\
105\end{array}$ & $\begin{array}{l}190 \\
178 \\
128 \\
138 \\
137 \\
137 \\
155 \\
130 \\
245 \\
296\end{array}$ & $\begin{array}{l}11 \\
12 \\
13 \\
14 \\
15 \\
16 \\
17 \\
18 \\
19 \\
20\end{array}$ & $\begin{array}{r}80 \\
84 \\
100 \\
130 \\
172 \\
166 \\
148 \\
124 \\
105 \\
94\end{array}$ & $\begin{array}{l}108 \\
124 \\
118 \\
117 \\
111 \\
109 \\
130 \\
200 \\
300 \\
350\end{array}$ & $\begin{array}{l}280 \\
240 \\
200 \\
170 \\
150 \\
130 \\
123 \\
118 \\
113 \\
106\end{array}$ & $\begin{array}{l}21 \\
22 \\
23 \\
24 \\
25 \\
26 \\
27 \\
28 \\
29 \\
30 \\
31\end{array}$ & $\begin{array}{r}83 \\
87 \\
83 \\
101 \\
113 \\
104 \\
130 \\
316 \\
641 \\
641\end{array}$ & $\begin{array}{l}400 \\
420 \\
440 \\
460 \\
479 \\
513 \\
404 \\
333 \\
268 \\
241 \\
196\end{array}$ & $\begin{array}{r}105 \\
104 \\
104 \\
105 \\
101 \\
98 \\
91 \\
90 \\
87 \\
86 \\
85\end{array}$ \\
\hline & & & & & & & & & $\begin{array}{r}148 \\
2.34\end{array}$ & $\begin{array}{r}257 \\
4.21\end{array}$ & $\begin{array}{r}143 \\
2.34\end{array}$ \\
\hline
\end{tabular}


GAST BRANCH OF WADING RIVER AT HARRISVITIE, N. J.

Location.-Lat. $39^{\circ} 39^{\prime} 47^{\prime \prime}$, long. $74^{\circ} 31^{\prime} 26^{\prime \prime}$, 50 feet downstream from highway bridge in Harrisville, Burlington County, and half a mile upstream from confluence with West Branch.

Drainage area.-64.0 square miles.

GAGE-HEIGHT RECORD.-Water-stage recorder graph.

STAGE-Discharge RELATION.-Defined by current-meter measurements below 435 second-feet.

Maxima.-June 1938: Discharge, 270 second-feet 3 p. m. June 29 to 2 a.m. June 30 (gage height, 3.98 feet).

July 1938: Discharge, 510 second-feet 2 to 4 a.m. July 21 (gage height, 5.58 feet).

1931 to May 1938: Discharge, about 859 second-feet Aug. 24, 1933.

Mean discharge, in second-feet, 1938

\begin{tabular}{r|r|r|r|r|r|r|r||r|r|r|r}
\hline Day & June & July & Aug. & Day & June & July & Aug. & Day & June & July & Aug. \\
\hline & & & & & & \\
1 & 55 & 152 & 119 & 11 & 45 & 81 & 164 & 21 & 53 & $\mathbf{4 8 2}$ & 67 \\
2 & 60 & 123 & 107 & 12 & 46 & 120 & 147 & 22 & 52 & 435 & 64 \\
3 & 98 & 110 & 97 & 13 & 60 & 107 & 132 & 23 & 52 & 420 & 61 \\
4 & 75 & 73 & 91 & 14 & 100 & 95 & 109 & 24 & 50 & 466 & 57 \\
5 & 72 & 60 & 93 & 15 & 93 & 104 & 92 & 25 & 47 & 482 & 54 \\
6 & 66 & 76 & 98 & 16 & 79 & 121 & 81 & 26 & 45 & 435 & 53 \\
7 & 56 & 63 & 95 & 17 & 71 & 92 & 75 & 27 & 58 & 338 & 52 \\
8 & 51 & 68 & 135 & 18 & 64 & 129 & 76 & 28 & 124 & 259 & 32 \\
9 & 48 & 47 & 188 & 19 & 58 & 322 & 76 & 29 & 244 & 198 & 47 \\
10 & 46 & 44 & 188 & 20 & 54 & 420 & 72 & 30 & 241 & 168 & 49 \\
\end{tabular}

Gage-height, in feet, and discharge, in second-feet, at indicated time, 1938

\begin{tabular}{|c|c|c|c|c|c|c|c|c|c|c|c|c|}
\hline \multirow{2}{*}{ Hour } & Feet & See-ft. & Teet & Sec.-ft. & Feet & Sec.-ft. & Feet & Sec, $-\mathrm{ft}$ & Feet & Sec.-ft. & Feet & Sec.-ft. \\
\hline & \multicolumn{2}{|c|}{ June 23} & \multicolumn{2}{|c|}{ June 24} & \multicolumn{2}{|c|}{ June 25} & \multicolumn{2}{|c|}{ June 26} & \multicolumn{2}{|c|}{ June 27} & \multicolumn{2}{|c|}{ June 28} \\
\hline \multirow[t]{2}{*}{$\begin{array}{c}2 \mathrm{a} . \mathrm{m} . \\
4 \\
6 \\
8 \\
10 \\
12 \mathrm{n} . \\
2 \mathrm{p} . \mathrm{m} . \\
4 \\
6 \\
8 \\
10 \\
12 \mathrm{~m} .\end{array}$} & & & & & & & & 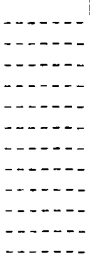 & $\begin{array}{l}1.90 \\
1.90 \\
1.90 \\
1.90 \\
1.92 \\
1.97 \\
2.02 \\
2.07 \\
2.08 \\
2.24 \\
2.39 \\
2.54\end{array}$ & $\begin{array}{r}44 \\
44 \\
44 \\
44 \\
46 \\
51 \\
56 \\
62 \\
63 \\
77 \\
88 \\
101\end{array}$ & $\begin{array}{l}2.61 \\
2.65 \\
2.68 \\
2.70 \\
2.72 \\
2.74 \\
2.77 \\
2.81 \\
2.88 \\
2.98 \\
3.09 \\
3.21\end{array}$ & $\begin{array}{l}107 \\
110 \\
113 \\
115 \\
117 \\
119 \\
122 \\
126 \\
133 \\
143 \\
155 \\
169\end{array}$ \\
\hline & \multicolumn{2}{|c|}{ June 29} & \multicolumn{2}{|c|}{ June 30} & \multicolumn{2}{|c|}{ July 1} & \multicolumn{2}{|c|}{ July 2} & \multicolumn{2}{|c|}{ July 3} & \multicolumn{2}{|c|}{ July 4} \\
\hline $\begin{array}{c}2 \text { a.m. } \\
4 \\
6 \\
8 \\
10 \\
12 \mathrm{n} . \\
2 \mathrm{p} . \mathrm{m} . \\
4 \\
6 \\
8 \\
10 \\
12 \mathrm{~m} .\end{array}$ & $\begin{array}{l}3.34 \\
3.50 \\
3.64 \\
3.79 \\
3.89 \\
3.94 \\
3.97 \\
3.98 \\
3.98 \\
3.98 \\
3.98 \\
3.98\end{array}$ & $\begin{array}{l}185 \\
205 \\
223 \\
244 \\
258 \\
265 \\
269 \\
270 \\
270 \\
270 \\
270 \\
270\end{array}$ & $\begin{array}{l}3.98 \\
3.97 \\
3.95 \\
3.93 \\
3.91 \\
3.88 \\
3.84 \\
3.79 \\
3.62 \\
3.41 \\
3.25 \\
3.16\end{array}$ & $\begin{array}{l}270 \\
269 \\
266 \\
263 \\
260 \\
256 \\
251 \\
244 \\
221 \\
193 \\
174 \\
163\end{array}$ & $\begin{array}{l}3.12 \\
3.10 \\
3.09 \\
3.09 \\
3.09 \\
3.08 \\
3.07 \\
3.05 \\
3.03 \\
3.01 \\
2.98 \\
2.95\end{array}$ & $\begin{array}{l}158 \\
156 \\
155 \\
155 \\
155 \\
154 \\
153 \\
150 \\
148 \\
146 \\
143 \\
140\end{array}$ & $\begin{array}{l}2.92 \\
2.90 \\
2.87 \\
2.84 \\
2.81 \\
2.78 \\
2.74 \\
2.71 \\
2.68 \\
2.65 \\
2.62 \\
2.59\end{array}$ & $\begin{array}{l}137 \\
135 \\
132 \\
129 \\
126 \\
123 \\
119 \\
115 \\
113 \\
110 \\
108 \\
105\end{array}$ & $\begin{array}{l}2.57 \\
2.54 \\
2.52 \\
2.50 \\
2.47 \\
2.44 \\
2.42 \\
2.39 \\
2.37 \\
2.34 \\
2.32 \\
2.30\end{array}$ & $\begin{array}{r}103 \\
101 \\
99 \\
97 \\
95 \\
92 \\
91 \\
88 \\
87 \\
8.5 \\
83 \\
82\end{array}$ & $\begin{array}{l}2.28 \\
2.26 \\
2.25 \\
2.24 \\
2.22 \\
2.20 \\
2.18 \\
2.15 \\
2.14 \\
2.12 \\
2.10 \\
2.10\end{array}$ & $\begin{array}{l}80 \\
79 \\
78 \\
77 \\
76 \\
74 \\
72 \\
70 \\
69 \\
67 \\
65 \\
65\end{array}$ \\
\hline
\end{tabular}


Gage height in feet, and discharge, in second-feet, at indicated time, 1938-Continued

\begin{tabular}{|c|c|c|c|c|c|c|c|c|c|c|c|c|}
\hline \multirow{2}{*}{ Hour } & Feet & Sec.-ft. & Feet & Sec.-ft. & Feet & Sec. $-\mathrm{ft}$. & Feet & Sec. $-\mathrm{ft}$. & Feet & Sec.-ft. & Feet & Sec.-ft. \\
\hline & \multicolumn{2}{|c|}{ July 5} & \multicolumn{2}{|c|}{ July 6} & \multicolumn{2}{|c|}{ July 7} & \multicolumn{2}{|c|}{ July 8} & \multicolumn{2}{|c|}{ July 9} & \multicolumn{2}{|c|}{ July 10} \\
\hline 2 a.m. & 2.08 & 63 & 2.24 & 77 & 2.10 & 65 & 2.18 & 72 & & & & \\
\hline & 2.08 & 63 & 2.29 & 81 & 2.09 & 64 & 2.18 & 72 & & & & \\
\hline 6 & 2.07 & & 2.31 & 83 & 2.08 & & 2.18 & 72 & & & & \\
\hline & 2.06 & 6 & 2.31 & 83 & 2.07 & 62 & 2.18 & 72 & & & & \\
\hline 10 & 2.06 & 6 & 2.30 & 82 & 2.07 & 6 & 2.16 & 70 & & & $\ldots$ & \\
\hline $12 \mathrm{n}$. & 2.05 & 60 & 2.27 & 80 & 2.06 & 6 & 2.1 & 69 &.- & $\ldots$ & $\ldots$ & $\ldots$ \\
\hline $2 \mathrm{p.m}$. & 2.04 & 58 & 2.24 & 77 & 2.05 & 6 & 2.1 & 67 & & & & \\
\hline & 2.03 & 57 & & & 2.04 & 58 & 2.11 & 66 & $-\cdots$ & -..... & $\ldots . .$. & $\ldots$ \\
\hline 6 & 2.02 & 56 & 2.17 & 71 & 2.04 & 58 & 2.10 & 65 & $\cdots$ & & -..... & $\ldots$ \\
\hline $\begin{array}{r}8 \\
10\end{array}$ & $\begin{array}{l}2.02 \\
2.03\end{array}$ & $\begin{array}{l}56 \\
57\end{array}$ & $\begin{array}{l}2.14 \\
2.12\end{array}$ & $\begin{array}{l}69 \\
67\end{array}$ & $\begin{array}{l}2.06 \\
2.12\end{array}$ & $\begin{array}{l}6 \\
6\end{array}$ & $\begin{array}{l}2.08 \\
2.07\end{array}$ & $\begin{array}{l}63 \\
62\end{array}$ & $\cdots$ & - & $-\cdots$ & $\cdots$ \\
\hline $12 \mathrm{~m}$. & 2.14 & 69 & 2.11 & 66 & 2.16 & 70 & 2.06 & 61 & & & $-1-1$ & \\
\hline
\end{tabular}

Gage-height, in feet, and discharge, in second-feet, at indicated time, 1938

\begin{tabular}{|c|c|c|c|c|c|c|c|c|c|c|c|c|}
\hline \multirow{2}{*}{ Hour } & Feet & Sec.-ft. & Feet & Sec. $-\mathrm{ft}$. & Feet & Sec.-ft. & Feet & Sec.-ft. & Feet & Sec.-ft. & Feet & Sec.-ft. \\
\hline & \multicolumn{2}{|c|}{ July 17} & \multicolumn{2}{|c|}{ July 18} & \multicolumn{2}{|c|}{ July 19} & \multicolumn{2}{|c|}{ July 20} & \multicolumn{2}{|c|}{ July 21} & \multicolumn{2}{|c|}{ July 22} \\
\hline $\begin{array}{c}2 \mathrm{a} . \mathrm{m} . \\
4 \\
6 \\
8 \\
10 \\
12 \mathrm{n.} \\
2 \mathrm{p.m} . \\
4 \\
6 \\
8 \\
10 \\
12 \mathrm{~m} .\end{array}$ & 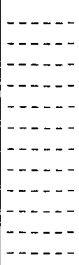 & 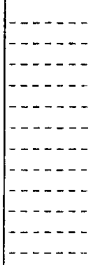 & $\begin{array}{l}2.36 \\
2.35 \\
2.34 \\
2.34 \\
2.32 \\
2.31 \\
2.30 \\
2.29 \\
3.26 \\
3.75 \\
4.00 \\
4.14\end{array}$ & $\begin{array}{r}86 \\
86 \\
85 \\
85 \\
83 \\
83 \\
82 \\
81 \\
175 \\
238 \\
273 \\
293\end{array}$ & $\begin{array}{l}4.24 \\
4.28 \\
4.28 \\
4.22 \\
4.17 \\
4.14 \\
4.15 \\
4.24 \\
4.46 \\
4.61 \\
4.72 \\
4.80\end{array}$ & $\begin{array}{l}307 \\
312 \\
312 \\
304 \\
297 \\
293 \\
294 \\
307 \\
339 \\
362 \\
378 \\
390\end{array}$ & $\begin{array}{l}4.84 \\
4.88 \\
4.90 \\
4.90 \\
4.88 \\
4.91 \\
5.01 \\
5.03 \\
5.12 \\
5.27 \\
5.44 \\
5.55\end{array}$ & $\begin{array}{l}396 \\
402 \\
405 \\
405 \\
402 \\
406 \\
422 \\
424 \\
438 \\
462 \\
488 \\
505\end{array}$ & $\begin{array}{l}5.58 \\
5.58 \\
5.54 \\
5.51 \\
5.44 \\
5.40 \\
5.36 \\
5.33 \\
5.30 \\
5.26 \\
5.20 \\
5.16\end{array}$ & $\begin{array}{l}510 \\
510 \\
503 \\
499 \\
488 \\
482 \\
476 \\
471 \\
466 \\
460 \\
451 \\
445\end{array}$ & $\begin{array}{l}5.14 \\
5.11 \\
5.08 \\
5.06 \\
5.04 \\
5.04 \\
5.06 \\
5.09 \\
5.10 \\
5.10 \\
5.10 \\
5.08\end{array}$ & $\begin{array}{l}441 \\
437 \\
432 \\
429 \\
426 \\
426 \\
429 \\
434 \\
435 \\
435 \\
435 \\
432\end{array}$ \\
\hline & \multicolumn{2}{|c|}{ July $2 \dot{3}$} & \multicolumn{2}{|c|}{ July 24} & \multicolumn{2}{|c|}{ July 25} & \multicolumn{2}{|c|}{ July 26} & \multicolumn{2}{|c|}{ July 27} & \multicolumn{2}{|c|}{ July 28} \\
\hline $\begin{array}{c}2 \text { a.m. } \\
4 \\
6 \\
8 \\
10 \\
12 \mathrm{n} . \\
2 \mathrm{p.m} . \\
4 \\
6 \\
8 \\
10 \\
12 \mathrm{~m} .\end{array}$ & $\begin{array}{l}5.06 \\
5.03 \\
4.99 \\
4.95 \\
4.92 \\
4.88 \\
4.86 \\
4.83 \\
4.88 \\
4.94 \\
4.97 \\
4.98\end{array}$ & $\begin{array}{l}429 \\
424 \\
418 \\
412 \\
408 \\
402 \\
399 \\
394 \\
402 \\
411 \\
416 \\
417\end{array}$ & $\begin{array}{l}4.99 \\
5.02 \\
5.05 \\
5.29 \\
5.38 \\
5.43 \\
5.48 \\
5.52 \\
5.53 \\
5.54 \\
5.55 \\
5.55\end{array}$ & $\begin{array}{r}418 \\
423 \\
428 \\
464 \\
479 \\
486 \\
494 \\
500 \\
502 \\
503 \\
505 \\
505\end{array}$ & $\begin{array}{l}5.55 \\
5.53 \\
5.50 \\
5.49 \\
5.47 \\
5.44 \\
5.43 \\
5.41 \\
5.38 \\
5.35 \\
5.32 \\
5.30\end{array}$ & $\begin{array}{l}505 \\
502 \\
497 \\
496 \\
492 \\
488 \\
486 \\
484 \\
479 \\
474 \\
469 \\
466\end{array}$ & $\begin{array}{l}5.26 \\
5.24 \\
5.20 \\
5.17 \\
5.12 \\
5.08 \\
5.03 \\
4.97 \\
4.93 \\
4.87 \\
4.82 \\
4.77\end{array}$ & $\begin{array}{l}460 \\
457 \\
451 \\
446 \\
438 \\
432 \\
424 \\
416 \\
410 \\
400 \\
393 \\
386\end{array}$ & $\begin{array}{l}4.72 \\
4.67 \\
4.62 \\
4.57 \\
4.52 \\
4.47 \\
4.42 \\
4.37 \\
4.31 \\
4.26 \\
4.20 \\
4.16\end{array}$ & $\begin{array}{l}378 \\
370 \\
363 \\
356 \\
348 \\
340 \\
333 \\
326 \\
316 \\
309 \\
302 \\
295\end{array}$ & $\begin{array}{l}4.11 \\
4.06 \\
4.02 \\
3.97 \\
3.93 \\
3.88 \\
3.84 \\
3.80 \\
3.76 \\
3.72 \\
3.68 \\
3.64\end{array}$ & $\begin{array}{l}288 \\
281 \\
276 \\
269 \\
263 \\
256 \\
251 \\
245 \\
239 \\
234 \\
228 \\
223\end{array}$ \\
\hline
\end{tabular}

GREAT IGG RIVER AT FOISOM, N. J.

Location.-Lat. $39^{\circ} 35^{\prime} 42^{\prime \prime}$, long. $74^{\circ} 51^{\prime} 05^{\prime \prime}$, at highway bridge 1 mile south of Folsom, Atlantic County, and 2 miles upstream from Pennypot Stream.

Drainage area. - 56.3 square miles.

GAGE-HEIGHT RECORD.-Water-stage recorder graph.

Stage-discharge Relation.-Defined by current-meter measurements below 600 second-feet.

Maxima.-June 1938: Discharge, 483 second-feet 12 n. to 4 p.m. June 30 (gage height, 5.72 feet).

July 1938: Discharge, 535 second-feet 10 a.m. to 5 p.m. July 25 (gage height, 5.92 feet).

1925 to May 1938: Discharge, 599 second-feet Sept. 8, 1935 (gage height, 6.18 feet). 
Mean discharge, in second-feet, 1938

\begin{tabular}{|c|c|c|c|c|c|c|c|c|c|c|c|}
\hline Day & June & July & Aug. & Day & June & July & Aug. & Day & June & July & Aug. \\
\hline $\begin{array}{r}1 \\
2 \\
3 \\
4 \\
5 \\
6 \\
7 \\
8 \\
9 \\
10\end{array}$ & $\begin{array}{l}69 \\
58 \\
53 \\
50 \\
50 \\
49 \\
47 \\
46 \\
46 \\
44\end{array}$ & $\begin{array}{r}427 \\
307 \\
214 \\
161 \\
125 \\
95 \\
78 \\
68 \\
62 \\
57\end{array}$ & $\begin{array}{l}130 \\
121 \\
114 \\
104 \\
125 \\
141 \\
136 \\
152 \\
176 \\
318\end{array}$ & $\begin{array}{l}11 \\
12 \\
13 \\
14 \\
15 \\
16 \\
17 \\
18 \\
19 \\
20\end{array}$ & $\begin{array}{l}42 \\
43 \\
62 \\
77 \\
82 \\
82 \\
77 \\
66 \\
57 \\
51\end{array}$ & $\begin{array}{l}58 \\
85 \\
95 \\
88 \\
85 \\
80 \\
69 \\
68 \\
74 \\
88\end{array}$ & $\begin{array}{r}330 \\
245 \\
182 \\
141 \\
116 \\
97 \\
85 \\
82 \\
83 \\
86\end{array}$ & $\begin{array}{l}21 \\
22 \\
23 \\
24 \\
25 \\
26 \\
27 \\
28 \\
29 \\
30 \\
31\end{array}$ & $\begin{array}{r}47 \\
44 \\
46 \\
50 \\
44 \\
42 \\
70 \\
215 \\
427 \\
478\end{array}$ & $\begin{array}{l}156 \\
208 \\
274 \\
402 \\
530 \\
504 \\
427 \\
330 \\
235 \\
188 \\
161\end{array}$ & $\begin{array}{l}85 \\
80 \\
72 \\
68 \\
66 \\
63 \\
60 \\
60 \\
57 \\
56 \\
54\end{array}$ \\
\hline \multicolumn{9}{|c|}{$\begin{array}{l}\text { Monthly mean discharge, in second-feet. } \\
\text { Runoff, in inches. }\end{array}$} & $\begin{array}{l}87.1 \\
1.73\end{array}$ & $\begin{array}{r}187 \\
3.83\end{array}$ & $\begin{array}{r}119 \\
2.43\end{array}$ \\
\hline
\end{tabular}

Gage-height, in feet, and discharge, in second-feet, at indicated time, 1938

\begin{tabular}{|c|c|c|c|c|c|c|c|c|c|c|c|c|}
\hline \multirow[b]{2}{*}{ Hour } & Ieet & Sec.-ft. & Fect & Sec.-ft. & Feet & Sec,-ft. & Feet & Sec.-ft. & Feet & Sec.-ft. & Feet & Sec.-ft. \\
\hline & \multicolumn{2}{|c|}{ June 23} & \multicolumn{2}{|c|}{ June 24} & \multicolumn{2}{|c|}{ June 25} & \multicolumn{2}{|c|}{ June 26} & \multicolumn{2}{|c|}{ June 27} & \multicolumn{2}{|c|}{ June 28} \\
\hline \multirow[t]{2}{*}{$\begin{array}{l}2 \mathrm{a} . \mathrm{m} . \\
4 \\
6 \\
8 \\
10 \\
12 \mathrm{n} . \\
2 \mathrm{p} . \mathrm{m} . \\
4 \\
6 \\
8 \\
10 \\
12 \mathrm{~m} .\end{array}$} & 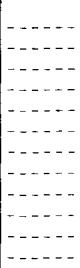 & 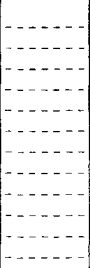 & 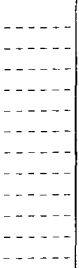 & 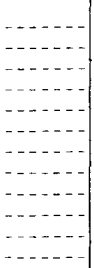 & 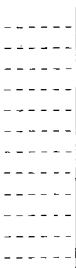 & 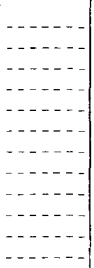 & 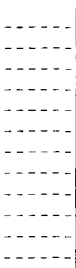 & 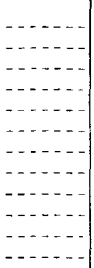 & $\begin{array}{l}3.59 \\
3.61 \\
3.63 \\
3.73 \\
3.80 \\
3.82 \\
3.84 \\
3.86 \\
3.89 \\
3.93 \\
3.97 \\
4.02\end{array}$ & $\begin{array}{r}42 \\
44 \\
47 \\
62 \\
72 \\
75 \\
78 \\
82 \\
86 \\
93 \\
101 \\
110\end{array}$ & $\begin{array}{l}4.08 \\
4.16 \\
4.25 \\
4.34 \\
4.42 \\
4.51 \\
4.62 \\
4.74 \\
4.88 \\
5.00 \\
5.11 \\
5.20\end{array}$ & $\begin{array}{l}121 \\
136 \\
152 \\
169 \\
184 \\
202 \\
224 \\
250 \\
281 \\
307 \\
332 \\
354\end{array}$ \\
\hline & \multicolumn{2}{|c|}{ June 29} & \multicolumn{2}{|c|}{ June 30} & \multicolumn{2}{|c|}{ July 1} & \multicolumn{2}{|c|}{ July 2} & \multicolumn{2}{|c|}{ July 3} & \multicolumn{2}{|c|}{ July 4} \\
\hline $\begin{array}{l}2 \mathrm{a} . \mathrm{m} . \\
4 \\
6 \\
8 \\
10 \\
12 \mathrm{n} . \\
2 \mathrm{p.m} . \\
4 \\
6 \\
8 \\
10 \\
12 \mathrm{~m} .\end{array}$ & $\begin{array}{l}5.28 \\
5.37 \\
5.42 \\
5.47 \\
5.50 \\
5.54 \\
5.56 \\
5.57 \\
5.59 \\
5.61 \\
5.62 \\
5.64\end{array}$ & $\begin{array}{l}372 \\
395 \\
407 \\
420 \\
427 \\
437 \\
442 \\
444 \\
450 \\
455 \\
457 \\
462\end{array}$ & $\begin{array}{l}5.66 \\
5.67 \\
5.69 \\
5.70 \\
5.71 \\
5.72 \\
5.72 \\
5.72 \\
5.71 \\
5.70 \\
5.68 \\
5.66\end{array}$ & $\begin{array}{l}468 \\
470 \\
475 \\
478 \\
481 \\
483 \\
483 \\
483 \\
481 \\
478 \\
473 \\
468\end{array}$ & $\begin{array}{l}5.64 \\
5.61 \\
5.58 \\
5.55 \\
5.52 \\
5.48 \\
5.44 \\
5.40 \\
5.36 \\
5.33 \\
5.28 \\
5.24\end{array}$ & $\begin{array}{l}462 \\
455 \\
447 \\
440 \\
432 \\
422 \\
412 \\
402 \\
392 \\
385 \\
372 \\
361\end{array}$ & $\begin{array}{l}5.21 \\
5.17 \\
5.12 \\
5.08 \\
5.03 \\
5.00 \\
4.95 \\
4.92 \\
4.87 \\
4.84 \\
4.80 \\
4.76\end{array}$ & $\begin{array}{l}356 \\
347 \\
335 \\
325 \\
314 \\
307 \\
296 \\
289 \\
278 \\
272 \\
263 \\
254\end{array}$ & $\begin{array}{l}4.73 \\
4.70 \\
4.66 \\
4.63 \\
4.60 \\
4.57 \\
4.54 \\
4.51 \\
4.48 \\
4.46 \\
4.43 \\
4.41\end{array}$ & $\begin{array}{l}248 \\
241 \\
233 \\
226 \\
220 \\
214 \\
208 \\
202 \\
196 \\
192 \\
186 \\
182\end{array}$ & $\begin{array}{l}4.40 \\
4.37 \\
4.36 \\
4.34 \\
4.32 \\
4.30 \\
4.28 \\
4.27 \\
4.25 \\
4.23 \\
4.21 \\
4.18\end{array}$ & $\begin{array}{l}180 \\
174 \\
172 \\
169 \\
165 \\
161 \\
157 \\
156 \\
152 \\
148 \\
145 \\
139\end{array}$ \\
\hline
\end{tabular}

Gage-height, in feet, and discharge, in second-feet, at indicated time, 1938

\begin{tabular}{|c|c|c|c|c|c|c|c|c|c|c|c|c|}
\hline \multirow{2}{*}{ Hour } & Feet & Sec.-ft. & Feet & S sc.ft. & Feet & Sec.ft. & Feet & Sec.-ft. & Feet & Sec.-ft. & Feet & Sec.-ft. \\
\hline & \multicolumn{2}{|c|}{ July 17} & \multicolumn{2}{|c|}{ July 18} & \multicolumn{2}{|c|}{ July 19} & \multicolumn{2}{|c|}{ July 20} & \multicolumn{2}{|c|}{ July 21} & \multicolumn{2}{|c|}{ July 22} \\
\hline $2 \mathrm{a} . \mathrm{m}$ & & & & & & & 3.82 & 75 & 4.16 & 136 & 4.39 & 178 \\
\hline & & & & & & & 3.82 & 75 & 4.2 & 145 & 4. 41 & 182 \\
\hline & & & & & & & & 78 & $\begin{array}{l}4.24 \\
4.25\end{array}$ & $\begin{array}{l}150 \\
152\end{array}$ & $\begin{array}{l}4.42 \\
4.43\end{array}$ & $\begin{array}{l}184 \\
186\end{array}$ \\
\hline & & & & & & & 3.85 & 80 & $\begin{array}{r}+27 \\
+.27\end{array}$ & 156 & 4.45 & $\begin{array}{l}180 \\
190\end{array}$ \\
\hline $12 \mathrm{n}$. & & & & & & & 3.8 & 83 & 4. & 157 & 4. & 204 \\
\hline & & & & & & & & 8 & 4. & 16 & $\begin{array}{r}4.63 \\
4.65\end{array}$ & 226 \\
\hline & & & & & & & & 95 & 4. & & & 233 \\
\hline & & & & & & & 4.1 & 121 & 4. & & & 237 \\
\hline & & & & & & & & 125 & & & & 241 \\
\hline & & & & & & & 4.12 & 129 & 4.37 & 174 & 4.72 & 245 \\
\hline
\end{tabular}


Gage height in feet, and discharge, in second-feet, at indicated time, 1938-Continued

\begin{tabular}{|c|c|c|c|c|c|c|c|c|c|c|c|c|}
\hline \multirow{2}{*}{ Hour } & Feet & Sec.-ft. & Feet & Sec.-ft. & Feet & Sec.-ft. & Feet & Sec.-ft. & Feet & Sec.-ft. & Feet & Sec.-ft. \\
\hline & \multicolumn{2}{|c|}{ Juily 23} & \multicolumn{2}{|c|}{ July 24} & \multicolumn{2}{|c|}{ July 25} & \multicolumn{2}{|c|}{ July 26} & \multicolumn{2}{|c|}{ July 27} & \multicolumn{2}{|c|}{ July 28} \\
\hline 2 a.m. & 4.74 & 250 & 5.10 & 330 & 5.83 & 512 & 5.87 & 522 & 5.65 & $46 \overline{5}$ & 5.27 & 371 \\
\hline & 4.75 & 252 & 5.15 & $8+2$ & 5.87 & 522 & 5.86 & 520 & 5.63 & 460 & 5.23 & 361 \\
\hline 6 & 4.77 & 256 & 5.22 & $3:$ & 5. 89 & $52 \overline{7}$ & 5.85 & & 5.59 & & 5.20 & 354 \\
\hline 8 & 4.77 & 25 & 5.32 & 383 & 5.90 & 53 & 5.84 & 51 & 5.57 & 44 & 5.17 & 347 \\
\hline 10 & 4.78 & 259 & 5.38 & 397 & 5.92 & 535 & 5.82 & 50 & 5.53 & -434 & 5.13 & 337 \\
\hline $12 \mathrm{n}$. & 4.79 & & 5.43 & 41 & 5.92 & 53 & 5.80 & & & 43 & 5.08 & 325 \\
\hline 2 p.m. & 4.81 & 265 & 5.48 & 422 & 5.92 & 535 & 5.78 & 49 & 5.47 & 42 & 5.05 & 318 \\
\hline & 4.86 & 276 & 5.55 & 440 & 5.92 . & 53 & 5.76 & 49 & 5.4 & 41 & 5.01 & 309 \\
\hline 6 & 4.98 & 30 & 5.6 & 45 & 5.91 & 53 & 5. & & & 40 & 4.97 & 300 \\
\hline 8 & 5.01 & 309 & 5.68 & 472 & 5.91 & 533 & 5.7 & 48 & 5.3 & 395 & 4.93 & 292 \\
\hline & 5.03 & 314 & 5.7 & 486 & 5.90 & 530 & $5 . ?$ & 47 & & 38 & 4.89 & 283 \\
\hline $12 \mathrm{~m}$. & 5.05 & 318 & 5.78 & 499 & 5.88 & 525 & 5.68 & 473 & 5.30 & 378 & 4.86 & 276 \\
\hline
\end{tabular}

\section{MANANTICO CREFX MEAR MILIVIIIE, N. J.}

Location.-Lat. $39^{\circ} 25^{\prime} 12^{\prime \prime}$, long. $74^{\circ} 58^{\prime} 00^{\prime \prime}$, at Millville-Milmay highway bridge 4 miles northeast of Millville, Cumberland County, and 7 miles upstream from the mouth. Datum of gage is 36.63 feet above mean sea level (general adjustment of 1929).

Drainage area.-22.3 square miles.

GAGE-HEIGHT REiORD.-Water-stage recorder graph.

Stage-discharge relation.-Defined by current-meter measurements below 300 second-feet, extended to peak stage on basis of area velocity study at bridge opening.

Maxima.-June 1938: Discharge, 74 second-feet 9 p.m. June 28 (gage height, 2.09 feet).

July 1938: Discharge, 474 second-feet 9 to 10 p.m. July 24 (gage height, 4.46 feet).

September 1938: Discharge, 413 second-feet 7 a.m. Sept. 22 (gage height, 4.19 feet).

1931 to May 1938: Discharge, 566 second-feet Sept. 7, 1935 (gage height, 5.72 feet).

REMARKs.-Low flow slightly regulated by operation of reservoir for irrigation at State institution above station.

Mean discharge, in second-feet, 1938

\begin{tabular}{|c|c|c|c|c|c|c|c|c|c|c|c|}
\hline Day & June & July & Aug. & $D u y$ & June & July & Aug. & Day & June & July & Aug. \\
\hline $\begin{array}{r}1 \\
2 \\
3 \\
4 \\
5 \\
6 \\
7 \\
8 \\
9 \\
10\end{array}$ & $\begin{array}{l}24 \\
17.5 \\
25 \\
28 \\
33 \\
28 \\
25 \\
23 \\
23 \\
23\end{array}$ & $\begin{array}{l}31 \\
26 \\
18.3 \\
23 \\
24 \\
23 \\
24 \\
23 \\
22 \\
23\end{array}$ & $\begin{array}{r}91 \\
86 \\
72 \\
65 \\
60 \\
56 \\
62 \\
98 \\
182 \\
187\end{array}$ & $\begin{array}{l}11 \\
12 \\
13 \\
14 \\
15 \\
16 \\
17 \\
18 \\
19 \\
20\end{array}$ & $\begin{array}{l}23 \\
23 \\
24 \\
23 \\
23 \\
23 \\
23 \\
22 \\
22 \\
22\end{array}$ & $\begin{array}{r}11.1 \\
5.6 \\
6.0 \\
19.7 \\
27 \\
23 \\
28 \\
27 \\
4.3 \\
70\end{array}$ & $\begin{array}{r}112 \\
79 \\
58 \\
53 \\
51 \\
48 \\
45 \\
43 \\
43 \\
42\end{array}$ & $\begin{array}{l}21 \\
22 \\
23 \\
24 \\
25 \\
26 \\
27 \\
28 \\
29 \\
30 \\
31\end{array}$ & $\begin{array}{l}22 \\
23 \\
23 \\
12.3 \\
10.8 \\
22 \\
28 \\
55 \\
50 \\
42\end{array}$ & $\begin{array}{r}95 \\
145 \\
163 \\
397 \\
346 \\
164 \\
104 \\
80 \\
77 \\
100 \\
119\end{array}$ & $\begin{array}{l}39 \\
39 \\
38 \\
49 \\
38 \\
35 \\
34 \\
34 \\
34 \\
37 \\
30\end{array}$ \\
\hline \multicolumn{9}{|c|}{$\begin{array}{l}\text { Monthly mean discharge, in second-feet } \\
\text { Runoff, in inches }\end{array}$} & $\begin{array}{l}25.5 \\
1.27\end{array}$ & $\begin{array}{l}73.8 \\
3.82\end{array}$ & $\begin{array}{l}62.6 \\
3.24\end{array}$ \\
\hline
\end{tabular}


Gage-height, in feet, and discharge, in second-feet, at indicated time, 1938

\begin{tabular}{|c|c|c|c|c|c|c|c|c|c|c|c|c|}
\hline \multirow{2}{*}{ Hour } & Feet & Sec.-ft. & Feet & Sec.-ft. & Feet & Sec.-ft. & Feet & Sec.-ft. & Feet & Sec.-ft, & Feet & Sec. $-\mathrm{ft}$. \\
\hline & \multicolumn{2}{|c|}{ June 23} & \multicolumn{2}{|c|}{ June 24} & \multicolumn{2}{|c|}{ June 25} & \multicolumn{2}{|c|}{ June 26} & \multicolumn{2}{|c|}{ June 27} & \multicolumn{2}{|c|}{ June 28} \\
\hline $\begin{array}{l}2 \mathrm{a} . \mathrm{m} . \\
4 \\
6 \\
8 \\
10 \\
12 \mathrm{n} . \\
2 \mathrm{p} . \mathrm{m} . \\
4 \\
6 \\
8 \\
10 \\
12 \mathrm{~m} .\end{array}$ & 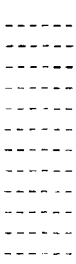 & 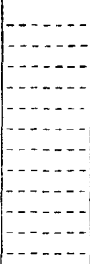 & $\begin{array}{l}1.52 \\
1.51 \\
1.55 \\
1.30 \\
1.19 \\
1.18 \\
1.17 \\
1.17 \\
1.17 \\
1.17 \\
1.17 \\
1.17\end{array}$ & $\begin{array}{l}24 \\
23 \\
26 \\
11.8 \\
7.1 \\
6.7 \\
6.3 \\
6.3 \\
6.3 \\
6.3 \\
6.3 \\
6.3\end{array}$ & $\begin{array}{l}1.17 \\
1.17 \\
1.16 \\
1.16 \\
1.16 \\
1.16 \\
1.15 \\
1.15 \\
1.45 \\
1.47 \\
1.48 \\
1.49\end{array}$ & $\begin{array}{r}6.3 \\
6.3 \\
6.0 \\
6.0 \\
6.0 \\
6.0 \\
5.6 \\
5.6 \\
19.8 \\
21 \\
22 \\
22\end{array}$ & $\begin{array}{l}1.49 \\
1.49 \\
1.51 \\
1.50 \\
1.51 \\
1.51 \\
1.48 \\
1.48 \\
1.49 \\
1.48 \\
1.49 \\
1.49\end{array}$ & $\begin{array}{l}22 \\
22 \\
23 \\
23 \\
23 \\
23 \\
22 \\
22 \\
22 \\
22 \\
22 \\
22\end{array}$ & $\begin{array}{l}1.49 \\
1.49 \\
1.52 \\
1.54 \\
1.60 \\
1.53 \\
1.48 \\
1.48 \\
1.59 \\
1.63 \\
1.82 \\
1.75\end{array}$ & $\begin{array}{l}22 \\
22 \\
24 \\
25 \\
30 \\
25 \\
22 \\
22 \\
29 \\
32 \\
48 \\
42\end{array}$ & $\begin{array}{l}1.68 \\
1.66 \\
1.76 \\
1.83 \\
1.90 \\
1.93 \\
1.95 \\
1.97 \\
2.00 \\
2.08 \\
2.07 \\
2.02\end{array}$ & $\begin{array}{l}36 \\
34 \\
43 \\
49 \\
55 \\
58 \\
60 \\
62 \\
65 \\
73 \\
72 \\
67\end{array}$ \\
\hline & \multicolumn{2}{|c|}{ June 29} & \multicolumn{2}{|c|}{ June 30} & \multicolumn{2}{|c|}{ July 1} & \multicolumn{2}{|c|}{ July 2} & \multicolumn{2}{|c|}{ July 3} & \multicolumn{2}{|c|}{ July 4} \\
\hline $\begin{array}{l}2 \mathrm{a} . \mathrm{m} . \\
4 \\
6 \\
8 \\
10 \\
12 \mathrm{n} . \\
2 \mathrm{p} . \mathrm{m} . \\
4 \\
6 \\
8 \\
10 \\
12 \mathrm{~m} .\end{array}$ & $\begin{array}{l}1.98 \\
1.95 \\
1.95 \\
1.91 \\
1.89 \\
1.88 \\
1.85 \\
1.83 \\
1.64 \\
1.63 \\
1.65 \\
1.67\end{array}$ & $\begin{array}{l}63 \\
60 \\
60 \\
56 \\
54 \\
54 \\
51 \\
49 \\
33 \\
32 \\
34 \\
35\end{array}$ & $\begin{array}{l}1.69 \\
1.69 \\
1.70 \\
1.80 \\
1.88 \\
1.80 \\
1.78 \\
1.77 \\
1.74 \\
1.72 \\
1.71 \\
1.69\end{array}$ & $\begin{array}{l}37 \\
37 \\
38 \\
46 \\
54 \\
46 \\
44 \\
43 \\
41 \\
39 \\
38 \\
37\end{array}$ & $\begin{array}{l}1.65 \\
1.65 \\
1.67 \\
1.67 \\
1.65 \\
1.61 \\
1.57 \\
1.56 \\
1.56 \\
1.61 \\
1.61 \\
1.59\end{array}$ & $\begin{array}{l}34 \\
34 \\
35 \\
3.5 \\
34 \\
50 \\
27 \\
27 \\
27 \\
30 \\
30 \\
29\end{array}$ & $\begin{array}{l}1.57 \\
1.56 \\
1.61 \\
1.57 \\
1.58 \\
1.55 \\
1.53 \\
1.53 \\
1.52 \\
1.52 \\
1.52 \\
1.53\end{array}$ & $\begin{array}{l}27 \\
27 \\
30 \\
27 \\
28 \\
26 \\
25 \\
25 \\
24 \\
24 \\
24 \\
25\end{array}$ & $\begin{array}{l}1.53 \\
1.53 \\
1.56 \\
1.55 \\
1.50 \\
1.30 \\
1.29 \\
1.31 \\
1.32 \\
1.34 \\
1.37 \\
1.40\end{array}$ & $\begin{array}{l}25 \\
25 \\
27 \\
26 \\
23 \\
11.8 \\
11.3 \\
12.3 \\
12.8 \\
13.8 \\
15.3 \\
16.9\end{array}$ & $\begin{array}{l}1.42 \\
1.44 \\
1.45 \\
1.54 \\
1.58 \\
1.55 \\
1.52 \\
1.50 \\
1.49 \\
1.49 \\
1.54 \\
1.53\end{array}$ & $\begin{array}{l}18.1 \\
19.2 \\
19.8 \\
25 \\
28 \\
26 \\
24 \\
23 \\
22 \\
22 \\
25 \\
25\end{array}$ \\
\hline
\end{tabular}

Supplemental records.-June 28,9 p.m., 2.09 ft., 74 sec.-ft.; July 4, 9 a.m., $1.65 \mathrm{ft} ., 34$ sec.-ft.

Gage-height, in feet, and discharge, in second-feet, at indicated time, 1938

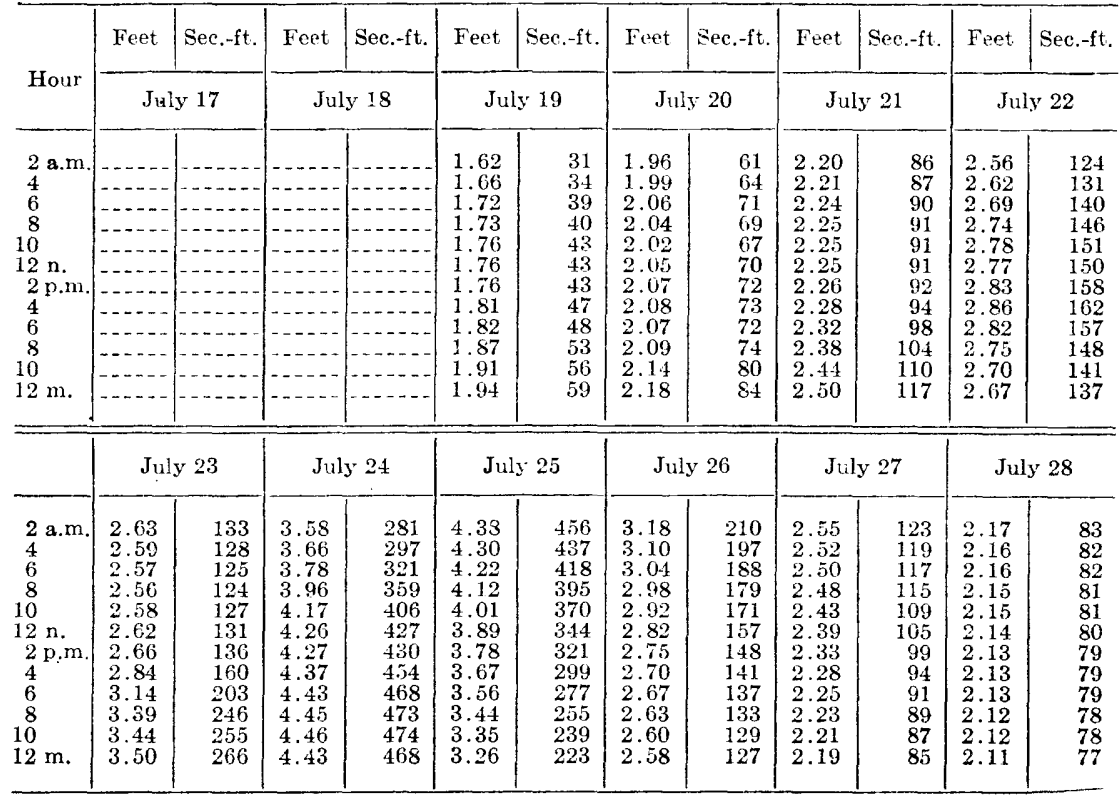


Gage height in teet, and discharge, in second-ieet, at indicated time, 1938-Continued

\begin{tabular}{|c|c|c|c|c|c|c|c|c|c|c|c|c|}
\hline \multirow{2}{*}{ Hour } & Feet & Sec.-ft. & Feet & Sec.-ft. & licet & Sec.-ft. & Feet & Sec.-ft. & Feet & Sec,-ft. & Feet & Sec.-ft. \\
\hline & \multicolumn{2}{|c|}{ July 29} & \multicolumn{2}{|c|}{ July 30} & \multicolumn{2}{|c|}{ July 31} & \multicolumn{2}{|c|}{ Aurust 1} & & & & \\
\hline 2 a.m. & 2.10 & 75 & 2.32 & 98 & 2.55 & 123 & & & & & & \\
\hline & 2.09 & 74 & 2.30 & 96 & 2.59 & 128 & & & & & & \\
\hline & 2.09 & 74 & 2.33 & 99 & 2.61 & 130 & & & & & & \\
\hline 8 & 2.07 & 72 & 2.36 & 102 & 2.60 & 129 & & & $\ldots$ & & & \\
\hline & 2.06 & 71 & 2.30 & 96 & 2.57 & 125 & & & & & & \\
\hline $12 \mathrm{n}$. & 2.04 & 69 & 2.20 & 86 & 2.54 & 122 & & & & & & \\
\hline 2 p.m. & 2.00 & 65 & 2.24 & 90 & 2.50 & 117 & & & & & & \\
\hline & 2.00 & 65 & 2.31 & 97 & 2.48 & 115 & $\ldots$ & $\ldots$ & $\ldots . .$. & & -1 & \\
\hline & 1.99 & 64 & 2.38 & 104 & 2.45 & 112 & & & & & & \\
\hline $\begin{array}{r}8 \\
10\end{array}$ & $\begin{array}{l}2.28 \\
2.39\end{array}$ & $\begin{array}{r}94 \\
105\end{array}$ & $\begin{array}{l}2.42 \\
2.47\end{array}$ & $\begin{array}{l}108 \\
114\end{array}$ & 2.43 & $\begin{array}{l}109 \\
108\end{array}$ & & $-\cdots$ & $\cdots$ & - & & $\cdots$ \\
\hline $12 \mathrm{~m}$. & 2.36 & 102 & 2.51 & 118 & 2.40 & 106 & & & & & & \\
\hline
\end{tabular}

Mean discharge, in second-feet, 1938

\begin{tabular}{c|c|c||c|c|c||c|c|c||c|c|c}
\hline Day & Sept. & Oct. & Day & Sept. & Oct. & Day & Sept. & Oct. & Day & Sept. & Oct. \\
\hline 1 & 25 & 65 & 9 & 23 & 46 & 17 & 30 & 39 & 25 & 77 & 52 \\
2 & 25 & 61 & 10 & 33 & 44 & 18 & 30 & 38 & 26 & 57 & 49 \\
3 & 25 & 52 & 11 & 36 & 42 & 19 & 62 & 37 & 27 & 54 & 45 \\
4 & 27 & 38 & 12 & 31 & 42 & 20 & 110 & 38 & 28 & 55 & 64 \\
5 & 42 & 36 & 13 & 32 & 40 & 21 & 238 & 43 & 29 & 54 & 71 \\
6 & 33 & 44 & 14 & 31 & 40 & 22 & 358 & 44 & 30 & 45 & 55 \\
8 & 28 & 49 & 15 & 30 & 40 & 23 & 196 & 43 & 31 & & 56 \\
\hline
\end{tabular}

Gage-height, in feet, and discharge, in second-feet, at indicated time, 1938

\begin{tabular}{|c|c|c|c|c|c|c|c|c|c|c|c|c|}
\hline \multirow{2}{*}{ Hour } & Feet & Sec.-ft. & Feet & Sec. $-\mathrm{ft}$. & Feet & Sec.-ft. & Feet & Sec.-ft. & Feet & Sec.-ft. & Feet & Sec.-ft. \\
\hline & \multicolumn{2}{|c|}{ September 18} & \multicolumn{2}{|c|}{ September 19} & \multicolumn{2}{|c|}{ September 20} & \multicolumn{2}{|c|}{ September 21} & \multicolumn{2}{|c|}{ September 22} & \multicolumn{2}{|c|}{ September 23} \\
\hline $1 \mathrm{a} . \mathrm{m}$ & & & & & & 104 & 2.68 & 139 & 4.04 & 377 & 352 & \\
\hline & & & & & $\frac{2}{2} .38$ & 104 & & $\begin{array}{l}140 \\
144\end{array}$ & $4.45-45$ & $\begin{array}{l}381 \\
388\end{array}$ & $\begin{array}{l}3.47 \\
3.42\end{array}$ & $\begin{array}{l}261 \\
252\end{array}$ \\
\hline & & & & & 2.35 & 101 & & 148 & 4.11 & & 3.37 & 243 \\
\hline & & & & & & 10 & 2 . & & & & & 234 \\
\hline & & & & & 2.3 & & 2.8 & & 4. & & & 228 \\
\hline & & & 1.69 & 37 & 2.6 & 104 & & & 4. & & & 225 \\
\hline & & & & 37 & 2.3 & 16 & 2.9 & 168 & 4. & & & 218 \\
\hline & & & 1.67 & 30 & 2.37 & & 2.94 & 174 & .1 & & 3. & 210 \\
\hline & & & & $3+4$ & & & & & & & & 202 \\
\hline & & & 1.6 & $3 \pm$ & 2.3 & is & 3.0 & & 4. & 3 & & 196 \\
\hline 1 p.m. & & 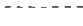 & 1.08 & +3 & 2.37 & 103 & 3. & 200 & 3. & 350 & $3.4 \quad-5$ & $\begin{array}{l}190 \\
184\end{array}$ \\
\hline & & & 1.9 & 55 & 23 & & & & & & & 178 \\
\hline & & & 2.1 & 83 & & & & & & & & 172 \\
\hline & & & 2.8 & & 2.4 & & 3. & & & & & 167 \\
\hline & & & 2. & 102 & & 11 & & & & & & 162 \\
\hline & & & 2.3 & & & & & & & & & 158 \\
\hline & & & & & & & & & & & & 154 \\
\hline 8 & & & $2+40$ & $\begin{array}{l}100 \\
100\end{array}$ & 2.6 & 1: & 3. & 340 & 3. & & & 150 \\
\hline & & & 2.39 & 105 & & $1:$ & & & & & & 148 \\
\hline & & & & 10 & & & & 36 & & & & 144 \\
\hline & & & 2.39 & 105 & 2.67 & 137 & 4.02 & 372 & 3.57 & 279 & 2.70 & 141 \\
\hline
\end{tabular}


Gage height in feet, and discharge, in second-feet, at indicated time, 1938-Continued

\begin{tabular}{|c|c|c|c|c|c|c|c|c|c|c|c|c|}
\hline \multirow{2}{*}{ Hour } & Feet & Sec.-ft. & Feet & Sec.-ft. & Feet & Sec.-ft. & Feet & Sec.-ft. & Feet & Sec.-ft. & Feet & Sec.-ft. \\
\hline & \multicolumn{2}{|c|}{ September 24} & \multicolumn{2}{|c|}{ September 25} & \multicolumn{2}{|c|}{ September 26} & \multicolumn{2}{|c|}{ September 27} & \multicolumn{2}{|c|}{ September 28} & \multicolumn{2}{|c|}{ September 29} \\
\hline$\frac{2}{4}$ a.m. & 2.65 & $\begin{array}{l}135 \\
130\end{array}$ & & & & & & & & & & \\
\hline $\begin{array}{l}+ \\
6\end{array}$ & 2.59 & 128 & & & & & & & & & & \\
\hline 8 & 2.56 & 1.24 & & & & & & & & & & $\ldots$ \\
\hline $\begin{array}{l}10 \\
12 \mathrm{n} .\end{array}$ & $\begin{array}{l}2.42 \\
2.20\end{array}$ & $\begin{array}{r}108 \\
86\end{array}$ & & & & & & 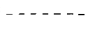 & & & $\ldots$ & 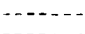 \\
\hline $\begin{array}{l}12 \mathrm{p} . \mathrm{m} . \\
2 \mathrm{p} .\end{array}$ & $\begin{array}{l}2.20 \\
2.11\end{array}$ & 77 & $\ldots$ & & & & & & & & & $-\cdots$ \\
\hline & 2.10 & 75 & & & & & & & & & & $\cdots$ \\
\hline 8 & $\begin{array}{l}2.10 \\
2.12\end{array}$ & 78 & & & & & & $-x_{1}$ & $\cdots$ & & $\cdots$ & n... \\
\hline & 2.14 & 80 & & & & & & & & & & \\
\hline & 2.1 & 81 & & & & & & & & & & \\
\hline
\end{tabular}

DELAWARE RIVER BASIN

EAST BRANCH OF DELAWARE RIVER AT MARGARETVIIIE, N. Y.

Location,-Lat. $42^{\circ} 08^{\prime} 40^{\prime \prime}$, long. $74^{\circ} 39^{\prime} 15^{\prime \prime}$, at bridge at southwest end of

Margaretville, Delaware County, and 13/4 miles downstream from Bush

Kill. Datum of gage is 1303.48 feet above mean sea level (general adjustment of 1912).

Drainage aREA.-163 square miles.

GAGE-HEIGHT RECORD.-Water-stage recorder graph.

Stage-discharge relation.--Defined by current-meter measurements to 5,000 second-feet and extended to peak stage by logarithmic plotting.

Maxima.-July-August 1938: Discharge, 4,120 second-feet 11:45 a.m. July 23

(gage height, 6.23 feet).

1937 to June 1938: Discharge, 6,000 second-feet May 15, 1937 (gage height, 7.6 feet).

Remarks.-Flood discharge not affected by storage or diversion.

Mean discharge, in second-feet, 1938

\begin{tabular}{r|c|c|c|c|c|c|c|c|c|c|c}
\hline Day & Juiy & August & Day & July & August & Day & July & August & Day & July & August \\
\hline $\mathbf{1}$ & 362 & 317 & 9 & 152 & 198 & 17 & 108 & 295 & 25 & 1,300 & 125 \\
2 & 420 & 310 & 10 & 160 & 172 & 18 & 242 & 350 & 26 & 920 & 115 \\
3 & 284 & 237 & 11 & 152 & 1,640 & 19 & 310 & 279 & 27 & 700 & 108 \\
4 & 252 & 199 & 12 & 196 & 760 & 20 & 222 & 219 & 28 & 570 & 100 \\
5 & 255 & 174 & 13 & 143 & 510 & 21 & 360 & 187 & 29 & 500 & 93 \\
6 & 193 & 154 & 14 & 148 & 394 & 22 & 2,000 & 171 & 30 & 413 & 89 \\
7 & 165 & 187 & 15 & 143 & 326 & 23 & 2,850 & 154 & 31 & 326 & 84 \\
8 & 143 & 192 & 16 & 120 & 284 & 24 & 1,980 & 138 & & & \\
\hline
\end{tabular}

Peak dischargo.--Aug. 11 (8 a.1n.) 2,590 sec.-it.

EAST BRANCF OF DELAWARE RIVER AT HARVARD, N. Y.

LoCATION-CLat. $42^{\circ} 01^{\prime} 15^{\prime \prime}$, long. $75^{\circ} 07^{\prime} 05^{\prime \prime}$, at highway bridge at Harvard, Delaware County, about 400 feet upstream from Baxter Brook. Datum of gage is $1,007.96$ feet above mean sea level (general adjustment of 1912).

Drainage area.--443 square miles.

GAGE-height RECoRD.-Water-stage recorder graph.

Stage-discharce relation.-Defined by cuirent-meter measurements to 10,000 second-feet and extended to peak stage on basis of logarithmic plotting and a slope-area determination of peak flow of March 1936. 
Maxima.-July-August 1938: Discharge, 14,500 second-feet 11:30 a.m. Aug.

11 (gage height, 12.67 feet).

1934 to June 1938: Discharge, 26,200 second-feet, Mar. 18, 1936 (gage height 15.58 feet), from rating curve extended above 10,000 second-feet on basis of logarithmic plotting and a slope-area determination of peak. Remarks.-Flood discharge not affected by storage or diversion.

Mean discharge, in second-feet, 1938

\begin{tabular}{|c|c|c|c|c|c|c|c|c|c|c|c|}
\hline Day & July & August & Day & July & August & Day & July & August & Day & July & August \\
\hline $\begin{array}{l}1 \\
2 \\
3 \\
4 \\
5 \\
6 \\
7 \\
8\end{array}$ & $\begin{array}{r}960 \\
1,060 \\
840 \\
688 \\
607 \\
564 \\
473 \\
424\end{array}$ & $\begin{array}{r}780 \\
780 \\
640 \\
538 \\
468 \\
460 \\
1,100 \\
820\end{array}$ & $\begin{array}{r}9 \\
10 \\
11 \\
12 \\
13 \\
14 \\
15 \\
16\end{array}$ & $\begin{array}{l}380 \\
180 \\
392 \\
477 \\
424 \\
360 \\
520 \\
408\end{array}$ & $\begin{array}{r}1,060 \\
790 \\
9,700 \\
4,450 \\
2,550 \\
1,840 \\
1,400 \\
1,120\end{array}$ & $\begin{array}{l}17 \\
18 \\
19 \\
20 \\
21 \\
22 \\
23 \\
24\end{array}$ & $\begin{array}{r}348 \\
370 \\
700 \\
580 \\
1,160 \\
3,700 \\
5,500 \\
5,100\end{array}$ & $\begin{array}{r}1,000 \\
1,080 \\
970 \\
760 \\
630 \\
550 \\
497 \\
433\end{array}$ & $\begin{array}{l}25 \\
26 \\
27 \\
28 \\
29 \\
30 \\
31\end{array}$ & $\begin{array}{r}3,000 \\
2,060 \\
1,580 \\
1,320 \\
1,160 \\
1,040 \\
870\end{array}$ & $\begin{array}{l}381 \\
336 \\
308 \\
277 \\
248 \\
230 \\
214\end{array}$ \\
\hline \multicolumn{10}{|c|}{$\begin{array}{l}\text { Monthly mean discharge, in second-feet } \\
\text { Runoff, in inches }\end{array}$} & $\begin{array}{r}1,211 \\
3.15\end{array}$ & $\begin{array}{r}1,175 \\
3.06\end{array}$ \\
\hline
\end{tabular}

Peak discharge.-July 23 (7 p.m.) 7,900 sec.-ft.

EAST BRANCH OY DELAWARE RIVER AT IISHS EDDY, N. Y.

Location.-Lat. $41^{\circ} 58^{\prime} 00^{\prime \prime}$, long. $75^{\circ} 10^{\prime} 50^{\prime \prime}$, at railroad bridge in Fishs Eddy,

Delaware County, about $41 / 2$ miles downstream from Beaver Kill. Datum of gage is 950.80 feet above mean sea level (general adjustment of 1912).

Drainage AREa.-783 square miles.

GAGE-HEIGHT RECORD.-Water-stage recorder graph except for Aug. 18, 19, 22 $25,28$.

Stage-discharge Relation.-Defined by current-meter measurements to 22,000 second-feet and extended to peak stage by logarithmic plotting.

Maxima.-July-August 1938: Discharge, 36,100 second-feet 11:30 a.m. Aug. 11, (gage height, 17.14 feet).

1912 to June 1938: Discharge, 53,300 second-feet Aug. 24, 1933 (gage height, 20.60 feet), from rating curve extended above 22,000 second-feet by logarithmic plotting.

The flood of Oct. 9, 1903, reached a stage of 23.6 feet, from reports obtained in April 1939 from local residents who had experienced the flood (discharge about 70,000 second-feet, from present rating curve extended above 22,000 second-feet by logarithmic plotting).

Remarks.-Flood discharge not affected by storage or diversion.

Mean discharge, in second-feet, 1938

\begin{tabular}{r|c|c||c|c|c||c|c|c|c|c|c|c}
\hline Day & July & August & Day & July & August & Day & July & August & Day & July & August \\
\hline & 1,700 & 1,620 & 9 & 750 & 3,200 & 17 & 825 & 1,760 & 25 & 6,000 & $a 760$ \\
2 & 1,980 & 2,140 & 10 & 1,260 & 1,940 & 18 & 810 & $a 2,060$ & 26 & 4,050 & 674 \\
3 & 1,600 & 1,520 & 11 & 1,000 & 21,200 & 19 & 1,280 & $a 1,680$ & 27 & 3,100 & 622 \\
4 & 1,300 & 1,200 & 12 & 1,300 & 9,100 & 20 & 1,320 & 1,400 & 28 & 2,550 & $a 560$ \\
5 & 1,140 & 1,040 & 13 & 1,120 & $4,750 \cdot$ & 21 & 2,900 & 1,180 & 29 & 2,200 & 502 \\
6 & 1,020 & 924 & 14 & 960 & 3,250 & 22 & 17,400 & $a 1,020$ & 30 & 2,000 & 473 \\
7 & 860 & 2,600 & 15 & 1,240 & 2,480 & 23 & 13,200 & $a 930$ & 31 & 1,680 & 463 \\
8 & 776 & 1,740 & 16 & 1,000 & 2,040 & 24 & 10,000 & $a 840$ & & & \\
\hline
\end{tabular}

a No gage-height record; discharge computed on basis of records for East Branch of Delaware River at Harvard and Beaver Kill at Cooks Falls.

Peak discharge.-July 22 (3 a.m.) 21,400 sec.-ft.; July 23 (6 p.m.) 16,500 вec.-ft. 
DEIAWARE RIVER AT PORT JERVIS, N. $Y$.

Location.-Lat. $41^{\circ} 22^{\prime} 20^{\prime \prime}$, long. $74^{\circ} 41^{\prime} 50^{\prime \prime}$, near highway bridge at Port Jervis, Orange County, 11/2 miles upstream from Neversink River. Datum of gage is 415.35 feet above mean sea level (general adjustment of 1929). Drainage AREA.-3,076 square miles; 369 square miles affected by storage in Lake Wallenpaupack and Toronto and Swinging Bridge Reservoirs.

GAGE-HEIGHT RECORD.--Water-stage recorder graph.

STAGE-DISCHARGE RELATION.-Defined by current-meter measurements to 45,000 second-feet and extended to peak stage on basis of slope-area determination at 14.95 feet and area-velocity study.

Maxima.-July-August 1938: Discharge, 68,300 second-feet 12:15 a.m. Aug. 12 (gage height, 12.40 feet).

1904 to June 1938: Discharge, 137,000 second-feet (revisẹd) Mar. 18, 1936 (gage height, 17.55 feet), from rating curve extended 100,000 second-feet by logarithmic plotting.

Maximum discharge known, 205,000 second-feet (revised) Oct. 10, 1904 (gage height, 23.1 feet, reported by U. S. Weather Bureau), from rating curve extended above 70,000 second-feet by logarithmic plotting and velocity-area studies; maximum stage known, 25.5 feet Mar. 8, 1904 (ice jam).

REMARKs.-Daily discharge not adjusted for storage in Lake Wallenpaupack at Wilsonville, Pa., or in Toronto and Swinging Bridge Reservoirs on Mongaup River. Large diurnal fluctuations at medium and low stages caused by power plants on tributary streams.

Cooperatron.-Records of storage furnished by Pennsylvania Power and Light Company for Lake Wallenpaupack and by Rockland Light and Power Company for Toronto and Swinging Bridge Reservoirs.

Mean discharge, in second-feet, 1938

\begin{tabular}{c|c|c|c|c|c||c|c|c|c|c|c|c}
\hline Day & July & August & Day & July & August & Day & July & August & Day & July & August \\
\cline { 3 - 6 } 1 & 5,400 & 5,100 & 9 & 3,100 & 5,500 & 17 & 2,120 & 6,100 & 25 & 16,800 & 3,550 \\
2 & 4,300 & 5,600 & 10 & 2,850 & 7,700 & 18 & 2,420 & 5,900 & 26 & 11,600 & 3,300 \\
3 & 4,450 & 5,400 & 11 & 3,150 & 18,800 & 19 & 3,350 & 5,900 & 27 & 8,700 & 3,200 \\
4 & 3,750 & 4,250 & 12 & 3,400 & 41,000 & 20 & 3,800 & 4,900 & 28 & 7,100 & 2,800 \\
5 & 3,150 & 3,650 & 13 & 3,450 & 16,200 & 21 & 4,150 & 4,200 & 29 & 6,400 & 2,700 \\
6 & 3,050 & 3,300 & 14 & 3,000 & 10,600 & 22 & 17,400 & 3,900 & 30 & 5,900 & 3,050 \\
7 & 3,300 & 3,200 & 15 & 2,500 & 8,500 & 23 & 27,500 & 3,900 & 31 & 5,500 & 2,950 \\
8 & 2,800 & 5,300 & 16 & 2,320 & 7,300 & 24 & 27,000 & 3,800 & & & \\
\hline
\end{tabular}

Peak discharge.-July $22(7$ p.m.) 37,400 sec.-ft.

†Storage in Lake Wallenpaupack and Toronto and Swinging Bridge Reservoirs.

\section{BROOK AT ARENA, N. Y.}

Location.-Lat. $42^{\circ} 06^{\prime} 30^{\prime \prime}$, long. $74^{\circ} 43^{\prime} 55^{\prime \prime}, 0.2$ mile upstream from highway bridge, 0.6 mile southeast of Arena, Delaware County, and about 1 mile upstream from mouth.

Drainage area.-25.0 square miles.

GAGE-HEIGHT RECORD.-Staff gage read to hundredths twice daily.

Stage-discharge Relation.--Defined by current-meter measurements to 1,000 second-feet and extended by logarithmic plotting on basis of area-velocity study. 
Maxima.-July-August 1938: Discharge, about 1,110 second-feet, 8 a.m., July 23 and 7 a.m. August 11 (gage height, 4.3 feet, from graph based on gage readings).

1937 to June 1938: Discharge, 1,550 second-feet Oct. 23, 1937 (gage height, 5.0 feet, from graph based on gage readings).

RemarKs.-Flood discharge not affected by storage or diversion.

Mean discharge, in second-feet, 1938

\begin{tabular}{|c|c|c|c|c|c|c|c|c|c|c|c|}
\hline Day & July & August & Day & July & August & Day & July & August & Day & July & August \\
\hline $\begin{array}{l}1 \\
2 \\
3 \\
4 \\
5 \\
6 \\
7 \\
8\end{array}$ & $\begin{array}{l}60 \\
54 \\
46 \\
42 \\
34 \\
30 \\
30 \\
26\end{array}$ & $\begin{array}{r}51 \\
46 \\
41 \\
38 \\
36 \\
-31 \\
29 \\
34\end{array}$ & $\begin{array}{r}9 \\
10 \\
11 \\
12 \\
13 \\
14 \\
15 \\
16\end{array}$ & $\begin{array}{l}49 \\
40 \\
54 \\
39 \\
30 \\
44 \\
52 \\
46\end{array}$ & $\begin{array}{r}31 \\
32 \\
626 \\
194 \\
139 \\
101 \\
75 \\
61\end{array}$ & $\begin{array}{l}17 \\
18 \\
19 \\
20 \\
21 \\
22 \\
23 \\
24\end{array}$ & $\begin{array}{r}30 \\
41 \\
44 \\
41 \\
305 \\
659 \\
734 \\
347\end{array}$ & $\begin{array}{l}60 \\
73 \\
47 \\
41 \\
37 \\
32 \\
29 \\
25\end{array}$ & $\begin{array}{l}25 \\
26 \\
27 \\
28 \\
29 \\
30 \\
31\end{array}$ & $\begin{array}{r}202 \\
139 \\
104 \\
97 \\
75 \\
62 \\
51\end{array}$ & $\begin{array}{l}22 \\
19 \\
16 \\
14 \\
13 \\
13 \\
13\end{array}$ \\
\hline \multicolumn{10}{|c|}{$\begin{array}{l}\text { Monthly mean discharge, in second-feet } \\
\text { Runoff, in inches. }\end{array}$} & $\begin{array}{r}116 \\
5.35\end{array}$ & $\begin{array}{l}65.1 \\
3.00\end{array}$ \\
\hline
\end{tabular}

TRTMPER KIIT NEAR SHA VERTOWN, N. Y.

Location.-Lat. $42^{\circ} 07^{\prime} 15^{\prime \prime}$, long. $74^{\circ} 49^{\prime} 10^{\prime \prime}$, 500 feet upstream from highway bridge, $2 \frac{1}{4}$ miles northeast of Shavertown, Delaware County, and $21 / 4$ miles upstream from mouth.

Drainage area.-33.0 square miles.

GAGE-HEIGHT RECORD.-Water-stage recorder graph.

Stage-discharge relation.-Defined by current-meter measurements to 600 second-feet and extended to peak stage by logarithmic plotting. Stagedischarge relation affected by shifting control, July 1 to Aug. 4 .

Maxima.-July-August 1938: Discharge, 1,420 second ${ }_{3}$ feet 5:45 a.m. Aug. 11 (gage height, 4.94 feet).

1937 to June 1938: Discharge, 1,800 second-feet Oct. 23, 1937 (gage height, 4.07 feet), from rating curve extended above 600 second-feet logarithmic plotting.

Remarks.-Flood discharge not affected by storage or diversion.

Mean discharge, in second-feet, 1938

\begin{tabular}{r|c|c||c|c|c||c|c|c|c|c|c}
\hline Day & July & August & Day & July & August & Day & July & August & Day & July & August \\
\hline & 71 & 34 & 9 & 21 & 24 & 17 & 18 & 47 & 25 & 100 & 15 \\
2 & 88 & 32 & 10 & 19 & 34 & 18 & 49 & 49 & 26 & 74 & 15 \\
3 & 51 & 27 & 11 & 22 & 600 & 19 & 35 & 39 & 27 & 64 & 12 \\
4 & 42 & 24 & 12 & 26 & 218 & 20 & 35 & 31 & 28 & 60 & 12 \\
5 & 36 & 20 & 13 & 20 & 137 & 21 & 78 & 27 & 29 & 54 & 11 \\
6 & 32 & 30 & 14 & 23 & 92 & 22 & 205 & 24 & 30 & 47 & 10 \\
7 & 32 & 35 & 15 & 24 & 70 & 23 & 225 & 20 & 31 & 38 & 9.5 \\
8 & 26 & 24 & 16 & 20 & 55 & 24 & 130 & 18 & & & \\
\hline
\end{tabular}

Peak discharge.-July 23 (8 a,m. 535 sec.-ft.

\section{TERRY CIOVE KILI NEAR PFPACTON, N. $\mathbf{Y}$.}

Location.-Lat. $42^{\circ} 07^{\prime} 45^{\prime \prime}$, long. $74^{\circ} 53^{\prime} 55^{\prime \prime}$, at timber farm bridge, $1 \frac{1 / 4}{1}$ miles upstream from confluence with Fall Clove Kill and $3^{\frac{1}{2}}$ miles north of Pepacton, Sullivan County. 
Drainage area.-14.1 square miles.

GAGE-HEIGHT RECORD.- Staff gage read to hundredths twice daily.

StAGE-discharge RELATION.-Defined by current-meter measurements to 350 second-feet and extended by logarithmic plotting.

Maxima.-July-August 1938: Discharge 755 second-feet about 6 a.m. Aug. 11 (gage height, 4.5 feet, from graph based on gage readings).

1937 to June 1938: Discharge, 850 second-feet Jan. 25, 1938 (gage height, 4.7 feet from graph based on gage readings), from rating curve extended above 350 second-feet by logarithmic plotting.

RemarKs.-Flood discharge not affected by storage or diversion.

Mean discharge, in second-feet, 1938

\begin{tabular}{r|c|c||c|c|c||c|c|c||c|c|c}
\hline Day & \multirow{2}{*}{ July } & August & Day & July & August & Day & July & August & Day & July & August \\
\cline { 3 - 7 } 1 & 29 & 36 & 9 & 7.8 & 26 & 17 & 4.4 & 27 & 25 & 44 & 8.4 \\
2 & 28 & 27 & 10 & 6.8 & 18 & 18 & 12 & 37 & 26 & 34 & 6.8 \\
3 & 21 & 20 & 11 & 10 & 349 & 19 & 10 & 23 & 27 & 38 & 6.3 \\
4 & 18 & 16 & 12 & 11 & 152 & 20 & 32 & 16 & 28 & 50 & 5.7 \\
5 & 14 & 13 & 13 & 6.8 & 84 & 21 & 31 & 13 & 29 & 49 & 5.2 \\
6 & 11 & 30 & 14 & 6.8 & 54 & 22 & 51 & 12 & 30 & 35 & 4.7 \\
7 & 9.6 & 36 & 15 & 7.0 & 40 & 23 & 86 & 11 & 31 & 30 & 4.4 \\
8 & 8.1 & 23 & 16 & 5.2 & 33 & 24 & 57 & 9.6 & & & \\
\hline
\end{tabular}

Peak discharge.-July 23 (9 a.m.) 152 sec.-ft.

BRAVRR KIII AT CRAIGIE CTAIR, N. Y.

Location.-Lat. $41^{\circ} 57^{\prime} 45^{\prime \prime}$, long. $74^{\circ} 52^{\prime} 00^{\prime \prime}, 100$ feet downstream from highway bridge at Craigie Clair, Sullivan County, and $2 \frac{1}{4}$ miles upstream from Spring Brook. Datum of gage is $\mathbf{1 3 9 9 . 6 9}$ feet above mean sea level (general adjustment of 1912).

Drainage area. -82 square miles.

GAGE-HEIGHT RECORD.-Water stage recorder graph.

Stage-dischargde relation.-Defined by current-meter measurements to 2,700 second-feet and extended to peak stage by logarithmic plotting.

Maxima.-July-August 1938: Discharge, 9,530 second-feet 6 a.m. Aug. 11, (gage height 10.11 feet).

1937 to June 1938: Discharge, 8,480 second-feet Oct. 23, 1937 (gage height, 9.76 feet).

REMARKs.-Flood discharge not affected by storage or diversion.

Mean discharge, in second-feet, 1938

\begin{tabular}{r|c|c||c|c|c||c|c|c||c|c|c}
\hline Day & July & August & Day & July & August & Day & July & August & Day & July & August \\
\cline { 3 - 8 } 1 & 178 & 242 & 9 & 238 & 460 & 17 & 165 & 240 & 25 & 850 & 105 \\
2 & 227 & 255 & 10 & 255 & 315 & 18 & 176 & 268 & 26 & 570 & 94 \\
3 & 170 & 176 & 11 & 208 & 4,650 & 19 & 226 & 218 & 27 & 420 & 90 \\
$\mathbf{4}$ & 149 & 154 & 12 & 255 & 1,100 & 20 & 211 & 179 & 28 & 335 & 83 \\
5 & 132 & 137 & 13 & 233 & 630 & 21 & 2,650 & 154 & 29 & 282 & 78 \\
6 & 123 & 178 & 14 & 240 & 442 & 22 & 3,950 & 137 & 30 & 237 & 75 \\
7 & 113 & 300 & 15 & 250 & 334 & 23 & 2,750 & 123 & 31 & 205 & 70 \\
$\mathbf{8}$ & 105 & 400 & 16 & 196 & 271 & 24 & 1,420 & 113 & & & \\
\hline
\end{tabular}


Gage height, in teet, and discharge, in second-feet, at indicated time, 1938

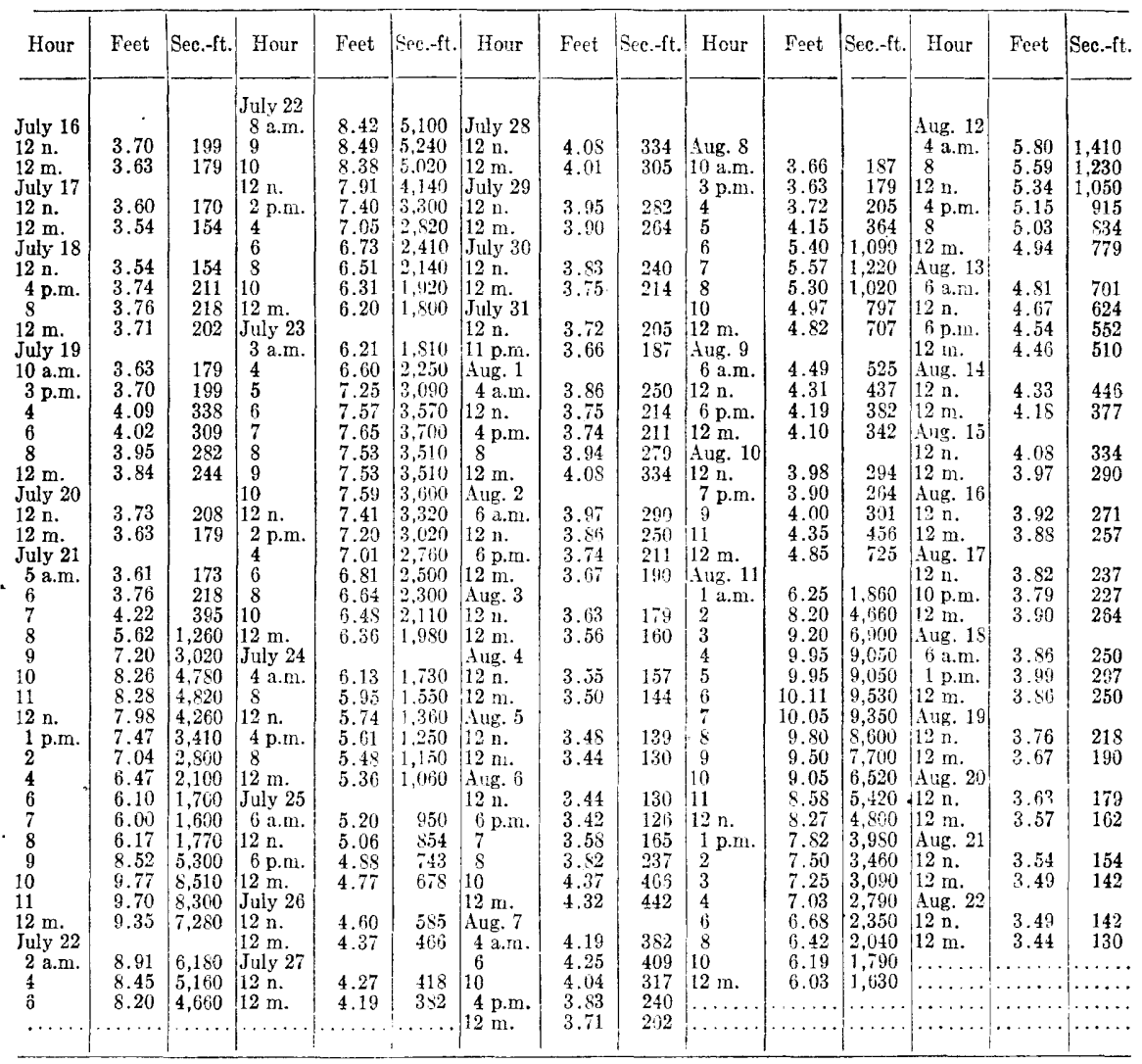

BEAVER KIEL AT COOKS TAILS, N. Y.

Location.-Lat. $41^{\circ} 56^{\prime} 50^{\prime \prime}$, long. $74^{\circ} 58^{\prime} 45^{\prime \prime}$, about 125 feet downstream from highway bridge in Cooks Falls, Delaware County, and $5 \frac{1}{2}$ miles downstream from Willowemoc Creek.

Drainage AREA.-241 square miles.

GAGE-HEIGHT RECORD.-Water-stage recorder graph.

Stage-discharge relation.-Defined by current-meter measurements below 9,500 second-feet and extended to peak stage on basis of slope-area determination and logarithmic plotting.

Maxima.-July-August 1938: Discharge, 17,500 second-feet 9 a.m. Aug. 11 (gage height, 14.51 feet).

1913 to June 1938: Discharge, about 19,000 second-feet Aug. 24, 1933

(gage height, 17.8 feet, from flood marks at site then in use.)

Remarks.-Flood discharge not affected by storage or diversion. 
Mean discharge, in second-feet, 1938

\begin{tabular}{|c|c|c|c|c|c|c|c|c|c|c|c|}
\hline Day & bin & Augist & Das' & Inly & August & Day & July & August & Day & July & August \\
\hline $\begin{array}{l}1 \\
2 \\
3 \\
4 \\
4 \\
5 \\
6 \\
7 \\
8\end{array}$ & $\begin{array}{l}480 \\
6.50 \\
478 \\
398 \\
372 \\
314 \\
278 \\
260\end{array}$ & $\begin{array}{r}740 \\
1,080 \\
620 \\
475 \\
401 \\
375 \\
1,560 \\
1,080\end{array}$ & $\begin{array}{r}9 \\
10 \\
11 \\
12 \\
13 \\
14 \\
15 \\
16\end{array}$ & $\begin{array}{l}390 \\
690 \\
540 \\
630 \\
530 \\
540 \\
570 \\
459\end{array}$ & $\begin{array}{r}1,760 \\
920 \\
9,300 \\
3,100 \\
1,700 \\
1.200 \\
910 \\
7.30\end{array}$ & $\begin{array}{l}17 \\
18 \\
19 \\
20 \\
21 \\
29 \\
23 \\
24\end{array}$ & $\begin{array}{r}388 \\
390 \\
500 \\
5+9 \\
5,160 \\
10,600 \\
6,600 \\
3,700\end{array}$ & $\begin{array}{l}750 \\
900 \\
710 \\
540 \\
458 \\
416 \\
372 \\
333\end{array}$ & $\begin{array}{l}25 \\
26 \\
27 \\
28 \\
29 \\
30 \\
31\end{array}$ & $\begin{array}{r}2,200 \\
1,460 \\
1,100 \\
880 \\
740 \\
650 \\
550\end{array}$ & $\begin{array}{l}306 \\
274 \\
254 \\
231 \\
214 \\
208 \\
203\end{array}$ \\
\hline & & & & & & & & & & $\begin{array}{r}1.320 \\
6.32\end{array}$ & $\begin{array}{r}1,037 \\
4.96\end{array}$ \\
\hline
\end{tabular}

Gage-height, in feet, and discharge, in second-feet, at indicated time, 1938

\begin{tabular}{|c|c|c|c|c|c|c|c|c|c|c|c|c|c|c|}
\hline Hour: & eet & ec.-ft. & Hour & Feet & Sec.-ft. & Hour & Feet & Sec.-ft. & Hour & Feet & Sec.-ft. & Hour & Feet & Sec.-ft. \\
\hline $\begin{array}{r}10 \mathrm{a} . \mathrm{m} . \\
2 \text { p.m. } \\
8 \mathrm{~m} . \\
12 \mathrm{~m} . \\
\text { July } 19 \\
8 \text { a.m. } \\
2 \text { p.m. } \\
5 \\
6 \\
7 \\
2 \\
\text { July } 20 \\
6 \text { a.m. } \\
22 \mathrm{n} . \\
6 \text { p.m. } \\
2 \text { m. } \\
\text { uly } 21 \\
6 \text { a.m. } \\
9 \\
10 \\
11 \\
12 \text { n. } \\
1 \text { p.m. } \\
2 \\
3 \\
4 \\
6 \\
8 \\
9 \\
10 \\
11 \\
12 \mathrm{~m} . \\
\text { July } 22 \\
1 \text { a.m. } \\
2 \\
3 \\
4 \\
6 \\
7 \\
8 \\
0 \\
1.1\end{array}$ & $\begin{array}{c}2.88 \\
2.74 \\
2.68 \\
2.57 \\
2.55 \\
2.65 \\
2.88 \\
2.87 \\
2.77 \\
2.78 \\
3.01 \\
3.17 \\
3.52 \\
3.34 \\
3.17 \\
3.07 \\
2.97 \\
2.86 \\
2.77 \\
2.86 \\
3.30 \\
6.75 \\
7.65 \\
7.95 \\
8.20 \\
7.80 \\
7.45 \\
6.82 \\
6.47 \\
6.80 \\
9.05 \\
11.85 \\
13.35\end{array}$ & $\begin{array}{r}463 \\
412 \\
391 \\
355 \\
349 \\
352 \\
463 \\
459 \\
422 \\
426 \\
514 \\
578 \\
719 \\
646 \\
578 \\
538 \\
498 \\
455 \\
422 \\
455 \\
630 \\
3,390 \\
4,520 \\
4,940 \\
5,290 \\
4,730 \\
4,260 \\
3,470 \\
3,080 \\
3,450 \\
6,570 \\
11,700 \\
14,700\end{array}$ & 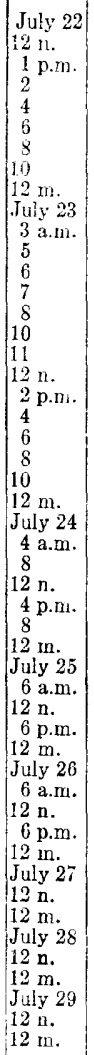 & $\begin{array}{r}12.42 \\
12.15 \\
11.70 \\
10.60 \\
9.65 \\
8.95 \\
8.42 \\
8.03 \\
7.69 \\
7.93 \\
8.70 \\
9.53 \\
9.95 \\
10.05 \\
10.14 \\
10.09 \\
9.81 \\
9.46 \\
9.10 \\
8.75 \\
8.44 \\
8.15\end{array}$ & $\begin{array}{l}4,550 \\
4,910 \\
6,030 \\
7,390 \\
8,130 \\
8,330 \\
8,470 \\
8,380 \\
7,880 \\
7,260 \\
6,650 \\
6,100 \\
5,640 \\
5,220\end{array}$ & 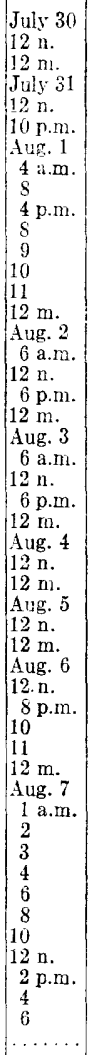 & $\begin{array}{l}5.50 \\
6.20 \\
6.23 \\
6.00 \\
5.55 \\
5.19 \\
4.89 \\
4.63 \\
4.50 \\
4.22 \\
4.06\end{array}$ & \begin{tabular}{|c}
1,260 \\
1,030 \\
.855 \\
790 \\
664 \\
620 \\
566 \\
522 \\
478 \\
431 \\
408 \\
368 \\
347 \\
354 \\
450 \\
570 \\
760
\end{tabular} & 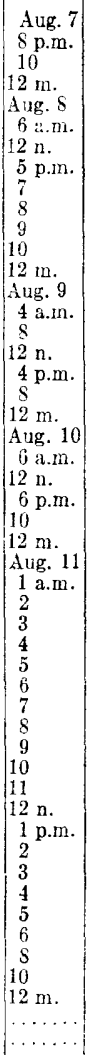 & $\begin{array}{r}3.94 \\
3.81 \\
3.66 \\
3.66 \\
3.92 \\
4.28 \\
5.10 \\
8.10 \\
10.90 \\
12.00 \\
12.85 \\
13.70 \\
14.30 \\
14.51 \\
14.10 \\
12.45 \\
11.95 \\
11.23 \\
10.75 \\
10.10 \\
9.70 \\
9.27 \\
8.61 \\
8.12 \\
7.73\end{array}$ & $\left\{\begin{array}{r}1,190 \\
1,790 \\
5,150 \\
9,870 \\
12,090 \\
13,700 \\
15,400 \\
1,9900 \\
17,500 \\
16,300 \\
14,900 \\
1,900 \\
11,800 \\
10,800 \\
9,580 \\
8,400 \\
7,680 \\
6,940 \\
5,900 \\
5,180 \\
4,630\end{array}\right.$ & 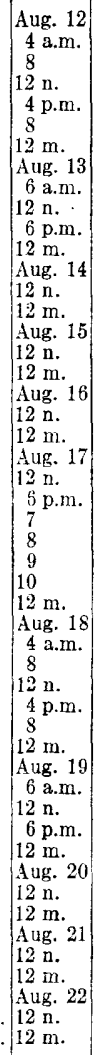 & $\begin{array}{l}5.22 \\
4.97 \\
4.74 \\
4.54 \\
4.31 \\
4.00 \\
3.83 \\
3.61\end{array}$ & $\begin{array}{l}3,910 \\
3,380 \\
2,930 \\
2,580 \\
2,300 \\
2,120\end{array}$ \\
\hline
\end{tabular}

WILLOWEMOC CREEK NEAR IIVINGSTON MANOR, N. Y.

Location.-Lat. $41^{\circ} 54^{\prime} 15^{\prime \prime}$, long. $74^{\circ} 48^{\prime} 50^{\prime \prime}$, three quarters of a mile upstream from highway bridge in Livingston Manor, Sullivan County, and $1 \frac{1}{2}$ miles upstream from Little Beaver Kill.

Drainage area.-63 square miles.

GAGE-HEIGHT RECORD.-Water-stage recorder graph. 
Stage-discharge relation.-Defined by current-meter measurements below 5,800 second-feet and extended by logarithmic plotting.

Maxima.-July-August 1938: Discharge, 6,200 second-feet 6:40 a.m. Aug. 11

(gage height, 7.87 feet).

1937 to June 1938: Discharge, 4,470 second-feet Oct. 23, 1937 (gage height, 6.72 feet).

Remarks.-Flood discharge not affected by storage or diversion.

Mean discharge, in second-feet, 1938

\begin{tabular}{r|c|c|c|c|c||c|c|c||c|c|c}
\hline Day & July & August & Day & July & August & Day & July & August & Day & July & August \\
\hline 1 & 101 & 485 & 9 & 124 & 540 & 17 & 74 & 270 & 25 & 500 & 91 \\
2 & 140 & 350 & 10 & 192 & 275 & 18 & 77 & 300 & 26 & 335 & $\mathbf{8 0}$ \\
3 & 103 & 180 & 11 & 128 & 3150 & 19 & 148 & 217 & 27 & 258 & 72 \\
4 & 85 & 135 & 12 & 135 & 820 & 20 & 145 & 160 & 28 & 206 & 62 \\
5 & 75 & 114 & 13 & 108 & 420 & 21 & 960 & 132 & 29 & 180 & 59 \\
6 & 68 & 144 & 14 & 99 & 296 & 22 & 3550 & 123 & 30 & 158 & 59 \\
7 & 63 & 410 & 15 & 103 & 232 & 23 & 1660 & 109 & 31 & 135 & 64 \\
8 & 59 & 430 & 16 & 85 & 195 & 24 & 880 & 104 & & & \\
\hline
\end{tabular}

Gage height, in feet, and discharge, in second-feet, at indicated time, 1938

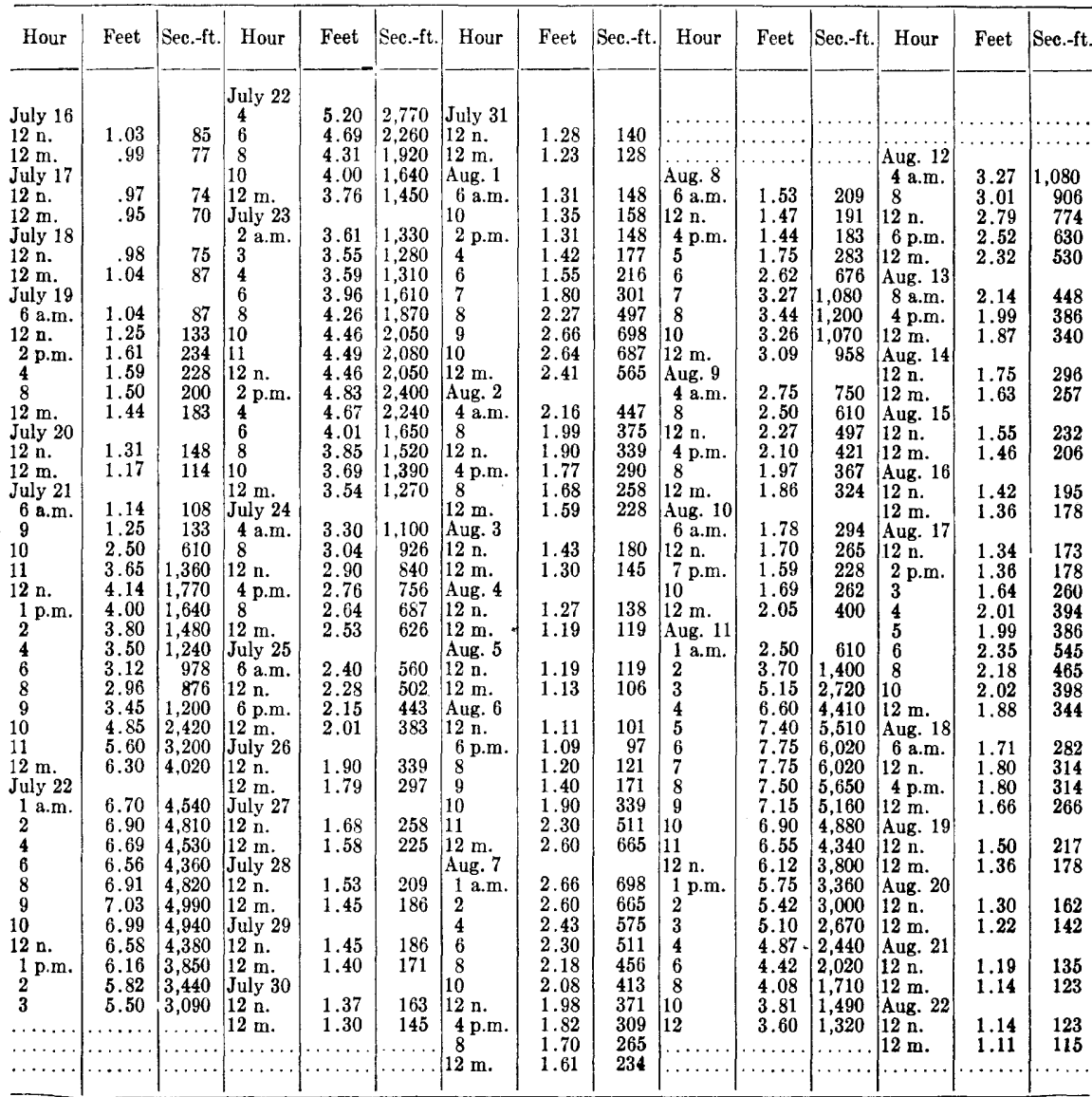




\section{IITTIA BEAVER KITI NEAR IIVINGSTON MANOR, N. Y.}

LOCATion.-Lat. $41^{\circ} 52^{\prime} 20^{\prime \prime}$, long. $74^{\circ} 47^{\prime} 55^{\prime \prime}, 2 \frac{1 / 2}{}$ miles southeast of Livingston Manor, Sullivan County, and 3 miles upstream from Cattail Brook. Datum of gage is $\mathbf{1 4 9 6 . 6 9}$ feet above mean sea level (general adjustment of 1912).

Drainage AREA. -19.8 square miles.

GAGE-HEIGHT RECORD.--Staff gage read to hundredths twice daily and more frequently during floods. Record for July 19, 21-23, Aug. 1, 6-12, 17, 18 taken from graph based on gage readings.

Stage-ischarge Relation.-Defined by current-meter measurements below 1,200 second-feet and extended to peak stage by logarithmic plotting.

Maxima.-July-August 1938: Discharge, 1,620 second-feet 8 a.m. July 22 (gage height, 6.10 feet, from graph based on gage readings).

1924 to June 1938: Discharge, 2,500 second-feet Aug. 26, 1928 (gage height, 8.7 feet, from floodmarks), from rating curve extended above 470 second-feet by logarithmic plotting on basis of slope-area determination. RemarKs.-Flood discharge not affected by storage or diversion.

Mean discharge, in second-feet, 1938

\begin{tabular}{r|r|r||c|c|c||c|c|c|c|c|c}
\hline Day & July & August & Day & July & August & Day & July & August & Day & July & August \\
\cline { 3 - 8 } 1 & 25 & 126 & 9 & 17 & 222 & 17 & 9.4 & 66 & 25 & 120 & 18 \\
2 & 48 & 137 & 10 & 17 & 104 & 18 & 12 & 65 & 26 & 76 & 16 \\
3 & 27 & 54 & 11 & 42 & 768 & 19 & 32 & 47 & 27 & 58 & 13 \\
4 & 19 & 39 & 12 & 31 & 204 & 20 & 26 & 35 & 28 & 43 & 13 \\
5 & 18 & 31 & 13 & 15 & 103 & 21 & 58 & 30 & 29 & 42 & 11 \\
6 & 14 & 112 & 14 & 11 & 72 & 22 & 963 & 26 & 30 & 32 & 9.9 \\
7 & 10 & 304 & 15 & 10 & 54 & 23 & 375 & 22 & 31 & 26 & 10 \\
8 & 10 & 259 & 16 & 10 & 43 & 24 & 201 & 20 & & & \\
\hline
\end{tabular}

Gage height, in feet, and discharge, in second-feet, at indicated time, 1938

\begin{tabular}{|c|c|c|c|c|c|c|c|c|c|c|c|c|c|c|}
\hline Hour & Feet & Sec.-ft. & Hour & Feet & Sec.-ft. & Hour & Feet & Sec.-ft. & Hour & Feet & Sec.-ft. & Hour & Feet & Sec.-ft. \\
\hline $\begin{array}{c}\text { uly } 16 \\
6 \text { a.m. } \\
6 \text { p.m. } \\
\text { illy } 17 \\
6 \text { a.m. } \\
5 \text { p.m. } \\
\text { uly } 18 \\
6 \text { a.m. } \\
6 \text { p.m. } \\
\text { uly } 19 \\
6 \text { a.m. } \\
2 \text { p.m. } \\
6 \\
12 \text { m. } \\
\text { July } 20 \\
6 \text { a.m. } \\
6 \text { p.m. } \\
\text { July } 21 \\
6 \text { a.m. } \\
6 \text { p.m. } \\
2 \\
12 \text { m. } \\
\text { July } 22 \\
1 \text { a.m. } \\
4 \\
7 \\
8 \\
0 \\
2 \text { n. } \\
2 \text { p.m. } \\
4 \\
6 \\
9 \\
2 \text { m. } \\
\end{array}$ & $\begin{array}{l}1.84 \\
1.88 \\
2.10 \\
5.70 \\
5.95 \\
5.65 \\
6.00 \\
6.10 \\
5.60 \\
4.80 \\
4.20 \\
3.82 \\
3.50 \\
3.24 \\
3.07\end{array}$ & $\begin{array}{r}27 \\
32 \\
62 \\
1,420 \\
\\
1,540 \\
1,400 \\
1,570 \\
1,620 \\
1,370 \\
970 \\
690 \\
540 \\
418 \\
326 \\
273\end{array}$ & $\begin{array}{c}\text { July } 23 \\
2 \text { a.m. } \\
4 \\
6 \\
9 \\
12 \text { n. } \\
3 \text { p.m. } \\
6 \\
9 \\
12 \text { m. } \\
\text { July } 24 \\
7 \text { a.m. } \\
6 \text { p.m. } \\
\text { July } 25 \\
6 \text { a.m. } \\
6 \text { p.m. } \\
\text { July } 26 \\
6 \text { a.m. } \\
6 \text { p.m. } \\
\text { July } 27 \\
6 \text { a.m. } \\
6 \text { p.m. } \\
\text { July } 28 \\
6 \text { a.m. } \\
6 \text { p.m. } \\
\text { July } 29 \\
6 \text { a.m. } \\
6 \text { p.m. } \\
\text { July } 30 \\
6 \text { a.m. } \\
6 \text { p.m. } \\
\ldots \ldots . .\end{array}$ & $\begin{array}{l}3.03 \\
3.18 \\
3.70 \\
4.10 \\
3.70 \\
3.30 \\
3.00 \\
2.92 \\
2.88 \\
\\
2.90 \\
2.70\end{array}$ & $\begin{array}{l}262 \\
307 \\
494 \\
650 \\
494 \\
346 \\
253 \\
231 \\
221 \\
\\
226 \\
177 \\
\\
138 \\
103\end{array}$ & $\begin{array}{c}\text { July } 31 \\
6 \text { a.m. } \\
6 \text { p.m. } \\
\text { Aug. } 1 \\
7 \text { a.m. } \\
12 \text { n. } \\
3 \text { p.m. } \\
6 \\
9 \\
12 \text { m. } \\
\text { Aug. } 2 \\
6 \text { a.m. } \\
6 \text { p.m. } \\
\text { Aug. } 3 \\
6 \text { a.m. } \\
6 \text { p.m. } \\
\text { Aug. } 4 \\
6 \text { a.m. } \\
6 \text { p.m. } \\
\text { Aug. } 5 \\
6 \text { a.m. } \\
6 \text { p.m. } \\
\text { Aug. } 6 \\
6 \text { a.m. } \\
6 \text { p.m. } \\
8 . \\
10 \\
12 \text { m. } \\
\text { Aug. } 7 \\
6 \text { a.m. } \\
12 \text { n. } \\
6 \text { p.m. } \\
12 \text { m. } \\
\ldots \ldots . . \\
\ldots \ldots . .\end{array}$ & $\begin{array}{l}1.84 \\
1.82 \\
2.00 \\
2.25 \\
2.57 \\
2.90 \\
3.07 \\
3.00 \\
2.70 \\
2.24 \\
2.10 \\
2.00 \\
1.96 \\
1.92 \\
1.88 \\
1.86 \\
1.84 \\
1.90 \\
2.80 \\
3.90 \\
3.94\end{array}$ & $\begin{array}{r}27 \\
25 \\
\\
47 \\
86 \\
149 \\
226 \\
273 \\
253 \\
\\
177 \\
85 \\
\\
62 \\
47 \\
\\
42 \\
37 \\
\\
32 \\
30 \\
\\
27 \\
34 \\
201 \\
571 \\
587\end{array}$ & 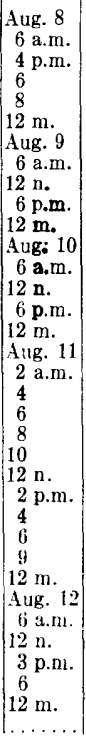 & $\begin{array}{l}2.46 \\
2.40 \\
4.00 \\
4.20 \\
3.65 \\
\\
3.10 \\
2.77 \\
2.56 \\
2.47 \\
\\
2.40 \\
2.30 \\
2.26 \\
2.65 \\
\\
4.70 \\
5.80 \\
5.90 \\
5.45 \\
4.75 \\
4.25 \\
3.98 \\
3.70 \\
3.40 \\
3.19 \\
3.11 \\
\\
3.04 \\
2.80 \\
2.69 \\
2.60 \\
2.50\end{array}$ & $\begin{array}{r}126 \\
114 \\
610 \\
690 \\
475 \\
\\
282 \\
194 \\
147 \\
128 \\
\\
114 \\
95 \\
88 \\
166 \\
\\
920 \\
1,470 \\
1,520 \\
1,300 \\
945 \\
712 \\
602 \\
494 \\
381 \\
310 \\
285\end{array}$ & $\begin{array}{c}\text { Aug. } 13 \\
7 \text { a.m. } \\
6 \text { p.m. } \\
\text { Aug. } 14 \\
7 \text { a.m. } \\
6 \text { p.m. } \\
\text { Aug. } 15 \\
6 \text { a.m. } \\
6 \text { p.m. } \\
\text { Aug. } 16 \\
6 \text { a.m. } \\
6 \text { p.m. } \\
\text { Aug. } 17 \\
6 \text { a.m. } \\
3 \text { p.m. } \\
4 \\
6 \\
12 \text { m. } \\
\text { Aug. } 18 \\
6 \text { a.m. } \\
12 \text { n. } \\
6 \text { p.m. } \\
12 \text { m. } \\
\text { Aug. } 19 \\
6 \text { a.m. } \\
6 \text { p.m. } \\
\text { Aug. } 20 \\
6 \text { a.m. } \\
6 \text { p.m. } \\
\text { Aug. } 21 \\
6 \text { a.m. } \\
6 \text { p.m. } \\
\text { Aug. } 22 \\
6 \text { a.m. } \\
6 \text { p.m. }\end{array}$ & $\begin{array}{l}2.20 \\
2.12 \\
2.08 \\
2.02 \\
\\
2.00 \\
1.94 \\
1.94 \\
1.94 \\
2.20 \\
2.50 \\
2.29 \\
2.10 \\
2.12 \\
2.14 \\
2.10 \\
2.04 \\
1.96\end{array}$ & $\begin{array}{r}78 \\
65 \\
59 \\
50 \\
\\
47 \\
39 \\
\\
39 \\
39 \\
78 \\
134 \\
93\end{array}$ \\
\hline
\end{tabular}


WEST BRANCH OF DELAWARE RIVER AT DEIHI, N. $Y$.

Location.-Lat. $42^{\circ} 16^{\prime} 15^{\prime \prime}$, long. $74^{\circ} 55^{\prime} 10^{\prime \prime}$, about 300 feet downstream from Steele Brook and about a quarter of a mile downstream from lower highway bridge in Delhi, Delaware County. Datum of gage is 1,345.97 feet above mean sea level (general adjustment of 1912).

Drainage AREA.-142 square miles.

GAGE-HEIGHT RECORD.-Water-stage recorder graph.

Stage-discharge relation.-Defined by current-meter measurements to 3,000 second-feet.

Maxima.--July-August 1938: Discharge 2,170 second-feet 8 a.m. Aug. 11 (gage height, 5.23 feet).

1937 to June 1938: Discharge, 4,290 second-feet Jan. 25, 1938 (gage height, 6.82 feet), from rating curve extended above 3,000 second-feet on basis of area-velocity studies.

Remarks.-Flood discharge not affected by storage or diversion.

\begin{tabular}{|c|c|c|c|c|c|c|c|c|c|c|c|}
\hline Day & July & August & Day & Iuly & August & Day & $J_{u l l y}$ & August & Day & July & August \\
\hline $\begin{array}{l}1 \\
2 \\
3 \\
4 \\
5 \\
6 \\
7 \\
8\end{array}$ & $\begin{array}{r}225 \\
275 \\
178 \\
150 \\
128 \\
113 \\
99 \\
90\end{array}$ & $\begin{array}{l}269 \\
286 \\
199 \\
166 \\
139 \\
118 \\
176 \\
202\end{array}$ & $\begin{array}{r}9 \\
10 \\
11 \\
12 \\
13 \\
14 \\
15 \\
16\end{array}$ & $\begin{array}{r}81 \\
74 \\
87 \\
126 \\
81 \\
72 \\
72 \\
163\end{array}$ & $\begin{array}{r}226 \\
200 \\
1,460 \\
640 \\
435 \\
336 \\
265 \\
229\end{array}$ & $\begin{array}{l}17 \\
18 \\
19 \\
20 \\
21 \\
22 \\
23 \\
24\end{array}$ & $\begin{array}{r}61 \\
198 \\
180 \\
134 \\
285 \\
580 \\
720 \\
510\end{array}$ & $\begin{array}{r}192 \\
232 \\
188 \\
144 \\
123 \\
115 \\
104 \\
92\end{array}$ & $\begin{array}{l}25 \\
26 \\
27 \\
28 \\
29 \\
30 \\
31\end{array}$ & $\begin{array}{l}400 \\
309 \\
335 \\
248 \\
465 \\
550 \\
300\end{array}$ & $\begin{array}{l}86 \\
79 \\
75 \\
69 \\
64 \\
62 \\
60\end{array}$ \\
\hline \multicolumn{10}{|c|}{$\begin{array}{l}\text { Monthly mean discharge, in second-ipet } \\
\text { Runoff, in inches }\end{array}$} & $\begin{array}{r}233 \\
1.89\end{array}$ & $\begin{array}{r}227 \\
1.84\end{array}$ \\
\hline
\end{tabular}

Peak discharge.-July 23 (4:30 1.'11.) 1,100 sec.-ft.

WEST BRANCH OF DRLAWARE RIVER AT HALI EDDY, N. Y.

Location.-Lat. $42^{\circ} 00^{\prime} 10^{\prime \prime}$, long. $75^{\circ} 23^{\prime} 15^{\prime \prime}$, at highway bridge in Hale Eddy,

Delaware County, 9 miles upstream from confluence with East Branch of Delaware River. Datum of gage is 946.34 feet above mean sea level (general adjustment of 1912).

Drainage AREA.-593 square miles.

GAGE-HEIGHT RECORD.-Water-stage recorder graph.

Stage-discharge relation.-Defined by current-meter measurements below 22,800 second-feet.

Maxima.-July-August 1938: Discharge, 19,600 second-feet 11 a.m. Aug. 11, (gage height, 13.75 feet).

1912 to June 1938: Discharge, about 26,500 second-feet Sept. 30, 1924 (gage height, 15.8 feet, from graph based on gage readings). Maximum discharge known, about 46,000 second-feet Oct. 10, 1903 (gage height, 20.3 feet).

Remarks.-Flood discharge not affected by storage or diversion. 
Mean discharge, in second-feet, 1938

\begin{tabular}{|c|c|c|c|c|c|c|c|c|c|c|c|}
\hline 1) ay & $\left.J_{11}\right]_{5}$ & Alugust & $I_{i 15}$ & July & August & Day & July & Augusi & Day & July & August \\
\hline $\begin{array}{l}1 \\
2 \\
5 \\
4 \\
5 \\
6 \\
7 \\
8\end{array}$ & $\begin{array}{r}\$ 80 \\
1 .(110 \\
870 \\
643 \\
550 \\
468 \\
407 \\
354\end{array}$ & $\begin{array}{r}5+4 \\
428 \\
7+7 \\
581 i \\
486 \\
411 \\
1,140 \\
870\end{array}$ & $\begin{array}{l}9 \\
10 \\
11 \\
12 \\
13 \\
14 \\
15 \\
16\end{array}$ & $\begin{array}{l}324 \\
802 \\
284 \\
385 \\
362 \\
295 \\
284 \\
258\end{array}$ & $\begin{array}{c}2,060 \\
1,310 \\
13,200 \\
6,300 \\
3,100 \\
2,110 \\
1,620 \\
1,300\end{array}$ & $\begin{array}{l}17 \\
18 \\
19 \\
20 \\
21 \\
22 \\
23 \\
24\end{array}$ & $\begin{array}{r}216 \\
415 \\
787 \\
529 \\
559 \\
1,340 \\
1,520 \\
2,180\end{array}$ & $\begin{array}{r}1,120 \\
1,560 \\
1,280 \\
940 \\
763 \\
673 \\
603 \\
524\end{array}$ & $\begin{array}{l}25 \\
26 \\
27 \\
28 \\
29 \\
30 \\
31\end{array}$ & $\begin{array}{r}1,510 \\
1,220 \\
1,040 \\
1,000 \\
910 \\
1,620 \\
1,120\end{array}$ & $\begin{array}{l}472 \\
420 \\
382 \\
346 \\
313 \\
281 \\
271\end{array}$ \\
\hline $\begin{array}{l}\text { Mont } \\
\text { Runo }\end{array}$ & $\begin{array}{l}y \text { nea } \\
\text { in inc }\end{array}$ & ischarse & $11 \mathrm{se}$ & f fou & - & & & & $-\cdots$ & $\begin{array}{r}777 \\
1.51\end{array}$ & $\begin{array}{r}1,520 \\
2.95\end{array}$ \\
\hline
\end{tabular}

Peak dir harde.-July 24 (12:30 a.m.) 2,580 sec.-ft.

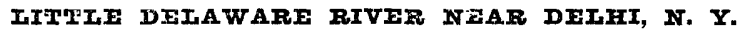

Location.-Lat. $42^{\circ} 15^{\prime} 10^{\prime \prime}$, long. $74^{\circ} 54^{\prime} 10^{\prime \prime}, 20$ feet downstream from highway bridge at Peck Hill, 11/2 miles upstream from mouth, and 2 miles south of

Delhi, Delaware County.

Drainace afea.-49.8 square miles.

GAGE-HEIGHT RECORD.-Staff gage read to hundredths twice daily.

Stage-discharce relation.-Defined by current-meter measurements below

970 second-feet and extended to peak stage by logarithmic plotting.

Maxima.-July-August 1938: Discharge, 1,500 second-feet about 6 a.m.

Aug. 11 (gage height, 5.7 feet from graph based on gage readings).

1937 to June 1938: Discharge, 2,180 second-feet Jan. 25, 1938 (gage

height, 6.95 feet), from rating curve extended above 750 second-feet by

logarithmic plotting.

REMARKs.-Flood discharge not affected by storage or diversion.

Mean discharge, in second-feet, 1938

\begin{tabular}{|c|c|c|c|c|c|c|c|c|c|c|c|}
\hline Day & July & Aligust & Day & July & August & Day & July & August & Day & July & August \\
\hline $\begin{array}{l}1 \\
2 \\
3 \\
4 \\
5 \\
6 \\
7 \\
8\end{array}$ & $\begin{array}{r}136 \\
162 \\
120 \\
87 \\
65 \\
23 \\
42 \\
37\end{array}$ & $\begin{array}{l}74 \\
78 \\
53 \\
46 \\
35 \\
35 \\
42 \\
56\end{array}$ & $\begin{array}{r}4 \\
10 \\
11 \\
12 \\
13 \\
14 \\
15 \\
16\end{array}$ & $\begin{array}{l}32 \\
26 \\
66 \\
15 \\
29 \\
28 \\
29 \\
26\end{array}$ & $\begin{array}{r}76 \\
62 \\
961 \\
302 \\
181 \\
1+8 \\
124 \\
104\end{array}$ & $\begin{array}{l}17 \\
18 \\
19 \\
20 \\
21 \\
22 \\
23 \\
24\end{array}$ & $\begin{array}{r}25 \\
49 \\
43 \\
85 \\
173 \\
331 \\
183 \\
343\end{array}$ & $\begin{array}{l}61 \\
84 \\
98 \\
66 \\
47 \\
44 \\
38 \\
34\end{array}$ & $\begin{array}{l}25 \\
26 \\
27 \\
28 \\
29 \\
30 \\
31\end{array}$ & $\begin{array}{l}250 \\
181 \\
164 \\
126 \\
212 \\
194 \\
101\end{array}$ & $\begin{array}{l}28 \\
27 \\
27 \\
26 \\
22 \\
19 \\
16\end{array}$ \\
\hline Iont & il & clarge & & & & & & & & $\begin{array}{r}121 \\
2.80\end{array}$ & $\begin{array}{l}97.2 \\
2.25\end{array}$ \\
\hline
\end{tabular}

Peak discharge.-July 23 (9 a.m.) 843 sec.-ft.

\section{NFVERSINK RIVIR AT HAILS MIILS, NEAR CURRY, N. Y.}

Location.-Lat. $41^{\circ} 52^{\prime} 40^{\prime \prime}$, long. $74^{\circ} 36^{\prime} 20^{\prime \prime}$, 1/1/4 miles downstream from covered wooden bridge at Halls Mills and 13/4 miles northwest of Curry, Sullivan County.

Drainage AREA.-68 square miles.

GAGE-Height RECORD.-Water-stage recorder graph.

StaGE-Discharge RELATION.--Defined by current-meter measurements below 5,100 second-feet and extended logarithmically to peak stage on basis of slope-area measurement. 
Maxima.-July-August 1938: Discharge, 12,400 second-feet 9 a.m. July 22 (gage height, 10.05 feet).

1937 to June 1938: Discharge, 13,000 second-feet Oct. 23, 1937 (gage height, 10.37 feet, from floodmarks).

REMARKs.-Flood discharge not affected by storage or diversion.

Mean discharge, in second-feet, 1938

\begin{tabular}{|c|c|c|c|c|c|c|c|c|c|c|c|}
\hline Day & July & August & Day & July & August & Day & July & August & Day & July & August \\
\hline $\begin{array}{l}1 \\
2 \\
3 \\
4 \\
5 \\
6 \\
7 \\
8\end{array}$ & $\begin{array}{r}139 \\
220 \\
149 \\
121 \\
114 \\
99 \\
91 \\
88\end{array}$ & $\begin{array}{l}410 \\
470 \\
279 \\
232 \\
206 \\
206 \\
265 \\
236\end{array}$ & $\begin{array}{r}9 \\
10 \\
11 \\
12 \\
13 \\
14 \\
15 \\
16\end{array}$ & $\begin{array}{r}140 \\
166 \\
136 \\
167 \\
135 \\
106 \\
106 \\
99\end{array}$ & $\begin{array}{r}232 \\
204 \\
3,600 \\
720 \\
405 \\
309 \\
257 \\
225\end{array}$ & $\begin{array}{l}17 \\
18 \\
19 \\
20 \\
21 \\
22 \\
23 \\
24\end{array}$ & $\begin{array}{r}84 \\
81 \\
300 \\
226 \\
1,640 \\
5,900 \\
3,250 \\
1,340\end{array}$ & $\begin{array}{l}218 \\
280 \\
228 \\
188 \\
172 \\
160 \\
147 \\
135\end{array}$ & $\begin{array}{l}25 \\
26 \\
27 \\
28 \\
29 \\
30 \\
31\end{array}$ & $\begin{array}{l}620 \\
425 \\
342 \\
335 \\
375 \\
325 \\
246\end{array}$ & $\begin{array}{r}129 \\
123 \\
117 \\
108 \\
105 \\
99 \\
94\end{array}$ \\
\hline \multicolumn{10}{|c|}{$\begin{array}{l}\text { Monthly mean discharge, in second-feet } \\
\text { Runoff, in inches. }\end{array}$} & $\begin{array}{r}567 \\
9.62\end{array}$ & $\begin{array}{r}341 \\
5.78\end{array}$ \\
\hline
\end{tabular}

Gage height, in feet, and discharge, in second-feet, at indicated time, 1938

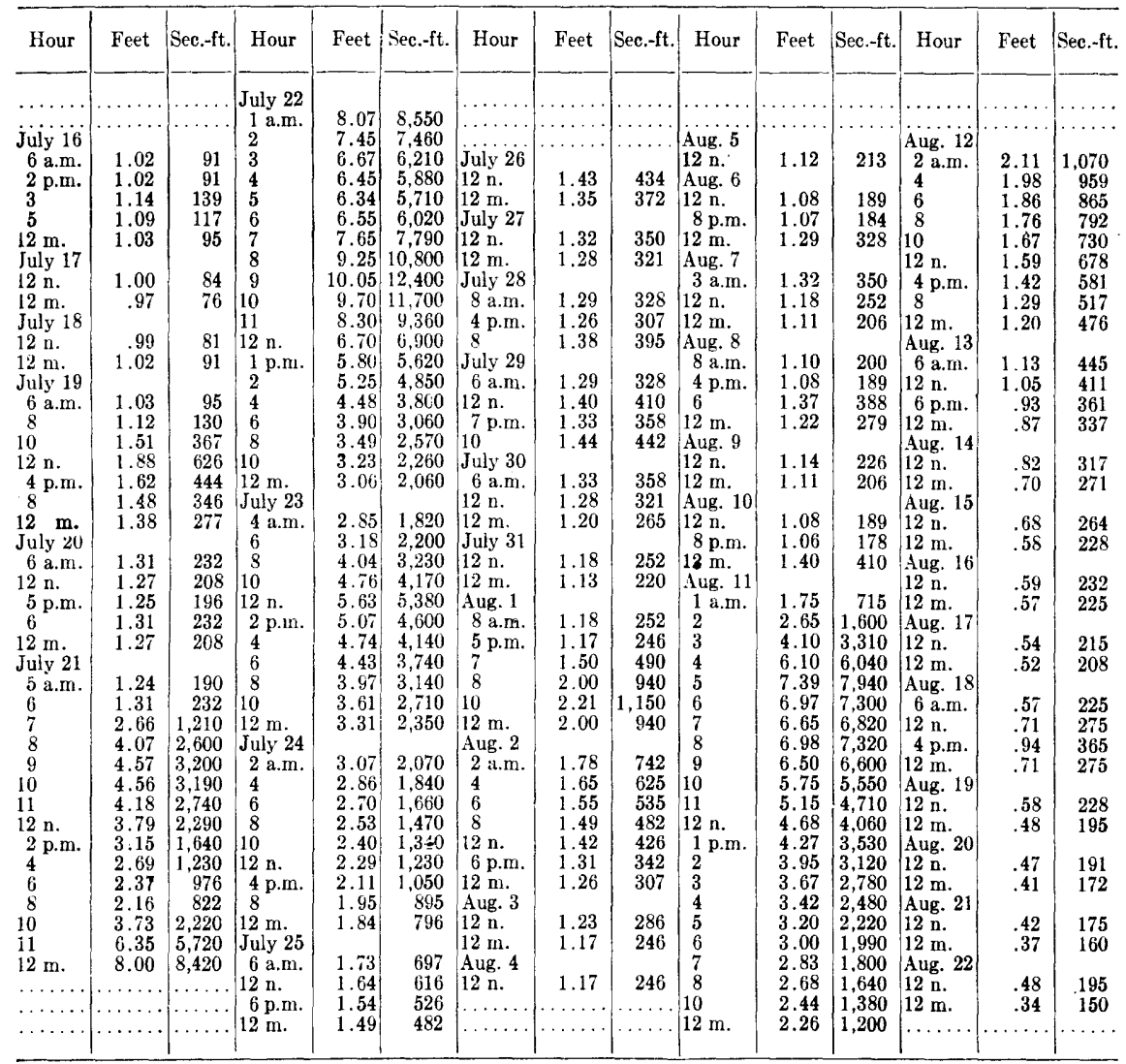




\section{NEVGRSINK RIVER AT WOODBOURNE, N. Y.}

Location,-Lat. $41^{\circ} 45^{\prime} 25^{\prime \prime}$, long. $72^{\circ} 35^{\prime} 55^{\prime \prime}$, a quarter of a mile downstream from bridge on State Highway 52 in Woodbourne, Sullivan County.

Drainage AREA.-113 square miles.

GAGE-HEIGHT RECORD.-Staff gage read to hundredths twice daily and more frequently during floods. Record for July 19-23, Aug. 6-8, 10-12, determined from graph based on gage readings.

Stage-discharge relation.-Defined by current-meter measurements below 9,000 second-feet and extended to peak stage by logarithmic plotting.

Maxima.-July-August 1938: Discharge, 12,300 second-feet 11 a.m. July 22

(gage height, 11.2 feet, from floodmarks and graph based on gage readings).

1937 to June 1938: Discharge, 11,000 second-feet Oct. 23, 1937 (gage height, 10.7 feet, from floodmarks and graph based on gage readings).

REMarKs.-Flood discharge not affected by storage or diversion.

Mean discharge, in second-feet, 1938

\begin{tabular}{r|c|c||c|c|c|c|c|c|c|c|c}
\hline Day & July & August & Day & July & August & Day & July & August & Day & July & August \\
\hline 1 & 193 & 464 & 9 & 150 & 795 & 17 & 132 & 310 & 25 & 1,200 & 162 \\
2 & 252 & 960 & 10 & 240 & 503 & 18 & 127 & 390 & 26 & 803 & 158 \\
3 & 200 & 537 & 11 & 170 & 4,560 & 19 & 200 & 366 & 27 & 610 & 150 \\
4 & 165 & 418 & 12 & 245 & 1,050 & 20 & 275 & 256 & 28 & 550 & 139 \\
5 & 155 & 372 & 13 & 201 & 522 & 21 & 1,340 & 233 & 29 & 580 & 132 \\
6 & 140 & 813 & 14 & 168 & 494 & 22 & 7.700 & 214 & 30 & 550 & 126 \\
7 & 130 & 1,280 & 15 & 162 & 394 & 23 & 4,820 & 188 & 31 & 418 & 115 \\
8 & 125 & 546 & 16 & 141 & 330 & 24 & 2,080 & 175 & & & \\
\hline
\end{tabular}

Gage height, in feet, and discharge, in second-feet, at indicated time, 1938

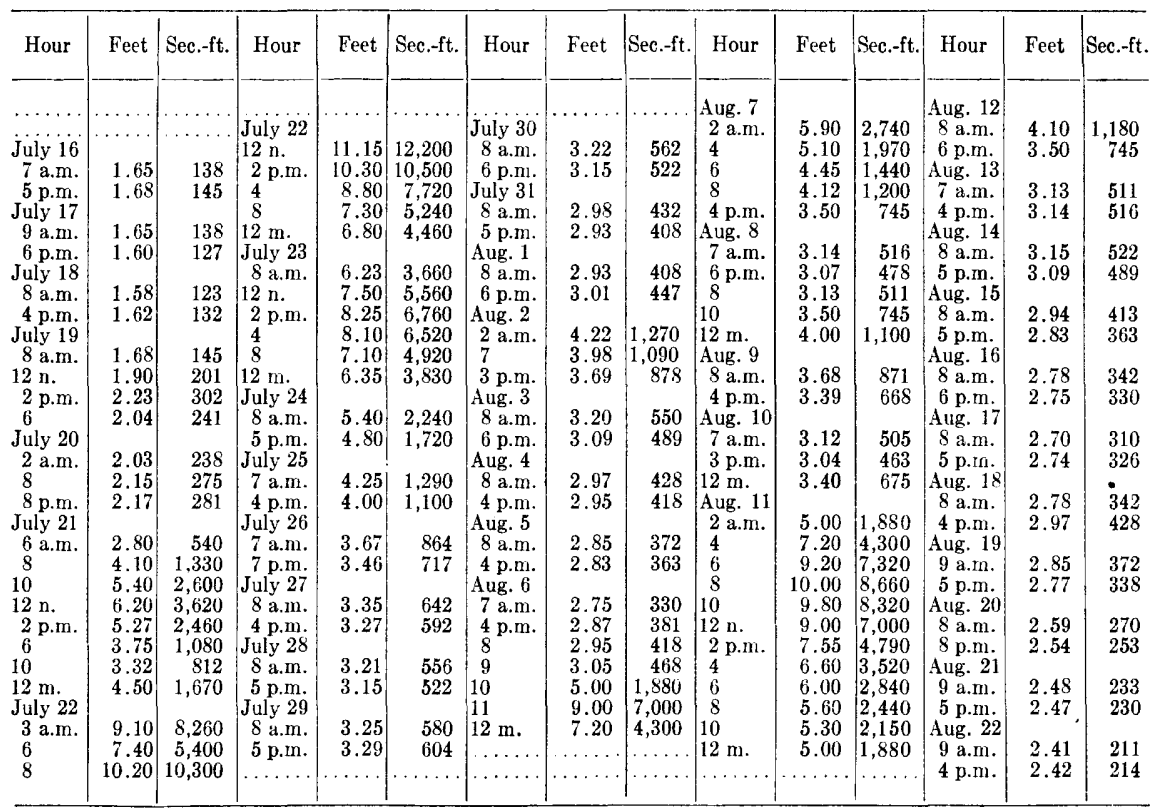


NEVMRSINK RIVER AT OAKTAND VAIIEY, N. Y.

Location.-Lat. $41^{\circ} 29^{\prime} 45^{\prime \prime}$, long. $74^{\circ} 38^{\prime} 45^{\prime \prime}$, 250 feet downstream from highway bridge known as Paradise Bridge, Orange County, and three-quarters of a mile south of Oakland Valley, Sullivan County. Datum of gage is 632.00 feet above mean sea level (general adjustment of 1912).

Drainage area.-222 square miles.

GAGE-HEIGHT ReCord.-Water-stage recorder graph.

STAGE-DISChARGE RELATION.-Defined by current-meter measurements below

7,500 second-feet and extended to peak stage by logarithmic plotting.

Maxima.-July-August 1938: Discharge, 14,500 second-feet 2 p.m. July 22 (gage height, 10.70 feet).

1928 to June 1938: Discharge, 20,000 second-feet Aug. 24, 1933 (gage height, 12.61 feet), from rating curve extended above 4,100 second-feet by logarithmic plotting.

REMARKS.-Flood discharge not affected by storage or diversion.

Mean discharge, in second-feet, 1938

\begin{tabular}{c|c|c||c|c|c||c|c|c|c|c|c}
\hline Day & July & August & Day & July & August & Day & July & August & Day & July & August \\
\hline 1 & 332 & 489 & 9 & 179 & 1,020 & 17 & 179 & 464 & 25 & 1,680 & 225 \\
2 & 345 & 1,140 & 10 & 410 & 560 & 18 & 176 & 519 & 26 & 1,120 & 209 \\
3 & 305 & 620 & 11 & 250 & 5,500 & 19 & 240 & 550 & 27 & 830 & 205 \\
4 & 246 & 494 & 12 & 355 & 2,240 & 20 & 520 & 409 & 28 & 714 & 200 \\
5 & 235 & +14 & 13 & 271 & 1,140 & 21 & 1,280 & 349 & 29 & 720 & 188 \\
6 & 219 & 369 & 14 & 235 & 792 & 22 & 9,500 & 311 & 30 & 780 & 176 \\
7 & 206 & 1,510 & 15 & 206 & 645 & 23 & 5,600 & 283 & 31 & 540 & 162 \\
8 & 203 & 600 & 16 & 197 & 529 & 21 & 3,350 & 252 & & & \\
\hline
\end{tabular}


Gage height, in feet, and discharge, in second-feet, at indicated time, 1938

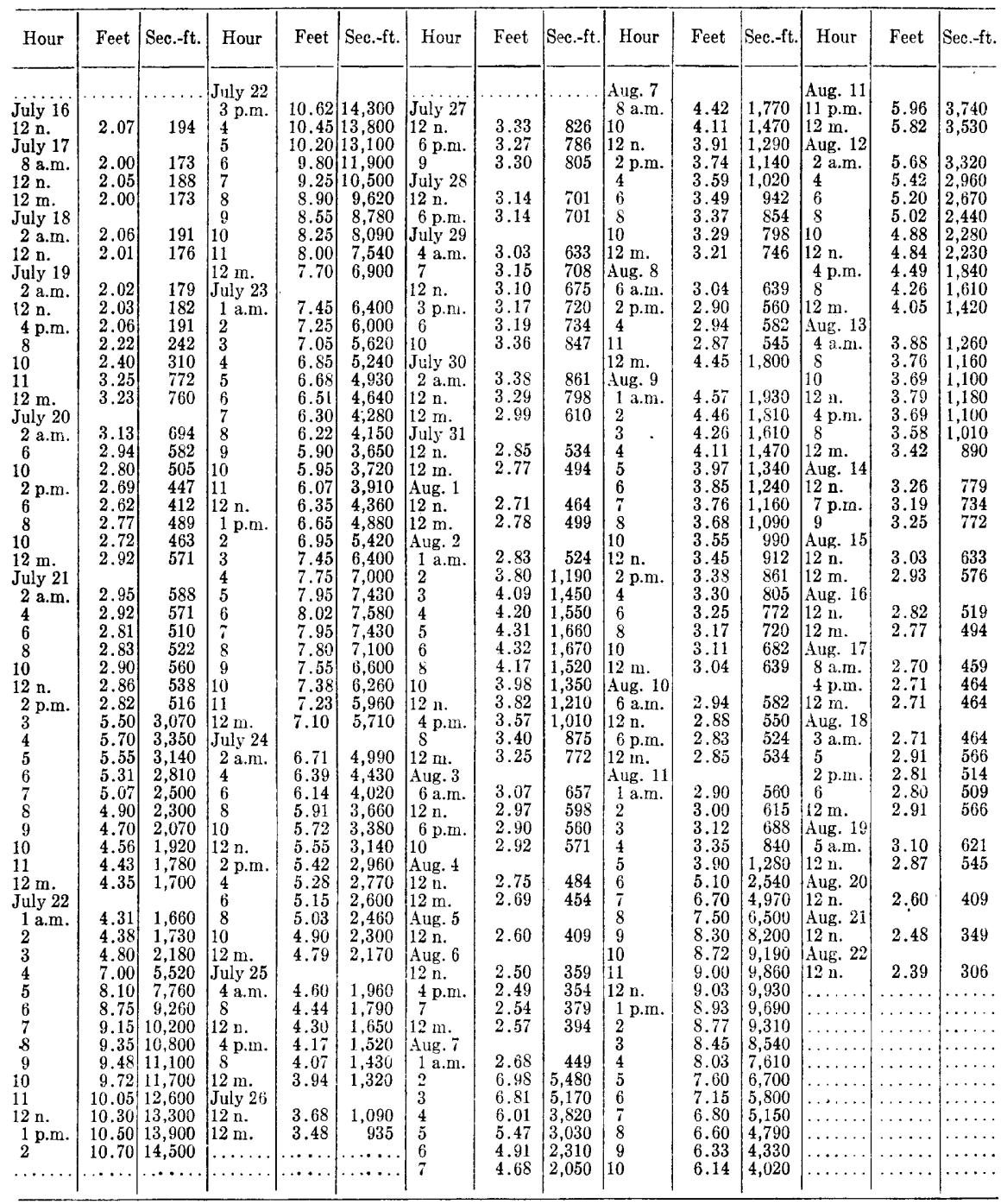


NEVERSINK RIVER AT GODEFFROY, N. Y.

Location.-Lat. $41^{\circ} 26^{\prime} 30^{\prime \prime}$, long. $74^{\circ} 36^{\prime} 10^{\prime \prime}$, at county highway bridge, half a mile downstream from Brasher Kill, three quarters of a mile southeast of Godeffroy, Orange County, and $8 \frac{1}{2}$ miles upstream from mouth.

Drainage AREA.-302 square miles.

GAGE-HEIGHT RECORD.-Water-stage recorder graph.

Stage-discharge Relation.-Defined by current-meter measurements below 8,100 second-feet and extended to peak stage by logarithmic plotting.

Maxima.-July-August 1938: Discharge, 16,100 second-feet 4:30 p.m. July 22 (gage height, 10.73 feet).

1903, 1909-14, 1937 to June 1938: Discharge, 12,800 second-feet Mar. 27, 1913 (gage height, 7.3 feet, present datum).

Flood of Oct. 9, 1903, reached a stage of about 10.5 feet, present datum (discharge not determined).

Remarks.-Flood discharge not affected by storage or diversion. Low and medium stages affected by operation of power plant above station.

Mean discharge, in second-feet, 1938

\begin{tabular}{r|r|r||c|c|c||c|c|c|c|c|c}
\hline Day & July & August & Day & July & August & Day & July & August & Day & July & August \\
\hline & 540 & 707 & 9 & 25.3 & 1,140 & 17 & 214 & 620 & 25 & 2,180 & 295 \\
2 & 500 & 1,320 & 10 & 480 & 680 & 18 & 206 & 670 & 26 & 1,580 & 274 \\
3 & 475 & 840 & 11 & 325 & 5,400 & 19 & 240 & 674 & 27 & 1,250 & 265 \\
4 & 355 & 666 & 12 & 425 & 2,650 & 20 & 590 & 508 & 28 & 1,080 & 260 \\
5 & 340 & 544 & 13 & 345 & 1,420 & 21 & 1,220 & 430 & 29 & 1,030 & 246 \\
6 & 310 & 485 & 14 & 295 & 1,050 & 22 & 9,700 & 382 & 30 & 1,110 & 232 \\
7 & 275 & 1,740 & 15 & 250 & 888 & 23 & 6,300 & 354 & 31 & 816 & 214 \\
8 & 270 & 760 & 16 & 232 & 724 & 24 & 4,000 & 332 & & & \\
\hline
\end{tabular}


Gage height, in feet, and discharge, in second-feet, at indicated time, 1938

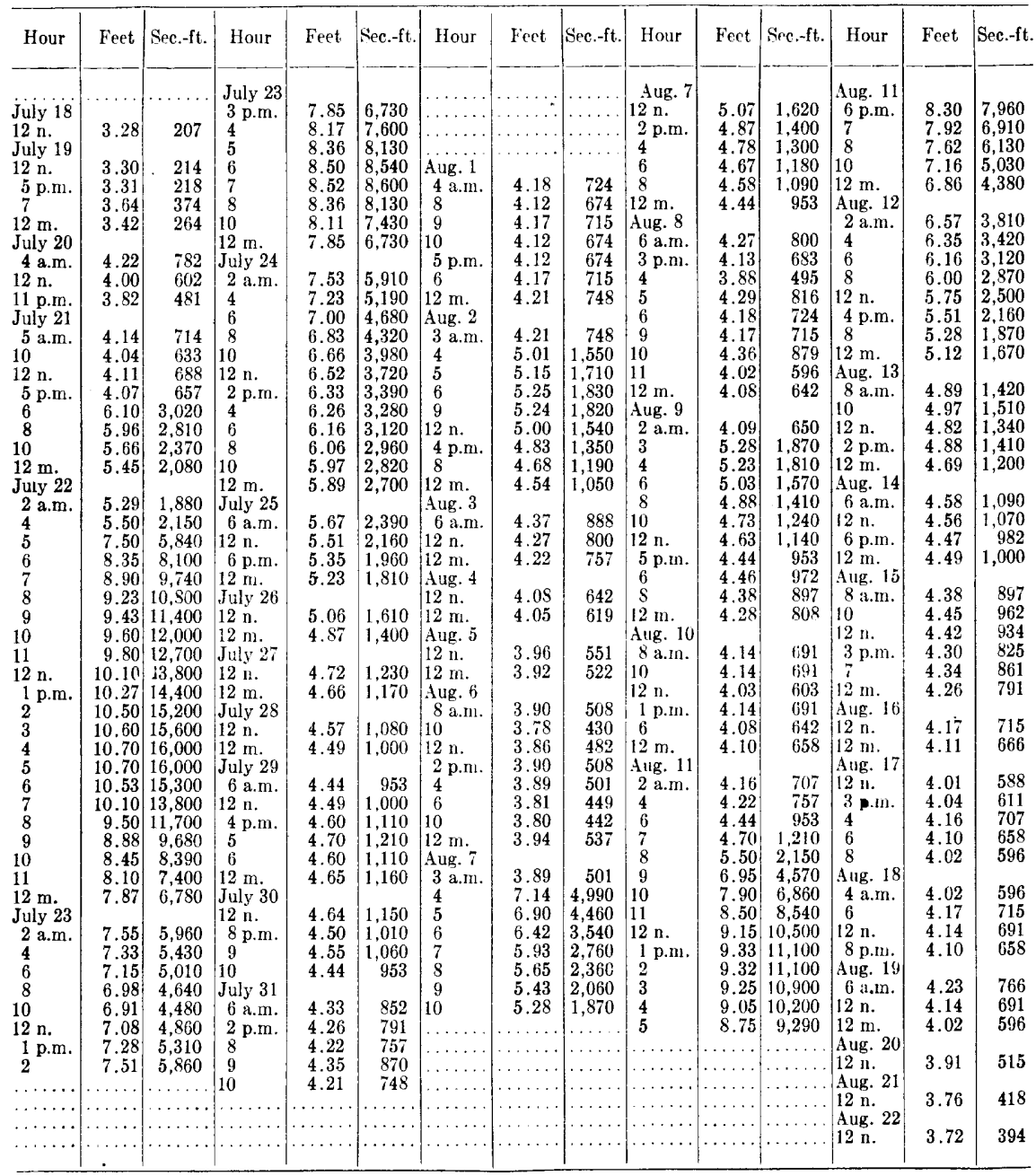

FIAT BROOK NEAR FLATBROOKVIIIE, N. J.

Location.-Lat. $41^{\circ} 06^{\prime} 24^{\prime \prime}$, long. $74^{\circ} 57^{\prime} 09^{\prime \prime}$, 1 mile upstream from Flatbrookville, Sussex County, and $1 \frac{1 / 2}{2}$ miles upstream from mouth. Datum of gage is 347.73 feet above mean sea level (general adjustment of 1929).

Drainage area.-65.1 square miles.

GAGE-HEIGHT RECORD.-Water-stage recorder graph.

Stage-discharge relation.-Defined by current-meter measurements below 700 second-feet; extended to peak stage on basis of slope-area determination at gage height 6.5 feet.

Maxima.-June 1938: Discharge, 1,560 second-feet 9 a.m. June 28 (gage height, 5.22 feet). 
July 1938: Discharge, 2,400 second-feet 2 a.m. July 24 (gage height, 6.14 feet).

September 1938: Discharge, 3,390 second-feet 3 a.m. Sept. 22 (gage height, 7.03 feet.

1923 to May 1938: Discharge,'3,470 second-feet Apr. 7, 1924, and Feb. 11, 1925 (gage height, 7.1 feet, from floodmarks), from rating curve extended above 700 second-feet on basis of slope-area measurement at gage height 6.5 feet.

REMARKs.-Flood discharge not materially affected by storage.

Mean discharge, in second-feet, 1938

\begin{tabular}{r|r|r|r|r|r|r|r||r|r|r|r}
\hline Day & June & July & Aug. & Day & June & July & Aug. & Day & June & July & Aug. \\
\hline & 56 & 211 & 161 & 11 & 40 & 70 & 228 & 21 & 47 & 102 & 107 \\
1 & 51 & 180 & 460 & 12 & 40 & 110 & 166 & 22 & 43 & 626 & 93 \\
2 & 65 & 145 & 230 & 13 & 87 & 88 & 112 & 23 & 54 & 1,010 & 84 \\
3 & 61 & 123 & 158 & 14 & 272 & 70 & 95 & 24 & 65 & 1,520 & 76 \\
5 & 54 & 107 & 151 & 15 & 158 & 70 & 86 & 25 & 50 & 616 & 68 \\
6 & 50 & 88 & 178 & 16 & 90 & 61 & 78 & 26 & 62 & 352 & 65 \\
7 & 45 & 80 & 128 & 17 & 70 & 53 & 98 & 27 & 303 & 257 & 61 \\
8 & 51 & 74 & 117 & 18 & 74 & 50 & 215 & 28 & 1.210 & 222 & 60 \\
9 & 54 & 68 & 112 & 19 & 61 & 72 & 215 & 29 & 617 & 177 & 54 \\
10 & 44 & 80 & 115 & 20 & 51 & 72 & 131 & 30 & 315 & 194 & 53 \\
\end{tabular}

Gage height, in feet, and discharge, in second-feet, at indicated time, 1938

\begin{tabular}{|c|c|c|c|c|c|c|c|c|c|c|c|c|}
\hline \multirow{2}{*}{ Hour } & Feet & Sec.ft. & Feet & Sxe. ft. & lent & Sec. $-\mathrm{ft}$. & Feet & Sec.-ft. & Feet & Sec.-ft. & Feet & Sec.-ft. \\
\hline & \multicolumn{2}{|c|}{ June 23} & \multicolumn{2}{|c|}{ June 24} & \multicolumn{2}{|c|}{ June 25} & \multicolumn{2}{|c|}{ June 26} & \multicolumn{2}{|c|}{ June 27} & \multicolumn{2}{|c|}{ - June 28} \\
\hline $\begin{array}{c}2 \mathrm{am} . \mathrm{m} . \\
4 \\
6 \\
8 \\
10 \\
12 \mathrm{n} . \\
2 \mathrm{p.m} . \\
4 \\
6 \\
8 \\
10 \\
\mathrm{i} 2 \mathrm{~m} .\end{array}$ & $\begin{array}{l}2.13 \\
2.13 \\
2.13 \\
2.13 \\
2.13 \\
2.13 \\
2.19 \\
2.27 \\
2.27 \\
2.35 \\
2.39 \\
2.38\end{array}$ & $\begin{array}{l}41 \\
41 \\
41 \\
41 \\
41 \\
41 \\
50 \\
63 \\
63 \\
78 \\
86 \\
84\end{array}$ & $\begin{array}{l}2.36 \\
2.34 \\
2.32 \\
2.31 \\
2.30 \\
2.28 \\
2.28 \\
2.27 \\
2.26 \\
2.25 \\
2.23 \\
2.22\end{array}$ & $\begin{array}{l}80 \\
78 \\
72 \\
70 \\
68 \\
65 \\
65 \\
63 \\
61 \\
60 \\
56 \\
54\end{array}$ & $\begin{array}{l}2.22 \\
2.21 \\
2.21 \\
2.20 \\
2.19 \\
2.19 \\
2.18 \\
2.18 \\
2.18 \\
2.17 \\
2.17 \\
2.16\end{array}$ & $\begin{array}{l}54 \\
53 \\
53 \\
51 \\
50 \\
50 \\
48 \\
48 \\
48 \\
47 \\
47 \\
45\end{array}$ & $\begin{array}{l}2.16 \\
2.16 \\
2.16 \\
2.16 \\
2.16 \\
2.16 \\
2.24 \\
2.30 \\
2.34 \\
2.43 \\
2.48 \\
2.52\end{array}$ & $\begin{array}{r}45 \\
45 \\
45 \\
45 \\
45 \\
45 \\
58 \\
68 \\
76 \\
95 \\
107 \\
117\end{array}$ & $\begin{array}{l}2.56 \\
2.57 \\
2.59 \\
2.60 \\
2.63 \\
2.65 \\
2.70 \\
2.85 \\
3.23 \\
3.79 \\
4.64 \\
4.12\end{array}$ & $\begin{array}{l}128 \\
131 \\
136 \\
139 \\
148 \\
154 \\
170 \\
222 \\
386 \\
714 \\
820 \\
860\end{array}$ & $\begin{array}{l}4.22 \\
4.48 \\
4.91 \\
5.19 \\
5.19 \\
5.09 \\
4.93 \\
4.74 \\
4.57 \\
4.39 \\
4.26 \\
4.13\end{array}$ & $\begin{array}{r}912 \\
1,070 \\
1,350 \\
1,550 \\
1,550 \\
1,470 \\
1,360 \\
1,230 \\
1,120 \\
1,010 \\
936 \\
865\end{array}$ \\
\hline i $2 \mathrm{~m}$. & \multicolumn{2}{|c|}{ June 29} & \multicolumn{2}{|c|}{ June 20} & \multicolumn{2}{|c|}{ July 1} & \multicolumn{2}{|c|}{ July 2} & \multicolumn{2}{|c|}{ July 3} & \multicolumn{2}{|c|}{ July 4} \\
\hline $\begin{array}{l}2 \mathrm{a} . \mathrm{m} . \\
4 \\
6 \\
8 \\
10 \\
12 \mathrm{n} . \\
2 \mathrm{p} . \mathrm{m} . \\
4 \\
6 \\
8 \\
10 \\
12 \mathrm{n} .\end{array}$ & $\begin{array}{l}4.00 \\
3.89 \\
3.81 \\
3.74 \\
3.67 \\
3.60 \\
3.54 \\
3.48 \\
3.43 \\
3.38 \\
3.33 \\
3.28\end{array}$ & $\begin{array}{l}800 \\
756 \\
724 \\
685 \\
642 \\
597 \\
860 \\
523 \\
494 \\
466 \\
438 \\
412\end{array}$ & $\begin{array}{l}3.24 \\
3.21 \\
3.16 \\
3.14 \\
3.11 \\
3.08 \\
3.06 \\
3.03 \\
3.00 \\
2.96 \\
2.93 \\
2.91\end{array}$ & $\begin{array}{l}391 \\
376 \\
352 \\
343 \\
329 \\
315 \\
307 \\
294 \\
281 \\
265 \\
253 \\
245\end{array}$ & $\begin{array}{l}2.89 \\
2.87 \\
2.86 \\
2.84 \\
2.83 \\
2.82 \\
2.81 \\
2.79 \\
2.79 \\
2.78 \\
2.78 \\
2.77\end{array}$ & $\begin{array}{l}237 \\
230 \\
226 \\
219 \\
215 \\
211 \\
208 \\
201 \\
201 \\
197 \\
197 \\
194\end{array}$ & $\begin{array}{l}2.76 \\
2.76 \\
2.75 \\
2.75 \\
2.75 \\
2.74 \\
2.73 \\
2.72 \\
2.71 \\
2.69 \\
2.68 \\
2.67\end{array}$ & $\begin{array}{l}190 \\
190 \\
187 \\
187 \\
187 \\
184 \\
180 \\
177 \\
173 \\
167 \\
164 \\
161\end{array}$ & $\begin{array}{l}2.66 \\
2.65 \\
2.64 \\
2.64 \\
2.63 \\
2.63 \\
2.62 \\
2.61 \\
2.60 \\
2.59 \\
2.58 \\
2.57\end{array}$ & $\begin{array}{l}158 \\
154 \\
151 \\
151 \\
148 \\
148 \\
145 \\
142 \\
139 \\
136 \\
134 \\
131\end{array}$ & $\begin{array}{l}2.56 \\
2.56 \\
2.55 \\
2.55 \\
2.54 \\
2.54 \\
2.54 \\
2.53 \\
2.52 \\
2.52 \\
2.51 \\
2.50\end{array}$ & $\begin{array}{l}128 \\
128 \\
126 \\
126 \\
123 \\
123 \\
123 \\
120 \\
117 \\
117 \\
115 \\
112\end{array}$ \\
\hline
\end{tabular}


Gage-height, in feet, and discharge, in second-feet, at indicated time, 1938

\begin{tabular}{|c|c|c|c|c|c|c|c|c|c|c|c|c|}
\hline \multirow{2}{*}{ Hour } & Feet & Sec.-ft. & Feet & Sec.-ft. & Feet & Sec,-ft. & Feet & Sec.-ft. & Feet & See.-ft. & Feet & Sec -ft. \\
\hline & \multicolumn{2}{|c|}{ July 17} & \multicolumn{2}{|c|}{ July 18} & \multicolumn{2}{|c|}{ July 19} & \multicolumn{2}{|c|}{ July 20} & \multicolumn{2}{|c|}{ July 21} & \multicolumn{2}{|c|}{ July 22} \\
\hline \multirow[t]{2}{*}{$\begin{array}{c}2 \text { a.m. } \\
4 \\
6 \\
8 \\
10 \\
12 \mathrm{n} . \\
2 \mathrm{p} . \mathrm{m} . \\
4 \\
6 \\
8 \\
10 \\
12 \mathrm{~m} .\end{array}$} & 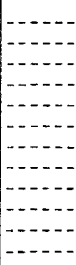 & 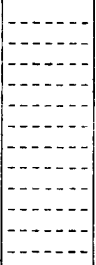 & 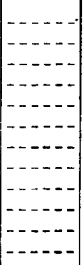 & 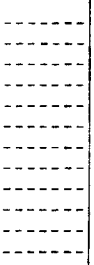 & $\begin{array}{l}2.22 \\
2.22 \\
2.25 \\
2.27 \\
2.31 \\
2.38 \\
2.40 \\
2.40 \\
2.38 \\
2.37 \\
2.36 \\
2.35\end{array}$ & $\begin{array}{l}54 \\
54 \\
60 \\
63 \\
70 \\
84 \\
88 \\
88 \\
84 \\
82 \\
80 \\
78\end{array}$ & $\begin{array}{l}2.33 \\
2.32 \\
2.31 \\
2.31 \\
2.31 \\
2.30 \\
2.31 \\
2.32 \\
2.33 \\
2.38 \\
2.38 \\
2.36\end{array}$ & $\begin{array}{l}74 \\
72 \\
70 \\
70 \\
70 \\
68 \\
70 \\
72 \\
74 \\
84 \\
84 \\
80\end{array}$ & $\begin{array}{l}2.33 \\
2.32 \\
2.31 \\
2.32 \\
2.38 \\
2.38 \\
2.40 \\
2.45 \\
2.53 \\
2.63 \\
2.70 \\
2.78\end{array}$ & $\begin{array}{r}74 \\
72 \\
70 \\
72 \\
84 \\
84 \\
88 \\
100 \\
120 \\
148 \\
170 \\
197\end{array}$ & $\begin{array}{l}2.83 \\
2.93 \\
3.10 \\
3.27 \\
3.52 \\
3.85 \\
4.10 \\
4.21 \\
4.24 \\
4.23 \\
4.22 \\
4.21\end{array}$ & $\begin{array}{l}215 \\
253 \\
324 \\
407 \\
547 \\
740 \\
850 \\
906 \\
924 \\
918 \\
912 \\
906\end{array}$ \\
\hline & \multicolumn{2}{|c|}{ July 23} & \multicolumn{2}{|c|}{ July 24} & \multicolumn{2}{|c|}{ July 25} & \multicolumn{2}{|c|}{ July 26} & \multicolumn{2}{|c|}{ July 27} & \multicolumn{2}{|c|}{ July 28} \\
\hline $\begin{array}{c}2 \text { a.m. } \\
4 \\
6 \\
8 \\
10 \\
12 \mathrm{n} . \\
2 \mathrm{p.m} . \\
4 \\
6 \\
8 \\
10 \\
12 \mathrm{~m} .\end{array}$ & $\begin{array}{l}4.16 \\
4.10 \\
4.03 \\
3.93 \\
3.92 \\
3.86 \\
4.18 \\
4.32 \\
4.41 \\
4.62 \\
5.28 \\
5.91\end{array}$ & $\begin{array}{r}880 \\
850 \\
815 \\
772 \\
768 \\
744 \\
890 \\
972 \\
1,030 \\
1,150 \\
1,620 \\
2,170\end{array}$ & $\begin{array}{l}6.14 \\
6.06 \\
5.83 \\
5.55 \\
5.31 \\
5.00 \\
4.72 \\
4.55 \\
4.39 \\
4.24 \\
4.12 \\
4.02\end{array}$ & $\begin{array}{r}2,400 \\
2,320 \\
2,100 \\
1,840 \\
1,650 \\
1,410 \\
1,210 \\
1,110 \\
1,010 \\
924 \\
860 \\
810\end{array}$ & $\begin{array}{l}3.92 \\
3.84 \\
3.76 \\
3.71 \\
3.64 \\
3.59 \\
3.54 \\
3.49 \\
3.46 \\
3.42 \\
3.38 \\
3.34\end{array}$ & $\begin{array}{l}768 \\
736 \\
697 \\
668 \\
623 \\
591 \\
560 \\
529 \\
512 \\
489 \\
466 \\
444\end{array}$ & $\begin{array}{l}3.32 \\
3.28 \\
3.24 \\
3.20 \\
3.18 \\
3.15 \\
3.12 \\
3.10 \\
3.08 \\
3.06 \\
3.03 \\
3.01\end{array}$ & $\begin{array}{l}433 \\
412 \\
391 \\
371 \\
362 \\
348 \\
333 \\
324 \\
315 \\
307 \\
294 \\
285\end{array}$ & $\begin{array}{l}3.00 \\
2.99 \\
2.98 \\
2.97 \\
2.95 \\
2.93 \\
2.92 \\
2.91 \\
2.90 \\
2.90 \\
2.90 \\
2.90\end{array}$ & $\begin{array}{l}281 \\
277 \\
273 \\
269 \\
261 \\
253 \\
249 \\
245 \\
241 \\
241 \\
241 \\
241\end{array}$ & $\begin{array}{l}2.90 \\
2.89 \\
2.87 \\
2.86 \\
2.85 \\
2.84 \\
2.83 \\
2.82 \\
2.81 \\
2.82 \\
2.82 \\
2.80\end{array}$ & $\begin{array}{l}241 \\
237 \\
230 \\
226 \\
222 \\
219 \\
215 \\
211 \\
208 \\
211 \\
211 \\
204\end{array}$ \\
\hline $12 \mathrm{~m}$ & \multicolumn{2}{|c|}{ July 29} & \multicolumn{2}{|c|}{ July 30} & \multicolumn{2}{|c|}{ July 31} & \multicolumn{2}{|c|}{ August 1} & \multicolumn{2}{|c|}{ August 2} & \multicolumn{2}{|c|}{ August 3} \\
\hline $\begin{array}{r}2 \text { a.m. } \\
4 \\
6 \\
8 \\
10 \\
12 \mathrm{n} . \\
2 \mathrm{p.m} . \\
4 \\
6 \\
8 \\
10 \\
12 \mathrm{~m} .\end{array}$ & $\begin{array}{l}2.76 \\
2.74 \\
2.73 \\
2.73 \\
2.72 \\
2.71 \\
2.71 \\
2.70 \\
2.70 \\
2.69 \\
2.69 \\
2.70\end{array}$ & $\begin{array}{l}190 \\
184 \\
180 \\
180 \\
177 \\
173 \\
173 \\
170 \\
170 \\
167 \\
167 \\
170\end{array}$ & $\begin{array}{l}2.73 \\
2.76 \\
2.77 \\
2.78 \\
2.78 \\
2.78 \\
2.78 \\
2.78 \\
2.78 \\
2.77 \\
2.76 \\
2.75\end{array}$ & $\begin{array}{l}180 \\
190 \\
194 \\
197 \\
197 \\
197 \\
197 \\
197 \\
197 \\
194 \\
190 \\
187\end{array}$ & $\begin{array}{l}2.74 \\
2.73 \\
2.72 \\
2.71 \\
2.70 \\
2.68 \\
2.67 \\
2.66 \\
2.65 \\
2.64 \\
2.62 \\
2.62\end{array}$ & $\begin{array}{l}184 \\
180 \\
177 \\
173 \\
170 \\
164 \\
161 \\
158 \\
154 \\
151 \\
145 \\
145\end{array}$ & $\begin{array}{l}2.62 \\
2.62 \\
2.62 \\
2.62 \\
2.62 \\
2.62 \\
2.62 \\
2.61 \\
2.65 \\
2.69 \\
2.86 \\
3.12\end{array}$ & $\begin{array}{l}145 \\
145 \\
145 \\
145 \\
145 \\
145 \\
145 \\
142 \\
154 \\
167 \\
226 \\
333\end{array}$ & $\begin{array}{l}3.31 \\
3.48 \\
3.56 \\
3.57 \\
3.53 \\
3.49 \\
3.43 \\
3.35 \\
3.29 \\
3.24 \\
3.16 \\
3.09\end{array}$ & $\begin{array}{l}428 \\
523 \\
572 \\
578 \\
554 \\
529 \\
494 \\
450 \\
417 \\
391 \\
352 \\
320\end{array}$ & $\begin{array}{l}3.02 \\
2.98 \\
2.94 \\
2.91 \\
2.88 \\
2.86 \\
2.84 \\
2.82 \\
2.80 \\
2.77 \\
2.75 \\
2.73\end{array}$ & $\begin{array}{l}290 \\
273 \\
257 \\
240 \\
234 \\
226 \\
219 \\
211 \\
204 \\
194 \\
187 \\
180\end{array}$ \\
\hline
\end{tabular}

Mean discharge, in second-feet, 1938

\begin{tabular}{|c|c|c|c|c|c|c|c|c|c|c|c|}
\hline Day & Sept. & Oet. & Day & Sept. & Oct. & Day & Sent. & Oct. & Day & Sept. & Oct. \\
\hline $\begin{array}{l}1 \\
2 \\
3 \\
4 \\
5 \\
6 \\
7 \\
8\end{array}$ & $\begin{array}{l}65 \\
58 \\
51 \\
53 \\
48 \\
44 \\
41 \\
43\end{array}$ & $\begin{array}{r}115 \\
102 \\
93 \\
88 \\
84 \\
86 \\
100 \\
84\end{array}$ & $\begin{array}{r}9 \\
10 \\
11 \\
12 \\
13 \\
14 \\
15 \\
16\end{array}$ & $\begin{array}{l}38 \\
36 \\
35 \\
34 \\
36 \\
36 \\
46 \\
60\end{array}$ & $\begin{array}{l}76 \\
72 \\
68 \\
66 \\
63 \\
61 \\
61 \\
60\end{array}$ & $\begin{array}{l}17 \\
18 \\
19 \\
20 \\
21 \\
22 \\
23 \\
24\end{array}$ & $\begin{array}{r}44 \\
41 \\
76 \\
439 \\
1,000 \\
2,050 \\
670 \\
376\end{array}$ & $\begin{array}{r}56 \\
54 \\
54 \\
58 \\
182 \\
110 \\
81 \\
112\end{array}$ & $\begin{array}{l}25 \\
26 \\
27 \\
28 \\
29 \\
30 \\
31\end{array}$ & $\begin{array}{l}253 \\
197 \\
167 \\
148 \\
131 \\
120\end{array}$ & $\begin{array}{r}224 \\
136 \\
112 \\
102 \\
100 \\
95 \\
86\end{array}$ \\
\hline \multicolumn{10}{|c|}{$\begin{array}{l}\text { Monthly mean discharge, in second-feet. } \\
\text { Runoff, in inches }\end{array}$} & $\begin{array}{r}215 \\
3.68\end{array}$ & $\begin{array}{l}91.7 \\
1.63\end{array}$ \\
\hline
\end{tabular}


Gage height, in feet, and discharge, in second-feet, at indicated time, 1938

\begin{tabular}{|c|c|c|c|c|c|c|c|c|c|c|c|c|}
\hline \multirow{2}{*}{ Hour } & Feet & Sec.-ft. & Feet & Sec.-ft. & Feet & Sec.-ft. & Feet & Sec.-ft. & Feet & Sec. $-\mathrm{ft}$. & Feet & Sec.-it. \\
\hline & \multicolumn{2}{|c|}{ September 18} & \multicolumn{2}{|c|}{ September 19} & \multicolumn{2}{|c|}{ September 20} & \multicolumn{2}{|c|}{ September 21} & \multicolumn{2}{|c|}{ September 22} & \multicolumn{2}{|c|}{ September 23} \\
\hline $\begin{array}{c}1 \mathrm{a} . \mathrm{m} . \\
2 \\
3 \\
4 \\
5 \\
6 \\
7 \\
8 \\
9 \\
10 \\
11 \\
12 \mathrm{n} . \\
1 \mathrm{p} . \mathrm{m} . \\
2 \\
3 \\
4 \\
5 \\
6 \\
7 \\
8 \\
9 \\
10 \\
11 \\
12 \mathrm{~m} .\end{array}$ & 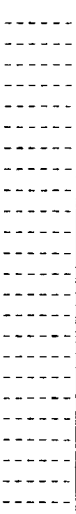 & 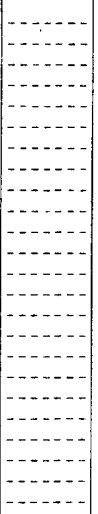 & $\begin{array}{l}2.13 \\
2.13 \\
2.13 \\
2.13 \\
2.13 \\
2.13 \\
2.14 \\
2.16 \\
2.21 \\
2.31 \\
2.34 \\
2.36 \\
2.38 \\
2.41 \\
2.37 \\
2.38 \\
2.39 \\
2.42 \\
2.44 \\
2.48 \\
2.51 \\
2.58 \\
2.63 \\
2.68\end{array}$ & $\begin{array}{r}41 \\
41 \\
41 \\
41 \\
41 \\
41 \\
43 \\
45 \\
53 \\
70 \\
76 \\
80 \\
81 \\
90 \\
82 \\
84 \\
80 \\
93 \\
98 \\
107 \\
115 \\
134 \\
148 \\
164\end{array}$ & $\begin{array}{l}2.73 \\
2.79 \\
2.87 \\
2.90 \\
2.98 \\
3.05 \\
3.12 \\
3.17 \\
3.23 \\
3.28 \\
2.34 \\
3.38 \\
3.43 \\
3.48 \\
3.52 \\
3.55 \\
3.56 \\
3.57 \\
3.57 \\
3.58 \\
3.57 \\
3.59 \\
3.58 \\
3.59\end{array}$ & $\begin{array}{l}180 \\
201 \\
230 \\
241 \\
273 \\
302 \\
333 \\
357 \\
386 \\
412 \\
444 \\
466 \\
494 \\
523 \\
547 \\
566 \\
572 \\
578 \\
578 \\
585 \\
578 \\
591 \\
585 \\
591\end{array}$ & $\begin{array}{l}3.59 \\
3.60 \\
3.63 \\
3.66 \\
3.71 \\
3.76 \\
3.80 \\
3.84 \\
3.87 \\
3.91 \\
3.94 \\
3.97 \\
4.03 \\
4.09 \\
4.28 \\
4.47 \\
4.60 \\
4.69 \\
4.76 \\
4.86 \\
5.06 \\
5.46 \\
5.96 \\
6.37\end{array}$ & $\begin{array}{r}591 \\
597 \\
616 \\
636 \\
668 \\
697 \\
720 \\
736 \\
748 \\
764 \\
776 \\
788 \\
815 \\
845 \\
948 \\
1,060 \\
1,140 \\
1,190 \\
1,240 \\
1,310 \\
1,450 \\
1,770 \\
2,220 \\
2,640\end{array}$ & $\begin{array}{l}6.77 \\
6.96 \\
7.03 \\
7.00 \\
6.92 \\
6.77 \\
6.57 \\
6.34 \\
6.14 \\
5.93 \\
5.71 \\
5.53 \\
5.37 \\
5.21 \\
5.05 \\
4.94 \\
4.81 \\
4.69 \\
4.59 \\
4.51 \\
4.44 \\
4.35 \\
4.28 \\
4.23\end{array}$ & $\begin{array}{r}3,080 \\
3,300 \\
3,390 \\
3,350 \\
3,250 \\
3,080 \\
2,860 \\
2,600 \\
2,400 \\
2,190 \\
1,990 \\
1,830 \\
1,700 \\
1,570 \\
1,440 \\
1,370 \\
1,280 \\
1,190 \\
1,130 \\
1,090 \\
1,040 \\
990 \\
948 \\
918\end{array}$ & $\begin{array}{l}4.17 \\
4.12 \\
4.07 \\
4.02 \\
3.98 \\
3.94 \\
3.89 \\
3.85 \\
3.82 \\
3.77 \\
3.74 \\
3.71 \\
3.67 \\
3.65 \\
3.62 \\
3.58 \\
3.56 \\
3.53 \\
3.51 \\
3.49 \\
3.46 \\
3.44 \\
3.42 \\
3.40\end{array}$ & $\begin{array}{l}885 \\
860 \\
835 \\
810 \\
792 \\
776 \\
756 \\
740 \\
728 \\
703 \\
685 \\
668 \\
642 \\
630 \\
610 \\
585 \\
572 \\
554 \\
541 \\
529 \\
512 \\
500 \\
489 \\
477\end{array}$ \\
\hline & Septer & mber 24 & Septer & nber 25 & Septer & nber 26 & Septer & nber 27 & Septel & nber 28 & Septer & nber 29 \\
\hline $\begin{array}{c}2 \text { a.m. } \\
4 \\
6 \\
8 \\
10 \\
12 \mathrm{n} . \\
2 \mathrm{p} . \mathrm{m} . \\
4 \\
6 \\
8 \\
10 . \\
12 \mathrm{~m} .\end{array}$ & $\begin{array}{l}3.36 \\
3.33 \\
3.29 \\
3.26 \\
3.24 \\
3.21 \\
3.18 \\
3.15 \\
3.13 \\
3.10 \\
3.07 \\
3.05\end{array}$ & $\begin{array}{l}455 \\
438 \\
417 \\
402 \\
391 \\
376 \\
362 \\
348 \\
338 \\
324 \\
311 \\
302\end{array}$ & $\begin{array}{l}3.02 \\
3.00 \\
2.99 \\
2.97 \\
2.94 \\
2.93 \\
2.92 \\
2.90 \\
2.89 \\
2.86 \\
2.84 \\
2.83\end{array}$ & $\begin{array}{l}290 \\
281 \\
277 \\
269 \\
257 \\
253 \\
249 \\
241 \\
237 \\
226 \\
219 \\
215\end{array}$ & 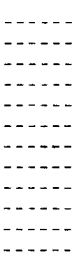 & 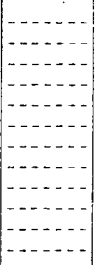 & 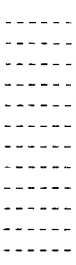 & 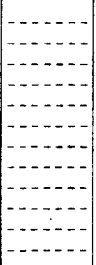 & 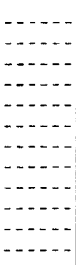 & 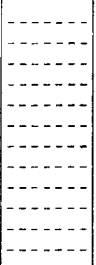 & 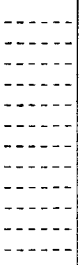 & 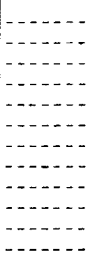 \\
\hline
\end{tabular}

PAULINS KIIL AT BLAIRSTOWN, N. J.

Location.-Lat. $40^{\circ} 58^{\circ} 44^{\prime \prime}$, long. $74^{\circ} 57^{\prime} 15^{\prime \prime}, 1,200$ feet upstream from highway bridge in Blairstown, Warren County, 1,400 feet upstream from Blairs Creek, and 10 miles upstream from mouth. Datum of gage is 335.86 feet above mean sea level (general adjustment of 1929).

Drainage AREA.-126 square miles.

GAGE-Height RECORD.-Water-stage recorder graph except 2:30 p.m. July 31 to 4:30 p.m. Aug. 9, and Aug. 15-22, and 2 a.m. Sept. 23 to 5 p.m. Sept. 29, for which periods recorder chart is missing.

StAGE-Discharge RELATION.-Defined by current-meter measurements below 1,500 second-feet; extended to peak stage on basis of determination of discharge gage height 6.92 feet by weir formula and slope-area method. 
Maxima.-June 1938: Discharge, 3,700 second-feet 8 a.m. June 28 (gage height, 7.08 feet).

July 1938: Discharge, 2,540 second-feet 2 a.m. July 24 (gage height, 6.16 feet).

September 1938: Discharge, 4,480 second-feet 3 a.m. Sept. 22 (gage height, 7.56 feet).

1921 to May 1938: Discharge, 3,480 second-feet Mar. 12, 1936 (gage height, 6.92 feet).

REMARKs.-Discharge for periods of no gage-height record computed on basis of records for Pequest River at Pequest. Flow affected by natural storage in Culver Lake, Lake Owassa, and Swartswood Lake.

Mean discharge, in second-feet, 1938

\begin{tabular}{|c|c|c|c|c|c|c|c|c|c|c|c|}
\hline Day & June & July & Aug. & Day & June & July & Aug. & Day & June & July & Aug. \\
\hline $\begin{array}{r}1 \\
2 \\
3 \\
4 \\
5 \\
6 \\
7 \\
8 \\
9 \\
10\end{array}$ & $\begin{array}{l}75 \\
68 \\
76 \\
79 \\
70 \\
66 \\
62 \\
84 \\
83 \\
70\end{array}$ & $\begin{array}{l}790 \\
598 \\
430 \\
337 \\
280 \\
222 \\
212 \\
186 \\
169 \\
165\end{array}$ & $\begin{array}{l}380 \\
400 \\
350 \\
300 \\
300 \\
400 \\
350 \\
280 \\
260 \\
224\end{array}$ & $\begin{array}{l}11 \\
12 \\
13 \\
14 \\
15 \\
16 \\
17 \\
18 \\
19 \\
20\end{array}$ & $\begin{array}{r}73 \\
82 \\
86 \\
164 \\
166 \\
117 \\
92 \\
103 \\
106 \\
81\end{array}$ & $\begin{array}{l}156 \\
2665 \\
241 \\
194 \\
173 \\
148 \\
130 \\
118 \\
161 \\
173\end{array}$ & $\begin{array}{l}559 \\
440 \\
310 \\
233 \\
200 \\
190 \\
220 \\
470 \\
500 \\
320\end{array}$ & $\begin{array}{l}21 \\
22 \\
23 \\
24 \\
25 \\
26 \\
27 \\
28 \\
29 \\
30 \\
31\end{array}$ & $\begin{array}{r}66 \\
61 \\
191 \\
232 \\
144 \\
220 \\
901 \\
2,880 \\
1,770 \\
1,180\end{array}$ & $\begin{array}{r}540 \\
1,050 \\
1,510 \\
2,040 \\
1,270 \\
910 \\
673 \\
544 \\
457 \\
474 \\
400\end{array}$ & $\begin{array}{r}210 \\
190 \\
169 \\
150 \\
136 \\
123 \\
114 \\
109 \\
100 \\
96 \\
98\end{array}$ \\
\hline & & & & & & & & & $\begin{array}{r}315 \\
2.79\end{array}$ & $\begin{array}{r}484 \\
4.43\end{array}$ & $\begin{array}{r}264 \\
2.42\end{array}$ \\
\hline
\end{tabular}

Gage height, in feet, and discharge, in second-feet, at indicated time, 1938

\begin{tabular}{|c|c|c|c|c|c|c|c|c|c|c|c|c|}
\hline \multirow{2}{*}{ Hour } & Feet & Sec.-ft. & Feet & Sec.-ft. & Feet & Sec.-ft. & Feet & Sec. $-\mathrm{ft}$. & Feet & Sec. $-\mathrm{ft}$. & Feet. & Sec.-ft. \\
\hline & \multicolumn{2}{|c|}{ June 23} & \multicolumn{2}{|c|}{ June 24} & \multicolumn{2}{|c|}{ June $2 \overline{5}$} & \multicolumn{2}{|c|}{ June 26} & \multicolumn{2}{|c|}{ June 27} & \multicolumn{2}{|c|}{ June 28} \\
\hline $\begin{array}{c}2 \text { a.m. } \\
4 \\
6 \\
8 \\
10 \\
12 \mathrm{n.} \\
2 \mathrm{p.m} . \\
4 \\
6 \\
8 \\
10 \\
12 \mathrm{~m} .\end{array}$ & $\begin{array}{l}1.33 \\
1.33 \\
1.37 \\
1.36 \\
1.34 \\
1.34 \\
1.35 \\
1.32 \\
2.24 \\
2.90 \\
2.70 \\
2.27\end{array}$ & $\begin{array}{r}58 \\
58 \\
70 \\
67 \\
61 \\
61 \\
64 \\
56 \\
388 \\
617 \\
544 \\
397\end{array}$ & $\begin{array}{l}2.05 \\
1.94 \\
1.88 \\
1.83 \\
1.80 \\
1.77 \\
1.76 \\
1.73 \\
1.73 \\
1.70 \\
1.64 \\
1.65\end{array}$ & $\begin{array}{l}327 \\
288 \\
265 \\
245 \\
233 \\
220 \\
216 \\
203 \\
203 \\
190 \\
165 \\
169\end{array}$ & $\begin{array}{l}1.65 \\
1.68 \\
1.58 \\
1.62 \\
1.56 \\
1.64 \\
1.58 \\
1.54 \\
1.50 \\
1.53 \\
1.53 \\
1.53\end{array}$ & $\begin{array}{l}169 \\
182 \\
141 \\
156 \\
133 \\
165 \\
141 \\
126 \\
111 \\
122 \\
122 \\
122\end{array}$ & $\begin{array}{l}1.53 \\
1.60 \\
1.56 \\
1.64 \\
1.61 \\
1.56 \\
1.55 \\
1.68 \\
1.69 \\
2.20 \\
2.56 \\
2.72\end{array}$ & $\begin{array}{l}122 \\
148 \\
133 \\
165 \\
152 \\
133 \\
130 \\
182 \\
186 \\
375 \\
495 \\
551\end{array}$ & $\begin{array}{l}2.72 \\
2.76 \\
2.88 \\
3.00 \\
3.26 \\
3.20 \\
3.42 \\
3.56 \\
4.08 \\
4.67 \\
5.05 \\
5.53\end{array}$ & $\begin{array}{r}551 \\
566 \\
610 \\
654 \\
754 \\
731 \\
818 \\
874 \\
1,080 \\
1,360 \\
1,600 \\
1,940\end{array}$ & $\begin{array}{l}6.12 \\
6.48 \\
6.88 \\
7.08 \\
6.95 \\
6.78 \\
6.61 \\
6.44 \\
6.30 \\
6.15 \\
5.99 \\
5.86\end{array}$ & $\begin{array}{l}2,490 \\
2,910 \\
3,420 \\
3,700 \\
3,520 \\
3,280 \\
3,060 \\
2,860 \\
2,690 \\
2,520 \\
2,360 \\
2,230\end{array}$ \\
\hline $12 \mathrm{~m}$ & \multicolumn{2}{|c|}{ June 29} & \multicolumn{2}{|c|}{ June 30} & \multicolumn{2}{|c|}{ Juy 1} & \multicolumn{2}{|c|}{ July 2} & \multicolumn{2}{|c|}{ July 3} & \multicolumn{2}{|c|}{ July 4} \\
\hline $\begin{array}{l}2 \mathrm{a} . \mathrm{m} . \\
4 \\
6 \\
8 \\
10 \\
12 \mathrm{n} . \\
2 \mathrm{p} . \mathrm{m} . \\
4 \\
6 \\
8 \\
10 \\
12 \mathrm{~m} .\end{array}$ & $\begin{array}{l}5.75 \\
5.66 \\
5.58 \\
5.48 \\
5.41 \\
5.33 \\
5.24 \\
5.14 \\
5.08 \\
4.97 \\
4.89 \\
4.80\end{array}$ & $\begin{array}{l}2,140 \\
2,050 \\
1,980 \\
1,900 \\
1,850 \\
1,790 \\
1,730 \\
1,660 \\
1,620 \\
1,540 \\
1,490 \\
1,440\end{array}$ & $\begin{array}{l}4.70 \\
4.64 \\
4.53 \\
4.44 \\
4.36 \\
4.26 \\
4.17 \\
4.08 \\
4.01 \\
3.89 \\
3.81 \\
3.74\end{array}$ & $\begin{array}{r}1,380 \\
1,340 \\
1,280 \\
1,240 \\
1,200 \\
1,150 \\
1,120 \\
1,080 \\
1,050 \\
1,010 \\
974 \\
946\end{array}$ & $\begin{array}{l}3.66 \\
3.62 \\
3.52 \\
3.44 \\
3.42 \\
3.32 \\
3.24 \\
3.15 \\
3.10 \\
3.07 \\
3.14 \\
3.17\end{array}$ & $\begin{array}{l}914 \\
898 \\
858 \\
826 \\
818 \\
778 \\
747 \\
712 \\
692 \\
681 \\
708 \\
719\end{array}$ & $\begin{array}{l}3.12 \\
3.10 \\
3.02 \\
2.95 \\
2.92 \\
2.84 \\
2.87 \\
2.73 \\
2.76 \\
2.62 \\
2.62 \\
2.60\end{array}$ & $\begin{array}{l}700 \\
692 \\
662 \\
636 \\
624 \\
595 \\
606 \\
555 \\
566 \\
516 \\
516 \\
509\end{array}$ & $\begin{array}{l}2.55 \\
2.52 \\
2.42 \\
2.44 \\
2.40 \\
2.34 \\
2.32 \\
2.32 \\
2.28 \\
2.25 \\
2.20 \\
2.20\end{array}$ & $\begin{array}{l}492 \\
481 \\
447 \\
454 \\
440 \\
420 \\
414 \\
414 \\
401 \\
391 \\
375 \\
375\end{array}$ & $\begin{array}{l}2.17 \\
2.19 \\
2.13 \\
2.06 \\
2.14 \\
2.10 \\
2.05 \\
2.07 \\
2.00 \\
1.98 \\
1.98 \\
1.99\end{array}$ & $\begin{array}{l}366 \\
372 \\
353 \\
330 \\
356 \\
344 \\
327 \\
334 \\
310 \\
303 \\
303 \\
306\end{array}$ \\
\hline
\end{tabular}


Gage height in feet, and discharge, in second-feet, at indicated time, 1938-Continued

\begin{tabular}{|c|c|c|c|c|c|c|c|c|c|c|c|c|}
\hline \multirow{2}{*}{ Hour } & Feet & Sec.-ft. & Feet & Sec.-ft. & Feet & Sec.-ft. & Feet & Sec.-ft. & Feet & Sec.-ft. & Feet & Sec.-ft. \\
\hline & \multicolumn{2}{|c|}{ July 5} & \multicolumn{2}{|c|}{ July 6} & \multicolumn{2}{|c|}{ July 7} & \multicolumn{2}{|c|}{ July 8} & \multicolumn{2}{|c|}{ July 9} & \multicolumn{2}{|c|}{ July 10} \\
\hline 2 a.m. & 1.97 & 299 & 1.87 & 261 & 1.76 & 216 & 1.70 & 190 & 1.66 & 173 & 1.64 & 165 \\
\hline & 1.98 & 303 & 1.89 & 269 & 1.80 & 233 & 1.70 & $\begin{array}{l}190 \\
190\end{array}$ & $\begin{array}{l}1.00 \\
1.66\end{array}$ & 173 & $\begin{array}{l}1.04 \\
1.70\end{array}$ & $\begin{array}{l}109 \\
190\end{array}$ \\
\hline 6 & 1.96 & 295 & 1.90 & 273 & 1.77 & 220 & 1.72 & 199 & 1.68 & 182 & 1.66 & 173 \\
\hline 8 & 1.89 & 269 & 1.84 & 249 & 1.77 & 220 & 1.71 & 194 & 1.67 & 177 & 1.66 & 173 \\
\hline 10 & 1.94 & 288 & 1.78 & 224 & 1.76 & 216 & 1.70 & 190 & 1.67 & 177 & 1.65 & 169 \\
\hline $12 \mathrm{n}$. & 1.88 & 265 & 1.88 & 265 & 1.73 & 203 & 1.70 & 190 & 1.60 & 148 & 1.59 & 144 \\
\hline 2 p.m. & 1.93 & 284 & 1.40 & 78 & 1.76 & 216 & 1.70 & 190 & 1.66 & 173 & 1.59 & 144 \\
\hline & 1.89 & 269 & 1.69 & 186 & 1.70 & 190 & 1.64 & 165 & 1.64 & 16 & 1. 62 & 156 \\
\hline & 1.92 & 280 & 1.82 & 241 & 1.76 & 216 & 1.70 & 190 & 1.68 & 18 & 1.68 & 182 \\
\hline 8 & 1.88 & 265 & 1.82 & 241 & 1.74 & 207 & 1.65 & 169 & 1.57 & $13 \overline{7}$ & 1.63 & 161 \\
\hline & 1. & 261 & 1.76 & 216 & 1.70 & 190 & 1.63 & 161 & 1.62 & 1.56 & 1.59 & 144 \\
\hline $12 \mathrm{~m}$. & & 257 & 1.7 & 216 & 1.70 & 190 & 1.65 & 169 & 1.63 & 161 & 1.60 & 148 \\
\hline
\end{tabular}

Supplemental records.-June 25, 3 p.m., 1.51 ft., 115 sec.-ft.; 5 p.m., 1.60 ft., 148 sec.-ft.; June 26 $6: 30$ a.m., $1.51 \mathrm{ft}$., 115 sec.-ft.; 5 p.m., 2.03 ft., 320 sec.-ft.; June 27,7 a.m., 3.09 ft., 688 sec.-ft.; 9 a.m. $2.92 \mathrm{ft} .624$ sec.-ft.; $7 \mathrm{p} . \mathrm{m} .4 .73 \mathrm{ft}, 1,400 \mathrm{sec}$-ft. July $5,6: 30$ a.1n., $2.10 \mathrm{ft}$., 344 sec.-ft.; 7 a.m., $1.87 \mathrm{ft}$. 261 sec.-ft.; $10: 30$ p.m., $1.83 \mathrm{ft} ., 245$ sec.-ft.; July 6, $5: 30$ a.m., $1.98 \mathrm{ft} ., 303$ sec.-ft.; $9: 30$ a.m., $1.47 \mathrm{ft} ., 101$ sec.-ft.; 3 p.m., 1.28 ft., 45 sec.-ft.; July 7, $12: 30$ p.m., 1.80 ft., 233 sec.-ft.; July 8,5 p.m., 1.72 ft., 199 sec.-ft.; July 9, 5 a.m., 1.72 ft., 199 sec.-ft.; $4: 30$ p.m., 1.58 ft., 141 sec.-ft.; July 10, 6:30 a.m., $1.60 \mathrm{ft}$., 148 sec.-ft.; $12: 30$ p.m., 1.68 ft., 182 sec.-ft.

Gage height, in feet, and discharge, in second-feet, at indicated time, 1938

\begin{tabular}{|c|c|c|c|c|c|c|c|c|c|c|c|c|}
\hline \multirow{2}{*}{ Hour } & Feet & Sec. $\mathrm{ft}$. & Feet & Sec.-ft. & Feet & Sec,-ft. & Feet & Sec.-ft. & Feet & Sec.-ft. & Feet & Sec.-ft. \\
\hline & \multicolumn{2}{|c|}{ July 17} & \multicolumn{2}{|c|}{ July 18} & \multicolumn{2}{|c|}{ July 19} & \multicolumn{2}{|c|}{ July 20} & \multicolumn{2}{|c|}{ July 21} & \multicolumn{2}{|c|}{ July 22} \\
\hline $\begin{array}{c}2 \mathrm{a} . \mathrm{m} . \\
4 \\
6 \\
8 \\
10 \\
12 \mathrm{n} . \\
2 \mathrm{p} . \mathrm{m} . \\
4 \\
6 \\
8 \\
10 \\
12 \mathrm{~m} .\end{array}$ & $\begin{array}{l}1.56 \\
1.62 \\
1.58 \\
1.60 \\
1.57 \\
1.50 \\
1.57 \\
1.55 \\
1.51 \\
1.55 \\
1.51 \\
1.52\end{array}$ & $\begin{array}{l}133 \\
156 \\
141 \\
148 \\
137 \\
111 \\
137 \\
130 \\
115 \\
130 \\
115 \\
118\end{array}$ & $\begin{array}{l}1.52 \\
1.52 \\
1.55 \\
1.51 \\
1.51 \\
1.47 \\
1.53 \\
1.45 \\
1.56 \\
1.51 \\
1.51 \\
1.55\end{array}$ & $\begin{array}{r}118 \\
118 \\
130 \\
115 \\
115 \\
101 \\
122 \\
94 \\
133 \\
115 \\
115 \\
130\end{array}$ & $\begin{array}{l}1.61 \\
1.63 \\
1.68 \\
1.67 \\
1.66 \\
1.64 \\
1.64 \\
1.58 \\
1.66 \\
1.63 \\
1.62 \\
1.60\end{array}$ & $\begin{array}{l}152 \\
161 \\
182 \\
177 \\
173 \\
165 \\
165 \\
141 \\
173 \\
161 \\
156 \\
148\end{array}$ & $\begin{array}{l}1.60 \\
1.64 \\
1.61 \\
1.62 \\
1.67 \\
1.73 \\
1.71 \\
1.69 \\
1.71 \\
1.69 \\
1.65 \\
1.66\end{array}$ & $\begin{array}{l}148 \\
165 \\
152 \\
156 \\
177 \\
203 \\
194 \\
186 \\
194 \\
186 \\
169 \\
173\end{array}$ & $\begin{array}{l}1.66 \\
1.69 \\
1.69 \\
1.65 \\
2.62 \\
2.85 \\
3.28 \\
3.51 \\
3.44 \\
3.45 \\
3.49 \\
3.55\end{array}$ & $\begin{array}{l}175 \\
186 \\
186 \\
169 \\
516 \\
598 \\
762 \\
854 \\
826 \\
830 \\
846 \\
870\end{array}$ & $\begin{array}{l}3.55 \\
3.53 \\
3.52 \\
3.54 \\
3.65 \\
3.97 \\
4.16 \\
4.31 \\
4.80 \\
4.46 \\
4.46 \\
4.53\end{array}$ & $\begin{array}{r}870 \\
862 \\
858 \\
866 \\
910 \\
1,040 \\
1,110 \\
1,180 \\
1,440 \\
1,250 \\
1,250 \\
1,280\end{array}$ \\
\hline & \multicolumn{2}{|c|}{ July 23} & \multicolumn{2}{|c|}{ July 24} & \multicolumn{2}{|c|}{ July 25} & \multicolumn{2}{|c|}{ July 26} & \multicolumn{2}{|c|}{ July 27} & \multicolumn{2}{|c|}{ July 28} \\
\hline $\begin{array}{l}2 \mathrm{a} . \mathrm{m} . \\
4 \\
6 \\
8 \\
10 \\
12 \mathrm{n} . \\
2 \mathrm{p} . \mathrm{m} . \\
4 \\
6 \\
8 \\
10 \\
12 \mathrm{~m} .\end{array}$ & $\begin{array}{l}4.57 \\
4.60 \\
4.57 \\
4.54 \\
4.49 \\
4.55 \\
4.75 \\
4.98 \\
5.28 \\
5.54 \\
5.67 \\
5.94\end{array}$ & $\begin{array}{l}1,300 \\
1,320 \\
1,300 \\
1,290 \\
1,260 \\
1,300 \\
1,410 \\
1,550 \\
1,760 \\
1,950 \\
2,060 \\
2,310\end{array}$ & $\begin{array}{l}6.16 \\
6.09 \\
5.97 \\
5.84 \\
5.69 \\
5.60 \\
5.49 \\
5.40 \\
5.28 \\
5.16 \\
5.09 \\
5.00\end{array}$ & $\begin{array}{l}2,540 \\
2,460 \\
2,340 \\
2,220 \\
2,080 \\
2,000 \\
1,910 \\
1,840 \\
1,760 \\
1,670 \\
1,620 \\
1,560\end{array}$ & $\begin{array}{l}4.92 \\
4.83 \\
4.75 \\
4.66 \\
4.57 \\
4.50 \\
4.40 \\
4.33 \\
4.25 \\
4.15 \\
4.09 \\
4.03\end{array}$ & $\begin{array}{l}1,510 \\
1,460 \\
1,410 \\
1,360 \\
1,300 \\
1,270 \\
1,220 \\
1,180 \\
1,150 \\
1,110 \\
1,090 \\
1,060\end{array}$ & $\begin{array}{l}3.97 \\
3.91 \\
3.83 \\
3.76 \\
3.66 \\
3.63 \\
3.52 \\
3.51 \\
3.43 \\
3.34 \\
3.34 \\
3.29\end{array}$ & $\begin{array}{r}1,040 \\
1,010 \\
982 \\
954 \\
914 \\
902 \\
858 \\
854 \\
822 \\
786 \\
786 \\
766\end{array}$ & $\begin{array}{l}3.24 \\
3.21 \\
3.13 \\
3.09 \\
3.01 \\
3.01 \\
2.90 \\
2.99 \\
2.94 \\
3.03 \\
3.07 \\
2.98\end{array}$ & $\begin{array}{l}746 \\
735 \\
703 \\
688 \\
658 \\
658 \\
617 \\
650 \\
632 \\
665 \\
681 \\
647\end{array}$ & $\begin{array}{l}2.89 \\
2.88 \\
2.80 \\
2.78 \\
2.69 \\
2.70 \\
2.61 \\
2.62 \\
2.59 \\
2.53 \\
2.54 \\
2.52\end{array}$ & $\begin{array}{l}613 \\
610 \\
580 \\
573 \\
540 \\
544 \\
512 \\
516 \\
506 \\
484 \\
488 \\
481\end{array}$ \\
\hline
\end{tabular}

\begin{tabular}{|c|c|c|c|c|c|c|c|c|c|c|c|}
\hline & \multicolumn{2}{|c|}{ July 29} & \multicolumn{2}{|c|}{ July 30} & \multicolumn{2}{|c|}{ July 31} & \multicolumn{2}{|c|}{ August 1} & \multicolumn{2}{|c|}{ August 2} & August 3 \\
\hline $\begin{array}{c}2 \mathrm{a} . \mathrm{m} . \\
4 \\
6 \\
8 \\
10 \\
12 \mathrm{n} . \\
2 \mathrm{p} . \mathrm{m} . \\
4 \\
6 \\
8 \\
10 \\
12 \mathrm{~m} .\end{array}$ & $\begin{array}{l}2.50 \\
2.52 \\
2.42 \\
2.40 \\
2.41 \\
2.40 \\
2.31 \\
2.36 \\
2.37 \\
2.62 \\
2.67 \\
2.61\end{array}$ & $\begin{array}{l}474 \\
481 \\
447 \\
440 \\
443 \\
440 \\
410 \\
427 \\
430 \\
516 \\
534 \\
512\end{array}$ & $\begin{array}{l}2.58 \\
2.54 \\
2.54 \\
2.55 \\
2.53 \\
2.56 \\
2.47 \\
2.49 \\
2.43 \\
2.36 \\
2.35 \\
2.34\end{array}$ & $\begin{array}{l}502 \\
488 \\
488 \\
492 \\
484 \\
495 \\
464 \\
471 \\
450 \\
427 \\
424 \\
420\end{array}$ & 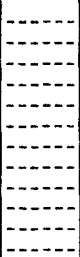 & 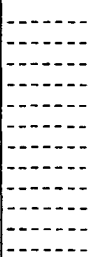 & 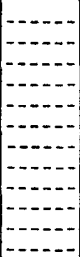 & 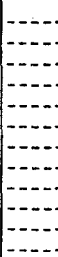 & 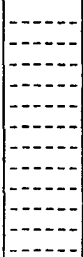 & 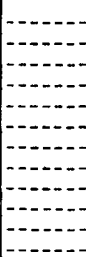 & 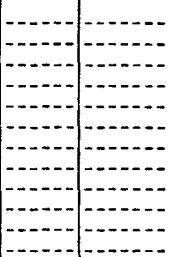 \\
\hline
\end{tabular}

Supplemental records.-July 21, 6:45 p.m., 3.81 ft., 974 sec.-ft.; July 22, 6:15 p.m., 4.95 ft., 1,530 sec.-ft. 
Mean discharge, in second-feet, 1938

\begin{tabular}{c|c|c||c|c|c||c|c|c||c|c|c}
\hline Day & Sept. & Oct. & Day & Sept. & Oct. & Day & Sept. & Oct. & Day & Sept. & Oct. \\
\hline 1 & 126 & 280 & 9 & 90 & 187 & 17 & 110 & 123 & 25 & 800 & 305 \\
2 & 117 & 249 & 10 & 74 & 169 & 18 & 99 & 115 & 26 & 700 & 244 \\
3 & 98 & 229 & 11 & 69 & 143 & 19 & 146 & 109 & 550 & 207 \\
27 & 20 & 701 & 122 & 250 & 190 \\
4 & 93 & 207 & 12 & 66 & 148 & 20 & 1,750 & 251 & 29 & 350 & 177 \\
5 & 92 & 194 & 13 & 68 & 142 & 21 & 170 & 313 & 161 \\
6 & 83 & 200 & 14 & 70 & 137 & 22 & 3,140 & 220 & 30 & 313 \\
7 & 78 & 200 & 15 & 110 & 133 & 23 & 1,800 & 179 & 31 & & 144 \\
8 & 86 & 208 & 16 & 135 & 126 & 24 & 1,000 & 202 & & & \\
\hline
\end{tabular}

Gage height, in feet, and discharge, in second-feet, at indicated time, 1938

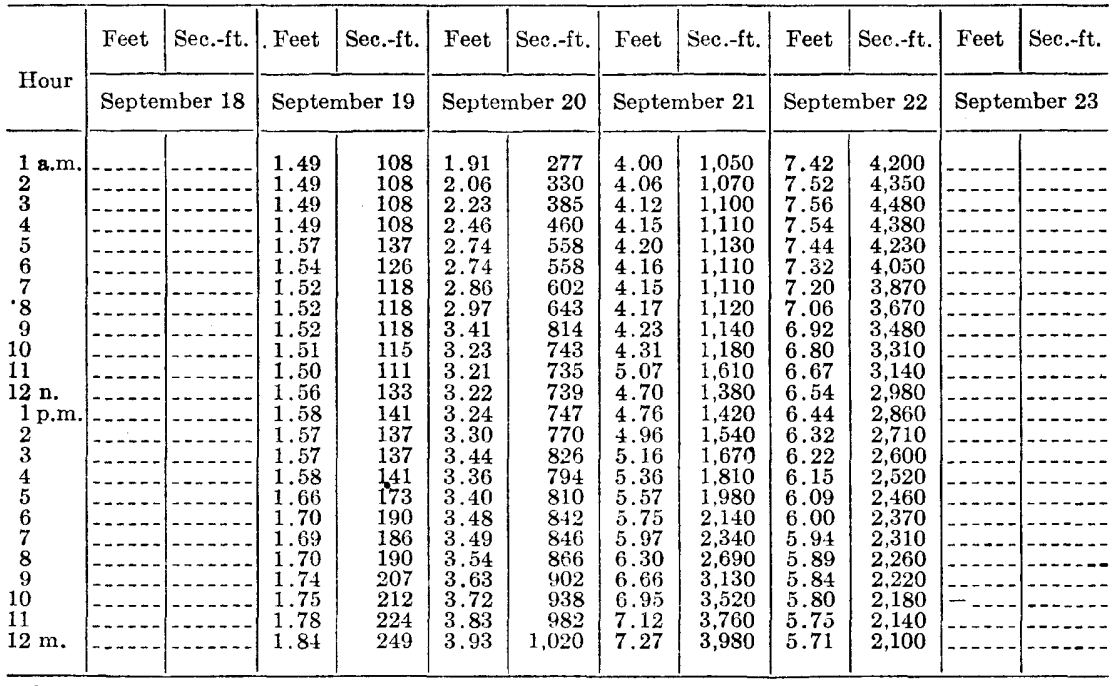

Supplemental records.-Sept. 19, $11: 30$ a.m., 1.45 ft., 94 sec.-ft.; $3: 30$ p.m., $1.55 \mathrm{ft} ., 130$ sec.-ft.; $7: 30$ p.m., $1.66 \mathrm{ft} ., 173$ sec.-ft.; Sept. 29,7 p.m., $2.11 \mathrm{ft} ., 347$ sec.-ft.

\section{IAKF HOPATCONG AT IANDING, N. J.}

Location,-Lat. $40^{\circ} 55^{\prime} 00^{\prime \prime}$, long. $74^{\circ} 39^{\prime} 50^{\prime \prime}$, on Musconetcong River at Lake Hopatcong Dam, Landing, Morris County. Datum of gage is 914.57 feet above mean sea level (New Jersey Geological Survey bench mark).

Drainage AREA.-25.6 square miles.

GAGE-HEIGHT RECORD.-Water-stage recorder graph except for period July 1621. Gage heights at midnight shown in table.

Remarks.-Capacity above sill of lowest gate (gage height, -3.1 feet) is about $800,000,000$ cubic feet. Crest of spillway is at gage height 8.89 feet. Table gives storage above gage height 4.12 feet. Recorder operated by employee of Morris Canal \& Banking Co. 
Gage height, in feet, and contents, in millions of cubic feet, 1938

\begin{tabular}{|c|c|c|c|c|c|c|c|c|c|c|}
\hline \multirow{2}{*}{ Day } & \multicolumn{2}{|c|}{ June } & \multicolumn{2}{|c|}{ July } & \multicolumn{2}{|c|}{ August } & \multicolumn{2}{|c|}{ September } & \multicolumn{2}{|c|}{ October } \\
\hline & $\begin{array}{l}\text { Gage } \\
\text { height }\end{array}$ & Contents & $\begin{array}{l}\text { Gage } \\
\text { height }\end{array}$ & Contents & $\begin{array}{l}\text { Gage } \\
\text { height }\end{array}$ & Contents & $\begin{array}{l}\text { Gage } \\
\text { height }\end{array}$ & Contents & $\begin{array}{l}\text { Gage } \\
\text { height }\end{array}$ & Contents \\
\hline $\begin{array}{r}1 \\
2 \\
3 \\
4 \\
5 \\
6 \\
7 \\
8 \\
9 \\
10 \\
11 \\
12 \\
13 \\
14 \\
15 \\
16 \\
17 \\
18 \\
19 \\
20 \\
21 \\
22 \\
23 \\
24 \\
25 \\
26 \\
27 \\
28 \\
29 \\
30 \\
31\end{array}$ & $\begin{array}{l}9.12 \\
9.10 \\
9.15 \\
9.13 \\
9.13 \\
9.11 \\
9.14 \\
9.16 \\
9.14 \\
9.12 \\
9.13 \\
9.18 \\
9.18 \\
9.19 \\
9.18 \\
9.15 \\
9.13 \\
9.14 \\
9.12 \\
9.11 \\
9.10 \\
9.08 \\
9.08 \\
9.07 \\
9.02 \\
9.30 \\
9.58 \\
9.72 \\
9.71 \\
9.63\end{array}$ & $\begin{array}{l}482 \\
480 \\
486 \\
483 \\
483 \\
481 \\
485 \\
487 \\
485 \\
482 \\
483 \\
489 \\
489 \\
490 \\
489 \\
486 \\
483 \\
485 \\
482 \\
481 \\
480 \\
478 \\
478 \\
477 \\
472 \\
502 \\
532 \\
547 \\
546 \\
537\end{array}$ & 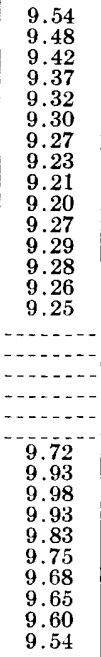 & \begin{tabular}{|c|}
528 \\
521 \\
515 \\
509 \\
504 \\
502 \\
499 \\
494 \\
492 \\
491 \\
499 \\
501 \\
500 \\
498 \\
496 \\
---- \\
--- \\
---- \\
--- \\
-547 \\
570 \\
575 \\
570 \\
559 \\
550 \\
543 \\
540 \\
534 \\
528
\end{tabular} & $\begin{array}{l}9.50 \\
9.47 \\
9.43 \\
9.39 \\
9.37 \\
9.40 \\
9.38 \\
9.35 \\
9.33 \\
9.35 \\
9.38 \\
9.34 \\
9.30 \\
9.27 \\
9.25 \\
9.23 \\
9.22 \\
9.20 \\
9.18 \\
9.17 \\
9.14 \\
9.13 \\
9.09 \\
9.07 \\
9.05 \\
9.02 \\
9.01 \\
9.00 \\
8.98 \\
8.97 \\
8.97\end{array}$ & $\begin{array}{l}523 \\
520 \\
516 \\
512 \\
509 \\
513 \\
510 \\
507 \\
505 \\
507 \\
510 \\
506 \\
502 \\
499 \\
496 \\
494 \\
493 \\
491 \\
489 \\
488 \\
485 \\
483 \\
479 \\
477 \\
475 \\
472 \\
471 \\
469 \\
467 \\
466 \\
466\end{array}$ & $\begin{array}{l}9.00 \\
8.97 \\
8.95 \\
8.92 \\
8.91 \\
8.88 \\
8.83 \\
8.81 \\
8.76 \\
8.74 \\
8.70 \\
8.65 \\
8.67 \\
8.62 \\
8.66 \\
8.63 \\
8.60 \\
8.59 \\
8.77 \\
9.06 \\
9.60 \\
9.76 \\
9.77 \\
9.68 \\
9.61 \\
9.53 \\
9.47 \\
9.42 \\
9.39 \\
9.31\end{array}$ & $\begin{array}{l}469 \\
466 \\
464 \\
461 \\
460 \\
457 \\
457 \\
450 \\
444 \\
442 \\
438 \\
433 \\
435 \\
430 \\
434 \\
431 \\
428 \\
427 \\
446 \\
476 \\
534 \\
551 \\
553 \\
543 \\
535 \\
527 \\
520 \\
515 \\
512 \\
503\end{array}$ & $\begin{array}{l}9.25 \\
9.19 \\
9.14 \\
9.09 \\
9.05 \\
9.04 \\
9.02 \\
9.00 \\
8.95 \\
8.92 \\
8.89 \\
8.86 \\
8.80 \\
8.78 \\
8.73 \\
8.69 \\
8.66 \\
8.60 \\
8.56 \\
8.63 \\
8.62 \\
8.60 \\
8.60 \\
8.65 \\
8.65 \\
8.61 \\
8.61 \\
8.60 \\
8.55 \\
8.52 \\
8.48\end{array}$ & $\begin{array}{l}496 \\
490 \\
485 \\
479 \\
475 \\
474 \\
472 \\
469 \\
464 \\
461 \\
458 \\
455 \\
449 \\
447 \\
441 \\
437 \\
434 \\
428 \\
424 \\
431 \\
430 \\
428 \\
428 \\
433 \\
433 \\
429 \\
429 \\
428 \\
423 \\
420 \\
415\end{array}$ \\
\hline \multirow{2}{*}{\multicolumn{6}{|c|}{$\begin{array}{l}\text { Change in contents, in millions of culsic feet } \\
\text { Change in contents, in equivalent second-feet. }\end{array}$}} & June & July & August & Sept. & Oet. \\
\hline & & & & & & $\begin{array}{l}+51 \\
+19.7\end{array}$ & $\begin{array}{l}-9 \\
-3.4\end{array}$ & $\begin{array}{l}-62 \\
-23.2\end{array}$ & $\begin{array}{l}+37 \\
+14.3\end{array}$ & $\begin{array}{l}-88 \\
-32.9\end{array}$ \\
\hline
\end{tabular}

MUSCONETCONG RIVER NEAR BIOOMSBURY, N. J.

Location.-Lat. $40^{\circ} 40^{\prime} 20^{\prime \prime}$, long. $75^{\circ} 03^{\prime} 40^{\prime \prime}$, at highway bridge $1 \frac{1}{2}$ miles upstream from Bloomsbury, Hunterdon County, and $9 \frac{1}{2}$ miles upstream from mouth. Datum of gage is 274.83 feet above mean sea level (general adjustment of 1929).

Drainage area.-143 square miles.

GAGE-HEIGHT RECORD.-Water-stage recorder graph except periods 8:30 p.m. July 10 to 12 n. July 16 , Oct. 16-21 when recorder graph is missing.

Stage-discharge RELATION.-Defined by current-meter measurements below 1,700 second-feet.

Maxima.-June 1938: Discharge, 904 second-feet 8 p.m. June 27 (gage height, 3.36 feet).

July 1938: Discharge, 1,900 second-feet 11 to $11: 30$ p.m. July 23 (gage height, 5.12 feet).

September 1938: Discharge, 1,910 second-feet 11 to 12 p.m. Sept. 21 (gage height, 5.14 feet).

1903-07, 1921 to May 1938: Daily discharge, 2,780 second-feet Oct. 10, 1903. Stage known, 8.0 feet, former datum, Oct. 10 or 11, 1903 (discharge not determined).

REMARKs.-Discharge for periods of no gage-height record computed on basis of records for station near Hackettstown. Discharge affected by storage in Lake Hopatcong, Lake Musconetcong, Cranbury Lake, and a number of small ponds. Monthly mean discharge and runoff, in inches, adjusted for storage in Lake Hopatcong. 
Mean discharge, in second-feet, 1938

\begin{tabular}{r|c|c|c||c|c|c|c||c|c|c|c}
\hline Day & June & July & Aug. & Day & June & July & Aug. & Day & June & July & Aug. \\
\hline 1 & 142 & 622 & 501 & 11 & 128 & 200 & 342 & 21 & 118 & 637 & 169 \\
2 & 142 & 560 & 473 & 12 & 138 & 250 & 329 & 22 & 105 & 900 & 171 \\
3 & 125 & 468 & 401 & 13 & 162 & 240 & 291 & 23 & 189 & 1,240 & 149 \\
4 & 116 & 368 & 355 & 14 & 187 & 230 & 268 & 24 & 130 & 1,440 & 150 \\
5 & 116 & 280 & 316 & 15 & 172 & 210 & 249 & 25 & 108 & 1,120 & 137 \\
6 & 118 & 242 & 509 & 16 & 146 & 200 & 227 & 26 & 148 & 923 & 131 \\
7 & 119 & 207 & 478 & 17 & 139 & 177 & 220 & 27 & 465 & 788 & 132 \\
8 & 171 & 190 & 396 & 18 & 226 & 171 & 212 & 28 & .810 & 684 & 125 \\
9 & 151 & 171 & 355 & 19 & 141 & 158 & 196 & 29 & 854 & 622 & 127 \\
10 & 128 & 170 & 316 & 20 & 134 & 368 & 175 & 30 & 726 & 643 & 122 \\
&
\end{tabular}

Gage height, in feet, and discharge, in second-feet, at indicated time, 1938

\begin{tabular}{|c|c|c|c|c|c|c|c|c|c|c|c|c|}
\hline \multirow{2}{*}{ Hour } & Feet & Sec.-ft. & Feet & Sec. $-\mathrm{ft}$. & Feet & Sec.-ft. & Feet & Sec.-ft. & Feet & Sec.-ft. & Feet & Sec.-ft. \\
\hline & \multicolumn{2}{|c|}{ June 23} & \multicolumn{2}{|c|}{ June 24} & \multicolumn{2}{|c|}{ June 25} & \multicolumn{2}{|c|}{ June 26} & \multicolumn{2}{|c|}{ June 27} & \multicolumn{2}{|c|}{ June 28} \\
\hline 2 a.m. & 1.55 & 146 & 1. 61 & 164 & 1.46 & 119 & 1.40 & 103 & 2.30 & 440 & 3.29 & 872 \\
\hline & 1.57 & 152 & 1.58 & 155 & 1.46 & 119 & 1.40 & 103 & 2.19 & $\begin{array}{l}440 \\
386\end{array}$ & 3.24 & 849 \\
\hline 6 & 1.53 & 139 & 1.55 & 146 & 1.45 & 116 & 1.42 & 108 & 2.10 & 346 & 3.10 & 788 \\
\hline 8 & 1.50 & 130 & 1.50 & 130 & 1.38 & 98 & 1.43 & 111 & 2.11 & 350 & 3.11 & 792 \\
\hline 10 & 1.48 & 125 & 1.59 & 158 & 1.48 & 125 & 1.43 & 111 & 2.06 & 329 & 3.09 & 784 \\
\hline $12 \mathrm{n}$. & 1.48 & 125 & 1.57 & 152 & 1.46 & 119 & 1.43 & 111 & 1.99 & 299 & 3.10 & 788 \\
\hline 2 p.m. & 1.83 & 238 & 1.45 & 116 & 1.43 & 111 & 1.43 & 111 & 1.99 & 299 & 3.11 & 792 \\
\hline & 2.02 & 312 & 1.24 & 66 & 1.31 & 81 & 1.44 & 114 & 2.28 & 430 & 3.15 & 810 \\
\hline 6 & 1.89 & $26 \overline{0}$ & 1.44 & 114 & 1.33 & 86 & 1.70 & 193 & 2.94 & 721 & 3.18 & 822 \\
\hline 8 & 1.81 & 231 & 1.48 & 125 & 1.43 & 111 & 1.71 & 196 & 3.36 & 904 & 3.21 & 836 \\
\hline 10 & 1.75 & 210 & 1.48 & 125 & 1.43 & 111 & 1.93 & 276 & 3.30 & 876 & 3.21 & 836 \\
\hline $12 \mathrm{~m}$. & 1. & 187 & 1.48 & 125 & 1.43 & 111 & 2.09 & 342 & 3.29 & 872 & 3.23 & 844 \\
\hline
\end{tabular}

\begin{tabular}{|c|c|c|c|c|c|c|c|c|c|c|c|c|}
\hline \multirow[b]{2}{*}{$\begin{array}{c}2 \mathrm{a} . \mathrm{m} . \\
4 \\
6 \\
8 \\
10 \\
12 \mathrm{n} . \\
2 \mathrm{p.m} . \\
4 \\
6 \\
8 \\
10 \\
12 \mathrm{~m} .\end{array}$} & \multicolumn{2}{|c|}{ June 29} & \multicolumn{2}{|c|}{ June 30} & \multicolumn{2}{|c|}{ July 1} & \multicolumn{2}{|c|}{ July 2} & \multicolumn{2}{|c|}{ July 3} & \multicolumn{2}{|c|}{ July 4} \\
\hline & $\begin{array}{l}3.27 \\
3.28 \\
3.29 \\
3.31 \\
3.29 \\
3.26 \\
3.24 \\
3.22 \\
3.17 \\
3.16 \\
3.13 \\
3.10\end{array}$ & $\begin{array}{l}862 \\
867 \\
872 \\
881 \\
872 \\
858 \\
849 \\
840 \\
818 \\
814 \\
801 \\
788\end{array}$ & $\begin{array}{l}3.07 \\
3.05 \\
3.02 \\
3.00 \\
3.00 \\
2.96 \\
2.93 \\
2.91 \\
2.83 \\
2.82 \\
2.80 \\
2.79\end{array}$ & $\begin{array}{l}775 \\
767 \\
754 \\
746 \\
746 \\
730 \\
717 \\
709 \\
676 \\
672 \\
664 \\
660\end{array}$ & $\begin{array}{l}2.79 \\
2.77 \\
2.76 \\
2.74 \\
2.74 \\
2.73 \\
2.73 \\
2.72 \\
2.70 \\
2.66 \\
2.65 \\
2.66\end{array}$ & $\begin{array}{l}660 \\
651 \\
647 \\
639 \\
639 \\
635 \\
635 \\
630 \\
622 \\
604 \\
600 \\
604\end{array}$ & $\begin{array}{l}2.66 \\
2.65 \\
2.63 \\
2.58 \\
2.59 \\
2.58 \\
2.54 \\
2.53 \\
2.51 \\
2.49 \\
2.47 \\
2.45\end{array}$ & $\begin{array}{l}604 \\
600 \\
591 \\
569 \\
574 \\
569 \\
551 \\
546 \\
538 \\
528 \\
519 \\
510\end{array}$ & $\begin{array}{l}2.43 \\
2.42 \\
2.41 \\
2.40 \\
2.38 \\
2.37 \\
2.32 \\
2.33 \\
2.32 \\
2.30 \\
2.28 \\
2.27\end{array}$ & $\begin{array}{l}501 \\
496 \\
492 \\
487 \\
478 \\
473 \\
449 \\
454 \\
449 \\
440 \\
430 \\
425\end{array}$ & $\begin{array}{l}2.27 \\
2.25 \\
2.23 \\
2.21 \\
2.18 \\
2.15 \\
2.07 \\
2.09 \\
2.09 \\
2.06 \\
2.05 \\
2.03\end{array}$ & $\begin{array}{l}425 \\
416 \\
406 \\
396 \\
382 \\
368 \\
333 \\
342 \\
342 \\
329 \\
324 \\
316\end{array}$ \\
\hline & \multicolumn{2}{|c|}{ July 5} & \multicolumn{2}{|c|}{ July 6} & \multicolumn{2}{|c|}{ July 7} & \multicolumn{2}{|c|}{ July 8} & \multicolumn{2}{|c|}{ July 9} & & \\
\hline $\begin{array}{c}2 \text { a.m. } \\
4 \\
6 \\
8 \\
10 \\
12 \mathrm{n} . \\
2 \mathrm{p} . \mathrm{m} . \\
4 \\
6 \\
8 \\
10 \\
12 \mathrm{~m} .\end{array}$ & $\begin{array}{l}2.01 \\
1.98 \\
1.97 \\
1.97 \\
2.01 \\
1.95 \\
1.93 \\
1.87 \\
1.91 \\
1.83 \\
1.87 \\
1.87\end{array}$ & $\begin{array}{l}307 \\
295 \\
291 \\
291 \\
307 \\
284 \\
276 \\
253 \\
268 \\
238 \\
253 \\
253\end{array}$ & $\begin{array}{l}1.86 \\
1.85 \\
1.85 \\
1.86 \\
1.85 \\
1.82 \\
1.91 \\
1.86 \\
1.83 \\
1.77 \\
1.80 \\
1.79\end{array}$ & $\begin{array}{l}249 \\
246 \\
246 \\
249 \\
246 \\
234 \\
268 \\
249 \\
238 \\
217 \\
227 \\
224\end{array}$ & $\begin{array}{l}1.76 \\
1.76 \\
1.68 \\
1.79 \\
1.73 \\
1.73 \\
1.71 \\
1.74 \\
1.75 \\
1.69 \\
1.72 \\
1.72\end{array}$ & $\begin{array}{l}213 \\
213 \\
187 \\
224 \\
203 \\
203 \\
196 \\
207 \\
210 \\
190 \\
200 \\
200\end{array}$ & $\begin{array}{l}1.70 \\
1.67 \\
1.68 \\
1.69 \\
1.70 \\
1.68 \\
1.71 \\
1.73 \\
1.66 \\
1.61 \\
1.68 \\
1.68\end{array}$ & $\begin{array}{l}193 \\
183 \\
187 \\
190 \\
193 \\
187 \\
196 \\
203 \\
180 \\
164 \\
187 \\
187\end{array}$ & $\begin{array}{l}1.67 \\
1.65 \\
1.65 \\
1.63 \\
1.66 \\
1.63 \\
1.62 \\
1.61 \\
1.51 \\
1.65 \\
\end{array}$ & $\begin{array}{l}183 \\
177 \\
177 \\
171 \\
180 \\
171 \\
167 \\
164 \\
133 \\
177 \\
170 \\
170\end{array}$ & 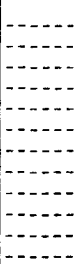 & 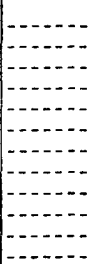 \\
\hline
\end{tabular}

Supplemental records.-June 23,3 p.m., 2.15 ft., 368 sec.-ft.; $4: 30$ p.m., 2.43 ft., 501 sec.-ft.; $7: 30$ p.m., $1.68 \mathrm{ft}$., 187 sec.-ft.; June $24,5 \mathrm{p.m}$., $1.13 \mathrm{ft}$., 45 sec.-ft.; June 25, 9 a.m., $1.21 \mathrm{ft} ., 60$ sec.-ft.; June 26 , 7 p.m., 1.78 ft., 220 sec.-ft.; 8:30 p.m., 1.67 tt., 183 sec.-ft.; June $27,1: 30$ p.m., 1.91 ft., 268 sec.-ft.; July 2 , 7 a.m., 2.54 ft., 551 sec.-ft.; July 5, 5 p.m., 1.98 ft., 295 sec.-ft.; 7 p.m., 1.76 ft., 213 sec.-ft.; July 6 , $10: 30$ p.m., $1.75 \mathrm{ft} ., 210$ sec. $-\mathrm{ft}$. 
Gage height, in feet, and discharge, in second-feet, at indicated time, 1938

\begin{tabular}{|c|c|c|c|c|c|c|c|c|c|c|c|c|}
\hline \multirow{2}{*}{ Hour } & Feet & Sec.-ft. & Feet & Sec. $-\mathrm{ft}$. & Feet & Sec.-ft. & Feet & Sec.-ft. & Feet & Sec.-ft. & Feet & Sec.-ft. \\
\hline & \multicolumn{2}{|c|}{ July 17} & \multicolumn{2}{|c|}{ July 18} & \multicolumn{2}{|c|}{ July 19} & \multicolumn{2}{|c|}{ July 20} & \multicolumn{2}{|c|}{ July 21} & \multicolumn{2}{|c|}{ July 22} \\
\hline $\begin{array}{l}2 \text { a.m. } \\
4 \\
6 \\
8 \\
10 \\
12 \mathrm{n} . \\
2 \mathrm{p.m} . \\
4 \\
6 \\
8 \\
10 \\
12 \mathrm{~m} .\end{array}$ & $\begin{array}{l}1.67 \\
1.67 \\
1.67 \\
1.67 \\
1.67 \\
1.66 \\
1.65 \\
1.63 \\
1.65 \\
1.60 \\
1.63 \\
1.63\end{array}$ & $\begin{array}{l}183 \\
183 \\
183 \\
183 \\
183 \\
180 \\
177 \\
171 \\
177 \\
161 \\
171 \\
171\end{array}$ & $\begin{array}{l}1.62 \\
1.62 \\
1.62 \\
1.73 \\
1.67 \\
1.68 \\
1.56 \\
1.65 \\
1.57 \\
1.65 \\
1.64 \\
1.51\end{array}$ & $\begin{array}{l}167 \\
167 \\
167 \\
203 \\
183 \\
187 \\
149 \\
177 \\
152 \\
177 \\
174 \\
133\end{array}$ & $\begin{array}{l}1.57 \\
1.55 \\
1.53 \\
1.55 \\
1.63 \\
1.63 \\
1.59 \\
1.55 \\
1.68 \\
1.61 \\
1.57 \\
1.61\end{array}$ & $\begin{array}{l}152 \\
146 \\
139 \\
146 \\
171 \\
17 \mathrm{~J} \\
158 \\
146 \\
187 \\
164 \\
152 \\
164\end{array}$ & $\begin{array}{l}1.61 \\
1.65 \\
1.68 \\
1.95 \\
2.30 \\
2.45 \\
2.82 \\
2.65 \\
2.38 \\
2.15 \\
2.03 \\
1.96\end{array}$ & $\begin{array}{l}164 \\
177 \\
187 \\
284 \\
440 \\
510 \\
672 \\
600 \\
478 \\
368 \\
316 \\
287\end{array}$ & $\begin{array}{l}1.93 \\
1.96 \\
1.99 \\
2.08 \\
2.40 \\
3.06 \\
3.25 \\
3.43 \\
3.52 \\
3.63 \\
3.33 \\
3.10\end{array}$ & $\begin{array}{r}276 \\
287 \\
299 \\
337 \\
487 \\
771 \\
854 \\
938 \\
982 \\
1,040 \\
890 \\
788\end{array}$ & $\begin{array}{l}3.07 \\
3.12 \\
3.21 \\
3.29 \\
3.35 \\
3.43 \\
3.43 \\
3.47 \\
3.57 \\
3.59 \\
3.56 \\
3.52\end{array}$ & $\begin{array}{r}775 \\
797 \\
836 \\
872 \\
900 \\
938 \\
938 \\
957 \\
1,010 \\
1,020 \\
1,000 \\
982\end{array}$ \\
\hline & \multicolumn{2}{|c|}{ July 23} & \multicolumn{2}{|c|}{ July 24} & \multicolumn{2}{|c|}{ July 25} & \multicolumn{2}{|c|}{ July 26} & \multicolumn{2}{|c|}{ Juily 27} & \multicolumn{2}{|c|}{ July 28} \\
\hline \multirow[t]{2}{*}{$\begin{aligned} & 2 \text { a.m. } \\
& 4 \\
& 6 \\
& 8 \\
& 10 \\
& 12 \mathrm{n} . \\
& 2 \mathrm{p.m} . \\
& 4 \\
& 6 \\
& 8 \\
& 10 \\
& 12 \mathrm{~m} .\end{aligned}$} & $\begin{array}{l}3.48 \\
3.47 \\
3.46 \\
3.47 \\
3.49 \\
3.51 \\
3.70 \\
4.37 \\
4.54 \\
4.77 \\
5.08 \\
5.11\end{array}$ & $\begin{array}{r}962 \\
957 \\
952 \\
957 \\
967 \\
977 \\
1,070 \\
1,450 \\
1,550 \\
1,690 \\
1,880 \\
1,890\end{array}$ & $\begin{array}{l}4.91 \\
4.64 \\
4.40 \\
4.27 \\
4.21 \\
4.20 \\
4.20 \\
4.20 \\
4.20 \\
4.15 \\
4.11 \\
4.06\end{array}$ & $\begin{array}{l}1,780 \\
1,610 \\
1,470 \\
1,390 \\
1,360 \\
1,350 \\
1,350 \\
1,350 \\
1,350 \\
1,320 \\
1,300 \\
1,270\end{array}$ & $\begin{array}{l}4.01 \\
3.96 \\
3.92 \\
3.93 \\
3.83 \\
3.78 \\
3.73 \\
3.68 \\
3.61 \\
3.60 \\
3.57 \\
3.53\end{array}$ & $\begin{array}{r}1,240 \\
1,210 \\
1,190 \\
1,200 \\
1,140 \\
1,110 \\
1,080 \\
1,060 \\
1,020 \\
1,020 \\
1,010 \\
986\end{array}$ & $\begin{array}{l}3.52 \\
3.50 \\
3.49 \\
3.47 \\
3.42 \\
3.40 \\
3.35 \\
3.31 \\
3.25 \\
3.22 \\
3.19 \\
3.17\end{array}$ & $\begin{array}{l}982 \\
972 \\
967 \\
957 \\
933 \\
923 \\
900 \\
881 \\
854 \\
840 \\
827 \\
818\end{array}$ & $\begin{array}{l}3.17 \\
3.16 \\
3.14 \\
3.12 \\
3.11 \\
3.09 \\
3.08 \\
3.06 \\
3.02 \\
2.97 \\
2.95 \\
2.96\end{array}$ & $\begin{array}{l}818 \\
814 \\
805 \\
798 \\
792 \\
784 \\
780 \\
771 \\
754 \\
734 \\
726 \\
730\end{array}$ & $\begin{array}{l}2.95 \\
2.95 \\
2.92 \\
2.91 \\
2.90 \\
2.90 \\
2.87 \\
2.88 \\
2.87 \\
2.78 \\
2.77 \\
2.75\end{array}$ & $\begin{array}{l}726 \\
726 \\
713 \\
709 \\
705 \\
705 \\
693 \\
697 \\
693 \\
656 \\
651 \\
643\end{array}$ \\
\hline & \multicolumn{2}{|c|}{ July 29} & \multicolumn{2}{|c|}{ July 30} & \multicolumn{2}{|c|}{ July 31} & \multicolumn{2}{|c|}{ August 1} & \multicolumn{2}{|c|}{ August 2} & \multicolumn{2}{|c|}{ August 3} \\
\hline $\begin{array}{l}2 \text { a.m. } \\
4 \\
6 \\
8 \\
10 \\
12 \mathrm{n} . \\
2 \mathrm{p.m} . \\
4 \\
6 \\
8 \\
10 \\
12 \mathrm{~m} .\end{array}$ & $\begin{array}{l}2.73 \\
2.72 \\
2.71 \\
2.70 \\
2.66 \\
2.63 \\
2.63 \\
2.61 \\
2.72 \\
2.73 \\
2.77 \\
2.90\end{array}$ & $\begin{array}{l}635 \\
630 \\
626 \\
622 \\
604 \\
591 \\
591 \\
582 \\
630 \\
635 \\
651 \\
705\end{array}$ & $\begin{array}{l}2.95 \\
2.90 \\
2.80 \\
2.75 \\
2.75 \\
2.75 \\
2.73 \\
2.72 \\
2.67 \\
2.66 \\
2.65 \\
2.64\end{array}$ & $\begin{array}{l}726 \\
705 \\
664 \\
643 \\
643 \\
643 \\
635 \\
630 \\
609 \\
604 \\
600 \\
596\end{array}$ & $\begin{array}{l}2.63 \\
2.63 \\
2.62 \\
2.61 \\
2.60 \\
2.58 \\
2.57 \\
2.55 \\
2.55 \\
2.53 \\
2.51 \\
2.50\end{array}$ & $\begin{array}{l}591 \\
591 \\
587 \\
582 \\
578 \\
569 \\
564 \\
556 \\
556 \\
546 \\
538 \\
533\end{array}$ & $\begin{array}{l}2.49 \\
2.47 \\
2.45 \\
2.44 \\
2.44 \\
2.41 \\
2.41 \\
2.40 \\
2.35 \\
2.38 \\
2.38 \\
2.43\end{array}$ & $\begin{array}{l}528 \\
519 \\
510 \\
505 \\
505 \\
492 \\
492 \\
487 \\
464 \\
478 \\
478 \\
501\end{array}$ & $\begin{array}{l}2.47 \\
2.47 \\
2.43 \\
2.40 \\
2.38 \\
2.38 \\
2.36 \\
2.37 \\
2.32 \\
2.30 \\
2.29 \\
2.25\end{array}$ & $\begin{array}{l}519 \\
519 \\
501 \\
487 \\
478 \\
478 \\
468 \\
473 \\
449 \\
440 \\
435 \\
416\end{array}$ & $\begin{array}{l}2.24 \\
2.25 \\
2.25 \\
2.25 \\
2.28 \\
2.25 \\
2.15 \\
2.23 \\
2.21 \\
2.16 \\
2.10 \\
2.15\end{array}$ & $\begin{array}{l}411 \\
416 \\
414 \\
416 \\
430 \\
416 \\
368 \\
406 \\
396 \\
373 \\
346 \\
368\end{array}$ \\
\hline
\end{tabular}

Mean discharge, in second-feet, 1938

\begin{tabular}{r|c|c||c|c|c||c|c|c||c|c|c}
\hline Day & Sept. & Oct. & Day & Sept. & Oct. & Day & Sept. & Oct. & Day & Sept. & Oct. \\
\hline 1 & 161 & 337 & 9 & 126 & 246 & 17 & 133 & 190 & 25 & 705 & 324 \\
2 & 139 & 316 & 10 & 119. & 246 & 18 & 127 & 180 & 26 & 600 & 287 \\
3 & 125 & 303 & 11 & 121 & 234 & 19 & 167 & 170 & 27 & 515 & 268 \\
4 & 116 & 276 & 12 & 131 & 224 & 20 & 586 & 200 & 28 & 445 & 265 \\
5 & 122 & 260 & 13 & 128 & 217 & 21 & 1,190 & 320 & 29 & 396 & 256 \\
6 & 116 & 276 & 14 & 133 & 213 & 22 & 1,530 & 257 & 30 & 373 & 246 \\
7 & 112 & 320 & 15 & 139 & 207 & 23 & 1,200 & 253 & 31 & & 245 \\
8 & 119 & 268 & 16 & 142 & 200 & 24 & 900 & 326 & & & \\
\hline
\end{tabular}


Gage height, in feet, and discharge, in second-feet, at indicated time, 1938

\begin{tabular}{|c|c|c|c|c|c|c|c|c|c|c|c|c|}
\hline \multirow{2}{*}{ Hour } & Feet & Sec.-ft. & Feet & Sec.-ft. & Feet & Sec.-ft. & Feet & Sec.-ft. & Feet & Sec.-ft. & Feet & Sec. $-\mathrm{ft}$. \\
\hline & \multicolumn{2}{|c|}{ September 18} & \multicolumn{2}{|c|}{ September 19} & \multicolumn{2}{|c|}{ September 20} & \multicolumn{2}{|c|}{ September 21} & \multicolumn{2}{|c|}{ September 22} & \multicolumn{2}{|c|}{ September 23} \\
\hline $\begin{array}{c}1 \mathrm{a} . \mathrm{m} . \\
2 \\
3 \\
4 \\
5 \\
6 \\
7 \\
8 \\
9 \\
10 \\
11 \\
12 \mathrm{n} . \\
1 \mathrm{p} . \mathrm{m} . \\
2 \\
3 \\
4 \\
5 \\
6 \\
7 \\
8 \\
9 \\
10 \\
11 \\
12 \mathrm{~m} .\end{array}$ & 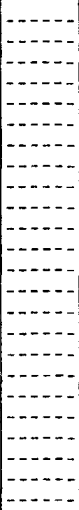 & \begin{tabular}{|l}
- \\
-1 \\
-
\end{tabular} & $\begin{array}{l}1.50 \\
1.54 \\
1.57 \\
1.54 \\
1.49 \\
1.46 \\
1.48 \\
1.64 \\
1.55 \\
1.64 \\
1.61 \\
1.64 \\
1.62 \\
1.60 \\
1.66 \\
1.56 \\
1.66 \\
1.66 \\
1.63 \\
1.71 \\
1.70 \\
1.78 \\
1.86 \\
1.83\end{array}$ & $\begin{array}{l}130 \\
142 \\
152 \\
142 \\
127 \\
119 \\
125 \\
174 \\
146 \\
174 \\
164 \\
174 \\
167 \\
161 \\
180 \\
149 \\
180 \\
180 \\
171 \\
196 \\
193 \\
220 \\
249 \\
238\end{array}$ & $\begin{array}{l}2.03 \\
2.05 \\
2.25 \\
2.43 \\
2.62 \\
2.85 \\
3.01 \\
3.03 \\
3.01 \\
2.98 \\
2.89 \\
2.79 \\
2.69 \\
2.61 \\
2.55 \\
2.49 \\
2.44 \\
2.41 \\
2.41 \\
2.46 \\
2.60 \\
2.80 \\
2.99 \\
3.09\end{array}$ & $\begin{array}{l}316 \\
324 \\
416 \\
501 \\
587 \\
684 \\
750 \\
759 \\
750 \\
738 \\
701 \\
660 \\
618 \\
582 \\
556 \\
528 \\
505 \\
492 \\
492 \\
515 \\
578 \\
664 \\
742 \\
784\end{array}$ & $\begin{array}{l}3.09 \\
3.10 \\
3.09 \\
3.07 \\
3.04 \\
3.00 \\
2.95 \\
2.88 \\
2.79 \\
2.78 \\
2.83 \\
2.99 \\
3.31 \\
3.82 \\
4.41 \\
4.87 \\
5.00 \\
5.00 \\
4.98 \\
5.00 \\
5.09 \\
5.12 \\
5.14 \\
5.14\end{array}$ & $\begin{array}{r}784 \\
788 \\
784 \\
775 \\
763 \\
746 \\
726 \\
697 \\
660 \\
656 \\
676 \\
742 \\
881 \\
1,130 \\
1,480 \\
1,750 \\
1,830 \\
1,830 \\
1,820 \\
1,830 \\
1,880 \\
1,900 \\
1,910 \\
1,910\end{array}$ & $\begin{array}{l}5.10 \\
5.02 \\
4.95 \\
4.81 \\
4.65 \\
4.50 \\
4.34 \\
4.24 \\
4.20 \\
4.20 \\
4.20 \\
4.24 \\
4.29 \\
4.35 \\
4.43 \\
4.45 \\
4.47 \\
4.46 \\
4.45 \\
4.44 \\
4.43 \\
4.39 \\
4.34 \\
4.29\end{array}$ & $\begin{array}{l}1,890 \\
1,840 \\
1,800 \\
1,720 \\
1,620 \\
1,530 \\
1,430 \\
1,370 \\
1,350 \\
1,350 \\
1,350 \\
1,370 \\
1,400 \\
1,440 \\
1,490 \\
1,500 \\
1,510 \\
1,510 \\
1,500 \\
1,490 \\
1,490 \\
1,460 \\
1,430 \\
1,400\end{array}$ & $\begin{array}{l}4.23 \\
4.20 \\
4.17 \\
4.14 \\
4.13 \\
4.11 \\
4.08 \\
4.06 \\
4.03 \\
3.99 \\
3.98 \\
3.95 \\
3.93 \\
3.90 \\
3.89 \\
3.85 \\
3.83 \\
3.78 \\
3.75 \\
3.74 \\
3.70 \\
3.68 \\
3.65 \\
3.63\end{array}$ & $\begin{array}{l}1,370 \\
1,350 \\
1,330 \\
1,310 \\
1,310 \\
1,300 \\
1,280 \\
1,270 \\
1,250 \\
1,220 \\
1,220 \\
1,200 \\
1,200 \\
1,180 \\
1,170 \\
1,150 \\
1,140 \\
1,110 \\
1,100 \\
1,090 \\
1,070 \\
1,060 \\
1,040 \\
1,040\end{array}$ \\
\hline & Septer & mber 24 & Septe & ber 25 & Septe & mber 26 & Septe & mber 27 & Septe & mber 28 & Septe & mber 29 \\
\hline $\begin{array}{c}2 \text { a.m. } \\
4 \\
6 \\
8 \\
10 \\
12 \text { n. } \\
2 \text { p.m. } \\
4 \\
6 \\
8 \\
10 \\
12 \mathrm{~m} .\end{array}$ & $\begin{array}{l}3.58 \\
3.53 \\
3.48 \\
3.42 \\
3.39 \\
3.34 \\
3.29 \\
3.17 \\
3.17 \\
3.13 \\
3.09 \\
3.07\end{array}$ & $\begin{array}{r}1,010 \\
986 \\
962 \\
933 \\
918 \\
895 \\
872 \\
818 \\
818 \\
801 \\
784 \\
775\end{array}$ & $\begin{array}{l}3.05 \\
3.02 \\
2.99 \\
2.95 \\
2.94 \\
2.93 \\
2.90 \\
2.86 \\
2.84 \\
2.81 \\
2.79 \\
2.78\end{array}$ & $\begin{array}{l}767 \\
754 \\
742 \\
726 \\
721 \\
717 \\
705 \\
689 \\
680 \\
668 \\
660 \\
656\end{array}$ & 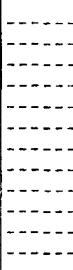 & 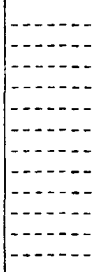 & 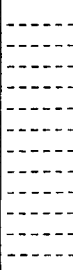 & 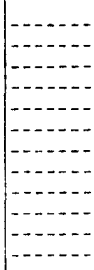 & 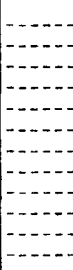 & 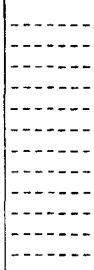 & 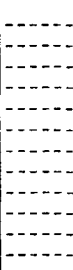 & 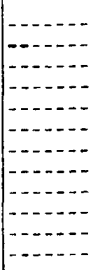 \\
\hline
\end{tabular}

Supplemental records.-Sept. 19, 6:30 p.m., 1.71 ft., 196 sec.-ft.; Sept. 26,9 a.m., 2.76 ft., 617 sec.-ft. 
ASSUNPINK CRERK AT TRENTON, N. J.

Location.-Lat. $40^{\circ} 13^{\prime} 29^{\prime \prime}$, long. $74^{\circ} 45^{\prime} 02^{\prime \prime}$, at Chambers Street Bridge in Trenton, Mercer County, 11/2 miles upstream from mouth. Datum of gage is 24.76 feet above mean sea level (New Jersey Geological Survey bench mark).

Drainage area.-89.4 square miles.

GaGe-HEIGHT RECORD.-Water-stage recorder graph except for periods 10 p.m. July 1 to 4 p.m. July 21 and 10:30 a.m. July 27 to 8 a.m. Aug. 1 when recorder graph is missing.

Stage-discharge Relation.-Defined by current-meter measurements below 1,300 second-feet.

Maxima.-June 1938: Discharge, 1,420 second-feet $7: 30$ to 10 p.m. June 28 (gage height, 6.86 feet).

July 1938: Discharge, 2,370 second-feet 10:30 p.m. July 23 (gage height 8.90 feet).

September 1938: Discharge, 3,320 second-feet 2:45 to 3:30 a.m. Sept. 22 (gage height, 10.74 feet).

1923 to May 1938: Discharge, 2,400 second-feet Apr. 7, 1924 (gage height, 7.85 feet).

REMARKs.-Flow not materially affected by storage. Discharge for periods of no gage-height records, July 1-21, 27-31, Aug. 1, computed on basis of range in stage and records for North Branch of Rancocas Creek at Pemberton.

Mean discharge, in second-feet, 1938

\begin{tabular}{|c|c|c|c|c|c|c|c|c|c|c|c|}
\hline Day & June & July & Aug. & Day & June & July & Aug. & Day & June & July & Aug. \\
\hline $\begin{array}{r}1 \\
2 \\
3 \\
4 \\
5 \\
6 \\
7 \\
8 \\
9 \\
10\end{array}$ & $\begin{array}{r}49 \\
42 \\
39 \\
37 \\
37 \\
36 \\
50 \\
195 \\
133 \\
88\end{array}$ & $\begin{array}{r}426 \\
280 \\
190 \\
130 \\
90 \\
80 \\
70 \\
62 \\
60 \\
58\end{array}$ & $\begin{array}{r}137 \\
124 \\
110 \\
107 \\
96 \\
148 \\
263 \\
211 \\
144 \\
119\end{array}$ & $\begin{array}{l}11 \\
12 \\
13 \\
14 \\
15 \\
16 \\
17 \\
18 \\
19 \\
20\end{array}$ & $\begin{array}{r}64 \\
105 \\
215 \\
356 \\
282 \\
231 \\
186 \\
133 \\
85 \\
70\end{array}$ & $\begin{array}{r}55 \\
52 \\
62 \\
140 \\
250 \\
150 \\
110 \\
90 \\
100 \\
500\end{array}$ & $\begin{array}{r}106 \\
92 \\
78 \\
67 \\
61 \\
56 \\
94 \\
105 \\
90 \\
67\end{array}$ & $\begin{array}{l}21 \\
22 \\
23 \\
24 \\
25 \\
26 \\
27 \\
28 \\
29 \\
30 \\
31\end{array}$ & $\begin{array}{r}57 \\
53 \\
87 \\
131 \\
85 \\
124 \\
860 \\
1,230 \\
1,130 \\
711\end{array}$ & $\begin{array}{r}970 \\
1,520 \\
1,490 \\
1,840 \\
1,440 \\
900 \\
567 \\
383 \\
278 \\
209 \\
164\end{array}$ & $\begin{array}{l}57 \\
52 \\
48 \\
46 \\
42 \\
41 \\
39 \\
39 \\
38 \\
36 \\
40\end{array}$ \\
\hline \multicolumn{9}{|c|}{$\begin{array}{l}\text { Monthly mean discharge, in second-feet } \\
\text { Runoff, in inches }\end{array}$} & 230 & $\begin{array}{r}410 \\
5.29\end{array}$ & $\begin{array}{l}88.8 \\
1.14\end{array}$ \\
\hline
\end{tabular}

Gage height, in feet, and discharge, in second-feet, at indicated time, 1938

\begin{tabular}{|c|c|c|c|c|c|c|c|c|c|c|c|c|}
\hline \multirow[b]{2}{*}{ Hour } & Feet & Sec. $-\mathrm{ft}$. & Feet & Sec.-ft. & Feet & Sec. $-\mathrm{ft}$. & Feet & Sec.-ft. & Feet & Sec.-ft. & Feet & Sec.-ft. \\
\hline & \multicolumn{2}{|c|}{ June 23} & \multicolumn{2}{|c|}{ June 24} & \multicolumn{2}{|c|}{ June 25} & \multicolumn{2}{|c|}{ June 26} & \multicolumn{2}{|c|}{ June 27} & \multicolumn{2}{|c|}{ June 28} \\
\hline $\begin{array}{c}2 \mathrm{a} . \mathrm{m} . \\
4 \\
6 \\
8 \\
10 \\
12 \mathrm{n} . \\
2 \mathrm{p} . \mathrm{m} . \\
4 \\
6 \\
8 \\
10 \\
12 \mathrm{~m} .\end{array}$ & $\begin{array}{l}2.31 \\
2.30 \\
2.30 \\
2.29 \\
2.30 \\
2.30 \\
2.30 \\
3.07 \\
2.78 \\
2.68 \\
2.68 \\
2.70\end{array}$ & $\begin{array}{r}54 \\
53 \\
53 \\
52 \\
53 \\
53 \\
53 \\
184 \\
129 \\
112 \\
112 \\
115\end{array}$ & $\begin{array}{l}2.75 \\
2.81 \\
2.84 \\
2.85 \\
2.86 \\
2.86 \\
2.83 \\
2.78 \\
2.75 \\
2.73 \\
2.70 \\
2.66\end{array}$ & $\begin{array}{l}124 \\
135 \\
140 \\
142 \\
144 \\
144 \\
138 \\
129 \\
124 \\
120 \\
115 \\
108\end{array}$ & $\begin{array}{l}2.63 \\
2.60 \\
2.57 \\
2.55 \\
2.53 \\
2.52 \\
2.49 \\
2.47 \\
2.45 \\
2.44 \\
2.43 \\
2.42\end{array}$ & $\begin{array}{r}103 \\
98 \\
93 \\
90 \\
87 \\
85 \\
80 \\
78 \\
74 \\
73 \\
72 \\
70\end{array}$ & $\begin{array}{l}2.41 \\
2.39 \\
2.38 \\
2.37 \\
2.36 \\
2.35 \\
2.34 \\
2.33 \\
2.32 \\
3.45 \\
4.15 \\
3.73\end{array}$ & $\begin{array}{r}68 \\
66 \\
64 \\
63 \\
61 \\
60 \\
59 \\
57 \\
56 \\
268 \\
455 \\
338\end{array}$ & $\begin{array}{l}3.85 \\
4.02 \\
4.87 \\
5.25 \\
5.68 \\
5.93 \\
5.87 \\
5.75 \\
6.38 \\
5.86 \\
5.80 \\
5.90\end{array}$ & $\begin{array}{r}370 \\
417 \\
701 \\
822 \\
963 \\
1,050 \\
1,030 \\
985 \\
1,220 \\
1,020 \\
1,000 \\
1,040\end{array}$ & $\begin{array}{l}5.92 \\
5.95 \\
6.00 \\
6.12 \\
6.27 \\
6.45 \\
6.60 \\
6.72 \\
6.80 \\
6.86 \\
6.86 \\
6.80\end{array}$ & $\begin{array}{l}1,050 \\
1,060 \\
1,080 \\
1,120 \\
1,180 \\
1,250 \\
1,310 \\
1,370 \\
1,400 \\
1,420 \\
1,420 \\
1,400\end{array}$ \\
\hline
\end{tabular}


Gage height in feet, and discharge, in second-feet, at indicated time, 1938-Continued

\begin{tabular}{|c|c|c|c|c|c|c|c|c|c|c|c|c|}
\hline \multirow[b]{2}{*}{ Hour } & Feet & Sec.ft. & Feet & Sec.-ft. & Feet & Sec.-ft. & Feet & Sec.-ft. & Feet & Sec.-ft. & Feet & Sec.-ft. \\
\hline & \multicolumn{2}{|c|}{ June 29} & \multicolumn{2}{|c|}{ June 30} & \multicolumn{2}{|c|}{ July 1} & \multicolumn{2}{|c|}{ July 2} & \multicolumn{2}{|c|}{ July 3} & \multicolumn{2}{|c|}{ July 4} \\
\hline $2 \mathrm{a} . \mathrm{m}$. & & ,370 & & 860 & & 523 & & & & & & \\
\hline & 6. & 1,330 & 5.27 & 829 & 4.3 & 501 & & & & & & \\
\hline & & 1,2 & & 798 & & & & & & & & \\
\hline & 6.2 & 1,17 & & & $\begin{array}{l}4.12 \\
4.12\end{array}$ & & & 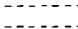 & & & & \\
\hline $12 \mathrm{n}$ & 6.13 & 1,120 & & & 4.04 & & & & & & & \\
\hline 2 p.m. & 5.98 & 1,070 & & & 3.9 & 408 & & & & & & \\
\hline & & 1,020 & & & & & & & & & & \\
\hline & $\begin{array}{l}5.75 \\
5.68\end{array}$ & $\begin{array}{l}985 \\
963\end{array}$ & $\begin{array}{r}4.66 \\
4.59\end{array}$ & $\begin{array}{l}624 \\
598\end{array}$ & 3.8 & $\begin{array}{l}375 \\
361\end{array}$ & & & & & & \\
\hline & $\begin{array}{l}5.56 \\
5.56\end{array}$ & 921 & 4.51 & 570 & $\begin{array}{l}3.77 \\
3.77\end{array}$ & 348 & & & & & & \\
\hline $12 \mathrm{~m}$. & 5.47 & 891 & 4.44 & 547 & & & & & & & & \\
\hline
\end{tabular}

Gage height, in feet, and discharge, in second-feet, at indicated time, 1938

\begin{tabular}{|c|c|c|c|c|c|c|c|c|c|c|c|c|}
\hline \multirow{2}{*}{ Hour } & Feet & Sec.-ft. & Feet & Sec.-ft. & Feet & Sec. $-\mathrm{ft}$. & Feet & Sec.-ft. & Feet & Sec.-ft. & Feet & Sec.-ft. \\
\hline & \multicolumn{2}{|c|}{ July 17} & \multicolumn{2}{|c|}{ July 18} & \multicolumn{2}{|c|}{ July 19} & \multicolumn{2}{|c|}{ July 20} & \multicolumn{2}{|c|}{ July 21} & \multicolumn{2}{|c|}{ July 22} \\
\hline \multirow[t]{2}{*}{$\begin{array}{l}2 \mathrm{a} . \mathrm{m} . \\
4 \\
6 \\
8 \\
10 \\
12 \mathrm{n} . \\
2 \mathrm{p} . \mathrm{m} . \\
4 \\
6 \\
8 \\
10 \\
12 \mathrm{~m} .\end{array}$} & & & & & & & & & $\begin{array}{l}- \\
5.93 \\
6.11 \\
6.33 \\
6.61 \\
6.93\end{array}$ & \begin{tabular}{l} 
\\
\hdashline \\
\hdashline \\
\hdashline 1,050 \\
\hdashline 1,200 \\
1,320 \\
1,450
\end{tabular} & $\begin{array}{l}7.03 \\
7.12 \\
7.18 \\
7.21 \\
7.37 \\
7.13 \\
7.02 \\
6.97 \\
6.96 \\
7.00 \\
6.99 \\
6.84\end{array}$ & $\begin{array}{l}1,490 \\
1,530 \\
1,560 \\
1,570 \\
1,640 \\
1,540 \\
1,490 \\
1,470 \\
1,460 \\
1,480 \\
1,480 \\
1,420\end{array}$ \\
\hline & \multicolumn{2}{|c|}{ July 23} & \multicolumn{2}{|c|}{ July 24} & \multicolumn{2}{|c|}{ July 25} & \multicolumn{2}{|c|}{ July 26} & \multicolumn{2}{|c|}{ July 27} & \multicolumn{2}{|c|}{ July 28} \\
\hline $\begin{array}{c}2 \mathrm{a} . \mathrm{m} . \\
4 \\
6 \\
8 \\
10 \\
12 \mathrm{n} . \\
2 \mathrm{p} . \mathrm{m} . \\
4 \\
6 \\
8 \\
10 \\
12 \mathrm{~m} .\end{array}$ & $\begin{array}{l}6.61 \\
6.36 \\
6.14 \\
6.01 \\
5.84 \\
6.10 \\
6.65 \\
6.89 \\
7.85 \\
8.50 \\
8.89 \\
8.73\end{array}$ & $\begin{array}{l}1,320 \\
1,210 \\
1,130 \\
1,080 \\
1,020 \\
1,110 \\
1,340 \\
1,440 \\
1,860 \\
2,170 \\
2,360 \\
2,280\end{array}$ & $\begin{array}{l}8.38 \\
8.09 \\
7.72 \\
7.49 \\
7.46 \\
7.55 \\
7.68 \\
7.73 \\
7.73 \\
7.65 \\
7.57 \\
7.50\end{array}$ & $\begin{array}{l}2,110 \\
1,980 \\
1,800 \\
1,700 \\
1,680 \\
1,720 \\
1,780 \\
1,800 \\
1,800 \\
1,770 \\
1,740 \\
1,700\end{array}$ & $\begin{array}{l}7.43 \\
7.38 \\
7.30 \\
7.18 \\
7.06 \\
6.90 \\
6.75 \\
6.60 \\
6.47 \\
6.33 \\
6.21 \\
6.10\end{array}$ & $\begin{array}{l}1,670 \\
1,650 \\
1,610 \\
1,560 \\
1,500 \\
1,440 \\
1,380 \\
1,310 \\
1,260 \\
1,200 \\
1,150 \\
1,110\end{array}$ & $\begin{array}{l}6.00 \\
5.90 \\
5.78 \\
5.68 \\
5.57 \\
5.46 \\
5.36 \\
5.26 \\
5.16 \\
5.07 \\
4.97 \\
4.88\end{array}$ & $\begin{array}{r}1,080 \\
1,040 \\
994 \\
963 \\
924 \\
888 \\
857 \\
826 \\
795 \\
766 \\
734 \\
704\end{array}$ & 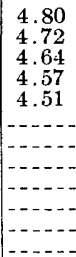 & \begin{tabular}{r}
677 \\
647 \\
617 \\
592 \\
570 \\
\hdashline \\
\\
\\
\\
\\
\end{tabular} & & 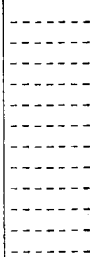 \\
\hline
\end{tabular}

Mean discharge, in second-feet, 1938

\begin{tabular}{|c|c|c|c|c|c|c|c|c|c|c|c|}
\hline Day & Sept. & Oct. & Day & Sept. & Oct. & Day & Sept. & Oct. & Day & Sept. & Oct. \\
\hline $\begin{array}{l}1 \\
2 \\
3 \\
4 \\
5 \\
6 \\
7 \\
8\end{array}$ & $\begin{array}{l}57 \\
48 \\
42 \\
39 \\
38 \\
36 \\
37 \\
36\end{array}$ & $\begin{array}{r}106 \\
100 \\
95 \\
88 \\
82 \\
101 \\
146 \\
133\end{array}$ & $\begin{array}{r}9 \\
10 \\
11 \\
12 \\
13 \\
14 \\
15 \\
16\end{array}$ & $\begin{array}{l}34 \\
32 \\
31 \\
32 \\
34 \\
36 \\
50 \\
42\end{array}$ & $\begin{array}{r}126 \\
115 \\
108 \\
98 \\
84 \\
79 \\
72 \\
70\end{array}$ & $\begin{array}{l}17 \\
18 \\
19 \\
20 \\
21 \\
22 \\
23 \\
24\end{array}$ & $\begin{array}{r}46 \\
54 \\
182 \\
686 \\
1,590 \\
2,830 \\
1,750 \\
787\end{array}$ & $\begin{array}{l}66 \\
67 \\
66 \\
70 \\
80 \\
76 \\
70 \\
85\end{array}$ & $\begin{array}{l}25 \\
26 \\
27 \\
28 \\
29 \\
30 \\
31\end{array}$ & $\begin{array}{l}397 \\
258 \\
190 \\
153 \\
144 \\
119\end{array}$ & $\begin{array}{r}96 \\
88 \\
85 \\
95 \\
129 \\
128 \\
124\end{array}$ \\
\hline \multicolumn{10}{|c|}{$\begin{array}{l}\text { Monthly mean discharge, in second-feet. } \\
\text { Runoff, in inches }\end{array}$} & $\begin{array}{r}327 \\
4.08\end{array}$ & $\begin{array}{l}94.5 \\
1.22\end{array}$ \\
\hline
\end{tabular}


Gage height, in feet, and discharge, in second-feet, at indicated time, 1938

\begin{tabular}{|c|c|c|c|c|c|c|c|c|c|c|c|c|}
\hline \multirow{2}{*}{ Hour } & Feet & Sec.-ft. & Feet & Sec.-ft. & Feet & Sec.-ft. & Feet & Sec.-ft. & Feet & Sec.-ft. & Feet & Sec.-ft. \\
\hline & \multicolumn{2}{|c|}{ September 18} & \multicolumn{2}{|c|}{ September 19} & \multicolumn{2}{|c|}{ September 20} & \multicolumn{2}{|c|}{ September 21} & \multicolumn{2}{|c|}{ September 22} & \multicolumn{2}{|c|}{ September 23} \\
\hline $\begin{array}{c}1 \text { a.m. } \\
2 \\
3 \\
4 \\
5 \\
6 \\
7 \\
8 \\
9 \\
10 \\
11 \\
12 \mathrm{n} . \\
1 \mathrm{p} . \mathrm{m} . \\
2 \\
3 \\
4 \\
5 \\
6 \\
7 \\
8 \\
9 \\
10 \\
11 \\
12 \mathrm{~m} .\end{array}$ & $\begin{array}{l}2.23 \\
2.23 \\
2.23 \\
2.24 \\
2.24 \\
2.24 \\
2.24 \\
2.24 \\
2.24 \\
2.24 \\
2.35 \\
2.44 \\
2.37 \\
2.33 \\
2.31 \\
2.30 \\
2.29 \\
2.29 \\
2.28 \\
2.36 \\
2.48 \\
2.39 \\
2.35 \\
2.33\end{array}$ & $\begin{array}{l}45 \\
45 \\
45 \\
46 \\
46 \\
46 \\
46 \\
46 \\
46 \\
46 \\
60 \\
73 \\
63 \\
57 \\
54 \\
53 \\
52 \\
52 \\
51 \\
61 \\
79 \\
66 \\
60 \\
57\end{array}$ & $\begin{array}{l}2.33 \\
2.32 \\
2.31 \\
2.31 \\
2.31 \\
2.37 \\
2.34 \\
2.35 \\
2.37 \\
2.36 \\
2.36 \\
3.10 \\
3.95 \\
3.50 \\
3.28 \\
3.27 \\
3.23 \\
3.29 \\
3.37 \\
3.48 \\
3.63 \\
3.80 \\
3.97 \\
4.02\end{array}$ & $\begin{array}{r}57 \\
56 \\
54 \\
54 \\
54 \\
63 \\
59 \\
60 \\
63 \\
61 \\
61 \\
190 \\
397 \\
280 \\
230 \\
226 \\
218 \\
231 \\
249 \\
275 \\
312 \\
356 \\
403 \\
417\end{array}$ & $\begin{array}{l}4.08 \\
4.11 \\
4.10 \\
4.17 \\
4.45 \\
4.38 \\
4.48 \\
4.45 \\
4.54 \\
4.65 \\
4.80 \\
4.93 \\
5.08 \\
5.19 \\
5.28 \\
5.29 \\
5.29 \\
5.27 \\
5.36 \\
5.41 \\
5.46 \\
5.41 \\
5.33 \\
5.34\end{array}$ & $\begin{array}{l}434 \\
443 \\
440 \\
461 \\
550 \\
527 \\
560 \\
550 \\
581 \\
620 \\
677 \\
721 \\
770 \\
804 \\
832 \\
835 \\
835 \\
829 \\
857 \\
872 \\
888 \\
872 \\
847 \\
850\end{array}$ & $\begin{array}{r}5.40 \\
5.50 \\
5.60 \\
5.74 \\
5.88 \\
5.98 \\
6.05 \\
6.14 \\
6.16 \\
6.26 \\
6.46 \\
6.48 \\
6.65 \\
7.07 \\
7.39 \\
7.71 \\
7.96 \\
8.27 \\
8.60 \\
9.12 \\
9.48 \\
9.88 \\
10.14 \\
10.43\end{array}$ & $\begin{array}{r}869 \\
900 \\
935 \\
982 \\
1,030 \\
1,070 \\
1,100 \\
1,130 \\
1,130 \\
1,170 \\
1,250 \\
1,260 \\
1,340 \\
1,510 \\
1,660 \\
1,800 \\
1,910 \\
2,060 \\
2,220 \\
2,480 \\
2,670 \\
2,870 \\
3,010 \\
3,170\end{array}$ & $\begin{array}{r}10.63 \\
10.71 \\
10.74 \\
10.71 \\
10.60 \\
10.47 \\
10.34 \\
10.22 \\
10.12 \\
10.01 \\
9.88 \\
9.70 \\
9.56 \\
9.51 \\
9.44 \\
9.42 \\
9.35 \\
9.34 \\
9.28 \\
9.23 \\
9.21 \\
9.13 \\
9.09 \\
8.98\end{array}$ & $\begin{array}{l}3,280 \\
3,310 \\
3,320 \\
3,310 \\
3,260 \\
3,190 \\
3,120 \\
3,050 \\
3,000 \\
2,940 \\
2,870 \\
2,780 \\
2,710 \\
2,680 \\
2,640 \\
2,630 \\
2,600 \\
2,590 \\
2,560 \\
2,540 \\
2,520 \\
2,480 \\
2,460 \\
2,410\end{array}$ & $\begin{array}{l}8.87 \\
8.80 \\
8.67 \\
8.56 \\
8.44 \\
8.34 \\
8.22 \\
8.12 \\
8.01 \\
7.86 \\
7.74 \\
7.61 \\
7.49 \\
7.36 \\
7.24 \\
7.12 \\
7.00 \\
6.87 \\
6.75 \\
6.62 \\
6.50 \\
6.37 \\
6.26 \\
6.14\end{array}$ & $\begin{array}{l}2,360 \\
2,320 \\
2,260 \\
2,200 \\
2,140 \\
2,100 \\
2,040 \\
1,990 \\
1,940 \\
1,860 \\
1,810 \\
1,750 \\
1,700 \\
1,640 \\
1,590 \\
1,530 \\
1,480 \\
1,430 \\
1,380 \\
1,320 \\
1,270 \\
1,220 \\
1,170 \\
1,130\end{array}$ \\
\hline
\end{tabular}

\begin{tabular}{|c|c|c|c|c|c|c|c|c|c|c|c|c|}
\hline \multirow[b]{2}{*}{$\begin{array}{c}2 \text { a.m. } \\
4 \\
6 \\
8 \\
10 \\
12 \mathrm{n} . \\
2 \mathrm{p.m} . \\
4 \\
6 \\
8 \\
10 \\
12 \mathrm{~m} .\end{array}$} & \multicolumn{2}{|c|}{ September 24} & \multicolumn{2}{|c|}{ September 25} & \multicolumn{2}{|c|}{ September 26} & \multicolumn{2}{|c|}{ September 27} & \multicolumn{2}{|c|}{ September 28} & \multicolumn{2}{|c|}{ September 29} \\
\hline & $\begin{array}{l}5.91 \\
5.72 \\
5.53 \\
5.37 \\
5.22 \\
5.08 \\
4.96 \\
4.83 \\
4.72 \\
4.60 \\
4.50 \\
4.40\end{array}$ & $\begin{array}{r}1,040 \\
976 \\
910 \\
860 \\
813 \\
770 \\
731 \\
687 \\
647 \\
602 \\
567 \\
533\end{array}$ & $\begin{array}{l}4.31 \\
4.23 \\
4.14 \\
4.08 \\
4.00 \\
3.95 \\
3.88 \\
3.83 \\
3.77 \\
3.72 \\
3.67 \\
3.63\end{array}$ & $\begin{array}{l}504 \\
479 \\
452 \\
434 \\
411 \\
397 \\
378 \\
364 \\
348 \\
335 \\
322 \\
312\end{array}$ & $\begin{array}{l}3.58 \\
3.53 \\
3.49 \\
3.46 \\
3.43 \\
3.40 \\
3.37 \\
3.34 \\
3.30 \\
3.28 \\
3.25 \\
3.23\end{array}$ & $\begin{array}{l}300 \\
288 \\
278 \\
270 \\
263 \\
256 \\
249 \\
242 \\
233 \\
229 \\
222 \\
218\end{array}$ & 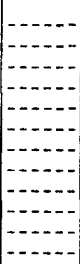 & 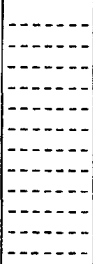 & 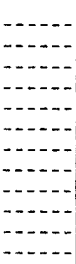 & 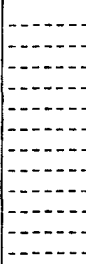 & 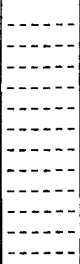 & 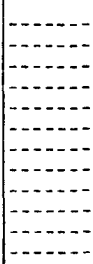 \\
\hline
\end{tabular}

Supplemental records.-Sept. 18,11:30 a.m., 2.62 ft., 101 sec.-ft.; Sept. 19, $12: 30$ p.rn., 4.40 ft., 533 sec.-ft.; $3: 30$ p.m., 3.44 ft., 266 sec.-ft.; Sept. 20 , $5: 20$ a.m., 4.54 ft., 581 sec.-ft.; $6: 30$ a.m., $4.56 \mathrm{ft}$., 588 sec.-ft.; Sept. $22,2: 45$ a.m., 10.74 ft., 3,320 sec.-ft.; $3: 30$ a.m., 10.74 ft., 3,320 sec.-ft.

\section{NORTH BRANCH OF RANCOCAS CREEK AT PEMBERTON, N. J.}

Location.-Lat. $39^{\circ} 58^{\prime} 13^{\prime \prime}$, long. $74^{\circ} 41^{\prime} 15^{\prime \prime}, 600$ feet downstream from highway bridge at Pemberton, Burlington County, and 12 miles upstream from confluence with South Branch. Datum of gage is 24.65 feet above mean sea level (general adjustment of 1929).

Drainage AREA.--111 square miles.

GAGE-HEIGHT RECORD.-Water-stage recorder graph except for periods 9 a.m. July 24 to 4 p.m. July 25, 1 p.m. Sept. 21 to 10 a.m. Sept. 24, 9 p.m. Sept 24 to 3:25 p.m. Sept. 26, and 9 p.m. Sept. 26 to 2:50 p.m. Oct. 12, when graph was computed on basis of floodmarks and shape of recorder graph before and after periods of no record.

StaGe-Discharge RELATION.-Defined by current-meter measurements to 1,400 second-feet.

Maxima.-June 1938: Discharge, 1,300 second-feet 2 to 5 p.m. June 29 (gage height, 8.78 feet).

July 1938: Discharge, 1,360 second-feet 5 to 9 p.m. July 24 (gage height, 9.08 feet from floodmark). 
September 1938: Discharge, 1,680 second-feet 6 to 10 p.m. Sept. 22 (gage height, 10.56 feet, from floodmark).

1921 to May 1938: Daily discharge, 1,310 second-feet Oct. 20, 1927.

REMARKs.-Discharge for periods of no gage-height record computed on basis of estimated gage-height graph and records for Assunpink Creek at Trenton. Diumal fluctuation caused by operation of gristmill just above station.

Mean discharge, in second-feet, 1938

\begin{tabular}{r|r|r|r||r|r|r|r||r|r|r|r}
\hline Day & June & July & Aug. & Day & June & July & Aug. & Day & June & July & Aug. \\
\hline 1 & 142 & 653 & 215 & 11 & 92 & 142 & 328 & 21 & 95 & 776 & 143 \\
2 & 129 & 347 & 213 & 12 & 109 & 96 & 309 & 22 & 108 & 921 & 129 \\
3 & 166 & 321 & 172 & 13 & 139 & 101 & 216 & 23 & 167 & 1,020 & 123 \\
4 & 148 & 250 & 196 & 14 & 191 & 122 & 205 & 24 & 120 & 1,280 & 117 \\
5 & 102 & 216 & 256 & 15 & 228 & 156 & 183 & 25 & 120 & 1,300 & 108 \\
6 & 113 & 188 & 378 & 16 & 215 & 142 & 154 & 26 & 97 & 1,070 & 105 \\
7 & 104 & 163 & 477 & 17 & 167 & 148 & 166 & 27 & 478 & 653 & 108 \\
8 & 111 & 147 & 477 & 18 & 159 & 189 & 150 & 28 & 1,210 & 303 & 102 \\
9 & 106 & 124 & 477 & 19 & 134 & 235 & 143 & 29 & 1,280 & 337 & 99 \\
10 & 98 & 122 & 401 & 20 & 122 & 359 & 146 & 30 & 1,050 & 293 & 96 \\
&
\end{tabular}

Gage height, in feet, and discharge, in second-feet, at indicated time, 1938

\begin{tabular}{|c|c|c|c|c|c|c|c|c|c|c|c|c|}
\hline \multirow{2}{*}{ Hour } & Feet & Sec.-ft. & Feet & Sec.-ft. & Feet & Sec.-ft. & Feet & Sec.-ft. & Feet & Sec.-ft. & Feet & Sec.-ft. \\
\hline & \multicolumn{2}{|c|}{ June 23} & \multicolumn{2}{|c|}{ June 24} & \multicolumn{2}{|c|}{ June 25} & \multicolumn{2}{|c|}{ June 26} & \multicolumn{2}{|c|}{ June 27} & \multicolumn{2}{|c|}{ June 28} \\
\hline $\begin{array}{l}2 \text { a.m. } \\
4 \\
6 \\
8 \\
10 \\
12 \mathrm{n} . \\
2 \mathrm{p} . \mathrm{m} . \\
4 \\
6 \\
8 \\
10 \\
12 \mathrm{~m} .\end{array}$ & $\begin{array}{r}1.52 \\
1.51 \\
1.53 \\
.88 \\
.80 \\
1.02 \\
1.37 \\
3.43 \\
3.58 \\
3.12 \\
2.67 \\
2.33\end{array}$ & $\begin{array}{r}124 \\
124 \\
125 \\
86 \\
81 \\
94 \\
115 \\
291 \\
308 \\
259 \\
216 \\
186\end{array}$ & $\begin{array}{r}2.10 \\
1.97 \\
1.88 \\
1.04 \\
.90 \\
.98 \\
1.10 \\
1.22 \\
1.33 \\
1.42 \\
1.48 \\
1.52\end{array}$ & $\begin{array}{r}166 \\
156 \\
149 \\
95 \\
87 \\
92 \\
99 \\
106 \\
113 \\
118 \\
122 \\
124\end{array}$ & $\begin{array}{l}1.55 \\
1.56 \\
1.55 \\
1.53 \\
1.51 \\
1.63 \\
1.44 \\
1.35 \\
1.31 \\
1.29 \\
1.27 \\
1.26\end{array}$ & $\begin{array}{l}126 \\
127 \\
126 \\
125 \\
124 \\
131 \\
119 \\
114 \\
112 \\
110 \\
109 \\
108\end{array}$ & $\begin{array}{r}1.24 \\
1.23 \\
1.21 \\
1.20 \\
.82 \\
.57 \\
.62 \\
.74 \\
1.18 \\
1.20 \\
1.27 \\
1.35\end{array}$ & $\begin{array}{r}107 \\
107 \\
106 \\
105 \\
82 \\
67 \\
70 \\
77 \\
104 \\
105 \\
109 \\
114\end{array}$ & $\begin{array}{l}1.39 \\
1.53 \\
1.72 \\
2.62 \\
3.59 \\
4.03 \\
5.21 \\
5.81 \\
6.75 \\
7.17 \\
7.61 \\
7.91\end{array}$ & $\begin{array}{r}116 \\
125 \\
137 \\
211 \\
309 \\
357 \\
506 \\
600 \\
801 \\
913 \\
1,020 \\
1,100\end{array}$ & $\begin{array}{l}8.02 \\
8.08 \\
8.14 \\
8.22 \\
8.32 \\
8.42 \\
8.48 \\
8.54 \\
8.57 \\
8.60 \\
8.64 \\
8.67\end{array}$ & $\begin{array}{l}1,120 \\
1,140 \\
1,150 \\
1,170 \\
1,190 \\
1,210 \\
1,230 \\
1,240 \\
1,250 \\
1,260 \\
1,270 \\
1,270\end{array}$ \\
\hline & \multicolumn{2}{|c|}{ June 29} & \multicolumn{2}{|c|}{ June 30} & \multicolumn{2}{|c|}{ July 1} & \multicolumn{2}{|c|}{ July 2} & \multicolumn{2}{|c|}{ July 3} & \multicolumn{2}{|c|}{ July 4} \\
\hline $\begin{array}{c}2 \text { a.m. } \\
4 \\
6 \\
8 \\
10 \\
12 \mathrm{n} . \\
2 \mathrm{p.m} . \\
4 \\
6 \\
8 \\
10 \\
12 \mathrm{~m} .\end{array}$ & $\begin{array}{l}8.68 \\
8.71 \\
8.74 \\
8.75 \\
8.76 \\
8.77 \\
8.78 \\
8.78 \\
8.76 \\
8.73 \\
8.64 \\
8.50\end{array}$ & $\begin{array}{l}1,280 \\
1,280 \\
1,290 \\
1,290 \\
1,290 \\
1,290 \\
1,300 \\
1,300 \\
1,290 \\
1,290 \\
1,270 \\
1,230\end{array}$ & $\begin{array}{l}8.31 \\
8.16 \\
8.03 \\
7.90 \\
7.78 \\
7.69 \\
7.58 \\
7.49 \\
7.39 \\
7.30 \\
7.19 \\
7.06\end{array}$ & $\begin{array}{r}1,190 \\
1,160 \\
1,130 \\
1,100 \\
1,070 \\
1,050 \\
1,020 \\
1,000 \\
974 \\
949 \\
918 \\
883\end{array}$ & $\begin{array}{l}6.95 \\
6.83 \\
6.72 \\
6.61 \\
6.40 \\
6.04 \\
5.72 \\
5.52 \\
5.49 \\
5.43 \\
5.32\end{array}$ & $\begin{array}{l}854 \\
822 \\
793 \\
766 \\
716 \\
642 \\
584 \\
553 \\
548 \\
540 \\
523 \\
504\end{array}$ & $\begin{array}{l}5.04 \\
4.87 \\
4.72 \\
4.07 \\
3.34 \\
3.15 \\
3.25 \\
3.40 \\
3.48 \\
3.52 \\
3.75 \\
3.84\end{array}$ & $\begin{array}{l}483 \\
459 \\
440 \\
362 \\
281 \\
262 \\
272 \\
288 \\
297 \\
301 \\
329 \\
336\end{array}$ & $\begin{array}{l}3.80 \\
3.76 \\
3.73 \\
3.70 \\
3.67 \\
3.75 \\
3.74 \\
3.73 \\
3.70 \\
3.65 \\
3.60 \\
3.54\end{array}$ & $\begin{array}{l}332 \\
328 \\
324 \\
321 \\
318 \\
326 \\
325 \\
324 \\
321 \\
316 \\
310 \\
303\end{array}$ & $\begin{array}{l}3.49 \\
3.44 \\
3.39 \\
3.25 \\
2.87 \\
2.80 \\
2.57 \\
2.62 \\
2.70 \\
2.85 \\
3.14 \\
3.13\end{array}$ & $\begin{array}{l}298 \\
292 \\
287 \\
272 \\
234 \\
228 \\
207 \\
212 \\
219 \\
232 \\
261 \\
260\end{array}$ \\
\hline
\end{tabular}


Gage height in feet, and discharge, in second-feet, at indicated time, 1938-Continued

\begin{tabular}{|c|c|c|c|c|c|c|c|c|c|c|c|c|}
\hline \multirow{2}{*}{ Hour } & Feet & Sec.-ft. & Feet & Sec. $\mathrm{ft}$. & Feet & Sec.-ft. & Feet & Sec.-ft. & Feet & Sec.-ft. & Feet & Sec.-ft. \\
\hline & \multicolumn{2}{|c|}{ July 5} & \multicolumn{2}{|c|}{ July 6} & \multicolumn{2}{|c|}{ July 7} & \multicolumn{2}{|c|}{ July 8} & \multicolumn{2}{|c|}{ July 9} & \multicolumn{2}{|c|}{ July 10} \\
\hline 2 a.m. & 3.00 & 247 & 2.38 & 190 & 2.23 & 177 & 1.90 & 150 & 1.72 & 137 & 1.24 & 107 \\
\hline & 2.91 & 238 & 2.42 & 194 & 2.21 & 175 & 1.90 & 150 & 1.68 & 135 & 1.30 & 111 \\
\hline & 2.85 & 232 & 2.43 & 195 & 2.20 & 174 & 1.90 & 150 & 1.67 & 134 & 1.36 & 115 \\
\hline 8 & 2.82 & 230 & 2.43 & 195 & 2.23 & 177 & 1.91 & 151 & 1.65 & 132 & 1.41 & 118 \\
\hline 10 & 2.82 & 230 & 2.41 & 193 & 2.10 & 166 & 1.91 & 151 & 1.75 & 140 & 1.35 & 114 \\
\hline $12 \mathrm{n}$. & 2.77 & 225 & 2.39 & 191 & 2.02 & 160 & 1.95 & 154 & 1.67 & 134 & 1.35 & 114 \\
\hline 2 p.m. & 2.73 & 222 & 2.36 & 188 & 2.03 & 160 & 1.85 & 146 & 1.71 & 137 & 1.35 & 11 \\
\hline & 2.86 & 233 & 2.34 & 187 & 2.00 & 158 & 1.83 & 145 & 1.32 & 11 & 1.36 & 115 \\
\hline & 2.50 & 201 & 2.32 & 185 & 1.91 & 151 & 1.82 & 144 & 1.11 & 100 & 1.38 & 116 \\
\hline & 2.03 & 160 & 2.28 & 181 & 1.90 & 150 & 1.80 & 143 & 1.09 & 98 & 1.41 & 118 \\
\hline & & 169 & 2.26 & 17 & 1.90 & 150 & 1.7 & 140 & 1.12 & 100 & 1.44 & 119 \\
\hline $12 \mathrm{~m}$. & & 181 & 2.24 & 178 & 1.90 & 150 & 1.74 & 139 & 1.17 & 103 & 2.83 & 231 \\
\hline
\end{tabular}

Supplemental records.—June 23, 5:20 p.m., 3.67 ft., 318 sec.-ft.

Gage height, in feet, and discharge, in second-feet, at indicated time, 1938

\begin{tabular}{|c|c|c|c|c|c|c|c|c|c|c|c|c|}
\hline \multirow{2}{*}{ Hour } & Feet & Sec.-ft. & Feet & Sec. $-\mathrm{ft}$. & Feet & Sec.-ft. & Feet & Sec.-ft. & Feet & Sec.-ft. & Feet & Sec.-ft. \\
\hline & \multicolumn{2}{|c|}{ July 17} & \multicolumn{2}{|c|}{ July 18} & \multicolumn{2}{|c|}{ July 19} & \multicolumn{2}{|c|}{ July 20} & \multicolumn{2}{|c|}{ July 21} & \multicolumn{2}{|c|}{ July 22} \\
\hline $\begin{array}{c}2 \mathrm{a} . \mathrm{m} . \\
4 \\
6 \\
8 \\
10 \\
12 \mathrm{n} . \\
2 \mathrm{p} . \mathrm{m} . \\
4 \\
6 \\
8 \\
10 \\
12 \mathrm{~m} .\end{array}$ & $\begin{array}{l}1.73 \\
1.73 \\
1.72 \\
1.72 \\
1.70 \\
1.76 \\
1.94 \\
2.02 \\
2.11 \\
2.06 \\
1.99 \\
1.95\end{array}$ & $\begin{array}{l}138 \\
138 \\
137 \\
137 \\
136 \\
140 \\
153 \\
160 \\
167 \\
163 \\
157 \\
154\end{array}$ & $\begin{array}{l}1.93 \\
1.93 \\
1.93 \\
2.12 \\
2.10 \\
1.98 \\
1.96 \\
1.76 \\
1.83 \\
3.70 \\
3.80 \\
3.45\end{array}$ & $\begin{array}{l}152 \\
152 \\
152 \\
168 \\
166 \\
156 \\
155 \\
140 \\
145 \\
321 \\
332 \\
294\end{array}$ & $\begin{array}{l}3.15 \\
2.99 \\
2.45 \\
1.52 \\
1.45 \\
2.26 \\
3.00 \\
3.25 \\
3.18 \\
3.53 \\
3.69 \\
3.60\end{array}$ & $\begin{array}{l}262 \\
246 \\
196 \\
124 \\
120 \\
179 \\
247 \\
272 \\
265 \\
302 \\
320 \\
310\end{array}$ & $\begin{array}{l}3.46 \\
3.35 \\
2.90 \\
2.29 \\
2.29 \\
3.90 \\
4.48 \\
4.68 \\
4.84 \\
5.18 \\
5.26 \\
5.36\end{array}$ & $\begin{array}{l}295 \\
282 \\
237 \\
182 \\
182 \\
343 \\
410 \\
434 \\
455 \\
502 \\
514 \\
529\end{array}$ & $\begin{array}{l}5.54 \\
5.85 \\
6.13 \\
6.34 \\
6.55 \\
6.70 \\
6.90 \\
7.25 \\
7.24 \\
7.20 \\
7.19 \\
7.18\end{array}$ & $\begin{array}{l}556 \\
607 \\
659 \\
703 \\
751 \\
788 \\
840 \\
935 \\
932 \\
921 \\
918 \\
916\end{array}$ & $\begin{array}{l}7.18 \\
7.17 \\
7.13 \\
7.10 \\
7.08 \\
7.11 \\
7.21 \\
7.30 \\
7.38 \\
7.45 \\
7.48 \\
7.53\end{array}$ & $\begin{array}{r}916 \\
913 \\
902 \\
894 \\
889 \\
897 \\
924 \\
949 \\
971 \\
988 \\
995 \\
1,010\end{array}$ \\
\hline & \multicolumn{2}{|c|}{ July 23} & \multicolumn{2}{|c|}{ July 24} & \multicolumn{2}{|c|}{ July 25} & \multicolumn{2}{|c|}{ July 26} & \multicolumn{2}{|c|}{ July 27} & \multicolumn{2}{|c|}{ July 28} \\
\hline $\begin{array}{c}2 \mathrm{a} . \mathrm{m} . \\
4 \\
6 \\
8 \\
10 \\
12 \mathrm{n} . \\
2 \mathrm{p} . \mathrm{m} . \\
4 \\
6 \\
8 \\
10 \\
12 \mathrm{~m} .\end{array}$ & $\begin{array}{l}7.57 \\
7.58 \\
7.59 \\
7.59 \\
7.59 \\
7.60 \\
7.59 \\
7.58 \\
7.62 \\
7.70 \\
7.78 \\
7.84\end{array}$ & $\begin{array}{l}1,010 \\
1,020 \\
1,020 \\
1,020 \\
1,020 \\
1,020 \\
1,020 \\
1,020 \\
1,030 \\
1,050 \\
1,070 \\
1,080\end{array}$ & $\begin{array}{l}7.89 \\
8.05 \\
8.38 \\
8.67 \\
8.87 \\
8.98 \\
9.04 \\
9.07 \\
9.08 \\
9.08 \\
9.07 \\
9.05\end{array}$ & $\begin{array}{l}1,100 \\
1,130 \\
1,210 \\
1,270 \\
1,310 \\
1,340 \\
1,350 \\
1,350 \\
1,360 \\
1,360 \\
1,350 \\
1,350\end{array}$ & $\begin{array}{l}9.02 \\
9.00 \\
8.97 \\
8.93 \\
8.89 \\
8.86 \\
8.82 \\
8.77 \\
8.72 \\
8.66 \\
8.60 \\
8.52\end{array}$ & $\begin{array}{l}1,340 \\
1,340 \\
1,330 \\
1,330 \\
1,320 \\
1,310 \\
1,300 \\
1,290 \\
1,280 \\
1,270 \\
1,260 \\
1,240\end{array}$ & $\begin{array}{l}8.43 \\
8.34 \\
8.24 \\
8.13 \\
7.98 \\
7.80 \\
7.64 \\
7.51 \\
7.39 \\
7.28 \\
7.22 \\
7.15\end{array}$ & $\begin{array}{r}1,220 \\
1,200 \\
1,180 \\
1,150 \\
1,120 \\
1,070 \\
1,030 \\
1,000 \\
974 \\
943 \\
927 \\
908\end{array}$ & $\begin{array}{l}7.07 \\
6.98 \\
6.87 \\
6.72 \\
6.35 \\
5.90 \\
5.67 \\
5.60 \\
5.49 \\
5.33 \\
5.10 \\
4.83\end{array}$ & $\begin{array}{l}886 \\
862 \\
832 \\
793 \\
705 \\
616 \\
576 \\
565 \\
548 \\
524 \\
491 \\
454\end{array}$ & $\begin{array}{l}4.61 \\
4.44 \\
4.30 \\
2.39 \\
2.51 \\
2.95 \\
3.25 \\
2.62 \\
3.68 \\
3.60 \\
3.55 \\
3.53\end{array}$ & $\begin{array}{l}425 \\
405 \\
388 \\
191 \\
210 \\
242 \\
272 \\
312 \\
319 \\
310 \\
304 \\
302\end{array}$ \\
\hline & \multicolumn{2}{|c|}{ July 29} & \multicolumn{2}{|c|}{ July 30} & \multicolumn{2}{|c|}{ July 31} & \multicolumn{2}{|c|}{ August 1} & \multicolumn{2}{|c|}{ August 2} & \multicolumn{2}{|c|}{ August 3} \\
\hline $\begin{array}{c}2 \text { a.m. } \\
4 \\
6 \\
8 \\
10 \\
12 \mathrm{n} . \\
2 \mathrm{p} . \mathrm{m} . \\
4 \\
6 \\
8 \\
10 \\
12 \mathrm{~m} .\end{array}$ & $\begin{array}{l}3.56 \\
3.60 \\
3.67 \\
3.52 \\
3.75 \\
4.17 \\
4.22 \\
4.25 \\
4.21 \\
4.08 \\
4.00 \\
3.91\end{array}$ & $\begin{array}{l}306 \\
310 \\
318 \\
301 \\
326 \\
373 \\
378 \\
382 \\
377 \\
363 \\
354 \\
344\end{array}$ & $\begin{array}{l}3.85 \\
3.79 \\
3.75 \\
2.94 \\
3.16 \\
3.28 \\
3.72 \\
3.73 \\
3.45 \\
3.21 \\
3.04 \\
2.96\end{array}$ & $\begin{array}{l}338 \\
331 \\
326 \\
241 \\
263 \\
275 \\
323 \\
324 \\
294 \\
268 \\
251 \\
243\end{array}$ & $\begin{array}{l}2.95 \\
2.95 \\
2.98 \\
3.01 \\
3.11 \\
3.28 \\
3.37 \\
3.37 \\
3.31 \\
3.25 \\
3.21 \\
3.17\end{array}$ & $\begin{array}{l}242 \\
242 \\
245 \\
248 \\
258 \\
275 \\
285 \\
285 \\
278 \\
272 \\
268 \\
264\end{array}$ & $\begin{array}{l}3.13 \\
3.10 \\
3.07 \\
2.55 \\
2.69 \\
2.61 \\
2.48 \\
2.47 \\
2.33 \\
2.30 \\
2.40 \\
2.53\end{array}$ & $\begin{array}{l}260 \\
257 \\
254 \\
206 \\
218 \\
211 \\
199 \\
198 \\
186 \\
183 \\
192 \\
204\end{array}$ & $\begin{array}{l}2.63 \\
2.67 \\
2.69 \\
2.70 \\
2.76 \\
2.70 \\
2.67 \\
2.58 \\
2.53 \\
2.52 \\
2.52 \\
2.52\end{array}$ & $\begin{array}{l}213 \\
216 \\
218 \\
219 \\
224 \\
219 \\
216 \\
208 \\
204 \\
203 \\
203 \\
203\end{array}$ & $\begin{array}{l}2.52 \\
2.51 \\
2.37 \\
2.50 \\
2.34 \\
1.99 \\
1.72 \\
1.83 \\
1.88 \\
1.92 \\
2.05 \\
2.20\end{array}$ & $\begin{array}{l}203 \\
202 \\
189 \\
201 \\
187 \\
157 \\
137 \\
145 \\
149 \\
152 \\
162 \\
174\end{array}$ \\
\hline
\end{tabular}


Mean discharge, in second-feet, 1938

\begin{tabular}{|c|c|c|c|c|c|c|c|c|c|c|c|}
\hline Day & Sept. & Oct. & Day & Sept. & Oct. & Day & Sept. & Oct. & Day & Sept. & Oct. \\
\hline $\begin{array}{l}1 \\
2 \\
3 \\
4 \\
5 \\
6 \\
7 \\
8\end{array}$ & $\begin{array}{r}111 \\
114 \\
91 \\
75 \\
102 \\
113 \\
103 \\
78\end{array}$ & $\begin{array}{l}210 \\
200 \\
190 \\
180 \\
170 \\
190 \\
230 \\
300\end{array}$ & $\begin{array}{r}9 \\
10 \\
11 \\
12 \\
13 \\
14 \\
15 \\
16\end{array}$ & $\begin{array}{r}68 \\
73 \\
75 \\
84 \\
85 \\
100 \\
77 \\
83\end{array}$ & $\begin{array}{l}280 \\
260 \\
240 \\
229 \\
208 \\
184 \\
144 \\
137\end{array}$ & $\begin{array}{l}17 \\
18 \\
19 \\
20 \\
21 \\
22 \\
23 \\
24\end{array}$ & $\begin{array}{r}93 \\
86 \\
149 \\
363 \\
1,050 \\
1,640 \\
1,580 \\
1,260\end{array}$ & $\begin{array}{l}152 \\
159 \\
158 \\
156 \\
173 \\
164 \\
159 \\
183\end{array}$ & $\begin{array}{l}25 \\
26 \\
27 \\
28 \\
29 \\
30 \\
31\end{array}$ & $\begin{array}{l}750 \\
500 \\
350 \\
300 \\
270 \\
230\end{array}$ & $\begin{array}{l}179 \\
190 \\
188 \\
247 \\
273 \\
301 \\
263\end{array}$ \\
\hline \multicolumn{10}{|c|}{$\begin{array}{l}\text { Monthly mean discharge, in second-feet. } \\
\text { Runoff, in inches. }\end{array}$} & $\begin{array}{r}335 \\
3.37\end{array}$ & $\begin{array}{r}203 \\
2.11\end{array}$ \\
\hline
\end{tabular}

Gage height, in feet, and discharge, in second-feet, at indicated time, September 1938

\begin{tabular}{|c|c|c|c|c|c|c|c|c|c|c|c|c|}
\hline \multirow{2}{*}{ Hour } & Feet & Sec.-ft. & Feet & Sec.-ft. & Feet & Sec.ft. & Feet & Sec.-ft. & Feet & Sec.-ft. & Feet & Sec.-ft. \\
\hline & \multicolumn{2}{|c|}{ September 18} & \multicolumn{2}{|c|}{ September 19} & \multicolumn{2}{|c|}{ September 20} & \multicolumn{2}{|c|}{ September 21} & \multicolumn{2}{|c|}{ September 22} & \multicolumn{2}{|c|}{ September 23} \\
\hline $1 \mathrm{am}$ & & & & & & & & & & & & \\
\hline$\frac{1}{2} \mathrm{a} . \mathrm{m}$ & $\begin{array}{l}1.58 \\
1.53\end{array}$ & & .74 & $\begin{array}{l}77 \\
78\end{array}$ & $\begin{array}{l}2.32 \\
2.56\end{array}$ & & 5.90 & 616 & $\begin{array}{l}9.91 \\
9.98\end{array}$ & & 10.54 & $\begin{array}{l}1,670 \\
1,670\end{array}$ \\
\hline & 1.47 & 121 & .77 & 79 & 2.84 & 232 & 6.08 & 649 & 10.07 & $\begin{array}{l}1,000 \\
1,570\end{array}$ & 10.49 & 1,670 \\
\hline 4 & 1.43 & 119 & .78 & 80 & 3.00 & 247 & 6.15 & 663 & 10.12 & 1,580 & 10.4 & 1,660 \\
\hline 5 & 1.38 & & .81 & 82 & 3.2 & & 6.2 & 673 & 10. & & 10.45 & 1,660 \\
\hline 6 & 1.33 & 11 & .84 & 83 & 3.51 & 300 & 6. & 712 & 10.21 & 1,600 & 10.4 & 1,650 \\
\hline 7 & 1.30 & 11 & .88 & 86 & 3.7 & 323 & 7.0 & 875 & 10.27 & 1,610 & 10.3 & 1,640 \\
\hline 8 & .92 & 88 & .99 & 92 & 4.16 & & 6.9 & $• 862$ & 10.32 & 1,620 & 10.36 & 1,630 \\
\hline 9 & .76 & 79 & 1.08 & 98 & 4.3 & 390 & 6. & 862 & 10.3 & 1,630 & 10.3 & 1,620 \\
\hline 10 & $.69^{\circ}$ & 74 & 1.28 & 110 & 4.3 & 398 & 7.0 & 872 & 10.3 & 1,640 & 10.2 & 1,620 \\
\hline 11 & .66 & 73 & 1.27 & 109 & 4. & & 7.0 & 889 & 10.4 & 1,650 & 10.22 & 1,600 \\
\hline $12 \mathrm{n}$. & .65 & 72 & 1.29 & 110 & 4. & & 7. & 929 & 10. & 1,650 & 10.18 & 1,600 \\
\hline 1 p.m & .64 & 71 & 1.58 & 128 & 4.30 & 38 & 7.54 & 1,010 & 10.49 & 1,670 & 10.14 & 1,590 \\
\hline & 64 & 71 & 1.94 & 153 & 4.2 & & 8.06 & & 10. & 1,670 & 10.09 & 1,580 \\
\hline$\overline{3}$ & .64 & 7 & 2.06 & 163 & 4.11 & 366 & 8.72 & 1,280 & 10.54 & 1,670 & 10.04 & 1,570 \\
\hline & .64 & 71 & 3.2 & 272 & 4.0 & 36 & 8.99 & 1,340 & 10.54 & 1,670 & 9.9 & 1,560 \\
\hline 5 & & & 3.30 & & 4. & & 9. & & & & & 1,550 \\
\hline 6 & .65 & 72 & 3.17 & 263 & 4.2 & 38 & 9. & 1,410 & 10. & 1,680 & 9.8 & 1,530 \\
\hline 7 & 65 & 72 & 2.99 & 246 & 4. & & 9. & & & & 9 . & 1,510 \\
\hline & & & & 22 & 4. & 43 & 9 & 1,4 & 10. & 1,6 & 9. & 1,500 \\
\hline 9 & .68 & 7 & 2.58 & 208 & 4. & 47 & 9. & 1,4 & 10. & 1,6 & 9. & 1,490 \\
\hline & .70 & 7 & 2.44 & 19 & 5. & & 9. & 1,4 & 10. & 1,6 & 9. & 1,480 \\
\hline & $\because$ & & 2.3 & 19 & 5. & & 9. & 1,500 & 10. & 1,670 & 9.5 & 1,460 \\
\hline & & & 2.33 & 186 & 5.75 & 59 & 9.81 & 1,520 & 10.54 & 1,670 & 9.49 & 1,450 \\
\hline
\end{tabular}

Supplemental records.-Sept. 19, 10:15 a.m., 1.33 ft., 113 sec.-ft.; $11: 30$ a.m., 1.25 ft., 108 sec.-ft.; 4:30 p.m., 3.35 ft., 282 sec.-ft.

OTDMANS CRERK NEAR WOODSTOWN, N. J.

Location.-Lat. $39^{\circ} 41^{\prime} 27^{\prime \prime}$, long. $75^{\circ} 19^{\prime} 09^{\prime \prime}$, at Woodstown-Swedesboro highway bridge, 2 miles north of Woodstown, Salem County, and 16 miles upstream from mouth.

Drainage AREa.--19.3 square miles.

GaGe-height RECORD.-Water-stage recorder graph.

Stage-Discharge RELATION.-Defined by current-meter measurements below 400 second-feet.

Maxima.-June 1938: Discharge, 1,190 second-feet 4 p.m. June 27 (gage height, 9.08 feet).

July 1938: Discharge, 222 second-feet 10 a.m. July 24 (gage height, 4.47 feet).

September 1938: Discharge, 756 second-feet 8 a.m. Sept. 20 (gage height, 6.71 feet).

1931 to May 1938: Discharge, 362 second-feet Aug. 27, 1937; gage height, 8.22 feet Aug. 23, 1933. 
Mean discharge, in second-feet, 1938

\begin{tabular}{r|c|c|c||c|c|c|c||c|c|c|c}
\hline Day & June & July & Aug. & Day & June & July & Aug. & Day & June & July & Aug. \\
\hline & & & & & & & & & \\
1 & 14.0 & 40 & 21 & 11 & 11.3 & 15.1 & 28 & 21 & 11.3 & 55 & 16.9 \\
2 & 13.4 & 42 & 25 & 12 & 12.0 & 34 & 23 & 22 & 11.3 & 36 & 15.1 \\
3 & 12.9 & 28 & 23 & 13 & 14.6 & 24 & 20 & 23 & 12.3 & 51 & 15.1 \\
4 & 13.4 & 26 & 43 & 14 & 12.3 & 16.3 & 18.8 & 24 & 11.8 & 176 & 14 \\
5 & 13.4 & 23 & 40 & 15 & 11.3 & 18.8 & 17.6 & 25 & 9.3 & 63 & 13.4 \\
6 & 12.3 & 21 & 33 & 16 & 10.3 & 17.6 & 16.9 & 26 & 13.1 & 42 & 13.4 \\
7 & 11.3 & 18.8 & 26 & 17 & 10.8 & 15.7 & 16.9 & 27 & 570 & 35 & 13.4 \\
8 & 16.1 & 17.6 & 71 & 18 & 10.8 & 16.9 & 31 & 28 & 387 & 28 & 12.9 \\
9 & 14.6 & 16.3 & 51 & 19 & 9.8 & 21 & 20 & 29 & 95 & 26 & 12.3 \\
10 & 12.3 & 15.7 & 35 & 20 & 8.8 & 25 & 20 & 30 & 43 & 26 & 12.3 \\
&
\end{tabular}

Gage height, in feet, and discharge, in second-feet, at indicated time, 1938

\begin{tabular}{|c|c|c|c|c|c|c|c|c|c|c|c|c|}
\hline \multirow{2}{*}{ Hour } & Feet & Sec.-ft. & Feet & Sec.-ft. & Feet & Sec.-ft. & Feet & Sec.-ft. & Feet & Sec. $-\mathrm{ft}$. & Feet & Sec.-ft. \\
\hline & \multicolumn{2}{|c|}{ June 23} & \multicolumn{2}{|c|}{ June 24} & \multicolumn{2}{|c|}{ June 25} & \multicolumn{2}{|c|}{ June 26} & \multicolumn{2}{|c|}{ June 27} & \multicolumn{2}{|c|}{ June 28} \\
\hline \multirow[t]{2}{*}{$\begin{array}{c}2 \mathrm{a} . \mathrm{m} . \\
4 \\
6 \\
8 \\
10 \\
12 \mathrm{n} . \\
2 \mathrm{p} . \mathrm{m} . \\
4 \\
6 \\
8 \\
10 \\
12 \mathrm{~m} .\end{array}$} & (1- & 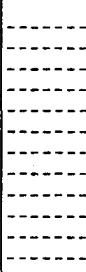 & & 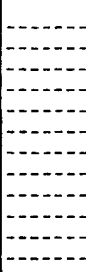 & 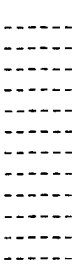 & 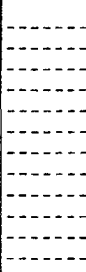 & $\begin{array}{l}1.35 \\
1.35 \\
1.35 \\
1.35 \\
1.35 \\
1.35 \\
1.35 \\
1.35 \\
1.34 \\
1.39 \\
2.03 \\
1.91\end{array}$ & $\begin{array}{r}8.0 \\
8.0 \\
8.0 \\
8.0 \\
8.0 \\
8.0 \\
8.0 \\
8.0 \\
7.5 \\
9.8 \\
48 \\
43\end{array}$ & $\begin{array}{l}2.65 \\
2.94 \\
3.72 \\
4.09 \\
5.20 \\
5.95 \\
8.60 \\
9.08 \\
8.80 \\
8.27 \\
7.72 \\
7.43\end{array}$ & $\begin{array}{r}70 \\
85 \\
143 \\
178 \\
321 \\
454 \\
1,070 \\
1,190 \\
1,120 \\
982 \\
845 \\
776\end{array}$ & $\begin{array}{l}7.03 \\
6.57 \\
6.20 \\
5.86 \\
5.56 \\
5.26 \\
5.02 \\
4.88 \\
4.70 \\
4.47 \\
4.22 \\
3.86\end{array}$ & $\begin{array}{l}684 \\
581 \\
503 \\
436 \\
382 \\
331 \\
294 \\
274 \\
251 \\
222 \\
192 \\
155\end{array}$ \\
\hline & \multicolumn{2}{|c|}{ June 29} & \multicolumn{2}{|c|}{ June 30} & \multicolumn{2}{|c|}{ July 1} & \multicolumn{2}{|c|}{ July 2} & \multicolumn{2}{|c|}{ July 3} & \multicolumn{2}{|c|}{ July 4} \\
\hline $\begin{array}{c}2 \text { a.m. } \\
4 \\
6 \\
8 \\
10 \\
12 \mathrm{n} . \\
2 \mathrm{p} . \mathrm{m} . \\
4 \\
6 \\
8 \\
10 \\
12 \mathrm{~m} .\end{array}$ & $\begin{array}{l}3.49 \\
3.42 \\
3.46 \\
3.49 \\
3.46 \\
3.34 \\
3.00 \\
2.58 \\
2.33 \\
2.17 \\
2.10 \\
2.04\end{array}$ & $\begin{array}{r}123 \\
118 \\
121 \\
123 \\
121 \\
112 \\
89 \\
67 \\
58 \\
53 \\
51 \\
49\end{array}$ & $\begin{array}{l}2.02 \\
2.00 \\
1.97 \\
1.95 \\
1.94 \\
1.91 \\
1.89 \\
1.86 \\
1.85 \\
1.84 \\
1.84 \\
1.84\end{array}$ & $\begin{array}{l}48 \\
47 \\
46 \\
45 \\
44 \\
43 \\
42 \\
40 \\
39 \\
39 \\
39 \\
39\end{array}$ & $\begin{array}{l}1.85 \\
1.86 \\
1.87 \\
1.88 \\
1.89 \\
1.88 \\
1.86 \\
1.84 \\
1.83 \\
1.83 \\
1.84 \\
1.87\end{array}$ & $\begin{array}{l}39 \\
40 \\
41 \\
41 \\
42 \\
41 \\
40 \\
39 \\
38 \\
38 \\
39 \\
41\end{array}$ & $\begin{array}{l}1.93 \\
2.00 \\
2.05 \\
2.06 \\
2.05 \\
2.01 \\
1.92 \\
1.84 \\
1.78 \\
1.73 \\
1.72 \\
1.72\end{array}$ & $\begin{array}{l}44 \\
47 \\
49 \\
50 \\
49 \\
48 \\
43 \\
39 \\
35 \\
31 \\
31 \\
31\end{array}$ & 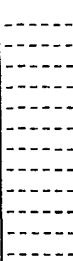 & 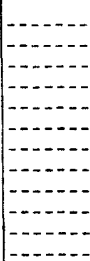 & 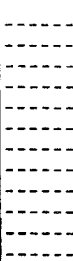 & 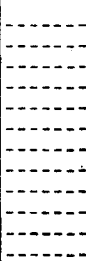 \\
\hline
\end{tabular}


Gage-height, in feet, and discharge, in second-feet, at indicated time, July 1938

\begin{tabular}{|c|c|c|c|c|c|c|c|c|c|c|c|c|}
\hline \multirow{2}{*}{ Hour } & Feet & Sec.-ft. & Feet & Sec.-ft. & Feet & Sec. $-\mathrm{ft}$. & Feet & Sec.-ft. & Feet & Sec.-ft. & Feet & Sec.-ft. \\
\hline & \multicolumn{2}{|c|}{ July 17} & \multicolumn{2}{|c|}{ July 18} & \multicolumn{2}{|c|}{ July 19} & \multicolumn{2}{|c|}{ July 20} & \multicolumn{2}{|c|}{ July 21} & \multicolumn{2}{|c|}{ July 22} \\
\hline \multirow[t]{2}{*}{$\begin{array}{l}2 \mathrm{a} . \mathrm{m} . \\
4 \\
6 \\
8 \\
8 \\
10 \\
12 \mathrm{n} . \\
2 \mathrm{p} . \mathrm{m} . \\
4 \\
6 \\
8 \\
80 \\
12 \mathrm{~m} .\end{array}$} & & & $\begin{array}{l}1.49 \\
1.51 \\
1.51 \\
1.51 \\
1.52 \\
1.52 \\
1.52 \\
1.52 \\
1.52 \\
1.53 \\
1.57 \\
1.60\end{array}$ & $\begin{array}{l}15.1 \\
16.3 \\
16.3 \\
16.3 \\
16.9 \\
16.9 \\
16.9 \\
16.9 \\
16.9 \\
17.6 \\
20 \\
22\end{array}$ & $\begin{array}{l}1.62 \\
1.63 \\
1.63 \\
1.63 \\
1.63 \\
1.62 \\
1.60 \\
1.58 \\
1.56 \\
1.54 \\
1.53 \\
1.52\end{array}$ & $\begin{array}{l}23 \\
24 \\
24 \\
24 \\
24 \\
23 \\
22 \\
21 \\
19.5 \\
18.2 \\
17.6 \\
16.9\end{array}$ & $\begin{array}{l}1.52 \\
1.52 \\
1.53 \\
1.53 \\
1.71 \\
1.75 \\
1.67 \\
1.63 \\
1.73 \\
1.72 \\
1.72 \\
1.72\end{array}$ & $\begin{array}{l}16.9 \\
16.9 \\
17.6 \\
17.6 \\
30 \\
33 \\
27 \\
24 \\
31 \\
31 \\
31 \\
31\end{array}$ & $\begin{array}{l}1.77 \\
2.04 \\
2.32 \\
2.34 \\
2.41 \\
2.71 \\
2.60 \\
2.31 \\
2.19 \\
2.17 \\
2.11 \\
2.02\end{array}$ & $\begin{array}{l}34 \\
49 \\
58 \\
58 \\
60 \\
74 \\
68 \\
57 \\
54 \\
53 \\
51 \\
48\end{array}$ & $\begin{array}{l}1.91 \\
1.83 \\
1.79 \\
1.76 \\
1.75 \\
1.75 \\
1.75 \\
1.75 \\
1.76 \\
1.77 \\
1.77 \\
1.74\end{array}$ & $\begin{array}{l}43 \\
38 \\
36 \\
34 \\
33 \\
33 \\
33 \\
33 \\
34 \\
34 \\
34 \\
32\end{array}$ \\
\hline & \multicolumn{2}{|c|}{ July 23} & \multicolumn{2}{|c|}{ July 24} & \multicolumn{2}{|c|}{ July 25} & \multicolumn{2}{|c|}{ July 26} & \multicolumn{2}{|c|}{ July 27} & \multicolumn{2}{|c|}{ July 28} \\
\hline $\begin{array}{l}2 \text { a.m. } \\
4 \\
6 \\
8 \\
10 \\
12 \mathrm{n} . \\
2 \mathrm{p} . \mathrm{m} . \\
4 \\
6 \\
8 \\
10 \\
12 \mathrm{~m} .\end{array}$ & $\begin{array}{l}1.71 \\
1.69 \\
1.69 \\
1.78 \\
1.83 \\
1.98 \\
2.19 \\
2.40 \\
2.56 \\
2.85 \\
2.91 \\
2.87\end{array}$ & $\begin{array}{l}30 \\
28 \\
28 \\
35 \\
38 \\
46 \\
54 \\
60 \\
66 \\
80 \\
84 \\
82\end{array}$ & $\begin{array}{l}3.45 \\
3.99 \\
4.38 \\
4.45 \\
4.47 \\
4.42 \\
4.37 \\
4.26 \\
4.10 \\
3.92 \\
3.69 \\
3.38\end{array}$ & $\begin{array}{l}120 \\
168 \\
212 \\
220 \\
222 \\
216 \\
210 \\
197 \\
179 \\
161 \\
139 \\
115\end{array}$ & $\begin{array}{l}3.07 \\
2.84 \\
2.65 \\
2.52 \\
2.41 \\
2.31 \\
2.22 \\
2.14 \\
2.07 \\
2.03 \\
1.99 \\
1.96\end{array}$ & $\begin{array}{l}93 \\
80 \\
71 \\
65 \\
60 \\
57 \\
55 \\
52 \\
50 \\
48 \\
47 \\
46\end{array}$ & $\begin{array}{l}1.93 \\
1.92 \\
1.92 \\
1.91 \\
1.88 \\
1.87 \\
1.87 \\
1.89 \\
1.88 \\
1.85 \\
1.83 \\
1.82\end{array}$ & $\begin{array}{l}44 \\
43 \\
43 \\
43 \\
41 \\
41 \\
41 \\
42 \\
41 \\
39 \\
38 \\
37\end{array}$ & $\begin{array}{l}1.81 \\
1.81 \\
1.80 \\
1.82 \\
1.83 \\
1.84 \\
1.80 \\
1.76 \\
1.73 \\
1.71 \\
1.70 \\
1.70\end{array}$ & $\begin{array}{l}37 \\
37 \\
36 \\
37 \\
38 \\
39 \\
36 \\
34 \\
31 \\
30 \\
29 \\
29\end{array}$ & 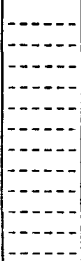 & 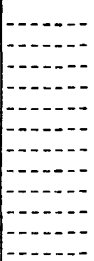 \\
\hline
\end{tabular}

Mean discharge, in second-feet, 1938

\begin{tabular}{r|c|c||c|c|c||c|c|c||c|c|c}
\hline Day & Sept. & Oct. & Day & Sept. & Oct. & Day & Sept. & Oct. & Day & Sept. & Oct. \\
\hline 1 & 25 & 51 & 9 & 11.3 & 30 & 17 & 15.1 & 26 & 25 & 40 & 42 \\
2 & 18.2 & 39 & 10 & 11.3 & 28 & 18 & 19.5 & 25 & 26 & 36 & 31 \\
3 & 14.6 & 34 & 11 & 11.8 & 28 & 19 & 63 & 24 & 27 & 35 & 28 \\
4 & 26 & 32 & 12 & 12.3 & 27 & 20 & 482 & 32 & 28 & 49 & 40 \\
5 & 17.3 & 30 & 13 & 12.3 & 27 & 21 & 521 & 52 & 29 & 69 & 57 \\
7 & 15.1 & 39 & 14 & 12.3 & 26 & 22 & 254 & 32 & 30 & 102 & 40 \\
8 & 11.0 & 46 & 15 & 14.6 & 26 & 23 & 64 & 28 & 31 & & 32 \\
\hline
\end{tabular}


Gage height, in feet, and discharge, in second-feet, at indicated time, September 1938

\begin{tabular}{|c|c|c|c|c|c|c|c|c|c|c|c|c|}
\hline \multirow{2}{*}{ Hour } & Feet & Scc. $-\mathrm{ft}$. & Feet & Sec.-ft. & Feet & Sec.-ft. & Feet & Sec. $-\mathrm{ft}$. & Feet & Sec. $\mathrm{ft}$. & Feet & Sec.-ft. \\
\hline & \multicolumn{2}{|c|}{ September 18} & \multicolumn{2}{|c|}{ September 19} & \multicolumn{2}{|c|}{ September 20} & \multicolumn{2}{|c|}{ September 21} & \multicolumn{2}{|c|}{ September 22} & \multicolumn{2}{|c|}{ September 23} \\
\hline 1 a.m. & & & 1.52 & 16.9 & 3.00 & 174 & 5.32 & 511 & 5.06 & 468 & 2.13 & 81 \\
\hline & & & 1.51 & 16.3 & 3.25 & 204 & 5.41 & 527 & 4.90 & 442 & 2.12 & 80 \\
\hline & & & 1.51 & 16.3 & 3.56 & 243 & 5.42 & 52 & 4.74 & 416 & 2.09 & 76 \\
\hline & & & 1.51 & 16.3 & 4.60 & 394 & 5.34 & 515 & 4.58 & 391 & 2.08 & 74 \\
\hline 5 & & & 1.50 & 15.7 & 5.4 & 53 & 5.2 & 49 & 4.4 & 368 & 2.0 & 71 \\
\hline 6 & & & 1.50 & 15.7 & 6.06 & 641 & 5.10 & 47 & 4.2 & 345 & 2.0 & 71 \\
\hline 7 & & & 1.50 & 15.7 & 6.57 & 73 & 4.96 & 452 & 4.1 & 32 & 2.0 & 70 \\
\hline 8 & & & 1.50 & 15.7 & 6.71 & 75 & 4.9 & 447 & 4.02 & 30 & 2.0 & 69 \\
\hline 9 & & & 1.50 & 15.7 & 6.63 & 743 & 4.74 & 416 & 3.89 & 28 & 2.04 & 69 \\
\hline 10 & & & 1.50 & 15.7 & 6.40 & 702 & 4.73 & 41 & 3.77 & 271 & 2.0 & 66 \\
\hline 11 & & & 1.54 & 18.2 & 6.10 & 648 & 4.76 & 42 & 3.67 & 25 & 2.02 & 66 \\
\hline $12 \mathrm{n}$. & & & 1.83 & 43 & 5.83 & 599 & 4.87 & 43 & 3.5 & 24 & 2.0 & 64 \\
\hline $1 \mathrm{p} ; \mathrm{m}$. & & & 2.24 & 95 & 5.56 & 55 & 5.08 & 471 & 3.4 & 23 & 2.01 & 64 \\
\hline 2 & & & 2.34 & 106 & 5.30 & 50 & 5.36 & 51 & 3.3 & 21 & 1.9 & 62 \\
\hline$\overline{3}$ & & & & 114 & 5.0 & 47 & 5.6 & & 3.2 & 20 & & 61 \\
\hline 4 & & & 2.46 & 118 & 4.8 & 439 & 5.96 & 62 & 3.0 & 18 & 1.98 & 61 \\
\hline 5 & & & 2.46 & 118 & 4.7 & 41 & 6.1 & 6 & 2. & 15 & 1. & 58 \\
\hline 6 & & & 2.45 & 117 & 4.6 & 39 & 6.19 & 66 & 2.6 & 13 & 1.95 & 57 \\
\hline 7 & & & 2.39 & 111 & & 39 & 6.15 & 65 & 2 . & 12 & 1.9 & 56 \\
\hline 8 & & & 2.35 & 107 & 4.6 & 40 & 6.0 & 63 & 2. & 112 & 1.9 & 55 \\
\hline 9 & & & 2.33 & 105 & 4.8 & $42 ?$ & 5.8 & 59 & 2.3 & 102 & 1.93 & $5 \tilde{5}$ \\
\hline 10 & & & 2.34 & 106 & 4.9 & 44 & 5.61 & 56 & 2.2 & 95 & 1.92 & 53 \\
\hline & & & 2.42 & 114 & 5.0 & 46 & 5.4 & 527 & 2.1 & 89 & 1.9 & 53 \\
\hline & & & 2.63 & 135 & 5.17 & 48 & 5.23 & 496 & 2.16 & 85 & 1.92 & 53 \\
\hline
\end{tabular}




\section{SUMMARY OF FLOOD DISCHARGES}

The results of the determinations of maximum flood flows at existing stream-gaging stations and other places (a total of 149 determinations) on streams affected by the storm of July 17-25 in New Jersey, New York, Connecticut, and Massachusetts are summarized in table 24. The time of day given in this table is eastern standard time. The map reference numbers conform to those given in Water-Supply Paper $847^{27}$ and have been plotted on plate 12 to aid in indentifying the location of the determinations. Several separate determinations have been given the same reference number because of their proximity to one another and their almost identical drainage areas.

${ }^{27}$ Williams, G. R., and Crawford, L. C., Maximum discharges at stream-measurement stations through December 31, 1937: U. S. Geol. Survey Water-Supply Paper 847, 272 pp., 1940. 
TABLE 24.-Maximum discharges during flood of July 1938

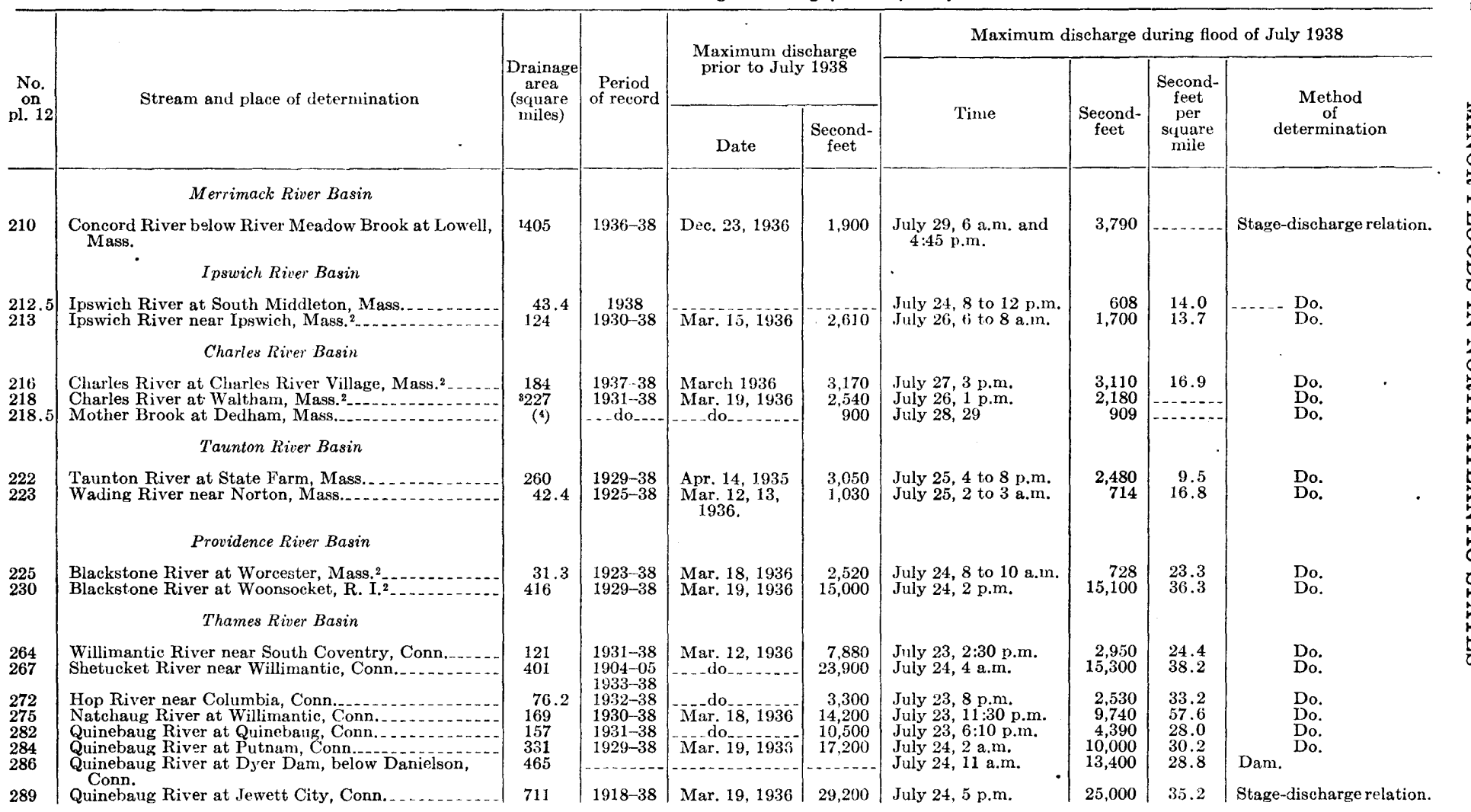


TABLE 24.-Maximum discharges during flood of July 1938-Continued

\begin{tabular}{|c|c|c|c|c|c|c|c|c|c|}
\hline \multirow{3}{*}{$\begin{array}{c}\text { No. } \\
\text { on } \\
\text { pl. } 12\end{array}$} & \multirow{3}{*}{ Stream and place of determination } & \multirow{3}{*}{$\begin{array}{l}\text { Drainage } \\
\text { area } \\
\text { square } \\
\text { miles }\end{array}$} & \multirow{3}{*}{$\begin{array}{l}\text { Period } \\
\text { of record }\end{array}$} & \multirow{2}{*}{\multicolumn{2}{|c|}{$\begin{array}{l}\text { Maximum discharge } \\
\text { prior to July } 1938\end{array}$}} & \multicolumn{4}{|c|}{ Maximum discharge during flood of July 1938} \\
\hline & & & & & & \multirow{2}{*}{ Time } & \multirow[b]{2}{*}{$\begin{array}{l}\text { Second- } \\
\text { feet }\end{array}$} & \multirow{2}{*}{$\begin{array}{l}\text { Second- } \\
\text { feet } \\
\text { per } \\
\text { square } \\
\text { mile }\end{array}$} & \multirow{2}{*}{$\begin{array}{l}\text { Method } \\
\text { of } \\
\text { determination }\end{array}$} \\
\hline & & & & Date & $\begin{array}{c}\text { Second- } \\
\text { feet }\end{array}$ & & & & \\
\hline & Saugatuck River Basin & & & & & & & & \\
\hline 466 & $\begin{array}{c}\text { Saugatuck River near Westport, Conn........... } \\
\text { Hudson River Basin }\end{array}$ & 77.5 & $1932-38$ & Mar. 12,1936 & 5,310 & July 24,2 a.m. & 3,120 & 40.3 & Do. \\
\hline $\begin{array}{l}538 \\
539 \\
540 \\
550 \\
553 \\
560 \\
561\end{array}$ & $\begin{array}{l}\text { Schoharie Creek at Prattsville, N. Y. } \\
\text { Schoharie Creek at Gilboa Dam, at Gilboa, N. Y } 814 \\
\text { Schoharie Creek at Middleburg, N. Y.815 } \\
\text { Catskill Creek at Oak Hill, N.Y.16 } \\
\text { Esopus Creek at Coldbrook, N. Y. } \\
\text { Rondout Creek near Lowes Corners, N. Y. } \\
\text { Rondout Creek near Larkawack, N. Y... }\end{array}$ & $\begin{array}{r}236 \\
314 \\
532 \\
98 \\
192 \\
38.5 \\
100\end{array}$ & $\begin{array}{l}1902-38 \\
1927-38 \\
1906-38 \\
1910-38 \\
1914-38 \\
1937-38 \\
1906-38\end{array}$ & $\begin{array}{l}\text { Nov. } 16,1926 \\
\text { Mar. } 18,1936 \\
\text { Nov. } 9,1913 \\
\text { Aug. } 24,1933 \\
\text { Oct. } 23,1937 \\
\text { Aug. } 26,1928\end{array}$ & $\begin{array}{r}1442,300 \\
32,000 \\
47,800 \\
1412,300 \\
145,5,000 \\
135,700 \\
1426,700\end{array}$ & $\begin{array}{l}\text { July } 23,2 \text { p.m. } \\
\text { July } 23,4 \text { p.m. } \\
\text { July } 23,6 \text { p.m. } \\
\text { July } 23,8: 30 \text { a.m. } \\
\text { July } 22,8: 40 \text { a.m. } \\
\text { July } 22,8 \text { a.m. } \\
\text { July } 22,9: 30 \text { a.m. }\end{array}$ & $\begin{array}{r}6,060 \\
5,880 \\
138,800 \\
1,390 \\
8,830 \\
7,600 \\
17,700\end{array}$ & $\begin{array}{l}25.7 \\
18.7 \\
16.5 \\
14.2 \\
46.0 \\
197 \\
177\end{array}$ & $\begin{array}{l}\text { Do. } \\
\text { Do. } \\
\text { Do. } \\
\text { Do. } \\
\text { Do. } \\
\text { Ioo. } \\
\text { Do. }\end{array}$ \\
\hline 562 & 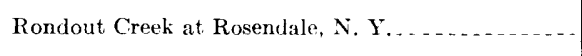 & 386 & $\left|\begin{array}{c}1901-03 \\
1906-19 \\
1926-38\end{array}\right|$ & Aug. 27, 1928 & 27,300 & July 23,9 p.m. & 14,900 & 38.6 & Do. \\
\hline 563 & $\begin{array}{l}\text { Chestnut Creek above Red Brook, at Grahamsville, } \\
\text { N. Y. }\end{array}$ & 12.2 & $1937-38$ & Oct. 23,1937 & 131,250 & July 22,8 a.m. & 132,600 & 213 & Do. \\
\hline $\begin{array}{l}563.5 \\
564 \\
566 \\
567.3 \\
567.7\end{array}$ & $\begin{array}{l}\text { Wallkill River near Unionville, N. Y. } \\
\text { Wallkill River at Pellets Island Mountain, N. Y. } \\
\text { Wallkill River at Gardiner, N. Y. } \\
\text { Pochuck Creek at Newport, near Pine Island, N. Y. } \\
\text { Quaker Creek at Florida, N. Y. }\end{array}$ & $\begin{array}{c}144 \\
385 \\
711 \\
98.0 \\
9.74\end{array}$ & $\begin{array}{r}1919-38 \\
1924-38 \\
1937-38 \\
-d_{-}\end{array}$ & $\begin{array}{l}\text { Jan. } 26,1938 \\
\text { Mar. } 14,1936 \\
\text { Mar. } 12,1936 \\
\text { Jan. } 26,1938 \\
\text { Jan. 25, } 1938\end{array}$ & $\begin{array}{r}1,710 \\
12,400 \\
18,000 \\
1,150 \\
387\end{array}$ & $\begin{array}{l}\text { July } 25,3 \text { a.m. } \\
\text { July } 24,5 \text { p.m. } \\
\text { July } 23,7 \text { p.m. } \\
\text { July } 25,7 \text { a.m. } \\
\text { July } 23,6 \text { p.m. }\end{array}$ & $\begin{array}{r}131,050 \\
4,880 \\
9,720 \\
1,180 \\
5360\end{array}$ & $\begin{array}{r}7.3 \\
12.7 \\
13.7 \\
12.0 \\
37.0\end{array}$ & $\begin{array}{l}\text { Do. } \\
\text { Do. } \\
\text { Do. } \\
\text { Do. } \\
\text { Do. }\end{array}$ \\
\hline & Harkensack Ri,cr Basin & & & & & & & & \\
\hline 575 & Hackensack River at New Milford, N. J.2 ${ }^{2} \ldots \ldots$ & 113 & $1921-38$ & Mar. 12, 13, & 2,800 & July 24,11 a.m. to & 2,350 & 20.8 & Do. \\
\hline 576 & $\begin{array}{c}\text { Pascack Brook at Westwood, N. J.s } \\
\text { Passaic River Basin }\end{array}$ & 29.6 & $1934-38$ & Mar. 12,1936 & 1,190 & July 24,9 to 10 a.m. & 600 & 20.3 & Do. \\
\hline 577 & Passaic River near Millington, N. J. & 55.4 & $\left\{\begin{array}{l}1903-06 \\
1921-38\end{array}\right\}$ & Mar. 8, 1904 & 2,000 & July 24,7 a.m. to & 719 & 13.0 & Do. \\
\hline 579 & Passaic River near Chatham, N. J. ..... & 100 & $\left\{\begin{array}{l}1903-11 \\
1937-38\end{array}\right\}$ & Jan, 9, 1905 & 2,990 & July 23 , I p.m. & 1,840 & 18.4 & Do. \\
\hline $\begin{array}{l}581 \\
582\end{array}$ & $\begin{array}{l}\text { Passaic River at Little lialls, N. J. }{ }^{2} \ldots \\
\text { Passaic River at Paterson, N. J.2. }\end{array}$ & $\begin{array}{l}761 \\
785\end{array}$ & $1898-1938$ & Oct. 10,1903 & 1728,000 & $\begin{array}{l}\text { July } 25 \\
\text { July } 25,6 \text { a.m. to } \\
6 \text { p.m. }\end{array}$ & $\begin{array}{l}7.000 \\
7,030\end{array}$ & $\begin{array}{l}9.2 \\
9.0\end{array}$ & $\begin{array}{l}\text { Do. } \\
\text { Stage-discharge and } \\
\text { power output-dis- } \\
\text { charge relations. }\end{array}$ \\
\hline
\end{tabular}




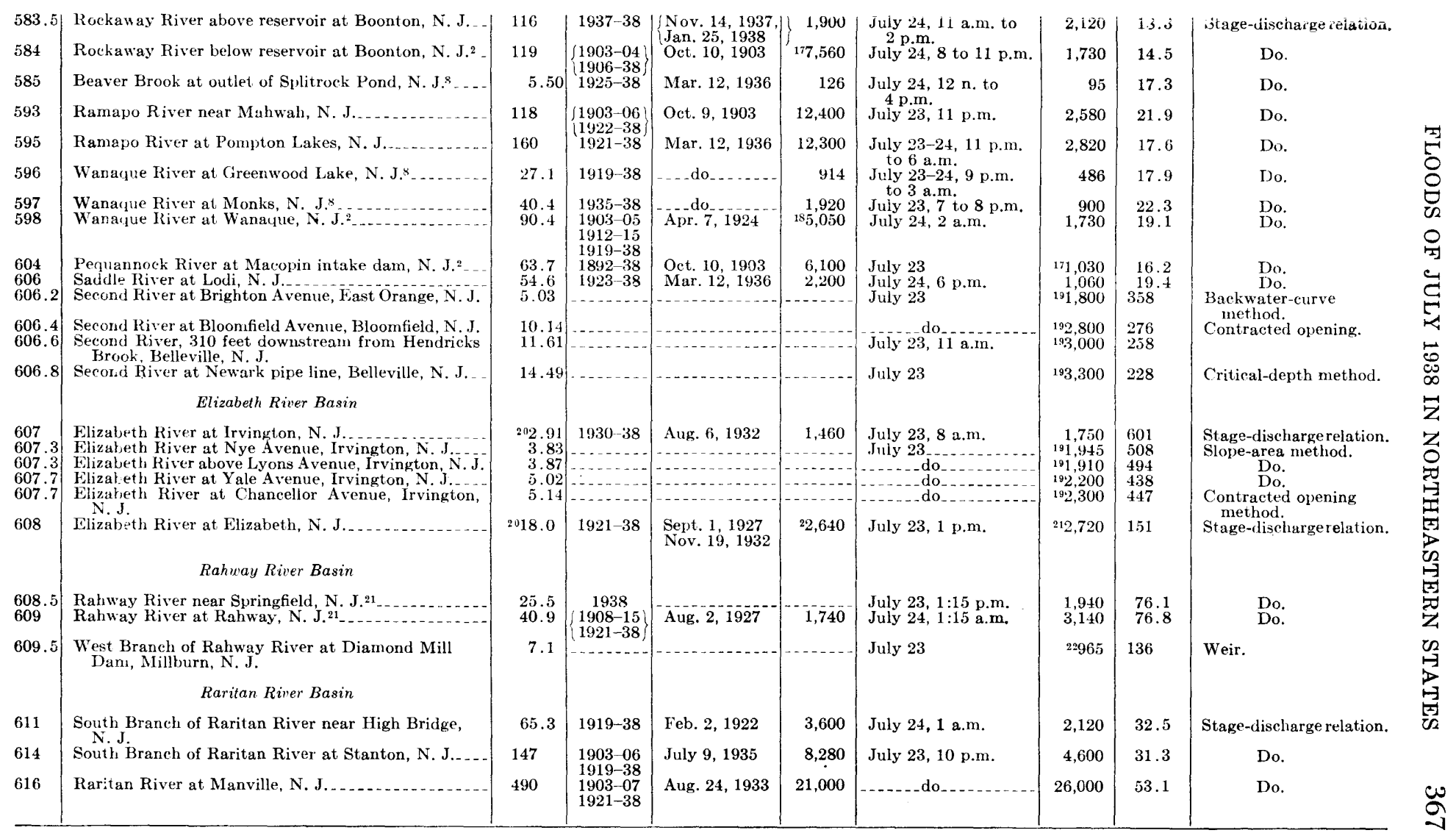


TABLE 24.-Maximum discharges during flood of July 1938-Continued

\begin{tabular}{|c|c|c|c|c|c|c|c|c|c|}
\hline \multirow{3}{*}{$\begin{array}{c}\text { No. } \\
\text { on } \\
\text { pl. } 12\end{array}$} & \multirow{3}{*}{ Stream and place of determination } & \multirow{3}{*}{$\begin{array}{c}\text { Drainage } \\
\text { area } \\
\text { (square } \\
\text { miles) }\end{array}$} & \multirow{3}{*}{$\begin{array}{l}\text { Period } \\
\text { of record }\end{array}$} & \multirow{2}{*}{\multicolumn{2}{|c|}{$\begin{array}{l}\text { Maximum discharge } \\
\text { prior to July } 1938\end{array}$}} & \multicolumn{4}{|c|}{ Maximum discharge during flood of July 1938} \\
\hline & & & & & & \multirow{2}{*}{ Time } & \multirow[b]{2}{*}{$\begin{array}{c}\text { Second- } \\
\text { feet }\end{array}$} & \multirow{2}{*}{$\begin{array}{l}\text { Second- } \\
\text { feet } \\
\text { per } \\
\text { square } \\
\text { mile }\end{array}$} & \multirow{2}{*}{$\begin{array}{l}\text { Method } \\
\text { of } \\
\text { determination }\end{array}$} \\
\hline & & & & Date & $\begin{array}{c}\text { Second- } \\
\text { feet }\end{array}$ & & & & \\
\hline $\begin{array}{l}619 \\
620 \\
622 \\
623 \\
624 \\
625\end{array}$ & $\begin{array}{l}\text { Neshanic River at Reaville, N. J. } \\
\text { North Branch of Raritan River near Far Hills, N. J. } \\
\text { North Branch of Raritan River at Milltown, N. J... } \\
\text { Black River near Pottersville, N.J. } \\
\text { Millstone River near Kingston, N.J.8. } \\
\text { Millstone River at Blackwells Mills, N. J.s. }\end{array}$ & $\begin{array}{r}25.7 \\
26.2 \\
190 \\
32.8 \\
171 \\
258\end{array}$ & $\begin{array}{l}1930-38 \\
1922-38 \\
1923-38 \\
1921-38 \\
1933-38 \\
1903-04 \\
1921-38\end{array}$ & $\begin{array}{l}\text { Aug. } 23,1933 \\
\text { July } 23,1919 \\
\text { Jan. } 3,1936 \\
\text { Nov. } 17,1927 \\
\text { Ang. } 24,1933 \\
\text { Oct. } 18,1927\end{array}$ & $\begin{array}{r}4,370 \\
7,000 \\
14,400 \\
1,600 \\
4,950 \\
7,000\end{array}$ & $\begin{array}{l}\text { July } 23,10: 30 \text { a.m. } \\
\text { July } 23,7 \text { p.m. } \\
\text { July } 23,4 \text { p.m. } \\
\text { July } 23,5 \text { p.m. } \\
\text { July } 23, \text { about } 10 \text { p.m. } \\
\text { July } 23,11 \text { p.m. }\end{array}$ & $\begin{array}{r}2,960 \\
938 \\
7,900 \\
370 \\
8,600 \\
12,400\end{array}$ & $\begin{array}{r}115 \\
35.8 \\
41.6 \\
11.3 \\
50.3 \\
48.1\end{array}$ & $\begin{array}{l}\text { Do. } \\
\text { Do. } \\
\text { Do. } \\
\text { Do. } \\
\text { Do. } \\
\text { Do. }\end{array}$ \\
\hline $\begin{array}{l}625 \cdot 5 \\
628 \\
629 \\
630\end{array}$ & $\begin{array}{l}\text { Green Brook at Plainfield, N. J. } \\
\text { Lawrence Brook at Farrington Dam, N. J.8. } \\
\text { Deep Run near Browntown, N. J. N. J.a } \\
\text { Tennent Brook near Browntown, N. J. } \\
\text { Coastal Basins }\end{array}$ & $\begin{array}{c}9.75 \\
34.4 \\
8.07 \\
5.25\end{array}$ & $\mid \begin{array}{l}1921-38 \\
1938 \\
1927-38 \\
1932-38 \\
- \\
-\end{array}$ & $\begin{array}{l}\text { July } 6,1928 \\
\text { Sept. } 9,1934 \\
\text { Sept. } 8,1934\end{array}$ & $\begin{array}{r}1,900 \\
917 \\
166\end{array}$ & $\begin{array}{l}\text { July } 23,11: 30 \text { a.m. } \\
\text { July } 23,7 \text { to } 9 \text { p.m. } \\
\text { July } 20,5: 30 \text { p.m. } \\
\text { July } 23,9 \text { p.m. }\end{array}$ & $\begin{array}{r}2,890 \\
1,050 \\
541 \\
92\end{array}$ & $\begin{array}{l}296 \\
30.5 \\
67.0 \\
17.5\end{array}$ & $\begin{array}{l}\text { Do. } \\
\text { Do. } \\
\text { Do. } \\
\text { Do. }\end{array}$ \\
\hline $\begin{array}{l}632 \\
633 \\
634\end{array}$ & $\begin{array}{l}\text { Swimming River near Red Bank, N. J.2 } \\
\text { Manasquan River at Squankum, N. J. } \\
\text { Toms River near Toms River, N. J. }\end{array}$ & $\begin{array}{r}48.5 \\
43.4 \\
124\end{array}$ & $\begin{array}{l}1922-38 \\
1931-38 \\
1928-38\end{array}$ & $\begin{array}{l}\text { Sept. } 9,1934 \\
\text { June } 28,1938 \\
\text { June } 29,1938\end{array}$ & $\begin{array}{l}2,930 \\
1,550 \\
1,240\end{array}$ & $\begin{array}{l}\text { July } 20,7: 30 \text { p.m. } \\
\text { July } 20,9 \text { p.m. } \\
\text { July } 25,12 \text { p.m. to }\end{array}$ & $\begin{array}{l}1,500 \\
1,480 \\
1,050\end{array}$ & $\begin{array}{l}30.9 \\
34.1 \\
8.47\end{array}$ & $\begin{array}{l}\text { Do. } \\
\text { Do. } \\
\text { Do. }\end{array}$ \\
\hline 635 & Cedar Creek at Lanoka Harbor, N. J........... & 56.0 & $1932-38$ & Feb. 16, 1936 & $\begin{array}{l}\text { (not } \\
\text { deter- } \\
\text { mined) }\end{array}$ & $\begin{array}{l}\text { July } 26,4 \text { a.m. } \\
\text { July } 25,3 \text { a.m. to } \\
\text { 1 p.m. }\end{array}$ & 367 & 6.55 & Do. \\
\hline $\begin{array}{l}636 \\
637\end{array}$ & $\begin{array}{l}\text { Batsto River at Batsto, N. J. } \\
\text { East Branch of Wading River at Harrisville, N. J... }\end{array}$ & $\begin{array}{l}70.5 \\
64.0\end{array}$ & $\begin{array}{l}1927-38 \\
1931-38\end{array}$ & Aug. 24,1933 & $\begin{array}{r}17824 \\
859\end{array}$ & $\begin{array}{l}\text { July } 25,10 \text { p.m. } \\
\text { July } 21,2 \text { to } 4 \text { a.m. } \\
\text { July } 24,9 \text { p.m. to }\end{array}$ & $\begin{array}{l}579 \\
510 \\
505\end{array}$ & $\begin{array}{l}8.21 \\
7.97 \\
7.89\end{array}$ & $\begin{array}{l}\text { Do. } \\
\text { Do. } \\
\text { Do. }\end{array}$ \\
\hline 639 & Great Egg River at Folsom, N. J................ & 56.3 & $1925-38$ & Sept. 8,1935 & 599 & $\begin{array}{l}\text { July } 25,2 \text { a.m. } \\
\text { July } 25,10 \text { a.m. to }\end{array}$ & 535 & 9.50 & Do. \\
\hline 641 & $\begin{array}{c}\text { Manantico Creek near Millville, N. J............. } \\
\text { Delaware River Basin }\end{array}$ & 22.3 & $1931-38$ & Sept. 7, 1935 & 566 & July 24,9 to 10 p.m. & 474 & 21.3 & Do. \\
\hline 642 & $\begin{array}{l}\text { East Branch of Delaware River at Margaretville, } \\
\text { N. Y. }\end{array}$ & 163 & $1937-38$ & May 15,1937 & 6,000 & July $23,11: 45$ a.m. & 4,120 & 25.3 & Do. \\
\hline $\begin{array}{l}643 \\
644 \\
646 \\
647 \\
648 \\
649 \\
650\end{array}$ & 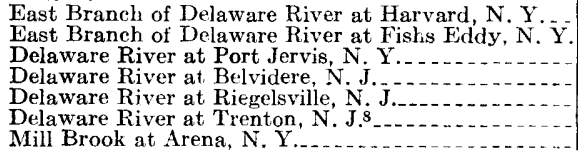 & $\begin{array}{r}443 \\
783 \\
3,076 \\
4.542 \\
6,344 \\
6,796 \\
25.0\end{array}$ & $\begin{array}{l}1934-38 \\
1912-38 \\
1904-38 \\
1922-38 \\
1906-38 \\
1913-38 \\
1937-38\end{array}$ & $\begin{array}{l}\text { Mar. } 18,1936 \\
\text { Oct. } 9,1903 \\
\text { Oct. } 10,1903 \\
\text { Mar. } 19,1936 \\
\text { Oct. } 23,1937\end{array}$ & $\left|\begin{array}{c}26,200 \\
2370,000 \\
23155,000 \\
220,000 \\
275,000 \\
227,000 \\
131,550\end{array}\right|$ & $\begin{array}{l}\text { July } 23,7 \text { p.m. } \\
\text { July } 22,3 \text { a.m. } \\
\text { July } 22,7 \text { p.m. } \\
\text { July } 23,6 \text { a.m. } \\
\text { July } 23,11 \text { a.m. } \\
\text { July } 23,8 \text { t.o } 10 \text { p.m. } \\
\text { July } 23,8 \text { a.m. }\end{array}$ & $\begin{array}{r}7,900 \\
21,400 \\
837,400 \\
853,500 \\
865,600 \\
81,500 \\
131,110\end{array}$ & $\begin{array}{l}17.8 \\
27.3 \\
12.2 \\
11.8 \\
10.3 \\
12.0 \\
44.4\end{array}$ & $\begin{array}{l}\text { Do. } \\
\text { Do. } \\
\text { Do. } \\
\text { Do. } \\
\text { Do. } \\
\text { Do. } \\
\text { Do. }\end{array}$ \\
\hline
\end{tabular}




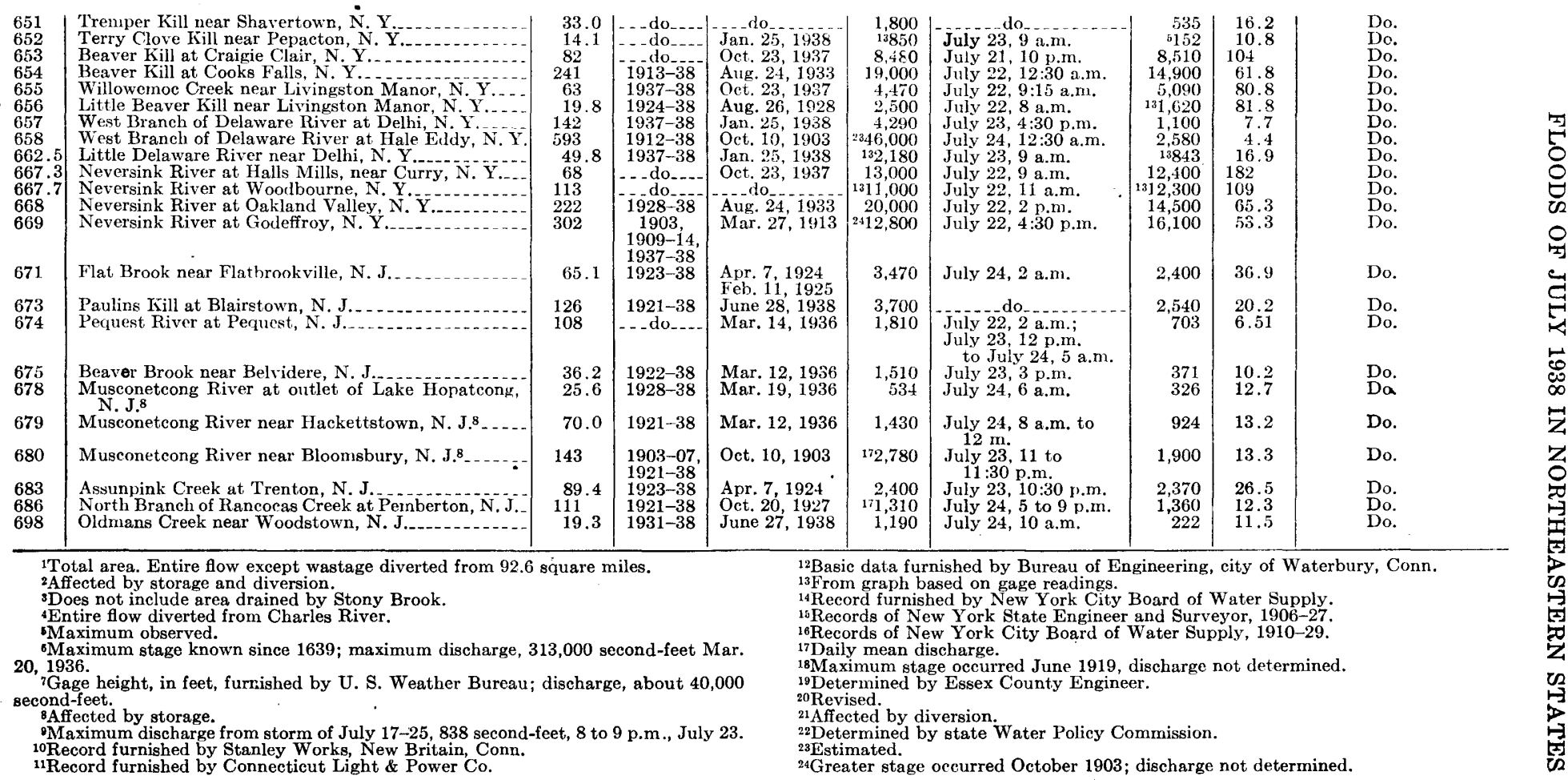


A study of the rates of flood discharge given in table 24 in relation to the corresponding drainage area is presented in figure 35. Size of drainage area is only one, though a major, factor influencing magnitude of flood discharge. The comparative influences of basic characteristics, such as slope, shape, and swamps, are not brought out in figure 35. Moreover, the effect of artificial storage is not segregated. The figure provides a convenient method for comparing flood discharges from drainage areas of widely varying sizes, but, in using it, influences other than drainage area should be kept in mind. Figure 35 shows that the greatest intensities of discharge were experienced in drainage areas in New Jersey and New York. Streams in metropolitan New Jersey discharged at especially high rates-one stream at the rate of 601 second-feet per square mile. In New York the discharge of 177 second-feet per square mile from Rondout Creek at Lacawack (100 square miles) is noteworthy. This discharge was exceeded, however, during August 1928. In Connecticut the discharge of the Quinebaug River at Jewett City (711 square miles, 35.2 second-feet per square mile) appears to rank highest, the size of drainage area considered. It should be noted that the Quinebaug River exceeded its discharge of July 1938 during the flood of March 1936.

In general the floods of July 1938 were exceeded by the widespread catastrophic floods of September 1938, 2 months later. In a sense, the floods were related. Both were nearly coincident with respect to geographic location, and the large amount of retention after the July storm doubtless diminished the retentive capacity of the ground during the September storm.

\section{STORAGE RESERVOIRS}

Basic data for most of the important storage reservoirs have been given in the section on "Stages and discharges at streamgaging stations." The section herewith is limited to a brief discussion of some of the examples of storage regulation.

The effect of storage in the many small ponds and lakes has been discussed in the study of the "Flood of January 1938 in Con. necticut."

The larger reservoirs, having appreciable storage capacity below the level of the spillway, have a marked effect on flood flow. Records for several reservioirs, presented on page 108, disclose some interesting facts. As during the flood of January 1938, the discharge gates at Otis Reservoir, at Cold Spring, Mass., were closed at the start of the flood and all the flow from 17.2 square miles of Farmington River drainage was retained from the evening of July 18 to July 26. Shenipsit Lake at Rockville, Conn., near the 


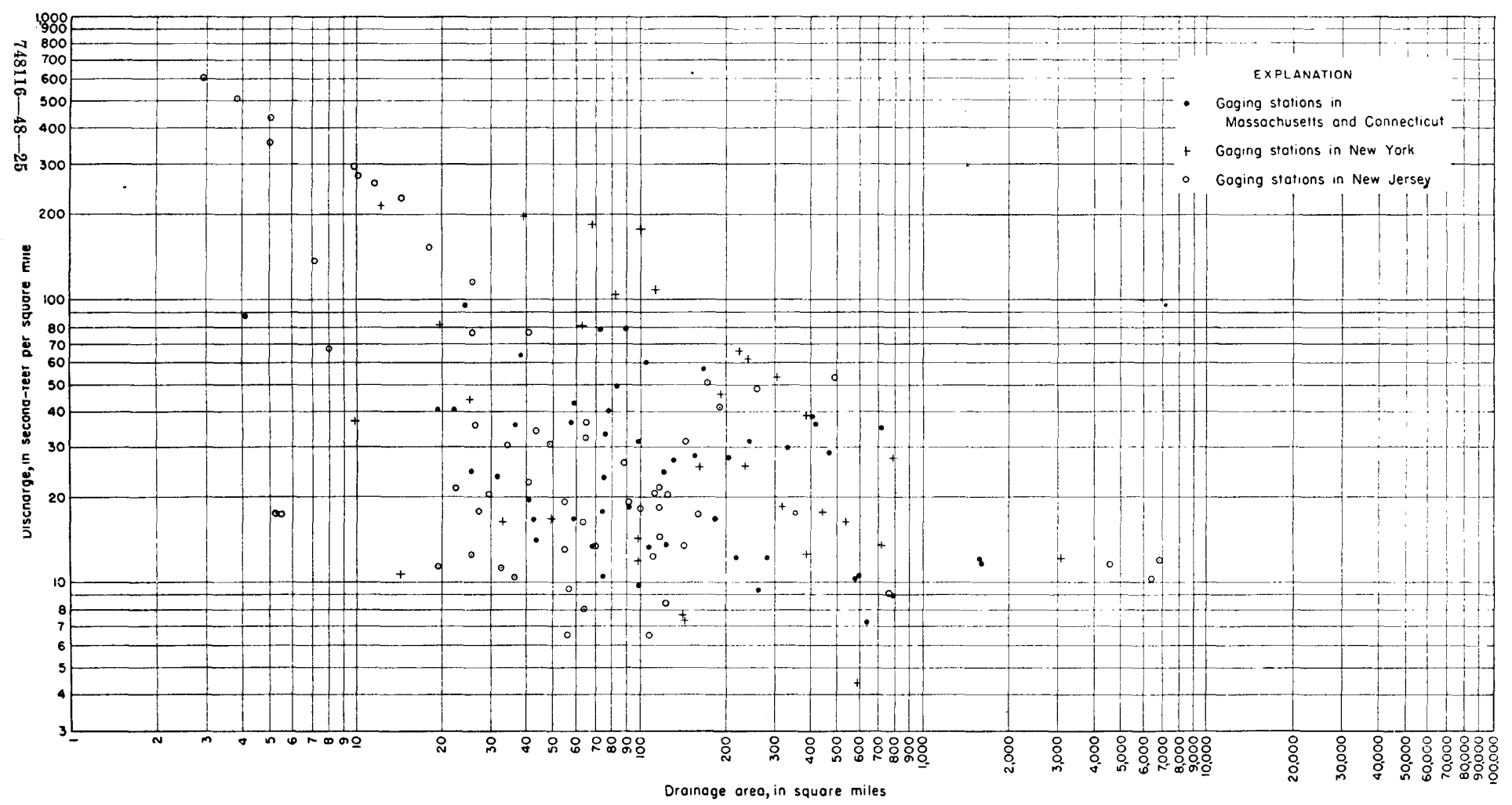

FIGURE 35. Chart showing maximum discharges during flood of July 1938, in second-feet per square mile, in relation to drainage area. 
source of the Hockanum River, began to spill water over the dam on July 22, and on July 23, the day of maximum natural runoff, the lake contents above the spillway increased the equivalent of 152 second-feet. From July 17 to 30 Candlewood Lake on Rocky River near New Milford, Conn., increased in contents the equivalent of 3.14 inches of water over its drainage area of 40.4 square miles.

The manner in which several reservoirs operated during the flood period of July 1938 can be illustrated by constructing hydrographs of observed and adjusted natural flow from the data given in the section "Stages and discharges at stream-gaging stations."

\section{FLOOD-CREST STAGES}

Immediately after the flood of July 1938 the Stream and Waterways Survey of the Works Project Administration, in cooperation with the Water Policy Commission of the State of New Jersey, began to identify and mark crest stages reached by the rivers in New Jersey in the flood area. Field parties were dispatched to obtain essential information with regard to these floodmarks and to refer them to mean sea-level datum. Their relative positions were identified by distances from the mouths of the respective rivers, based on comprehensive river surveys of the Stream and Waterways Survey.

Table 25 presents records of flood-crest stages for the major river systems in New Jersey during the flood of July 1938. The records are of special interest in the planning of future developments along the rivers. Flood-crest stages in New Jersey during other major floods are also published in Water-Supply Papers $\mathbf{7 9 9}^{28}$ and $867 .{ }^{29}$

\footnotetext{
${ }^{28}$ Grover, N. C., and others, The floods of March 1936, pt. 2, Hudson River to Susquehanna River region: U. S. Geol. Survey Water-Supply Paper 799, table 11, pp. 343-350, 1937.

${ }_{29}$ Paulsen, C. G., and others, Hurricane floods of September 1938: U. S. Geol. Survey WaterSupply Paper 867, table 19, pp. 510-517, 1940.
} 
TABLE 25.-Flood-crest stages, July 1938

(U. S. Coast and Geodetic Survey datum except as noted)

Stream and location

\section{Hackensack River Basin}

Hackensack River:

Rivervale, N. J., at upstream side of Poplar Road Bridge

Old Tappan, N. J., at upstream side of Harrington Avenue Bridge

Oradell, N. J., on right bank above Oradell Dam.....

New Milford, N. J., Geological Survey gage above dams at plant of Hackensack Water Co.

Pascack Brook:

Hillsdale, N. J., above Woodcliff Lake Dam.

Westwood, N. J., at upstream side of Broadway Bridge

Westwood, N. J., Geological Survey gage on right bank 75 feet upstream from Harrington Avenue Bridge and downstream from Musquapsink Creek.

Passaic River:

\section{Passaic River Basin}

Millington, N. J., Geological Survey gage on right bank 150 feet downstream from Davis Bridge

Gillette, N. J., at Woodland Avenue Bridge (Mountain Avenue)

Gillette, N. J., at Springfield Avenue Bridge just downstream from Delaware, Lackawanna \& Western R.R. bridge

Berkeley Heights, N. J., at Snyder Avenue Bridge

New Providence, N. J., at Central Avenue Bridge (Fairmount Avenue)

New Providence, N. J., at Passaic Avenue Bridge -

Chatham, N. J., at Mount Vernon Avenue Bridge and upstream from Chatham

Chatham, N. J., Geological Survey gage on left bank 150 feet downstream from Stanley Avenue Bridge

Chatham, N. J., at Watchung Avenue Bridge . . . .

Chatham, N. J., at Morris Avenue Bridge

Little Falls, N. J., on left bank upstream from Beattie Dam

Little Falls, N. J., on left bank at tailrace of plant of Passaic Valley Water Commission

Paterson, N. J., Geological Survey gage on right bank just upstream from Spruce Street Bridge

Clifton, N. J., on Dundee Dam

Rockaway River:

Dover, N. J., at Bergen Street Bridge _...

Boonton, N. J., Geological Survey gage on right bank at Morris Avenue Bridge

Boonton, N. J., on Boonton Reservoir at dam

Boonton, N. J., Geological Survey gage on right bank 1,500 feet downstream from Boonton Reservoir Dam

Ramapo River:

Mahwah, N. J., Geological Survey gage on left bank 150 feet downstream from bridge on State Highway 2 and 1 mile west of Mahwah.

Pompton Lakes, N. J., Geological Survey gage on right upstream abutment of Pompton Lakes Dam

Wanaque River:

The Glens, N. J., Geological Survey gage at left end of right spillway of Greenwood Lake Dam.

Greenwood Lake, N. J., Geological Survey gage on right bank 600 feet downstream from Greenwood Lake Dam

Monks, N. J., Geological Survey gage on left bank above weir just upstream from Wanaque Reservoir

Wanaque, N. J., on Wanaque Reservoir at Raymond Dam

Wanaque, N. J., Geological Survey gage 50 feet upstream from highway bridge

Saddle River:

Iodi, N. J., Geological Survey gage on left bank just upstream from Outwater Lane

Weasel Brook:

Clifton, N. J., Geological Survey gage above dam at Jewett Avenue

Third River:

Nutley, N. J., at upstream side of Chestnut Street Bridge

\begin{tabular}{|c|c|c|}
\hline $\begin{array}{l}\text { Miles } \\
\text { above } \\
\text { mouth }\end{array}$ & Date and time & $\underset{\text { (feet) }}{\text { Altitude }}$ \\
\hline 32.1 & July 23 or $24 \ldots$ & 37.0 \\
\hline 27.8 & 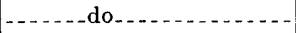 & 26.1 \\
\hline $\begin{array}{l}22.6 \\
21.8\end{array}$ & $\begin{array}{l}\text { July } 24 \\
\text { July } 24,11 \text { a.m. to } 2 \text { p.m. }\end{array}$ & $\begin{array}{r}121.88 \\
10.76\end{array}$ \\
\hline $\begin{array}{l}6.6 \\
5.2 \\
3.2\end{array}$ & July 24, & $\begin{array}{r}195.63 \\
250.03 \\
32.67\end{array}$ \\
\hline 76.4 & July 24,7 a.m. to 3 p.m. & 2222.81 \\
\hline 68.4 & July 23 or 24 & 211.55 \\
\hline 67.2 & $\ldots$ do $\ldots \ldots$ & 211.5 \\
\hline $\begin{array}{l}66.0 \\
64.9\end{array}$ & - do & $\begin{array}{l}211.0 \\
210.5\end{array}$ \\
\hline $\begin{array}{l}63.5 \\
62.3\end{array}$ & July 23 & $\begin{array}{l}209.0 \\
202.9\end{array}$ \\
\hline 61.8 & 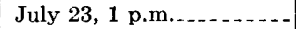 & 200.02 \\
\hline $\begin{array}{l}61.2 \\
59.9 \\
30.4\end{array}$ & $\begin{array}{l}\text { July } 23 \\
\text { July } 23 \text { or } 24 \\
\text { July } 25,8 \text { a.m., } 12 \mathrm{~m}\end{array}$ & $\begin{array}{c}195.8 \\
178.4 \\
2160.90\end{array}$ \\
\hline 30.0 & July $25,12 \mathrm{~m} . \ldots \ldots$ & .2128 .20 \\
\hline 26.1 & July 25,6 a.m. to 6 p.m. - & 2118.44 \\
\hline 18.1 & July 25, $6: 30$ p.m. & 2328.2 \\
\hline $\begin{array}{r}21.6 \\
9.0\end{array}$ & $\begin{array}{l}\text { July } 23 \\
\text { July } 24,11 \text { a.m. to } 2 \text { p.m. }\end{array}$ & $\begin{array}{l}25.58 .2 \\
2369.90\end{array}$ \\
\hline $\begin{array}{l}7.2 \\
6.8\end{array}$ & $\begin{array}{l}\text { July } 25 \\
\text { July } 24,8 \text { to } 11 \text { p.m. }\end{array}$ & $\begin{array}{r}12308.30 \\
2201.55\end{array}$ \\
\hline 12.4 & July 23,11 p.m. $\ldots$ & 260.93 \\
\hline 1.3 & $\begin{array}{l}\text { July } 23-24,11 \text { p.m. to } \\
6 \text { a.m. }\end{array}$ & 202.84 \\
\hline 16.8 & July 23 and $24 \ldots$ & ${ }^{2} 620.08$ \\
\hline 16.7 & $\begin{array}{l}\text { July } 23-24,9 \text { p.m. to } \\
3 \text { a.m. }\end{array}$ & ${ }^{2} 604.65$ \\
\hline 10.7 & July 23,7 to 8 p.m. & 2305.27 \\
\hline 4.4 & July 24 & 12302.27 \\
\hline 4.4 & 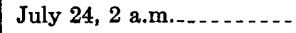 & 2215.66 \\
\hline 3.3 & July 24, 6 p.m. & 27.21 \\
\hline 2.6 & $\begin{array}{l}\text { July } 23,11: 30 \mathrm{a.m} \text {. to } \\
12 \mathrm{~m} .\end{array}$ & 70.85 \\
\hline 3.1 & July $23 \ldots \ldots$ & 60.84 \\
\hline
\end{tabular}


TABLE 25.-Flood-crest stages, July 1938-Continued

\begin{tabular}{|c|c|c|c|}
\hline Stream and location & $\begin{array}{l}\text { Miles } \\
\text { above } \\
\text { mouth }\end{array}$ & Date and time & $\underset{\text { (feet) }}{\text { Altitude }}$ \\
\hline $\begin{array}{l}\text { Nutley, N. J, at upstream side of Rutger Street and } \\
\text { Passaic Avenue Bridge }\end{array}$ & 2.3 & -do & 46.09 \\
\hline $\begin{array}{l}\text { Nutley, N. J., at downstream side of Rutger Street and } \\
\text { Passaic Avenue Bridge }\end{array}$ & 2.3 & do & 45.29 \\
\hline $\begin{array}{l}\text { Nutley, N. J., on Kingsland Park Dam } \\
\text { Clifton, N.J., upstream from River Road on Yantacaw } \\
\text { Pond Dam }\end{array}$ & $\begin{array}{r}1.9 \\
.7\end{array}$ & (ndo & $\begin{array}{l}43.0 \\
16.8\end{array}$ \\
\hline Second River: & & & \\
\hline $\begin{array}{l}\text { Orange, N. J., at upstream side of North Day Street } \\
\text { Bridge }\end{array}$ & 4.9 & ....do & 149.8 \\
\hline $\begin{array}{l}\text { East Orange, N. J., at upstream side of North Park } \\
\text { Street Bridge }\end{array}$ & 4.6 & 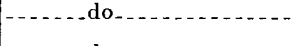 & 144.45 \\
\hline $\begin{array}{l}\text { East Orange, N. J., at upstream side of Midland Avenue } \\
\text { Bridge }\end{array}$ & 4.3 & do & 136.94 \\
\hline $\begin{array}{l}\text { Bloomfield, N. J., at Glenwood Avenue Bridge } \\
\text { Bloomfield, N. J, on front of Walter Kidde plant up- } \\
\text { stream from West Street Bridge }\end{array}$ & $\begin{array}{l}3.5 \\
2.7\end{array}$ & do & $\begin{array}{l}118.63 \\
109.62\end{array}$ \\
\hline $\begin{array}{l}\text { Belleville, N. J., Geological Survey gage } 360 \text { feet down- } \\
\text { stream from Franklin Avenue extension }\end{array}$ & 1.4 & July 23,11 & 69.7 \\
\hline $\begin{array}{l}\text { Belleville, N. J., at upstream side of bridge on State } \\
\text { Highway } 21 \text { (Main Street) }\end{array}$ & .1 & July 23 & 10.60 \\
\hline $\begin{array}{l}\text { Nishayne Brook: } \\
\text { Orange, N. J., at downstream side of Orange Road } \\
\text { Bridge }\end{array}$ & 6 & lo & 248.50 \\
\hline $\begin{array}{l}\text { Orange, N. J., southeast corner of Essex County High- } \\
\text { way Garage property at Thomas Street upstream } \\
\text { from Dodd Street }\end{array}$ & .5 & & 194.69 \\
\hline $\begin{array}{l}\text { Orange, N. J., at upstream side of East Day Street } \\
\text { Bridge }\end{array}$ & .0 & - do_ & 145.6 \\
\hline Elizabeth River Basin & & & \\
\hline X & & & \\
\hline $\begin{array}{l}\text { Irvington, N. J., Geological Survey gage } 200 \text { feet down- } \\
\text { stream from Valley Avenue (Orange Avenue) }\end{array}$ & 9.7 & July 23,8 a & 412.1 \\
\hline $\begin{array}{l}\text { Irvington, N. J., at upstream side of Lyons Avenue } \\
\text { Bridge }\end{array}$ & 8.7 & July 23 & .116 .0 \\
\hline $\begin{array}{l}\text { Irvington, N. J., at upstream side of Yale Avenue } \\
\text { Bridge }\end{array}$ & 8.4 & do & 109.67 \\
\hline $\begin{array}{l}\text { Irvington, N. J., } 100 \text { feet downstream from Yale } \\
\text { Avenue }\end{array}$ & 8.4 & 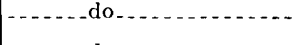 & 108.89 \\
\hline $\begin{array}{l}\text { Irvington, N. J., at upstream side of Chancellor } \\
\text { Avenue twin pipes }\end{array}$ & 8.1 & $\mathrm{do}$ & 109.3 \\
\hline $\begin{array}{l}\text { Irvington, N. J., at downstream side of Chancellor } \\
\text { Avenue twin pipes }\end{array}$ & 8.1 & & 100.4 \\
\hline $\begin{array}{l}\text { Irvington, N. J., } 100 \text { feet upstream from Mill Road } \\
\text { Bridge }\end{array}$ & 7.7 & 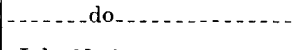 & 80.53 \\
\hline $\begin{array}{l}\text { Hillside, N. J., at upstream side of Mill Road Bridge }- \\
\text { Hillside, N. J., at upstream side of Union Avenue } \\
\text { Bridge }\end{array}$ & $\begin{array}{l}7.7 \\
7.3\end{array}$ & $\begin{array}{l}\text { July } 23,1 \\
\text { July } 23,-\end{array}$ & $\begin{array}{l}279.8 \\
262.4\end{array}$ \\
\hline $\begin{array}{l}\text { Union, } N \text {. J., at upstream side of bridge on State High- } \\
\text { way } 29\end{array}$ & 6.5 & 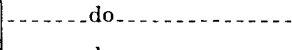 & ${ }^{2} 45.3$ \\
\hline $\begin{array}{l}\text { Union, N. J., above d } \\
\text { Union, N. J., at upstr }\end{array}$ & $\begin{array}{l}5.5 \\
5.5\end{array}$ & & $\begin{array}{l}237.5 \\
235.5\end{array}$ \\
\hline $\begin{array}{l}\text { Union, N. J., at downstream side of Lehigh Valley R.R. } \\
\text { Bridge }\end{array}$ & 5.2 & & 230.8 \\
\hline $\begin{array}{l}\text { Union, N. J., on left bank at culvert } 400 \text { feet down- } \\
\text { stream from Lehigh Valley R.R. bridge }\end{array}$ & 5.1 & $\mathrm{~d} 0$ & 230.7 \\
\hline $\begin{array}{l}\text { Union, N. J., at upstream side of North Avenue Bridge } \\
\text { Elizabeth, N. J.. above Ursino Lake Dam and upstream } \\
\text { from Trotters Lane Bridge }\end{array}$ & $\begin{array}{l}4.2 \\
3.9\end{array}$ & -.......do_. & $\begin{array}{l}227.7 \\
225.1\end{array}$ \\
\hline Elizabeth, N. J., below Ursino Lake Dam $\ldots \ldots$ & 3.9 & & 218.5 \\
\hline $\begin{array}{l}\text { Elizabeth, N. J., at upstream side of Trotters Lane } \\
\text { Bridge }\end{array}$ & & & \\
\hline $\begin{array}{l}\text { Elizabeth, N. J., at downstream side of Irvington } \\
\text { Avenue Bridge }\end{array}$ & 3.6 & 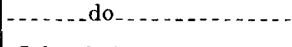 & 220.0 \\
\hline $\begin{array}{l}\text { Elizabeth, N. J., Geological Survey gage above dam } \\
\text { and just upstream from Westfield Avenue Bridge }\end{array}$ & 3.3 & July 23,1 p.m. & 18.28 \\
\hline $\begin{array}{l}\text { Elizabeth, N.J., on right bank } 150 \text { feet downstream } \\
\text { from Westfield Avenue Bridge }\end{array}$ & 3.3 & July 23 & 18.1 \\
\hline $\begin{array}{l}\text { Elizabeth, N. J., at upstream side of Crane Street } \\
\text { Bridge }\end{array}$ & 3.3 & & 17.6 \\
\hline $\begin{array}{l}\text { Elizabeth, N. J., at upstream end of Mulford Coal \& } \\
\text { Lumber Co's building and downstream from Central } \\
\text { R.R. of New Jersey Bridge }\end{array}$ & 3.2 & do & 15.7 \\
\hline $\begin{array}{l}\text { Elizabeth, N. J., at upstream side of West Grand Street } \\
\text { Bridge }\end{array}$ & 3.2 & & 15.5 \\
\hline $\begin{array}{l}\text { Elizabeth, N. J., on left bank } 100 \text { feet downstream } \\
\text { from West Grand Street }\end{array}$ & 3.1 & & 14.6 \\
\hline
\end{tabular}


TABLE 25.-Flood-crest stages, July 1938-Continued

Stream and location

West Branch of Elizabeth River:

Union, N. J., at upstream side of Chestnut Street

Bridge
Union, N. J., at downstream side of Self Master Parkway Bridge

Union, N. J., at downstream side of Morris Avenue Bridge

Union, N. J., at upstream side of Sayre Road Bridge

\section{Rahway River Basin}

East Branch of Rahway River (head of Rahway River): South Orange, N. J., at upstream side of Montrose Avenue Bridge

South Orange, N. J., at downstream side of Montrose Avenue Bridge

South Orange, N. J., on right bank 100 feet upstream from South Orange Avenue

Maplewood, N. J., at upstream side of Millburn Avenue Bridge

Maplewood, N. J., at downstream side of Millburn Avenue Bridge

Springfield, N.J., at downstream side of Springfield Avenue Bridge

Rahway River:

Springfield, N. J., at upstream side of Morris Avenue Bridge

Springfield, N. J., at upstream side of Rahway Valley R.R. bridge

Springfield, N. J., at downstream side of Milltown Road Bridge

Springfield, N. J., Geological Survey gage on left bank 50 feet downstream from State Highway 29

Cranford, N. J., at downstream side of Kenilworth Boulevard Bridge

Cranford, N. J., at upstream side of north bridge on Springfield Avenue

Cranford, N. J., at downstream side of south bridge on Eastman Street

Cranford, N.J., at upstream side of south bridge on Springfield Avenue

Cranford, N. J., above Hansel Dam

Cranford, N. J., at upstream side of Union Avenue Bridge

Cranford, N. J., at upstream side of North Avenue Bridge

Cranford, N. J., at upstream side of South Avenue

Bridge
Cranford, N. J., above Droescher Dam.

Cranford, N. J., at upstream side of High Street Bridge

Cranford, N.J., at downstream side of Lehigh Valley

R.R. bridge

Cranford, N. J., at upstream side of Raritan Road Bridge

Clark Township, N. J., above Sperry Dam.

Clark Township, N. J., below Sperry Dam

Clark Township, N. J., above Bloodgood Dam

Clark Township, N. J., below Bloodgood Dam.....

Clark Township, N. J., above Jackson Dam.

Clark Township, N. J., below Jackson Dam

Rahway, N. J., Geological Survey gage on left bank 100 feet upstream from St. George Avenue

Rahway, N. J., at upstream side of Church Street

Bridge
Rahway, N. J., at upstream side of Whittier Street Bridge

Rahway, N. J., at upstream side of Grand Street Bridge

Rahway, N. J., at upstream side of Elizabeth Avenue Bridge

West Branch of Rahway River:

West Orange, N.J., on Orange Reservoir spillway and just upstream from West Orange-South Orange village line

Millburn, N. J., above Diamond Mill Dam

Millburn, N. J., at upstream side of Glen Avenue Bridge

Millburn, N. J., at downstream side of Glen Avenue Bridge

\begin{tabular}{|c|c|c|}
\hline $\begin{array}{l}\text { Miles } \\
\text { above } \\
\text { mouth }\end{array}$ & Date and time & $\underset{\text { (feet) }}{\text { Altitude }}$ \\
\hline 2.0 & $\ldots$ do $\ldots \ldots$ & 256.4 \\
\hline 1.8 & 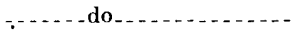 & 55.2 \\
\hline 1.1 & 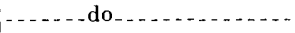 & 254,4 \\
\hline .6 & $\ldots \ldots$ do $\ldots \ldots \ldots \ldots$ & 253.7 \\
\hline 22.6 & $\ldots+\ldots$ do $\ldots+\ldots$ & 148.06 \\
\hline 22.6 & 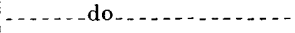 & 147.46 \\
\hline 21.7 & $\ldots$. do $_{-} \ldots \ldots \ldots \ldots$ & 140.94 \\
\hline 19.4 & $\ldots$ do $\ldots \ldots$ & 98.89 \\
\hline 19.4 & $\ldots \ldots$ do $\ldots \ldots \ldots \ldots$ & 97.42 \\
\hline 18.8 & $\ldots$ do & 86.3 \\
\hline 18.3 & $\ldots \ldots$ do $_{-} \ldots \ldots \ldots \ldots$ & 86.6 \\
\hline $17 . \overline{5}$ & $\ldots \ldots$ do $\ldots \ldots \ldots$ & 79.7 \\
\hline 16.7 & 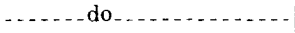 & 77.6 \\
\hline 16.1 & July 23, 1:15 p.m. $\ldots$ & 73.58 \\
\hline 14.5 & July $23 \ldots \ldots \ldots$ & 69.0 \\
\hline 13.2 & July $23,8: 20$ p.m. $\ldots$ & 66.4 \\
\hline 12.8 & July $23 \ldots$ & 66.0 \\
\hline 12.5 & $\ldots$ do $\ldots \ldots \ldots$ & 6.5 .2 \\
\hline $\begin{array}{l}12.3 \\
12.3\end{array}$ & do $\ldots$ do & $\begin{array}{l}63.3 \\
63.1\end{array}$ \\
\hline 12.1 & $\ldots-\ldots$ do $\ldots \ldots \ldots$ & 61.8 \\
\hline 12.0 & $\ldots$ do $\ldots \ldots$ & 61.7 \\
\hline $\begin{array}{l}11.7 \\
11.7 \\
10.8\end{array}$ & {$\left[\begin{array}{l}\ldots \\
\ldots \\
\ldots\end{array}\right.$} & $\begin{array}{l}59.3 \\
59.7 \\
52.5\end{array}$ \\
\hline 10.2 & $\ldots \ldots$ do $\ldots \ldots \ldots \ldots \ldots$ & 47.4 \\
\hline $\begin{array}{l}9 \cdot 7 \\
9 \cdot 7 \\
8 \cdot 7 \\
8 \cdot 7 \\
7 \cdot 0 \\
7 \cdot 0 \\
6 \cdot 2\end{array}$ & $\begin{array}{c}\text { July } 23-24 \ldots \\
\text { July } 24,1 ; 15 \text { a.m. }\end{array}$ & $\begin{array}{l}46.9 \\
43.5 \\
37.4 \\
33.8 \\
28.0 \\
23.7 \\
15.12\end{array}$ \\
\hline 5.9 & July $24 \ldots$ & 13.7 \\
\hline 5.7 & $\ldots$. & 109 \\
\hline 5.3 & $\ldots \ldots$ do_. & 6.7 \\
\hline 5.2 & - - ndo & 6.6 \\
\hline 4.6 & July $23 \ldots$ & 330.9 \\
\hline 1.9 & 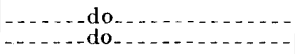 & $\begin{array}{l}176.1 \\
157.31\end{array}$ \\
\hline 1.7 & $\ldots \ldots$ do $\ldots \ldots \ldots$ & 154.56 \\
\hline
\end{tabular}


TABLE 25.-Flood-crest stages, July 1938-Continued

Stream and location

\begin{tabular}{|c|c|c|}
\hline $\begin{array}{l}\text { Miles } \\
\text { above } \\
\text { mouth }\end{array}$ & Date and time & $\underset{\text { (feet) }}{\text { Altitude }}$ \\
\hline 1.3 & - . ndo... & 133.98 \\
\hline 1.2 & $\ldots$............ & 131.68 \\
\hline 1.0 & ....... do . . & 112.2 \\
\hline $\begin{array}{l}.8 \\
.7 \\
.6 \\
.3\end{array}$ & 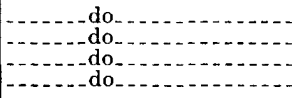 & $\begin{array}{r}107.2 \\
97.2 \\
90.3 \\
86.5\end{array}$ \\
\hline .3 & . ndo & 282.7 \\
\hline 3.8 & _...... do.... & ${ }^{2} 46.7$ \\
\hline 2.3 & - _ _ do. . . & $246 . \tilde{\jmath}$ \\
\hline 2.2 & ...... do - & 229.4 \\
\hline 1.3 & . . . . do..... & 216.7 \\
\hline 1.1 & $\ldots$....... do & 215.0 \\
\hline .9 & $\ldots \ldots$ do $\ldots$ & 212.9 \\
\hline .5 & $\ldots$ do $\ldots$ & ${ }^{2} 13.2$ \\
\hline .2 & - . . do $\ldots . .$. & 29.6 \\
\hline 27.8 & July 24,1 a.m. & 2291.79 \\
\hline 16.5 & July 23, 10 p.m.- & 133.52 \\
\hline $\begin{array}{r}5.3 \\
.8\end{array}$ & July $23_{10} \ldots$ & $\begin{array}{l}68.40 \\
60.32\end{array}$ \\
\hline $\begin{array}{l}26.8 \\
25.5 \\
23.2\end{array}$ & July 23,10 p.m. & $\begin{array}{l}42.20 \\
41.80 \\
38.36\end{array}$ \\
\hline 21.5 & July 23,11 p.m... & 35.90 \\
\hline 20.5 & July 23,10 p.m. & 32.21 \\
\hline 19.3 & July $23 \ldots$ & 28.77 \\
\hline 17.7 & $\ldots \ldots$ do $\ldots \ldots$ & 25.21 \\
\hline 6.4 & $\begin{array}{l}\text { July } 20,9 \text { a.m. } \\
\text { July } 23,10: 30 \text { a.m. }\end{array}$ & $\begin{array}{l}118.46 \\
118.58\end{array}$ \\
\hline 3.1 & $\begin{array}{l}\text { July } 20,6 \text { a.m. } \\
\text { July } 23,1 \text { p.m. }\end{array}$ & $\begin{array}{l}269.58 \\
269.72\end{array}$ \\
\hline 15.0 & July 23,7 p.m. & ${ }^{2} 228.18$ \\
\hline 10.1 & July 23 & ${ }^{2} 108.00$ \\
\hline $\begin{array}{l}3.7 \\
1.4\end{array}$ & July 23,4 p.m. & $\begin{array}{r}262.26 \\
\quad 59.35\end{array}$ \\
\hline 11.4 & July 23,5 p.m. & 2287.26 \\
\hline $\begin{array}{l}6.3 \\
1.8\end{array}$ & July 23 & $\begin{array}{r}125.80 \\
86.40\end{array}$ \\
\hline .3 & - do & 79.5 \\
\hline
\end{tabular}

Millburn, N. J., at upstream side of Holmes Street Bridge

Millburn, N. J., at rear of F. W. Woolworth Building on Millburn Avenue

Millburn, N. J., at upstream eide of Ridgewood Road Bridge

Millburn, N. J., at Fandango Mill Pond

Millburn, N. J below dam of Fandango Mill Pond -

Millburn, N. J., opposite river lane.

Springfield, N. J., at upstream side of Springfield Avenue Bridge

Van Winkle Creek:

Springfield, N. J., at downstream side of Rahway Valley R.R. bridge

Robinsons Branch of Rahway River:

Clark Township, N. J., at upstream side of Raritan Road Bridge

Clark Township, N. J., above dam upstream from Madison Hill Road

Clark Township, N. J., at upstream side of Madison Hill Road

Rahway, N. J., at upstream side of Maple Avenue Bridge

Rahway, N. J., at upstream side of Jefferson Avenue Bridge

Rahway, N. J., at upstream side of Central Avenue Bridge

Rahway, N. J., at upstream side of New Church Street Bridge

Rahway, N. J., at upstream side of Hamilton Street Bridge

\section{Raritan River Basin}

South Branch of Raritan River:

High Bridge, N. J., Geological Survey gage 200 feet upstream from Lake Solitude and 1 mile upstream from High Bridge

Stanton, N. J., Geological Survey gage just downstream from highway bridge near Stanton railroad station.

Neshanic Station, N. J., at highway bridge.........

South Branch, N.' J., at highway bridge..............

Raritan River:

Raritan, N. J., at waterworks . . . . . . . . . . . . . .

Somerville, N. J.

Manville, N. J., Geological Survey gage on left bank just downstream from Manville-Finderne highway bridge

Manville, N. J., on left bank just upstream from Millstone River

Bound Brook, N. J., on left bank at Calco Chemical Co. plant and 1 mile west of Bound Brook

Bound Brook, N. J., at Main Street opposite Queens Bridge to South Bound Brook

Fieldville, N. J., above dam

Neshanic River:

Reaville, N. J., Geological Survey gage at highway bridge to Muirhead and half a mile southwest of Reaville

Walnut Brook:

Flemington, N. J., Geological Survey gage $11 / 4$ miles northwest of Flemington

North Branch of Raritan River:

Far Hills N. J., Geological Survey gage above Ravine Lake Dam, 2 miles north of Far Hills

Far Hills, N. J., at Moores Bridge on State Highway 31 and $11 / 2$ miles south of Far Hills

North Branch, N. J., at highway bridge

Milltown, N. J., Geological Survey gage 400 feet upstream from State Highway 29

Black River (head of Lamington River):

Pottersville, N. J., Geological Survey gage 1 mile upstream from Pottersville

Lamington River:

Lamington, N. J., at arch bridge

Lamington, N. J., at Rattlesnake Brjdge, 2 miles south of Lamington

Burnt Mills, N. J., at highway bridge 
TABLE 25.--Flood-crest stages, July 1938-Continued

Stream and location

\begin{tabular}{|c|c|c|}
\hline $\begin{array}{l}\text { Miles } \\
\text { above } \\
\text { mouth }\end{array}$ & Date and time & $\begin{array}{c}\text { Altitude } \\
\text { (feet) }\end{array}$ \\
\hline 16.2 & $\ldots d p_{\ldots}$ & 55.54 \\
\hline 16.2 & . & 54.50 \\
\hline 15.1 & July 23 , about 10 p.m. & 251.37 \\
\hline $\begin{array}{r}14.1 \\
9.9 \\
6.2\end{array}$ & July 23 do & $\begin{array}{l}47.00 \\
42.50 \\
40.19\end{array}$ \\
\hline $\begin{array}{l}4.2 \\
1.5\end{array}$ & July 23 do. & $\begin{array}{l}39.70 \\
36.60\end{array}$ \\
\hline
\end{tabular}

Millstone River:

Princeton, N. J., above Kingston Dam of Lake Carnegie

Princeton, N. J., below Kingston Dam of Lake Carnegie

Kingston, N. J., Geological Survey gage 1 mile downstream from Heathcots Brook

Rocky Hill, N. J., at highway bridge

Griggstown, N. J., at highway bridge

Blackwells Mills, N. J., Geological Survey gage just downstream from highway bridge

Millstone, N. J., at highway bridge

Weston, N. J., at mouth of Royces Branch

Green Brook:

Scotch Plains, N. J., above Seely's lower dam . ......

Scotch Plains, N. J., above dam upstream from Union Avenue

Scotch Plains, N. J., at upstream side of Union Avenue Bridge

Scotch Plains, N. J., at upstream side of Park Avenue Bridge

Scotch Plains, N. J., at downstream side of Mountain Avenue Bridge

Plainfield, N. J., at downstream side of Terrill Road Bridge

Plainfield, N. J., at upstream side of Raymond Avenue Bridge

Plainfield, N. J., at upstream side of Leland Avenue Bridge

Plainfield, N. J., at upstreanı side of Farragut Road Bridge

Plainfield, N. J., at upstream side of Norwood Avenue Bridge

Plainfield, N. J., at upstream side of Westervelt Avenue Bridge

Plainfield, N. J., at upstream side of Watchung Avenue Bridge

Plainfield, N. J., at Somerset Street Bridge

Plainfield, N. J., at upstream side of Washington Avenue Bridge

Plainfield, N. J., Geological Survey gage 200 feet downstraam from Sycamore Avenue

Plainfield, N. J., at upstream side of Geraud Avenue Bridge

Plainfield, N. J., at upstream side of Clinton Avenue Bridge

Blue Brook:

Borough of Mountainside, N. J., on Lake Surprise Dam

Borough of Mountainside, N. J., at upstream side of New Providence Road Bridge

Stony Brook:

North Plainfield, N. J., at bridge on State Highway 29

North Plainfield, N. J., at Grove Street Bridge

North Plainfield, N. J., at Green Brook Road Bridge-

Cedar Brook:

Plainfield, N. J., at Randolph Road Bridge

Ambrose Brook:

East Bound Brook, N. J., at Union and Raritan Avenues

Lawrence Brook:

Milltown, N. J., Geologieal Survey gage on left bank above Farrington Dam and half a mile southwest of Millown

Deep Run:

Browntown, N. J., Geological Survey gage at Spring Valley Road Bridge and $1 \frac{3}{4}$ miles south of Brown town

Tennent Brook:

Browntown, N. J., Geological Survey gage $11 / 4$ miles northeast of Browntown

\section{Coastal basins}

Swimming River:

Red Bank, N. J., Geological Survey gage on right bank above dam of Monmouth Consolidated Water Co. and 4 miles upstream from Red Bank

118 . do 8196.5

$11.1 \quad \ldots \ldots$ do..............

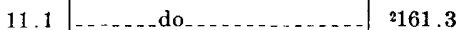

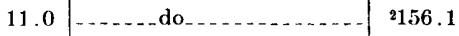

10.5 ......................... 2142.9

10,2

9.8 ..... do . . . 2128.1

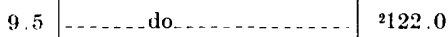

9.0 ...... do _............ 2115.0

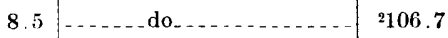

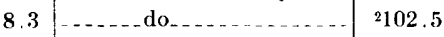

8.1 _... do .

7.9 ...... do. . . . . . . . 294.0

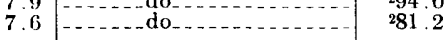

\begin{tabular}{l|l|l}
7.5 & July $23,11: 30$ a.m. ..... & 76.19
\end{tabular}

7.3 July 23............... 275.6

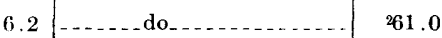

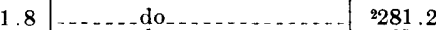

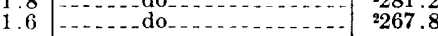

2. 2

$2.1 \quad \ldots \ldots$ do

1.8 .

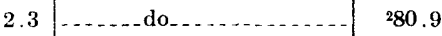

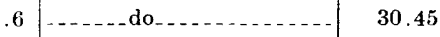

4.8

July 23, 7.to 9 p.m...... $\quad 425.40$

July 20, 5:30 p.m. $\ldots \ldots . .46 .70$

July $24,1: 30$ p.m....... $\quad 45.83$

2.4

July 23,9 p.m.......... 219.18

July 24, 11 a.m........ $\quad 219.15$

4. 0

July 20, 7:30 p.m.

July 24,2 to 3 p.m...... 44.34 
TABLE 25.--Flood-crest stages, July 1938-Continued

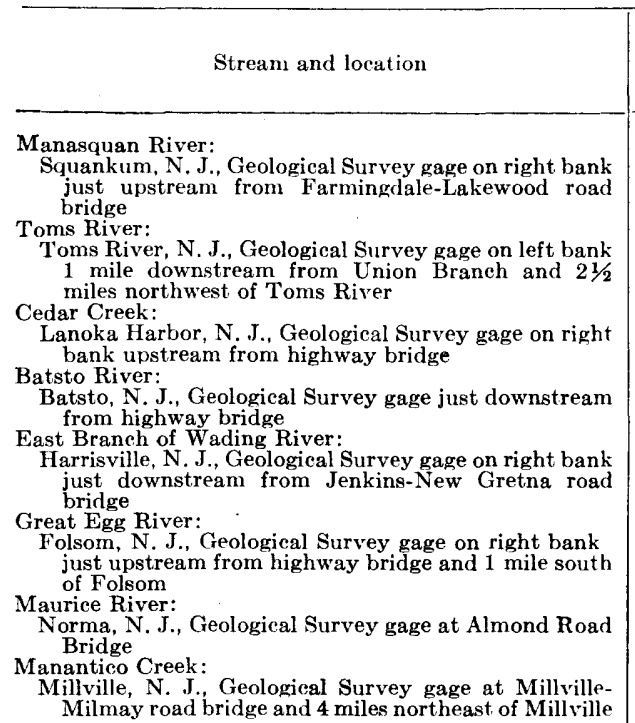

\section{Delaware River Basin}

Delaware River:

Milford, Pa., Geological Survey gage on highway bridge

Dingmans Ferry, Pa., U. S. Weather Bureau gage on highway bridge

Portland, Pa., Geological Survey gage on highway bridge

Delaware, N. J., Geological Survey gage on highway bridge

Belvidere, N. J., Geological Survey gage on left bank just downstream from Pequest River

Easton, Pa., Geological Survey gage on highway bridge

Riegelsville, N. J., Geological Survey gage on left bank just upstream from suspension bridge

Milford, N. J., Geological Survey gage on highway bridge

Frenchtown, N. J., Geological Survey gage on highway bridge

Point Pleasant, Pa., Geological Survey gage on highway

Lumberville, Pa., Geological Survey gage on highway bridge

Stockton, N. J., Geological Survey gage on highway bridge

Lambertville, N. J., Geological Survey gage on highway bridge

Washington Crossing, N. J., Geological Survey gage on highway bridge

Yardley, Pa., Geological Survey gage on highway bridge

Trenton, N. J., Geological Survey gage on left bank, 200 feet upstream from Calhoun Street

Flat Brook:

Flatbrookville, N. J., Geological Survey gage 1 mile upstream from Flatbrookville

Paulins Kill:

Blairstown, N. J., Geological Survey gage 1,200 feet upstream from bridge on State Highway 8

Pequest River:

Pequest, N. J., Geological Survey gage 100 feet upstream from Lehigh \& Hudson River Ry. bridge

Beaver Brook:

Belvidere, N. J., Geological Survey gage 2,000 feet upstream from mouth and 2 miles east of Belvidere

212.4 203.7

173.1

170.9

163.4

149.5

140.6

133.6

130.4

123.2

121.5

118.0

114.9

108.0

104.1

100.6

1.2

9.8

6.6

.4
July $23-24,12$ p.m. to
5 a.m.

July $22,9 \mathrm{p}, \mathrm{m}$

July 24,7 to $9 . . . . . . . .$. July 22,11 to 12 p.m.July 23, 12 p.m........ July 23,6 to 7 a.m..... July 24,6 to 11 a.m. July 23,6 to 7 a.m. July 24,10 a.m. to $12 \mathrm{n}$.July 23,6 a.m....... July 24,9 a.m. to 12 n... July 23,10 a.m........ July 24,9 to 11 a.m..... July 23, 11 a.m.......... July 24,9 to 10 a.m.... July 23,12 n. to 1 p.m. July 24, 11 a.m......... July 23,1 to 2 p.m.

and 6 p.m.................

.

July 23,5 p.m..........

July 23, 7 p.m

July 23, 2 p.m

...d

July 23,8 to 10 p.m.

July 24, 2 a.m.

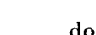

July 22,2 a.m...........

July 23, 3 p.m.
Altitude (feet)

49. 96

49.08

17.75

18.25

24.11

24.12

45.27

45.58

45.55

45.92

51.47

41.09

$3385.48^{\circ}$

3383.33

367.02

365.31

278.67

277.85

5268.16

5267.36

239.43

238.88

169.76

169.49

140.64

140.62

119.96

119.86

110.65

110.59

385.15

78.47

366.74

57.14

36.69

26.80

16.50

353.87

342.02

402.12

402.12

306.68 
TABLE 25.-Flood-crest stages, July 1938-Continued

\begin{tabular}{|c|c|c|c|}
\hline Stream and location & $\begin{array}{l}\text { Miles } \\
\text { above } \\
\text { mouth }\end{array}$ & Date and time & $\underset{\text { (feet) }}{\text { Altitude }}$ \\
\hline $\begin{array}{l}\text { Musconetcong River: } \\
\text { Landing, N.J., Geological Survey gage just above dam }\end{array}$ & 42.4 & July $24-25,7$ p.m. to & 2924.54 \\
\hline $\begin{array}{l}\text { Landing, N. J., Geological Survey gage just upstream } \\
\text { from highway bridge and } 300 \text { feet downstream from } \\
\text { Lake Hopatcong }\end{array}$ & 42.3 & July 24,6 a.m. & 2907.45 \\
\hline $\begin{array}{l}\text { Hackettstown, N. J., Geological Survey gage above } \\
\text { Saxon Falls Dam and } 3 \text { miles northeast of Hacketts- } \\
\text { town }\end{array}$ & 33.1 & July 24,8 a.m. to $12 \mathrm{n}$. & ${ }^{2} 633.55$ \\
\hline $\begin{array}{l}\text { Hackettstown, N. J., on left bank } 500 \text { feet upstream } \\
\text { frrom Delaware, Lackawanna \& Western R.R. bridge } \\
\text { and } 3 \text { miles northeast of Hackettstown }\end{array}$ & 32.7 & $\ldots$ do_ & 2608.87 \\
\hline $\begin{array}{l}\text { Bloomsbury, N. J., Geological Survey gage just down- } \\
\text { stream from highway bridge and } 11 / 2 \text { miles upstream } \\
\text { from Bloomsbury }\end{array}$ & 9.4 & July 23,11 to $11: 30$ p.m. - & 279.95 \\
\hline $\begin{array}{l}\text { ssunpink Creek: } \\
\text { Trenton, N. J., Geological Survey gage at Chambers } \\
\text { Street Bridge }\end{array}$ & 1.5 & July $23,10: 30$ p.m.-- & 233.66 \\
\hline $\begin{array}{l}\text { Torth Branch of Rancocas Creek: } \\
\text { Pemberton, N. J., Geological Survey gage } 600 \text { feet } \\
\text { downstream from highway bridge }\end{array}$ & 12.0 & July 24,5 to 9 p.m.... & 33.73 \\
\hline $\begin{array}{l}\text { Oldmans Creek: } \\
\text { Woodstown, N. J., Geological Survey gage just up- } \\
\text { stream from Woodstown-Swedesboro highway bridge } \\
\text { and } 2 \text { miles north of Woodstown }\end{array}$ & 16.0 & July 24, 10 a.m...- & 44.47 \\
\hline
\end{tabular}

1Reading at 8 a.m., peak stage may have been higher.

${ }_{2}^{2}$ New Jersey Geological Survey datum.

${ }^{3}$ Highest stage observed; peak stage may have been higher.

Assumed datum.

5Pennsylvania Railroad bench mark. 
TABLE 26-Altitude, in feet, at indicated places in the Elizabeth River Basin for floods in which the peak discharge was 1,200 second-feet or more at Westfield Avenue, Elizabeth, N.J.

\begin{tabular}{|c|c|c|c|c|c|c|c|c|c|c|c|c|c|c|c|c|c|c|}
\hline \multirow{3}{*}{ Date } & \multicolumn{13}{|c|}{ Elizabeth River } & \multicolumn{5}{|c|}{ West Branch of Elizabeth River } \\
\hline & \multirow[b]{2}{*}{ 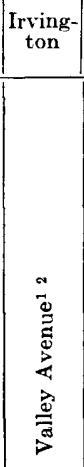 } & \multicolumn{2}{|c|}{ Hillside } & \multicolumn{6}{|c|}{ Union } & \multicolumn{4}{|c|}{ Elizabeth } & \multicolumn{5}{|c|}{ Union } \\
\hline & & 宽 & 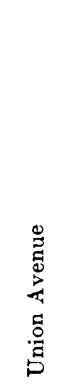 & 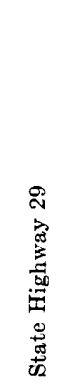 & 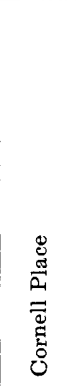 & 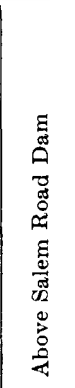 & 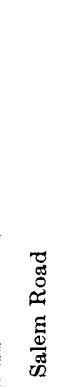 & 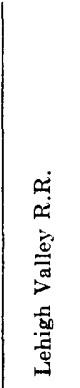 & 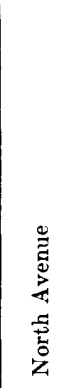 & 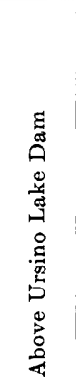 & 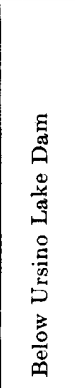 & 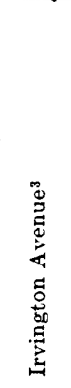 & 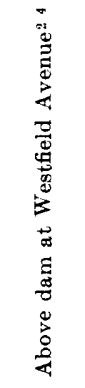 & 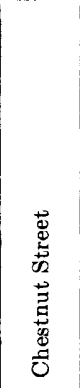 & 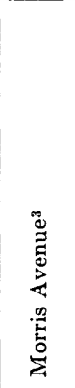 & 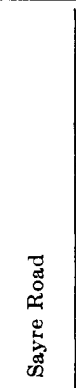 & 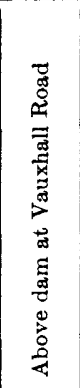 & 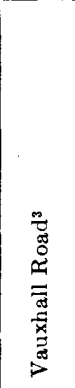 \\
\hline Distance above mouth, in miles. & 9.7 & 7.7 & 7.3 & 6.5 & 6.2 & 5.5 & 5.5 & 5.2 & 4.2 & 3.9 & 3.9 & 3.6 & 3.3 & 2.0 & 1.1 & 0.6 & 0.3 & 0.3 \\
\hline $\begin{array}{l}\text { 1924, Apr. } 6,7 \ldots \\
1924, \text { July } 8, \ldots \\
1925 \text {, July } 31 \ldots \ldots \\
1926 \text {, Sept. } 6 \ldots \ldots\end{array}$ & - & & . & & & & & & & & & & $\begin{array}{l}13.38 \\
13.39 \\
13.41 \\
13.29\end{array}$ & & & & & $\cdots$ \\
\hline 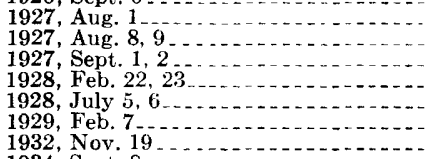 & 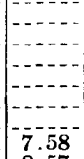 & $\begin{array}{l}76.0 \\
73.4 \\
73.9 \\
73.6 \\
75.3 \\
74.6 \\
75.1\end{array}$ & $\begin{array}{l}62.3 \\
60.7 \\
61.8 \\
58.5 \\
61.9 \\
60.2 \\
62.7\end{array}$ & $\begin{array}{l}44.7 \\
43.6 \\
45.4 \\
44.4 \\
45.8\end{array}$ & $\begin{array}{l}42.6 \\
42.3 \\
41.9 \\
41.0 \\
41.6 \\
41.6 \\
42.3\end{array}$ & $\begin{array}{l}36.4 \\
35.4 \\
37.4 \\
36.6 \\
36.6 \\
35.5 \\
37.6\end{array}$ & $\begin{array}{l}35.0 \\
33.0 \\
35.4 \\
33.8 \\
34.4 \\
31.7 \\
35.5\end{array}$ & $\begin{array}{r}27.9 \\
325.6 \\
29.6 \\
27.1 \\
29.4 \\
26.8 \\
29.3\end{array}$ & $\begin{array}{l}24.9 \\
23.0 \\
25.4 \\
24.0 \\
24.7 \\
23.9 \\
24.4\end{array}$ & $\begin{array}{l}24.6 \\
22.7 \\
24.5 \\
22.9 \\
23.5 \\
23.5 \\
23.7\end{array}$ & $\begin{array}{l}17.6 \\
15.0 \\
18.1 \\
15.5 \\
16.7 \\
15.6\end{array}$ & $\begin{array}{l}14.2 \\
12.3 \\
15.5 \\
13.5 \\
14.1 \\
13.8 \\
13.7\end{array}$ & $\begin{array}{l}14.53 \\
13.99 \\
14.94 \\
13.29 \\
14.05 \\
13.34 \\
14.96\end{array}$ & $\begin{array}{l}54.2 \\
54.7 \\
54.4 \\
54.2 \\
55.2 \\
55.0\end{array}$ & $\begin{array}{l}50.7 \\
51.3 \\
51.2 \\
51.8 \\
50.2 \\
50.5 \\
51.8\end{array}$ & $\begin{array}{l}49.8 \\
50.4 \\
50.5 \\
50.3 \\
49.6 \\
48.6 \\
49.8\end{array}$ & $\begin{array}{l}49.9 \\
50.0 \\
50.2 \\
50.0 \\
47.6 \\
45.5\end{array}$ & $\begin{array}{l}41.3 \\
41.6 \\
41.9 \\
41.6 \\
41.6 \\
40.9\end{array}$ \\
\hline $\begin{array}{l}\text { 1934, Sept. 8, } \\
\text { 1938, July } 23 \text {. }\end{array}$ & $\begin{array}{c}8.57 \\
12.1\end{array}$ & 79.8 & 62.4 & $4 \overline{5} \cdot \overline{3}$ & (n) & $-\overline{37} \cdot \overline{5}$ & 35.5 & 330.8 & $2 \overline{7} . \overline{7}$ & $2 \overrightarrow{5} . \overline{1}$ & 18.5 & 20.0 & $\begin{array}{l}12.44 \\
18.28\end{array}$ & 56.4 & 54.4 & 53.7 & (n) & (n) \\
\hline
\end{tabular}


The Essex County Park Commission has furnished tabulations of flood-crest stages based on floodmarks and staff-gage readings at several places in the Elizabeth River, Rahway River, and Green Brook basins during major floods antedating the flood of July 1938. This information is furnished in tables 26-28. 
TABLE 27.-Altitude, in feet, at indicated places in the Rahway River Basin for floods

\begin{tabular}{|c|c|c|c|c|c|c|c|c|c|c|c|c|c|c|c|c|c|c|}
\hline & \multirow{2}{*}{\multicolumn{3}{|c|}{$\begin{array}{l}\begin{array}{l}\text { East Branch of } \\
\text { Rahway River }\end{array} \\
\text { South Orange }\end{array}$}} & \multicolumn{15}{|c|}{ Rahway River } \\
\hline & & & & \multicolumn{3}{|c|}{ Springfield } & \multicolumn{12}{|c|}{ Cranford } \\
\hline Date & 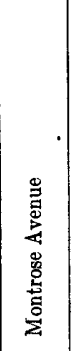 & 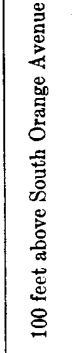 & 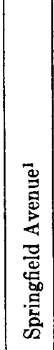 & 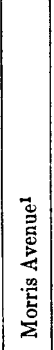 & 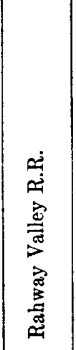 & 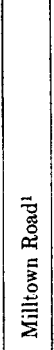 & 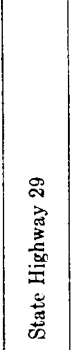 & 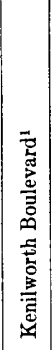 & 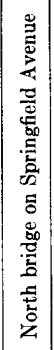 & 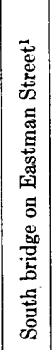 & 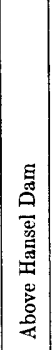 & 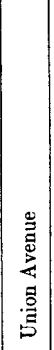 & 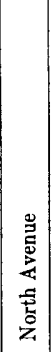 & 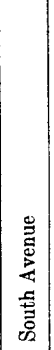 & 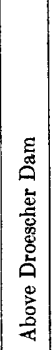 & 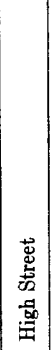 & 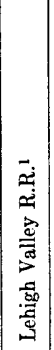 & 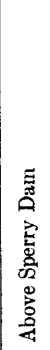 \\
\hline $\begin{array}{l}\text { Distance above } \\
\text { mouth, in miles } \\
\text { 1924, Apr. } 7 \\
\text { 1924, July } 9\end{array}$ & 22.6 & 21.7 & \begin{tabular}{l}
18.8 \\
\hdashline
\end{tabular} & $\begin{array}{l}18.3 \\
83.6\end{array}$ & $\begin{array}{l}17.5 \\
78.6\end{array}$ & $\begin{array}{l}16.7 \\
75.7\end{array}$ & $\begin{array}{l}16.1 \\
73.6\end{array}$ & 14.5 & $\begin{array}{l}13.2 \\
64.7\end{array}$ & 12.8 & 12.3 & $\begin{array}{l}12.3 \\
61.5\end{array}$ & 12.1 & 12.0 & 58.7 & $\mid \begin{array}{l}11.7 \\
55.9\end{array}$ & $\begin{array}{l}10.8 \\
52.2\end{array}$ & $\begin{array}{r}9.7 \\
45.8\end{array}$ \\
\hline 1925, Feb. 12 & - & $-\ldots$ & 84.4 & 81.9 & 77.7 & 73.7 & $\begin{array}{l}71.7 \\
70.8\end{array}$ & - & 62.8 & 62.7 & 62.3 & 59.5 & $58 . \overline{9}$ & 58.5 & 57.9 & $\left|\begin{array}{l}54.6 \\
54.2\end{array}\right|$ & 49.4 & 44.7 \\
\hline 1927, Aug. 1,2 & 150.0 & 141.9 & 85.8 & 84.8 & 80.9 & 77.2 & & 67.1 & 64.4 & 63.3 & 62.5 & 61.7 & 60.1 & 60.0 & 59.5 & 55.9 & 50.9 & 45.9 \\
\hline 1927, Aug. 9 & $|-\ldots|$ & $\ldots$ & 83.8 & 82.1 & 79.1 & 74.5 & 71.7 & $\mid 66.4$ & 63.4 & 62.6 & $\mid \begin{array}{r}82.0 \\
6.7\end{array}$ & 60.9 & $|59.5|$ & $\mid 59.0$ & $\mid 58.2$ & $\mid 55.2$ & $\mid 50.1$ & 45.3 \\
\hline 1927 , Oct. 18,19 & $\cdots$ & & 83.8 & 82.0 & & 74.0 & 70.6 & 65.8 & 62.8 & 62.0 & 61.7 & 60.6 & 59.3 & 58.8 & 56.3 & 54.8 & 49.7 & 45.4 \\
\hline 1928 , July 6 & and & & 85.6 & $\mid \begin{array}{l}83.0 \\
83.3\end{array}$ & $\begin{array}{l}79.8 \\
80.8\end{array}$ & $\begin{array}{l}75.6 \\
76.1\end{array}$ & \begin{tabular}{|l|}
72.4 \\
72.1
\end{tabular} & $\left|\begin{array}{l}67.0 \\
66.2\end{array}\right|$ & $\left|\begin{array}{l}64.1 \\
63.4\end{array}\right|$ & $\begin{array}{l}63.2 \\
62.3\end{array}$ & 62.4 & $\left|\begin{array}{l}61.7 \\
60.4\end{array}\right|$ & $\left|\begin{array}{l}60.3 \\
59.1\end{array}\right|$ & $\mid \begin{array}{l}59.6 \\
58.8\end{array}$ & $\left|\begin{array}{l}58.3 \\
57.7\end{array}\right|$ & $\begin{array}{l}56.1 \\
55.0\end{array} \mid$ & $\begin{array}{l}50.4 \\
50.1\end{array} \mid$ & $\mid \begin{array}{l}45.7 \\
45.2\end{array}$ \\
\hline 1932 , Nov. $19-20$ & & & 86.1 & 83.7 & 81.1 & 76.3 & 73.1 & 66.4 & 63.8 & 63.1 & 62.6 & 61.4 & 59.4 & 59.3 & 58.1 & 55.4 & 50.8 & 45.6 \\
\hline $\begin{array}{l}1933 \text {, Sept. 15, } 16- \\
1936 \text {, Mar. 11, } 12\end{array}$ & 145.35 & 136.6 & 84.4 & 84.2 & -77.5 & 75.4 & $\mid \begin{array}{l}72.4 \\
70.0\end{array}$ & $\left|\begin{array}{l}67.0 \\
65.6\end{array}\right|$ & $\mid \begin{array}{l}64.6 \\
63.4\end{array}$ & $|-\overline{62.4}|$ & $\mid--.9$ & $\left|\begin{array}{l}61.7 \\
60.5\end{array}\right|$ & $\left|\begin{array}{l}60.4 \\
59.2\end{array}\right|$ & 58.8 & 58.0 & $\left|\begin{array}{l}56.5 \\
55.1\end{array}\right|$ & 50.2 & $\begin{array}{l}46.0 \\
45.3\end{array}$ \\
\hline 1938 , July 23,24 & 148.06 & 140.94 & 86.3 & 86.6 & \pm 79.7 & 77.6 & 473.58 & 69.0 & 66.4 & 66.0 & 63.3 & 63.1 & 61.8 & 61.7 & 59.3 & 59.7 & 52.5 & 46.9 \\
\hline
\end{tabular}

'Downstream side of bridge.

Altitude referred to New Jersey Geological Survey datum.

stream-masurement station.

TABLE 28.-Altitude, in feet, at indicated places for several previous

\begin{tabular}{l} 
Date \\
\hline
\end{tabular}

IDownstream side of bridge

${ }^{2}$ U. S. Coast and Geodetic Survey datum.

iStream-measurement station. 


\section{RAINFALL AND RUNOFF STUDIES}

The depths of mean areal precipitation on each drainage basin were computed from the isohyetal map for the storm of July 1938 reproduced as plate 11 . The results are shown in column 5 of table 29. The values of direct flood runoff resulting from this rain are shown in column 6. Computations were based on records of discharge at the gaging stations published in this report and were computed by the following procedure:

TABle 29.-Precipitation and associated direct runoff for flood of July 1938 [Mean depth in inches over drainage area]

\begin{tabular}{|c|c|c|c|c|c|c|}
\hline $\begin{array}{c}\text { No. } \\
\text { on } \\
\text { pl. } 12\end{array}$ & Stream & Location & $\begin{array}{l}\text { Drain- } \\
\text { age } \\
\text { area } \\
\text { (square } \\
\text { miles) }\end{array}$ & $\begin{array}{c}\text { Pre- } \\
\text { cipita- } \\
\text { tion }\end{array}$ & $\begin{array}{c}\text { Run- } \\
\text { off }\end{array}$ & $\begin{array}{l}\text { Differ- } \\
\text { ence }\end{array}$ \\
\hline & Merrimac River Basin & & & & & \\
\hline 210 & $\begin{array}{l}\text { Concord River } \\
\text { Ipswich River Basin }\end{array}$ & $\begin{array}{l}\text { Below River Meadow Brook, } \\
\text { at Lowell, Mass. }\end{array}$ & 1312 & 8.0 & 2.85 & 5.15 \\
\hline \multirow[t]{2}{*}{$\begin{array}{l}212.5 \\
213\end{array}$} & $\begin{array}{r}\text { Ipswich River } \\
\text { Do }\end{array}$ & $\begin{array}{l}\text { South Middieton, Mass } \\
\text { Ipswich, Mass } \ldots\end{array}$ & 43.4 & $\begin{array}{l}8.3 \\
8.15\end{array}$ & $\begin{array}{l}3.9 \\
4.05\end{array}$ & $\begin{array}{l}4.4 \\
4.1\end{array}$ \\
\hline & Charles River Basin & & & & & \\
\hline $\begin{array}{l}216 \\
218\end{array}$ & $\begin{array}{l}\text { Charles River } \\
\text { Do } \\
\text { Taunton River Basin }\end{array}$ & $\begin{array}{l}\text { Charles River Village, Mass .. } \\
\text { Waltham, Mass }\end{array}$ & $\begin{array}{l}184 \\
2251\end{array}$ & $\begin{array}{l}10.4 \\
10.1\end{array}$ & $\begin{array}{r}4.75 \\
--.-1\end{array}$ & 5.65 \\
\hline \multirow[t]{2}{*}{$\begin{array}{l}222 \\
223\end{array}$} & $\begin{array}{l}\text { Taunton River } \\
\text { Wading River }\end{array}$ & $\begin{array}{l}\text { State Farm, Mass ... } \\
\text { Norton, Mass ..... }\end{array}$ & 260 & $\begin{array}{l}5 \cdot 1 \\
7.7\end{array}$ & $\begin{array}{l}2.1 \\
3.25\end{array}$ & $\begin{array}{l}3.0 \\
4.45\end{array}$ \\
\hline & Providence River Basin & & & & & \\
\hline \multirow[t]{2}{*}{$\begin{array}{l}225 \\
230\end{array}$} & $\begin{array}{r}\text { Blackstone River } \\
\text { Do }\end{array}$ & $\begin{array}{l}\text { Worcester, Mass } \\
\text { Woonsocket, R. I }\end{array}$ & 31.3 & $\begin{array}{l}7.0 \\
9.5\end{array}$ & $\begin{array}{l}3.4 \\
4.75\end{array}$ & $\begin{array}{l}3.6 \\
4.75\end{array}$ \\
\hline & Thames River Basin & & & & & \\
\hline $\begin{array}{l}264 \\
267 \\
272 \\
275 \\
282 \\
284 \\
289 \\
295.5 \\
298 \\
301\end{array}$ & 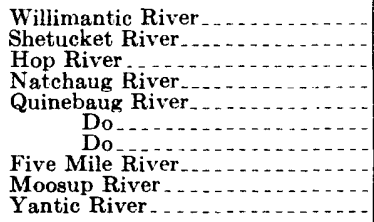 & $\begin{array}{l}\text { South Coventry, Conn } \\
\text { Willimantic, Conn } \\
\text { Columbia, Conn } \\
\text { Willimantic, Conn } \\
\text { Quinebaug, Conn } \\
\text { Putnam, Conn } \\
\text { Jewett City, Conn } \\
\text { Killingly, Conn ... } \\
\text { Moosup, Conn } \\
\text { Yantic, Conn }\end{array}$ & $\begin{array}{c}121 \\
401 \\
76.2 \\
169 \\
157 \\
331 \\
711 \\
58.2 \\
83.5 \\
88.6\end{array}$ & $\begin{array}{r}7.35 \\
8.9 \\
8.35 \\
10.0 \\
8.05 \\
8.35 \\
9.1 \\
11.0 \\
9.3 \\
10.0\end{array}$ & $\begin{array}{l}2.4 \\
3.6 \\
3.25 \\
4.65 \\
2.75 \\
3.85 \\
4.3 \\
5.1 \\
5.3 \\
5.6\end{array}$ & $\begin{array}{l}4.95 \\
5.3 \\
5.1 \\
5.35 \\
5.3 \\
4.5 \\
4.8 \\
5.9 \\
4.0 \\
4.4\end{array}$ \\
\hline & Connecticut River Basin & & & & & \\
\hline $\begin{array}{l}413 \\
415 \\
416 \\
419 \\
423 \\
427 \\
428 \\
429 \\
431 \\
432 \\
433.3 \\
433.7\end{array}$ & $\begin{array}{l}\text { Scantic River } \\
\text { Farmington River } \\
\text { Do } \\
\text { Do } \\
\text { Burlington Brook } \\
\text { South Branch of Park River } \\
\text { Park River } \\
\text { North Branch of Park River } \\
\text { Hockanum River } \\
\text { Salmon River } \\
\text { East Branch of Eightinile River.- } \\
\text { West Branch of Eightmile River }\end{array}$ & $\begin{array}{l}\text { Broad Brook, Conn } \\
\text { New Boston, Mass } \\
\text { Riverton, Conn } \\
\text { Tariff ville, Conn } \\
\text { Burlington, Conn } \\
\text { Hartford, Conn } \\
\text { Do, } \\
\text { Do } \\
\text { East Hartford, Conn } \\
\text { East Hampton, Conn } \\
\text { Nurth Lyme, Conn } \\
\text { Do. ....... }\end{array}$ & $\begin{array}{l}98.4 \\
92.0 \\
216 \\
578 \\
4.1 \\
40.6 \\
74.0 \\
25.3 \\
74.5 \\
105 \\
22.0 \\
19.2\end{array}$ & $\begin{array}{l}4.5 \\
4.4 \\
4.8 \\
5.75 \\
6.8 \\
6.3 \\
6.5 \\
6.3 \\
6.45 \\
8.9 \\
8.95 \\
9.2\end{array}$ & $\begin{array}{l}1.55 \\
1.2 \\
1.55 \\
1.95 \\
2.55 \\
2.55 \\
2.5 \\
2.9 \\
1.5 \\
3.0 \\
3.2 \\
3.5\end{array}$ & $\begin{array}{l}2.95 \\
3.2 \\
3.25 \\
3.8 \\
4.25 \\
3.75 \\
4.0 \\
3.4 \\
4.95 \\
5.9 \\
5.75 \\
5.7\end{array}$ \\
\hline & Quinnipiac River Basin & & & & & \\
\hline 435 & Quinnipiac River & Wallingford, Conn ....... & 109 & 6.4 & 1.6 & 4.8 \\
\hline
\end{tabular}


TABLE 29.-Precipitation and associated direct runoff for flood of July 1938-Continued

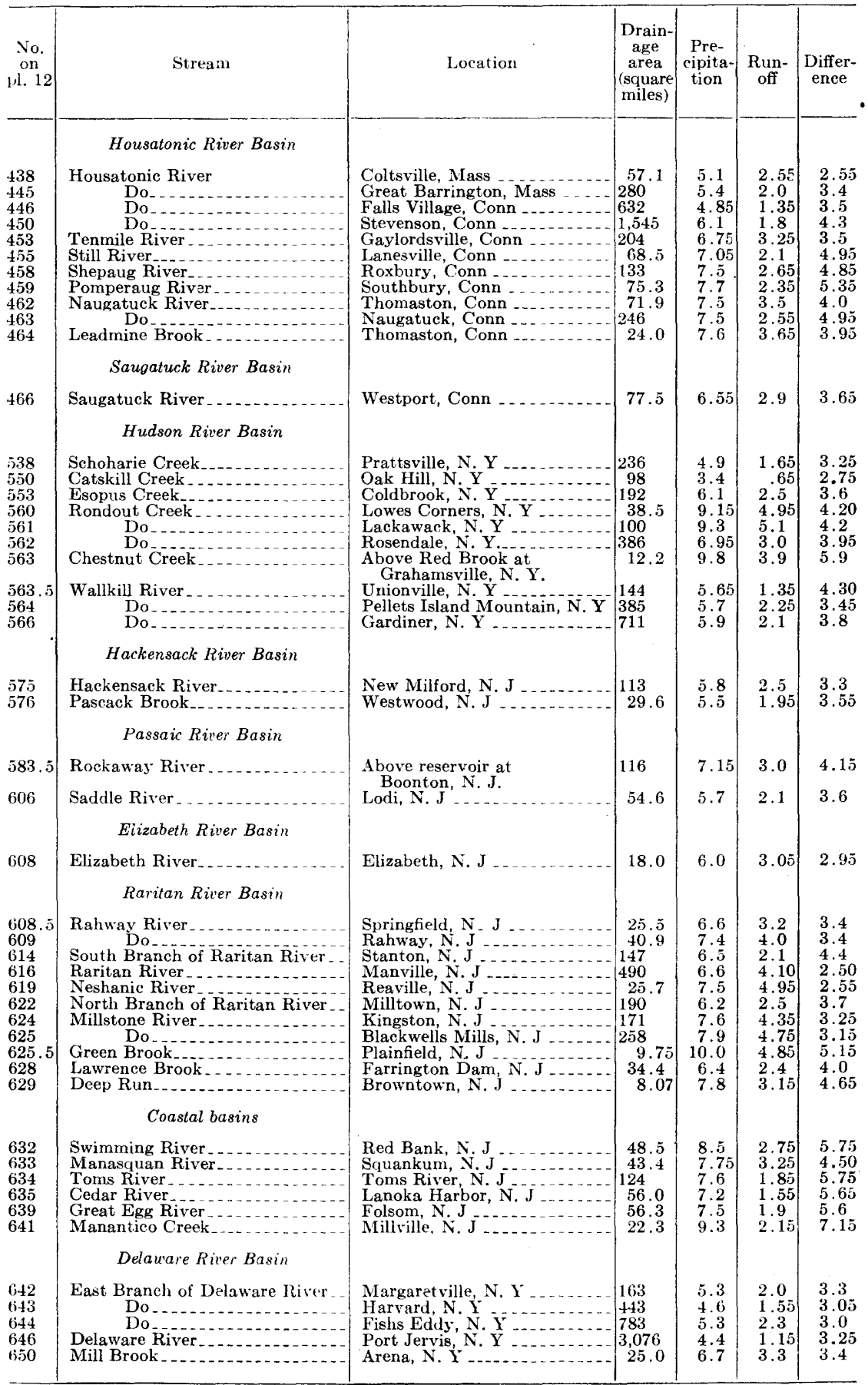


TABLE 29.-Precipitation and associated direct runoff for flood of July 1938-Continued

\begin{tabular}{|c|c|c|c|c|c|c|}
\hline $\begin{array}{c}\text { No. } \\
\text { on } \\
\text { pl. } 12 \\
.\end{array}$ & Stream & Location & $\begin{array}{c}\text { Drain- } \\
\text { age } \\
\text { area } \\
\text { (square } \\
\text { miles) }\end{array}$ & $\begin{array}{c}\text { Pre- } \\
\text { cipita- } \\
\text { tion }\end{array}$ & $\begin{array}{c}\text { Run- } \\
\text { off }\end{array}$ & $\begin{array}{l}\text { Differ- } \\
\text { ence }\end{array}$ \\
\hline & Tremper Kill & Shavertown, N. Y & 33.0 & 3.3 & .75 & 2.55 \\
\hline $\begin{array}{l}652 \\
653\end{array}$ & Terry Clove Kill_ & 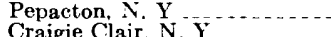 & 14.1 & 3.1 & $\begin{array}{r}.70 \\
4.55\end{array}$ & $2 \cdot 40$ \\
\hline $\begin{array}{l}653 \\
654\end{array}$ & $\begin{array}{l}\text { Beaver hil........ } \\
\text { Do }\end{array}$ & Cooks Falls, N. Y & & 7.0 & 年 1.75 & $\begin{array}{l}3.75 \\
3.25\end{array}$ \\
\hline & Willowemoc Creek & Livingston $\mathrm{Nanor}, \mathrm{N} . \mathrm{Y}$ & 63 & 7.9 & 4.3 & 3.6 \\
\hline $\begin{array}{l}656 \\
650\end{array}$ & Little Beaver Kill & Do & 19.8 & 7.4 & 3.2 & $\begin{array}{l}8.0 \\
4.2\end{array}$ \\
\hline & West Branch of Delaware River & Delhi, N. Y Y & & 4.0 & 0.65 & 3. 35 \\
\hline $\begin{array}{l}658 \\
662.5 \\
667.3\end{array}$ & $\begin{array}{l}\text { Do } \\
\text { Little Delaware River }\end{array}$ & $\begin{array}{l}\text { Hale Eddy, N. Y } \\
\text { Delhi, N. Y }\end{array}$ & $\begin{array}{l}593 \\
49.8\end{array}$ & $\begin{array}{l}3.3 \\
4.75\end{array}$ & $\begin{array}{r}.40 \\
1.2 \\
6.75\end{array}$ & $\begin{array}{l}2.90 \\
3.55 \\
2.55\end{array}$ \\
\hline & Neyorsink River & near Curry, $N$. Y. & & 885 & & \\
\hline & & Oakland Valley, N. Y & 1132 & $\begin{array}{l}8.80 \\
7.3\end{array}$ & $\begin{array}{l}3.5 \\
3.45\end{array}$ & $\begin{array}{l}3.55 \\
3.85\end{array}$ \\
\hline & & Godeffroy, N. Y & 302 & 6.8 & 2.7 & $\begin{array}{l}0.1 \\
4.1\end{array}$ \\
\hline 671 & Flat Brook- & Flatbrookville. N. J & 65.1 & 5.9 & 2.55 & 3.35 \\
\hline & Paul & Blairstown, N. J & 126.4 & 5.75 & 2.15 & 3.60 \\
\hline & Musconetcong River. & Bloomsbury, N. J & & 6.95 & 2.25 & 4.70 \\
\hline 683 & Assunpink Creek & Trenton, N. J & 89.4 & 7.25 & 3.7 & 3.55 \\
\hline & $\begin{array}{l}\text { North Branch of Rancocas Creek } \\
\text { Oldmans Creek }\end{array}$ & $\begin{array}{l}\text { Pemberton, N, J } \\
\text { Woodstown, N. J }\end{array}$ & 111 & 7.15 & 2.3 & $\begin{array}{l}4.85 \\
5.40\end{array}$ \\
\hline
\end{tabular}

tDoes not include 92.6 square miles in Sudbury and Lake Cochituate Basins, from which water is diverted by Metropolitan Water District of Boston.

2Includes area drained by Stony Brook.

A discharge hydrograph for parts of July and August was constructed for each gaging-station record to be analyzed, similar to the part of the hydrograph for the Naugatuck River near Thomaston, Conn., presented in figure 36 to illustrate the method of analysis. The graph outlined by letters $A-B \cdot C-D-E-F$ is the observed discharge past the gaging station. The hydrographs of other streams differed radically from this hydrograph. (as shown by figs. 25-28) because of erratic distribution and intensity of rainfall. The marked rise at $E$, for example, did not occur in streams east of the Connecticut River, and the hydrographs were thereby much simplified. But at all streams analyzed the flow at point $A$ consisted of ground-water flow. Subsequent rains caused a rise in stream flow and increased or steadied the ground-water flow. At $B$ the stream discharge again consisted largely of groundwater flow with possibly some subsurface water that was still draining off after the rains.

If no subsequent rain had accurred the stream flow would have continued approximately as from $B$ to $H$. However, the flood-producing storms began on the morning of July 18 and occurred intermittently thereafter until about July 24, raising the streams to successive peaks of varying heights depending on the rainfall distribution in the various basins. Rains occurring after July 25 are not treated in this report, and the line D-G-F represents the approximate stream discharge that would have occurred if there had been no rain after July 25 . 
The total area under the discharge hydrograph B-C.D-G.F represents the runoff that reached the stream channels during the period, both as surface and as ground-water runoff resulting from rainfall during the period July 17-25 plus the runoff under $B-H$

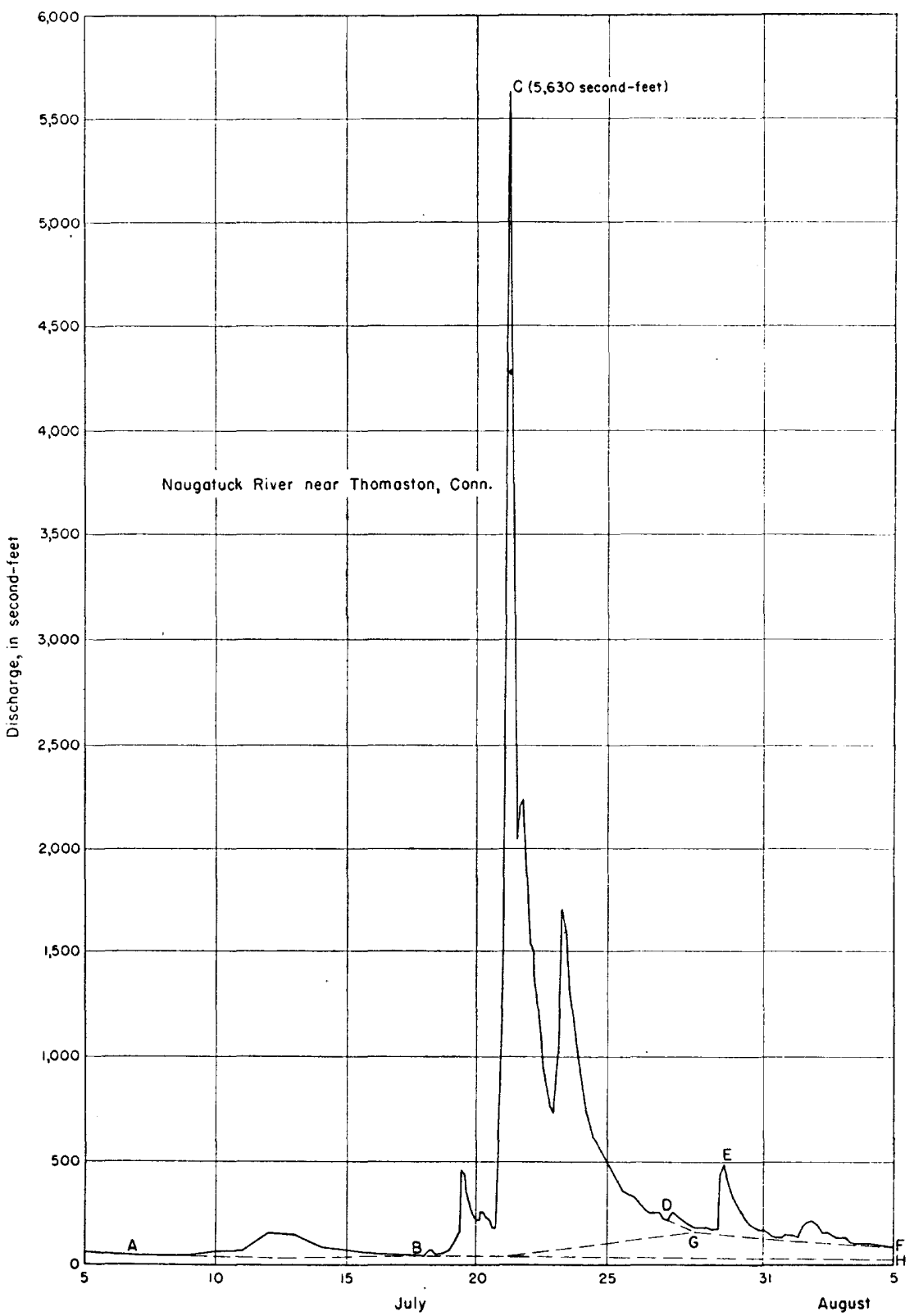

Figure 30.--Hydrograph of discharge of Naugatuck River near Thomaston, Conn., showing method of analysis used in determining the direct runoff associated with the flood of July 1938. 
that would have been maintained if there had been no increment of supply after July 17 . The area under $B-G$ represents the estimate of ground-water flow during the period, and the area between this line and $B-C \cdot D-G$ probably includes essentially all the direct surface runoff resulting from the storm precipitation and may include some ground water that was discharged into stream channels with a promptness approaching that of surface runoff.

For most streams, point $G$ was close to or coincident with the observed discharge hydrograph, but for some it was necessary to estimate the short recession curve $D-G$. Also for some streams it was necessary to draw recession curves at point $B$. Other investigators might make other estimates of direct runoff by drawing the various separation curves differently. But, in general, differences in estimates would be relatively small in relation to the magnitude of direct runoff.

Volumes of direct runoff, as reported in table 29, are based on records of observed stream flow, adjusted where necessary for changes of contents in reservoirs, where records of such changes are available to compute the runoff under natural conditions. Retarding basins other than those for which records are included in this report probably affect the flow, but no records were available for determining their effect. During periods of low flow many streams were affected by diurnal fluctuations caused by the operation of relatively small millponds upstream. The storage capacity of these ponds is generally limited to less than 1 or 2 days' supply of normal low flow, and the plotted discharge hydrographs were adjusted during the periods of low flow to balance the diurnal fluctuations and thus improve accuracy in determining the trend and amount of ground-water flow.

If the records of precipitation and values of direct runoff are substantially correct, as shown in table 29, then the difference shown in column 7 represents the basin retention or the amount of water that was retained in the basin as surface and ground storage and soil-moisture accretion or that was transpired and evaporated during the flood period. Considering the erratic distribution of rainfall, these values seem reasonably consistent.

The results of the rainfall and runoff studies have been partly summarized in table 29 for each of the regular river-measurement stations. Index numbers to the left of the station names refer to their plotted locations on plate 12, and figures in column 4 show their respective drainage areas. The values of direct flood runoff shown in column 6 are the result of the 7 days of intermittent rainfall from July 17 to 25 , listed in column 5 . Direct runoff should be less than the rainfall by the amount of evaporation, transpira- 
tion, change in soil moisture, and accretion to the ground-water table. Total values of this retention or abstraction are shown in column 7 .

The data compiled in table 29 afford an appraisal of the runoff and retention characteristics of the basins and the accuracy and adequacy of the basic information used to evaluate them. As the direct runoff generally is believed to be accurate within 10 percent, large inconsistencies may indicate deficiencies in other basic data or limitations in methods of analysis of the data. The geographic distribution of the flood-producing storms was variable and therefore probably not well defined, particularly in those areas deficient in rainfall records. Figures 37-39 present graphical comparisons of the total storm rainfall with direct runoff. They illustrate that runoff generally increased with the rainfall. On figures 37 and 38, applicable to Massachusetts and Connecticut areas and to New York areas, respectively, the plotted points are sufficiently consistent to define an indicated trend. It should be noted that the slopes of the upper parts of these trends approach $45^{\circ}$, indicating the influence of a high degree of soil saturation as rainfall increased. The limit of retention associated with this condition seemed to be about 5 inches in Massachusetts and Connecticut and about 3.5 inches in New York (Catskill Mountain Region). However, for the basins in Connecticut it has been computed that about 40 percent of the retention reappeared as stream flow in the form of ground-water or base runoff during but mainly, subsequent to the storm. The remainder became an increment to soil moisture and was available for evaporation and transpiration.

In New Jersey the points scatter (see fig. 39), and no approach to uniform amount of retention is noted. However, an appreciable difference is indicated in the behavior of basins in the southern part of that State and those in the northern part with respect to volumes of direct runoff from similar rainfall. For the southern part this reflects a greater absorptive capacity of the soil and probably also the greater ground-water and surface swamp storage that seems characteristic of the region. It is significant that the total annual runoff does not vary greatly over the State, except as accountable by differences in precipitation or temperature.

The amount of rainfall retained from direct runoff consists essentially of transpiration, evaporation, change in soil moisture, and accretion to the ground-water table. These factors have been analyzed in the Park River Basin in Connecticut, wherein precipitation is defined as accurately as in any drainage area studied in this report. For the period July 18-31, 1938, the following factors were determined: Average precipitation over the basin 


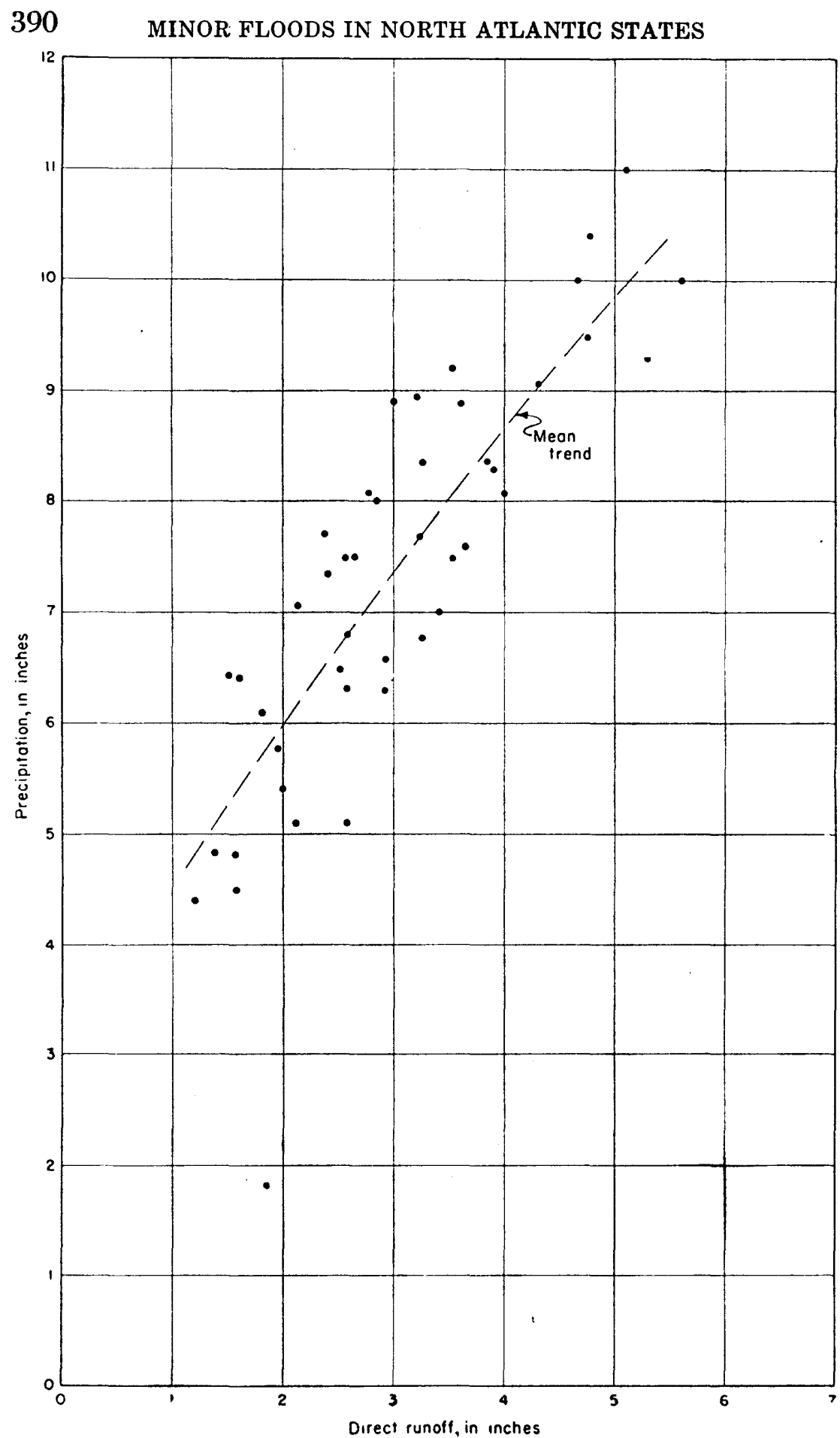

Figure 37.-Relation between precipitation and associated direct runoff during flood of July 17-25, 1938, for basins in Massachusetts and Connecticut. 


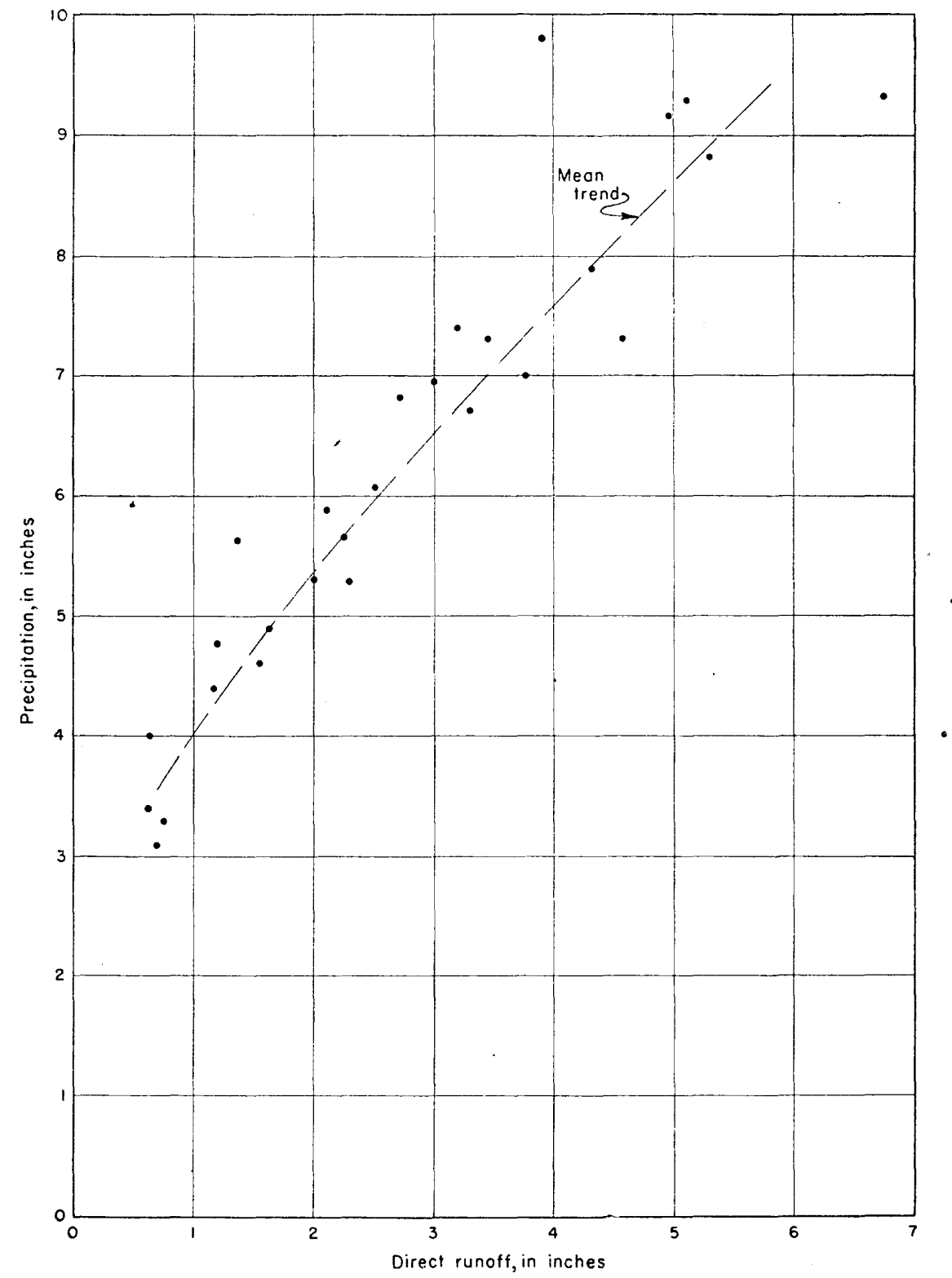

IGURE 38.--Relation between precipitation and associated direct runoff during flood of July $17-25,1938$, for basins in New York. 


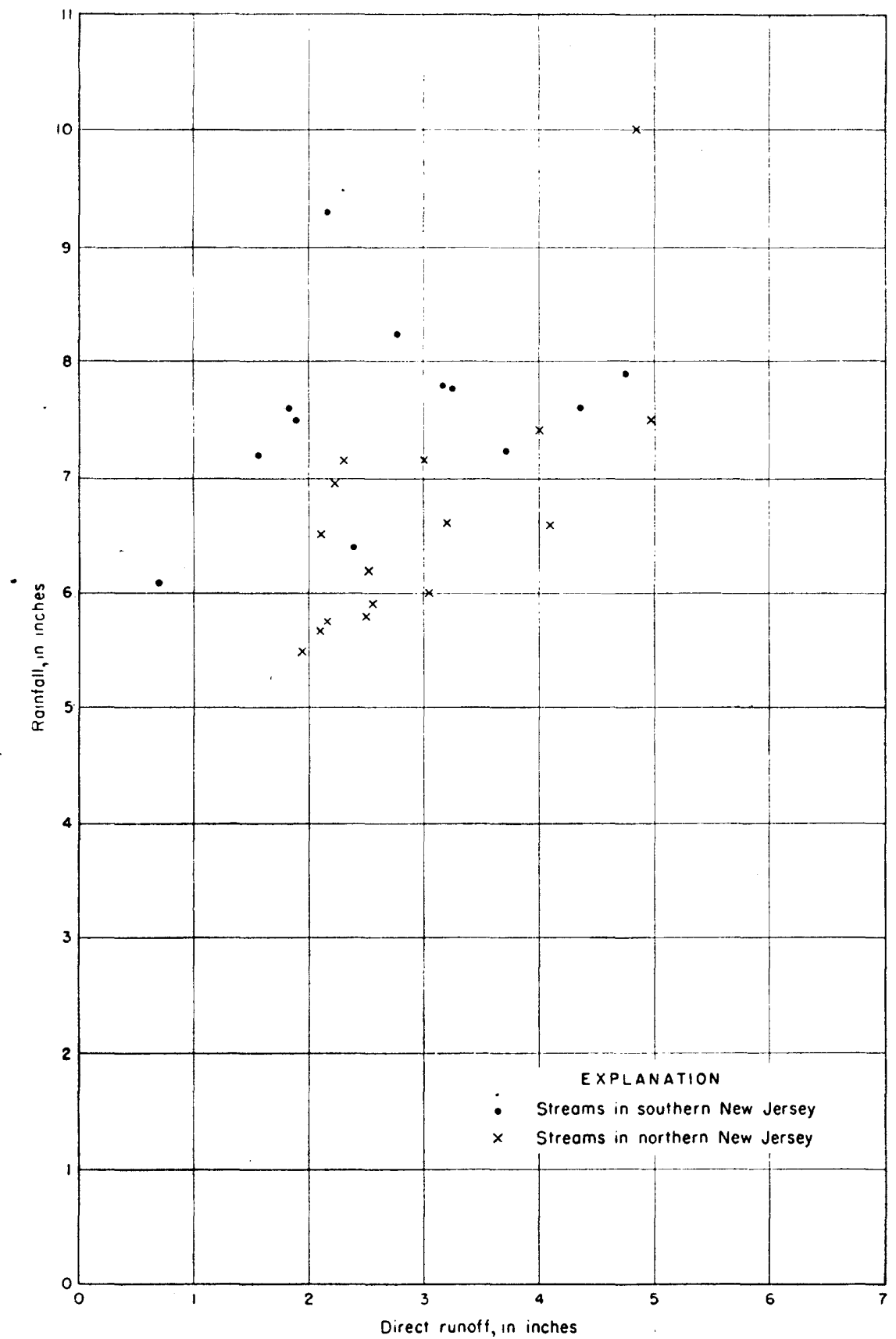

Ficure 39.--Relation between precipitation and associated direct runoff during flood of July $17-25,1938$, for basins in New Jersey. 


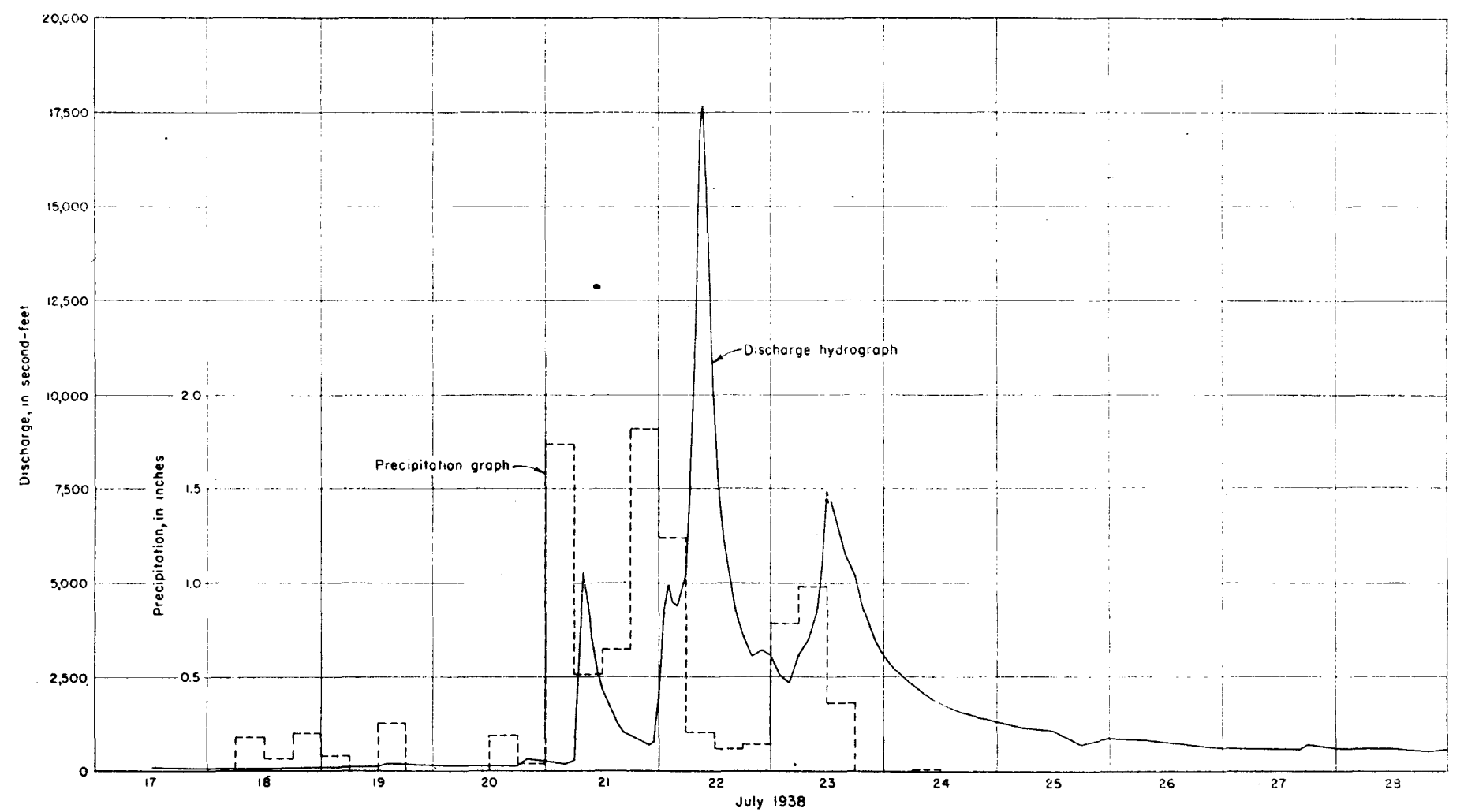


was 7.05 inches; average temperature at Hartford was $75^{\circ} \mathrm{F}$.; and direct surface runoff and accretion to ground-water storage (computed similarly to methods previously described) ${ }^{30}$ were 2.65 inches and 1.0 inch, respectively. Thus, about 3.4 inches of water remained, which was accounted for by transpiration, evaporation, and change in soil moisture. Using graphs developed by Meyer, ${ }^{31}$ adjusted on the basis of a year's record to make them applicable to the Park River Basin and adjusted also for the unusual conditions from July 18 to 31 , it may be roughly estimated that transpiration and evaporation amounted to 2.4 inches in the basin and that the soil moisture accordingly increased about 1.0 inch. It should be understood that these latter figures are estimates, presented only to indicate possible distribution of the rainfall. Figure 32 also portrays the changes in soil moisture from April 1 to September 30,1938 , in the Park River Basin.

To illustrate stream-flow behavior in the Catskill Mountain region, figure 40 shows rainfall and runoff for Rondout Creek near Lackawack, N. Y., during the storm and flood. The graph of the 6-hour rainfall shown on figure 40 is based on records of rainfall read once daily at seven nearby stations, supplemented by information of rainfall distribution at three recording rain gages adjoining the Catskill Mountain region. On July 17 there was no rain. In the period July 18-20 about 1.0 inch fell without any appreciable effect on river discharge. After these initial rains, rainfall during July 21, 22, and 23 resulted in large increments to stream flow. The flood crest occurred on July 22 following the intense rains that began over this basin about 6 p.m. on July 21 and that continued to 6 a.m. on July 22. (See table 30.)

TABLE 30.-Approximate volumes of rainfall and runoff, in inches, of Rondout Creek, near Lackawack Basin during the storm of July 17-25, 1938

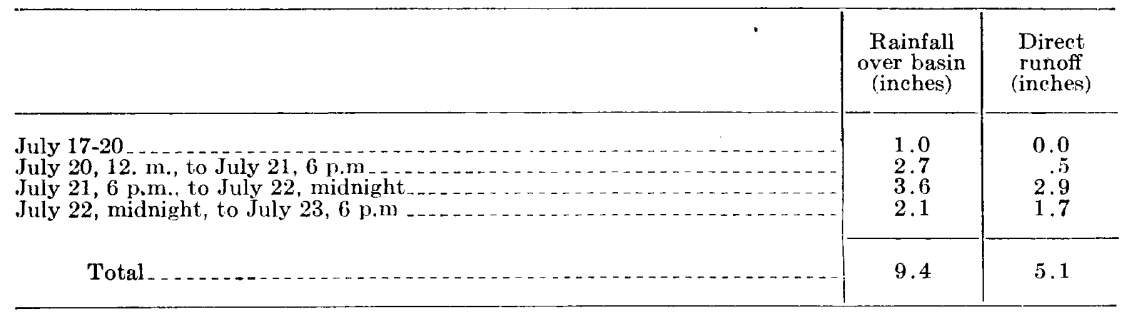

Table 30 indicates a significant increase in the part of the rainfall converted into runoff as the storm continued. The difference between total precipitation and direct runoff is 4.3 inches. How-

\footnotetext{
${ }^{30}$ Langbein, W. B., and others, Maximum winter and nonwinter floods in selected basins in New York and Pennsylvania: U. S. Geol. Survey Water-Supply Paper 915.

${ }^{31}$ Meyer, A. F., Elements of hydrology, 2d ed. (revised), figs. 164 and 272, pp. 263 and 457, New York, John Wiley \& Sons, 1928.
} 
ever, about 2.5 inches of the retention is accounted for by groundwater runoff during the storm and subsequent thereto, leaving about 1.8 inches as increment to soil moisture, evaporation, and transpiration.

The infiltration index for a particular basin and flood has been defined as a rate of rainfall so selected that the accumulated volume of rainfall received in excess of that rate will equal the volume of direct storm runoff. The method of computation was described by Langbein..$^{32}$ For the drainage basins above each of the following gaging stations the index, in inches per hour, was determined as indicated:

Infiltration index

(inch per hour)

Wading River near Norton, Mass. 0.18

Scantic River at Broad Brook, Conn. .10

Burlington Brook near Burlington, Conn. ................................ .17

Park River at Hartford, Conn. ................................................ .12

Shepaug River near Roxbury, Conn............................................. .17

Rockaway River above reservoir at Boonton, N. J. ................. .15

Rahway River at Rahway, N. J.

Deep Run near Brownton, N. J.

.21

Unfortunately, because of the variations in rainfall, accurate computations could not be made for areas that lacked recording rain-gage records, as in the Catskill Mountain region. The rates shown above are within the range defined for basins in the same areas by Water-Supply Paper $867^{33}$ during the hurrican floods of September 1938.

\section{FLOOD OF AUGUST 1938 IN THE CATSKILL MOUNTAIN REGION, NEW YORK}

By C. C. McDonald and W. B. Langbein

\section{INTRODUCTION AND GENERAL FEATURES}

The flood of August 1938 in the Catskill Mountain region was the result of a heavy rainstorm that had a maximum of more than 8 inches at the center and that was located over almost exactly the same area as the flood of July 17-25. Although the rainfall during the July storm was greater, the retention during that storm so diminished the absorptive capacity of the ground that the volumes of runoff in the subsequent flood were of comparable magnitudes in most basins. The total damage reported during the July flood exceeded that of the storm and flood of August 1938, but river stages on some rivers, particularly in the Delaware River drainage basin, exceeded those reached in July.

\footnotetext{
${ }^{32}$ Langbein, W. B., and others, op. cit.

${ }^{33}$ Paulsen, C. G., and others, Hurricane floods of September 1938: U. S. Geol. Survey WaterSupply Paper 867, pp. 440-442, 1940.
}

$748116-48-27$ 
There were three separate rainstorms in the period August 6-11. The first rain fell during the night of August 6 and reached a maximum of 3.21 inches at Grahamsville. As shown on figures $41-43$, this storm produced a sharp peak in runoff near midnight August 6. Light rainfall during the night of August 8-9 produced a rise in stream flow that was crested lower than the first peak. Maximum rain recorded during this period was 1.91 inches at Sundown.

The third rainstorm, on August 10 and 11, was the immediate cause of the flood of August 1938. Not only was it the heaviest of the three, but it fell on ground the absorptive capacity of which had been materially reduced by the preceding two rains. The maximum recorded rainfall for this storm was 4.90 inches, as measured at Balsam Lake on the morning of August 11, but more than 3 inches of rain fell on an area of more than 3,000 square miles in the Catskill Mountain region. Hydrographs of stream flow at selected gaging stations are shown on figures 41-43.

Large though not record-breaking floods occurred on August 11 in Rondout Creek, East and West Branches of the Delaware River, and Neversink River, draining a total area of about 1,600 square miles in the east, south, and west sections of the Catskill Mountains.

The location of these streams and of other places in the region are shown on figure 44. The Catskill Mountains, which reach as high as 4,204 feet at Slide Mountain, are rugged with steep land and stream slopes. In the East Branch of the Delaware River Basin above Fishs Eddy, for example, the average slope of the land is about 1,200 feet per mile (23 percent), and the tributary streams have a mean gradient of 122 feet per mile (2.3 percent). The upper part of the Wallkill River Basin is located south of the Catskill Mountains, and its valley above Pellets Island Mountain contains much swamp land and associated storage in natural channels. Otherwise there are relatively few large lakes or ponds that would provide natural storage for the reduction of flood discharges.

The discharge at five river-measurement stations exceeded 100 second-feet per square mile, and the greatest rate per square mile was 154 second-feet, recorded on Chestnut Creek above Red Brook, at Grahamsville, with a drainage area of 12.2 square miles. None of these five stations had areas in excess of 100 square miles. A study of discharge with respect to size of drainage area indicates that discharge was greatest on East Branch of Delaware River at Fishs Eddy, where the discharge from 783 square miles was 36,100 second-feet; on Rondout Creek near Lackawack (100 square 


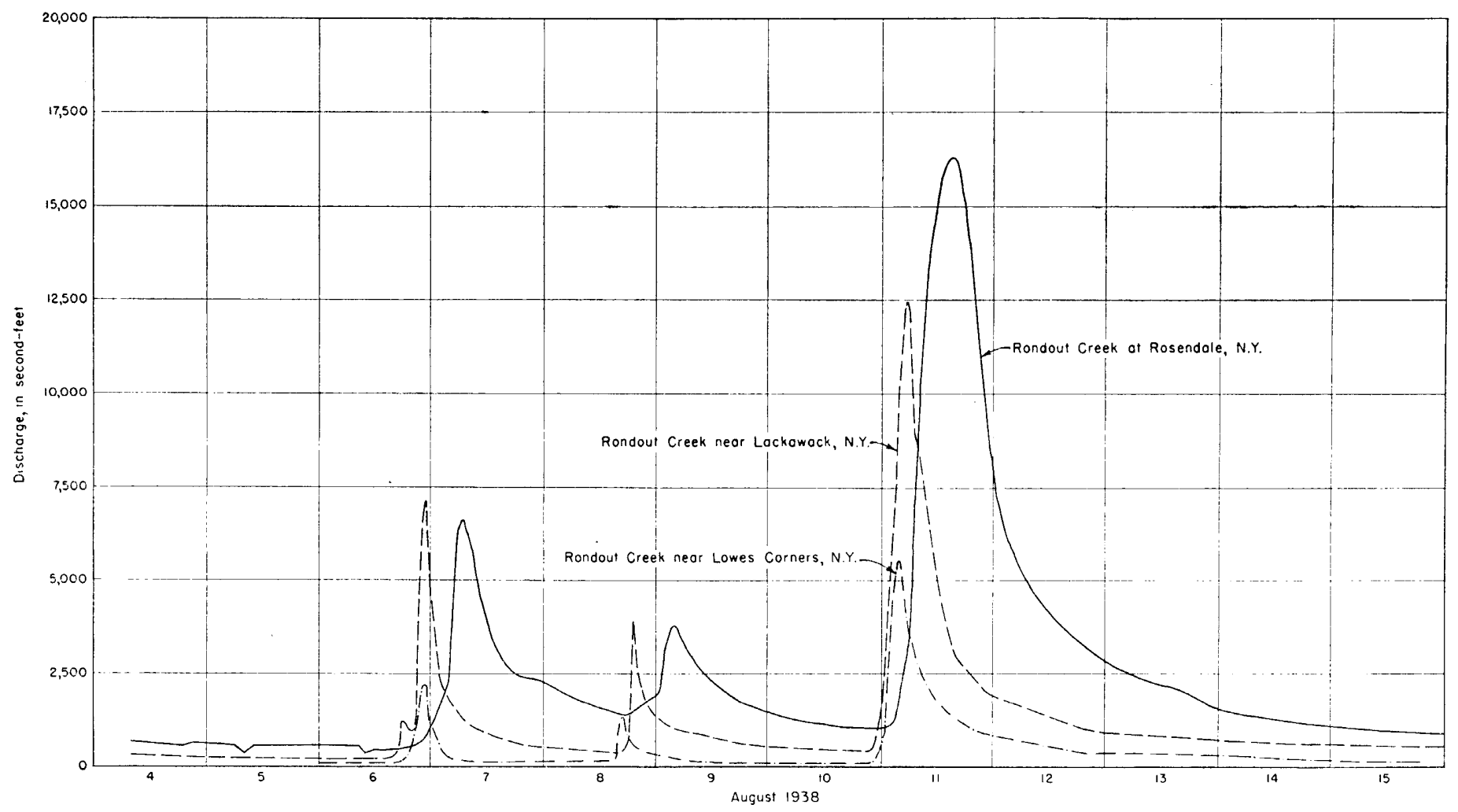

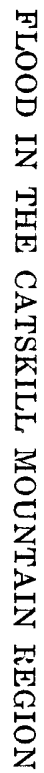

Figure 41.-Fydrographs of discharge at stream-gaging stations on Rondout Creek during the flood of August 1938. 


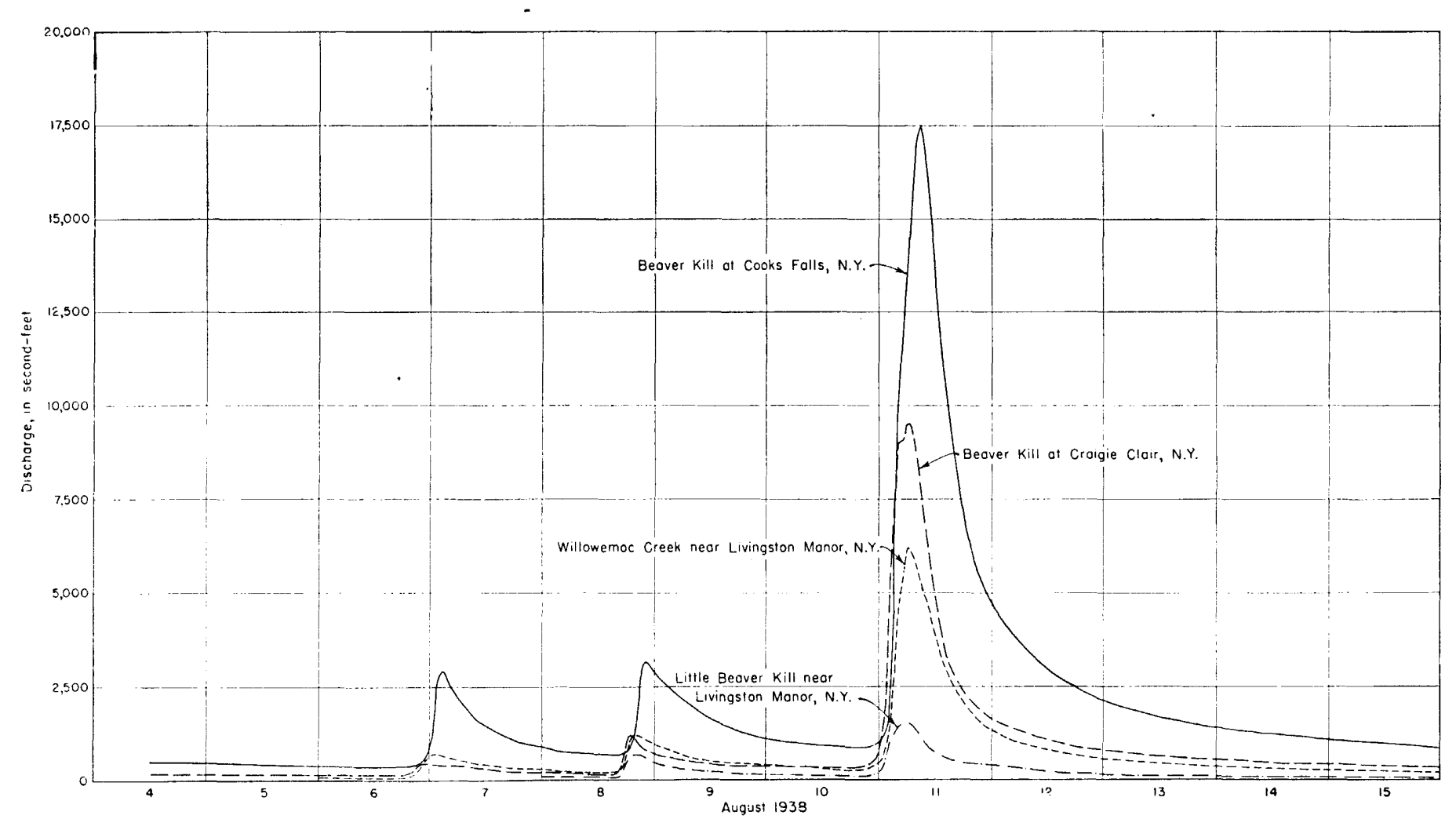

Figure 42.-Hydrographs of discharge at stream-gaging stations in the Beaver Kill Basin during the flood of August 1938. 


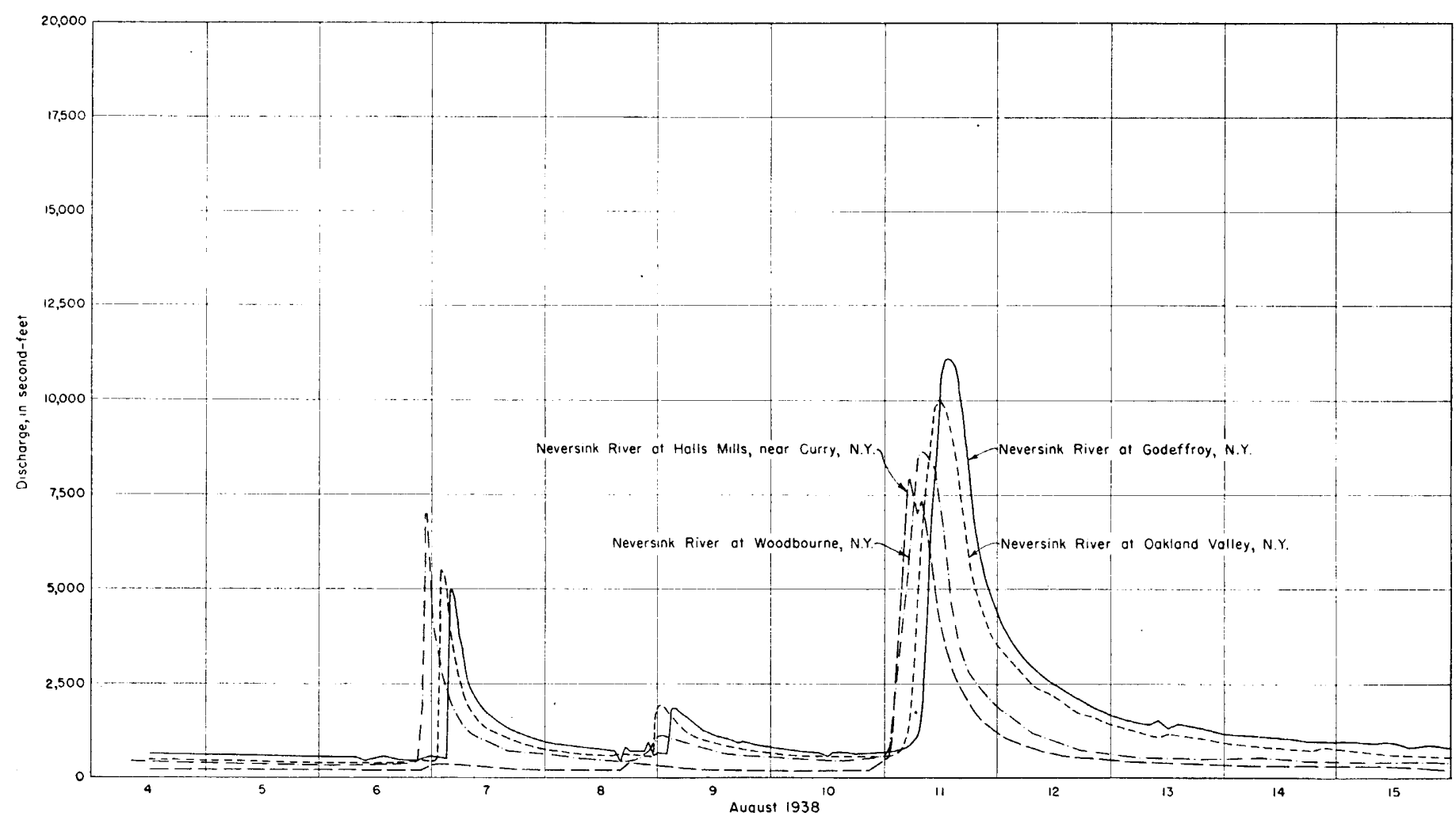

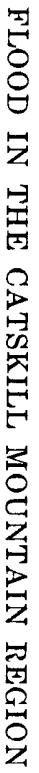

Figure 43.- Hydrographs of discharge at stream-gaging stations on Neversink River during the flood of August 1938 . 


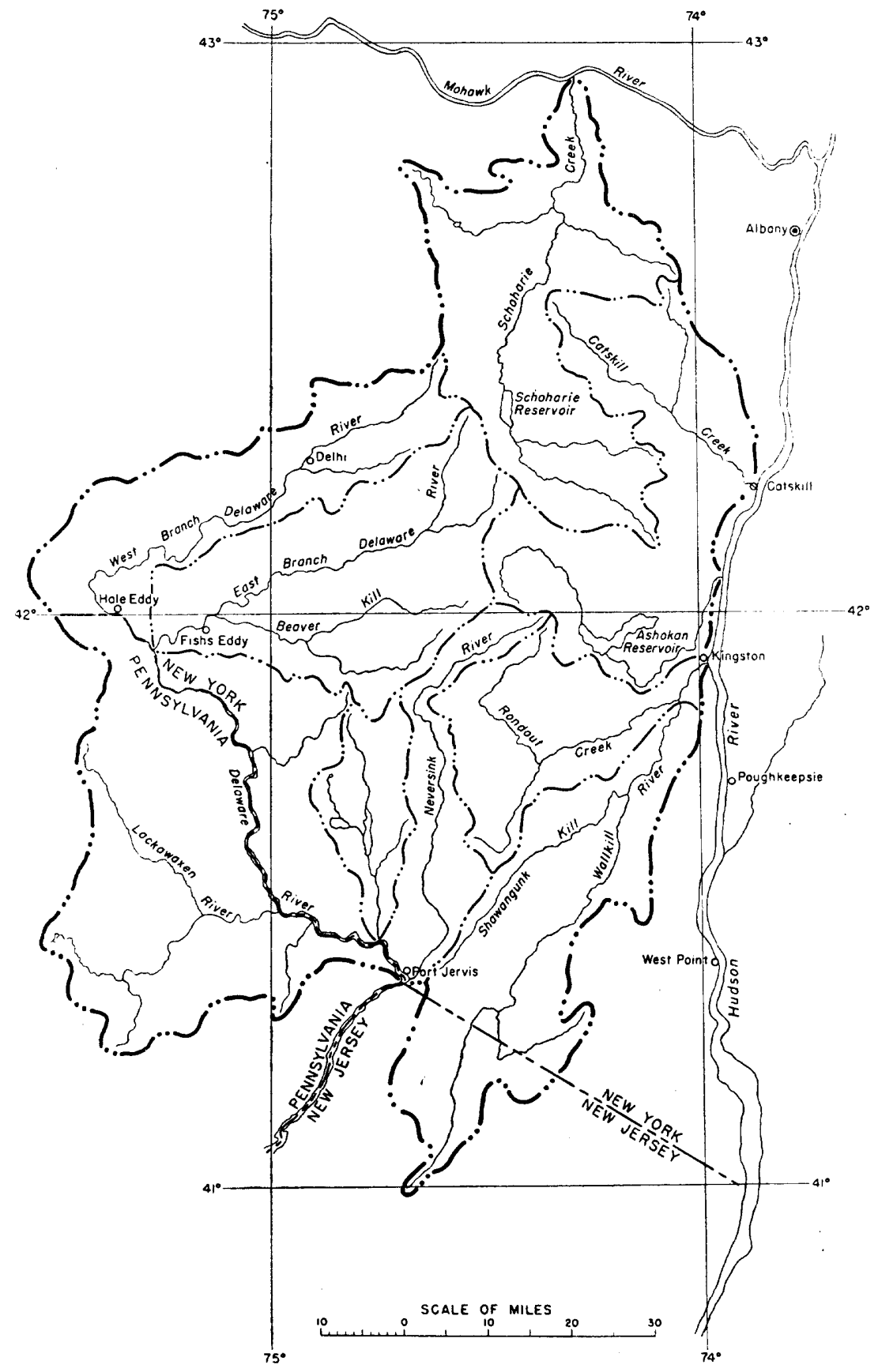

FIGUak 44.--Drainage map of Catskill Mountain region, New York. 
miles), where the discharge was 12,400 second-feet; on Rondout Creek near Lowes Corners (38.5 square miles) with a discharge of 5,600 second-feet; and Chestnut Creek above Red Brook, at Grahamsville (12.2 square miles), where the discharge was 1,880 second-feet. Comparisons of flood discharge on the basis of area alone, however, disregard the flood-producing characteristics of individual basins and the areal distribution of the precipitation.

Although the floods were widespread throughout the region and there was considerable interference with normal routine, very little information is available concerning monetary damages suffered. The streets of Livingston Manor were submerged during the flood of both July and August, as shown in plate 13, A. Electric service was interrupted in Roscoe and several nearby villages. Low-lying residences suffered, as shown in plate $13, \mathbf{B}$, and the tracks of the New York, Ontario and Western Railway were washed out at several points along Little Beaver Kill between Youngs Gap and Parksville. Seven bridges over Neversink River and Willowemoc Creek were destroyed, and State highways near Liberty, N. Y., and Cuddebackville, N. Y., were overflowed during the August flood. (See pl. 14.) Damage in Rondout Creek Basin and parts of Wallkill River Basin, resulting from the July flood, and in Upper Beaver Kill Basin, resulting from the August flood, was reported to be the greatest since the floods of August 1928. No loss of life was reported.

The floods in the Catskill Mountain region during these periods were not generally record breaking and were outshadowed by the great floods of September 1938,,$^{34}$ especially in the larger streams. They were, nevertheless, floods of greater than average intensity. It is believed that the information herein presented will serve to complete the hydrologic history of 1938 in the region and thus assist in an understanding of the flood characteristics of the Catskill Mountain region so necessary for formulating sound and effective measures for flood protection. This report contains information with respect to the outstanding flood of August 1938 similar in form and purpose to previous reports by the Geological Survey on the widespread inundations of March 1936 and the catastrophic floods of September 1938, both of which also affected the Catskill Mountain region to a serious extent.

\section{ANTECEDENT CONDITIONS}

The summer of 1938 in this region was unique in having three notable floods. In almost every stream one of these floods was the greatest of record. A study of maximum annual floods of Rondout

${ }^{34}$ Paulsen, C. G., and others, op. cit., $562 \mathrm{pp}$. 
Creek near Lackawack and Delaware River at Port Jervis summarized in table 31 discloses the following monthly distribution of floods during the period of record previous to 1938 at these places:

More than half the floods occurred during the three "break-up" months of late winter and early spring-February to April. Less than a fifth occurred from June to August. Considering that annual precipitation is relatively evenly distributed during the year, hydrologic conditions in summer apparently do not favor the production of great floods in this region and suggest that the three notable floods of the summer season of 1938 were events of rare occurrence indicative of a combination of unusual conditions. A heavy rainstorm, by increasing the soil moisture, lays the basis for a second flood; the effect of two heavy storms on the runoff from a third, all occurring at comparatively close intervals, is even more marked.

TABLE 31.-Monthly distribution of annual floods at two river-measurement stations in the Catskill Mountain region

\begin{tabular}{|c|c|c|}
\hline$\cdot$ & $\begin{array}{l}\text { Rondout Creek } \\
\text { near Lackawack }\end{array}$ & $\begin{array}{c}\text { Delaware River } \\
\text { at Port Jervis }\end{array}$ \\
\hline 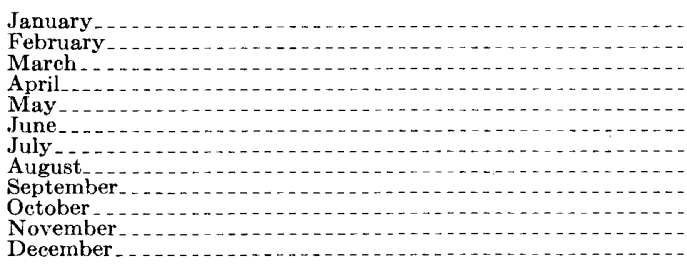 & $\begin{array}{l}4 \\
8 \\
6 \\
1 \\
1 \\
1 \\
2 \\
1 \\
1 \\
4 \\
3\end{array}$ & 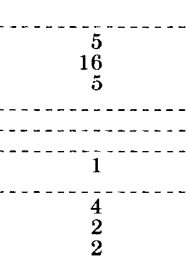 \\
\hline Years of recoro & 32 & 35 \\
\hline
\end{tabular}

TABLE 32.-Monthly precipitation and temperature at Jeffersonville, N. Y., during the spring and summer of 1938

\begin{tabular}{|c|c|c|c|c|c|}
\hline \multirow{2}{*}{ Month } & \multicolumn{3}{|c|}{ Precipitation, in inches } & \multicolumn{2}{|c|}{$\begin{array}{c}\text { Temperature, } \\
\text { in degrees Fahrenheit }\end{array}$} \\
\hline & Total & $\begin{array}{l}\text { Departure } \\
\text { from normal }\end{array}$ & $\begin{array}{l}\text { Cumulative } \\
\text { departure } \\
\text { from normal }\end{array}$ & Mean & $\begin{array}{l}\text { Departure } \\
\text { from normal }\end{array}$ \\
\hline 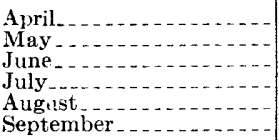 & $\begin{array}{l}3.96 \\
3.86 \\
3.65 \\
7.58 \\
5.39 \\
7.99\end{array}$ & $\begin{array}{r}+0.76 \\
+.62 \\
+.14 \\
+2.94 \\
+.77 \\
+4.33\end{array}$ & $\begin{array}{l}+0.76 \\
+1.38 \\
+1.24 \\
+4.18 \\
+4.95 \\
+9.28\end{array}$ & $\begin{array}{l}47.0 \\
52.6 \\
63.6 \\
68.4 \\
68.8 \\
56.0\end{array}$ & $\begin{array}{r}+2.4 \\
-2.8 \\
+.2 \\
+.5 \\
+2.9 \\
-4.0\end{array}$ \\
\hline
\end{tabular}

NoTE.--Based on data furnished by U. S. Weather Bureau. 
TABLE 33.-Daily precipitation, in inches, Aug. 5-12, 1938, at stations in and near the Catskill Mountain region, New York

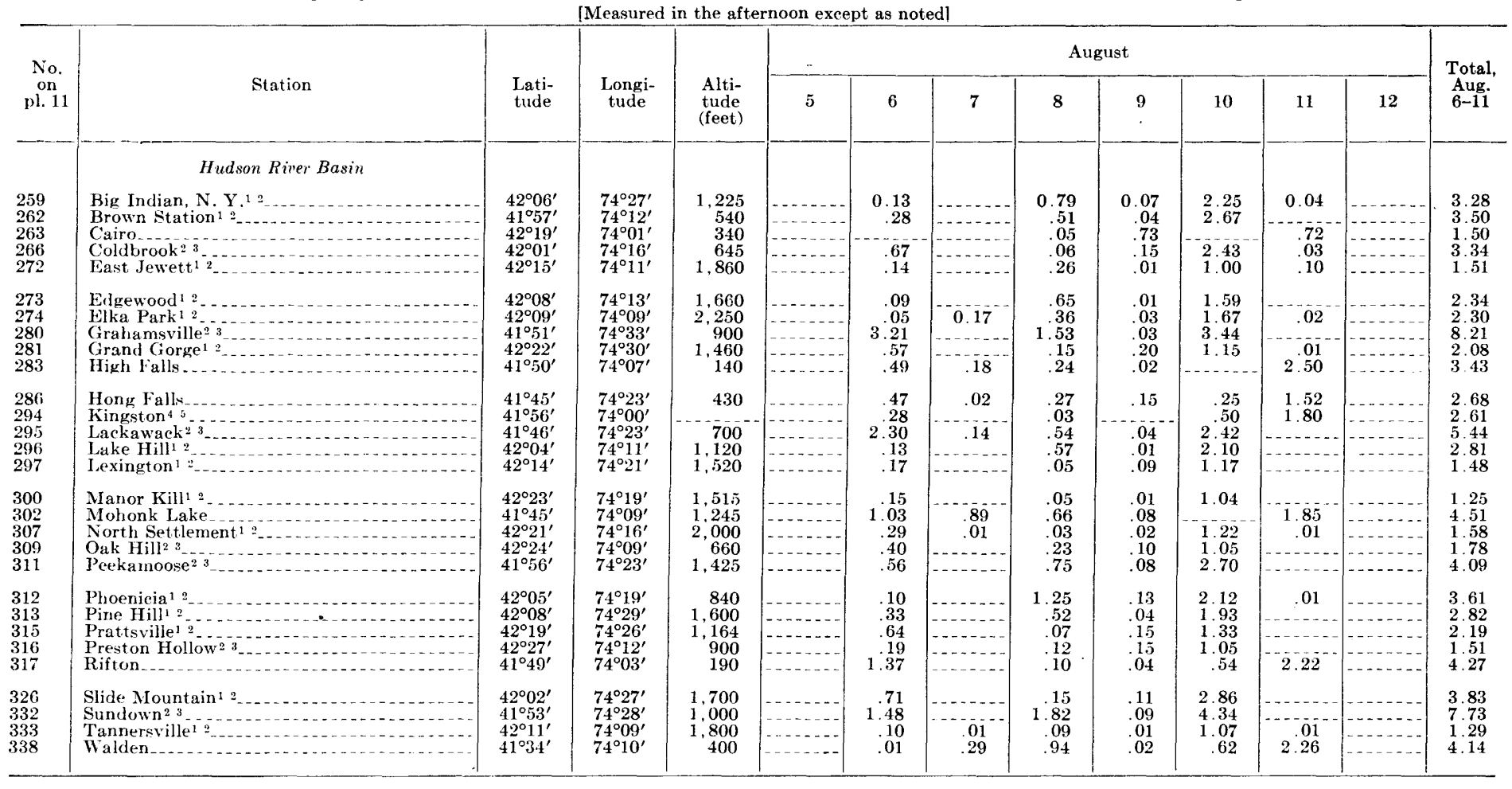


TABLE 33--Daily precipitation, in inches, Aug. 5-12, 1938, at stations in and near the Catskill Mountain region, New York-Continued

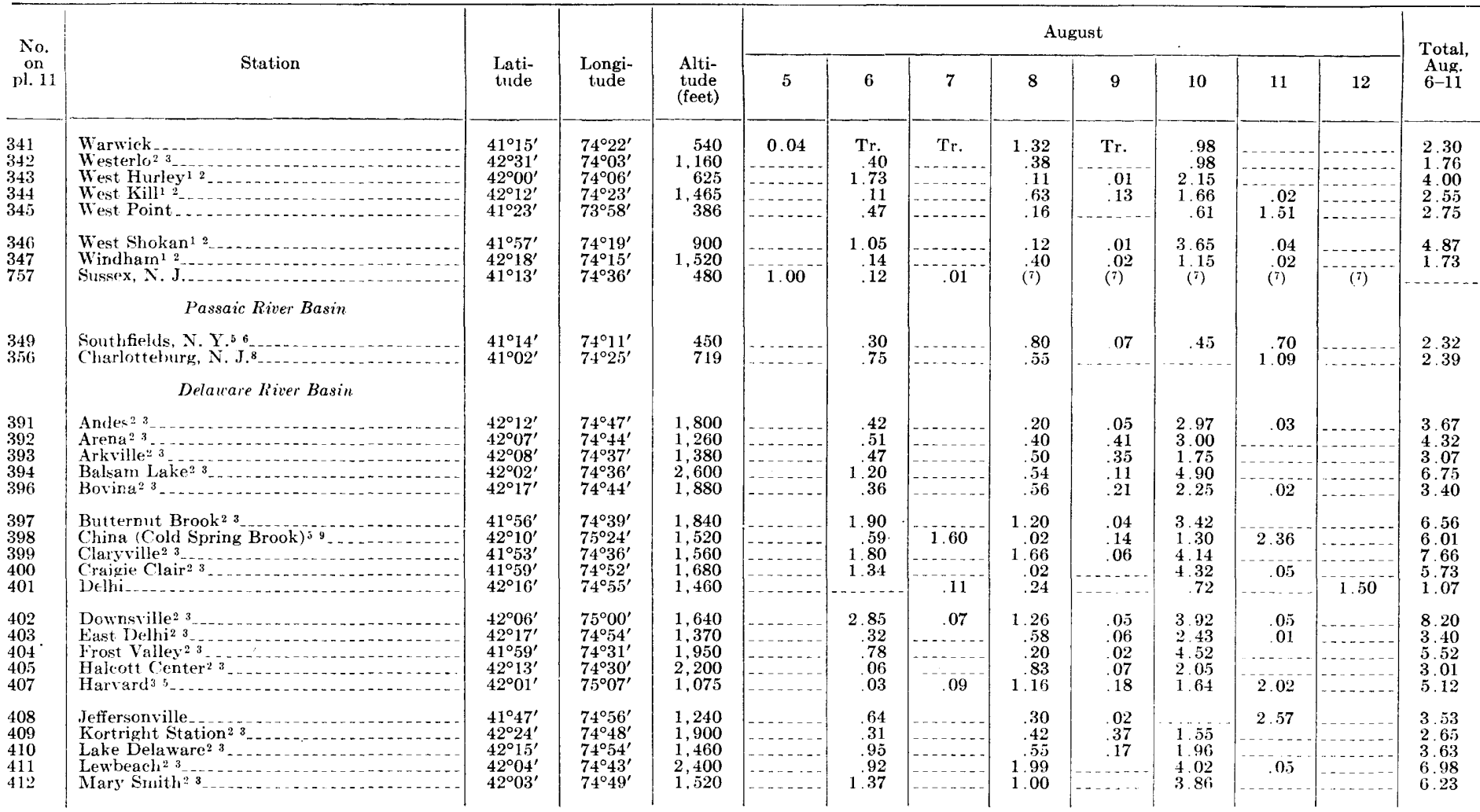




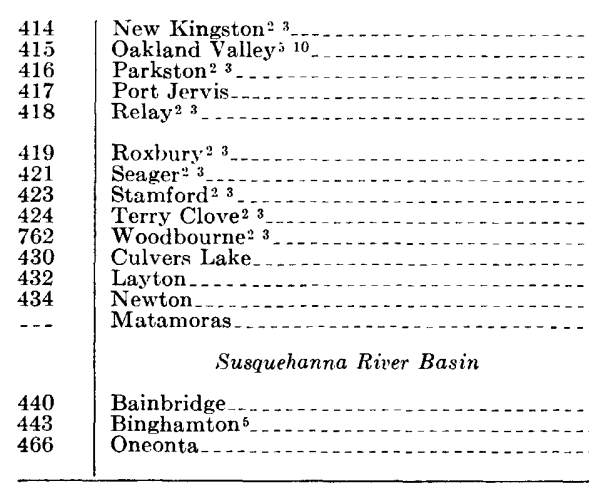

1New York City Department of Water Supply, Gas, and Electrieity. 3Neasured in morning after day indicated.

${ }^{4}$ City of Kingston.

Measured at midnight.

\begin{tabular}{|c|c|c|c|c|c|c|c|c|c|c|c|}
\hline $\begin{array}{l}42^{\circ} 13^{\prime} \\
41^{\circ} 30^{\prime} \\
41^{\circ} 54^{\prime} \\
41^{\circ} 22^{\prime} \\
42^{\circ} 19^{\prime}\end{array}$ & $\begin{array}{l}74^{\circ} 41^{\prime} \\
74^{\circ} 39^{\prime} \\
74^{\circ} 49^{\prime} \\
74^{\circ} 42^{\prime} \\
74^{\circ} 38^{\prime}\end{array}$ & $\begin{array}{r}1,780 \\
654 \\
1,500 \\
550 \\
2,080\end{array}$ & $\mid$\begin{tabular}{c}
$-\ldots \ldots$ \\
\hdashline$\ldots$ \\
\hdashline$-\ldots$
\end{tabular} & $\begin{array}{r}.35 \\
.99 \\
.03 \\
1.50\end{array}$ & 01 & $\begin{array}{r}1.05 \\
.42 \\
1.04 \\
.18 \\
.48\end{array}$ & $\begin{array}{l}.20 \\
.08 \\
.02 \\
.20\end{array}$ & $\begin{array}{r}2.46 \\
.79 \\
2.92 \\
.31 \\
1.86\end{array}$ & $\begin{array}{r}.04 \\
1.31 \\
.04 \\
1.03 \\
.18\end{array}$ & $\mid \begin{array}{l}-- \\
-- \\
-\cdots \\
-\cdots\end{array}$ & $\begin{array}{l}4.10 \\
2.60 \\
4.99 \\
1.58 \\
4.22\end{array}$ \\
\hline $\begin{array}{l}42^{\circ} 17^{\prime} \\
42^{\circ} 04^{\prime} \\
42^{\circ} 24^{\prime} \\
42^{\circ} 08^{\prime} \\
41^{\circ} 45^{\prime} \\
41^{\circ} 09^{\prime} \\
41^{\circ} 14^{\prime} \\
41^{\circ} 03^{\prime}\end{array}$ & $\begin{array}{l}74^{\circ} 35^{\prime} \\
74^{\circ} 33^{\prime} \\
74^{\circ} 37^{\prime} \\
74^{\circ} 54^{\prime} \\
74^{\circ} 36^{\prime} \\
74^{\circ} 47^{\prime} \\
74^{\circ} 51^{\prime} \\
74^{\circ} 46^{\prime}\end{array}$ & $\begin{array}{r}1,494 \\
2,100 \\
1,827 \\
1,380 \\
1,260 \\
760 \\
480 \\
769\end{array}$ & \begin{tabular}{|l}
14 \\
.20
\end{tabular} & $\begin{array}{r}.35 \\
.30 \\
.40 \\
1.32 \\
.25 \\
.56 \\
.02 \\
.40\end{array}$ & $\begin{array}{c}\mathrm{Tr} . \\
.01\end{array}$ & $\begin{array}{r}.03 \\
1.18 \\
.02 \\
.20 \\
\\
\end{array}$ & $\begin{array}{l}.08 \\
.42 \\
.82 \\
.12 \\
.06 \\
05 \\
20\end{array}$ & $\begin{array}{r}1.95 \\
2.10 \\
1.28 \\
3.60 \\
2.70 \\
\\
\end{array}$ & $\begin{array}{l}.10 \\
1.14 \\
1.05 \\
1.40\end{array}$ & & $\begin{array}{l}2.51 \\
3.58 \\
2.12 \\
4.92 \\
3.15 \\
1.82 \\
1.13 \\
1.86 \\
1.65\end{array}$ \\
\hline $\begin{array}{l}42^{\circ} 18^{\prime} \\
42^{\circ} 06^{\prime} \\
42^{\circ} 27^{\prime}\end{array}$ & $\begin{array}{l}75^{\circ} 29^{\prime} \\
75^{\circ} 55^{\prime} \\
75^{\circ} 04^{\prime}\end{array}$ & $\begin{array}{r}1,006 \\
871 \\
1,112\end{array}$ & Tr. & .06 & $\begin{array}{l}.08 \\
.10 \\
.06\end{array}$ & $\begin{array}{l}01 \\
.15\end{array}$ & $\begin{array}{l}06 \\
.08\end{array}$ & $\begin{array}{l}.02 \\
.94 \\
.38\end{array}$ & $\begin{array}{l}3.06 \\
1.09 \\
1.40\end{array}$ & $\begin{array}{l}\mathrm{Tr} . \\
\mathrm{Tr} .\end{array}$ & $\begin{array}{l}3.22 \\
2.14 \\
2.13\end{array}$ \\
\hline
\end{tabular}

${ }^{6} \mathrm{By}$ Corps of Engineers, U. S. Army.

8City of Newark, Department of Public Affairs.

qU. S. Geological Survey.

10Federal-State Flood Foreasting Service of Pennsylvania, Harrisburg, Pa. 
Table 32 lists monthly rainfall at Jeffersonville, N. Y., in the Catskill Mountain region, during the spring and summer of 1938 . It shows that during each month except June there was a surplus of precipitation, the cumulated excess above normal at the end of July being 4.18 inches. Temperatures from April to July averaged about normal.

\section{PRECIPITATION}

Table 33 lists the daily amounts of precipitation measured during the rainstorm at 71 stations within or adjacent to the Catskill Mountain region maintained by the Weather Bureau, the city of New York, and other agencies as credited. The maximum for the period August 6-11 was 8.21 inches at Grahamsville, N. Y., in the upper Rondout Creek Basin, where the storm of July 1938 also was a maximum. The total rainfall for the storm period at the stations listed in table 33 has been plotted at their proper location on a map, and lines of equal rainfall have been drawn. (See fig. 45.) The isohyetal map shows a well-marked axis of maximum rainfall extending northwestward across the mountain region. There were two centers, each with more than 8 inches precipitation at the "eye."

The areas encompassed by the several isohyetal lines shown on figure 45 were measured by the planimeter, with results as given in table 34 .

TABLE 34.--Areas enclosed within indicated isohyets for storm of August 6-11, 1938

\begin{tabular}{|c|c|c|}
\hline \multirow[b]{2}{*}{ Isohyet } & \multicolumn{2}{|c|}{ Area, in square miles } \\
\hline & East center & West center \\
\hline 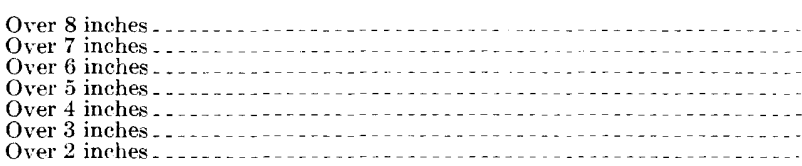 & $\begin{array}{r}4 \\
62 \\
230 \\
950 \\
1,730 \\
3,080 \\
4,500\end{array}$ & $\begin{array}{r}\begin{array}{r}4 \\
66 \\
210\end{array} \\
\end{array}$ \\
\hline Total area in Catskill Mountain region affected by storm. & 6,400 & \\
\hline
\end{tabular}

These data were used to compute the mean areal precipitation within the isohyetal lines and then to prepare an enveloping curve relating mean areal precipitation to the corresponding area. From this enveloping curve the following points showing mean precipitation over indicated areas for the storm of August 6-11, 1938, were taken in order to aid comparison of the storm with others in the region: 


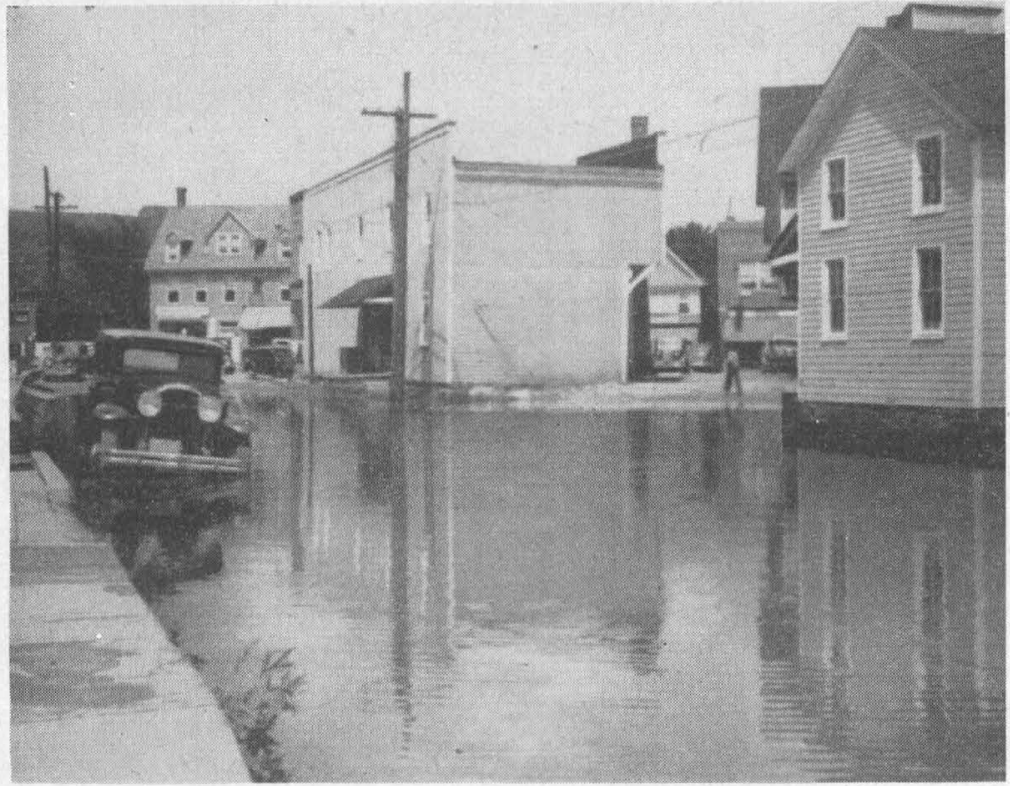

A. PEARL STREET, LIVINGSTON MANOR, N, Y.

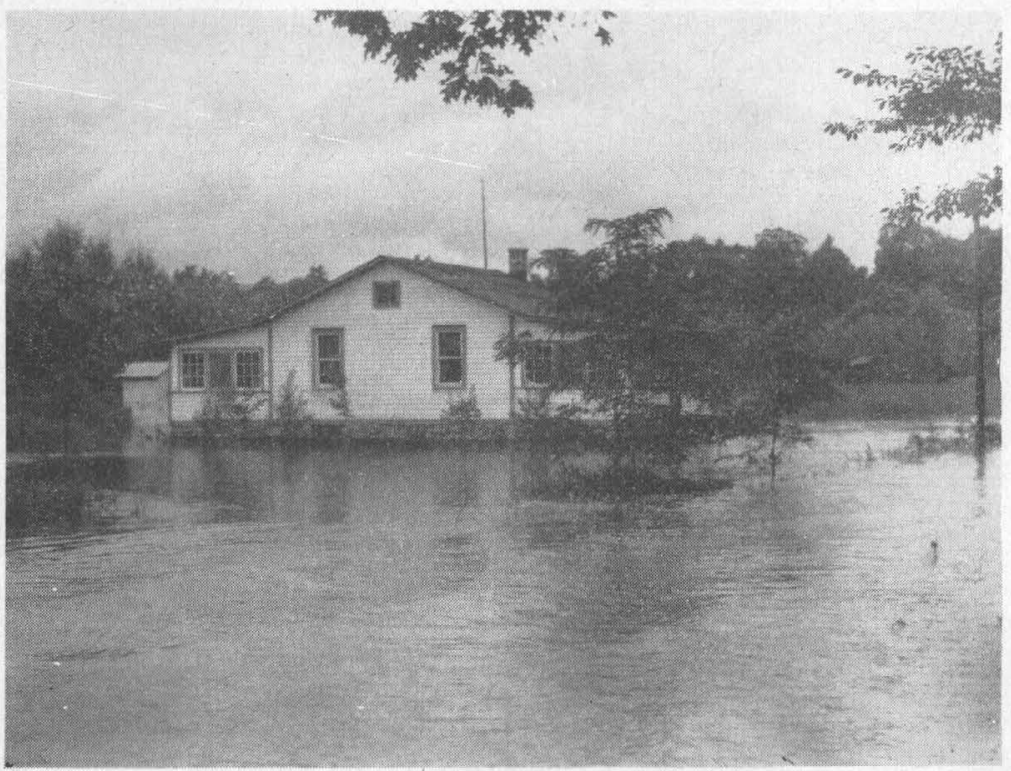

B. SUMMER RESIDENCE NEAR GODEFFREY, N. Y.

FLOOD SCENES, AUGUST 1938.

Photos"by Middletown (N. Y.) Times-Herald. 


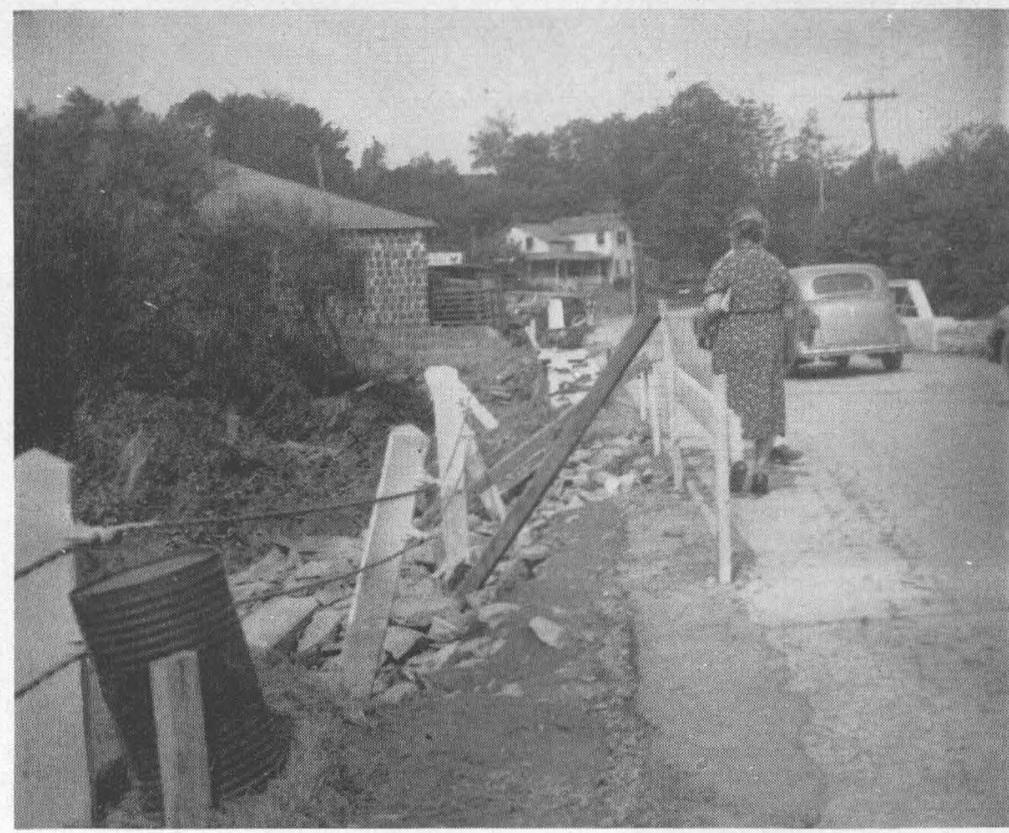

A. STATE HIGHWAY 52 NEAR LIBERTY, N. Y., AFTER BEING OVERFLOWED BY MONGAUP RIVER.

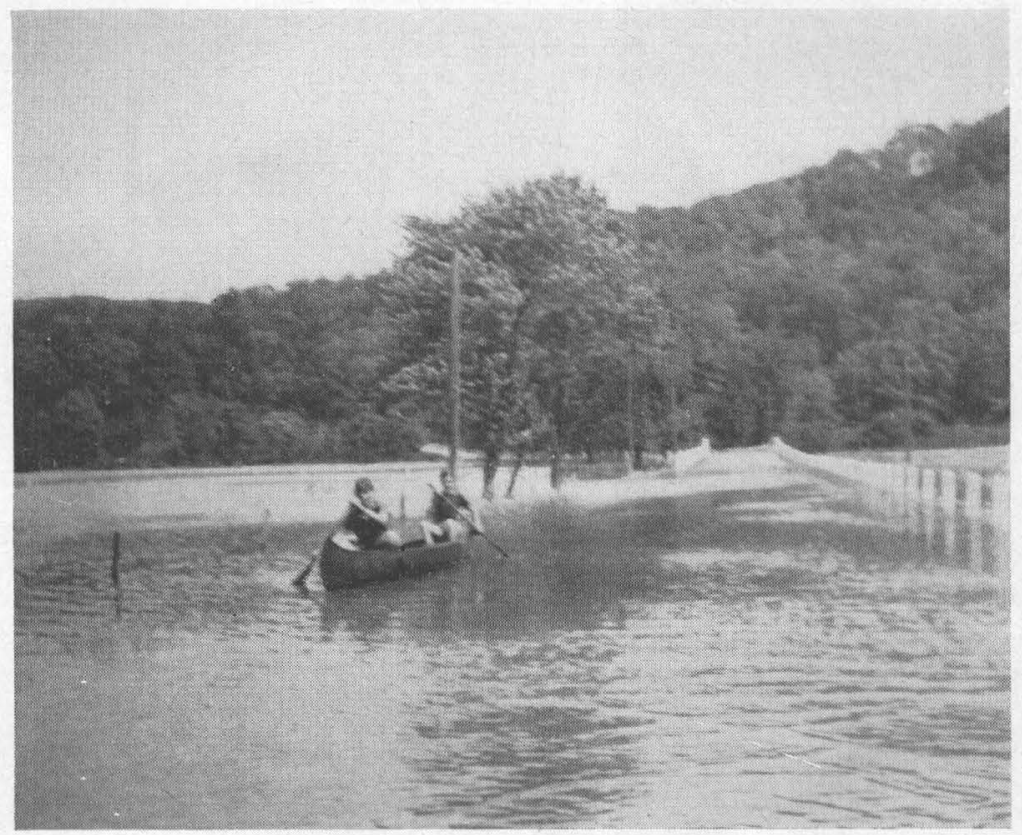

B. STATE HIGHWAY 211 NEAR CUDDEBACKVILLE, N. Y., OVERFLOWED BY NEVERSINK RIVER.

HIGHWAY SCENES, FLOOD OF AUGUST 1938.

Photos by Middletown (N. Y.) Times-Herald. 


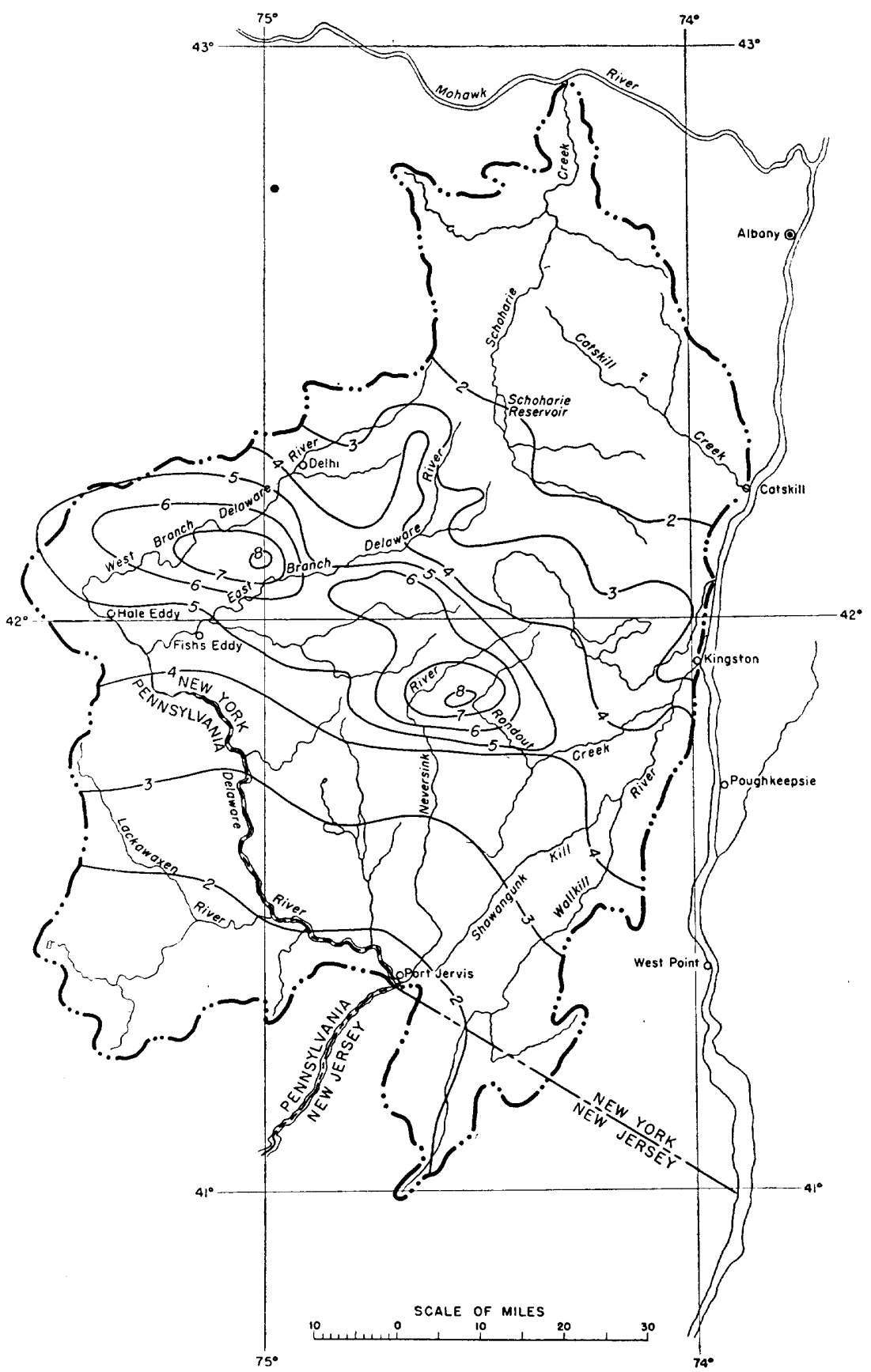

Figure 45.-Map of Catskill Mountain region showing lines of equal precipitation, August 6-11, 1938. 


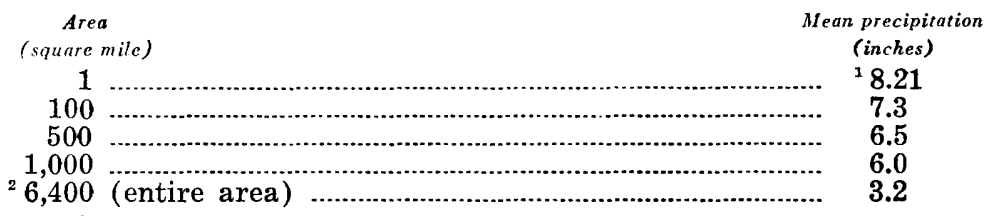

1 Total storm precipitation recorded at Grahamsville.

2 Total area in Catskill Mountain region affected by storm.

The mean precipitation on 500 square miles and less in the foregoing table correctly evaluates the area-depth relations in the storm centered in the Catskill Mountain region. As shown on figure 45 , the 5 -inch isohyetal, enclosing an area of 950 square miles, is nearly closed within the outlines of the region being considered. Isohyetals of less amounts extend beyond the boundaries, and the areas here reported within those isohyetals include only the part within the boundaries shown on figure 45. As a result, the computed mean areal precipitation over areas greater than 950 square miles given in table 34 are not necessarily the greatest values associated with the storm of August 6-11.

On the basis of data given in the table above, the storm had less precipitation over the indicated areas than any listed by the Miami Conservancy District ${ }^{35}$ for 5-day periods.

The precipitation, however, as shown on figure 45 , was not uniform during the period, most of it having fallen during the night of August 10. This rainfall produced the maximum stages and discharges that marked the flood.

As indicated by the recording rainfall records listed in table 35 and shown graphically on figure 46, rain began falling between 6 and 9 p.m. on August 10 and continued until about 8 a.m. to noon August 11, the duration varying between 12 and 19 hours. None of the recording gages were in the central storm area, so observations of maximum hourly rainfall are not available. However, the hourly records available indicate that about a fifth of the total rainfall occurred in the maximum hour, and accordingly it may be estimated that about 1.0 inch of rain fell in 1 hour at Balsam Lake, where a total of 4.90 inches of rain was measured.

Figure 47 shows isohyetal lines of precipitation on the night of August 10, based on records of daily rainfall in table 33. For those rain gages read on the morning of August 11 but recorded as of August 10, the map is based on the entry August 10. For those rain gages read during the evening and recorded as of the day read, the total of the measurements made on August 10 and 11 is used.

\footnotetext{
${ }^{35}$ Storm rainfall of eastern United States: Miami Conservancy District, Tech. Repts., pt. 5 (revised), table 6, pp. 278-279, 1936.
} 


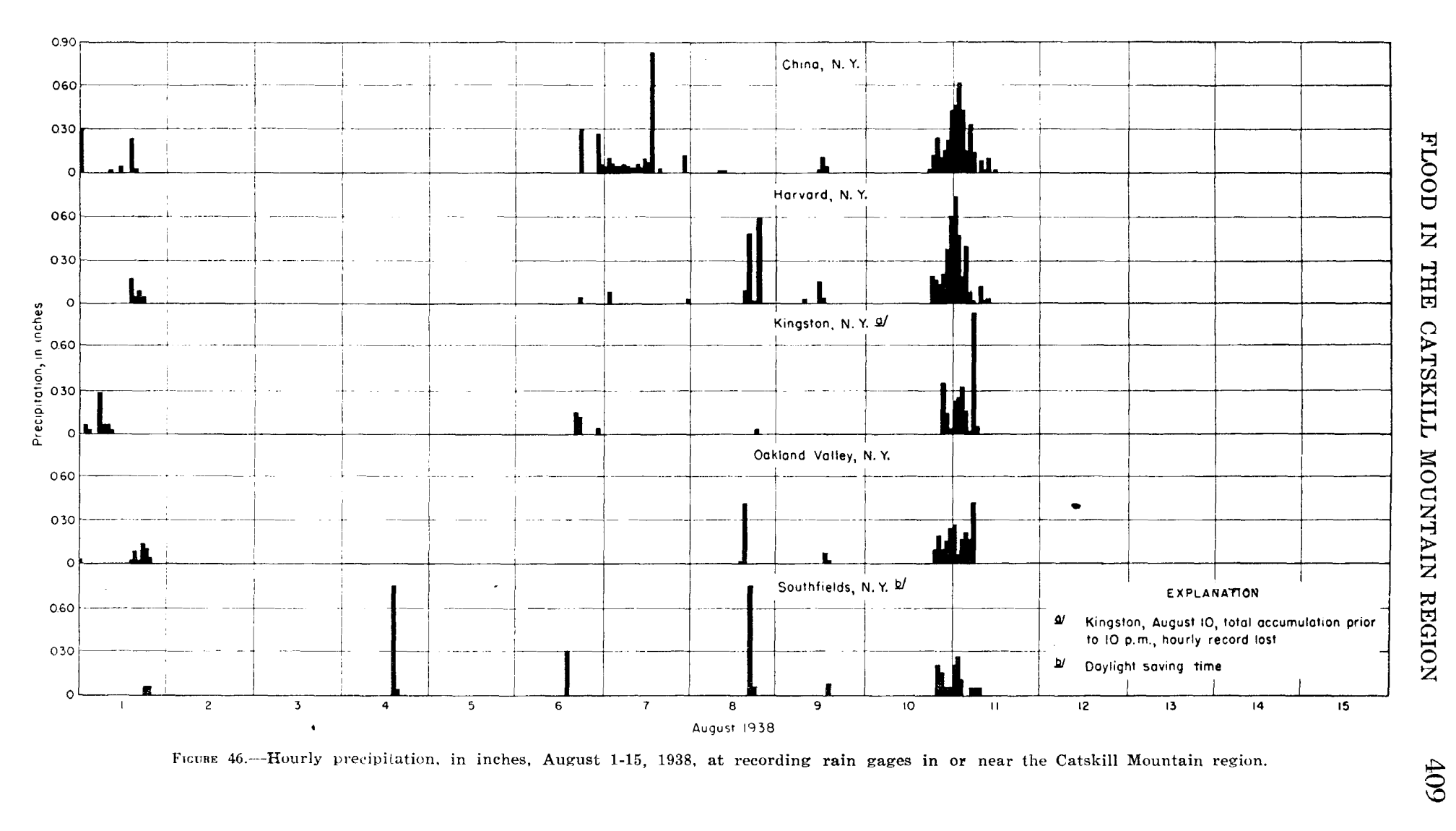


TABLE 35.-Precipitation, in inches, for period

\begin{tabular}{|c|c|c|c|c|c|c|c|c|}
\hline \multirow{2}{*}{$\begin{array}{l}\text { No. } \\
\text { on } \\
\text { pl. } 11\end{array}$} & \multirow[b]{2}{*}{ Station } & \multirow[b]{2}{*}{ Day } & & & & & & \\
\hline & & & 1 & 2 & 3 & 4 & 5 & 6 \\
\hline 294 & $\begin{array}{l}\text { Kingston, N. Y. } \\
\text { City engineer, Kingston, N. Y... }\end{array}$ & $\begin{array}{r}6 \\
7 \\
8 \\
9 \\
10 \\
11\end{array}$ & \begin{tabular}{|l|} 
\\
\hdashline \\
0.22 \\
\end{tabular} & \begin{tabular}{|c|}
.- \\
\hdashline 0.24 \\
0
\end{tabular} & \begin{tabular}{c}
$\cdots$ \\
$\cdots$ \\
\hdashline 0.31 \\
\hdashline$\overline{0}$
\end{tabular} & \begin{tabular}{|c|} 
\\
\hdashline \\
\hdashline 0.15 \\
\end{tabular} & {$\left[\begin{array}{c}\cdots \\
\hdashline 0.01 \\
\hdashline\end{array}\right.$} & \begin{tabular}{|c} 
\\
0.83 \\
0.
\end{tabular} \\
\hline 349 & $\begin{array}{l}\text { Southfields, N. Y. } \\
\text { Corps of Engineers, U. S. Army }\end{array}$ & $\begin{array}{r}6 \\
7 \\
8 \\
9 \\
10 \\
11\end{array}$ & $\left|\begin{array}{c}-\cdots \\
-1 . \\
\hdashline .25 \\
\hdashline \\
\hdashline .0 \\
\end{array}\right|$ & \begin{tabular}{|c|}
-10 \\
.10
\end{tabular} & … & 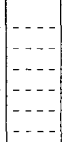 & \begin{tabular}{|c|c} 
\\
0.05 \\
.05
\end{tabular} & {$\left[\begin{array}{c}\ldots \\
\hdashline .05 \\
\hdashline .05 \\
\hdashline\end{array}\right.$} \\
\hline 398 & $\begin{array}{l}\text { China, N. Y. } \\
\text { U.S. Geological Survey } \ldots \ldots \ldots\end{array}$ & $\begin{array}{r}6 \\
7 \\
8 \\
9 \\
10 \\
11\end{array}$ & \begin{tabular}{|c|}
-.04 \\
-04 \\
.46
\end{tabular} & \begin{tabular}{c}
.09 \\
\hdashline .62 \\
\hdashline
\end{tabular} & $\begin{array}{c}.06 \\
-43 \\
-1.2 \\
-.43\end{array}$ & $\begin{array}{r}.04 \\
\hdashline .15 \\
\hdashline \\
\hdashline\end{array}$ & $\begin{array}{c}.04 \\
-24 \\
-34\end{array}$ & \begin{tabular}{c}
.05 \\
-14 \\
\hdashline .15
\end{tabular} \\
\hline 407 & $\begin{array}{l}\text { Harvard, N. Y. } \\
\text { New York City Board of Water Supply .......... }\end{array}$ & $\begin{array}{r}6 \\
7 \\
8 \\
9 \\
10 \\
11\end{array}$ & 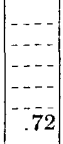 & \begin{tabular}{r}
-.07 \\
\hdashline .46 \\
.07 \\
\end{tabular} & \begin{tabular}{|c}
$\ldots$ \\
\hdashline$\ldots$ \\
\hdashline 18 \\
\hdashline .18 \\
\hdashline
\end{tabular} & \begin{tabular}{|r|}
.. \\
.40
\end{tabular} & \begin{tabular}{|c|c}
- \\
.08
\end{tabular} & \begin{tabular}{c}
0. \\
\hdashline .01 \\
\hdashline .01 \\
0
\end{tabular} \\
\hline 415 & $\begin{array}{l}\text { Oakland Valley, N. Y. } \\
\text { Federal-State Flood Forecasting Service of Pennsylvania, } \\
\text { Harrisburg, Pa. }\end{array}$ & $\begin{array}{r}6 \\
7 \\
8 \\
9 \\
10 \\
11\end{array}$ & 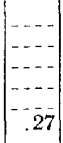 & \begin{tabular}{|c|} 
\\
\hdashline .06 \\
.06
\end{tabular} & \begin{tabular}{c}
- \\
\hdashline .17 \\
\hdashline
\end{tabular} & \begin{tabular}{|r|} 
\\
\hdashline- \\
-22 \\
.22 \\
\end{tabular} & \begin{tabular}{|l|} 
\\
\hdashline
\end{tabular} & \begin{tabular}{|c}
$\ldots$ \\
.42 \\
.4 \\
.4 \\
\end{tabular} \\
\hline
\end{tabular}

The area of greatest precipitation during this period was generally coincident with the belt of maximum precipitation shown on the isohyetal map of total precipitation for the period August 6-11. The area-depth relation computed in a manner similar to that used for the total storm period is given below for the storm of August 10, 1938.

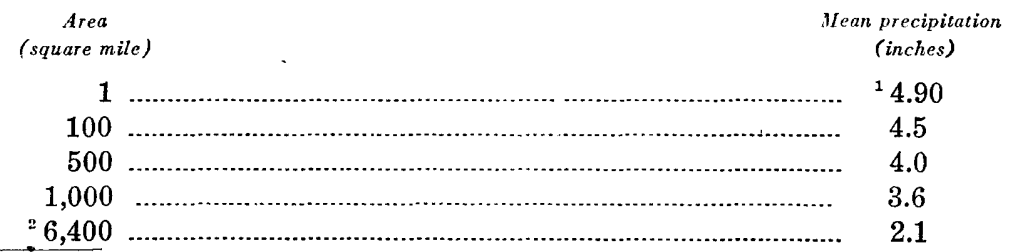

1 Recorded at Balsam Lake.

= Total area in Catskill Mountain region affected by storm.

The precipitation during the night of August 10 was less for equal areas than any other 1-day storm reported by the Miami Conservancy District ${ }^{36}$.

As an isolated storm event the rain during the night of August 10 would probably have passed without much effect, but the ex-

\footnotetext{
${ }^{36}$ Op. cit. (Storm rainfall of eastern United States), p. 278.
} 
ending at indicated time, August 1938

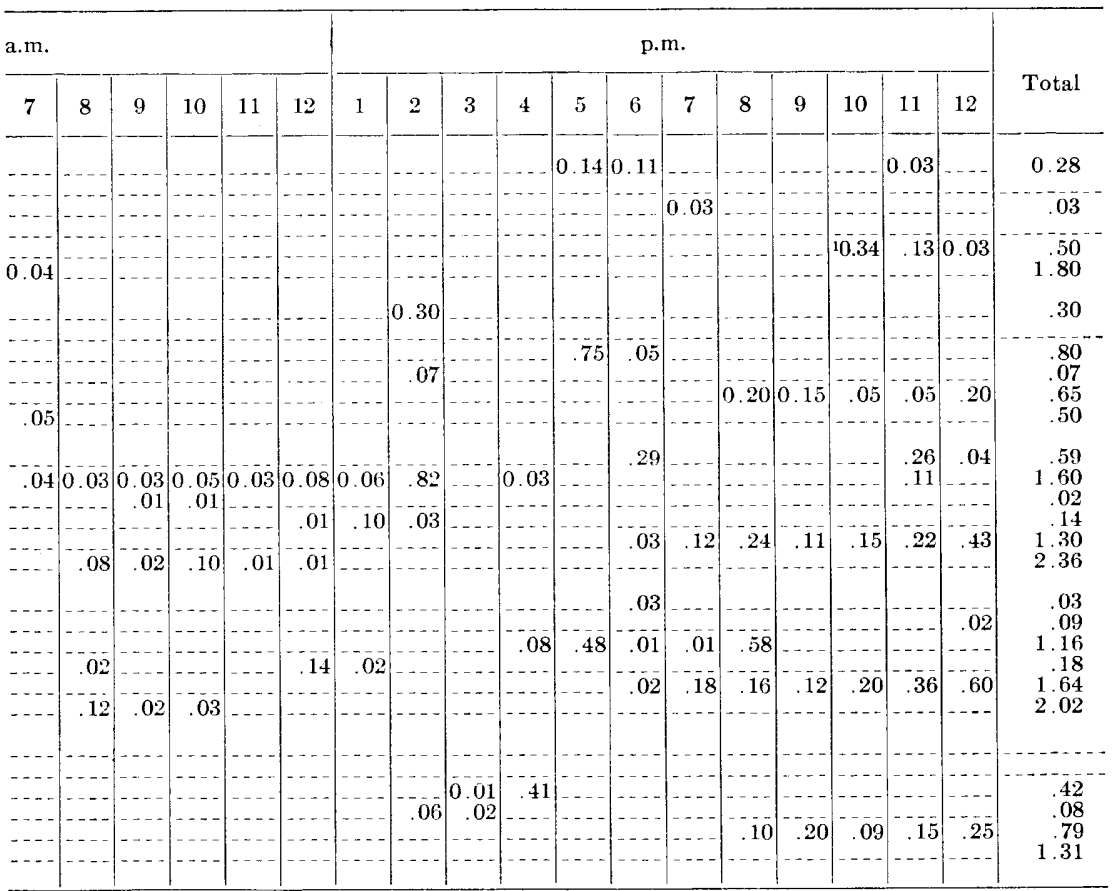

'Total prior to 10 p.m.

cessive rainfall that preceded it, as previously pointed out, decreased the absorptive capacity of the ground to the extent that an unusually large part of the storm rainfall appeared as direct runoff in stream channels.

\section{STAGES AND DISCHARGES AT RIVER-MEASUREMENT STATIONS}

Records of stage and discharge at 28 stations in the region affected by the floods are included in the section on "Floods of July 1938 in the northeastern States."

In general, the data presented for each stream-gaging station comprise a description of the station, a table showing mean daily discharges for July and August 1938, and a table showing the stage and corresponding discharge at indicated times during the flood period in sufficient detail for reasonably reliable delineation of hydrographs. The latter table is presented only for those stations in the areas experiencing the most severe floods. These tables are discussed fully on pages 8 to 11 .

Hydrographs of discharge at stream-gaging stations on several selected streams in the region during the August flood, as plotted from data given in this report, are shown on figures 41-43. 


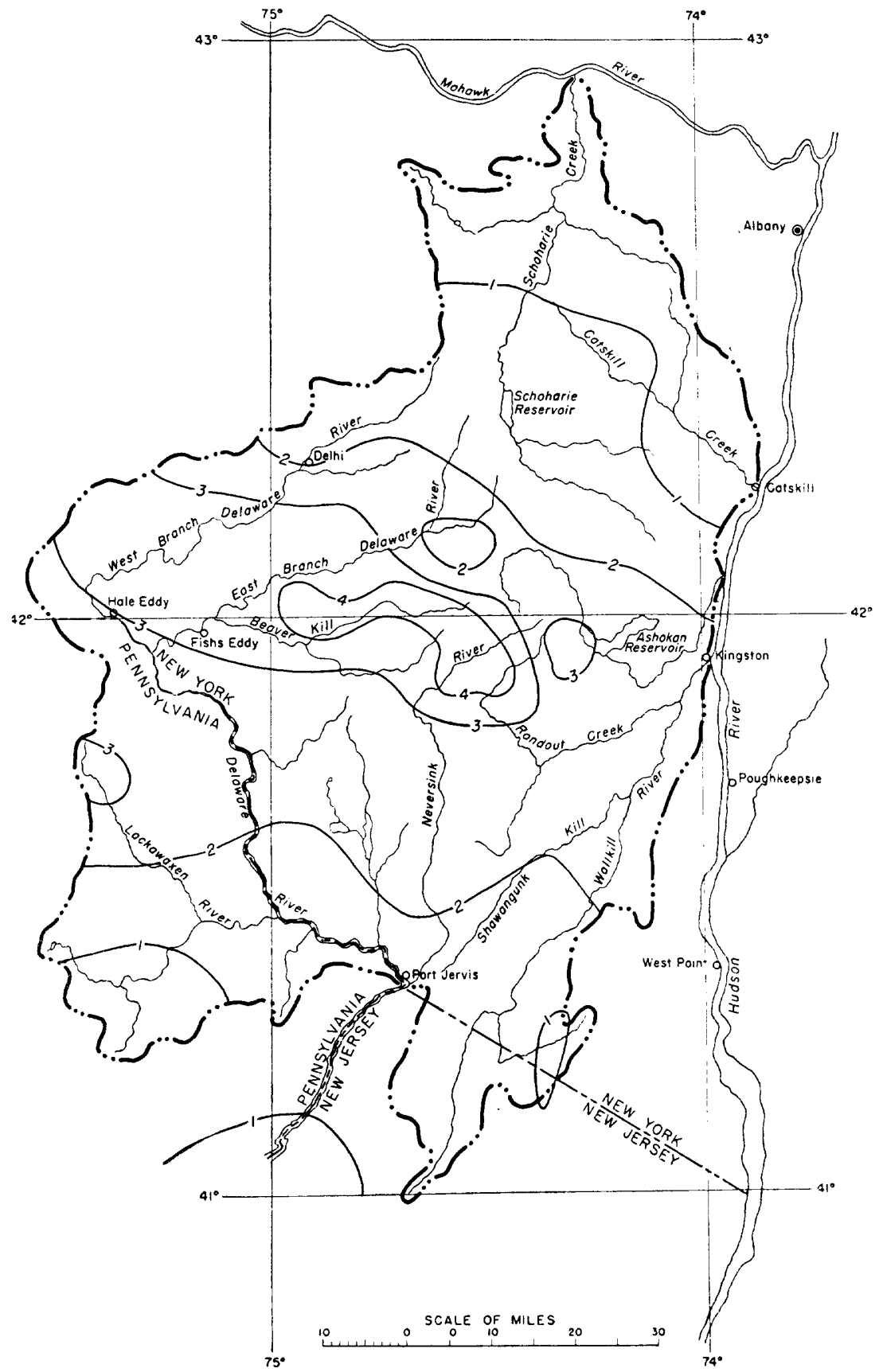

Ficuse 47.-Map of Catskill Mountain reyion showing lines of equal precipitation, night of August 10, 1938. 


\section{STORAGE}

The principal reservoirs in the Catskill Mountain region, as shown on figure 44, are Schoharie Reservoir on Schoharie Creek, Ashokan Reservoir on Esopus Creek, and Swinging Bridge and Toronto Reservoirs in the Mongaup River Basin. The impounding of the floodwaters in these reservoirs contributed materially to the attenuation of flood discharges in the lower reaches of these streams. For example, the crest discharge of Schoharie Creek at Prattsville, N. Y., on August 11 was 634 second-feet, whereas downstream the discharge over Gilboa Dam, which impounds Schoharie Creek in Schoharie Reservoir, did not exceed 150 secondfeet.

\section{SUMMARY OF FLOOD STAGES AND DISCHARGES}

The maximum flood discharges at the stream-gaging stations in the Catskill Mountain region during the flood of August 1938 are summarized in table 36. The numbers assigned to each gaging station in the table conform to those given in Water-Supply Paper $847^{37}$ and refer to its location, as shown on plate 12 and in the section on the flood of July 1938.

Comparisons of flood discharge during August with that of the preceding July indicate that the August flood was the greater in the basins of the East and West Branches of the Delaware River, an area of about 1,400 square miles. In the Beaver Kill Basin, tributary to the East Branch of the Delaware River, the August flood was also greater than that of September 1938. At Cooks Falls, where there were 25 years of continuous record, the crest discharge was 17,500 second-feet in comparison with the maximum of record of 19,000 second-feet reached in August 1933. At no other station with more than 2 years of record did the flood discharge of August so closely approach the maximum of record.

In order to define more completely the range of flood discharges in three of the principal streams draining the Catskill Mountain region, table 37 summarizes the annual maximum discharges in second-feet, with the date of occurence, at five selected streamgaging stations. Figure 48 presents graphically these annual maximum discharges, together with the maximum discharges that occurred during the floods of July, August, and September 1938. This graph vividly portrays the relative magnitude of the July and August floods and the hurricane flood of September, which, by its magnitude and great areal extent, tended to obscure the July and August floods, which might otherwise have been considered major floods in their respective localities.

${ }^{37}$ Williams, G. R., and Crawford, L. C., Maximum discharges at stream-measurement stations through December 31, 1937 ; U. S. Geol. Survey Water-Supply Paper 847, 272 pp., 1940. 
Table 36.-Maximum discharges during flood of August 1938 in the Catskill Mountain region.

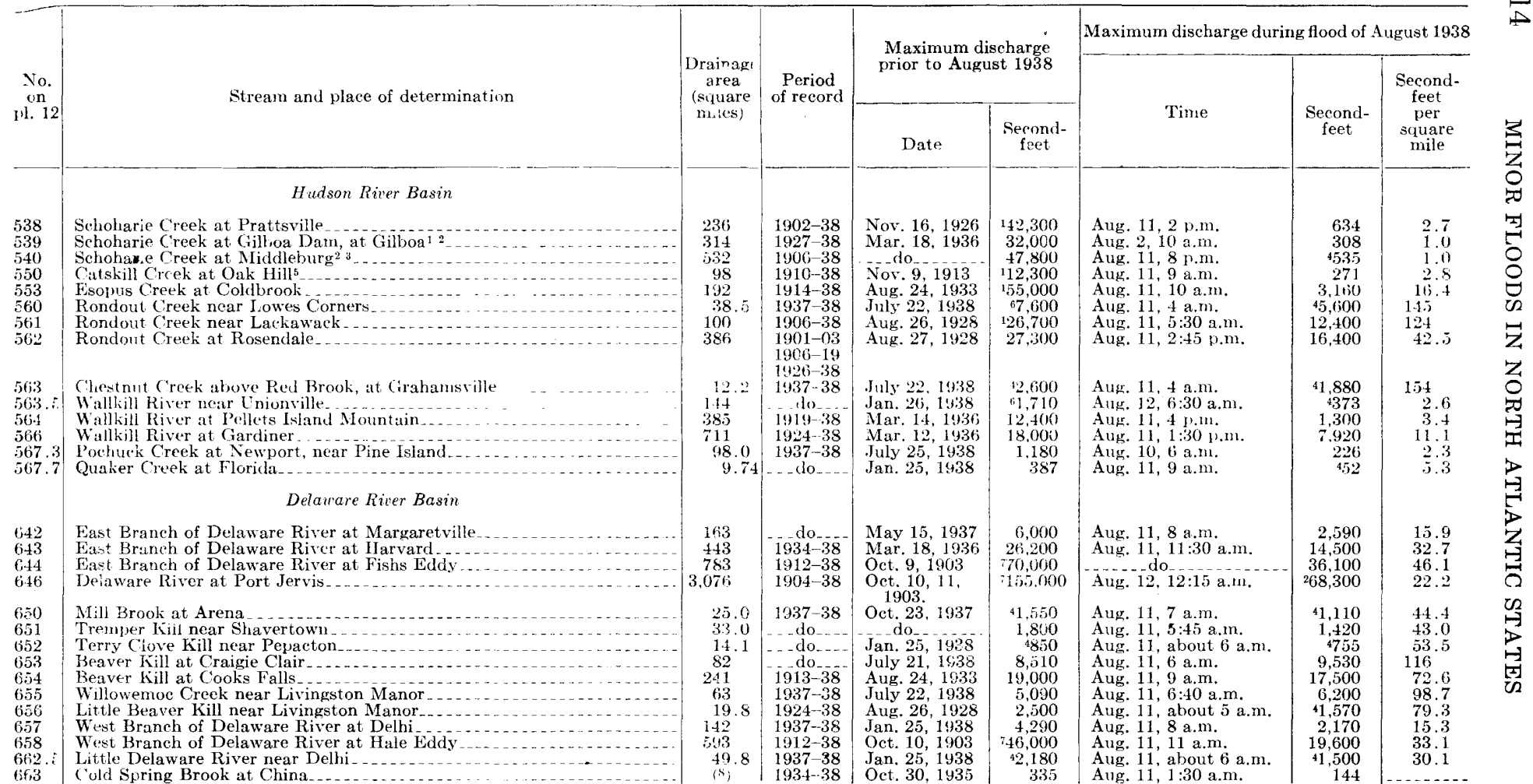




\begin{tabular}{|c|c|c|c|c|c|c|c|c|}
\hline $\begin{array}{l}667 \cdot 3 \\
667.7 \\
668 \\
669\end{array}$ & $\begin{array}{l}\text { Neversink River at Halls Mills, near Curry } \\
\text { Neversink River at Woodbourne } \\
\text { Neversink River at Oakland Valley } \\
\text { Neversink River at Godeffroy }\end{array}$ & $\begin{array}{r}68 \\
113 \\
222 \\
302\end{array}$ & $\begin{array}{l}1937-38 \\
-1928-38 \\
1903 \\
1909-14 \\
1937-38\end{array}$ & $\begin{array}{l}\text { Oct. } 23,1937 \\
\text { July } 22,1938 \\
\text { Aug. } 24,1933 \\
\text { July } 22,1938\end{array}$ & $\begin{array}{r}13,000 \\
112,300 \\
20,000 \\
16,100\end{array}$ & $\begin{array}{l}\text { Aug. 11, 5 a.m. } \\
\text { Aug. 11, about } 8 \text { a.m. } \\
\text { Aug. 11, } 11: 30 \text { a.m. } \\
\text { Aug. } 11,1: 30 \text { p.m. }\end{array}$ & $\begin{array}{r}7,940 \\
4,660 \\
9,960 \\
11,200\end{array}$ & $\begin{array}{r}117 \\
76.6 \\
44.9 \\
37.1\end{array}$ \\
\hline $\begin{array}{l}\text { 1Rec } \\
{ }^{2} \mathrm{Aff} \\
{ }^{3} \mathrm{Rec} \\
{ }^{4} \mathrm{Fro}\end{array}$ & $\begin{array}{l}\text { ords furnished by New York City Board of Water Supply. } \\
\text { ected by storage. } \\
\text { ords of New York State engineer and surveyor, 1906-27. } \\
\text { m graph based on gage readings. }\end{array}$ & & $\begin{array}{l}\text { 5Records } \\
\text { 6Observec } \\
\text { 7Estimat } \\
\text { 8Not det }\end{array}$ & $\begin{array}{l}\text { of New York } \\
\text { maximum. } \\
\text { d. } \\
\text { rmined. }\end{array}$ & & Supply, 1910-29. & & \\
\hline
\end{tabular}




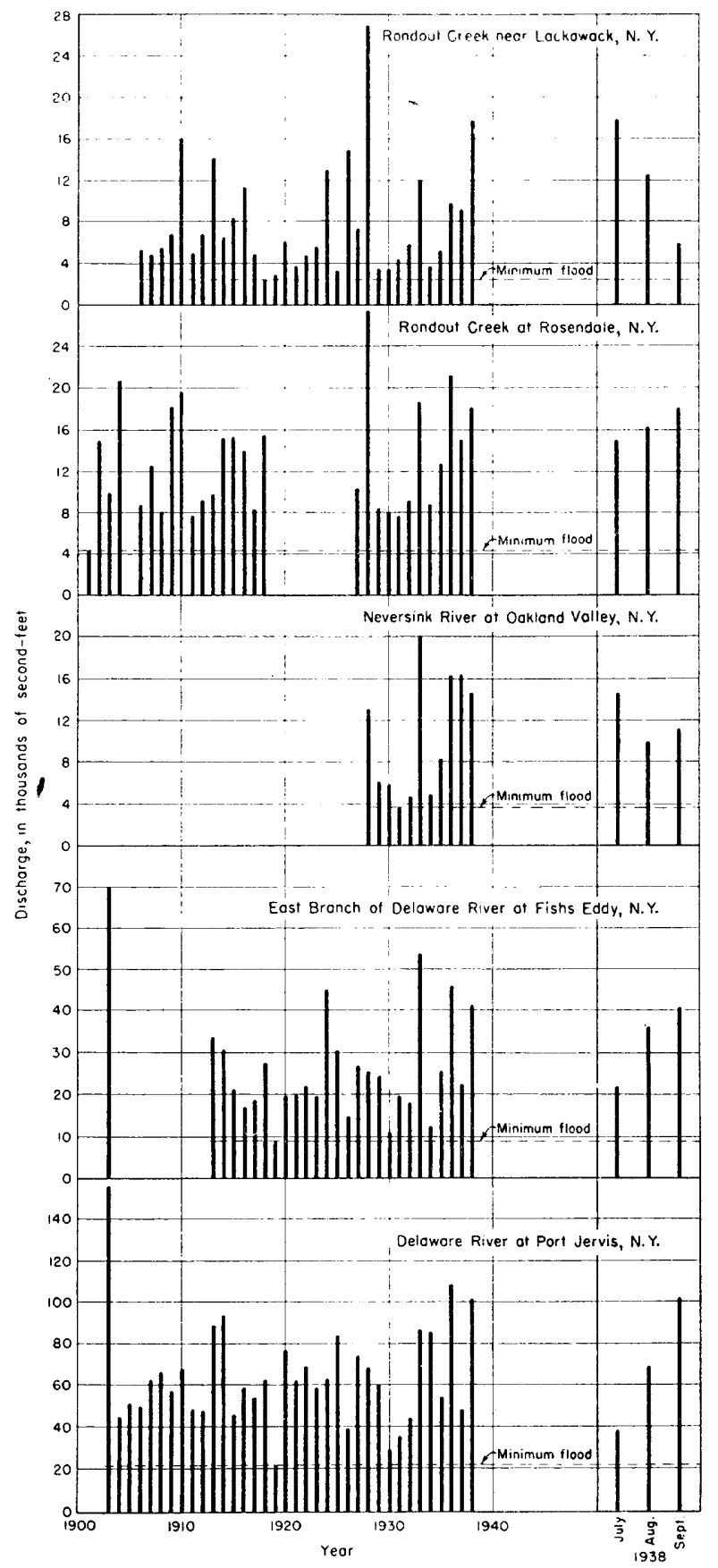

Figure 48.-Graph of annual floods at five selected stream-gaging stations in the Catskill Mountain region. 
TABLE 37.-Annual floods at five selected stream-gaging stations in the Catskill Mountain region

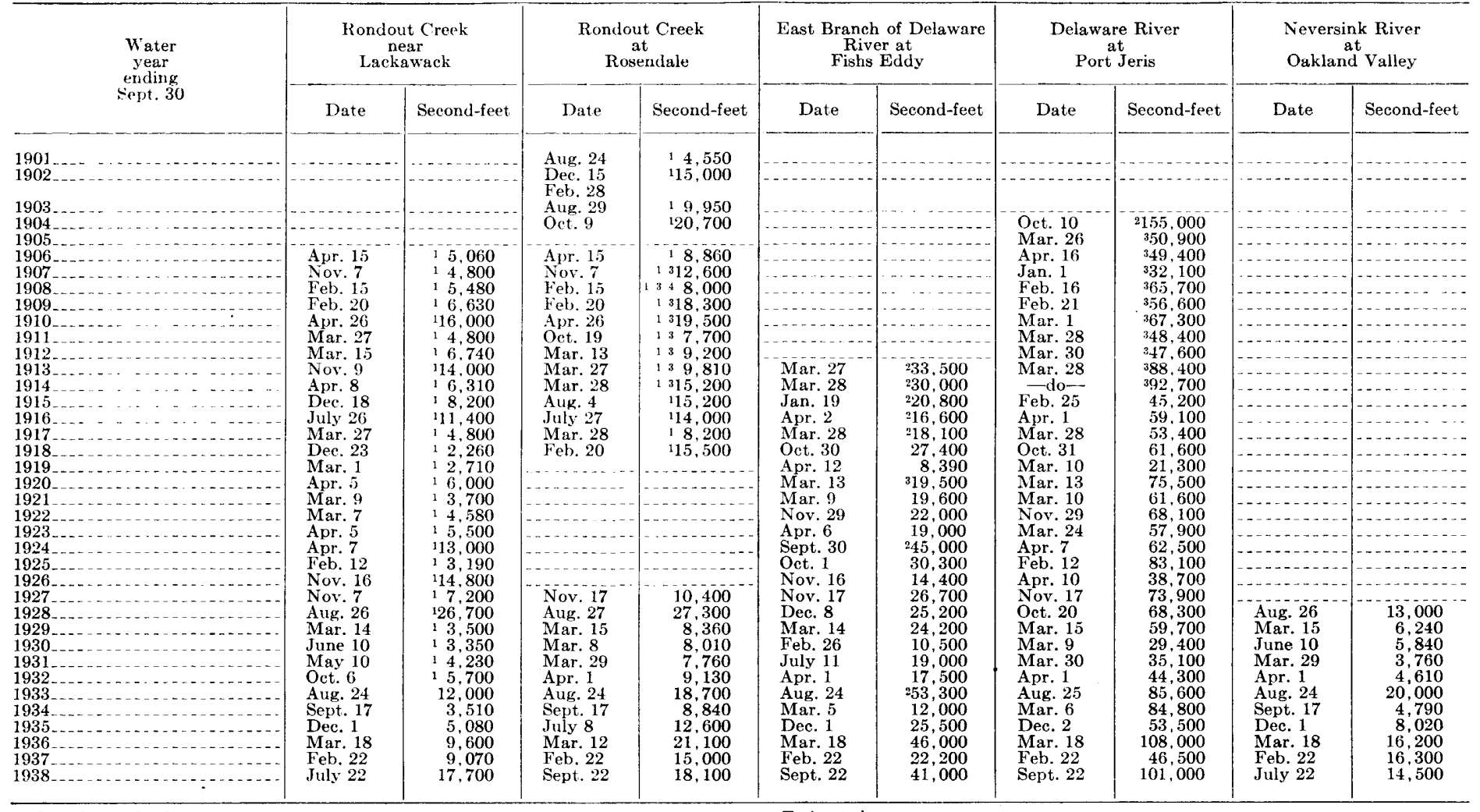

4 Estimated.

NOTE.-Records for Rondout Creek near Lackawack for 1906-32 and Rondout 


\section{RAINFALL AND RUNOFF STUDIES}

The mean depths of precipitation over the several basins were computed from the isohyetal map shown on figure 45 . The results, in inches, are listed in table 38. The direct runoff is given in this table in terms of mean depth, in inches, over the contributing drainage basin for ready comparison with rainfall. The method used for computing the volume of direct runoff, by using the records of stream flow included in this report, is illustrated on figure 49, where a hydrograph of discharge of Rondout Creek near Lackawack has been divided into direct runoff and base-flow components, as follows. During the morning and early afternoon of August 6 the river flow consisted of ground-water effluent seepage, generally termed base flow. The average flow, at point $A$ on

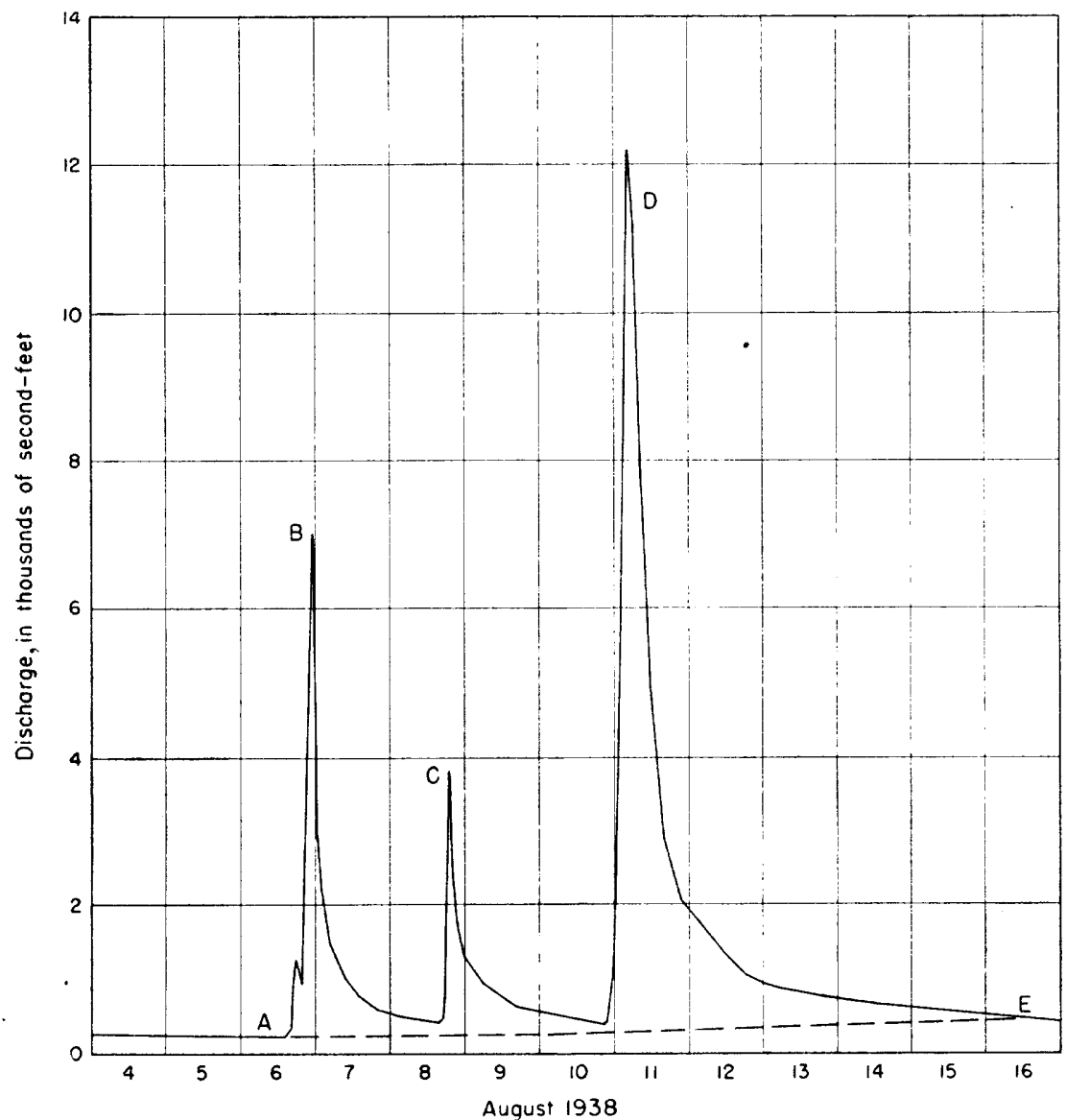

Figure 49.--Hydrograph of discharge of Rondout Creek near Lackawack, N. Y., showing method of analysis used in determining direct runoff associated with the flood of August 1938. 
figure 49, at the several gaging stations was 1.67 second-feet per square mile. During the afternoon of August 6 stream flow rose sharply in response to rainfall and reached a peak, $B$, within a few hours. After cessation of rainfall, stream flow again receded until the afternoon of August 8, when additional rainfall for a few hours produced a second isolated rise to a peak, $C$, on figure 49 , which in most streams was the lowest of the three. Stream flow again receded almost to base-flow level until the late afternoon of

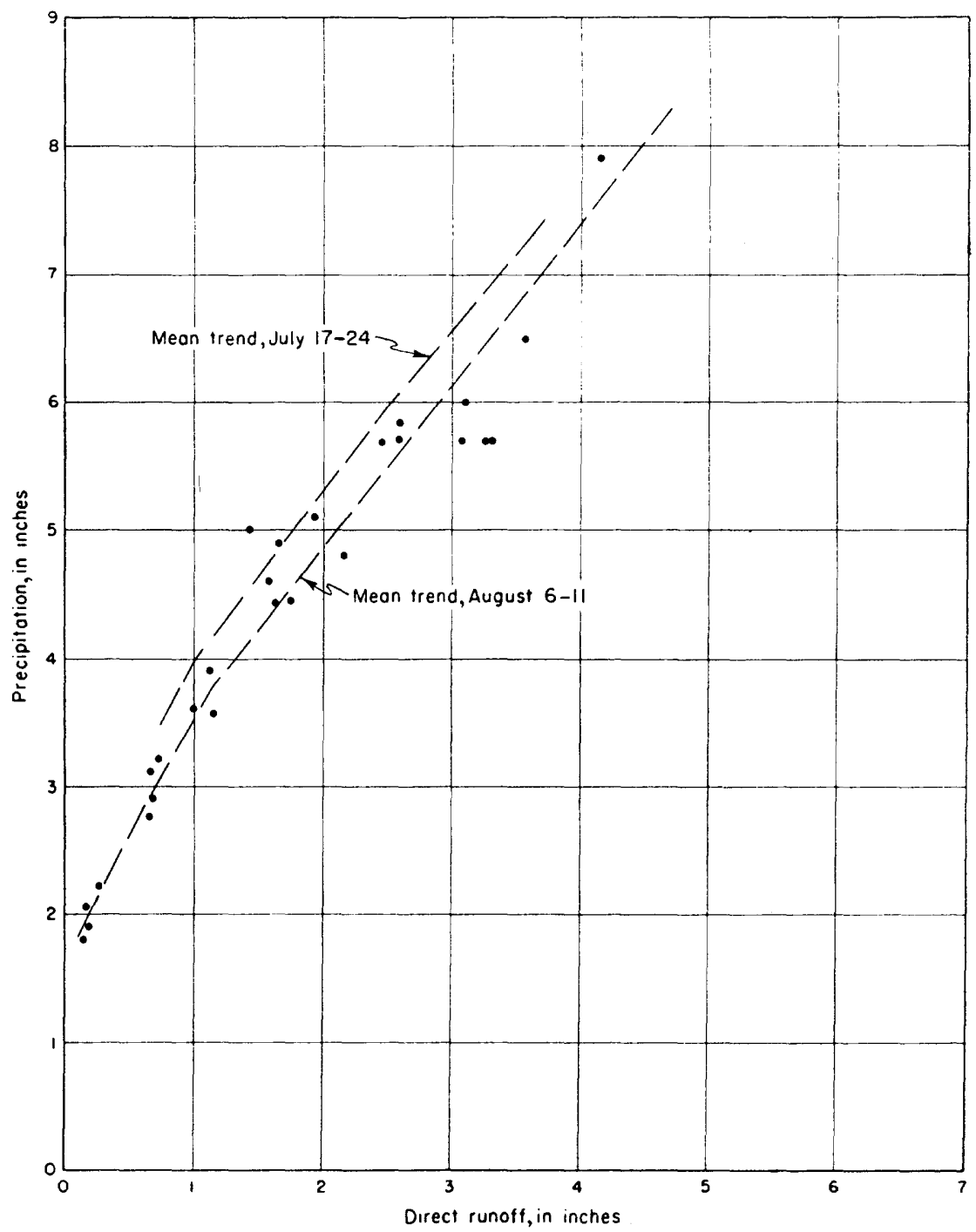

Ficure 50.--Relation between precipitation and associated direct runoff during flood of August 1938. 
August 10, when the heavy rainfall shown on figure 47 produced a maximum flood discharge during the storm period shown as point $D$ on figure 49. Rainfall generally ended before noon on August 11, and flow receded until light rainfall on August 17 and 18 produced a small rise not shown on figure 49. However, it was believed that stream flow on August 16, identified by point $E$ on figure 49, consisted largely of base flow. The average rate of flow at the several gaging stations at this time was 2.10 second-feet per square mile. A line was drawn between points $A$ and $E$ to repre-

TABLE 38.-Precipitation and associated direct runoff of flood of August 1938 [Mean depth, in inches, over drainage areas]

\begin{tabular}{|c|c|c|c|c|c|c|}
\hline $\begin{array}{c}\text { No. } \\
\text { on } \\
\text { pl. } 12\end{array}$ & Stream & Location & $\begin{array}{l}\text { Drain- } \\
\text { age } \\
\text { area } \\
\text { (square } \\
\text { miles) }\end{array}$ & $\begin{array}{l}\text { Pre- } \\
\text { cipita- } \\
\text { tion }\end{array}$ & $\begin{array}{c}\text { Run- } \\
\text { off }\end{array}$ & $\begin{array}{l}\text { Differ- } \\
\text { ence }\end{array}$ \\
\hline . & Hudson River Basin & & & & & \\
\hline $\begin{array}{l}538 \\
550 \\
553 \\
560 \\
561 \\
562 \\
563\end{array}$ & $\begin{array}{l}\text { Schoharie Creek } \ldots \\
\text { Catskill Creek } \\
\text { Esopus Creek } \\
\text { Rondout Creek } \\
\text { Do Do } \\
\text { Do } \\
\text { Chestnut Creek }\end{array}$ & $\begin{array}{l}\text { Prattsville, N, Y. } \\
\text { Oak Hill, N. Y. } \\
\text { Coldbrook, N. Y. } \\
\text { Lowes Corners, N. Y. } \\
\text { Lackawack, N. Y. } \\
\text { Rosendale, N. Y. } \\
\text { Above Red Brook, } \\
\text { at Grahamsville, N. Y. }\end{array}$ & $\begin{array}{c}236 \\
98 \\
192 \\
38.5 \\
100 \\
386 \\
12.2\end{array}$ & $\begin{array}{l}2.05 \\
1.8 \\
3.2 \\
5.7 \\
6.5 \\
4.8 \\
7.9\end{array}$ & $\begin{array}{r}0.15 \\
.13 \\
.72 \\
3.29 \\
3.58 \\
2.13 \\
4.14\end{array}$ & $\begin{array}{l}1.90 \\
1.67 \\
2.48 \\
2.41 \\
2.92 \\
2.67 \\
3.76\end{array}$ \\
\hline $\begin{array}{l}563 \\
564 \\
566\end{array}$ & $\begin{array}{c}\text { Wallkill River } \\
\text { Do } \\
\text { Do } \\
\text { Delauare River Basin }\end{array}$ & $\begin{array}{l}\text { Lnion ville, N. Y. } \\
\text { Pellets Island Mountain, N. Y. } \\
\text { Gardiner, N. Y. }\end{array}$ & $\begin{array}{l}144 \\
385 \\
711\end{array}$ & $\begin{array}{l}1.9 \\
2.2 \\
2.75\end{array}$ & $\begin{array}{l}.19 \\
.27 \\
.66\end{array}$ & $\begin{array}{l}1.71 \\
1.93 \\
2.09\end{array}$ \\
\hline $\begin{array}{l}642 \\
643 \\
644 \\
646 \\
650 \\
651 \\
652 \\
653 \\
654 \\
655 \\
656 \\
657 \\
658 \\
662.5 \\
667.3\end{array}$ & $\begin{array}{l}\text { East Branch of Delaware River } \\
\text { Do } \\
\text { Do } \\
\text { Delaware River } \\
\text { Mill Brook } \\
\text { Tremper Kill } \\
\text { Terry Clove Kill } \\
\text { Beaver Kill } \\
\text { Do } \\
\text { Willowemoc Creek } \\
\text { Little Beaver Kill } \\
\text { West Branch of Delaware River } \\
\text { Do Do } \\
\text { Neverte Delaware River. }\end{array}$ & $\begin{array}{l}\text { Margaret rille, N. Y... } \\
\text { Harvard, N. Y. } \\
\text { Fishs Eddy, N. Y. } \\
\text { Port Jervis, N. Y. } \\
\text { Arena, N. Y. } \\
\text { Shavertown, N. Y. } \\
\text { Pepacton, N. Y. } \\
\text { Craigie Clair, N. Y... } \\
\text { Cooks Falls, N. Y. } \\
\text { Livingston Manor, N. Y. } \\
\text { Delhi, No, Y. } \\
\text { Hale Eddy, N. Y... } \\
\text { Delhi, Y. Y. } \\
\text { At Halls Mills, }\end{array}$ & \begin{tabular}{|c|}
163 \\
443 \\
783 \\
3.076 \\
25.0 \\
33.0 \\
14.1 \\
82 \\
241 \\
63 \\
19.8 \\
142 \\
593 \\
49.8 \\
68
\end{tabular} & $\begin{array}{l}3.1 \\
4.6 \\
5.1 \\
3.6 \\
5.0 \\
3.9 \\
4.9 \\
6.0 \\
5.7 \\
5 \cdot 7 \\
5.7 \\
2.9 \\
4.45 \\
3.55 \\
5.7\end{array}$ & $\begin{array}{l}.65 \\
1.59 \\
1.93 \\
1.00 \\
1.42 \\
1.12 \\
1.66 \\
3.10 \\
2.56 \\
3.08 \\
3.27 \\
.68 \\
1.65 \\
1.13 \\
2.45\end{array}$ & $\begin{array}{l}2.45 \\
3.01 \\
3.17 \\
2.60 \\
3.58 \\
2.78 \\
3.24 \\
2.90 \\
3.14 \\
2.62 \\
2.43 \\
2.22 \\
2.80 \\
2.42 \\
3.25\end{array}$ \\
\hline $\begin{array}{l}667 \cdot 7 \\
668 \\
669\end{array}$ & $\begin{array}{l}\text { Do }_{\ldots} \ldots \ldots \\
\text { Do }_{1} \ldots \ldots \\
\text { Do }_{-} \ldots \ldots\end{array}$ & $\begin{array}{l}\text { Woodbourne, N. Y. } \\
\text { Oakland Valley, N. Y. } \\
\text { Godeffroy, N. Y. }\end{array}$ & $\begin{array}{l}113 \\
222 \\
302\end{array}$ & $\begin{array}{l}5.85 \\
4.45 \\
4.05\end{array}$ & $\begin{array}{l}2.57 \\
1.76 \\
1.35\end{array}$ & $\begin{array}{l}3.28 \\
2.69 \\
2.70\end{array}$ \\
\hline
\end{tabular}

sent the rate of base flow during the flood period. The area within the hydrograph and above this line represents the volume of direct runoff associated with the meteorologic events of August 6-11, and was computed in terms of second-foot-days and then converted into inches over the contributary drainage basin.

The results of these computations are given in table 38 and are shown graphically in relation to the corresponding rainfall on figure 50. The graph indicates that only total storm rainfall in excess of 2 inches was effective in producing significant direct run- 
off and that approximately two-thirds of the rainfall above 2 inches was converted into direct runoff. Above 6 inches rainfall, the data seem to define a retention of about 3.5 inches.

Many factors influence the proportion of rainfall that is converted into runoff. Among these, the principal ones are volume, intensity, and distribution of precipitation, and antecedent soilmoisture conditions. The influence of the volume of precipitation, as shown by figure 50, has been mentioned. The plotting of the points with respect to the mean trend suggests a general uniformity of conditions over the area with respect to central soil moisture and rainfall distribution. However, as the area covered by the storm of July 17-24 nearly coincided with that of August 6-11, the basins of low precipitation during the latter storm were also those of low precipitation during the former, and consequently there may have been a chance variation in antecedent soil moisture between the several basins which associated with precipitation in such a manner as to produce the curve shown on figure $\mathbf{5 0 .}$

TABLE 39.-Precipitation and direct runoff assoriated with the several peaks during the flood of August 1938

[Mean depth in inches over drainage area]

\begin{tabular}{|c|c|c|c|c|c|c|c|c|c|c|}
\hline \multirow[b]{2}{*}{$\begin{array}{l}\text { Stream and point } \\
\text { of measurement }\end{array}$} & \multirow[b]{2}{*}{$\begin{array}{c}\text { Drain- } \\
\text { age } \\
\text { area } \\
\text { (square } \\
\text { miles) }\end{array}$} & \multicolumn{2}{|c|}{ August $6-7$} & \multicolumn{2}{|c|}{ August 8} & \multicolumn{3}{|c|}{ August $10-11$} & \multicolumn{2}{|c|}{ August $6-11$} \\
\hline & & $\begin{array}{c}\text { Precipi- } \\
\text { tation }\end{array}$ & Runoft & $\begin{array}{c}\text { Precipi- } \\
\text { tation }\end{array}$ & Runoff & $\begin{array}{c}\text { Precipi- } \\
\text { tation }\end{array}$ & Runoff & $\begin{array}{l}\text { Infil- } \\
\text { tration } \\
\text { index } \\
\text { (inches } \\
\text { per } \\
\text { hour) }\end{array}$ & $\begin{array}{c}\text { Precipi- } \\
\text { tation }\end{array}$ & Runoff \\
\hline $\begin{array}{l}\text { Rondout Creek } \\
\text { near Lacka- } \\
\text { wack, N. Y. }\end{array}$ & 100.0 & 2.1 & 0.60 & 1.1 & 0.43 & 3.3 & 2.48 & 0.07 & 6.5 & 3.58 \\
\hline $\begin{array}{l}\text { Chestnut Creek } \\
\text { above Red } \\
\text { Brook, at } \\
\text { Grahamsville, } \\
\text { N.Y. }\end{array}$ & 12.2 & 2.75 & 1.10 & 1.6 & .75 & 3.55 & 2.29 & .09 & 7.9 & 4.14 \\
\hline $\begin{array}{l}\text { Terry Clove Kill } \\
\text { near Pepacton, } \\
\text { N. Y. }\end{array}$ & 14.1 & 1.25 & .15 & .15 & .02 & 3.5 & 1.49 & .19 & 4.90 & 1.66 \\
\hline
\end{tabular}

The curve showing mean trend for the storm and floods of July 17-24 is also shown on figure 50. For equal rainfall there was about 0.35 inch more of runoff under the hydrologic conditions existing during the storm of August 6-11 than for those existing during the storm of July 17-24.

The relation shown on figure 50 applies only to the conditions pertaining to the total storm. For example, the first 2 inches out of the total 6.5 inches of precipitation in Rondout Creek Basin above Lackawack, owing to differences in distribution, would not necessarily produce the same amount of runoff as the upper Wallkill River Basin, where the total 4-day rainfall was about 2 inches. 
The rainfall-runoff conditions existing during each of the three separate rises in flood between August 6 and 11 are given in table 39 , which lists the volume of rainfall and direct runoff associated with each rise for three streams in the central storm area. Examination of the amounts of rainfall and runoff during each of the separate periods indicates a progressive tendency for an increase in the part of rainfall appearing as direct runoff.

The infiltration index for the third period was computed by the method explained in the section on the flood of July 1938. The erratic distribution of the rainfall during the first two periods and the lack of sufficient recording gages for defining the hourly rainfall over broad areas under these conditions prevented the determining of the infiltration index during the first two periods. Rainfall during the last period, however, was more general and uniform with respect to timing so that a computation of the infiltration index was possible. The results for the three basins thus subdivided, as shown above, varied from 0.07 and 0.09 inch per hour in the two basins with the greatest antecedent rainfall to 0.19 inch per hour in Terry Clove Kill Basin, which had the least antecedent rainfall. 


\section{INDEX}

Abstract

Acknowledgments

Administration and personnel

Antecedent conditions, flood of August

$1938 \ldots \ldots \ldots \ldots \ldots \ldots$. . . . 401-402

flood of January $1938 \ldots \ldots \ldots \ldots$ 24-29

flood of June $1938 \ldots \ldots \ldots \ldots .128-129$

floods of July $1938 \ldots \ldots \ldots \ldots$. . . . .

general, description of ...... 5-7

Arena, N. Y., Mill Brook at ......329-330

Assunpink Creek, at Trenton, N. J. . .354-356

B

Barkhamsted Reservoir, near Barkhamsted, Conn. .....70-71, 235-236

Batsto River, at Batsto, N. J. . . . . . 320

Beaver Kill, at Cooks Falls, N. Y....332-333

at Craigie Clair, N. Y. . . . . . 331-332

Blackstone River, at Woonsocket, R. I. 212-213

at Worcester, Mass. . . . . . . 211-212

Blackwells Mills, at N. J., Millstone

River at ..........305-306

Blairstown, N. J., Paulins Kill at....346-349

Bloomsbury, N. J., Musconeteong

River near .........350-353

Boonton, N. J., Rockaway River

at $\ldots \ldots \ldots \ldots 287-288,289-290$

Boonton Reservoir, at Boonton, N. J. 288-289

Broad Brook, Conn., Scantic River at $\ldots \ldots \ldots \ldots \ldots 65-66,229-230$

Brownton, N. J., Deep Run near..... 310-312

Burlington Brook, near Burlington,

Conn. ........73-74, 238-239

\section{C}

Catskill Creek, at Oak Hill, N. Y....

Catskill Mountain region, N. Y.,

flood in ............... 395-422

Cedar Creek, at Lanoka Harbor, N. J. 318-320

Charles River, at Waltham, Mass....206-208

Charles River Basin ............205-209

Charles River Village, Mass., Charles

River at $\ldots \ldots \ldots \ldots 205-206$

Chestnut Creek, at Grahamsville, N. Y. 279-280

Coastal Basins in New Jersey....... 312-327

Coldbrook, N. Y., Esopus Creek at... 274

Cold Spring, Mass., Otis Reservoir at $\ldots \ldots \ldots \ldots 69-70,234-235$

Collinsville, Conn., Nepaug Reservoir near .........72-73, 237-238

Coltsville, Mass., Housatonic River at. 252 Columbia, Conn., Hop River near 54-55, 216-217 Concord River, at Lowell, Mass....... 201-202
Page

Connecticut, floods in ........12-124, 214-230 231-234, 235-251, 254-271

Connecticut River, at Hartford,

Conn. ..........64-65, 228

Connecticut River Basin ..64-84, 123, 228-250

Cooks Falls, N. Y., Beaver Kill at. . . 332--333

Craigie Clair, N. Y., Beaver Kill at. .331-332

Curry, N. Y., Neversink River near. .337-338

\section{D}

Dedham, Mass., Mother Brook at....208-209

Deep Run, near Brownton, N. J....310-312

Delaware River, at Port Jervis, N. Y.. $\quad 329$

East Branch, at Fishs Eddy, N. Y.. $\quad 328$

at Harvard, N. Y. . . . . . 327-328

West Branch, at Delhi, N. Y. ... 336

at Hale Eddy, N. Y. ......336-337

Delaware River Basin ..........327-362

Delhi, N. Y., Delaware River, West

Branch at ........... 336

Little Delaware River near..... 337

$\mathbf{E}$

East Branch Reservoir, at New Hartford, Conn. ......71-72, 236-237

East Hampton, Conn., Salmon River near $\ldots \ldots \ldots \ldots 81-82,247-248$

East Hartford, Conn., Hockanum River near .....79-80, 245-246

Eightmile River, East Branch, near North Lyme, Conn. 82-83, 248-249

Elizabeth River, at Elizabeth, N. J. . 293-294

at Irvington, N. J. . . . . . . 292-293

Elizabeth River Basin ...........292-294

Esopus Creek, at Coldbrook, N. Y.... 274

\section{F}

Falls Village, Conn., Housatonic River at ......86-87, 254-255

Farmington River, at Riverton,

Conn. ......666-67, 231-232

at Tariffville, Conn. . . ...67-69, 233-234

near New Boston, Mass. .......230-231

Farrington Dam, N. J., Lawrence

Brook at ...........309-310

reservoir on Lawrence Brook at . .308-309

Fishs Eddy, N. Y., Delaware River,

East Branch at ........ 328

Five Mile River, at Killingly,

Conn. .......60-61, 224-225

Flat Brook, near Flatbrookville, N. J...343-346

Floods, in New Jersey, monthly dis-

tribution of $\ldots \ldots \ldots \ldots \ldots 127-128$

Flood-crest stages, flood of July 1938 . 372-383 
Folsom, N. Y., Great Egg River at. . .322-324 Frost in the ground, prior to flood of January $1938 \quad \ldots \ldots \ldots \ldots \quad 45-46$

\section{G}

Gardiner, N. Y., Wallkill River at.,281-282 Gaylordsville, Conn., Tenmile River near $\ldots \ldots \ldots \ldots$ 89-90, 257-258

Gilboa, N. Y., Schoharie Creek at. ...272-273 Godeffroy, N. Y., Neversink River at. .342-343 Grahamsville, N. Y., Chestnut Creek at 279-280 Great Barrington, Mass., Housatonic

River near .......... 253

Great Egg River, at Folsom, N. J....322-324 Green Brook, at Plainfield, N. J.....307-308

\section{H}

Hackensack River, at New Milford, N. J. . . . . . . . . 283-284

Hackensack River Basin ..........282-286

Hale Eddy, N. Y., Delaware River, West Branch, at ......336-337

Harrisville, N. J., Wading River, East Branch at .........321-322

Harvard, N. Y., Delaware River, East Branch at $\ldots \ldots \ldots \ldots \ldots 327-328$

Hartford, Conn., Connecticut River at $\ldots \ldots \ldots \ldots \ldots \ldots 64-65,228$

Park River at ........74-78, 240-244 Hillsdale, N. J., Woodeliff Lake at . .284-285 Hockanum River, at Rockville,

Conn. . . . . . . 78-79, 244-245

near East Hartford, Conn...79-80, 245-246

Hop River, near Columbia, Conn. 54-55, 216-217

Housatonic River, at Coltsville, Mass. 252

at Falls Village, Conn....86-87, 254-255

at Stevenson, Conn. .....88-89, 256-257

near Great Barrington, Mass. .... 253

Housatonic River Basin 86-101, 123-124, 252-270

Hudson River Basin ...........272-282

Ipswich River, at South Middleton,

Mass. .............203-204

near Ipswich, Mass. . . . . . . . 204-205

Ipswich River Basin ...........203-205

Irvington, N. J., Elizabeth River at..292-293

$$
\mathbf{J}
$$

Jewett City, Quinebaug River

at $\ldots \ldots \ldots \ldots \ldots \ldots 5-60,222-223$

\section{$\mathbf{K}$}

Killingly, Conn., Five Mile River at $\ldots \ldots \ldots \ldots \ldots 60-61,224-225$

Kingston, N. J., Millstone River near. .304-305
$\mathbf{L}$

Page

Lackawack, N. Y., Rondout Creek near .............276-277

Lake Carnegie, at Princeton, N. J... . 303-304

Lake Hopatcong, at Landing, N. J. . 349-350 Lanesville, Conn., Still River near . . . . .....91-93, 260-261

Lanoka Harbor, N. J., Cedar Creek at. .318-320

Lawrence Brook, at Farrington Dam, N. J...........308-310

Leadmine Brook, near Thomaston, Conn. .......99-100, 268-269

Little Beaver Kill, near Livingston

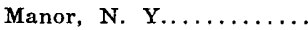

Little Delaware River, near Delhi, N. $Y$ 337

Livingston Manor, N. Y, Little Beaver Kill near .......... 335

Willowemoc Creek near........333-334

Lodi, N. J., Saddle River at. . . . . . 291-292 Lowell, Mass., Concord River at. . . . 201-202 Lowes Corners, N. Y., Rondout Creek near $\ldots \ldots \ldots \ldots \ldots \ldots 274-275$

M

Manantico Creek, near Millville, N. J. 324-327 Manasquan River, at Squankum, N. J...315-316 Manville, N. J., Raritan River at....299-300 Massachusetts, floods in....201-212, 230-231, $234-235,252-253$

Merrimack River Basin...........201-203

Mill Brook, at Arena, N. Y........329-330

Millstone River, at Blackwells Mills, N. J...........305-306

near Kingston, N. J..........304-305

Milltown, N. J., Raritan River, North Branch, at .........302-303

Millville, N. J., Manantico Creek near 324-327 Moosup River, at Moosup, Conn. 62-63, 225-226 Mother Brook, at Dedham, Mass.....208-209 Musconetcong River, near Bloomsburg, N. J. ...........350-353

\section{$\mathbf{N}$}

Natchaug River, at Willimantic, Conn. ........55-56, 218-219

Naugatuck River, near Naugatuck, Conn. ........98-99, 266-268 near Thomaston, Conn.....97-98, 100-101, 265-266, 269-270

Nepaug Reservoir, near Collinsville, Conn. ........72-73, 237-238

Neshanic River, at Reaville, N. J. . . 300-301 Neversink River, at Godeffroy, N. Y...342-343 at Oakland Valley, N. Y.......340-341 at Woodbourne, N. Y. . . . . . . 339 near Curry, $N$. Y.......... 337-338 New Boston, Mass., Farmington River near ............230-231 
New Hartford, Conn., East Branch Reservoir at......71-72, 236-237

New Jersey, floods in $124-151,282-327,343-362$

New Milford, Conn., Rocky River near ........90 91, 258259

New York, floods in. .272-282, 327-343, 395-422

North Lyme, Conn., Eightmile River,

East Branch, near. .82-83, 248-249

Eightmile River, West Branch, near ..........83-84, 249-250

Norton, Mass., Wading River near....210-211

\section{o}

Oak Hill, N. Y., Catskill Creek at....

Oakland Valley, N. Y., Neversink

River at $\ldots \ldots \ldots \ldots \ldots, 340-341$

Oldmans Creek, near Woodstown, N. J. 359-362

Oradell Reservoir, at Oradell, N. J.... 282

Otis Reservoir, at Cold Spring, Mass. $69-70,234-235$

\section{$\mathbf{P}$}

Park River, at Hartford, Conn. 76-77, 241-242 Pascack Brook, at Westwood, N. J...285-286 Passaic River Basin. .............287-292 Paulins Kill, at Blairstown, N. J....346-349 Pellets Island Mountain, N. Y., Walkill River at ..............

Pemberton, N. J., Rancocas Creek, North Branch at.......356-359

Plainfield, N. J., Green Brook at.....307-308 Pomperaug River, at Southbury,

Conn. ........96-97, 264-265

Port Jervis, N. Y., Delaware River at 329 Precipitation, flood of August 1938..403-405,

flood of January 1938, area-depth $406-411,412$ relations of ...38-39; pls. 3,4 flood of January 1938, areal distribution of $\ldots \ldots \ldots \ldots, 38$

records of $\ldots \ldots \ldots 29-39$; pls. 3,4

flood of June 1938, records of...131-142 floods of July 1938, area-depth

relations of .....198-199; pl. 11 areal distribution of..197-198; pl. 11 records of ............165-197

Precipitation records, description of.. 7-8 Prattsville, N. Y., Schoharie Creek at 272 Princeton, N. J., Lake Carnegie at...303-304 Providence River Basin............211-213 Putnam, Conn., Quinebaug River at $\ldots \ldots \ldots \ldots \ldots 58-59,221-222$

\section{Q}

Quinebaug River, at Jewett City,

Conn. .........59-60, 222-223 at Putnam, Conn.........58-59, 221-222 at Quinebaug, Conn........56-57, 219-220
Quinnipiac River, at Wallingford,

Conn. ........85-86, 250-251

Quinnipiac River Basin.......85-86, 250-251

$\mathbf{R}$

Rahway River, at Rahway, N. J.....296-297 near Springfield, N. J.........295-296

Rahway River Basin............295-297

Rainfall-runoff studies, explanation of 12 flood of August 1938.........418-422 flood of January 1938, comparison with other floods.......119-121 details of $\ldots \ldots \ldots \ldots \ldots \ldots 109-119$ in Connecticut River Basin 123 ; pl. 4 in Housatonic River Basin..123-124; pls. 4,5 in Thames River Basin 122 ; pls. 4,5 flood of June $1938 \ldots \ldots \ldots 147-151 ;$ pl. 6 floods of July $1938 \ldots \ldots \ldots \ldots \ldots 384-395$ Rancocas Creek, North Branch, at

Pemberton, N. J.......356-359

Raritan River, at Manville, N. J.....299-300

North Branch, at Milltown, N. J...302-303

South Branch, at Stanton, N. J...298-299

Raritan River Basin.............298-312

Reaville, N. J., Neshanic River at...300-301

Red Bank, N. J., Swimming River

near .............313-315

Tinton Falls Reservoir near. . . . 312-313

Rhode Island, floods in...........212-213

Riverton, Conn., Farmington River at $\ldots \ldots \ldots \ldots \ldots 66-67,231-232$

Rockaway River, at Boonton, N. J. . . . . 28.287-288, 289-290

Rockville, Conn., Hockanum River at $\ldots \ldots \ldots \ldots \ldots, 78-79,244-245$

Rocky River, near New Milford, Conn. ........90-91, 258-259

Rondout Creek, at Rosendale, N. Y....277-278 near Lackawack, N. Y........276-277 near Lowes Corners, N. Y.......274-275 Rosendale, N. Y., Rondout Creek at..277-278 Roxbury, Conn., Shepaug River near .........94-95, 262-263

$\mathbf{S}$

Saddle River, at Lodi, N. J. $.291-292$ Salmon River, near East Hampton, Conn. . . . . 247-248

Saugatuck River, near Westport

Conn. ........101-103, 270-271

Saugatuck River Basin......65-66, 229-230

Schoharie Creek, at Gilboa, N. Y.....272-273

at Prattsville, N. Y........... 272

Shavertown, N. Y., Tremper Kill..... 330 
Shepaug River, at Woodville,

Conn. ........ 93-94, 261-262

near Roxbury, Conn......94-95, 262-263

Shetucket River, near Willimantic Conn. ........52-53, 215-216

Snow, flood of January $1938 \ldots \ldots .39-45 ;$ pl. 5

Southbury, Conn., Pomperaug River at $\ldots \ldots \ldots \ldots \ldots 96-97,264-265$

South Coventry, Conn., Willimantic River near ......51-52, 214-215

South Middleton, Mass., Ipswich River at $\ldots \ldots \ldots \ldots \ldots \ldots \ldots 203-204$

Springfield, N. J., Rahway River near 295-296

Squankum, N. J., Manasquan River at $\ldots \ldots \ldots \ldots \ldots \ldots \ldots \ldots \ldots+315$

Stages and discharges, explanation of records of $\ldots \ldots \ldots \ldots \ldots$ 8-11

flood of August 1938.....397-399, 411 flood of January $1938 \ldots \ldots \ldots \ldots 46-124$ flood of June $1938 \ldots \ldots \ldots \ldots \ldots 143-147$ floods of July $1938 \ldots \ldots \ldots \ldots \ldots 153-157$,

$199-370$; pls. 11,12

summary of $\ldots \ldots \ldots 11,103-106,144-147$, $363-370,413-417$

Stanton, N. J.. Raritan River, South Branch, at .........298-299

State Farm, Mass., Taunton River at. .209-210

Stevenson, Conn., Housatonic River at $\ldots \ldots \ldots \ldots \ldots 88-89,256-257$

Zoar Lake at........... 87-88, 255

Still River, near Lanesville,

Conn. ........91-93, 260-261

Storage reservoirs, regulation of..106, 108-109, $370-372,413$

Swimming River, near Red Bank,

N. J. ...........313-315

$\mathbf{T}$

Tariffville, Conn., Farmington River at $\ldots \ldots \ldots \ldots \ldots 67-69,233-234$

Taunton River, at State Farm, Mass...209-210

Taunton River Basin............209-211

Tenmile River, near Gaylordsville

Conn. . . . . 257-258

Thames River Basin.....51-64, 122, 214-228

Thomaston, Conn., Leadmine Brook

near .........99-100, 268-269

Naugatuck River near.....97-98, 100-101, 265-266, 269-270

Tinton Falls Reservoir, near Red

Bank, N. J.........312-313 Zoar Lake, at Stevenson, Conn....87-88, 255
Page

Toms River, near Toms River, N. J...316-318

Tremper Kill, near Shavertown, N. Y.. 330

Trenton, N. J., Assunpink Creek at..354-356

$\mathbf{U}$

Unionville, N. Y., Walkill River near 280

$\mathbf{w}$

Wading River, (Mullica River Basin) East Branch, at Harrisville, N. J. . ........321-322

Wading River (Taunton River Basin), near Norton, Mass. ......210-211

Wallingford, Conn., Quinnipiac River at $\ldots \ldots \ldots \ldots \ldots \ldots 85-86,250-251$

Wallkill River, at Gardiner, N. Y....281-282

at Pellets Island Mountain, N. Y. 281

near Unionville, N. Y.......... 280

Waltham, Mass., Charles River at...206-208

Weather, associated with flood of January $1938 \ldots \ldots \ldots \ldots$ 17-24 associated with flood of June $1938 \ldots \ldots \ldots \ldots \ldots \ldots \ldots$ 129-131

associated with floods of July $1938 \ldots \ldots \ldots \ldots \ldots \ldots \ldots 159-162$

West Branch of Eightmile River, near North Lyme, Conn. 83-84, 249-250 near ....101-103, 107, 270-271

Westwood, N. J., Pascack Brook at..285-286

Willimantic, Conn., Natchaug River at $\ldots \ldots \ldots \ldots \ldots 5-56,218-219$

Shetucket River near.....52-53, 215-216

Willimantic River, near South Coventry,

Conn. ........51-52, 214-215

Willowemoc Creek, near Livingston Manor, N. Y.........333-334

Woodburne, N. Y., Neversink River at $\ldots \ldots \ldots \ldots \ldots \ldots \ldots .339$

Woodcliff Lake, at Hillsdale, N. J....284-285 Woodstown, N. J., Oldmans Creek near .............359-362

Woodville, Conn., Shepaug River at $\ldots \ldots \ldots \ldots \ldots$ 93-94, 261-262

Woonsocket, R. I., Blackstone River at 212-213 Worcester, Mass., Blackstone River at 211-212

\section{$\mathbf{Y}$}

Yantic River, at Yantic, Conn. 63-64, 226-228 $\mathbf{Z}$

is U, S. GOVERNMENT PRINTING OFFICE: 1948 -748116
Westport, Conn., Saugatuck River 